\title{
Rechtsbescherming bij bestuurlijke boeten : balanceren op een magische lijn?
}

Citation for published version (APA):

Albers, C. L. G. F. H. (2002). Rechtsbescherming bij bestuurlijke boeten : balanceren op een magische lijn? [Doctoral Thesis, Maastricht University]. Sdu Uitgevers. https://doi.org/10.26481/dis.20021220ca

Document status and date:

Published: 01/01/2002

DOI:

$10.26481 /$ dis.20021220ca

Document Version:

Publisher's PDF, also known as Version of record

\section{Please check the document version of this publication:}

- A submitted manuscript is the version of the article upon submission and before peer-review. There can be important differences between the submitted version and the official published version of record.

People interested in the research are advised to contact the author for the final version of the publication, or visit the DOI to the publisher's website.

- The final author version and the galley proof are versions of the publication after peer review.

- The final published version features the final layout of the paper including the volume, issue and page numbers.

Link to publication

\footnotetext{
General rights rights.

- You may freely distribute the URL identifying the publication in the public portal. please follow below link for the End User Agreement:

www.umlib.nl/taverne-license

Take down policy

If you believe that this document breaches copyright please contact us at:

repository@maastrichtuniversity.nl

providing details and we will investigate your claim.
}

Copyright and moral rights for the publications made accessible in the public portal are retained by the authors and/or other copyright owners and it is a condition of accessing publications that users recognise and abide by the legal requirements associated with these

- Users may download and print one copy of any publication from the public portal for the purpose of private study or research.

- You may not further distribute the material or use it for any profit-making activity or commercial gain

If the publication is distributed under the terms of Article $25 \mathrm{fa}$ of the Dutch Copyright Act, indicated by the "Taverne" license above, 
Rechtsbescherming bij bestuurlijke boeten 



\title{
Rechtsbescherming bij bestuurlijke boeten
}

\author{
Balanceren op een magische lijn?
}

\section{PROEFSCHRIFT}

ter verkrijging van de graad van doctor aan de Universiteit Maastricht, op gezag van de Rector Magnificus, Prof.dr. A.C. Nieuwenhuijzen Kruseman volgens het besluit van het College van Dekanen, in het openbaar te verdedigen op vrijdag 20 december 2002 om 14.00 uur

door

CATHARINA LEONORA GERTRUDA FRANCISCA HENDRIKA ALBERS 
Promotores:

Prof.mr. A.W. Heringa

Prof.mr. F.A.M. Stroink

Beoordelingscommissie:

Prof.mr. L.F.M. Verhey (voorzitter)

Prof.mr. G.P.M.F. Mols

Prof.mr. R.J.G.M. Widdershoven (Universiteit Utrecht)

C 2002 Sdu Uitgevers BV, Den Haag

Omslagontwerp: André Klijsen, Villa Y, Den Haag

Van deze studie is een handelsuitgave verschenen bij Sdu Uitgevers onder ISBN: 9054093552 
Aan mijn ouders 



\section{Woord vooraf}

Sinds mijn afstuderen in 1996 heeft de idee om een proefschrift over de bestuurlijke boete te schrijven mij niet losgelaten. Om die reden ben ik in januari 1998 in dienst getreden als docent (vergelijkend) publiekrecht bij de UM. Ondanks een behoorlijke onderwijslast probeerde ik zo veel mogelijk tijd te reserveren voor het schrijven van mijn dissertatie. Vanaf september 1999 kreeg ik, als universitair docent, de kans om meer tijd te besteden aan mijn onderzoek. Mede daardoor is dit boek tot stand gekomen.

Allen die op enigerlei wijze hebben meegewerkt aan de totstandkoming van dit boek wil ik daarvoor hartelijk danken. Dit geldt zeker voor de (oud) collega's van capaciteitsgroep publiekrecht. Vele (pittige) discussies heb ik met hen gevoerd. Regelmatig gebeurde dat tijdens spontaan georganiseerde borrels of lunches. Dit tekent tevens de prettige werksfeer die heerst bij de capaciteitsgroep publiekrecht. Een werksfeer die mij heeft gestimuleerd deze dissertatie met veel enthousiasme te schrijven.

Een bijzonder woord van dank gaat uit naar beide promotoren; prof. mr. A.W. Heringa en prof. mr. F.A.M. Stroink. Aalt Willem Heringa heeft mij, sinds ik als docent in dienst trad bij de UM, gestimuleerd om te werken aan mijn proefschrift. Hij bood mij de kans om het boek te schrijven. Hij stimuleerde mij verder om steeds op kritische wijze naar mijn eigen werk te kijken. Frits Stroink nam met name de bestuursrechtelijke aspecten van de begeleiding voor zijn rekening. Zonder hem zou dit boek niet zijn geworden wat het nu is.

Daarnaast bedank ik de leden van de leescommissie; prof. mr. L.F.M. Verhey, prof. mr. G.P.M.F. Mols en prof. mr. R.J.G.M. Widdershoven. Zij vormden zich binnen enkele weken een oordeel over het manuscript.

Mijn dank gaat voorts uit naar prof. mr. A.H. Klip. Aan de hand van zijn waardevolle commentaar op het manuscript kon ik met name de straf(proces)rechtelijke puntjes op de i zetten. Mike Walker (Senior Enforcement Counsel bij het Environmental Protection Agency te Washington DC), verschafte met het nodige enthousiasme veel informatie over de Amerikaanse boeteregeling. Ook aan hem ben ik dank verschuldigd.

Prof. mr. A.Q.C. Tak en Ass. Iur. H. Schneider brachten mij, reeds in de eindfase van mijn studie Nederlands Recht aan (destijds nog) de RL, ertoe de door mij tijdens een stage bij het ministerie van justitie opgedane, en in mijn afstudeerscriptie nader uitgewerkte, kennis m.b.t. de bestuurlijke boete te gebruiken voor het schrijven van een dissertatie. Zonder hen was dit proefschrift niet tot stand gekomen.

Een bijzonder woord van dank gaat bovendien uit naar alle kamergenoten met wie ik gedurende kortere of langere tijd een werknimte heb gedeeld in het Oud Gouverne- 
ment. Zij hebben allen op hun eigen wijze een bijdrage geleverd aan de totstandkoming van dit proefschrift.

Ook Nettie Litjens en Bregtje Schwenke kunnen niet onvermeld blijven. In de laatste fase van mijn proefschrift namen zij vele administratieve klussen van mij over. Bregtje maakte het manuscript bovendien camera-ready. Wies Rayar ben ik dank verschuldigd voor het vertalen van de samenvatting in het Engels.

Als laatste noem ik Raymond en Maarten. Raymond, die als geen ander weet wat het is om een proefschrift te schrijven, zorgde ervoor dat ik bleef vertrouwen in mijn eigen kunnen. Hij stond voor me klaar in een periode waarin voor hem ook heel veel veranderde in zijn leven. Maarten tenslotte, heeft in de eerste maanden dat hij bij ons was de aandacht van zijn moeder moeten delen met deze dissertatie. Die tijd is nu voorbij.

Het literatuur- en jurisprudentie-onderzoek werd op I mei 2002 afgesloten. Met latere publicaties en jurisprudentie kon slechts incidenteel rekening worden gehouden.

Maastricht/Nieuwstadt, september 2002

Karianne Albers 


\section{Inhoud}

Woord vooraf

Inhoud

Lijst van afkortingen

\section{Hoofdstuk 1}

Inleiding

1.1

Algemeen

De bestuurlijke boete

1.2.1 De bestuurlijke boete - definitie -

1.2.2 Opkomst van de bestuurlijke boete

1.2.3 Karakter

1.3 Nadere uitwerking probleemstelling

1.3.1 Centrale onderzoeksvraag

1.3.2 Rechtsbescherming

1.3.2.a Rechtsbescherming in bestuursrechtelijke context

1.3.2.b Rechtsbescherming in strafrechtelijke context

1.3.2.c Rechtsbescherming in bestuursstrafrechtelijke context Behandelplan

Deel I De bestuurlijke boete in Nederland

\section{Hoofdstuk 2}

De bestuurlijke boete in het algemeen

2.2 De bestuurlijke boete en andere sancties

$\begin{array}{lll}2.2 .1 & \text { De bestuurlijke boete } & 17\end{array}$

2.2.2 Het verschil tussen de bestuurlijke en de strafrechtelijke boete 19

2.2.2.1 Intermezzo - plaats van het strafrecht ten opzichte van het bestuursrecht - 19

$\begin{array}{ll}\text { 2.2.2.2 Sanctieoplegger en waarborgen } & 22\end{array}$

2.2.3 De bestuurlijke boete en enkele andere administratieve sancties 23
2.2.3.1 Inleiding

2.2.3.2.a Reparatoire en punitieve administratieve sancties - gevolgen van kwalificatie - 25

2.2.3.2.b Reparatoire en punitieve administratieve sancties - definitiekwestie - 26 
2.2.3.3 Vijf administratieve sancties (kritisch) beschouwd 37

2.2.3.3.a Intrekking van een begunstigende beschikking 37

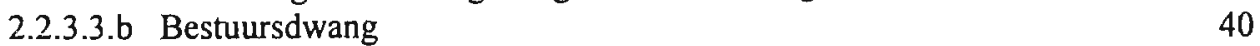

2.2.3.3.c Dwangsom 43

2.2.3.3.d De maatregel in het sociale zekerheidsrecht en daarmee vergelijkbare sancties $\quad 46$

$\begin{array}{lll}\text { 2.2.3.3.e De bestuurlijke boete } & 48\end{array}$

2.2.3.4 Administratieve sancties - conclusie - $\quad 52$

2.3 Sanctionering door middel van bestuurlijke boeten (in de plaats van strafrechtelijke afdoening) 54

2.3.1 Inleiding 54

2.3.2 Opvattingen in de literatuur 56

2.3.2.1 Wetsdelicten - normen met een geringe normatieve lading - 56

2.3.2.2 Frequentiecriterium 63

2.3.2.3 Ontbreken van een doorslaggevend criterium 65

2.3.2.4 Oplegging van punitieve sancties door de strafrechter 68

$\begin{array}{ll}\text { 2.3.2.5 Opvattingen in de literatuur - conclusie - } & 70\end{array}$

$\begin{array}{lll}\text { 2.3.3 Het rapport van de Toetsingscommissie } & 71\end{array}$

2.3.3.1 'Decriminalisering' $\quad 72$

2.3.3.2 Criteria voor bestuursrechtelijke sanctionering volgens
de Toetsingscommissie

$\begin{array}{lll}2.4 & \text { Afsluitend } & 78\end{array}$

\section{Hoofdstuk 3}

Verdragsrechtelijke waarborgen bij de oplegging van bestuurlijke boeten

$3.1 \quad$ Inleiding

$\begin{array}{lll}3.2 & \text { Criminal charge } & 84\end{array}$

3.2.1 Criminal charge - algemeen - $\quad 84$

3.2.1.a Classificatie naar nationaal recht $\quad 86$

3.2.1.b Aard van de overtreding $\quad 89$

3.2.1.c Aard en zwaarte van de sanctie 95

3.2.1.d De drie criteria - resumé - $\quad 110$

3.2.2 Cumulatieve of alternatieve criteria? 112

$\begin{array}{lll}3.2 .3 & \text { Charge } & 115\end{array}$

$\begin{array}{ll}\text { 3.2.4 Afsluitend 'criminal charge' } & 118\end{array}$

$\begin{array}{lll}3.3 & \text { 'Criminal charge' ex artikel 14 IVBPR } & 120\end{array}$

$\begin{array}{ll}3.4 & \text { Waarborgen uit het EVRM en IVBPR } \\ 3.421\end{array}$

$\begin{array}{ll}\text { 3.4.1 De waarborgen - een opsomming - } & 121\end{array}$

$\begin{array}{lll}\text { 3.4.2 De onschuldpresumptie } & 124\end{array}$

3.4.3 Het nemo tenetur-beginsel en het zwijgrecht 132

3.4.4 Het nullum crimen sine lege-beginsel, het nulla poena sine lege-beginsel en het beginsel dat de overtreder dient te profiteren van een, na het begaan van het strafbare feit, totstandgekomen wetswijziging die voorziet in de oplegging van een lichtere straf 
3.4.4.a Het nullum crimen sine lege-beginsel

3.4.4.b Het nulla poena sine lege-beginsel

3.4.4.c Het beginsel dat de overtreder dient te profiteren van een, na het begaan van het strafbare feit, totstandgekomen wetswijziging die voorziet in de oplegging van een lichtere straf

\section{Hoofdstuk 4}

De bestuurlijke boete in Nederland

$\begin{array}{llr}4.1 & \text { Inleiding } & 151 \\ 4.2 & \text { Voorontwerp en waarborgen? } & 152 \\ 4.2 .1 & \text { Het voorontwerp - een inleiding - } & 152 \\ 4.2 .2 & \text { Het voorontwerp - artikelsgewijs - } & 159 \\ 4.2 .2 .1 & \text { Titel 5.1 Algemene bepalingen } & 160 \\ 4.2 .2 .2 & \text { Titel 5.4 Bestuurlijke boete } & 184 \\ 4.3 & \text { Resumé } & 264\end{array}$

$\begin{array}{ll}\text { Deel II De Verenigde Staten } & 269\end{array}$

Inleiding

\section{Hoofdstuk 5}

Korte introductie in het administratiefrecht van de Verenigde Staten

$5.1 \quad$ Inleiding

$\begin{array}{lll}5.2 & \text { Bevoegde bestuursorgaan } & 275\end{array}$

5.2.1 Agency

5.2.2 Quasi bevoegdheden en de 'separation of powers' doctrine 277

5.2.2.1 Quasi wetgevende bevoegdheid 278

5.2.2.2 Quasi rechtsprekende bevoegdheid 279

5.2.2.3 Een algemeen wettelijk kader voor de quasi bevoegdheden 282

$\begin{array}{lll}5.2 .3 & \text { Wijze van boete oplegging } 284\end{array}$

$\begin{array}{lll}5.3 & \text { Bevoegde (administratief)rechte(r)lijke instanties } & 291\end{array}$

$\begin{array}{ll}\text { 5.3.1 Indeling federale rechterlijke macht } & 291\end{array}$

5.3.2 Bevoegde artikel III rechter t.a.v. agency-besluiten 294

$\begin{array}{ll}\text { 5.3.3 Wijze van toetsing door de artikel III rechter } & 296\end{array}$

5.3.3.1 Toetsing uitgesloten 296

$\begin{array}{lll}\text { 5.3.3.2 Toetsingsbevoegdheid } & 298\end{array}$

$\begin{array}{lll}5.4 & \text { Afsluitend } & 303\end{array}$

\section{Hoofdstuk 6}

De Amerikaanse bestuurlijke boete

6.1 Opkomst van de bestuurlijke boete in de Verenigde Staten 
6.2 De bestuurlijke boete zoals die wordt opgelegd door het Environmental Protection Agency (EPA)

6.2.1 De boeteregeling uit de Clean Air Act en de Marine Protection, Research, and Sanctuaries Act.

6.2.1 .a De boeteregeling uit de Clean Air Act en de Marine Protection, Research, and Sanctuaries Act in het kader van de straf(proces)rechtelijke waarborgen

6.2.2 De 'consolidated Rules of Practice Governing the Administrative Assess-ment of Civil Penalties and the Revocation/Termination or Suspension of Permits'

6.2.2.a De boeteregeling uit de Rules of Practice in het kader van de straf(proces)rechtelijke waarborgen

6.2.3 Het boetebeleid van het EPA

6.2.3.a Het boetebeleid van het EPA nader belicht 347

6.3 Afsluitend

\section{Hoofdstuk 7}

Constitutionele waarborgen bij de oplegging van de bestuurlijke boete

7.1 Inleiding

7.2 Constitutionele waarborgen

7.3 Opvattingen in de rechtspraak

De rechtspraak van het Supreme Court

7.3.1.a Boyd versus United States (1886)

7.3.1.b Helvering versus Mitchell (1938)

7.3.1.c Kennedy versus Mendoza Martinez (1963)

7.3.1.d United States versus Ward (1980)

7.3.1.e United States versus One Assortment of 89 Firearms (1984)

7.3.1.f United States versus Halper (1989)

7.3.1.g Austin versus United States (1993)

7.3.1.h Montana Dept. of Revenue versus Kurth Ranch (1994) 380

7.3.1.i United States versus Ursery (1996)

7.3.1.j Hudson Et Al versus United States (1997)

7.2 .2

Schematisch overzicht

7.3 Afsluitend

\section{Hoofdstuk 8}

Verenigde Staten - conclusie -

8.1 Inleiding

8.2 Het Amerikaanse administratiefrecht

8.3 Verhoogde rechtsbescherming? 


\section{Hoofdstuk 9}

Rechtsbescherming bij bestuurlijke boeten. balanceren op een magische lijn?

9.2.2 Verdragsrecht als uitgangspunt

9.2.3 Het eigen karakter van de bestuurlijke boete verzet zich tegen onverkorte

\subsubsection{Algemeen}

9.2.3.2 Toegang tot een rechter die beschikt over 'full jurisdiction'

$\begin{array}{lll}\text { 9.2.3.3 Andere verdragsrechtelijke waarborgen } & 417\end{array}$

$\begin{array}{lll}\text { 9.2.3.4 Ten slotte } & 417\end{array}$

9.2.4 Doelmatigheidsargumenten lijken de overhand te hebben 418

9.3 Externe rechtsvergelijking 420

9.3.1 Boete oplegging en waarborgen in de Verenigde Staten 420

$\begin{array}{lll}\text { 9.3.1.1 Algemeen } & 420\end{array}$

9.3.1.2 De boeteregeling in de Verenigde Staten 420

9.3.1.3 Straf(proces)rechtelijke constitutionele waarborgen 422

9.3.2 Vergelijking met de Nederlandse procedure - wijze lessen? - $\quad 424$

9.3.2.1 Algemeen 424

$\begin{array}{lll}\text { 9.3.2.2 Hellend Vlak? } & 424\end{array}$

9.3.2.3 Pluspunten 425

9.4 Suggesties aan de hand van de bevindingen 428

9.4.1 Regeling uit het Voorontwerp van de vierde tranche 429

$\begin{array}{ll}\text { 9.4.2 Aparte regeling } & 430\end{array}$

$\begin{array}{lll}\text { 9.4.2.1 Algemeen } & 430\end{array}$

9.4.2.2 Volledig van de Awb losstaande regeling 430

9.4.2.3 Awb-conforme regeling $\quad 432$

$\begin{array}{lll}\text { 9.4.2.4 Ten slotte } & 433\end{array}$

9.4.3 'Derde spoor' 434

9.4.3.1 Voorgestelde regeling 435

9.4.3.2 Voordelen OM-boete 438

9.4.3.3 Vormgeving regeling 439

9.4.4 Bestuursrechtelijke transactie 441

9.4.4.1 Algemeen 441

9.4.4.2 Bestuursrechtelijke en gemengde variant 441

$\begin{array}{lll}\text { 9.4.4.3 Bezwaren } & 442\end{array}$

\begin{tabular}{lll}
9.4 .4 .4 & Slotsom & 444 \\
\hline & Variatie & 444
\end{tabular}

$\begin{array}{lll}9.4 .5 & \text { Variatie } & 444\end{array}$

$\begin{array}{lll}9.5 & \text { Slot } & 445\end{array}$ 
INHOUD

Summary

Appendix I APA "formal adjudication"

Appendix II APA "judicial review"

Appendix III 40 CFR 22 - Consolodated Rules of Practice -

Overzicht van geraadpleegde literatuur

Kamerstukken, beleidsnota's en overige overheidspublicaties

Rechtspraak

Trefwoordenregister

Curriculum vitae 


\section{Lijst van gebruikte afkortingen}

$\begin{array}{ll}\text { AA } & \text { Ars Aequi } \\ \text { AB } & \text { Administratiefrechtelijke beslissingen } \\ \text { ABRS } & \text { Afdeling bestuursrechtspraak van de Raad van State } \\ \text { ABW } & \text { Algemene Bijstandswet } \\ \text { AGRS } & \text { Afdeling geschillen van bestuur van de Raad van State } \\ \text { ALJ } & \text { Administrative Law Judge } \\ \text { APA } & \text { Administrative Procedure Act } \\ \text { ARB } & \text { Administratieve en rechterlijke beslissingen } \\ \text { ARRS } & \text { Afdeling rechtspraak van de Raad van State } \\ \text { Awb } & \text { Algemene wet bestuursrecht } \\ & \\ \text { BNB } & \text { Beslissingen in belastingzaken } \\ \text { B.Y.U.L. } & \text { Brigham Young University Law Review } \\ \text { CAA } & \text { Clean Air Act } \\ \text { CBB } & \text { College van Beroep voor het bedrijfsleven } \\ \text { CBSf } & \text { College van Beroep studiefinanciering } \\ \text { CFR } & \text { Code of Federal Regulations } \\ \text { CRvB } & \text { Centrale Raad van Beroep } \\ \text { CSV } & \text { Coőrdinatiewet Sociale verzekering } \\ & \\ \text { DD } & \text { Delikt en Delinkwent } \\ \text { diss. } & \text { Dissertatie }\end{array}$

ECRM

EHRC

EHRM

ELR

EPA

EVRM

FED

Geo. L.J.

Gst

Gw

Hastings L.J.

$\mathrm{HR}$

HRC
Europese Commissie voor de Rechten van de Mens

European Human Rights Cases

Europees Hof voor de Rechten van de Mens

Environmental Law Reporter

Environmental Protection Agency

Europees Verdrag tot bescherming van de Rechten van de Mens

Fiscaal Weekblad

Georgetown Law Journal

Gemeentestem

Grondwet

Hastings Law Journal

Hoge Raad

Human Rights Committee 
IBG

IVBPR

JAWB

JB

JBplus

MPRSA

M\&R

MvT

$\mathrm{Mw}$

\section{NJ}

NJB

NJV

Nma

NTB

OIRA

OMB

$O M$

OPTA

OvJ

PG Awb I

PG Awb II

PG Awb III

Pres.

RM Themis

RSV

Rules of Practice

RWW

S. Ct.

Seton Hall L. Rev

$\mathrm{Sr}$

Sv
Informatie Beheer Groep

Internationaal Verdrag inzake Burgerrechten en Politieke Rechten

Jurisprudentie Algemene Bijstandswet en Rijksgroepsregelingen Jurisprudentie Bestuursrecht

Jurisprudentie Bestuursrecht plus

Marine Protection, Research, and Sanctuaries Act

Milieu en Recht

Memorie van Toelichting

Mededingingswet

Nederlandse Jurisprudentie

Nederlands Juristenblad

Nederlandse Juristen Vereniging

Nederlandse mededingingsautoriteit

Nederlands Tijdschrift voor Bestuursrecht

Office of Information and Regulatory Affairs

Office of Management en Budget

Openbaar Ministerie

Onafhankelijke Post- en Telecommunicatie Autoriteit

Officier van Justitie

Parlementaire Geschiedenis van de Algemene wet bestuursrecht Eerste tranche, samengesteld door E.J. Daalder en G.R.J. de Groot Parlementaire Geschiedenis van de Algemene wet bestuursrecht Tweede tranche, samengesteld door E.J. Daalder, G.R.J. de Groot en J.M.E. van Breugel

Parlementaire Geschiedenis van de Algemene wet bestuursrecht Derde tranche, samengesteld door E.J. Daalder, G.R.J. de Groot en J.M.E. van Breugel

President

Rechtsgeleerd Magazijn Themis

Rechtspraak Sociale Verzekering

Consolidated Rules of Practice Governing the Administrative Assessment of Civil Penalties and the Revocation/Termination or Suspension of Permits

Rijksgroepsregeling werkloze werknemers

Supreme Court

Seton Hall Law Review

Wetboek van Strafrecht

Wetboek van Strafvordering 
TvO

U.S.C.

USZ

VAR

Vgl.

$\mathrm{VN}$

VR

VS

$\mathrm{Vz}$

WAHV

WAO

WVW

WVW 1994

WW

Yale L.J.

ZW
Tijdschrift voor Openbaar Bestuur

United States Code

Uitspraken Sociale Zekerheid

Vereniging voor bestuursrecht

Vergelijk

Verenigde Naties

Verkeersrecht

Verenigde Staten

Voorzitter

Wet administratiefrechtelijke handhaving verkeersvoorschriften

Wet op de Arbeidsongeschiktheidsverzekering

Wegenverkeerswet

Wegenverkeerswet 1994

Werkloosheidswet

Yale Law Journal

Ziektewet 





\section{Hoofdstuk 1}

\section{Inleiding}

\section{$1.1 \quad$ Algemeen}

De laatste twee decennia lijkt het 'bestuursstrafrecht' ${ }^{1}$ steeds meer aandacht te krijgen. Kort gezegd gaat het in het bestuursstrafrecht om de oplegging van punitieve sancties (sancties met een bestraffend karakter) door bestuursorganen. ${ }^{2}$ Met name de bestuurlijke boete lijkt een wezenlijke rol te vervullen. Veel is reeds geschreven met betrekking tot het bestuursstrafrecht en over de bestuurlijke boete. Zo bestaat er bijvoorbeeld inmiddels een tiental dissertaties en oraties waarin op enigerlei wijze aandacht uitgaat naar dit rechtsgebied. ${ }^{3}$

Bovendien heeft de wetgever inmiddels in een flink aantal bijzondere bestuursrechtelijke wetten de mogelijkheid tot het opleggen van bestuurlijke boeten neergelegd. ${ }^{4}$ Het sluitstuk lijkt vooralsnog de boeteregeling uit het Voorontwerp van de vierde tranche van de Awb. ${ }^{5}$

Ondanks het feit dat er reeds veel is geschreven biedt het bestuursstrafrecht nog voldoende stof voor een dissertatie. Met name de boeteregeling zoals die is neergelegd in het Voorontwerp geeft aanleiding tot een nadere beschouwing. In dat kader speelt de vraag naar de mate waarin rechtsbescherming zou moeten worden geboden bij een procedure tot oplegging van bestuurlijke boeten een belangrijke rol.

I Onder 'bestuursstrafrecht' dient volgens Hartmann en Van Russen Groen het volgende te worden verstaan: '...het van het strafrecht en het bestuursrecht te onderscheiden deel van het recht waarin publickrechtelijke bestuursorganen, zonder tussenkomst van de betrokkene of een onathankelijke rechter, sancties met een bestraffend karakter kunnen opleggen.' (Vgl. A.R. Hartmann en P.M. van Russen Groen, Contouren van het bestuursstrafrecht (diss. EUR), Deventer 1998, p. 74).

2 Hiema zal nog blijken dat de oplegging van bestuursstrafrechtelijke sancties zich onderscheidt van de strafrechtelijke procedure tot bestraffing alsmede van de 'traditionele' (reparatoire) bestuursrechtelijke wijze van bestraffing.

3 Een greep uit het geheel van publicaties levert het volgende beeld op: M.W.C. Feteris, Fiscale administratieve sancties en het recht op een behoorlijk proces (diss. UvA), Kluwer, Deventer 1993, W.G.A. Hazewindus, Administratieve sancties en vreemdelingenrecht (diss. UvA), Gouda Quint bv, Amhem 1994, J.F.L. Roording, Sanctierecht in de belastingen en de sociale zekerheid (diss.Nijmegen), Ars Aequi Libri, Nijmegen 1994, F.C.M.A. Michiels, De boete in opmars?, W.E.J. Tjeenk Willink, Zwolle 1994, A.R. Hartmann en P.M. van Russen Groen, Contouren van het bestuursstrafrecht (diss. EUR), Deventer 1998, A.R. Hartmann, Bewijs in het bestuursstrafrecht (diss. EUR), Amhem 1998, P.M. van Russen Groen, Rechtsbescherming in het bestuursstrafrecht (diss. EUR), Gouda Quint 1998, E.E.V. Lenos, Bestuurlijke sanctietoepassing en strafrechtelijke waarborgen in de sociale zekerheid, Koninklijke Vermande, 1998, O.J.D.M.L. Jansen, Het Handhavingsonderzoek (diss. UvA 1999), Nijmegen 1999, L.J.J. Rogier, Straffend bestuur, Gouda Quint, Rotterdam 200I, P.G. Wiewel, Rechtsbescherming tegen bestraffing (diss. UvA 2001), Nijmegen 2001, en H.M.J. Quaedvlieg, Ondememende autoriteiten (diss. UM), Maastricht 2001.

4 Handhaving door middel van bestuurlijke boeten is onder meer mogelijk in het kader van de Wet administratiefrechtelijke handhaving verkeersvoorschriften, de sociale zekerheidswetgeving (bijv. de WW en de WAO), de Algemene bijstandswet, de Algemene wet inzake rijksbelastingen, de Mededingingswet, de Wet toezicht effectenverkeer, de Wet geneesmiddelenprijzen en de Wet op de particuliere beveiligingsorganisaties.

5 Zie: Voorontwerp Algemene wet bestuursrecht vierde tranche, Commissie wetgeving algemene regels van bestuursrecht, Den Haag 7 september 1999 (hierna: Voorontwerp). 


\subsection{De bestuurlijke boete}

\subsection{De bestuurlijke boete - definitie -}

Centraal in dit boek staat de bestuurlijke boete. Het lijkt dan ook zinvol op deze plaats aan te geven wat onder een 'bestuurlijke boete' wordt verstaan. In dit kader zal geen poging worden ondemomen om aan de hand van de diverse reeds ontwikkelde definities van het begrip 'bestuurlijke boete' tot een nieuwe omschrijving te komen. Hier zal (gemakshalve ${ }^{6}$ ) worden uitgegaan van de definitie van de bestuurlijke boete zoals die in het Voorontwerp van de vierde tranche van de Awb is opgenomen. Lezing van artikel 5.4.1.1 in samenhang met artikel 5.0.2 van het Voorontwerp leidt tot de volgende definitie van de term bestuurlijke boete:

'een door een bestuursorgaan wegens een overtreding ${ }^{7}$ bij beschikking opgelegde onvoorwaardelijke verplichting tot betaling van een geldsom, die gericht is op bestraffing van de overtreder'.

Aan de hand van deze omschrijving van de bestuurlijke boete kan worden vastgesteld dat het bestuursorgaan zélf de boete oplegt nadat schending van een bepaalde norm is geconstateerd. Dit brengt met zich dat de (bestuurs)rechter zich eerst een oordeel kan vormen omtrent de rechtmatigheid van de bestuurlijke boete nadat deze (door het bestuursorgaan) is opgelegd. Het hangt bovendien van het initiatief van de beboete (rechts)persoon af of de (bestuurs)rechter zich kan uitspreken omtrent de (rechtmatigheid van de) opgelegde bestuurlijke boete. Alleén als de overtreder, aan wie een boete is opgelegd, een bezwaarschrift indient en vervolgens in beroep gaat bij de bestuursrechter kan deze laatste een oordeel geven over de rechtmatigheid van de boete. De bestuurlijke boete onderscheidt zich op dit punt van de traditionele (strafrechtelijke) boete. Oplegging van een strafrechtelijke boete vindt immers plaats na een, met straf(proces)rechtelijke waarborgen omklede, gerechtelijke procedure door de (onafhankelijke en onpartijdige) strafrechter.

Het feit dat het bij de bestuurlijke boete gaat om een punitieve sanctie die zonder voorafgaande tussenkomst van de onafhankelijke en onpartijdige rechter wordt opgelegd brengt onherroepelijk de vraag met zich naar de wijze waarop rechtsbescherming geboden zou moeten worden aan de vermoedelijke overtreder. Gelden hier strafrechtelijke regels en beginselen? Er is immers sprake van een punitieve sanctie. Of kan het bestuurs(proces)recht, al dan niet onverkort, worden toegepast? Deze (en andere) vragen, die nauw samenhangen met de probleemstelling, zullen in dit boek aan de orde worden gesteld.

6 De boeteregeling uit het Voorontwerp vervult immers een centrale rol in dit boek.

7 In artikel 5.0.1 van het Voorontwerp wordt een definitie gegeven van de term 'overtreding': '-1. In deze wet word: verstaan onder overtreding: een gedraging die in strijd is met het bepaalde bij of krachtens enig wettelijk voorschrift.' 


\subsubsection{Opkomst van de bestuurlijke boete}

Hoewel de bestuurlijke boete in het fiscale recht reeds een lange geschiedenis kent ${ }^{8}$ heeft deze sanctie op andere bestuursrechtelijke terreinen met name sinds het begin van de jaren tachtig van de vorige eeuw aan populariteit gewonnen. De invoering van de Wet administratiefrechtelijke handhaving verkeersvoorschriften in 1989 heeft de opkomst van de bestuurlijke boete ogenschijnlijk in een stroomversnelling gebracht. Bij de invoering van de bestuurlijke boete op grotere schaal lijkt met name de wens om te komen tot een effectieve handhaving van het (bijzonder) bestuursrecht een rol te spelen.

De opkomst van de bestuurlijke boete houdt in het bijzonder verband met het zogenaamde 'handhavingstekort'. ' Daadwerkelijke handhaving van (uitvoering van) bestuursrechtelijke wetgeving (b)leek vaak moeilijk realiseerbaar te zijn. ${ }^{10}$ Eén van de oorzaken daarvan was de overbelasting van het Openbaar Ministerie (OM) en het strafrechtelijke apparaat. " Het OM was destijds in het kader van veel bestuursrechtelijke overtredingen de enige instantie die genoemde overtredingen op een effectieve wijze kon handhaven door over te gaan tot strafvervolging. De bestuursorganen zelf beschikten op basis van het bestuursrecht veelal niet over effectieve (punitieve) sanctiebevoegdheden. Vaak bleef derhalve alleen de mogelijkheid van sanctionering door middel van strafrechtelijke sancties over. Het overbelaste OM diende echter (ook destijds) prioriteiten te stellen wat betreft het vervolgingsbeleid. De consequentie daarvan was, althans zo wordt beweerd, dat met name de, als minder ernstig ervaren, bestuursrechtelijke overtredingen ongesanctioneerd bleven. ${ }^{12}$

Vanwege een gebrek aan handhaving van overtredingen van bestuursrechtelijke regelgeving aan de strafrechtelijke zijde werd, onder andere door de Toetsingscommissie in het CTW-rapport, gezocht naar alternatieven in de bestuursrechtelijke context. In dat kader vond de Toetsingscommissie het belangrijk bestuursorganen een eigen verantwoordelijkheid toe te bedelen bij de handhaving van bestuursrechtelijke regelgeving. ${ }^{13}$ Door invoering van de mogelijkheid tot oplegging van bestuurlijke boeten dacht de

8 Vgl. Feteris a.w. 1993, p. 38 e.v. en J. van der Poel, Rondom compositie en compromis (fiscale studie in bestuurs- en strafrecht) (diss. RUU), Uitg. -Mij. NV Kemink en Zn., Utrecht 1942.

9 Genoemd handhavingstekort wordt door de commissie Michiels omschreven als het wél moeten handhaven maar niet kunnen of willen handhaven. Vgl. commissie Michiels, Handhaven op niveau, W.E.J. Tjeenk Willink, Deventer 1998, p. 36 en 57.

10 Zie m.b.t. het handhavingstekort ook de, in vergaderjaar 1990/1991 uitgebrachte, beleidsnota's: Recht in beweging, Kamerstukken II, 21 829, nr. 1-2 en Met vaste hand, Kamerstukken II, 22 045, nr. 1-2. Zie voorts: Handhaving door bestuurlijke boeten, Commissie voor de toetsing van wetgevingsprojecten, (CTW 94/1-12 januari 1994), p. 7 (hiema: CTW-rapport). Tenslotte kan nog gewezen worden op het Voorontwerp van de vierde tranche van de Awb (a.w. 1999) p. 90.

11 Zie ook: de commissie Michiels a.w. 1998, p. 53 e.v. De Commissie Michiels noemt daar een achttal oorzaken voor de aanwezigheid van handhavingstekorten op diverse beleidsterreinen.

12 Dat er sprake is van een handhavingstekort lijkt het in het algemeen heersende beeld te zijn. Door bepaalde auteurs is er echter op gewezen dat het daadwerkelijke bestaan van een handhavingstekort, althans empirisch, niet expliciet is aangetoond. Vgl. G.J.M. Corstens, Een stille revolutie in het strafrecht (Afscheidsrede Nijmegen 1995), Gouda Quint bv, Arnhem 1995, p. 13-14, G.J.M. Corstens, Bestuurlijke boeten, in het bijzonder in het financiele recht, SEW 2001, p. 242-247, i.h.b. p. 242, J.B.J.M. Ten Berge en F.C.M.A. Michiels, Besturen door de overheid, Deventer 2001, p. 388 en Quaedvlieg. a.w. 2001, p. 188-189.

Vgl. CTW-rapport p. 7.8 
Toetsingscommissie aan de eigen verantwoordelijkheid van bestuursorganen bij handhaving van bestuursrechtelijke regelgeving invulling te kunnen geven.

In genoemd CTW-rapport is door de Toetsingscommissie vervolgens een eerste aanzet gegeven tot een algemene bestuursrechtelijke boeteregeling. Een nadere uitwerking daarvan heeft in het bijzonder plaatsgevonden door de commissie Scheltema in het, in het najaar van 1999 gepresenteerde, Voorontwerp van de vierde tranche van de Awb. ${ }^{14}$ De door de commissie Scheltema voorgestelde regeling zal, indien deze wet wordt, dienen als algemeen kader voor alle in de bijzondere bestuursrechtelijke wetten aan bestuursorganen toegekende boetebevoegdheden.

\subsubsection{Karakter}

De bestuurlijke boete heeft primair bestraffing van de overtreder ten doel. De bestuurlijke boete is derhalve een punitieve sanctie. Een punitieve sanctie heeft in het bijzonder leedtoevoeging ten doel. ${ }^{15}$ Het punitieve karakter van de bestuurlijke boete speelt een belangrijke rol in dit boek.

Bestraffing door middel van leedtoevoeging is (van oudsher) een typisch strafrechtelijk sanctiedoel. Met het oog daarop kan dan ook de vraag worden opgeworpen of, bij de oplegging van een bestuurlijke boete, niet bepaalde straf(proces)rechtelijke waarborgen in acht zouden moeten worden genomen door de sanctieoplegger. Aan deze, met de centrale probleemstelling verband houdende, vraag zal in dit boek uitvoerig aandacht worden besteed.

\subsection{Nadere uitwerking probleemstelling}

In het kader van de vorige paragraaf kwamen al enkele vragen naar voren die relevant lijken met het oog op het centrale onderwerp van dit boek: de bestuurlijke boete. Zo is hiervoor aangegeven dat de vraag naar de mate waarin rechtsbescherming zou moeten worden geboden in het kader van een procedure tot oplegging van bestuurlijke boeten een belangrijke rol speelt. Voorts is, onder meer, met het oog op het karakter van de bestuurlijke boete, de vraag gesteld of, bij de oplegging van de bestuurlijke boete, strafrechtelijke regels en beginselen (zouden moeten) gelden. Er is immers sprake van een punitieve sanctie. Onlosmakelijk daarmee verbonden is de vraag of het bestuurs(proces)recht, al dan niet onverkort, kan worden toegepast. Uit het voorgaande volgt dat met name de rechtsbescherming van de vermoedelijke overtreder een belangrijke rol speelt in het kader van dit onderzoek.

\subsubsection{Centrale onderzoeksvraag}

Centraal in dit boek staat de vraag of er voldoende rechtsbescherming geboden wordt aan vermoedelijke overtreders van bestuursrechtelijke voorschriften in het bestuursstrafrecht, en dan in het bijzonder bij de oplegging van bestuurlijke boeten. In dat ka-

I4 Zoals hiervoor reeds is aangegeven zijn er in de tussentijd reeds in verscheidene bijzondere bestuursrechtelijke wetten mogelijkheden opgenomen tot oplegging van bestuurlijke boeten.

15 In hoofdstuk twee zal uitvoeriger ingegaan worden op de term 'punitieve sanctie'. Ook zal daar aangegeven worden wanneer er sprake is van leedtoevoeging. 
der gaat (vanzelfsprekend) aandacht uit naar de vraag in welke mate (aan de vermoedelijke overtreder) rechtsbescherming geboden wordt bij de oplegging van bestuurlijke boeten. Daamaast is de vraag relevant in welke mate rechtsbescherming geboden zou moeten worden bij de oplegging van bestuurlijke boeten. Met andere woorden; welke (fundamentele) (straf(proces)rechtelijke) waarborgen, regels en beginselen zouden (in ieder geval) in acht moeten worden genomen bij de oplegging van bestuurlijke boeten? Een andere deelvraag die in dat kader naar voren komt, zo volgt reeds uit het voorgaande, is tot welk rechtsgebied (bestuursrecht of strafrecht) de bestuurlijke boete vanuit materieelrechtelijk oogpunt gerekend zou moeten worden. Deze laatste vraag speelt immers een rol bij het bepalen van de aard en omvang van de rechtsbescherming. Moet de oplegging van een bestuurlijke boete tot het strafrecht (in ruime zin) worden gerekend dan dienen immers (de essentiële) straf(proces)rechtelijke waarborgen, regels en beginselen in het kader van de rechtsbescherming van de vermoedelijke overtreder in acht genomen te worden. Dit zou anders zijn indien de oplegging van een bestuurlijke boete van (zuiver) bestuursrechtelijke aard is.

\subsubsection{Rechtsbescherming}

Aangezien de vraag centraal staat of voldoende rechtsbescherming geboden wordt in het bestuursstrafrecht dient in dit kader kort stil te worden gestaan bij de term 'rechtsbescherming'. Wat immers, dient verstaan te worden onder 'rechtsbescherming'?

Het geven van een definitie van de term rechtsbescherming in de context van het bestuursstrafrecht is geen eenvoudige opgave. Dit heeft onder meer te maken met het feit dat aan de term rechtsbescherming in de strafrechtelijke context een andere invulling wordt gegeven dan in de bestuursrechtelijke context. ${ }^{16}$ Desalniettemin zal een poging worden ondemomen. Voordat een definitie gegeven wordt van rechtsbescherming in bestuursstrafrechtelijke context zal kort aandacht worden besteed aan de bestuursrechtelijke en de strafrechtelijke interpretatie van het begrip.

\subsection{2.a Rechtsbescherming in bestuursrechtelijke context}

Rechtsbescherming in het bestuursrecht lijkt in het bijzonder te zien op 'rechtsbescherming (van de burger) tegen de overheid'. ${ }^{17}$ De Haan, Drupsteen en Fernhout koppelen de term 'rechtsbescherming' aan de meeromvattende waarborgfunctie van het (algemeen) bestuursrecht. ${ }^{18}$ Onder rechtsbescherming lijken zij te verstaan: 'mogelijkheden

16 Vgl. Van Russen Groen a.w. 1998, p. 18-27.

17 Vgl. F.H. van der Burg, G.J.M. Cartingy en G. Overkleeft-Verburg, Rechtsbescherming tegen de overheid, vijfde herziene druk, Nijmegen 1985, p. 2, J.B.J.M. ten Berge en A.Q.C. Tak, Hoofulijnen van het Nederlands administratief procesrecht, tweede herziene druk, Zwolle 1990, p. 3, P. de Haan, Th. G. Drupsteen, en R. Fernhout, Bestuursrecht in de sociale rechtsstaal, Deel I, organisatie, ontwikkeling, instrumentarium, vijfde, geheel herziene druk, Kluwer, Deventer 2001, p. 31-32 en p. 52, H.D. van Wijk/W. Konijnenbelt en R.M. van Male, Hoofdstukken van bestuursrecht, elfde druk, Elsevier Bedrijfsinformatie B.V., Den Haag 1999. i.h.b. p. 531 (Van Wijk c.s. spreken van 'rechtsbescherming tegen het bestuur') en J.B.J.M. ten Berge en R.J.G.M. Widdershoven, Bescherming tegen de overheid, zesde druk, W.E.J. Tjeenk Willink, Deventer 2001, o.m. p. 9.

$18 \mathrm{Vgl}$. De Haan/Drupsteen/Femhout a.w. 2001, p. 52. De rechtsbescherming vormt in dat kader een waarborg achteraf. D.w.z. nadat de bestuursbeslissing is genomen (VgI. P. de Haan, Th. G. Drupsteen, en R. Fernhout, Bestuursrecht in de sociale rechtsstaat, Deel II, Bestuurshandelingen en waarborgen, vierde, geheel herziene druk, KJuwer, Deventer 1998, p. 267). 
van bezwaar en beroep en het recht op schadevergoeding bij rechtmatig of onrechtmatig overheidshandelen. ${ }^{19}$ In Van Wijk, Konijnenbelt en Van Male wordt de volgende definitie gegeven van 'rechtsbescherming': 'Rechtsbescherming tegen het bestuur is gericht op het bindend vaststellen van de inhoud van een bestuursrechtelijke rechtsbetrekking, alsook op het naleven en handhaven ervan. ${ }^{20}$ Genoemde rechtsbescherming wordt volgens laatstgenoemde auteurs niet alleen geboden door rechterlijke instanties maar ook door het bestuur. ${ }^{21}$ De opvattingen van De Haan, Drupsteen en Fernhout en Van Wijk, Konijnenbelt en Van Male komen mijns inziens in essentie op hetzelfde neer. Het voorgaande geldt eveneens voor de wijze waarop Ten Berge en Widdershoven het begrip 'rechtsbescherming' bezigen. ${ }^{22}$

Ook in de wat oudere bestuursrechtelijke werken lijkt van een vergelijkbare definitie van de term rechtsbescherming uit te worden gegaan. Van der Burg, Cartingy en Overkleeft-Verburg schrijven: 'Onder het hoofd 'rechtsbescherming' komen ter sprake de mogelijkheden die het Nederlandse recht biedt om klachten omtrent overheidsoptreden voor te leggen aan rechterlijke of administratieve instanties die bevoegd zijn beslissingen te nemen waarmede de grieven geheel of gedeeltelijk kunnen worden weggenomen bijvoorbeeld door de formele constatering dat de overheid onjuist gehandeld heeft of door toekenning van een schadevergoeding. ${ }^{.23}$ Opvallend is dat in de hiervoor aangehaalde bestuursrechtelijke (standaard)werken ook de bestuursrechtelijke voorziening van bezwaar en administratief beroep tot de rechtsbescherming tegen de overheid worden gerekend.

Het voorgaande leidt tot de volgende slotsom. In het bestuursrecht kan onder 'rechtsbescherming' worden verstaan: 'Het aanwenden van rechtsmiddelen door belanghebbenden teneinde de (on)rechtmatigheid van een bepaald overheidshandelen op bindende wijze vast te laten stellen.' Zoals gezegd vallen, volgens de hierboven aangehaalde auteurs, niet alleen het beroep en hoger beroep bij de bestuursrechter onder deze rechtsmiddelen. Daarnaast dient ook het bezwaar en het administratief beroep aangemerkt te worden als rechtsmiddel. Men kan zich echter afvragen in hoeverre door middel van deze bestuursrechtelijke voorzieningen daadwerkelijk rechtsbescherming kan en zal worden geboden. Met name in het kader van de bezwaarschriftprocedure, die moet worden gevolgd bij het bestuursorgaan dat het aangevochten besluit heeft genomen, lijkt deze vraag gerechtvaardigd te zijn. ${ }^{24}$

19 Vgl. De Haan/Drupsteen/Fernhout a.w. 2001, p. 52.

20 Van Wijk/Konijnenbelt/Van Male a.w. 1999, p. 531.

21 Van Wijk/Konijnenbelt/Van Male a.w. 1999, p. 533.

22 Ten Berge/Widdershoven a.w. 2001, p. 6.

23 Van der Burg/Cartingy/Overkleeft-Verburg a.w. 1985, p. 1.

24 Aangezien het bestuursorgaan in de bezwaarschriftprocedure niet als onpartijdige instantie kan worden gezien kan mijns inziens in bezwaar niet op een juiste wijze invulling worden gegeven aan de rechtsbeschermingsidee. Rechtsbescherming wordt in het bestuursrecht immers opgevat als rechtsbescherming tegen de overheid. Een bestuursorgaan zal in de bezwaarschriftfase echter proberen het (eigen) besluit te 'redden'. Dit streven zal voorop staan. De belangen van de appellerende burger lijken in dat kader door het bestuursorgaan al snel als een belemmering gezien te worden. De bezwaarschriftprocedure kan mijns inziens dan ook hooguit worden gezien als een vorm van 'pseudo rechtsbescherming'. Vgl. A.Q.C. Tak, De Algemene wet bestuursrecht, Zwolle 1992, p. 18, A.Q.C. Tak, Het moment X, TvO 1990/6, p. 134 ev. en zeer recent A.Q.C. Tak, Het Nederlandse bestuursprocesrecht in theorie en praktijk, deel I, 's-Gravenhage 2002, p. 25 ev. Tak geeft overigens aan dat naar zijn mening zelfs de term 'oneigenlijke rechtsbescherming' in het kader van bezwaar en administratief beroep strikt genomen 


\subsection{2.b Rechtsbescherming in strafrechtelijke context}

Anders dan in de bestuursrechtelijke standaardwerken is in de straf(proces)rechtelijke standaardwerken gén definitie van de term 'rechtsbescherming' aan te treffen. Over rechtsbescherming lijkt in het strafrecht slechts in ruime zin iets gezegd te kunnen worden. 'Rechtsbescherming in het strafrecht betekent in zijn algemeenheid bescherming van de burger tegen inbreuken op zijn rechten en vrijheden door de overheid', zo schrijft Wiewel. ${ }^{25}$ Deze ruime en vage omschrijving van rechtsbescherming in de strafrechtelijke context lijkt voort te vloeien uit de ambivalentie van het straf(proces)recht. In het strafproces gaat het er om de strafwet op efficiënte wijze toe te passen op schuldigen en de toepassing van genoemde wet op onschuldigen te verhinderen. Wil de strafrechter in het strafrecht gebruik kunnen maken van zijn bevoegdheid om sancties op te leggen, dan zullen in het kader van die sanctionering bevoegdheden moeten worden toegekend aan functionarissen die belast zijn met de opsporing en vervolging van strafbare feiten en - in bescheiden mate - aan burgers. ${ }^{26}$

$\mathrm{Bij}$ het toekennen van die bevoegdheden moet er voor gewaakt worden dat de uitoefening van die bevoegdheden niet leidt tot inbreuken op de rechten en vrijheden van een verdachte die verder gaan dan noodzakelijk is in het kader van toepassing van de strafwet.

Corstens schrijft daarover:

'Strafprocessuele bevoegdheden zijn geen blanco cheques die door de wetgever zijn afgegeven. Ze zijn steeds geclausuleerd, bijv. door de bevoegdheid alleen aan bepaalde functionarissen toe te kennen, deze alleen in bepaalde gevallen te laten hanteren, de grond waarop ze mogen worden gebruikt aan te geven, deze aan bepaalde termijnen te binden. De bevoegdheidstoedeling gaat steeds gepaard met beperkingen. Daarmee is de ambivalentie van het strafproces aangetoond. Enerzijds legitimeert het de overheid op een bepaalde, vaak voor de betrokkenen bezwarende wijze op te treden. Anderzijds worden tegelijk grenzen aangegeven waaraan de hanteerders van de bevoegdheid zich hebben te houden. ${ }^{27}$

In het kader van een goede strafvordering worden derhalve tot op zekere hoogte inbreuken op bepaalde fundamentele burgerlijke rechten en vrijheden toegestaan. De bevoegdheid tot het maken van inbreuken op genoemde vrijheden gedurende de fase van opsporing en vervolging is echter geclausuleerd in de wet (bijvoorbeeld in de Wetboeken Strafrecht en Strafvordering). Hiermee wordt invulling gegeven aan de rechtsbeschermingsidee. Daamaast wordt in het strafrecht rechtsbescherming geboden door een onafhankelijke en onpartijdige rechter die bij uitsluiting bevoegd is tot het opleggen van straffen (aan een schuldig bevonden verdachte) ${ }^{28}$ De strafrechter beschikt in dat kader over ruime bevoegdheden die mede ten doel hebben 'ongelijkheidscompen-

misplaatst is. Vgl. Tak a.w. 2002 , p. 25.

25 Wiewel a.w. 2001, p. 14.

26 G.J.M. Corstens, het Nederlands strafprocesrecht, derde druk, Gouda Quint, Deventer 1999 , p. 5.

27 Corstens aw. 1999 , p. 6 . 't Hart wijst ook op genoemde ambivalentie. Hij beschouwt de rechtsbescherming in het strafrecht als noodzakelijke, in het recht ingebouwde, tegenhanger van het 'instrumentalisme'. Vgl. A.C. 't Hart, Openbaar Ministerie en rechtshandhaving, Gouda Quint, Amhem 1994, p. 202-232 en 235-265 en R. Foqué en A.C. 't Hart, Instrumentaliteit en rechtsbescherming, Amhem/Antwerpen 1990, p. 13-30.

28 Uiteraard dient niet uil het oog te worden verloren dat in het strafrecht veel lichte overtredingen buitengerechtelijk kunnen worden afgedaan (bijv. door middel van een transactie). 
satie' te bieden aan de verdachte. Tegen de uitspraak van de strafrechter staat vervolgens nog hoger beroep open. Ook daarmee wordt de rechtsbescherming van de verdachte gediend.

Van Russen Groen komt met betrekking tot de term rechtsbescherming in strafrechtelijke context, mede met het oog op het voorgaande, tot de volgende definitie:

'In het strafrecht is rechtsbescherming in de zin van bescherming tegen strafrechtelijk optreden van de overheid niet beperkt tot mogelijkheden van bezwaar, verzet of beroep. Als men het heeft over rechtsbescherming in het strafrecht dan doelt men doorgaans op de talloze waarborgen die het proces biedt en die zijn gecodificeerd in de Wetboeken van Strafrecht en Strafvordering (en in bijzondere strafwetten) en op het feit dat alle strafbare feiten zijn omschreven in het materiële strafrecht. ${ }^{29}$

De hiervoor beschreven aspecten van rechtsbescherming in strafrechtelijke context zien volgens Van Russen Groen slechts op één kant van de rechtsbescherming. Namelijk de rechtsbescherming die de verdachte geniet in het kader van de opsporing, vervolging en bestraffing. Daarnaast kent het strafrecht nog een ander rechtsbeschermingsperspectief. In dat geval gaat het om de rechtsbescherming die het strafrecht beoogt te bieden aan de samenleving door (de van) de samenleving (deel uit makende burgers) te beschermen tegen criminaliteit. ${ }^{30} \mathrm{Ik}$ vraag me af of in dit kader gesproken moet worden van rechtsbescherming. Van Russen Groen beschrijft hier mijns inziens het 'instrumentele aspect' van het strafrecht. Dit ziet met name op effectieve en doelmatige handhaving van de strafwet. Criminaliteitsbestrijding (crime control) staat daarbij voorop. 't Hart spreekt in dit kader van 'rechtshandhaving'. Hij maakt een onderscheid tussen rechtshandhaving en rechtsbescherming. Rechtshandhaving wordt volgens 't Hart veelal gezien als overheidsoptreden tegen verdachten. $\mathrm{Bij}$ rechtsbescherming gaat het om bescherming van de verdachte tegen de overheid. ${ }^{31}$ 't Hart geeft aan dat rechtshandhaving en rechtsbescherming niet los van elkaar kunnen worden gezien. Zij vormen 'twee kanten van dezelfde medaille ${ }^{, 32}$ :

'Handhaving van het recht (de rechtsorde) is immers ook altijd handhaving van de rechten van een verdachte - hoe zou het ook anders kunnen! - en individuele rechtsbescherming is ook altijd (juist door het in stand houden van een rechtsorde) bescherming van alle individuen, zowel van verdachten als van andere burgers zoals slachtoffers. ${ }^{33}$

In dit boek zal rechtsbescherming in de strafrechtelijke context opgevat worden als bescherming van de verdachte tegen de overheid. De term rechtsbescherming omvat daarmee in het strafrecht meer dan het bestuursrecht. Bescherming van de verdachte tegen de overheid krijgt immers niet alleen gestalte middels de mogelijkheid van verzet, bezwaar of beroep, ofwel; 'het aanwenden van rechtsmiddelen door belanghebbenden teneinde de (on)rechtmatigheid van een bepaald overheidshandelen op bindende wijze vast te laten stellen'. Bestudering van strafrechtelijke en bestuursrechtelijke re-

29 Van Russen Groen a.w. 1998, p. 23.

30 Vgl. Van Russen Groen a.w. 1998, p. 21.

31 A.C. 't Hart, Hier gelden wetten! Over strafrecht, Openbaar Ministerie en multiculturalisme, Leiden 2001, p. 39.

32 't Hart a.w. 2001, p. 38-39 en 43.

33 't Hart a.w. 2001, p. 38-39. 
gelgeving leidt voorts tot de conclusie dat in de strafrechtelijke regelgeving de rechtsbescherming van de verdachte (zeker in het kader van de opsporing en vervolging) uitvoeriger en nauwgezetter is geregeld. ${ }^{34}$

\subsection{2.c Rechtsbescherming in bestursstrafrechtelijke context}

Zoals gezegd omvat de term rechtsbescherming in het strafrecht meer dan in het bestuursrecht. Voorts lijken de uitgangspunten van de wetgever bij het bieden van rechtsbescherming (middels wettelijke regeling) uiteenlopend te zijn. Zou men zowel in het kader van bestuursrechtelijke als strafrechtelijke rechtsbescherming ${ }^{35}$ kunnen spreken van rechtsbescherming tegen de overheid, wat betreft de aard en de omvang van de rechtsbescherming lijken er duidelijk verschillen te zijn.

In het kader van het strafrecht is er duidelijk het bewustzijn dat de verdachte (zoveel mogelijk) beschermd moet worden tegen inbreuken op zijn (fundamentele) rechten en vrijheden door de overheid. Voorts dient de rechtsbescherming in strafrechtelijke context er toe te leiden dat alleen schuldigen gestraft worden. Anderzijds moet de overheid (waaronder het $\mathrm{OM}$ ) over voldoende bevoegdheden beschikking om de strafwet op effectieve wijze te kunnen handhaven.

In die zin is er, zoals Corstens stelt, in het kader van het strafrecht, sprake van een zekere ambivalentie. Enerzijds dient de overheid (in het bijzonder het OM) te beschikken over voldoende (ruime) bevoegdheden en middelen om de schuldige verdachte te kunnen vervolgen. Anderzijds dient de verdachte in het kader van de opsporing en vervolging voldoende rechtsbescherming te genieten zodat er geen sprake is van (ongebreidelde) inbreuken op diens (fundamentele) rechten en vrijheden.

In de bestuursrechtelijke context lijkt rechtsbescherming te worden gezien als het aanwenden van rechtsmiddelen door belanghebbenden teneinde de (on)rechtmatigheid van een bepaald overheidshandelen op bindende wijze vast te laten stellen. Aan de vraag of en in hoeverre door dergelijk overheidshandelen een inbreuk op (fundamentele) rechten en vrijheden van de burger wordt gemaakt wordt in de bestuursrechtelijke context (in ieder geval op expliciete wijze) in mindere mate aandacht besteed. ${ }^{36}$ Desalniettemin zal ook in het bestuursrecht de bescherming van de burger tegen (ongebreidelde) inbreuken op (fundamentele) rechten en vrijheden van de burger een wezenlijke rol spelen bij het bieden van rechtsbescherming. Rechtsbescherming wordt in het bestuursrecht, zoals gezegd, met name opgevat als het (uiteindelijk) bij een rechterlijke instantie kunnen ageren tegen overheidshandelen.

In het kader van dit onderzoek staat de rechtsbescherming in het bestuursstrafrecht centraal. De vraag is hoe de term rechtsbescherming in deze context opgevat zou moeten worden. Aangezien het bestuursstrafrecht mijns inziens niet zonder meer als be-

In hoofdstuk vier en het slotdeel zal op dit aspect nog uitvoerig worden ingegaan.

Voor zover het de rechtsbescherming van de verdachte betreft.

36 Hoewel uiteraard ook in het kader van bestuursrechtelijke geschillen vrijwel altijd (fundamentele) rechten en vrijheden een rol zullen spelen. Gewezen kan worden op de beperking van het eigendomsrecht doordat voor het verrichten van bepaalde activiteiten door een burger op grond die bij hem in eigendom is toestemming van overheidswege nodig is (bijv. d.m.v. een bouwvergunning of een milieuvergunning). 
stuursrecht gekwalificeerd kan worden ${ }^{37}$ lijkt aansluiting bij de bestuursrechtelijke definitie van rechtsbescherming niet voor de hand te liggen. Eerder nog, zou, gelet op het punitieve karakter van bestuursrechtelijke sancties zoals de bestuurlijke boete, in het kader van het bestuursstrafrecht aansluiting gezocht moeten worden bij de strafrechtelijke interpretatie van de term rechtsbescherming.

Van Russen Groen, die ook lijkt te worstelen met dit probleem, komt met de volgende, nogal ruime, definitie: '... de bescherming van subjectieve belangen van burgers én van objectieve rechtsstatelijke belangen door rechtsregels. ${ }^{38}$ De voorkeur van Wiewel gaat uit naar een uitvoeriger definitie. Hij probeert daarbij zowel de bestuursrechtelijke als de strafrechtelijke opvatting met betrekking tot de term rechtsbescherming weer te geven. Wiewel komt met de volgende definitie:

'Rechtsbescherming is een mogelijkheid om een geschil over de inhoud van de rechtsbetrekking te beslechten, zowel als die rechtsbetrekking bestaat in onderzoek naar aanleiding van een verdenking als wanneer die rechtsbetrekking bestaat in het opleggen van een straf. Inhoudelijk is deze voorziening te omschrijven als het tot gelding brengen van de in het recht besloten liggende beperkingen met betrekking tot het maken van inbreuken op rechten en vrijheden van burgers, waaronder begrepen het opleggen van straffen. ${ }^{39}$

De definitie van Wiewel maak ik niet tot de mijne. Met name de eerste volzin werkt mijns inziens niet bepaald verhelderend.

Ik kom tot de volgende slotsom. Bescherming van de burger tegen (ongebreidelde) inbreuken op diens (fundamentele) rechten en vrijheden door de overheid staat zowel in het kader van het bestuursrecht als in het kader van het strafrecht centraal. Middels rechtsregels, neergelegd in internationale Verdragen, de Grondwet en wetten (in formele zin), wordt deze bescherming primair geboden. ${ }^{40}$ Gelet op het zowel in het strafrecht als in het bestuursrecht geldende legaliteitsbeginsel dienen de bestuursorganen en het OM de hen (op grond van de wet) toekomende bevoegdheden uit te voeren conform de wet. Men zou in dat kader kunnen spreken van rechtsbescherming in ruime zin. Of de bestuursorganen in het bestuursrecht, en het $O M$ in het strafrecht, op een juiste wijze gebruik hebben gemaakt van de hen op grond van de wet toekomende bevoegdheden kan uiteindelijk door de rechter worden getoetst. Men zou in dat kader kunnen spreken van rechtsbescherming in enge zin. In het kader van het bestuursstrafrecht is daarbij voorts relevant dat onder rechtsbescherming in enge zin tevens moet worden begrepen de vaststelling door een onafhankelijke en onpartijdige rechter, die in dat kader beschikt over voldoende bevoegdheden, van de schuld van de verdachte.

Op basis van het voorgaande zou rechtsbescherming in het bestuursstrafrecht als volgt gedefinieerd kunnen worden:

Onder rechtsbescherming dient, in de context van het bestuursstrafrecht, te worden verstaan; bescherming, primair door verdragsrecht, de Grondwet en overige wetten (in

37 Later zal ik daar nog uitvoerig op terugkomen.

38 Van Russen Groen a.w. 1998, p. 25.

39 Wiewel a.w. 2001 , p. 15.

$40 \mathrm{Vgl}$. De Haan/Drupsteen/Femhout aw. 2001, p. 52. Zij geven aan dat de gebondenheid van het bestuur aan het recht gezien kan worden als de primaire waarborgfunctie van het recht. 
formele zin) en secundair door een tot finale geschilbeslechting bevoegde rechter, van de burger tegen (ongebreidelde) inbreuken op diens (fundamentele) rechten en vrijheden door de overheid.

Ik ben me er van bewust dat dergelijke formele en abstracte definities eerst verhelderend werken als er een concrete invulling aan wordt gegeven door bijvoorbeeld bepaalde (straf(proces)rechtelijke) waarborgen op te sommen die relevant zijn in het kader van de rechtsbescherming bij de oplegging van bestuurlijke boeten. In de hierna volgende hoofdstukken zal dat uiteraard gebeuren.

Ten slotte dient opgemerkt te worden dat de hierboven weergeven probleemstelling zowel ziet op rechtsbescherming in ruime als in enge zin. Bij de rechtsbescherming in ruime zin gaat het met name om de vraag of de bevoegdheden van bestuursorganen in het kader van de oplegging van bestuurlijke boeten in voldoende mate geclausuleerd zijn zodat zij geen onevenredige, niet met het doel van de toegekende bevoegdheid overeenstemmende, inbreuken op fundamentele rechten en vrijheden van burgers tot gevolg hebben. In het kader van de rechtsbescherming in enge zin zal in het bijzonder aandacht uitgaan naar het procesrecht. Ten eerste staat daarbij de vraag centraal of de bestuursrechter, op basis van het bestuursprocesrecht en de bijzondere bepalingen uit de (voorgestelde) boeteregeling, voldoende bevoegdheden heeft om een (objectief) oordeel te vormen over de schuld van de verdachte. Daarnaast gaat aandacht uit naar de vraag of de bestuursrechter voldoende procesrechtelijke bevoegdheden heeft in het kader van de bestraffing van de schuldig bevonden verdachte.

\subsection{Behandelplan}

Dit boek bestaat uit drie delen. Deel I ziet met name op de regeling tot oplegging van bestuurlijke boeten zoals deze in Nederland gestalte heeft gekregen. Genoemd deel bestaat uit een drietal hoofdstukken.

Deel II ziet op de Amerikaanse regeling inzake bestuurlijke boeten en bestaat uit vier hoofdstukken. De Amerikaanse boeteregeling is bestudeerd in het kader van externe rechtsvergelijking. In dit boek is gekozen voor rechtsvergelijking met de Verenigde Staten vanwege een aantal redenen. De keuze voor rechtsvergelijking met de Verenigde Staten, in de plaats van bijvoorbeeld Duitsland, Frankrijk of Engeland lag met name voor de hand omdat grotere verschillen tussen de te bestuderen Nederlandse en Amerikaanse boeteregeling te verwachten waren vanwege het feit dat de Verenigde Staten, anders dan genoemde West-Europese landen, geen partij zijn bij het EVRM. Voorts is gekozen voor de Verenigde Staten vanwege het common-law stelsel. In het commonlaw stelsel is de traditionele scheiding tussen privaatrecht en publiekrecht, die in de meeste continentale stelsels sedert de Franse revolutie scherp is waar te nemen, immers diffuus. ${ }^{41}$ Tenslotte heeft de toegankelijkheid van Amerikaanse rechtspraak en regelgeving bij die keuze een rol gespeeld.

41 Ter illustratie kan gewezen worden op de benaming van de bestuurlijke boete in de Verenigde Staten. Men spreekt van 'the administrative assessment of a civil penalty'. Voorts kent men in de Verenigde Staten wettelijke regelingen op grond waarvan een bestuursorgaan (en soms zelfs een burger) de rech- 
$\mathrm{Na}$ het extern-rechtsvergelijkende tweede deel volgt tenslotte deel III. In dit deel zal worden aangegeven of er (op basis van de in het Voorontwerp van de vierde tranche van de Awb voorgestelde regeling) in voldoende mate rechtsbescherming geboden wordt/kan worden, bij de oplegging van bestuurlijke boeten (en andere punitieve sancties) in Nederland. Voorzover de geboden rechtsbescherming gebreken vertoont zal in deel III gepoogd worden de (Awb-)wetgever suggesties aan de hand te doen ter verbetering van de rechtsbeschermingspositie van de vermoedelijke overtreder in het kader van de oplegging van bestuurlijke boeten (en andere punitieve administratieve sancties).

\subsubsection{Deel I}

Alvorens over gegaan kan worden tot beantwoording van de vraag of voldoende rechtsbescherming geboden wordt in het bestuursstrafrecht, in het bijzonder bij de oplegging van bestuurlijke boeten, dient vastgesteld te worden tot welk rechtsgebied (bestuursrecht of strafrecht?) de oplegging van bestuurlijke boeten, in materieel opzicht, gerekend moet worden. Met het oog daarop zal in hoofdstuk twee een algemeen (theoretisch en rechtshistorisch) kader worden geschetst waarbij de aard en de opkomst van de bestuurlijke boete centraal staan. Daarnaast zal de oplegging van bestuurlijke boeten vergeleken worden met strafrechtelijke sanctionering enerzijds en de oplegging van andere bestuursrechtelijke sancties anderzijds. Ook zal daarbij aandacht uitgaan naar de vraag welke normschendingen zich in het bijzonder lenen voor sanctionering door middel van bestuurlijke boeten.

In het kader van de beantwoording van de vraag tot welk rechtsgebied de oplegging van bestuurlijke boeten, in materieel opzicht, gerekend moet worden is voorts de, in hoofdstuk drie van dit boek te bespreken, rechtspraak van het Europese Hof voor de Rechten van de Mens (EHRM) relevant. In het bijzonder de jurisprudentie over het 'criminal charge'-begrip speelt wat dat betreft een rol van betekenis. Genoemde rechtspraak legt in Nederland veel gewicht in de schaal in het kader van de ontwikkeling van de rechtsbescherming in de bestuurlijke 'boetesfeer'. Aangezien er, op basis van relevante rechtspraak van het $\mathrm{EHRM}^{42}$, van uit kan worden gegaan dat de oplegging van een bestuurlijke boete aangemerkt moet worden als 'criminal charge' in de zin van artikel 6 van het Europees Verdrag tot bescherming van de Rechten van de Mens (EVRM) dienen de uit artikel 6 EVRM voortvloeiende (straf(proces)rechtelijke) waarborgen in acht genomen te worden. Daarnaast moet rekening gehouden worden met artikel 7 EVRM. Bovendien zal de nationale boeteregeling ook in overeenstemming moeten zijn met de eisen die voortvloeien uit de artikelen 14 en 15 van het Internatio-

ter kan verzoeken via een civiele procedure (civil action) een boete op te leggen wegens overtreding van een bestuursrechtelijke regeling of een bestuursrechtelijk voorschrift. Tenslotte kan gewezen worden op het feit dat bestuursorganen de naleving van hun besluiten slechts af kunnen dwingen via een civiele procedure.

42 Zie de zaak Özturk, EHRM 21 februari 1984, Series A, Vol. 73, NJ 1988, 937 m. nt. E.A. Alkema, en Engel and Others v, the Netherlands, EHRM 8 juni 1976, Series A vol. 22, NJ 1978, 223. 
naal Verdrag inzake Burgerrechten en Politieke Rechten (IVBPR), ${ }^{43}$ Zoals gezegd wordt een en ander in hoofdstuk drie uiteengezet.

Tenslotte zal in het laatste hoofdstuk van deel I (hoofdstuk vier) de procedure tot oplegging van bestuurlijke boeten, zoals die in Nederland gestalte heeft gekregen, dan wel lijkt te krijgen, aan de orde komen. De juridische normering van procedures tot het opleggen van een bestuurlijke boete en de rechtsbescherming van de (vermoedelijke) overtreder in dat kader zullen daarbij centraal staan. De boeteregeling zoals die is voorgesteld door de commissie Scheltema in het Voorontwerp van de vierde tranche van de Awb zal hierbij als uitgangspunt dienen. De door genoemde commissie voorgestelde boeteregeling kan immers worden gezien als een algemene regeling waarin de meeste, zo niet alle, aspecten van reeds bestaande bestuurlijke boeteregelingen zijn neergelegd. $\mathrm{Na}$ inwerkingtreding van de vierde tranche zullen bovendien de algemene bepalingen die in de bijzondere wetten zijn opgenomen, met betrekking tot de oplegging van bestuurlijke boeten, in de regel verdwijnen.

In hoofdstuk vier zal de voorgestelde boeteregeling worden beschreven en bekeken in het licht van de (onder meer, uit artikel 6 en 7 EVRM en 14 en 15 IVBPR, voortvloeiende) fundamentele straf(proces)rechtelijke waarborgen. Ten eerste zal aangegeven worden of er door de commissie Scheltema in het Voorontwerp in voldoende mate rekening is gehouden met de essentiële straf(proces)rechtelijke waarborgen, waaronder de, in hoofdstuk drie van dit boek nader geanalyseerde, verdragsrechtelijke waarborgen. Daarbij zal met name aandacht uitgaan naar die (verdragsrechtelijke) waarborgen waaraan in onvoldoende mate invulling lijkt te zijn gegeven door genoemde commissie. Daarnaast zal in hoofdstuk vier aandacht geschonken worden aan de vraag of op basis van het bestuursprocesrecht, met het oog op de rechtsbescherming van de vermoedelijke overtreder, op een juiste wijze invulling gegeven kan worden aan de oplegging van punitieve bestuursrechtelijke sancties, in het bijzonder bestuurlijke boeten.

\subsubsection{Deel II}

In deel II staat handhaving door middel van bestuurlijke boeten in de Verenigde Staten centraal. Deel II bestaat, zoals gezegd, uit een viertal hoofdstukken. In hoofdstuk vijf zal eerst aandacht uitgaan naar het Amerikaanse bestuursrecht in het algemeen. Vervolgens komt, in hoofdstuk zes, de wijze van oplegging van de bestuurlijke boete in Amerika aan bod. Daarbij gaat tevens aandacht uit naar de waarborgen die in dat kader op grond van de boeteregeling in acht genomen moeten worden bij de oplegging van bestuurlijke boeten. Daarna wordt ingegaan op de vraag in hoeverre de constitutionele (straf(proces)rechtelijke) waarborgen bij de oplegging van bestuurlijke boeten in acht moeten worden genomen (hoofdstuk zeven). In hoofdstuk acht wordt vervolgens de balans opgemaakt. Daarbij zal met name ingegaan worden op de vraag in hoeverre oplegging van de bestuurlijke boete in de Verenigde Staten met essentiële (straf(proces)rechtelijke) waarborgen is omkleed. Daarmee kan tevens worden aangegeven in welke mate in de Verenigde Staten rechtsbescherming geboden wordt bij de opleg- 
ging van punitieve bestuursrechtelijke sancties, en dan in het bijzonder ten aanzien van bestuurlijke boeten.

Op basis van het onderzoek in deel II van dit boek zal in het slotdeel (deel III) worden aangegeven in hoeverre de Nederlandse wetgever daar lering uit kan trekken.

\subsubsection{Deel III}

In deel III gaat aandacht uit naar beantwoording van de vraag of er voldoende rechtsbescherming geboden wordt in het bestuursstrafrecht, en dan in het bijzonder bij de oplegging van bestuurlijke boeten. In dat kader zal ingegaan worden op de vraag in hoeverre de Nederlandse wetgever lering kan trekken uit de in deel II beschreven Amerikaanse boeteregeling. Tenslotte zal in deel III aangegeven worden op welke wijze eventuele gebreken in het kader van de rechtsbescherming van de (vermoedelijk) overtreder bij de oplegging van bestuurlijke boeten ondervangen zouden kunnen worden. Daartoe wordt een aantal (mogelijke) oplossingen aangedragen.

Zo zal onder meer een voorstel worden gedaan voor een aparte wettelijke regeling in het kader van het bestuursstrafrecht. Die aparte wettelijke regeling zou onder meer kunnen dienen als (procesrechtelijke) kader voor de oplegging van bestuurlijke boeten. Met het oog op de rechtsbescherming van de vermoedelijke overtreder gaat de voorkeur uit naar een dergelijke regeling. Ter bevordering van efficiënte en effectieve handhaving lijkt het voorts aanbevelenswaardig een nadere studie te verrichten naar het op grotere schaal invoeren van de bestuursrechtelijke transactie. De rechtsbescherming van de vermoedelijke overtreder moet dan echter wél gegarandeerd zijn. En tenslotte zou de (op bestuursrechtelijke leest geschoeide) OM-boete een aardig alternatief kunnen vormen voor de bestuurlijke boete. Het voordeel van de OM-boete is dat, bij het toekennen van de bevoegdheid tot oplegging van (bestuurlijke) boeten aan het OM, de regels uit de Wetboeken van Strafrecht en Strafvordering onverkort toegepast kunnen worden. Een nadere uitwerking van deze drie suggesties vindt plaats in deel III van dit boek. 


\section{Deel I}

\section{De bestuurlijke boete in Nederland}





\section{Hoofdstuk 2}

\section{De bestuurlijke boete in het algemeen}

\subsection{Inleiding}

In hoofdstuk twee van dit boek komt een aantal algemene onderwerpen met betrekking tot de bestuurlijke boete aan de orde. Allereerst zal kort aandacht worden besteed aan de vraag wat nu precies een bestuurlijke boete is. Voorts komt het onderscheid tussen de bestuurlijke boete en de strafrechtelijke boete aan de orde. Ook zal ingegaan worden op het verschil tussen de bestuurlijke boete en bepaalde andere bestuursrechtelijke sancties. Daarbij zal in het bijzonder aandacht uitgaan naar het onderscheid tussen punitieve en reparatoire bestuursrechtelijke sancties. 'Vervolgens wordt aangegeven in welke situaties gekozen wordt voor sanctionering door middel van een bestuurlijke boete in plaats van strafrechtelijke afdoening van een overtreding. In dit hoofdstuk zal slechts beknopt worden ingegaan op de waarborgen die dienen te gelden bij de oplegging van een bestuurlijke boete. Aan de waarborgen die bij de oplegging van bestuurlijke boeten in acht moeten worden genomen zal in hoofdstuk drie en vier nog uitvoerig aandacht worden besteed.

In dit hoofdstuk wordt het Nederlandse recht(stelsel) als uitgangspunt genomen. Voor wat betreft het onderscheid tussen punitieve en reparatoire sancties en beantwoording van de vraag in welke gevallen voor sanctionering door middel van de bestuurlijke boete kan worden gekozen zal in dit hoofdstuk ook (in beperkte mate) gebruik gemaakt worden van (met name) Duitse literatuur. De reden die daaraan ten grondslag ligt is dat in Duitsland reeds langere tijd bestuur(straf)rechtelijke leerstukken in ontwikkeling zijn. Zo schreef Goldschmidt reeds in 1902 zijn boek 'Das Verwaltungsstrafrecht ${ }^{2}$ waarin hij onderzoek heeft gedaan naar het grensgebied tussen het strafrecht en het bestuursrecht.

\subsection{De bestuurlijke boete en andere sancties}

\subsubsection{De bestuurlijke boete}

De bestuurlijke boete kan op verschillende wijzen worden gedefinieerd. Zo zou de bestuurlijke boete, volgens Michiels, kunnen worden omschreven als: 'een verplichting tot het betalen van een geldsom aan de overheid, welke verplichting door een bestuursorgaan, zonder tussenkomst van de rechter [curs. KA], kan worden opgelegd wegens overtreding van een bij of krachtens de wet gesteld voorschrift'. ${ }^{3}$ In het Voorontwerp van de vierde tranche van de $\mathrm{Awb}^{4}$ wordt de bestuurlijke boete in artikel 5.4.1.1 eerste

1 Zie in dit kader ook: C.L.G.F.H. Albers, 'Etikettenschwindel' in het administratieve sanctierecht?, NJB 2001, p. 1157-1 162. Een deel van dit hoofdstuk is gebaseerd op genoemde NJB-bijdrage.

2 J. Goldschmidt, Das Verwaltungsstrafrecht. Eine Untersuchung der Grenzgebiete zwischen Strafrecht und Verwaltungsrecht auf rechtsgeschichtlicher und rechtsvergleichender Grundlage, Berlin 1902.

3 F.C.M.A. Michiels, De boete in opmars?, W.E.J. Tjeenk Willink, Zwolle, 1994, p. 6.

4 Voorontwerp Algemene wet besturrsrecht vierde tranche, Commissie wetgeving algemene regels van 
lid als volgt gedefinieerd: 'Onder bestuurlijke boete wordt verstaan: de bestuurlijke sanctie, inhoudende een onvoorwaardelijke verplichting tot betaling van een geldsom, die gericht is op bestraffing van de overtreder. ${ }^{.5}$

In de uit 1994 daterende omschrijving van Michiels is het, voor de bestuurlijke boete karakteristieke, punitieve element niet uitdrukkelijk terug te vinden. De commissie Scheltema geeft in het Voorontwerp van de vierde tranche van de Awb wel uitdrukkelijk aan dat de bestuurlijke boete een bestraffende sanctie is. Kort gezegd gaat het bij de bestuurlijke boete om het door een bestuursorgaan opleggen van een bestraffende sanctie inhoudende de onvoorwaardelijke verplichting tot betaling van een geldsom.

In dit boek zal niet gepoogd worden aan de hand van de diverse reeds ontwikkelde definities tot een nieuwe omschrijving te komen. Hier zal worden uitgegaan van de definitie van de bestuurlijke boete, in samenhang met de definitie van de term bestuurlijke sanctie, zoals die in het Voorontwerp van de vierde tranche van de Awb zijn opgenomen. Lezing van artikel 5.4.1.1 in samenhang met artikel 5.0.2 van het Voorontwerp leidt dan tot de volgende definitie van de term bestuurlijke boete: 'een door een bestuursorgaan wegens een overtreding ${ }^{6}$ bij beschikking opgelegde onvoorwaardelijke verplichting tot betaling van een geldsom, die gericht is op bestraffing van de overtreder'.

Aan de hand van deze omschrijving van de bestuurlijke boete kan worden vastgesteld dat het bestuursorgaan zélf de boete oplegt nadat schending van een bepaalde norm is geconstateerd. De (bestuurs)rechter kan zich derhalve eerst een oordeel vormen omtrent de rechtmatigheid van de bestuurlijke boete nadat deze (door het bestuursorgaan) is opgelegd. ' Het hangt bovendien van het initiatief van de beboete (rechts)persoon af of de (bestuurs)rechter zich kan uitspreken omtrent de (rechtmatigheid van de) opgelegde bestuurlijke boete. Alleén als de overtreder aan wie een boete is opgelegd een bezwaarschrift indient en vervolgens in beroep gaat bij de bestuursrechter kan deze laatste een oordeel geven over de rechtmatigheid van de opgelegde bestuurlijke boete. De bestuurlijke boete onderscheidt zich op dit punt van de traditionele (strafrechtelijke) boete. Oplegging van een strafrechtelijke boete vindt immers plaats na een, met straf(proces)rechtelijke waarborgen omklede, gerechtelijke procedure door de (onafhankelijke en onpartijdige) strafrechter. ${ }^{8}$

bestuursrecht, Den Haag 7 september 1999, hiema: Voorontwerp.

5 In artikel 5.0.2 van het Voorontwerp wordt vervolgens aangegeven wat wordt verstaan onder een bestuurlijke sanctie: '-1. In deze wet wordt verstaan onder: a. bestuurlijke sanctie: een door een bestuursorgaan wegens en overtreding bij beschikking opgelegde verplichting of genomen maatregel;'

6 In artikel 5.0.1 van het Voorontwerp wordt een definitie gegeven van de term 'overtreding': - 1 . In deze wet wordt verstaan onder overtreding: een gedraging die in strijd is met het bepaalde bij of krachtens enig wettelijk voorschrift.'

7 Voorzover het gaat om oplegging van een bestuurlijke boete door een bestuursorgaan dient doorgaans eerst bezwaar te worden gemaakt bij het bestuursorgaan alvorens de bestuurlijke boete in beroep bij de bestuursrechter kan worden aangevochten (artikel 7:1 en 8:1 van de Awb). Zie hierover: F.A.M. Stroink, Kem van de bestuursrechtspraak, Elsevier bedrijfsinformatie bv, 's-Gravenhage 2000, hoofdstuk 6.

8 In de volgende paragraaf kom ik daar nog op terug. 


\subsubsection{Het verschil tussen de bestuurlijke en de strafrechtelijke boetc}

\subsubsection{Intermezzo - Plaats van het strafrecht ten opzichte van het bestuursricht -}

Zoals uit het bovenstaande reeds bleek bestaan er verschillen tussen de oplegging van een bestuurlijke boete en strafrechtelijke sanctionering. Los daarvan staat echter de vraag of het strafrecht deel uit maakt van het bestuursrecht of dat het een zelfstandige plaats inneemt binnen het recht. Vast staat dat het strafrecht deel uit maakt van het publiekrecht. ${ }^{9}$ Daarnaast kan de vraag gesteld worden of het strafrecht (in ieder geval ook voor een deel) deel uit maakt van het bestuursrecht. Concreet betekent dit dat de vraag gesteld zou kunnen worden of op strafvorderlijk handelen van de overheid nok bestuursrechtelijke normen van toepassing zijn. ${ }^{10}$ Een eenduidig antwoord op de vraag lijkt niet te geven te zijn.

Uit artikel 1:6 van de Awb zou afgeleid kunnen worden dat het strafrecht deel uit maakt van het bestuursrecht. In artikel 1:6 onder a Awb is namelijk bepaald dat de hoofdstukken 2 tot en met 8 en 10 van de Awb niet van toepassing zijn op de opsporing en vervolging van strafbare feiten, alsmede de tenuitvoerlegging van strafrechtelijke beslissingen. Deze expliciete uitzondering impliceert dat zonder het bestaan van artikel 1:6 Awb deze algemeen bestuursrechtelijke wet van toepassing zou zijn op strafrechtelijk gebied. In de Memorie van Toelichting wordt ten aanzien van artikel 1:6 van de Awb een soortgelijke redenering gevolgd:

'Zou deze uitzondering niet in de wet worden opgenomen. dan zouden ook de typisch in de sfeer van de strafvordering en de executie gelegen besluiten en handelingen van de betrokken bestuursorganen (de algemene en bijzondere opsporingsambtenaren, het upenbatar ministerie en de Minister van Justitie) onder het bereik van de wet vallen. Gelet op de eigenstandige positie van het (materiële en formele) strafrecht en op het feit dat de strafrechtelijke regelgeving uitputtend is bedoeld, zou dat tot ongewenste vermenging van rechtssferen leiden. ${ }^{1}$ '

Uit de hiervoor aangehaalde passage uit de Memorie van Toelichting kan echter niet zonder meer worden afgeleid dat het strafrecht ook (een vorm van bijzonder) bestuursrecht is. In de literatuur bestaan daaromtrent verschillende opvattingen. Er wordt een onderscheid gemaakt tussen de 'autonome zienswijze' en de 'heteronome zienswijze'. ${ }^{12}$

9 Zie L. Rogier en A. Hartmann, Verschillen en overeenkomsten tussen strafrecht en bestuursrecht, DD 1993, p. 1042-1058, p. 1043 en A.C. 't Hart, Straf, recht en waarden, in de bundel: Hoe punitief is Nederland?, onder redactie van M. Moerings, Amhem 1994, p. 31-44, i.h.b. p. 35. Zie voorts A. Mulder, in zijn VAR-preadvies, De verhouding van administratieve sancties en straffen, Geschriften van de vereniging voor administratiefrecht no. XXXVI, H.D. Tjeenk Willink \& Zoon N.V., Haarlem 1957, p. 45-85, i.h.b. p. 52 en 53.

10 Een andere vraag is natuurlijk of in het kader van de oplegging van (punitieve) administraticve sancties door een bestuursorgaan de straf(proces)rechtelijke regels (en beginselen) acht genomen moeten worden. Later in dit hoofdstuk zal ook naar die vraag aandacht uitgaan.

11 Zie PG Awb I, p. 162.

12 Zie hierover onder meer: A.R. Hartmann en P.M. van Russen Groen, Bestuursstrafrecht, in: Opstellen over bestuursstrafrecht, onder redactie van H. de Doelder en L.J.J. Rogier, SI-EUR-reeks, deel 3, Gouda Quint, Amhem 1994, p. 21 -59, i.h.b. p. 41 e.v. 
De 'autonome zienswijze' houdt (beknopt weergegeven) in dat aan het (materiële) strafrecht een zelfstandige plaats wordt toegekend. ${ }^{13}$ Door ' $t$ Hart wordt er op gewezen dat er voor gewaakt moet worden dat autonomie niet verward wordt met autarkie. ${ }^{14}$ Autarkie kan volgens 't Hart worden gedefinieerd als individualistische ('atomistische') zelfgenoegzaamheid. ${ }^{15}$ Met autonomie van het strafrecht wordt niet meer en niet minder bedoeld dan dat het strafrecht eigen, specifieke kenmerken heeft. Dit impliceert niet dat het strafrecht los staat van andere rechtsgebieden. Er bestaan zeker overeenkomsten tussen verschillende rechtsgebieden zoals het strafrecht en het bestuursrecht maar ook verschillen. Derhalve is het bijvoorbeeld niet mogelijk de algemene beginselen van behoorlijk bestuur rechtstreeks en onverkort in het strafprocesrecht toe te passen. ${ }^{16}$

Op grond van de 'heteronome zienswijze' wordt er van uit gegaan dat het strafrecht een bijzondere vorm van bestuursrecht is. ${ }^{17}$ Dit brengt met zich dat het (toepassen van het) strafrecht wordt opgevat als een 'gewone' overheidsactiviteit. Een nadrukkelijk onderscheid tussen het strafrecht en het bestuursrecht wordt daarmee ontkend. De heteronome zienswijze lijkt (mede) ingegeven te zijn door de ontwikkelingen in het strafrecht die resulteren in de mogelijkheid om strafrechtelijke overtredingen steeds vaker buitengerechtelijk (en daarmee op een (semi-)bestuursrechtelijke wijze) af te doen, terwij] in het bestuursrecht tegelijkertijd (van oorsprong) strafrechtelijke sancties zoals de bestuurlijke boete worden 'binnengehaald'. ${ }^{18}$ Vermeldenswaardig is dat Oostenbrink deze (destijds nog niet zeer manifeste) ontwikkeling reeds in 1967 signaleerde. Hij sprak in dit kader over zogenaamde 'osmose-verschijnselen' met betrekking tot administratiefrechtelijke en strafrechtelijke sanctionering. ${ }^{19}$

Welk standpunt de Hoge Raad in dit kader inneemt is niet geheel duidelijk. In ieder geval kan niet onverkort gezegd worden dat de Hoge Raad uit gaat van de hierboven beschreven heteronome visie, in die zin dat het bestuursrecht (rechtstreeks en onverkort) doorwerkt in het strafrecht en het strafprocesrecht. Duidelijk is wel dat de Hoge Raad het bestuursrecht en het strafrecht niet ziet als twee volstrekt gescheiden rechtsgebieden. Illustratief in dat kader is een arrest van genoemd rechtscollege van 30 maart 2001 (Staat/Lavrijsen) waarin is bepaald dat schade, veroorzaakt tijdens een rechtmatige huiszoeking, ten aanzien van de niet als verdachte aangemerkte huurster op grond van het egalité-beginsel moet worden vergoed. ${ }^{20}$ Zoals ook annotator Schlössels aan-

13 Zie: H.A. Demeersseman, De autonomie van het materièle strafrecht (diss. VU), Amhem 1985.

14 A.C. 't Hart, Hier gelden wetten! Over strafrecht, Openbaar Ministerie en multiculturalisme, Leiden 2001.

15 't Hart a.w. 2001 , p. 190.

16 Aldus 't Hart a.w. 2001, p. 193.

17 Zie: G.J.M. Corstens, Interne en externe convergentie van strafprocesrecht, in: D.R. Doorenbos en R.J. Verweij (red.), Hercodificatie Wetboek van Strafvordering. Nijmegen 1991, i.h.b. p. 9-13.

18 Zie hierover onder meer: A.R. Hartmann en P.M. van Russen Groen, Contouren van het bestuursstrafrecht (diss. EUR), Deventer 1998, p. 37-48, zie voorts: G. Knigge, De verkalking voorbij... over de verhouding van het strafrecht tot het bestuursrecht, RM Themis 2000, p. 83-96, p. 83, het stuk van Rogier en Hartmann a.w. 1993. Zie tenslotte Mulder, a.w. 1957, p. 82-83, die in 1957 reeds signaleert dat het strafrecht en het administratiefrecht 'naar elkaar toe groeien'.

19 J.J. Oostenbrink, administratieve sancties, Serie Bestuursrechtelijke Verkenningen, Uitgeverij VUGA nv, 's-Gravenhage, 1967 , i.h.b. p. 134.

20 HR 30 maart 2001, JB 2001/107, m. nt. R.J.N. Schlossels, Gst. 2001, 7143 no. 3, m. nt. H. Hennekens, en AA 2001, p. 657-663, m. nt. L.J.A. Damen (Staat/Lavrijsen). 
geeft, merkt de Hoge Raad het, aan artikel 3:4, tweede lid Awb ten grondslag liggende egalité-beginsel aan als een (algemeen ${ }^{21}$ ) beginsel dat van toepassing in op alle overheidshandelen. Dus ook op die handelingen waarop de Awb niet direct, indirect, geheel of gedeeltelijk van toepassing is bijvoorbeeld omdat genoemde handeling in artikel 1:6 Awb is uitgezonderd.

Men zou kunnen stellen dat men zowel bij hantering van de autonome (doch niet autarkische) visie als bij hantering van de heteronome visie tot een vrijwel vergelijkbaar resultaat komt. ${ }^{22}$ Duidelijk is immers dat het strafrecht als (noodzakelijk) rechtsgebied bestaat. Overeenstemming lijkt, tussen beide visies, bovendien te bestaan over het feit dat bepaalde bestuursrechtelijke regels, leerstukken en beginselen een rol kúnnen spelen in het straf(proces)recht. Daarmee is mijns inziens tevens helder dat bestuursrechtelijke regels, leerstukken en beginselen slechts naast, of in samenhang met, het straf(proces)recht een rol kunnen spelen in strafzaken. De discussie lijkt zich derhalve met name toe te spitsen op de vraag of die bestuursrechtelijke regels, leerstukken en beginselen onverkort (zoals zij in het bestuursrecht gelden) of 'invullend' (d.w.z. bekeken door een strafrechtelijke bril) moeten worden toegepast in het straf(proces)recht voor zover zij in dat kader een rol spelen.

Het gaat echter te ver om daar in het kader van dit boek uitvoerig bij stil te staan. In dit werk wordt er van uit gegaan dat het strafrecht en het bestuursrecht van oudsher twee afzonderlijke rechtsgebieden vormen. ${ }^{23}$ Tussen genoemde rechtsgebieden bestaan veel verschillen maar zij vertonen op bepaalde punten ook (soms in de loop van de tijd ontwikkelde ${ }^{24}$ ) overeenkomsten. ${ }^{25}$ Het voorgaande brengt met zich dat bepaalde bestuursrechtelijke regels, leerstukken en beginselen (al dan niet onverkort) een rol kúnnen spelen in het straf(proces)recht (en vice versa). Tenslotte verdient opmerking dat er, in ieder geval historisch gezien, verschillen zijn tussen sancties van strafrechtelijke aard en sancties van bestuursrechtelijke aard. ${ }^{26}$

21 Zie m.b.t de al dan niet algemene status van het beginsel, Damen a.w. 2001, p. 662 en J.M.H.F. Teunissen, De emancipatie van het bestuursrecht. Een beschouwing over de opkomst van een publiekrechtelijk vermogensrecht en over de betekenis van het legalteitsbeginsel, in de bundel: Uit de school geklapt, onder redactie van M.A. Heldeweg, E.C.H.J. van der Linden en R.J.N. Schlossels, Den Haag 1999 , p. 245-274, i.h.b. 250. Teunissen noemt het beginsel van de egalité devant les charges publiques een voor het publiekrecht typisch rechtsbeginsel.

22 Voor een nadere beschrijving van verschillende zienswijzen verwijs ik naar de hierboven aangehaalde werken van Rogier en Hartmann. Zie voorts O.J.D.M.L. Jansen, Bestuursrecht en strafprocesrecht: doorwerken of afgrenzen? in: T. Hoogenboom en L.J.A. Damen (redactic), In de sfeer van administratief recht (Konijnenbeltbundel), Utrecht 1994, p. 257-283, i.h.b. p. 260 e.v., en O.J.D.M.L. Jansen, De eindige toekomst van artikel 1:6 Awb, NTB 1999, p. 150-156.

23 Zie hierover ook: J. van der Poel, Rondom compositie en compromis (fiscale studie in bestuurs- en strafrecht) (diss. RUU), Uitg. -Mij. NV Kemink en $\mathrm{Zn.}$., Utrecht 1942, p. 8 e.v.

24 Zie hierover ook: G. Knigge, De verkalking voorbij ... over de verhouding van het strafrecht tot het bestuursrecht, RM Themis 2000 , p. 83-96.

25 Zie in dit kader ook: O.J.D.M.L. Jansen, Het Handhavingsonderzoek (diss. UvA 1999), Nijmegen 1999.

26 Zie hierover ook Knigge a.w. 2000, en Rogier en Hartmann, a.w. 1993. Zoals later in dit hoofdstuk nog zal blijken heeft met name de komst van de bestuurlijke boete er voor gezorgd dat er een soort versmelting tussen het strafrecht en het bestuurs(rechtelijke sanctie)recht heeft plaats gevonden. 


\subsubsection{Sanctieoplegger en waarborgen}

De bestuurlijke boete en de strafrechtelijke boete hebben met elkaar gemeen dat de overheid de initiërende partij is en dat zij het handhavingsproces beheerst. ${ }^{27}$ Voor het overige bestaan er echter ook duidelijke verschillen tussen het opleggen van een bestuurlijke boete en strafrechtelijke sanctionering. ${ }^{28}$ De bestuurlijke boete heeft, zoals ik reeds eerder heb aangegeven, als voomaamste kenmerk dat zij door een bestuursorgaan wordt opgelegd. De strafrechtelijke boete wordt daarentegen opgelegd door de rechter nadat het Openbaar Ministerie (OM) de procedure heeft ingeleid. In het geval dat er een strafrechtelijke boete opgelegd kan worden bij overtreding van een bepaalde norm oordeelt de rechter of de boete opgelegd zal worden. Indien de (straf)rechter tot de conclusie komt dat de boete opgelegd kan worden bepaalt hij vervolgens (voor zover het niet om een vast boetebedrag per overtreding gaat) hoe hoog deze boete in het concrete geval zal zijn. ${ }^{29}$

Corstens geeft aan waarom de (straf)rechter bij uitsluiting bevoegd is een straf op te leggen:

'De straf mag alleen door de rechter worden opgelegd. Dat is niet zo verwonderlijk, omdat met strafoplegging leedtoevoeging wordt beoogd. Dat behoeft meer rechtvaardiging dan concreet herstel van aangedaan onrecht, al dan niet in de vorm van schadevergoeding. ... Leedtoevoeging gaat aanzienlijk verder. De zwaardere fundering daarvan is onder meer gelegen in de verplichte rechterlijke tussenkomst en in de eis dat er schuld moet zijn, wil de straf mogen worden opgelegd. ${ }^{30}$

Voor de 'verdachte' vloeit uit de strafrechtelijke procedure een aantal waarborgen voort. Deze waarborgen moeten in acht worden genomen bij de oplegging van een strafrechtelijke sanctie. Daarbij kan bijvoorbeeld gedacht worden aan het legaliteitsbeginsel uit artikel I van het Wetboek van Strafrecht (Sr), het zwijgrecht en de cautieplicht (artikel 29 van het Wetboek van Strafvordering (Sv)), het beginsel dat geen straf wordt opgelegd zonder aanwezigheid van schuld bij de dader en het ne bis in idem-beginsel (artikel $68 \mathrm{Sr}$ ).

In het nationale bestuursprocesrecht, zoals dit in de Algemene wet bestuursrecht (Awb) is neergelegd, zijn er (momenteel nog) geen vergelijkbare waarborgen gecreëerd. ${ }^{31}$ Op

27 Zie G.J.M. Corstens, het Nederlands strafprocesrecht, derde druk, Gouda Quint, Deventer, 1999, p. 2.

28 Zie voor een korte en bondige weergave van de strafrechtelijke en bestuursrechtelijke procedures ook: P.G. Wiewel, Rechtsbescherming tegen bestraffing (diss. UvA 2001), Nijmegen 2001, i.h.b. hoofdstuk 2. Zie m.b.t. het strafprocesrecht voorts Corstens a.w. 1999.

29 Uiteraard moet niet uit het $00 \mathrm{~g}$ verloren worden dat ook in het strafrecht veel lichte overtredingen buitengerechtelijk (kunnen) worden afgedaan (bijv. middels een transactie). Bovendien wordt vanuit de strafrechtelijke hoek zelfs gepleit voor een verbreding van de wettelijke basis voor buitengerechtelijke afdoening (bij voorkeur buitengerechtelijke afdoening middels een OM-boete (genoemde boete kan gezien worden als een bestuurlijke boete)). Vgl. in dat kader: M.S. Groenhuijsen en G. Knigge (red.), Het onderzoek ter zitting. Eerste interimrapport Onderzoeksproject Strafvordering 2001, Groningen 1999 i.h.b. p. 59-90 en M.S. Groenhuijsen en G. Knigge (red.), Het vooronderzoek in strafzaken. Tweede interimrapport Onderzoeksproject Strafvordering 2001, Deventer 2001, i.h.b. p. 119-124.

Zie Corstens a.w. 1999, p. 3. Zie hierover ook: G.J.M. Corstens, Bestuurlijke boeten in de vierde tranche Awb, NJB aflevering 24, 16 juni 2000, p. 1185-1190, in het bijzonder p. 1188.

31 Momenteel (mei 2002) bevat de Awb in hoofdstuk vijf slechts bepalingen met betrekking tot 'toezicht op de naleving' (afdeling 5.2), 'bestuursdwang' (afdeling 5.3), en de 'dwangsom' (afdeling 5.4). 
het eerste oog lijkt de burger, die een bepaalde bestuursrechtelijke norm heeft geschonden, waarvoor hem een bestuurlijke boete wordt opgelegd, dan ook te beschikken over minder procedurele waarborgen. Opmerking verdient echter dat inmiddels voorzien is in een algemene regeling omtrent de (oplegging van) bestuurlijke boeten in het Voorontwerp Algemene wet bestuursrecht vierde tranche. Dit Voorontwerp bevat ook bepaalde waarborgen die vergelijkbaar zijn met (verdragsrechtelijke) waarborgen die in het straf(proces)recht in acht genomen worden bij de oplegging van een straf. ${ }^{32}$ Daarnaast is in een aantal bijzondere bestuursrechtelijke wetten, op grond waarvan bestuurlijke boeten opgelegd kunnen worden, een aantal - uit het straf(proces)recht en verdragsrecht voortvloeiende - waarborgen opgenomen. ${ }^{33}$

In dit boek zal nog blijken dat ten aanzien van de oplegging van de bestuurlijke boete, op grond van de in Nederland bestaande bestuurlijke boeteregelingen, met name bepaalde uit het EVRM en IVBPR voortvloeiende waarborgen in acht moeten worden genomen. Deze waarborgen moeten gerespecteerd worden door het bestuursorgaan dat de boete oplegt en door de bestuursrechter die vervolgens het boetebesluit in beroep moet toetsen.

Op basis van het voorgaande kan vastgesteld worden dat het grootste verschil tussen de oplegging van een bestuurlijke boete en strafrechtelijke sanctionering schuilt in de sanctionerende instantie. Oplegging van de bestuurlijke boete geschiedt door het bevoegde bestuursorgaan (zonder tussenkomst van de bestuursrechter) op basis van het bestuurs(proces)recht. Terwijl de oplegging van een strafsanctie (in beginsel ${ }^{34}$ ) plaats vindt na een, met straf(proces)rechtelijke waarborgen omklede, gerechtelijke procedure door de (onafhankelijke en onpartijdige) strafrechter. ${ }^{35}$

\subsubsection{De bestuurlijke boete en enkele andere bestuursrechtelijke sancties}

\subsubsection{Inleiding}

Alvorens hier ingegaan zal worden op de diverse sancties die ons bestuursrecht rijk is volgt een korte uiteenzetting met betrekking tot de term bestuursrechtelijke sancties. Vele werken waarin de term bestuursrechtelijke (of administratieve ${ }^{36}$ ) sancties voorkomt bevatten een definitie van dit begrip. ${ }^{37}$ In het kader van dit boek gaat het te ver

32 Op de boeteregeling uit het Voorontwerp zal in dit boek nog uitvoerig worden ingegaan.

33 Vgl. bijv. de Wet boeten, maatregelen en terug- en invordering sociale zekerheid, Stb 1996, 248.

34 Vgl. de situatie waarin de strafzaak wordt afgedaan buiten proces middels een transactie (op grond van artikel $74 \mathrm{Sr}$ ).

35 Zie hierover Hartmann en van Russen Groen a.w. 1998, p. 76. Zie voorts Corstens a.w. 2000, p. 1188 en 1189 en P.M. van Russen Groen, Rechtsbescherming in het bestuursstrafrecht (diss. EUR), Gouda Quint 1998, p. 209. Zie in dit kader voorts de afscheidsrede van G.J.M. Corstens, Een stille revolutie in het strafrecht (Afscheidsrede Nijmegen 1995), Gouda Quint bv, Amhem 1995, i.h.b. p. 18.

In de oudere bestuursrechtelijke werken wordt in de regel gesproken over administraticve sancties. In dit boek zal in beginsel de term bestuursrechtelijke sancties gebezigd worden. Voor zover echter verwezen wordt naar oudere werken zal ook met enige regelmaat de term administratieve sanctie worden gebruikt.

37 Vgl. bijv. Oostenbrink a.w. 1967, p. 21 en W.G.A. Hazewindus, Administratieve sancties en vreemdelingenrecht (diss. UvA 1994), Gouda Quint bv, Amhem 1994, p. 11-13. Nadat Hazewindus op p. 11 en 12 de definities van de term administratieve sancties zoals omschreven door Oostenbrink, Van Ange- 
om bij al deze definities stil te staan. Ter illustratie wordt op deze plaats derhalve slechts één definitie van genoemde term weergegeven.

Gekozen is voor de definitie van de term administratieve sancties zoals deze is neergelegd in het handboek 'Hoofdstukken van bestuursrecht'. ${ }^{38}$ In genoemd werk wordt het begrip administratieve sancties als volgt omschreven: 'de door het publiekrecht voorziene, belastende maatregelen die de overheid kan aanwenden als reactie op nietnaleving van de verplichtingen die voortvloeien uit administratiefrechtelijke normen. ${ }^{39}$ Deze beschrijving van de term administratieve sancties is naar mijn mening volledig en eenduidig. Uit genoemde beschrijving blijkt dat het bij administratieve (ofwel bestuursrechtelijke) sancties gaat om een, in een publiekrechtelijke regeling neergelegde, bevoegdheid, toegekend aan een bestuursorgaan, om een belastende maatregel te treffen als reactie op schending van een publiekrechtelijke norm. Belangrijkste kenmerk van de bestuursrechtelijke sanctie is dat het bestuursorgaan (en niet de rechter) bevoegd is tot het opleggen van de sanctie.

Bestuursorganen beschikken doorgaans over verschillende (bestuursrechtelijke) sanctiebevoegdheden teneinde op te kunnen treden tegen handelen in strijd met, bij of krachtens de wet, gestelde voorschriften. Het gaat te ver om alle bestuursrechtelijke sancties in het kader van dit boek te bespreken. In dit hoofdstuk wordt, naast de bestuurlijke boete, een viertal bestuursrechtelijke sancties (weliswaar beknopt) besproken. Het gaat dan om de intrekking van een begunstigende beschikking bij wijze van sanctie, het toepassen van bestuursdwang, het opleggen van een last onder dwangsom en de maatregel in het sociale zekerheidsrecht (en daarmee vergelijkbare sancties). Deze sancties worden momenteel, anders dan bijvoorbeeld de bestuurlijke waarborgsom $^{40}$ en de bestuursrechtelijke transactie ${ }^{41}$, in het Nederlandse bestuursrecht veelvuldig toegepast.

Voordat de hierboven vermelde bestuursrechtelijke sancties beschreven worden zal nog ingegaan worden op het onderscheid tussen punitieve en reparatoire (ofwel situatieve) bestuursrechtelijke sancties.

ren, Duk, Konijnenbelt en Rogier heeft weergegeven, volgt op p. 3 zijn eigen definitie: 'Administratieve sancties zijn publiekrechtelijke reacties van een bestuursorgaan op niet-naleving van verplichtingen voortvloeiend uit administratiefrechtelijke normen, waardoor degene die zo'n verplichting niet naleeft in zijn belang wordt getroffen.'

H.D. van Wijk/W. Konijnenbelt en R.M. van Male, elfde druk, Elsevier Bedrijfsinformatie B.V., Den Haag 1999.

39 Van Wijk/Konijnenbelt/Van Male a.w. 1999. p. 475.

40 Zie over de bestuurlijke waarborgsom: M.V. van Drumpt en G.H. Addink, De bestuurlijke waarborgsom in het bestuursrecht: begrip, plaats, inhoud en karakter, NTB 1999 no. 5, p. 118-126.

41 Zie over de bestuursrechtelijke transactie: A.B. Blomberg en F.C.M.A. Michiels, Handhaven met effect, VUGA Uitgeverij B.V., Den Haag 1997, i.h.b. p. 346-347; Commissie Michiels, Handhaven op niveau, W.E.J. Tjeenk Willink, Deventer 1998, p. 81-82; F.C.M.A. Michieis, De bestuurlijke boete in het milieurecht, Milieu en Recht 1998 no. 3, p. 69-73, i.h.b. p. 71 en 72 . Zie voorts het Transactiebesluit milieudelicten, Stb. 2000, 320, op grond waarvan vanaf 1 november 2000 door een aantal in het besluit aangewezen bestuursorganen op experimentele wijze overgegaan kan worden tot het doen van een strafrechtelijke transactievoorstel. 


\subsubsection{2.a Reparatoire en punitieve bestuursrechtelijke sancties}

- gevolgen van kwalificatie -

Het onderscheid tussen reparatoire en punitieve bestuursrechtelijke sancties is om twee redenen van belang. Ten eerste is het zo dat het opleggen van een punitieve sanctie (in de regel) wordt aangemerkt als een 'criminal charge' in de zin van artikel 6 EVRM. $^{42}$ De kwalificatie van de oplegging van een punitieve bestuursrechtelijke sanctie als 'criminal charge' brengt met zich dat alle waarborgen die uit artikel 6 EVRM voortvloeien in acht moeten worden genomen. Uit artikel 6 EVRM vloeit, naast het recht op een eerlijk proces, een aantal verdedigingsrechten (waaronder de onschuldpresumptie en het $z w i j g r e c h t^{43}$ ) voort. Bovendien moeten ten aanzien van de oplegging van genoemde punitieve bestuursrechtelijke sancties bók de waarborgen die voortvloeien uit artikel 7 EVRM en uit artikel 14 en $15^{44}$ IVBPR in acht worden genomen. In artikel 7 EVRM en 15 IVBPR zijn onder meer het nullum crimen sine lege-beginsel, het nulla poena sine lege-beginsel en het lex certa-beginsel neergelegd. ${ }^{45}$

Er is daamaast nog een tweede consequentie verbonden aan het aanmerken van een bestuursrechtelijke sanctie als punitieve sanctie. In feite vloeit deze consequentie voort uit de in artikel 6 EVRM neergelegde eis van 'full jurisdiction'. ${ }^{46}$ De nationale bestuursrechter moet namelijk (de hoogte of zwaarte van) punitieve bestuursrechtelijke sancties die op basis van een bevoegdheid met beleidsvrijheid zijn opgelegd volledig toetsen aan het, in artikel 3:4 lid 2 Awb neergelegde, evenredigheidsbeginsel. ${ }^{47}$ De bestuursrechter dient zich af te vragen of er evenredigheid bestaat tussen de ernst van de overtreding en de zwaarte van de opgelegde sanctie. ${ }^{48}$ Dit in tegenstelling tot de normale

42 EHRM 21 februari 1984, NJ 1988, 937 m. nt. E.A. Alkema (Oztürk). Waarin het punitieve karakter van de in de zaak Özturk in het geding zijnde bestuursrechtelijke sanctie werd aangemerkt als eén (van de) doorslaggevende factoren voor het vaststellen van een 'criminal charge'. In hoofdstuk 3 zal overigens uitvoerig worden ingegaan op de verdragsrechtelijke aspecten die een rol spelen bij de oplegging van punitieve bestuursrechtelijke sancties (voor zover deze sancties tevens als 'criminal charge' aangemerkt moeten worden). In dat hoofdstuk zal tevens uitgebreid aandacht worden besteed aan de criteria die relevant zijn om vast te kunnen stellen of er sprake is van een 'criminal charge' in de zin van artikel 6 van het EVRM. Uit genoemd hoofdstuk zal ook nog blijken dat de rechtspraak van het EHRM dermate casuïstisch is dat van de oplegging van bepaalde punitieve sancties vooraf niet met zekerheid valt te zeggen of zij door het EHRM als 'criminal charge' worden aangemerkt. Vgl. in dit kader: E.A. Alkema, Regels voor bestuurlijke sancties in Awb, bijzondere wet of verdrag?, in de bundel: De grootste gemene deler (Drupsteen bundel), onder redactie van M. Lurks, W. den Ouden, J.E.M. Polak en A.E. Schilder, Leiden 2002, p. $111-124$, i.h.b. p. 114 en 124. EHRM 25 februari 1993, NJ 1993, 485 m. nt. Knigge (Funke).

44 CRvB I maart 2000, JB 2000/107 m. nt. C.L.G.F.H. Albers.

45 In hoofdstuk drie zal uitvoeriger op deze beginselen worden ingegaan.

46 Zie hierover: EHRM 23 juni 1981, NJ 1982, 602 (Le Compte, Van Leuven, en De Meyere), en EHRM 10 februari 1983, NJ 1987, 315 (Albert en Le Compte). In artikel 6 EVRM wordt het recht op toegang tot de rechter gegarandeerd (om de 'criminal charge' aan te kunnen vechten). De rechter die oordeelt over een bepaalde zaak dient vervolgens, op grond van artikel 6 EVRM, te beschikken over een volle toetsingsbevoegdheid ('full jurisdiction').

47 ABRS 4 juni 1996, JB 1996/172, m. nt. E. v.d. Linden (Huisman APK). Zie hierover ook: P. Nicolai,, het tandvlees van het recht, in de bundel: Recht op scherp ('Duk-bundel'), W.E.J. Tjeenk Willink, Zwolle 1984, p. 3-54, i.h.b. p. 48. Nicolaï neemt, onder verwijzing naar Duk, in 1984 reeds het standpunt in dat punitieve administratieve sancties niet marginaal maar volledig aan het evenredigheidsbeginsel moeten worden getoetst.

48 Aangezien art. 3:4 lid 2 Awb alleen ziet op bevoegdheden met beleidsvrijheid kunnen, vanuit het 
situatie waarin de bestuursrechter de uitoefening van beleidsvrije bevoegdheden slechts marginaal mag toetsen aan artikel 3:4 lid 2 Awb, hetgeen betekent dat de bestuursrechter (slechts) beoordeelt of het bestuursorgaan in redelijkheid tot het genomen besluit heeft kunnen komen. ${ }^{49}$

De vraag of er sprake is van een punitieve of een reparatoire bestuursrechtelijke sanctie is dus - kort samengevat - relevant omdat er ten aanzien van (de oplegging van) punitieve bestuursrechtelijke sancties, die vallen onder het 'criminal charge'-begrip, sprake is van 'verhoogde' rechtsbescherming. Het bestuursorgaan zal bij de oplegging van een punitieve bestuursrechtelijke sancties méér waarborgen in acht moeten nemen terwijl de bestuursrechter de opgelegde sanctie indringender moet toetsen. ${ }^{50}$

\subsubsection{2.b Reparatoire en punitieve bestuursrechtelijke sancties - definitiekwestie -}

\section{Reparatoire sancties}

In de (bestuursrechtelijke) literatuur wordt een theoretisch onderscheid gemaakt tussen reparatoire en punitieve bestuursrechtelijke sancties. ${ }^{51}$ Een reparatoire sanctie ziet op het aanbrengen van een wijziging in een bepaalde toestand. ${ }^{52}$ Een reparatoire sanctie heeft ten doel de (onrechtmatige) situatie, die is ontstaan door de normovertreding, op te heffen, of te veranderen in een situatie die in overeenstemming is met de norm. Wie de overtreder is en of de overtreder enige schuld heeft aan de overtreding van de norm speelt hierbij geen rol. ${ }^{54} \mathrm{Bij}$ het toepassen van bestuursdwang en het opleggen

nationale (bestuurs)recht geredeneerd, problemen ontstaan bij de toetsing van de evenredigheid van punitieve bestuurstechtelijke sancties die in het kader van een gebonden bestuursbevoegdheid worden opgelegd. Zie hierover CRvB 5 juli 2000, JB $2000 / 256$ m. nt. C.L.G.F.H. Albers. Zie voorts: C.L.G.F.H. Albers, De bestuurlijke boete. Magische lijn of hellend vlak?. in JBplus 2000, p. 138-152, i.h.b. p. 147-149, en tenslotte hoofdstuk vier van dit boek.

49 ABRS 9 mei 1996, JB 1996/158 m. nt. F.A.M. Stroink (Maxis \& Praxis).

50 Zie hierover ook Nicolaï a.w. 1984, p. 44. Op p. 44 schrijft Nicolaï: 'Met Duk ben ik van mening dat voor 'reparatoire' en 'retributieve' (= punitieve [KA]) sancties verschillende maatstaven gelden; een verschil dat m.i. voortvloeit uit het verschil in aard van die sancties. Anders dan de 'reparatoire' sanctie beoogt immers de 'retributieve' sanctie mér dan enkel 'reparatie'; zij reageert primair op en strekt vaak mede tot beïnvloeding van het gedrag van de persoon. Terwijl bij de reparatoire sanctie de aantasting van de vrijheid van het individu 'slechts' een consequentie is van sanctietoepassing, kan zij bij de retributieve sanctie het eigenlijke doel vormen. Het element van terechtwijzing van de persoon door een instantie die gerechtigd is om als reactie op zijn gedrag zijn vrijheden aan te tasten, schept m.i. de behoefte aan 'zwaardere' maatstaven voor retributieve sancties.'

51 Zie bijvoorbeeld de dissertatie van E.E.V. Lenos, Bestuurlijke sanctietoepassing en strafrechtelijke waarborgen in de sociale zekerheid, Koninklijke Vermande, 1998. Zie ook de dissertatie van L.J.J. Rogier, Strafsancties, administratieve sancties en het una-via beginsel, Gouda Quint, Amhem 1992, i.h.b. p. 32.

52 J.J. Oostenbrink, administratieve sancties, Serie Bestuursrechtelijke Verkenningen, Uitgeverij VUGA nv, 's-Gravenhage, 1967, p. 64. Zie ook: W. Duk, Handhaving van bestuursrecht, NTB 1988 no. 4, p. 105-110, i.h.b. p. 105-106.

53 In dit kader wordt in de bestuursrechtelijke literatuur zowel gesteld dat een reparatoire sanctie ziet op herstel van een onrechtmatige toestand (in een rechtmatige toestand) als op herstel van de rechtmatige toestand.

Zie ook Van Wijk/Konijnenbelt/Van Male a.w. 1999, p. 477. 
van een last onder dwangsom ${ }^{55}$ is naar de huidige opvatting van de wetgever en de bestuursrechter sprake van een reparatoire sanctie.

Op deze plaats wil ik er op wijzen dat de term 'reparatoire sanctie' maar mijn mening niet helemaal zuiver is. Indien men er vanuit gaat dat de woorden 'sanctie' en 'straf' als synoniemen moeten worden opgevat zou er hooguit sprake kunnen zijn van een 'reparatoire handhavingsactie'. ${ }^{56}$ Met de term straf wordt gedoeld op; 'de weloverwogen leedtoebrenging aan de schuldige dader vanwege diens overtreding van een rechtsregel door een daartoe bevoegde overheidsinstantie. ${ }^{57}$ Aangezien bij een reparatoire sanctie, anders dan bij een punitieve sanctie, geen sprake is van 'weloverwogen leedtoebrenging' kan naar mijn mening niet gesproken worden van een reparatoire sanctie. De term 'reparatoire handhavingsactie' zou in dit kader meer op zijn plaats zijn.

\section{Punitieve sancties}

Een punitieve bestuursrechtelijke sanctie heeft als voornaamste doel leedtoevoeging. ${ }^{58}$ Met deze leedtoevoeging kunnen vervolgens verschillende doelen worden beoogd. ${ }^{59}$ Een belangrijk doel is de generale en speciale ${ }^{60}$ preventie die uit gaat van leedtoevoeging. Daamaast speelt vergelding (volgens Duk een eufemisme voor dysfunctionele wraak $^{61}$ ) een wezenlijke rol. ${ }^{62}$

$\mathrm{Er}$ is ten eerste sprake van leedtoevoeging als de sanctie verder gaat dan herstel in de rechtmatige toestand vergt. Daarnaast kan worden gesproken van leedtoevoeging als er een sanctie wordt opgelegd terwijl herstel van de rechtmatige toestand niet meer mogelijk is en deze sanctie niet slechts schadevergoeding (compensatie) behelst. ${ }^{63}$ Schreuder-Vlasblom meent dat van 'straf' - en daarmee van een punitieve sanctie die leedtoe-

55 Zie ABRS 19 september 1996, JB 1996/215 m. nt. R.J.N. Schlossels, AB 1997, 91 m. nt. P. van Buuren en ABRS II februari 2000, JB 2000/75 m. nt. C.L.G.F.H. Albers. Later in dit hoofdstuk zal overigens nog blijken dat het kwalificeren van een dwangsom als reparatoire sanctie niet onomstreden is.

56 Op zich lijkt 'reparatoire maatregel' een aardige term. Vertaald naar het strafrecht is ook deze term wellicht niet geheel zuiver. Maatregelen zien in strafrechtelijke context immers op bescherming van de samenleving tegen het gedrag van de veroordeelde. Er is geen relatie tussen de ernst van het feit en het leed dat de maatregel aan de veroordeelde toebrengt (vgl. D.H. de Jong en G. Knigge, Van BemmelenVan Veen: Het materißle strafrecht, Algemeen deel, dertiende druk, Gouda Quint, Deventer 1998, p. 270).

57 J. Remmelink, Mr. D. Hazewinkel-Suringa's 'Inleiding tot de studie van het Nederlandse Strafrecht', vijftiende druk, Gouda Quint bv, Deventer 1996, i.h.b. p. 10, en De Jong/Knigge aw. 1998, p. 13. Zie voorts: Hazewindus a.w. 1994, p. 27.

58 Zie ook: de oratie van W. Duk, Tanden van het recht - orienterende beschouwingen over sancties -, Tjeenk Willink, Zwolle 1973. Duk spreekt over 'repressieve sancties' (Duk a.w. 1973, p. 19). In Handhaving van bestuurstecht (Duk a.w. 1998 p. 105-106) spreekt Duk niet meer over 'repressieve sancties' maar over 'retributieve sancties'.

59 Zie m.b.t. de strafrechtstheorieesn waarin wordt aangegeven wat het doel is van de met de straf beoogde leedtoevoeging: Remmelink a.w. 1996, i.h.b. p. 889 e.v.

60 Speciale preventie kan overigens ook gerealiseerd worden zonder leedtoevoeging. Vgl. Remmelink a.w. 1996, i.h.b. 900 .

61 Duk a.w. 1973, p. 19.

62 Zie m.b.t. de doeleinden van het straffen voorts: Y. Buruma, De strafrechtelijke handhaving van bestuurswetten (diss. RUL), Gouda Quint, Amhem 1993, p. 280 e.v. Vgl. Duk a.w. 1973, p. 18-19 en Duk a.w. 1988, p. 105-106. 
voeging ten doel heeft - sprake is als datgene waarop, ondanks de gepleegde rechtsschennis aanspraak is blijven bestaan, wordt onthouden of ontnomen. ${ }^{64} \mathrm{Zie}$ ik het goed, dan is dit het geval als een sanctie verder gaat dan voor herstel van de rechtmatige toestand nodig is of als de sanctie meer behelst dan compensatie van de schade ontstaan door het onrechtmatige handelen.

In dat kader moet nog worden opgemerkt dat volgens Kelk sanctionering óók als straf (en dus als punitieve sanctie) moet worden aangemerkt als leedtoevoeging niet het primaire doel is van de sanctie maar wel dermate zeker of hoogstwaarschijnlijk is dat subjectieve leedervaring als gevolg aan de sanctie verbonden zal zijn. ${ }^{65}$ Met andere woorden, als voorzienbaar is dat een bepaalde sanctie in het algemeen door overtreders als leedtoevoegend zal worden ervaren moet deze sanctie aangemerkt worden als punitieve sanctie, ongeacht of het primaire doel van de sanctie toevoeging van leed is. Men zou kunnen stellen dat deze opvatting nogal verstrekkend is. Subjectieve leedervaring zou niet doorslaggevend moeten zijn. Toch valt er mijns inziens in ieder geval wat voor te zeggen niet blind te varen op (expliciet in de parlementaire geschiedenis neergelegde) doelstellingen van de wetgever. Gelet op de verhoogde rechtsbescherming die dient te gelden bij de oplegging van punitieve sancties zou de wetgever immers in de verleiding kunnen komen het doel van de sanctie (leedtoevoeging) te verbloemen. Daarnaast bestaat de mogelijkheid dat een bestuursorgaan een reparatoire sanctiebevoegdheid gebruikt (misbruikt) teneinde een punitief uitwerkende sanctie op te leggen. ${ }^{66}$ Derhalve moet mijns inziens in ieder geval verder gekeken worden dan het uit de parlementaire geschiedenis naar voren komende sanctiedoel. Dit brengt met zich dat een materieel criterium gehanteerd zou moeten worden teneinde vast te kunnen stellen of er sprake is van een punitieve sanctie.

Op basis van het voorgaande kom ik tot de volgende slotsom. Doorslaggevend, voor beantwoording van de vraag of een bestuursrechtelijke sanctie aangemerkt moet worden als punitieve sanctie, is mijns inziens of de sanctionering leedtoevoeging behelst. Of er sprake is van leedtoevoeging dient vast te worden gesteld aan de hand van een materieel criterium. Dit brengt met zich dat het doel van de sanctie zoals dat is weergegeven in (de wetgeschiedenis van) de wettelijke regeling niet zonder meer doorslaggevend is. De sanctie zal los daarvan bekeken moeten worden. Vervolgens zijn er twee situaties denkbaar waarin sprake is van leedtoevoeging. Ten eerste is dat het geval als de sanctie verder gaat dan herstel van de (on)rechtmatige toetstand vergt. Daarnaast kan worden gesproken van leedtoevoeging als er een sanctie wordt opgelegd terwij] herstel van de rechtmatige toestand niet meer mogelijk is en deze sanctie niet slechts schadevergoeding (compensatie) behelst.

64 M. Schreuder-Vlasblom, Kroniek bestuursprocesrecht, NTB 2001 (hiema a.w. 200lb), p. 126-136, i.h.b. p. 129. Vgl. C. Kelk, Verbreding van het punitieve spectrum, in de bundel: Hoe punitief is Nederland?, onder redactic van M. Moerings, Amhem 1994, p. 13-29, i.h.b. p. 15.

66 Vgl. ABRS 13 maart 2001, JB 2001/95 (Dwangsom Coberco) m. nt. C.L.G.F.H. Albers. 
Leedtoevoeging sorteert slechts effect ten aanzien van de schuldig bevonden dader. Van een punitieve sanctie kan volgens Kelk dan ook alleen maar sprake zijn indien de normovertreding berust op schuld (in de zin van verwijtbaarheid) van de persoon die de norm heeft overtreden. ${ }^{67}$ Ik vraag me af of dit zuiver gesteld is. Een punitieve sanctie herkent men mijns inziens, zoals hierboven is weergegeven, aan haar leedtoevoegende karakter. Los daarvan staat de vraag of de sanctie alleen wordt opgelegd aan een schuldig bevonden dader. Een sanctie die leedtoevoeging behelst kan immers best (ten onrechte) opgelegd worden aan een persoon ten aanzien waarvan de schuld aan een normschending niet vast staat. Desondanks blijft de sanctie punitief van aard. Een dergelijke praktijk druist echter wél in tegen het fundamentele strafrechtelijke beginsel 'geen straf zonder schuld'. Schuld (in de zin verwijtbaarheid) moet derhalve gezien worden als een vereiste voor het opleggen van een punitieve sanctie en niet als een kenmerk van een punitieve sanctie.

Oostenbrink ${ }^{68}$ benadrukt ook het schuldaspect bij punitieve sancties. Derhalve spreekt hij niet over punitieve sancties maar over 'personele' sancties. Een 'personele' sanctie richt zich volgens Oostenbrink voomamelijk tegen de persoon van de overtreder en ziet op vergelding van schuld. Genoemde sanctie is in veel geringere mate gericht op (herstel van) een bepaalde toestand (situatie). In dit kader kan ook gewezen worden op Belinfante die in zijn VAR-preadvies uit 1957 het volgende stelt:

'De straf heeft een andere functie dan het feitelijk herstel van onrecht: zij dient tot effening van de maatschappelijke ontwrichting, die door overtreding van een norm is ontstaan. Zij dient om het onmaatschappelijke, het subsociale in het gewraakte gedrag te effenen. ${ }^{69}$

Oostenbrink meent dat dergelijke punitieve administratieve sancties dicht tegen strafrechtelijke sancties aan liggen. Hij geeft dit als volgt weer: 'Het ligt voor de hand, dat de administratie in een dergelijke casus de functie van de straffen opleggende rechter dicht benadert. ${ }^{70} \mathrm{Hij}$ geeft vervolgens aan dat het opleggen van punitieve bestuursrechtelijke sancties naar zijn mening aan de strafrechter is voorbehouden:

'Hoewel constitutioneel bezien tegen een sterke expansie van de categorie van de personéle administratieve sancties (d.w.z. punitieve bestuursrechtelijke sancties [KA]) geen bezwaar hoeft te worden gernaakt, is er toch wel veel voor te zeggen de typisch op een vergelding van schuld gebaseerde overheidsreactie op overtredingen over te laten aan de strafrechter, als de op dat terrein meest deskundige functionaris. ${ }^{.71}$

De door Belinfante en Oostenbrink gesignaleerde strafrechtelijke karakteristieken van punitieve bestuursrechtelijke sancties maken dat deze sancties niet zonder meer deel uit maken van het bestuursrecht. $\mathrm{Zij}$ vallen, anders dan reparatoire bestuursrechtelijke

67 Vgl. Kelk a.w. 1994, p. 15-16.

68 Oostenbrink a.w., p. 64 en 65. Zie voorts: Van Wijk/Konijnenbelt/Van Male a.w. 1999, p. 477.

69 A.D. Belinfante in zijn VAR-preadvies, Strafrechtelijke en administratiefrechtelijk sancties, in De verhouding van administratieve sancties en straffen, Geschriften van de vereniging voor administratiefrecht no. XXXVI, H.D. Tjeenk Willink \& Zoon N.V., Haarlem 1957, p. 11.

70 Zie: Oostenbrink a.w. 1967, p. 134

71 Oostenbrink a.w. 1967, p. 137. 
sancties, onder een meeromvattende noemer. Het bestuursstrafrecht. ${ }^{72}$ Hartmann en Van Russen Groen omschrijven deze laatste term als volgt; bestuursstrafrecht is:

'...het van het strafrecht en het bestuursrecht te onderscheiden deel van het recht waarin publiekrechtelijke bestuursorganen, zonder tussenkomst van de betrokkene of een onafhankelijke rechter, sancties met een bestraffend karakter kunnen opleggen. ${ }^{73}$

Het bestuursstrafrecht is, volgens Hartmann en Van Russen Groen, dat gedeelte van het recht waarin sancties met een bestraffend karakter kunnen worden opgelegd buiten het - formeel gezien - strafrechtelijk kader. ${ }^{74}$

Met het oog op het voorgaande zou men zich af kunnen vragen of punitieve sancties (ongeacht of het punitieve bestuursrechtelijke sancties dan wel punitieve strafrechtelijke sancties zijn), gelet op het aan genoemde sancties ten grondslag liggende doel, niet zonder meer deel uit maken van het strafrecht in ruimere zin. Naar mijn mening is dat het geval. De Duitse auteur Michels ${ }^{75}$ neemt eenzelfde standpunt in. Hij stelt het volgende:

'Vielmehr deutet schon die Gegenüberstellung von Begriffen wie Kriminalstrafrecht einerseits und Ordnung- oder Verwaltungsstrafrecht andererseits durch die Formulierung an, daß die beiden Glieder des Gegensatzes Teile eines größeren Ganzen, des Strafrechts im weitesten Sinne sind. ${ }^{76}$

Michels onderbouwt deze stelling als volgt:

'Die im konstituierenden Grundwert von Justiz und Verwaltung begründete verschiedene materiale Ausgestaltung der einzelnen Handlungselemente beider Bereiche steht der einheitlichen Unterordnung unter das "Strafrecht" nicht entgegen. Strafrecht als Kategorie in diesem weiteren Sinne umfaßt vielmehr unabhängig vom materiellen Wesensgehalt des Unrechts im Einzelfall alle Rechtsnormen, die Gebote oder Verbote unter eine repressive

72 Vgl. Hartmann en Van Russen Groen a.w. 1998, p. 74 en pagina 105 en verder. De term bestuursstrafrecht is echter niet nieuw getuige de dissertatie van Van der Poel uit 1942 (zie: Van der Poel a.w. 1942, p. 264). Zie F.C.M.A. Michiels, Bestuurlijke handhaving in ontwikkeling, in: Handhaving van het bestuursrecht, VAR preadvies no. 114, Alphen aan den Rijn; Samsom H.D. Tjeenk Willink 1995, p. 7119, i.h.b. p. 62: 'Inmiddels is de term bestuursstrafrecht voor hetgeen ermee wordt aangeduid niet erg logisch. Bij bedoelde sancties gaat het immers om bestuursrecht: om punitief bestuursrecht. De term 'punitief bestuursrecht' verdient dan ook de voorkeur.' Zie in dezelfde zin: O.J.D.M.L. Jansen, De dynamiek van het publiekrechtelijke sanctierecht, Handelingen NJV 2002-1, p. 167-255, i.h.b. p. 183-184. Aangezien punitieve bestuursrechtelijke sancties mijns inziens gerekend kunnen worden tot het strafrecht in ruime zin (zoals hierna nog zal blijken) is er naar mijn mening niets op tegen om de term bestuursstrafrecht in dit kader te gebruiken. Dit klemt te meer nu bij de oplegging van punitieve administratieve sancties het bestuurs(proces)recht mijns inziens niet onverkort toegepast kan worden. Hartmann en Van Russen Groen a.w. 1998, p. 74.

74 Zie Hartmann en Van Russen Groen a.w. 1998, p. 74 en Hartmann en Van Russen Groen, a.w. 1994, p. 21-61. Zie voorts Oostenbrink a.w. die op p. 61 en p. 134 aangeeft dat punitieve administratieve sancties een grote gelijkenis vertonen met strafrechtelijke sancties.

75 H.G. Michels, Strafbare Handlung und Zuwiderhandlung. Versuch einer materiellen Unterscheidung zwischen Kriminal- und Verwaltungsstrafrecht, Neue Kölner Rechtswissenschaftiche Abhandlungen, herausgegeben von der Rechtswissenschaftlichen Fakultat der Universitat zu Koln, Heft 24, Walter de Gruyter \& Co., Berlin 1963.

Michels a.w. 1963, p. 30. 
Sanktionsandrohung stellen, gleichgültig ob es sich um "Strafe" oder "Buße" als Sanktion handelt. ${ }^{77}$

Onder het strafrecht in ruimere zin vallen derhalve, los van de ernst van de normschending, alle gebods- en verbodsnormen die worden gehandhaafd met punitieve sancties. Op zich vormt de idee dat alle punitieve sancties onder het strafrecht in ruimere zin vallen geen onaantrekkelijke gedachte. Niet alleen de Duitser Michels, maar ook Nederlandse juristen als Corstens ${ }^{78}$ en Knigge, gaan er van uit dat punitieve bestuursrechtelijke sancties deel uit maken van het strafrecht in ruimere zin. Knigge schrijft in dat kader het volgende:

'Waarom wordt zo krampachtig volgehouden dat de oplegging van een bestuurlijke boete geen strafrecht is? Kennelijk is de gedachte dat wat een bestuursorgaan doet buiten het strafrecht valt, omdat strafrecht is wat de strafrechter doet. Dat echter is, naar ik heb betoogd, een achterhaald gedachtengoed. Het verschil in actoren vormt geen basis meer voor een bevredigend onderscheid tussen strafrecht en bestuursrecht. De straf wordt er niet anders van als zij niet door de rechter wordt opgelegd. Een bestursorgaan kan daarom bij de oplegging van een boete 'gewoon' de regels van het strafrecht toepassen, net zoals de strafrechter gewoon regels van civiel recht toepast als hij moet oordelen over de vordering van de benadeelde partij. ${ }^{79}$

Zelfs de Centrale Raad van Beroep lijkt het standpunt in te nemen dat punitieve bestuursrechtelijke sancties vallen onder het strafrecht in ruime zin. ${ }^{80}$ In een uitspraak van 5 april $2002^{81}$ heeft de Centrale Raad immers het volgende overwogen:

'Daarnaast merkt hij (de raad [toevoeging KA]) nog op dat het bestuursprocesrecht zijn eigen bepalingen en leerstukken kent, die zijn toegespitst op de eigen aard van de bestuurs(proces)rechtelijke verhoudingen tussen partijen. Het strafprocesrecht - zijn bepalingen en leerstukken - is niet (rechtstreeks) van kracht binnen de door het bestuursrecht en bestuursprocesrecht geregelde verhoudingen, tenzij een bepaalde bestuurs(proces)rechtelijke verhouding tussen partijen een zo sterke overeenkomst vertoont met de straf(proces)rechtelijke verhoudingen dat op basis van internationaal-rechtelijke bepalingen, dan wel algemeen-rechtelijke leerstukken, die straf(proces)rechtelijke bepalingen of leerstukken van toepassing zijn te achten.'

Uit het vervolg van de uitspraak volgt dat een dergelijke situatie zich voordoet als het in de bestuursrechtelijke procedure centraal staande besluit is aan te merken als een 'criminal charge' in de zin van artikel 6 EVRM. $^{82}$

77 Michels a.w. 1963 , p. 30 .

78 Corstens a.w. 2000, p. I 187: 'Een bestuurlijke boete is nu eenmaal matericel cen strafsanctic, zodat de grondbeginselen van het straf- en strafprocesrecht moeten worden gerespecteerd.' Vgl. voorts, in dezelfde zin, Rogier a.w. 2001 , p. 10.

79 Knigge a.w. 2000 , p. 95.

80 Bovendien lijkt ook de Hoge Raad (impliciet) te erkennen dat er sprake is van een strafrecht in ruime zin. Zie in dit kader: HR 26 oktober 1999, NJ 2000, 240 (Police Dog) m. nt. Knigge.

81 CRvB 5 april 2002, JB 2002/173.

82 Zoals hiervoor reeds is aangegeven geldt ten aanzien van de meeste punitieve sancties dat zijn vallen onder het 'criminal charge'-begrip zoals dat door het EHRM is uitgewerkt. De oplegging van een bestuurlijke boete kan gekwalificeerd worden als een 'criminal charge'. 
Anders dan bijvoorbeeld Corstens, Knigge en de Centrale Raad lijkt de werkgroep 'Sancties in de sociale zekerheid' in het rapport 'Sancties in de sociale zekerheid: bestuursstrafrecht of strafrechtelijk bestuursrecht? $?^{83}$ uit te gaan van een minder vergaand standpunt. Het volgende wordt betoogd:

\begin{abstract}
'Al met al is het beeld van het sanctierecht complexer geworden dan - zeg - tien jas geleden: op de lijn tussen sancties die als typisch bestuursrechtelijk (resp. typisch reparatoir) zijn asn te merken aan de ene kant en aan de andere kant sancties met een evident strafrechtelijk karakter (zij het opgenomen in bestuursrechtelijke wetgeving) is er kennelijk sprake van een tussencategorie. Voor deze tussencategorie - aan te duiden als criminal charges - geldt dat op deze sancties of maatregelen weliswaar niet zonder meer de beginselen en de watarborgen van het strafrecht van toepassing zijn, maar dat de vereiste mate van aanwezigheid van extra waarborgen voor de 'verdachte' wel dicht kan aanleunen tegen hetgeen op strafrechtelijk gebied gebruikelijk is. ${ }^{84}$
\end{abstract}

Onverkorte toepassing van het strafrecht zoals door Knigge bepleit acht de werkgroep Riphagen dus niet noodzakelijk. Ik deel die mening tot op zekere hoogte. ${ }^{85}$ Desalniettemin kan aan de door Michels, Corstens en Knigge voorgestane, en door mij onderschreven, opvatting, dat punitieve bestuursrechtelijke sancties deel uit maken van het strafrecht in ruimere zin, een belangrijke consequentie verbonden worden. Namelijk de consequentie dat bij de oplegging van punitieve bestuursrechtelijke sancties tenminste de grondslagen van het (nationale) straf(proces)recht door het sanctionerende bestuursorgaan in acht moeten worden genomen. ${ }^{86}$ Veel problemen die momenteel spelen in het bestuursstrafrecht, en die ook hun weerslag vinden in de boeteregeling uit het Voorontwerp van de vierde tranche van de $A w^{87}$, zouden op deze wijze opgelost kunnen worden. In dit kader dient opgemerkt te worden dat het positieve straf(proces)recht echter niet onverkort en tot in de details toegepast kan worden bij de oplegging van punitieve bestuursrechtelijke sancties door het bestuursorgaan. Een nadere wettelijke uitwerking zou moeten plaatsvinden. Later in dit werk zal ik op het hiervoor gestelde nog terug komen.

\title{
Andere (onderscheidende) criteria
}

In de literatuur wordt wel betoogd dat de term 'punitief weinig verhelderend is. ${ }^{88}$ Hartmann en Van Russen Groen delen die mening. Teneinde de vraag te beantwoorden

Sancties in de sociale zekerheid: bestuursstrafrecht of strafrechtelijk bestuursrecht?, rapport opgesteld door de werkgroep 'Sancties in de sociale zekerheid' onder voorzitterschap van J. Riphagen, Kluwer, Deventer 1994.

84 Riphagen a.w. 1994, p. 69.

85 Later in dit boek kom ik daar nog op terug.

86 Daarbij dient gedacht te worden aan essentiẻle straf(proces)rechtelijke regels en beginselen zoals; geen straf zonder schuld, samenloopregelingen, het ne bis in idem-beginsel, het nemo tenetur-beginsel, het legaliteitsbeginsel, het lex certa-vereiste, enz.

87 Zie hoofdstuk vier. Vgl. voorts: C.L.G.F.H. Albers, De bestuurlijke boete. Magische lijn of hellend vlak?, JBplus 2000, p. 138-152 en C.L.G.F.H. Albers en R.J.N. Schlossels, De bestuurlijke boete: een koekoeksei in het bestuursprocesrecht?, NTB 2002/7 p. 187-198.

88 Zie in dit kader onder andere Hartmann en Van Russen Groen a.w. 1998, p. $82-83$ en J.F.L. Roording, Sanctierecht in de belastingen en de sociale zekerheid (diss.Nijmegen), Ars Aequi Libri, Nijmegen 1994, p. 28. 
of er sprake is van een 'criminal charge' in de zin van artikel 6 van het $E$ RM ${ }^{89}$ vragen Hartmann en Van Russen Groen zich daarom niet af op de sanctie punitief van aard is. Zij maken, ter beantwoording van die vraag, een onderscheid tussen een originaire en een secundaire rechtsbetrekking. De originaire rechtsbetrekking is volgens Hartmann en Van Russen Groen: '...een op een wettelijk voorschrift gebaseerde verhouding tussen overheid en burger, die bestaat uit wederzijdse rechten en verplichtingen. ${ }^{.90}$ Ten aanzien van de secundaire rechtsbetrekking stellen zij:

'De overheid kan echter in sommige gevallen besluiten de burger een verplichting op te leggen die niet de nakoming van een verplichting uit de originaire rechtsbetrekking beoogt te bewerkstelligen. Een dergelijke verplichting strekt verder dan de verplichtingen die uit de originaire rechtsbetrekking volgen en beoogt de burger in te scherpen dat de schending van het onderliggende wettelijk voorschrift hem te verwijten is. Door het opleggen van een dergelijke verplichting wordt door de overheid een tweede, een secundaire rechtsbetrekking geschapen. Dergelijke verplichtingen, die bestaan binnen een secundaire rechtsbetrekking zijn op te vatten als sancties die vallen onder het begrip 'criminal charge' in de zin van artikel 6 EVRM. ${ }^{91}$

Een en ander komt er op neer dat de sanctie-oplegging aangemerkt moet worden als een 'criminal charge' als de sanctie verder gaat dan de te vergoeden schade of indien de sanctie uitgaat boven hetgeen verschuldigd is op grond van een reeds bestaande onderliggende betalingsverplichting. ${ }^{92}$ Is dat het geval dan creëert de overheid een tweede, op de originaire rechtsbetrekking gebaseerde, rechtsbetrekking, door Hartmann en Van Russen Groen de secundaire rechtsbetrekking genoemd.

Het door Hartmann en Van Russen Groen weergegeven onderscheid tussen sancties die binnen de originaire rechtsbetrekking worden opgelegd en sancties die een nieuwe, secundaire, rechtsbetrekking creëren lijkt in veel gevallen tevens dienst te kunnen doen als onderscheidend criterium bij reparatoire en punitieve sancties. Bovendien lijken Hartmann en van Russen Groen in hun voorlopige conclusie weer terug te grijpen naar laatstgenoemd onderscheid getuige de hierna weergegeven passage:

'Uit het voorgaande volgt dat een sanctie onder het begrip 'criminal charge' valt indien de sanctie niet gericht is op het ongedaan maken van een onrechtmatige, dan wel het herstellen van een rechtmatige situatie, maar verder gaat dan de te vergoeden schade of uitgaat boven hetgeen verschuldigd is op grond van de reeds bestaande onderliggende betalingsverplichting. De sanctie-oplegging krijgt daardoor een leedtoevoegend karakter [curs. KA] ${ }^{93}$

89 Zoals later in dit boek nog zal blijken is namelijk het punitieve karakter van een sanctie (in hoge mate) bepalend voor de vraag of er sprake is van een 'criminal charge' in de zin van artikel 6 van het EVRM.

90 Hartmann en Van Russen Groen a.w. 1998, p. 84. Zie ook W.G. Vegting, Het algemeen Nederlands administratiefrecht, eerste deel, N. Samsom N.V., Alphen aan den Rijn, 1954, p. 414.

91 Hartmann en Van Russen Groen a.w. 1998, p. 84-85.

92 Hartmann en Van Russen Groen a.w. 1998, p. 85.

93 Hartmann en Van Russen Groen a.w. 1998, p. 85. Zie in deze zin ook: P.M. van Russen Groen, Rechtsbescherming in het bestuursstrafrecht (diss. EUR), Gouda Quint 1998, p. 7-8. Ook Van Russen Groen gebruikt woorden als: 'ter vaststelling of een sanctie 'bestraffend' is, (...)' en 'De sanctieoplegging krijgt daardoor een leedtoevoegend karakter.' Mijns inziens komen auteurs hiermee toch weer terug op het welhaast 'traditionele' onderscheid tussen reparatoire en punitieve sancties. 
Zie ik het goed dan benaderen Hartmann en van Russen Groen hiermee Duk's visie zeer nauw. ${ }^{94}$ Duk heeft immers het volgende gesteld:

'- Een sanctie noem ik 'reparatoir', als met de toepassing daarvan uitsluitend wordt beoogd: hetzij bewerkstelliging of herstel van de toestand die zou zijn ingetreden, dan wel blijven bestaan, zo de overtreding (waarop de sanctie reageert) niet was begaan, hetzij benadering van de toestand door compensatie (zoals vergoeding van de aangerichte schade). - Alle andere sancties zijn, in de hier gevolgde terminologie, 'retributief.' 95

Met het onderscheid tussen de originaire en de secundaire rechtsbetrekking lijken Hartmann en Van Russen Groen derhalve, gelet op de hierboven aangehaalde passage uit hun dissertatie, weliswaar ongewild, tóch terug te grijpen naar het onderscheid reparatoir - retributief (ofwel punitief).

Zoals later in dit hoofdstuk nog zal blijken gaat de gelijkenis tussen het ontstaan van een secundaire rechtsbetrekking en de kwalificatie van een sanctie als punitieve sanctie echter niet in alle gevallen op. Er zijn sancties die volgens Hartmann en Van Russen Groen geen secundaire rechtsbetrekking in het leven roepen maar die mijns inziens toch duidelijk leedtoevoegend zijn. In dit kader kan gewezen worden op de intrekking van een begunstigende beschikking die door Hartmann en Van Russen Groen niet: wordt aangemerkt als een 'criminal charge' omdat er in het kader van de toepassing van deze sanctie geen secundaire rechtsbetrekking wordt geconstitueerd. ${ }^{96}$ Ondanks het feit dat er in die situatie, op basis van de door Hartmann en Van Russen Groen gevolgde redenering, geen sprake is van het ontstaan van een secundaire rechtsbetrekking kan er mijns inziens toch zeer wel sprake zijn van een punitieve bestuursrechtelijke sanctie ${ }^{97}$ en daarmee van een 'criminal charge'. 98

Naast het door Hartmann en Van Russen Groen gemaakte onderscheid tussen de originaire en de secundaire rechtsbetrekking zijn nog andere criteria denkbaar ter onderscheiding van verschillende soorten bestuursrechtelijke sancties. Hazewindus wijst in zijn proefschrift op een aantal, in de literatuur aangedragen, indelingscriteria. Veelal gaat het om indelingen die in wezen een variant zijn op het onderscheid tussen punitieve en reparatoire sancties. ${ }^{99}$ In feite wordt voor genoemd onderscheid slechts een andere terminologie gebruikt. Het gaat dan bijvoorbeeld om het onderscheid tussen 'personele administratieve sancties' en 'situatieve administratieve sancties', 'eigenlijke administratieve sancties' en 'oneigenlijke administratieve sancties', en 'retributieve' en 'reparatoire sancties'. De aard van het onderscheid tussen genoemde sancties wijkt mijns inziens niet (wezenlijk) af van het onderscheid tussen punitieve en reparatoire sancties.

Vgi. Duk a.w. 1988, p. 105-106.

Vgl. Duk a.w. 1988, p. 105-106.

Hartmann en Van Russen Groen a.w. 1998, p. 92.

Later in deze paragraaf zal ik daar nog op terug komen.

Daarbij moet echter niet uit het oog worden verloren dat het EHRM het begrip 'criminal charge' autonoom uitlegt. Ten aanzien van sancties die op basis van de door mij aangereikte definitie van de term 'punitief' als punitieve sanctie aangemerkt zouden moeten worden zou het EHRM kunnen concluderen dat deze niet zijn aan te merken als 'criminal charge'.

Hazewindus aw. 1994, p. 20-24. 
Naast varianten op het onderscheid tussen punitieve en reparatoire sancties zijn ook andere indelingen mogelijk. Hazewindus wijst bijvoorbeeld op het, in de literatuur gemaakte, onderscheid tussen verplichte en facultatieve sancties. ${ }^{100}$ Zelf oppert Hazewindus aarzelend dat misschien onderscheiden zou kunnen worden tussen sancties die een zware inbreuk maken op iemands belang en sancties die een mindere zware inbreuk maken op dat belang. ${ }^{101}$ Hoe zwaarder de inbreuk van de sanctie op iemands rechtsbelang is hoe meer waarborgen in het kader van de rechtsbescherming zouden moeten gelden volgens Hazewindus. Hij komt echter tot de conclusie dat een dergelijk onderscheid op procedureel gebied niet (goed) uitvoerbaar is. ${ }^{102}$

\section{Reparatoir - punitief: géén scherp onderscheid}

Hoewel derhalve wel wat af te dingen valt op het onderscheid tussen punitieve en reparatoire sancties wordt meestal toch vastgehouden aan dit onderscheid. Ook ik zal dat in dit boek onderscheiden tussen reparatoire en punitieve sancties, al is genoemd onderscheid niet altijd eenvoudig te maken bij gebreke aan heldere 'indelingscriteria'. Een tweetal redenen ligt aan deze keuze ten grondslag. Ten eerste wordt genoemd onderscheid in de literatuur vrijwel altijd gehanteerd. In dit kader kan bijvoorbeeld gewezen worden op, Hazewindus ${ }^{103}$, Lenos ${ }^{104}$ en Michiels ${ }^{105}$ die allen het onderscheid tussen punitieve en reparatoire bestuursrechtelijke sancties maken. Bovendien wordt dit onderscheid ook gehanteerd in het Voorontwerp van de vierde tranche van de Awb dat in hoofdstuk vier van dit boek nog uitvoerig aan de orde zal komen. Daarbij moet wel worden opgemerkt dat de commissie Scheltema in het Voorontwerp reparatoire sancties aanduidt als 'herstelsancties'. Uit de toelichting bij het Voorontwerp blijkt echter dat dit slechts een definitiekwestie is. ${ }^{106}$ Met de term 'herstelsanctie' doelt de commissie Scheltema op de sancties die in de literatuur bekend zijn onder de naam reparatoire sancties.

100 Hazewindus a.w. 1994, p. 23. Genoemd onderscheid ziet op een indeling van bestuursrechtelijke sancties in gebonden sanctiebevoegdheden en beleidsvrije sanctiebevoegdheden. M.a.w. is het bestuursorgaan op basis van de wettelijke regeling verplicht een sanctie op te leggen of heeft het bestuursorgaan de ruimte om zelf (aan de hand van een belangenafweging) te bepalen of er gesanctioneerd moet worden.

Hazewindus a.w. 1994, p. 94-95.

102 Hazewindus a.w. 1994, p. 95.

103 Hazewindus a.w. 1994 , p. 25 , p. $95-96$, en p. $263-264$. Hazewindus onderscheidt overigens tussen punitieve en situatieve administratieve sancties omdat de term situatieve sanctie in zijn ogen zuiverder is dan de term reparatoire sanctie. Zoals hij zelf ook stelt betreft dit slechts een terminologische kwestie (zie p. 96).

104 Lenos a.w. 1998, p. 6 en p. 22-23.

105 F.C.M.A. Michiels, Bestuurlijke handhaving in ontwikkeling, in Handhaving van het bestuursrecht, VAR-Reeks no. 114, Samson H.D. Tjeenk Willink, Alphen aan den Rijn, 1995, p. 51. Zie voorts: Rogier a.w. 1992, p. 32, Oostenbrink a.w. 1967, p. 64, en Duk a.w. 1988, p. 105-106.

$106 \mathrm{Zie}$ de toelichting op het Voorontwerp p. 110: 'Bestuurlijke sancties worden doorgaans onderscheiden in reparatoire en punitieve sancties. Punitieve sancties zijn gericht op het bestraffen van de dader, repa. ratoire sancties - in dit wetsvoorstel aangeduid als herstelsancties - zijn gericht op het beëindigen of ongedaan maken van de overtreding of de gevolgen daarvan, dan wel het voorkomen van herhaling.' 
Met het onderscheid tussen punitieve en reparatoire sancties is overigens nog geen volledige duidelijkheid geschapen. Sancties kunnen immers een deels reparatoir- deels punitief karakter hebben. ${ }^{107}$ In navolging van Duk ${ }^{108}$ ga ik er vanuit dat alle sancties die verder gaan dan voor herstel van de rechtmatige toestand nodig is ${ }^{109}$ (in ieder geval ten dele) een leedtoevoegend karakter hebben. ${ }^{110}$ Deze sancties zijn in mijn visie (deels) punitief. ${ }^{\text {II }}$ Daarmee is overigens niet gezegd dat deze sancties tevens in alle gevallen aan te merken zijn als 'criminal charge' in de zin van artikel 6 van het EVRM, hoewel daarvoor wel sterke indicaties aanwezig zijn in de rechtspraak van het Europese Hof voor de Rechten van de Mens. ${ }^{12}$

Daarnaast is voorts verdedigbaar dat niet op alle (deels) punitieve sancties zondermeer alle (essentiële) straf(proces)rechtelijke waarborgen van toepassing zouden moeten zijn. ${ }^{113}$ De omvang van het punitieve aspect van de sanctie zal per geval (kunnen) verschillen. ${ }^{114}$ Men zou dan ook kunnen verdedigen dan voor de oplegging van een hoofdzakelijk punitieve sanctie meer waarborgen in het kader van de rechtsbescherming zouden moeten gelden dan ten aanzien van minder punitieve sancties en sancties met een hoofdzakelijk reparatoir karakter. Gelet op problemen die dan ontstaan wat betreft de afbakening tussen de diverse bestuursrechtelijke sancties met een punitief gehalte lijkt mij een dergelijke gedifferentieerde toepassing van strafrechtelijke waarborgen

107 Zie hierover ook: M.W.C. Feteris, Fiscale administratieve sancties en het recht op een behoorlijk proces (diss. UvA), Kluwer, Deventer 1993, p. 17-18. Zie ter illustratie voorts de hiema behandelde bestuursrechtelijke sancties zoals de bestuurlijke dwangsom en het intrekken van een begunstigende beschikking.

108 Duk a.w. 1988, p. 105-106.

109 Of, indien herstel van de rechtmatige toestand niet meer mogelijk is, sancties die niet zuiver zien op compensatie van de door het onrechtmatig handelen veroorzaakte schade.

110 Hazewindus uit zich overigens kritisch over het in zijn ogen te zwart-witte onderscheid van Duk. Zie Hazewindus aw. 1994, p. 15. Zie voorts Roording a.w. 1994, p. 28. Op deze plaats wil ik nog het volgende opmerken. Alle sancties die verder reiken dan voor herstel van de rechtmatige toestand nodig is (reparatie-reparatoir) bezitten zoals gezegd naar mijn mening, een punitief karakter. Boetebedingen in civiele contracten hebben in feite vanuit die optiek ook een punitief karakter. Het strafrecht en/of de verdragsrechtelijke waarborgen hoeven daarop naar mijn mening niet van toepassing te zijn omdat er sprake is van een wederkerige rechtsbetrekking. De contractspartijen stemmen zelf in met het boetebeding. In het strafrecht en het bestuursstrafrecht is naar mijn mening. (in ieder geval met betrekking tot de oplegging van een (punitieve) sanctie), van een (op basis van wilsovereenstermming aangegane) wederkerige rechtshetrekking geen sprake. Derhalve dienen in het strafrecht en het bestuursstrafrecht wel de (extra) straf(proces)rechtelijke waarborgen te gelden. Zie in dit kader ook de bundel: Eenzijdig en wederkering, onder redactie van E.C.H.J. van der Linden en A.Q.C. Tak, Kluwer, Deventer 1995.

111 Zie in deze zin ook M.L.W.M. Viering. Het toepassingsbereik van artikel 6 EVRM (diss. KUN), W.E.J. Tjeenk Willink, Zwolle 1994, i.h.b. p. 163-164.

112 In hoofustuk drie zal uitvoerig ingegaan worden op het 'criminal charge'-begrip zoals dat tot op heden is ontwikkeld in de Straatsburgse jurisprudentie. Voor de bestuurlijke boete staat overigens vast dat deze gekwalificeerd moet worden als 'criminal charge'. Aangezien de bestuurtijke boete in dit boek centraal staat zal in dit boek verder niet (uitvoerig) geanalyseerd worden of andere bestuursrechtelijke sancties die naar mijn oordeel een punitief karakter hebben tevens aangemerkt moeten worden als 'criminal charge'.

113 Zie in dit kader ook Roording a.w. 1994, p. 28-29.

114 Zie in dit kader Hazewindus a.w. 1994, p. 16. 
niet gewenst en in ieder geval zeer onpraktisch. Derhalve houd ik het bij Duk's redenering. 115

\subsubsection{Vijf bestuursrechtelijke sancties (kritisch) beschouwd}

$\mathrm{Na}$ deze uiteenzetting met betrekking tot punitieve en reparatoire bestuursrechtelijke sancties en de relevantie van genoemd onderscheid volgt nu een beschrijving van vijf bestuursrechtelijke sancties. Aan de orde komen achtereenvolgens; de intrekking van een begunstigende beschikking (bij wijze van sanctie), het toepassen van bestuursdwang, het opleggen van een last onder dwangsom, de maatregel in het sociale zekerheidsrecht (en daarmee vergelijkbare sancties) en tenslotte de bestuurlijke boete. Per sanctie wordt tevens ingegaan op al dan niet punitieve karakter van de sanctie.

\subsubsection{3. a Intrekking van een begunstigende beschikking}

Een bestuursorgaan kan overgaan tot het intrekken van een begunstigende beschikking bij wijze van sanctie. ${ }^{116}$ Een taxivergunning zou bijvoorbeeld ingetrokken kunnen worden bij onbehoorlijk gedrag van de taxichauffeur tegenover zijn klanten. Een milieuvergunning bij overtreding van de voorschriften verbonden aan die vergunning. Volstrekt gebonden begunstigende beschikkingen kunnen doorgaans ${ }^{117}$ alleen ingetrokken worden voor zover dit op grond van de wettelijke regeling mogelijk is. ${ }^{118}$ Een uitzondering wordt echter gemaakt in het geval dat de begunstigende beschikking is verleend op basis van door de aanvrager verschafte onjuiste of onvolledige informatie. ${ }^{119}$ Dan mag een gebonden begunstigende beschikking wél worden ingetrokken ook als dat op grond van de wettelijke regeling niet expliciet is toegestaan. Indien de (verlening van de) begunstigende beschikking gebaseerd is op een (beleids)vrije bevoegdheid is intrekking als sanctie zelfs mogelijk als een uitdrukkelijke wettelijke grondslag daartoe in de wettelijke regeling ontbreekt.

Ten aanzien van de intrekking van een begunstigende beschikking bij wijze van sancitie kan niet zonder meer gezegd worden of deze is aan te merken als een reparatoire of een punitieve sanctie. Dit zal van geval tot geval moeten worden vastgesteld. In dit kader is

115 Duk a.w. 1988, p. 105-106.

116 Deze wijze van intrekking staat hier centraal. Op andere wijzen van intrekking zal hier niet ingegaan worden. Desalniettemin moet niet uit het $00 \mathrm{~g}$ verloren worden dat er ook diverse andere vormen van intrekking van een begunstigende beschikking bestaan die niet gekwalificeerd kunnen worden als sanctie. Denk bijv. aan de intrekking van een WW-uitkering omdat iemand inmiddels weer in loondienst werkzaam is (zijn recht op de uitkering is dan immers komen te vervallen). Waar in deze paragraaf (kortheidshalve) gesproken wordt van de intrekking van een begunstigende beschikking wordt gedoeld op intrekking van een begunstigende beschikking bij wijze van sanctie.

117 Zie ABRS 30 december 1999, AB 2000, 47 m. nt. M. Schreuder-Vlasblom (intrekking wapenverlof). In die zaak werd naast de wettelijke intrekkingsgronden ook een ongeschreven intrekkingsgrond erkend. In dit kader moet niet uit het $00 \mathrm{~g}$ verloren worden dat in het de zaak 'intrekking wapenverlof' niet ging om intrekking van een begunstigende beschikking bij wijze van punitieve sanctie. Indien de intrekking van een begunstigende beschikking als punitieve sanctie aangemerkt moet worden dient de intrekking in ieder geval op grond van artikel 7 EVRM gebasecrd te zijn op een specifieke, voldoende duidelijke wettelijke grondslag.

118 Zie Van Wijk/KonijnenbeltVVan Male a.w. 1999, p. 499 en verder.

119 Zie Van Wijk/KonijnenbeltVan Male a.w. 1999, p. 427 en verder. 
relevant of met de intrekking van de begunstigende beschikking slechts herstel van de rechtmatige toestand wordt beoogd of dat de intrekking verder gaat dan voor herstel van de rechtmatige toestand noodzakelijk is waardoor tevens sprake is van leedtoevoeging. Vegting signaleert reeds in 1954 dat er, volgens bepaalde juristen, bij de intrekking van een vergunning sprake is van de oplegging van een sanctie die overgelaten zou moeten worden aan de strafrechter:

'De ernstige ingreep in de belangen van de betrokkenen, welke deze sancties, gelijk ook die van intrekking van een vergunning, wanneer daarvan de bedrijfsuitoefening afhangt, betekent, maakt, dat sommigen - overigens de noodzakelijkheid dezer sancties in de huidige maatschappij ten volle erkennend - hier of een scherp controlerende werkzaamheid van de rechter verlangen, ò zich zelfs de vraag stellen, of niet de beslissing over het intreden van zo gewichtige sancties, met name de intrekking van een vergunning tot bedrijfsuitoefening, overgelaten moet worden aan de strafrechter. ${ }^{120}$

Daarmee lijken de door Vegting aangehaalde juristen de intrekking van een dergelijke vergunning te zien als een punitieve sanctie. Ook Oostenbrink kwalificeert de intrekking van een begunstigende beschikking bij wijze van sanctie (afhankelijk van de omstandigheden van het geval) als een punitieve sanctie. ${ }^{121}$

De Afdeling Bestuursrechtspraak van de Raad van State (ABRS) merkt de intrekking van een begunstigende beschikking slechts in bepaalde gevallen aan als een punitieve sanctie. In een uitspraak van 4 juni $1996^{122}$ werd het intrekken van de erkenning tot het uitvoeren van APK-keuringen aangemerkt als een punitieve sanctie. Hetzelfde geldt, blijkens een uitspraak van 12 oktober 2000, voor de (tijdelijke) intrekking van een exploitatievergunning en het schrappen van de lijst van inrichtingen waar de verkoop van softdrugs wordt gedoogd, van een coffeeshop ${ }^{123} \mathrm{en}$, blijkens een uitspraak van 30 maart 2001, voor de intrekking van een vergunning voor een vaste standplaats op de markt voor de duur van één week, vanwege het met een metalen stang van een kledingrek toebrengen van lichamelijk letsel door de standplaatshouder aan een andere persoon. ${ }^{124}$

In een uitspraak van 8 februari $2000^{125}$ kwam de ABRS echter tot een andere conclusie. In die zaak oordeelde de ABRS dat de volledige intrekking van een subsidie géén punitieve sanctie betrof. ${ }^{126}$ In de betreffende zaak ging het om volledige intrekking van

120 Zie: Vegting a.w. 1954, p. 415.

121 Oostenbrink a.w. 1967 p. 19.

122. ABRS 4 juni 1996, JB 1996/172, m. nt. E. v.d. Linden (Huisman APK) zie voorts: ABRS 15 februari 2001, JB 2001/88 m. nt. C.L.G.F.H. Albers.

123 ABRS 12 oktober 2000, JB 2000/328 (Coffeeshop Amsterdam).

124 ABRS 30 maan 2001, JB 2001/129 (Standplaatsvergunning Amsterdam) m. nt. C.L.G.F.H. Albers.

!25 ABRS 8 februari 2000, JB 2000/91 m. nt. C.L.G.F.H. Albers, AB 2001, $118 \mathrm{~m}$. nt. L. Damen (Haagse woningverbeteringssubsidies).

126 Haaks hierop staat de opvatting van het kabinet in het Kabinetsstandpunt inzake het toezicht en het publiek domein, Kamerstukken II, 2001/2002, 26604 en 26 345, nr. 14. Het kabinet stelt in genoemd standpunt dat het intrekken van een begunstigende beschikking (bij wijze van sanctie), zoals bijvoorbeeld intrekking van een vergunning, ontheffing of subsidie, aangemerkt moet worden als een punitieve sanctie die primair ziet op bestraffing van de overtreder (Vgl. Kabinetsstandpunt inzake het toezicht en het publiek domein, p. 18-19). 
een subsidie (zonder wettelijke grondslag) terwijl, op basis van verstrekking van onjuiste gegevens, slechts eenderde deel van de subsidie daadwerkelijk ten onrechte was ontvangen. De volledige intrekking van de subsidie is in die zaak door de Afdeling Bestuursrechtspraak mijns inziens ten onrechte aangemerkt als een reparatoire sanctie. Damen neemt, in zijn noot onder genoemde uitspraak, een zelfde standpunt in. ${ }^{127}$ Door ook over te gaan tot intrekking van het deel van de subsidie dat terecht aan de aanvrager is verstrekt kan slechts leedtoevoeging worden beoogd. Ook Rogier is van mening dat in een situatie zoals hierboven aan de orde volledige intrekking van een subsidie moet worden aangemerkt als punitieve sanctie. ${ }^{128}$

Hartmann en Van Russen Groen komen tot een andere conclusie. Zij gaan er van uit dat er bij de intrekking van een begunstigende beschikking bij wijze van sanctie geen secundaire rechtsbetrekking ontstaat en dat er derhalve ook geen sprake is van een 'criminal charge'. ${ }^{129}$ Ik deel de mening van Hartmann en Van Russen Groen niet. Bepaalde vormen van intrekking van een begunstigende beschikking bij wijze van sanctie beogen mijns inziens duidelijk leedtoevoeging omdat de gevolgen van de sanctie verder strekken dan voor herstel van de rechtmatige toestand nodig is. Is dit het geval dan dient intrekking van een begunstigende beschikking aangemerkt te worden als een punitieve sanctie en dientengevolge (doorgaans) als 'criminal charge'. Zelfs de ABRS neemt een ruimer standpunt in dan Hartmann en Van Russen Groen in hun dissertatie. Bepaalde vormen van intrekking van een begunstigende beschikking bij wijze van sanctie worden immers door de Afdeling wél als punitieve sanctie gekwalificeerd.

Het ontstaan van een secundaire rechtsbetrekking kan dan ook niet worden gezien als doorslaggevende factor voor de kwalificatie van een sanctie als (punitieve sanctie én) 'criminal charge'. Dit kan overigens ook worden afgeleid uit de dissertatie van Hartmann en Van Russen Groen. Zij merken namelijk de maatregel in het sociale zekerheidsrecht (onder bepaalde omstandigheden) wél aan als punitieve sanctie terwijl mijns inziens ook daar geen secundaire rechtsbetrekking ontstaat. ${ }^{130}$ De maatregel in het sociale zekerheidsrecht, die doorgaans bestaat uit gehele of gedeeltelijke, tijdelijke of blijvende weigering van een uitkering, vertoont mijns inziens dermate veel overeenkomsten met intrekking van een begunstigende beschikking dat het door Hartmann en Van Russen Groen gemaakte onderscheid met betrekking tot het karakter van beide sancties naar mijn oordeel geen hout snijdt.

De intrekking van een begunstigende beschikking dient derhalve, voor zover deze leedtoevoeging behelst, aangemerkt te worden als punitieve sanctie, en daarmee (doorgaans ook) als 'criminal charge', ongeacht of er een secundaire rechtsbetrekking ontstaat of niet. Als de intrekking van de begunstigende beschikking moet worden aange-

127 Zie voorts: L.J.A. Damen, Van algemene rechtsbeginselen en gemene rechtsleren, in de bundel De autonomie van het bestuursrecht, onder redactie van H. Koning en E.J.M. Crombag, Boom juridische uitgevers 2001 , p. 57-71.

128 Zie hierover: L.J.J. Rogier, De bestuurlijke boete in de Algemene wet bestuursrecht?, in de bundel: Opstellen over bestuursstrafrecht, onder redactie van H. de Doelder en L.J.J. Rogier, SI-EUR-recks, deel 3, Gouda Quint, Amhem 1994, p. 157-172, i.h.b. p. 160-161.

129 Hartmann en Van Russen Groen aw. 1998, p. 92.

130 Hartmann en Van Russen Groen a.w. 1998, p. 94-95. Zie in dit kader ook het Voorontwerp van de vierde tranche Awb, a.w. 1999, p. 120-121. 
merkt als een punitieve sanctie (én 'criminal charge') betekent dit dat de verdragsrechtelijke waarborgen bij intrekking in acht moeten worden genomen. Daarnaast moet de bestuursrechter indringender toetsen aan het (in artikel 3:4 lid 2 Awb neergelegde) evenredigheidsbeginsel.

\subsubsection{3.b Bestuursdwang}

In afdeling 5.3 van de $A w b$ is een algemene regeling opgenomen met betrekking tot het toepassen van bestuursdwang door een (daartoe bevoegd) bestuursorgaan. In artikel 5:21 Awb wordt bestuursdwang als volgt gedefinieerd: 'Het door feitelijk handelen door of vanwege een bestuursorgaan optreden tegen hetgeen in strijd met bij of krachtens enig wettelijk voorschrift gestelde verplichtingen is of wordt gedaan, gehouden of nagelaten. ${ }^{131}$ Bestuursdwang ziet derhalve op het herstellen van een rechtmatige toestand. Daarbij kan gedacht worden aan het afbreken van een illegaal gebouwd bouwwerk.

De bevoegdheid tot het toepassen van bestuursdwang bestaat alleen indien zij bij of krachtens de wet is toegekend (artikel 5:22 Awb). Gewezen kan worden op artikel 125 lid 1 Gemeentewet waarin de bevoegdheid tot toepassing van bestuursdwang voor het gemeentebestuur is neergelegd. In veel wetten is de bevoegdheid tot het opleggen van bestuursdwang geformuleerd als een discretionaire bevoegdheid. Derhalve is een bestuursorgaan in beginsel niet verplicht tot het toepassen van bestuursdwang. Aan de beslissing van het bestuursorgaan om al dan niet over te gaan tot het toepassen van bestuursdwang dient een belangenafweging ten grondslag te liggen (artikel 3:4 lid 1 Awb).

Uit recente rechtspraak kan worden afgeleid dat (met name in het ruimtelijk bestuursrecht) als hoofdregel geldt dat een bestuursorgaan een 'beginselplicht' tot handhaving heeft. ${ }^{132}$ In essentie komt genoemde beginselplicht er op neer dat een bestuursorgaan in beginsel gehouden is handhavend op te treden als een belanghebbende derde bij het bestuursorgaan daartoe een verzoek heeft ingediend. ${ }^{133}$ Van handhavend optreden kan

131 In het Voorontwerp van de vierde tranche treffen we een gewijzigde definitie aan van de term 'bestuursdwang'. Het nieuwe artikel 5:21 Awb luidt als volgt: 'Onder bestuursdwang wordt verstaan: de herstelsanctie, inhoudende het door feitelijk handelen optreden tegen een overtreding.' Zie voor een uitvoerige beschrijving van de bevoegdheid tot het toepassen van bestuursdwang ook: P.P.J. van Buuren, G.T.J.M. Jurgens, en F.C.M.A. Michiels, Bestuursdwang en dwangsom, tweede druk, W.E.J. Tjeenk Willink, Deventer 1999.

132 Zie hierover: ABRS 2 februari 1998, AB 1998, 181 m. nt. F. Michiels (Lisse). Hoewel in de zomer van 1999 werd gesuggereerd dat de 'beginselplicht'-jurisprudentie achterhaald zou zijn lijkt de Afdeling Bestuursrechtspraak nog steeds vast te houden aan de beginselplicht tot handhaving. Zie in dit kader: ABRS 13 juli 1999, AB 2000, 140 (Crematorium Bilthoven-Noord) en ABRS 15 juli 1999, AB 2000, 141 ('Bourgondische Hoeve' Elsloo) m. nt. Jurgens en ABRS 11 september 2000, JB 2000/299 m. nt. C.L.G.F.H. Albers (Tuincentrum Milder). Zie voorts: F.C.M.A. Michiels, Belangenafweging bij sanctiebesluiten, Ars Aequi 2000, nr. 2, p. 111-117 en F.R. Vermeer, De beginselplicht tot handhaving en de ruimte om te gedogen, JBplus 2001, p. 76-85.

133 Zelfs als er geen verzoek tot handhaving is gedaan door een belanghebbende derde lijkt de ABRS uit te gaan van een beginselplicht tot handhaving. Vgl. ABRS 3 april 2000, AB 2000, 406 (Kampwinkel Garderen) m. nt. Struiksma, ABRS 10 juli 2001, AB 2001, $411 \mathrm{~m}$. nt. De Gier en ABRS 14 november 2001, JB 2002/3 (Stillegging bouwwerkzaamheden Steenbergen) m. nt. C.L.G.F.H. Albers. In deze drie zaken is er sprake van ambtshalve handhaving. Ook in dat kader overweegt de Afdeling dat slechts 
slechts worden afgezien als er sprake is van bijzondere omstandigheden of als er concreet zicht bestaat op legalisering van de onrechtmatige situatie.

Er moet een onderscheid worden gemaakt tussen de beslissing tot toepassing van bestuursdwang en de feitelijke toepassing van bestuursdwang. De beslissing tot toepassing van bestuursdwang wordt op schrift gesteld en is een beschikking (artikel 5:24 lid 1 Awb). Het toepassen van bestuursdwang is een feitelijk handelen. Bij de toepassing van bestuursdwang door of namens een bestuursorgaan zal overigens de nodige zorgvuldigheid betracht moeten worden zodat geen onnodige schade wordt veroorzaakt. ${ }^{1.44}$ Heeft naar het oordeel van degene ten aanzien waarvan bestuursdwang is toegepast de toepassing van bestuursdwang op een onzorgvuldige wijze plaatsgevonden dan staat voor hem de weg naar de burgerlijke rechter open. ${ }^{135}$ Degene ten aanzien waarvan bestuursdwang is toegepast moet dan wel aannemelijk kunnen maken dat er sprake is van een onrechtmatige overheidsdaad.

De overtreder is de kosten die verbonden zijn aan de toepassing van bestuursdwang verschuldigd, tenzij de kosten redelijkerwijze niet of niet geheel te zijnen laste behoren te komen, aldus het eerste lid van artikel 5:25 Awb. ${ }^{136}$

Het preventief toepassen van bestuursdwang is slechts mogelijk indien er sprake is van een klaarblijkelijk gevaar van een op zeer korte termijn te verwachten overtreding. Bovendien is het preventief toepassen van bestuursdwang, met het oog op artikel 3:4 lid $2 \mathrm{Awb}$, alleen toegestaan bij de meer emstige overtredingen. ${ }^{137}$ Deze laatste eis lijkt de latste tijd in de jurisprudentie overigens niet meer onverkort gesteld te worden. ${ }^{138}$ Wellicht meent de Afdeling hiermee te anticiperen op de in het Voorontwerp neerge-

in bijzondere gevallen van het bestuursorgaan kan worden verlangd dat het afziet van handhavend optreden tegen een illegale situatie.

134 Zie HR 3 april 1947, NJ 1947, 381 m. nt. E.M. Meijers (Loosdrechts Bootenhuis). De gemeente Loosdrecht had een illegaal gemeerd botenhuis niet verplaatst (naar een haven) maar afgebroken. De gemeente had echter volgens de Hoge Raad de moeite moeten nemen om het botenhuis weg te slepen en daarvoor een ligplaats moeten huren in de haven. Deze kosten konden immers op de overtreder verhaald worden. Het afbreken van het botenhuis leverde derhalve een onrechtmatige (overheids)daad op.

135 Men kan de beoordeling van schadeclaims inzake de feitelijke uitoefening van bestuursdwang via het zelfstandig schadebesluit onder de competentie van de bestuursrechter brengen door de formele connexiteitseis los te laten. Zie in dit kader: R.J.N. Schlössels, Het besluitbegrip: doos van Pandora of hoofd van Medusa?, NTB 2000, p. 1-13, i.h.b. p. 12.

136 Zie voor een geval waarbij de kosten niet ten laste van de overtreder behoorden te blijven ARRvS 9 december 1977, AB 1978, 76 m. nt. F.H. van den Burg (Faraomieren). De besmetting van een woning met faraomieren was niet te wijten aan de onderhoudstoestand of de bouwkundige toetstand van de woning, terwijl de reden voor het aanzeggen van bestuursdwang in overwegende mate was gelegen in het voorkomen van een uitbreiding van de ongedierteplaag naar andere woningen in de stad.

137 Zie hierover: ABRS 24 februari 1995, AB 1995, 527 m. nt. F. Michiels en VzABRS I februari 1999, AB 1999, $302 \mathrm{~m}$. nt. G. Jurgens waarin de Voorzitter van de Afdeling Bestuursrechtspraak het volgende heeft overwogen: 'Blijkens de jurisprudentie van de Afdeling (onder andere de uitspraak var de Afdeling van 4 september 1997, nr. H01.96.0240, AB 1997, 396) kan een dergelijk besluit tot het voorkomen van een daadwerkelijke overtreding slechts worden genomen indien sprake is van een klaarblijkelijk gevaar van een op zeer korte termijn te verwachten overtseding van een concreet bij of krachtens de wet gesteld voorschrift waardoor emstige schade zal ontstaan, en indien die overtreding in de beschikking kan worden omschreven met die mate van duidelijkheid die uit een oogpunt van rechtszekerheid ten aanzien van handhavingsbeschikkingen is vereist.'

$138 \mathrm{Vgl}$. O.m. ABRS 29 september 2000, JB $2000 / 304 \mathrm{~m}$. nt. C.L.G.F.H. Albers (Brandende oplegger), en ABRS 26 september 2001, AB 2002, 67 m. nt. F.R. Vermeer. 
legde regeling tot preventieve handhaving. In artikel 5.0.7 van het Voorontwerp lijkt de commissie Scheltema, in eerste opzicht, immers ook uit te gaan van minder strenge eisen teneinde over te kunnen gaan tot het preventief toepassen van bestuursdwang. Artikel 5.0.7 van het Voorontwerp luidt: 'Een herstelsanctie kan worden opgelegd zodra het gevaar voor de overtreding klaarblijkelijk dreigt.' Dit neemt echter, volgens de commissie Scheltema, niet weg dat het evenredigheidsbeginsel door het bestuursorgaan in acht moet worden genomen in het kader van preventieve handhaving. ${ }^{139}$ Het voorgaande brengt met zich dat (ook op basis van de in het Voorontwerp van de vierde tranche voorgestelde regeling) preventief optreden alleen bij de ernstigere overtredingen mogelijk is.

Het toepassen van bestuursdwang moet worden aangemerkt als en reparatoire sanctie. ${ }^{140}$ Het doel van genoemde sanctie is immers het ongedaan maken van een onrechtmatige toestand. Toch kan men zich afvragen of het afbreken van een illegaal gebouwd woonhuis in opdracht van een bestuursorgaan en het daarmee gepaard gaande kostenverhaal tenminste in bepaalde gevallen geen leedtoevoeging veroorzaken. Daarnaast bestaat nog de mogelijkheid dat in eerste instantie een dwangsom is opgelegd (en verbeurdverklaard) terwijl daarna nog bestuursdwang wordt toegepast inclusief kostenverhaal. ${ }^{141}$ Moet dan het opleggen van de dwangsom en/of het toepassen bestuursdwang (onder die omstandigheden) niet gekwalificeerd worden als punitieve sanctie? ? $^{142}$ Voorts kan gewezen worden op bestuursdwang in de vorm van sluiting van (bijvoorbeeld) een café (in verband met handel in harddrugs) ${ }^{143}$ Ook daarbij vraag ik me af of zonder meer gesproken kan worden van een reparatoire sanctie. In ieder geval lijkt het niet uitgesloten te zijn dat een in theorie als reparatoire sanctie bedoelde bestuursrechtelijke sanctie in de praktijk door een bestuursorgaan gebruikt (misbruikt) wordt als punitieve sanctie. ${ }^{144}$

Derhalve dient mijns inziens, zoals gezegd, de vraag of er sprake is van leedtoevoeging (en daarmee van een punitieve sanctie) beantwoord te worden aan de hand van een materieel criterium. Het doel van de sanctie zoals dat is weergegeven in (de wetgeschiedenis van) de wettelijke regeling is dan niet zonder meer doorslaggevend. Relevant is de vraag of de sanctie verder gaat dan herstel van de (on)rechtmatige toetstand vergt. Daarnaast is er sprake van leedtoevoeging als er een sanctie wordt opgelegd terwijl herstel van de rechtmatige toestand niet meer mogelijk is en deze sanctie niet slechts schadevergoeding (compensatie) behelst. Deze laatste situatie zou zich in het

139 Voorontwerp p. 115.

140 Michiels noemt bestuursdwang een 'directe sanctie'. Dit in tegenstelling tot de dwangsom en de bestuurlijke boete dit zijn volgens hem 'indirecte sancties'. Michiels a.w. 1995, p. 57-58.

141 Zie artikel 5:31 en 5:36 Awb.

142 Zie in dit kader ook: G. Knigge, De bestuurlijke boete als teken aan de wand, Milieu en Recht 1998, no 3 , p. $63-68$, p. 68 voetnoot 31 .

143 Zie: ABRS 15 juli 1996, AB 1996, $414 \mathrm{~m}$. nt. F. Michiels (Sluiting café 'De Windmolen') en ABRS 11 juni 1998, AB 998, $297 \mathrm{~m}$. nt. F. Michiels (Sluiting café 'Lindsay's Place').

144 Vgl. (m.b.t. de - door de wetgever - eveneens als reparatoire sanctie bedoelde dwangsom) ABRS 13 maart 2001, JB 2001/95 (Dwangsom Coberco) m. nt. C.L.G.F.H. Albers. 
kader van de toepassing van bestuursdwang bijvoorbeeld voor kunnen doen bij de sluiting van een café zoals hierboven weergegeven.

\subsubsection{C Dwangsom}

In afdeling 5.4 van de Awb is een regeling getroffen omtrent het opleggen van een last onder dwangsom door een (daartoe bevoegd) bestuursorgaan. Op grond van artikel 5:32 Awb kan een bestuursorgaan dat bevoegd is bestuursdwang toe te passen in de plaats daarvan aan de overtreder een last onder dwangsom opleggen. Genoemde last strekt er, volgens artikel 5:32, tweede lid Awb, toe de overtreding ongedaan te maken of verdere overtreding, dan wel herhaling van de overtreding, te voorkomen.

Het opleggen van een dwangsom is met name bij overtredingen die zich met enige regelmaat voordoen een meer geschikte sanctie dan het toepassen van bestuursdwang. Daarbij kan gedacht worden aan het regelmatig méér geluid produceren dan op grond van de voorschriften, behorende bij een milieuvergunning van een discotheek, is toegestaan. Het bevoegde bestuursorgaan kan dan in de dwangsombeschikking bepalen dat de eigenaar van de discotheek iedere keer dat hij het geluidsvoorschrift overtreedt een dwangsom verbeurt (artikel 5:32 lid $4 \mathrm{Awb}$ ).

Het preventief opleggen van een dwangsom is evenals het preventief toepassen van bestuursdwang slechts mogelijk indien er sprake is van een klaarblijkelijk gevaar van een op zeer korte termijn te verwachten ernstige overtreding. ${ }^{145}$

De Awb-wetgever gaat er zonder meer van uit dat het opleggen van een last onder dwangsom een reparatoire sanctie is. ${ }^{146}$ Ook Rikmenspoel is van mening dat de last onder dwangsom een reparatoir karakter heeft. ${ }^{1.97}$

Een aantal andere juristen gaat er van uit dat de oplegging van de last onder dwangsom als een reparatoire bestuursrechtelijke sanctie gekwalificeerd kan worden. Op het moment dat een opgelegde dwangsom verbeurd verklaard wordt moet er volgens deze juristen echter gesproken worden van een punitieve sanctie. Hazewindus, bijvoorbeeld, maakt het onderscheid tussen het opleggen van de last onder dwangsom en de verbeurdverklaring ervan. Hij meent dat het besluit tot het opleggen van de dwangsom een situatief (ofwel reparatoir) karakter kent, en dat de verbeurdverklaring gekenmerkt wordt door een punitief karakter. ${ }^{188}$ Een zelfde standpunt wordt ingenomen door Addink en Sluijs ${ }^{149}$, Rogier ${ }^{150}$, en Hartmann en van Russen Groen. ${ }^{151}$ Hartmann en Van

145 ABRS 4 september 1997, AB 1997, 396 m. nt. F. Michiels. Zie voorts: Rb. Maastricht 5 februari 2001, JB 200I/84 m. nt. C.L.G.F.H. Albers (In den Ouden Vogelstruys). De Maastrichtse rechtbank lijkt in laatstgenoemde zaak ten onrechte het standpunt ingenomen te hebben dat er sprake was van ecn preventief opgelegde last onder dwangsom.

146 Zie PG Awb III, pagina 380.

147 M.J.H.T. Rikmenspoel, De bestuurlijke boete: traditie, trend en toekomst. Gemeentestem no. 6990. 15 juli 1995. p. 321-324.

148 W.G.A. Hazewindus, De administratieve dwangsom: een situatieve en punitieve sanctic, NJB 1992, p. 1068-1072, p. 1068.

149 G.H. Addink en M.J. Sluijs, De Algemene wet bestuursrecht op scherp. NTB 1992, p. 33-45, p. 41 en verder.

150 Zie hierover: L.J.J. Rogier, a.w. 1994, De bestuurlijke boete in de Algemene wet bestuursrecht?, p. 159-160. Rogier spreekt overigens - m.i. ten onrechte - over de inning (i.p.v. verbeurverklaring) als 
Russen Groen komen (wederom) tot de kwalificatie, van de verbeurdverklaring (en inning) van de dwangsom als 'criminal charge' vanwege het feit dat er een secundaire rechtsbetrekking ontstaat. Zij stellen het volgende:

'De verbeurte en inning van de dwangsom kan slechts geschieden indien na de overtreding naar aanleiding waarvan de dwangsom is opgelegd, een andere, een tweede overtreding heeft plaatsgevonden. Hierdoor (curs. KA) behelst het doel van de verbeurte en invordering niet meer het ongedaan maken van een onrechtmatige, dan wel het herstellen van een rechtmatige situatie. Er wordt een secundaire rechtsbetrekking geconstitueerd die verder gaat dan de originaire rechtsbetrekking waarin de burger zich dient te houden aan de wettelijke regelgeving en die reeds bestond tussen de betrokken burger en de overheid. ${ }^{152}$

Hoewel Hartmann en van Russen Groen misschien gelijk hebben als zij stellen dat er een secundaire rechtsbetrekking ontstaat ten tijde van de verbeurte van de dwangsom is de hierboven weergegeven redenering mijns inziens niet geheel sluitend. Indien in het besluit tot oplegging van de last onder dwangsom de overtreder een termijn gesteld wordt om een bepaalde onrechtmatige situatie ongedaan te maken en de overtreder laat dat na, dan is er immers geen sprake van een tweede overtreding en daarmee, volgens de theorie van Hartmann en Van Russen Groen, niet van het ontstaan van een secundaire rechtsbetrekking (en dus ook niet van een 'criminal charge'). Desalniettemin zou de verbeurdverklaring óók dan punitief kunnen zijn. Bovendien hoeft de verbeurdverklaring en invordering van de dwangsom (na de tweede overtreding), anders dan genoemde auteurs lijken te suggereren, niet altijd punitief van aard te zijn. In bepaalde gevallen zou het immers zo kunnen zijn dat het verbeurde bedrag slechts toereikend is voor compensatie van de, door het onrechtmatige handelen, ontstane schade of voor herstel van de rechtmatige toestand.

De verbeurdverklaring (en de inning) van de dwangsom zal echter anders dan het kostenverhaal bij de toepassing van bestuursdwang, in bepaalde gevallen wél leiden tot een financiële belasting voor de overtreder die (aanzienlijk) groter is dat het bedrag dat het bestuursorgaan nodig zou hebben ter compensatie van het onrechtmatige handelen of herstel van de rechtmatige toestand. Dit lijkt ook het geval geweest te zijn in de zaak waarin de ABRS op 11 februari 2000 uitspraak heeft gedaan ${ }^{153}$, hoewel aan de hand van de gegevens in de Afdelingsuitspraak niet met zekerheid vastgesteld kan worden of de maximum dwangsom meer bedraagt dan nodig is ter compensatie van de door de normschending geleden schade. In de hierboven genoemde zaak was overtreding van een voorschrift uit de milieuvergunning reeds strafrechtelijk gesanctioneerd met een boete van $f 50.000$,- (waarvan $f 25.000$,- voorwaardelijk). Vervolgens werd ten aanzien van diezelfde overtreding een dwangsom opgelegd van $f$ 25.000,- per overtreding tot een maximum van $f 500.000,-$. Aangezien het volgens de Afdeling Bestuursrechtspraak ging om andersoortige sancties, namelijk een punitieve sanctie (de strafrechte-

punitieve sanctie). Vgl. A. de Moor-van Vugt, Maten en gewichten, Het evenredigheidsbeginsel in Europees perspectief (diss. KUB), Zwolle 1995, p. 186.

151 Hartmann en Van Russen Groen a.w. 1998, p. 89 en 90.

152 Hartmann en Van Russen Groen a.w. 1998, p. 89 en 90.

153 ABRS 11 februari 2000, JB 2000/75, m. nt. C.L.G.F.H. Albers. 
lijke boete) en een reparatoire sanctie (de bestuursrechtelijke dwangsom), was er, zo meende althans de Afdeling Bestuursrechtspraak, geen sprake van schending van het ne bis in idem-beginsel of het una via-beginsel.

In dit kader is bovendien een uitspraak van de Afdeling Bestuursrechtspraak van 13 maart 2001 vermeldenswaardig. ${ }^{154}$ In die uitspraak heeft de Afdeling het standpunt ingenomen dat de hoogte van de (maximaal te verbeuren) dwangsom niet mag worden afgestemd op, door de overtreder (in verband met uitgestelde investeringen om de zuivering van afvalwater beter (lees: rechtmatig) te laten verlopen), behaald financieel voordeel. Indien het reeds behaalde financieel voordeel ten grondslag wordt gelegd aan de hoogte van de dwangsom krijgt de dwangsom volgens de Afdeling namelijk het karakter van een punitieve sanctie (en dat is niet de bedoeling). ${ }^{155}$

Niet door alle auteurs wordt overigens de opvatting verdedigd dat de verbeurdverklaring en invordering van de dwangsom (onder omstandigheden) een punitief karakter bezit. Michiels ${ }^{156}$, Blomberg ${ }^{157}$, Jurgens, Van Buuren ${ }^{158}$ en Verweij ${ }^{159}$ menen dat met name de invordering van de dwangsom géén punitief karakter heeft. Een expliciete verwijzing naar het moment van verbeurdverklaring en de aard van het verbeuren van de dwangsom tref ik bij deze auteurs niet aan. Genoemde auteurs lijken allen het standpunt te huldigen dat de invordering reparatoir is omdat de oplegging van de last reparatoir is. Blomberg en Michiels drukken zich als volgt uit: 'Wij zijn echter van mening dat de invordering niet los kan worden gezien van de oplegging en dat de dwangsom om die reden een reparatoire sanctie is. ${ }^{160}$ Verweij stelt in haar dissertatie:

'De invordering kan geen ander doel hebben dan de oplegging van de dwangsom en is reeds daarom niet bestraffend. Zelfs als dat anders zou zijn, mag uit het feit dat de invordering niet altijd meer dwingende werking heeft, niet worden afgeleid dat tenuitvoerlegging van de last. onder dwangsom dan dus vergeldend is. ${ }^{161}$

Ook de wijze waarop Michiels dit standpunt reeds eerder heeft onderbouwd is voor discussie vatbaar. ${ }^{162}$ Michiels:

'Het gaat er in wezen om of de constutering van voortzetting of herhaling van de overtreding, die de grondslag vormt van de eigenlijke invorderingshandeling en die, indicn zij correct is, de betalingsschuld van rechtswege meebrengt, als criminal charge moet worden opgevat. Is de constatering terecht gedaan, dan is de invordering daima niet punitief: er wordt slechts een reeds bestaande schuld ingevorderd. De rechtmatigheid van de

157 A.B.Blow. 1994. p. 9.

A.B. Blomberg en F.C.M.A. Michiels, Handhaven met effect, Den Haag 1997, p. 77.

158 Van Buuren, Jurgens, Michiels a.w. 1999, p. 19.

159 Zie de dissertatie van: J.H. Verweij, De bestuurlijke dwangsom (diss. UU), Utrecht 1997, in het bijzonder p. 85-98.

160 Blomberg en Michiels a.w. 1997, p. 77.

161 Verweij a.w. 1997, p. 98

162 Michiels aw. 1994, p. 9 . 
oplegging brengt in dat geval de rechtmatigheid van de invordering mee. Ook de invorering van een boete en de invordering van bestuursdwangkosten zijn niet punitief. ${ }^{, 163}$

Indien er van uitgegaan wordt dat er sprake van invordering van een reeds bestande betalingsschuld, waarbij de grond voor invordering is gelegen in de last onder dwingsom (waaraan door een overtreder niet is voldaan), dan moet mijns inziens de lasionder dwangsom zelf gekwalificeerd worden als punitieve sanctie voorzover de (maximum) dwangsom hoger is dan voor herstel van de rechtmatige toestand noodzakelik is. Ik kom hier nog op terug.

Naar mijn mening snijden de hierboven weergegeven redeneringen van Blomterg, Michiels en Verweij geen hout. Ondanks het feit dat de last onder dwangsom doc de wetgever bedoeld is als reparatoire sanctie kan op basis van genoemde last order dwangsom naar mijn mening in bepaalde gevallen een punitieve sanctie opgelegd vorden. Dit is namelijk het geval voor zover het bedrag van de dwangsom hoger is dar het bedrag dat het bestuursorgaan nodig heeft voor herstel van de rechtmatige toestand of ter compensatie van de, door de onrechtmatige handeling, ontstane schade. ${ }^{164}$ Zelfs de Afdeling Bestuursrechtspraak lijkt dit te onderkennen getuige de hierboven weergegeven uitspraak van 13 maart 2001 . $^{165}$

Punt van discussie is mijns inziens slechts of in een dergelijk geval de last onder dwangsom of de verbeurdverklaring als punitieve sanctie moet worden aangemerkt. In dit kader kan ik de redenering vam Michich's onúersciüjven. Miet andere woorder het karakter van de verbeurdverklaring volgt het karakter van de last. Dit brengt met zich dat dan de last onder dwangsom als punitieve sanctie gekwalificeerd moet worden.

Deze redenering heeft ook procestechnisch gezien voordelen. Indien immers de invordering van een verbeurd verklaarde dwangsom problemen oplevert is het de ciriele rechter die oordeelt over de rechtmatigheid van de invordering. Dit zal niet anders worden na invoering van de regeling met betrekking tot bestuursrechtelijke geldschulden uit de vierde tranche van de Awb. ${ }^{166}$ De civiele rechter zal in het kader van het executiegeschil uit gaan van de rechtmatigheid van de last onder dwangsom (dit inmiddels formele rechtskracht heeft verkregen). ${ }^{167}$ Het voorgaande brengt met zicl. dat het aan de bestuursrechter is te oordelen over de rechtmatigheid van de opgelegde last onder dwangsom. In dit kader dient de bestuursrechter acht te slaan op de vraag of de last aangemerkt moet worden als een punitieve sanctie.

\subsubsection{3.d De maatregel in het sociale zekerheidsrecht en daarmee vergelijkhare sancties}

De maatregel in het sociale zekerheidsrecht die gehele of gedeeltelijke, tijdelijke of blijvende intrekking van de uitkering behelst, wordt door de wetgever en de Centrale

Michicls a.w. 1994, pagina 9.

164 Zie in deze zin ook: F.J. van Ommeren, De verplichting verankerd (diss. UU), Utrecht 1996, p. 128.

165 ABRS 13 maart 2001, JB 2001/95 (Dwangsom Coberco) m. nt. C.L.G.F.H. Albers.

166 Vgl. Voorontwerp p. 58 en 137 e.v.

167 Vgl. Gerechtshof Leeuwarden, 27 februari 2002, JB 2002/136 m. nt. C.L.G.F.H. Albers (Ooststellingerwerf - Stichting Woningbeheer Noord-Nederland) 
Raad van Beroep aangemerkt als reparatoire sanctie. In een uitspraak van 5 april $2000^{168}$ heeft de Centrale Raad aangegeven dat ook na de invoering van het nieuwe sanctiesysteem ${ }^{169}$ de maatregel moet worden aangemerkt als een reparatoire sanctie.

Evenals de Centrale Raad van Beroep neemt de commissie Scheltema in het Voorontwerp van de vierde tranche van de Awb het standpunt in dat de maatregel een reparatoire sanctie is. ${ }^{170} \mathrm{Ik}$ deel deze opvatting niet zonder meer. Mijns inziens dient de maatregel in het sociale zekerheidsrecht aangemerkt te worden als punitieve sanctie voor zover de gehele of gedeeltelijke, tijdelijke of blijvende weigering van de uitkering het benadelingsbedrag (eventueel vermeerderd met administratiekosten) te boven gaat. Dit standpunt wordt ook ingenomen door Hartmann en Van Russen Groen, Addink en Duijkersloot, De Raat en Widdershoven en Jansen. ${ }^{171}$

Daarnaast kan gewezen worden op een korting op de tegemoetkoming in de schade tengevolge van de (preventieve) ruiming van een veestapel (i.v.m. bijvoorbeeld het uitbreken van mond- en klauwzeer of de varkenspest). Daarvoor geldt mijns inziens hetzelfde als voor de maatregel in het sociale zekerheidsrecht. Ook deze kortingen worden echter naar geldend recht niet gezien als punitieve sanctie. ${ }^{172}$ De kortingen die kunnen worden toegepast, wegens soms zeer geringe verzuimen in het kader van de gevoerde administratie van de veehouder, zijn aanzienlijk. In het verleden zijn kortingen op de tegemoetkoming in de schade toegepast van respectievelijk $35 \%, 70 \%$ en $100 \%{ }^{173}$ Niet zelden gaat het dan om bedragen tussen de $f 100.000$ en $f 200.000$ of hoger.

Illustratief is een, in de Volkskrant van 15 augustus 2001, aangehaald voorbeeld. De veestapel van boer Prins werd preventief geruimd vanwege de mond- en klauwzeercrisis. Op de aan genoemde boer toegekende tegemoetkoming wordt een bedrag van $f 120.000$ ingehouden vanwege het feit dat de identificatie en registratie van het vee niet in orde zou zijn geweest. Naar zeggen van Prins ging het er om dat op de dag van de ruiming twee koeien beide oormerken verloren waren, een aantal andere koeien éen oormerk misten, en drie kalfjes, die waren gestorven aan diarree, nog niet afgemeld waren. In de media wordt, in het kader van de discussie omtrent de korting op de tegemoetkoming van de schade, geleden vanwege in verband met de mond- en klauwzeer epidemie geruimd vee, gesproken van 'straffen' en 'strafkortingen'. Zelfs het woord

168 CRvB 5 april 2000, JB 2000/144 m. nt. C.L.G.F.H. Albers.

169 Gedoeld wordt op de Wet boeten, maatregelen en terug- en invordering sociale zekerheid, Stb 1996, 248.

170 Zie art. 5.4.1.1, tweede lid van het Voorontwerp en de toelichting daarbij (p. 120-121).

17I Hartmann en Van Russen Groen aw. 1998 p. 94-95, G.H. Addink en A.P.W. Duijkersloot, Kantiekeningen bij 'Bestuurlijke handhaving' in Voorontwerp 4e tranche Awb, NTB 1999, p. 255-266, i.h.b. p. 258. Y. De Raat en R.J.G.M. Widdershoven, De bestuurlijke boete in de algemene wet bestuursrecht, NJCM-bulletin 2000, p. 771-788, i.h.b. p. 777 e.v. Zie tenslotte O.J.D.M.L. Jansen, Punitief en evenredig? Jurisprudentiele ontwikkelingen bij punitieve sancties en het evenredigheidsbeginsel, in JBplus 2000 , p. $38-49$, i.h.b. p. $42-44$.

172 Zie o.m. ABRS 1 november 1999, JB 1999/301 m. nt. C.L.G.F.H. Albers en R.J.G.H. Seerden, CBB 29 februari 2000, AB 2000, $206 \mathrm{~m}$. nt. J.H. v.d. Veen, CBB 8 februari 2001, ELRO-nummer AB0037 (te raadplegen op www.rechtspraak.nl) en CBB 17 juli 2001, ELRO-nummers AB3002, AB2999, AB3000, AB2997).

173 Zie de hierboven aangehaalde rechtspraak. 
'boetes' ontbreekt in de Volkskrant en het NRC Handelsblad niet. ${ }^{174}$ En wat te denken van de volgende overweging van het College van Beroep voor het Bedrijfsleven:

'Hoewel het begrijpelijk is dat appellante het toepassen van de kortingsregeling ervaart als een boete op overtreding van voorschriften, is het in wezen geen boete. 175

Het voorgaande duidt er mijns inziens op dat ten aanzien van genoemde kortingen niet eenvoudigweg gesteld kan worden dat het hier niet gaat om punitieve sancties. De door minister Brinkhorst getrokken parallel met het verzekeringsrecht, waarbij sprake is van een privaatrechtelijke wederkerige rechtsbetrekking, snijdt in dat kader zeer zeker geen hout. ${ }^{176}$

\subsubsection{3.e Bestuurlijke boete}

Zoals in paragraaf 2.2.1 reeds is aangegeven kan onder een bestuurlijke boete worden verstaan: een door een bestuursorgaan wegens een overtreding bij beschikking opgelegde onvoorwaardelijke verplichting tot betaling van een geldsom, die gericht is op bestraffing van de overtreder. ${ }^{177}$ De bestuurlijke boete onderscheidt zich van de last onder dwangsom. De bestuurlijke boete wordt namelijk opgelegd ten aanzien van een reeds gepleegde overtreding en is derhalve aan te merken als een onvoorwaardelijke sanctie. Een last onder dwangsom wordt opgelegd ter voorkoming van verdere overtredingen van een bepaalde norm. Eerst op het moment dat de volgende overtreding zich voordoet (of indien een reeds gepleegde overtreding nog wordt voortgezet na het verstrijken van de begunstigingstermijn) kan verbeurdverklaring en invordering van de dwangsom plaats vinden. ${ }^{178}$

Aangezien in paragraaf 2.2.1 en 2.2.2 al wat uitvoeriger aandacht is besteed aan de bestuurlijke boete zal op deze plaats alleen ingegaan worden op het karakter van de sanctie. In feite kan uit de hierboven opgenomen definitie van de bestuurlijke boete al direct worden afgeleid dat het om een punitieve sanctie gaat. ${ }^{179}$ Het doel van de bestuurlijke boete is namelijk bestraffing van de overtreder en niet het herstellen van een

174 Zie bijvoorbeeld: De Volkskrant, 15 augustus $200 \mathrm{l}$, p. 3. Twee artikelen zijn gewijd aan de MKZkortingen. Het eerste draagt de titel: 'Betoog Brinkhorst klopt niet, straffen buiten proporties', het tweede: 'Kamer: hoge MKZ-korting boeren nog 'onacceptabel". Het NRC Handelsblad kopt op dezelfde datum: 'Brinkhorst houdt vast aan boetes'.

175 CBB I7 juli 2001, ELRO-nummer AB3002.

176 In de Volkskrant van 15 augustus 2001 is aangegeven dat Brinkhorst de vergoeding van de schade, geleden door het (preventief) ruimen van vee, vergelijkt met een uitkering van de brandverzekering. In dat kader stelt hij het volgende: 'Als iemand een handeling nalaat of verricht waardoor wordt bijgedragen aan het ontstaan van brand, zal de verzekering ook gedeeltelijk of helemaal niet uitkeren.' Dit vergelijk gaat m.i. niet op. Ten eerste is bij de meeste veehouders preventief geruimd hetgeen impliceert dat het vee op de geruimde boerderij niet besmet was met het MKZ-virus. De preventieve ruiming heeft voorts van overheidswege plaats gevonden in het algemeen belang. Van een met een privaatrechtelijke rechtsbetrekking vergelijkbare rechtsbetrekking is in dit kader dan ook geen sprake. In hoofdstuk vier zal op het voorgaande nog worden teruggekomen.

177 Zie artikel 5.4.1.1 in samenhang met artikel 5.0.2 van het Voorontwerp van de vierde tranche.

178 Zie hierover ook: I.Y. de Raat, De bestuurlijke boete in het milieurecht, Ars Aequi no. 6, 1993, p. 445450 , in het bijzonder p. 449.

179 Zie ook: Michiels a.w. 1994, p. 7, Hartmann en Van Russen Groen a.w. 1998, p. 96, en Rikmenspoel a.w. 1995. 
rechtmatige toestand. Ook Van der Poel gaf reeds in 1942 aan dat er bij een administratieve boete sprake is van straf omdat iemand leed aangedaan wordt vanwege zijn schuld aan overtreding van een norm. Deze straf hoeft. zo oordeelt Van der Poel, echter niet door de strafrechter te worden opgelegd. ${ }^{180}$ Eerder in dit hoofdstuk is al aangegeven dat Oostenbrink daar anders over denkt. Hij is van mening dat sanctionering door middel van punitieve administratieve sancties overgelaten zou moeten worden aan de strafrechter. $^{81}$

Belinfante neemt in zijn preadvies een (uitzonderlijk) afwijkend standpunt in wat betreft het karakter van de bestuurlijke boete. Hij gaat er van uit dat de bestuurlijke boete géén punitieve sanctie is. ${ }^{182} \mathrm{Hij}$ ziet de bestuurlijke boete, anders dan onder andere Van der Poel en Oostenbrink ${ }^{183}$, als een 'gefixeerde schadeloosstelling' die niet de oplegging van extra leed ten doel heeft of mag hebben, 'maar alleen een wegnemen van het voordeel van het niet opvolgen van de norm en de aansporing om zulks in het vervolg wel te doen. ${ }^{184}$

Een korte blik over de grens leert dat ook in Duitsland de bestuurlijke boete wordt aangemerkt als een punitieve sanctie. Michels geeft dit als volgt weer:

'Denn letztlich handelt es sich bei der Geldbuße des Ordnungswidrigkeitenrecht -- ebenso wie bei der "kriminellen" Strafe - um eine staatliche Übelszufügung für ein in der Vergangenheit liegendes Unrecht. Insoweit unterscheiden sich "Strafe" und "Geldbuße" keineswegs - im Gegensatz zum "Verwaltungszwang" als Beugemaßnahme gegen gegenwärtige verwaltungswidrige Handlungen oder Zustände. Beide "Strafe" und "Geldbuße", sind repulsive Unrechtsfolgen: ein persönlich vorwerfbares Unrecht soll "geahndet", nicht ein verwaltungswidriger Zustand gebrochen werden. ${ }^{185}$

Ook Michels ziet de bestuurlijke boete derhalve als een sanctie die leedtoevoeging ten doel heeft. De bestuurlijke boete wordt, ook in zijn visie, opgelegd vanwege schuld aan een reeds begane onrechtmatige gedraging. Deze opvatting sluit aan bij de in Nederland heersende idee dat de bestuurlijke boete als punitieve sanctie moet worden aangemerkt.

180 Van der Poel a.w. 1942, p. 264. Volgens Van der Poel is er wel sprake van strafrecht, namelijk bestuursstrafrecht. Ten aanzien van dit bestuursstrafrecht hoeft de strafrechter niet de sanctionerende instantie te zijn. Zie over de term bestuursstrafrecht ook: Hartmann en Van Russen Groen a.w. 1998, p. 74. Zie voons: Hartmann en Van Russen Groen a.w. 1998, p. 105 en verder.

181 Oostenbrink a.w. 1967, p. 137.

182 Belinfante a.w. 1957, p. 37: 'Er zijn ook sancties, die niet meer de feitelijke toestand scheppen, die de norm eist, maar die toch geen strafsancties zijn, omdat zij niet, zoals strafsancties moeten doen, een extra leed opleggen. Zij beogen in tegendeel het zoveel mogelijk uitdenken (m.i. heeft Belinfante 'uitdeuken' bedoeld [KA]) van de rechtsorde doordat zij althans de gevolgen van de normoverschrijding voor de overueder niet voordelig maken. Hier treedt de administratieve boete op.'

183 Zic Van der Poel a.w. hoofdstuk VI. Zie ook Mulder in zijn VAR-preadvies (a.w. 1957), op p. 47 geeft Mulder aan dat Van der Poel in zijn artikel 'Een nieuw kleed voor het fiscaal strafrecht' in het Tijdschrift van Strafrecht LX (1951) uitdrukkelijk afstand neemt van het 'schadevergoedingsidee'. Zie voorts Oostenbrink a.w. 1967, p. 33.

Michels a.w. 1963, p. 33. 
Op deze plaats zij nog opgemerkt dat het, mede met het oog op artikel $113 \mathrm{Gw}$, constitutioneel mogelijk wordt geacht dat een bestuursorgaan de bevoegdheid heeft om (in eerste instantie) punitieve (bestuursrechtelijke) sancties op te leggen. ${ }^{186}$ Desalniettemin kunnen mijns inziens uit rechtsstatelijk oogpunt enkele kritische kanttekeningen bij genoemd standpunt worden geplaatst.

In het eerste lid van artikel $113 \mathrm{Gw}$ is bepaald dat de berechting van strafbare feiten opgedragen is aan de rechterlijke macht. Uit de parlementaire geschiedenis volgt dat gedragingen die gesanctioneerd kunnen worden door de oplegging van een bestuurlijke boete niet vallen onder de in genoemde bepaling gehanteerde term strafbare feiten:

'Aangetekend zij voorts, dat de voorgestelde grondwetsbepaling niet het oog heeft op (berechting van) gedragingen waarbij een voorschrift waaraan een administratieve sanctie, zoals een administratieve boete of de intrekking van een vergunning, is vastgeknoopt, is overtreden. (...) Deze sancties zijn te onderscheiden van strafsancties, die door de strafrechter worden opgelegd als bijzonder leed wegens de overtreding van rechtsvoorschriften die de overheid heeft gegeven als handhaver van de openbare rechtsorde. ${ }^{187}$

Gelet op hetgeen eerder in dit hoofdstuk is geschreven met betrekking tot het punitieve karakter van de bestuurlijke boete lijkt de bovenstaande redenering van de Grondwetgever voor discussie vatbaar te zijn. Leedtoevoeging is immers een typisch kenmerk van de bestuurlijke boete. Gelet op dit (punitieve) kenmerk van de bestuurlijke boete kan deze bestuursrechtelijke sanctie dan ook worden gerekend tot het strafrecht in ruime zin. De formele benaming van de sanctie (bestuurlijke boete) en de sanctionerende instantie (een bestuursorgaan) kunnen dit karakter niet aan de bestuurlijke boete ontnemen. Zou het dan ook niet beter zijn als de Grondwetgever zich niet had verscholen achter een formeel criterium (nl. het 'strafbaar feit' in de traditionele betekenis) maar gebruik had gemaakt van een materieel in te vullen begrip. Door het hanteren van een formeel criterium geeft de Grondwetgever immers zijn macht voor een groot deel uit handen. Hij creëert zodoende een mogelijk voor de wetgever (in formele zin) om te bepalen of er al dan niet sprake is van een 'strafbaar feit', ongeacht de (werkelijke) aard van de sanctie waarmee de normschending bestraft wordt. De Wet Administratiefrechtelijke Handhaving Verkeersvoorschriften (WAHV) vormt in dit kader een helder voorbeeld. Werden voor inwerkingtreding van de WAHV de (lichte) verkeersovertredingen, die op grond van genoemde wet middels bestuurlijke boeten kunnen worden gesanctioneerd, aangemerkt als 'strafbaar feit', na inwerkingtreding van genoemde wet

186 Zie (t.a.v. de oude Grondwet) Mulder a.w. 1957, p. 59. Zie voorts: M.J.H.T. Rikmenspoel, De bestuurlijke boete en artikel 113 Grondwet: een spanningsveld, de Gemeentestem No. 7023, p. 7-11, het CTW-rapport, p. 40, en A.W. Heringa en T. Zwart, De Nederlandse Grondwet, derde druk, W.E.J. Tjeenk Willink, Zwolle 1991, p. 227. Heringa en Zwart plaatsen op p. 227 (a.w.) enige kanttekeningen bij de aldaar aangehaalde passage uit de MvT bij art. $113 \mathrm{Gw}$ waaruit blijkt dat bestuursrechtelijke sancties, waaronder de bestuurlijke boete, niet in strijd zijn met voornoemde bepaling. Zie overigens ook de kritische kantiekeningen van Hartmann en Van Russen Groen a.w. 1994, Van strafrecht naar bestuursstrafrecht: de derde decriminaliseringsgolf?, in: Opstellen over bestuursstrafrecht onder redactie van H. de Doelder en L.J.J. Rogier, SI-EUR-reeks, deel 3, Gouda Quint, Amhem 1994, p. 61-78, i.h.b. p. 76. Zij onderkennen een 'rechtsstatelijke spanning' bij de oplegging van bestuurlijke boeten. Zie tensionte: C.A.J.M. Kortmann, Constitutioneel recht, Kluwer Deventer 2001, p. 262-264.

187 Kamerstukken 11 1979-1980, 16 I62, no. 3, p. 11. 
is dat niet langer meer het geval. Daarmee zijn de lichte verkeersovertredingen door de wetgever in formele zin onttrokken aan de werkingsfeer van artikel 113, eerste lid $\mathrm{Gw}$. Het standpunt van de Nederlandse wetgever lijkt bovendien moeilijk verenigbaar te zijn met de opvatting van het Straatsburgse Hof voor de Rechten van de Mens. Genoemd Hof ziet het begrip 'criminal charge' (strafvervolging - vgl. 'berechting van strafbare feiten' -) als een autonoom begrip. ${ }^{188}$ Onder dit begrip kunnen ook bestuurlijke boeten vallen aangezien het Europese Hof voor de Rechten van de Mens het begrip 'criminal charge' vanuit een materieel gezichtspunt uitlegt. Doorslaggevend is (in beginsel) of de sanctie een afschrikkende werking heeft en of de sanctie punitief van aard is, zo blijkt uit de rechtspraak van het EHRM. ${ }^{189}$ Dat de bestuurlijke boete beide eigenschappen bezit lijkt onomstotelijk vast te staan.

De in artikel $113 \mathrm{Gw}$ gebruikte terminologie - 'berechting van strafbare feiten' - lijkt nauw aan te sluiten bij de aan artikel 6 EVRM ontleende term 'criminal charge'. De Nederlandse (Grond)wetgever hanteert echter, zoals gezegd, anders dan het EHRM, géén materieel criterium ter beantwoording van de vraag of er sprake is van de 'berechting van strafbare feiten'. Doorslaggevend is het formele etiket 'strafbaar feit'. Op het punitieve karakter van de sanctie wordt in dat kader door de Grondwetgever geen acht geslagen. Op deze wijze lijkt de Grondwetgever (indirect ${ }^{190}$ ) de mogelijkheid te scheppen voor bestuursorganen om (bestuurs)strafrechtelijke sancties op te leggen zonder tussenkomst van de onafhankelijke en onpartijdige (straf)rechter. Men zou zich in dat kader af kunnen vragen wat, bij een dergelijke houding van de Grondwetgever, nog de waarde is van artikel $113 \mathrm{Gw}$.

Aangezien er volgens de Grondwetgever bij de oplegging van een bestuurlijke boete geen sprake is van de berechting van strafbare feiten hoeft een tweede, in artikel 113, eerste lid Gw neergelegde, 'hobbel' niet meer genomen te worden. In genoemd Grondwetsartikel is bepaald dat de berechting van strafbare feiten opgedragen is aan de rechterlijke macht. Het bestuursorgaan dat de bestuurlijke boete oplegt maakt in ieder geval geen deel uit van de rechterlijke macht. Bovendien moet niet uit het oog verloren worden dat de hoger beroepsinstanties in het bestuursrecht (in beginsel) geen deel uit maken van de rechterlijke macht. ${ }^{191}$ Het voorgaande brengt met zich dat de bestuurlijke boete, die in eerste instantie wordt opgelegd door een bestuursorgaan, in (ieder geval in) hoger beroep niet wordt beoordeeld door een tot de rechterlijke macht behorend gerecht.

De voorgaande aspecten hebben voor de (Grond)wetgever echter geen belemmering gevormd bij het verschaffen van medewerking aan het uitbouwen van het wettelijke systeem van bestuurs(straf)rechtelijke handhaving. In dit kader moet echter niet uit het oog verloren worden dat tijdens de totstandkoming van het huidige artikel $113 \mathrm{Gw}$ het

$188 \mathrm{Vgl}$. hoofdstuk drie van dit buek.

189 Vgl. hoofdstuk drie van dit boek en EHRM 21 februari 1984, NJ 1988, 937 m. nt. E.A. Alkema (Öztürk).

190 Doorgaans zal de wetgever in formele zin immers aan een (bestuurlijke) boeteregeling gestalte moeten geven.

19. Vgl. Wet op de Rechterlijke Organisatie artikel 1, Heringa en Zwart aw. 1991, p. 224-22.5 en Kortmann a.w. 2001 , p. 243 e.v. 
Europese Hof nog niet het bekende 'Öztürk-Arrest ${ }^{192}$ had gewezen. Voor de Grondwetgever was op dat moment wellicht dan ook nog niet duidelijk dat het EHRM in het kader van de uitleg van het autonome verdragsrechtelijke begrip 'criminal charge' uit zou gaan van een materieel criterium. ${ }^{193}$ Het blijft echter de vraag of de Grondwetgever anders, in navolging van het EHRM, op een materiële wijze invulling zou hebben gegeven aan de term 'strafbaar feit'.

\subsubsection{Bestuursrechtelijke sancties - conclusie -}

Zoals in de inleiding bij deze paragraaf reeds is aangegeven is slechts op een aantal bestuursrechtelijke sancties ingegaan in deze paragraaf. $\mathrm{Bij}$ de beschrijving van de sancties is met name aandacht uitgegaan naar de vraag of de diverse bestuursrechtelijke sancties aangemerkt moeten worden als punitieve dan wel reparatoire sancties. De kwalificatie van een sanctie als punitieve dan wel reparatoire sanctie is van belang vanwege het feit dat ten aanzien van punitieve bestuursrechtelijke sancties een 'verhoogde' rechtsbescherming geldt. De artikelen 6 en 7 EVRM en 14 en 15 IVBPR dienen doorgaans - namelijk in de gevallen dat er tevens sprake is van een 'criminal charge' - in acht genomen te worden bij oplegging van een punitieve bestuursrechtelijke sanctie. Daarnaast moet de bestuursrechter punitieve sancties, die zijn opgelegd op basis van een bevoegdheid met beleidsvrijheid, vol toetsen aan het (in artikel 3:4 lid 2 Awb neergelegde) evenredigheidsbeginsel.

Doorslaggevend, voor beantwoording van de vraag of een bestuursrechtelijke sanctie aangemerkt moet worden als punitieve sanctie, is mijns inziens of de sanctionering leedtoevoeging behelst. Of er sprake is van leedtoevoeging dient vast te worden gesteld aan de hand van een materieel criterium. Dit brengt met zich dat het doel van de sanctie zoals dat is weergegeven in (de wetgeschiedenis van) de wettelijke regeling niet zonder meer doorslaggevend is. Gelet op de verhoogde rechtsbescherming die dient te gelden bij de oplegging van punitieve sancties zou de wetgever immers in de verleiding kunnen komen het doel van de sanctie (leedtoevoeging) te verbloemen. Daarnaast bestaat de mogelijkheid dat een bestuursorgaan een reparatoire sanctiebevoegdheid gebruikt (misbruikt) teneinde een punitief uitwerkende sanctie op te leggen.

Op basis van het materiële criterium kan er ten eerste gesproken worden van leedtoevoeging als de sanctie verder gaat dan herstel van de (on)rechtmatige toetstand vergt. Daarnaast kan worden gesproken van leedtoevoeging als er een sanctie wordt opgelegd terwijl herstel van de rechtmatige toestand niet meer mogelijk is en deze sanctie niet slechts schadevergoeding (compensatie) behelst. Schreuder-Vlasblom meent dat van een straf (en dus van een punitieve sanctie die leedtoevoeging behelst) sprake is bij het onthouden of ontnemen van datgene waarop ondanks de gepleegde rechtsschennis

192 EHRM 21 februari 1984, NJ 1988, 937 m. nt. E.A. Alkema (Özturk).

193 Op deze plaats wil ik nogmaals aangeven dat bij artikel $113 \mathrm{Gw}$ naar mijn mening met name vanu? rechtstatelijk oogpunt kritische kanttekeningen geplaatst moeten worden. De door de (Grond)wetgever gecreeerde mogelijkheid tot het opleggen van bestuurlijke boeten levert, zo volgt onder meer uil de zaak Özturk, geen strijd op met artikel 6 EVRM, voor zover de procedure tot oplegging van de stuurlijke boete in zijn geheel beschouwd in overeenstemming is met (het eerste, tweede en derde $3 i d$ van) artikel 6 EVRM. 
rechtens aanspraak blijft bestaan. ${ }^{194} \mathrm{Zie}$ ik het goed dan komt dit vrijwel op hetzelfde neer.

Een analyse van de diverse in de Awb en bijzondere bestuursrechtelijke wetgeving neergelegde bestuursrechtelijke sancties, en van recente rechtspraak, leert dat in het Nederlandse recht veelal wordt vastgehouden aan een formeel onderscheid tussen reparatoire en punitieve sancties. Daarbij lijkt soms ten onrechte voorbij te worden gegaan aan de daadwerkelijke karakteristieken van bepaalde bestuursrechtelijke sancties. Ook de door mij beschouwde reparatoire sancties blijken bij een nadere bestudering niet zonder meer te passen in hun 'formele keurslijf'. De intrekking van een begunstigende beschikking, de last onder dwangsom, de maatregel in het sociale zekerheidsrecht en de korting op de schadevergoeding bij (preventieve) ruiming van een veestapel hebben mijns inziens in veel gevallen een punitief karakter. Dit is het geval als genoemde sancties niet slechts betrekking hebben op herstel van de rechtmatige toestand of compensatie van geleden schade.

Het lijkt er op dat de Nederlandse wetgever en de rechter deze bestuursrechtelijke sancties echter bij voorkeur kwalificeren als 'reparatoir', in plaats van 'punitief teneinde geen 'verhoogde' rechtsbescherming te hoeven bieden. Ik noem dit 'Etikettenschwindel. ${ }^{195}$ 'Etikettenschwindel' lijkt voor de wetgever en rechter een middel te zijn om te komen tot een vorm van effectieve en efficiënte handhaving zonder in allerlei omslachtige, met waarborgen (voor de overtreder) omklede, (straf(proces)rechtelijke) procedures verzeild te raken. Wetgever en rechter lijken zich daarmee willens en wetens bloot te stellen aan het risico dat het Europese Hof voor de Rechten van de Mens hen eens terug zal fluiten (wegens strijd met artikel 6 en/of 7 van het EVRM). ${ }^{196}$ Tot die tijd is effectieve en efficiënte handhaving echter gegarandeerd.

Tenslotte een opmerking over de bestuurlijke boete, die immers centraal staat in dit boek. Ten aanzien van die sanctie staat buiten kijf dat het een punitieve sanctie is. Voor de bestuurlijke boete geldt derhalve dat de hierboven genoemde bepalingen uit het EVRM en het IVBPR in ieder geval in acht genomen moeten worden. Bovendien moet de bestuursrechter de hoogte van een bestuurlijke boete, die is opgelegd op basis van een bevoegdheid met beleidsvrijheid, vol toetsen aan het, in artikel 3:4 lid 2 Awb neergelegde, evenredigheidsbeginsel.

196 Vgl. Alkema a.w. 2002, p. 113 en 116. 
2.3 Sanctionering door middel van bestuurlijke boeten (in de plaats van strafrechtelijke afdoening)

\subsubsection{Inleidling}

In de loop van de twintigste eeuw hebben diverse (bestuursrecht)juristen zich gebogen over de vraag in welke gevallen overtredingen van bij of krachtens de wet gestelde voorschriften niet strafrechtelijk maar bestuursrechtelijk afgedaan zouden kunnen worden. De belangstelling onder juristen voor dit vraagstuk lijkt met narne ingegeven te zijn door de wens om te komen tot een effectievere handhaving van het (bijzonder) bestuursrecht. De zoektocht naar effectievere handhavingsmiddelen in het bestuursrecht is gerelateerd aan het zogenaamde 'handhavingstekort' - door de commissieMichiels omschreven als het wél moeten handhaven maar niet kunnen of willen handhaven ${ }^{197}$ - dat met name tegen het einde van de twintigste eeuw steeds nadrukkelijker werd gesignaleerd. ${ }^{198}$ Daadwerkelijke handhaving van (de uitvoering van) bestuursrechtelijke wetgeving (b)leek vaak moeilijk realiseerbaar te zijn. ${ }^{199}$ Één van de oorzaken daarvan was de overbelasting van het Openbaar Ministerie en het strafrechtelijke apparaat. ${ }^{200}$ Veel overtredingen van bestuursrechtelijke wetgeving konden op dat moment niet (voldoende) effectief bestuursrechtelijk worden gesanctioneerd. Vaak bleef dan alleen de mogelijkheid van sanctionering door middel van strafrechtelijke sancties over. Het overbelaste Openbaar Ministerie diende echter prioriteiten te stellen wat betreft het vervolgingsbeleid. De consequentie daarvan was, althans zo wordt beweerd, dat met name de (als minder emstig ervaren) bestuursrechtelijke overtredingen ongesanctioneerd bleven. ${ }^{201}$

197 Commissie Michiels, Handhaven op niveau, W.E.J. Tjeenk Willink, Deventer 1998, p. 36 en 57.

198 Zie voor een uitvoerige uiteenzetting de dissertatie van: Hartmann en Van Russen Groen a.w. 1998, p. 50 e.v. en voorts A.R. Hartmann en P.M. van Russen Groen, Van strafrecht naar bestuursstrafrecht: de derde decriminaliseringsgolf?, in: Opstellen over bestuursstrafrecht onder redactie van $\mathbf{H}$. de Doelder en L.J.J. Rogier, SI-EUR-reeks, deel 3, Gouda Quint, Amhem 1994, p. 61-78. Zie ook: Commissie Michiels a.w. 1998, in het bijzonder hoofdstuk 3; 'Het handhavingstekort', p. 35 e.v. en F.C.M.A. Michiels, Het handhavingstekort en de bestuurlijke boete, in: De bestuurlijke boete in perspectief, onder redactie van H. de Doelder, M.E. Meijer en D. Otto, Gouda Quint 1999, p. 63-77. Dat het handhavingstekort zich echter niet alleen voordoet in deze tijd moge blijken uit het proefschrift van Van der Poel (a.w. 1942, p. 17): 'Het (de (bestuurlijke) compositie (='afkoop' ofwel transactie) [toevoeging $\mathrm{KA}$ ]) verdween dan ook niet geheel, het bleef vooral voortleven in de administratieve - waterschapsen fiscale- wetgeving, tot het ook op breeder terrein weer waardeering vond. En dat is onder meer weder het gevolg hiervan, dat het aantal sancties juist in het bijzonder in administratieve wetten zó toenam, dat wetshandhaving volgens de lijnen van het strafprocesrecht, en met toepassing van het straffensysteem van het Wetboek van Strafrecht, practisch niet doenlijk bleek.'

199 Zie m.b.t. het handhavingstekort ook de, in vergaderjaar 1990/1991 uitgebrachte, beleidsnota's: Rechi in beweging, Kamerstukken II, 21 829, nr. 1-2 en Met vaste hand, Kamerstukken II, 22 045, nr. 1-2. Zie voorts: Handhaving door bestuurlijke boeten, Commissie voor de toetsing van wetgevingsprojecten, (CTW 94/1 - 12 januari 1994), p. 7 (hierna: CTW-rapport). Tenslotte kan nog gewezen worden op het Voorontwerp van de vierde tranche van de Awb (a.w. 1999) p. 90.

200 Zie ook Commissie Michiels a.w. 1998, p. 53 e.v. De Commissie Michiels noemt daar een achttal oorzaken voor de aanwezigheid van handhavingstekorten op diverse beleidsterreinen.

201 Dat er sprake is van een handhavingstekort lijkt het in het algemeen heersende beeld te zijn. Door bepaalde auteurs is er echter op gewezen dat het daadwerkelijke bestaan van een handhavingstekor, althans empirisch, niet expliciet is aangetoond. Vgl. Corstens a.w. 1995, p. 13-14, G.J.M. Corstens, 
De Toetsingscommissie heeft in het CTW-rapport aangegeven op welke wijze het (beweerdelijk bestaande) handhavingstekort verminderd zou kunnen worden. Daartoe heeft de Toetsingscommissie in het CTW-rapport een aanzet gegeven tot de mogelijkheid om over te gaan tot 'decriminalisering ${ }^{202}$ van bepaalde overtredingen van bestuursrechtelijke regels in de zin dat die overtredingen in de toekomst gehandhaafd zouden (kunnen) worden door middel van administratiefrechtelijke sancties. Daarbij dacht de Toetsingscommissie met name aan handhaving door middel van de bestuurlijke boete. ${ }^{203}$

In deze paragraaf zal in eerste instantie aandacht besteed worden aan de in de juridische literatuur geuite opvattingen omtrent de vraag welke overtredingen van bij of krachtens de wet gestelde voorschriften niet uitsluitend strafrechtelijk maar ook - of zelfs bij voorkeur - bestuursrechtelijk afgedaan kunnen worden. ${ }^{204} \mathrm{Bij}$ bestuursrechtelijke afdoening gaat het dan in het bijzonder om bestuursrechtelijke afdoening door middel van punitieve bestuursrechtelijke sancties zoals bijvoorbeeld de bestuurlijke boete. ${ }^{205}$ Nadat aandacht is besteed aan de opvattingen in de literatuur zal ingegaan worden op het rapport van de Toetsingscommissie en de opvatting van de Toetsingscommissie omtrent de vraag welke overtredingen door middel van bestuurlijke boeten gesanctioneerd kunnen worden, en derhalve overgeheveld kunnen worden van het strafrecht naar het bestuurs(straf)recht.

Bestuurlijke bocten, in het bijzonder in het financiele recht, SEW 2001, p. 242-247, i.h.b. p. 242, J.B.J.M. Ten Berge en F.C.M.A. Michiels, Besturen door de overheid, Deventer 2001, p. 388 en H.M.J. Quaedvlieg, Ondememende autoriteiten (diss. UM), Maastricht 2001, p. 188-189.

202 Zie hierover ook (kritisch): Hartmann en Van Russen Groen a.w. 1994, Van strafrecht naar bestuursstrafrecht: de derde decriminaliseringsgolf?, p. 61-78, i.h.b. p. 75: '..., dat de huidige ontwikkeling, de 'derde decriminaliseringsgolf', niet beschouwd,kan worden als decriminalisering in zijn oorspronkelijke betekenis, maar veeleer gezien moet worden in de context van een instrumentalisering van het recht.' en p. 76: 'De begrippen decriminalisering en depenalisering dienen ons inziens in verband te worden gebracht met het uitgangspunt dat zo min mogelijk gebruik dient te worden gemaakt van punitieve overheidsreacties. Hieronder mocten niet alleen strafrechtelijke sancties worden verstaan, mât punitieve sancties in het algemeen.'

203 De Commissie Michiels bepleit overigens terughoudendheid bij de verdere invoering van de bestuurlijke bocte. Zie Commissie Michiels a.w. 1998, p. 82. Het kabinet deelt deze mening niet. In het Kabinetsstandpunt Handhaven op Niveau, Kamerstukken II, 1999-2000, 26800 VI, nr. 67, wordt daarnoc het volgende gesteld: 'Bij de aanbevolen terughoudendheid met verdere invoering van de bestuurlijke boete plaats het kabinet een nuancering. Op specifieke terreinen of voor specifieke nomen voorziet de toepassing van de bestuurlijke boete of toepassing van de door het bestuur aan te bieden strafrechtelijke transactie in een grote behoefte en is aannemelijk dat het niveau van naleving er daadwerkelijk baat bij heef. In dergelijke situaties wil het kabinet verruiming van de armslag van het bestuur met punitieve middelen positief tegenoet treden. (...) Anderzijds wil het kabinet niet schromen aan de slag te gain met verniming van de punitieve armslag van het bestuur op de terreinen waar kwantitatieve en kwalitatieve handhavingswinst geboekt kan worden met de introductie van een door het bestuur aan te bieden strafrechtelijke transactie of een bestuurlijke boete.' (Kabinetsstandpunt Handhaven op Niveau p. 8-9).

204 Zie voor een overzicht van de opvattingen in de Duitse literatuur: Michels a.w. 1963, i.h.b. p. 6 e.v.

205 Volledigheidshalve moet in dit kader nog worden opgemerkt dat vrijheidsstraffen uiteraard niet door een bestuursorgaan kunnen worden opgelegd. Artikel 113 (derde lid) Gw en artikel 5 van het EVRM sluiten die mogelijkheid uit. 


\subsubsection{Opvattingen in de literatuur}

Over de voorwaarden waaronder sanctionering, en dan in het bijzonder de oplegging van een boete, niet voorbehouden is aan de onafhankelijke en onpartijdige strafrechter lijkt onder de verschillende rechtsgeleerden geen volledige overeenstemming te bestaan. ${ }^{206}$ Een aantal auteurs komt tot de conclusie dat bestuursrechtelijke afdoening met name geëigend is bij overtredingen die het rechtsbewustzijn in de samenleving niet in ernstige mate schaden. ${ }^{207}$ Ook het frequentiecriterium, waarbij bepalend is of een overtreding (zeer) veelvuldig voorkomt, wordt genoemd als onderscheidend criterium. Andere auteurs menen echter dat er geen doorslaggevende maatstaf is op grond waarvan de vraag beantwoord kan worden welke overtredingen het meest geeigend zijn voor afdoening door middel van een bestuurlijke boete (of een andersoortige punitieve bestuursrechtelijke sanctie). Zij komen dan ook tot de conclusie dat de keuze aan de wetgever moet worden gelaten. $\mathrm{Bij}$ de keuze van de wetgever voor afdoening door middel van punitieve bestuursrechtelijke sancties zullen, volgens deze auteurs, met name aspecten van pragmatische aard doorslaggevend zijn. Tenslotte zijn er auteurs die van oordeel zijn dat punitieve bestuursrechtelijke sancties door de (straf)rechter moeten worden opgelegd.

\subsubsection{Wetsdelicten - normen met een geringe normatieve lading -}

Van der Poel behoort tot de auteurs die van mening zijn dat bestuursrechtelijke afdoening van overtredingen met name geëigend is bij normschendingen met een geringe normatieve lading. Evenals Von Feuerbach onderscheidt hij wetsdelicten en rechtsdelicten. ${ }^{208}$ Van der Poel baseert zich op het historisch gefundeerde onderscheid tussen contraventieën (breucken), die van oudsher worden gesanctioneerd door middel van hestuurssancties, en crimen die van oudsher strafrechtelijk worden afgedaan. Bestuurlijke boeten werden in de landsheerlijke tijd door middel van een administratieve procedure opgelegd bij overtreding (contraventie of breuck genaamd) van het zogenaamde 'politierecht'. Onder het 'politierecht' viel alle regelgeving die betrekking had op het huishoudelijk bestuur van het land, de staten of de steden. ${ }^{209}$ Het ging daarbij om regels die zagen op behartiging van het algemeen welzijn, op handhaving van de openbare orde, op welvaartspolitiek en op overheidszorg, inclusief de sancties die stonden op overtreding van die regels.

206 I $\mathrm{k}$ wil er op wijzen dat het in het kader van de boek niet mogelijk was om zeer uitvoering in te gaan op alle in de literatuur aangedragen criteria m.b.t. de vraag welke normschendingen gesanctioneerd kunnen worden door middel van (punitieve) bestuursrechtelijke sancties. Ik heb er voor gekozen om in te gaan op de meest gehanteerde criteria. De nadruk ligt daarbij op criteria die zien op de normatieve lading van de normschending. Dergelijke onderscheidingscriteria rechtvaardigen de indeling van in strafrechtelijke en bestuursstrafrechtelijke normschendingen naar mijn oordeel in grotere mate dan criteria die bijvoorbeeld zien op de doelmatigheid van bestuursrechtelijke handhaving.

207 De vraag wanneer er sprake is van een overtreding het rechtsbewustzijn in de samenleving niet in ernstige mate schaadt zal ik in deze paragraaf, aan de hand van de opvattingen daaromtrent in de literatuur, proberen te beantwoorden.

208 Zie m.b.t. de denkbeelden van Von Feuerbach: Michels a.w. 1963, p. 7.

209 Zie m.b.t. het 'politierecht' ook de dissertatie van J.M.H.F. Teunissen: Het burgerlijk kleed van de staat, W.E.J. Tjeenk Willink, Zwolle 1996, i.h.b. p. 58 e.v. 
'Crimineel' waren die schendingen van het recht die dermate ernstig waren dat zij de rust in de maatschappij op een gewelddadige wijze stoorden. Met name feiten waarop de doodstraf, lijfstraffen, of een gevangenisstraf stonden vallen onder het begrip. ${ }^{210}$ Crimen zijn vergrijpen tegen 'eeuwige', 'natuurlijke' wetten. ${ }^{211}$ Het onderscheid tussen de 'eeuwige' delicten en de uit het politierecht voortvloeiende 'wetsdelicten' beschrijft Van der Poel als volgt:

'De tegenstelling blijft, dat t.a.v. de eerste categorie (de 'crimen' [KA]) in den beginne het booze was en als reagens daarop de vergelding kwam, wortelende in het gemene rechtsbewustzijn. Bij Bestuursrecht is er eerst een regel met als noodzakelijk sequeel een sanctie daarop, omdat de overheid dit wil en zoo groot als zij dit wil. ${ }^{212}$

Later, in de periode van de Republiek der Zeven Verenigde Nederlanden, ontstond de driedeling contraventie, delict, criem. ${ }^{213}$ Van der Poel bestempelt het delict als een 'middensoort'; 'een amphibie, in oorsprong bestuurscontraventie, in werkelijke beteekenis echter van zooveel gewicht, dat het meer strafrechtelijk werd gezien. ${ }^{214}$ Deze driedeling tussen contraventie, delict en criem, bestaat aan het einde van de achttiende eeuw nog steeds. Korte tijd later, om precies te zijn in 1811, worden de drie rechtsfiguren gedefinieerd in artikel 1 van de Code Pénal. ${ }^{215}$ Met de invoering van de Code Pénal in Nederland gaat de van oudsher bestuursstrafrechtelijke contraventie derhalve deel uit maken van het Wetboek van Strafrecht. ${ }^{216}$ Het eerder bestaande scherpe onderscheid

210 Van der Poel a.w., p. 38 en verder. Van der Poel plaatst bij zijn beschrijving van het bestuursstrafrecht in de landsheerlijke tijd de termen 'civiel' en 'crimineel' tegenover elkaar. 'Civiel' is elke op geld waardeerbare vordering onafhankelijk van de vraag wie tegenover de betrokken burger de andere partij is en ongeacht de rechtsbetrekking die aan de vordering ten grondslag ligt. Dit betekent dat in de landshecriijke tijd ook de (bestuurlijke) boete tot het 'civiel' recht behoorde. 'Crimineel' zijn, zoal's gezegd, die schendingen van het recht die dermate emstig zijn dat zij de rust in de maatschappij op een gewelddadige wijze storen. Met name feiten waarop de doodstraf, lijfstraffen, of een gevangenisstraf staan vallen onder het begrip. Daamaast plaatst Van der Poel de termen 'politie' en 'justitie' tegenover elkaar. Onder het 'politierecht' viel, zo bleek reeds hierboven, alle regelgeving die betrekking had op het huishoudelijk bestuur van het land, de staten of de steden. Het ging daarbij om regels die zagen op behartiging van het algemeen welzijn, op handhaving van de openbare orde op welvaartspolitick en op overheidszorg, inclusief de sancties die stonden op overtreding van de regels. De uitoefening van 'justitie' (rechtspraak) was opgedragen aan 'zelfstandige colleges'. De rechtspraak vond plaats op grond van 'volksrecht'. De termen 'civiel' en 'politie' horen bij elkaar. Hetzelfde geldt voor de termen 'crimineel' en 'justitie'. Dit betekent dat overtredingen van 'politierecht' door middel van 'civielrecht' (daaronder viel ook de (bestuurlijke) boete) werden afgedaan. 'Crimen' werden afgedaan door 'justitic'.

211 Van der Poel a.w., p. 51.

212 Van der Poel a.w., p. 85 . Zie ook p. 89 en p. 429. Op p. 429 concludeent Van der Poel: 'Echt strafrecht is aanvankelijk alleen datgene wat leed toebrengt wegens aangedaan lichamelijk leed, wegens vergrijpen tegen de "natuurwet", al of niet geconcretiseerd in het positief recht. Daamaast is er bestuursrecht (normen gesteld door de hooge overheid ter bevordering van de welvaart en ter bewaring van orde, rust en veiligheid, tot het "oirbaar" van de gemeenschap) dat sancties moet bevatten, wil het kunnen worden gehandhaafd; die sancties zijn boeten, welke worden opgelegd alleen reeds bij het simpele contrafacere. Dat eerste is crimineel recht in den ouden zin, het tweede behoort in den toenmaligen gedachtengang, met de regeling van de betrekkingen tusschen burgers onderling, tot het civiele recht.'

Van der Poel a.w., p. 104

214 Van der Poel a.w., p. 104

215 Van der Poel a.w., p. 186 en 194

216 Van der Poel a.w., p. 194-195. 
tussen 'eeuwige (ofwel rechts-) delicten' en 'wetsdelicten' gaat derhalve met de komst van de Code Pénal verloren. ${ }^{217}$ Van der Poel schrijft hierover het volgende:

'Het wetsdelict werd althans uitwendig als rechtsdelict erkend, met alle procedurele gevolgen, met alle materieeie consequenties, ook t.a.v. de berechtende 'machten', die eraan verbonden waren. Niet alleen was er geen delict zonder een wet, doch ieder wetsdelict, de overtreding van een door de wet strafbaar gesteld feit, zei men, was ook een rechtsdelict.'218

Van der Poel komt, op basis van zijn rechtshistorisch onderzoek, tot de conclusie dat wetsdelicten ofwel contraventies bestuursrechtelijk gesanctioneerd kunnen worden. ${ }^{219}$

Het 'echte strafrecht' moet als ultimum remedium dienen en zal dan ook slechts gebruikt moeten worden als er geen andere, eenvoudige, minder 'pijnlijke', handhavingsmogelijkheden voorhanden zijn die tot hetzelfde doel kunnen leiden. ${ }^{220}$ Strafrechtelijke afdoening van normschendingen heeft namelijk een stigmatiserend effect. ${ }^{221}$ Dit effect ontbreekt bij sanctionering door middel van punitieve bestuursrechtelijke sancties. De Amerikaanse hoogleraar Cheh ${ }^{222}$ geeft, evenals Van der Poel, aan dat stigmatisering een belangrijke rol speelt bij de oplegging van strafrechtelijke sancties:

'Often the basic objective of the criminal law is to deter and punish socially deviant or harmfull behaviour. In this there may be substantial overlap with many civil proceedings. One major difference between the two is that the criminal justice system and the law of criminal procedure constitute society's formal means of determining and pronouncing guilt and innocence, right and wrong. One distinction between criminal and civil sanctions, then, lies in the criminal law's "judgement of community condemnation" on a transgressor. For

217 Van der Poel schrijft hierover in zijn proefschrift (op p. 195): 'Het standpunt, dat in Frankrijk - en in navolging in Nederland - ter zake wordt ingenomen is dit: Nulla poena sine lege. Allereerst is een delict, dit woord in algemeenen zin gebruikt, wat de wet strafbaar stelt. Wet is oorzaak, recht gevolg. lets is een delict omdat en wanneer de wet het strafbaar stelt. De vraag om welke redenen een wet iets "strafbaar" maakt, wordt niet gesteld, verschil tusschen strijd met "natuurlijke wetten", of "eeuwige geboden", of strijd met bestuursgeboden, wordt niet gemaakt. Het eenige wat daarvan overblijft is de onderscheiding in drie namen: contraventie (politie rechter) delict (correctioneele rechter), en crime (crimineele rechter) en aanvankelijk het verschil in rechter waarvoor die vergrijpen respectievelijk worden gebracht.'

218 Van der Poel a.w., p. 208.

219 Aldus Van der Poel (a.w. p. 215-216): 'De vraag of iets civiel is, moet men beoordelen naar het criterium, of er betrekkingen tusschen burgers onderling te regelen vallen. Is dit niet het geval, dan is de verhouding publiekrechtelijk. Komen daarbij sancties te pas, dan beteekent dit geenszins, dat het nu "strafrecht" in den zin van "criem" is, en dat alles waarop sanctie staat volgens die regels, althans volgens de groote, algemeene regels van het strafrecht, moet worden behandeld. Er is een tweede vorm, de sanctie van het Bestuursrecht, die althans als het contraventies betreft, op afzonderlijke wijze moet worden beschouwd. De sanctie op het begaan van contraventien, het overtreden van bestuursgeboden, is bestuursrecht, waarvoor om verschillende redenen andere regelen mocten gelden (zie p. 103). Toen men beide categorieên later in het eéne wetboek van strafrecht bracht, bleef, in de technische uitwerking daarvan, van het verleden ( $=$ bij contraventie straf op simpel contrafacere) als voomaamste dit over, dat voor overtredingen ("wetsdelicten") naar schuld niet werd gevraagd, doch voor misdrijven ("rechtsdelicten") schuld voor strafbaarheid als vereischte werd gesteld.'

220 Van der Poel a.w., p. 281.

221 Van der Poel a.w., p. 257.

222 Mary M. Cheh, Constitutional Limits on Using Civil Remedies To Achieve Criminal Law Objectives: Understanding and Transcending the Criminal-Civil Law Distinction, Hastings Law Jouma, 42 Hastings L.J. 1325-1413, july 1991. 
some commentators, therefore, the ultimate difference between civil and criminal proceedings is that a criminal conviction, unlike civil judgement, carries with it the stigma, or brand, of societal condemnation. ${ }^{223}$

Ook Oostenbrink is van oordeel dat stigmatisering een specifiek kenmerk van strafrechtelijke sanctionering is. Hij stelt met betrekking tot de keuze voor bestuursrechtelijke sanctionering van normschendingen het volgende:

'Bovendien kan de administratieve sanctie in die gevallen, waarin deze feitelijk dezelfde inhoud heeft als de door de strafrechter opgelegde straf (men denke bijv. aan de boete) voor burgers soms aantrekkelijker zijn, omdat hij daardoor het onterende element, dat vanouds aan het strafrechtelijk optreden eigen is, kan ontgaan. ${ }^{, 24}$

Tenslotte kan gewezen worden op Michels ${ }^{225}$ en Corstens ${ }^{226}$ die er van uit dat de bestuurlijke boete een stigmatiserend effect ontbeert. De aan het strafrecht eigen stigmatisering lijkt met name gewenst te zijn bij moreel verwerpelijke delicten, door Van der Poel rechtsdelicten genaamd.

Evenals Van der Poel kent Belinfante gewicht toe aan de normatieve lading van de overtreding. Hij huldigt het standpunt dat strafrechtelijke sanctionering slechts plaats dient te vinden ten aanzien van 'een werkelijk afkeurenswaardig niet-opvolgen van administratiefrechtelijke normen (...). ${ }^{227} \mathrm{Hij}$ lijkt echter niet uit te gaan van het door Van der Poel gemaakte onderscheid tussen wetsdelicten en rechtsdelicten.

Ook de door Goldschmidt in 'Das Verwaltungsstrafrecht' uitgewerkte theorie lijkt op hoofdlijnen overeen te komen met de theorie van Van der Poel over het onderscheid tussen wetsdelicten en rechtsdelicten. ${ }^{228}$ In het kader van dit boek zal slechts op beknopte wijze de theorie van Goldschmidt worden weergeven. Goldschmidt maakt, in zijn complexe en omvangrijke werk, een onderscheid tussen 'Verfassung' en 'Verwaltung' en daarmee tussen 'Verfassungsstrafrecht' en 'Verwaltungsstrafrecht'. 'Verfassung' definieert Goldschmidt als volgt:

'Die Verfassung der menschlichen Gesellschaft, d.i. die Rechtsordnung im eigentlichen, formellen Sinn, ist die Erklärung des algemeinen Willens über den z. Zt. anziuerkennenden Umfang der Machtsphären der verschiedenen Willensträger. Wo die Erklärungen - Rechtssătze - anscheinend nicht die Machtsphäre eines Willensträgers abgrenzen, sondern ein subjektloses ideelles Gut als solches schützen, wird das subjektlose ideelle Gut nur um

223 Cheh a.w. 1991, p. 1352. Op deze plaats dient te worden opgemerkt dat de bestuurlijke boete in de Verenigde Staten aangemerkt wordt als een 'civil penalty'. Men spreekt onder meer over 'the administrative assessment of a civil penalty'. In deel II van dit boek zal uitvoerig andacht worden besteed aan de Amerikaanse bestuurlijke boeteregeling. Zie ook: Quaedvlieg a.w. 2001, p. 62.

224 Oostenbrink a.w. 1967, p. 27-28, zie ook p. 99-100.

225 Michels a.w. 1963, p. 58: 'Es fehlen der Geldbuße die diffamierende Wirkung einesi sozialethisch deklassierenden Tadels; ...'

226 Corstens a.w. 1995, p. 20: 'Strafrechtelijk optreden wordt als meer stigmatiserend ervaren dan de oplegging van bestuursboeten.' Zie voorts p. 31-33.

227 Belinfante a.w. 1957, p. 42.

228 J. Goldschmidt, Das Verwaltungsstrafrecht. Eine Untersuchung der Grenzgebiete zwischen Strafrecht: und Verwaltungsrecht auf rechtsgeschichtlicher und rechtsvergleichender Grundlage, Berlin 1902. 
deswillen geschützt, weil es für die von der Rechtsordnung vorgenommene Abgrenzung der Machtsphären der Willensträger von Wert ist. ${ }^{229}$

'Die Verwaltung der menschlichen Gesellschaft ist' volgens Goldschmidt 'die auf Wohlfahrtsförderung gerichtete menschliche Thätigkeit.' Hij voegt daar aan toe: 'Wo anscheinend die Machtsphäre eines Willensträgers Fürsorgeobjekt bildet, steht stets die Wohlfahrt im Hintergrunde. ${ }^{.230}$

Inbreuken op normen die deel uit maken van de 'Verfassung' beschouwt Goldschmidt als inbreuken op rechtsgoederen en rechtsregels. Hij kwalificeert dergelijke inbreuken als (formeel) onrecht. ${ }^{231}$ Formeel onrecht dient te worden gesanctioneerd middels 'Verfassungsstrafrecht'. Het 'Verwaltungsstrafrecht' dient ter sanctionering van 'Verwaltungsdelikten'. Goldschmidt definieert het 'Verwaltungsstrafrecht' als volgt:

'Nach alledem ist das Verwaltungsstrafrecht der Inbegriff derjenigen Vorschriften, durch welche die mit Förderung des öfentliches oder Staat-Wohls betraute Staatverwaltung im Rahmen staatsrechtlicher Ermächtigung in der Form von Rechtssätzen an die Uebertretung einer Verwaltungsvorschrift als Thatbestand eine Strafe als Verwaltungsfolge knüpft. ${ }^{232}$

Goldschmidt geeft in het slothoofdstuk van zijn werk overigens aan dat het onderscheid tussen 'Vewaltungsstrafrecht' en 'Verfassungsstrafrecht' slechts relatief is. ${ }^{233}$

Daarnaast kan gewezen worden op het door Mayer gemaakte onderscheid tussen 'Kulturnormen' en (blote) 'Rechtsnormen' dat naar mijn mening wederom neer komt op een met het onderscheid tussen wetsdelicten en rechtsdelicten vergelijkbaar onderscheid. ${ }^{234}$ Michels geeft de 'Kultumormentheorie' van Mayer als volgt weer:

'Er (Mayer [toevoeging KA]) geht davon aus, daß die Rechtsnormen in der Regel übereinstimmen mit Kulturnormen, deren Verbindlichkeit das Individuum kennt und anerkennt. Unter Kultumormen versteht er die Gesamtheit derjenigen Gebote und Verbote, die als religiöse, moralische, konventionelle, als Forderungen des Verkehrs und des Berufs an das Individuum herantreten. Es gibt grundsătzlich kein Verhalten, welches der Staat verbietet, ohne daß es vor ihm die Kultur verboten hat. Dennoch kennt das Recht ausnahmsweise auch Pflichten, die weder im Widerspruch noch in Übereinstimmung mit Kultumormen stehen, weil die Kultur die betreffende Materie überhaupt nicht ergreift. Es sind dies die Normen des Verwaltungsstrafrechts. Sie sind kulturell indifferent und dadurch charakterisiert, daß sie bloß einer Rechtsnorm, nicht aber einer Kulturnorm widersprechen. Während das Kriminaldelikt stets ebensowohl mit einer Kulturnorm als einer Rechtsnorm in Widerspruch steht, erschopt sich das Verwaltungsdelikt darin, einer Rechtsnorm zu widersprechen. Das kriminelle Unrecht ist kraft Gesetzes und auf Grund seiner kulturellen Schädlichkeit Unrecht, das polizeiliche Unrecht ist Unrecht nur kraft Gesetzes. ${ }^{235}$

230 Goldschmidt a.w. 1902, p. 532.

231 Goldschmidt a.w. 1902, p. 539-540 en 548.

232 Goldschmidt a.w. 1902, p. 577.

233 Goldschmidt a.w. 1902, p. 585.

234 M.E. Mayer, Rechtsnormen und Kulturnormen, Strafrechtliche Abhandlungen, heft 50, Breslau 1903.

235 Michels a.w. 1963, p. 11. 
Michels is, zo bleek reeds eerder in dit hoofdstuk, van mening dat het bestuursstrafrecht deel uit maakt van het strafrecht in ruimere zin. ${ }^{2.6}$ Als onderscheidend criterium, voor beantwoording van de vraag of een bepaalde normschending bestuurs(straf)rechtelijk of strafrechtelijk afgedaan moet worden, wijst hij op het verschil van aard van het aan het bestuursstrafrecht en het 'gewone' strafrecht ten grondslag liggende onrecht. ${ }^{237}$ Het strafrecht in enge zin, door Michels 'Kriminalstrafrecht' genaamd, is gereserveerd voor sociaal-ethisch onverdraagbare normschendingen: '... so kann als Straftat im eigentlichen Sinne nur eine solche Tat angesehen werden, die in ihrer sozialen Erscheinungsform mit der sozialethisch vorgegebenen Wertordnung in unerträglichem Widerspruch steht. ${ }^{1238}$ Dergelijke, sociaal-ethisch onverdraagbare, handelingen zijn niet eerst 'onrecht' als de wet die handelingen strafbaar stelt:

'Die vom Gesetz mit Strafe bedrohte Handlung wird auch unabhängig von der gesetzlichen Regelung als sozialethisch wertwidrig empfunden. Die Rechtsnorm ist hier primär nicht Bestimmungs-, sondern Bewertungsnorm, d.h.: das Gesetz hat das Recht bzw. Unrecht in diesem weiteren Sinne nicht konstitutiv geschaffen, sondern vorgefunden; es knupft lediglich an die im Gesellschaftsleben herrschenden sozialethischen Wertvorstellungen deklaratorisch an, es transformiert die bereits sozialethisch evidente Wertwidrigkeit lediglich in eine rechtliche. Das gesetzliche Verbot und die Strafdrohung fugen der Handlung an materieller Unwertsubstanz nichts hinzu. Sie wird auf Grund ihrer sozialethischen Wertwidrigkeit als strafwürdig empfunden, ehe sie noch für strafbar erklärt wurde. ${ }^{239}$

Het bestuursstrafrecht ('Verwaltungsstrafrecht') dient, in de visie van Michels, ter handhaving van algemeen verbindende voorschriften die zijn opgesteld teneinde: '... ein möglichst störungsloses Zusammenleben der einzelnen Individuen zu gewährleisten (Ordnungsinteresse), und (...), die gemeinschaftlichen Zwecke bestmöglichst zu organisieren (Verwaltungsinteresse). ${ }^{.240}$ Het door middel van bestuursstrafrecht gesanctioneerde gedrag zou los van de verbodsbepaling niet als onwaardig worden ervaren. Het gaat om gedrag dat de wetgever vanwege doelmatigheidsoverwegingen verboden heeft. Dit verboden gedrag is 'sozialetisch vollig neutral und indifferent..241

Uit het bovenstaande blijkt duidelijk dat ook het door Michels aangegeven onderscheid herleidbaar is tot het onderscheid tussen wetsdelicten en rechtsdelicten. Het door Michels aangedragen criterium kan als onderscheidend criterium worden aangemerkt om 'Straftaten' van 'Ordnungswidrigkeiten' (ofwel 'Zuwiderhandlungen mit Bußfolgen') te scheiden. Problematisch is echter de tussencategorie bestaande uit 'Zuwiderhandlungen mit Straffolgen'. ${ }^{42}$ Deze laatste categorie bestaat in feite uit wetsdelicten met een 'kriminellen Gehalt'. ${ }^{243}$ Het gaat daarbij om overtreding van normen die op zich 'wertneutral' zijn maar die door de wetgever in bepaalde gevallen op grond van bepaalde objec-

236 Michels a.w. 1963, p. 30 e.v.

237 Michels a.w. 1963, p. 33

238 Michels a.w. 1963, p. 46.

239 Michels a.w. 1963, p. 46.

240 Michels a.w. 1963, p. 48.

241 Michels a.w. 1963, p. 50.

242 Michels a.w. 1963, p. 23, en 58 e.v.

243 Michels a.w. 1963, p. 59. 
tieve of subjectieve aspecten in bepaalde mate sociaal-ethisch relevant geacht worden. $^{244}$

Het onderscheid tussen wetsdelicten en rechtsdelicten lijkt vergelijkbaar met het in het strafrecht door de wetgever gemaakte onderscheid tussen misdrijven en overtredingen $^{245}$ getuige de nu volgende passage uit Hazewinkel-Suringa's 'Inleiding tot de studie van het Nederlandse Strafrecht ${ }^{246}$ :

'Sindsdien (1886 [toevoeging KA]) heeft ons strafrecht een verdeling in tweeën, namelijk in misdrijven en overtredingen, waardoor de gerechtshoven hun rechtspraak in eerste aanleg verloren. Ligt nu aan deze onderscheiding wel iets principieels ten grondslag? Is er tussert deze groepen een kwalitatief onderscheid, een wezensverschil? De MvT wil dat doen geloven, gezien de volgende uiteenzetting: 'Er zijn feiten die het regt, er zijn andere die de wet eerst als strafbaar stempelt. Nu eens wordt straf bedreigd tegen een feit, dat reeds onregt was, vòordat de wetgever sprak en waarvan wij het onregtvaardige zouden beseffen, ook al had de wetgever niet gesproken. In dit geval is er misdrijf. Dan weder geldt het een feit, dat in den hoogeren, regtswijsgeerigen zin eerst onregt wordt door de wet, waarvan ons het onregtvaardige alleen uit de wet bekend kan zijn. In dit geval bestaat eene overtreding.' In navolging van de woorden van deze Memorie sprak men van misdrijven als "rechts"delicten, van overtredingen als "wets"delicten, van onrecht vòòr de wet en van onrecht dór de wet. $^{247}$

Remmelink geeft (in navolging van Hazewinkel-Suringa) aan dat er tussen misdrijven en overtredingen naar zijn mening geen 'wezenverschil' bestaat. ${ }^{248}$

Knigge maakt binnen het strafrecht een onderscheid tussen het klassieke strafrecht en het ordeningsstrafrecht. Hij geeft dit als volgt weer:

'Binnen het strafrecht kan een ruw onderscheid gemaakt worden tussen het commune of klassieke strafrecht enerzijds en het ordeningsstrafrecht anderzijds. Het commune strafrecht staat daarbij voor het 'gewone' strafrecht, het strafrecht dat is verankerd in de positieve moraal en dat is neergelegd in het Wetboek van Strafrecht. Het ordeningsstrafrecht staat voor het strafrecht dat te vinden is in de vele 'bijzondere' strafwetten: wetten die primair gericht zijn op de ordening van de samenleving (in het bijzonder op social-economisch terrein), waarbij de strafsanctie niet voorop staat maar fungeert als noodzakelijk sluitstuk van de regelgeving. ${ }^{249}$

Dit door Knigge gemaakte onderscheid lijkt eveneens nauw samen te hangen met het onderscheid tussen wetsdelicten en rechtsdelicten. Knigge geeft, evenals Remmelink en

244 Michels a.w. 1963 , p. 59.

245 Zie hierover: E.M. de Koning-de Jong, Het rapport: 'Handhaving door Bestuurlijke Boeten' op de keper beschouwd, in de bundel: Opstellen over bestuursstrafrecht, onder redactie van $H$. de Doelder en L.J.J. Rogier, Gouda Quint, Arnhem 1994, p. 173-189, i.h.b. p. 178.

246 J. Remmelink, Mr. D. Hazewinkel-Suringa's 'Inleiding tot de studie van het Nederiandse Strafrecht', vijftiende druk, Gouda Quint bv, Deventer 1996.

247 Remmelink a.w. 1996, p. 102.

248 Remmelink a.w. 1996, p. 103. Op deze plasts wil ik er nog(maals) op wijzen dat ook Goldschmidt en Michels signaleerden dat er slechts sprake is van een relatief onderscheid.

249 G. Knigge, De bestuurlijke boete als teken aan de wand, Milieu en Recht, maart 1998, no. 3, p. 63-68, i.h.h. p. 63. 
Goldschmidt, aan dat: 'de gemaakte onderscheiding niet meer (is) dan een ruwe karakteristiek die in concrete gevallen geen criterium oplevert met voldoende onderscheidend vermogen. ${ }^{.250}$

Uit het voorgaande overzicht van opvattingen in de Nederlandse en Duitse (juridische) literatuur blijkt dat aan er de hand van verschillende criteria een onderscheid gemaakt kan worden met betrekking tot de normatieve lading van normschendingen. Zo kan er worden onderscheiden tussen 'wetsdelicten' en 'rechtsdelicten', tussen (blote) 'Rechtsnormen' en 'Kuitumormen', tussen 'Verfassungsstrafrecht' en 'Verwaltungsstrafrecht' en tussen normen met een ethisch gehalte en normen zonder een ethisch gehalte.

Daarmee is echter nog niet de vraag beantwoord of een dergelijk onderscheid voldoende mogelijkheid biedt om vast te stellen welke normschendingen niet strafrechtelijk maar bestuursrechtelijk afgedaan zouden kunnen worden. Van der Poel, Remmelink, Knigge, Goldschmidt en Michels lijken bovenstaande criteria in ieder geval niet voor alle normschendingen als doorslaggevend criterium aan te merken, zo zal in de hiernavolgende paragrafen nog blijken.

\subsubsection{Frequentiecriterium}

Schaffmeister geeft in zijn preadvies voor de Nederlandse Juristenvereniging aan, dat de keuze voor een andere dan strafrechtelijke afdoening, van alle slechts met een vermogenssanctie te bedreigen en te sanctioneren misdragingen, een theoretische fundering vereist. ${ }^{251}$ Die theoretische fundering is naar zijn mening echter niet gelegen in het onderscheid tussen wetsdelicten en rechtsdelicten (door Schaffmeister 'het wezensverschil' genaamd). Schaffmeister onderbouwt deze stelling aan de hand van Duits en Nederlands recht. ${ }^{252}$

Onder verwijzing naar de Duitse 'Ordnungswidrigkeiten' en het in Nederland oorspronkelijk gemaakte onderscheid tussen misdrijven en overtredingen ${ }^{253}$ concludeert Schaffmeister:

'Het lot dat de onderverdeling van de strafbare feiten in misdrijven en overtredingen hier te. lande heeft ondergaan, toont een duidelijke parallelliteit met de ontwikkeling die zich in Duitsland ten aanzien van de afsplitsing van de 'Ordnungswidrigkeiten' van de overige 'Straftaten (Verbrechen und Vergehen)' heeft voorgedaan. De oorspronkelijk door de wetgever in beide landen aangehangen leer van een wezensverschil tussen de onderscheiden kategorieên van repressief gesanctioneerd onrecht is gestrand; de analyse van de rechtsstof

250 Knigge a.w. 1998. p. 66.

251 D. Schaffmeister. Politiële en justitiele delikten, in 'Handelingen 1984 der Nederlandse JuristenVereniging deel 1, eerste stuk', W.E.J. Tjeenk Willink, Zwolle 1984, p. 127-291, i.h.b. p. 136. Zie $m$.b.t. het frequentiecriterium voorts: D. Schaffmeister, Handhaving van het bestuursrecht door boete of straf?, in de bundel: Van boeteatelier tot boetefabriek. onder redactic van W.G.A. Hazewindus en O.J.D.M.L. Jansen, Deventer 1995, p. 58-80.

252 Schaffmeister aw. 1984, p. 138-147.

253 Zie de hierboven opgenomen passage uit de MvT bij het Wetboek van Strafrecht. 
in beide landen leidt tot de konklusie dat geen enkel van de tot nu toe aangedragen onderscheidingscriteria deugdelijk kan worden genoemd. ${ }^{254}$

Schaffmeister komt derhalve met een nieuw 'onderscheidend criterium'; het frequentiecriterium. Frequent voorkomende delicten kunnen volgens hem op een andere dan strafrechtelijke wijze worden afgedaan. ${ }^{255} \mathrm{Hij}$ komt tot die conclusie aan de hand van de volgende redenering:

'Op grond van deze overwegingen lijkt mij de hypothese plausibel dat de zin van de tweedeling van de strafbare feiten gelegen is in het aanbrengen van een onderscheid tussen normen die in de maatschappij een hoge feitelijke 'gedragsgelding' hebben, en normen waarvan dat nog niet of niet meer kan worden gezegd, maar die de wetgever niettemin of juist daarom met strafrechtelijke middelen wil afdwingen. Maatstaf voor de verdeling van strafbare feiten over beide kategorieën zou dan zijn een oordeel over de 'gedragsgeldigheid' dus een oordeel over de mate waarin het strafbaar gestelde aansluit op het in de maatschappij geldend gedrag; of omgekeerd - en onder het gezichtspunt van de beperkte kapaciteit van het strafrechterlijk systeem belangrijker - een schatting over het aantal misdragingen dat invoering van de norm zal opleveren. (...) Uitgebreidere strafbaarstelling. intensieve kontrole en matige bestraffing, maar dan wél in nagenoeg alle gevallen past bij schending van normen die in de maatschappij nog niet veel weerklank hebben. Als niet zou worden opgetreden of te veel ontsnappingsmogelijkheden zouden bestaan, is er minder kans voor de norm om algemeen erkend te worden. ${ }^{256}$

Handhaving van normen die veelvuldig geschonden worden is noodzakelijk. Het strafrechtelijk apparaat is daarvoor echter niet geschikt. Derhalve moeten volgens Schaffmeister de frequent voorkomende delicten van de commune delicten worden gescheiden. Voor de frequent voorkomende delicten moet vervolgens een aparte procedure worden gecreëerd waarbij sanctionering door middel van vermogenssancties geschiedt. $^{259}$

Ook in het 'Kabinetsstandpunt Handhaven op Niveau' wordt het frequentiecriterium genoemd. Weliswaar niet als criterium voor beantwoording van de vraag of sanctionering door middel van een bestuurlijke boete geëigend is maar vanuit het oogpunt dat bestuursrechtelijke afdoening meer geschikt is als het gaat om massaal te geven beschikkingen. ${ }^{258}$ Voor die visie kan ook steun gevonden worden in het werk van Schaffmeister zoals blijkt uit de hierboven opgenomen passage uit diens preadvies. ${ }^{259}$

254 Schaffmeister a.w. 1984, p. 145. Ook ten aanzien van het Oostenrijkse 'Verwaltungsstrafgesetz' geldt dat er geen algemene materiěle omschrijving kan worden gegeven van de delikten die daar onder (kunnen) vallen. Rechtspolitieke- en doelmatigheidsoverwegingen lijken doorslaggevend te zijn bij de keuze om een bepaald delict onder te brengen in het 'Verwaltungsstrafgesetz' (zie Schaffmeister a.w. 1984, p. 162).

255 Zie in dit kader ook de dissertatie van J.F.L. Roording, Sanctierecht in de belastingen en de sociale zekerheid, Ars Aequi Libri, Nijmegen 1994. Roording spreekt in zijn dissertatie over acht toedelingscriteria waaronder de geringe ernst van de overtreding en de massaliteit van de overtreding. Roording a.w. 1994, p. 138-142.

256 Schaffmeister a.w. 1984, p. 226-227, zie voorts p. 239-240.

257 Schaffmeister a.w. 1984, p. 240-241.

258 Kabinetsstandpunt Handhaven op Niveau, a.w. p. 10.

259 Zie Schaffmeister a.w. 1984, p. 227: 'Tenslotte zijn ook de eenvormige toepassing van vermogenssancties volgens tevoren opgestelde lijsten, de afdoeningsmogelijkheden buiten geding en de vereen- 
Schaffmeister gaat er van uit dat met name normen die in de maatschappij (nog) niet veel weerklank gevonden hebben massaal geschonden zullen worden. Men kan zich daarbij afvragen of het niet juist de normen met een geringe normatieve lading zijn die in de maatschappij niet veel weerklank vinden. Mij lijkt de stelling dat juist de normen met een geringe normatieve lading niet veel weerklank vinden in de maatschappij zeer wel verdedigbaar. Dit brengt ons mijns inziens weer terug bij het onderscheid tussen wetsdelicten en rechtsdelicten aangezien ook ten aanzien van de wetsdelicten (in hun oorspronkelijke, door Van der Poel beschreven, vorm) gezegd kan worden dat zij, in tegenstelling tot de rechtsdelicten, een geringe normatieve lading bezitten. ${ }^{260} \mathrm{Het}$ frequentiecriterium zelf lijkt derhalve weinig vernieuwend te zijn. ${ }^{261}$

\subsubsection{Ontbreken van een doorslaggevend criterium}

Zoals gezegd is een aantal auteurs van mening dat er geen doorslaggevend criterium bestaat aan de hand waarvan kan worden vastgesteld of een overtreding strafrechtelijk dan wel bestuursrechtelijk moet worden afgedaan. Mulder, bijvoorbeeld, lijkt een onderscheid tussen wetsdelicten en rechtsdelicten niet doorslaggevend te achten voor de vraag of een bepaalde overtreding zich leent voor bestuurs(straf)rechtelijke afdoening. Ten aanzien van het onderscheid tussen rechtsdelicten en wetsdelicten merkt hij het volgende op:

'a. uit een oogpunt van verzekering van de orde in de gemeenschap kan door bepaalde contraventies b.v. van de verkeersvoorschriften of van waterschapsverordeningen (denk aan het doorsteken van een dam) zelfs ernstiger verstoring ontstaan dan door sornmige overtredingen van het verbod om te mishandelen of te beledigen, welke feiten toch onder de rechtsdelikten gerangschikt plegen te worden;

b. uit oogpunt van zelfhandhaving of verdere vorming der gemeenschap valt elk onderscheid zelfs weg; daarbij is vooral beslissend in welke omstandigheden de gemeenschap verkeert; in geval van voedselnood kan het onttrekken van tarwe aan de distributie een veel ernstiger gevaar opleveren, dan zelfs diefstal, verduistering of oplichting om van de droge klap of de eenvoudige belediging niet te spreken;

voudigde gerechtelijke procedure er eerder op gericht de af te wikkelen massa van frekwent voorkomende delicten te kunnen verwerken dan op het bevorderen van een evenwichtige verhouding tussen de betekenis van de zaak en de zwaarte van de procedure.

260 Zie in dit kader voorts Schaffmeister a.w. 1984, p. 288. Schaffmeister kwalificeert frequent voorkomende normschendingen als 'politiele delicten'. Hij plaats genoemde 'politiele delicten' vervolgens tegenover de zogenaamde 'justitiěle delicten'. Opmerkelijk genoeg maakt ook Van der Poel dit onderscheid (zie Van der Poel a.w. 1942, p. 38 e.v.). Van der Poel beschouwt de term 'politiẻle delicten' als synoniem voor de term 'wetsdelicten' en, hoe kan het ook anders, de term 'justitiële delicten' als synoniem voor de term 'rechtsdelicten'.

261 Misschien zou wel gezegd kunnen worden dat het een handzamer criterium is ter beantwoording van de vraag of bepaalde normschendingen bestuursrechtelijk gesanctioneerd kunnen worden. Maar ook ten aanzien van het frequentiecriterium zullen er afbakeningsproblemen ontstaan. Hoe frequent moet de normschending zich voordoen teneinde over te gaan tot bestuursstrafrechtelijke sanctionering? Waar ligt de grens? Moet die grens verschillen afhankelijk van het soort normschending? Vragen die alle aanleiding kunnen geven tot ingewikkelde afbakeningsproblemen. 
c. de rechtsopvattingen verschuiven; overtreding van het verbod kinderen in fabricken te laten werken werd in 1880 een wetsdelikt geacht nu zal het eerder onder de rechtsdelikten te rangschikken zijn. ${ }^{262}$

$\mathrm{Na}$ aandacht besteed te hebben aan een mogelijk onderscheid tussen 'rechtsdelikten' (ofwel 'eeuwige delikten') en 'wetsdelikten' (ofwel 'tijdelijke delikten') (waartoe hij ook de administratiefrechtelijke contraventie rekent) komt hij tot de volgende conclusie:

Niet alleen is de rechtsopvatting niet statisch en mag men mitsdien niet tussen "eeuwige delikten" en "tijdelijke" gaan onderscheiden, bovendien ligt eventueel onderscheid op het gebied van de verhouding recht en moraal, terwijl het bij dwangmiddelen gaat om de funktie van het recht ten aanzien van de orde of van de zelfhandhaving en verdervorming van de gemeenschap. ${ }^{263}$

Zie ik het goed dan acht Mulder desalniettemin de morele verwerpelijkheid van een normschending doorslaggevend. Hij benadert het onderscheid tussen wetsdelicten en rechtsdelicten echter op een rechtspositivistische wijze ${ }^{264}$, en komt derhalve tot de conclusie dat genoemd onderscheid niet doorslaggevend is. Deze redenering wijkt af van (bijvoorbeeld) de benadering van Van der Poel.

Ook Van der Poel geeft overigens in zijn dissertatie aan dat de rechtsopvatting niet statisch is. Dit betekent dat wetsdelicten na verloop van tijd in de maatschappij ervaren kunnen worden als eeuwige (ofwel rechts) delicten en vice versa. ${ }^{265}$

Rogier lijkt, evenals Mulder, het onderscheid tussen wetsdelicten en rechtsdelicten niet doorslaggevend te achten. ${ }^{266}$ Hoewel hij erkent dat het onderscheid tussen wetsdelicten en rechtsdelicten in bepaalde gevallen relevant is voor de wijze van afdoening van overtredingen, is hij van mening dat de ethische (on)aanvaarbaarheid ${ }^{267}$ van bepaald gedrag géén doorslaggevend criterium is aan de hand waarvan sancties kunnen worden onderscheiden. ${ }^{268}$ Dit heeft te maken met het feit dat slechts in de uiterste gevallen duidelijk is of er sprake is van een wetsdelict of een rechtsdelict. ${ }^{269}$ Voor alle overtre.

262. Mulder a.w. 1957, p. 65-66.

263 Mulder a.w. 1957, p. 66.

264 Dit blijkt uit de hierboven als eerste aangehaalde passage uit zijn preadvies.

265 Van der Poel a.w., p. 85.

266 Rogier, a.w. 1992.

267 Zie ook Michels a.w. 1963 die (op p. 11-12) de ethische onaanvaardbaarheid aanmerkt als een apart criterium. Naar mijn mening zijn de ethische aanvaardbaarheid, en de respectievelijke onderscheiden tussen wets- en rechtsdelicten, cultuur- en rechtsnormen, 'Verfassungsstrafrecht' en 'Verwaltungsstrafrecht' zo nauw met elkaar verwant dat er feitelijk slechts sprake is van een definitieverschil.

268 Rogier, a.w. 1992, p. 27-29. Op p. 29 komt Rogier tot de volgende conclusie: 'Mij lijkt de keuze van de wetgever tussen strafrecht en besturursrecht grotendeels historisch bepaald. Alleen de uitersten zijn duidelijk. Gedrag dat van oudsher met zware sancties via het strafrecht is bestreden en in brede kring zwaar wordt afgekeurd, zoals misdrijven tegen het leven, zal niet snel worden overgeheveld naar het bestuursrecht. Gedragingen waarop vrijheidsstraffen staan worden kennelijk als zo emstig beschouwd dat alleen de strafrechter als sanctie-oplegger kan optreden. De ethische onwaarde is hier wel een van de bepalende factoren. (...) Gedrag dat met administratieve sancties wordt bestreden, is veelal gedrag waarbij men zich aan administratieve regels en procedures onttrekt.'

269 Ook Michels neemt, zoals reeds is gebleken, een soortgelijk standpunt in. Zic hierover Michels aw. 1963, p. 56 e.v. en p. 83. 
dingen die niet absoluut ethisch onaanvaardbaar zijn, en derhalve niet zonder nicer als rechtsdelict aangemerkt moeten worden, biedt het onderscheid tussen wetsdelicten en rechtsdelicten derhalve geen uitkomst.

Ook de door Goldschmidt gehuldigde opvatting vertoont overeenkomsten met de upvatting van Mulder. Goldschmidt, die het 'Verfassungsstrafrecht' van het 'Verwaltungsstrafrecht' onderscheidt, geeft aan dat genoemd onderscheid slechts relatief is:

'Aus dieser schliesslichen Harmonie von Recht und Verwaltung erklärt sich denn auch, dass nicht - wonach man bisher stets gesucht - ein absoluter, sondern ein relativer Unterscheid zwischen Rechts- und Verwaltungsdelikten besteht, dass es von der zeitlichen und örlichen Auffassung über die Natur des Deliktsmoments abhängt. ob ein Delikt Rechts- oder Verwaltungsdelikt ist, und dass es wohl kaum ein Delikt giebt, welches nicht beider Auffassungen fähig ist. Daher kommt es denn auch, dass die meisten Rechtsdelikte noch Gegenstand der Beschäftigung der Verwaltung sind. Und aus dieser Thatsache erklärt sich weiter die Erscheinung, welche sich durch die ganze Rechts- und Staatgeschichte hindurchzieht: der Abschichtungsprozess zwischen Verwaltungs- und Verfassungsstrafrecht. Wenige Rechtsdelikte, die nicht das Stadium des Verwaltungsdelikts durchschritten hätten, und die nicht gerade deshalb noch als Rechtsdelikte Gegenstand der Beschäftigung der Verwaltung wären. wenn sie auch mit ihrer Erhebung zu Rechtsdelikten Verwaltungsdelikte zu sein aufgchört haben.'270

Hartmann en Van Russen Groen hechten aan het onderscheid tussen eeuwige delicten en wetsdelicten in het geheel geen waarde voor beantwoording van de vraag of een overtreding zich leent voor bestuurs(straf)rechtelijke afdoening. ${ }^{271}$ Zij komen, evenals Remmelink $^{272}$, Michiels ${ }^{273}$, en een aantal andere hedendaagse Nederlandse juristen, tot de conclusie dat er geen inhoudelijk criterium is ter onderscheiding van normschendingen die geschikt zijn voor strafrechtelijke sanctionering en normschendingen waarvoor bestuursrechtelijke sanctionering het meest geëigend is ${ }^{274}$, en stellen vervolgens:

'De toedeling van onrecht aan de betreffende rechtsgebieden kan daarom geschieden op basis van pragmatische gronden. (...) Hoe men de verschillen en overeenkomsten tussen het strafrecht en het bestuursrecht ook waardeert, een sanctic wordt in het bestuursrecht opgelegd door een bestuursorgaan en in het strafrecht door de rechter. Ter onderscheiding

Goldschmidt a.w. 1902, p. 585.

271 Hartinann en Van Russen Groen a.w. 1998, p. 28-37

272 Remmelink a.w. 1996, p. 103: 'Geen enkel materieel criterium ter onderscheiding is, strikt genomen, houdbaar: er zijn geen strafbare feiten, die op grond van een bepaald begrippenstelstel misdrijven, andere die deswege overtredingen zijn. Doorslaggevend is de betekenis van hel gesichonden rechtsgoed, de omvang van de krenking, de wijze van aantasting. etc. Bestond er een wezensverschil, dan zou de wetgever een delict toch moeilijk van indeling kunnen laten veranderen.'

273 Michiels a.w. 1995, p. 65: 'Er vallen geen principiele toedelingscriteria te formuleren. De wetgever zal per regeling of beleidsterrein moeten bepalen welk systeem het meest in aanmerking komt hoofdzakelijk op grond van overwegingen van doelmatigheid of doeltreffendheid.' Zis in deze zin ook: J.T.K. Bos, De bestuurlijke boete, raakvlakken van bestuurs- en strafrecht, in Handhaving van het bestuursrecht, VAR-Reeks no. 114, Samsom H.D. Tjeenk Willink, Alphen aan den Rijn, 1995, p. 119-167, i.h.b. p. 129.

274 Hartmann en Van Russen Groen a.w. 1998, p. 47, zie voorts Hartmann en Van Russen Groen a.w. 1994, p. 35 c.v. 
van het strafrecht van het bestuursrecht kan uitgegaan worden van dit (louter formele) criterium, namelijk dat van de sanctie-opleggende instantie. ${ }^{.275}$

Gelet op het voorgaande gaan Hartmann en Van Russen Groen, evenals de andere hierboven genoemde hedendaagse Nederlandse juristen, er van uit dat er, bij gebreke aan een doorslaggevend criterium ter vaststelling of een bepaalde normschending strafrechtelijk dan wel bestuursrechtelijk kan worden afgedaan, op basis van doelmatigheidsoverwegingen gekozen kan worden voor bestuursrechtelijke afdoening. ${ }^{276}$

\subsubsection{Oplegging van punitieve sancties door de strafrechter}

Tenslotte is er nog een aantal auteurs dat van mening is dat punitieve bestuursrechtelijke sancties door de strafrechter opgelegd moeten worden. Oostenbrink, bijvoorbeeld, hecht weinig waarde aan het onderscheid tussen wetsdelicten en rechtsdelicten. Hij heeft betoogd dat het opleggen van punitieve bestuursrechtelijke sancties aan de strafrechter is voorbehouden:

'Hoewel constitutioneel bezien tegen een sterke expansie van de categorie van de personéle administratieve sancties (d.w.z. punitieve bestuursrechtelijke sancties [KA]) geen bezwaar hoeft te worden gemaakt, is er toch wel veel voor te zeggen de typisch op een vergelding van schuld gebaseerde overheidsreactie op overtredingen over te laten aan de strafrechter, als de op dat terrein meest deskundige functionaris.' 277

Mulder heeft in zijn preadvies eveneens die voorkeur uitgesproken. ${ }^{278}$ Knigge gaat er vanuit dat de bestuurlijke boete - als punitieve sanctie - deel uit maakt van het strafrecht. ${ }^{279} \mathrm{Hij}$ pleit er derhalve voor de bestuurlijke boete onder te brengen bij het strafrecht. $^{280}$ Hoewel de redenering van Corstens binnen de strafrechtelijke context geplaatst is kan daaruit mijns inziens worden afgeleid dat ook hij van oordeel is dat punitieve bestuursrechtelijke sancties door de strafrechter opgelegd zouden moeten worden. Corstens stelt het volgende:

'De straf mag alleen door de rechter worden opgelegd. Dat is niet zo verwonderlijk, omdat met strafoplegging leedtoevoeging wordt beoogd. Dat behoeft meer rechtvaardiging dan concreet herstel van aangedaan onrecht, al dan niet in de vorm van schadevergoeding. ... Leedtoevoeging gaat aanzienlijk verder. De zwaardere fundering daarvan is onder meer

Hartmann en Van Russen Groen a.w. 1998, p. 47-48. Zie ook: Hartmann en Van Russen Groen aw. 1994, p. 42. In deze zin ook Hazewindus a.w. 1994, p. 13, p. 34-35 en p. 39.

276 Zie: Hartmann en Van Russen Groen a.w. 1998, p. 47-48, Bos a.w. 1995, p. 129 en Michiels a.w. 1995, p. 65.

277 J.J. Oostenbrink, administratieve sancties, Serie Bestuursrechtelijke Verkenningen, Uitgeverij VUGA nv, 's-Gravenhage, 1967, p. 137.

278 Mulder komt tot de conclusie dat 'de rechter' als hoofdregel bevoegd zou moeten zijn tot het toepassen van dwangmiddelen. Mulder: 'Zij het niet zonder voorbehoud, zouden wij toch deze regel willen formuleren: Tenzij om bepaalde redenen de voordelen van het inschakelen van een administratieve diensi niet alleen de nadelen daarvan overtreffen, maar bovendien aanzienlijk sterker wegen dan de voordelen van het inschakelen van een rechter, behoort het toepassen van dwangmiddelen aan den rechter te worden overgelaten.' Mulder a.w. 1957, p. 80.

279 Knigge a.w. 1998, p. 63.

280 Knigge a.w. 1998. 
gelegen in de verplichte rechterlijke tussenkomst en in de eis dat er schuld moet zijn, wil de strat mogen worden opgelegd. ${ }^{281}$

Tenslotte kan nog gewezen worden op Michels. Zoals reeds eerder is aangegeven gaat Michels er van uit dat de bestuurlijke boete deel uit makt van het strafrecht in ruimere zin. $^{282}$ Dit impliceert dat hij, evenals Knigge, van mening is dat de boete in eerste instantie wel opgelegd mag worden door een bestuursorgaan maar dat aan de overtreder altijd de keuze voorbehouden moet zijn de zaak vervolgens voor te leggen aan de strafrechter:

'In vielen Fällen ist sie (den Verwaltungsbehörden [toevoeging KA]) hierzu auf Grund iłrer spcziellen Fachkentnisse besonders geeignet. Von Rechtsstaatlichen Gesichtspunkten her (Trennung der Gewalten, Art. $92 \mathrm{GG}$ ) ist gegen ein derartiges "Verwaltungs-vorverfahren" solange nichts einzuwenden, als es durch den Willen des Betroffenen in ein Strafverfahren vor den ordentlichen Gerichten übergeleitet werden kann, wobei die Möglichkeit der Anfechtung der verwaltungsbehördlichen Bescheide durch eine umfassende tatsächliche und rechtliche Nachprüfung vor den ordentlichen Gerichten genügt. ${ }^{283}$

De opvatting dat punitieve bestuursrechtelijke sancties door de strafrechter moeten worden opgelegd is naar mijn mening verdedigbaar. De vraag is echter of de idee van oplegging vал punitieve bestuursrechtelijke sancties door de strafrechter ook praktisch uitvoerbaar is (gelet op het (beweerdelijk) bestaande handhavingstekort). Mijns inziens is dit slechts mogelijk als voorzien wordt in een ruime mogelijkheid tot buitengerechtelijke afdoening. Het bestuursorgaan (waaronder begrepen het Openbaar Ministerie ${ }^{284}$ ) zou dan in eerste instantie de boete (eventueel in de vorm van een bestuursrechtelijke transactie) op kunnen leggen terwijl aan de overtreder daarbij de keuze wordt gelaten om de zaak (vervolgens) (in beroep) voor te leggen aan de strafrechter. Door te voorzien in een ruime mogelijkheid van buitengerechtelijke afdoening laat men echter de oorspronkelijke idee, dat punitieve (bestuursrechtelijke) sancties alleen door de strafrechter mogen worden opgelegd, weer ten dele varen. Genoemde variant heeft wel een groot voordeel. Het straf(proces)recht zou namelijk (onverkort) van toepassing kunnen zijn bij de oplegging van punitieve bestuursrechtelijke sancties. ${ }^{285}$ In dat kader spreekt de opvatting van Michels en Knigge, dat de bestuurlijke boete deel uit maakt van het strafrecht (in ruimere zin), bijzonder aan. Naar mijn mening brengt deze idee met zich dat in ieder geval de essentiële straf(proces)rechtelijke beginselen in acht moeten worden genomen bij oplegging van bestuurlijke boeten.

281 Zie Corstens a.w. 1999, p. 3. Zic hierover ook: Corstens a.w. 2000, p. 1188

282 Michels a.w. 1963, p. 30.

283 Michels a.w. 1963, p. 35

284 Vgl. Groenhuijsen en Knigge (red.) a.w. 1999 i.h.b. p. 59-90 en Groenhuijsen Knigge (red.), a.w. 2001, i.h.b. p. 119-124.

285 In hoofdstuk vier zal nog blijken dat (onverkorte) toepassing van het straf(proces)recht bij de oplegging van punitieve administratieve sancties aanmerkelijke voordelen met zich zou kunnen brengen (met het oog op de rechtsbescherming van de vermoedelijke overtreder). 


\subsubsection{Opvattingen in de literatuur - conclusie -}

Het onderscheid tussen wetsdelicten en rechtsdelicten, (en het daarmee zeer nauw verwante onderscheid tussen 'Rechtsnormen' en 'Kulturnormen', 'Verfassungsstrafrecht' en 'Verwaltungsstrafrecht', en normen met- en zonder een ethisch gehalte) lijkt nog het meest plausibel teneinde vast te stellen of er sprake is van een normschending die afgedaan kan worden door middel van een bestuurlijke boete. Met name schending van normen met een geringe normatieve lading, met een daaraan inherent kleiner draagvlak in de maatschappij, vallen onder de definitie van de term wetsdelicten.

Het feit dat de als wetsdelicten aan te merken normschendingen een geringe normatieve lading hebben brengt met zich dat overtreding van dergelijke normen veelvuldig, of althans in veel grotere mate, voor zal komen dan overtreding van normen die aangemerkt worden als rechtsdelicten. Dit betekent dat het door Schaffmeister als onderscheidend criterium aangedragen frequentiecriterium onlosmakelijk verbonden is met het onderscheid tussen rechtsdelicten en wetsdelicten. ${ }^{286}$

Enige nuancering, ten aanzien van de stelling dat het onderscheid tussen wetsdelicten en rechtsdelicten dienst kan doen als onderscheidend criterium, dient op deze plaats wel te worden aangebracht. Met Rogier ben ik van mening dat aan de hand van het onderscheid tussen wetsdelicten en rechtsdelicten alleen de normschendingen die als 'uitersten' kunnen worden aangemerkt eenvoudig te kwalificeren zijn. Er is echter sprake van een glijdende schaal. Naast normschendingen die duidelijk als wetsdelict of rechtsdelict gekwalificeerd kunnen worden zijn er tal van normschendingen die minder eenvoudig in een van beide categorieën ondergebracht kunnen worden. Voor dergelijke normschendingen biedt het onderscheid tussen wetsdelicten en rechtsdelicten geen uitkomst. Daarnaast is de rechtsopvatting niet statisch. Een normschending die vijftig jaar geleden als rechtsdelict beschouwd werd kan heden evenzogoed als wetsdelict worden gekwalificeerd.

Er lijkt derhalve inderdaad geen doorslaggevend criterium te zijn aan de hand waarvan vrij eenvoudig voor alle normschendingen bepaald kan worden of deze strafrechtelijk dan wel bestuursrechtelijk afgedaan moet worden. Slechts ten aanzien van werkelijk moreel verwerpelijke delicten (dit zullen in de regel rechtsdelicten zijn) geldt dat zij strafrechtelijk afgedaan zullen moeten worden. Dit lijkt mede ingegeven te zijn door het stigmatiserende effect van de strafrechtelijke procedure. ${ }^{287}$ De consequentie van het voorgaande is dan dat alle normschendingen die niet zonder meer moreel verwerpelijk zijn eventueel (in eerste instantie) afgedaan zouden kunnen worden met een bestuurlijke boete.

Op deze plaats wil ik nog opmerken dat niet uit het oog verloren moet worden dat Oostenbrink, Mulder, Knigge, Corstens en Michels voorstander zijn van de (uiteinde-

286 Zie in deze zin ook: Hartmann en Van Russen Groen a.w. 1998, p. 33.

287 Zie in dit kader ook: Corstens a.w. 1995, p. 20 en 31-33. Op deze plaats wil ik nog opmerken dat ook het EHRM er van uit lijkt te gaan dat de strafrechtelijke procedure een stigmatiserend effect heeft (EHRM 25 augustus 1987, NJ 1988, 938 m. nt. E.A. Alkema (Lutz), i.h.b. §57. Uit genoemde overweging blijkt dat het EHRM yan mening is dat 'minor offences which are not so discreditable that the offenders deserve the stigma of a criminal penalty' afgedaan kunnen worden door middel van een (punitieve) administratieve sanctie. 
lijke) oplegging van punitieve bestuursrechtelijke sancties door de (straf)rechter. De aard van de geschonden norm is in dat kader niet relevant. Misschien is het geen slecht idee om de definitieve oplegging van punitieve sancties voor te behouden aan de (straf)rechter. Een punitieve sanctie blijft, vanwege het leedtoevoegende karakter, nu eenmaal een typische strafsanctie en daarbij horen ook tenminste de essentiële waarborgen ${ }^{288}$ uit het straf(proces)recht.

De bestuurlijke boete (eventueel in de vorm van een bestuursrechtelijke transactie) zou in eerste instantie wel door een bestuursorgaan (waaronder het $\mathrm{OM}$ ) opgelegd kunnen worden. Indien echter het gesanctioneerde rechtssubject het niet eens is met de opgelegde bestuurlijke boete zou dan vervolgens een procedure bij de straf(- of bestuurs)rechter, met inachtneming van de essentiële beginselen van het straf(proces)recht, moeten volgen. ${ }^{289}$

\subsubsection{Het rapport van de Toetsingscommissie}

De Commissie voor de Toetsing van Wetgevingsprojecten (de Toetsingscommissie) heeft begin 1994 het rapport 'Handhaving door Bestuurlijke Boeten' (CTW-rapport) uitgebracht. ${ }^{290}$ De Toetsingscommissie heeft, zoals in de inleiding van deze paragraaf reeds is aangegeven, in het CTW-rapport aangegeven op welke wijze het handhavingstekort verminderd zou kunnen worden. De gedachte van een eigen verantwoordelijkheid van het bestuur voor de handhaving staat daarbij voorop. ${ }^{291}$ Strafrechtelijke handhaving wordt door de Toetsingscommissie gezien als ultimum remedium waarvan slechts in uitzonderlijke gevallen gebruik kan worden gemaakt. ${ }^{292}$ Daarom heeft de Toetsingscommissie in het CTW-rapport een aanzet gegeven ter realisering van de mogelijkheid om over te gaan tot 'decriminalisering' van bepaalde overtredingen van bestuursrechtelijke regels, in de zin dat die overtredingen in de toekomst gehandhaafd zouden (kunnen) worden door middel van bestuursrechtelijke sancties. Daarbij dacht de Toetsingscommissie met name aan handhaving door middel van de bestuurlijke boete. In het CTW-rapport heeft de toetsingcommissie een aantal criteria ontwikkeld aan de hand waarvan vastgesteld kan worden of een bepaalde overtreding van bestuursrechtelijke regelgeving afgedaan kan worden door middel van een bestuurlijke boete. Hierna zal aandacht geschonken worden aan die criteria. Daarbij zal, waar nodig, ook ingegaan worden op het 'Kabinetsstandpunt Handhaven op Niveau'. In genoemd kabinetsstand-

Denk daarbij bijvoorbeeld aan het 'geen straf zonder schuld-beginsel', regels m.b.t. eendaadse en meerdaadse samenloop, de ne bis in idem-regeling, het legaliteitsbeginsel, het lex certa-vereiste, het zwijgrecht, enz.

289 Op deze opvatting zal later in dit werk nog worden teruggekomen. Er zal dan ook een nadere uitwerking van genoemde opvatting volgen. Vgl. M.S. Groenhuijsen en G. Knigge (red.), Dwangmiddelen en Rechtsmiddelen. Derde interimrapport onderzoeksproject Strafvordering 2001 (concept).

290 Zit voor een (kritisch) commentaar op het CTW-rapport: E.M. de Koning-de Jong a.w. 1994, p. 173 189. De Koning-de Jong spreekt, m.b.t. de in het CTW-rapport voorgestelde boeteregeling, over het inschakelen van een ander rechtsstelsel, waarbinnen de rechtsbescherming, zoals die is gegroeid binnen het strafrechtelijke systeem, wordt gemarginaliseerd (zie a.w. 1994, p. 187). Zie voorts Corstens a.w. 1995.

292 CTW-rapport, p. 7. 
punt worden een aantal indicaties voor de toepassing van de bestuurlijke boete gegeven. 'Deze indicaties vormen een verdere ontwikkeling van wat in het kabinetsstandpunt bestuurlijke boeten van 1994 de "voorwaarden" werd genoemd voor toepassing van de bestuurlijke boete. ${ }^{.293}$

\subsubsection{1 'Decriminalisering'}

Zoals gezegd is de Toetsingscommissie voorstander van 'decriminalisering' van de van oorsprong strafrechtelijke overtredingen. Hartmann en Van Russen Groen hebben echter kritiek geuit op de wijze waarop de Toetsingscommissie de term 'decriminalisering' hanteert. ${ }^{294} \mathrm{Zij}$ stellen daaromtrent het volgende:

'Door de ontwikkeling van het strafrecht naar het bestuursstrafrecht te betitelen als decriminalisering, wordt verhuld dat het hier gaat om een punitieve sanctiewijze. Het heeft iets weg van "Etikettenschwindel" en "window-dressing": men zegt er eigenlijk niets mee. Men maakt pas ernst met het "ultimum remedium"-karakter van het strafrecht indien men zich richt op het gebruiken van zo min mogelijk punitieve sancties. Niet het strafrecht, doch de punitieve sanctie in het algemeen dient uit het oogpunt van decriminalisering "ultimum remedium" te zijn. ${ }^{295}$

Knigge heeft zich op een zelfde kritische wijze geuit met betrekking tot het zogenaamde 'ultimum-remedium karakter' van het strafrecht:

'Hier is van belang dat het argument nergens meer op slaat zodra er vanuit gegaan wordt dat ook de buiten-gerechtelijke bestraffing tot het strafrecht (in ruime zin) moet worden gerekend. Het gaat dan helemaal niet om een keuze tussen het strafrecht en een ander remedium, het gaat dan om precies hetzelfde remedium, namelijk om een boete, en de enige vraag is door wie die boete het beste kan worden opgelegd (rechter, OM of uitvoeringsorgaan). ${ }^{296}$

Naar mijn mening is deze kritiek van Knigge en Hartmann en Van Russen Groen niet onterecht. Dit zou anders zijn als de term 'decriminalisering' wordt beschouwd als synoniem voor 'destigmatisering'. Daar is echter, mijns inziens, geen sprake van. Het lijkt er immers op dat de vraag of van sanctionering al dan niet een stigmatiserende werking uit moet gaan geen rol heeft gespeeld bij overheveling van de sanctionering van bepaalde normschendingen van het strafrecht naar het bestuursrecht. Het is immers niet zo dat alle overtredingen die nog steeds binnen het strafrecht vallen daaronder vallen omdat van bestraffing van die overtredingen een stigmatiserend effect uit zou moeten gaan. De keuze voor overheveling van overtredingen van het strafrecht naar het bestuursrecht, zo zal hiema nog blijken, is in de praktijk veelal pragmatisch van aard.

293 Kabinetsstandpunt Handhaven op Niveau a.w. 1998, p. 10.

294 Zie Hartmann en Van Russen Groen a.w. 1994, Van strafrecht naar bestuursstrafrecht: de derde decriminaliseringsgolf?, p. 61-78, i.h.b. p. 75 en 76 (zie de in de inleiding van deze paragraaf aangehaalde passages).

295 Zie Hartmann en Van Russen Groen a.w. 1994, Van strafrecht naar bestuursstrafrecht: de derde decriminaliseringsgolf?, p. 61-78, i.h.b. p. 78.

296. Knigge a.w. 1998, p. 68. 
Effectieve en efficiënte handhaving vormen immers, althans daar heeft het alle schijn van, het belangrijkste doel van de overhevelingsoperatie. ${ }^{297}$

\subsubsection{Criteria voor bestuursrechtelijke sanctionering volgens de Toetsingscommissie.}

De Toetsingscommissie heeft in hoofdstuk vijf van haar rapport de criteria geformuleerd waaraan een normschending moet voldoen wil deze kunnen worden gesanctioneerd met een bestuurlijke boete. $\mathrm{Zij}$ onderscheidt daarbij primaire en aanvullende criteria en stelt omtrent genoemd onderscheid:

'De primaire criteria wegen zwaar en kunnen in het algemeen als voorwaarden voor bestuursrechtelijke handhaving worden beschouwd. Daarnaast kunnen onder omstandigheden nog andere factoren een rol spelen; die zijn geformuleerd als aanvullende criteria., ${ }^{298}$

Hierna zullen de primaire en secundaire criteria worden weergegeven. Met name ten aanzien van enkele primaire criteria zal vervolgens nog een nadere uitwerking volgen.

Als primaire criteria ${ }^{299}$ noemt de Toetsingscommissie:

Ia. De overtreden norm heeft een geringe normatieve lading.

Ib. De overtreding pleegt geen letsel aan personen of schade aan goederen toe te brengen.

II. De norm is zodanig duidelijk in de wet of in nadere regelgeving omschreven dat het mogelijk is om op grond van wettelijke normen in de praktijk een vaste gedragslijn te ontwikkelen.

III. De ambtenaar of dienst die belast wordt met de handhaving beschikt over voldoende expertise om aan die handhaving adequaat gestalte te geven.

IV. Voor de handhaving van de norm zijn geen vrijheidsbenemende of andere ingrijpende dwangbevoegdheden nodig.

Als aanvullende criteria noemt de Toetsingscommissie:

V. De overtreding leent zich voor vaste afdoeningstarieven.

VI. Documentatie in verband met recidive is niet nodig.

VII. De overtreding wordt niet in belangrijke mate door of ten dienste van criminele organisaties gepleegd.

Zoals gezegd zal hier nog nader ingegaan worden op een aantal, door de Toetsingscommissie gehanteerde (primaire) criteria. Ten eerste wordt (kort) stil gestaan bij criterium la; de geringe normatieve lading van de overtreden norm.

297 Vgl. Th. A. de Roos, Beheerste reactie of overkill? Hedendaagse punitiviteit in de strafrechtspolitiek, in de bundel: Hoe punitief is Nederland?, onder redactie van M. Mocrings, Amhem 1994, p. 45-58, i.h.b. p. 52.

298 CTW-rapport, p. 18.

299 CTW-rapport, p. 19-20. 
De geringe normatieve lading van een bepaalde overtreding vormt voor de Toetsingcommissie, zoals gezegd, de eerste reden om sanctionering door middel van bestuurlijke boeten mogelijk te achten. Daarbij wijst de Toetsingscommissie op het onderscheid tussen wetsdelicten en rechtsdelicten. De als wetsdelicten gekwalificeerde overtredingen zijn volgens de commissie geschikt voor bestuurs(straf)rechtelijke afdoening. ${ }^{300}$ De commissie geeft overigens aan dat de grens tussen wetsdelicten en de, als schokkend ervaren, rechtsdelicten niet altijd even scherp is. Bovendien kunnen de opvattingen over de normatieve lading van een bepaalde norm in de loop van de tijd veranderen. De commissie deelt op dit punt derhalve de mening van onder andere Mulder $^{301}$ en Van der Poel. ${ }^{302}$ De Toetsingcommissie komt vervolgens tot de volgende conclusie: 'De wetgever zal zich op dit punt van geval tot geval een oordeel moeten vormen. ${ }^{303}$

Op basis van het voorgaande, en mede met het oog op de conclusie uit de vorige paragraaf van dit werk, kan mijns inziens criterium Ia (De overtreden norm heeft een geringe normatieve lading) niet worden aangemerkt als een scherp criterium met voldoende onderscheidende waarde. In feite maakt criterium Ia het mogelijk om alle normschendingen die de rechtsorde niet ernstig kunnen schokken door middel van een bestuurlijke boete af te doen. Niettemin lijkt dit criterium, zo volgt ook reeds uit de vorige paragraaf, in vergelijking tot alternatieve onderscheidingscriteria het meest plausibel.

Tenslotte dient, in rechtsvergelijkend perspectief, nog het volgende opgemerkt te worden. Ook in de Bondsrepubliek Duitsland zijn de overtredingen met een geringe normatieve lading overgeheveld van het strafrecht naar het bestuursstrafrecht (Ordnungswidrigkeitengesetz). Göhler schrijft daarover het volgende:

\begin{abstract}
'Ausgangspunkt für diese Entwicklung (het totstandkomen van het Ordnungswidrigkeitengesetz [KA]) ist das Bestreben gewesen, den Kreis strafrechtlicher Tatbestände einzuengen, um das Strafrecht auf die wirklich strafwürdigen Fälle zu beschränken. Deshalb sollen Zuwiderhandlungen gegen staatliche Gebote und Verbote, die - idR - ethisch nich vorwerfbar sind und deshalb nicht den Makel der Strafe verdienen oder erfordern, deren Bekämpfung aber zum Schutze von individuellen Rechtsgütern bereits in einem Vorfeld oder im Interesse der ordnenden Verwaltungstätigkeit des Staates erforderlich ist, anders behandelt werden als kriminelle Verhaltensweisen. Die "Strafe" soll den Fällen vorbehalten bleiben, in denen sie als schärfste Form staatlicher Reaktion auf ein vorausgegangenes rechtswidriges Verhalten angemessen und erforderlich ist. ${ }^{304}$
\end{abstract}

Vervolgens wordt aandacht besteed aan Criterium Ib (De overtreding pleegt geen letsel aan personen of schade aan goederen toe te brengen). Criterium Ib is door de Toetsingcommissie ontleend aan de Wet Mulder. ${ }^{305}$ Criterium Ib moet worden beschouwd

CTW-rapport, p. 19 (en p. 7).

Mulder a.w. 1957, p. 66.

Van der Poel a.w. p. 85

CTW-rapport, p. 19.

Zie: E. Gơhler, Ordnungswidrigkeitengeset, 12. neubearbeitete Auflage, Verlag C.H. Beck, München 1998, p. 1. Zie voor een uitvoerigere beschrijving van het 'Ordnungswidrigkeitengesetz' (in een rechtsvergelijkend perspectief) ook: Mulder a.w. 1957, p. 49-51, Schaffmeister a.w. 1984, p. 138-147 en p. 182-206, en Hartmann en Van Russen Groen a.w. 1998, p. 122- 123.

Ook wel de Wet administratiefrechtelijke handhaving verkeersvoorschriften genaamd. 
als een (nadere) uitwerking van criterium Ia. Aanwezigheid van een concreet slachtoffer of concrete schade maakt dat de rechtsorde ernstiger geschokt is dan wanneer bij een vergelijkbare normschending een concreet slachtoffer of concrete schade ontbreekt. ${ }^{306}$ In geval bij de normschending een concreet slachtoffer te betreuren valt of daadwerkelijke schade optreedt dient sanctionering van die normschending voorbehouden te zijn aan de strafrechter. Michels wijst ook op theorieen waarbij als onderscheidend criterium, voor de keuze van administratiefrechtelijke- dan wel strafrechtelijke sanctionering, geldt het al dan niet berokkenen van letsel of veroorzaken van concrete schade. $^{307}$

De overige (primaire en secundaire) criteria zijn mijns inziens met name relevant voor beantwoording van de vraag of het voor een bestuursorgaan op een niet al te gecompliceerde wijze mogelijk is om handhavend op te treden. Het gaat derhalve met name om criteria met het oog op de effectiviteit en efficiency van bestuursrechtelijke sanctionering. ${ }^{308}$ Criterium Ia en Ib zijn fundamenteler van aard. Zij knopen in feite aan bij de uit de rechtsliteratuur voortvloeiende theorieën.

De ideeën van de Toetsingscommissie zijn overigens niet nieuw. In 1936 presenteerde de commissie Van den Dries haar verslag met betrekking tot de herziening van het fiscaal strafrecht en strafprocesrecht. ${ }^{309}$ De commissie Van den Dries stelde in dit verslag omtrent de afdoening van overtredingen van (wettelijke) belastingvoorschriften door middel van bestuurlijke boeten het volgende:

\begin{abstract}
"Van de overige overtredingen zullen die zich het beste leenen tot toepassing van de administratieve boete, waarbij de boete kan bestaan in een betrekkelijk laag vast bedrag of in eene betrekkelijk matige percentsgewijze verhooging van de geldswaarde van niet nagekomen verplichtingen, waarbij het feit van de overtreding doorgaans weinig tot geschil aanleiding geeft of ter beslissing aan den burgerlijken rechter of administratieven rechter behoort te worden opgedragen, waarbij tenslotte vragen van schuld niet van groot belang zijn. Onder die omstandigheden kan, (...), de administratieve boete boven de strafrechtelijke boete de voorkeur verdienen ter vermijding van aan het belang van de zaak onevenredig ambtelijke bemoeiingen, ter bevordering van eene vlotte afwikkeling, en ter voorkoming van het betrekken van de overtreders in eene justitieele strafvervolging." ${ }^{310}$
\end{abstract}

Vrijwel al deze overwegingen zijn ook terug te vinden in het rapport van de Toetsingscommissie.

Tenslotte wordt op deze plaats nog gewezen op het 'Kabinetsstandpunt Handhaven op Niveau'. ${ }^{31}$ Zoals gezegd worden in het kabinetsstandpunt voordelen en indicaties voor

Verslag van de Commissie tot herziening van het fiscaal strafrecht en strafprocesrecht, (hierna: commissie Van den Dries), Alg. Landsdrukkerij 1936.

310 Commissie Van den Dries, a.w., p. 36-37. Zie voort het CTW-rapport, p. 7-9.

311 Kabinetsstandpunt Handhaven op Niveau, a.w. 1998. 
de toepassing van bestuurlijke boeten opgesomd. ${ }^{312}$ Het kabinet geeft aan dat er een vijftal voordelen zijn voor de keuze van de toepassing van bestuurlijke boeten ten opzichte van strafrechtelijke sanctionering. Ten eerste komt de eigen verantwoordelijkheid van het bestuursorgaan voor de handhaving tot uitdrukking met toepassing van een bestuurlijke boeteregeling. ${ }^{313}$ Het tweede voordeel van sanctionering door middel van een bestuurlijke boete is dat eigen verantwoordelijkheid van het bestuur kan leiden tot intensievere controles en verhoging van de pakkans voor delicten ten aanzien waarvan door het OM niet tot 'sanctionering' zou worden overgegaan. ${ }^{314}$ Ten derde leidt toepassing van bestuurlijke boeten in plaats van strafrechtelijke afdoening bij sommige delicten tot doelmatigheidswinst. ${ }^{315}$ In de vierde plaats is het bestuursrecht wat meer toegesneden op massaal te geven beschikkingen. Bij massaal gepleegde overtredingen is sanctionering door middel van bestuurlijke boeten derhalve aantrekkelijk. ${ }^{316}$ Tenslotte, zo stelt het kabinet, 'kan een rol spelen dat, gelet op het naar verwachting geringe aantal zaken, het de moeite niet loont om binnen het strafrechtelijk apparaat de zeer specialistische deskundigheid op te bouwen die voor strafrechtelijke afdoening nodig is. $^{317}$

Daarnaast is er volgens het kabinet nog een aantal indicaties voor toepassing van de bestuurlijke boete. Zoals gezegd vormen deze indicaties de verdere ontwikkeling van wat in het (op het CTW-rapport gebaseerde) 'Kabinetsstandpunt bestuurlijke boeten van $1994^{1318}$ de 'voorwaarden' werd genoemd voor toepassing van de bestuurlijke boete. Op deze plaats wordt slechts aandacht besteed aan de mate waarin nadere invulling is gegeven aan de criteria van de Toetsingscommissie zoals die hierboven zijn weergegeven.

Ten aanzien van criterium II (De norm is zodanig duidelijk in de wet of in nadere regelgeving omschreven dat het mogelijk is om op grond van wettelijke normen in de praktijk een vaste gedragslijn te ontwikkelen) is in het 'Kabinetsstandpunt Handhaven op Niveau' de volgende nuancering aangebracht:

'In gevallen dat een zo duidelijke omschrijving niet mogelijk is, kan de bestuurlijke boete slechts worden toegepast wanneer deze wordt opgelegd door een bijzondere, voor het opleggen van boetes toegeruste, gespecialiseerde organisatie. ${ }^{319}$

Ten aanzien van het vierde criterium (Voor de handhaving van de norm zijn geen vrijheidsbenemende of andere ingrijpende dwangbevoegdheden nodig) stelt het kabinet een ander criterium in de plaats: 'Voor het opleggen van een bestuurlijke boete zijn

312 Kabinetsstandpunt Handhaven op Niveau, a.w. 1998, p. 9-13.

313 Kabinetsstandpunt Handhaven op Niveau, a.w. 1998, p. 9.

314 Kabinetsstandpunt Handhaven op Niveau, a.w. 1998, p. 10.

315 Kabinetsstandpunt Handhaven op Niveau, a.w. 1998, p. 10.

316 Kabinetsstandpunt Handhaven op Niveau, a.w. 1998, p. 10.

317 Kabinetsstandpunt Handhaven op Niveau, a.w. 1998, p. 10.

318 Kabinetsstandpunt bestuurlijke boeten 1994, Kamerstukken II, vergaderjaar 1993-1994, no. 23400 VI, nr. 48.

319 Kabinetsstandpunt Handhaven op Niveau, a.w. 1998, p. 11. 
alleen dwangmiddelen nodig met het oog op het vaststellen van de identiteit van de dader. ${ }^{.320}$

Aan de hand van de genoemde voordelen en indicaties komt het kabinet tot de conclusie dat er een aantal (typen) normen is die zonder bezwaar met een bestuurlijke boete kunnen worden gehandhaafd. Het gaat daarbij om 'normen aan de randen van de harde kern van het strafrecht'. Het kabinet somt vervolgens een drietal (typen) normen op. Ten eerste gaat het om secundaire bepalingen, die het toezicht door het bestuur mogelijk moeten maken. Ik neem aan dat het kabinet daarmee bijvoorbeeld doelt op de in het sociale zekerheidsrecht bestaande inlichtingenplicht. ${ }^{321}$ In de tweede plaats gaat het om financiële en administratieve verplichtingen waarvan afdoening door het strafrecht geen toegevoegde waarde heeft. En verder gaat het om: 'normering van gedrag op door de overheid gereguleerde markten, waarbij de wetgever gespecialiseerde instellingen belast heeft met punitieve handhaving. ${ }^{322}$ Het kabinet wijst daarbij onder meer op de Onafhankelijke Post- en Telecommunicatie Autoriteit (OPTA) en de Nederlandse mededingingsautoriteit (Nma).

De hierboven weergegeven, in het 'Kabinetsstandpunt Handhaven op Niveau' neergelegde, conclusie met betrekking tot de vraag welke normschendingen middels bestuursrechtelijke (punitieve) sancties kunnen worden afgedaan, vormt naar mijn mening niet bepaald een verheldering ten opzichte van de criteria die daartoe zijn aangedragen in het rapport van de Toetsingscommissie. Op hoofdlijnen houdt men vast aan de criteria uit het rapport van de Toetsingscommissie. Door de Toetsingscommissie en het kabinet werd immers in 1994 als primair criterium de (geringe) normatieve lading van de overtreden norm genoemd. De Toetsingscommissie verwijst daarbij naar het onderscheid tussen wetsdelicten en rechtsdelicten. Het zal de lezer niet ontgaan zijn dat dit criterium weinig anders in kan houden dan het, in het 'Kabinetsstandpunt Handhaven op Niveau' gehanteerde, doch abstracter omschreven, criterium 'normen aan de randen van de harde kern van het strafrecht'.

Zoals gezegd biedt ook het, uit 1994 daterende, primaire criterium van de Toetsingscommissie naar mijn mening niet veel houvast. Alleen normschendingen die de samenleving (zeer) ernstig schokken moeten op grond van genoemd criterium strafrechtelijk worden gesanctioneerd. Het voorgaande leidt tot de slotsom dat aan de hand van de door de Toetsingscommissie genoemde criteria en de in het 'Kabinetsstandpunt Handhaven op Niveau' neergelegde indicaties door de wetgever in feite ten aanzien van alle normschendingen die de rechtsorde niet in ernstige mate schokken bepaald kan worden dat deze afgedaan kunnen worden door middel van bestuurlijke boeten.

Men kan zich uiteraard afvragen of een dergelijke ontwikkeling wenselijk is. Het stellen van deze vraag lijkt echter weinig zin te hebben. Genoemde ontwikkeling is immers

320 Kabinetsstandpunt Handhaven op Niveau, a.w. 1998, p. 11.

321 Zie bijvoorbeeld art. $25 \mathrm{WW}$ in samenhang met art. 27a WW. Zie in dit kader ook de dissertatic van E.E.V. Lenos a.w. 1998, p. 106 e.v.

322 Kabinetsstandpunt Handhaven op Niveau, a.w. 1998, p. 12. 
reeds in volle gang en lijkt bovendien onomkeerbaar te zijn. Vermindering van het handhavingstekort staat voorop. In dat kader is gezocht naar nieuwe wegen die de oplegging van punitieve sancties, zonder een al te omslachtige (strafrechtelijke) procedure, mogelijk maken. Een nieuwe en belangrijke weg lijkt te zijn gevonden in de vorm van de bestuurlijke boete. Invoering van deze bestuursrechtelijke sanctie ter vermindering van het handhavingstekort heeft echter alleen zin indien een behoorlijk arsenaal van normschendingen overgeheveld kan worden van het strafrecht naar het bestuursrecht. Derhalve wordt wellicht uit gegaan van het hierboven weergegeven ruime criterium op grond waarvan de wetgever in feite ten aanzien van alle normschendingen die de rechtsorde niet in ernstige mate schokken kan bepalen dat deze afgedaan kunnen worden door middel van bestuurlijke boeten.

Op zich is er ook niet veel op tegen dat een punitieve sanctie met betrekking tot een dergelijke normschending in eerste instantie door een bestuursorgaan wordt opgelegd. Daarbij moet echter niet uit het oog verloren worden dat gesteld kan worden dat de bestuurlijke boete deel uit maakt van het strafrecht in ruime zin. Dientengevolge zouden in ieder geval de essentiële straf(proces)rechtelijke waarborgen in acht moeten worden genomen bij oplegging van dergelijke boeten.

Gelet op het feit dat de opkomst van de bestuurlijke boete niet meer tegen te houden is lijkt het zinvoller zich hierna te concentreren op de vraag op welke wijze voldoende rechtsbescherming kan worden geboden aan de vermoedelijke overtreder in het bestuursstrafrecht. Zolang bij de oplegging van bestuursrechtelijke punitieve sancties een aan het strafrecht gelijkwaardige rechtsbescherming wordt geboden is op genoemde overheveling immers niet veel tegen.

\section{$2.4 \quad$ Afsluitend}

De bestuurlijke boete kan gedefinieerd worden als een door een bestuursorgaan wegens een overtreding bij beschikking opgelegde onvoorwaardelijke verplichting tot betaling van een geldsom, die gericht is op bestraffing van de overtreder. Het verschil tussen de strafrechtelijke boete en de bestuurlijke boete is derhalve met name gelegen in het feit dat de bestuurlijke boete wordt opgelegd door het bestuursorgaan terwijl de strafrechtelijke boete (in beginsel) wordt opgelegd door de onafhankelijk en onpartijdig geachte strafrechter.

In het kader van dit onderzoek is het van belang te onderscheiden tussen reparatoire en punitieve bestuursrechtelijke sancties. Reparatoire sancties zien (met name) op herstel van een (on)rechtmatige toestand. Punitieve sancties hebben met name leedtoevoeging ten doel. Of er sprake is van leedtoevoeging dient vast te worden gesteld aan de hand van een materieel criterium. Dit brengt met zich dat het doel van de sanctie zoals dat is weergegeven in (de wetgeschiedenis van) de wettelijke regeling niet zonder meer doorslaggevend is. Op basis van het materiële criterium kan er ten eerste gesproken worden van leedtoevoeging als de sanctie verder gaat dan herstel van de (on)rechtmatige toestand vergt. Daamaast kan worden gesproken van leedtoevoeging als er een sanctie wordt opgelegd terwijl herstel van de rechtmatige toestand niet meer mogelijk is en deze sanctie niet slechts schadevergoeding (compensatie) behelst. 
Het onderscheid tussen reparatoire en punitieve sancties is relevant omdat er bij punitieve sancties sprake is van een 'verhoogde rechtsbescherming'. Een punitieve bestuursrechtelijke sanctie moet doorgaans worden aangemerkt als een 'criminal charge' in de zin van artikel 6 EVRM. $^{323}$ Dientengevolge moet het bestuursorgaan bij de oplegging; van een punitieve bestuursrechtelijke sanctie de waarborgen die voorvloeien uit artikel 6 en 7 EVRM, en uit artikel 14 en 15 IVBPR in acht nemen. Daarnaast moet de bestuursrechter de opgelegde sanctie indringender toetsen.

Ten aanzien van de intrekking van een begunstigende beschikking moet van geval tot geval bepaald worden of er sprake is van een punitieve of reparatoire sanctie. Het toepassen van bestuursdwang wordt gekwalificeerd als een reparatoire sanctie. Hoewel de last onder dwangsom op grond van de wetsgeschiedenis en rechtspraak aangemerkt moet worden als een administratieve sanctie met een reparatoir karakter dient deze sanctie naar mijn mening in bepaalde gevallen aangemerkt te worden als een punitieve sanctie. Het voorgaande geldt eveneens voor de maatregel in het sociale zekerheidsrecht en daarmee vergelijkbare (financiële) sancties. De bestuurlijke boete, tenslotte, is (onomstreden) een punitieve sanctie.

In dit algemene hoofdstuk is vervolgens ingegaan op de vraag welke normschendingen afgedaan kunnen worden door middel van (punitieve) bestuursrechtelijke sancties. Daarbij is aandacht geschonken aan (rechtshistorische) theorieën uit de literatuur en aan het rapport van de Toetsingscommissie 'Handhaving door bestuurlijke boeten'. Met betrekking tot de opvattingen in de literatuur kan worden opgemerkt dat de criteria die verband houden met de normatieve lading van de normschending het meest plausibel zijn. De geringe normatieve lading is ook voor de Toetsingscommissie het belangrijkste criterium om sanctionering door middel van een bestuurlijke boete mogelijk te achten. Het probleem is echter dat op basis van criteria met betrekking tot de normatieve lading van de normschending alleen ten aanzien van de meest extreme gevallen kwalificatie eenvoudig is. Er zullen tal van normschendingen zijn die minder eenvoudig te kwalificeren zijn. Voor dergelijke normschendingen biedt het onderscheid tussen wetsdelicten en rechtsdelicten geen uitkomst. Een doorslaggevend criterium aan de hand waarvan vrij eenvoudig ten aanzien van alle normschendingen vastgesteld kan worden of deze strafrechtelijk dan wel bestuursrechtelijk afgedaan mocten worden ontbreekt derhalve. Slechts ten aanzien van werkelijk moreel verwerpelijke delicten (rechtsdelicten) geldt dat zij strafrechtelijk afgedaan zullen moeten worden. Dit hangt samen met het stigmatiserende effect van de strafrechtelijke procedure. De consequentie van het voorgaande is dat alle normschendingen die niet zonder meer moreel verwerpelijk zijn afgedaan kunnen worden door middel van een bestuurlijke boete.

In de literatuur wordt ook wel oplegging van punitieve bestuursrechtelijke sancties door de strafrechter bepleit. Punitieve bestuursrechtelijke sancties worden in dat kader gerekend tot het strafrecht in ruime zin. Deze opvatting spreekt mij aan. Indien de bestuurlijke boete gerekend wordt tot het strafrecht in ruime zin, zou de boete mijns inziens in eerste instantie wel door een bestuursorgaan opgelegd kunnen worden. Eventueel kan daarbij gedacht worden aan de bestuursrechtelijke transactie als alternatieve

323 Ik zal hier in hoofdstuk 3 nog uitvoerig op terug komen. 
sanctie. Indien het gesanctioneerde rechtssubject het niet eens is met de opgelegde bestuurlijke boete of de bestuursrechtelijke transactie zou dan vervolgens een procedure bij de bestuurs- of strafrechter moeten volgen. Gedurende de (gehele) sanctieprocedure zouden dan in ieder geval de essentiêle straf(proces)rechtelijke beginselen in acht moeten worden genomen. ${ }^{324}$ Bestuursstrafrechtelijke sanctionering op deze wijze spreekt mij het meest aan. Later in dit boek zal ik daar nog uitvoerig op terugkomen.

324 Deze essentielle straf(proces)rechtelijke waarborgen dienen bij de oplegging van alle bestuurlijke boeten (en andere punitieve bestuursrechtelijke sancties) in acht genomen te worden ongeacht de emst van de overtreding of de zwaarte van de sanctie. D.w.z. dat geen differentiatie plaats vindt in de zin dat meer waarborgen moeten gelden indien een zwaardere overtreding gesanctioneerd wordt of een hogere boete opgelegd wordt. De normen die middels punitieve bestuursrechtelijke sancties worden gehandhaafd vormen een categorie op zich. Binnen die categorie dienen voor alle te bestraffen normschendingen dezelfde waarborgen in het kader van de rechtsbescherming te gelden. Zie in dit kader ook hoofdstuk vier. 


\section{Verdragsrechtelijke waarborgen bij de oplegging van bestuurlijke boeten}

\section{$3.1 \quad$ Inleiding}

In hoofdstuk drie zal aandacht uitgaan naar de verdragsrechtelijke waarborgen die op basis van het EVRM en het IVBPR' in acht genomen moeten worden bij de oplegging van een bestuurlijke boete. ${ }^{2}$ Daarbij zal de nadruk liggen op de uit het EVRM voortvloeiende waarborgen. Dit heeft te maken met het feit dat de verdragsrechtelijke rechtsbescherming in het kader van het IVBPR (beduidend) minder ver strekt dan de rechtsbescherming die op basis van de directe klachtprocedure bij het Europese Hof voor de Rechten van de Mens (EHRM) wordt geboden. Met name het feit dat het Comité voor de Rechten van de Mens van de Verenigde Naties, in tegenstelling tot het EHRM, géén bindende uitspraken kan doen leidt tot die conclusie. ${ }^{3}$ Voor zover in het EVRM dezelfde waarborgen zijn neergelegd als in het IVBPR zal een klager (in Nederland) derhalve eerder kiezen voor de Straatsburgse procedure. ${ }^{4}$ Aangezien ten aanzien van de oplegging van een bestuurlijke boete in artikel 6 en 7 EVRM vrijwel dezelfde waarborgen zijn neergelegd als in artikel 14 en 15 IVBPR zal de (Nederlandse)

1 Nederland is zowel partij bij het EVRM als het IVBPR. Het voorgaande betekent dat bepalingen uit genoemde verdragen (rechtstreeks) door kunnen werken in ons nationale rechtsstelsel. Naar nationaal recht hebben de bepalingen uit het EVRM en IVBPR, op grond van artikel $93 \mathrm{Gw}$, voor zover het grat om bepalingen die naar hun inhoud eenieder kunnen verbinden, verbindende kracht nadat de verdragen zijn bekendgemaakt. Daarnaast blijkt uit artikel $94 \mathrm{Gw}$ dat nationale wettelijke voorschriften, welker toepassing niet verenigbaar is met eenieder verbindende bepalingen uit verdraigen, buiten toepassing dienen te worden gelaten. Zie in dit kader ook: A.W. Heringa, Van Europese Conventie tot Nederlandse Constitutie voor de rechten van de mens, in de bundel: 40 jaar Europees verdrag voor de Rechten van de Mens: opstellen over de ontwikkeling van het EVRM in Straatsburg en in Nederland, onder redactie van A.W. Heringa en J.G.C. Schokkenbroek, Leiden 1990, p. 317-335. Aangezien door de Nederlandse rechter de incorporatietheorie wordt toegepast werken ook uitspraken van het EHRM uitgeproken ten aanzien van andere lidstaten door in Nederland. Vgl. T. Barkhuysen, M.L. van Emmerik en J.P. Loof, 50 jaar EVRM en het Nederlandse staats- en bestuursrecht - ontwikkelingen en vooruitzichten in de bundel: 50 jaar Europees Verdrag voor de Rechten van de Mens, onder redactie van R.A. Lawson en E. Myjer, Leiden 2000, p. 237-408, i.h.b. p. 330-331.

2 Op deze plaats wil ik er op wijzen dat de bepalingen uit het EVRM slechts zogenaamde 'minimum normen' bevatten. Het voorgaande betekent dat de partijstaten (onder omstandigheden) verdergaande waarborgen in acht kunnen (of moeten) nemen (zie art. 53 EVRM). Ten aanzien van bepalingen die in het IVBPR zijn neergelegd geldt eveneens dat het slechts gaat om zogenaamde 'minimum normen' blijkens artikel 5 lid 2 IVBPR.

3 Zie voor een beknopt overzicht van de klachtprocedure bij het EHRM en het VN Comité voor de Rechten van de Mens: P.H. Kooijmans, Internationaal publiekrecht in vogelvlucht, Wolters-Noordhoff, Groningen 1997, i.h.b. p. 371-375. Opmerking verdient dat Kooijmans uitgaat van het individuele klachtrecht zoals dat ten aanzien van het EVRM bestond voor inwerkingtreding van het elfde protocol op 1 november 1998. Zie voor een korte beschrijving van de klachtprocedure bij het EHRM na inwerkingtreding van het elfde protocol: Koopmans' Compendium van het Staatsrecht, bewerkt door: Th.L. Bellekom, A.W. Heringa, J. van der Velde en L.F.M. Verhey, Kluwer, Deventer 2002, i.h.b. p. 295296.

4 Zie in dit kader ook: P.M. van Russen Groen, Rechtsbescherming in het bestuursstrafrecht (diss. EUR), Gouda Quint, 1998 i.h.b. p. 61. 
burger doorgaans een beroep doen op de betreffende bepaling uit het EVRM. Het voorgaande impliceert, zoals ook Van Russen Groen signaleert ${ }^{5}$, dat er ten aanzien van de waarborgen uit het EVRM meer rechtspraak voorhanden is die kan leiden tot een beter inzicht (in de inhoud) van de op basis van het EVRM (en IVBPR) in acht te nemen waarborgen.

Alvorens ingegaan wordt op de specifieke verdragsrechtelijke waarborgen, die in acht genomen moeten worden bij het opleggen van een 'strafsanctie', dient vastgesteld te worden wanneer deze 'straf(proces)rechtelijke' waarborgen van toepassing zijn. Essentieel, in dat kader, is de term 'criminal charge' (strafvervolging) uit artikel 6 EVRM. Alle overige straf(proces)rechtelijke waarborgen die uit artikel 6 (en 7) EVRM voortvloeien zijn in feite opgehangen aan deze 'kapstok'. Ten eerste zal in dit hoofdstuk dan ook ingegaan worden op de vraag wanneer er sprake is van een 'criminal charge' in de zin van artikel 6 EVRM. Ter beantwoording van die vraag zal met name aandacht uitgaan naar de rechtspraak van het Europees Hof voor de Rechten van de Mens (EHRM). ${ }^{6}$ Dit vanwege het feit dat het EHRM de term 'criminal charge' autonoom uitlegt. Opvattingen van de nationale wetgevers en rechters in deze zijn derhalve niet (zonder meer) maatgevend. ${ }^{7}$

In dit hoofdstuk wordt niet gestreefd naar het geven van een uitputtende opsomming - als dat al mogelijk zou zijn - van sancties die volgens het EHRM moeten worden aangemerkt als 'criminal charge'. Centraal staan de criteria op basis waarvan het EHRM vaststelt of er sprake is van een 'criminal charge'. Bij bestudering van dit hoofdstuk zal blijken dat de rechtspraak van het Hof nogal casuittisch is. Derhalve lijkt het niet zinvol érg veel waarde te hechten aan een lijst van sancties waarvan de oplegging in eerdere uitspraken van het EHRM al dan niet als 'criminal charge' werden aangemerkt. De kans bestaat immers dat de oplegging van een vrijwel identieke sanctie in een andere uitspraak van het EHRM niet als 'criminal charge' wordt gekwalificeerd. Belangrijker is het, op basis van de door het Hof gehanteerde criteria, te beoordelen welke criteria, of kenmerken van de sancties, (veelal) doorslaggevend zijn voor de kwalificatie van de procedure tot oplegging van de sanctie als 'criminal charge'.

Na de beschrijving van de term 'criminal charge' aan de hand van de rechtspraak van het EHRM zal nog aandacht geschonken worden aan een aantal specifieke straf(proces)rechtelijke waarborgen dat voortvloeit uit artikel 6 en 7 EVRM en uit artikel 14 en 15 IVBPR. In dat kader verdient opmerking dat in artikel 14 en 15 IVBPR vrijwel

5 Van Russen Groen a.w. 1998, p. 61.

6 Op de totstandkomingsgeschiedenis van het EVRM (en IVBPR) zal ik niet ingaan. Zie hierover o.m.: Council of Europe, collected edition of the 'Traveaux Préparatoires' of the European Convention on Human Rights, Volume I-VIII, Martinus Nijhoff Publishers, Dordrech//Boston/Lancaster, 1985; Y. Klerk, De ontstaansgeschiedenis van de Europese Conventie, in de bundel: 40 jaar Europees verdrag voor de Rechten van de Mens: opstellen over de ontwikkeling van het EVRM in Straatsburg en in Nederland, onder redactie van A.W. Heringa en J.G.C. Schokkenbroek, Leiden 1990, p. 3-15; en M.L.W.M. Viering, Het toepassingsbereik van artikel 6 EVRM (diss. KUN), W.E.J. Tjeenk Willink, Zwolle 1994, i.h.b. hoofdstuk 3. Bovendien zal in dit werk geen aandacht worden geschonken aan de Travaux Préparatoires omdat daaruit niet erg veel valt af te leiden voor wat betreft de interpretatie van de term 'criminal charge' en de andere waarborgen (zie in dit kader Viering a.w. 1994, p. 44). Derhalve volsta ik met bestudering en beschrijving van de jurisprudentic van het EHRM.

7 Zie de zaak Ozturk, EHRM 21 februari 1984, Series A, Vol. 73, NJ 1988, 937 m. nt. E.A. Alkena, i.h.b. $\S 49$ en 50 . 
dezelfde waarborgen zijn opgenomen als in artikel 6 en 7 EVRM. Op zich is dit niet vreemd. Genoemde bepalingen uit het EVRM en IVBPR zijn op elkaar afgestemd. Viering geeft dit in zijn dissertatie als volgt weer:

'Historisch blijkt er een nauwe samenhang te bestaan tussen art. 6 EVRM, art. 10 Iniversele Verklaring en art. 14 IVBPR. Een ontwerp van de laatstgenoemdc bepaling vormue de basis voor de tekst van art. 6 EVRM. Het is aannemelijk dat de opstellers van art. 6 benogden dit artikel eenzelfde reikwijdte te geven als het (ontwerp van) art. 14 IVBPR. ${ }^{8}$

Uit de preambule bij het EVRM blijkt bovendien dat men met het EVRM heeft willen aansluiten bij de Universele Verklaring van de Rechten van de Mens die in diezelfde periode door de Verenigde Naties is opgesteld.

In het bijzonder zal in dit hoofdstuk, voor wat betreft de verdragsrechtelijke waarborgen, ingegaan worden op de onschuldpresumptie en het nemo tenetur-beginsel (tezamen met het zwijgrecht). Daarnaast zal kort aandacht besteed worden aan het nullum crimen sine lege-beginsel, het nulla poena sine lege-beginsel en het beginsel dat de overtreder dient te profiteren van een, na het begaan van het strafbare feit, totstandgekomen wetswijziging die voorziet in de oplegging van een lichtere straf. In het kader van het nullum crimen sine lege-beginsel en het nulla poena sine lege-beginsel zal tevens aandacht uitgaan naar het lex certa-vereiste.

Genoemde waarborgen komen in dit hoofdstuk uitdrukkelijk aan de orde omdat de uitleg die het EHRM aan deze waarborgen geeft niet gemist kan worden teneinde vast te stellen of de boeteregeling in het Voorontwerp van de vierde tranche van de Awb met voldoende waarborgen is omkleed. Meer in het bijzonder gaat het dan om de vraag of in het Voorontwerp door de commissie Scheltema een juiste uitleg wordt gegeven aan de verdragsrechtelijke waarborgen. Een antwoord op deze laatste vraag zal overigens gegeven worden in hoofdstuk vier en in deel III van dit boek.

Op het ne bis in idem-beginsel zal in dit hoofdstuk niet ingegaan worden. Het ne bis in idem-beginsel is weliswaar neergelegd in artikel 4 van het zevende protocol bij het EVRM en in artikel 14, zevende lid IVBPR. De bepaling uit het zevende protocol bij het EVRM is echter niet geratificeerd door Nederland terwijl ten aanzien van het zevende lid van artikel 14 van het IVBPR door Nederland een voorbehoud is gemaakt inhoudende dat uit genoemde bepaling geen verdergaande verplichtingen voortvloeien dan de verplichtingen die voortvloeien uit artikel $68 \mathrm{Sr}^{9}$ Derhalve zal met name aangehaakt moeten worden bij jurisprudentie van de Hoge Raad inzake de toepassing van artikel $68 \mathrm{Sr}$. In hoofdstuk vier van dit boek zal ik, met name aan de hand van rechtspraak van de Hoge Raad, uitvoeriger ingaan op het ne bis in idem-beginsel en het daarmee samenhangende una via-beginsel. Zijdelings zal daarbij overigens ook de rechtspraak van het EHRM aan de orde komen.

Ik wil er nadrukkelijk op wijzen dat hoofdstuk drie een overzicht van bepaalde verdragsrechtelijke waarborgen en de daarbij behorende jurisprudentie op hoofdlijnen

8 Zie Viering a.w. 1994, p. 48. Zie voorts: M. Nowak, U.N. Convenant on Civil and Political Rights, CCPR commentary, N.P. Engel Publisher, Kehl, Strasbourg. Arlington 1993, i.h.b. p. 236. Zie voor een beknopt overzicht van de waarborgen die zijn neergelegd in artikcl 6 EVRM en artikel 14 IVBPR; Van Russen Groen, a.w. 1998, p. 77-78.

Zie hierover ook: Van Russen Groen, a.w. 1998, p. 294-295. 
biedt. ${ }^{10}$ Voor een uitvoeriger overzicht wijs ik, zonder overigens volledig te zijn, op de dissertaties van Den Hartog ${ }^{11}$, Feteris ${ }^{12}$, Viering ${ }^{13}$ en Van Russen Groen. ${ }^{14}$

\subsection{Criminal charge}

\subsubsection{Criminal charge - algemeen-}

De interpretatie van het EHRM van de term 'criminal charge' is, zoals reeds in de inleiding van dit hoofdstuk is aangegeven, essentieel voor beantwoording van de vraag met welke verdragsrechtelijke waarborgen rekening moet worden gehouden bij de oplegging van een bestuurlijke boete. ${ }^{15}$ Alleen als de oplegging van een bestuurlijke boete aangemerkt moet worden als 'criminal charge' in de zin van artikel 6 EVRM zijn de uit artikel 6 en 7 EVRM voortvloeiende straf(proces)rechtelijke waarborgen van toepassing bij de oplegging van een bestuurlijke boete.

De term 'criminal charge' wordt, zoals gezegd, door het EHRM autonoom geünterpreteerd. In de zaak 'Öztürk' heeft het Hof daaromtrent het volgende gesteld:

'The Convention is not opposed to States, in the performance of their task as guardians of the public interest, both creating or maintaining a distinction between different categories of offences for the purpose of their domestic law and drawing the deviding line, but it does not follow that the classification thus made by the States is decisive for the purposes of the Convention [curs. KA] By removing certain forms of conduct from the category of criminal offences under domestic law, the law-maker may be able to serve the interests of the individual (...) as well as the needs of the proper administration of justice, in particular in so far as the judicial authorities are thereby relieved of the task of prosecuting and punishing contraventions - which are numerous but of minor importance - of road traffic rules. The Convention is not opposed to the moves towards "decriminalisation" which are taking place - in extremely varied forms - in the member States of the Council of Europe. The Guvernment quite rightly insisted on this point. Nevertheless, if the Contracting States were able at their discretion, by classifying an offence as "regulatory" instead of criminal, to exclude the operation of the fundamental clauses of Articles 6 and 7 (art. 6, art. 7), the application of these provisions would be subordinated to their sovereign will. A latitude extending thus far might lead to results incompatible with the object and purpose of the Convention. Having thus reaffirmed the "autonomy" of the notion of "criminal" as conceived of under Article 6 (art. 6), what the Court must determine is whether or not the "regulatory

10 De rechtspraak van het Hof is in hoge mate casuïstisch en niet in alle gevallen voor eenduidige uitleg vatbaar. In het kader van dit boek zal ik aangeven wat de hoofdlijn is in de rechtspraak van het Hof ten aanzien van de artikelen 6 en 7 EVRM. De uitzonderingen op, en afwijkingen van de hoofdregel zullen in dit werk nict aan bod komen.

11 Anita den Hartog, Artikel 6 EVRM: grenzen aan het streven de straf eerder op de daad te doen volgen (diss. RUG), MAKLU uitgevers, Antwerpen-Apeldoom 1992.

12 M.W.C. Feteris, Fiscale administratieve sancties en het recht op een behoorlijk proces (diss. UvA), Kluwer, Deventer 1993.

13 Viering a.w. 1994.

14 Van Russen Groen a.w. 1998.

15 Zoals uit het voorgaande al blijkt zal ik in dit hoofdstuk werken met de engelse term 'criminal charge'. In de Nederlandstalige bepaling van artikel 6, eerste lid EVRM wordt gesproken van 'het bepalen van de gegrondheid van een tegen hem ingestelde vervolging'. De Nederlandstalige equivalent van het begrip 'criminal charge' zal in dit hoofdstuk verder niet gehanteerd worden. 
offence" committed by the applicant was a "criminal" one within the meaning of that Article
(art. 6) [curs. KA].'

Het is derhalve niet de partijstaat zelf, maar het Hof dat (uiteindelijk) bepaalt of sanctionering van een bepaalde normschending aangemerkt moet worden als een 'criminal charge'.

Teneinde de vraag te beantwoorden of er sprake is van een 'criminal charge' hanteert het EHRM een drietal criteria. Deze criteria zijn door het EHRM ontwikkeld en voor het eerst naar voren gebracht in de zaak 'Engel and Others v. the Netherlands'. ${ }^{17}$ In de zaak 'Öztürk' geeft het Hof, na benadrukking van het autonome karakter van het begrip 'criminal charge', de drie criteria weer:

'..., what the Court must determine is whether or not the "regulatory offence" committed by the applicant was a "criminal" one within the meaning of that Article (art. 6). For this purpose, the Court will rely on the criteria adopted in the above-mentioned Engel and Others judgment (...). The first matter to be ascertained is whether or not the text defining the offence in issue belongs, according to the legal system of the respondent State, to criminal law; next, the nature of the offence and, finally, the nature and degree of severity of the penalty that the person concerned risked incurring must be examined, having regard to the object and purpose of Article 6 (art. 6), to the ordinary meaning of the terms of that Article (art. 6) and to the laws of the Contracting States. ${ }^{18}$

Ten eerste dient vastgesteld te worden of de normschending naar nationaal recht als strafbaar feit geclassificeerd wordt. Daamaast is, in de tweede plaats, de aard van de overtreding van belang. Het derde criterium op basis waarvan het Hof tot de conclusie zou kunnen komen dat er sprake is van een 'criminal charge' is de aard en de zwaarte van de sanctie. In de volgende subparagrafen zal ik uitvoerig ingaan op de drie, door het EHRM gehanteerde, criteria. ${ }^{19}$ Daarbij dient echter opgemerkt te worden dat het onderscheid tussen het tweede en derde criterium in de rechtspraak van het Hof niet altijd even scherp is. Om vast te stellen wat de aard van de overtreding is gaat het Hof in bepaalde gevallen ook in op de aard of het doel van de sanctie. ${ }^{20}$ De consequentie daarvan is dat bij de beantwoording van de vraag of er in een concreet geval sprake is van een 'criminal charge' door het Hof niet altijd strikt wordt onderscheiden tussen het tweede en het derde criterium.

16 'Öztürk', i.h.b. $\$ 49$ en 50. Zie ook: Engel and Others v. the Netherlands, EHRM 8 juni 1976, Series A vol. 22 , NJ 1978, 223 i.h.b. $\$ 81$ en 82.

17 'Engel and Others v. the Netherlands', EHRM 8 juni 1976, Series A vol. 22, NJ 1978, 223.

18 'Öztürk', $\$ 50$.

19 Den Hartog (a.w. 1992, p. 97) maakt een onderscheid tussen een formeel criterium en autonome criteria: 'Bij het formele criterium gaat het om het etiket dat de lidstaat op het delict heeft geplakt en bij de autonome criteria gaat het om criteria, die - los van het nationale recht - ontwikkeld zijn binnen het verdragsrechtelijke kader.'

20 Zie bijvoorbeeld de zaak 'Özturk' § 52: 'The second criterion stated above - the very nature of the offence, considered also in relation to the nature of the corresponding penalty - represents a factor of appreciation of greater weight.'

21 Zie in dit kader ook Viering a.w. 1994 p. 15I. Viering geeft aan dat het (tweede) criterium 'de aard van de overtreding' kan worden onderverdeeld in twee subcriteria te weten het normadressaat-criterium en het sanctiedoel-criterium. Bij het derde criterium 'de aard en de zwaarte van de sanctie' speelt het sanctiedoel-criterium uiteraard ook een rol. 
Nadat de drie, door het EHRM, gehanteerde criteria aan de hand van rechtspraak van het Hof nader zijn geanalyseerd zal in deze paragraaf tenslotte aandacht uitgaan naar de vraag hoe de drie criteria zich tot elkaar verhouden. Met name zal in dat kader de vraag aan orde komen of het om cumulatieve of alternatieve criteria gaat. ${ }^{22}$

\subsection{1.a Classificatie naar nationaal recht}

Zoals gezegd wordt als eerste criterium door het Hof aangedragen; de classificatie van de normschending naar nationaal recht. Dit (formele) criterium is het minst relevant. ${ }^{23}$ Met name in de gevallen waarin een partijstaat een normschending niet als een strafrechtelijke overtreding ${ }^{24}$ aanmerkt hecht het Hof weinig waarde aan de classificatie van de normschending naar nationaal recht. Dat heeft vanzelfsprekend te maken met het feit dat het begrip 'criminal charge' autonoom wordt uitgelegd door het EHRM. ${ }^{25}$

Het eerste criterium lijkt derhalve alleen doorslaggevend te zijn als de normschending naar nationaal recht wordt ondergebracht in het strafrecht. ${ }^{26}$ In 'Engel and Others v. the Netherlands' gaat het Europese Hof voor de Rechten van de Mens er van uit dat er voor het Hof geen taak weggelegd is, voor wat betreft de vaststelling dat er al dan niet spra$\mathrm{ke}$ is van een 'criminal charge', als een partijstaat een normschending zelf onderbrengt in het strafrecht. In paragraaf 81 van de zaak 'Engel and Others' heeft het Hof daaromtrent het volgende gesteld:

'The Convention without any doubt allows the States, in the performance of their function as guardians of the public interest, to maintain or establish a distinction between criminal law and disciplinary law, and to draw the dividing line, but only subject to certain conditions. The Convention leaves the States free to designate as a criminal offence an act or omission not constituting the normal exercise of one of the rights that it protects. This is made especially clear by Article 7 (art. 7). Such a choice, which has the effect of rendering applicable Articles 6 and 7 (art. 6, art. 7), in principle escapes supervision by the Court.'

Volgens het Hof is er in die gevallen altijd sprake van een 'criminal charge'. ${ }^{27}$ In de zaak 'Adolf ${ }^{28}$ lijkt het EHRM zelfs nog verder te gaan. In die zaak heeft het Hof bepaald dat ook niet-strafbare en ongesanctioneerde normschendingen onder het begrip 'criminal charge' vallen als de normschending naar nationaal recht deel uit maakt van het strafrecht.

Indien een partijstaat een normschending niet als strafrechtelijke overtreding classificeert acht het Hof de classificatie naar nationaal recht niet zonder meer doorslaggevend. In de zaak 'Engel and Others' neemt het Hof het volgende standpunt in:

In dat kader zijn onder meer de zaken 'Bendenoun' (EHRM 24 februari 1994, Series A vol. 284, NJ 94, 496, m. nt. E.A. Alkema) en 'Garryfallou AEBE' (EHRM 24 september 1997, no. 93/1996/712/909, JB 1997/281, m. nt. A.W. Heringa) relevant.

24 Het woord overtreding moet in dit kader worden gelezen als normschending (derhalve niet als overtreding i.t.t. misdrijf).

25 Zie in dit kader ook 'Demicoli v. Malta', i.h.b. \$31.

26 Zie in deze zin ook Den Hartog a.w. 1992, p. 97-98.

27 Zie in dit kader ook Viering a.w. 1994, p. 146-147.

28 EHRM 26 maart 1982, Series A vol. 49 (Adolf).

29 'Adolf', § 31-34. 
The converse choice, for its part, is subject to stricter rules. If the Contracting States were able at their discretion to classify an offence as disciplinary instead of criminal, or to prosecute the author of a "mixed" offence on the disciplinary rather than on the criminal plane, the operation of the fundamental clauses of Articles 6 and 7 (art. 6, art. 7) would be subordinated to their sovereign will. A latitude extending thus far might lead to results incompatible with the purpose and object of the Convention. The Court therefore has jurisdiction, under Article 6 (art. 6) and even without reference to Articles 17 and 18 (art. 17, art. 18), to satisfy itself that the disciplinary does not improperly encroach upon the criminal. In short, the "autonomy" of the concept of "criminal" operates, as it were, one way only. ${ }^{30}$

Teneinde te voorkomen dat de partijstaten de effectieve werking van de waarborgen die zijn neergelegd in de artikelen 6 en 7 EVRM frustreren acht het Hof zich derhalve bevoegd na te gaan of er al dan niet sprake is van een 'criminal charge' indien een partijstaat een bepaalde normschending niet heeft ondergebracht in het strafrecht. De term 'criminal charge' wordt in dat kader door het Hof autonoom uitgelegd (aan de hand van materiële criteria).

Hoewel het EHRM in de zaak 'Engel and Others' heeft aangegeven dat het Hof de keuze van een partijstaat om de normschending onder te brengen in het strafrecht respecteert lijkt het in de zaak 'Escoubet v. Belgium' ${ }^{\prime 31}$ een ander standpunt in te nemen. In die zaak heeft het EHRM ten aanzien van de classificatie van de normschending naar nationaal recht ${ }^{32}$ het volgende bepaald:

The court notes further that the fact that immediate withdrawal is a measure governed by the consolidating Acts of 16 March 1968, which constitute a seperate criminal statute, is not decisive. The fact that a measure is provided for in a criminal statute of a respondent State does not itself signify that it falls within the scope of Article 6 of the Convention. ${ }^{33}$

De classificatie van de normschending naar nationaal recht als strafrechtelijk vergrijp betekent volgens het Hof niet dat sanctionering van de overtreding zonder meer valt onder het toepassingsbereik van artikel 6 EVRM. Deze overweging staat haaks op de hierboven weergegeven overweging van het EHRM in de zaak 'Engel and Others'. Het Hof heeft in die zaak immers uitdrukkelijk aangegeven dat de classificatie naar nationaal recht, met het oog op het autonome karakter van de term 'criminal charge', alléén dan geen rol speelt als er naar nationaal recht géén sprake is van een strafrechtelijke overtreding. Slecht in die gevallen zou het Hof, op basis van de andere twee criteria, mogen toetsen of er toch sprake is van een 'criminal charge'. Op het moment dat een Partijstaat zelf de normschending onder brengt in het strafrecht is er voor het Hof, voor

\section{0 'Engel and Others' $\$ 81$.}

31 EHRM 28 oktober 1999, no. 26780/95, EHRC 1999/6 m. nt. Karianne Albers (Escoubet tegen Belgie).

32 Door het EHRM in die zaak geformuleerd als: 'the legal classification of the measure in question in national law'.

33 'Escoubet v. Belgium', $\$ 34$. Op deze plaats moet nog wel worden opgemerkt dat het er op lijkt dat er volgens het Hof in de zaak 'Escoubet $v$. Belgium' nog geen sprake was van een 'charge' op het moment dat Escoubet zijn rijbewijs in beslag genomen werd (voor zeven dagen), in verband met betrokkenheid bij een verkeersongeval vermoedelijk begaan onder invloed van alcohol. Tulkens, Fischbach en Casadevall kunnen, blijkens hun dissenting opinion, de opvattingen van het EHRM, waaruit volgt dat er geen sprake was van een 'criminal charge', niet onderschrijven. Ik deel die mening. 
wat betreft de vaststelling of er al dan niet sprake is van een 'criminal charge', geen taak meer weggelegd. Artikel 6 en 7 EVRM zijn dan van toepassing. ${ }^{34}$

In deze zin lijkt de opvatting van het EHRM in de zaak 'Escoubet v. Belgium' niet te stroken met de verdragsdoelstelling en met de motivering die in de zaken 'Engel and Others' en 'Öztürk' door het Hof ten grondslag is gelegd aan de opvatting dat de term 'criminal charge' moet worden gezien als autonoom begrip. ${ }^{35}$ Daarmee doel ik op de overweging dat de classificatie naar nationaal recht, volgens het EHRM niet doorslaggevend kan zijn omdat de partijstaten op die wijze sanctionering van normschending zouden kunnen onttrekken aan de waarborgen die bij een 'criminal charge' uit het verdrag voortvloeien. Daarbij gaat het in het bijzonder om (sanctionering van) normschendingen die naar nationaal recht géén deel uitmaken van het strafrecht.

In de zaak 'Escoubet v. Belgium' was de normschending juist ondergebracht in het strafrecht. Desondanks merkte het EHRM de onmiddellijke inbeslagname (voor zeven dagen) van het rijbewijs van Escoubet, in verband met betrokkenheid bij een verkeersongeval vermoedelijk begaan onder invloed van alcohol, niet aan als een 'criminal charge'. Derhalve hoefden de waarborgen die uit artikel 6 en 7 EVRM voortvloeien bij de onmiddellijke inbeslagneming van een rijbewijs niet in acht genomen te worden.

Een soortgelijke uitspraak deed het EHRM in een ontvankelijkheidsbeslissing in de zaak 'W.S. v. Poland' ${ }^{36}$ In die zaak werd de procedure tot oplegging van boeten, wegens overtredingen van de 'Fiscal Criminal Act', niet aangemerkt als 'criminal charge' in de zin van artikel 6 EVRM. Het Hof heeft in die ontvankelijkheidsbeslissing het volgende overwogen:

'As to the first of these criteria, the Court considers that the Fiscal Criminal Act should clearly be regarded als belonging to the criminal law. (...) However, this factor is only of relative weight and serves only as a starting-point (...).'

Vervolgens gaat het Hof in op de twee andere criteria (de aard van de overtreding en de aard en zwaarte van de sanctie). Op basis daarvan komt het Hof tot de (vreemde) conclusie dat de boeten, ondanks het punitieve karakter, niet voldoende zwaar zijn dat zij op basis daarvan als 'criminal charge' zouden moeten worden aangemerkt.

In beide laatstgenoemde zaken lijkt het Hof derhalve een onderscheid aan te brengen tussen het door de partijstaat onderbrengen van bepaalde normschendingen en de sanctionering daarvan in het (nationale) strafrecht, en de kwalificatie van de in het kader van die regeling opgelegde sanctie als 'criminal charge'. Eerder, in de zaak 'Engel' en 'Öztürk', lijkt het Hof niet van het bestaan van een dergelijk onderscheid uit te zijn gegaan. Is het Hof dan omgegaan in de zaken 'Escoubet v. Belgium' en 'W.S. v. Poland'? Dat is niet met zekerheid te zeggen. Gelet op de doelstelling van het verdrag zou er in de zaak 'Escoubet v. Belgium', evenals in de ontvankelijkheidsbeslissing in de zaak 'W.S. v. Poland', sprake kunnen zijn van een (enigszins vreemde en wellicht door de specifieke casus ingegeven) uitzondering op de hoofdregel. In dit kader wil ik nog wijzen op de dissenting opinion van Tulkens, Fischbach en Casadevall in de zaak 'Es-

36 EHRM 15 juni 1999, no. $37607 / 97$ (W.S. v. Poland). 
coubet v. Belgium'. Zij zijn van mening dat er wél sprake is van een 'criminal charge' in de zaak 'Escoubet v. Belgium'. Ook zij wijzen op de enigszins vreemde redenering van het Hof gelet op de doelstelling van het verdrag en het daaraan gerelateerde autonome karakter van het begrip 'criminal charge':

'Lastly, although - as stated in the judgment - "classification in the domestic law is not decisive for the purposes of the Convention" ( $\$ 33$ ), the Court has, nevertheless, stated on many occasions that it will not apply its method of interpretation unless the national law contains elements which make it impossible for the guarantees under Article 6 to apply: the autonomy of the notion of a criminal charge works "one-way" only. The purpose of an autonomous interpretation is to secure procedural guarantees to those subject to the jurisdiction of the courts where the classification under the domestic law might restrict the scope of the Convention. Where there are sufficient factors in the national law to indicate that the measure in question belongs to the criminal sphere, it is paradoxical to take the opposite view and rule out the application of Article 6 of the Convention. ${ }^{37}$

Na de uitspraak in de zaak 'Escoubet $\mathbf{v}$. Belgium' en in de ontvankelijkheidsbeslissing in de zaak 'W.S. v. Poland' kan, zoals gezegd, niet meer met zekerheid gezegd worden dat de classificatie naar nationaal recht doorslaggevend is indien de normschending is ondergebracht in het strafrecht. Ondanks dat neem ik aan dat het Hof in beginsel wel van dit uitgangspunt uit zal gaan. Zie ik het goed dan impliceert het voorgaande dat er in beginsel sprake is van een 'criminal charge' in de zin van artikel 6 EVRM bij de sanctionering van normschendingen, die naar nationaal recht zijn ondergebracht in het strafrecht. Het eerste criterium zal dan in de regel ook doorslaggevend zijn. Toetsing aan het tweede en derde criterium is dan in beginsel niet meer nodig. Desalniettemin kan zich de situatie voordoen dat de sanctionering van een normschending die onder het nationale strafrecht valt door het Hof niet aangemerkt wordt als 'criminal charge' omdat (eventueel de aard van de overtreding maar doorgaans) de aard (en de zwaarte) van de sanctie niet duidt op een 'criminal charge'.

Gaat het om sanctionering van overtredingen die naar nationaal recht niet zijn ondergebracht in het strafrecht (maar bijvoorbeeld in het bestuursrecht) dan wordt het eerste criterium zonder meer niet van doorslaggevende betekenis geacht. ${ }^{38}$ Op basis van het (materiële) tweede en/of derde criterium dient in dat geval te worden beoordeeld of er toch sprake is van een 'criminal charge'.

Gelet op het voorgaande zal het Hof in beginsel, zowel bij sanctionering van overtredingen die naar nationaal recht zijn ondergebracht in het strafrecht als bij sanctionering van overtredingen die naar nationaal recht niet zijn ondergebracht in het strafrecht, impliciet dan wel expliciet, het tweede en/of derde criterium betrekken bij de beantwoording van de vraag of er sprake is van een 'criminal charge'.

\subsection{1.b Aard van de overtreding}

In het algemeen inleidend gedeelte van $\S 3.2 .1$ is reeds aangegeven dat het Hof niet altijd een strikte scheiding maakt tussen de aard van de overtreding en de (in $\S 3.2 .1$.c

De dissenting opinion van Tulkens, Fischbach en Casadevall in de zaak 'Escoubet v. Belgium'.

Zie in deze zin ook 'Engel and Others' $\$ 82$ : 'This however provides no more than a starting point. The indications so afforded have only a formal and relative value and must be examined in the light of the common denominator of the respective legislation of the various Contracting States.' 
te behandelen) aard en de zwaarte van de sanctie. Met name het doel van de sanctie speelt in bepaalde gevallen, in het kader van het tweede criterium (de aard van de overtreding), volgens het Hof een rol. ${ }^{39}$ Teneinde de vraag te beantwoorden of de overtreding 'criminal' van aard is kent het Hof dan tevens gewicht toe aan het doel van de sanctie.

Mede vanuit praktische overwegingen ${ }^{40}$ zal hier, bij bespreking van het tweede criterium; de aard van de overtreding, alleen ingegaan worden op het zogenaamde 'normadressaat-criterium'. ${ }^{41}$ Genoemd normadressaat-criterium ziet op de vraag tot wie de overtreden norm zich richt: tot een specifieke (beroeps)groep danwel tot alle burgers. ${ }^{42}$ Een uitvoerigere analyse van het sanctiedoel-criterium zal plaatsvinden bij behandeling van het derde criterium. Desalniettemin moet niet uit het oog verloren worden dat het Hof het criterium 'de aard van de overtreding' soms onder lijkt te verdelen in het normadressaat-criterium en het sanctiedoel-criterium.

Tenslotte wil ik op deze plaats nog opmerken dat de emst van de overtreding geen rol lijkt te spelen bij beantwoording van de vraag of er sprake is van een 'criminal charge' op basis van het criterium 'de aard van de overtreding'. In de zaak 'Öztürk' heeft het Hof daaromtrent het volgende overwogen:

There is in fact nothing to suggest that the criminal offence referred to in the Convention necessarily implies a certain degree of seriousness. (...) Furthermore, it would be contrary to the object and purpose of Art. 6, (...) if the States were allowed to remove from the scope of this Article a whole category of offences merely on the ground of regarding them as petty. ${ }^{43}$

Derhalve zal bij de bespreking van het tweede criterium (de aard van de overtreding) plaats slechts aandacht uitgaan naar het normadressaat-criterium.

Zoals Viering in zijn dissertatie heeft aangegeven behelst het normadressaat-criterium met name de vraag tot wie de overtreden norm zich richt. Op basis van het normadressaat-criterium lijkt het EHRM met name te komen tot een onderscheid tussen tuchrechtelijke overtredingen (ofwel overtredingen van 'disciplinaire' aard), waarbij regels die (bijvoorbeeld) specifiek voor een bepaalde beroepsgroep in het kader van de beroepsuitoefening in het leven zijn geroepen, overtreden worden, en strafrechtelijke overtredingen, waarbij het gaat om het overtreden van regels die gericht zijn tot alle burgers (eventueel in een bepaalde hoedanigheid).

Bij beantwoording van de vraag of er sprake is van tuchtrecht of van strafrechtelijke normen die gericht zijn tot alle burgers (eventueel in een bepaalde hoedanigheid) kunnen de volgende kenmerken en verschillen tussen beiden in ogenschouw worden genomen. Overtredingen van tuchtrechtelijke aard zullen alleen (binnen het tuchtrechte-

39 Zie in dit kader bijvoorbeeld 'Özturk' $\$ 53$.

40 M.i. is het helderder bij bespreking van het derde criterium 'de aard en de zwaarte van de sanctie' stil te staan bij deze aspecten.

41 Zie m.b.t. het normadressaat-criterium: Viering a.w. 1994, p. 151, p. 153-159 en p. 178-179.

42 Viering a.w. 1994, p. 154.

43 'Öztürk' \& 53. Zie voorts: EHRM 25 augustus 1987, Series A vol. 123, NJ 1988, 938 m. nt. E.A. Alkema (Lutz), i.h.b. $\S 57$. Uit genoemde overweging blijkt dat het EHRM van mening is dat (alléen) 'minor offences which are not so discreditable that the offenders deserve the stigna of a criminal penalty afgedaan kunnen worden door middel van een (punitieve) bestuursrechtelijke sanctie. 
lijke kader) strafbaar zijn als zij door een persoon die deel uitmaakt van de beroepsgroep (doorgaans) tijdens of in het kader van de uitoefening van zijn beroep zijn begaan. ${ }^{44}$ Wordt dezelfde handeling verricht door een burger die geen deel uitmaakt van de (beroeps)groep dan levert dit géén overtreding op van het tuchtrecht en doorgaans (afhankelijk van de vraag of de gedraging al dan niet een strafbaar feit in de zin van het algemene nationale strafrecht oplevert) ook anderszins geen strafbare handeling.

Levert de, met de tuchtrechtelijke overtreding vergelijkbare, gedraging van de burger wél een strafbaar feit op dan is dat tegelijkertijd een indicatie dat er zélfs in het kader van het tuchtrecht, sprake zou kunnen zijn van een overtreding die 'criminal' van aard is. Zo heeft het Hof bepaald in de zaak Campbell en Fell. ${ }^{45}$

In die zaak ging het om sanctionering van gevangenen wegens het veroorzaken van, en deelnemen aan, een gevangenisoproer en het toebrengen van zwaar lichamelijk letstel aan een bewaker. De overtredingen worden naar Engels recht gekwalificeerd als overtredingen van (interne) displinaire regels die in acht genomen dienen te worden (door gevangenen) in de gevangenis. Het EHRM overweegt ten aanzien van de aard van de overtreding, en dan in het bijzonder ten aanzien van het normadressaat-criterium het volgende:

'In this respect, it has to be borne in mind that misconduct by a prisoner may take different forms; certain acts are clearly no more than a question of intemal discipline, whereas others cannot be seen in the same light. Firstly, some matters may be more serious than others; (...) Secondly, the illegality of some acts may not turn on the fact that they were committed in prison: certain conduct which constitutes an offence under the Rules may also amount to an offence under the criminal law. Thus, doing gross personal violence to a prison officer may correspond to the crime of 'assault occasioning actual bodily harm' and, although mutiny and incitement to mutiny are not as such offences under the general criminal law, the underlying facts may found a criminal charge of conspiracy (...). It also has to be remembered that, theoretically at least, there is nothing to prevent conduct of this kind being the subject of both criminal and disciplinary proceedings (ibid.).

The Court considers that these factors, whilst not of themselves sufficient to lead to the conclusion that the offences with which the applicant was charged have to be regarded as "criminal" for Convention purposes, do give them a certain colouring which does not entirely coincide with that of a purely disciplinary matter. ${ }^{46}$

Als hoofdregel geldt echter dat een door een tot een specifieke (beroeps)groep behorend lid gepleegde overtreding van een tuchtrechtelijke bepaling niet 'criminal' van aard is.

Dit is anders als een burger een voorschrift overtreedt dat tot alle burgers (eventueel in een bepaalde hoedanigheid) is gericht. In de zaak 'Öztürk' bepaalde het Hof ten aanzien van een door Öztilrk gepleegde verkeersovertreding in dat kader het volgende:

'The rule of law infringed by the applicant has, for its part, undergone no change of content. It is a rule that is directed, not towards a given group possessing a special status - in the

Naast tuchtrecht dat toepasselijk is in een bepaalde beroepsgroep kan ook gedacht worden aan tuchtrechtelijke bepalingen die bijvoorbeeld gelden in het gevangeniswezen. Op grend van dergelijke bepalingen dienen gedetineerden bepaalde regels in acht te nemen binnen de gevangenis. Zie in dit kader de zaak 'Campbell and Fell', EHRM 28 juni 1984, Series A vol. 80.

46 'Campbell and Fell' § 71 . 
manner, for example, of disciplinary law -, but towards all citizens in their capacity as roadusers; it prescribes conduct of a certain kind and makes the resultant requirement subject to a sanction that is punitive. ${ }^{47}$

Öztürk heeft derhalve een regel overtreden die niet gericht is tot een bepaalde groep die een specifieke status bezit zoals dat in het tuchtrecht, bijvoorbeeld ten aanzien van bepaalde beroepsgroepen, het geval is. De (verkeers)regel die Öztürk heeft overtreden is gericht tot alle burgers in hun hoedanigheid van weggebruikers. Derhalve kan de overtreding als strafrechtelijk van aard worden beschouwd. ${ }^{48}$

De hoofdregel lijkt dan ook de volgende te zijn. Is de overtreden regel gericht tot leden van een bepaalde (beroeps)groep en gelden deze regels slechts in een bepaalde omgeving of sfeer dan is overtreding van de regel niet 'criminal' maar 'disciplinary' van aard. Is de overtreden regel gericht tot alle burgers dan zal de overtreding (doorgaans), op basis van het normadressaat-criterium, als 'criminal' van aard worden beschouwd. Hiermee is echter niet tevens de vraag beantwoord of er sprake is van een 'criminal charge'. Van een 'criminal charge' is (in beginsel), zo volgt uit de rechtspraak van het EHRM, eerst sprake als de sanctie daarnaast punitief van aard is. Om die reden lijkt het sanctiedoel-criterium in bepaalde gevallen door het EHRM bij het criterium 'de aard van de overtreding' betrokken te worden. ${ }^{49}$

Het voorgaande impliceert dat op basis van het normadressaat-criterium alleen vastgesteld kan worden of een overtreding al dan niet 'criminal' van aard is. Is de regeling algemeen (gericht tot alle burgers) dan kán er sprake zijn van een 'criminal charge'. Dat laatste kan echter pas vastgesteld worden na toetsing aan het, van het derde criterium deel uitmakende, subcriterium; de aard van de sanctie. Bovendien kan, onder bepaalde omstandigheden, sanctionering van een overtreding die 'disciplinary' van aard is op basis van het derde criterium (de aard en de zwaarte van de sanctie) aangemerkt worden als 'criminal charge'. ${ }^{50}$ Dit was bijvoorbeeld het geval in de zaak 'Engel and Others'. 51

47 'Oztük' $\$ 53$. De aangehaalde passage illustreert tevens dat het EHRM ook in de zaak 'Özturk' het tweede en derde criterium tegelijkertijd toepast. Naast overwegingen met betrekking tot de aard van de geschonden norm wordt door het Hof gewezen op het punitieve karakter van de sanctie. Zie overigens in dit kader ook de reeds eerder aangehaalde passage uit $\S 52$ van de zaak 'Oztürk'.

48 In de zaak 'Ozturk' (\$ 52) lijkt het EHRM naast het normadrassaat-criterium ook gewicht toe te kennen aan de wijze waarop andere partijstaten het delict hebben geclassificeerd: 'In addition, misconduct of the kind committed by Mr. Oztlurk continues to be classified as part of the criminal law in the vast majority of the Contracting States, as it was in the Federal Republic of Germany until the entry into force of the 1968/1975 legislation; in those other States, such misconduct, being regarded as illegal and reprehensible, is punishable by criminal penalties.' In de latere rechtspraak van het EHRM komt dit aspect, zoals hierna nog zal blijken, doorgaans niet meer aan de orde. Het normadressaat-criterium en de aard van de sanctie bieden het EHRM dan blijkbaar genoeg houvast om te bepalen of de oplegging van een sanctie aangemerkt moet worden als 'criminal charge'.

49 Zie voorts 'Bendenoun v. France' (EHRM 24 februari 1994, NJ 1994, 496 m. nt. E.A. Alkema) $\$ 47$ : In the first place, the offences with which Mr Bendenoun was charged came under Article $1729 \$ 1$ of the General Tax Codc. That provision covers all citizens in their capacity as taxpayers, and not a given group with a particular status.'

so NB. d.w.z. dat de overtreding op zich 'displinary' van aard is maar dat er desalniettemin, op basis van het derde criterium sprake is van een 'criminal charge'.

51 Zie \$3.2.1.c van dit hoofdstuk. 
In het kader van het normadressaat-criterium is onder meer de zaak 'Demicoli v. Malta' illustratief. Demicoli werd, in zijn hoedanigheid als journalist, beschuldigd van het maken van een inbreuk op de parlementaire onschendbaarheid. Hij had namelijk een smaadschrift gepubliceerd waarin enkele parlementariërs beledigd werden. Demicoli werd veroordeeld tot het betalen van een boete van 250 Maltezer Liri en het publiceren van de veroordeling in het tijdschrift waarin het smaadschrift had gestaan. Ten aanzien van de vraag of de inbreuk op de parlementaire onschendbaarheid 'criminal' van aard was heeft het EHRM het volgende overwogen:

'Mr Demicoli was not a Member of the House. In the Court's view, the proceedings taken against him in the present case for an act of this sort done outside the House are to be distinguished from other types of breach of the privilege proceedings which may be said to be disciplinairy in nature in that they relate to the internal regulation and ordely functioning of the House [curs. KA]. Section 11(I)(k) potentially affects the whole population since it applies whether the alleged offender is a Member of the House or not and irrespective of where in Malta the publication of the defamatory libel takes place. For the offence thereby defined the Ordinance provides for the imposition of a penal sanction and not a civil claim for damages. From this point of view, therefore, the particular breach of privilege in question is akin to a criminal offence under the Press Act 1974 [curs. KA].' ${ }^{52}$

In de zaak 'Ravnsborg v. Sweden'53 staat het EHRM een andere benadering voor. Aan Ravnsborg waren drie boeten opgelegd voor het doen van onbehoorlijke uitlatingen zijnerzijds in schriftelijke processtukken die door hem ten grondslag waren gelegd aan een gerechtelijke procedure. Het EHRM kwam op basis van het normadressaatcriterium tot de conclusie dat de in de zaak 'Ravnsborg v. Sweden' opgelegde maatregel niet 'criminal' maar 'disciplinary' van aard was:

'The court notes that Chapter 9, Article 5, second sentence, of the Code of Judicial Procedure applies to improper statements made orally or in writing to a court by a person attending or taking part in the proceedings, but not such statements made in a different context or by a person falling outside the circle of people covered by that provision (see paragraph 19 above). It is for the court sitting in the particular proceedings in which the misconduct has occurred to examine, of its own accord, whether the misconduct falls foul of Article 5 (see paragraph 21 above). In this respect the situation is different from those at issue in the cases of Weber en Demicoli, where the Court found Article 6 (art. 6) to be applicable (...). Rules enabling a court to sanction disorderly conduct in proceedings before it are a common feature of legal systems of the Contracting States. Such rules and sanctions derive from the indispensable power of a court to ensure the proper and orderly functioning of its own proceedings. Measures ordered by courts under such rules are more akin to the exercise of disciplinary powers than to the imposition of a punishment for commission of a criminal offence. ${ }^{54}$

Beknopt weergegeven redeneert het EHRM in de zaak 'Ravnsborg v. Sweden' als volgt. Alleen onbehoorlijke uitlatingen van personen die betrokken zijn bij een rechtszaak

54 'Ravnsborg v. Sweden' $\$ 34$. Zie in dit kader ook de zaak 'Putz v. Austria', EHRM 22 februari 1996, no. $18892 / 91 \S 33$. 
kunnen beboet worden. De overtreden regel dient slechts in acht genomen te worden door de personen die op enigerlei wijze deel nemen aan de gerechtelijke procedure. De regel is derhalve niet gericht tot alle burgers maar tot een bepaalde groep. Bovendien geldt de regel slechts in een bepaalde omgeving. De overtreding is derhalve niet 'criminal' van aard.

Daarmee lijkt het Hof in de zaak 'Ravnsborg v. Sweden' het vereiste dat de geschonden norm gericht moet zijn tot een bepaalde groep behoorlijk op te rekken. In de zaken 'Demicoli v. Malta' en 'Weber' doelde het Hof met de term 'speciale groep' op een specifieke (beroeps)groep die eenvoudig te duiden was. In de zaak 'Demicoli v. Malta' wijst het EHRM erop dat Demicoli geen 'Member of the House' is. Deze overweging lijkt voor het Hof relevant te zijn om te komen tot kwalificatie van de overtreding als 'criminal offence'. Dat het Hof de term 'speciale groep' behoorlijk heeft opgerekt in de zaak 'Ravnsborg v. Sweden' komt mijns inziens nog sterker tot uitdrukking bij vergelijking van genoemde uitspraak met het in 1990 (derhalve vier jaar vóór de uitspraak in de zaak 'Ravnsborg v. Sweden') door het Hof gewezen arrest in de zaak 'Weber'. Daarin heeft het Hof het volgende overwogen:

'Disciplinary sanctions are generally designed to ensure that the members of particular groups comply with the specific rules governing their conduct. Furthermore, in the great majority of the Contracting States disclosure of information about an investigation still pending constitutes an act incompatible with such rules and punishable under a variety of provisions. As persons who above all others are bound by the confidentiality of an investigation, judges, lawyers, and all those closely associated with the functioning of the courts are liable in such an event, independently of any criminal sanctions, to disciplinary measures on account of their profession. The parties, on the other hand, only take part in the proceedings as people subject to the jurisdiction of the courts, and they therefore do not come within the disciplinary sphere of the judicial system. As Article 185 (of the Vaud Code of Criminal Procedure [KA]), however, potentially affects the whole population, the offence it defines, and to which it attaches a punitive sanction, is a "criminal" one for the purpose of the second criterion [curs. KA]. ${ }^{55}$

Het Hof geeft aan dat ten aanzien van rechters en advocaten tuchtrechtelijke normen in het geding kunnen zijn indien zij hun geheimhoudingsplicht gedurende een (gerechtelijk) vooronderzoek schenden. Voor de partijen die deelnemen aan de rechtszaak geldt dit, zo stelt het Hof, echter niet. Indien een burger in zijn hoedanigheid van procespartij de geheimhoudingsplicht gedurende een (gerechtelijk) vooronderzoek schendt moet deze overtreding worden aangemerkt als 'criminal offence'.

Gelet op de grote gelijkenis met betrekking tot de feiten in de zaken 'Weber' en 'Ravnsborg v. Sweden' valt moeilijk te verklaren waarom het Hof in 1990 wél tot de conclusie kwam dat er, op basis van het normadressaat-criterium, sprake was van een 'criminal offence' terwijl het in 1994, toen het arrest in de zaak 'Ravnsborg v. Sweden' werd gewezen, tot een volledig tegengestelde uitspraak komt.

Het voorgaande leidt tot de constatering dat het na de uitspraak van het Hof in de zaak 'Ravnsborg v. Sweden' minder eenvoudig is geworden om vast te stellen welke personen een 'speciale groep' vormen. De 'speciale groep' is blijkbaar niet langer beperkt tot 
een vrij eenvoudige af te bakenen specifieke (beroeps)groep. Het lijkt in 'Ravnsborg v. Sweden' te gaan om alle personen die op enigerlei wijze, in welke hoedanigheid dan ook, deelnemen aan de gerechtelijke procedure. Zoais gezegd een duidelijk ruimere groep dan de 'speciale groep' waarop het Hof in de zaken 'Demicoli v. Malta' en 'Weber' leek te doelen.

Met betrekking tot het normadressaat-criterium ${ }^{56}$ kom ik tot de volgende conclusie. Is de regeling algemeen van aard (d.w.z. gericht tot alle burgers) dan is de overtreding doorgaans 'criminal' van aard en daarmee kán er sprake zijn van een 'criminal charge'. Dat laatste zal in de regel eerst vastgesteld kunnen worden na toetsing aan het derde criterium, in het bijzonder de aard van de sanctie.

Is de overtreden regel gericht tot leden van een bepaalde (beroeps)groep en gelden deze regels slechts in een bepaalde sfeer of omgeving dan is overtreding van de regel (doorgaans) niet 'criminal' maar 'disciplinary' van aard. Dit laatste neemt echter niet weg dat, onder bepaalde omstandigheden, sanctionering, van een overtreding die 'discplinary' van aard is, op basis van het derde criterium aangemerkt moet worden als een 'criminal charge'. Het voorgaande impliceert dat het tweede criterium op zich (in de regel) niet doorslaggevend is. Met name de aard, maar ook de zwaarte, van de sanctie lijken in dat kader ook nog een wezenlijke rol te spelen, zo zal straks nog blijken.

Beantwoording van de vraag of er sprake is van een norm die gericht is tot een 'speciale groep' lijkt in bepaalde gevallen tot problemen te leiden. Hoewel het Hof aanvankelijk slechts leek te doelen op beroepsgroepen of groepen waarvan de leden allen een bepaalde 'status' bezitten ${ }^{57}$ lijkt de term 'speciale groep' in 'Ravnsborg v. Sweden' door het Hof aanzienlijk te zijn opgerekt.

\subsection{1.c Aard en zwaarte van de sanctic}

Binnen het, nu te behandelen, derde criterium kan onderscheiden worden tussen twee subcriteria. Het eerste subcriterium, de aard van de sanctie ofwel het sanctiedoelcriterium, zal hierna eerst aan de orde komen. Daarna zal nog aandacht besteed worden aan het tweede subcriterium dat betrekking heeft op de zwaarte van de sanctie. Wellicht ten overvloede merk ik op deze plaats nogmaals op dat het Hof het sanctiedoelcriterium in bepaalde gevallen als subcriterium van het tweede hoofdcriterium (de aard van de overtreding) aanmerkt. In dat kader onderscheidt het EHRM dan tussen het normadressaat-criterium en het sanctiedoel-criterium.

56 In het onder voozitterschap van J. Riphagen, door de werkgroep 'Sancties in de sociale zekerheid' opgestelde rapport Sancties in de sociale zekerheid: bestuursstrafrecht of strafrechtelijk bestuursrecht? (Kluwer, Deventer 1994) lijkt de genoemde werkgroep in het normadressaatcriterium, mijns inziens ten onrechte, een vierde criterium te ontwaren. Zie: Riphagen a.w. 1994, p. 15-16. Na een opsomming van de drie gebruikelijke criteria vervolgt de werkgroep Riphagen (op p. 16) het betoog met de zin: Tevens moet het gaan om cen algemeen werkende regel, d.w.z. een regel die niet slechts gericht is op een bepaalde groep met een bepaalde status - het EHRM noemt in dit verband zelf als voorbeeld het tuchtrecht.'

57 Denk daarbij bijvoorbeeld aan gedetineerden. Zie in dit kader de zaak 'Camphell and Fell', EHRM 28 juni 1984, Series A vol. 80. 
Aard van de sanctie - sanctiedoel-criterium -

Gaat van een sanctie een afschrikkende werking uit en heeft de sanctie een punitief karakter dan is er doorgaans sprake van een 'criminal charge'. Vaak bestaan dergelijke (punitieve en afschrikkende) sancties uit geldboeten of uit vrijheidsberovende maatregelen. In de zaak 'Öztürk' heeft het Hof het voorgaande als volgt weergegeven:

'Nonetheless, the Court would firstly note that, according to the ordinary meaning of the terms, there generally come within the ambit of the criminal law offences that make their perpetrator liable to penalties intended, inter alia, to be deterrent and usually consisting of fines and of measures depriving the person of his liberty. (...) Moreover, the changes resulting from the $1968 / 1975$ legislation relate essentially to procedural matters and to the range of sanctions, henceforth limited to Geldbussen. Whilst the latter penalty appears less burdensome in some respects than Geldstrafen, it has nonetheless retained a punitive character, which is the customary distinguishing feature of criminal penalties. (...) Indeed, the sanction - and this the Government did not contest - seeks to punish as well as to deter. It matters little whether the legal provision contravened by Mr. Öztürk is aimed at protecting the rights and interests of others or solely at meeting the demands of road traffic. These two ends are not mutually exclusive. Above all, the general character of the rule and the purpose of the penalty, being both deterrent and punitive, suffice to show that the offence in question was, in terms of Article 6 (art. 6) of the Convention, criminal in nature. ${ }^{58}$

De constatering van het Hof dat de sanctie zowel afschrikkend als punitief was lijkt in belangrijke mate te hebben bijgedragen aan de conclusie dat de aan Öztürk opgelegde verkeersboete als een 'criminal charge' in de zin van artikel 6 EVRM moet worden aangemerkt.

Op deze plaats wil ik, onder verwijzing naar hoofdstuk twee, een opmerking plaatsen bij het door het Hof gemaakte onderscheid tussen het punitieve karakter van de sanctie en het afschrikkende (preventieve) karakter van de sanctie. Met het punitieve karakter van de sanctie wordt mijns inziens afschrikkende werking beoogd. Afschrikkende werking lijkt in de context van artikel 6 EVRM te kunnen worden beschouwd als een synoniem van de term 'preventieve werking'. Het voorgaande komt duidelijk naar voren bij een vergelijking van de Engelstalige en de Franstalige overweging uit $\S 53$ van de zaak 'Öztürk'. De Engelse tekst luidt als volgt:

'Above all, the general character of the rule and the purpose of the penalty, being both deterrent and punitive [curs. KA], suffice to show that the offence in question was, in terms of Article 6 (art. 6) of the Convention, criminal in nature.'

Hetzelfde fragment is in de Franstalige versie van de uitspraak als volgt weergegeven:

'Ozturk' \$ 53. NB. zoals gezegd wordt het sanctiedoel-criterium in de zaak 'Özturk' beschouwd als suberiterium van het tweede hoofdcriterium; 'de aard van de overtreding'. Zie voorts de zaak 'Lut' (EHRM 25 augustus 1987, Series A vol. 123, NJ 1988, $938 \mathrm{~m}$. nt. E.A. Alkema) \$ 54 . In de zaak 'Luz' gaat het evenals in de zaak 'Öztirk' om sanctionering van een verkeersovertreding (een zogenaamie Ordnungswidrigkeit) met een bestuurlijke boete. Het Hof herhaalt in de zaak 'Lutz', onder verwijzing naar $\S 53$ uit de zaak 'Ozturk', dat: 'the general character of the legal provision contravened by Mr. Lutz and the purpose of the penalty, which was both deterrent and punitive, sufficed to show that the offence in question was, for the purposes of Art. 6 , criminal in nature.' 
'surtout, le caractère général de la norme et le but, à la fois préventif et répressif (curs. KA), de la sanction suffisent à établir, au regard de l'article 6 (art. 6) de la Convention, la nature pénale de l'infraction litigieuse.'

In hoofdstuk twee van dit boek heb ik aangegeven dat een punitieve sanctie als voornaamste doel leedtoevoeging heeft. Met leedtoevoeging kunnen vervolgens verschillende doelen worden beoogd. Een belangrijk doel van leedtoevoeging is, zoals gezegd, generale en (veelal ook) speciale preventie. ${ }^{59}$ Derhalve kan naar mijn mening gezegd worden dat het punitieve karakter van een sanctie generale en speciale preventie impliceert. ${ }^{60}$ Het voorgaande zou betekenen dat het Hof op basis van de constatering dat een sanctie een punitief karakter heeft al tot de kwalificatie van de oplegging van de sanctie als 'criminal charge' zou kunnen komen. In dit kader kan gewezen worden op de zaak 'Weber' waarin het Hof volstaat met de constatering dat de sanctie punitief van aard is:

'As Article 185, however, potentially affects the whole population, the offence it defines, and to which it attaches a punitive sanction, is a 'criminal' one for the purposes of the second criterion. ${ }^{61}$

De rechtspraak van het Hof lijkt echter niet geheel consistent te zijn. Illustratief in dit kader is de zaak 'Malige v. France. ${ }^{62}$ In genoemde zaak werd, naast oplegging van een strafrechtelijke boete aan Malige, vanwege een door Malige gepleegde verkeersovertreding, op basis van een administratiefrechtelijk puntensysteem, een aantal punten van het rijbewijs van Malige afgetrokken. Genoemde puntenaftrek wordt door het EHRM gekwalificeerd als een 'criminal charge'. Ten aanzien van het punitieve en afschrikkende karakter van de puntenaftrek stelde het Hof:

'With regard to the severity of the measure, the Court notes that the deduction of points mily in time entail invalidation of the licence. It is indisputable that the right to drive a motor vehicle is very useful in everyday life and for carrying on an occupation. The Court, like the Commission, accordingly infers that, although the deduction of points has a preventive character, it also has a punitive and deterrent character and is accordingly similar to a secondary penalty. The fact that Parliament intended to dissociate the sanction of deducting points from the other penalties imposed by the criminal courts cannot change the nature of the measure. ${ }^{.63}$

Het Hof redeneert als volgt; hoewel het puntenaftreksysteem een preventief karakter heeft, heeft het eveneens een punitief en afschrikkend karakter, derhalve is er sprake van een tweede straf (in de zin van een 'criminal charge'). Gelet op de hierboven (en in hoofdstuk twee) door mij weergegeven opvatting lijkt het Hof in de zaak 'Malige v. France' verstrikt te raken in een cirkelredenering. Het Hof lijkt daarbij het preventieve

59 Zie in dit kader ook $\$ 2.2 .3 .2$.a van dit boek. Daaruit volgt dat leedtoevoeging naast generale en speciale preventie ook vergelding ten doel heeft.

60 Zie in deze zin ook Feteris a.w. 1993, p. 18 en Riphagen a.w. 1994, p. 22.

61 'Weber' $\$ 33$. Uit de hierboven opgenomen passage kan worden afgeleid dat het Hof in de zaak 'Weber' in is gegaan op de aard van de sanctie als subcriterium van, het als tweede criterium aangemerkte, criterium; 'de aard van de overtreding'. Bij behandeling van het derde criterium ging het Hof vervolgens alleen nog in op de zwaarte van de sanctie (zie $\$ 34$ van de zaak 'Weber').

62 EHRM 23 september 1998 (Malige v. France), verkort weergegeven in het NJCM-Bulletin 1999, p. 278-279

63 'Malige v. France' $\S 39$. 
karakter van de sanctie van een andere (niet 'criminal'??) aard te vinden dan het punitieve en afschrikkende karakter.

Mede gelet op de hierboven weergegeven opvatting en de vergelijking van de Franstalige en Engelstalige versie van de overwegingen in de zaak 'Öztürk' is deze redenering naar mijn mening niet geheel zuiver. Mocht het echter niet zo zijn dat afschrikkende werking en preventieve werking in de context van artikel 6 EVRM als synomiemen kunnen worden beschouwd, dan blijft desalniettemin, althans zo meen ik, de redenering, dat leedtoevoeging het middel is om te bereiken dat van een sanctie een afschrikkende dan wel een preventieve werking uitgaat, steekhoudend. Met andere woorden, wil een sanctie afschrikkend en/of (i.h.b. generaal ${ }^{64}$ ) preventief werken dan zal deze punitief moeten zijn. Met de kwalificatie van een sanctie als punitieve sanctie is dan in feite ook alles gezegd.

Dit alles overziend kom ik tot de conclusie dat volstaan kan worden met de constatering dat een sanctie punitief is ten einde te komen tot de kwalificatie van een sanctie als 'criminal charge'. Het Hof lijkt zelf ook van dit standpunt uit te gaan getuige de hierboven weergegeven passage uit de zaak 'Weber'. Omtrent de vraag wanneer een sanctie 'punitief' is schept het Hof geen duidelijkheid. Uit de zaak 'Bendenoun v. France' zou afgeleid kunnen worden dat het EHRM met de term 'punitief' uit gaat van een onderscheid tussen punitieve en reparatoire sancties. ${ }^{65}$ Het EHRM stelt in de zaak 'Bendenoun' het volgende:

'... the tax surcharges are intended not as pecuniary compensation for damage but essentially as a punishment to deter reoffending. ${ }^{66}$

De term 'punitief' in de zin van artikel 6 EVRM wordt hiermee echter niet bepaald duidelijker. ${ }^{67}$ Feteris heeft in zijn dissertatie ook gesignaleerd dat op basis van de rechtspraak van het EHRM moeilijk kan worden vastgesteld wat door het Hof wordt verstaan onder de term 'punitief. Vervolgens probeert hij zelf tot een definitie van de term 'punitief' te komen. Feteris schrijft het volgende:

'Het Hof heeft niet nader aangegeven wat de term 'punitive' precies inhoudt. Mijns inziens moet het gaan om een repressieve maatregel, die genomen wordt om te laten merken dat overtreding van de norm wordt afgekeurd, hetgeen met zich meebrengt dat het om een onaangenaam bedoelde maatregel zal gaan. ${ }^{68}$

De definitie van Feteris verduidelijkt mijns inziens echter in onvoldoende mate wat nu precies bedoeld wordt met het punitieve karakter van de sanctie. De termen punitief en repressief lijken immers, gelet op de hierboven weergegeven Engelstalige en Franstalige tekst uit de zaak 'Öztürk', elkaars synoniemen te zijn. Een onaangenaam bedoelde nodig is.

65 Zie ook hoofdstuk twee van dit boek, i.h.b. $\$ 2.2 .3 .2$.a.

66 'Bendenoun v. France' $\S 47$. Zie in deze zin voorts EHRM 14 november 2000, no. 27783/95, EHRC $2000 / 94$ m. nt. C.L.G.F.H. Albers (T. v. Austria) $\$ 65$.

67 Opmerkelijk is wel dat het Hof in de zaak 'Bendenoun' bestraffing (punishment) ook lijkt te zien als middel wa zmee preventieve werking (afschrikking) kan worden bewerkstelligd.

Feteris a.w. 1993, p. 255. 
maatregel impliceert voorts dat het moet gaan om enige vorm van leedtoevoeging. Dit alles brengt ons weer terug bij die ene term: 'punitief' (er van uitgaande dat punitief en leedtoevoeging in feite synoniemen zijn).

Naast Feteris signaleren ook andere juristen dat de term 'punitief weinig verhelderend is. ${ }^{69}$ Roording stelt bijvoorbeeld:

'De typering van een strafsanctie in de zin van artikel 6 EV'RM als een sanctie die "deterrent and punitive" is bedoeld, is eigenlijk niet veel meer dan een vage aanduiding, die op veel (bijv. bestuursrechtelijke) sancties van toepassing kan worden geacht..$^{70}$

In dezelfde zin oordeelt de werkgroep Riphagen:

'Het is in dit verband wellicht zinvol op te merken dat het gevaar bestaat dat in de discussie over het criminal charge-begrip elementen als 'strafwaardigheid' of 'het punitieve karakter' van een straf of van een regel als probleemoplossing naar voren worden geschoven, terwijl deze begrippen het probleem slechts verplaatsen. Valt feilloos aan te geven waar de scheiding ligt op de lijn tussen een evident wel en een evident niet strafwaardig gedrag? In wiens ogen moet een sanctie punitief zijn om die sanctie met recht een dergelijk karakter toe te kennen? Wat valt eigenlijk onder punitief te verstaan in deze ${ }^{71}$

Daamaast worstelt Den Hartog in haar dissertatie met de vraag wanneer een sanctie punitief van aard is. Volgens Den Hartog moet onder een sanctie met een punitieve aard worden verstaan: 'een leedtoevoegende reactie op (veronderstelde) 'guilt'. ${ }^{72} \mathrm{Zij}$ vervolgt: 'Wordt punitief op een dergelijke wijze opgevat dan heeft dit als consequentie dat elke keer indien de grondslag van de leedtoevoeging bestaat uit 'guilt' artikel 6 EVRM van toepassing is. ${ }^{73}$ Vervolgens geeft zij aan wanneer er sprake is van leedtoevoeging: 'Omdat er geen aanwijzingen te vinden zijn voor een beperktere opvatting van de term 'leedtoevoeging' lijkt het, gelet op de doeleinden van het EVRM (...) niet onjuist te stellen dat elke inperking van de individuele vrijheid aan te merken is als een leedtoevoeging. ${ }^{74}$

Mijns inziens slaagt de door Den Hartog ondernomen poging om tot verheldering van de term 'punitief te komen hiermee niet in voldoende mate. In hoofdstuk twee zagen wij immers dat oplegging van een punitieve sanctie (die altijd leedtoevoeging beoogt) slechts mogelijk is als er sprake is van aanwezigheid van schuld, in de zin van verwijtbaarheid, bij de overtreder. Dat de grondslag voor leedtoevoeging (en daarmee voor de oplegging van een punitieve sanctie) gelegen is in de aanwezigheid van schuld aan de gepleegde overtreding bij de dader moet derhalve ingelezen worden in de term punitief. Gelet op de doelstellingen die aan bestraffing in de vorm van leedtoevoeging ten grondslag liggen heeft het immers geen zin een onschuldige te straffen.

Bovendien is de interpretatie van Den Hartog van de term leedtoevoeging wel erg ruim. Een jurist met een enigszins creatieve geest zou vrijwel iedere vorm van intrekking of wijziging van een begunstigende beschikking (bij wijze van sanctie) als leedtoevoeging 
kunnen kwalificeren aan de hand van deze definitie. Het voorgaande zou zelfs op kunnen gaan voor (in essentie) reparatoire adminstratieve sancties. Van een inperking op de individuele vrijheid is immers al snel sprake.

Gelet op rechtspraak van het EHRM lijkt het Hof in ieder geval een beduidend minder vergaand standpunt in te nemen dan Den Hartog. In de zaak 'Tre Traktörer" ${ }^{75}$ werd de intrekking van een vergunning, op grond waarvan alcoholhoudende dranken mochten worden verkocht in een restaurant, wegens ongeschiktheid van de houder van de vergunning tot het verkopen van genoemde dranken, namelijk niet aangemerkt als punitieve sanctie. Dit terwijl de ongeschiktheid tot verkoop van aicoholhoudende drank zelfs, onder bepaalde omstandigheden afgeleid kon worden uit het niet (goed) bijhouden van een boekhouding. Veelal betekent de intrekking van de vergunning dat de onderneming van de vergunninghouder failliet gaat. De intrekking van genoemde vergunning levert mijns inziens onmiskenbaar een inperking van de individuele vrijheid op, máár volgens het EHRM géén punitieve sanctie.

Hoewel men het er in de literatuur, zoveel is duidelijk, over eens is dat de term 'punitief' weinig verhelderend is lijken pogingen om tot een meer grijpbare omschrijving van de term 'punitief te komen, zoals ook reeds in hoofdstuk twee is gesignaleerd, weinig vruchten af te werpen. Zie ik het goed dan komen ook alle hiervoor weergegeven beschijvingen uiteindelijk ongeveer op hetzelfde neer. Een sanctie is punitief als er sprake is van leedtoevoeging. Leedtoevoeging wordt vervolgens niet eenduidig en soms nogal ruim omschreven. Desalniettemin komen de beschrijvingen van leedtoevoeging in essentie overeen. Een onaangenaam bedoelde maatregel zal immers veelal een inperking van de individuele vrijheid behelzen. Zoals gezegd zijn deze definities van leedtoevoeging mijns inziens nogal ruim geformuleerd. Voor een meer nauwgezette omschrijving van laatstgenoemde term verwijs ik naar hoofdstuk twee waar een en ander reeds uitvoerig aan de orde is geweest.

Wat het EHRM nu precies onder 'punitief' verstaat is, zoals gezegd, niet duidelijk. Gelet op de casuïstische wijze van rechtspreken van het EHRM en gelet op het feit dat het EHRM de term 'criminal charge' autonoom uitlegt kan ten aanzien van sancties die niet eerder door het Hof zijn beoordeeld in beginsel dan ook niet met zekerheid gesteld worden of zij moeten worden aangemerkt als een 'criminal charge' in de zin van het EVRM. ${ }^{76}$ Ten aanzien van die sancties staat immers niet vast of zij naar het oordeel van het Hof punitief (en afschrikkend) van aard zijn.

\section{Zwaarte van de sanctie - sanctiezwaarte-criterium -}

Voordat hier inhoudelijk ingegaan wordt op het tweede subcriterium van het derde criterium; de zwaarte van de sanctie, wil ik er op wijzen dat dit criterium niet zonder

76 Ik wil daarbij wijzen op de maatregel in het sociale zekerheidsrecht die naar mijn mening in bepaalde gevallen een punitief karakter heeft. Hetzelfde geldt voor de intrekking van een begunstigende beschikking zoals bijvoorbeeld een subsidie. Zie ten aanzien van het sanctiedoel-criterium ook Viering a.w. 1994, p. 159-166. Viering komt op p. 163 tot de volgende, mijns inziens enigszins dubbelzinnige. conclusie: 'Al met al is het sanctiedoel-criterium een bruikbare maar niet gemakkelijk te hanteren maatstaf.' 
meer doorslaggevend lijkt te zijn indien er sprake is van een relatief lichte sanctie. Is een relatief lichte sanctie punitief (en afschrikkend) van aard en is de geschonden norm algemeen (en derhalve niet tuchtrechtelijk ofwel 'disciplinary') van aard dan is er doorgaans toch sprake van een 'criminal charge'. Het voorgaande was ook het geval in de zaak 'Öztürk'. De (bestuurlijke) boete die aan Öztürk werd opgelegd wegens de door hem gepleegde verkeersovertreding bedroeg 'slechts' 60,- Deutsche Mark. Het EHRM overwoog met betrekking tot de toepasselijkheid van artikel 6 EVRM:

'Above all, the general character of the rule and the purpose of the penalty, being both deterrent and punitive, suffice to show that the offence in question was, in terms of Article 6 (art. 6) of the Convention, criminal in nature. (...) As the contravention committed by Mr. Öztürk was criminal for the purposes of Art. 6 Convention, there is no need to examine it also in the light of the final criterion stated above (...). The relative lack of seriousness of the penalty at stake cannot divest an offence of its inherently criminal character ${ }^{17}$

Recentelijk heeft het Hof, in de zaak 'Lauko v. Slovakia', dit standpunt nogmaals bevestigd. ${ }^{78}$ Het tweede subcriterium van het derde criterium lijkt derhalve met name relevant te zijn indien er sprake is van een zware sanctie terwijl een lichte sanctie niet altijd het ontbreken van een 'criminal charge' impliceert.

Ten tweede wil ik op deze plaats nog opmerken dat het Hof bij het vaststellen van de zwaarte van de sanctie uitgaat van de maximumsanctie die in het kader van de overtreding van een bepaalde wettelijke regeling kan worden opgelegd. 'Bij de zwaarte van de sanctie gaat het om de te riskeren sanctie, niet o(m [toevoeging $\mathrm{KA}$ ]) de in concreto opgelegde straf.'; zo stelt Riphagen. ${ }^{79}$ Viering deelt deze op rechtspraak van het EHRM gebaseerde mening en geeft voorts aan dat genoemde opvatting: '... strookt met de hiervoor reeds geuite gedachte, dat de nationale wetgever voorafgaande aan een procedure moet beslissen met welke waarborgen hij deze wil omkleden. ${ }^{80}$ In dit kader kan


coli v. Malta', ${ }^{82}$, 'Ravnsborg v. Sweden ${ }^{83}$, 'Putz v. Austria' ${ }^{18}$ en 'T. v. Austria' ${ }^{85}$ ' waarin het Hof spreekt over 'the maximum penalty' en 'the fine the applicant risked incurring'.

78 EHRM 2 september 1998, no. 26138/95 (Lauko v. Slovakia). De in die zaak opgelegde boete bedroeg slechts 300 Slovaakse Kronen (ongeveer $€ 7,50$ ). Het Hof kwam op basis van het criterium; de aard van de overtreding, en het criterium; de aard van de sanctie, tot de conclusie dat er sprake was van een 'criminal charge' in de zin van artikel 6 EVRM. Daartoe overwoog het Hof in $\$ 58$ het volgende: 'In sum, the general character of the legal proivision infringed by the applicant together with the deterrent and punitive purpose of the penalty imposed on him, suffice to show that the offence in question was, in terms of Article 6 of the Convention, criminal in nature. Accordingly, there is no need to examine it also in the light of the third criterion stated above (...). The relative lack of seriousness of the penalty at stake cannot deprive an offence of its inherently criminal character (...).' Idem: EHRM 2 september 1998, no. 27061/95 (Kadubec v. Slovakia), i.h.b. $\$ 52$.

79 Riphagen a.w. 1994, p. 16.

80 Viering a.w. 1994, p. 167.

81 'Weber' $\$ 34$.

82 'Demicoli v. Malta' $\$ 34$

83 'Ravnsborg v. Sweden' $\$ 35$

84 'Pulz v. Austria' \$ 37.

85 T. v. Austria' $\$ 63-67$. 
Hierna zal inhoudelijk ingegaan worden op het sub-criterium; 'de zwaarte van de sanctie'. Ook ten aanzien van dit criterium zal (weer) blijken dat het weinig houvast biedt. Met name ten aanzien van boeten die niet zonder meer omgezet kunnen worden in vervangende hechtenis is moeilijk vast te stellen of zij dermate zwaar zijn dat zij aangemerkt moeten worden als 'criminal charge' in de zin van artikel 6 EVRM. Ik zal hierna eerst ingaan op sancties die bestaan uit vrijheidsberoving. ${ }^{86}$ Daarna komen de boeten aan de orde.

De sancties waar het in de context van artikel 6 EVRM om gaat zijn, zoals uit het bovenstaande reeds blijkt, veelal boeten of vrijheidsstraffen ${ }^{87}$ Op deze plaats moet echter worden opgemerkt dat niet alleen boeten of vrijheidsbenemende maatregelen aangemerkt kunnen worden als 'criminal charge' in de zin van artikel 6 EVRM. De reeds eerder aangehaalde zaak 'Malige v. France' is in dit kader illustratief. Naast oplegging van een strafrechtelijke boete wordt ten aanzien van Malige, vanwege een door hem gepleegde verkeersovertreding, op basis van een administratiefrechtelijk puntensysteem, een aantal punten van zijn rijbewijs afgetrokken. Genoemde puntenaftrek wordt door het EHRM gekwalificeerd als een 'criminal charge'.

In het kader van dit onderzoek zal echter, voor wat betreft het sanctiezwaarte-criterium, slechts ingegaan worden op vrijheidsbenemende maatregelen en boeten. Dit met name omdat op dit punt de meeste rechtspraak voorhanden is. Daarnaast uiteraard omdat de bestuurlijke boete het centrale onderwerp is van dit onderzoek.

\section{Vrijheidsbenemende maatregelen}

In de zaak 'Engel and Others' ging het om vrijheidsstraffen die opgelegd werden aan militairen. Op basis van het eerste en tweede criterium kwam het EHRM niet tot de kwalificatie van de oplegging van de sanctie als 'criminal charge'. Het ging immers om overtreding van regels van (militair) tuchtrecht. Op basis van het sanctiezwaartecriterium kwam het EHRM wel tot de conclusie dat er ten aanzien van een aantal militairen sprake was van een 'criminal charge'. ${ }^{88}$ Namelijk vanwege het feit dat vrijheidsberovende maatregelen bij wijze van straf waren opgelegd. Het Hof overwoog daaromtrent in de zaak 'Engel and Others' het volgende:

'However, supervision by the Court does not stop there (bij de constatering dat er op basis van het eerste en tweede criterium geen sprake is van een "criminal charge" [toevoeging $\mathrm{KA}]$ ). Such supervision would generally prove to be illusory if it did not also take into consideration the degree of severity of the penalty that the person concerned risks incurring. In a society subscribing to the rule of law, there belong to the "criminal" sphere deprivations of liberty liable to be imposed as a punishment, except those which by their nature, duration or manner of execution cannot be appreciably detrimental. The seriousness of what is at stake, the traditions of the Contracting States and the importance attached by the Convention to respect for the physical liberty of the person all require that this should be so $(\ldots) .{ }^{89}$

Zie voor een nadere uitwerking van de term 'vrijheidsberoving' in de context van het EVRM Viering a.w. 1994, p. 168-170.

87 'Öztürk' \$ 53.

88 Vgl. EHRM 26 februari 2002, no. $38784 / 97$ (Morris v. the United Kingdom), i.h.b. §38.

89 'Engel and Others' \$82. 
Vrijheidsberoving bij wijze van straf behoort tot de 'criminal sphere' tenzij zij vanwege haar aard, duur of wijze van tenuitvoerlegging niet als nadelig wordt ervaren. Zo luidt het (weinig verhelderend) ${ }^{90}$ standpunt van het EHRM ten aanzien van het derde criterium in de zaak 'Engel and Others'. Vervolgens beoordeelt het Hof per maximaal op te leggen sanctie of er sprake is van een 'criminal charge':

The maximum penalty that the Supreme Military Court could pronounce consisted in four days' light arrest for Mr. van der Wiel, two days' strict arrest for Mr. Engel (third punishment) and three or four months' committal to a disciplinary unit for Mr. de Wit, Mr. Dona and Mr. Schul. Mr. van der Wiel was therefore liable only to a light punishment not occasioning deprivation of liberty (...). For its part, the penalty involving deprivation of liberty that in theory threatened Mr. Engel was of too short a duration to belong to the "criminal" law. He ran no risk, moreover, of having to undergo this penalty at the close of the proceedings instituted by him before the Supreme Military Court on 7 April 1971, since he had already served it from 20 to 22 March (...). On the other hand, the "charges" against Mr. de Wit, Mr. Dona and Mr. Schul did indeed come within the "criminal" sphere since their aim was the imposition of serious punishments involving deprivation of liberty (...). The Supreme Military Court no doubt sentenced Mr. de Wit to twelve days' aggravated arrest only, that is to say, to a penalty not occasioning deprivation of liberty (...), but the final outcome of the appeal cannot diminish the importance of what was initially at stake. ${ }^{.91}$

Alleen de langdurigere vrijheidsstraffen worden aldus door het Hof als 'criminal charge' gekwalificeerd. Waar het omslagpunt tussen langdurige en niet langdurige vrijheidsstraffen ligt kan uit de rechtspraak van het Hof spijtig genoeg niet worden afgeleid. ${ }^{92}$

Vrijheidsberoving speelde ook in de zaak 'Campbell and Fell' een rol. Een aantal gevangenen werden in die zaak beschuldigd van het veroorzaken van, en deelnemen aan, een gevangenisoproer en het toebrengen van zwaar lichamelijk letsel aan een bewaker. Vanwege de veroorzaakte oproer en het toebrengen van zwaar lichamelijk letsel werd onder meer een deel van Campbell's vervroegde invrijheidsstelling ingetrokken. Concreet kwam het er op neer dat 570 dagen strafvermindering vervielen. Het Hof was van oordeel dat deze straf dermate zwaar was dat er sprake was van een 'criminal charge' in de zin van het EVRM:

'In its above-mentioned Engel and Others judgment (...), the Court stated that deprivation of liberty liable to be imposed as a punishment was, in general, a penalty that belonged to the "criminal" sphere. It is true that in the present case the legal basis for the detention remained, even after the Board's award, the original sentence of imprisonment and that nothing was added thereto (...). However, the Court is of the opinion that the forfeiture of

90 Zie in deze zin ook Viering a.w. 1994, p. 170-172.

91 'Engel and Others' $\$ 85$. Meer recent heeft het EHRM in de zaak 'Smith and Ford v. the United Kingdom' (EHRM, 29 september 1999, no. 00037475/97 en 00039036/97) t.a.v. de Engelse militairetuchtrechtelijke procedure een vergelijkbare uitspraak gedaan. Een duidelijk analyse op basis van de drie toetsingscriteria uit de zaak 'Engel and Others' heeft in die zaak echter niet plaats gevonden. Het Hof lijkt in die zaak op basis van de aard van de overtreding en de (aard en) zwaarte van de (maximaal op te leggen) sanctie tot de conclusie te komen dat er sprake is van een 'criminal charge' (zie 'Smith and Ford' $§ 19)$.

92 Zie in deze zin ook Viering a.w. 1994, p. 171. 
remission which Mr. Campbell risked incurring and the forfeiture actually awarded involved such serious consequences as regards the length of his detention that these penalties have to be regarded, for Convention purposes, as "criminal". By causing detention to continue for substantially longer than would otherwise have been the case, the sanction came close to, even if it did not technically constitute, deprivation of liberty and the object and purpose of the Convention require that the imposition of a measure of such gravity should be accompanied by the guarantees of Article 6 (art. 6). This conclusion is not altered by the fact that a considerable number of days of remission were subsequently restored to the applicant $(\ldots) .^{93}$

Resumerend kan ten aanzien van het 'criminal charge'-karakter van vrijheidsberovende maatregelen (vanwege de zwaarte van genoemde maatregel) uit de rechtspraak van het Hof het volgende worden afgeleid. Vrijheidsberoving bij wijze van straf behoort tot de 'criminal sphere' tenzij zij vanwege haar aard, duur of wijze van tenuitvoerlegging niet als nadelig wordt ervaren. In beide, hierboven weergegeven, zaken lijkt het Hof vervolgens niet expliciet stil te staan bij de vraag of er sprake is van vrijheidsberoving bij wijze van straf. Kennelijk gaat het Hof er van uit dat niet ter discussie staat dat er spra$k e$ is van vrijheidsberoving bij wijze van straf. Vervolgens wordt met name aandacht besteed aan ernst van de gevolgen van oplegging van de vrijheidsberovende maatregel. In dat kader lijkt met name de duur van de vrijheidsberoving relevant te zijn. Waar het omslagpunt ligt tussen een vrijheidsberovende straf die dermate lang is dat deze als 'criminal charge' aangemerkt zou kunnen worden en een straf die kort genoeg is om niet als 'criminal charge' aangemerkt te worden blijkt echter niet uit de rechtspraak van het Hof. ${ }^{94}$

\section{Boeten}

Naast vrijheidsstraffen spelen ook boeten vaak een rol in het kader van de 'criminal charge'-context van artikel 6 EVRM. De 'zwaarte' van de boete kan dan ook relevant zijn in het kader van de vaststelling dat de oplegging van de boete aangemerkt moet worden als 'criminal charge'. Met het oog op het onderwerp van dit onderzoek is bovendien de vraag of een (bestuurlijke) boete dermate zwaar is dat deze, op basis van het sanctiezwaarte-criterium, moet worden aangemerkt als een 'criminal charge', in hogere mate relevant dan de vraag of vrijheidsberovende maatregelen vanwege hun zwaarte onder het 'criminal charge' begrip dienen te vallen. Nu zal dan ook aandacht uit gaan naar de vraag wanneer een opgelegde (of op te leggen) boete vanwege haar zwaarte onder het 'criminal charge' begrip valt.

In dit kader kan ten eerste gewezen worden op de zaak 'Weber'. Aan Weber was een boete opgelegd wegens schending van de geheimhoudingsplicht, door openbaring van gegevens uit een strafrechtelijke procedure, gedurende een strafrechtelijk (voor)onder-

94 Op basis van cen analyse van de zaak 'Engel and Others' en de zaak 'Campbell and Fell' komt Viering tot een vergelijkbare conclusic. Hij stelt dat niet iedere vrijheidsberovende maatregel een strafsanctie is. Hij motiveert deze stelling als volgt: 'Er moet voldaan zijn aan twee voorwaarden: de sanctie moet à titre répressif opgelegd kunnen worden en tevens nadeel kunnen berokkenen. (...) Aldus lijkt vooral de crnst van de (mogelijke) gevolgen van de sanctie voor de normovertreder, bepalend voor het strafrechtelijke karakter van de normschending.' Viering a.w. 1994, p. 173. 
zoek. In de zaak 'Weber' heeft het Hof ten aanzien van de maximaal aan Weber op te leggen boete, in het kader van het sanctiezwaarte-criterium, het volgende over-wogen:

'As regards the third criterion - the nature and the degree of severity of the penalty incurred - the Court notes that the fine could amount to 500 Swiss francs (...) and be converted into a term of imprisonment in certain circumstances (...). What was at stake was thus sufficiently important to warrant classifying the offence with which the applicant was charged as a criminal one [curs. KA] under the Convention. ${ }^{95}$

Een vrijwel identieke overweging is aan te treffen in de uitspraak van het Hof in de zaak 'Demicoli v. Malta'. ${ }^{96}$ Deze twee uitspraken bieden overigens weinig houvast. In beide zaken kon de boete vervangen worden door hechtenis. Men kan zich derhalve afvragen of de mogelijkheid van vervangende hechtenis doorslaggevend is geweest voor het Hof om tot de conclusie te komen dat er sprake was van een 'criminal charge'. ${ }^{97}$ Daarnaast kan nog een rol hebben gespeeld dat in beide zaken het Hof ook reeds op basis van het tweede criterium (de aard van de overtreding) tot de conclusie was gekomen dat er sprake was van een 'criminal charge'. ${ }^{98}$

Dit laatste aspect zou tevens kunnen verklaren waarom het Hof in de zaken 'Ravnsborg' en 'Putz v. Austria' niet tot de conclusie kwam dat de in die zaken opgelegde vergelijkbare sancties (nl. boeten eventueel te vervangen door hechtenis) op grond van het sanctiezwaarte-criterium als 'criminal charge' aangemerkt dienden te worden. In de zaken 'Ravnsborg' en 'Putz v. Austria' was er op basis van het normadressaat-criterium namelijk géén sprake van een 'criminal charge'. ${ }^{99}$ In de zaak 'Ravnsborg' heeft het Hof het volgende overwogen:

'A fine imposed under Article 5 in Chapter 9 could amount to 1,000 kronor and actually did so in all three instances in the present case. Moreover, the fine was convertible under Swedish law into a term of imprisonment (...). However, in the Court's view, the possible amount of each fine did not attain a level such as to make it a "criminal" sanction. Unlike ordinary fines, the kind at issue was not to be entered on the police register (...). A decision to convert the fines could only be taken by the District Court in limited cicumstances (...). What is more, it would then have been necessary to summon the applicant to appear before the District Court for an oral hearing in separate proceedings. Accordingly, the Court shares the opinion of the Government and the Commission that what was at stake for the applicant was not sufficiently important [curs. KA] to warrant classifying the offences as "criminal"., 100

Deze onderbouwing van de conclusie 'that what was at stake for the applicant was not sufficiently important to warrant classifying the offences as 'criminal" werkt weinig

\section{5 'Weber' $\$ 34$.}

96 'Demicoli v. Malta' $\S 34$ : The Court notes that in the present case, whilst the house imposed a fine of 250 Maltese liri on the applicant which has not yet been paid or enforced, the maximum penalty he risked was imprisonment for a period not exceeding sixty days or a fine not exceeding 500 Maltese liri or both. What was at stake was thus sufficiently important to warrant classifying the offence with which the applicant was charged as a criminal one [curs. KA] under the convention (...).'

97 Zie in deze zin ook Viering a.w. 1994, p. 174. Latere rechtspraak wijst overigens niet in die richting. Vgl. EHRM 23 juli 2002, no. $36985 / 97$ (Vastberga Taxi Aktiebolag en Vulic v. Sweden), i.h.b. $\$ 80$.

98 Zie hierover $\$ 3.2 .1$.b van dit hoofdstuk.

99 Zie hierover $\$ 3.2 .1$ b van dit hoofdstuk.

100 'Ravnsborg' §35. 
verhelderend. Dit heeft mede te maken met het feit dat het Hof zich in de zaken 'Demicoli v. Malta' en 'Weber' heeft beperkt tot een zeer beknopte overweging in het kader van het sanctiezwaarte-criterium.

Een viertal criteria is volgens het Hof relevant in het kader van de vraag of de opgeleg. de boeten in zaak 'Ravnsborg' op basis van het sanctiezwaarte-criterium 'criminal' van aard zijn. Ten eerst speelt de hoogte van de boete een rol. In casu waren de boeten volgens het Hof niet dermate hoog dat zij daardoor 'criminal' van aard zouden zijn. Ten tweede worden de opgelegde boeten (anders dan andere strafrechtelijke boeten) niet geregistreerd in de politieregisters. Vervolgens is omzetting van de boete in hechtenis slechts mogelijk in bepaalde situaties en dient deze omzetting te geschieden door de rechter. Tenslotte is van belang dat Ravnsborg gehoord zou moeten worden voordat de boete omgezet zou worden in hechtenis. In welke mate deze factoren doorslaggevend zijn geweest voor de conclusie dat er in casu geen sprake was van een 'criminal charge' en in hoeverre deze criteria al dan niet een rol hebben gespeeld in de zaken 'Demicoli v. Malta' en 'Weber' is niet helder. Derhalve blijft onduidelijk in hoeverre genoemde criteria houvast kunnen bieden in het kader van het sanctiezwaarte-criterium.

In de zaak 'Putz v. Austria' ging het vervolgens (wederom) om een sanctie die, afgezien van blijkbaar niet doorslaggevende procedurele verschillen, niet veel wezenlijke verschillen vertoont met de sancties die konden worden opgelegd in de zaken 'Weber', 'Demicoli v. Malta' en 'Ravnsborg'. In alle vier de zaken is immers sprake van de oplegging van boeten die (eventueel) vervangen kunnen worden door hechtenis. Het tuchtrechtelijke karakter van de sanctie lijkt dan ook doorslaggevend te zijn én te leiden tot de conclusie; 'that what was at stake for the applicant was not sufficiently important to warrant classifying the offences as 'criminal", getuige de hierna weergegeven passage uit de zaak 'Putz v. Austria':

'The Court notes that Article 235 of the Code of Criminal Procedure concerning responsibility for keeping order at hearings provides for the imposition of a fine not exceeding ATS 10,000 or, where essential for maintaining order, a custodial sentence not exceeding eight days. If the fine proves to be irrecoverable, the custodial sentence will be for a term of at most eight days (Article 7 of the Code of Criminal Procedure - see paragraph 21 above). As regards written proceedings, Article 220 of the Code of Civil Procedure provides for the imposition of a fine not exceeding ATS 20,000 and, in the event of inability to pay, a custodial sentence not exceeding ten days. In the instant case the Austrian courts sentenced Mr Putz to pay fines of ATS 5,000, 7,500 and 10,000 (...). Two of them were converted into prison sentences, but after payment the applicant did not have to serve these (..). In this respect, the Court notes a number of dissimilarities between the instant case and the Ravnsborg case, in which the amount of the fines could not exceed 1,000 Swedish kronor and the decision to convert them into custodial sentences required a prior hearing of the person concerned. This finding, however, is qualified by three features of the instant case: firstly, as in the Ravnsborg case, the fines are not entered in the criminal record; secondly, the court can only convert them into prison sentences if they are unpaid, and an appeal lies against such decisions (...), as it does against custodial sentences imposed straight away at the hearing where that course was essential for maintaining order; lastly, whereas in the Ravnsborg case the term of imprisonment into which a fine could be converted ranged from fourteen days to three months, in the instant case it cannot exceed ten days. However real they may be, the dissimilarities, which reflect the characteristics of the two national legal 
systems, therefore do not appear to be decisive. In both cases the penalties are designed to enable the courts to ensure the proper conduct of court proceedings (...). Having regard to all these factors the Court considers, like the Government, that what was at stake for the applicant was not sufficiently important to warrant classifying the offences as 'criminal'.'

Dat er in casu hogere boeten opgelegd kunnen worden dan in de zaak 'Ravnsborg' en dat omzetting van de boete in hechtenis zonder voorafgaande hoorprocedure mogelijk is, is zo volgt uit bovenstaande passage, niet relevant. De verschillen die bestaan tussen de procedures tot oplegging van de boeten en procedures tot omzetting van die boeten in vervangende hechtenis in de zaken 'Ravnsborg' en 'Putz v. Austria' lijken in zijn algemeenheid niet doorslaggevend te zijn. Uit de hierboven weergegeven passage kan bovendien worden afgeleid dat met name het 'tuchtrechtelijke' karakter van de procedure doorslaggevend is geweest in het kader van de constatering van het Hof dat er geen sprake was van een 'criminal charge' in de zaak 'Putz v. Austria'.

Zoals gezegd zijn de sancties die in de vier hierboven weergegeven zaken opgelegd konden worden vergelijkbaar. Telkens gaat het om boeten die vervangen kunnen worden door hechtenis. De hoogte van de (maximaal) op te leggen boeten varieert overigens wel. Dit lijkt voor het Hof (gelet op de overwegingen in de zaak 'Putz v. Austria') echter niet van doorslaggevende betekenis te zijn bij de kwalificatie van de oplegging van een boete als 'criminal charge' op basis van het sanctiezwaarte-criterium. Het voorgaande brengt met zich dat de hoogte van de maximaal op te leggen boete geen doorslaggevend criterium lijkt te zijn in het kader van het sanctiezwaarte-criterium.

Aanvankelijk leek bovendien de vraag relevant te zijn of de boete zonder voorafgaande hoorprocedure ${ }^{101}$ omgezet kan worden in hechtenis. Onder meer vanwege het feit dat de gesanctioneerde burger gehoord moest worden voordat de boete omgezet kon worden in hechtenis leek het Hof in de zaak 'Ravnsborg' tot de conclusie te komen dat de sanctie niet dermate zwaar was dat er sprake was van een 'criminal charge'. Het ontbreken van een dergelijke hoorprocedure was in de zaak 'Putz v. Austria' volgens het Hof echter niet doorslaggevend ter beantwoording van de vraag of er sprake was van een 'criminal charge'. In de zaken 'Weber' en 'Demicoli v. Malta' heeft het Hof geen aandacht besteed aan de vraag op welke wijze omzetting van de boete in hechtenis plaats vond (of plaats zou moeten vinden). In die zaken lijkt het Hof te hebben volstaan met de constatering dát de boete omgezet kon worden in hechtenis. Het bestaan van deze mogelijkheid lijkt, ongeacht de procedure op basis waarvan de boete omgezet kan worden in hechtenis, in de zaken 'Weber' en 'Demicoli v. Malta' voldoende te zijn geweest (in samenhang met de hoogte van de boete) om te komen tot de constatering dat de boete 'criminal' was op basis van het sanctiezwaarte-criterium.

Het al dan niet moeten volgen van een hoorprocedure voordat de boete omgezet kan worden in hechtenis lijkt dan ook niet doorslaggevend te zijn voor beantwoording van de vraag of de sanctie 'criminal' is op basis van het sanctiezwaarte-criterium. Ook de hoogte van de (maximaal op te leggen) boete lijkt geen fundamentele rol te spelen. Wel relevant lijkt de constatering dat de sanctie, op basis van het tweede criterium, tuchtrechtelijk ofwel disciplinair van aard is. Op het moment dat het Hof in de zaken 
'Ravnsborg' en 'Putz v. Austria' tot die conclusie komt lijkt het erop dat er wat de zwaarte van de sanctie betreft naar het gewenste resultaat (geen 'criminal charge') toegeredeneerd wordt. Illustratief in dit kader is met name de hierboven aangehaalde passage uit de zaak 'Putz v. Austria' waarin het Hof, (enigszins verkapt) overweegt dat het tuchtrechtelijke/disciplinaire karakter van de sanctie doorslaggevend is ter beantwoording van de vraag of de sanctie dermate zwaar is dat de oplegging daarvan als 'criminal charge' moet worden aangemerkt.

Uit de vier hierboven weergegeven uitspraken van het EHRM kan worden afgeleid dat het Hof bij de beantwoording van de vraag of een boete dermate zwaar is dat de oplegging daarvan als 'criminal charge' moet worden aangemerkt (in het bijzonder) rekening houdt met de aard van de overtreding. Is een overtreding naar het oordeel van het Hof tuchtrechtelijk/disciplinair van aard dan lijkt de oplegging van een boete op basis van het sanctiezwaarte-criterium niet als 'criminal charge' gekwalificeerd te worden. ${ }^{102}$

Gelet op het voorgaande is het opmerkelijk dat het Hof recentelijk, in de zaak 'T. v. Austria', op basis van het derde criterium (de aard én de zwaarte van de sanctie) de oplegging van een boete wel als 'criminal charge' heeft aangemerkt terwijl de geschonden norm volgens het Hof tuchtrechtelijk van aard was. ${ }^{103}$ Met de uitspraak van het EHRM in de zaak 'T. v. Austria' lijkt de hierboven weergegeven 'lijn' in de rechtspraak van het Hof (voor zover daarvan sprake is/was) derhalve te zijn doorbroken.

Evenals in de zaken 'Ravnsborg' en 'Putz v. Austria', en anders dan in de zaken 'Weber' en 'Demicoli v. Malta', was er in de zaak 'T. v. Austria' op basis van het tweede criterium sprake van een overtreding die tuchtrechtelijk van aard was. De aard én de zwaarte van de sanctie waren in de zaak 'T. v. Austria', anders dan in de zaken 'Ravnsborg' en 'Putz. v. Austria', echter voor het Hof wél doorslaggevend om te komen tot de conclusie dat er sprake was van een 'criminal charge'. Dienaangaande heeft het Hof in de zaak T. v. Austria het volgende overwogen:

'The Commission observed that the maximum penalty of ATS 400,000 , which the applicant risked incurring under section 69 in conjunction with section $220 \S 1$ of the Code of Civil Procedure, was considerably higher than in comparable cases relating to penalties for misconduct in court proceedings. The penalty of ATS 30,000 actually imposed was also more important than any of the penalties imposed in these cases (see the above-mentioned Weber judgment, pp. 9 and $18, \$ \$ 16$ and 34 ; the Ravnsborg judgment, previously cited, pp. $30-31, \S 35$; the Putz judgment, previously cited, pp. 326, $\S 37$ ). The Govemment argued that the amount of the penalty at stake in itself cannot bring the matter into the criminal sphere. It is true that in the Bendenoun judgment to which the Government referred, the Court did not only rely on the high amount of the penalty at stake, but also had regard to other factors, in particular the nature of the penalty which was punitive rather than

102 Vgl. in dit kader: EHRM 23 oktober 1995, Series A vol. 328-C (Gradinger v. Austria), i.h.b. $\$ 36$, EHRM 23 oktoher 1995, Series A vol. 328-B (Umlauft v. Austria), i.h.b. $\$ 31$ en EHRM 23 oktober 1995, Series A vol. 328-A (Schmautzer v. Austria), i.h.b. $\$ 28$. Op basis van de terminologie van de bestuursrechtelijke overtreding in het nationale recht (Verwaltungsstraftaten) en het feit dat de (bestuurlijke) boete omgezet kon worden in vervangende hechtenis kwalificeert het Hof in die zaken de gepleegde overtredingen als 'criminal offences'.

103 D.w.z. dat op basis van het tweede criterium niet geconcludeerd kon worden dat er sprake was van een 'criminal charge' omdat Oostenrijk volgens het Hof de nomschending terecht had ondergebracht bij het tuchtrecht (zie $\$ 62$ van de zaak T. v. Austria'). 
compensatory (see the Bendenoun v. France judgment, previously cited, p. 20. $\S 47$ ). In the present case too, the fine the applicant risked incurring was very substantial, coming within the range of fines provided for in the Penal Code (see paragraph 47 above), and it was not intended as compensation for damage but was punitive in character. Finally, the Government argued that the term of ten days' imprisonment in default, which was at stake and was actually imposed on the applicant in the present application, was much shorter than the one at stake in the Ravnsborg case. However, in the latter case, the Court attached importance to the fact that a conversion of the fine into a prison term required an oral hearing in separate court proceedings (sce the Ravnsborg judgment, ibid.). No such guarantees were attached to the conversion of the fine in the present case. In conclusion the Court, having regard to the punitive nature and the high amount of the penalty at stake and the possibility of converting it into a prison term without the guarantee of a hearing, finds that what was at stake for the applicant was sufficiently important to warrant classifying the offence as criminal within the meaning of Article $6 \$ 1 .^{104}$

Ook in deze zaak lijkt het Hof derhalve niet slechts op basis van het sanctiezwaartecriterium tot de conclusie te komen dat de opgelegde boete aangemerkt moest worden als een 'criminal charge'. De punitieve aard van de sanctie en het feit dat de boete zonder voorafgaande hoorprocedure omgezet kan worden in een gevangenisstraf lijken mede doorslaggevend te zijn voor de kwalificatie van de sanctie ais 'criminal charge'. Voorts zou het feit, dat in casu de vervangende hechtenis daadwerkelijk door de overtreder is ondergaan, nog een rol gespeeld kunnen hebben bij de oordeelsvorming van het Hof. Ten aanzien van de vraag in welke gevallen het sanctiezwaarte-criterium op zichzelf van doorslaggevende betekenis zou kunnen zijn wordt in deze, sterk op de concrete casus toegespitste, zaak door het Hof echter spijtig genoeg geen helderheid geschapen.

Op basis van het voorgaande kan geconcludeerd worden dat het sanctiezwaartecriterium als zodanig nauwelijks houvast biedt. Voor zover een sanctie bestaat uit een vrijheidsberovende maatregel lijkt, naast het bestraffende karakter van de vrijheidsberoving, in het bijzonder de duur van de vrijheidsberoving relevant te zijn. Waar het omslagpunt ligt tussen een vrijheidsberovende straf die dermate lang is dat zij als 'criminal charge' aangemerkt zou kunnen worden en een straf die kort genoeg is om niet als 'criminal charge' aangemerkt te worden blijkt echter, zoals gezegd, niet uit de rechtspraak van het Hof.

Ten aanzien van de oplegging van boeten lijkt de hoogte van de boete op zich niet voldoende te zijn om op basis van het sanctiezwaarte-criterium tot de conclusie te komen dat er sprake is van een 'criminal charge'. Andere factoren zijn daamaast steeds relevant. Deze factoren variëren van de aard van de overtreding (tuchtrechtelijk of niet) tot het punitieve karakter van de sanctie (aard van de sanctie) en de mogelijkheid tot omzetting van de boete in een vrijheidsberovende maatregel (met of zonder voorafgaande hoorprocedure). Bovendien komt het Hof in de hierboven weergegeven zaken doorgaans op basis van een tenminste enigszins schamele motivering tot de conclusie: 'that what was at stake for the applicant was (not) sufficiently important to warrant classifying the offence as criminal within the meaning of Article $6 \S 1$.' 
Het Hof gebruikt termen als 'datgene wat op het spel stond' en 'ernstige gevolgen'. Deze termen koppelt het Hof vervolgens aan een bepaald feitencomplex. Maar wáárom bepaalde feiten niet voldoende emstig zijn om te komen tot de conclusie dat er sprake is van een 'criminal charge' wordt doorgaans door het Hof niet geëxpliciteerd. Aangezien termen zoals 'datgene wat op het spel stond' en 'de emst van de gevolgen' (van de sanctie) naar mijn mening zeer nauw verwant zijn met de term 'de zwaarte van de sanctie' bieden deze frases uit de rechtspraak van het Hof nauwelijks houvast. ${ }^{105}$ Relevant is de maximum hoogte van een boete of de maximale lengte van een vrijheidsberovende maatregel die in het concrete geval kan worden opgelegd.

Over de vraag hoe hoog een boete maximaal mag zijn of hoelang een vrijheidsberovende maatregel maximaal mag duren om op basis van het sanctiezwaarte-criterium al dan niet als 'criminal charge' aangemerkt te worden laat het Hof zich niet uit. Dit is overigens niet onbegrijpelijk.

Het voorgaande brengt met zich dat er geen andere conclusie mogelijk is dan dat de rechtspraak van het Hof ten aanzien van het derde criterium zeer casuïstisch is en nauwelijks aanknopingspunten biedt op basis waarvan kan worden bepaald of een sanctie vanwege de zwaarte 'criminal' is. De zwaarte van de sanctie lijkt in de regel dan ook slechts in relatie tot een van de andere criteria een rol te kunnen spelen. ${ }^{106}$ Derhalve kan op basis van het sanctiezwaarte-criterium op zich weinig helderheid verkregen worden omtrent de vraag of een bepaalde sanctie aangemerkt moet worden als een 'criminal charge'.

\subsection{1.d De drie criteria - resumé-}

Ter afsluiting van deze subparagraaf volgt een beknopt overzicht van de onderzoeksresultaten met betrekking tot de drie door het Hof geformuleerde criteria, die gehanteerd worden ter beantwoording van de vraag, of de oplegging van een bepaalde sanctie aangemerkt moet worden als 'criminal charge' in de zin van artikel 6 EVRM.

Het eerste criterium; de classificatie van de normschending naar nationaal recht, is het minst relevant. Met name in gevallen waarin een partijstaat een normschending niet als

105 Zie in deze zin ook: P. van Dijk en G.J.H. van Hoof, in samenwerking met A.W. Heringa, J.G.C. Schokkenbroek, B.P. Vermeulen, M.L.W.M. Viering en L.F. Zwaak, Theory and Practice of the European Convention on Human Rights, third edition, Kluwer Law intemational, The Hague/London/Boston 1998, i.h.b. p. 412-417. Genoemde auteurs pleiten er dan ook voor de waarborgen, die op grond van artikel 6 EVRM in acht genomen moeten worden bij de oplegging van een 'criminal charge', toe te passen indien een sanctie kan bestaan uit een vrijheidsherovende maatregel (ongeacht de duur daaran) of als een (tuchtrechtelijke) sanctie een duidelijk punitief karakter heeft: 'In our opinion, it would be desirable and create the required clarity if the third criterion were applied in such a way that in any case where the penalty may consist of a deprevation of liberty in the sense assigned thereto in the case-taw conceming Article 5, the guarantees of Article 6 should be observed in the procedure that may result in such a deprivation.' (Van Dijk/Van Hoof a.w. 1998, p. 414) ... 'Outside the sphere of disciplinary proceedings, with respect to 'fiscal penalties', the Court has adopted the position that those penalties which are not compensatory in nature, but are of a punitive character, such as fines and disqualification, give the proceedings a criminal character for the purposes of Article 6 . In our opinion the same approact should be followed with respect to disciplinary penalties: if they are of a clearly punitive charactet which makes them similar to criminal sanctions as to their nature and effect, there would seem to be no convincing reason why their imposition should not, in the final resort, be subjected to a judicial review that fulfils the requirements of Article 6.' (Van Dijk/Van Hoof a.w. 1998, p. 416). Zie bijv.: EHRM 29 augustus 1997, no. 19958/92 (A.P., M.P. and T.P. v. Switzerland), \$ 39-43. 
een strafrechtelijke overtreding aanmerkt hecht het Hof (in beginsel) weinig waarde aan de classificatie van de normschending naar nationaal recht. Op zich ligt dit voor de hand aangezien het Hof de term 'criminal charge' autonoom uitlegt. Het eerste criterium lijkt daarom in de regel slechts doorslaggevend te kunnen $^{107}$ zijn als de normschending naar nationaal recht wordt ondergebracht in het strafrecht.

Teneinde te voorkomen dat de partijstaten de effectieve werking van de waarborgen, die voortv]oeien uit de artikelen 6 en 7 van het EVRM, frustreren acht het Hof zich bevoegd na te gaan of er, op basis van het (materieel getinte) tweede of derde criterium, al dan niet sprake is van een 'criminal charge' indien een partijstaat een bepaalde normschending niet heeft ondergebracht in het strafrecht.

Bij het tweede criterium; de aard van de overtreding, is hierboven alleen aandacht besteed aan het normadressaat-criterium (als subcriterium) hoewel de aard van de sanctie (ofwel het sanctiedoel-criterium) door het Hof soms wordt aangemerkt als subcriterium van het tweede (hoofd)criterium. Zoals hierboven is aangegeven is er in dit boek, mede om praktische redenen, voor gekozen om de aard van de sanctie in beschouwing te nemen bij behandeling van het derde criterium (de aard en de zwaarte van de sanctie). Het normadressaat-criterium behelst met name de vraag tot wie de overtreden norm zich richt. Teneinde op basis van het normadressaat-criterium tot de conclusie te komen dat er sprake is van een overtreding die 'criminal' van aard is dient de overtreden regel van algemene strekking te zijn in die zin dat de regel gericht is tot alle burgers (eventueel in een bepaalde hoedanigheid). Is de overtreden regel echter gericht tot een bepaalde (beroeps)groep die een specifieke status bezit, en gelden de regels slechts in een bepaalde sfeer of omgeving, dan is de geschonden regel niet 'criminal' maar 'disciplinary' van aard. De aard van de overtreding, en dan in het bijzonder het normadressaatcriterium, lijkt echter in de regel niet doorslaggevend te zijn. Vaak speelt, zoals hierna zal blijken, daarnaast ook het derde criterium, om precies te zijn het sanctiedoelcriterium, een belangrijke rol.

Tenslotte kom ik hier beknopt terug op het derde criterium dat onderverdeeld kan worden in het subcriterium; de aard van de sanctie, en het subcriterium; de zwaarte van de sanctie. Ten eerste zal ik ingaan op de aard van de sanctie (ook wel sanctiedoelcriterium genaamd). Op basis van dit subcriterium kan een sanctie als 'criminal' in de zin van artikel 6 EVRM worden aangemerkt als de sanctie een punitief karakter en een afschrikkende werking heeft. Aangezien punitieve sancties (onder meer) generale en speciale preventie (dus afschrikking) ten doel hebben kan naar mijn mening in de 'criminal charge'-context worden volstaan met de constatering dat de sanctie punitief is. Deze constatering zou met zich moeten brengen dat er sprake is van een sanctie die 'criminal' van aard is in de zin van artikel 6 EVRM. Wanneer een sanctie 'punitief van aard is blijkt uit de rechtspraak van het EHRM spijtig genoeg in onvoldoende mate. Een handzame definitie wordt niet gegeven door het Hof.

Het tweede subcriterium, het sanctiezwaarte-criterium, is in het kader van dit onderzoek met name relevant voor wat betreft de hoogte/zwaarte van een op te leggen of

107 Dat dit niet altijd het geval hoeft te zijn kan worden afgeleid uit de zaken 'Escoubet v. Belgium' en 'W.S. v. Poland'. 
opgelegde boete. Volledigheidshalve is echter ook aandacht uit gegaan naar het sanctiezwaarte-criterium met betrekking tot vrijheidsberovende maatregelen.

Ten aanzien van de zwaarte van de sanctie kan het volgende geconcludeerd worden. Voor zover de sanctie bestaat uit een vrijheidsberovende maatregel lijkt, naast het bestraffende karakter van de vrijheidsberoving, in het bijzonder de duur van de vrijheidsberoving van belang te zijn. Waar het omslagpunt ligt tussen een vrijheidsberovende straf die dermate lang is dat de oplegging daarvan als 'criminal charge' aangemerkt zou kunnen worden, en een straf die kort genoeg is om op de oplegging daarvan niet als 'criminal charge' aan te merken, blijkt echter niet uit de rechtspraak van het Hof.

Ten aanzien van de oplegging van boeten kan geconstateerd worden dat de hoogte van de boete op zich niet voldoende lijkt te zijn om op basis van het sanctiezwaartecriterium te concluderen dat er sprake is van een 'criminal charge'. Andere factoren, zoals de aard van de sanctie (punitief of niet), de aard van de overtreden norm (al dan niet tuchtrechtelijk) en de mogelijkheid tot omzetting van de boete in een vrijheidsberovende maatregel (met of zonder voorafgaande hoorprocedure), zijn daarnaast steeds relevant.

Aangezien de zwaarte van de sanctie in de regel slechts in relatie tot een van de andere criteria een rol lijkt te kunnen spelen kan op basis van dit laatste criterium (alleen) weinig helderheid verkregen worden omtrent de vraag of de oplegging van een bepaalde sanctie aangemerkt moet worden als een 'criminal charge' in de zin van artikel 6 EVRM.

\subsubsection{Cumulatieve of alternatieve criteria?}

$\mathrm{Na}$ de beschrijving van de drie criteria die relevant zijn ter beantwoording van de vraag of de oplegging van een bepaalde sanctie aangemerkt moet worden als 'criminal charge' in de zin van artikel 6 EVRM dient uiteraard ook aandacht te worden besteed aan de onderlinge verhouding tussen de drie criteria. Met name de vraag of het gaat om alternatieve of cumulatieve criteria is daarbij relevant. In deze paragraaf zal aan die vraag aandacht worden besteed.

Hiervoor is reeds opgemerkt dat er een tweedeling is tussen de criteria. Aan de ene kant treffen we het eerste criterium aan, te weten de classificatie van de normschending naar nationaal recht. Aan de andere kant het tweede en derde criterium, te weten de aard van de overtreding en de aard en de zwaarte van de sanctie. Deze tweedeling wordt ook door Den Hartog gesignaleerd in haar dissertatie. Zij noemt dit het onderscheid tussen een formeel criterium en autonome criteria: 'Bij het formele criterium gaat het om het etiket dat de lidstaat op het delict heeft geplakt en bij de autonome criteria gaat het om criteria, die - los van het nationale recht - ontwikkeld zijn binnen het verdragsrechtelijk kader. ${ }^{108}$

Zoals reeds blijkt uit $\S 3.2 .1$ en 3.2.1.a van dit hoofdstuk is het eerste criterium, door Den Hartog het formele criterium genoemd, slechts van ondergeschikt belang omdat het EHRM de term 'criminal charge' autonoom uitlegt. Aan het feit dat een sanctie naar nationaal recht niet is ondergebracht in het strafrecht kent het EHRM in de regel geen (of weinig) gewicht toe. Veel belangrijker en doorgaans doorslaggevend zijn het twee- 
de en derde criterium. Juist ten aanzien van deze twee materieel getinte criteria heeft enige tijd onduidelijkheid bestaan met betrekking tot de vraag of het Hof deze criteria als alternatieve dan wel cumulatieve criteria heeft bedoeld.

In 1987 gaf het Hof in de zaak 'Lutz' uitdrukkelijk aan dat het tweede en derde criterium als alternatieve criteria beschouwd moeten worden:

'The Court points out that the second and third criteria adopted in the judgements in the Engel and Others case and the Öztürk case are alternative and not cumulative ones: for Art. 6 to apply in virtue of the words "criminal charge", it suffices that the offence in question should by its nature be "criminal" from the point of view of the Convention, as in the instant case, or should have made the person concerned liable to a sanction which, in its nature and degree of severity, belongs in general to the "criminal" sphere (...). ${ }^{.109}$

In 1994 ontstond echter onduidelijkheid toen het Hof in de zaak 'Bendenoun v. France' het volgende overwoog:

In the first place, the offences with which Mr Bendenoun was charged came under Article 1729 para. 1 of the General Tax Code (...). That provision covers all citizens in their capacity as taxpayers, and not a given group with a particular status. It lays down certain requirements, to which it attaches penalties in the event of non-compliance. Secondly, the tax surcharges are intended not as pecuniary compensation for damage but essentially as a punishment to deter reoffending. Thirdly, they are imposed under a general rule, whose purpose is both deterrent and punitive. Lastly, in the instant case the surcharges were very substantial, amounting to FRF 422,534 in respect of Mr Bendenoun personally and FRF 570,398 in respect of his company (...); and if he failed to pay, he was liable to be committed to prison by the criminal courts (...). Having weighed the various aspects of the case, the Court notes the predominance of those which have a criminal connotation. None of them is decisive on its own, but taken together and cumulatively they made the "charge" in issue a "criminal" one within the meaning of Article 6 para. 1 (art. 6-1), which was therefore applicable [curs. KA]."

Alle factoren die van belang zijn in het kader van het tweede en derde criterium spelen in de zaak 'Bendenoun' een rol en zijn volgens het Hof relevant om de oplegging van de sanctie als 'criminal charge' te kunnen kwalificeren. Betekent dit nu dat altijd aan het tweede én derde criterium (en de daarbij behorende subcriteria) voldaan moet zijn om tot de kwalificatie 'criminal charge' te komen? Een discussie onder juristen laaide op. Een enkeling meende dat het Hof sinds 'Bendenoun' uitging van het standpunt dat het tweede en derde criterium aangemerkt moeten worden als cumulatieve criteria. Dit zou dan met zich brengen dat een sanctie op basis van beide criteria 'criminal' zou moeten zijn, om de oplegging van deze sanctie als 'criminal charge' aan te kunnen merken. Anderen meenden dat het Hof geen afstand had genomen van het in de zaak 'Lutz' ingenomen standpunt. Derhalve zou nog steeds uitgegaan kunnen worden van het alternatieve karakter van het tweede en derde criterium. ${ }^{111}$

109 'Lutz' § 55.

110 'Bendenoun' $\$ 47$.

III Zie voor een overzicht van de discussie (na de uitspraak van het Hof in de zaak 'Bendenoun') over het alternatieve dan wel cumulatieve karakter van het tweede en derde criterium: M.L.W.M. Viering, Het arrest Bendenoun: een stap terug?, NJB 1994, p. 1061-1063, A.R. Hartmann en P.M. van Russen Groen, 'Criminal charge' uitgekleed? Bendenoun gerelativeerd, NJB 1994, p. 1520-1526, P. van Dijk, 
Het Hof verschafte uiteindelijk zelf duidelijkheid toen het uitspraak deed in de zaak 'Garryfallou AEBE'. ${ }^{12}$ In genoemde zaak heeft het EHRM ten aanzien van het alternatieve dan wel cumulatieve karakter van het tweede en derde criterium het volgende overwogen:

'It is apparent from section 8 of Law no. 936/1979 (...) that the fine imposed on the applicant company is not characterised under domestic law as a criminal sanction. Moreover, this was common ground among those appearing before the Court. It is consequently necessary to examine the sanction in the light of the second and third criteria mentioned above (...). In this respect, the Court recalls that these criteria are alternative and not cumulative ones: for Article 6 to apply by virtue of the words "criminal charge", it suffices that the offence in question should by its nature be "criminal" from the point of view of the Convention, or should have made the person concerned liable to a sanction which, in its nature and degree of severity, belongs in general to the "criminal" sphere (...). This does not exclude that a cumulative approach may be adopted where the separate analysis of each criterion does not make it possible to reach a clear conclusion as to the existence of a "criminal charge" (see, for instance, the Bendenoun v. France judgment of 24 February 1994, Series A no. 284, p. $20, \S 47) !^{113}$

Onder verwijzing naar de zaak 'Lutz' heeft het Hof in de zaak 'Garyfallou AEBE' aangegeven dat het tweede en derde criterium een alternatief karakter hebben. Daarnaast heeft het Hof in de zaak 'Garyfallou AEBE' aangegeven dat een cumulatieve benadering wel mogelijk is als de oplegging van een sanctie op basis van het tweede of derde criterium afzonderlijk niet als 'criminal charge' kan worden gekwalificeerd. ${ }^{114}$

De in 'Garyfallou AEBE' weergegeven redening komt ook in recentere rechtspraak van het Hof regelmatig voor. ${ }^{115}$ Derhalve kan er van uit worden gegaan dat het tweede en derde criterium beschouwd moeten worden als alternatieve criteria. Slechts aan een van beiden hoeft, volgens het EHRM, voldaan te zijn om de oplegging van een sanctie aan te kunnen merken als 'criminal charge' in de zin van artikel 6 EVRM. Indien op basis van het tweede of derde criterium afzonderlijk niet geconcludeerd kan worden dat er sprake is van een 'criminal charge' kan een cumulatieve toets aan het tweede en derde criterium echter toch tot de conclusie leiden dat een bepaalde sanctie als 'criminal charge' moet worden gekwalificeerd.

Bendenoun binnen proporties, NJB 1994, p. 1526- 1527, P.J. Wattel, Bendenoun, boeten en belastingen, NJB 1994, p. 1527-1529 en P.J. Wattel, Enkele mensenrechtelijke problemen in belastingszaken, in de bundel: 45 jaar Europees verdrag voor de rechten van de mens, onder redactie van A.W. Heringa en E. Myjer, Leiden 1996, p. 187-202, i.h.b. p. 192-195.

1!2 EHRM 24 september 1997, no. 93/1966/712/909, JB 1997/281 m. nt. A.W. Heringa (Garyfallou AEBE).

113 'Garyfallou AEBE' $\$ 33$.

114 Zie hierover ook: M.L.W.M. Viering en J.W.A. Fleuren, Bendenoun revisited, NJB 1997, p. 19321943. Zij komen tot de conclusie dat: '... in het arrest Garyfallou AEBE het Hof in een 'obiter dictum' een nadere precisering heeft gegeven van de wijze waarop kan worden vastgesteld of er sprake is van een 'criminal charge' in de zin van artikel 6 EVRM. De aanvullende cumulatieve toets lijkt een bruikbare maatstaf en kan potentieel leiden tot een uitbreiding van het toepassingsgebied van artikel 6 EVRM.' (Viering en Fleuren a.w. 1997, p. 1943).

115 Zie bijvoorbeeld: 'W.S. v. Poland' en 'Lauko' § 57. 
Zoals gezegd kan er dus, volgens het EHRM, al sprake zijn van een 'criminal charge' als voldaan is aan het tweede of het derde criterium. Bestudering van de rechtspraak van het Hof leert dat in het bijzonder de aard van de sanctie van belang lijkt te zijn bij beantwoording van de vraag of de oplegging van een sanctie aangemerkt moet worden als 'criminal charge' in de zin van artikel 6 EVRM. Met name het punitieve (en afschrikkende) karakter van de sanctie lijkt in dat kader doorslaggevend te zijn. ${ }^{116}$

\subsubsection{Charge}

Met de drie hierboven weergegeven criteria wordt door het EHRM invulling gegeven aan de term 'criminal'. Op basis van de drie genoemde criteria kan derhalve slechts uitspraak gedaan worden over het 'strafkarakter' van de (oplegging van de) sanctie. Daarnaast is, voor de toepasselijkheid van artikel 6 EVRM, uiteraard de vraag relevant of er sprake is van een 'charge'.117

Ten aanzien van de vraag wanneer er sprake is van een 'criminal charge' bestaat minder onduidelijkheid dan ten aanzien van de vraag wanneer de sanctionering van de normschending 'criminal' van aard is. In de zaak 'Foti and Others' ${ }^{118}$ heeft het Hof omtrent het moment waarop sprake is van een 'charge' het volgende bepaald:

'Whilst "charge", for the purpose of Article $6 \S 1$, may in general be defined as "the official notitication given to an individual by the competent authority of an allegation that he has committed a criminal offence", it may in some instances take the form of other measures which carry the implication of such an allegation and which likewise substantially affect the situation of the suspect. ${ }^{119}$

Het moet derhalve gaan om een officiële kennisgeving van een bevoegde instantie aan een bepaalde persoon waarin deze persoon beschuldigd wordt van het begaan van een overtreding ${ }^{120}$ (criminal offence). ${ }^{12}$ In bepaalde gevallen kan een vervolging (charge) echter ook de vorm aannemen van andere maatregelen (dan de officiële kennisgeving) die een beschuldiging impliceren en die eveneens de positie van de verdachte wezenlijk beïnvloeden. ${ }^{122}$

Ten aanzien van de, in de zaak 'Foti and Others' genoemde andere maatregelen kan gewezen worden op de arrestatie van een verdachte of de aanvang van een (gerechte-

116 Zie in deze zin ook Den Hartog a.w. p. 114-115, Hartmann en Van Russen Groen a.w. 1998, p. 82 en Michicls a.w. 1995, p. 67-68. Michiels stelt in zijn preadvies het volgende: 'Als de sanctie punitief van aard is (in de termen van het EHRM: bestraffend en afschrikwekkend) en de overtreden bepaling zich tot een ieder richt, is art. 6 van toepassing.'

117 Zie hierover voorts: Viering a.w. 1994, p. 185-195.

118 EHRM 10 december 1982. Series A vol. 56, NJ 1987, 828, m. nt. P. van Dijk (Foti and Others).

119 'Foti and Others' \$ 52.

120 Onder de term overtreding dient in dit kader te worden verstaan; elke normschending die gesanctioneerd kan worden middels een 'criminal charge'. Daartoe behoren derhalve meer normschendingen dan op basis van ons nationale recht onder het strafrechtelijk begrip overtreding vallen.

121 EHRM 27 februari 1980, Series A vol. 35, NJ 1980, 561 (essentie) (Deweer v. Belgium), i.h.b. $\$ 46$.

122 'Foti and Others' $\$ 52$. In de zaak 'Foti and Others' wordt aan het begrip 'charge' een ruimere uitleg gegeven dan in de zaak 'Deweer'. Op basis van de zaak 'Deweer' was er namelijk slechts sprake van cen 'charge' indien er sprake was van: 'the official notification given to an individual by the competent authority of an allegation that he has committed a criminal offence.' ('Deweer' $\$ 46$ ). Zie voor een overzicht van rechtspraak van het EHRM ten aanzien van het begrip 'charge' voorts: Van Dijk/Van Hoof 1998, i.h.b. p. $407-409$. 
lijk) vooronderzoek. ${ }^{123}$ In Van Dijk/Van Hoof wordt daarnaast gewezen op de volgende maatregelen: 'Examples of such measures are the search of the person's home and/or seizure of certain goods, the request that a person's immunity be lifted and the confir. mation by the judge of the sealing of a building. ${ }^{124}$ Het voorgaande impliceert dat artikel 6 EVRM ook al (deels) van toepassing kan zijn in de fase vóór de gerechtelijke procedure (trial). ${ }^{125}$

In de zaken 'Deweer' en 'Foti and Others' is overigens een uitwerking aan de term 'charge' gegeven met het oog op het 'redelijke termijn vereiste' ${ }^{126}$ uit artikel 6 EVRM. De redelijke termijn vangt aan op het moment dat er sprake is van een 'charge', zoals deze is gedefinieerd in de zaak 'Foti and Others'. ${ }^{127}$ Op basis van het voorgaande zou men zich de vraag kunnen stellen of de andere, in artikel 6 EVRM neergelegde, waarborgen ook eerst gelden vanaf het moment dat er sprake is van een 'criminal charge'.

Den Hartog meent van niet. $\mathrm{Zij}$ stelt het volgende: 'Het ten aanzien van het recht op een behandeling binnen redelijke termijn ontwikkelde begin- en eindpunt kan niet zonder meer worden toegepast ten aanzien van de overige door artikel 6 EVRM beschermde rechten. ${ }^{128}$ Lenos komt in haar dissertatie tot een soortgelijke conclusie. ${ }^{129}$ De rechtspraak van het Hof lijkt echter een andere kant op te wijzen. In de zaak 'Escoubet' stelde het Hof omtrent de toepasselijkheid van de waarborgen uit artikel 6 EVRM het volgende:

The fact that a measure is provided for in a criminal statute of a respondent State does not in itself signify that it falls within the scope of Article 6 of the Convention. That Article is not applicable unless there is a "criminal charge" against a particular person (...), that is, after the individual has received the "official notification by the competent authority of an allegation that he has committed a criminal offence" (..) or has been the subject of "measures which carry the implication of such an allegation and which likewise substantially affect the situation of the suspect" (...). The procedural safeguards laid down in Article 6 do not, as a rule, apply to the various preliminary measures which may be taken as part of a criminal investigation before bringing a "criminal charge", such as the arrest or

123 Zie; EHRM 21 juni 1983, Series A vol. 65 (Eckle v. Germany), i.h.b. $\$ 73$ : 'In criminal matters, the 'reasonable time' referred to in Article 6 par. I (art. 6-1) begins to run as soon as a person is 'charged'; this may occur on a date prior to the case coming before the trial court (..), such as the date of amest, the date when the person concemed was officially notified that he would be prosecuted or the date when preliminary investigations were opened.'

124 Van Dijk/Van Hoof a.w. 1998, p. 408.

125 Zie: EHRM 24 november 1993, Series A vol. 275 (Imbrioscia v. Switzerland) i.h.b. \$ 36.

126 Artikel 6, eerste lid, luidt in de Nederlandse vertaling (voor zover in dit kader relevant is): '...bij het bepalen van de gegrondheid van een tegen hem ingestelde vervolging heeft een ieder recht op ees (..) behandeling van zijn zaak, binnen een redelijke termijn, (...)'.

127 De redelijke termijn eindigt op het moment waarop definitief over de 'charge' is beslist, zo blijkt uit de zaken 'Neumeister' (EHRM 27 juni 1968, Series A vol. 8, i.h.b. \$19) en 'Delcourt' (EHRM 17 januari 1970 , Series A vol. 11, i.h.b. $\$ 25$ en 26).

128 Den Hartog a.w. 1992, p. 120.

129 Lenos a.w. 1998, p. 186: 'Dit betekent dat sommige waarborgen reeds kunnen worden ingerocptn. zodra sprake is van een criminal charge en mogelijk zelfs voór dit moment, indien en voorzover een uiteindelijk proces door het daaraan voorafgaand niet inachtnemen van een waarborg emstig word geschaad.' 
interviewing of a suspect (...), measures which may, however, be governed by other provisions of the Convention, in particular Articles 3 and $5(\ldots) .{ }^{130}$

Hoofdregel lijkt dan ook te zijn dat de waarborgen uit artikel 6 EVRM eerst van toepassing zijn vanaf het moment dat er sprake is van een 'criminal charge' zoals gedefinieerd in de zaak 'Foti and Ohters'. ${ }^{131}$ Uitzonderingen zijn wellicht mogelijk. Het Hof overweegt immers: 'The procedural safeguards laid down in Article 6 do not, as a rule [curs. KA], apply to the various preliminary measures which may be taken as part of a criminal investigation before bringing a 'criminal charge',...'.

Ook Feteris is van mening dat de waarborgen uit artikel 6 van het EVRM normaal gesproken eerst gelden op het moment dat der sprake is van een 'charge'. ${ }^{32}$ Hij plaats daarbij echter de volgende kanttekening:

'Het voorgaande wil niet zeggen dat gebeurtenissen die aan de 'charge' vooraf gaan nooit van belang zouden kunnen zijn voor de toepassing van art. 6 EVRM. Als het tot een 'charge' komt moet het proces als geheel aan de eisen van art. 6 voldoen, waarbij gebeurtenissen voor het moment van de 'charge' ook een rol kunnen spelen. Eventuele tekortkomingen in de rechten van verdediging in die fase zouden later hersteld kunnen worden, maar dat moet dan wel mogelijk zijn, en ook daadwerkelijk gebeuren. Anders zou het proces in zijn geheel toch noch 'unfair' kunnen zijn.' 133

Het lijkt erop dat Feteris een vooruitziende blik heeft gehad. Ruim drie jaar na het verschijnen van zijn dissertatie deed het EHRM, op 17 december 1996, uitspraak in de zaak 'Saunders'. ${ }^{134}$ Saunders werd in het stadium voordat er sprake was van een 'charge', op basis van een 'inlichtingenplicht', gedwongen ${ }^{135}$ een belastende verklaring tegen zichzelf af te leggen met betrekking tot de onrechtmatige beïnvloeding van de koers op de beurs van aandelen Guinness. Centraal stond de vraag hoe deze, middels een boete of vrijheidsstraf te sanctioneren, inlichtingenplicht, die geldt in de fase dat er nog geen sprake is van een 'criminal charge', zich verhoudt tot het in artikel 6 lid 1 besloten liggende nemo tenetur-beginsel.

Het EHRM stelt dat in de fase voorafgaand aan de 'charge' de waarborgen uit artikel 6 nog geen rol spelen. ${ }^{136}$ Het gebruik van de in die fase onder dwang verkregen belastende verklaring tijdens de strafrechtelijke procedure kan echter wel leiden tot de conclusie dat de verdachte geen 'fair trial' (eerlijk proces) heeft gehad aldus het Hof:

'Moreover the fact that statements were made by the applicant prior to his being charged does not prevent their later use in criminal proceedings from constituting an infringement of the right (not to incriminate oneself [KA]). It follows form the above analysis and from the

130 'Escoubet v. Belgium' $§ 34$. Opvallend is overigens dat in de zaak 'Eckle', anders dan in de zaak 'Escoubet v. Belgium', de arrestatie van een verdachte genoemd werd als mogelijk beginpunt voor de 'charge'. Het Hof lijkt hier in de zaak 'Escoubet v. Belgium' al dan niet bewust aan voorbij te gaan.

131 Zie in deze zin ook: Van Dijk/Van Hoof a.w. 1998, i.h.b. p. 407. In ieder geval staat vast dat de redelijke termijn gaat lopen op het moment dat er sprake is van een 'criminal charge'.

132 Feteris a.w. 1993, p. 306-307. Zie ook Van Russen Groen a.w. 1998, p. 81.

133 Feteris a.w. 1993, p. 307.

134 EHRM 17 december 1996, EHRC Reports 1996-VI, p. 2044, NJ 1997, 699, m. nt. Knigge (Saunders v. the United Kingdom).

135 Indien Saunders zou hebben geweigerd te antwoorden kon hem een boete of een gevangenisstraf van maximaal twee jaar worden opgelegd.

136 'Saunders' $\$ 67$. 
fact that section 434 (5) of the Companies Act 1985 authorises, as noted by both the trial judge and the Court of Appeal, the subsequent use in criminal proceedings of statements obtained by the Inspectors that the various procedural safeguards to which reference has been made by the respondent Government (...) cannot provide a defence in the present case since they did not operate to prevent the use of the statements in the subsequent criminal proceedings. Accordingly, there has been an infringement in the present case of the right not to incriminate oneself., 137

Gelet op de hierboven weergegeven passages uit de zaak 'Escoubet' en de zaak 'Saunders' lijkt het inderdaad zo te zijn dat de waarborgen uit artikel 6 EVRM normaal gesproken eerst van toepassing zijn vanaf het moment dat er sprake is van een 'criminal charge' zoals gedefinieerd in de zaak 'Foti and Others'. ${ }^{138}$ Het voorgaande staat er echter niet aan in de weg dat gebeurtenissen of feiten die hebben plaatsgevonden voordat er sprake was van een 'charge', en waarop de waarborgen uit artikel 6 EVRM op dat moment niet van toepassing waren, aanleiding kunnen geven tot de conclusie dat er geen sprake is geweest van een 'fair trial' of dat een van de andere waarborgen uit artikel 6 EVRM is geschonden.

\subsubsection{Afsluitend 'criminal charge'}

Hoewel de drie (alternatieve) criteria, die door het EHRM in de zaken 'Engel and Others' en 'Öztürk' zijn geformuleerd, voor de partijstaten een helder toetsingskader zouden moeten verschaffen lijkt het er eerder op dat het EHRM de partijstaten met een kluitje in het riet heeft gestuurd. Feteris beschrijft dit als volgt:

'Welk gewicht het Hof precies aan alle besproken factoren toekent, is niet duidelijk. (...) De methode die het Hof volgt lijkt in te houden dat het aan de hand van een reeks factoren onderzoekt welke strafelementen er in een overtreding te onderkennen zijn, en op basis daarvan een afweging maakt van het karakter van de overtreding, waarbij die factoren niet stuk voor stuk noodzakelijkerwijs in de richting van een strafrechtelijk karakter behoeven te wijzen. (...) Een dergelijk, enigszins gevoelsmatig procédé maakt de gedachtengang van het Hof erg moeilijk te voorspellen, aangezien er geen nauwkeurige formule bestaat om aan te geven of een bepaalde combinatie van factoren al dan niet tot een strafrechtelijk karakter leidt. ${ }^{139}$

Veel helderheid bieden genoemde criteria, zoveel is duidelijk, niet. ${ }^{140}$ Dat heeft mede te maken met het feit dat de rechtspraak van het Hof zeer casuïstisch en weinig voorspelbaar is. ${ }^{141}$

Men kan zich dan ook afvragen wat het nut is van de hierboven opgenomen uitvoerige beschrijving van (met name) de rechtspraak van het EHRM. Mijns inziens is voorgaand

137 'Saunders' $\$ 74-76$. Zie in die zin ook de door Feteris gemaakte opmerking. Feteris a w. 1993, p. 315 316.

138 Zie in deze zin ook: Van Dijk/Van Hoof a.w. 1998, i.h.b. p. 407.

139 Feteris a.w. 1993, p. 257.

140 Vgl. T. Barkhuysen, M.L. van Emmerik en J.P. Loof, 50 jaar EVRM en het Nederlandse staats- en bestuursrecht - ontwikkelingen en vooruitzichten, in de bundel: 50 jaar Europees Verdrag voor de Rechten van de Mens, onder redactic van R.A. Lawson en E. Myjer, Leiden 2000, p. 237-408, i.h.b. p.401.

141 Zie in deze zin ook Van Russen Groen, a.w. 1998, p. 67. Vgl. Alkema, a.w. 2002, p. 114 en 124. 
overzicht niettemin zinvol aangezien het EHRM in ieder geval op hoofdlijnen de koers heeft uitgezet. Met name relevant is de opvatting van het EHRM dat de nationale wetgever gelet op het autonome karakter van de term 'criminal charge' de verdragswaarborgen niet kan frustreren door een ander etiket op een sanctie te plakken. ${ }^{142}$ Vanwege genoemd autonome karakter van de term 'criminal charge' kan bijvoorbeeld ook de oplegging van een bestuursrechtelijke sanctie als 'criminal charge' gekwalificeerd worden.

Teneinde vast te stellen of er sprake is van een 'criminal charge' zijn met name het tweede en derde criterium zoals geformuleerd in de zaken 'Engel and Others' en 'Öztürk' van belang. Met name het punitieve karakter van de sanctie (in samenhang met de algemene strekking van de geschonden norm) lijkt doorslaggevend te zijn bij de vaststelling dat de oplegging van een sanctie aangemerkt moet worden als 'criminal charge' in de zin van artikel 6 EVRM ${ }^{143}$ Het voorgaande komt duidelijk tot uitdrukking in de hiervoor reeds aangehaalde uitspraak van het EHRM in de zaak 'Lauko v. Slovakia'. In die zaak wordt door het Hof aangegeven dat de algemene strekking van de geschonden norm en het punitieve en afschrikkende karakter van de opgelegde boete leiden tot de conclusie dat er sprake is van een 'criminal charge'. Dat de geschonden norm niet onder is gebracht in het strafrecht is volgens het Hof niet relevant. Evenmin kan de geringe hoogte van de boete ( 300 Slovaakse Kronen - ongeveer $€ 7,50-$ ) leiden tot een andere conclusie. ${ }^{144}$

Bij de beantwoording van de vraag of de oplegging van een sanctie aan de hand van het tweede en/of derde criterium, en dan in het bijzonder vanwege het punitieve karakter (en de algemene strekking van de overtreden norm), aangemerkt moet worden als 'criminal charge' doet zich, zoals hierboven is weergeven, het probleem voor dat de criteria niet uitblinken in helderheid. Genoemde criteria bieden derhalve een houvast op hoofdlijnen maar meer ook niet. ${ }^{145}$

142 Zie in deze zin ook Riphagen a.w. 1994, p. 17-21. Op p. 17 stelt Riphagen het volgende: 'De onder 2.1 aangegeven criteria van het Europese Hof lijken helder en duidelijk, maar zijn het niet. Eigenlijk is de boodschap van het Hof slechts daar boven twijfel verheven, waar het Hof duidelijk maakt dat het criminal charge begrip een eigen europeesrechtelijke inhoud heef, los van de kwalificatie in het eigen nationale recht. Evenzeer is het Hof duidelijk voorzover het aangeeft dat een lidstaat een sanctie niet aan de waarborgen van art. 6 kan onttrekken door het 'etiket' op een sanctie te veranderen (met name van strafrechtelijk in administratief).' De idee dat de classificatie van de sanctie niet zonder meer doorslaggevend hoeft te zijn was ten tijde van de zaak 'Engel and Others' en de zaak 'Ozturk' echter niet nieuw. Duk heeft tijdens zijn oratie reeds aangegeven dat de classificatie van de reactie op onrechtmatig gedrag in feite niet ter zake doet. Belangrijker is volgens Duk het werkelijk karakter van de sanctie. Zie hierover Duk a.w. 1973, p. 21.

143 Zie in deze zin N. Verheij, Onder dexel van politie, het Nederlands bestuursrecht onder het EVRM, in de bundel: 40 jaar Europees verdrag voor de Rechten van de Mens: opstellen over de ontwikkeling van het EVRM in Straatsburg en in Nederland, onder redactie van A.W. Heringa en J.G.C. Schokkenbroek, Leiden 1990, p. 225-248, i.h.b. p. 233. Zie voorts Den Hartog a.w. p. 114-115 en Hartmann en Van Russen Groen a.w. 1998, p. 82. In Van Dijk/Van Hoof c.s. wordt tenslotte gesteld dat het afgelopen moet zijn met de onduidelijke jurisprudentie m.b.t. het 'criminal charge' begrip. De auteurs van genoemd werk (en dan i.h.b. Viering) tonen zich een voorstander van de toepasselijkheid van de uit artikel 6 EVRM voorvloeiende waarborgen bij de oplegging van alle punitieve sancties. Aan de zwaarte van de sanctie zou voor de vaststelling van het karakter van een sanctie (criminal of niet) volgens genoemde auteurs geen gewicht moeten toekomen (zie Van Dijk/Van Hoof a.w. 1998, p. 418).

I45 Zie in deze zin ook Riphagen a.w. 1994, p. 20-21. 
Het verdient opmerking dat de Nederlandse wetgever er van uitgaat dat, de oplegging van een bestuurlijke boete, op grond van de criteria uit de zaak 'Öztürk', aangemerkt moet worden als een 'criminal charge' in de zin van artikel 6 EVRM. Het voorgaande standpunt is door de commissie Scheltema in de toelichting op het Voorontwerp van de boeteregeling uit de vierde tranche van de Awb ook uitdrukkelijk ingenomen. Genoemde commissie heeft in dat kader het volgende gesteld:

'De vraag wat deze criteria precies inhouden, heeft heel wat pennen in beweging gebracht. Niettemin kan deze discussie hier blijven rusten. Inmiddels is in Nederland namelijk onomstreden, dat het opleggen van een bestuurlijke boete in (zo goed als) alle gevallen een $<$ criminal charge $>$ oplevert.' ${ }^{146}$

Op basis van die constatering gaat de commissie Scheltema uit van de toepasselijkheid van artikel 6 en 7 EVRM en artikel 14 en 15 IVBPR. Gelet op de hierboven weergegeven opvatting van de commissie Scheltema zal ik hierna ook uitgaan van de toepasselijkheid van genoemde verdragsartikelen bij de oplegging van een bestuurlijke boete. Los daarvan ben ik overigens van mening dat de bestuurlijke boete onmiskenbaar een punitieve sanctie is en dat derhalve de essentiële straf(proces)rechtelijke waarborgen, zoals onder meer neergelegd in het EVRM en IVBPR, bij de oplegging van een dergelijke sanctie in acht genomen zouden moeten worden. ${ }^{147}$

\section{3 'criminal charge' ex artikel 14 IVBPR}

Op deze plaats dient voorts aandacht uit te gaan naar de vraag of met de termen 'criminal charge' en 'criminal offence' in artikel 14 IVBPR gedoeld wordt op dezelfde vormen van 'strafvervolging' als de vormen van 'strafvervolging' die volgens het EHRM onder het begrip 'criminal charge' vallen. Heldere jurisprudentie van het Human Rights Committee is daaromtrent niet voorhanden. ${ }^{148}$ Gelet op de nauwe verwevenheid en de totstandstandkomingsgeschiedenis van het EVRM en het IVBPR kan er echter vanuit gegaan worden dat de criteria die door het EHRM zijn ontwikkeld in de zaken 'Öztürk' en 'Engel and Others' ook relevant zijn in het kader van artikel 14 IVBPR. ${ }^{149}$ Derbalve is het mijns inziens gerechtvaardigd te stellen dat voor de beantwoording van de vragg of er sprake is van een 'criminal charge' in de zin van artikel I4 IVBPR getoetst kan worden aan de criteria die door het EHRM in de zaken 'Öztürk' en 'Engel and Others' zijn ontwikkeld. ${ }^{150}$

147 Zie in dat kader ook hoofdstuk twee van dit boek.

148 Vgl. Nowak a.w. 1993, p. 244. Ook in de, op intemet te raadplegen, (recentere) uitspraken van het Human Rights Committee wordt overigens, voor zover ik na heb kunnen gaan, geen nadere uitwerking gegeven aan de term 'criminal offence'.

149 Vgl. Nowak a.w. 1993, p. 238: 'Resort to this latter source (de rechtspraak van het EHRM [KA]] appears justified in the light of the great similarity of the two provisions and their common historical background.'

150 Zie in deze zin ook: Feteris a.w. 1993, p. 260. Zie voorts een uitspraak van de Centrale Raad van Beroep van 14 februari 2001 (JB 2001/80 m. nt. C.L.G.F.H. Albers) waarin ook de Centrale Raad val dat standpunt uitgaat. 


\section{4} Waarborgen uit het EVRM en IVBPR

Na een uitvoerige analyse van de rechtspraak van het EHRM inzake het 'criminal charge'-begrip zal nu ingegaan worden op de uit de artikelen 6 en 7 EVRM en 14 en 15 JVBPR voortvloeiende rechten. Eerst volgt een opsomming van alle (straf(proces)rechtelijke) waarborgen die uit genoemde artikelen voorvloeien. Een aantal daarvan zal vervolgens nader belicht worden. Zoals gezegd gaat het daarbij in het bijzonder om de de essentiële straf(proces)rechtelijke waarborgen die met het oog op hoofdstuk vier van dit boek het meest relevant zijn en die in het kader van de bestaande en voorgestelde Nederlandse bestuurlijke boeteregelingen doorgaans problemen opleveren bij implementatie.

Een beschrijving van alle, uit de genoemde verdragsbepalingen voortvloeiende, waarborgen is naar mijn oordeel in het kader van dit onderzoek niet noodzakelijk. Er is immers recentelijk een aantal dissertaties verschenen waarin daaraan uitvoerig aandacht is besteed. In het kader van dit onderzoek volsta ik, ten aanzien van een aantal waarborgen, met een verwijzing naar genoemde werken.

In dit boek komen de volgende waarborgen uitvoeriger aan de orde; de onschuldpresumptie, het nemo tenetur-beginsel, het nullum crimen sine lege-beginsel, het nulla poena sine lege-beginsel en het beginsel dat de overtreder dient te profiteren van een, na het begaan van het strafbare feit, totstandgekomen wetswijziging die voorziet in de oplegging van een lichtere straf. ${ }^{151}$ In het kader van het nullum crimen sine legebeginsel en het nulla poena sine lege-beginsel zal voorts aandacht uitgaan naar het lex certa-beginsel.

Naar de twee eerstgenoemde beginselen zal de meeste aandacht uitgaan. De drie laatstgenoemde beginselen zullen beknopter beschreven worden omdat ten aanzien van deze beginselen minder onduidelijkheden bestaan en/of minder jurisprudentie voorhanden is. De hiervoor genoemde waarborgen komen in dit hoofdstuk uitdrukkelijk aan de orde omdat de uitleg die het EHRM aan deze waarborgen geeft niet gemist kan worden teneinde vast te stellen of de in Nederland inmiddels bestaande regelingen tot oplegging van bestuurlijke boeten en (meer in het bijzonder) de boeteregeling in het Voorontwerp van de vierde tranche van de Awb met voldoende (straf(proces)rechtelijke) waarborgen zijn omkleed in het kader van de rechtsbescherming van de vermoedelijke overtreder. Daarbij staat de vraag centraal of in het Voorontwerp door de commissie Scheltema een juiste uitleg wordt gegeven aan de verdragsrechtelijke waarborgen. Een antwoord op deze laatste vraag zal gegeven worden in hoofdstuk vier en in het slotdeel van dit boek.

\subsubsection{De waarborgen - een opsomming -}

Van Russen Groen heeft met betrekking tot de waarborgen die uit artikel 6 EVRM en 14 IVBPR voortvloeien in zijn dissertatie een overzicht gegeven. ${ }^{152}$ De door Van Rus-

151 Uit voorgaande opsomming blijkt dat met name de waarborgen uit het eerste lid van artikel 6 EVRM niet aan de orde zullen komen. Een beschrijving van de in artikel 6 lid I opgenomen waarborgen is onder meer opgenomen in de dissertatie van Van Russen Groen, a.w. 1998, hoofdstuk 5, daar wil ik dan op deze plaats ook naar verwijzen. Zie voorts Van Dijk/Van Hoof a.w. 1998, p. 406-458.

152 Van Russen Groen a.w. 1998, p. 77-78. 
sen Groen gehanteerde catalogus zal ik hier ook aanhouden. Ten eerste vloeit een aantal rechten zowel voort uit artikel 6 EVRM als uit artikel 14 IVBPR. Het gaat dan om de volgende rechten:

1. toegang tot een rechter ${ }^{153}$

2. aanwezigheid bij de behandeling van de zaak $^{154}$

3. eerlijke behandeling van de $z^{2} k^{155}$

4. behandeling van de zaak door een onafhankelijke rechter ${ }^{156}$

5. behandeling van de zaak door een onpartijdige rechter ${ }^{157}$

6. behandeling van de zaak door een gerecht dat door de wet is ingesteld

7. behandeling van de zaak binnen redelijke termijn ${ }^{158}$

8. openbare behandeling van de zaak ${ }^{159}$

9. openbare uitspraak in de $z^{2}{ }^{160}$

10. onschuldig worden gehouden totdat de schuld in rechte is komen vast te staan

11. onverwijld in een taal die de verdachte verstaat en in bijzonderheden op de hoogte worden gesteld van de gronden waarop de beschuldiging berust ${ }^{161}$

12. voldoende tijd en faciliteiten voor de verdediging ${ }^{162}$

13. (kosteloze) bijstand door een raadsman ${ }^{163}$

14. het (doen) ondervragen van getuigen à charge en à décharge ${ }^{164}$

15. kosteloze bijstand door een tolk ${ }^{165}$

Uit artikel 14 IVBPR vloeien vervolgens nog een vijftal 'aanvullende' rechten voort, namelijk:

153 Zie m.b.t. de toegang tot een rechter: Van Russen Groen a.w. 1998, p. 93 e.v. en 139. Hieronder valt ook het recht op rechtspraak door een rechter die beschikt over 'full jurisdiction', vgl. Van Russen Groen a.w. 1998, p. 125 e.v. In hoofdstuk vier zullen overigens bepaalde aspecten van het recht op toegang tot de rechter en het vereiste van 'full jurisidiction' nader belicht worden.

154 Zie m.b.t. de aanwezigheid bij de behandeling van de zaak: Van Russen Groen a.w. 1998, p. 95.

155 Zie m.b.t. een eerlijke behandeling van de zaak: Van Russen Groen a.w. 1998, p. 176 e.v.

156 Zie m.b.t. de behandeling van de zaak door een onafhankelijke rechter: Van Russen Groen a.w. 1998, p. 144 e.v.

157 Zie m.b.t. de behandeling van de zaak door een onpartijdige rechter: Van Russen Groen a.w. 1998, p. 146 e.v.

158 Zie m.b.t. de redelijke termijn in het bestuursrecht: A.M.L. Jansen, De redelijke termijn met name in het bestuursrecht, Den Haag: Boom Juridische Uitgevers 2000. Zie voorts: Van Russen Groen aw. 1998 , p. 157 e.y.

159 Zie m.b.t. de openbare behandeling van de zaak: Van Russen Groen a.w. 1998, p. 172 e.v.

160 Zie m.b.t. de openbare uitspraak in de zaak: Van Russen Groen a.w. 1998, p. 172 e.v.

161 Zie m.b.t. de inkennisstelling in een verstaanbare taal: Van Russen Groen a.w. 1998, p. 215 e.v. ti O.J.D.M.L. Jansen, Het handhavingsonderzoek (diss. UvA 1999), Nijmegen 1999, p. 145 e.v.

162 Zie m.b.t. voldoende tijd en faciliteiten voor de verdediging: Van Russen Groen a.w. 1998, p. 224 e.r. en Jansen a.w. 1999, p. 147 e.v.

163 Zie m.b.t. (kosteloze) bijstand door een raadsman: Van Russen Groen a.w. 1998, p. 229 e.v. en Jansen a.w. 1999 , p. 150.

164 Zie m.b.t. het (doen) ondervragen van getuigen à charge en à décharge: Van Russen Groen a.w. 1998. p. 240 e.v. en Jansen a.w. 1999, p. 153 e.v.

165 Zie m.b.t. kosteloze bijstand door een tolk: Van Russen Groen a.w. 1998, p. 256 e.v. en Jansen a.w. 1999 , p. 151 e.v. 
16. gelijke toegang tot de rechter ${ }^{166}$

17. het nemo tenetur-beginsel ${ }^{167}$

18. recht op rechtspraak in twee (feitelijke) ${ }^{168}$ instanties ${ }^{169}$

19. recht op schadevergoeding bij gerechtelijke dwaling

20. het ne bis in idem-beginsel

Bovendien zijn de artikelen 7 EVRM en 15 IVBPR van belang bij de oplegging van bestuurlijke boeten. ${ }^{170}$ Ook ten aanzien van artikel 7 EVRM en 15 IVBPR geldt weer dat een aantal waarborgen zowel in artikel 7 EVRM als in artikel 15 IVBPR is neergelegd. Daarnaast voorziet artikel 15 IVBPR op één punt in een omvangrijkere regeling. Ten eerste komen de waarborgen aan de orde die uit beide bepalingen voortvloeien. Het gaat dan om:

1. het nullum crimen sine lege-beginsel

2. het nulla poena sine lege-beginsel

Daamaast vloeit uit artikel 15 IVBPR nog de volgende waarborg voort:

3. de overtreder dient te profiteren van een, na het begaan van het strafbaar feit, totstandgekomen wetswijziging die voorziet in de oplegging van een lichtere straf

166 Anders dan Van Russen Groen meen ik dat genoemd recht ook kan worden afgeleid uit artikel 6 EVRM.

167 Hoewel het nemo tenetur-beginsel niet expliciet is opgenomen in artikel 6 EVRM lecst het EHRM dit beginsel wel in, in artikel 6 (eerste lid) van het EVRM zo blijkt uit de zaak 'Funke' (EHRM 25 februari 1993, NJ 1993, 485, m. nt. Knigge, ook gepubliceerd in Ars Aequi, 1993, p. $672-680$ m. nt. A.H.J. Swart).

168 Vgl. Human Rights Committee 20 juli 2000, nr. $701 / 1996$ (C. Gómez Vázquez v. Spain), FED $2000 / 683$.

169 Zie m.b.t. het recht op rechtspraak in twee instanties: Van Russen Groen a.w. 1998, p. e.v. Overigens verdient opmerking dat genoemd recht ook deel uit maakt van het zevende protocol bij het EVRM. Dit protocol is echter (tot op heden) niet geratificeerd door Nederland. Bij ondertekening, op 22 november 1984, heeft de Nederlandse regering bovendien het volgende verklaard: "The Netherlands Government interprets paragraph 1 of Article 2 thus that the right conferred to everyone convicted of a criminal offence to have conviction or sentence reviewed by a higher tribunal relates only to convictions or sentences given in the first instance by tribunals which, according to Netherlands law, are in charge of jurisdiction in criminal matters.' Gelet op hetgeen in hoofdstuk twee van dit boek is geschreven over artikel $113 \mathrm{Gw}$ lijkt de Nederlandse regering het recht op rechtspraak in twee (feitelijke) instanties bij de oplegging van bestuurlijke boeten destijds derhalve niet erkend te hebben. Op basis van het huidige bestuursrechtelijke rechtsbeschermingsstelstel wordt in de praktijk overigens wel voldaan aan het vereiste van recht op rechtspraak in twee feitelijke instanties. Derhalve zal bij de bespreking van de Nederlandse boeteregeling geen aandacht uitgaan naar deze waarborg. In de Verenigde Staten lijkt dit anders te liggen. In deel Il zal derhalve wel aandacht besteed worden aan genoemde waarborg.

170 De term 'criminal offence' in artikel 7 EVRM en 15 IVBPR kan op dezelfde wijze worden geinterpreteerd als de term 'criminal charge'. Zie Van Dijk/Van Hoof a.w. 1998, p. 479: 'It seems obvious that the meaning of the word 'criminal offence' is closely related to the notion of 'criminal charge' of Article 6 . Thus, it is appropriate to argue that Article 7 is also applicable to those disciplinary and administrative convictions which come within the scope of Article 6.' Zie ook: Nowak a.w. 1993, p. 276-277: The scope of application of the principle of 'nullem crimen sine lege' relates to all criminal offences, that is to acts and omissions alike. In accordance with a systematic interpretation of the Convention pursuant to Art. 31(1) of the VCLT, this must be interpreted atonomously in conformity with the term 'criminal charge' ('accusation en matière pénale') in Art. 14(1). In any event, the scope of application of Art. 15 goes beyond formal criminal law in the sense of the respective national legal systems.' 
Tot zover de opsomming van de waarborgen die uit de artikelen 6 en 7 EVRM en 14 en 15 IVBPR voortvloeien. Zoals gezegd zal nu aandacht worden besteed aan een aantal van de hierboven weergegeven waarborgen. In de hiemavolgende paragrafen zullen achtereenvolgens aan de orde komen; de onschuldpresumptie, het nemo teneturbeginsel (en het zwijgrecht), het nullum crimen sine lege-beginsel, het nulla poena sine lege-beginsel, het lex certa-beginsel en het beginsel dat de overtreder dient te profiteren van een, na het begaan van het strafbare feit, totstandgekomen wetswijziging die voorziet in de oplegging van een lichtere straf.

$\mathrm{Bij}$ behandeling van de diverse waarborgen zal blijken dat niet ten aanzien van elke waarborg evenveel jurisprudentie voorhanden is. Met name ten aanzien van de waarborgen die exclusief uit het IVBPR voortvloeien is een nadere uitwerking soms vrijwel onmogelijk omdat jurisprudentie in dat kader vaak ontbreekt of in ieder geval zeer schaars is terwijl de travaux préparatoires en de toelichting bij de goedkeuringswet van het IVBPR ook weinig helderheid bieden. ${ }^{171}$ In die gevallen zal derhalve volstaan moeten worden met de verdagstekst als zodanig.

\subsubsection{De onschuldpresumptie}

\section{Algemeen}

De onschuldpresumptie ${ }^{172}$ is neergelegd in artikel 6, tweede lid EVRM en in artikel 14, tweede lid IVBPR. De bepaling uit het EVRM luidt (in de Nederlandse vertaling): 'Een ieder tegen wie een vervolging is ingesteld, wordt voor onschuldig gehouden totdat zijn schuld in rechte is komen vast te staan.' De onschuldpresumptie kan worden gezien als een bijzondere uitwerking van het 'fair trial'-beginsel uit het eerste lid van artikel 6 EVRM. ${ }^{173}$

In de zaak 'Barberà, Messegué and Jabardo' ${ }^{174}$ is ten aanzien van de onschuldpresump. tie het volgende bepaald:

'Paragraph 2 (art. 6-2) embodies the principle of the presumption of innocence. It requires, inter alia, that when carrying out their duties, the members of a court should not start with the preconceived idea that the accused has committed the offence charged; the burden of proof is on the prosecution, and any doubt should benefit the accused. It also follows that it is for the prosecution to inform the accused of the case that will be made against him, so that he may prepare and present his defence accordingly, and to adduce evidence sufficient to convict him. ${ }^{175}$

171 Men kan zich bovendien afvragen in hoeverre de, uit de veertiger jaren van de vorige eeuw daterende. travaux préparatoires heden ten dage nog relevant zijn (vgl. M. Akehurst, A Modem Introduction to International Law, sixth edition, London 1987, i.h.b. p. 203-204). De ontwikkeling van de samenlering heeft immers niet stilgestaan. Daar komt nog bij dat de veranderde samenleving ook veranderde juricische inzichten met zich heeft gebracht waar destijds geen rekening mee kon worden gehouden. Zo zal men bij de totstandkoming van het IVBPR (en het EVRM) bijvoorbeeld geen rekening hebben geholden met de (enorme) opkomst van de mogelijkheid om normschendingen af te doen met besturrlijk boeten. Bijgevolg zal bijvoorbeeld ook geen aandacht zijn besteed aan de vraag of dergelijke normschendingen als 'criminal offence' gezien moeten worden.

172 Zie ten aanzien van de onschuldpresumptie voorts: Van Russen Groen aw. 1998, p. 181-213.

173. Van Dijk/Van Hoof a.w. 1998, p. 458 en Van Russen Groen aw. 1998, p. 78. EHRM 6 december 1988, Series A no. 146 (Barberà, Messegué and Jabardo). 
Het Hof lijkt derhalve twee consequenties te verbinden aan de onschuldpresumptie. ${ }^{176}$ Ten eerste dient de rechter uit te gaan van de onschuld van de verdachte. ${ }^{177}$ Ten tweede is het aan de (openbare) aanklager aan te tonen dat de verdachte inderdaad schuldig is. ${ }^{178}$ Op deze plaats zal ik kort stil staan bij de houding van het Hof ten opzichte van bewijs in het kader van de 'criminal charge'-context en de toelaatbaarheid van onrechtmatig verkregen bewijs. Daarna zal ik ingaan op de onschuldpresumptie als zodanig.

\section{Bewijs}

Het EVRM bevat geen regels met betrekking tot het bewijs van strafbare feiten. Deze regelgeving laat het EHRM expliciet over aan de partijstaten. ${ }^{179}$ Illustratief in dit kader is de uitspraak van het Hof in de zaak 'Schenk'. ${ }^{80}$ In die zaak bepaalde het EHRM dat zelfs ten aanzien van onrechtmatig verkregen bewijs niet kan worden uitgesloten dat het toelaatbaar is:

'While Art. 6 Convention guarantees the right to a fair trial, it does not lay down any rules on the admissibility of evidence as such, which is therefore primarily a matter for regulation under national law. The Court therefore cannot exclude as a matter of principle and in the abstract that unlawfully obtained evidence of the present kind may be admissible. It has only to ascertain whether Mr. Schenk's trial as a whole was fair.'181

Uit het voorgaande kan worden afgeleid dat het EHRM zich slechts sporadisch, over de band van het fair trial-beginsel, uit zal laten over de toelaatbaarheid van bewijs in het kader van een 'criminal charge'-procedure. Dat het Hof zich op deze wijze inderdaad in bepaalde gevallen heeft uitgesproken over de wijze waarop een partijstaat om moet gaan met bewijs(garing) zal, later in dit hoofdstuk, bij de beschrijving van jurisprudentie, nog blijken. In dit kader wil ik, zonder overigens volledig te zijn, reeds wijzen op de zaken 'Salabiaku' ${ }^{\prime 82}$ en 'Saunders' die later in dit hoofdstuk nog uitvoerig aan de orde zullen komen.

Vgl. Van Russen Groen a.w. 1998, p. 181.

Dit vereiste vloeit in feite (in ruimere zin) ook voort uit het onpartijdigheidsvereiste zoals neergelegd in het eerste lid van artikel 6 EVRM (zie: EHRM 7 oktober 1988, Series A vol. 141-A, NJ 1991, 351, m. nt. E.A. Alkema (Salabiaku) i.h.b. \& 28).

178 Zie in dit kader ook: A.R. Hartmann, Bewijs in het bestuursstrafrecht (diss. EUR), Arnhem 1998. De situatie lijkt in het Nederlandse strafrecht anders te zijn. Zie in dit kader: J.F. Nijboer, Strafrechtelijk bewijsrecht. vierde herziene druk, Nijmegen 2000 , p. 35 : 'In strikte zin kent het strafprocesrecht in Nederland geen bewijslast voor de verdediging en eigenlijk ook niet voor het Openbaar Ministerie (al behoort dit wel zoveel materiaal aan te dragen dat er niet van een lichtvaardige vervolging kan worden gesproken). Men moet wat betreft het Nederlandse strafprocesrecht constateren dat het eerder de rechter is die moet bewijzen (in de zin van vaststellen) dan dat de partijen of alléen het Openbaar Ministerie een bewijslast zouden dragen (in de zin van aantonen).'

Zie daaromtrent uitvoeriger Van Russen Groen a.w. 1998, p. 198-213.

EHRM 12 juli 1988, Series A vol. 140, NJ 1988, 85 I m. nt. E.A. Alkema (Schenk tegen Zwitserland). 'Schenk tegen Zwitserland' § 46. Dat het EHRM dit standpunt nog steeds huldigt kan worden afgeleid uit de zaak 'Mantovanelli v. France' (EHRM 18 maart 1997, ECHR Reports 1997-J1, NJ 1998, 278 m. nt. H.J. Snijders (Mantovanelli v. France), i.h.b. \$34).

EHRM 7 oktober 1988, Series A vol. 141-A, NJ 199I, 351, m. nt. E.A. Alkema (Salabiaku). 


\section{Reikwijdte onschuldpresumptie}

$\mathrm{Na}$ deze korte weergave van de houding van het EHRM ten aanzien van bewijs in de 'criminal charge'-context zal nu aandacht uitgaan naar de onschuldpresumptie als zodanig. ${ }^{183}$ In de zaak 'Barberà, Messegué and Jabardo' heeft het Hof aangegeven dat de onschuldpresumptie in ieder geval is geschonden indien:

'..., without the accused's having previously been proved guilty according to a law, a judicial decision concerning him reflects an opinion that he is guilty. ${ }^{184}$

Een dergelijke, zij het iets uitvoerigere, overweging heeft het Hof ook ten grondslag gelegd aan de uitspraak in de zaak 'Minelli'. ${ }^{185}$ In die zaak was er door een particuliere klager een strafklacht ingediend tegen journalist Minelli wegens smaad. De zaak Minelli werd enige tijd aangehouden omdat de Zwitserse autoriteiten de uitkomst van een strafzaak tegen een andere journalist, ten aanzien van dezelfde kwestie, wilden afwachten. Tegen de tijd dat uitspraak werd gedaan in de analoge strafzaak tegen de andere journalist was de zaak tegen Minelli inmiddels verjaard. Strafvervolging was ten aanzien van Minelli dan ook niet meer mogelijk. Ondanks het voorgaande werd Minelli veroordeeld tot het betalen van $2 / 3$ deel van de gerechtskosten en een onkostenvergoeding aan de twee particuliere aanklagers. ${ }^{186}$ Aangezien deze kostenveroordeling was gebaseerd op de veronderstelling dat Minelli schuldig zou zijn verklaard (gelet op de strafzaak tegen de andere joumalist) als zijn zaak niet zou zijn verjaard, is genoemde kostenveroordeling volgens het EHRM in strijd met de onschuldpresumptie. $^{187}$

In de zaak 'Minelli' heeft het EHRM tevens aangegeven dat de onschuldpresumptie zich uitstrekt over de gehele strafprocedure. ${ }^{188}$ Bovendien mag ook in een andere (strafrechtelijke, civielrechtelijke of bestuursrechtelijke) rechtszaak, die gerelateerd is aan de strafrechtelijke procedure, niet worden uitgegaan (van het vermoeden) van schuld van een verdachte nadat deze strafrechtelijk is vrijgeproken of ontslagen van rechtsvervolging. ${ }^{189}$ Tenslotte kan een inbreuk op de onschuldpresumptie niet alleen gemaakt wor-

183. Uit de hiema te bespreken jurisprudentie van het EHRM zal overigens blijken dat de onschuldpre. sumptie als zodanig en de bewijslastverdeling zeer naww met elkaar verweven zijn.

184 'Barberả, Messegué and Jabardo' § 91.

185 EHRM 25 maar 1983, Series A vol. 62, NJ 1986, 698 m. nt. E.A. Alkema (Minelii) (Franstalig), Series A vol. 62 (Engelstalig): 'In the court's judgement, the presumption of innocence will be violated if, without the accused's having previously been proved guilty according to law and, notably, without his having had the opportunity of exercising his rights of defence, a judicial decision concerning him reflects an opinion that he is guilty. This may be so even in the absence of any formal finding; it sufflces that the court regards the accused as guility.' (\$ 37).

186 'Minelli' \& 12.

187 'Minelii' $\$ 13$ en 3841 .


entirity, irrespective of the outcome of the prosecution, and not solely the examination of the merits of the charge (...).' Zie voorts: EHRM 25 augustus 1993, Series A vol. 266-A, NJ 1994, 1, m. nt. Krigge (Sekanina), i.h.b. $\$ 30$.

189 Vgl. 'Sekanina', i.h. b. \& 30, en EHRM 21 maart 2000, no. 28389/95 (Asan Rushiti v. Austria), i.h. \& 27 en 28: The Court recalls that the applicant can rely on Article $6 \$ 2$ of the Convention, irrespective of the fact that the contested decision was given after his acquitial had become final, (...). Zie voorts Van Dijk/Van Hoof a.w. 1998, p. 462: 'Article 6(2) may even be relevant after the formal determination of the 'charge', for instance when a decision has to be taken with regard to the costs of the suit or the compensation for pre-trial detention claimed by the former suspect. Article 6 applies to these decisions 
den door een rechter of rechtbank maar ook door andere publiek(rechtelijk)e instanties. Daarbij kan (ter illustratie) gewezen worden op een minister die tijdens een persconferentie bepaalde (insinuerende) uitlatingen doet (op het moment dat een verdachte pas gearresteerd is) of de politie die zich bezig houdt met het vooronderzoek. ${ }^{190}$

\section{Wettelijk of feitelijk vermoeden van schuld}

In het kader van dit onderzoek is de vraag relevant of er, gelet op artikel 6, tweede lid EVRM, uit mag worden gegaan van een (objectief) vermoeden van schuld als het daderschap vaststaat. ${ }^{191}$ Het EHRM heeft deze vraag in de zaak 'Salabiaku' bevestigend beantwoord. ${ }^{192}$

Salabiaku werd veroordeeld wegens het smokkelen van (soft)drugs. Salabiaku had op het vliegveld een (ongeadresseerde) koffer in bezit genomen waarvan hij vermoedde dat deze door zijn familie uit Zaüre was toegezonden. De inhoud van de koffer zou uit Afrikaans eten bestaan. Na controle door douane bleek de koffer een pakket met als inhoud tien kilogram (soft)drugs te bevatten. Aangezien Salabiaku de koffer in bezit had genomen werd hij geacht schuldig te zijn aan het smokkelen van genoemde drugs. De (niet onweerlegbare) beschuldiging van het smokkelen van de (soft)drugs was volgens Salabiaku in strijd met de onschuldpresumptie zoals die is neergelegd in artikel 6, tweede lid EVRM. Het EHRM deelde die mening niet:

'In particular, and again in principle, the Contracting States may, under certain conditions, penalise a simple or objective fact as such, irrespective of whether it results from criminal intent or from negligence. Examples of such offences may be found in the laws of the Contracting States. (...) Presumptions of fact or of law operate in every legal system. Clearly, the Convention does not prohibit such presumptions in principle. It does, however, require the Contracting States to remain within certain limits in this respect as regards criminal law. (...) Article 6 para. 2 (art. 6-2) does not therefore regard presumptions of fact or of law provided for in the criminal law with indifference. It requires States to confine them within reasonable limits which take into account the importance of what is at stake and maintain the rights of the defence.'

Het is derhalve naar het oordeel van het EHRM niet in strijd met de onschuldpresumptie als een sanctionerende instantie ${ }^{193}$ (tot op zekere hoogte) uitgaat van een wettelijk of feitelijk vermoeden van schuld. De partijstaten moeten bij het formuleren van dergelijke strafbepalingen wel acht slaan op de belangen (van de verdachte) die in het geding zijn en daarnaast moeten de verdedigingsrechten van de verdachte intact blijven. Dit laatste impliceert dat het schuldvermoeden weerlegbaar moet kunnen zijn. ${ }^{194}$

as long as the question to be answered can be regarded as 'a consequence and, to some extent, the concomitant of the criminal proceedings'.'

190 EHRM 10 februari 1995, Series A vol. 308, NJ 1997, 523, m. nt. E.J. Daalder (Allenet de Ribemont v. France).

191 De aanwezigheid van 'schuld' bij de dader hoeft door de sanctionerende instantie niet aangetoond te worden maar wordt verondersteld aanwezig te zijn. De dader zal zich zelf moeten beroepen op een schulduitsluitingsgrond. In feite is er derhalve sprake van een 'omkering van de bewijslast'.

192 EHRM 7 oktober 1988, Series A vol. 141-A, NJ 1991, 351, m. nt. E.A. Alkema (Salabiaku). Zie voons: EHRM 25 september 1992, Series A vol. 243, NJ 1995, 593 m. nt. E.A. Alkema (Pham Hoang Y. France).

193 Waaronder de strafrechter en het (boeteopleggende) bestuursorgaan.

194 Zie: 'Pham Hoang' $\$ 34$. Zoals in het volgende hoofdstuk nog zal blijken is met name ten aanzien van 


\section{Zwijgende verdachte}

Opmerking verdient voorts dat het Hof er van uit gaat dat een rechter de bevoegdheid heeft om onder omstandigheden uit het zwijgen van de verdachte af te leiden dat deze schuldig is aan het plegen van een bepaalde overtreding. Een dergelijke veronderstelling is niet in strijd met de onschuldpresumptie indien de openbare aanklager daamaast over voldoende ander bewijsmateriaal beschikt waaruit blijkt dat de verdachte de overtreding gepleegd heeft. Dit bewijs 'vraagt' immers om een uitleg van de verdachte omtrent de aanwezigheid of het ontbreken van schuld. Het voorgaande kan worden afgeleid uit de zaak 'John Murray v. the United Kingdom'. ${ }^{195}$ In het arrest met betrekking tot die zaak heeft het EHRM het volgende overwogen:

'The question in each particular case is whether the evidence adduced by the prosecution is sufficiently strong to require an answer. The national court cannot conclude that the accused is guilty merely because he chooses to remain silent. It is only if the evidence against the accused "calls" for an explanation which the accused ought to be in a position to give that a failure to give any explanation "may as a matter of common sense allow the drawing of an inference that there is no explanation and that the accused is guilty". (...) In sum it is only common-sense inferences which the judge considers proper, in the light of the evidence against the accused, that can be drawn under the Order. ${ }^{196}$

In een situatie zoals hierboven weergegeven is er volgens het EHRM geen sprake van een met de onschuldpresumptie strijdige verschuiving van de bewijslast van de openbare aanklager naar de overtreder. ${ }^{197}$ Dat dit anders is in een geval waarin de vervolgende instantie in feite in het geheel niet beschikt over enig bewijsmateriaal moge duidelijk zijn. Desondanks heeft het EHRM dit tegenover Oostenrijk duidelijk moeten maken in de zaak 'Telfner v. Austria'. ${ }^{198}$

Telfner werd veroordeeld vanwege het veroorzaken van letsel wegens onachtzaamheid. Hij zou iemand aangereden hebben met de auto van zijn moeder. Deze (aangereden)

dat laatste vereiste een en ander af te dingen op de boeteregeling uit de WAHV.

EHRM 8 februari 1996, EC.HR-Reports 1996-I, NJ 1996, 725, m. nt. Knigge (Murray v. the trited Kingdom).

196 'Murray v. the United Kingdom' \& 51.

197 'Murray v. the United Kingdom' $\$ 54$. Zie voorts, ter illustratie, EHRM 2 mei 2000, no. 3571897. 'Condron v. the UK'. In deze zaak had de rechter de jury niet goed geinstrueerd wanneer en op welke wijze uit het zwijgen van de verdachte geconcludeerd mocht worden dat hij schuldig was aan het misdrijf. Derhalve was in die zaak het fair trial-beginsel uit artikel 6 lid 1 EVRM geschonden ('Condron $v$. UK' \$ 61-66). Zie daarnaast: EHRM 6 juni 2000, no. $36408 / 97$ (Averill v. UK), In die zaak leidde het, (onder meer) uit het zwijgen van de verdachte afleiden dat hij schuldig was, volgens het EHRM niet to een schending van het fair trial-beginsel. Vgl. HR 12 maart 1996, NJ 1996, 539 en HR 19 maar 1996, NJ $1996,540 \mathrm{~m}$. nt. Schalken, waarin de HR een terughoudender standpunt in lijkt te nemen dan het EHRM (vgl. de annotatie van Schalken). Zie voorts: HR 3 juni 1997, NJ 1997, 584 en HR 10 novem. ber 1998, NJ 1999, 139. In beide laatstgenoemde arresten overweegt de Hoge Raad: 'De omstandigheil dat een verdachte weigert een verklaring af te leggen of een bepaalde vraag te beantwoorden kan op zichzelf, mede gelet op het bepaalde in art. 29 , eerste lid, Sv, niet tot het bewijs bijdragen. Dat breng! echter niet mee dat de rechter, indien een verdachte voor een omstandigheid, die op zichzelf of in samenhang met de verdere inhoud van de bewijsmiddelen beschouwd redengevend moet worden geach: voor het bewijs van het aan hem telastegelegde feit, geen redelijke, die redengevendheid ontzenuwende, verklaring heeft gegeven, zulks niet in zijn overwegingen omtrent het gebezigde bewijsmaterial zou mogen betrekken.' 
persoon had dientengevolge licht letsel aan zijn arm opgelopen. Het enige dat vaststond was dat de aanrijding had plaatsgevonden met de auto die op naam van de moeder van Telfner stond. De aangereden persoon had echter niet gezien wie er in de auto zat. Hij kon zelfs niet aangeven of het om een man of een vrouw ging. Telfner maakte gedurende de strafzaak gebruik van zijn zwijgrecht. Toch werd Telfner veroordeeld. Hem werd een boete van 24.000 Oostenrijkse Schilling (waarvan 12.000 voorwaardelijk) opgelegd. Daarnaast moest hij een schadevergoeding van 1.000 Schilling aan het slachtoffer betalen.

De motivering die door Het Bezirksgericht van Silz aan deze veroordeling ten grondslag werd gelegd is mijns inziens ronduit stuitend. Het Bezirksgericht onderbouwt de veroordeling als volgt:

'As the injured party, [Mr K.], could not determine at the time of the accident who had been driving the vehicle, the only evidence which remained in connection with this point were the observations of the Obermieming police station, according to which it was common knowledge that the vehicle in question was mainly driven by the accused, ... On the basis of those observations the court is also satisfied that [the applicant] was driving the vehicle at the material time and caused the accident. The additional circumstance that, according to the observations of the Obermieming police station, the accused was not at home after the accident and had evidently still not retumed by 8 p.m. that day and, moreover, that no one knew where he was, leads to the sole, unequivocal conclusion that only the accused could have committed the offence; presumably he refused to make a statement because he was under the influence of alcohol, but there is no evidence for that finding.'

Het EHRM is van oordeel dat de veroordeling en sanctionering in strijd zijn met de onschuldpresumptie omdat er sprake is van een onrechtmatige verschuiving van de bewijslast. Het Hof onderbouwt dit standpunt als volgt:

'It is true, as the Government pointed out, that legal presumptions are not in principle incompatible with Article $6(.$.$) ; nor is the drawing of inferences from the accused's silence$ (...).

However, the present case does not concern the application of a legal presumption of fact or law, nor is the Court convinced by the Government's argument that the domestic courts could legitimately draw inferences from the applicant's silence. The Court recalls that the above-mentioned John Murray judgment concerned a case in which the law allowed for the drawing of common-sense inferences from the accused's silence, where the prosccution had established a case against him, which called for an explanation. Considering that the evidence adduced at the trial constituted a formidable case against the applicant, the Court found that the drawing of such inferences, which was moreover subject to important procedural safeguards, did not violate Article 6 in the circumstances of the case (ibid.). The Court considers that the drawing of inferences from an accused's silence may also be permissible in a system like the Austrian one where the courts freely evaluate the evidence before them, provided that the evidence adduced is such that the only common-sense inference to be drawn from the accused's silence is that he had no answer to the case against him.

In the present case, both the District Court and the Regional Court relied in essence on a report of the local police station that the applicant was the main user of the car and had not been home on the night of the accident. However, the Court cannot find that these elements of evidence, which were moreover not corroborated by evidence taken at the trial in an adversarial manner, constituted a case against the applicant which would have called for an 
explanation from his part. In this context, the Court notes, in particular, that the victim of the accident had not been able to identify the driver, nor even to say whether the driver had been male or female, and that the Regional Court, after supplementing the proceedings, found that the car in question was also used by the applicant's sister. In requiring the applicant to provide an explanation although they had not been able to establish a convincing prima facie case against him, the courts shifted the burden of proof from the prosecution to the defence. In addition, the Court notes that both the District Court and the Regional Court speculated about the possibility of the applicant having been under the influence of alcohol which was, as they admitted themselves, not supported by any evidence. Although such speculation was not directly relevant to establishing the elements of the offence with which the applicant had been charged, it contributes to the impression that the courts had a preconceived view of the applicant"s guilt:" 199

Op het moment dat geen enkel steekhoudend bewijs voorhanden is mag uit het zwijgen van de verdachte derhalve niet zijn schuld worden afgeleid. Gebeurt dat wel, dan leidt dat tot een ontoelaatbare, met artikel 6, tweede lid EVRM, strijdige omkering van de bewijslast.

\section{Alléén de overtreder zelf kan gestraft worden}

De onschuldpresumptie brengt tenslotte met zich dat alléén de overtreder zelf, die een verwijt gemaakt kan worden, bestraft mag worden. Het Hof heeft dit in de zaak 'E.L., R.L., and J.O.-L. v. Switzerland' aangegeven. ${ }^{200}$ In die zaak werd het opleggen van een straf aan de erfgenamen, wegens een strafbaar feit dat door de erflater was gepleegd, door het EHRM in strijd met de onschuldpresumptie verklaard. Het Hof heeft daartoe het volgende overwogen:

'Imposing criminal sanctions on the living for acts apparently committed by a deceased person is, however, a different matter. Such a situation calls for careful scrutiny by the Court.

(...)

Pursuant to Article $130 \S 1$ of the Ordinance on Direct Federal Tax, the proceedings were brought against the applicants themselves and the fine was imposed on them (...).

It must therefore be accepted that, whether or not the late $\mathrm{Mr} \mathrm{L}$. was actually guilty, the applicants were subjected to a penal sanction for tax evasion allegedly committed by him.

It is a fundamental rule of criminal law that criminal liability does not survive the person who has committed the criminal act. This is in fact recognised by the general criminal law of Switzerland, particularly by Article $48 \S 3$ of the Swiss Criminal Code, under which a fine lapses if the convicted person dies (...).

In the Court's opinion, such a rule is also required by the presumption of innocence enshrined in Article $6 \S 2$ of the Convention. Inheritance of the guilt of the dead is not compatible with the standards of criminal justice in a society governed by the rule of law. There has accordingly been a violation of Article $6 \S 2 .^{201}$

'Telfner' \$ 16-19.

200 EHRM 29 augustus 1997, no. $20919 / 92$ ECHR Reports 1997-V (E.L., R.L., and J.O.-L. v. Switzerand i.h.b. $\$ 51-53$, vgl. EHRM 29 augustus 1997, no. 19958/92 ECHR Reports 1997-V (A.P., M.P. and T.P. v. Sw tzerland).

201 'E.L., R.L., and J.O.-L. v. Switzerland' i.h.b. § 51-53. 
Deze uitspraak van het Hof is mijns inziens voor de hand liggend. Bestraffing kan immers alleen plaatsvinden ten aanzien van een persoon die schuldig is (schuldig moet daarbij worden opgevat in de zin van verwijtbaarheid). Een persoon, die niet op enigerlei wijze als dader aangemerkt kan worden, straffen heeft geen enkele zin omdat ten aanzien van die persoon de met de straf beoogde doelen niet bereikt zullen worden. Leedtoevoeging, bij wijze van 'vergelding' van schuld, sorteert immers alleen effect ten aanzien van de schuldige overtreder. Ook zal van bestraffing van een onschuldige, niet als dader aan te merken, persoon, geen (generale en speciale) preventieve werking uitgaan. $^{202}$

\section{Resumé}

Samenvattend kan ten aanzien van de onschuldpresumptie het volgende worden gezegd. Uit de onschuldpresumptie, die een bijzondere uitwerking van het fair trialbeginsel betreft, vloeien volgens het Hof twee eisen voort.

Ten eerste dient de rechter uit te gaan van de onschuld van de verdachte. ${ }^{203}$ De onschuldpresumptie dient zich daarbij uit te strekken over de gehele strafrechtelijke procedure. Het voorgaande brengt tevens met zich dat de onschuldpresumptie ook in acht dient te worden genomen in andere rechtszaken tegen de gewezen verdachte (bijvoorbeeld in een rechtszaak over vergoeding van proceskosten na vrijspraak). De onschuldpresumptie moet tenslotte niet alleen in acht genomen worden door de rechter of de rechtbank maar ook door andere publiek(rechtelijk)e instanties zoals bijvoorbeeld de politie.

Ten tweede is het aan de (openbare) aanklager aan te tonen dat de verdachte inderdaad schuldig is. ${ }^{204}$ Het EVRM bevat geen regels met betrekking tot het bewijs van strafbare feiten. Het EHRM laat dergelijke regelgeving over aan de partijstaten. Desondanks heeft het EHRM zich toch in bepaalde gevallen uitgelaten over de (omkering van de) bewijslast.

Zo is het bijvoorbeeld naar het oordeel van het EHRM niet in strijd met de onschuldpresumptie als een sanctionerende instantie (tot op zekere hoogte) uitgaat van een wettelijk of feitelijk vermoeden van schuld. De partijstaten moeten bij het formuleren van strafbepalingen, die een wettelijk of feitelijk vermoeden van schuld bevatten, wel acht siaan op de belangen van de verdachte die in het geding zijn en daamaast moeten de verdedigingsrechten van de verdachte volledig intact blijven. Dit impliceert dat er sprake moet zijn van een weerlegbaar vermoeden van schuld.

Niet alleen een weerlegbaar vermoeden van schuld kan de toets der kritiek van het Europese Hof doorstaan. Daarnaast mag de rechter, volgens het EHRM, onder omstandigheden uit het zwijgen van de verdachte afleiden dat hij schuldig is aan het hem tenlastegelegde feit.

$202 \mathrm{Vgl} \S 2.2 .3 .2$, b van dit boek.

203 En rechter heeft in de strafzaak echter wel de bevoegheid om, onder bepaalde omstandigheden, uit het zwijgen van de verdachte af te leiden dat deze schuldig is.

204 Vgl. de Nederlandse (strafrechtelijke) situatie waarbij geen sprake is van een op het Openbaar Ministerie rustende bewijslast. Het Openbaar Ministerie moet wel zoveel materiaal aan dragen dat er niet van een lichtvaardige vervolging kan worden gesproken maar de bewijslast rust in feite op de strafrechter. 


\subsubsection{Het nemo tenetur-beginsel en het zwijgrecht}

\section{Algemeen}

Uit artikel 6 EVRM vloeit niet rechtstreeks een zwijgrecht voor de verdachte voort. Evenmin is het (verderstrekkende) nemo tenetur beginsel ${ }^{205}$, inhoudende dat niemand mag worden gedwongen aan zijn eigen veroordeling mee te werken ${ }^{206}$, in het EVRM gecodificeerd. In artikel 14, derde lid, onder $g$ IVBPR is wel een bepaling van dien aard neergelegd. Genoemde bepaling luidt (in de Nederlandse vertaling): 'Bij het bepalen van de gegrondheid van een tegen hem ingestelde strafvervolging heeft een ieder, in volle gelijkheid, recht op de volgende minimumgaranties: (g) niet te worden gedwongen tegen zichzelf te getuigen of een bekentenis af te leggen.'

Ondanks het feit dat het zwijgrecht of het nemo tenetur-beginsel niet expliciet is neergelegd in artikel 6 EVRM heeft het Hof deze beginselen wél ingelezen in het eerste lid van de genoemde verdragsbepaling. Het voorgaande blijkt uit de zaak 'Funke'. In die zaak werd de in Frankrijk woonachtige Duitser Funke middels een rechterlijk bevel gedwongen de douane inzage te verstrekken in afschriften van verschillende bankrekeningen. Voor iedere dag dat Funke dit naliet verbeurde hij een bedrag van 20 Franse Francs. Bovendien werd hem door de rechtbank een boete opgelegd van 1200 Franse Francs voor het weigeren van inzage in de documenten in een eerder stadium van het onderzoek.

Het EHRM dient de vraag te beantwoorden hoe een dergelijke, middels straffen te handhaven, medewerkingplicht zich verhoudt tot artikel 6 EVRM. Het Hof komt tot de conclusie dat er sprake is van schending van het fair trial-beginsel uit artikel 6, eerste lid EVRM, indien iemand op een dergelijke wijze wordt gedwongen om mee te werken aan zijn eigen vervolging:

'The Court notes that the customs secured Mr Funke's conviction in order to obtain certain documents which they believed must exist, although they were not certain of the fact. Being unable or unwilling to procure them by some other means, they attempted to compel the applicant himself to provide the evidence of offences he had allegedly committed. The special features of customs law (...) cannot justify such an infringement of the right of anyone 'charged with a criminal offence', within the autonomous meaning of this expression in Art. 6, to remain silent and not to contribute to incriminating himself. There has accordingly been a breach of Art. $6 \S 1 .^{207}$

Het voorgaande impliceert dat het Hof van oordeel is dat het zwijgrecht en het nemo tenetur-beginsel bij de oplegging van een punitieve sanctie in acht moeten worden genomen omdat zowel het zwijgrecht als het nemo tenetur-beginsel deel uit maken van

205 Het beginsel luidt voluit: 'nemo tenetur prodere se ipsum' hetgeen betekent dat niemand gehouden is zichzelf te belasten.

206 Zie Corstens a.w. 1999 p. 263, Van Russen Groen a.w. 1998, p. 261, en J.M. Reijntjes: Nemo tenetur. een holle leus?, in de bundel: Nemo tenetur, onder redactie van J.M. Reijntjes, Gouda Quint bv, Amhem 1996. p. 9-21. Reijntjes geeft aan dat het beginsel in (drie) verschillende betekenissen wordt gebruikt (Reijntjes a.w. 1996, p. 9). Zie voorts Quaedvlieg (a.w. 2001 , p. 354 e.v.) die aangeeft dat er onderscheiden kan worden tussen een eng en een ruim nemo tenetur-beginsel. Het enge ziet slechts op het zwijgrecht cn heeft ten doel 'miscarriages of justice' te voorkomen. Het ruime ziet op medewerking van de verdachte in ruime zin en hangt samen met de idee dat de verdachte eigenmachtig zijn procespositie moet kunnen bepalen.

207 'Funke' § 44 
het fair trial-beginsel. Dit standpunt heeft het EHRM expliciet verwoord in de zaak 'Saunders':

'The Court recalls that, although not specifically mentioned in Article 6 of the Convention (art. 6), the right to silence and the right not to incriminate oneself are generally recognised international standards which lie at the heart of the notion of a fair procedure under Article 6 (art. 6). Their rationale lies, inter alia, in the protection of the accused against improper compulsion by the authorities thereby contributing to the avoidance of miscarriages of justice and to the fulfilment of the aims of Article 6 (art. 6) (...). The right not to incriminate oneself, in particular, presupposes that the prosecution in a criminal case seek to prove their case against the accused without resort to evidence obtained through methods of coercion or oppression in defiance of the will of the accused. In this sense the right is closely linked to the presumption of innocence contained in Article 6 para. 2 of the Convention (art. 6-2).208

\section{Vanaf het moment dat er sprake is van een 'charge'}

Uit de zaak 'Funke' kan worden afgeleid dat het zwijgrecht en het nemo teneturbeginsel eerst gelden op het moment dat er sprake is van een 'criminal charge' ${ }^{209}$ In de zaak 'Saunders ${ }^{210}$ heeft het EHRM, onder verwijzing naar de zaak 'Fayed' ${ }^{211}$, bovendien nadrukkelijk aangegeven dat het zwijgrecht en het nemo tenetur-beginsel niet in acht hoeven te worden genomen bij een algemeen onderzoek ter controle op de naleving van bepaalde regelgeving:

'In this respect the Court recalls its judgment in Fayed v. the United Kingdom where it held that the functions performed by the inspectors under section 432 (2) of the Companies Act 1985 were essentially investigative in nature and that they did not adjudicate either in form or in substance. Their purpose was to ascertain and record facts which might subsequently be used as the basis for action by other competent authorities - prosecuting, regulatory, disciplinary or even legislative (judgment of 21 September 1994, Series A no. 294-B, p. 47, para. 61). As stated in that case, a requirement that such a preparatory investigation should be subject to the guarantees of a judicial procedure as set forth in Article 6 para. 1 (art. 6-1) would in practice unduly hamper the effective regulation in the public interest of complex financial and commercial activities (ibid., p. 48, para. 62). ${ }^{212}$

\section{Informatie onder dwang verkregen voordat er sprake is van een vervolging ('charge')}

Het zwijgrecht en het nemo tenetur-beginsel hoeven derhalve niet in acht genomen te worden tijdens een, niet als 'criminal charge' aan te merken, (controle)onderzoek. ${ }^{213}$

208 'Saunders' $\$ 68$. Zie overigens ook: EHRM 21 december 2000, no. $34720 / 97$ (Heaney and Mc Guinness v. Ireland) i.h.b. \$ 40 en EHRM 21 december 2000, no. $36887 / 97$ (Quinn v. Ireland). In beide laatstgenoemde zaken heeft het EHRM tevens overwogen dat gebruik van onder dwang verkregen verklaringen, die afhankelijk zijn van de wil van de verdachte, als bewijs in een strafzaak niet alleen strijd oplevert met het fair trial-beginsel uit artikel 6, eerste lid, van het EVRM maar dat diarnce tevens sprake is van schending van de onschuldpresumptie uit artikel 6, tweede lid van het EVRM ('Heaney and $\mathrm{Mc}$ Guinness v. Ireland' i.h.b. $\$ 59$ en 'Quinn v. Ireland' $\$ 60$ ).

209 Zie met betrekking tot het begrip 'charge' in de context van artikel 6 EVRM $\$ 3.2 .3$ van dit hoek.

210 Zie hierover ook: T. Schalken en K. Rozemond, Straatburgse duidelijkheid over nemo tenetur, NJB 1997 , p. 808-809.

211 EHRM 21 september 1994, Series A vol. 294-B, NJ 1995, 463 (Fayed tegen Grunt-Brittannië).

212 'Saunders' \$ 67.

213 Zie in deze in ook de zaak van (de met Saunders van dezelfde beursfraude verdachte) I.J.L.., G.M.R., en A.K.P.: EHRM 19 september 2000, no.'s: 29522/95, 30056/96 en 30574/96 (I.J.L., G.M.R. and A.K.P. 
Zelfs niet indien iemand tijdens een dergelijk onderzoek (onder bedreiging van een sanctie) gedwongen wordt (op basis van een inlichtingenplicht) gegevens te verstrekken, die afhankelijk zijn van zijn wil ${ }^{214}$ en waarmee hij zichzelf incrimineert. Het voorgaande neemt echter niet weg dat bewijs dat afhankelijk is van de wil van de verdachte én dat onder dwang is verkregen gedurende een dergelijk controle onderzoek, niet mag worden gebruikt tijdens een strafvervolging. Zou dit bewijsmateriaal wél gebruikt worden in een strafzaak dan levert dat alsnog strijd op met het zwijgrecht en het nemo tenetur-beginsel. Het voorgaande is door het Hof uitdrukkelijk gesteld in de zaak 'Saunders':

'The right not to incriminate oneself is primarily concerned, however, with respecting the will of an accused person to remain silent. As commonly understood in the legal systems of the Contracting Parties to the Convention and elsewhere, it does not extend to the use in criminal proceedings of material which may be obtained from the accused through the use of compulsory powers but which has an existence independent of the will of the suspect such as, inter alia, documents acquired pursuant to a warrant, breath, blood and urine samples and bodily tissue for the purpose of DNA testing. In the present case the Court is only called upon to decide whether the use made by the prosecution of the statements obtained from the applicant by the inspectors amounted to an unjustifiable infringement of the right. This question must be examined by the Court in the light of all the circumstances of the case. In particular, it must be determined whether the applicant has been subject to compulsion to give evidence and whether the use made of the resulting testimony at his trial offended the basic principles of a fair procedure inherent in Article 6 para. 1 of which the right not to incriminate oneself is a constituent element.

It has not been disputed by the Government that the applicant was subject to legal compulsion to give evidence to the inspectors. He was obliged under sections 434 and 436 of the Companies Act $1985(\ldots)$ to answer the questions put to him by the inspectors in the course of nine lengthy interviews of which seven were admissible as evidence at his trial. A refusal by the applicant to answer the questions put to him could have led to a finding of contempt of court and the imposition of a fine or committal to prison for up to two years (...) and it was no defence to such refusal that the questions were of an incriminating nature (...). (...) Like the Commission, it (the Court [KA]) considers that the general requirements of fairness contained in Article 6, including the right not to incriminate oneself, apply to criminal proceedings in respect of all types of criminal offences without distinction from the most simple to the most complex. The public interest cannot be invoked to justify the use of answers compulsorily obtained in a non-judicial investigation to incriminate the accused

v. the UK) i.h.b. $\$ 100$ : 'However the applicants are not correct in their assertion that a legal requirement for an individual to give information demanded by an administrative body necessarily infringes Article 6 of the Convention. The Court considers that whether or not information obtained under compulsory powers by such a body violates the right to a fair hearing must be seen from the standpoint of the use made of that information at the trial. (...)' Van Russen Groen (a.w. 1998, p. 271) gaat er, mijns inziens ten onrechte, van uit dat het EHRM het zwijgrecht van toepassing heeft verklaard op verklaringen die zijn afgelegd tijdens een controle onderzoek. Hij schrijft immers het volgende: 'Daarmee past het Hof artikel 6 EVRM toe op een fase waarin nog geen sprake is van een 'criminal charge' in de zin van dit artikel. Dit wijkt af van de vrij algemeen gevolgde opvatting dat het zwijgrecht in een zo vroeg stadium nog niet kan worden ingeroepen, een standpunt dat tot nu toe ook door de Hoge Raad words ingenomen.'

214 Gegevens die afhankelijk zijn van de wil van de verdachte zullen doorgaans bestaan uit mondelinge of schriftelijke verklaringen van de verdachte met betrekking tot feiten die de vervolgende instantic nie onafhankelijk van de wil van de verdachte kan verkrijgen. Zie hierover: 'Saunders' §69. 
during the trial proceedings. It is noteworthy in this respect that under the relevant legislation statements obtained under compulsory powers by the Serious Fraud Office cannot, as a general rule, be adduced in evidence at the subsequent trial of the person concerned. Moreover the fact that statements were made by the applicant prior to his being charged does not prevent their later use in criminal proceedings from constituting an infringement of the right.

It follows from the above analysis and from the fact that section 434 (5) of the Companies Act 1985 authorises, as noted by both the trial judge and the Court of Appeal, the subsequent use in criminal proceedings of statements obtained by the inspectors that the various procedural safeguards to which reference has been made by the respondent Government (see paragraph 63 above) cannot provide a defence in the present case since they did not operate to prevent the use of the statements in the subsequent criminal proceedings.

Accordingly, there has been an infringement in the present case of the right not to incriminate oneself. ${ }^{215}$

\section{Gegevens en informatie onathankelijk van de wil}

Het Hof lijkt in de zaak 'Saunders' een minder ver strekkende uitleg to geven aan het nemo tenetur-beginsel dan in de zaak 'Funke'. De documenten die Funke moest overleggen (bankafschriften) bestonden namelijk onafhankelijk van zijn wil. Gelet op de interpretatie van het nemo tenetur-beginsel door het EHRM in de zaak 'Saunders' zouden dergelijke documenten, met het oog op de uitspraak van het Hof in de laatstgenoemde zaak, nu wellicht wél gebruikt mogen worden als bewijs tijdens een strafzaak omdat het bestaan van dit bewijsmateriaal niet afhankelijk is van de wil van de overtreder. $^{216}$

Overigens is niet geheel duidelijk of het Hof in de zaak 'Saunders' inderdaad gekozen heeft voor een minder ver strekkende uitleg van het nemo tenetur-beginsel. Het zou ook zo kunnen zijn dat het EHRM met de zaken 'Funke' en 'Saunders' aan heeft willen sluiten bij de Amerikaanse rechtspraak met betrekking tot het 'privilege against self incrimination'. Beide arresten van het EHRM zijn immers conform de lijn die door het Amerikaanse Supreme Court wordt gevolgd. ${ }^{217}$ Lenos beschrijft de (mogelijke) parallel tussen de rechtspraak van het Supreme Court en het EHRM als volgt:

'De Amerikaanse rechter beperkt het grondrecht tot bewijs van testimonial or communicative nature. Daaronder valt bijvoorbeeld niet het afnemen van bloed of het meedoen aan een schrijfproef. De plicht tot het overleggen van documenten is in beginsel evenmin in strijd met dit privilege. Echter, in sommige gevallen kan het overleggen van documenten wel testimonial or communicative van aard zijn. Namelijk indien het bestaan en de locatie van de documenten niet reeds uit een andere bron aan de overheid bekend waren. Het verstrekken van documenten betekent dan dat de houder het bestaan en het bezit van de documenten erkent, hetgeen testimomial self-incrimination kan zijn. Waarschijnlijk heeft het EHRM in het Funke-arrest eveneens slechts willen oordelen dat de onzekerheid ten

\section{5 'Saunders' \$ 69-70 en 74-76.}

216 Vgl. Knigge in zijn noot onder de zaak 'Saunders' en Van Russen Groen, a.w. 1998, p. 265.

$217 \mathrm{Vgl}$. P. Bal, Murphy's law? Over de uitholling van het nemo tenetur beginsel in Amerika, in de bundel: Nemo tenetur, onder redactie van J.M. Reijntjes, Gouda Quint bv, Amhem 1996, p. 23-40. 
aanzien van het bestaan van de documenten de strijdigheid met het nemo-teneturrecht veroorzaakte. $^{.218}$

Uit een arrest van het Hof van 3 mei 2001, in de zaak 'J.B. tegen Zwitserland'219, lijkt inderdaad afgeleid te kunnen worden dat het Hof in het kader van het nemo teneturbeginsel aansluiting heeft gezocht bij de Amerikaanse rechtspraak in het kader van het 'privilege against self incrimination'.

Ten aanzien van klager J.B. is in 1987 in Zwitserland, door de federale belastingdienst (Eidgenössische Steuerverwaltung), een procedure gestart vanwege vermeende belastingontduiking. In het kader van deze procedure wordt klager drie maal verzocht bepaalde documenten en informatie te verstrekken. Op basis van de federale belastingverordening zijn belastingplichtigen gehouden aan een degelijk verzoek medewerking te verlenen. Aangezien J.B. meedere malen weigert gevolg te geven aan dit verzoek worden hem, vanwege de weigeringen, een viertal boeten (Ordnungsbussen) opgelegd. Tijdens de procedure bij het Hof staat de vraag centraal of een met een (bestuurlijke) boete te handhaven inlichtingenplicht in strijd kan komen met het nemo teneturbeginsel.

Het Hof stelt allereerst dat de belastingdienst klager probeerde te dwingen bepaalde documenten te verstrekken door te dreigen met (bestuurlijke) boeten. Deze documenten zouden, volgens de belastingdienst, informatie moeten bevatten met betrekking tot het inkomen van klager. Genoemde informatie was voor de belastingdienst om twee redenen relevant. Ten eerste had de belastingdienst genoemde informatie nodig voor het bepalen van de door J.B. verschuldigde belasting (teneinde een naheffingsaanslag vast te stellen). Daarnaast was de informatie relevant voor beantwoording van de vraag of J.B. inkomsten had genoten waarover geen belasting was betaald (teneinde eventueel een - als 'criminal charge' aan te merken - belastingontduikingsprocedure te starten). Het Hof stelt dat J.B. niet uit kon sluiten dat de informatie (die was neergelegd in de door hem te verstrekken documenten) met betrekking tot bepaalde inkomsten die hij genoten had, zou kunnen leiden tot beschuldiging van belastingontduiking.

Het Hof wijst er vervolgens op dat er in casu geen sprake is van bewijsmateriaal dat bestaat onafhankelijk van de wil van verdachte, zoals bijvoorbeeld bloed en urinemonsters of tachograafschijven. Het Hof is er voorts niet van overtuigd geraakt dat J.B. niet gedwongen werd zichzelf te incrimineren omdat, zoals Zwitserland stelt, de belastingdienst wist dat de informatie bestond terwijl J.B. zelf had aangegeven om welke bedragen aan inkomsten het ging. In dat geval was de belastingdienst, zo stelt het Hof, niet zo hardnekkig blijven proberen de informatie te verkrijgen. De belastingdienst heeft immers, tussen 1987 en 1990, J.B. tot acht maal toe verzocht de informatie te verstrekken. Aangezien dit door J.B. werd geweigerd werden hem bovendien vier (bestuurlijke) boeten opgelegd. Met het oog op het voorgaande acht het Hof het, in artikel 6, eerste lid EVRM neergelegde, nemo tenetur-beginsel geschonden. ${ }^{220}$

218 E.E.V. Lenos, De sociale en fiscale inlichtingenplicht en het zwijgrecht sinds Saunders, NJB 1997, p. 795-800, i.h.b. p. 796. Zie in deze zin ook Reijntjes a.w. 1996, p. 17-18.

219 EHRM 3 mei 2001, no. 31827/96, EHRC 2001/45, m. nt. K. Albers (J.B. tegen Zwitserland).

220 'J.B. tegen Zwitserland' § 65-71. 
Zoals uit bovenstaande weergave van het arrest van het Hof blijkt, wilde de belastingdienst weten uit welke bron J.B. de niet opgegeven inkomsten had genoten. Het Hof komt tot het (spijtig genoeg weinig gemotiveerde en daardoor moeilijk te begrijpen) oordeel dat deze informatie niet onafhankelijk is van de wil van J.B. Op zich is dit vreemd omdat uit het arrest blijkt dat de belastingdienst onder meer om bankafschriften heeft gevraagd. ${ }^{221}$ Zie ik het goed dan speelt in dat kader een rol dat de belastingdienst volgens het Hof niet met zekerheid wist of J.B. de gevraagde informatie kon verstrekken. Dit laatste kan immers, als het Hof aansluiting heeft gezocht bij de Amerikaanse rechtspraak, ook relevant zijn ten aanzien van bijvoorbeeld bankafschriften (die bestaan onafhankelijk van de wil van de verdachte). Op basis van het voorgaande lijkt de conclusie gerechtvaardigd dat het Hof op dezelfde lijn zit als de Amerikaanse rechter.

\section{Slotsom}

Op basis van het voorgaande kan geconcludeerd worden dat het zwijgrecht en het nemo tenetur-beginsel bij de oplegging van een punitieve sanctie in acht genomen moeten worden. Dit omdat zij beiden deel uit maken van het, in artikel 6 EVRM neergelegde, fair trial-beginsel. Genoemde waarborgen brengen volgens het Hof in het bijzonder met zich dat bewijs, dat afhankelijk is van de wil van de verdachte én dat onder dwang is verkregen, niet gebruikt mag worden tijdens een 'strafvervolging'. Met name mondelinge en schriftelijke verklaringen lijken relevant te zijn in het kader van het zwijgrecht en het nemo tenetur-beginsel omdat genoemde verklaringen afhankelijk kunnen zijn van de wil van de verdachte. Ten aanzien van verklaringen die afhankelijk zijn van de wil van de verdachte en die zijn afgelegd gedurende een controle onderzoek ${ }^{222}$ geldt eveneens dat zij niet mogen worden gebruikt als bewijs van het plegen van een 'strafbaar feit'.

Het Hof lijkt in zijn rechtspraak uit te gaan van een redelijk enge uitleg van het nemo tenetur-beginsel. Zoals gezegd ziet het enge nemo tenetur-beginsel slechts op het zwijgrecht en heeft het ten doel 'miscarriages of justice' te voorkomen. Het EHRM lijkt veel gewicht toe te kennen aan laatstgenoemd doel in het kader van het nemo teneturheginsel. ${ }^{223}$ Daarbij verdient echter opmerking dat het Hof zich in de rechtspraak niet seperkt tot een zwijgrecht in strikte zin. Mondelinge en schriftelijke verklaringen vallen onder het zwijgrecht en het nemo tenetur-beginsel voor zover zij informatie bevatten die de vervolgende instantie niet onafhankelijk van de wil van de verdachte had kunnen bemachtigen.

Gegevens die in feite onafhankelijk van de wil van verdachte bestaan, zoals bijvoorbeeld bankafschriften, lijken tevens relevant te zijn in het kader van genoemd beginsel. Voor zover de vervolgende instantie niet reeds op basis van een andere bron op de hoogte is van het bestaan en de locatie van die gegevens of documenten lijken deze, als zij onder dwang zijn verkregen, niet te mogen worden gebruikt als bewijs tegen een verdachte in een strafzaak.

222 D.w.z. op een moment dat er nog geen sprake was van een 'criminal charge'.

223 Vgl. bijv. 'Saunders' $\$ 68$, en 'J.B. tegen Zwitseland' $\$ 64$. 
3.4.4 Het nullum crimen sine lege-beginsel, het nulla poena sine lege-beginsel en het beginsel dat de overtreder dient te profiteren van een, na het begaan van het strafbare feit, totstandgekomen wetswijziging die voorziet in de oplegging van een lichtere straf.

In artikel 7 EVRM en artikel 15 IVBPR is, in vrijwel gelijkluidende bepalingen, het nullum crimen sine lege-beginsel en het nulla poena sine lege-beginsel neergelegd. ${ }^{224}$ Artikel 7, eerste lid EVRM luidt (in de Nederlandse vertaling): 'Niemand mag worden veroordeeld wegens een handelen of nalaten, dat geen strafbaar feit naar nationaal of internationaal recht uitmaakte ten tijde dat het handelen of nalaten geschiedde. Evenmin mag zwaardere straf worden opgelegd dan die, die ten tijde van het begaan van het strafbare feit van toepassing was.' In het tweede lid wordt vervolgens een 'uitzondering' gemaakt op het eerste lid voor wat betreft een handelen of nalaten dat ten tijde van het handelen of nalaten een misdrijf was overeenkomstig de algemene rechtsbeginselen die door de beschaafde volken worden erkend.

Het EHRM heeft in de zaak 'S.W. v. the United Kingdom' ${ }^{225}$ uitdrukkelijk aangegeven dat artikel 7 EVRM een zeer belangrijke plaats inneemt binnen het verdrag:

'The guarantee enshrined in Article 7 (art. 7), which is an essential element of the rule of law, occupies a prominent place in the Convention system of protection, as is underlined by the fact that no derogation from it is permissible under Article 15 (art. 15) in time of war or other public emergency. It should be construed and applied, as follows from its object and purpose, in such a way as to provide effective safeguards against arbitrary prosecution, conviction and punishment.'

De spiegelbepaling uit artikel 15 IVBPR is praktisch gelijkluidend. Het grootste verschil schuilt in de, aan het eerste lid toegevoegde, derde volzin die ziet op toepassing van de lichtere sanctie bij een tussentijdse wetswijziging. ${ }^{226}$ De in artikel 15 , eerste lid, derde volzin IVBPR neergelegde bepaling luidt (in de Nederlandse vertaling) als volgt: 'Indien, na het begaan van het strafbare feit de wet mocht voorzien in de oplegging van een lichtere straf, dient de overtreder daarvan te profiteren.'

Ik zal in deze paragraaf met name ingaan op het nullum crimen sine lege-beginsel, het nulla poena sine lege-beginsel en het in dat kader tevens relevante lex certa-beginsel. Op het beginsel dat de overtreder dient te profiteren van een, na het begaan van het strafbare feit, totstandgekomen wetswijziging die voorziet in de oplegging van een lichtere straf zal ik in deze paragraaf minder uitvoerig ingaan. Voor zover ten aanzien van de bepaling onduidelijkheden mochten bestaan kunnen deze niet aan de hand van jurisprudentie van het Human Rights Committee worden verduidelijkt simpelweg omdat, voor zover ik na heb kunnen gaan, niet voldoende jurisprudentie voorhanden is. Aangezien laatstgenoemd beginsel niet tevens is opgenomen in artikel 7 EVRM biedt ook de rechtspraak van het EHRM in dit kader geen uitkomst. november 1995, Series A vol. 335-A, NJ 1997, 1, m. nt. Knigge (C.R. v. the United Kingdom). 


\subsection{4.a Het nullum crimen sine lege-beginsel}

In de eerste volzin van het eerste lid van artikel 7 EVRM en artikel 15 IVBPR is het nullum crimen sine lege-beginsel gecodificeerd. ${ }^{227}$ Het nullum crimen-beginsel brengt niet alleen met zich dat niemand mag worden veroordeeld wegens een handelen of nalaten, dat geen strafbaar feit naar nationaal of intemationaal recht uitmaakte ten tijde dat het handelen of nalaten geschiedde. Daarnaast vloeit uit genoemd beginsel, vanuit het oogpunt van rechtszekerheid, voort dat het onrechtmatige gedrag nauwkeurig, duidelijk en ondubbelzinnig moet worden beschreven (lex certa-vereiste). Bovendien is het niet toegestaan delictsomschrijvingen ${ }^{228}$ middels een extensieve interpretatie naar analogie toe te passen op andere gedragingen. ${ }^{229}$ Het voorgaande is door het EHRM expliciet verwoord in de zaak 'Kokkinakis v. Greece':

The Court points out that Article 7 para. 1 (art. 7-1) of the Convention is not confined to prohibiting the retrospective application of the criminal law to an accused's disadvantage. It also embodies, more generally, the principle that only the law can define a crime and prescribe a penalty (nullum crimen, nulla poena sine lege) and the principle that the criminal law must not be extensively construed to an accused's detriment, for instance by analogy; it follows from this that an offence must be clearly defined in law. This condition is satisfied where the individual can know from the wording of the relevant provision and, if need be, with the assistance of the courts' interpretation of it, what acts and omissions will make him liable. ${ }^{230}$

Het voorgaande impliceert dat de delictsomschrijving, met het oog op het lex certabeginsel, zelf niet tot in de details het strafbare gedrag hoeft weer te geven, zolang op basis van rechtspraak wél is vast te stellen welk gedrag precies strafbaar is. In 'Kokkinakis v. Greece' heeft het EHRM daaromtrent het volgende gesteld:

'The court has already noted that the wording of many statutes is not absolutely precise. The need to avoid excessive rigidity and to keep pace with changing circumstances means that many laws are inevitably couched in terms which, to a greater or lesser extent, are vague (...). Criminal-law provisions on proselytism fall within this category. The interpretation and application of such enactments depend on practice. In this instance there existed a body of settled national case-law (...). This case-law, which had been published and was accessible, supplemented the letter of section $\mathbf{4}$ and was such as to enable Mr Kokkinakis to regulate his conduct in the matter. ${ }^{231}$

Een nadere uitwerking van deze opvatting is neergelegd in de uitspraak van het EHRM in de zaak 'C.R. v. the United Kingdom'. In die zaak heeft het Hof, in paragraaf 34, het volgende gesteld:

$227 \mathrm{Vgl}$. Van Dijk/Van Hoof a.w. 1998, p. 480-483 en Nowak a.w. 1993, p. 275-277.

228 Met de term 'delictsomschrijving' doel ik dan niet alleen op de omschrijving van strafbare handelingen in het strafrecht (in enge zin) maar ook op de omschrijving van (alle) andere strafbare handelingen die gesanctioneerd kunnen worden met punitieve sancties buiten het (traditionele) strafrecht (bijv. middels cen bestuurlijke boete).

229 Vgl. Van Dijk/Van Hoof a.w. 1998, p. 481 en Nowak a.w. 1993, p. 276. Zie voorts EHRM 25 mei 1993. Series A vol. 260 - A (Kokkinakis v. Greece), i.h.b. $\$ 52$.

230 'Kokkinakis v. Greece' $\$ 52$.

231 'Kokkinakis v. Greece' $\$ 40$. 
'Article 7 of the Convention cannot be read as outlawing the gradual clarification of the rules of criminal liability through judicial interpretation from case to case, provided that the resultant development is consistent with the essence of the offence and could reasonable be foreseen.'

De precieze betekenis en inhoud van een delictsomschrijving hoeft derhalve niet steeds van meet af aan (volledig) helder te zijn. Een nadere casuïstische uitwerking is toegestaan. De rechtsontwikkeling ten aanzien van de delictsomschrijving moet dan volgens het EHRM wél in overeenstemming zijn met de essentie van de delictsomschrijving. Bovendien stelt het Hof dat de rechtsontwikkeling redelijkerwijs voorzienbaar moet zijn zodat voor de potentiêle overtreder duidelijk is dat zijn handelen strafbaar is. Aldus lijkt het Hof potentiële overtreders te willen behoeden voor een al te ruime (nietvoorzienbare) uitleg van strafbepalingen.

\section{Accessibility en foreseeability}

Bij de beantwoording van de vraag of een delictsomschrijving nauwkeurig, duidelijk en ondubbelzinnig is geformuleerd betrekt het EHRM een tweetal aspecten. Ten eerste beoordeelt het Hof of de delictsomschrijving (of de daarop gebaseerde jurisprudentie ingeval de delictsomschrijving zelf enigszins vaag is) 'accessible' is. Daarnaast bekijkt het Hof of op basis van de delictsomschrijving (of jurisprudentie) voor de (potentiële) overtreder 'foreseeable' is welke vormen van handelen of nalaten strafbaar zijn. ${ }^{232}$ In dit kader verdient het opmerking dat voorzienbaarheid in feite impliceert dat een strafbepaling nauwkeurig, duidelijk en ondubbelzinnig is geformuleerd. ${ }^{233}$ Het EHRM lijkt met name uit te gaan van de criteria 'accessibility' en 'foreseeability' omdat het daarbij gebruik kan maken van de reeds bestaande, uitvoerige jurisprudentie met betrekking tot de term 'prescribed by law' uit (onder meer) artikel 10, tweede lid EVRM. ${ }^{234}$

Het EHRM verwijst in de zaak 'G. v. France' immers uitdrukkelijk naar rechtspraak met betrekking tot artikel 10, tweede lid van het EVRM. Derhalve kan er van uitgegaan worden dat genoemde jurisprudentie gebruikt kan worden teneinde vast te stellen of de delictsomschrijving 'accessible' is en of, op basis van genoemde omschrijving, voor de (potentiële) overtreder 'foreseeable' is welke vormen van handelen of nalaten strafbaar zijn. $^{235}$ Dat dit standpunt juist is blijkt ook uit de zaak 'C.R. v. the United Kingdom'. In genoemde zaak stelt het Hof in dat kader het volgende:

'The Court thus indicated that when speaking of "law" Article 7 (art. 7) alludes to the very same concept as that to which the Convention refers elsewhere when using that term, a concept which comprises written as well as unwritten law and implies qualitative requirements, notably those of accessibility and foreseeability (see, as a recent authority, the Tolstoy Miloslavsky v. the United Kingdom judgment of 13 July 1995, Series A no. 316-B, pp. $71-72$, para. 37$),{ }^{236}$

232 Zic de hierboven weergegeven passage uit $\$ 40$ van de zaak 'Kokkinakis v. Greece'. Zie voorts: EHRM 27 september 1995, Scries A vol. 325-B, NJ 1996, 49 m. nt. Knigge (G. v. France), i.h.b. \$25.

233 Zite in dit kader ook de uitspraak van het EHRM van 25 november 1997, no. 24348/94 (Grigoriades v. Greece), i.h.b. $\$ 37$.

234 Zie: EHRM 26 april 1979, Series A vol. 30, NJ 1980, 146 m. nt. Alkema (Sunday Times), i.h.b. $\$ 49$.

235 'G. v. France' $\$ 25$

236 'C.R. v. the United Kingdom' \$33. 
Ten aanzien van de vraag of de delictsomschrijving 'accessible' is lijken zich geen, of althans weinig, problemen voor te doen. Rechtspraak van het EHRM te dien aanzien is in elk geval nauwelijks aanwezig. Wat de voorzienbaarheid betreft lijkt er meer onduidelijkheid te zijn. Of voor de overtreder voorzienbaar was dat zijn handelen of nalaten een strafbaar feit opleverde hangt bijvoorbeeld onder meer af van de status van de geadresseerde.

Illustratief in het kader van het voorzienbaarheidsvereiste is de zaak 'Cantoni v. France'. ${ }^{237}$ In die zaak ging het om de vraag of op basis van de algemene definitie in de wet van de term 'medicinal product' voor Cantoni voorzienbaar was dat hij strafbaar was omdat hij in zijn supermarkt farmaceutische produkten verkocht die hij niet mocht verkopen aangezien zij aangemerkt moesten worden als een 'medicinal product'. Door het Hof wordt in die zaak ten aanzien van het voorzienbaarheidsvereiste het volgende gesteld:

'The Court recalls that the scope of the notion of foreseeability depends to a considerable degree on the content of the text in issue, the field it is designed to cover and the number and status of those to whom it is addressed (...). A law may still satisfy the requirement of foreseeability even if the person concerned has to take appropriate legal advice to assess, to a degree that is reasonable in the circumstances, the consequences which a given action may entail (...). This is particularly true in relation to persons carrying on a professional activity, who are used to having to proceed with a high degree of caution when pursuing their occupation. They can on this account be expected to take special care in assessing the risks that such activity entails. ${ }^{238}$

Factoren als de inhoud van de delictsomschrijving, het (rechts)gebied waar de delictsomschrijving op ziet, het aantal personen en de status van de personen tot wie de delictsomschrijving is gericht spelen derhalve een rol bij beantwoording van de vraag of 'strafbaarheid' op basis van de delictsomschrijving foreseeable is. De delictsomschrijving voldoet aan het voorzienbaarheidscriterium als een burger, eventueel na (juridisch) advies, kan bepalen welke handelingen overtreding van de rechtsregel teweeg, kunnen brengen. ${ }^{239}$ Ruim geformuleerde criteria derhalve, die niet echt veel houvast bieden. Per geval zal beoordeeld moeten worden of op basis van de in de rechtspraak genoemde factoren voldaan is aan het voorzienbaarheidsvereiste. In de zaak 'Cantoni v. France' komt het EHRM aan de hand van bovenstaande factoren tot de volgende conclusie:

'With the benefit of appropriate legal advice, Mr Cantoni, who was, moreover, the manager of a supermarket (status van de geadresseerde [KA]), should have appreciated at the material time that, in view of the line of case-law stemming from the Court of Cassation and from some of the lower courts, he ran a real risk of prosecution for unlawful sale of medicinal products. ${ }^{240}$

EHRM 15 november 1996, no. 17862/91 (Cantoni v. France).

238 'Cantoni v. France' § 35. Zie voorts de zaak 'Vogt' (EHRM 26 september 1995, Series A vol. 323, § 48).

239 Zie in dit kader ook: 'Muller and Others', EHRM 24 mei 1988, Series A vol. 133, $\$ 29$.

240 'Cantoni v. France' $\$ 35$. 
Het voorzienbaarheidscriterium, dat impliceert dat een wettelijke bepaling nauwkeurig, duidelijk en ondubbelzinnig is geformuleerd, vormt in feite geen beletsel voor het opnemen van discretionaire bevoegdheden in een wettelijke bepaling. Uiteraard stelt het EHRM daarbij een aantal randvoorwaarden. Het Hof bepaalde, onder meer in de zaak 'Margareta and Roger Andersson v. Sweden' ${ }^{241}$, met betrekking tot het vereiste van voorzienbaarheid in relatie tot discretionaire bevoegdheden het volgende:

'The Court recalls that the expression "in accordance with the law", within the meaning of Article 8 para. 2 (art. 8-2), requires firstly that the impugned measures should have a basis in domestic law. It also refers to the quality of the law in question, requiring that it be accessible to the persons concerned and formulated with sufficient precision to enable them - if need be, with appropriate advice - to foresee, to a degree that is reasonable in the circumstances, the consequences which a given action may entail. A law which confers a discretion is not in itself inconsistent with this requirement, provided that the scope of the discretion and the manner of its exercise are indicated with sufficient clarity, (...), to give the individual adequate protection against arbitrary interference $(\ldots)^{.242}$

Gelet op het feit dat het Hof in de zaak 'C.R. v. UK' heeft bepaald dat aan het voorzienbaarheidsvereiste in het kader van artikel 7 EVRM dezelfde invulling wordt gegeven als elders in het verdrag waar de term 'law' wordt gebruikt lijkt de conclusie dat discretionaire sanctiebevoegdheden (in beginsel) stroken met het voorzienbaarheidsvereiste, voor zover de omvang van de discretionaire bevoegdheid en de wijze van uitoefening van de discretionaire bevoegdheid voldoende duidelijk zijn aangegeven, gerechtvaardigd.

Op zich bieden ook de criteria, aan de hand waarvan moet worden vastgesteld of een discretionaire bevoegdheid in overeenstemming is met het voorzienbaarheidsvereiste, niet veel houvast. Van geval tot geval zal bepaald moeten worden of de omvang van de discretionaire bevoegdheid en de wijze van uitoefening van de discretionaire bevoegdheid voldoende duidelijk zijn omschreven. ${ }^{243}$ Slechts als sanctionering een daad van willekeur oplevert of kan opleveren is volstrekt helder dat de discretionaire sanctiebevoegdheid in strijd is met het lex certa-beginsel.

Opmerking verdient nog wel dat ook de mogelijkheid van rechterlijke toetsing van de wijze waarop het bestuursorgaan de discretionaire bevoegdheid interpreteert en uitoefent een rol lijkt te spelen met betrekking tot het voorzienbaarheidscriterium. De bevoegdheid tot rechterlijke toetsing van discretionaire bevoegdheden lijkt voor het Hof van belang te zijn omdat op die wijze voorzien kan worden in: 'adequate protection against arbitrary interference. ${ }^{.244}$

241 EHRM 25 februari 1992, Series A vol. 226-A (Margareta and Roger Andersson v. Sweden).

242 'Margareta and Roger Andersson v. Sweden' § 75.

243 Zie voorts: EHRM 13 juli 1995, Series A vol. 316-B (Tolstoy Miloslavsky v. UK) $\S 37-44$. Uit deze uitspraak van het EHRM kan mijns inziens worden afgeleid dat het Hof vrij snel aanneemt dat een wettelijke bepaling die een discretionaire bevoegdheid bevat voldoet aan het voorzienbaarheidsvereiste.

244 Zie in dit kader: EHRM 8 juli 1999, no. $23536 / 94$ en 24408/94 (Başkaya and okçuoglu judgement) i.h.b. $\$ 39$. Men kan zich dan ook de vraag stellen of deze jurisprudentie problemen oplevert voor z0. ver bestuursrechtelijke (punitieve) delictsomschrijvingen een discretionaire bevoegdheid bevarten aangezien de uitoefening van die bevoegdheid dan, op basis van het Nederlandse bestuursprocesrecht, door de Nederlandse bestuursrechter slechts marginaal getoetst kan worden. Aangezien het Hof spreekt over 'adequate protection against arbitrary interference' lijkt de Nederlandse rechter te kunnen volstaan 


\section{Slotsom}

Ten aanzien van het nullum crimen sine lege-beginsel dat, op basis van de redactie van artikel 7 EVRM en artikel 15 IVBPR, met zich brengt dat niemand mag worden veroordeeld wegens een handelen of nalaten, dat geen strafbaar feit naar nationaal of internationaal recht uitmaakte ten tijde dat het handelen of nalaten geschiedde, lijken er zich in beginsel alleen enkele onduidelijkheden voor te doen met betrekking tot de vraag of een delictsomschrijving nauwkeurig, duidelijk en ondubbelzinnig is geformuleerd (het zogenaamde lex certa-vereiste). Voor zover het Hof de vraag moet beantwoorden of een delictsomschrijving met terugwerkende kracht is toegepast op een bepaald handelen (of nalaten) lijken er zich, in de regel, blijkens de rechtspraak van het EHRM, geen problemen voor te doen. ${ }^{245}$

Hierboven is aan de hand van relevante rechtspraak van het EHRM aangegeven op welke wijze, en aan de hand van welke criteria, het Hof vaststelt of een delictsomschrijving voldoet aan het voorzienbaarheidsvereiste (foreseeability). Zoals gezegd impliceert het genoemde voorzienbaarheidsvereiste dat de delictsomschrijving (of de daarop gebaseerde jurisprudentie) nauwkeurig, duidelijk en ondubbelzinnig moet zijn geformuleerd. Factoren als de inhoud van de delictsomschrijving, het (rechts)gebied waar de delictsomschrijving op ziet, het aantal personen en de status van de personen tot wie de delictsomschrijving is gericht, spelen een rol bij beantwoording van de vraag of 'strafbaarheid' op basis van de delictsomschrijving 'foreseeable' is. De delictsomschrijving voldoet aan het voorzienbaarheidscriterium als een burger, eventueel na (juridisch) advies, kan bepalen welke welke handelingen overtreding van de rechtsregel teweeg kunnen brengen.

\subsection{4.b Het nulla poena sine lege-beginsel}

Naast het nullum crimen sine lege-beginsel is in het eerste lid van artikel 7 EVRM en artikel 15 IVBPR het nulla poena sine lege-beginsel opgenomen. Laatstgenoemd beginsel houdt in dat geen zwaardere straf mag worden opgelegd dan die, die ten tijde van het begaan van het strafbare feit van toepassing was. Ten eerste zal hier, in het kader van het nulla poena sine lege-beginsel, kort ingegaan worden op de vraag wanneer er (naar het oordeel van het EHRM) sprake is van een straf ('penalty'). Daarna wordt nog aandacht besteed aan de vraag wanneer er sprake is van een 'zwaardere' straf en tenslotte zal nog aandacht uitgaan naar het lex certa-beginsel. Genoemd beginsel

met een toetsing aan het willekeur-criterium (NB. Zoals in hoofdstuk twee is aangegeven geldt het voorgaande (marginale toetsing van de uitoefening van een beleidsvrije bevoegdheid) nict voor toetsing van de opglegde sanctie door de bestuursrechter aan het evenredigheidsbeginsel).

245 In dit kader moet echter gewezen worden op de (op een bijzondere situatie betrekking hebbende) zaken: 'K.-H. W. v. Germany' (EHRM 22 maart 2001, no. 37201/97) en 'Streletz, Kessler and Krenz v. Germany' (EHRM 22 maart 2001, no.'s 43044/96, 35532/97, en 44801/98) waarin bestraffing van voormalige DDR-functionarissen en éen (destijds) dienstplichtige soldaat door de BRD, wegens het doden van de DDR ontvluchtende burgers aan de grens, niet in strijd met artikel 7, eerste lid (!!) EVRM werd geacht. Genoemde gedragingen waren volgens het Hof ten tijde van het begaan ook naar DDR-recht (én naar internationaal recht) strafbaar. Bovendien waren de strafbepalingen volgens het Hof destijds 'accessible' en de strafbaarheid van de gedragingen was 'foreseeable'. Dat deze opvatting van het EHRM voor kritiek vatbaar is moge blijken uit: J.A.W. Lensing en Th. Mertens, Het Europees Hof voor de rechten van de mens en de 'muurschutters'. De 'formulering van Radbruch' of innerlijke tegenstrijdigheid, NJB 2001, p. 1699-1706. 
doet immers ook zijn werking voelen in het kader van het nulla poena sine legebeginsel.

\section{Penalty}

In de zaak 'Welch v. UK' ${ }^{246}$ heeft het EHRM onder meer bepaald dat de term 'penalty' evenals bijvoorbeeld de term 'criminal charge' een autonoom verdragsbegrip is. De motivering van het Hof te dien aanzien is vergelijkbaar met de motivering met betrekking tot het autonome karakter van de term 'criminal charge':

'To render the protection offered bij Article 7 (art. 7) effective, the Court must remain free to go behind appearances and assess for itself whether a particular measure amounts in substance to a "penalty" within the meaning of the provision. ${ }^{247}$

Een sanctie die wordt opgelegd wegens het plegen van een 'criminal offence', nadat een strafvervolging ('criminal charge') heeft plaatsgevonden, lijkt - voor zover die sanctie punitief is - , in de regel als 'penalty' aangemerkt te kunnen worden:

'The wording of Article 7 para. I (art. 7-1), second sentence, indicates that the starting-point in any assessment of the existence of a penalty is whether the measure in question is imposed following conviction for a "criminal offence". Other factors that may be taken into account as relevant in this connection are the nature and purpose of the measure in question; its characterisation under national law; the procedures involved in the making and implementation of the measure; and its severity. ${ }^{248}$

Aan de hand van de zaak 'Welch v. UK' kan worden vastgesteld dat het punitieve karakter van de maatregel of sanctie, die wordt opgelegd nadat iemand is veroordeeld wegens het plegen van een 'criminal offence', in beginsel doorslaggevend is. Welch werd, bij wijze van hoofdstraf, veroordeeld tot tweeëntwintig jaar gevangenisstraf wegens zijn betrokkenheid bij drugshandel. Daarnaast werd hem zijn wederrechtelijk verkregen voordeel ontnomen middels een 'confiscation order'. De vraag die centraal stond in de zaak 'Welch' was of de 'confiscation order' een 'penalty' was in de zin van artikel 7 van het EVRM. Deze vraag was relevant omdat de wet, op basis waarvan de 'confiscation order' kon worden opgelegd, nog niet in werking was getreden op het moment dat Welch de strafbare feiten pleegde. Het Hof komt, op basis van de hiema weergegeven uitvoerige analyse, tot de conclusie dat er inderdaad sprake is van een 'penalty':

'In assessing the nature and purpose of the measure, the Court has had regard to the background of the $1986 \mathrm{Act}$, which was introduced to overcome the inadequacy of the existing powers of forfeiture and to confer on the courts the power to confiscate proceeds after they had been converted into other forms of assets (...). The preventive purpose of confiscating property that might be available for use in future drug-trafficking operations is well as the purpose of ensuring that crime does not pay are evident from the ministerial statements that were made to Parliament at the time of the introduction of the legislation (...). However it cannot be excluded that legislation which confers such broad powers of

EHRM 9 februari 1995. Series A vol. 307-A, NJ 1995, 606, m. nt. Knigge (Welch v. UK).

247 'Welch $v$. UK' $\$ 27$.

248 'Welch v. UK' $\$ 28$. De factoren die het Hof hierboven noemt sluiten nauw aan bij de drie criteria die het Hof hanteert in het kader van de 'criminal charge'-jurisprudentie (zie $\$ 3.2$ van dit hoofdstuk). 
confiscation on the courts also pursues the aim of punishing the offender. Indeed the aims of prevention and reparation are consistent with a punitive purpose and may be seen as constituent elements of the very notion of punishment. (...)

However, there are several aspects of the making of an order under the 1986 Act which are in keeping with the idea of a penalty as it is commonly understood even though they may also be considered as essential to the preventive scheme inherent in the $1986 \mathrm{Act}$. The sweeping statutory assumptions in section 2 (3) of the 1986 Act that all property passing through the offender's hands over a six-year period is the fruit of drug trafficking unless he can prove otherwise (...); the fact that the confiscation order is directed to the proceeds involved in drug dealing and is not limited to actual enrichment or profit (...); the discretion of the trial judge, in fixing the amount of the order, to take into consideration the degree of culpability of the accused (...); and the possibility of imprisonment in default of payment by the offender $(\ldots)$ - are all elements which, when considered together, provide a strong indication of, inter alia, a regime of punishment.

Finally, looking behind appearances at the realities of the situation, whatever the characterisation of the measure of confiscation, the fact remains that the applicant faced more far-reaching detriment as a result of the order than that to which he was exposed at the time of the commission of the offences for which he was convicted (see, mutatis mutandis, the Campbell and Fell v. the United Kingdom judgment of 28 June 1984, Series A no. 80, p. 38, para. 72).

Taking into consideration the combination of punitive elements outlined above, the confiscation order amounted, in the circumstances of the present case, to a penalty. ${ }^{249}$

Het lijkt, op basis van het voorgaande, dan ook gerechtvaardigd te concluderen dat een punitieve maatregel of sanctie, die wordt opgelegd nadat iemand is veroordeeld wegens het plegen van een 'criminal offence', aangemerkt moet worden als een 'penalty' in de zin van artikel 7 EVRM. Mijns inziens zijn er sterke indicaties dat de bestuurlijke boete, op grond van genoemde jurisprudentie, zonder meer aangemerkt kan worden als penalty.

In dat kader is relevant dat het in de zaak 'Welch v. UK' en in de (hiema nader te bespreken) zaak 'Jamil v. France'250 ging om bijkomende straffen/maatregelen die naast de hoofdstraf konden worden opgelegd/toegepast. Welch werd namelijk, bij wijze van hoofdstraf, veroordeeld tot tweeëntwintig jaar gevangenisstraf wegens zijn betrokkenheid bij drugshandel. Daarnaast werd hem zijn wederrechtelijk verkregen voordee] ontnomen middels genoemde 'confiscation order'. Het Hof kwam tot de conclusie dat de 'confiscation order' een 'penalty' was. Toepassing van de wetgeving, op basis waarvan de 'confiscation order' kon worden opgelegd, met terugwerkende kracht ten aanzien van Welch leverde derhalve strijd op met artikel 7, eerste lid van het EVRM.

Jamil werd onder meer beschuldigd van het smokkelen van verboden goederen (cocaïne). Derhalve werd hij veroordeeld tot een gevangenisstraf van acht jaar, volgde verbeurdverklaring van inbeslaggenomen goederen en werd hij veroordeeld tot het betalen

'Welch v. UK' \$ 30-35. Vgl. EHRM 8 juni 1995, NJ 1996, 1, m. nt. Krigge (Jamil v. France) i.h.b. \$ 32. Zie in deze zin ook Nowak a.w. 1993, p. 278: 'The interpretation of the term 'penalty' is closely related to that of 'criminal offence'. In conformity with the meaning of these terms in Art. 14 and the broad interpretation by Opsahl and de Zayas, every sanction that has not only a preventive but also a retributive and/or deterrent character is thus to be termed a penalty, regardless of its severity or the formal qualification by law and the organ imposing it.'

EHRM 8 juni 1995, NJ 1996, l, m. nt. Knigge (Jamil v. France). 
van een geldboete met lijfsdwang aan de douane die als medevervolgende instantie was opgetreden. In het kader van de zaak bij het EHRM stond de vraag centraal of de lijfsdwang (een soort hechtenis), die dient als middel om betaling van de boete (bij wanbetaling) alsnog af te dwingen, een 'penalty' in de zin van artikel 7 EVRM was. Het EHRM merkte de lijfsdwang aan als 'penalty'.

Het feit dat het in de twee bovengenoemde zaken ging om bijkomende straffen bemoeilijkte beantwoording van de vraag of er sprake was van een 'penalty' enigszins. Ten aanzien van de in dit boek centraal staande bestuurlijke boete lijkt dit probleem zich niet voor te doen. De (punitieve) bestuurlijke boete vormt immers de hoofdstraf hetgeen mijns inziens impliceert dat er sprake is van een 'penalty' in de zin van artikel 7 van het EVRM, mede omdat de procedure tot oplegging van de bestuurlijke boete aangemerkt moet worden als 'criminal charge'.

\section{Zwaardere straf}

Op deze plaats moet nog worden opgemerkt dat het niet in alle gevallen eenvoudig is aan te geven of een, na het begaan van de overtreding tot stand gekomen wetswijziging met betrekking tot de op te leggen straf, leidt tot het opleggen van een zwaardere straf. Indien het gaat om een verhoging van de (maximum)straf die op basis van de oude regeling kon worden opgelegd (bijvoorbeeld verhoging van de maximum boete of de maximum gevangenisstraf) doet zich geen probleem voor. Dit wordt echter anders als een sanctie van een bepaalde soort (bijvoorbeeld een geldboete) in de nieuwe wetsbepaling wordt vervangen door een andere sanctie (bijvoorbeeld een gevangenisstraf). Welke sanctie zwaarder is, is dan niet zonder meer vast te stellen. Jurisprudentie van het EHRM is op dit punt niet voorhanden. Blijkbaar levert de term 'heavier penalty' in de praktijk dan ook niet vaak een probleem op. ${ }^{251}$ Een verklaring daarvoor zou kunnen zijn dat bij verzwaring van de sanctie de nationale wetgevers doorgaans de bestaande sanctie verzwaren (door bijvoorbeeld te voorzien in een hogere maximum boete, of een langere maximum gevangenisstraf).

\section{Lex cirta-be'ginsel}

Ten aanzien van het nullum crimen sine lege-beginsel geldt dat op basis van een toegankelijke (accessible) delictsomschrijving voorzienbaar moet zijn welk handelen of nalaten strafbaar is, zo zagen wij in de vorige subparagraaf. Het voorgaande geldt tevens ten aanzien van het nulla poena sine lege-beginsel. Dit brengt met zich dat de sanctiebepaling nauwkeurig, duidelijk en ondubbelzinnig geformuleerd moet zijn. Het voorgaande blijkt uit de zaak 'Başkaya and Okçuoğlu':

'I he Court recalls that, according to its case-law, Article 7 embodies, inter alia, the principle that only the law can define a crime and prescribe a penalty (nullum crimen, nulla poena sine lege) and the principle that the criminal law must not be extensively construed to an accused's detriment, for instance by analogy. From these principles it follows that an offence and the sanctions provided for it must be clearly defined in the law..$^{252}$

251 Zie in dit kader ook: EHRM 27 februari 2001, no. 29295/95 en 29363/95 (Ecer and Zeyrek v. Turkey).

252 EHRM 8 juli 1999, no. $23536 / 94$ en $24408 / 94$ (Başkaya and Okçuoğlu judgement), i.h.b. $\$ 36$. 
Het EHRM gaat er derhalve van uit dat óók de sanctiebepaling nauwkeurig, duidelijk en ondubbelzinnig geformuleerd moet zijn. Dit brengt met zich dat het voorzienbaarheidscriterium, en de daaromtrent bestaande jurisprudentie van het Hof, eveneens ten aanzien van de op te leggen sanctie relevant is. Daarnaast geldt uiteraard ook het vereiste dat de sanctiebepaling toegankelijk (accessible) moet zijn.

Vermeldenswaardig is nog dat het EHRM in de zaak 'Başkaya and Okçuoğlu' tot de conclusie kwam dat aan Okçuoğlu een gevangenisstraf was opgelegd in strijd met het in artikel 7 van het EVRM neergelegde nulla poena sine lege-beginsel. De reden hiervoor was dat aan Okçuoğlu als uitgever een sanctie was opgelegd, wegens een publicatie die 'should be considered separatist propaganda against the indivisibility of the State', terwijl die sanctie op basis van de wettelijke bepaling alleen kon worden opgelegd aan redacteuren. De sanctiebepaling was naar het oordeel van het EHRM ten onrechte naar analogie toegepast op Okçuoğlu als uitgever:

'On the other hand, the second applicant complained that he had been sentenced to a term of imprisonment under a provision in section 8 (2) which expressly applied to the sentencing of editors, while publishers could only be punished by a fine. In this connection, the Government stressed that the application of section $8(2)$ to publishers would normally entail a more favourable sentence than under section 8 (1). Although this may be so, it rather appears that section $8(2)$ was a lex specialis on the sentencing of editors and publishers and that the sentence imposed on the applicant publisher in the present case was based on an extensive construction, by analogy, of the rule in the same sub-section on the sentencing of editors. In these circumstances, the Court considers that the imposition of a prison sentence on the second applicant was incompatible with the principle nulla poena sine lege embodied in Article $7 .{ }^{253}$

\section{Afsluitend}

Met betrekking tot het nulla poena sine lege-beginsel kan het volgende geconcludeerd worden. Een maatregel of sanctie, die punitief van aard is en die wordt opgelegd nadat ienand is veroordeeld wegens het plegen van een 'criminal offence' moet in de regel aangemerkt worden als een 'penalty'.

Beantwoording van de vraag wanneer een straf moet worden aangemerkt als een zwaardere straf lijkt in de praktijk geen problemen op te leveren. Tenslotte geldt ten aanzien van de sanctiebepaling (evenals ten aanzien van de delictsomschrijving) dat deze nauwkeurig, duidelijk en ondubbelzinnig geformuleerd moet zijn, zodat voor de burger voorzienbaar is welke sanctie kan worden opgelegd bij schending van de strafbepaling.

\subsection{4.c Het beginsel dat de overtreder dient te profiteren van een, na het begaan van het strafbare feit, totstandgekomen wetswijziging die voorziet in de oplegging van een lichtere straf}

Op het beginsel dat de overtreder dient te profiteren van een, na het begaan van het strafbare feit, totstandgekomen wetswijziging die voorziet in de oplegging van een 
lichtere straf zal ik, zoals gezegd, minder uitvoerig ingaan. Genoemd beginsel is slechts neergelegd in artikel 15, eerste lid, derde volzin IVBPR. In artikel 7 EVRM treffen we het niet aan. Voor zover ten aanzien van de bepaling onduidelijkheden mochten bestaan kunnen deze niet aan de hand van jurisprudentie van het Human Rights Committee worden verduidelijkt simpelweg omdat geen noemenswaardige jurisprudentie voor handen is.

Aangezien laatstgenoemd beginsel, zoals gezegd, niet tevens is opgenomen in artikel 7 EVRM biedt ook de rechtspraak van het EHRM geen houvast. Nowak wijst er op dat de redactie van artikel 15, eerste lid, derde volzin IVBPR zo vaag is dat er een flink aantal interpretatieproblemen zullen ontstaan. ${ }^{254}$ Daarbij kan gewezen worden op de term 'lichtere straf. Maar ook de vraag tot welk moment de lichtere straf met terugwerkende kracht moet worden toegepast kan worden opgeworpen. Op basis van de redactie van artikel 15, eerste lid, derde volzin IVBPR, zou bijvoorbeeld gesteld kunnen worden dat ook de lichtere sanctie opgelegd moet worden als de verandering van wetgeving heeft plaatsgevonden na de definitieve veroordeling en bestraffing van een persoon. ${ }^{25.5}$ Mijns inziens gaat dat echter te ver. Na definitieve veroordeling en bestraffing, als het vonnis onherroepelijk is geworden, of nadat een boetebesluit formele rechtskracht heeft gekregen, kan naar mijn oordeel niet meer getornd worden aan de opgelegde sanctie.

Zoals gezegd is het beginsel dat de overtreder dient te profiteren van een, na het begaan van het strafbare feit, totstandgekomen wetswijziging die voorziet in de oplegging van een lichtere straf, niet neergelegd in artikel 7 EVRM. Dit neemt echter niet weg dat het EHRM zich een voorstander lijkt te tonen van het opleggen van een lichtere straf in een dergelijke situatie. Het voorgaande standpunt werd door het EHRM expliciet ingenomen in de zaak 'G. v. France ${ }^{, 256}$ getuige de hierna weergegeven passage uit genoemde uitspraak:

'According to the Court's case-law, Article 7 para. 1 (art. 7-1) of the Convention embodies generally the principle that only the law can define a crime and prescribe a penalty and prohibits in particular the retrospective application of the criminal law where it is to an accused's disadvantage [curs. KA] (...). In the present case the Court, like the Commission, is of the opinion that the offences of which the applicant was accused fell within the scope of the former Articles 332 and 333 of the Criminal Code, which satisfied the requirements of foreseeability and accessibility (...). There was consistent case-law from the Court of Cassation, which was published and therefore accessible, on the notions of violence and abuse of authority. As regards the notion of violence, the new provisions in the new Articles 332 and 333 of the Criminal Code merely confirmed this case-law. The Court notes that the acts of which the applicant was accused also fell within the scope of the new legislation. On the basis of the principle that the more lenient law should apply both as regards the definition of the offence and the sanctions imposed, the national courts applied the new Article 333 of the Criminal Code for the imposition of sanctions as that provision downgraded the offence of which $\mathrm{Mr} \mathrm{G}$. was accused from serious offence (crime) to less serious offence (délit) (...). Its application, admittedly retrospective, therefore operated in

255 Zie in deze zin ook: Nowak a.w. 1993, p. 279.

256 EHRM 27 september 1995, Series A vol. 325-B, NJ 1996, 49, m. nt. Knigge (G. v. France). 
the applicant's favour. In conclusion, there has been no violation of Article 7 para. 1 (art. 7 1) of the Convention [curs. KA].257

Ten aanzien van het beginsel dat de overtreder dient te profiteren van een, na het begaan van het strafbare feit, totstandgekomen wetswijziging die voorziet in de oplegging van een lichtere straf, kan, op basis van het voorgaande, het volgende worden geconcludeerd. Genoemd beginsel is slechts opgenomen in artikel 15 IVBPR en niet in artikel 7 EVRM. De redactie van artikel 15, eerste lid, derde volzin IVBPR is op punten niet duidelijk. Dit zou kunnen leiden tot interpretatieproblemen. ${ }^{258}$ Tenslotte kan uit rechtspraak van het EHRM worden afgeleid dat het zich een voorstander toont van het opleggen van een lichtere straf in het geval dat er na het begaan van het strafbare feit, een wetswijziging tot stand is gekomen die resulteert in de oplegging van een lichtere straf.

\subsection{Afsluitend}

In dit hoofdstuk is een poging ondernomen om de (in het kader van dit onderzoek relevante) verdragsrechtelijke waarborgen, die in acht moeten worden genomen bij de oplegging van een bestuurlijke boete, in kaart te brengen. Genoemde waarborgen vloeien voort uit artikel 6 en 7 EVRM en 14 en 15 IVBPR. In dit hoofdstuk is in eerste instantie uitvoerig stilgestaan bij de jurisprudentie van het EHRM met betrekking tot de term 'criminal charge'. Deze jurisprudentie is relevant omdat op basis daarvan de vraag beantwoord kan worden of de oplegging van een bestuurlijke boete aangemerkt moet worden als een 'criminal charge'. Alleen indien deze laatste vraag bevestigend beantwoord wordt gelden de andere, uit artikel 6 en 7 EVRM en 14 en 15 IVBPR voortvloeiende, waarborgen die specifiek zien op 'strafvervo]ging'. ${ }^{259}$

Geconcludeerd kan worden dat het EHRM op hoofdlijnen een koers heeft uitgezet op basis waarvan, overigens niet altijd even eenvoudig, vastgesteld kan worden of de oplegging van een sanctie of maatregel in concreto een 'criminal charge' oplevert. Het EHRM gaat uit van het autonome karakter van de term 'criminal charge'. Dit betekent dat lidstaten de verdragswaarborgen niet kunnen frustreren door een ander 'etiket' (dan straf/strafrecht) op een sanctie te plakken. Het feit dat de bestuurlijke boete naar nationaal recht een bestuursrechtelijke en géen strafrechtelijke sanctie is neemt derhalve niet weg dat de oplegging van deze boete op basis van autonome, door het EHRM ontwikkelde, criteria moet worden aangemerkt als 'criminal charge'.

Vanwege de algemene strekking van de overtreden norm (het autonome criterium 'de aard van de overtreding') en het punitieve karakter van de bestuurlijke boete (het autonome criterium 'de aard van de sanctie') kan ten aanzien van de oplegging van een bestuurlijke boete gezegd worden dat deze onder het 'criminal charge-begrip' valt.

257 'G. v. France' $\$ 24$ tot en met 27.

258 Gelet op de (vrijwel geheel) ontbrekende rechtspraak van het Human Rights Commitee op dit punt is onduidelijk in hoeverre er (in de praktijk) reeds interpretatieproblemen gerezen zijn.

259 In hoofdstuk twee heb ik overigens al aangegeven dat mijn inziens ook los van het veruragsrecht rekening moet worden gehouden met de essentięle straf(proces)rechtelijke regels en beginsel bij de. oplegging van punitieve sancties. Genoemde sancties maken naar mijn mening immers deel uit van het strafrecht in nume zin. 
Aangezien de oplegging van een bestuurlijke boete aangemerkt moet worden als een 'criminal charge' in de zin van het EVRM zijn de straf(proces)rechtelijke waarborgen die voortvloeien uit artikel 6 en 7 EVRM en 14 en 15 IVBPR van toepassing bij de oplegging van deze boete.

In dit hoofdstuk is vervolgens aandacht geschonken aan een aantal straf(proces)rechtelijke waarborgen die voortvloeien uit artikel 6 en 7 EVRM en 14 en 15 IVBPR. In het bijzonder is ingegaan op de onschuldpresumptie, het nemo tenetur-beginsel, het nullum crimen sine lege-beginsel, het nulla poena sine lege-beginsel, het lex certabeginsel en het beginsel dat de overtreder dient te profiteren van een, na het begaan van het strafbare feit, totstandgekomen wetswijziging die voorziet in de oplegging van een lichtere straf. Genoemde waarborgen - inclusief de (nadere) uitwerking die daaraan door het EHRM is gegeven - zijn in het bijzonder relevant in het kader van de hierna, in hoofdstuk vier, te bespreken Nederlandse boeteregelingen waaronder in het bijzonder de regeling uit het Voorontwerp van de vierde tranche van de Awb. 


\section{Hoofdstuk 4}

\section{De bestuurlijke boete in Nederland}

\subsection{Inleiding}

Nadat in hoofdstuk twee de bestuurlijke boete vanuit een algemeen-theoretisch perspectief is bekeken en in hoofdstuk drie aandacht is uitgegaan naar de verdragsrechtelijke waarborgen die bij de oplegging van een bestuurlijke boete tenminste in acht genomen moeten worden, zal in dit hoofdstuk de procedure tot oplegging van bestuurlijke boeten, zoals die in Nederland gestalte heeft gekregen, dan wel lijkt te krijgen, aan de orde komen. De juridische normering van de procedure tot het opleggen van een bestuurlijke boete en de rechtsbescherming van de (vermoedelijke) overtreder in dat kader zullen daarbij centraal staan. Hierbij zal worden uitgegaan van de boeteregeling zoals die is voorgesteld door de commissie Scheltema in het Voorontwerp van de vierde tranche van de Awb. ${ }^{1}$ De door genoemde commissie voorgestelde boeteregeling kan worden gezien als een algemene regeling waarin de meeste, zo niet alle, aspecten van reeds bestaande bestuurlijke boeteregelingen zijn neergelegd. $\mathrm{Na}$ inwerkingtreding van de vierde tranche zullen de algemene bepalingen die in de bijzondere wetten zijn opgenomen, met betrekking tot de oplegging van bestuurlijke boeten, doorgaans verdwijnen. Afwijking van de Awb en maatwerk in de bijzondere bestuursrechtelijke wetten blijft uiteraard mogelijk. De vierde tranche beoogt echter het algemene kader te bieden dat als hoofdregel van toepassing zal zijn op boeteregelingen uit de bijzondere bestuursrechtelijke wetten. Gelet op het voorgaande zal hier dan ook niet expliciet aandacht uit gaan naar reeds bestaande wettelijke regelingen op basis waarvan bestuurlijke boeten kunnen worden opgelegd. ${ }^{2}$

In dit hoofdstuk zal de voorgestelde boeteregeling worden beschreven en bekeken in het licht van de, onder meer uit artikel 6 en 7 EVRM en 14 en 15 IVBPR voortvloeiende, fundamentele straf(proces)rechtelijke waarborgen. Ten eerste zal aangegeven worden of er door de commissie Scheltema in het Voorontwerp in voldoende mate rekening is gehouden met de, in hoofdstuk drie van dit boek nader geanalyseerde, verdragsrechtelijke waarborgen. Daarbij zal in het bijzonder aandacht uitgaan naar die verdragsrechtelijke waarborgen waaraan in onvoldoende mate invulling lijkt te zijn gegeven door de commissie Scheltema.

Daarnaast zal in hoofdstuk vier aandacht geschonken worden aan de vraag of op basis van het bestuursprocesrecht op een juiste wijze vorm gegeven kan worden aan de procedure tot oplegging van punitieve bestuursrechtelijke sancties zoals de bestuurlijke boete. De bestuurlijke boete maakt, zoals ik in hoofdstuk twee reeds aangegeven heb,

Zie: Voorontwerp Algemene wet bestuursrecht vierde tranche, Commissie wetgeving algemene regels van bestuursrecht, Den Haag 7 september 1999 (hiema: Voorontwerp). Zie met betrekking tot de opkomst van de bestuurlijke boete $\S 2.3 .1$ van dit boek.

Op deze plaats wil ik nog wijzen op de in de inleiding van dit boek genoemde dissertaties en andere publicaties waarin reeds bestaande bestuurlijke boeteregelingen uitvoerig zijn beschreven. Men denke daarbij bijwoorbeeld aan de boeteregeling uit de WAO en de WW, of de bestuurlijke boeten die opgelegd worden ten aanzien van de lichtere verkeersovertredingen (op grond van de WAHV). 
naar mijn mening deel uit van het strafrecht in ruime zin. Derhalve dienen mijns inziens, ook los van het verdragsrecht, tenminste de fundamentele straf(proces)rechtelijke beginselen in acht genomen te worden bij de oplegging van een bestuurlijke boete. Men kan echter de vraag stelien of het bestuursproces, waarin de rechter niet wordeelt over de bewezenverklaring van het feit, de strafbaarheid van de overtreder en de oplegging van een straf, maar waarin de rechtmatigheid van een bestuursbesluit centraal staat, zich leent voor het bieden van rechtsbescherming in het kader van bestuurlijke boeten.

Hiema zal voorts blijken dat de commissie Scheltema in het Voorontwerp bepaalde delen uit het nationale straf(proces)recht (soms afwijkend) heeft overgenomen. Het voorgaande impliceert dat ten aanzien van die straf(proces)rechtelijke aspecten de strafrechter en de bestuursrechter naar verwachting uiteenlopende rechtspraak zullen gaan ontwikkelen. ${ }^{3}$ Naar al deze aspecten zal, aan de hand van een artikelsgewijs commentaar op de door de commissie Scheltema voorgestelde boeteregeling, aandacht uitgaan.

\subsection{Voorontwerp en waarborgen?}

\subsubsection{Het Voorontwerp - een inleiding -}

\section{Algemeen}

Hoofdstuk vijf van de Awb heeft betrekking op bestuurlijke handhavingsbevoegdheden. Met de invoering van de derde tranche van de Awb hebben het toezicht op de naleving (afdeling 5.2), bestuursdwang (afdeling 5.3) en de dwangsom (afdeling 5.4) reeds een plaats gekregen in hoofdstuk vijf van de Awb. Het Voorontwerp van de vierde tranche van de Awb voegt aan hoofdstuk vijf nog de algemene regeling tot oplegging van een bestuurlijke boete toe. ${ }^{4}$ Het opnemen van de bepalingen omtrent (het opleggen van) de bestuurlijke boete in de vierde tranche van de Awb brengt ook enige wijzigingen mee ten aanzien van de inmiddels in genoemd hoofdstuk opgenomen bepalingen aangaande bestuursdwang en de dwangsom. Genoemde wijziging zullen in dit boek verder buiten beschouwing blijven. ${ }^{5}$ Hiema zal slechts aandacht uit gaan naar de bepalingen uit het Voorontwerp die relevant zijn in het kader van de voorgestelde boeteregeling. Voordat echter op specifieke bepalingen ingegaan zal worden zal eerst nog aandacht uitgaan naar een aantal algemene aspecten van de voorgestelde boeteregeling.

\section{Handhavingstekort en doelmatige handhaving}

De (reeds eerder ingezette tendens tot) invoering van de bestuurlijke boete (op grote(re) schaal) moet ook ${ }^{6}$ volgens de commissie Scheltema worden gezien in het licht van het

3 Zie in dit kader ook de kritiek van Corstens (a.w. 2000, p. 1189-1190).

4 Uiteraard geldt voor de bestuurlijke boete (evenals voor bestuursdwang) dat de bevoegdheid tot hit opleggen van de boete neergelegd moet zijn in een bijzondere bestuursrechtelijke wet. Zie hierover at. tikel 5.0 .4 van het Voorontwerp.

5 De belangrijkste wijzigingen komen aan de orde in: G.H. Addink en M.J. Duijkersloot; Kanttekeningen bij 'bestuurlijke handhaving' in het Voorontwerp 4e tranche Awb, NTB $1999 / 10$ p. $255 \mathrm{t} / \mathrm{m} 262$ en A.R. Neerhof en R.J.N. Schlossels, De vierde tranche van de Algemene wet bestuursrecht en hat ruimtelijk bestuursrecht, Bouwrecht 2000 p. 1020-1038, i.h.b. p. 1024-1034.

6 Zie het CTW-rapport a.w. 1994, p. 7-9. Ook daarin werd de bestuurlijke boete gezien als middel om 
handhavingstekort. ${ }^{7}$ Met betrekking tot de wenselijkheid om het bestuur een aandeel in de punitieve handhaving te geven stelt de commissie Scheltema het volgende:

'Het bijzondere bestuursrecht is de neerslag van door democratisch gelegitimeerde organen in het algemeen belang geformuleerd overheidsbeleid. Wil dit beleid zijn doel bereiken, dan zal dit bijzondere bestuursrecht voldoende moeten worden gehandhaafd. Daarvoor zijn veelal punitieve sancties nodig. Het opleggen daarvan was vanouds de taak van de strafrechtelijke autoriteiten. Zoals hiervoor uiteengezet heeft de ervaring echter geleerd dat het wenselijk kan zijn ook het bestuur een aandeel in de punitieve handhaving te geven. Dat kan zijn omdat het wenselijk is om uitvoering en handhaving, dan wel reparatoire en punitieve handhaving, gedeeltelijk in één hand te brengen, en aldus te benadrukken dat het bestuur ook voor de handhaving verantwoordelijkheid draagt. (...) Een andere reden kan zijn, dat de handhaving specialistische deskundigheid vergt, terwijl het, gelet op de relatief geringe aantallen zaken, voor het strafrechtelijk apparaat niet lonend is deze deskundigheid op te bouwen. (...) Een derde reden kan zijn dat de geringe ernst van de overtredingen de inzet van strafrechtelijke procedures niet rechtvaardigt. (...) Tenslotte kan de massaliteit van de overtredingen een argument zijn voor bestuursrechtelijke afdoening. (...) Vaak gaat het om een combinatie van genoemde argumenten. ${ }^{8}$

De argumenten die de commissie Scheltema aanvoert voor afdoening van, voorheen strafrechtelijk gesanctioneerde, schendingen van bepalingen uit het bijzonder bestuursrecht, middels bestuurlijke boeten komen overeen met de in hoofdstuk twee van dit boek weergeven criteria die gehanteerd zouden kunnen worden ter motivering van de keuze voor bestuursrechtelijke sanctionering. ${ }^{9}$ Opvallend is dat de geringe ernst niet als een criterium van bijzondere waarde genoemd lijkt te worden. Het komt pas aan bod na opsomming van een aantal criteria die voomamelijk pragmatisch van aard zijn. Zie ik het goed dan toont de commissie Scheltema zich met name vanwege pragmatische redenen een voorstander van sanctionering middels bestuurlijke boeten. Er is naar mijn mening dan ook duidelijk sprake van een tendens om, vanwege doelmatigheidsoverwegingen, afdoening van bepaalde normschendingen over te hevelen van het strafrecht naar het bestuursrecht.

\section{Voorgeschiedenis}

Het op steeds grotere schaal creëren van bestuurlijke boetebevoegdheden lijkt een onomkeerbare ontwikkeling te zijn. ${ }^{10}$ Derhalve is in het kader van de bestuurlijke boetediscussie momenteel met name de vraag naar de te volgen (boete)procedure relevant. In dit kader wordt op deze plaats nog eens kort stil gestaan bij de eerste aanzet tot het formuleren van een algemene regeling tot oplegging van bestuurlijke boeten.

het handhavingstekor (ten dele) op te lossen.

7 Zie Voorontwerp p. 90. Zie in dit kader ook \$ 2.3.1 van dit boek. Zie voorts: M.J.C. Visser, Zorgplichtbepalingen in het strafrecht (diss. UM), Gouda Quint, 2001, p. 208-219.

Voorontwerp p. 94-95.

9 Zie $\$ 2.3$ van dit boek

10 Hoewel wat betreft het creẻren van boetebevoegdheden op decentraal niveau een pas op de plaats gemaakt lijkt te worden. De regering geeft daar (in bepaalde gevallen) de voorkeur aan strafrechtelijke handhaving. Vgl. L.J.J. Rogier, Kronick handhaving van het bestuursrecht, NTB 2002, p. 72 . Zie voorts: Kamerstukken II, 2001-2002, 26604 en 26 345, nr. 14. 
In 1994 werd in het CTW-rapport aangegeven dat twee typen boetenregelingen denkbaar zijn. " De Toetsingcommissie maakte daarbij een onderscheid tussen model A en model B. Op basis van model A is het strafrecht in beginsel uitgesloten (slechts ten aanzien van overtredingen waarbij letsel aan personen is ontstaan of schade aan goede. ren is toegebracht kan bepaald worden dat voorzieningen van strafrechtelijke of strafvorderlijke aard niet zijn uitgesloten). Daarnaast wordt in model A in de wet aangegeven welke boete maximaal mag worden opgelegd, terwijl in een bijlage in de wet is bepaald welke boete per afzonderlijke overtreding moet worden opgelegd. De hoogte van de boete dient derhalve uitputtend geregeld te worden op basis van model A. Gezien de geringe flexibiliteit moet in de boeteregeling conform model A volgens de Toetsingscommissie wel een hardheidsclausule opgenomen worden. ${ }^{12}$

In model B is zowel bestuursrechtelijke als strafrechtelijke sanctionering, ten aanzien van dezelfde overtreding, mogelijk. Met het oog op het ne bis in idem-beginsel en het una via-beginsel kunnen beide sancties uiteraard niet gelijktijdig worden opgelegd. Op grond van het voorgestelde model B dient in de wet slechts aangegeven te worden welke boete maximaal mag worden opgelegd, terwijl de hoogte van de boete in een concreet geval moet worden afgestemd op de ernst van de gedraging, de mate van verwijtbaarheid en de omstandigheden waarin de overtreder verkeert. ${ }^{13}$

De Toetsingscommissie geeft aan dat de voorkeur uit gaat naar toepassing van model A. De boeteregeling uit model $\mathbf{A}$ biedt het sanctionerende bestuursorgaan nagenoeg geen ruimte om een eigen beleid te voeren. Dit is van belang in verband met de duidelijkheid van de regeling en uit rechtszekerheidsoogpunt. ${ }^{14}$

Uit het Voorontwerp kan worden afgeleid dat de commissie Scheltema géén keuze heeft gemaakt voor ofwel model A ofwel model B. Op basis van de voorgestelde regeling is zowel beboeting op grond van model A als op grond van model B mogelijk. De keuze voor het ene dan wel het andere model heeft de commissie Schelterna overgelaten aan de bijzondere wetgever. ${ }^{15}$

\section{Punitief-reparatoir}

Volgens artikel 5.4.1.1 van het Voorontwerp wordt onder een bestuurlijke boete verstaan: 'de bestuurlijke sanctie, inhoudende een onvoorwaardelijke verplichting tot betaling van een geldsom, die is gericht op bestraffing van de overtreder.' Daarmee onderscheidt de bestuurlijke boete zich enerzijds van de strafrechtelijke boete, omdat deze laatste opgelegd wordt door de onafhankelijke en onpartijdige strafrechter. Anderzijds onderscheidt de bestuurlijke boete zich vanwege haar bijzondere karakter van de twee andere sancties die zijn opgenomen in hoofdstuk vijf van de Awb; de bevoegdheid tot het toepassen van bestuursdwang en het opleggen van een last onder dwangsom. Aan genoemd onderscheid tussen de bestuurlijke boete enerzijds en bestuursdwang en de dwangsom anderzijds is in hoofdstuk twee van dit boek reeds aandacht besteed. Volledigheidshalve zal ik op deze plaats nog kort op dit onderscheid ingaan.

II CTW-rapport, a.w. 1994, p. 68.

12 CTW-rapport, a.w. 1994, p. 68. De boeteregeling uit de WAHV is bijvoorbeeld gebaseerd op modelA

13 CTW-rapport, a.w. 1994, p. 69.

14 CTW-rapport, a.w. 1994, p. 69-70.

15 Voorontwerp p. 96-97. 
De bestuurlijke boete onderscheidt zich van de twee andere, in hoofdstuk vijf van de Awb, opgenomen sancties in die zin dat de bestuurlijke boete aangemerkt moet worden als een punitieve sanctie terwijl de toepassing van bestuursdwang en de last onder dwangsom in het Voorontwerp (en naar geldend recht) worden aangemerkt als herstelsancties (ook wel reparatoire sancties genoemd). ${ }^{16}$ Aangezien de oplegging van een punitieve sancties door het EHRM (in beginsel ${ }^{17}$ ) wordt aangemerkt als een 'criminal charge' dienen ten aanzien van de oplegging van een dergelijke sanctie, zo blijkt mede uit hoofdstuk drie van dit boek, extra waarborgen te gelden. Het gaat daarbij niet alleen om de waarborgen die voortvloeien uit artikel 6 EVRM maar ook om de waarborgen uit artikel 7 EVRM, en artikel 14 en 15 IVBPR. De commissie Scheltema is zich hiervan bewust zo blijkt uit het Voorontwerp:

'Dit alles (argumenten voor handhaving door middel van bestuurlijke boeten [KA]) laat vanzelfsprekend onverlet, dat, hoe sterk ook de doelmatigheidsargumenten voor bestuurlijke handhaving mogen zijn, een rechtsstaat bij het opleggen van punitieve sancties dient te voorzien in voldoende, aan het strafrecht gelijkwaardige, rechtsbescherming van de burger. Dit volgt ook uit artikel 6 EVRM. (...) De artikelen 6 en 7 van het Europees Verdrag tot Bescherming van de Rechten van de Mens en de Fundamentele Vrijheden (EVRM) en de artikelen 14 en 15 van het Internationale Verdrag inzake Burgerrechten en Politieke Rechten (IVBPR) bevatten een aantal belingrijke rechten en waarborgen voor degene tegen wie een "strafvervolging» (in de authentieke Engelse tekst: «a criminal charge») wordt ingesteld. ${ }^{18}$

Voor een deel zijn de uit artikel 6 en 7 EVRM en 14 en 15 IVBPR voortvloeiende waarborgen dan ook in het Voorontwerp van de vierde tranche opgenomen. $\mathrm{Z}_{0}$ is in het Voorontwerp onder meer voorzien in een regeling omtrent het legaliteitsbeginsel ${ }^{19}$, het ne bis in idem-beginse $\left.\right|^{20}$, het zwijgrecht en de cautie. ${ }^{21}$ Een aantal andere waarborgen lijkt echter te ontbreken ${ }^{22}$ Zo bestaat er bijvoorbeeld bij bestuurlijke boeten die minder bedragen dan 340,- Euro geen hoorplicht voor het bestuursorgaan dat voornemens is de bestuurlijke boete op te leggen. ${ }^{23}$ Dit betekent dat de overtreder zijn zienswijze (for-

16 Voorontwerp p. 92. Zie overigens ook $§ 2.2 .3 .3 . c$ van dit boek. Daarin heb ik aangegeven dat naar mijn mening de last onder dwangsom onder omstandigheden als punitieve sanctie aan moet worden gemerkt.

17 Zie hoofdstuk drie van dit boek (waaruit volgt dat het niet altijd even eenvoudig is om aan de hand van de rechtspraak van het EHRM vast te stellen of oplegging van een bepaalde sanctie moet worden gekwalificeerd als een 'criminal charge').

18 Voorontwerp p. 95. Zie ook: Voorontwerp p. 96 en 98-100

19 Het legaliteitsbeginsel is terug te vinden in artikel 5.0.4 Voorontwerp voor bestuurlijke sancties in het algemeen, en in artikel 5.4.1.7 Voorontwerp in het bijzonder ten aanzien van de bestuurlijke boete.

20 Het ne bis in idem-beginsel is met betrekking tot de bestuurlijke boete terug te vinden in artikel 5.4.1.4 van het Voorontwerp. Daarnaast treffen we in artikel 5.0 .6 en 5.0 .8 Voorontwerp cen regeling aan met betrekking tot cumulatie van herstelsancties en een regeling met betrekking tot (eendaadse en meerdaadse) samenloop voor bestuurlijke sancties in het algemeen

21 Het zwijgrecht en de cautie zijn geregeld in artikel 5.0.11 en artikel 8:28a Voorontwerp.

22 Uiteraard, dit dient niet uit het oog verloren te worden, zijn in het strafrecht in het kader van een door het OM aangeboden transactie ook niet alle waarborgen uit het EVRM en IVBPR (onverkort) van toepassing. De vermoedelijke overtreder kan er in dat geval echter voor kiezen niet in te stemmen met het transactievoorstel teneinde de zaak voor laten komen bij de strafrechter. In het bestuursrecht bestaat voor de vermoedelijke overtreder niet de mogelijkheid te kiezen voor een procedure waarin méer rechtsbescherming geboden kan worden.

Zie hierover artikel 5.4.2.6 Voorontwerp. 
meel) niet naar voren kan brengen (zich niet kan verdedigen) voordat de boete opgelegd wordt. ${ }^{24}$ De vraag is of dit in overeenstemming is met de uit artikel 6 EVRM voortvloeiende onschuldpresumptie. Daarnaast kan gewezen worden op een beperkte invulling van het zwijgrecht en de in bepaalde gevallen té beperkte toetsingsbevoegdheid van de bestuursrechter. Op deze, en andere, aspecten van de beperkte uitwerking van bepaalde verdragsrechtelijke waarborgen zal ik hierna nog ingaan. ${ }^{25}$

\section{Strafrecht}

Onder meer vanwege het 'criminal charge'-karakter van de bestuurlijke boete meent de commissie Scheltema dat het punitief bestuursrecht niet nodeloos moet afwijken van het strafrecht. ${ }^{26}$ Vervolgens plaatst de commissie daar meteen de volgende kanttekening bij: 'Niettemin brengt het gegeven dat de bestuurlijke boete vooral bedoeld is voor relatief eenvoudige delicten, mee dat aan bepaalde leerstukken in het bestuursrecht geen behoefte bestaat. ${ }^{27}$ Zoals ik in de inleiding reeds heb aangegeven zal, bij de arikelsgewijze bespreking van het Voorontwerp nog blijken dat de commissie Scheltema in dat kader op bepaalde punten afwijkt van het straf(proces)recht of een andere uitleg geeft aan strafprocesrechtelijke leerstukken. Deze ontwikkeling wordt niet door alle juristen toegejuicht. In het bijzonder Corstens ${ }^{28}$ en Knigge ${ }^{29}$ hebben kritiek op de frag. mentarische en eigen wijze waarop de commissie Scheltema straf(proces)rechtelijke bepalingen in het Voorontwerp heeft overgenomen. Corstens stelt dienaangaande het volgende:

'Het Voorontwerp regelt een aantal uit het 'klassieke' strafrecht bekende leerstukken afzonderlijk. Onderwerpen als daderschap en deelneming, het ne-bis-in-idem-beginsel en de samenloop zijn voorwerp van in boek I van het Wetboek van Strafrecht opgenomen bepalingen en van de onder meer daarop gebaseerde, in de loop van de eeuwen totstand. gekomen jurisprudentie en ontwikkelde dogmatiek. Waarom heeft de Commissie Scheltena zich niet de moeite bespaard van het ontwerpen van bepalingen die aan die leerstukken gestalte geven voor wat betreft de bestuurlijke boeten? Het is onduidelijk welk voordeel wordt behaald door het opnemen van nieuwe formuleringen in de Awb. Het gevaar is groot dat juist ook door die vaak net iets afwijkende formuleringen de rechtsontwikkeling met betrekking tot vraagstukken die gemeen zijn aan zowel de klassieke tak van het punitief strafrecht als aan de moderne tak ervan, te weten het boeterecht, gaat uiteenlopen. ${ }^{30}$

Corstens lijkt, zo meen ik uit het bovenstaande op te kunnen maken, te vrezen voor een verval van de, ten aanzien van strafrechtelijke leerstukken bestaande, rechtseenheid. Corstens pleit in dat kader voor een harmoniserende regeling tot het opleggen van be-

24 Het feit dat een hoorplicht ontbreekt neemt niet weg dat het bestuursorgaan desalniettemin de $b c$ voegdheid heeft om een overtreder de mogelijkheid te bieden zijn zienswijze naar voren te brengen.

25 Zie over de boeteregeling uit het Voorontwerp van de vierde tranche van de Awb in relatie tot dic verdragsrechtelijke waarborgen: I.Y. De Raat en R.J.G.M. Widdershoven, De bestuurlijke boete in de Algemene wet bestuursrecht, NJCM-Bulletin 2000, p. 771-788 en C.L.G.F.H. Albers, De bestuurlije boete. Magische lijn of hellend vlak?, JBplus 2000, p. 138-152.

26 Voorontwerp p. 100.

27 Voorontwerp p. 100.

28 Corstens a.w. 2000, p. 1189-1190.

29 Knigge a.w. 2000 , p. 92 en $94-95$.

30 Corstens a.w. 2000, p. 1189-1190. 
stuurlijke boeten waarin, waar nodig, gewerkt wordt met uit het strafrecht afkomstige leerstukken. In de harmoniserende regeling moet zoveel mogelijk worden volstaan met het verwijzen naar de strafrechtelijke leerstukken. Het is dan, zo begrijp ik, aan de bestuursrechter zo nodig te variëren op de strafrechtelijke leerstukken. ${ }^{31}$ Knigge gaat nog een stap verder dan Corstens. Hij lijkt er vanuit te gaan dat de oplegging van een bestuurlijke boete onder het strafrecht valt:

'Waarom wordt, zo vraag ik mij af, het Algemeen Deel van het Wetboek van Strafrecht in het Voorontwerp vierde tranche Awb niet simpel van overeenkomstige toepassing verklaard? Nu is veel energie gestoken in het ontwerpen van 'schaduwstrafrecht', dat frappante overeenkomsten met het Wetboek van Strafrecht laat zien, maar daarvan ook weer op tal van punten afwijkt. (...) De vraag was waarom het strafrecht niet simpel van overeenkomstige toepassing is verklaard op de oplegging van bestuurlijke boetes. Eigenlijk zou die vraag nog iets moeten worden aangescherpt. De overeenkomstige toepassing van bepalingen impliceert, dat die bepaling eigenlijk niet van toepassing is. De vraag is echter of dat wel zo is. $^{32}$

In de slotparagraaf van zijn artikel stelt Knigge dat de oplegging van boeten door een bestuursorgaan strafrecht is 'voor zover het daarbij om bestraffing gaat'. ${ }^{33}$ Daaruit leid ik af dat Knigge er van uit gaat dat het strafrecht zonder meer (dus onverkort) van toepassing is op de oplegging van bestuurlijke boeten. ${ }^{34}$

Met Corstens en Knigge ben ik van mening dat het niet wenselijk is dat in het positieve bestuursrecht op een andere wijze invulling wordt gegeven aan leerstukken die in het strafrecht door de jaren heen zijn ontwikkeld. Dit zou de rechtseenheid, in het kader van het strafrecht in ruime zin, niet ten goede komen. Het op een andere wijze invulling geven aan strafrechtelijke leerstukken zou bovendien rechtsonzekerheid in de hand kunnen werken. Gelet op het voorgaande is het wenselijk dat de bestuursrechters putten uit de van oudsher in de strafrechtspraak bestaande deskundigheid in het kader van de oplegging van punitieve sancties. Waarom zou er immers in het bestuursrecht bijvoorbeeld moeten worden uitgegaan van een ruimere uitleg van het begrip 'functioneel daderschap"?

Daartegenover staat echter dat het mijns inziens niet mogelijk én zinvol is het gehele nationale straf(proces)recht van overeenkomstige toepassing te verklaren (hetgeen volgens Knigge overigens niet eens nodig is - aangezien het strafrecht volgens hem immers van toepassing is -) op het bestuursstrafrecht. In het kader van de oplegging van punitieve sancties zoals de bestuurlijke boete, die veelal zien op normschendingen uit de strafrechtelijke overtredingensfeer, is immers geen behoefte aan de toepasselijkheid van alle bepalingen uit het Wetboek van Strafrecht en Strafvordering. In het slothoofdstuk (deel III) zal ik hier op terugkomen.

Knigge a.w. 2000, p. 96.

Vgl. Groenhuijsen en Knigge (red.) a.w. 200I, p. 119 
De zware en lichte boeteprocedure

In het Voorontwerp wordt, zoals hierboven reeds is aangegeven, een onderscheid gemaakt tussen een zware en een lichte boeteprocedure. De lichte boeteprocedure geldt indien een bestuurlijke boete wordt opgelegd van ten hoogste 340 Euro. De zwaardere procedure is van toepassing op de boeten die hoger zijn dan 340 Euro. Bij de lichte procedure gelden ten aanzien van de overtreder minder (procesrechtelijke) waarborgen. Aan de keuze van de commissie Scheltema om in het Voorontwerp naast de zware procedure een lichte, met minder warbogen omklede, procedure op te nemen liggen met name doelmatigheidsoverwegingen ten grondslag. ${ }^{35}$

De verschillen tussen de lichte en zware boeteprocedure zijn weergegeven in het navolgende schema. Op deze plaats dient voor de volledigheid nog wel opgemerkt te worden dat op grond van titel 5.1 (Algemene bepalingen) en titel 5.4 (Bestuurlijke boete) een aantal waarborgen altijd in acht genomen moet worden bij de boeteoplegging. Dit geldt bijvoorbeeld voor het zwijgrecht en de cautie en voor de onschuldpresumptie. ${ }^{36}$

35 Voorontwerp p. 97: 'Bij boeten van minder dan 340 Euro zou de zware procedure in de meeste gevallen tot onevenredige lasten leiden. Daarom geldt voor deze boeten in beginsel de lichte procedure.'

36 Een en ander zal straks nog blijken aan de hand van een artikelsgewijze bespreking van het Voorontwerp. 


\begin{tabular}{|c|c|}
\hline $\begin{array}{l}\text { ZWARE PROCEDURE } \\
\text { (boeten hoger dan } 340 \text { Euro) }\end{array}$ & $\begin{array}{l}\text { LICHTE PROCEDURE } \\
\text { (boeten ten hoogste } 340 \text { Euro) }\end{array}$ \\
\hline 1. Ambtenaar constateert een overtreding & 1. Ambtenaar constateert een overtreding \\
\hline $\begin{array}{l}\text { 2. Ambtenaar maakt een rappott op (art. } \\
\text { 5.4.2.6 lid } 2 \text { Voorontwerp) }\end{array}$ & $\begin{array}{l}\text { 2. Ambtenaar is niet verplicht een rapport } \\
\text { op te maken (art. 5.4.2.1 Voorontwerp) }\end{array}$ \\
\hline $\begin{array}{l}\text { 3. Toezending rapport aan het bestuursor- } \\
\text { gaan dat bevoegd is de boete op te leggen }\end{array}$ & $\begin{array}{l}\text { 3. eventueel toezending rapport aan het } \\
\text { besfuursorgaan dat bevoegd is de boete } \\
\text { op te leggen }\end{array}$ \\
\hline $\begin{array}{l}\text { 4. Ambtenaar van het bestuursorgaan bereidt } \\
\text { de boetebeschikking voor. Dit moet een } \\
\text { andere ambtenaar zijn dan de ambtenaar die } \\
\text { de overtreding heeft geconstateerd en het } \\
\text { rapport heeft opgemaakt (i.v.m. eis van } \\
\text { functiescheiding - zie art. 5.4.2.6. lid } 4 \\
\text { Voorontwerp -) }\end{array}$ & $\begin{array}{l}\text { 4. De eis van functiescheiding geidt niet } \\
\text { bij de lichte procedure }\end{array}$ \\
\hline $\begin{array}{l}\text { 5. - Het bestuursorgaan stelt de overtreder } \\
\text { in de gelegenheid zijn zienswijze naar } \\
\text { voren te brengen (art. 5.4.2.6. lid } 3 \text { Voor- } \\
\text { ontwerp) }\end{array}$ & $\begin{array}{l}\text { 5. Het horen van de overtreder is in de } \\
\text { lichte procedure niet verplicht }\end{array}$ \\
\hline $\begin{array}{l}\text { En uiterlijk op dat moment dient het rapport } \\
\text { aan de overtreder te worden toegezonden (met } \\
\text { het oog op artikel } 6 \text { lid } 3 \text { van het EVRM) (zie } \\
\text { art. 5.4.2.3 Voorontwerp) }\end{array}$ & $\begin{array}{l}\text { Eventueel toezenden rapport aan overtreder } \\
\text { (namelijk zoor zover het sanctionerende be- } \\
\text { stuursorgaan overgaat tot het horen van de } \\
\text { overtreder). }\end{array}$ \\
\hline $\begin{array}{l}\text { En het zwijgrecht dient in ieder geval vanaf dat } \\
\text { moment te gelden (art. 5.0.11 Voorontwerp) }\end{array}$ & $\begin{array}{l}\text { Eventueel zwijgrecht (art. } 5.0 .11 \text { Voorontwerp) } \\
\text { (namelijk voor zover het sanctionerende be- } \\
\text { stuursorgaan overgaat tot het horen van de } \\
\text { overtreder) }\end{array}$ \\
\hline $\begin{array}{l}\text { En de overtreder heeft het recht op inzag } \\
\text { afschriften van stukken die aan het voome } \\
\text { tot boete-oplegging ten grondslag liggen } \\
\text { kel 5.4.2.2. Voorontwerp) }\end{array}$ & $\begin{array}{l}\text { En de overtreder heeft het recht op inzage en } \\
\text { afschriften van stukken die aan het voormemen } \\
\text { tot boete-oplegging ten grondslag liggen (arti- } \\
\text { kel 5.4.2.2. Voorontwerp) }\end{array}$ \\
\hline $\begin{array}{l}\text { 6. Boete-oplegging bij beschikking (art. } \\
\text { 5.4.2.5 Voorontwerp). Indien het bestuurs- } \\
\text { orgaan na het horen afziet van de oplegging } \\
\text { van een boete dient dit schriftelijk aan de } \\
\text { overtreder medegedeeld te worden (art. } \\
\text { 5.4.2.3. lid 2 Voorontwerp) } \\
\end{array}$ & $\begin{array}{l}\text { 6. Boete-oplegging bij beschikking (art. } \\
\text { 5.4.2.5 Voorontwerp). Indien het bestuurs- } \\
\text { orgaan na het horen afziet van de oplegging } \\
\text { van een boete dient dit schriftelijk aan de } \\
\text { overtreder medegedeeld te worden (art. } \\
\text { 5.4.2.3. lid } 2 \text { Voorontwerp) }\end{array}$ \\
\hline $\begin{array}{l}\text { 7. Verjaringstermijn van vijf jaar (art. } \\
\text { 5.4.1.6 lid 2 Voorontwerp) }\end{array}$ & $\begin{array}{l}\text { 7. Verjaringstermijn van twee jaar (art. } \\
\text { 5.4.1.6. lid } 1 \text { Voorontwerp) }\end{array}$ \\
\hline
\end{tabular}

\subsubsection{Het Voorontwerp - artikelsgewijs -}

De voorgestelde regeling

Zoals gezegd zal ik in dit hoofdstuk de voorgestelde boeteregeling uit het Voorontwerp artikelsgewijs bespreken. Daarbij zal onder meer aandacht uitgaan naar de vraag of de voorgestelde regeling zich verdraagt met de verdragsrechtelijke waarborgen uit het EVRM en het IVBPR. Voorts zal aandacht uitgaan naar de vraag of het bestuursprocesrecht geschikt is om gestalte te geven aan de rechtsbescherming in het kader van de 
oplegging van punitieve bestuursrechtelijke sancties waaronder in het bijzonder de bestuurlijke boeten. Tenslotte zal ingegaan worden op afwijkend gebruik van strafrechtelijke leerstukken in de boeteregeling.

Het signaleren van mogelijke tekortkomingen in het kader van de rechtsbescherming van de vermoedelijke overtreder staat in dit deel van het hoofdstuk centraal. Soms zal, ten aanzien van een gesignaleerde tekortkoming, reeds op hoofdlijnen een oplossing aangedragen worden. Een nadere uitwerking daarvan zal plaatsvinden in het slotdeel van dit boek.

Uit het in het Voorontwerp voorgestelde hoofdstuk vijf (Handhaving) zijn met het oog op de bestuurlijke boete met name titel 5.1 (Algemene bepalingen) en titel 5.4 (Bestuurlijke boete) van belang. $\mathrm{Bij}$ een aantal bepalingen uit deze twee titels zal hiema worden stilgestaan. ${ }^{37}$ Uiteraard zal eerst aandacht uitgaan naar titel 5.1 (Algemene bepalingen). Daarna zal ingegaan worden op titel 5.4 (Bestuurlijke boete).

\subsubsection{Titel 5.I Algemene bepalingen}

Artikel 5.0.1 overtreding en overtreder

Overtreding

Titel 5.1 van het Voorontwerp vangt aan met artikel 5.0.1 waarin een definitie van de termen overtreding en overtreder wordt gegeven. Een overtreding is, zo kan worden afgeleid uit het eerste lid van genoemde bepaling, een gedraging die in strijd is met het bepaalde bij of krachtens enig wettelijk voorschrift. Hoewel er in artikel 5.0 .1 lid l bij de definitie van de term overtreding gesproken wordt van een 'gedraging' blijkt uit de toelichting op het Voorontwerp dat de term 'gedraging' mede een nalaten omvat. Daarbij kan gedacht worden aan het laten voortbestaan van een onrechtmatige toestand. ${ }^{38}$

\section{Overtreder}

Overtreder is blijkens artikel 5.0.1 lid 2 degene die de overtreding pleegt of mede. pleegt. Het daderschap (aan wie kan de gedraging zoals deze feitelijk heeft plaatsgevonden worden toegerekend?) staat daarbij centraal. Daarnaast is, in het kader van de bevoegdheid tot het opleggen van een bestuurlijke boete, de vraag relevant tot wie hat overtreden voorschrift zich richt. Alleen de normadressaat (degene tot wie het overtreden voorschrift zich richt) kan namelijk als overtreder worden aangemerkt (voor zover hij de overtreding (van de norm), al dan niet functioneel, pleegt ${ }^{39}$ of medepleegt). ${ }^{40}$

Ten aanzien van het daderschap kan het volgende worden opgemerkt. Niet alleen degene die door zijn fysieke handelingen de bestanddelen van het delict vervult kan worden aangemerkt als dader ofwel overtreder. Daarnaast kan ook de 'functionele dader' een strafbaar feit plegen. ${ }^{41}$ In dat kader kan worden gewezen op het 'IJzerdraad-amest'

Zie in dit kader voorts: Addink en Duijkersloot, a.w. 2000, Neerhof en Schlössels a.w. 2000, i.h.b. p. 1024-1034 en M.W.C. Feteris, De bestuurlijke boete in het Voorontwerp vierde tranche Awb, Weekblad voor Fiscaal Recht 2000/6380, p. $465-478$ (hiema: Feteris a.w. 2000a).

38 Voorontwerp p. 105.

39 Zie m.b.t. plegen: Hazewinkel-Suringa, bewerkt door Remmelink a.w. 1996, p. 427-428.

40 Zie Voorontwerp p. 105-106.

41 Voorontwerp p. 106. Zie voorts: Hazewinkel-Suringa, bewerkt door Remmelink a.w. 1996, p. 150-153. 
waaruit, volgens de commissie Scheltema, volgt dat een sanctie niet alleen kan worden opgelegd aan degene die de gedraging in fysieke zin heeft verricht, maar ook aan degene die maatschappelijk gezien voor de gedragingen verantwoordelijk is.

De VAR-werkgroep geeft overigens aan dat de commissie Scheltema de strekking van het arrest van de Hoge Raad niet op een volledig juiste wijze heeft weergegeven in de toelichting. Er zijn namelijk, zo stelt ook de VAR-werkgroep, ingevolge dat arrest twéé criteria relevant in het kader van het 'functioneel daderschap. ${ }^{43}$ Ten eerste dienen de fysieke handelingen die het delict opleveren in de machtssfeer van de functioneel dader te liggen. Dit is bijvoorbeeld het geval als de fysieke handelingen worden verricht door een ondergeschikte. Ten tweede moet het zo zijn dat de functioneel dader deze handelingen heeft aanvaard of in het algemeen placht te aanvaarden. ${ }^{44}$ Van het voorgaande is reeds sprake indien de functionele dader is tekortgeschoten in hetgeen redelijkerwijs van hem mocht worden verwacht om de wederrechtelijke gedraging te voorkomen. ${ }^{45}$

\section{Medeplegen}

Naast degene die de overtreding (al dan niet functioneel) pleegt wordt, op grond van artikel 5.0.1, tweede lid, van het Voorontwerp, ook de 'medepleger' als overtreder aangemerkt. Van medeplegen is sprake als twee of meer personen gezamenlijk een delict plegen terwijl er voorts sprake is van een min of meer gelijkwaardige en bewuste samenwerking. ${ }^{46}$ De medeplegers moeten derhalve een gelijkwaardig aandeel hebben in het plegen van de overtreding. Op dit punt onderscheidt het 'medeplegen' zich van 'medeplichtigheid' in die zin dat een medeplichtige slechts een ondergeschikt aandeel in het delict heeft. ${ }^{47}$

Voor de uit het strafrecht afkomstige deelnemingsvorm 'medeplichtigheid' (artikel 48 $\mathrm{Sr}$ ) is, evenals voor de deelnemingsvormen 'doen plegen ${ }^{\prime 48}$ en 'uitlokken'49 (artikel 47 $\mathrm{Sr}$ ), in het vijfde hoofdstuk van het Voorontwerp geen equivalent opgenomen. Medeplichtigheid is slechts strafbaar bij misdrijven. Aangezien medeplichtigheid bij overtredingen niet strafbaar is bestaat volgens de commissie Scheltema geen behoefte

42 HR 23 februari 1954, NJ 1954, 378. Een ondememer werd in die zaak gestraft voor fraude bij de export van ijzerdraad, terwijl een van zijn werknemers daadwerkelijk bepaalde formulieren onjuist had ingevuld en aldus had gefraudeerd.

43 Zie het rapport van de VAR-werkgroep (onder voorzitterschap van prof. mr. L.J.A. Damen), gepubliceerd onder de titel: De vierde tranche Awb. Commentaar en vraagpunten, Den Haag, Boom Juridische uitgevers, 2000, i.h.b. p. 36: 'Voor wat betreft het leerstuk van daderschap wordt in de toelichting op pagina 106 opgemerkt dat in het strafrecht een sanctie niet alleen kan worden opgelegd aan degene die de gedraging in fysieke zin verricht, maar ook aan 'degene die daarvoor maatschappelijk gezien verantwoordelijk is'. Deze invulling is in het strafrecht echter omstreden gezien hetgeen jurisprudentieel dienaangaande is bepaald (niet de maatschappelijke verantwoordelijkheid, maar het 'beschikken en aanvaarden' is bepalend).

44 Zie het IJzerdraadarrest (NJ 1954, 378): 'Dat toch handelingen (...), slechts dan waren aan te merken als gedragingen van verd, indien verd. erover vermocht te beschikken, of die handelingen al dan niet plaatsvonden, en deze behoorden tot de zodanige, welker plaatsvinden blijkens den loop van zaken door verd. werd aanvaard of placht te worden aanvaard.'

45 Voorontwerp p. 106.

46 Ziè voor een uitvoerige beschrijving van de termen medeplegen en medeplichtigheid en het onderscheid tussen beiden: Hazewinkel-Suringa, bewerkt door Remmclink a.w. 1996, p. 435-454.

47 Voorontwerp p. 107.

48 Zie m.b.t doen plegen: Hazewinkel-Suringa, bewerkt door Remmelink a.w. 1996, p. 428-435.

49 Zie m.b.t. uitlokking: Hazewinkel-Suringa, bewerkt door Remmelink a.w. 1996, p. 454-466. 
aan het opnemen van genoemde deelnemingsvorm in het Voorontwerp. ${ }^{50}$ Bestuurlijke boeten worden immers opgelegd ten aanzien van minder ernstige normschendingen, vergelijkbaar met de normschendingen die in het strafrecht gekwalificeerd worden als overtreding.

Aan het opnemen van de andere deelnemingsvormen zoals het doen plegen en uitlokken bestaat volgens de commissie Scheltema ook geen behoefte. ${ }^{51}$ Volgens de commissie kunnen problemen die ontstaan door het ontbreken van genoemde deelnemingsvormen in het Voorontwerp middels de regeling van het functioneel daderschap worden opgelost. ${ }^{52}$ Knigge waarschuwt er in dit kader voor dat de, ook in het strafrecht voorkomende, ontwikkeling dat bepaalde deelnemingsfiguren voor een deel door de leer van het functionele daderschap worden 'opgeslokt', zich in het bestuursrecht wel eens versterkt zou kunnen doorzetten. ${ }^{53}$

Tenslotte dient in het kader van het tweede lid van artikel 5.0.1 van het Voorontwerp nog opgemerkt te worden dat een bestuurlijke boete en een dwangsom slechts opgelegd kunnen worden aan de overtreder ${ }^{54}$ terwijl een bestuursdwangaanschrijving niet per definitie gericht hoeft te zijn tot de overtreder. Ook ten aanzien van de niet-overtreder, die het feitelijk in zijn macht heeft de rechtmatige toestand te herstellen, kan bestuursdwang worden toegepast. Kostenverhaal is ten aanzien van deze niet-overtreder echter niet mogelijk (zie artikel 5:25, eerste lid Awb). ${ }^{55}$

\section{Overtreding door rechtspersoon}

In artikel 5.0.1, derde lid, van het Voorontwerp wordt tenslotte bepaald dat, ingeval een overtreding is gepleegd door een rechtspersoon (functioneel daderschap) ${ }^{56}$, tevens

50 Voorontwerp p. 107.

51 Voorontwerp p. 107.

52 Voorontwerp p. 107.

53 Knigge a.w. 2000 , p. 93. Knigge merkt op genoemde pagina voorts op: 'Omdat de uitlokker - de man achter de schermen - niet direct aansprakelijk is, zal de druk om het (mede)plegen functioneel (dat vil zeggen: ruim) uit te leggen, toenemen.'

54 Naar huidig recht kan een dwangsom slechts opgelegd worden aan de overtreder die het (feitelijk en juridisch) in zijn macht heeft de overtreding te beěindigen. Zie daarover: ABRS 28 april 1997, AB 1999/43, m. nt. C.L. Knijff onder AB 1999/45 en ABRS 28 december 1999, AB 2000/107, m. nt. F. Michiels, zie voorts: P.J.J. van Buuren, G.T.J.M. Jurgens, en F.C.M.A. Michiels, Bestuursdwang ea dwangsom, tweede druk, W.E.J. Tjeenk Willink, Deventer 1999, i.h.b. p. 67 e.v. Ik ga er van uit dat dit ook nog zo zal zijn na inwerkingtreding van de vierde tranche van de Awb.

55 Voorontwerp p. 107-108. Illustratief in dit kader is ook een uitspraak van de Afdeling Bestuursrechtspraak van 29 september 2000 (ABRS 29 september 2000, JB 2000/304, m. nt. C.L.G.F.H. Albers).

56 Vgl. Hazewinkel-Suringa, bewerkt door Remmelink a.w. 1996, p. 137 e.v. i.h.b. p. 151. Zie voorts: HR 1 juli 1981, NJ 1982, 80 m. nt. Th. W. van Veen (Kabeljauwvangst) en HR 14 januari 1992, NJ 1992, $413 \mathrm{~m}$. nt. ' $\mathrm{t}$ Hart (Firma Café Nol). In de laatste zaak is door de Hoge Raad aangegeven dat de vennootschap onder firma (VOF) Café Nol aangemerkt kan worden als dader ten aanzien van discriminerend optreden feitelijk gepleegd door een bij genoemde firma in dienst zijnde uitsmijter. De Hoge Raad heeft daartoe overwogen: 'Van daderschap van een vennootschap onder firma van door een zodanig persoon (een persoon in dienst van dan wel handelend voor of namens een VOF [KA]) verrichte handelingen als strafbaar gesteld in evengenoemde bepaling kan immers eveneens sprake zijn indien de vennootschap erover vermocht te beschikken of die handelingen al dan niet zouden plaatsvinden en deze behoor'en tot de zodanige welker plaatsvinden blijkens de feitelijke gang van zaken door de verdachte werd aanvaard of placht te worden aanvaard.' 
degene die tot de overtreding opdracht heeft gegeven of daaraan feitelijk leiding heeft gegeven als overtreder kan worden aangemerkt. Knigge geeft aan dat deze bepaling 'interessant' is. Hij licht dit als volgt toe:

'Deze constructie vormt dogmatisch gezien een enorme breuk met art. $51 \mathrm{Sr}$, dat gebaseerd is op een onderscheid tussen het daderschap van de rechtspersoon en de aansprakelijkheid daarvoor van de opdrachtgever of de feitelijk leidinggever: tegen de laatsten kunnen, als het feit 'begaan' is door de rechtspersoon, 'de straffen worden uitgesproken'. Het Voorontwerp introduceert nu het daderschap van de feitelijk leidinggever. ${ }^{57}$

Knigge vraagt zich af of het verschil in constructie tussen artikel $51 \mathrm{Sr}$ en 5.0.1, derde lid Voorontwerp een verschil in aansprakelijkheid met zich mee zal brengen. ${ }^{58}$ Mijns inziens hoeft dit niet het geval te zijn. Ik heb namelijk de indruk dat de commissie Scheltema over het hoofd heeft gezien dat zij een, om met de woorden van Knigge te spreken, 'dogmatisch interessante' bepaling creëerde met het derde lid van artikel 5.0.1. In de toelichting op genoemde bepaling uit het Voorontwerp geeft de commissie namelijk het volgende aan:

'Indien een overtreding is gepleegd door een rechtspersoon, kan de bestuurlijke sanctie daarnaast of in plaats daarvan ook worden opgelegd aan degenen die tot de overtreding opdracht hebben gegeven of daaraan feitelijk leiding hebben gegeven. Zulks wordt, naar analogie van artikel $51 \mathrm{WvSr}$, in de bestuursrechtelijk jurisprudentie reeds aanvaard (...); het ligt in de rede deze jurisprudentie thans te codificeren. ${ }^{59}$

De commissie Scheltema had mijns inziens dan ook de intentie aan artikel 5.0.1, derde lid van het Voorontwerp een, met artikel 51 Sr vergelijkbare, invulling te geven.

De commissie Scheltema merkt ten aanzien van het derde lid van artikel 5.0.1 tenslotte nog op dat, indien een publiekrechtelijke rechtspersoon overtreder is en hem dientengevolge een punitieve bestuursrechtelijke sanctie kan worden opgelegd, daarbij rekening dient te worden gehouden met de jurisprudentie inzake strafrechtelijke aansprakelijkheid van decentrale overheidslichamen. In het 'Pikmeer II' arrest ${ }^{60}$ heeft de Hoge Raad daaromtrent bepaald dat strafrechtelijke sanctionering van decentrale overheden in beginsel mogelijk is, tenzij de strafbare gedraging werd verricht ter uitvoering van een exclusieve overheidstaak. ${ }^{61}$ Het voorgaande brengt met zich dat ten aanzien van decentrale overheden in beginsel alleen punitieve bestuursrechtelijke sancties kunnen worden opgelegd in het kader van gedragingen die niet werden verricht ter uitvoering van een exclusieve overheidstaak terwijl de immuniteit van de staat onbeperkt is. ${ }^{62}$

57

60 HR 6 januari 1998, NJ 1998, 367, JB 1998/4 (Pikmeer II). Zie voorts: D. Roef, De ommekeer in Pikmeer. Over de vervolgbaarheid van overheden na Pikmcer II, JB 1998/47, p. 215-226 en D. Rocf, Strafbare overheden (diss. UM), Antwerpen-Groningen 2001.

61 Voorontwerp p. 109

62 Bijgevolg kunnen ten aanzien van de staat gén punitieve bestuursrechteljjke sancties op worden gelegd. Vgl. (m.i. terecht kritisch) De Raat en Widdershoven a.w. 2000, p. 779 en HR 25 januari 1994 , NJ 1994, 598, m. nt. Corstens (Vliegbasis Volkel). 
Het is overigens maar de vraag of de regering in het definitieve wetsvoorstel bovenstaand standpunt van de commissie Scheltema onderschrijft. Inmiddels is op verzoek van het kabinet een rapport verschenen inzake de strafrechtelijke aansprakelijkheid van de staat. ${ }^{63}$ Daarin spreekt de commissie Roelvink zich uit vóór strafrechtelijke aansprakelijkheid van zelfstandige onderdelen van de staat (en strafrechtelijke aansprakelijkheid van publiekrechtelijke rechtspersonen op decentraal niveau), ongeacht of er sprake is van de uitoefening van een exclusieve overheidstaak. De commissie Roelvink stelt ten aanzien van de strafrechtelijke aansprakelijkheid van zelfstandige onderdelen van de staat het volgende:

'De commissie denkt hierbij aan diensten, instellingen en andere organisatorische eenheden van de staat die met een voldoende mate van zelfstandigheid in het maatschappelijk verkeer kunnen optreden. De staat als zodanig zou moeten worden uitgesloten van strafrechtelijke aansprakelijkheid. ${ }^{64}$

Opvallend is dat de strafrechtelijke aansprakelijkheid van de onderdelen van de staat volgens de commissie Roelvink in het bijzonder betrekking zou moeten hebben op overtredingen van ordeningswetgeving. ${ }^{65}$ Het is immers met name de ordeningswetgeving ten aanzien waarvan op steeds grotere schaal de mogelijkheid tot het opleggen van bestuurlijke boeten wordt ingevoerd. Dit brengt naar mijn mening met zich dat, indien het kabinet het voorstel van de commissie Roelvink tot het zijne maakt ${ }^{66}$, oplegging van bestuurlijke boeten ten aanzien van zelfstandige onderdelen van de staat en ten aanzien van publiekrechtelijke rechtspersonen op decentraal niveau mogelijk zou moeten zijn.

Tenslotte verdient opmerking dat volgens de commissie Roelvink in de praktijk reeds bestuurlijke boeten worden opgelegd aan decentrale overheden en aan onderdelen van de centrale overheid. ${ }^{67}$

\section{Artikel 5.0 .2 bestuurlijke sanctie en herstelsanctie}

Nadat de commissie Scheltema in artikel 5.0.1 een definitie van de termen overtreding en overtreder heeft gegeven volgt in artikel 5.0.2 van het Voorontwerp een definitie van de termen bestuurlijke sanctie en herstelsanctie.

In artikel 5.0.2, eerste lid, onder a, van het Voorontwerp is aangegeven dat onder een bestuurlijke sanctie wordt verstaan een door een bestuursorgaan wegens een overtreding bij beschikking opgelegde verplichting of genomen maatregel. Enige nadere toelichting verdienen de termen 'opgelegde verplichting' en 'genomen maatregel'. Met de term 'opgelegde verplichting' doelt de commissie Scheltema blijkens de toelichting bij het Voorontwerp op: 'een verplichting om een geldsom te betalen, zoals bij de bestuur-

63 Comnissic Roelvink, Strafrechtelijke aansprakelijkheid van de staat, Den Haag 2002 (hiema: commissie Roelvink).

64 Commissic Roelvink a.w. 2002, p. 5.

o5 Commissie Roelvink a.w. 2002, p. 5.

o6 Hoewel het kabinet nog geen definitief standpunt heeft ingenomen lijkt de kans groot dat in ieder geval de hierboven weergegeven aspecten uit het voorstel van de commissie Roelvink door het kabinet worden overgenomen. Vgl. Kamerstukken II, 2001/2002, 25294 , nr. 15, Strafrechtelijke aansprakelijkheid van overheidsorganen, brief van de minister van justitie. 
lijke boete, maar ook een verplichting om een overtreding te beëindigen in combinatie met een voorwaardelijke verplichting om een geldsom te betalen, zoals bij de last onder dwangsom. ${ }^{68}$ Met de term 'genomen maatregel' doelt genoemde commissie in de eerste plaats op bestuursdwang. De commissie geeft daarbij expliciet aan dat het begrip maatregel derhalve meer omvat dan de 'maatregel' uit het sociale zekerheidsrecht. ${ }^{69}$

In artikel 5.0.2, eerste lid, onder b, van het Voorontwerp volgt de definitie van de zogenaamde 'herstelsanctie'. De herstelsanctie is een bestuurlijke sanctie die strekt tot het geheel of gedeeltelijk ongedaan maken of beëindigen van een overtreding, tot het voorkomen van herhaling van een overtreding, dan wel tot het wegnemen of beperken van de gevolgen van een overtreding. Een herstelsanctie, ook wel reparatoire sanctie genoemd, ziet derhalve, kort gezegd, op beëindiging van een onrechtmatige situatie dan wel het herstel van een rechtmatige toestand.

Gelet op de redactie van artikel 5.0.2, eerste lid, onder b, lijkt partiële handhaving door middel van een herstelsanctie niet uitgesloten te zijn. Of de commissie Scheltema welbewust de mogelijkheid tot partiële handhaving heeft willen creëren kan echter niet uit het Voorontwerp worden afgeleid. De VAR-werkgroep geeft aan dat de commissie Scheltema op dit punt meer duidelijkheid had moeten verschaffen. ${ }^{70}$ Dit omdat op het moment van het verschijnen van het Voorontwerp ook uit de (Afdelings)rechtspraak niet goed kon worden afgeleid of, en zo ja, in welke gevallen, partiêle handhaving tot de mogelijkheden zou kunnen behoren. ${ }^{11}$ Inmiddels lijkt de Afdeling Bestuursrechtspraak er echter van uit te gaan dat partiële handhaving in beginsel uitgesloten is. De Afdeling heeft, in een uitspraak van 27 februari 2002, immers gesteld dat slechts onder bijzondere omstandigheden een handhavingsbesluit kan worden genomen dat betrekking heeft op gedeeltelijke ongedaanmaking van de overtreding. ${ }^{72}$

Tenslotte wordt door de commissie Scheltema in het tweede lid van artikel 5.0.2 van het Voorontwerp aangegeven dat een last tot het verrichten van bepaalde handelingen geen bestuurlijke sanctie is. Op basis van bepaalde bestuursrechtelijke wetten kan aan een bestuursorgaan de bevoegdheid toekomen om een burger bepaalde handelingen te laten verrichten ter naleving van wettelijke voorschriften. Men denke daarbij bijvoorbeeld aan een aanschrijving tot woningverbetering op grond van artikel 14 Woningwet. Een dergelijke last wordt vaak opgelegd naar aanleiding van een gepleegde overtreding. Toch is de last zelf géén bestuurlijke sanctie. Eerst tegen het niet uitvoeren van een last kan door het bestuursorgaan doorgaans met bestuurlijke sancties worden opgetreden. $^{73}$

68 Voorontwerp p. 109.

69 Voorontwerp p. $109-110$.

70 VAR-werkgroep a.w. 2000 , p. 50-51.

71 Vgl. o.m. ABRS 10 oktober 2001, JB 2001/315 (Sanders Beneden Leeuwen BV) m. nt. C.L.G.F.H. Albers, Vz. ABRS 7 december 2000, AB 2001, 317 en Vz. ABRS 21 november 2000, AB 2000, 318 beiden $m$. nt. G. Jurgens.

72 Zie ABRS 27 februari 2002, AB 2002, $224 \mathrm{~m}$. nt. F. Michiels (Tuinbouwbedrijf Van den Wijngaart). De Afdeling lijkt in het kader van partiele handhaving aansluiting te zoeken bij de in het algemeen in het kader van de handhaving uitgezette lijn m.b.t. de 'beginselplicht'-jurisprudentie. Vgl. $\$ 2.2 .3 .3 . \mathrm{b}$ van dit boek.

Voorontwerp p. 110. 
Artikel 5.0.4 legaliteitsbeginsel

\section{Legaliteitsbeginsel}

In artikel 5.0.4 van het Voorontwerp komt vervolgens het legaliteitsbeginsel aan de orde. ${ }^{74}$ In het eerste lid van artikel 5.0.4 is bepaald dat de bevoegdheid tot het opleggen van een bestuurlijke sanctie slechts bestaat voor zover zij bij of krachtens de wet is verleend. ${ }^{75}$ In het tweede lid van genoemd artikel is aangegeven dat een bestuurlijke sanctie slechts wordt opgelegd wegens een gedraging die in strijd is met hetgeen voorafgaand aan de gedraging bij of krachtens enig wettelijk voorschrift is bepaald. Blijkens de toelichting heeft de commissie Scheltema met het voorgestelde artikel 5.0.4 invulling willen geven aan het uit het strafrecht afkomstige beginsel: 'nullum crimen sine praevia lege criminalia, nulla poena sine praevia lege poenali' (geen strafbaar feit en geen straf zonder voorafgaande wettelijke strafbepaling). Genoemd beginsel is voor het strafrecht gecodificeerd in artikel $16 \mathrm{Gw}$ en artikel $1 \mathrm{Sr}$. Op grond van artikel 7 EVRM en 15 IVBPR geldt genoemd beginsel tevens voor punitieve bestuursrechtelijke sancties. ${ }^{76}$ Bovendien acht de commissie Scheltema het legaliteitsbeginsel ook toepasselijk bij reparatoire sancties: '...; voor reparatoire sancties - althans voor de bestuursdwang en de last onder dwangsom - geldt het beginsel naar algemene opvatting evenzeer, maar is het nergens vastgelegd. Het ligt daarom ook voor de hand, dit beginsel in titel 5.1 te codificeren." 77

Een belangrijk aspect uit het tweede lid van artikel 5.0.4 van het Voorontwerp is het verbod een sanctie op te leggen met terugwerkende kracht. Er lijkt in de redactie van genoemd tweede lid echter een onvolkomenheid geslopen te zijn. Lezing van het tweede lid brengt mij tot de conclusie dat slechts vereist is dat de te sanctioneren gedraging in strijd is met een bij of krachtens wettelijk voorschrift gestelde norm (hierna: de verbodsbepaling) die reeds in werking is getreden ten tijde van de verrichte handeling (of het eventuele nalaten). Uit het tweede lid van artikel 5.0.4, gelezen in samenhang met het eerste lid, volgt echter niet dat naast de verbodsbepaling op het moment van de onrechtmatige gedraging ook reeds een bepaling met betrekking tot de strafbedreiging moet bestaan waarin is bepaald welke sanctie staat op het overtreden van de verbodsbepaling. ${ }^{78}$ Ik vraag me dan ook af of in dat kader met de regeling uit artikel 5.0.4 in voldoende mate invulling is gegeven aan het legaliteitsbeginsel.

Daarnaast dient gewezen te worden op het feit dat in artikel 5.4.1.7, eerste en vierde lid, van het Voorontwerp specifiek voor de bestuurlijke boete nog een nadere uitwerking van het legaliteitsbeginsel is neergelegd (de maximale hoogte van de boete moet neergelegd zijn in de wet en bij verandering van wetgeving wordt de lagere boete opgelegd). Gelet op de hierboven weergegeven overwegingen van de commissie Schel-

74 Zie in dit kader ook: F.J. van Ommeren, De verplichting verankerd (diss. UU), Deventer 1996. Van Ommeren is van mening dat een eenzijdig door de overheid opgelegde verplichting op een specifieke wettelijke grondslag dient te berusten teneinde de burger tegen ongebreideld overheidsoptreden te beschermen (zie Van Ommeren a.w. 1996, p. 113-115).

75 Zie in dit kader ook ABRS 4 november 1993, AB 1994, 182, m. nt. N. Verheij. In die zaak was een (naar het oordeel van de Afdeling bestuurlijke) boete opgelegd terwijl een wettelijke grondslag daartoe ontbrak.

76 Voorontwerp p. 111. Zie in dit kader ook $\$ 3.4 .3$ van dit boek.

77 Voorontwerp p. 111.

78 Zie in deze zin ook: Knigge a.w. 2000, p. 93. 
tema omtrent de codificatic van het legaliteitsbeginsel in titel 5.1 is deze nadere uitwerking ten aanzien van de bestuurlijke boete, in titel 5.4, op zijn minst vreemd.

Voorts wordt met artikel 5.4.1.7 van het Voorontwerp de, ten aanzien van artikel 5.0.4 gesignaleerde onvolkomenheid, niet ondervangen. Ook in het kader van de bestuurlijke boete, bestaat derhalve de mogelijkheid iemand te bestraffen voor een gedraging die ten tijde van het begaan wel verboden was maar waarvoor nog geen bepaling in het kader van de strafbedreiging aanwezig was. Uiteraard realiseer ik me dat deze onvolkomenheid in de praktijk wellicht geen problemen op zal leveren aangezien een verbodsbepaling zonder daaraan gelieerde bepaling met betrekking tot de strafbedreiging weinig betekenis heeft. In de praktijk zal het niet snel voorkomen dat de bepaling met betrekking tot de strafbedreiging pas in werking treedt na het plegen van de (vooraf reeds) verboden gedraging. Wetgevingstechnisch gezien lijkt het me echter zinvol dat men zich beraadt over een andere redactie van het in artikel 5.0.4 neergelegde legaliteitsbeginsel.

\section{Lex certa-beginsel}

Tenslotte wijst de commissie Scheltema nog op de, uit de rechtspraak van het EHRM voortvloeiende, eis 'dat een voorschrift dat door bestuurlijke sancties wordt gehandhaafd, voldoende duidelijk, voorzienbaar en kenbaar moet zijn. ${ }^{79}$ Mijns inziens is deze, door de commissie Scheltema gegeven, interpretatie van het lex certa-beginsel te beperkt. Op grond van de rechtspraak van het EHRM geldt het voorzienbaarheidsvereiste niet alleen ten aanzien van te handhaven norm maar ook ten aanzien van de op te leggen sanctie. Het EHRM gaat er vanuit dat ook de sanctie, nauwkeurig, duidelijk en ondubbelzinnig geformuleerd moet zijn. ${ }^{80}$

Voorts kan met het oog op het lex certa-beginsel nog het volgende worden opgemerkt. In artikel 5.0.4 van het Voorontwerp is het legaliteitsbeginsel, met inbegrip van het lex certa-vereiste, in algemene zin gecodificeerd. De bijzondere wetgever dient er zorg voor te dragen dat bestuursrechtelijke normen voldoen aan het lex certa-beginsel. Dit betekent dat hij er voor dient te waken dat voorschriften die door bestuurlijke sancties worden gehandhaafd, alsmede de bepalingen waarin de op te leggen sancties zijn opgenomen, voldoende duidelijk, voorzienbaar en kenbaar zijn.

Door diverse auteurs is gewezen op bestuursrechtelijke normen die niet voldoen aan het lex certa-beginsel. Feteris geeft aan dat de duidelijkheid en voorspelbaarheid van fiscale normen nogal eens te wensen over laten. ${ }^{81}$ Ook de zogenaamde 'zorgplichtbepalingen' zijn soms dermate vaag en onduidelijk geformuleerd dat zij niet voldoen aan het

79 Voorontwerp p. 111. Zie hierover ook $\$ 3.4 .3$ van dit boek. Zie voorts: Rechtbank Dordrecht, 14 december 2001, JB 2002/57 (Woningstichting Progrez) m. nt. C.L.G.F.H. Albers en Rechtbank Den Haag. 23 december 1998, JB 1999/57 m. nt. Karianne Albers. Volgens de Haagse rechtbank was artikel 7la, eerste lid WAO (oud) onvoldoende duidelijk en niet ondubbelzinnig, in de zin dat voor de werkgever uit genoemde bepaling niet voldoende duidelijk bleek welke verplichtingen op hem rustten (met betrekking tot zieke werknemers) teneinde sanctionering door middel van een bestuurlijke boete te voorkomen.

80 Zie $\$ 3.4 .3 .6$ van dit boek.

81 Zie: M.W.C. Feteris, De fiscale bestuurlijke boete en de Vierde tranche van de Awb in de bundel: Commentaren op het Voorontwerp Algemene wet bestuursrecht Vierde tranche, onder redactie van L.J.J. Rogier. Rotterdam 2000, p. 1-35, i.h.b. p. 6 (hierna: Feteris a.w. 2000b). 
lex certa-vereiste. ${ }^{82}$ Tak en Teunissen wijzen in dit kader op de in artikel 1.la $\mathrm{Wm}$ neergelegde algemene zorgplichtbepaling die, zoals zij aangeven, ók is 'bedoeld als een grondslag om bestuursrechtelijk - via bestuursdwang of dwangsom - op te treden terzake van schending van de in deze bepaling vervatte zorgplicht. ${ }^{183}$ Mede gelet op de (beperkte) rechtsbescherming, die bovendien op basis van het bestuursprocesrecht eerst na sanctionering door het bestuursorgaan plaats vindt, tonen genoemde auteurs zich en dan druk ik me nog zacht uit - bepaald geen voorstanders van regulering van de samenleving middels algemeen geformuleerde zorgplichtbepalingen. Dergelijke zeer algemeen geformuleerde zorgplichtbepalingen die bedoeld zijn als algemene grondslag om handhavend op te treden staan, volgens Teunissen en Tak, op gespannen voet met de eisen van de rechtsstaat en het lex certa-vereiste (door Teunissen en Tak gelijkgesteld met het 'Bestimmtheitsgebot'). ${ }^{84}$ Van Ommeren lijkt die mening te delen. Hij stelt in zijn dissertatie dat hij moeite heeft met bestuursrechtelijke en strafrechtelijke handhaving van zorgplichtbepalingen omdat genoemde bepalingen te algemeen van aard zijn. $^{85}$

Michiels neemt, in zijn noot onder een uitspraak van de Afdeling Bestuursrechtspraak van 5 juli 1994, anders dan bijvoorbeeld Visser ${ }^{86}$, een genuanceerder standpunt in ${ }^{87}$ In genoemde uitspraak stond de zorgplichtbepaling uit de Wet bodembescherming (thans artikel $13 \mathrm{Wbb}$ ) centraal. Hoewel ook Michiels, met het oog op het lex certa-vereiste, zijn twijfels lijkt te hebben bij een algemeen geformuleerde zorgplicht meent hij dat deze twijfels niet langer gegrond zijn als het bestuur in de handhavingsbeschikking (zijnde een bestuursdwangaanschrijving of een last onder dwangsom) voldoende duidelijkheid verschaft omtrent de verboden handelingen die beëindigd moeten worden. Ik plaats daarbij de volgende kanttekeningen. Dergelijke concretiserende normstelling door het bestuur, vóórdat overgegaan wordt tot daadwerkelijke handhaving, is alleen

82 Zie bijvoorbeeld: Visser a.w. 2001, p. 442. Zie voorts: Roef a.w. 2001, p. 49-51.

83 J.M.H.F. Teunissen en A.Q.C. Tak, Recht ist was der Umwelt nutzt?, NJB 1994, p. 605-616 (a.w. 1994a), i.h.b. p. 605. Op deze plaats dient te worden opgemerkt dat het uit artikel 7 EVRM voortvloeiende lex certa-vereiste, gelet op de definitie van de term 'penalty', wellicht niet van toepassing is in het kader van de toepassing van bestuursdwang en het opleggen van een last onder dwangsom. Zoals gezegd gaat de commissie Scheltema er echter van uit dat artikel 5.0.4 Voorontwerp, het lex certavereiste incluis, niet alleen ziet op de bestuurlijke boete maar ook op herstelsancties.

84 Teunissen en Tak, a.w. 1994a p. 606. Teunissen en Tak wijzen er, op p. 606, op dat vage wettelijke normen als bevoegdheidsgrondslag voor de overheid én als algemene rechtsplicht voor de burger zeer omstreden zijn. 'Is het in overeenstemming met de eisen van de rechtsstaat, indien de wet vastlegt dat het bestuur dwang mag uitoefenen jegens burgers indien zij onvoldoende zorg in acht nemen voor enig algemeen belang?'; vragen zij zich op p. 608 af. $\mathrm{Zij}$ wijzen in dit kader ook op het in de Duitse Bondsrepubliek in de constitutie verankerde 'Bestimmtheitsgebot' (zie over het 'Bestimmtheitsgebot' bij de oplegging van puntitieve bestuursrechtelijke sancties ook: Göhler a.w. 1998, p. 36-39, G. Rosenkotter, Das Recht der Ordnungswidrigkeiten, Richard Boorberg Verlag, Stutgart/München/Hannover/Berlin' Weimar/Dresden 1995, p. 20-23, Hazewinkel-Suringa bewerkt door Remmelink a.w. 1996, p. 486-487, en (meer in algemene zin) B. Kastner, Verdachtsunabhăngige Personenkontrollen im Lichte des Verfassungsrechts, Verwaltungsarchiv 92 2001, p. 216-260, i.h.b. 243-244). Zie tenslotte: A.Q.C. Tak en J.M.H.F. Teunissen, Wie zorgt er voor de rechtsstaat? Een voortgezet debat, Recht en Kritiek, 1994, p. 340-354 (a.w. 1994b).

85 Van Ommeren a.w. 1996, p. 143-145.

86 Zie Visser a.w. 2001, p. 442.

ABRS 5 juli 1994, AB 1994, 636 m. nt. F. Michiels (Nuisker Car Coating). 
mogelijk bij reparatoire sancties. Bovendien was het bij een duidelijker geformuleerde verplichting misschien nooit tot een overtreding gekomen.

De door Michiels gevolgde redenering snijdt, bij de oplegging van een punitieve bestuursrechtelijke sanctie, zoals de bestuurlijke boete, in ieder geval geen hout. Voor de overtreder moet dan van tevoren, dus op basis van een wettelijke bepaling ${ }^{88}$, voldoende duidelijk zijn welke gedragingen strafbaar zijn. Indien dat niet mogelijk is voldoet de algemene zorgplichtbepaling niet aan het lex certa-vereiste. Teunissen en Tak delen die mening. ${ }^{89}$

Ten aanzien van door middel van punitieve sancties te handhaven algemeen geformuleerde zorgplichtbepalingen staat mijns inziens in voldoende mate vast dat zij moeten voldoen aan het lex certa-vereiste. Daarnaast kan men zich afvragen of algemeen geformuleerde zorgplichtbepalingen waarvan de schending met reparatoire sancties wordt gesanctioneerd niet óbk zouden moeten voldoen aan het lex certa-vereiste. Ik meen van wel. Indien een schending van een wettelijke (zorgplicht)bepaling gesanctioneerd kan worden, moet deze bepaling, ongeacht de aard van de sanctie, voldoen aan genoemd lex certa-vereiste. Een burger moet immers van tevoren kunnen weten welke gedragingen al dan niet kunnen leiden tot schending van de wettelijke norm en derhalve tot 'bestraffing.'..$^{90}$ Teunissen en Tak nemen een zelfde standpunt in. ${ }^{91} \mathrm{Zie}$ ik het goed dan wordt laatstgenoemd standpunt ook door de commissie Scheltema ingenomen. Zij gaat immers, zo leid ik uit het Voorontwerp af, expliciet uit van de toepasselijkheid van het lex certa-vereiste bij punitieve én reparatoire sancties. ${ }^{92}$ Dit lijkt mij een juist uitgangspunt.

\section{Artikel 5.0.5 Rechtvaardigingsgrond}

Evenals in artikel 5.0.4 is in artikel 5.0.5 van het Voorontwerp een van oorsprong strafrechtelijk beginsel neergelegd. Artikel 5.0 .5 luidt als volgt: 'Het bestuursorgaan legt geen bestuurlijke sanctie op voor zover voor de overtreding een rechtvaardigingsgrond bestond.' Een rechtvaardigingsgrond impliceert dat het feit niet strafbaar is (de verboden gedraging is in het concrete geval niet wederrechtelijk). Een schulduitsluitingsgrond daarentegen ziet op de strafbaarheid van de dader. Dit brengt volgens de commissie Scheltema met zich dat rechtvaardigingsgronden voor alle bestuurlijke sancties van belang zijn terwijl schulduitsluitingsgronden daarentegen alleen een rol kunnen spelen in het kader van bestuurlijke boeten. Verwijtbaarheid is immers niet vereist teneinde een herstelsanctie op te kunnen leggen. ${ }^{93}$

88 Gelet op de rechtspraak van het EHRM hoeft dit géén wet in formele zin te zijn (ook beleidsregels zouden derhalve onder de materiěle detinitie van de term 'law' kunnen vallen). Vgl. \$ 3.4.3.a van dit boek.

89 Teunissen en Tak a.w. 1994a, p. 605-608. Zie in deze zin ook Roef a.w. 2001, p. 51.

90 Vgl. R.J.N. Schlossels, Wederkerigheid en specialiteit in het bestuursrecht, in de bundel: Eenzijdig en wederkerig?, onder redactie van E.C.H.J. van der Linden en A.Q.C. Tak, Deventer 1995, p. 153-190, i.h.b. p. $159-160$.

9l Teunissen en Tak a.w. 1994a, i.h.b. p. 607-608.

92 Voorontwerp p. 111.

93 Voorontwerp p. 111-112. Zie m.b.t. strafuitsluitingsgronden in het algemeen voorts: HazewinkelSuringa bewerkt door Remmelink a.w. 1996, p. 263 e.v. 
Een opsomming van de rechtvaardigingsgronden is bewust niet opgenomen in het Voorontwerp. De commissie Scheltema gaat namelijk, in afwijking van het strafrecht, uit van een open stelsel van rechtvaardigingsgronden. ${ }^{94}$ Daarbij lijkt de commissie niet uit te sluiten dat in het bestuursrecht van het strafrecht afwijkende opvattingen worden ingenomen ten aanzien van de rechtvaardigingsgronden. De commissie Scheltema stelt te dien aanzien het volgende: 'Het is aan het bestuur en uiteindelijk aan de rechter om daaraan (het open stelsel van rechtvaardigingsgronden [KA]) verder invulling te geven. Niettemin ligt het natuurlijk voor de hand, dat bestuur en rechter daarbij de strafrechtelijke jurisprudentie en de klassieke strafuitsluitingsgronden tot uitgangspunt zullen nemen. ${ }^{.95}$ Hoofdregel is dat de overtreder zelf een gemotiveerd beroep moet doen op een rechtvaardigingsgrond. ${ }^{96}$

Van der Hulst vindt de keuze van de commissie Scheltema voor een open stelsel van rechtsvaardigingsgronden niet zo gelukkig. ${ }^{97} \mathrm{Naar}$ zijn oordeel wordt onnodig afgeweken van het strafrecht. Bovendien lijkt de rechtszekerheid van de burger er mee gediend dat de burger een catalogus van strafuitsluitingsgronden wordt aangereikt aan de hand waarvan hij zich nader kan bezinnen op zijn procespositie, zo stelt Van der Hulst. ${ }^{98}$

\section{Artikel 5.0.6 cumulatie van herstelsancties}

Artikel 5.0 .6 bevat een bepaling met betrekking tot cumulatie van herstelsancties. De regeling uit artikel 5.0.6 van het Voorontwerp is in feite gelijk aan de regeling uit het huidige artikel 5:31 en 5:36 van de Awb. Van cumulatie van (herstel)sancties is volgens de toelichting bij het Voorontwerp sprake als op overtreding van éen bepaald voorschrift meer dan één sanctie is gesteld terwijl de verschillende sancties gelijktijdig opgelegd (kunnen) worden. ${ }^{99}$ Op basis van artikel 5.0.6 is cumulatie van twee of meer herstelsancties verboden. ${ }^{100}$ Het na elkaar toepassen van herstelsancties ten aanzien van dezelfde overtreding is wel mogelijk. Het 'ne bis in idem'-beginsel geldt derhalve niet voor herstelsancties. Dit is niet vreemd. Zolang de onrechtmatige toestand voort blijft bestaan moet het bestuur kunnen beschikken over (reparatoire) sancties teneinde normconform gedrag af te dwingen. Ook in het strafrecht geldt dit uitgangspunt. In dit kader kan worden gewezen op het in het strafrecht bestaande, zogenaamde voortdurend delict. Van een dergelijk delict is sprake als de overtreding bestaat uit het doen bestaan of

94 Voorontwerp p. 112

95 Voorontwerp p. 112.

96 De vraag is of deze praktijk wenselijk is. Vgi. C.L.G.F.H. Albers en R.J.N. Schlossels, De bestuurlijke boete: een koekoeksei in het bestuursprocesrecht, NTB 2002/7, p. 187-198.

97 Dat Van der Hulst niet de enige is die dit standpunt inneemt blijkt uit de bijdrage van Knigge in RM Themis (a.w. 2000, p. 93).

98 J.W. van der Hulst, Enige bepalingen over de bestuurlijke boete belicht vanuit strafrechtelijk perspectief, in de bundel: Commentaren op het Voorontwerp Algemene wet bestuursrecht Vierde tranche, onder redactie van L.J.J. Rogier, Rotterdam 2000 (a.w. 2000 a), p. 65-76, i.h.b. p. 67.

99 Voorontwerp p. 113. Cumulatie is niet hetzelfde als samenloop. Bij samenloop (5.0.8 Voorontwerp) gaat het om overtreding van twee of meer voorschriften door eén gedraging.

100 In dit kader kan gewezen worden op een uitspraak van de Afdeling Bestuursrechtspraak van 16 januari 1996 (ABRS 16 januari 1996, AB 1996, 409 m. nt. G. Jurgens (Ahold)) die moeilijk verenigbaar lijkt te zijn met dit standpunt. De Afdeling achtte in genoemde zaak cumulatie van een strafrechtelijke en bestuursrechtelijke reparatoire sanctie ten aanzien van dezelfde overtreding toegestaan. 
voortbestaan van een verboden toestand. ${ }^{101} \mathrm{Bij}$ een voortdurend delict mag ook in het strafrecht herhaaldelijk, zo lang het delict voortduurt, gestraft worden. Het ne bis in idem-beginsel verzet zich hier, volgens de Hoge Raad ${ }^{102}$, niet tegen. ${ }^{103}$

\section{Artikel 5.0.7 preventieve handhaving}

De mogelijkheid om door middel van herstelsancties preventief te handhaven is neergelegd in artikel 5.0.7 van het Voorontwerp: 'Een herstelsanctie kan worden opgelegd zodra het gevaar voor de overtreding klaarblijkelijk dreigt.' Feitelijk behelst artikel 5.0.7 slechts de codificatie van de bestuursrechtspraak ten aanzien van preventieve handhaving. ${ }^{104} \mathrm{Om}$ over te kunnen gaan tot preventieve handhaving moet met grote mate van waarschijnlijkheid vaststaan dat de overtreding zal plaatsvinden. Uit de rechtspraak met betrekking tot preventieve handhaving vloeit voorts de eis voort dat de te verwachten overtreding een emstige schade moet veroorzaken. Deze eis wordt gesteld met het oog op het in artikel 3:4, tweede lid, van de Awb neergelegde evenredigheidsbeginsel. Het vereiste dat de overtreding ernstige schade moet veroorzaken is echter niet expliciet opgenomen in artikel 5.0.7 van het Voorontwerp. De commissie Scheltema acht dit niet noodzakelijk en motiveert dit standpunt als volgt: 'Evenmin is het nodig de eis van ernstige schade afzonderlijk in de wet neer te leggen, nu als gezegd reeds uit artikel 3:4, tweede lid, voortvloeit dat preventief optreden alleen bij meer emstige overtredingen mogelijk is. ${ }^{105}$ Dat de eis van te verwachten ernstige schade niet expliciet gesteld wordt in artikel 5.0.7 van het Voorontwerp neemt derhalve niet weg dat deze eis blijft gelden in het kader van preventieve handhaving.

Opvallend is dat de eis van te verwachten emstige schade de laatste tijd in de Afdelingsjurisprudentie niet meer onverkort gesteld lijkt te worden. ${ }^{106}$ Men kan zich, er van uitgaande dat de Afdeling anticipeert op de regeling uit het Voorontwerp, de vraag stellen of dit voortvloeit uit het feit dat in artikel 5.0.7 van het Voorontwerp de eis van emstige schade niet expliciet is verwoord. Niet iedere rechter zal immers de toelichting op artikel 5.0.7 paraat hebben. De consequentie is dat zich in de rechtspraak een, door de commissie Scheltema kennelijk niet gewenste, versoepeling van eisen, die in het kader van preventieve handhaving in acht genomen moeten worden, voor lijkt te doen. Met het oog op het voorgaande is het wellicht aanbevelenswaardig de eis van te verwachten ernstige schade expliciet te verwoorden in artikel 5.0.7 van het Voorontwerp.

101 Zie: Hazewinkel-Suringa bewerkt door Remmelink a.w. 1996, p. 120.

$102 \mathrm{Vgl.} \mathrm{HR} 7$ mei 1923, NJ 1923, 932, W I 1082 en meer recent HR I december 1975, NJ 1976. 254.

$103 \mathrm{Vgl}$. Van Bemmelen-Van Veen bewerkt door De Jong en Knigge a.w. 1998, p. 253.

104 Zie in dit kader $\$ 2.2 .3 .4$ en 2.2.3.5 van dit boek.

105 Voorontwerp p. 115. Zie omtrent preventieve handhaving en relevante jurisprudentie in dit kader voorts de NTB-kroniek: Handhaving van het bestuursrecht, van L.J.J. Rogier, NTB 2001/3, p. 77-84, i.h.b. p. 79, en ABRS 29 september 2000, JB 2000/304 m. nt. C.L.G.F.H. Albers, AB 2000, $474 \mathrm{~m}$. nt. F. Michiels (Brandende oplegger). Zie voorts: Rechtbank Maastricht, 5 februari 2001, JB 2001/84 m. nt. C.L.G.F.H. Albers (Statafels Vrijthof) waarin de Maastrichtse rechtbank ten onrechte aanneemt dat er sprake is van preventie oplegging van een last onder dwangsom.

Vgl. o.m. ABRS 29 september 2000, JB 2000/304 m. nt. C.L.G.F.H. Albers (Brandende oplegger), en ABRS 26 septenber 2001, $A B$ 2002, 67 m. nt. F.R. Vermeer. 


\section{Artikel 5.0.8 eendaadse en meerdaadse samenloop}

\section{Algemeen}

In artikel 5.0.8 van het Voorontwerp is de, uit het strafrecht afkomstige, complexe figuur van eendaadse en meerdaadse samenloop geregeld. Genoemd artikel luidt als volgt: 'Indien twee of meer voorschriften zijn overtreden, kan voor de overtreding van elk afzonderlijk voorschrift een bestuurlijke sanctie worden opgelegd, tenzij slechts één gedraging plaatsvond.' Indien derhalve door een bepaald feitelijk handelen (of nalaten) twee of meer voorschriften worden overtreden komt de vraag aan de orde of er slechts één gedraging heeft plaatsgevonden. Heeft er slechts éen gedraging plaatsgevonden dan is er, strafrechtelijk gesproken, sprake van eendaadse samenloop, en kan er slechts één sanctie worden opgelegd (bovendien is 'bis in idem' uitgesloten). Is er sprake van meer dan één gedraging dan gaat het om meerdaadse samenloop. Bij meerdaadse samenloop kunnen de op de verschillende gedragingen gestelde sancties bij elkaar worden opgeteld/tezamen worden opgelegd. De sanctie moet, bij meerdaadse samenloop, in zijn geheel wel in overeenstemming zijn met het, in artikel 3:4, tweede lid van de Awb, neergelegde evenredigheidsbeginsel.

\section{Eén gedraging}

Essentieel voor beantwoording van de vraag of er sprake is van eendaadse dan wel meerdaadse samenloop is de vraag of er sprake is van één gedraging. Van meerdaadse samenloop is volgens de commissie Scheltema sprake als een fysieke handeling kan worden uiteengerafeld in verschillende gedragingen, die ook afzonderlijk hadden kunnen worden gepleegd en die verschillende belangen schenden. ${ }^{107}$ Eendaadse samenloop doet zich volgens de commissie voor, als onder de gegeven omstandigheden overtreding van de ene bepaling noodzakelijkerwijs ook overtreding van de andere bepaling impliceert, dan wel indien beide bepalingen dezelfde strekking hebben omdat zij dezelfde belangen beschermen. ${ }^{108}$ De constatering dat de geschonden normen al dan niet dezelfde belangen beschermen lijkt derhalve doorslaggevend te zijn bij beantwoording van de vraag of er sprake is van eén gedraging of van meerdere gedragingen en of daarmee sprake is van eendaadse of meerdaadse samenloop.

De VAR-werkgroep plaatst kritische kanttekeningen bij de door de commissie Scheltema gegeven uitleg. ${ }^{109}$ Ten aanzien van de in artikel 5.0.8 door de commissie Scheltema gehanteerde term één gedraging stelt de VAR-werkgroep het volgende:

'De bedoeling van de opstellers van het Voorontwerp lijkt te zijn dat wordt voorkomen dat curnulatic van sancties plaatsvindt in het geval dat verschillende voorschriften zijn over-

107 Voorontwerp p. 115. Zie ik het goed dan neemt de Afdeling Bestuursrechtspraak een vergelijkbaar standpunt in (zie in dit kader: ABRS 30 maart 2001, JB 2001/129 m. nt. C.L.G.F.H. Albers, AB 2001, 189 m. nt. L. Damen). Vgl. HR 24 november 1987, NJ 1988, 665.

108 Voorontwerp p. 116.

109 VAR-werkgroep 2000 , p. 37-40. Op p. 38 schrijt de werkgroep het volgende: 'De vraag is nu: wanneer is sprake van eén gedraging? De toelichting verschaft op dit punt weinig helderheid. Verdedigbaar is dat men bij het invullen van het begrip 'gedraging' vooral zou moeten kijken naar hetgeen feitelijk plaatsvindt. Blijkens de toelichting lijkt echter ook het wettelijk voorschrift dat een gedraging als overtreding kwalificeert, een rol te spelen. Dit zou ertoe kunnen leiden dat in een situatie waarin feitelijk (fysiek) slechts eên handeling plaatsvindt, er toch sprake is van meer gedragingen in de zin van de Awb ter zake waarvan tegelijkertijd meerdere sancties kunnen worden opgelegd.' 
treden, die strekken ter bescherming van dezelfde belangen. Wanneer de voorschriften verschillende belangen beschermen, zouden dan dus wel meerdere sancties kunnen worden opgelegd. Een nadere onderbouwing van dit uitgangspunt ontbreekt overigens in de toelichting. Het zou aanbeveling verdienen om, indien dit uitgangspunt wordt gehanteerd, dit ook met zoveel woorden in een wettelijke bepaling vast te leggen. Het hanteren van het begrip 'gedraging', waarbij in het kader van artikel 5.0.8 niet de puur feitelijke handeling wordt aangeduid, maar waarbij de strekking van de overtreden normen maakt dat sprake is van een of meer 'gedragingen', werkt onnodig complicerend. Het verdient aanbeveling om het begrip 'gedraging' te reserveren voor de aanduiding van hetgeen feitelijk plaatsvindt.'110

De werkgroep heeft mijns inziens gelijk als zij stelt dat de commissie Scheltema artikel 5.0 .8 helderder had kunnen formuleren door niet in de toelichting maar in de bepaling zelf aan te geven dat de strekking van de geschonden norm doorslaggevend is. " Dat de commissie Scheltema er van uit gaat dat er sprake is van meerdaadse samenloop als de geschonden normen niet dezelfde belangen (doelen) beschermen is vanuit bestuursrechtelijk oogpunt echter niet vreemd. Deze idee vloeit (wellicht) voort uit het in het bestuursrecht geldende specialiteitsbeginsel. ${ }^{112} \mathrm{Nu}$ dit beginsel met zich brengt dat iedere bestuurswet enkel op haar eigen doelgebonden gebied mag worden toegepast zal ook met de handhaving van verschillende, uit de bijzondere bestuursrechtelijke wetten voortvloeiende, normen een ander (materieel) doel ${ }^{113}$ beoogd worden.

Bovendien lijkt ook de Hoge Raad in strafrechtelijke zaken waarde te hechten aan de vraag of de geschonden normen dezelfde belangen (beogen te) beschermen bij de vaststelling dat er (al dan niet) sprake is van eendaadse samenloop. Illustratief in dit kader is een arrest van 14 april 1998. ${ }^{114}$ Verdachte had heroüne vanuit Nederland naar België geëxporteerd. De heroïne had hij in België geruild voor kleding, keukengerei, parfum en speelgoed. De verdachte wist dat deze laatste goederen door een misdrijf waren verkregen. Hij werd beschuldigd van het exporteren van verboden middelen (i.c. heroïne), hetgeen op grond van artikel 2 van de Opiumwet verboden is, en van opzetheling (strafbaar gesteld in artikel $416 \mathrm{Sr}$ ). De Hoge Raad komt tot het oordeel dat genoemde bepalingen een verschillende strekking hebben zodat er geen sprake is van eendaadse samenloop. Hetzelfde geldt voor bestraffing wegens het plegen van een gewapende overval (strafbaar gesteld in artikel $312 \mathrm{Sr}$ ) en het overtreden van artikel 3 Vuurwapenwet 1919 wegens het, tijdens de overval, voorhanden hebben van vuurwapens. ${ }^{115} \mathrm{Er}$

110 VAR-werkgroep 2000 , p. 39

111 Deze kritiek zou overigens ook geuit kunnen worden m.b.t. art. 55 (eendaadse samenloop) en art. $57 \mathrm{Sr}$ (meerdaadse samenloop) nu daarin gesproken wordt van éen feit en meerdere feiten die als op zichzelf staande handelingen moeten worden beschouwd.

112 Zie in dit kader: R.J.N. Schlossels, Het specialiteitsbeginsel. Over de structuur van bestuursbevoegdheden, wetmatigheid van bestuur en beleidsvrijheid (diss. UM Maastricht), Den Haag 1998. Zie voor een overzicht van recente rechtspraak m.b.t. genoemd beginsel: R.J.N. Schløssels, Het specialiteitsbeginsel. Een verkenning van recente rechtspraak, JBplus 2001, p. 33-47.

$113 \mathrm{lk}$ doel dan niet op het algemene doel van een sanctie (leedtoevoeging of herstel van een rechtmatige toestand) maar op een concreet, aan de wettelijke regeling ten grondslag liggend, doel (bijv. milieubescherming, of het waarborgen van goede arbeidsomstandigheden).

114 HR 14 april 1998, NJ 1998, 609. Vgl. HR 22 september 1981, NJ 1981, 644 m. nt. Th. W. van Veen.

115 HR 24 april 1984, NJ 1984, 639. De Hoge Raad heeft in genoemd arrest helder weergegeven wat het verschil in strekking tussen art. $312 \mathrm{Sr}$ en art. 3 Vuurwapenwet 1919 is: 'Het hiervoor onder 4 vermelde sub 2 bewezen verklaarde is niet - ook niet deels - hetzelfde feit als het sub 1 als bewezen aangenomene. Immers bij het medeplegen van poging tot diefstal met geweldpleging is de zin van de strafbaar- 
is volgens de Hoge Raad wél sprake van eendaadse samenloop bij het binnen het grondgebied van Nederland brengen en het aanwezig hebben van (dezelfde) heroïne (op dezelfde tijd en plaats) omdat art. 2 lid 1 onder A en art. 2 lid 1 onder $C$ van de Opiumwet dezelfde strekking hebben. ${ }^{116}$

\section{Evenredig?}

Men kan zich overigens afvragen in hoeverre het standpunt dat er bij meerdaadse samenloop in beginsel sprake zal zijn van een cumulatie van sancties die in overeenstemming is met het evenredigheidsbeginsel, reěel is. ${ }^{17}$ Niet zelden zullen immers, in het kader van meerdaadse samenloop, verschillende bestuursorganen bevoegd zijn tot het opleggen van een sanctie. ${ }^{118}$ Hoe groot is de kans dat de verschillende bestuursorganen zich er van bewust zijn dat (wellicht) door de gedraging van de vermoedelijke overtreder ook een bepaling uit een andere wettelijke regeling - in het kader waarvan aan het betreffende bestuursorgaan geen sanctiebevoegdheden toekomen - is geschonden? En wat als zij allen op basis van een wettelijk gefixeerd boetestelsel een bestuurlijke boete moeten opleggen (terwijl aan de rechter in dit kader met betrekking tot de evenredigheid van de afzonderlijke boeten geen toetsingsbevoegdheid toekomt)? ${ }^{119}$ Een onevenredige boeteregen, of cumulatie van andere bestuursrechtelijke sancties, lijkt mij, met het oog op het voorgaande, in ieder geval zeker niet in alle gevallen uitgesloten. ${ }^{120}$

Voor de meermaals gesanctioneerde burger leidt een dergelijke opeenstapeling van sancties er bovendien toe dat hij in verschillende, naast elkaar lopende, juridische procedures verzeild raakt. Om zijn recht te kunnen halen zal hij in principe alle, ten aanzien van hem genomen sanctiebesluiten, die zien op dezelfde gedraging, aan moeten vechten. Hoe een en ander vervolgens in de praktijk uitwerkt kan men zich afvragen. Het is immers niet ondenkbaar dat de in bezwaar oordelende bestuursorganen ieder tot een andere beslissing komen. Voorts kan zich ook nog de situatie voordoen dat in be-

heid van het aanwezig hebben van vuurwapenen gelegen in het gevaar dat daarmee diefstal wordt voorbereid of gemakkelijk gemaakt of dat hetzij de vlucht mogelijk wordt gemaakt hetzij het bezit van het gestolene wordt verzekerd, terwijl de strafbaarheid van het sub 2 bewezene, dat is omschreven in art. 3 Vuurwapenwet 1919 - volgens de $\mathrm{MvT}$ - de strekking heeft in het algemeen de gevaren, welke uit de onbelemmerde verspreiding van wapenen onder de bevolking voortvloeien, te keren, wasrbij kennelijk wordt gedoeld op gevaren van allerlei aard en niet slechts op misbruik van vuurwapenen bij het begaan van diefstal.' Vgl. HR 19 februari 1980, NJ 1980, 384.

116 HR 3 januari 1984, NJ 1984, $420 \mathrm{~m}$. nt. 't Hart. Vgl. HR I juli 1981, NJ 1981, $616 \mathrm{~m}$. nt. Th. W. van Veen. Zie voorts: HR 11 mei 1982, NJ 1982,592. Verdachte heeft een voetganger aangereden en daarna gewond bij koud weer achtergelaten. Die persoon is naderhand gestorven ten gevolge van een longontsteking. Verdachte wordt beschuldigd van dood door schuld (art. $307 \mathrm{Sr}$ ) en het doorrijden na een ongeval (destijds strafbaar gesteld in art. 30 WVW, nu art. 7 WVW). Overtreding van genoemde bepalingen levert volgens de Hoge Raad eendaadse samenloop op. Er is geen sprake van eendaadse samenloop bij bestraffing wegens het besturen van een voertuig onder invloed (art. 8 WVW) en bestraffing wegens het in gevaar brengen van de veiligheid op de weg (art. 5 WVW) (zie: HR 19 januari 1982, NJ 1982, 354).

117 Vgl. Voorontwerp p. 116

118 Vgl. ABRS 10 februari 1997, AB 1997, 427 m. nt. N. Verheij.

119 Vgl. O.J.D.M.L. Jansen, De dynamiek van het publiekrechtelijke sanctierecht, Handelingen NJV 20021, Deventer 2002, p. 167-255, i.h.b. p. 198-201. Zie voorts m.b.t. de problematiek rondom wettelijk gefixeerde boeten de in dit hoofdstuk opgenomen toelichting op artikel 5.4.1.7, lid 3 Voorontwerp. Vgl. Albers en Schlossels a.w. 2002, \$9.1 en (in ruimere zin) Jansen a.w. 2002, p. 198-201. 
roep verschillende rechters bevoegd zijn. Dit leidt mijns inziens tot zeer mistige toestanden. De rechtszekerheid van een (vermoedelijk) overtreder is in ieder geval met een dergelijk sanctiesysteem niet gediend. Ik vraag me af of de commissie Scheltema zich daar rekenschap van heeft gegeven bij het opstellen van het Voorontwerp. ${ }^{121}$

\section{Cumulatie punitieve en reparatoire sanctie}

Op deze plaats wil ik tenslotte nog opmerken dat de regeling die in artikel 5.0.8 van het Voorontwerp is neergelegd gelijktijdige oplegging van een punitieve en reparatoire sanctie ingeval van eendaadse samenloop uitsluit. De VAR-werkgroep meent dat de commissie Scheltema dit over het hoofd heeft gezien: 'Deze consequentie is merkwaardig omdat in het algemeen een combinatie van een herstelsanctie met een bestuurlijke boete niet problematisch wordt geacht. Hier is sprake van een onbedoeld neveneffect van artikel 5.0.8. ${ }^{122}$ Deze kritiek lijkt terecht te zijn. Bij de toelichting op artikel 5.0.6 van het Voorontwerp heeft de commissie Scheltema namelijk het volgende gesteld: 'Cumulatie van een punitieve sanctie (...) met een herstelsanctie is in beginsel mogelijk, omdat beide typen sancties naar doel en strekking verschillen. ${ }^{123}$ Het kan toch niet zo zijn dat het voorgaande ten aanzien van eendaadse samenloop dan niet zou gelden? Anderzijds zou het ook zo kunnen zijn dat de commissie Scheltema er van uit gaat dat het feit dat punitieve sancties en herstelsancties naar doel en strekking verschillen met zich brengt dat ook de geschonden normen niet dezelfde belangen beschermen. Met andere woorden, zodra é̉n 'feitelijk feit' een normschending oplevert die middels een herstelsanctie gehandhaafd wordt, en een normschending die middels een punitieve sanctie gehandhaafd wordt, zal er per definitie geen sprake zijn van eendaadse samenloop. Het is echter de vraag of deze redenering in alle denkbare gevallen plausibel is.

\section{Artikel 5.0.9 inhoud van de sanctiebeschikking}

Artikel 5.0.9 van het Voorontwerp bevat enkele bepalingen met betrekking tot de inhoud van de beschikking tot oplegging van een bestuurlijke sanctie. In ieder geval dienen in de beschikking de overtreding en het overtreden voorschrift vermeld te worden (artikel 5.0.9 onder a van het Voorontwerp). Daarnaast dienen zonodig - namelijk voor zover dit nodig is om de gedraging te identificeren - de plaats waar, en het tijdstip waarop de overtreding is geconstateerd te worden vermeld. Ten aanzien van beschikkingen waarbij een bestuurlijke boete wordt opgelegd gelden nog enkele aanvullende

121 Hier manifesteert zich een probleem dat zich op vele plaatsen in het Voorontwerp voordoet. Namelijk het probleem dat het huidige bestuur(proces)rechtelijke systeem zich niet (onverkort) leent voor de oplegging van punitieve sancties. In het strafrecht zullen de hierboven geschetste problemen in het kader van meerdaadse samenloop zich immers niet (snel) voordoen.

122 VAR-werkgroep 2000 , p. $39-40$

123 Voorontwerp p. 113. Zie in dit kader ook ABRS 11 februari 2000, JB 2000/75 m. nt. C.L.G.F.H. Albers. In die zaak oordeelde de Afdeling dat ten aanzien van dezelfde overtreding (van aan een milieuvergunning verbonden voorschriften) naast een strafrechtelijke boete ook een last onder dwangsom kan worden opgelegd. De dwangsom en de strafrechtelijke boete dienen namelijk andere doelen. De Afdeling wijst daarbij op het onderscheid reparatoir/punitief. Gelet op het feit dat genoemde sancties andere doelen dienen is er volgens de Afdeling geen sprake van strijd met de beginselen van ne bis in idem en una via. Of een dergelijke, door de Afdeling voorgestane, benadering in het kader van de oplegging van een last onder dwangsom naast een strafrechtelijke boete wenselijk is, is een andere vraag (vgl. \$2 2.2.3.c van dit boek) 
eisen. Deze eisen zijn neergelegd in artikel 5.4.2.5 van het Voorontwerp. Op grond van laatstgenoemd artikel dienen in de beschikking tevens de naam van de overtreder en het bedrag van de boete vermeld te worden.

Houdt de beschikking de verplichting tot betaling van een geldsom in (bijvoorbeeld oplegging van een bestuurlijke boete) dan moet de beschikking voorts voldoen aan de eisen die voorvloeien uit het tweede lid van artikel 4.4.1.2 van het Voorontwerp. De te betalen geldsom en de termijn waarbinnen de geldsom betaald moet worden dienen in een dergelijk geval tevens in de beschikking vermeld te worden.

Mocht niet aan al deze eisen zijn voldaan in een beschikking tot oplegging van een bestuurlijke sanctie dan kan een dergelijk 'vormverzuim' eventueel gepasseerd worden op grond van artikel 6:22 Awb. Het passeren van een vormverzuim is echter slechts mogelijk indien de vermoedelijke overtreder door de onvolkomenheid in de beschikking niet in zijn (verdedigings) belangen is geschaad. ${ }^{124}$

Met de artikelen 5.0.9 en 5.4.2.5 van het Voorontwerp lijkt de commissie Scheltema onder meer invulling te willen geven aan artikel 6 lid 3 aanhef en onder a EVRM. Op grond van laatstgenoemde bepaling heeft een ieder, die wegens een strafbaar feit wordt vervolgd, het recht om onverwijld, in een taal welke hij verstaat, en in bijzonderheden, op de hoogte te worden gesteld van de aard en de reden van de tegen hem ingebrachte beschuldiging. Van Russen Groen wijst er in zijn dissertatie terecht op dat met name ten aanzien van punitieve bestuursrechtelijke sancties het recht op volledige informatie ontrent de aanklacht een absolute eis is. ${ }^{125}$ Dit heeft onder meer te maken met het feit dat de beschikking tot oplegging van een bestuurlijke boete in de regel ook een inbeschuldigingstelling inhoudt. In een dergelijk geval moet de gesanctioneerde zonder meer een behoorlijke verdediging kunnen voeren. Specifieke informatie omtrent het gepleegde feit en de redenen waarom een boete (van een bepaalde hoogte) zal worden (of wordt) opgelegd is dan vereist. ${ }^{126}$

Is een punitieve sanctiebeschikking niet specifiek genoeg dat voldoet deze beschikking niet aan de eisen die voortvloeien uit het EVRM. Gesteld kan worden dat de verdedigingsrechten van de vermoedelijke overtreder dan geschonden zijn. Er dient dan ook voor gewaakt te worden dat onvoldoende specifieke beschikkingen, ondanks dat zij in strijd zijn met de uit artikel 6 lid 3 aanhef en onder a EVRM voortvloeiende eisen, in stand gelaten worden onder toepassing van artikel 6:22 Awb. ${ }^{127}$ Dit geldt in het bijzonder als door genoemd 'vormverzuim' in rechte géén goede verdediging meer kan worden gevoerd.

In dit kader kan bovendien de vraag gesteld worden of het niet noodzakelijk is bij de oplegging van bestuurlijke boeten altijd te werken met een aankondiging waarin het bestuursorgaan aangeeft voornemens te zijn een boete op te leggen. De vermoedelijke

127 Vgl. Albers en Schlössels a.w. 2002, § 8.2. Zie in dit kader ook: CRvB 29 juni 2000, JB 2000/254 m. nt. C.L.G.F.H. Albers. De Afdeling Bestuursrechtspraak lijkt niet zo veel moeite te hebben met het passeren van vormverzuimen in dit kader. Vgl. ABRS 28 augustus 2002, LNN-nummer AE 6927 (WIN-boete Zeist). 
overtreder zou bovendien altijd ${ }^{128}$ in de gelegenheid gesteld moeten worden om zijn zienswijze naar voren te brengen ten aanzien van genoemd voomemen vóórdat de definitieve boetebeschikking volgt. Ik kom hier later nog op terug.

\section{Artikel 5.0.10 geldsom komt toe aan bestuursorgaan}

In artikel 5.0.10 eerste lid van het Voorontwerp is geregeld dat de, bij wijze van sanctie te betalen, geldsom toekomt aan het bestuursorgaan dat de sanctie heeft opgelegd ('tenzij bij wettelijk voorschrift anders is bepaald'). Het gaat dan om geldsommen in de vorm van een bestuurlijke boete, een verbeurde dwangsom of de kosten van bestuursdwang. Volgens de toelichting op het Voorontwerp komt de geldsom toe aan de rechtspersoon waartoe het bestuursorgaan dat de sanctie heeft opgelegd behoort. ${ }^{129}$ In die zin is de redactie van het eerste lid van artikel 5.0.10 van het Voorontwerp niet eenduidig met de uitwerking die daaraan gegeven wordt in de toelichting.

In het tweede lid van artikel 5.0.10 van het Voorontwerp is bepaald dat het bestuursorgaan de dwangsom kan invorderen bij dwangbevel. De invordering geschiedt derhalve volgens de regels uit afdeling 4.4.4 van het Voorontwerp betreffende aanmaning en invordering bij dwangbevel. Mevis wijst er op dat de regeling tot invordering bij bestuurlijke boeten daarmee afwijkt van de regeling tot invordering in het kader van het strafrecht. ${ }^{130}$ Op grond van de in het Voorontwerp voorgestelde regeling kunnen namelijk bepaalde kosten, zoals bijvoorbeeld de kosten van het dwangbevel en de aanmaning ${ }^{131}$, worden verhaald op de overtreder. Deze kosten mogen in het kader van een strafrechtelijke procedure niet op de overtreder verhaald worden. De Hoge Raad gaat er namelijk vanuit dat het bedrag van het dwangbevel niet hoger mag zijn dat de som van de oorspronkelijke geldboete en de ingevolge artikel $24 \mathrm{~b}$, eerste en tweede lid $\mathrm{Sr}$ daarop toegepaste verhogingen. ${ }^{132}$

\section{Artikel 5.0.11 zwijgrecht en cautie}

In artikel 5.0.11 van het Voorontwerp heeft de commissie Scheltema invulling proberen te geven aan het nemo tenetur-beginsel (in enge zin) en de cautieplicht. ${ }^{133}$ In het eerste lid is het nemo tenetur-beginsel in enge zin neergelegd: 'Degene die aan een handeling van het bestuursorgaan redelijkerwijs de gevolgtrekking kan verbinden dat aan hem een bestuurlijke sanctie, niet zijnde een herstelsanctie, zal worden opgelegd, is niet langer verplicht ten behoeve van deze oplegging inlichtingen omtrent de overtre-

128 En derhalve niet slechts indien een boete van meer dan 340 Euro wordt opgelegd.

129 Voorontwerp p. 118.

$130 \mathrm{VgI}$. P.A.M. Mevis in de noot onder HR 10 oktober 2000, NJ 2001, 266.

$131 \mathrm{Vgl}$. arikel 4.4.4.8 Voorontwerp.

$132 \mathrm{Vgl}$. HR 10 oktober 2000, NJ 2001, 266 m. nt. P.A.M. Mevis.

133 Het zwijgrecht zoals dat is geregeld in artikel 5.0.11 Voorontwerp ziet op het zwijgrecht gedurende de voorbereiding van het sanctiebesluit en de bezwaarfase. In de beroepsfase (bij de bestuursrechter) voorziet artikel 8:28a Voorontwerp in een regeling met betrekking tot het zwijgrecht en de cautic (zie Voorontwerp p. 118). Hartmann vraagt zich af of de commissie Scheltema terecht uitgaat van toepasselijkheid van artikel 5.0.11 in de bezwaarfase. Hij pleit ervoor de bepaling omtrent zwijgrecht en cautic in afdeling 5.4.2 op te nemen. In genoemde bepaling zou dan ook expliciet het zwijgrecht voor bezwaar en beroep geregeld moeten worden. Zie: A.R. Hartmann, Het zwijgrecht en de cautieverplichting, in de bundel: Commentaren op het Voorontwerp Algemene wet bestuursrecht Vierde tranche, onder redactie van L.J.J. Rogier, Rotterdam 2000, p. 37-63, i.h.b. p. 57-59 en 61-63. 
ding te verstrekken.' Het nemo tenetur-beginsel is onder meer opgenomen in artikel 14 , derde lid onder $g$ van het IVBPR. Bovendien heeft het EHRM in de zaak 'Funke ${ }^{134}$ geoordeeld dat genoemd beginsel deel uit maakt van het 'fair trial'-vereiste uit artikel 6 lid 1 van het EVRM. ${ }^{135}$ Het zwijgrecht en de cautieverplichting zijn voorts neergelegd in artikel $29 \mathrm{~Sv}$.

De commissie Scheltema zoekt in het bijzonder aansluiting bij de verdragsrechtelijke bepalingen en de uitleg die daaraan is gegeven door het EHRM. Bij de uitwerking die genoemde commissie aan het uit het IVBPR en EVRM voortvloeiende nemo teneturbeginsel geeft vallen twee zaken op. Ten eerste de beperking van het nemo teneturbeginsel tot 'het zwijgrecht in strikte zin'. Ten tweede de aanvang van het zwijgrecht, namelijk pas vanaf het moment dat er sprake is van een 'criminal charge' in de zin van artikel 6 van het EVRM. Op beide aspecten zal ik hierna ingaan. Daarbij staat de vraag centraal of de commissie Scheltema met het voorgestelde artikel 5.0.11 in voldoende mate invulling heeft gegeven aan het, onder meer uit genoemde verdragen voortvloeiende, nemo tenetur-beginsel.

\section{Zwijgrecht in strikte zin}

Volgens de commissie Scheltema garandeert artikel 6 EVRM slechts het zwijgrecht in strikte zin: 'het recht om niet te worden gedwongen een bekentenis of verklaring tegen zichzelf af te leggen. ${ }^{136} \mathrm{Zie}$ ik het goed dan vallen schriftelijke verklaringen niet onder 'het zwijgrecht in strikte zin'. Men kan zich afvragen of de commissie op deze wijze, mede gelet op de rechtspraak van het EHRM, niet een te beperkte uitleg van de strekking van het nemo tenetur-beginsel voorstaat. In hoofdstuk drie heb ik, op basis van een analyse van de rechtspraak van het EHRM ten aanzien van het nemo teneturbeginsel (en het daarvan deel uit makende zwijgrecht) het volgende geconcludeerd. Mondelinge én schriftelijke verklaringen ${ }^{137}$ van de verdachte vallen onder het nemo tenetur-beginsel voor zover zij informatie bevatten die de vervolgende instantie niet onafhankelijk van de wil van de verdachte zou kunnen bemachtigen. ${ }^{138}$

Niet alleen het EHRM maar ook de strafkamer van de Hoge Raad lijkt van dit standpunt uit te gaan. In een tweetal arresten van respectievelijk 21 oktober $1997^{139}$ en 22 juni $1999^{140}$ heeft de Hoge Raad uitdrukkelijk aangegeven dat ook het verschaffen van schriftelijke inlichtingen onder het zwijgrecht, zoals dat is neergelegd in artikel $29 \mathrm{~Sv}$, valt. In laatstgenoemd arrest heeft de Hoge Raad in dat kader het volgende overwogen:

'Bij de beoordeling van die klacht moet worden vooropgesteld dat in het Nederlandse recht niet een onvoorwaardelijk recht of beginsel is verankerd dat een verdachte op generlei wijze kan worden verplicht tot het verlenen van medewerking aan het verkrijgen van voor hem mogelijk bezwarend bewijsmateriaal. Wel brengt het aan art. $29 \mathrm{~Sv}$ ten grondslag liggende

134 EHRM 25 februari 1993, NJ 1993, 485 m. nt. Knigge (Funke).

$135 \mathrm{Zie}$, voor de uitleg die het EHRM geeft aan het nemo tenetur-beginsel en het zwijgrecht, ook $\$ 3.4 .2$ van dit boek.

136 Voorontwerp p. 118.

137 Onder deze laatste categorie lijken zelfs (onder bepaalde omstandigheden) bankafschriften te kunnen vallen. Vgl. \$3.4.2 van dit boek.

138 Zie $\$ 3.4 .2$ van dit boek.

139 HR 21 oktober 1997, NJ 1998, 173.

140 HR 22 juni 1999, NJ 1999, 648. 
beginsel mee dat een verdachte niet kan worden verplicht tot het afleggen van een verklaring - het verschaffen van schriftelijke inlichtingen daaronder begrepen [curs. KA] - omtrent zijn betrokkenheid bij een strafbaar feit, waarvan niet kan worden gezegd dat zij in vrijheid is afgelegd. Voorts ligt in art. 6 EVRM besloten dat, indien ten aanzien van een verdachte sprake is van een 'criminal charge' in de zin van die bepaling, deze het recht heeft 'to remain silent' en 'not to incriminate oneself..' ${ }^{141}$

Bovendien lijkt de belastingkamer van de Hoge Raad bij de oplegging van bestuurlijke boeten uit te gaan van een ruimer standpunt dan de commissie Scheltema. Vermeldenswaardig in dit kader is een arrest van de belastingkamer van de Hoge Raad van 8 maart 2002. 142 In genoemd arrest heeft de Hoge Raad, onder verwijzing naar de zaak 'Saunders', bepaald dat, gelet op het uit het EVRM voortvloeiende nemo teneturbeginsel, de aanduiding van gronden van het bezwaar in zaken waar een verhoging (vgl. bestuurlijke boete) aan de orde is, summier mag zijn en onder omstandigheden ook erin kan bestaan dat de belastingplichtige stelt het niet eens te zijn met de voor de verhoging gegeven gronden. De belastingplichtige kan, volgens de Hoge Raad, volstaan met deze stelling als hij daarbij tevens stelt dat standpunt niet nader te kunnen motiveren zonder zichzelf te incrimineren. Uit deze overweging volgt dat het nemo tenetur-beginsel volgens de Hoge Raad ook ziet op schriftelijke verklaringen. ${ }^{143}$

De (tè beperkte) interpretatie door de commissie Scheltema van het zwijgrecht strookt niet met de ruimere uitleg die door het EHRM en de Hoge Raad (onder meer in het kader van artikel $29 \mathrm{~Sv}$ ) aan genoemd recht wordt gegeven. Dit is op zijn minst vreemd te noemen. Ook in de literatuur is deze discrepantie, die leidt tot een verminderde rechtsbescherming in het bestuursstrafrecht, gesignaleerd. Ik wijs in dat kader onder meer op het rapport van de VAR-werkgroep ${ }^{144}$ en een bijdrage van Hartmann aan de bundel 'Commentaren op het Voorontwerp Algemene wet bestuursrecht Vierde tranche'. ${ }^{145}$ Zowel de VAR-werkgroep als Hartmann ${ }^{146}$ zijn van mening dat het zwijgrecht en de cautieverplichting van toepassing zouden moeten zijn ten aanzien van mondelinge en schriftelijke verklaringen. ${ }^{147}$

141 HR 22 juni 1999 , NJ 1999,648 r.0. 4.5.I en 4.5.2.

142 HR 8 maart 2002, JB 2002/112 m. nt. R.M.P.G. Niessen-Cobben en A.W. Heringa.

143 Voorts kan uit genoemd arrest worden afgeleid dat de normaal in het bestuursprocesrecht bestaande plicht tot het aanvoeren van gronden (vgl. artikel 6:5 Awb en artikel 8:69 Awb) niet onverkort geldt in het kader van besluiten tot oplegging van punitieve sancties. In ieder geval mag het niet aanvoeren van (gemotiveerde) gronden niet (zonder meer) leiden tot een niet-ontvankelijk verklaring.

144 VAR-werkgroep a.w. 2000 , p. 44.

145 Hartmann a.w. 2000.

146 Dat de VAR-werkgroep en Hartmann deze mening delen is overigens niet vreend. De bijdrage van Hartmann aan de bundel Commentaren op het Voorontwerp Algemene wet bestuursrecht Vierde tranche is namelijk deels gebaseerd op het commentaar dat Hartmann als lid van genoemde VARwerkgroep heeft geschreven.

147 VAR-werkgroep a.w. 2000, p. 44, Hartmann a.w. 2000, p. 47-49. Zie voorts de oratie van De Moorvan Vugt (A.J.C. de Moor-van Vugt, Toezicht achter matglas (oratie KUB), Den Haag 2001). Ook zij komt, weliswaar wat weifelend, tot de conclusie dat het (onder het nemo tenetur-beginsel vallende) zwijgrecht, gelet op het Saunders-arrest, ook in acht genomen moet worden bij schriftelijke verklaringen (De Moor-van Vugt a.w. 2001, p. 25). 


\section{'Charge'}

Onder verwijzing naar de zaken 'Funke' en 'Saunders' geeft de commissie Scheltema aan dat het zwijgrecht geldt vanaf het moment dat er sprake is van een 'criminal charge ${ }^{148}$ : 'Aangenomen wordt dat van een "criminal charge» sprake is vanaf het moment dat de overtreder uit handelingen van het bestuursorgaan redelijkerwijs kan afleiden dat hem een boete zal worden opgelegd. ${ }^{149}$ In hoofdstuk drie van dit boek ben ik reeds ingegaan op de rechtspraak van het EHRM met betrekking tot het begrip 'charge'. ${ }^{150}$ In genoemd hoofdstuk heb ik aangegeven dat er sprake is van een 'charge' als een bepaalde persoon een officiële kennisgeving van een bevoegde instantie ontvangt waarin deze persoon wordt beschuldigd van een overtreding (offence). In bepaalde gevallen kan een vervolging (charge) echter ook de vorm aannemen van andere maatregelen die een beschuldiging impliceren en die eveneens de positie van de verdachte wezenlijk beïnvloeden.

De commissie Scheltema geeft aan dat 'het enkele bestaan of uiten van een verdenking - ook tijdens een controle of verhoor $\rightarrow(\ldots)$ nog niet genoeg (is [toevoeging KA]) om een "charge» aan te nemen. ${ }^{151}$ De commissie vervolgt: 'Op grond van mededelingen van het bestuursorgaan moet de betrokkene er ook van doordrongen zijn dat er een kans bestaat tot oplegging van een sanctie. ${ }^{1152}$ Impliciet lijkt de commissie Scheltema hiermee aan te geven dat voor het beginpunt van het zwijgrecht geen aansluiting wordt gezocht bij de regeling uit de artikelen 29 en 27 Sv, op basis waarvan aan iedere verdachte het zwijgrecht toekomt. Op grond van artikel 27, eerste lid Sv wordt iemand reeds als verdachte aangemerkt als te diens aanzien uit feiten of omstandigheden een redelijk vermoeden van schuld aan enig strafbaar feit voorvloeit. Uit het voorgaande kan worden afgeleid dat het zwijgrecht op grond van Nederlands strafprocesrecht reeds in een eerder stadium kan worden ingeroepen dan op grond van het EVRM mogelijk is. ${ }^{15.3}$ Ons nationale (strafproces)recht biedt in dit kader dus meer rechtsbescherming. Desondanks gaat de commissie Scheltema er van uit dat het zwijgrecht pas kan worden ingeroepen als er sprake is van een 'charge'.

Gelet op het feit dat de rechtsbescherming in het bestuursstrafrecht niet optimaal is nu opsporing, vervolging en 'berechting' (in eerste instantie) doorgaans aan één en hetzelfde bestuursorgaan is overgelaten, terwijl daarnaast vaak ook nog een middels punitieve sancties te handhaven inlichtingenplicht voor de burger bestaat, had de commissie Scheltema mijns inziens volledig aansluiting moeten zoeken bij de regeling uit artikel 29 (juncto 27) Sv ${ }^{154}$ Het zwijgrecht zou dan reeds in een eerder stadium, immers voordat er sprake is van een 'charge' in de zin van artikel 6 EVRM, gelden. Dit zou als positief gevolg met zich brengen dat het sanctionerende bestuursorgaan minder lang ge-

148 Zie over het beginpunt van het zwijgrecht ook Hartmann a.w. 2000, p. $51-57$

149 Voorontwerp p. 119.

150 Zie $\$ 3.2 .3$ van dit boek.

151 Voorontwerp p. 119.

152 Voorontwerp p. 119.

153 Zie in deze zin ook Knigge a.w. 2000, p. 94.

154 Hartmann en Knigge stellen zich ook op dit standpunt. Vgl. Hartmann a.w. 2000, p. 56-57, Knigge a.w. 2000 , p. 94 . 
bruik kan maken van zijn toezichtsbevoegdheden ${ }^{155}$ teneinde bewijs tegen de overtreder te verzamelen.

\section{Inlichtingenplicht}

Tenslotte gaat de commissie Scheltema bij de toelichting op artikel 5.0.11 nog in op de verhouding tussen de, in bepaalde bestuursrechtelijke wetten bestaande, inlichtingenplicht ${ }^{156}$ en het zwijgrecht. De commissie stelt dienaangaande:

'Het zwijgrecht geldt voorts niet, zolang er nog geen «criminal charge» is. Wel blijkt uit het Saunders-arrest dat onder omstandigheden bewijs dat onder dwang is verkregen in de fase veorafgaand aan de "criminal charge», niet mag worden gebruikt ter onderbouwing van een daaropvolgende punitieve sanctie. Dit betekent echter geenszins, dat ter naleving van een inlichtingenplicht verstrekte informatie nooit mag worden gebruikt voor het bewijs van een overtreding waarop een punitieve sanctie staat. 159

Met name de laatste zin komt wat vreemd over. Indien de commissie Scheltema doelt op informatie die bestaat onafhankelijk van de wil van de verdachte is de redenering van de commissie conform de door het EHRM in de zaak 'Saunders' gegeven uitleg aan het nemo tenetur-beginsel. ${ }^{158}$ Maar wellicht gaat de commissie Scheltema uit van een ruimer standpunt. Dit valt af te leiden uit het feit dat genoemde commissie in dat kader refereert aan de dissertatie van Jansen. ${ }^{159}$ Jansen stelt in zijn dissertatie met betrekking tot het gebruik van, ter naleving van een inlichtingenplicht verstrekte informatie, als bewijs van een overtreding, met het oog op de zaak 'Saunders' het volgende:

'In het Saunders-arrest is het zeer belastende gebruik tijdens het strafproces in die zaak van verklaringen die onder druk (er gold voor het afleggen ervan een medewerkingsplicht) waren verkregen in strijd geacht met het nemo teneturbeginsel. Dit betekent dat dezelfde verklaringen - onder druk verkregen vóórdat er sprake was van een criminal charge - wel voor het bewijs van een criminal charge kunnen worden gebruikt, in een situatie waarin tijdens het strafproces op een minder belastende manier daarvan gebruik wordt gemaakt. ${ }^{160}$

Spijtig genoeg motiveert Jansen deze laatste stelling niet. Hoe kan van bewijs, onder dwang verkregen voordat er sprake was van een 'criminal charge', op een minder belastende manier gebruik gemaakt worden? Wordt dergelijk bewijs niet in alle gevallen op een belastende wijze gebruikt? De commissie Scheltema heeft echter dankbaar gebruik gemaakt van de door Jansen voorgestane beperkte interpretatie van het Saundersarrest.

Vgl. artikel 5:16 en 5:20 Awb.

Een uitkeringsgerechtigde wordt op basis van de inlichtingenplicht, door dreiging met de oplegging van een bestuurlijke boete (op grond van bijv. artikel 25 jo. 27 a WW), in feite gedwongen alle informatie die relevant is voor zijn recht op uitkering aan het bestuursorgaan te verstrekken. Deze verplichting geldt uiteraard ook in het geval de uitkeringsgerechtigde door de verstrekte informatie het bestuursorgaan attent maakt op een door hem gepleegde overtreding die kan leiden tot de oplegging van een (andere) bestuurlijke boete. Zie in dit kader ook: Albers a.w. 2000, p. 138-152, i.h.b. p. 147.

Voorontwerp p. 119.

Zie $\$ 3.4 .2$ van dit boek.

Jansen a.w. 1999.

Jansen a.w. 1999, p. 143. 
Zoals Jansen in zijn dissertatie zelf ook aangeeft staat niet iedereen in Nederland een dergelijke beperkte opvatting voor. Een aantal auteurs gaat er van uit dat het gebruik van, ter naleving van een inlichtingenplicht verstrekte informatie, als bewijs van een overtreding in een procedure die 'criminal' van aard is, zonder meer niet is toegestaan. lk wijs in dit kader op de dissertatie van Lenos ${ }^{161}$, een NTB kroniek van Widdersho$v^{16 n^{162}}$, een artikel in RM Themis van Knigge ${ }^{163}$ en op de bijdrage van Feteris in de bundel 'Commentaren op het Voorontwerp Algemene wet bestuursrecht Vierde tranche'. Feteris stelt het volgende:

'Waar het naar mijn oordeel vooral op aankomt is of de aldus onder dwang van een wettelijke verplichting verstrekte informatie als bewijs voor de boete gebruikt mag worden.

Het Saunders-arrest van het EHRM vormt een aanwijzing dat dit niet is toegestaan indien het gaat om informatie die afhankelijk is van de wil van betrokkene. De memorie van toclichting bij het Voorontwerp (p. 119) suggereert dat de reikwijdte van dit arrest zeer beperkt is, door erop te wijzen dat het in de zaak Saunders om een bijzondere, nogal atypische casus ging. Ik betwijfel of men het arrest zo beperkt mag opvatten. Beslissend voor het Hof is naar mijn indruk geweest dat de verklaringen die Saunders onder dwang had afgelegd 'were used in the course of the proceedings in a manner which sought to incriminatie the applicant (...).' Daarom nam het Hof aan dat art. 6 EVRM geschonden was, en dat is een situatie die toch niet zo atypisch is. ${ }^{164}$

Naar mijn mening dient, mede met het oog op de rechtsbeschermingsidee die ten grondslag ligt aan artikel 6 EVRM, uitgegaan te worden van de door Lenos, Widdershoven, Knigge en Feteris voorgestane uitleg van het Saunders-arrest. Ook het EHRM lijkt een ruimer standpunt in te nemen dan de commissie Scheltema in het Voorontwerp. ${ }^{165}$ Dat valt mijns inziens niet alleen uit de zaak 'Saunders', maar ook uit een uitspraak van het Hof van 3 mei 2001 (in de zaak 'J.B. tegen Zwitserland') ${ }^{166}$, af te leiden. In die zaak werd de van belastingontduiking verdachte J.B., door met bestuurlijke boeten te dreigen, gedwongen belastende verklaringen af te leggen en bankafschriften te overleggen. J.B. weigerde dit. Vanwege het weigeren van zijn medewerking werd hem vervolgens een viertal bestuurlijke boeten opgelegd. Aangezien er in casu volgens het EHRM sprake was van bewijsmateriaal dat afhankelijk ${ }^{167}$ was van de wil van verdachte oordeelde genoemd Hof deze praktijk in strijd met nemo tenetur-beginsel. ${ }^{168}$

161 Lenos a.w. 1998, p. 241. Zie voorts: Lenos a.w. 1997, p. 800.

162 R.J.G.M. Widdershoven, NTB-kroniek Bestuursprocesrecht, NTB 1997, p. 351-364, i.h.b. p. 359: 'Kont en goed kan uit het arrest (Saunders [toevoeging KA]) worden afgeleid dat verklaringen die in de bestuurlijke fase zijn afgelegd in strijd met het verbod van zelfincriminatie niet als bewijs kunnen worden gebruikt voor het opleggen van de sanctie.'

163 Knigge a.w. 2000, p. 94, noot 53: 'Uit het arrest-Saunders (...) kan mijns inziens worden afgeleid dat informatie die de burger verplicht was te verstrekken, in geen geval tegen hem mag worden gebruikt in een strafproces.'

164 Feteris a.w. 2000 b, p. 17.

165 Geheel duidelijk is dit niet gelet op de casuistische rechtspraak van het EHRM. Vgl. M.W.C. Feteris, Belastingen en mensenrechten, NJCM-bulletin 2002, p. 43-60, i.h.b. p. 48-49 en de in voetnoot 15 aangehaalde uitspraken van het Hof uit 2000.

166 EHRM 3 mei 200l, no. 31827/96, EHRC 2001/45, m. nt. Karianne Albers, 'J.B. tegen Zwiserland'.

167 Het EHRM stelt dit in het algemeen. M.i. kan daanuit worden afgeleid dat het zowel geldt voor de verklaringen als voor de bankafschriften.

168 Zie m.b.t. 'J.B. tegen Zwitserland' ook $\$ 3.4 .2$ van dit boek. 
Het voorgaande brengt mijns inziens met zich dat onder dwang van een wettelijke verplichting tijdens een controle onderzoek verstrekte mondelinge of schriftelijke informatie, waarvan de verkrijging of totstandkoming afhankelijk is van de wil van de vermoedelijke overtreder ${ }^{169}$, niet mag worden gebruikt als bewijs voor de oplegging van een bestuurlijke boete. Indien genoemde informatie middels de medewerkings- of inlichtingenplicht pas is verkregen op het moment dat er al sprake was van een 'charge' is gebruik van die informatie mijns inziens zonder meer in strijd met het nemo teneturbeginsel.

In het rapport van de VAR-werkgroep wordt gesuggereerd een bepaling in de Awb op te nemen inhoudende dat informatie, die is verkregen onder bedreiging van een gesanctioneerde medewerkingsplicht, niet mag worden gebruikt voor het opleggen van een punitieve sanctie, tenzij de betrokkene óók zijn medewerking zou hebben verleend zonder dat hij daartoe was gedwongen of tenzij de desbetreffende informatie ook zonder de medewerking van betrokkene had kunnen worden verkregen. ${ }^{170}$ Dit voorstel van de VAR-werkgroep verdient mijn instemming. Door het opnemen van een dergelijke bepaling in de Awb wordt immers voorkomen dat belastende informatie, in strijd met de (onder meer) uit het EVRM voortvloeiende eisen, wordt gebruikt bij de oplegging van een punitieve sanctie. ${ }^{171}$

\section{Cautieplicht}

Op grond van het tweede lid van artikel 5.0.11 van het Voorontwerp dient het sanctionerende bestuursorgaan de (vermoedelijke) overtreder te wijzen op zijn zwijgrecht. Deze cautieplicht is gebaseerd op de regeling uit artikel $29 \mathrm{~Sv}{ }^{172}$ Zoals gezegd geldt ook ten aanzien van de cautieplicht volgens de commissie Scheltema dat deze alleen geldt ten aanzien van mondelinge verklaringen. ${ }^{173} \mathrm{Er}$ van uitgaande dat onder het zwijgrecht, op grond van de rechtspraak van het EHRM en de Hoge Raad, ó́k schriftelijke verklaringen vallen, is dat uitgangspunt te beperkt. De cautieverplichting dient dan ook te gelden ten aanzien van mondelinge én schriftelijke verklaringen. ${ }^{174}$

\section{Slotsom}

Dit alles overziend kan met betrekking tot artikel 5.0.11 van het Voorontwerp het volgende worden geconcludeerd. De commissie Scheltema gaat, naar mijn mening, uit van een te beperkte uitleg van het zwijgrecht. Ten eerste omdat genoemde commissie slechts het 'zwijgrecht in strikte zin' erkent. Daarmee lijkt de commissie Scheltema genoemd recht slechts van toepassing te achten aanzien van mondelinge verklaringen.

169 Duidelijkheid omtrent de vraag welke informatie al dan niet afhankelijk is van de wil van de verdachte ontbreekt naar mijn mening in de rechtspraak van het EHRM. Zie in dat kader ook mijn noot onder 'J.B. v. Zwitserland' en $\$ 3.4 .2$ van dit boek.

170 VAR-werkgroep a.w. 2000, p. 45.

171 Vgl. T. Barkhuysen, M.L. van Emmerik en J.P. Loof, 50 jaar EVRM en het Nederlandse staats- en bestuursrecht - ontwikkelingen en vooruitzichten, in de bundel: 50 jaar Europees Verdrag voor de Rechten van de Mens, onder redactie van RA. Lawson en E. Myjer, Leiden 2000, p. 237-408, i.h.b. p. 402 .

172 Voorontwerp p. 119. Sommige auteurs menen dat de cautieplicht ook moet worden ingelezen in artikel 6 EVRM. Zie in dit kader bijvoorbeeld Hartmann a.w. 2000, p. 48-49.

173 Vgl. Voorontwerp p. 119-120.

174 Zie: Hartmann a.w. 2000, p. 49-51, VAR-werkgroep a.w. 2000, p. 44 
Hetzelfde geldt overigens voor de cautie. Het zwijgrecht en de cautieverplichting gelden mijns inziens, (onder meer) met het oog op het Saunders-arrest, zowel ten aanzien van mondelinge als van schriftelijke verklaringen die afhankelijk zijn van de wil van de vermoedelijke overtreder.

Ten tweede zou de rechtsbescherming van de vermoedelijke overtreder er mee gediend zijn als het zwijgrecht reeds ingeroepen zou kunnen worden op het moment dat de vermoedelijke overtreder als verdachte in de zin van artikel $27 \mathrm{~Sv}$ moet worden aangemerkt. De commissie Scheltema neemt echter het standpunt in dat het zwijgrecht pas geldt vanaf een later in de tijd gelegen moment en haakt in dat kader aan bij de term 'charge' uit artikel 6 EVRM. Knigge wijst er mijns inziens terecht op dat er op deze wijze verschillen ontstaan tussen de strafvorderlijke en de bestuursrechtelijke regeling die niet door de aard van de materie worden gerechtvaardigd. ${ }^{175}$

Tenslotte gaat genoemde commissie er van uit dat onder dwang van een wettelijke verplichting verstrekte mondelinge of schriftelijke informatie, die afhankelijk is van de wil van de vermoedelijke overtreder, in bepaalde gevallen mag worden gebruikt als bewijs voor de oplegging van een bestuurlijke boete. Ook op dit punt gaat de commissie mijns inziens uit van een nogal schrale interpretatie van het Saunders-arrest die niet lijkt te stroken met de bedoeling van het EHRM. ${ }^{176}$

\subsubsection{Titel 5.4 Bestuurlijke boete}

\section{Afdeling 5.4.1 Algemene bepalingen}

Titel 5.4 van het Voorontwerp staat in het teken van de bestuurlijke boete. Genoemde titel vangt aan met Afdeling 5.4.1. Daarin is een aantal algemene bepalingen met betrekking tot de bestuurlijke boete opgenomen. Afdeling 5.4 .1 bestaat uit 7 artikelen. Deze artikelen zullen hierna worden besproken.

\section{Artike] 5.4.1.1 bestuurlijke boete}

In artikel 5.4.1.1 is een definitie van de term bestuurlijke boete opgenomen. Het eerste lid van artikel 5.4.1.1 luidt: 'Onder bestuurlijke boete wordt verstaan: de bestuurlijke sanctie, inhoudende een onvoorwaardelijke verplichting tot betaling van een geldsom, die gericht is op bestraffing [curs. KA] van de overtreder.' In het tweede lid wordt vervolgens, kennelijk om dit buiten twijfel te stellen, aangegeven dat de intrekking of wijziging van een aanspraak op financiële middelen géén bestuurlijke boete is.

De bestuurlijke boete is gericht op bestraffing van de overtreder. Daarmee onderscheidt de bestuurlijke boete zich (naar geldend recht) van bestuursrechtelijke sancties als de last onder dwangsom ${ }^{177}$ en de toepassing van bestuursdwang aangezien deze sancties als reparatoire sancties worden gekwalificeerd. Zoals gezegd brengt het punitieve karakter van de boete met zich dat de oplegging van deze boete aangemerkt moet worden als 'criminal charge' in de zin van artikel 6 van het EVRM ${ }^{178}$ Derhalve dient het be-

175 Knigge a.w. 2000, p. 94, Vgl. Jansen aw. 2002, p. 220-221.

176 Zie in dit kader ook Van Russen Groen a.w. 1998, p. 67.

177 Zoals ik reeds in hoofdstuk twee heb aangegeven kan de last onder dwangsom mijns inziens niet zonder meer gekwalificeerd worden als een reparatoire sanctie.

178 Vgl. p. 98-99 Voorontwerp. Zie cok $\$ 2.2 .3$ van dit boek. 
stuursorgaan bij de oplegging van een bestuurlijke boete rekening te houden met bepaalde typisch straf(proces)rechtelijke waarborgen die onder andere voortvloeien uit genoemd verdragsartikel.

Opmerkelijk is de op een na laatste volzin van de toelichting op het eerste lid. Daarin stelt de commissie Scheltema het volgende: 'Aan een boete onder de opschortende voorwaarde dat de overtreder binnen een bepaalde periode niet opnieuw een overtreding pleegt, bestaat geen behoefte, nu zij op hetzelfde neerkomt als een last onder dwangsom. ${ }^{179}$ Deze redenering roept bij mij (wederom) de vraag op naar de werkelijke aard van de last onder dwangsom. ${ }^{180}$ Kan de commissie Scheltema, gelet op het door haar ingenomen standpunt, in redelijkheid vasthouden aan de kwalificatie van de dwangsom als reparatoire sanctie? Ik betwijfel dat. ${ }^{181}$ De Raat en Widdershoven lijken deze mening te delen. ${ }^{182}$

\section{Wederkerig?}

De in het tweede lid gemaakte 'uitzondering' inhoudende dat de intrekking of wijziging van een aanspraak op financiële middelen géén bestuurlijke boete is heeft veel pennen in beweging gebracht. Het tweede lid ziet bijvoorbeeld op korting of beëindiging van een uitkering in verband met het niet naleven van de aan het recht op uitkering verbonden voorschriften. Als voorbeeld kan de maatregel in het sociale zekerheidsrecht dienen. Daarnaast kan gedacht worden aan een korting op de tegemoetkoming in de schade tengevolge van de (preventieve) ruiming van een veestapel (i.v.m. bijvoorbeeld het uitbreken van mond- en klauwzeer of de varkenspest). Volgens de commissie Scheltema is er in het geval dat een dergelijke maatregel wordt opgelegd geen sprake van een punitieve sanctie:
'Dit (de opgelegde maatregel [toevoeging KA]) is geen punitieve sanctie, omdat conse- quenties worden verbonden aan gedragingen die op zichzelf niet verboden zijn, maar slechts in strijd met de voorwaarden waaronder de aanspraak is verleend. Gedacht kan worden aan het geval dat een uitkering wordt ingetrokken omdat betrokkene onvoldoende solliciteert. Op zichzelf is solliciteren geen rechtsplicht; die plicht ontstaat pas door het genieten van de uitkering. Het recht op uitkering en de plichten van de uitkeringsgerechtigde zijn twee kanten van dezelfde medaille; worden de plichten niet nagekomen, dan kan ook het recht niet (volledig) geldend worden gemaakt. Door dit element van wederkerigheid heeft een dergelijke rechtsverhouding een wezenlijk ander karakter dan de rechtsverhouding tussen overheid en overtreder bij het opleggen van een boete. ${ }^{183}$

Deze redenering komt op mij zeer vreemd over. Anders dan de Awb-wetgever en commissie Scheltema ga ik niet uit van het bestaan van een wederkerige rechtsbetrekking $^{184}$ tussen burger en overheid in het bestuursrecht. Ook (onder meer) Stroink ${ }^{185}$,

179 Voorontwerp p. 120.

180 Zie in dit kader ook $\$ 2.2 .3 .2$ van dit boek.

181 Zie in dit kader $\$ 2.2 .3 .2$ waarin ik reeds (uitvoerig) heb aangegeven dat de last onder dwangsom onder bepaalde omstandigheden als punitieve sanctie moet worden gekwalificeerd. Deze mening, zo bleek ook in genoemd hoofdstuk, wordt door anderen gedeeld. Zie voorts Albers a.w. 2001. p. 1161-1162.

183 De Raat en Widdershoven a.w. 2000, p. 776-777.

183 Voorontwerp p. 120.

184 Vgl. PG Awb I, p. 3-40. Zie voorts de bijdragen van Beurskens, Simon, Heldeweg, Schlossels, Van der 
$\operatorname{Tak}^{186}$, Simon ${ }^{187}$, en Schlössels ${ }^{188}$ onderschrijven het wederkerige rechtsbetrekkingconcept. niet. Stroink plaatst kritische kanttekeningen bij het aspect van de wederkerig. heid en de term rechtsbetrekking in het bestuursrecht. ${ }^{189} \mathrm{Hij}$ stelt het volgende:

'Ik ben niet zo gelukkig met de termen wederkerig en rechtsbetrekking in het bestuursrecht. (...) Mijn bezwaar is dat de uit het privaatrecht stammende termen versluierend werken. Het is niet zo dat eenzijdigheid een typisch kenmerk is van het negentiende-eeuwse bestuursrecht. Ook in een modeme democratische en sociale rechtsstaat is eenzijdigheid een essentieel kenmerk van het overheidsoptreden. Het feit dat burgers over allerlei rechten beschikken zoals inspraak en het recht om gehoord te worden en dat niet alleen de wet maar ook de algemene beginselen van behoorlijk bestuur eisen dat op allerlei manieren met rechten en belangen van burgers rekening moet worden gehouden, neemt niet weg dat uiteindelijk het bestuur, zo nodig tegen de zin van de burger, een besluit kan nemen en handhaven. In die eenzijdigheid zit hem nu juist het typische van de overheid. (...) De term rechtsbetrekking kan naar mijn oordeel beter gereserveerd worden voor privaatrechtelijke verhoudingen. Ik prefereer het (klassieke) onderscheid tussen enerzijds de overheid die het positieve recht vaststelt en handhaaft (via overheidsbesluiten zoals algemeen verbindende voorschriften, beschikkingen en rechterlijke uitspraken) en anderzijds natuurlijke en rechtspersonen die onderling rechtsbetrekkingen kunnen aangaan die (mede) worden beheerst door het positieve recht.' ${ }^{190}$

De Haan, Drupsteen en Fernhout onderschrijven, zij het op genuanceerde wijze ${ }^{191}$, bovenstaand standpunt. $\mathrm{Zij}$ gaan er van uit dat er in de algemene verhouding burgeroverheid géén sprake kan zijn van een wederkerige rechtsbetrekking. Weliswaar kunnen binnen het algemene kader burger-overheid door publiekrechtelijke rechtshandelingen of concrete wetsbepalingen publiekrechtelijke rechtsbetrekkingen gevestigd worden maar de wederkerigheid daarvan zal in veel gevallen slechts zeer betrekkelijk zijn, zo stellen zij. ${ }^{192}$ Ik zou daar aan toe willen voegen dat met name in het kader van (punitieve) bestuursrechtelijke handhaving de wederkerigheid mijns inziens zeer be-

Linden, Van der Meulen, en Teunissen in de bundel: Eenzijdig en wederkerig?, onder redactie van E.C.H.J. van der Linden en A.Q.C. Tak, Deventer 1995 en L.J.A. Damen, Bestaat de Awbmens? In: Aantrekkelijke gedachten, beschouwingen over de Algemene wet bestuursrecht, Deventer 1993, p. $10^{\circ}$ e.v.

185 F.A.M. Stroink, De algemene wet bestuursrecht en het sociale zekerheidsrecht, Tijdschrift voor Sociaal Recht, 1989/10, p. 256 en 257, en F.A.M. Stroink, Boekbeschouwing C.P.J. Goorden, 'Rechtsbevoegdheid in het bestuursrecht', NTB 1990, p. 295-297, i.h.b. p. 296.

186 A.Q.C. Tak, De overheid in het burgertijk recht, 's-Gravenhage 1997, p. 50-58, i.h.b. p. 57.

187 H.J. Simon, Publiekrecht of privaatrecht? (diss. VU), Zwolle 1993, p. 201-210, i.h.b. p. 202-203.

188 SchlUssels a.w. 1998, p. 40-48.

189 Hirsch Ballin lijkt, als voortrekker van de 'Tilburgse school', een actieve bijdrage geleverd te hebben aan de invoering van de 'wederkerige rechtsbetrekking-idee' in de Awb. Vgl. E.M.H. Hirsch Ballin, Wederkerig bestuursrecht, RM Themis 1989/1, p. 1 e.v. en Tak a.w. 1997, p. 50 . Zie voorts: P. de Haan, Th. G. Drupsteen en R. Femhout, Bestuursrecht in de sociale rechtsstaat, deel I, Deventer 2001, p. 36-37.

190 Stroink a.w. 1990, p. 296 . Vgl. Simon a.w. 1993, p. 202-203 en De Haan/Drupsteen/Fernhout a.w. 2001, p. 37 en p. 40.

191 Vgl. hun commentaar op de 'Maastrichtse school' in dat kader, De Haan/Drupsteen/Fernhout a.w. 200l, p. 44.

192 De Haan/Drupsteen/Femhout aw. 2001, p. 40 en 44. 
trekkelijk is. Sterker nog, van wederkerigheid kan naar mijn oordeel in dat kader geen sprake zijn. De Haan, Drupsteen en Fernhout lijken dit standpunt te delen. ${ }^{193}$

Van der Meulen betwist eveneens dat in het kader van het bestuursrecht in het algemeen, en ten aanzien van bestuursrechtelijke handhaving in het bijzonder, gesproken kan worden van een 'wederkerige rechtsbetrekking'. ${ }^{194}$ Van der Meulen stelt in dit kader het volgende:

'In de meeste gevallen strekt de bestuursrechtelijke normstelling tot het opleggen van verplichtingen aan burgers of tot het aan hen toekennen van rechten volgens een model dat uiteindelijk - bij het besluit - door het bestuur wordt bepaald. De burger is uiteindelijk, of hij dit nu wil of niet, gebonden door de publiekrechtelijke normstelling, die het produkt is van het bestuurlijke besluitvormingsproces. De handhavingsbevoegdheden vormen het sluitstuk van deze gebondenheid. Zij verschaffen het bestuur de instrumenten om de naleving van deze normstelling af te dwingen, zonodig tegen de wil van de betrokken burgers. Deze handhaving is gebaseerd op de geweldsbevoegdheid van de overheid. Uit het monopoliekarakter van deze bevoegdheid vloeit voort dat handhaving een bij uitstek eenzijdige aangelegenheid is. Dat zie ik dan ook niet als overheidskant van wederkerigheid. maar als ontmaskering van de publiekrechtelijke rechtsbetrekking - ook onder de Awb-als een uiteindelijk eenzijdige (of zo men wil, verticale). De overheid stelt de rechten en plichten van de burgers vast en de overheid dwingt de naleving ervan af. ${ }^{195}$

I $\mathrm{k}$ kan dit standpunt onderschrijven. Voor zover er sprake is van een gevraagde begunstigende beschikking (bijv. een bouwvergunning) kan van een aanvrager uiteraard een zekere medewerking worden verlangd in het kader van de voorbereiding van de beschikking. ${ }^{196}$ Het gaat mijns inziens echter te ver om daar uit af te leiden dat er in het bestuursrecht, in het algemeen, sprake zou zijn van een wederkerige rechtsbetrekking tussen burger en bestuur. Men kan immers moeilijk stellen dat een rechtsverhouding ${ }^{197}$ tussen bijvoorbeeld een werkloze (die niet beschikt over middelen om te voorzien in zijn levensonderhoud) en de Raad van bestuur van het Uitvoeringsinstituut werknemersverzekeringen (Uwv) ${ }^{198}$ (als bevoegd bestuursorgaan) wederkerig is in de zin dat aan die rechtsverhouding op een gelijkwaardige wijze door beide partijen invulling wordt gegeven. De uitkeringsgerechtigde heeft geen keuze. Als hij een uitkering wenst te ontvangen zal hij zich moeten conformeren aan de daartegenover door de bijzondere

193 De Haan/Drupsteen/Fernhout a.w. 2001, p. 44.

194 Zie: B.J.M. van der Meulen, Handhaving, in de bundel: Eenzijdig en wederkerig?, onder redactie van E.C.H.J. van der Linden en A.Q.C. Tak, Deventer 1995, i.h.b. p. 223-247. Zie voons Tak a.w. 1997, hij stelt op p. 57: 'Wanneer in het bestuursrecht wordt overgegaan tot handhaving, is de rechtsrelatic tussen overheid en burger zonneklaar volstrekt eenzijdig en verticaal.' Zie tenslotte Hartmann en Van Russen Groen a.w. 1998, p. 131.

195 Van der Meulen a.w. 1995, p. 231

196 Vgl. artikel 4:2 lid 2 Awb.

197 Het is bovendien merkwaardig te spreken van een 'rechtsbetrekking' (tussen burger en bestuur) in de context van het bestuursrecht vandaar het gebruik van de term 'rechtsverhouding' in de hoofdtekst. Vgl. Stroink a.w. 1990, p. 296.

198 Met ingang van 1 januari 2002 is de Wet structuur uitvoeringsorganisatie werk en inkomen in werking getreden. Ingevolge de Invoeringswet Wet structuur uitvoeringsorganisatie werk en inkomen treedt de Raad van bestuur van het Uitvoeringsinstituut werknemersverzekeringen (Uwv) in de plaats van het Landelijk instituut sociale verzekeringen (Lisv). 
wetgever en het Uwv (in bijvoorbeeld beleidsregels) gestelde eisen. Het is een kwestie van slikken of stikken. Van wederkerigheid is dan ook geen sprake.

\section{Géén boete - althans niet punitief-}

De commissie Scheltema gaat, zoals gezegd, uit van het standpunt dat de intrekking of wijziging van een aanspraak op financiêle middelen géén bestuurlijke boete is. Doorslaggevend lijkt voor genoemde commissie te zijn of de sanctie opgelegd kan worden binnen een reeds bestaande 'wederkerige rechtsbetrekking'. Is dit het geval dan is er géén sprake van een bestuurlijke boete of een andere punitieve bestuursrechtelijke sanctie. ${ }^{199}$

De commissie Scheltema stelt, op basis van het 'wederkerige' rechtsbetrekkingcriterium, dat de maatregel in het sociale zekerheidsrecht en de intrekking van een subsidie géén bestuurlijke boeten zijn. Dat genoemde sancties niet als bestuurlijke boete kunnen worden bestempeld mag dan juist zijn, maar dat is slechts een formele kwalificatie. Zou het niet beter zijn te kiezen voor en meer materiekle benadering waarbij de 'wederkerige rechtsbetrekking' en de formele kwalificatie van de sanctie niet relevant zijn? Met andere woorden, is niet slechts relevant of een sanctie, op basis van materiële criteria ${ }^{200}$, als punitieve sanctie aangemerkt moet worden?

In dit kader valt bijzonder op dat de commissie met artikel 5.4.1.1, tweede lid van het Voorontwerp in wezen wil zeggen dat sancties die binnen de bestaande 'wederkerige rechtsbetrekking' vallen, zoals bijvoorbeeld de maatregel in het sociale zekerheidsrecht en de intrekking van een subsidie, géén punitieve sancties zijn. ${ }^{201}$ Man en paard worden echter alleen in de toelichting genoemd. Aangezien de hiervoor genoemde sancties volgens de commissie Scheltema niet te kwalificeren zijn als punitieve sanctie zijn bij de oplegging van deze sancties niet alle waarborgen van toepassing die wél in acht genomen moeten worden bij de oplegging van de bestuurlijke boete. Dit lijkt een belangrijke reden te zijn voor de commissie Scheltema om vast te houden aan genoemde formele benadering waarbij de 'wederkerige rechtsbetrekking' als uitgangspunt wordt genomen.

Zoals gezegd is er naar mijn mening in de relatie tussen burger en bestuursorgaan géén sprake van wederkerigheid is in de zin dat aan de rechtsverhouding op een gelijkwaardige wijze door beide partijen invulling wordt gegeven. De uitkeringsgerechtigde bijvoorbeeld heeft, zoals gezegd, feitelijk geen keuze. Als hij een uitkering wenst te ontvangen zal hij zich moeten conformeren aan de daartegenover door de bijzondere wetgever en het Uwv (in bijvoorbeeld beleidsregels) gestelde eisen. Men zou er echter van

199 Voorontwerp p. 120. Zie voorts: Addink en Duijkersloot a.w. 1999 p. 258, De Raat en Widdershoven a.w. 2000 p. 777-778, Hartmann en Van Russen Groen 1998, p. 94-95.

200 Zie in dit kader hoofdstuk 2.

201 Z'ic p. 120 Voorontwerp: 'Dit (de opgelegde maatregel [toevoeging KA]) is geen punitieve sanctie [curs. KA], omdat consequenties worden verbonden aan gedragingen die op zichzelf niet verboden zijn, maar slechts in strijd met de voorwaarden waaronder de aanspraak is verleend.' Zie voorts het commentaar van De Raat en Widdershoven, zij geven aan dat artikel 5.4.1.1, tweede lid in feite overbodig is: 'Wanneer het juist is dat de intrekking en korting van een uitkering of subsidie wegens het niet nakomen van daaraan verbonden verplichtingen geen punitieve sancties zijn, vallen zij niet onder het begrip 'bestuurlijke boete' in de zin van het eerste lid van artikel 5.4.1.1, omdat zij niet op bestraffing zijn gericht. Alsdan is het niet noodzakelijk om deze 'sancties' vervolgens expliciet uit te zonderen.' De Raat en Widdershoven, a.w. 2000, p. 777. 
uit kunnen gaan dat binnen deze min of meer onvrijwillig aangegane rechtsverhouding desalniettemin sprake is van wederkerigheid omdat op beide partijen rechten en plichten rusten. ${ }^{202}$ Maar zelfs in dat geval levert de 'wederkerige rechtsverhouding' géén steekhoudend criterium op teneinde sancties te kwalificeren als niet-punitieve sancties. Doorslaggevend blijft immers of de sanctie leedtoevoegend is. ${ }^{203}$ In hoofdstuk twee heb $\mathrm{ik}$ reeds aangegeven dat de maatregel in het sociale zekerheidsrecht en de intrekking van een begunstigende beschikking (zoals bijvoorbeeld de intrekking van een subsidie) mijns inziens onder omstandigheden leedtoevoeging kunnen veroorzaken. Genoemde sancties kunnen derhalve zeer wel punitief zijn. ${ }^{204}$ Addink en Duijkersloot ${ }^{205}$ nemen eveneens het standpunt in dat de aan de orde zijnde sancties een onmiskenbaar punitief karakter hebben en dat derhalve extra (verdragsrechtelijke) rechtsbescherming geboden zou moeten worden in het kader van de oplegging van die sancties. ${ }^{206}$ In dat kader is mijns inziens moeilijk te plaatsen dat de commissie Scheltema bij de oplegging van deze sancties genoemde extra rechtsbescherming aan de burgers wil onthouden. Dit laatste is immers de consequentie van de stelling dat genoemde sancties niet als bestuurlijke boete, én ook niet als punitieve sanctie, zijn aan te merken. Het zal toch niet zo zijn dat de commissie Scheltema met artikel 5.4.1.1, tweede lid Voorontwerp heeft gepoogd een aantal sancties, die naar mijn mening tenminste in bepaalde gevallen punitief van aard zijn, te onttrekken aan de extra rechtsbescherming die, in ieder geval, op grond van artikel 6 (en 7) $\mathrm{EVRM}^{207}$ bij de oplegging van punitieve sancties geboden moet worden? $?^{208}$

\section{Artikel 5.4.1.2 geen straf zonder schuld}

Artikel 5.4.1.2 van het Voorontwerp behelst de idee dat aan de overtreder geen boete opgelegd kan worden als de overtreding hem niet verweten kan worden; 'geen straf

202 Waarbij de uitkeringsgerechtigde door het accepteren van de uitkering instemt met de daar tegen over staande verplichtingen. Vgl. Van Ommeren a.w. 1996, p. 351-352.

$203 \mathrm{Vgl}$. De Raat en Widdershoven a.w. 2000, p. 778: '... Aldus werkt de 'rechtsverhouding' als criterium voor beperking van het boetebegrip wel erg arbitrair uit. De gelet op artikel 6 EVRM relevante vraag of een sanctie bestraffend en afschrikwekkend is bedoeld, raakt bovendien buiten zicht. (...) Dit is, gelet op de aanzienlijke verschillen in geldende waarborgen, niet aanvaardbaar. Al met al zou de toepassing van het 'rechtsverhoudingscriterium' nog eens kritisch moeten worden bezien.'

$204 \mathrm{Zie} \$ 2.2 .3$ van dit boek. Dit is bijvoorbeeld het geval als een maatregel in het sociale zekerheidsrecht het benadelingsbedrag te boven gaat.

205 Addink en Duijkersloot a.w. 1999, p. 258: 'Bovendien worden in het nationale en Europese bestuursrecht wettelijke wijzigingsbevoegdheden juist wel aangemerkt als punitieve bestuurlijke sancties die inhoudelijk gezien heel dicht aanliggen tegen de hier bedoelde bestuurlijke boete.'

206 Zie voorts Hartmann en Van Russen Groen a.w. 1998, p. 94-95 en mijn NJB-artikel: 'Etikettenschwindel' in het administratieve sanctierecht?, a.w. 2001.

207 Uiteraard voorzover ook het EHRM van oordeel is dat de in artikel 5.4.1.1 Voorontwerp bedoelde sancties aangemerkt moeten worden als 'criminal charge'. Zoals gezegd is dat, gelet op de casuitische jurisprudentie van het Hof m.b.t. het 'criminal charge'-begrip niet altijd met evenveel zekerheid te zeggen.

208 Overigens lijkt het 'wederkerige' rechtsbetrekkingcriterium ook anderszins niet steekhoudend. Gewezen kan worden op een door De Raat en Widdershoven in dit kader aangedragen voorbeeld waaruit blijkt dat bepaalde sancties in het ene geval kunnen vallen binnen de bestaande rechtsverhouding, waardoor zij niet als punitieve sanctie zijn aan te merken, terwijl dezelfde sancties in een andere situatie als bestuurlijke boete moeten worden aangemerkt. Vgl. De Raat en Widdershoven a.w. 2000, p. 778 . 
zonder schuld'. Schuld in de zin van verwijtbaarheid ${ }^{209}$ is bij bestuursrechtelijk gesanctioneerde overtredingen doorgaans geen bestanddeel van het delict. Het bestuursorgaan hoeft derhalve de verwijtbaarheid niet te bewijzen maar mag, volgens de commissie Scheltema, uitgaan van aanwezigheid van schuld als het daderschap vaststaat. ${ }^{210} \mathrm{De}$ overtreder moet zelf een beroep doen op afwezigheid van (alle) schuld en het ontbreken van schuld aannemelijk maken. ${ }^{211}$

\section{Nationaal strafrecht}

Corstens geeft aan dat de strafrechter, anders dan de bestuursrechter, verplicht is bij afwezigheid van schuld ontslag van alle rechtsvervolging uit te spreken, zelfs al zou de verdachte daarop geen beroep hebben gedaan. ${ }^{212}$ Dit lijkt met zich te brengen dat in het kader van de strafrechtelijke procedure, wat dit aspect van de onschuldpresumptie betreft, mér rechtsbescherming wordt geboden dan op basis van de voorgestelde boeteregeling mogelijk is. ${ }^{213}$

Voor het overige sluit de door de commissie Scheltema voorgestelde bepaling overigens aan bij het, in het strafrecht ontwikkelde, leerstuk dat geen straf mag worden opgelegd als de overtreder niets verweten kan worden. ${ }^{214}$ Ook in het strafrecht maakt schuld in de zin van verwijtbaarheid doorgaans geen bestanddeel uit van het delict.

Van oudsher werd in het strafrecht bij overtredingen schuld niet als bestanddeel opgenomen. Er werd volstaan met omschrijving van het materiële feit. Had iemand het materiële feit begaan dan volgde veroordeling (ongeacht of hem een verwijt gemaakt kon worden), tenzij met succes een beroep op een van de in de wet opgenomen strafuitsluitingsgronden werd gedaan. ${ }^{215}$ De Hoge Raad bracht hier in 1916 verandering in met het 'melk en water-arrest'. ${ }^{216}$ De volgende casus was in genoemd arrest aan de orde: Jan Doorn leverde in opdracht van zijn werkgever (een veehouder) aangelengde melk, als zijnde volle melk, af op een bepaald adres. Dit was destijds strafbaar gesteld in de APV van Amsterdam. Jan Doom was niet op de hoogte van het feit dat de melk aangelengd was. Desalniettemin had hij het materiële feit zoals beschreven in de APV gepleegd.

Zie: Van Bernmelen-Van Veen bewerkt door De Jong en Knigge a.w. 1998, p. 39-40, i.h.b. p. 39: 'Er valt pas iets te verwijten als de dader 'het kon helpen', 'er iets aan kon doen'. Schuld heeft daaron te maken met de mogelijkheid van een keuze. Zijn gedrag kan de dader verweten worden als hij de (reêle) mogelijkheid had zich anders te gedragen dan hij deed. Men zegt ook wel dat de inbreuk op de strafwet voor de dader vermijdbaar moet zijn geweest. (...) Vermijdbaarheid moet dan ook niet opgevat worden als de objectieve mogelijkheid zich anders te gedragen. Het gaat om een op de persoon van de dader toegesneden oordeel, om de keuzemogelijkheid die hij, mede gelet op zijn (subjectieve) kennis van de werkelijkheid, had. Wat de dader wordt verweten is zijn verkeerde keuze. Dat is alleen reěl als de dader de consequenties van zijn keuze kon overzien.'

210 Voorontwerp p. 121.

211 Gelet op de aard van de procedure (oplegging van een punitieve sanctie) is echter niet ondenkbaar dat in dit kader ook een onderzoeksplicht op de bestuursrechter rust. Dit met het oog op zijn verplichting tot anbtshalve toetsing (Vgl. Albers en Schlossels a.w. 2002, $\$ 5.5$ en Corstens a.w. 1999, p. 53 en p. 678). Ik kom daar later nog op terug.

2.12 Corstens a.w. 1999, p. 53 en p. 678.

213 Vgl. voorts: Albers en Schlossels a.w. $2002, \$ 5.5$ en 5.8.

214 Zie: Van Bemmelen-Van Veen bewerkt door De Jong en Knigge a.w. 1998, p. 38-42 en HazewinkelSuringa bewerkt door Remmelink a.w. 1996, p. 193-201.

215 Zie: Van Bemmelen-Van Veen bewerkt door De Jong en Knigge a.w. 1998, p.38.

216 HR 14 februari 1916, NJ 1916,681. 
De Hoge Raad diende de vraag te beantwoorden of Jan Doorn strafbaar was. De Hoge Raad heeft daaromtrent het volgende overwogen:

$\therefore$...dat in de omschrijving van het volgens voormelde artikelen strafbare, feit wel niet vitdrukkelijk is vermeld, dat bij hem, die dit feit pleegt, althans eenige schuld aanwezig moet zijn, doch hieruit geenszins mag worden afgeleid, dat bij geheel gemis van schuld de bepaling nochtans van toepassing is; dat toch niets, bepaaldelijk niet de geschiedenis van het Wetb. van Strafr., er toe dwingt om aan te nemen, dat bij het niet-vermelden van schuld als element in de omschrijving van een strafbaar feit, in het bijzonder van een overtreding, onze wetgever het stelsel huldigt, dat bij gebleken afwezigheid van alle schuld niettemin strafbaarheid zou moeten worden aangenomen, tenzij er een grond tot uitsluiting daarvan in de wet mocht zijn aangewezen; dat om deze tegen het rechtsgevoel en het - ook in het strafrecht gehuldigde - beginsel 'geen straf zonder schuld' indruischende leer te aanvaarden, de noodzakelijkheid daarvan uitdrukkelijk uit de omschrijving van het strafbare feit zou moeten volgen, hetgeen te deze niet het geval is;...

De Hoge Raad heeft in het 'melk en water-arrest' aangegeven dat in ons strafrecht het beginsel 'geen straf zonder schuld' onverkort geldt. Schuld is derhalve een vereiste voor strafbaarheid. Dit geldt ook ten aanzien van overtredingen waarbij slechts het materiële feit, en derhalve niet de aanwezigheid van schuld, bewezen hoeft te worden. Afwezigheid van alle schuld levert een buitenwettelijke strafuitsluitingsgrond op. ${ }^{217}$

\section{EVRM}

De in het Voorontwerp voorgestelde regeling ${ }^{218}$ is volgens de commissie Scheltema niet in strijd met de in artikel 6, tweede lid, van het EVRM neergelegde onschuldpresumptie. Dit volgt uit de arresten 'Salabiaku'219 en 'Pham Hoang'220, waarin het EHRM heeft bepaald dat het niet in strijd is met de onschuldpresumptie als een sanctionerende instantie tot op zekere hoogte uitgaat van een (weerlegbaar) wettelijk of feitelijk vermoeden van schuld. Het ontbreken van een schorsende werking van de bezwaar- en beroepsprocedure doet aan het voorgaande niet af volgens de commissie. ${ }^{221}{ }^{222}$ Bovendien biedt artikel 6:16 van de Awb de bijzondere wetgever de mogelijkheid om in bijzondere gevallen van de hoofdregel (het ontbreken van schorsende werking) af te wijken. In specifieke gevallen kan daarvoor volgens de commissie aanleiding bestaan.

217 Zle over afwezigheid van alle schuld uitvoeriger: Hazewinkel-Suringa bewerkt door Remmelink a.w. 1996 , p. 375 e.v.

218 Een geschreven catalogus met schulduitsluitingsgronden wordt overigens niet opgenomen in de vierde tranche van de Awb (zie: Voorontwerp p. 121). Zie in dit kader Van der Hulst (a.w. 2000a, p. 67) en Knigge (a.w. 2000, p. 93) die kritische kanttekeningen plaatsen bij het niet opnemen van een catalogus met strafuitsluitingsgrond (waaronder rechtvaardigingsgronden en schulduitsluitingsgronden) in het Voorontwerp.

219 EHRM 7 oktober 1988, NJ 1991, 351 m. nt. E.A. Alkema.

220 EHRM 25 september 1992, NJ 1995, 593, m. nt. E.A. Alkema.

221 Op deze plaats dient opgemerkt te worden dat het kabinet in het kabinetsstandpunt ten aanzien van het CTW-rapport 'Handhaving door bestuurlijke boeten' een ander standpunt innam. Dit lijkt mede ingegeven te zijn door het feit dat de Toetsingscommissie met het oog op artikel 6 lid 2 EVRM in ieder geval adviseerde uit te gaan van schorsende werking van het bezwaar voor zover geen sprake was van een hoorplicht in de primaire fase (zie CTW-rapport p. 57). Het kabinet heeft in genoemd kabinetsstandpunt overwogen dat de schorsende werking van het bezwaar als uitgangspunt zou moeten worden genomen (zie Kamerstukken II, 1993-1994, 23400 VI, nr. 48, i.h.b. p. 15).

222 Een motivering van dit standpunt ontbreekt echter in de toelichting (zie Voorontwerp p. 121). 
Bijvoorbeeld als er in de primaire fase (vóór de totstandkoming van het primaire boetebesluit) géén hoorplicht bestaat ${ }^{223}$ of als de boeten zéér hoog zijn en directe invordering derhalve leidt tot onevenredige financiële lasten voor de overtreder. ${ }^{224}$

Om de aanzuigende werking van een dergelijke regeling op het aantekenen van bezwaar en beroep te voorkomen zou een zekerheidsstelling verlangd kunnen worden. Daarbij moet niet uit het oog verloren worden dat een dergelijke zekerheidsstelling het recht op toegang tot te rechter niet al te zeer mag beperken. ${ }^{225}$ Ook zou men kunnen voorzien in een regeling op grond waarvan wettelijke rente verschuldigd is als de opgelegde boete gedurende bezwaar en beroep in stand blijft.

\section{Wettelijk of feitelijk vermoeden van schuld}

Uit de zaak 'Salabiaku' blijkt inderdaad dat het naar het oordeel van het EHRM niet in strijd is met de onschuldpresumptie als een sanctionerende instantie (tot op zekere hoogte) uitgaat van een (weerlegbaar) wettelijk ${ }^{226}$ of feitelijk vermoeden van schuld. De partijstaten moeten echter, zo stelt het EHRM, bij het formuleren van dergelijke strafbepalingen wel acht slaan op de belangen van de verdachte die in het geding zijn en daamaast moeten de verdedigingsrechten van de verdachte volledig intact blijven. ${ }^{227}$ Feteris wijst er op, en ik kan daar mee instemmen, dat het gebruik van wettelijke bewijsvermoedens moet worden gezien als een instrument dat slechts bij uitzondering behoort te worden gebruikt. ${ }^{228}$ Hij geeft aan wanneer naar zijn oordeel een bewijsvermoeden is toegestaan:

'De redelijkheid brengt mijns inziens met zich mee dat wettelijke vermoedens in het strafrecht alleen gebruikt worden wanneer zij in de overgrote meerderheid van de gevallen in overeenstemming zijn met de werkelijkheid, en het praktisch bezwaarlijk is om rechtstreeks bewijs te leveren van datgene wat vermoed wordt. ${ }^{229}$

223 Dit is het geval bij boeten onder de 340 Euro.

224 Voorontwerp p. 121-122.

225 Zie in dit kader: HR 31 januari 1995, NJ 1995, 598, m. nt. Corstens. In die zaak waren aan eiseres zestien boeten opgelegd op grond van de WAHV. Eiseres stelde beroep in tegen de opgelegde boeten en gaf aan als uitkeringsgerechtigde niet in de mogelijkheid te zijn het bedrag van de zekerheidsstelling van $f 800$, (zijnde zestien maal $f 50,-$ ) te kunnen voldoen. Vanwege het feit dat eiseres geen zekerheid heeft gesteld volgt niet-ontvankelijk verklaring van het beroep van eiseres tegen de zestien boeten door de Kantonrechter. De Hoge Raad vernietigde de beslissingen van de Kantonrechter onder de overweging dat onverkorte toepassing van het vereiste van zekerheidsstelling als voorwaarde voor ontvankelijkheid in het concrete geval strijd oplevert met artikel 6, eerste lid EVRM omdat het recht op toegang tot een onafhankelijke en onpartijdige rechter door de omvang van de gevraagde zekerheidsstelling te ernstig wordt beperkt.

226 Vgl. de zaak 'Salabiaku'. Op grond van Franse douanewetgeving wordt de bezitter van goederen strafrechtelijke aansprakelijk geacht voor het smokkelen van deze goederen. Het bezit van bepaalde goederen leidt er derhave toe dat de eigenaar schuldig wordt geacht aan het smokkelen van deze goederen. $\mathrm{Vgl}$. de 'kentekenaansprakelijkheid' in het kader van de WAHV.

227 Corstens lijkt deze opvatting van het EHRM nogal vergaand te vinden (Corstens a.w. 1999, p. 53).

228 Feteris a.w. 1993, p. 600.

229 Feteris a.w. 1993, p. 599. 
Ontbreken schorsende werking bezwaar en beroep - kritische reflectie In de door de commissie Scheltema voorgestelde regeling wordt van bepaalde standpunten uitgegaan die mijns inziens moeilijk te rijmen zijn met de onschuldpresumptie zoals onder andere neergelegd in artikel 6 , tweede lid EVRM. ${ }^{230}$ Ten eerste kan gewezen worden op het ontbreken van schorsende werking van bezwaar en beroep. Bezwaar en beroep hebben, met het oog op de slagvaardigheid van de handhaving, geen schorsende werking hetgeen impliceert dat de boete moet worden betaald, en invorderbaar is, voordat schuld definitief in rechte is komen vast te staan. ${ }^{231}$ Bovendien is er alleen sprake van een hoorplicht vóór de totstandkoming van het primaire boetebesluit bij boeten die hoger zijn dan 340,- Euro. Dit betekent dat de boete in de regel reeds invorderbaar is vóórdat de vermoedelijke overtreder de aanwezigheid van, de op basis van daderschap aanwezig geachte, schuld heeft kunnen betwisten ten overstaan van een onafhankelijke en onpartijdige rechter.

De commissie Scheltema stelt dat dit volgens de heersende leer toegestaan is. ${ }^{232} \mathrm{Ter}$ onderbouwing wijst de commissie op de zaak 'Källander'. ${ }^{233}$ Ik vraag me af of het gerechtvaardigd is uit een eenmalig (overigens niet in helderheid uitblinkend) oordeel van de Europese Commissie voor de Rechten van de Mens af te leiden dat invordering van een bestuurlijke boete gedurende de periode dat nog bezwaar of (hoger) beroep mogelijk is, is toegestaan. In de zaak 'Källander' ging het namelijk om een reeds te betalen belastingverhoging wegens onjuiste aangifte, die door een onafhankelijke en onpartijdige rechter was vastgesteld, terwijl hoger beroep tegen de rechterlijke uitspraak nog mogelijk was. Hoewel ook in de zaak Källander nog geen sprake was van formele rechtskracht (in dat geval van de rechterlijke uitspraak) is dat mijns inziens toch een duidelijk andere situatie dan de situatie waarin een bestuursorgaan de punitieve sanctie oplegt en vervolgens al overgaat tot invordering voordat een rechter zich uberhaupt over de rechtmatigheid van het besluit heeft kunnen buigen.

Alles wijst er dan ook op dat er bij de door de commissie Scheltema voorgestelde regeling sprake is van bestraffing vóórdat schuld in rechte vaststaat. Van Russen Groen is van mening dat deze praktijk op gespannen voet staat met de onschuldpresumptie uit artikel 6 lid 2 EVRM. Van Russen Groen stelt het volgende:

\begin{abstract}
'Het verbinden van directe gevolgen aan een voorlopig oordeel over de rechtmatigheid van een bestuursbesluit past in een zuivere bestuursrechtelijke wijze van denken, maar staat op gespannen voet met de presumptie van onschuld dat (lees: die [KA]) ten grondslag ligt aan een strafrechtelijke wijze van denken. Aangezien aan het opleggen van een bestuurlijke boete een rechtsvermoeden van schuld ten grondslag ligt dient in het bestuursstrafrecht, in verband met de onschuldpresumptie, op de hoofdregel van artikel 6:16 Awb, dat geen schorsende werking verbindt aan bezwaar of beroep, een uitzondering te worden gecreëerd. ${ }^{234}$
\end{abstract}

$230 \mathrm{Vgl}$. de in hoofdstuk 3 weergegeven passage uit de zaak 'Minelli' (\$ 37).

231 Voorontwerp p. 121.

232 Voorontwerp p. 121.

233

ECRM 6 maart 1989, BNB 1997/5 m. nt. M.W.C. Feteris onder BNB 1997/6.

Van Russen Groen a.w. 1998, p. 191-192, zie ook p. 209. Zie voorts Van der Hulst, a.w. 2000a, p. 70 : 'In de lijn van deze ontwikkeling past de opvatting van de opstellers van het Voorontwerp dat art. 6 EVRM niet in de weg staat aan invordering van een nog niet onherroepelijk geworden boete. Met deze opvatting lijkt de rechtsbescherming van de burger er niet op vooruit te zijn gegaan. Waar vroeger de 
Lenos $^{235}$, Roording ${ }^{236}$ en Rogier ${ }^{237}$ nemen een vergelijkbaar standpunt in. Zij zijn van oordeel dat, gelet op de onschuldpresumptie, uit moet worden gegaan van schorsende werking van bezwaar en beroep. ${ }^{238}$ De werkgroep 'Sancties in de sociale zekerheid' onder voorzitterschap van Riphagen lijkt ook twijfels te hebben bij het ontbreken van schorsende werking van bezwaar en beroep. Het innemen van een standpunt gaat de werkgroep echter uit de weg (met het oog op effectieve en efficiënte handhaving?):

'Het ontbreken van schorsende werking kan - althans voor zover het criminal charges betreft - daarom europeesrechtelijk gezien twijfelachtig lijken, waarbij echter meteen de kanttekening valt te plaatsen dat een tegenovergestelde situatie - derhalve de aanwezigheid van schorsende werking - het instellen van bezwaar of beroep wel erg aantrekkelijk kan maken. ${ }^{.239}$

Feteris meent dat er alleen sprake is van schending van de onschuldpresumptie als de sancties bestaan uit maatregelen die zich niet lenen voor ongedaanmaking als de rechter de sanctie vernietigt of vermindert. ${ }^{240}$ Ondanks dit genuanceerde standpunt acht hij het wenselijk dat sancties waarover het oordeel van de rechter nog kan worden ingeroepen nog niet ten uitvoer worden gelegd. Een uitzondering zou vervolgens kunnen gelden voor 'lichte vermogenssancties'. ${ }^{241}$ Feteris motiveert het door hem ingenomen standpunt als volgt:

'Met dit uitstel van betaling brengt de administratie tot uitdrukking dat zij de procedure voor de rechter serieus neemt, en vermijdt zij in ieder geval de schijn dat zij de betrokkene die zich tot de rechter wil wenden behandelt alsof hij al schuldig is verklaard. ${ }^{242}$

Ik vraag me af of Feteris met deze motivering niet het door hem ingenomen standpunt, dat er alleen sprake is van schending van de onschuldpresumptie als de sancties bestaan uit maatregelen die zich niet lenen voor ongedaanmaking, ondergraaft.

Uit bovenstaande volgt dat een aantal juristen meent dat het ontbreken van schorsende werking van het boetebesluit gedurende bezwaar en beroep zich niet verdraagt met de in artikel 6, tweede lid EVRM neergelegde onschuldpresumptie. Aangezien duidelijke rechtspraak van het EHRM niet voorhanden is kan mijns inziens echter niet met zekerheid gesteld worden dat het ontbreken van schorsende werking van het boetebesluit gedurende bezwaar en beroep, naar het oordeel van het EHRM, strijd met artikel 6 lid 2 EVRM zal opleveren. ${ }^{243}$ Gelet op de strekking van de onschuldpresumptie acht ik het

weg van het strafrecht een eindoordeel van de rechterlijke macht garandeerde en tenuitvoerlegging van een boete pas mogelijk was na dit cordeel, lijken met de introductie van de bestuurlijke boete deze beide waarborgen definitief verdwenen.'

235 Lenos a.w. 1998, p. 194.

236 Roording a.w. 1994, p. 219-220.

237 Rogier a.w. 1994, 'De bestuurlijke boete in de Algemene wet bestuursrecht?', p. 169.

238 Ook Tak lijkt er van uit te gaan dat de opvatting van de commissie Scheltema, dat het beginsel 'geen straf zonder schuld' niet in de weg staat aan de hoofdregel van artikel 6:16 Awb inzake de nictschorsende werking van bezwaar en beroep dubieus is. Vgl. Tak a.w. 2002, p. 54.

239 Riphagen a.w. 1994, p. 57.

240 Feteris a.w. 1993, p. 731.

241 Feteris a.w. 1993, p. 734.

242 Feteris a.v. 1993, p. 734.

243 Enige tijo nadat het literatuur- en jurisprudentie onderzoek was afgesloten verschenen de arresten 
echter niet uitgesloten dat het ontbreken van schorsende werking van bezwaar en beroep onder omstandigheden strijd oplevert met genoemde verdragsbepaling. In de regel is de boete namelijk reeds invorderbaar vóórdat de vermoedelijke overtreder de aanwezigheid van (de op basis van daderschap aanwezig geachte) schuld heeft kunnen betwisten ten overstaan van een onafhankelijke en onpartijdige rechter.

Gelet op het voorgaande lijkt het dan ook aanbevelenswaardig niet over te gaan tot invordering van de bestuurlijke boete alvorens het boetebesluit formele rechtskracht ${ }^{244}$ heeft verkregen. ${ }^{245}$

Er wordt wel op gewezen dat het ontbreken van schorsende werking gedurende bezwaar en (hoger) beroep kan worden ondervangen middels de gewone voorlopige voorzieningsprocedure (artikel 8:81 e.v. Awb). ${ }^{246}$ Deze stelling is op zijn minst voor kritiek vatbaar. Het is op zich al onwenselijk dat, anders dan in het strafrecht, het initiatief om de rechtmatigheid van de boete aan te vechten bij de vermoedelijke overtreder ligt. Vervolgens wordt ook nog van deze vermoedelijke overtreder verwacht dat hij een voorlopige voorzieningsprocedure start, én derhalve ten tweede male griffierecht betalt. Bovendien is het maar de vraag of er bij opgelegde boetebesluiten sprake is van onverwijlde spoed, die, gelet op de betrokken belangen, vereist dat er een voorlopige voorziening wordt getroffen. ${ }^{247}$

Västberga Taxi Aktiebolag en Vulic v. Sweden (EHRM 23 juli 2002, no. 36985/97) en Janosevic v. Sweden (EHRM 23 juli 2002, no. $34619 / 97$, EHRC 2002/88 m. nt. Widdershoven). In genoemde arresten stelt het Hof - met het oog op de onschuldpresumptie - ten aanzien van de mogelijkheid tot invordering van fiscale straftoeslagen (boeten), voordat de sanctiebeschikkingen formele rechtskracht hebben verkregen, het volgende: The Court notes that neither Article 6 nor, indeed, any other provision of the Convention can be seen as excluding, in principle, enforcement measures being taken before decisions on tax surcharges have become final.' Dan volgt de volgende nuancering: 'However, considering that the early enforcement of tax surcharges may have serious implications for the person concerned and may adversely affect his or her defence in the subsequent court proceedings, as with the position with the use of presumptions in criminal law, the States are required to confine such enforcement within reasonable limits that strike a fair balance between the interests involved. This is especially important in cases like the present one in which enforcement measures were taken on the basis of decisions by an administrative authority, that is, before there had been a court determination of the liability to pay the surcharges in question [curs. KA]. ' Dit brengt m.i. met zich dat het ontbreken van schorsende werking van bezwaar en beroep onder bepaalde omstandigheden strijd op zou kunnen leveren met artikel 6 lid 2 EVRM. Voorts verdient opmerking dat twee rechters ( $n$ l. Casedevall en Thomassen) de opvatting van het Hof niet volledig kunnen onderschrijven. Zij lijken de voorkeur te geven aan een 'omgekeerde' benadering. Invordering van fiscale straftoeslagen (boeten), voordat de sanctiebeschikkingen formele rechtskracht hebben verkregen, zou dan in beginsel strijd opleveren met de onschuldpresumtie.

244 Zie m.b.t. formele rechtskracht: E.C.H.J. van der Linden, Formele en materiële rechtskracht. De ḱleren van de keizer (diss. UM), Den Haag 1998.

245 Overigens zijn er verschillende mogelijkheden om te komen tot een wijze van sanctionering die (duidelijker) in overeenstemming is met de onschuldpresumptie. Ik kom daar later nog op terug. Vgl. Albers en Schlössels a.w. $2002, \$ 4.3$.

246 Zie: CTW-rapport (a.w. 1994) p. 57, Kabinetsstandpunt Handhaving door bestuurlijke boeten, p. 15, Michiels a.w. 1995, p. 91 , en Riphagen a.w. 1994, p. 56-58. Riphagen stelt op p. 56: 'De vraag is dan ook of hier sprake is van een verboden inbreuk op de onschuldpresumptie. Het antwoord hierop zal ontkennend luiden indien men er de nadruk op legt dat het effect van het ontbreken van schorsende werking in de eerste plaats gemitigeerd kan worden door, waar zinvol, een voorlopige voorziening te vragen, inhoudende een schorsing van de onmiddellijke tenuitvoerlegging van het besluit (...).'

247 Zie: Stroink a.w. 2000, p. 153-159. Zie voorts: Van Wijk/Konijnenbelv Van Male a.w. 1999, p. 692- 
Jurisprudentie is op dit punt ten aanzien van de bestuurlijke boete vooralsnog slechts in zeer beperkte mate voorhanden. Gewezen kan worden op een uitspraak van de Voorzitter van het (inmiddels opgeheven) College van Beroep Studiefinanciering van 25 oktober $1999 .^{248}$ In de zaak waarin de Voorzitter uitspraak moest doen was een bestuurlijke boete opgelegd van $f 3300,-$ vanwege overschrijding van de bijverdiengrens. Door verzoekster werd gevraagd een voorlopige voorziening te treffen inhoudende dat de Voorzitter zou bepalen dat de Informatie Beheer Groep (IBG) de invordering van het bedrag, dat verzoekster ingevolge het boetebesluit aan de IBG verschuldigd was, moest opschorten. De Voorzitter wees het verzoek om een voorlopige voorziening af onder de volgende overwegingen:

'Dienaangaande overweegt de voorzitter dat verzoekster geen spoedeisend belang (meer) heeft: bij de door haar gevraagde voorlopige voorziening, nu verweerster het ingevolge het besluit van 16 augustus 1999 verschuldigde bedrag bij besluit van 1 oktober 1999 heeft omgezet in een rentedragende lening, terwijl voorts niet is gesteld en, mede gelet op hetgeen verweerster hieromtrent heeft verklaard, ook niet aannemelijk is dat dit omzettingsbesluit ertoe heeft geleid, of er op korte termijn toe zal leiden, dat het reeds voorafgaande aan het besluit van 16 augustus 1999 maandelijks door verzoekster verschuldigde aflossingsbedrag op haar langlopende schuld zal worden verhoogd.'

Aan de hand van deze overwegingen kan moeilijk gezegd worden of de Voorzitter van het College van Beroep Studiefinanciering bepaalde algemene richtsnoeren hanteert. Dat de gevraagde voorlopige voorziening niet voor toewijzing in aanmerking komt is echter op zijn minst enigszins vreemd te noemen. In zijn overwegingen ten overvloede lijkt de Voorzitter immers aan te geven dat het primaire boetebesluit dat in het kader van de bezwaarschriftenprocedure voorligt bij de IBG onrechtmatig is. Kennelijk heeft de Voorzitter in het vermoeden dat het primaire besluit onrechtmatig was geen reden gezien om de voorlopige voorziening toe te wijzen. ${ }^{249}$

Aangezien aan de hand van een enkele uitspraak van de Voorzitter van het College van Beroep Studiefinanciering weinig gezegd kan worden over de vraag in hoeverre een voorlopige voorziening, in het kader van de schorsing van de invordering van bestuurlijke boeten, toegewezen zal worden is het wellicht zinvol een blik te werpen op andere relevante rechtspraak in dit kader.

Met het oog op het voorgaande kan gewezen worden op een uitspraak van de president van het College van Beroep voor het Bedrijfsleven met betrekking tot een beschikking in het kader van de superheffing (in casu ten bedrage van $f 80.742,21)^{250}$ en een uitspraak van genoemde president met betrekking tot een korting van $35 \%$ op de tegemoctkoming voor de ruiming van een varkensstapel van een veehouder. ${ }^{251}$ De President vangt zijn beoordeling, in de uitspraak van 28 januari 1998, aan met een overweging,

698.

248 Vz. College van Beroep Studiefinanciering, 25 oktober 1999, JB 2000/15 m. nt. C.L.G.F.H. Albers, AB 2000, 278 m. nt. G.A.C.M. van Ballegooij.

249 Men kan zich afvragen of dit anders zou zijn geweest als het boetebedrag niet omgezet zou zijn in een rentedragende lening maar in zijn geheel gevorderd zou zijn.

250 Pres. CBB, 10 november 1994, KG 1994/447.

251 Pres. CBB, 28 januari 1998, AB 1998, $228 \mathrm{~m}$. nt. J.H. van der Veen. Opgemerkt zij overigens dat zowel de heffing als de korting naar geldend recht niet als punitieve sanctie aangemerkt worden. 
die door de President van de Centrale Raad van Beroep ook gevolgd wordt in een voorlopige voorzieningszaak die betrekking heeft op beëindiging van een bijstandsuitkering in verband met 'fraude'. ${ }^{252}$ De President van het CBB stelt het volgende:

'In het voetspoor van zijn eerdere uitspraken is de president van oordeel dat voor het treffen van een voorlopige voorziening in een zaak als de onderhavige waar het gaat om een financieel belang als de aanspraak op een tegemoetkoming in geleden schade, in beginsel slechts plaats zal zijn indien voorshands emstig betwijfeld moet worden of de korting van de tegemoetkoming in de schade op juiste gronden is geschied en bovendien verzoeker feiten en omstandigheden aanwijst, die meebrengen dat zijn belang vordert dat het gevraagde voorschot op een hogere tegemoetkoming in de schade dan door verweerder vastgesteld, bij wege van onverwijlde voorziening bij voorraad aan hem wordt toegekend.'

Met andere woorden de onrechtmatigheid van het bestreden besluit of de aangevochten uitspraak moet met een grote mate van waarschijnlijkheid vast staan. Is dat het geval dan moet de verzoeker van de voorlopige voorziening ook nog aantonen dat zijn belang het treffen van een voorlopige voorziening vordert. Kort gezegd stelt de President van het $\mathrm{CBB}$ vervolgens in genoemde uitspraken dat een belang dat louter financieel van aard is, terwijl er geen sprake is van een onherstelbare situatie ${ }^{253}$, geen belang is dat een onverwijlde voorziening bij voorraad vordert. Deze redenering zou ook gevolgd kunnen worden door de bestuursrechters ten aanzien van opgelegde bestuurlijke boeten (de Voorzitter van het College van Beroep Studiefinanciering lijkt dit ook te doen). In veel gevallen zou dat ertoe leiden dat de bestuursrechter geen belang aanwezig acht voor de beboete persoon bij het treffen van een voorlopige voorziening. Daarmee heeft de vermoedelijke overtreder dan in ieder geval zijn griffierecht 'verspeeld'. Dit alles overziend lijkt de opvatting dat, bij het ontbreken van schorsende werking van bezwaar en beroep, nog altijd kan worden teruggevallen op de procedure ingevolge artikel 8:81 en verder Awb, te lichtvaardig. ${ }^{254}$

Aanpassing van de algemene voorlopige voorzieningsprocedure voor punitieve bestuursrechtelijke sancties zou in dit kader een oplossing kunnen bieden. Het feit dat het gaat om een louter financieel belang zou bij beantwoording van de vraag of de verzoeker belang heeft bij het treffen van een voorlopige voorziening dan geen rol mogen

\section{Pres. CRvB 14 april 1999, JABW 1999/90.}

253 Wellicht was, volgens de President van de CRvB wel sprake van onherstelbare schade bij de korting op een RWW-uitkering van 50\% gedurende drie maanden (Pres. CRvB 22 juni 1994, RSV 1995/16). Genoemd kortingsbesluit kwam voor schorsing in aanmerking aangezien het niet zorgvuldig was voorbereid. Spijtig genoeg bevat de uitspraak slechts een zeer algemene overweging met betrekking tot het belang van verzoekster: 'Wij zijn evenwel van oordeel dat evenbedoelde gedraging van verzoekster op zichzelf niet een zo ingrijpende sanctie als bij het bestreden besluit is opgelegd rechtvaardigt, zulks mede in aanmerking nemend dat in het kader van de toepassing van artikel 14 van de RWW geen directe betekenis toekomt aan de aan verzoekster in 1988 opgelegde sanctie. Gezien het hiervoor overwogene zijn Wij van oordeel dat aan het nadeel dat verzoekster door voortgezette tenuitvoerlegging van de opgelegde sanctie lijdt een groter gewicht moet worden toegekend dan aan het met de onmiddellijke uitvoering van het bestreden besluit te dienen belang van gedaagde, zodat gelet op de betrokken belangen onverwijlde spoed vereist dat een voorlopige voorziening wordt getroffen.' Zie voorts voor een vergelijkbaar geval: President Rechtbank Den Bosch, 20 oktober 2000, TAR 2001/10. Zie ten slotte Stroink a.w. 2000, p. 156. Stroink stelt op p. 156: 'Het doel van een voorlopige voorzieningsprocedure is dat door het nemen van een tijdelijke maatregel een onherstelbare situatie wordt voorkomen dan wel dat wordt voorkomen dat onevenredige schade wordt geleden.'

254 Zie in deze zin ook: Lenos a.w. 1998, p. 191-192. 
spelen. Voorts zou geen griffierecht geheven moeten worden. Met een dergelijke aanpassing van de voorlopige voorzieningsprocedure voor punitieve bestuursrechtelijke sanctiebesluiten zou echter de, door de commissie Scheltema, aan het ontbreken van schorsende werking van boetebesluiten, ten grondslag gelegde doelstelling worden ondergraven. Namelijk het garanderen van een slagvaardige handhaving en het voorkomen van een aanzuigende werking van bezwaar en beroep.

Dat brengt mij er toe vast te houden aan het standpunt dat er, gelet op de onschuldpresumptie, niet over zou moeten worden gegaan tot invordering van de bestuurlijke boete alvorens het boetebesluit formele rechtskracht heeft verkregen. Artikel 6:16 Awb blijft dan van toepassing. Van schorsende werking is immers geen sprake. Slechts de invordering van de boete is niet mogelijk. Het voorgaande brengt met zich dat in de boeteregeling een bepaling moet worden opgenomen waaruit volgt dat invordering van de bestuurlijke boete niet mogelijk is zolang het boetebesluit nog niet onherroepelijk is.

In de literatuur wordt voorts betoogd dat, indien na het opleggen van een bestuurlijke boete in bezwaar of (hoger) beroep blijkt dat de boete ten onrechte is opgelegd de negatieve gevolgen van het primaire besluit volledig kunnen worden teruggedraaid. ${ }^{255}$ Derhalve zou er geen sprake zijn van schending van de onschuldpresumptie. Ik betwijfel dat. Een punitieve sanctie kan mijns inziens, ongeacht of die in een later stadium nog teruggedraaid kan worden, gelet op de onschuldpresumptie eerst worden opgelegd als de schuld van de verdachte in rechte is komen vast te staan.

Daar komt nog bij dat ook de oplegging en invordering van (met name hoge) bestuurlijke boeten onomkeerbare gevolgen kan hebben. In het CTW-rapport wordt in dat kader gewezen op een faillissement als 'de facto' onomkeerbaar gevolg van de inning van een hoog geldbedrag. ${ }^{256}$ Lenos wijst op het te gelde maken van andere vermogensbestanddelen, zoals bijvoorbeeld een huis, ten einde een hoge boete te betalen. ${ }^{257}$

Zoals gezegd kan op grond van de bestaande rechtspraak van het EHRM niet worden gesteld dat het ontbreken van schorsende werking van bezwaar en beroep zonder meer verenigbaar is met de onschuldpresumptie. Ik ben van oordeel dat het ontbreken van genoemde schorsende werking in bepaalde gevallen zeer wel strijd op zou kunnen leveren met artikel 6 lid 2 EVRM. Doorgaans is de boete (als hoofdstraf ${ }^{258}$ ) namelijk reeds invorderbaar vóórdat de vermoedelijke overtreder de aanwezigheid van, de op basis van daderschap aanwezig geachte, schuld heeft kunnen betwisten ten overstaan van een onafhankelijke en onpartijdige rechter. Het feit dat (wellicht slechts in uitzonderlijke gevallen) op grond van de procedure zoals neergelegd in artikel 8:81 en verder Awb schorsing van de tenuitvoerlegging kan worden gevraagd doet daar mijns inziens niet aan af. Hetzelfde geldt voor het feit dat de invordering van de boete doorgaans niet leidt tot onomkeerbare gevolgen.

255 Zie bijvoorbeeld: Riphagen a.w. 1994, p. 57.

256 CTW-rapport a.w. 1994, p. 57.

257 Lenos a.w. 1998, p. 192. Zie voorts Feteris a.w. 1993, p. 733.

258 In die zin kan een parallel met de voorlopige hechtenis niet getrokken worden. Ook in het kader van de voorlopige hechtenis is er bovendien sprake van een zekere spanning met de onschuldpresumptie. Bovendien is voorlopige hechtenis slechts in een beperkt aantal gevallen, en dan met name ten aanzien van misdrijven, mogelijk (Vgl. Corstens a.w. 1999, p. 370 e.v.). 
Beter is het, eerst over te gaan tot invordering van de bestuurlijke boete als het besluit tot oplegging van de bestuurlijke boete formele rechtskracht heeft verkregen. Daarbij zou men in overweging kunnen nemen wettelijke rente over het boetebedrag te vorderen indien de appellant uiteindelijk niet in het gelijk gesteld wordt.

In plaats van 'het verbod tot invordering' zou gekozen kunnen worden voor een andere variant. Daarbij zou dan, in afwijking van artikel 6:16 Awb, wel moeten worden uitgegaan van schorsende werking van bezwaar en beroep tegen boetebesluiten. Kiest men voor deze variant dan zou het bestuursorgaan wel de mogelijkheid moeten krijgen om de rechter, gelet op zwaarwegende handhavingsbelangen, om opheffing van de schorsende werking te verzoeken. De rechter moet dan overigens niet al te snel een dergelijk verzoek tot opheffing honoreren. Gedacht kan worden aan situaties waarin het bezwaar of beroep volgens de rechter kennelijk ongegrond is.

\section{Ontbreken schorsende werking van bezwaar en beroep - uitzonderingen -}

De commissie Scheltema geeft in het Voorontwerp aan dat in specifieke gevallen aanleiding kan bestaan om af te wijken van de hoofdregel van artikel 6:16 Awb (geen schorsende werking van bezwaar en beroep). ${ }^{259}$ Ten eerste wijst de commissie op het feit dat schorsende werking van bezwaar nuttig kan zijn als er in de primaire fase gén hoorplicht geldt ${ }^{260}$ 'om feitelijke onjuistheden nog voor het invorderbaar worden van de boete te kunnen herstellen. ${ }^{261}$ Daarnaast kan er, volgens de commissie Scheltema, reden zijn voor schorsende werking als de opgelegde boeten zeer hoog zijn. ${ }^{262}$ Maar dan zou in de bijzondere wet wel voorzien moeten worden in zekerheidsstelling bij het instellen van beroep of verschuldigdheid van wettelijke rente als de opgelegde boete in beroep in stand blijft. Dit laatste stelt de commissie Scheltema voor teneinde de aanzuigende werking van de schorsende werking op het indienen van bezwaar en beroep te beperken. ${ }^{263}$

\section{Uitzondering I: géén hoorplicht in de primaire fase}

Ten aanzien van de eerste, door de commissie Scheltema, genoemde reden om in de bijzondere wet een uitzondering te maken op artikel 6:16 Awb wil ik het volgende opmerken. Op basis van de in het Voorontwerp voorgestelde regeling zou een hoorplicht niet nodig zijn bij overtredingen waarvoor 'slechts' een boete van minder dan 340 Euro opgelegd kan worden. ${ }^{264}$ Moet nu, gelet op de toelichting op het Voorontwerp, ten aanzien van al deze lagere boeten uitgegaan worden van de schorsende werking van bezwaar? Ik kan me niet voorstellen dat de commissie Scheltema dat voor ogen had.

Desondanks is het wenselijk dat ten minste in alle gevallen waarin een hoorplicht in de primaire fase ontbreekt uit wordt gegaan van schorsende werking van bezwaar ${ }^{265}$ of een

259 Voorontwerp p. 121.

260 Zie in deze zin ook Michiels a.w. 1995, p. 91.

261 Voorontwerp p. 121.

262 Wellicht stelt de commissie zich op dit standpunt met het oog op onomkeerbaarheid van de gevolgen van invordering.

263 Voorontwerp p. 122.

264 Zie artikel 5.4.2.6 van het Voorontwerp.

265 Zie in deze zin ook: CTW-rapport a.w. 1994, p. 57, Kabinetsstandpunt Handhaving door bestuurlijke boeten, p. 14, en Riphagen a.w. 1994, p. 57-58. 
'verbod tot invordering'. Mijns inziens gaat dit met het oog op de onschuldpresumptie nog niet ver genoeg. Ik ben, zoals gezegd, van mening dat invordering van de boete in geen enkel geval mag plaatsvinden voordat de opgelegde bestuurlijke boete onherroepelijk is geworden. ${ }^{266}$ Wel zou bepaald kunnen worden dat, ingeval van kennelijk onredelijk gebruik van procesrecht, wettelijke rente betaald moet worden over de op te leggen boete. Uiteraard ben ik me er van bewust dat het voorgaande moeilijk te rijmen valt met de door de commissie Scheltema voorgestane idee van slagvaardige handhaving. ${ }^{267}$ Het is immers niet eenvoudig efficiënte en effectieve handhaving van regelgeving te realiseren als ten aanzien van de vermoedelijke overtreder bij sanctionering vergaande (straf(proces)rechtelijke) waarborgen in acht moeten worden genomen. Desalniettemin mag efficiënte en effectieve handhaving niet zonder meer als argument gebruikt worden voor het negeren van bepaalde straf(proces)rechtelijke waarborgen in het bestuursstrafrecht. Daarbij teken ik aan dat in dat kader mijns inziens niet slechts relevant is of (nog) voldaan wordt aan de waarborgen die voortvloeien uit het EVRM. Aangezien ik er van uit ga dat punitieve sancties deel uit maken van het strafrecht in ruime zin dienen genoemde waarborgen ook los van het verdragsrechtelijke kader door een zichzelf respecterende rechtsstaat in acht genomen te worden. ${ }^{268}$

\section{Uitzondering II: zéér hoge boeten}

Ten tweede is er, zoals gezegd, naar het oordeel van de commissie Scheltema ruimte voor schorsende werking van bezwaar en beroep indien het gaat om de oplegging van zeer hoge boeten. In de bijzondere wet moet dan wel voorzien worden in zekerheidsstelling bij het instellen van beroep of verschuldigdheid van wettelijke rente als de opgelegde boete in beroep in stand blijtt. De commissie lijkt over het hoofd te zien dat in het kader van het bestuurlijke boeterecht niet in absolute zin gesproken kan worden van 'zeer hoge boeten'. Een boete van bijvoorbeeld 200 Euro die wordt opgelegd op grond van Algemene bijstandswet kan immers de gesanctioneerde burger vele malen harder treffen dan een boete van 50.000 Euro die wordt opgelegd aan een multinational.

Zoals gezegd dient er volgens de commissie Scheltema in de bijzondere wet wel iets geregeld te worden teneinde de nadelige gevolgen ${ }^{269}$ van schorsende werking zoveel mugelijk te elimineren. Ten eerste wordt in het Voorontwerp gewezen op de mogelijkheid van zekerheidsstelling. De figuur van zekerheidsstelling wordt momenteel al toegepast in de Wet bestuursrechtelijke handhaving verkeersvoorschriften (WAHV). De Hoge Raad is, blijkens een arrest van 9 november $1993^{270}$, van oordeel dat genoemde zekerheidsstelling niet in strijd is met het onschuldvermoeden uit artikel 6, tweede lid FVRM. De verplichting tot zekerheidsstelling loopt immers niet vooruit op de door de rechter te beantwoorden vraag of een betrokkene een gedraging in de zin van de

Vgl. Van Russen Groen a.w. 1998, p. 212.

267 Wellicht dat de hierboven door mij als rweede variant gepresenteerde mogelijkheid het bestuur iets meer ruimte biedt. Het bestuursorgaan zou op basis van die variant immers een verzoek kunnen doen tot opheffing van de schorsende werking.

$268 \mathrm{Vgl}$. hoofdstuk 2.

269 De zogenaamde 'aanzuigende werking' van bezwaar en beroep.

270 HR 9 november 1993, NJ 1994, 198. 
WAHV heeft verricht en beperkt evenmin de verdedigingsmogelijkheden waarover een betrokkene kan beschikken, aldus de Hoge Raad.

Zekerheidsstelling kan, volgens de Hoge Raad, wél om een andere reden strijd opleveren met artikel 6 EVRM. Namelijk omdat onverkorte toepassing van het vereiste van zekerheidsstelling als voorwaarde voor ontvankelijkheid in het concrete geval strijd kan opleveren met artikel 6, eerste lid EVRM. ${ }^{271}$ Het recht op toegang tot een onafhankelijke en onpartijdige rechter kan immers door de omvang van de gevraagde zekerheidsstelling te emstig worden beperkt. ${ }^{272}$ Opgemerkt zij dat volgens de Hoge Raad met name de zekerheidsstelling bij hoge boetebedragen, gelet op de financiële positie van de vermoedelijke overtreder, strijd op kan leveren met artikel 6 EVRM. ${ }^{273}$ Laten het nu juist die hoge boeten zijn waarbij de commissie Scheltema, in 'ruil' voor schorsende werking van bezwaar en beroep, een zekerheidsstelling eist. De voorgestelde regeling staat derhalve ook op dit punt op gespannen voet met artikel 6 EVRM. Is het niet vanwege de onschuldpresumptie dan wel vanwege de belemmering van de toegang tot de rechter. ${ }^{274} 275$

\section{Weerlegbaar vermoeden van schuld?}

Zoals gezegd moet er, gelet op de onschuldpresumptie, sprake zijn van een weerlegbaar vermoeden van schuld. Het voorgaande kan worden afgeleid uit de zaken 'Salabiaku' en 'Pham Hoang'. ${ }^{276}$ Bij de boeteregeling in het kader van de WAHV is van een weerlegbaar vermoeden van schuld naar mijn mening echter in veel gevallen géén sprake. Op grond van artikel 5 WAHV wordt uitgegaan van een zogenaamde 'kentekenaansprakelijkheid'. De bestuurlijke boete wordt opgelegd aan degene op wiens

27 Vgl. EHRM 19 juni 200I, no. 28249/95 (Kreuz v. Poland), waarin het EHRM aangeeft dat het heffen van (met name hoge) griffierechten of het vorderen van andere bedragen teneinde toegang te krijgen tot de rechter de effectieve toegang tot de rechter onder omstandigheden dermate kan beperken dat het vorderen van dergelijke bedragen strijd oplevert met artikel $6 \mathrm{EVRM}$. Vgl. voorts ABRS 21 november 2001, JB 2002/7 m. nt. A.W. Heringa.

272 Zie: HR 31 januari 1995, NJ 1995, 598, m. nt. Corstens. Zie in dit kader ook: HR 28 juni 1994, NJ 1994, 657. Hetzelfde geldt overigens wellicht in bepaalde gevallen m.b.t. heffing van griffierecht op grond van artikel 8:41 Awb. Vgl. Barkhuysen/Van Emmerik/Loof a.w. 2000, p. 237-408, i.h.b. p. 386387. Zie tenslotte EHRM 27 februari 1980, Series A vol. 35, NJ 1980, 561 (essentie) (Deweer v. Belgium). Uit dit arrest van het Hof kan worden afgeleid dat onder omstandigheden ók een transactievoorstel het recht op toegang tot de rechter op een met artikel 6 EVRM strijdige wijze kan beperken.

273 Zie voor een overzicht van jurisprudentie in het kader van de zekerheidsstelling op grond van de WAHV: J.W. van der Hulst, Artikel 6 EVRM en de WAHV, VR 1999/6 p. 164-167.

274 Zie hierover ook: P.M. van Russen Groen, Een juridische evaluatie van de Wet Mulder, in de bundel: De wet Mulder in bedrijf, onder redactie van J.W. van der Hulst, Amhem 1994, p. 71-88, i.h.b. p. 82. Zie voorts Van Russen Groen a.w. 1988, p. 141.

275 Mols signaleert in dit kader overigens nog een beperking met betrekking tot de toegang tot de rechter in de Wet Mulder-zaken. Hoger beroep kan alleen ingesteld worden bij het gerechtshof te Leeuwarden. Mols vraagt zich (m.i. terecht) af of voor bepaalde overtseders (bijvoorbeeld degenen die afkomstig zijn uit Maastricht) met de verre reis naar Leeuwarden geen (de toegang tot de rechter beperkende) drempel wordt opgeworpen voor de rechtzoekende. Deze wordt op genoemde wijze immers gestimuleerd om niet in hoger beroep te gaan of om af te zien van een mondelinge behandeling (Vgl. G.P.M.F. Mols, Het rapport van de commissie-werkbelasting strafkamer Hoge Raad, DD 1997, p. 651-659, i.h.b. p. 656-657).

276 EHRM 25 september 1992, Series A vol. 243, NJ 1995, 593, m. nt. E.A. Alkema, 'Pham Hoang tegen Frankrijk' i.h.b. $\$ 34$, waaruit blijkt dat het vermoeden van schuld niet onweerlegbaar (irrebuttable) mag zijn. 
naam het kenteken ten tijde van de gedraging in het kentekenregister was ingeschreven (omdat op deze pragmatische wijze efficiënt en effectief kan worden gehandhaafd ${ }^{277}$ ). In artikel 8 WAHV zijn vervolgens drie 'disculpatiegronden' opgenomen. ${ }^{278}$ De officier van justitie dient, in administratief beroep ${ }^{279}$, op grond van laatstgenoemd artikel het boetebesluit ten eerste te vernietigen indien er sprake was van joy-riding of diefstal ten tijde van de geconstateerde overtreding. De kentekenhouder moet dit aannemelijk maken. Ten tweede volgt vernietiging van het boetebesluit indien de auto op het moment van de geconstateerde overtreding bedrijfsmatig was verhuurd (voor ten hoogste drie maanden). Tenslotte wordt het boetebesluit vernietigd als de aangeschreven persoon een vrijwaringsbewijs kan overleggen waaruit blijkt dat hij ten tijde van de gedraging geen eigenaar of houder meer was van het motorrijtuig. ${ }^{280}$

Den Hartog stelt terecht dat de kentekenhouder, ingeval een beroep op één van de gronden uit artikel 8 WAHV niet mogelijk is, kan worden gestraft voor een gedraging die een ander heeft verricht. ${ }^{281} \mathrm{Zij}$ komt dan ook tot de volgende conclusie:

'Door de wet Mulder is het mogelijk geworden dat iemand gestraft wordt zonder dat hij iets te maken heeft met het gepleegde delict of dat personen een zogenaamde 'Verdachtsstrafe' wordt opgelegd. Zodra dit gebeurt, is dit in strijd met het tweede lid van artikel 6 EVRM. ${ }^{282}$

Uit een arrest van 15 juli 1993 blijkt dat de Hoge Raad, anders dan Den Hartog, meent dat toepassing van artikel 5 WAHV in samenhang met artikel 8 WAHV niet in strijd is met de onschuldpresumptie. ${ }^{283}$ De motivering van de Hoge Raad is op zijn minst curieus te noemen, zoveel moge duidelijk zijn op basis van de hiema weergegeven passage:

'Gelet op het hiervoren onder 5.3. overwogene dient art. 5 WAHV aldus te worden verstaan dat, bij oplegging van een administratieve sanctie op de voet van die bepaling aan de kentekenhouder, aan deze niet een gedraging als bedoeld in art. 2 eerste lid WAHV wordt

277 Zie: Kamerstukken II, 1987/1988, 20329, no. 3, p. 11. In de memorie van antwoord (Kamerstukken II, $1987 / 1988,20329$, no. 6 i.h.b. p. 12-14) wordt vervolgens gesproken over risico-aansprakelijkheid. Een term die mijns inziens niet thuis hoort in het bestuursstrafrecht.

278 Ook beroep op de kantonrechter is slechts mogelijk op basis van, in artikel 9 WAHV, enumeratief opgesomde beroepsgronden.

279 Bij de bestuurlijke boeten die op grond van de WAHV worden opgelegd geldt een bijzondere procedure die afwijkt van de in het bestuursrecht gebruikelijke procedure. De boete wordt opgelegd door een met toezicht op de naleving van voorschriften gesteld bij of krachtens de WVW, Prov.w, of Gem.w belaste ambtenaar (art. 2 en 3 WAHV). Tegen het boetebesluit staat administratief beroep open bij de officier van justitie (art. 6 e.v. WAHV). Daarna kan de (vermoedelijke) overtreder beroep instellen bij het kantongerecht (art. 9 e.v. WAHV) en tenslotte kan hoger beroep worden ingesteld bij het gerechtshof te Leeuwarden (art. 14 e.v. WAHV).

280 Zie voor een overzicht van de belangrijkste ontwikkelingen op het terrein van de WAHV over de afgelopen tien jaar: J.W. van der Hulst, Tien jaar administratiefrechtelijke handhaving verkeersvoorschriften, NTB 2000/9 (a.w. 2000b), p. 271-276. Zie ook: HR 20 april 1999, VR 2000, 52. De Hoge Raad lijkt in dat arrest het standpunt in te nemen dat vernietiging van de beschikking eventueel wel mogelijk zou kunnen zijn als de kentekenhouder aannemelijk weet te maken dat zijn auto zich op het tijdstip van de geconstateerde gedraging op een andere plaats bevond dan de plaats waar de gedraging is geconstateerd.

281 Den Hartog a.w. 1992, p. 289.

282 Den Hartog a.w. 1992, p. 297.

283 Vgl. HR 15 juli 1993, NJ 1994, 177, m. nt. Corstens. Dit in tegenstelling tot de Utrechtse kantonrechter wiens beslissing werd aangevochten in genoemd arrest. 
verweten, doch op de kentekenhouder slechts de last komt te rusten het bedrag van de opgelegde administratieve sanctie voor de bestuurder als degene die zich aan de desbetreffende gedraging heeft schuldig gemaakt te voldoen, om dat bedrag vervolgens desgewenst op deze te verhalen. Laat de kentekenhouder na de daartoe geêigende maatregelen te nemen, dan neemt hij daarmede het risico in dat verhaal niet te zullen slagen. Voorts in aanmerking genomen enerzijds

a. de massaliteit van het zich vaak met grote snelheid voortbewegend gemotoriseerde verkeer en de grote frequentie waarin daarbij verkeersregels worden overtreden;

b. de beperkte mogelijkheden tot staandehouding van verkeersovertreders en opsporing van verkeersovertredingen;

c. de onwenselijkheid verkeersovertredingen onbestraft te laten alsmede het belang dat de samenleving heeft om daartegen wèl te kunnen optreden;

en anderzijds

d. de omstandigheid dat mag worden aangenomen dat in het merendeel van de gevallen - zeker bij het "particuliere" deel van het wegverkeer - de bestuurder van het motorrijtuig tevens de kentekenhouder is;

e. de mogelijkheden die de art. 8 en 9 WAHV de kentekenhouder geven zich tegen de oplegging van de administratieve sanctie te verweren;

f. de burgerrechtelijke mogelijkheden voor de kentekenhouder om in de gevallen waarin hij de administratieve sanctie niet op grond van de art. 8 of 9 WAHV kan afweren het bedrag dier sanctie te verhalen op de bestuurder; en ten slotte

g. het feit dat het bij de oplegging van de administratieve sanctie om een financiële sanctie van slechts beperkte omvang gaat, is de toepassing van art. 5 WAHV, verstaan zoals uiteengezet in 5.3 en 5.4 , niet onverenigbaar met het tweede lid van art. 6 EVRM.'

Met het oog op de wetsgeschiedenis acht de Hoge Raad 'risico-aansprakelijkheid' niet in strijd met de onschuldpresumptie. Efficiënte en effectieve handhaving lijken voor de Hoge Raad van groter belang dan de rechtsbescherming van de burger bij de oplegging van punitieve bestuursrechtelijke sancties. Deze laatste term (punitieve administratieve sanctie) lijkt de Hoge Raad in het arrest overigens bewust te vermijden (evenals de term 'criminal charge'). Binnen een (bestuurs)strafrechtelijke context, waar het adagium 'geen straf zonder schuld' een prominente plaats inneemt, gedijen termen als 'risicoaansprakelijkheid' en verhaal van het boetebedrag door de onschuldige kentekenhouder op de schuldige overtreder immers niet. Corstens geeft dit in zijn noot onder genoemd arrest helder weer:

'Dit betekent - daarover mag geen misverstand bestaan - dat de Hoge Raad in navolging van de wetgever het loslaten van het schuldbeginsel op dit onderdeel van het strafirecht goedkeurt. In materiële zin is er sprake van strafrechtelijke sancties. Het uitgangspunt "geen straf zonder schuld" geldt volgens de Hoge Raad hier dus niet. (...) Maar wat te denken van het loslaten van het schuldbeginsel? Als men straf ziet als een reactie op verwijtbaar onrecht, past het niet te straffen als er niet te verwijten is. Een essentiale ontbreckt: hoe kan men iemand straffen voor iets dat niet op zijn conto is te schrijven? Schuld in de hier bedoelde ruime betekenis is fundament van de straf. Bij gebreke daarvan mag er niet worden gestraft. Het fundamenteel en intrinsiek verband tussen een gedraging die men achterwege had behoren te laten en de straf ontbreekt (...). Daarom mogen erfgenamen ook niet worden gestraft voor door de erflater begane vergrijpen. De Commissie Van Slooten heeft om die reden dan ook voorgesteld erfgenamen niet fiscaal te beboeten voor feiten die de erflater heelt gepleegd (Rapport herziening fiscaal boetestelsel, par. 16). Dat is in het wetsvoorstel 
23470 overgenomen. In de memorie van toelichting op het desbetreffend art. 67i Algemene wet inzake rijksbelastingen (AWR) staat: "Straf is bedoeld als bewuste leedtoevoeging aan de dader en daarom gebonden aan de persoon zelf; zij kan niet worden toegediend indien de dader overleden is". ${ }^{284}$

Zoals gezegd kan uit de rechtspraak van het EHRM worden afgeleid dat een wettelijke vermoeden van schuld weerlegbaar moet zijn. Op grond van de regeling in de WAHV is dit slechts in een zeer beperkt aantal situaties (neergelegd in artikel 8 WAHV) het geval. ${ }^{285}$ Daarnaast zou, met het oog op de aan punitieve sancties ten grondslag gelegde doelstelling, gesteld kunnen worden dat aan een persoon géén punitieve sanctie opgelegd kan worden met betrekking tot een strafbaar feit dat door een ander is gepleegd. ${ }^{286}$ Op grond van de WAHV is dat wél mogelijk.

Sanctionering op basis van risico-aansprakelijkheid ${ }^{287}$, ongeacht of de bestrafte persoon schuldig is, druist mijns inziens in tegen fundamentele beginselen van het strafrecht. Reden genoeg, derhalve, althans zo meen ik, om de risico-aansprakelijkheidsregeling uit de WAHV in ieder geval strijd met de onschuldpresumptie te achten. Het is dan ook niet vreemd dat in de juridische literatuur meer auteurs, waaronder Van Russen Groen $^{288}$ en Den Hartog ${ }^{289}$, die mening toegedaan zijn. ${ }^{290} 291$

\section{Bewijs(lastverdeling)}

Opgemerkt zij voorts dat uit de onschuldpresumptie zoals die is neergelegd in artikel 6 EVRM niet alleen afgeleid wordt dat de rechter uit moet gaan van de onschuld van de verdachte totdat zijn schuld in rechte is komen vast te staan (hetgeen impliceert dat géén straf mag worden opgelegd zonder schuld aan de zijde van de verdachte). Daarnaast volgt uit het tweede lid van artikel 6 EVRM dat de bewijslast rust op de vervol-

284 Corstens in zijn noot onder HR 15 juli 1993 (NJ 1994, 177). Zie in deze zin ook: Feteris a.w. 1993, p. 614 en 638. Zie voorts: EHRM 29 augustus 1997, no. 20919/92 Reports 1997-V (E.L., R.L., and J.O.L. v. Switzerland). In die zaak heeft het EHRM aangegeven dat het in strijd is met de onschuldpresumptie als aan de erfgenamen een straf wordt opgelegd wegens een strafbaar feit dat door de erflater is gepleegd.

285 Op deze plaats verdient het opmerking dat Nederland met deze vorm van kentekenaansprakelijkheid een beduidend verdergaande regeling heeft getroffen dan bijvoorbeeld Belgie en Duitsland. Zie in dit kader: S.T.M. Boos, Kentekenaansprakelijkheid in vergelijkend perspectief, VR 2000/4 p. 109-118.

286 Dit volgt uit de zaak 'E.L., R.L., and J.O.-L. v. Switzerland'. Tevens wordt dit uitgangspunt aangetroffen in artikel 5.4.1.3 van het Voorontwerp (Voorontwerp p. 122).

287 Sanctionering op basis van risico-aansprakelijkheid lijkt overigens ook op andere terreinen van het (traditionele) strafrecht in zwang te raken (Vgl. o.m. S.A.M. Stolwijk, Schuld, DD 1998, p. 983-987, i.h.b. p. 984, en Th. A. de Roos, Groepsgeweld en strafrecht, AA 1998, p. 148-155).

288 Van Russen Groen a.w. 1998, p. 184-189.

289. Den Hartog a.w. 1992, p. 288-297 en p. 50-57.

290 Zie voorts: J.M. van Bemmelen, Th. W. van Veen, bewerkt door D.H. de Jong en G. Knigge a.w. 1998, p. 42 en Th. A. de Roos, De Mensenrechtenverdragen en het strafproces, in: Hoofdstukken strafprocesrecht, onder redactie van G.P.M.F. Mols, Gouda Quint, Deventer 1999, p. 65-80, i.h.b. p. 77-78.

291 Anders: J.H.A. Steenbrink en F.K.G. Westerbeke, De risico-aansprakelijkheid van de kentekenhouder, in de bundel: De wet Mulder in perspectief onder redactie van H. de Doelder, L.J.J. Rogier en P.M. van Russen Groen, Amhem 1990, p. 51-65, i.h.b. p. 64-65 en A. Kors, Administratiefrechtelijke handhaving: toekomstperspectief, in dezelfde bundel, p. 77-84, i.h.b. p. 80 . Genoemde auteurs menen uit de zaak 'Salabiaku' af te kunnen leiden dat de risico-aansprakelijkheidsregeling uit de WAHV niet in strijd is met artikel 6, tweede lid EVRM. 
gende instantie. ${ }^{292}$ Het voorgaande blijkt uit de zaak 'Barberà, Messegué and Jabardo. ${ }^{293}$ In genoemd arrest is ten aanzien van de onschuldpresumptie het volgende bepaald:

'Paragraph 2 (art. 6-2) embodies the principle of the presumption of innocence. It requires, inter alia, that when carrying out their duties, the members of a court should not start with the preconceived idea that the accused has committed the offence charged; the burden of proof is on the prosecution, and any doubt should benefit the accused. It also follows that it is for the prosecution to inform the accused of the case that will be made against him, so that he may prepare and present his defence accordingly, and to adduce evidence sufficient to convict him. ${ }^{294}$

Op grond van artikel 6, tweede lid EVRM dient het sanctionerende bestuursorgaan aan te tonen dat een bestuursrechtelijke norm is geschonden en dat derhalve de oplegging van de boete gerechtvaardigd en rechtmatig is. ${ }^{295}$ Het lijkt te gaan om een materieel criterium nu, zoals in hoofdstuk drie van dit boek reeds is aangegeven, aan artikel 6 van het EVRM geen regels, met betrekking tot de wijze waarop strafbare feiten moeten worden bewezen, kunnen worden ontleend. Deze regelgeving laat het EHRM expliciet over aan de partijstaten. ${ }^{296}$

Alvorens ingegaan wordt op de bewijslastverdeling bij oplegging van bestuurlijke boeten, zoals voorgesteld in het Voorontwerp, zal eerst nog aandacht uit gaan naar het in het strafrecht en in het algemeen bestuursrecht geldende bewijsrecht ${ }^{297}$ en daarmee nauw verwante procesrechtelijke leerstukken. Het materiële bewijsrecht, en dan in het bijzonder de bewijslastverdeling, zal in dat kader een centrale rol vervullen. Minder aandacht zal uitgaan naar het formele bewijsrecht (waarmee met name gedoeld wordt op de (wettelijke) bewijsmiddelen).

\section{Bewijs(lastverdeling) in het Nederlandse strafprocesrecht}

Het Nederlandse strafprocesrecht kent een negatief-wettelijk bewijsstelstel. ${ }^{298}$ Een strafbaar feit kan slechts worden bewezen aan de hand van in de wet opgesomde be-

292 Zie m.b.t. artikel 6 lid 2 EVRM $\$ 3.4 .1$ van dit boek. In het kader van de oplegging van bestuurlijke boeten dient het boete opleggende bestuursorgaan aangemerkt te worden als vervolgende instantie.

293 EHRM 6 december 1988, A series no. 146 (Barberà, Messegué and Jabardo).

294 'Barberà, Messegué and Jabardo' $\S 77$. De situatie lijkt in het Nederlandse strafrecht anders te zijn. In feite rust de bewijslast hier op de strafrechter. Zie in dit kader: J.F. Nijboer, Strafrechtelijk bewijsrecht, vierde herziene druk, Nijmegen 2000, p. 35.

295 Zie in dit kader ook de zaak 'Telfner v. Austria' (EHRM 20 maart 200l, no. 33501/96) zoals beschreven in $\$ 3.4 .1$ van dit boek. Telfner werd gestraft terwijl enig steekhoudend bewijsmateriaal ontbrak. Het EHRM was van mening dat de veroordeling en sanctionering in strijd waren met de onschuldpresumptie omdat er sprake was van een onrechtmatige verschuiving van de bewijslast.

296 Zie daaromtrent uitvoeriger Van Russen Groen a.w. 1998, p. 198-213.

297 In het kader van het bestuursrecht zal het bewijsrecht in het algemeen beschreven worden. Gelet op het feit dat het bewijsrecht zoals dat voortvloeit uit de Awb van toepassing is op zeer diverse soorten bcsluiten zal in de praktijk een zekere differentiatie plaats vinden. Dit brengt met zich dat het niet ondenkbaar is dat de bestuursrechter ten aanzien van punitieve sancties specifieke eisen zal (gaan) stellen aan het bewijs. Voor zover dit in de praktijk reeds gebeurt zal dit aangegeven worden in deze paragraaf.

298 Zie m.b.t. het strafrechtelijk bewijsrecht voorts: J.B.H.M. Simmelink, Bewijsrecht en bewijsmotivering, in Groenhuijsen en Knigge a.w. 1999, p. 397 e.v. 
wijsmiddelen. ${ }^{299}$ De rechter mag het feit niet bewezen verklaren als hij uit de bewijsmiddelen niet de overtuiging heeft gekregen dat het ten laste gelegde feit door de verdachte is gepleegd. Voorts gelden er bewijsminima hetgeen wil zeggen dat ten aanzien van bepaalde wettelijke bewijsmiddelen is aangegeven dat zij niet uitsluitend kunnen dienen als bewijs voor het ten laste gelegde. De rechter kan bijvoorbeeld de verdachte niet schuldig achten alléén op basis van de verklaring van de verdachte dat hij het ten laste gelegde heeft gepleegd. ${ }^{300}$ Dat de verdachte het ten laste gelegde heeft begaan zal dan ook nog uit een of meerdere andere wettige bewijsmiddelen moeten blijken.

Naast deze formele regels van bewijsrecht is voorts het materiële bewijsrecht relevant. In dat kader gaat op deze plaats aandacht uit naar de bewijslastverdeling. Nijboer merkt met betrekking tot de verdeling van de bewijslast in het strafprocesrecht het volgende op:

'In strikte zin kent het strafprocesrecht in Nederland geen bewijslast voor de verdediging en eigenlijk ook niet voor het Openbaar Ministerie (al behoort dit wel zoveel materiaal aan te dragen dat er niet van een lichtvaardige vervolging kan worden gesproken). Men moet wat betreft het Nederlandse strafprocesrecht constateren dat het eerder de rechter is die moet bewijzen (in de zin van vaststellen) dan dat de partijen of alléen het Openbaar Ministerie een bewijslast zouden dragen (in de zin van aantonen). ${ }^{301}$

Uit het voorgaande kan worden afgeleid dat, voor zover er in het strafrecht gesproken kan worden van een bewijslast, deze uiteindelijk rust op de strafrechter ${ }^{302} \mathrm{Hij}$ vervult (naast het Openbaar Ministerie) dan ook een actieve rol bij de bewijsgaring. ${ }^{303}$ Materieel betekent dit dat (de politie in opdracht van) het Openbaar Ministerie in eerste instantie het bewijs vergaart. Het OM treft in feite de voorbereiding voor de strafrechtelijke procedure en zal het bewijs van het ten laste gelegde (in belangrijke mate) 'rond' moeten hebben. Onder meer op basis van het door de Officier van Justitie naar voren gebrachte bewijs zal de rechter na de rechtszitting zijn uitspraak doen. ${ }^{304}$

Dat de strafrechter geen lijdelijke rol vervult vloeit voort uit het 'gematigd accusatoire' karakter van het Nederlandse strafprocesrecht. ${ }^{305}$ Teneinde een beeld te kunnen vormen van het zogenaamde 'gematigd accusatoire', ofwel 'getemperd inquisitoire', karakter van het strafprocesrecht zal op deze plaats beknopt aangegeven worden wat het onderscheid is tussen een accusatoir en een inquisitoir proces. Corstens geeft genoemd onderscheid als volgt weer:

'In het accusatoire proces strijden twee gelijkwaardige partijen met elkaar ten overstaan van een lijdelijke, passieve rechter die zich beperkt tot vervulling van de rol van scheidsrechter: hij ziet toe, dat de partijen de regels van het processuele spel in acht nemen, maar verder laat hij de zaken aan hen over; een beslissing over de zaak geeft hij pas, als de partijen hem daarom vragen. In het inquisitoire proces is de justitie actief op zoek naar de waarheid. Hier

Zie artikel 338-344a Sv.

300 Het voorgaande blijkt uit artikel 341 lid 4 Sv. Zie voorts artikel 342 lid 3 en 344 a Sv.

301 Nijboer a.w. 2000 , p. 35.

302 Zie artikel $350 \mathrm{~Sv}$.

303 Corstens a.w. 1999, p. 617-618. Zie voor een uitvoerige beschrijving van het strafrechtelijk bewijsrecht: Nijboer a.w. 2000 en Corstens a.w. 1999, p. 615-673.

$304 \mathrm{Vgl}$. Nijboer a.w. 2000, p. 5.

305 Zie Corstens a.w. 1999, p. 7-8. Corstens spreekt overigens over een 'getemperd inquisitoir' karakter. 
verschijnen een vervolger en een beschuldigde tegenover elkaar. Die beschuldigde is geen gelijkwaardige procespartij, maar object van onderzoek. De justitie is in dit proces bekleed met allerlei bevoegdheden die inbreuk maken op anders door het recht gewaarborgde rechten. ${ }^{306}$

Het nationale strafprocesrecht is, zoals gezegd, 'gematigd accusatoir' van aard omdat de verdachte in de voorfase (d.w.z. voor het onderzoek ter zitting) blootgesteld is aan de uitoefening van dwangmiddelen door het Openbaar Ministerie. Hij heeft de uitoefening van deze dwangmiddelen (doorgaans) te dulden. Hij is het object van het onderzoek. Tijdens de zitting wordt de verdachte, voor zover mogelijk, op dezelfde wijze behandeld als het Openbaar Ministerie.

Desalniettemin blijven ook ter zitting wezenlijke verschillen bestaan tussen beide (proces)partijen. ${ }^{307}$ Zo wordt bijvoorbeeld de Officier van Justitie tijdens de zitting, anders dan de verdachte, niet door de rechter verhoord. De verdachte (de naam zegt het in feite al) wordt iets verweten door het OM. Alleen de verdachte kan op basis van het strafproces gestraft worden.

Juist vanwege die ongelijke positie lijken in het Wetboek van Strafvordering vergaande onderzoeksbevoegdheden aan de strafrechter te zijn toegekend (ongelijkheidscompensatie $^{308}$ ). Zoals gezegd kan de strafrechter (bijvoorbeeld) zelf actief (nieuwe) bewijsmiddelen ten aanzien van de te laste gelegde feiten vergaren. Tenslotte verdient opmerking dat vanwege de onschuldpresumptie op de verdachte zelf geen bewijslast rust. Van hem wordt niet verlangd dat hij in de strafzaak zijn onschuld bewijst. Bovendien behoort de strafzaak bij twijfel een voor de verdachte gunstige uitkomst te hebben. ${ }^{309}$

Uit het voorgaande kan worden afgeleid dat in het strafproces de materièle waarheidsvinding, met het oog op een juiste toepassing van de (straf)wet, centraal staat. ${ }^{310}$ Het is primair aan de Officier van Justitie om bewijs aan te dragen. De uiteindelijke bewijslast ligt echter bij de rechter die, onder meer in verband met de idee van ongelijkheidscompensatie, ambtshalve (aanvullend) onderzoek kan doen. ${ }^{311}$ Van de strafrechter wordt dan ook een actieve (niet-lijdelijke) houding verwacht. ${ }^{312}$

\section{Bewijs(lastverdeling) in het Nederlandse bestuursprocesrecht}

\section{Algemeen}

In het bestuursprocesrecht ligt dit anders. ${ }^{313}$ Ten eerste staat daar (de rechtmatigheid van) een besluit centraal. ${ }^{314}$ De bestuursrechter dient derhalve, in het kader van de

306 Corstens a.w. 1999 , p. 7

307 Zie Corstens a.w. 1999, p. 8.

308 Zie hierover: J.F. Nijboer, Ongelijkheidscompensatie en ongelijkheidsarticulatie in het strafrecht, in: Ongelijkheidscompensatie als roode draad in het recht, Liber Amiconum voor Prof.mr. M.G. Rood (red. Betten, Boelhouwer e.a.), Deventer 1997, p. 218-220.

309 Vgl. Nijboer a.w. 2000, p. 206 e.v.

310 Vgl. bijv. Groenhuijsen en Knigge a.w. 1999, p. 17 en Simmelink in Groenhuijsen en Knigge a.w. 1999 , p. 398.

311 Vgl. Corstens a.w. 1999, p. 618 en Nijboer a.w. 2000, p. 35.

312 Vgl. Groenhuijsen en Knigge a.w. 1999, p. 23.

313 Daar gelden niet de strafrechtelijke bewijsregels. Ook niet bij de oplegging van (punitieve) bestuursrechtelijke sancties (zie: ABRS 15 juli 1996, AB 1996, $414 \mathrm{~m}$. nt. F. Michiels (Sluiting café 'De Windmolen') en ABRS 11 juni 1998, AB 998, 297 m. nt. F. Michiels (Sluiting café 'Lindsay's Place'). 
oplegging van punitieve sancties, niet rechtstreeks te oordelen over de vraag of de vermoedelijke overtreder strafbaar is. Van belang is dat de bestuursrechter het bij hem aangevochten besluit ex tunc dient te toetsen. Dit houdt in dat hij moet beoordelen of het door het bestuursorgaan genomen besluit in strijd is met het ten tijde van het nemen van het besluit toepasselijke recht. Er is geen sprake van hernieuwde besluitvorming. ${ }^{315}$ Voorts speelt in het actuele bestuursprocesrecht de partijautonomie een belangrijke rol. Omdat geschillenbeslechting en rechtsbescherming ${ }^{316}$ in de Awb centraal staan heeft het bestuursprocesrecht zich, mede onder invloed van de 'wederkerige rechtsbetrekking-idee', ontwikkeld van een inquisitoir procesrecht naar een contradictoir procesrecht. ${ }^{317}$ De rechter is daarmee in belangrijke delen van het bestuursprocesrecht in grotere mate lijdelijk ${ }^{318}$ dan in het strafprocesrecht.

De omvang van het bestuursrechtelijke geschil ${ }^{319}$ wordt in beginsel bepaald aan de hand van de gronden die in het beroepschrift, door de eisende partij, worden aangevoerd ${ }^{320}$ De bestuursrechter mag op grond van artikel 8:69, eerste lid Awb, bij de beoordeling van het geschil niet treden buiten de aangevoerde gronden. Dit brengt met zich dat de bestuursrechter die onderdelen van het besluit waartegen niet is opgekomen in beginsel buiten beschouwing moet laten (verbod van 'ultra petita' gaan). ${ }^{321}$ Wel mag hij, met het oog op het beginsel van ongelijkheidscompensatie ${ }^{322}$, een 'juridische ver-

314 Vgl. E.J. Daalder en M. Schreuder-Vlasblom, Balanceren boven nul. De vaststelling van feiten in het bestuursprocesrecht, NTB 2000 , p. 214-221, i.h.b. p. 221.

315 Vgl. Daalder en Schreuder-Vlasblom a.w. 2000, p. 221.

316. Zie PG Awb II, p. 463 en het evaluatie-onderzoek: Hoger beroep, door: R.J.G.M. Widdershoven. R.J.N. Schlossels, F.A.M. Stroink, J.B.J.M. ten Berge, A.J. Bok, W.J.M. Voermans, B.W.N. de Waard en P.A. Willemsen, Boom juridische uitgevers 2001(hiema: Widdershoven/Schløssels/Stroink), p. 43 en p. 225.

317 Zie M. Schreuder-Vlasblom, De Awb; het bestuursprocesrecht, Deventer 2001 (hierna: a.w. 2001a). p. 151-152. Deze ontwikkeling leidt tot de minder wenselijke consequentie dat aan het beginsel van ongelijkheidscompensatie slechts op een vrij marginale wijze invulling wordt gegeven (vlg. Widdershoven/Schlössels/Stroink a.w. 2001, p. 225).

318 De mate van lijdelijkheid kan overigens per instantie verschillen. De Centrale Raad van Beroep lijkt doorgaans minder lijdelijk te zijn dan de Afdeling Bestuursrechtspraak van de Raad van State.

319 Zie m.b.t. de omvang van het bestuursrechtelijk geding: Widdershoven/Schlossels/Stroink (a.w. 2001), M. Schreuder-Vlasblom, De afbakening van het geding in hoger beroep door de Centrale Raad van Beroep, NTB 1998, p. 117-125, T. Hoogenboom, De Afdeling bestutrsrechtspraak van de Raad van State als appelirechter, NTB 1998 , p. 126-135, het nawoord M. Schreuder-Vlasblom en T. Hoogenboom eveneens in NTB 1998, p. 136, de reactie van A.Q.C. Tak, Devolutieve werking van het appell, NTB 1998, p. 210-211 op de NTB-bijdrage van Schreuder-Vlasblom en het naschrift van M. SchreuderVlasblom in NTB 1998, p. 212-213. Zie voorts: R.H. de Bock, Hoger beroep in het bestuursrecht: herkansing, afvalrace, of roulette?, NJB 1999, p. 1148-1156, met reacties van Schreuder-Vlasblom en Blommestein en een nawoord van De Bock in NJB 1999, p. 1651-1655, R.J.N. Schlossels, Tussen finaliteit en fuik? Over de omvang van het bestuursrechtelijk geding in eerste aanleg en appel, in de bundel: Uit de school geklapt?, onder redactie van: M.A. Heldeweg, E.C.H.J. van der Linden en R.J.N. Schlössels, Den Haag 1999, p. 177-203, R.H. de Bock, De toetsing van feiten door de bestuursrechter en het vriespunt van de afdeling bestuursrechtspraak, JBplus 2000, p. 66-77, E.J. Daalder en M. Schreuder-Vlasblom, Balanceren boven nul. De vaststelling van feiten in het bestuursprocesrecht, NTB 2000 , p. 214-221 en tenslotte: R. Kooper, Wie is er bang voor de aanvulling van rechtsgronden? Over de terminologie van 8:69 Awb, NTB 2000, p. 167-177.

320 Daamaast zijn de overgelegde stukken, het verhandelde tijdens het vooronderzoek en het onderzoek ter zitting relevant.

321 Zie PG Awb II, p. 463.

322 Vgl. Schlбssels a.w. 1999, p. 188-190. Zie m.b.t. ongelijkheidscompensatie voorts: Widdershoven! 
taalslag' toepassen op de aangevoerde gronden. Dit volgt uit artikel 8:69, tweede lid $\mathrm{Awb}^{323}$ Tenslotte $\mathrm{kan}^{324}$ de bestuursrechter, weliswaar binnen de, op grond van het beroepschrift vastgestelde, omvang van het geding, ambtshalve feiten aanvullen, zo blijkt uit artikel 8:69, derde lid Awb. ${ }^{325}$ Dit betekent dat de rechter zich in beginsel niet hoeft neer te leggen bij de feiten zoals die door de partijen tijdens het geding worden gepresenteerd.

Buiten de strekking van artikel 8:69, eerste lid Awb valt de ambtshalve toetsing van regels die van 'openbare orde' zijn. In dat kader moet met name gedacht worden aan regels inzake bevoegdheid en ontvankelijkheid. De toepassing van deze regels van openbare orde staat niet ter vrije beschikking van de partijen. De bestuursrechter dient derhalve ambtshalve na te gaan of hij bevoegd is kennis te nemen van de zaak en of het beroep ontvankelijk is. In dat kader dient hij tevens na te gaan of het bestuursorgaan bevoegd was het primaire besluit en het besluit op bezwaar te nemen, en of de burger in de bezwaarfase terecht ontvankelijk is verklaard. ${ }^{326}$ Uit rechtspraak blijkt dat de term regels van openbare orde, nader uitgewerkt in de termen bevoegdheid en ontvankelijkheid, met name op bepaalde terreinen van het bijzonder bestuursrecht, ruim uitgelegd worden. ${ }^{327}$

\section{Feitenvaststelling}

Ten aanzien van de vaststelling van de feiten door de bestuursrechter (o.m. op grond van artikel 8:69, derde lid Awb) gelden twee beperkingen. Ten eerste is er sprake van een beperking omdat de rechter (doorgaans), met het oog op de zogenaamde ex tunc toetsing, de besluitvorming van het bestuursorgaan voor wat betreft de feitenvaststelling niet over mag doen. Het voorgaande betekent dat in beroep (of hoger beroep) geen nieuwe feiten of gegevens aangedragen kunnen worden met betrekking tot de (on)rechtmatigheid van het bestreden besluit als die feiten of omstandigheden zich hebben voorgedaan nadat het besluit op bezwaar is genomen.

Schlössels/Stroink a.w. 2001, p. 39-40.

323 Vgl. M.F.J.M. de Werd, lus curia novit. Ambtshalve aanvulling van rechtsgronden door de bestuursrechter, NJB 1998, p. 687-694.

324 De bestuursrechter is derhalve wel bevoegd maar niet verplicht om ambtshalve feiten aan te vullen. Blijkens de Memorie van Antwoord is bewust gekozen voor een discretionaire bevoegdheid. De rechter kan zijn bevoegdheid gebruiken ter compensatie van de ongelijkheid tussen de procespartijen. Naarmate de ongelijkheid tussen de procespartijen groter is, zal er voor de rechter - zo valt af te leiden uit de MvA - meer aanleiding kunnen zijn om van de bevoegdheid tot het ambtshalve aanvullen van feiten gebruik te maken (zie PG Awb I, p. 464).

325 Zie PG Awb Il, p. 463. Zie voor een uitvoerige uiteenzetting van de ambtshalve door de bestuursrechter te verrichten activiteiten voorts hoofdstuk 5 van het Evaluatie rapport Hoger beroep (Widdershoven/Schlössels/Stroink aw. 2001).

326 Zie PG Awb II, p. 464, Schreuder-Vlasblom a.w. 2001a, p. 129-132 en hoofdstuk 5 van Widdershoven/Schlossels/ Stroink (a.w. 2001).

327 Zie voor een overzicht van rechtspraak Schseuder-Vlasblom a.w. 2001a, p. 129-132 en hoofdstuk 5 van Widdershoven/Schlossels/Stroink (a.w. 2001). Vgl. De Werd a.w. 1998. De Werd is van mening dat in het bestuursrecht de grenzen voor ambtshalve toetsing nogal 'eng' getrokken worden. Daardoor dreigt met name het gevaar dat de bestuursrechter voorbij gaat aan zijn verdragsrechtelijke en grondwettelijke toetsingsplichten. 
Voorts wordt in de literatuur, in het bijzonder door Schreuder-Vlasblom ${ }^{328}$, het, voor kritiek vatbare ${ }^{329}$, standpunt ingenomen dat bewijs ten aanzien van feiten ${ }^{330}$ dat reeds in een eerder stadium van de procedure naar voren had kunnen worden gebracht door de rechter niet meegenomen hoeft te worden; dit met het oog op het vereiste van een behoorlijke procesorde, de proceseconomie, en de afbakening van het feitenonderzoek. ${ }^{331}$ In dat kader kan worden gesproken van de zogenaamde 'bewijsfuik'. ${ }^{332}$ De Afdeling Bestuursrechtspraak lijkt (in bepaalde gevallen) ook uit te gaan van deze 'bewijsfuik' waarbij bepalend is of in beroep aangevoerde argumenten (in de vorm van bewijs ten aanzien van feiten) reeds tijdens bezwaar of een openbare voorbereidingsprocedure naar voren zijn gebracht. ${ }^{333}$ Gegevens en bewijsmiddelen ten aanzien van de feiten die reeds in een eerdere fase van het geding aangevoerd hadden kunnen worden mogen, op basis van deze visie, door de (appèl)rechter niet (meer) meegenomen worden. ${ }^{334}$

Dit is in beginsel slechts anders als blijkt dat het bestuursorgaan zelf het verwijt kan worden gemaakt dat het bij de voorbereiding van het besluit niet de nodige kennis heeft vergaard omtrent de relevante feiten en af te wegen belangen. ${ }^{335}$ Immers: 'Het alsnog

328. Zie de hiervoor aangehaalde werken van haar hand.

329 Vgl. Widdershoven/Schlossels/Stroink a.w. 2001, p. 222-225 en De Bock a.w. 2000, i.h.b. p. 73-75.

330 In dit kader verdient aantekening dat het in beginsel moet gaan om bewijsmiddelen ten aanzien van feiten die door de rechter met het oog op de ex tunc toetsing meegenomen mogen worden. Daarbij kan bijvoorbeeld gedacht worden aan nieuwe bewijsstukken ten aanzien van de situatie zoals die was ten tijde van het nemen van het besluit in primo. Vgl. De Bock a.w. 2000, p. 74 en Widdershoven/Schlossels/Stroink a.w. 2001, p. 74.

331 Vgl. Schreuder-Vlasblom a.w. 2001 a, p. 133 en p. 256 en Daalder en Schreuder-Vlasblom a.w. 2000, p. 218-219 en 220. Zie m.b.t. de feitenvaststelling voorts: Widdershoven/Schlossels/Stroink a.w. 2001, p. 69-79. E.e.a. lijkt overigens m.b.t. de oplegging van punitieve sancties anders te liggen. Vgl. ABRS 15 april 1999, JB 1999/150 m. nt. C.L.G.F.H. Albers.

332 Vgl. Schlossels a.w. 1999, p. 178. De term is overigens afkomstig van Damen. Zie in dit kader: L.J.A. Damen, De bewijsfuik: hoe en wanneer moet een oud-mijnwerker zijn silicose bewijzen?, Ars Aequi 2000 , p. 61-69, i.h.b. p. 66). Men kan zich overigens afvragen hoe deze praktijk zich verhoudt tot het beginsel van ongelijkheidscompensatie.

333 Vgl. ABRS 21 september 1998, JB 1998/241 m. nt. H.J. Simon (woonruimtevordering Sliedrecht), ABRS 27 augustus 1998, JB 1998/273 m. nt. R.J.N. Schlössels (melknundveehouderij Hoogwoud), ABRS 15 oktober 1998, JB 1998/278 m. nt. R.J.N. Schlössels (Verkeersbesluit Weert), ABRS 1 juni 1999, AB 1999, 326 m. nt. M. Schreuder-Vlasblom (Rechtsbijstand Kombé) en ABRS 28 juni 1999, JB 1999/197 m. nt. R.J.N. Schlossels, AB 1999, 360 m. nt. M. Schreuder-Vlasblom (HRCT-scan). De Centrale Raad van Beroep lijkt in beginsel welwillender te staan tegenover het meenemen van in een later stadium ingebrachte feiten vgl.: CRvB 23 juli 1996, RSV 1997, 17 en CRvB 28 oktober 1997, AB 1998,14 m. nt. FP, vgl. voorts: Widdershoven/Schlossels/Stroink a.w. 2001, p. 69-79.

334 Nu dit met name speelt ten aanzien van feiten die door de burger op grond van artikel 4:2 Awb reeds in de voorfase ingebracht hadden moeten worden heeft dit bij ambtshalve op te leggen punitieve sancties in beginsel geen nadelige consequenties (zo zal hiema nog blijken). Vgl. Daalder en SchreuderVlasblom a.w. 2000, p. 217.

335 Zie Schreuder-Vlasblon a.w. 200 a, p. 133 en ABRS 19 augustus 1999, AB 1999, 403 m. nt. M. Schreuder-Vlasblom. In dit kader kan nog worden opgemerkt dat de aanvrager van een besluit op grond van artikel 4:2, tweede lid Awb het bestuursorgaan gegevens en bescheiden, die voor de beslissing nodig zijn en waarover hij redelijkerwijs de beschikking kan krijgen, dient te verschaffen. (ook in dat kader speelt de handelwijze van het bestuursorgaan met het oog op artikel 3:2 Awb een rol voor wat betreft beantwoording van de vraag of de rechter nieuw aangevoerde feiten en gegevens mee moet nemen bij zijn beoordeling van het geschil (zie hierover de noot van Schreuder-Vlasblom onder ABRS 19 augustus 1999 en Daalder en Schreuder-Vlasblom a.w. 2000, p. 217-219). Ten aanzien van de oplegging van bestuurlijke boeten is artikel 4:2 Awb echter niet van toepassing. Het gaat inimers om ambtshalve te nemen besluiten. 
aanvoeren voor de rechter van geheel nieuwe gegevens, heeft zin ter adstructie van de stelling dat het bestuur ze zelf boven water had moeten brengen en door dat niet te doen art. 3:2 Awb heeft geschonden, want als dat waar is, is het besluit onrechtmatig. ${ }^{336}$ De bestuursrechter mag, voorzover de beginselen van een goede procesorde (in het bijzonder het beginsel van hoor en wederhoor) zich daar niet tegen verzetten ${ }^{337}$, bij zijn oordeel over de rechtmatigheid van een besluit die gegevens betrekken waarover het bestuursorgaan beschikte, of (op grond van artikel 3:2 Awb) had kunnen en moeten beschikken, ten tijde van het nemen van het bestreden besluit. ${ }^{338}$ Het aanvoeren van nieuwe gegevens bij de bestuursrechter wordt ook aanvaard als daarmee kan worden aangetoond dat het bestuursorgaan het bestreden besluit niet deugdelijk heeft gemotiveerd. $^{339}$

Het voorgaande impliceert dat in beginsel, namelijk voorzover de beginselen van een goede procesorde (in de zin van hoor en wederhoor) zich daar niet tegen verzetten, bij ambtshalve te nemen belastende beschikkingen in het kader van een beroep op artikel 3:2 of artikel 3:46 Awb in (hoger) beroep nieuwe argumenten en bewijstechnische feiten aangevoerd kunnen worden die de bestuursrechter bij zijn oordeel omtrent de rechtmatigheid van het besluit moet betrekken. Het moet dan wél gaan om informatie waarover het bestuursorgaan op grond van artikel 3:2 Awb ten tijde van het bestreden besluit had kunnen, en moeten beschikken. Met het oog op artikel 3:2 Awb worden aan het bestuur hogere eisen gesteld in het kader van ambtshalve te nemen belastende besluiten. Ten aanzien van genoemde belastende beschikkingen geldt immers géén medewerkingsplicht ex artikel 4:2, tweede lid Awb, voor de burger. De bewijslast rust dan in beginsel volledig op het bestuursorgaan. Tegenbewijs kan door de burger worden geleverd in de beroepszaak. ${ }^{340}$

Tenslotte verdient opmerking dat ten aanzien van punitieve sancties, zoals bijvoorbeeld de bestuurlijke boete, de bewijsfuik geen rol lijkt te spelen. In dit kader kan gewezen worden op een uitspraak van de Afdeling Bestuursrechtspraak van 15 april $1999 .{ }^{341}$ In die uitspraak ging het om eerst in hoger beroep aangevoerd ontlastend bewijs ten aanzien van de feiten. Genoemd bewijs was het bestuursorgaan ten tijde van het nemen van het besluit tot oplegging van de punitieve sanctie niet bekend. Evenmin hoefde genoemd bewijs op dat moment op grond van artikel 3:2 Awb bij het bestuursorgaan bekend te zijn. De Afdeling heeft over de toelaatbaarheid van dit, eerst in hoger beroep aangevoerd, ontlastend bewijs ten aanzien van de feiten het volgende overwogen:

'Verweerder heeft de door appellant ter zitting gegeven lezing van de feiten niet bestreden. Hij heeft niettemin medegedeeld hierin geen aanleiding te zien alsnog nader onderzoek te doen naar de vraag of de sanctie wel terecht is opgelegd. Hiertoe voert verweerder aan dat gelet op het ex tunc karakter van de rechterlijke toetsing niet met vrucht een beroep kan

336 Aldus Schreuder-Vlasblom in haar noot onder ABRS 19 augustus 1999 (AB 1999, 403). Zij stelt dat het voor de bestuursrechter gaat om de vraag of het besluit op onrechtmatige grondslag genomen werd (ex tunc toetsing), gelet op de informatie waarover het bestuur toen beschikte, of bij naleving van alle zorgvuldigheidsverplichtingen, redelijkerwijs had kunnen beschikken.

$337 \mathrm{Vgl}$. Widdershoven/Schlossels/Stroink a.w. 2001, p. 139-145.

338 Vgl. De Bock a.w. 2000, p. 66-67.

339 Zie in dit kader: ABRS 15 april 1999, JB 1999/150 m. nt. Karianne Albers.

340 Vgl. Daalder en Schreuder-Vlasblom a.w. 2000, p. 217.

341 ABRS 15 april 1999, JB 1999/150 m. nt. C.L.G.F.H. Albers. 
worden gedaan op feiten en omstandigheden die het bestuursorgaan ten tijde van het nemen van de bestreden beslissing niet bekend waren noch behoefden te zijn.

De Afdeling stelt voorop dat allereerst de vraag dient te worden beantwoord of de door appellant ter zitting gegeven uiteenzetting van de wijze waarop de TWAO-procedure is nageleefd, al dan niet buiten beschouwing dient te worden gelaten.

Naar het oordeel van de Afdeling moet de vermindering van de rijksvergoeding wegens overtreding van de in de TWAO neergelegde bepalingen worden aangemerkt als een punitieve sanctie, waarop artikel 6 van het Europees Verdrag van de Rechten van de Mens (hierna te noemen: het EVRM) ziet.

De in de TWAO neergelegde onvoorwaardelijke vermindering van de rijksvergoeding beoogt bestraffend en preventief te werken in het geval de in de TWAO dwingend voorgeschreven procedure niet is gevolgd. De vermindering is blijkens de Memorie van Toelichting niet bedoeld als compensatie voor geleden schade (TK, vergaderjaar 1991-1992, 22324 , nr 3, p.22).

Uit de onschuldpresumptie neergelegd in het tweede lid van artikel 6 van het EVRM vloeit voort dat de bewijslast voor wat betreft de (rechts)feiten, welke de overtreding constitueren, ligt bij het bestuursorgaan dat de bestuurlijke boete heeft opgelegd.

Dit brengt met zich mee dat de Afdeling het bestreden besluit ook in dat licht ten volle moet beoordelen. Op grond van het voorgaande als ook in aanmerking nemende dat door verweerder de juistheid van de uiteenzetting van appellant niet is bestreden, is de Afdeling van oordeel dat de in het bestreden besluit neergelegde motivering voor het opleggen van een sanctie in dit geval als ontoereikend moet worden aangemerkt.'

\section{Omvang van het geding in appèl}

In het kader van de bewijsvoering is voorts relevant de wijze waarop afbakening van het geding plaats vindt in appèl. De omvang van het geding in appèl hangt af van de vraag wat als object van het hoger beroep moet worden aangemerkt (en, de daarmee nauw verwante vraag, welke functie toebedeeld moet worden aan het hoger beroep ${ }^{342}$ ). Object van het hoger beroep kan het in eerste aanleg aangevochten besluit zijn of de uitspraak in eerste aanleg. ${ }^{343} \mathrm{Bij}$ de Centrale Raad van Beroep lijkt in dit kader geen vaste lijn te bestaan. Soms staat het in eerste aanleg aangevochten besluit centraal. In andere gevallen speelt de inhoud van de aangevallen uitspraak, direct dan wel indirect, los van of naast het bestreden besluit, een rol bij de beoordeling van het geschil. ${ }^{344}$ Doorgaans vindt bij de Centrale Raad wel een volledige nieuwe behandeling van de zaak plaats in de zin dat in ieder geval de mogelijkheid geboden wordt in eerste aanleg gemaakte feitelijke of juridische fouten te herstellen. ${ }^{345}$ Het appèl heeft dan een 'replayfunctie'. ${ }^{346}$ De Raad gaat vanwege genoemde replay-functie doorgaans soepel om met

342 Vgl. Widdershoven/Schlössels/Stroink a.w. 2001, p. 20-28.

343 Zie voor een uitvoerig overzicht: Widdershoven/Schlossels/Stroink a.w. 2001, p. 47-57.

344 Zie: Widdershoven/Schlössels/Stroink a.w. 2001, p. 49-50, p. 56-57. Vgl. Schreuder-Vlasblom a.w. 2001a, p. 252-253.

345 Zie: Widdershoven/Schlossels/Stroink a.w. 2001, p. 57. Deze opvatting m.b.t. de functie van appèl lijkt te zijn ingegeven door het civiele recht en hangt samen met het in dat rechtsgebied geldende uitgangspunt dat het hoger beroep devolutieve werking heeft (zie De Bock aw. 1999, p. 1150). Ook in de Wet Voltooiing eerste fase herziening rechterlijke organisatie wordt overigens uitgegaan van een volledig nieuwe behandeling van het bestuursrechtelijk geschil in appel (vgl. De Bock a.w. 1999, p. 11501151).

$346 \mathrm{Vgl}$. Tak a.w. 1998, p. 210-211. Tak toont zich een (uitgesproken) voorstander van deze benadering- 
(geheel) nieuwe gronden die (binnen de context van het object van geschil; het in eerste aanleg betwiste besluit ${ }^{347}$ ) eerst in appèl worden aangevoerd. ${ }^{348}$ Dit impliceert dat de Centrale Raad een ruime uitleg geeft aan artikel 8:69 Awb. De handhaving van het objectieve recht lijkt daarbij een belangrijke plaats in te nemen. ${ }^{349}$

De Afdeling Bestuursrechtspraak stelt niet het in eerste aanleg aangevochten besluit, maar de bestreden uitspraak centraal bij de beoordeling van het geschil. ${ }^{350}$ In beginsel is de Afdeling dan ook terughoudend wat betreft het meenemen van nieuwe gegevens, nieuw bewijs ten aanzien van feiten ${ }^{351}$ en/of nieuwe gronden in appèl. ${ }^{352}$ Deze benadering sluit aan bij de idee van het 'trechtermodel'. Zeer pregnant komt de terughoudende opstelling van de Afdeling Bestuursrechtspraak tot uiting in een uitspraak van de Afdeling van 3 april $2000^{353}$, waarin het ging om in hoger beroep (tardief) ingebrachte specificaties van proces- en deskundigenkosten. In genoemde uitspraak heeft de Afdeling het volgende overwogen:

'De Afdeling stelt voorop dat in hoger beroep vooreerst de uitspraak van de rechtbank ter toets staat. Voorts was het in de eerste plaats aan appellanten om aannemelijk te maken dat de door hen, in afwijking van de bij de beslissing op bezwaar toegekende bedragen, geclaimde kosten in het kader van de schadevaststelling zijn gemaakt.

Op grond van de stukken en het verhandelde ter zitting is de Afdeling van oordeel dat de rechtbank terecht tot de conclusie is gekomen dat het beroep in dit opzicht onvoldoende was onderbouwd en om die reden in zoverre ongegrond moest worden verklaard. Weliswaar is, anders dan de rechtbank heeft overwogen, reeds in het inleidende verzoek een bedrag van $f 35.000$ aan kosten van rechtsbijstand geclaimd doch dat bedrag is nadien niet onderbouwd. Verder blijkt uit de stukken op geen enkele wijze dat, anders dan eerst in de beroepsfase bij

347 Vgl. Tak a.w. 1998, p. 210-211 en De Bock a.w. 1999, p. I 153. Zie voorts: CRvB 29 januari 2002, JB $2002 / 100$ m. nt. C.L.G.F.H. Albers.

348 Vgl. Schreuder-Vlasblom a.w. 2001 a, p. 256 en Widdershoven/Schløssels/Stroink a.w. 2001, p. 138139.

349 Zie ter illustratie van de liberale houding van de Centrale Raad ten aanzien van artikel 8:69 Awb: CRvB 18 december 1998, JB 1999/18, CRvB 6 oktober 1998, JB 1998/264, CRvB 26 januari 1999, JB 1999/54 allen m. nt. R.J.N. Schlössels, CRvB 29 juni 1999, JB 1999/206 en CRvB 14 oktober 1999, JB $1999 / 303 \mathrm{~m}$. nt. H.L. Janssen. Bijzonder illustratief in het kader van dit onderzoek is een uitspraak van de Centrale Raad van 29 juni 2000 (JB 2000/254 m. nt. C.L.G.F.H. Albers). In die zaak werd aan appellante, op basis van art. 12 Coördinatiewet Sociale verzekering (CSV), een bestuurlijke boete van $f 5.363$,- opgelegd wegens het niet/niet juist opgeven van loonbetalingen waarvoor sociale verzekeringspremies behoorden te worden afgedragen. Eerst tijdens de zitting bij de rechtbank deed appellante een beroep op artikel 6 EVRM. De rechtbank betrok de tardief ingebrachte grond niet bij haar oordeelsvorming. In hoger beroep bij de Centrale Raad wordt door appellante wederom een berocp gedaan op artikel 6 EVRM. De Centrale Raad gaat, zonder daar verder woorden aan vuil te maken, in op genoemde (hoger) beroepsgrond.

350 Vgl. Widdershoven/Schløssels/Stroink a.w. 2001, p. 48 e.v. en Schreuder-Vlasblom a.w. 2001 a, p. 253-255.

351 Zoals hiervoor reeds is aangegeven lijkt de Afdeling Bestuursrechtspraak in het kader van het bewijs van de feiten bij punitieve sancties géén fuik te hanteren. Of een dergelijke opstelling eveneens geldt ten aanzien van eerst in (hoger) beroep naar voren gebrachte gronden kan niet met zekerheid gezegd worden.

352 Vgl. Widdershoven/Schlossels/Stroink a.w. 2001 , p. 48 e.v., p. 69-79 en p. 110 e.v. Zie voorts (o.m. voor een overzicht van Afdelingsuitspraken in dat kader): Schreuder-Vlasblom a.w. 2001a. p. 256, De Bock a.w. 1999, p. 1148 en Ten Berge en Widdershoven a.w. 2001, p. 245.

353 ABRS 3 april 2000, AB 2000/222 m. nt. M. Schreuder-Vlasblom (nadeelcompensatie reconstructic Venloseweg) i.h.b. overweging 2.3 . 
de rechtbank, ten aanzien van de deskundigenkosten een bedrag is genoemd. Het in de beroepsfase genoemde bedrag is overigens evenmin onderbouwd.

Aangezien de rechtbank op dit punt tot een juist oordeel is gekomen, kunnen de in hoger beroep overgelegde specificaties, daargelaten in hoeverre deze zien op kosten die in het kader van de schadevaststelling zijn gemaakt, niet leiden tot toekenning van een hogere vergoeding.'

Deze vorm van afbakening van het geding in appèl brengt, volgens de voorstanders van deze strikte benadering, waaronder in het bijzonder Schreuder-Vlasblom, een aantal voordelen met zich. Gewezen kan worden op het bevorderen van de rechtseenheid ${ }^{354}$, het beperken van de werklast van de appèlcolleges, de proceseconomie, de procestechnische positie van derden, en het voorkomen van té langdurige procedures. ${ }^{355}$

Binnen de omvang van het object van het hoger beroep heeft de appèlrechter overigens dezelfde taak in het kader van de toetsing als de rechter die in eerste instantie oordeelt. Artikel 8:69 Awb geldt immers ook in hoger beroep. ${ }^{356}$

\section{'Vrij' bewijsleer}

Tenslotte volgen nog enkele opmerkingen over de wijze waarop in het bestuursrechte. lijke geding de bewijslast wordt verdeeld. Het bestuursprocesrecht kent geen regels van materieel bewijsrecht. Een regeling met betrekking tot bewijslastverdeling is derhalve niet neergelegd in de Awb. In het bestuursprocesrecht is sprake van een 'vrije' bewijsleer. ${ }^{357}$ Dit uitgangspunt houdt in dat de bestuursrechter in beginsel de bewijslast naar eigen inzicht kan verdelen tussen bestuur en burger. ${ }^{358}$ Enige houvast bieden de artikelen 3:2 Awb, betreffende de zorgvuldige voorbereiding van besluiten, en 3:46 Awb, betreffende het vereiste dat een besluit deugdelijk gemotiveerd moet zijn. De bestuursrechter heeft vervolgens de taak op basis van genoemde bepalingen nadere regels te formuleren aangaande de bewijslastverdeling. Uit rechtspraak volgt dat het vereiste van een zorgvuldige voorbereiding en een deugdelijke motivering, in verband met het bestuursrechtelijke bewijsrecht, een belangrijke rol spelen, zeker als het gaat om ambtshalve te nemen belastende besluiten zoals een besluit tot oplegging van een (punitie$\mathrm{ve}^{359}$ ) bestuursrechtelijke sanctie. ${ }^{360}$ De eisen die de bestuursrechter met het oog op

354 Derhalve moet er zorg voor gedragen worden dat de appèlrechters niet overbelast raken en dat de colleges beperkt van omvang blijven. Met ruime toegang tot de hoger beroepsinstanties kan deze doelstelling niet worden gerealiseerd. Aldus Schreuder-Vlasblom in haar noot onder ABRS 3 april 2000. AB 2000/222 (nadeelcompensatie reconstructie Venloseweg). Men kan zich echter de vraag stellen in hoeverre daadwerkelijke 'rechtseenheid' in het bestuursrecht gerealiseerd kan worden zolang verschillende hoger beroepsinstanties naast eikaar in hoogste instantie rechtspreken (vgl. reeds de uiteenlopende visies van de Afdeling Bestuursrechtspraak en de Centrale Raad m.b.t. de omvang van het geschil in appil).

355 Vgl. Schreuder-Vlasblom a.w. 2001 a, p. 256 en 258, p. 118 van het NTB artikel van Schreuder-Vlasblom uit 1998 m.b.t. de afbakening van het geding in hoger beroep door de CRvB, het naschrift van Schreuder-Vlasblom op de reactie van Tak a.w. 1998, p. 212-213 en de annotatie van SchreuderVlasblom onder ABRS 3 april 2000, AB 2000/222 (nadeelcompensatie reconstructie Venloseweg).

356 Vgl. Schreuder-Vlasblom a.w. 2001 a, p. 262, De Bock a.w. 1999, p. 155.

357 Zie PG Awb Il, p. 175-176.

358 Zie over bewijsleer in het bestuursrecht: H.J. Simon, Bewijzen in het bestuursrecht, JBplus 1999, 1, p. 25-39. Zie voorts Hartmann a.w. 1998, p. 215-216 en PG Awb II, p. 175 en J.B.J.M. ten Berge en R.J.G.M. Widdershoven, Bescherming tegen de overheid, zesde druk, Deventer 2001, p. 224-230. 
artikel 3:2 en 3:46 Awb aan een dergelijk (bestreden) besluit stelt zijn doorgaans hoog. De bewijslast rust (in essentie) op het bestuursorgaan dat het bestreden besluit heeft genomen. ${ }^{361}$ Illustratief in dit kader is een uitspraak van de Afdeling Bestuursrechtspraak $^{362}$ waarin een besluit tot sluiting van een Nijmeegs café, in verband met koop en verkoop van gestolen goederen aldaar, de rechterlijke toets niet kon doorstaan vanwege het ontbreken van een zorgvuldige voorbereiding en een deugdelijke motivering. Het kwam er op neer dat de aan de sluiting ten grondslag gelegde heling door de burgemeester van de gemeente Nijmegen niet bewezen kon worden geacht. De Afdeling Bestuursrechtspraak heeft in genoemde uitspraak het volgende overwogen ${ }^{363}$ :

'De Afdeling stelt voorop dat appellant bij de uitoefening van de hem in art. 2.4. eerste lid APV gegeven bevoegdheid een ruime mate van beoordelings- en beleidsvrijheid toekomt.

Dit neemt niet weg dat een op basis van dit artikel gegeven sluitingsbevel op grond van dit artikel zorgvuldig moet worden voorbereid en dat het moet steunen op een draagkrachtige feitelijke motivering.

Indien tegen een sluitingsbevel beroep wordt ingesteld bij de bestursrechter en door appellant wordt aangevoerd dat de verstoring of bedreiging van de openbare orde, waarvan de burgemeester is uitgegaan, zich in feite niet heeft voorgedaan, zal de rechter moeten beoordelen of de door de burgemeester aan het sluitingsbevel ten grondslag gelegde feiten en omstandigheden voldoende aannemelijk zijn.

In dat kader hebben de strafrechtelijke bewijsregels geen gelding, maar dit laat onverlet dat ook in het bestuursrechtelijk geding ter toets staat of de vaststelling van de feiten op deugdelijke wijze is geschied. Bij de aangevallen uitspraak is in dit opzicht geen onjuiste maatstaf aangelegd, zodat de hierop betrekking hebbende grieven van appellant (de burgemeester van de gemeente Nijmegen [KA]) moeten worden afgewezen.

Aan het in geding zijnde sluitingsbevel is - samengevat - ten grondslag gelegd dat het café "De Windmolen" een centrum is van koop en verkoop van gestolen goederen, zonder dat Engels daaraan een einde heeft kunnen of willen maken.

Dat van de gestelde helingsactiviteiten sprake zou zijn, heeft Engels van meet af aan bestreden. Daarbij is gemotiveerd betwist dat uit de van de processen-verbaal deel uitmakende verklaringen, waarop appellant zich ter zake heeft beroepen, voldoende steun kan worden gevonden. In dit verband heeft Engels voorts onweersproken gesteld dat zij in de twintig jaren dat zij het café exploiteerde nimmer eerder met een vermoeden van helingsactiviteiten is geconfronteerd.

De rechtbank heeft met recht overwogen dat appellant de aan het sluitingsbevel ten grondslag liggende feitelijke vaststelling niet deugdelijk heeft gemotiveerd. Het betoog van appellant dat hij mede op grond van het veelvuldige contact dat hij als korpsbeheerder met de korpschef onderhoudt tot de stellige overtuiging is gekomen dat zijn stellingen overeenstemmen met de werkelijkheid, is daarvoor bij gebrek aan nadere onderbouwing met concrete, te verifiëren gegevens niet voldoende.

360 Vgl. Daalder en Schreuder-Vlasblom a.w. 2000, p. 217.

361 Zie ABRS 15 april 1999, JB 1999/150 m. nt. C.L.G.F.H. Albers.

362 ABRS 15 juli 1996, AB 1996, $414 \mathrm{~m}$. nt. F. Michiels (Sluiting cafe 'De Windmolen'). Vgl. ARRvS 17 november 1977, AB 1987, 97 m. nt. B. de Goede (Mw. Cupido).

363 Hiema is een omvangrijke passage uit de uitspraak van de Afdeling weergegeven. Deze keuze is bewust gemaakt. Op basis van de uitvoerige motivering van de Afdeling in deze zaak kan immers een beter beeld gevormd worden van de wijze waarop een bestuursorgaan ambtshalve te nemen belastende besluiten zoals een besluit tot oplegging van een (punitieve) bestuursrechtelijke sanctie moet voorbereiden en motiveren. 
De Afdeling overweegt voorts dat, gelet op het ingrijpende karakter van een sluitingsbevel en de gevolgen daarvan, de daarop betrekking hebbende besluitvorming met grote zorgvuldigheid moet zijn omgeven.

Zoals de rechtbank terecht heeft overwogen, is niet alleen nagelaten Engels voorafgaande aan het sluitingsbevel te horen, maar is zij ook nadien niet in de gelegenheid gesteld om een reactie te geven op nadere gegevens, die hebben bijgedragen aan appellants overtuiging dat sprake was van de helingsactiviteiten in het café.

Aldus is niet gebleken dat appellant heeft voldaan aan de verplichting om de nodige kennis omtrent de relevante feiten en de af te wegen belangen te vergaren.

Uit al het vorenstaande volgt dat de bestreden beslissing op bezwaarschrift niet met de vereiste zorgvuldigheid is voorbereid en genomen en voorts niet kan worden gedragen door de motivering, die appellant daaraan ten grondslag heeft gelegd.'

Ook in meer recente uitspraken neemt de Afdeling Bestuursrechtspraak het standpunt in dat, in ieder geval bij een punitieve sanctie, aan de bewijsvoering van de overtreding en de motivering van het sanctiebesluit strenge eisen moeten worden gesteld. De Centrale Raad van Beroep lijkt eveneens hogere eisen te stellen wat betreft de zorgvuldige voorbereiding. Daarmee legt ook dit rechterlijk college de bewijslast ten aanzien van de rechtmatigheid van de opgelegde (punitieve) bestuursrechtelijke sancties bij het bestuursorgaan. $^{364}$

\section{Regels van formeel bewijsrecht}

Uit het voorgaande is reeds gebleken dat het bestuursprocesrecht geen regels kent van materieel bewijsrecht. Wél zijn er verschillende bepalingen van formeel bewijsrecht opgenomen in de Awb. In dit kader kan bijvoorbeeld gewezen worden op bepalingen omtrent het horen van getuigen en deskundigen (vgl. artikel 8:60 en 8:63 Awb). Een gesloten stelsel van wettige bewijsmiddelen, zoals dat in het strafrecht bestaat ${ }^{365}$, kent het bestuursprocesrecht echter niet. Dit brengt bijvoorbeeld met zich dat aan een in het kader van een overtreding opgemaakt rapport (vgl. 5.4.2.1, eerste lid Juncto 5.4.2.6, tweede lid Voorontwerp) in rechte, anders dan aan een ambtsedig opgemaakt procesverbaal (vgl. artikel 339, eerste lid aanhef onder 5, Juncto artikel 344, tweede lid Sv) géén bijzondere bewijsstatus toekomt. ${ }^{366}$

364 Zie in dit kader: ABRS 15 april 1999, JB 1999/150 m. nt. C.L.G.F.H. Albers en ABRS 15 februari 2001, JB 2001/88 m. nt. C.L.G.F.H. Albers. De Afdeling overweegt in de laatstgenoemde zaak, ten aanzien van de intrekking van de erkenning van appellant voor zijn APK-keuringsplaats gedurende twaalf weken, het volgende: 'Juist omdat het gaat om een punitieve sanctie, dienen aan de bewijsvoering van de overtreding en aan de motivering van het sanctiebesluit strenge eisen te worden gesteld.' Zie voorts: Rechtbank Amsterdam 4 september 2000, JABW 2001/12, ELRO-nummer AA8926 (te raadplegen via intemet: http://www.rechtspraak.nl). Volgens de rechtbank vloeit uit het punitieve karakter van de opgelegde sanctie (een bestuurlijke boete) voort, dat op verweerder de bewijslast rust om aannemelijk te maken dat eiser zijn inlichtingenplicht ingevolge artikel 65 Abw heeft geschonden. Aangezien verweerder dit niet aannemelijk heeft kunnen maken vemietigt de rechtbank het bestreden besluit, en trekt deze, onder toepassing van artikel 8:72, vierde lid Awb, tevens het primaire boetebesluit in. Zie tenslotte: CRvB 24 april 1997, AB 1997, 319 m. nt. H. Hennekens.

365 Vgl. artikel $339 \mathrm{~Sv}$.

366 Vgl. H.J. Simon, Handboek bestuurs(proces)recht volgens de Awb, Den Haag 1997, p. 315. Ik kom hier later nog op terug. 
Consequenties van de toepassing van het bestuursprocesrechtelijke 'bewijsmodel' bij oplegging van punitieve sancties

Vergelijking van het strafrechtelijk bewijsstelsel met het bestuursrechtelijke toont dat er opmerkelijke verschillen zijn. Op zich is dat niet vreemd. Het gaat immers om twee verschillende rechtsgebieden waaraan (deels) andere beginselen ten grondslag liggen. Ten aanzien van de oplegging van punitieve bestuursrechtelijke sancties kan mijns inziens echter niet onverkort het bestuursprocesrechtelijke stelstel, gebaseerd op artikel 8:69 Awb, worden toegepast. Oplegging van punitieve sancties is tenslotte geen typisch bestuursrechtelijke taak. Een punitieve sanctie waarmee bestraffing wordt beoogd hoort van oorsprong thuis in het strafrecht. Een punitieve sanctie kan door overheveling naar het bestuursrecht niet worden ontdaan van haar wezenlijke kenmerken. Punitieve bestuursrechtelijke sancties, waaronder de bestuurlijke boete, vormen daarmee een buitengemene categorie besluiten in het bestuursrecht. Het kan dan ook moeilijk vol gehouden worden dat op genoemde sancties het bestuursprocesrecht onverkort van toepassing is. Dit laatste geldt ook ten aanzien van het bewijsrecht en de (daarmee samenhangende) wijze waarop in het bestuursprocesrecht het geding wordt afgebakend. Hierna worden de belangrijkste bestuursprocesrechtelijke knelpunten weergegeven.

Ten eerste staat in het kader van het bestuursproces de rechtmatigheid van het aangevochten besluit centraal en niet de (materiële) vraag of de overtreder het 'tenlastegelegde' feit heeft begaan. Een algemeen bezwaar tegen de (onverkorte) toepassing van het bestuursprocesrecht bij besluiten tot oplegging van een bestuurlijke boete hangt voorts samen met het feit dat binnen het bestuursprocesrecht de partijautonomie een belangrijke rol speelt. Hoewel de rechter de mogelijkheid heeft de ongelijkheid tussen partijen te compenseren lijkt deze bevoegdheid tot ongelijkheidscompensatie (zeker in de huidige praktijk ${ }^{367}$ ) veel minder ver te strekken dan de ruime bevoegdheid van de strafrechter in dat kader op grond van het Wetboek van Strafvordering. Daarbij moet bovendien niet uit het oog verloren worden dat in het bestuursprocesrecht geen sprake is van verplichte procesvertegenwoordiging.

Eveneens bezwaarlijk is dat de bestuursrechter in de regel slechts bevoegd is ex tunc te toetsen. Dit wil zeggen dat de bestuursrechter (slechts) beoordeelt of het bestuursorgaan het bestreden besluit destijds rechtmatig heeft genomen met inachtneming van de toen bestaande feiten en omstandigheden op basis van het toen geldende recht. ${ }^{368} \mathrm{Ui}$ terst merkwaardig in dat kader is dat de bestuursrechter, gelet op het ex tunc karakter van de toetsing, geen rekening mag houden met een gewijzigde wettelijke regeling die strafverlaging behelst als die regeling tot stand is gekomen nadat het besluit op bezwaar door het bestuursorgaan is genomen. ${ }^{369}$ Daarmee wordt in het bestuursprocesrecht geen onverkorte toepassing gegeven aan de fundamentele bepaling uit artikel 1 , tweede lid Sr. Overigens is de kans groot dat de wetgever deze, uit het Voorontwerp afkomstige, regel niet zal overnemen. Bovendien neemt in ieder geval de Centrale Raad het standpunt in dat wél rekening moet worden gehouden met de wettelijke regeling die strafverlaging behelst. ${ }^{370}$

367 Zie Widdershoven/Schlössels/Stroink a.w. 2001, p. 225.

368 Zie Van Wijk/Konijnenbelt/Van Male a.w. 1999, p. 660.

$369 \mathrm{Vgl}$. Art. 5.4.1.7 lid 4 Voorontwerp. Ik kom hier later nog op terug.

370 lk kom hier later nog op terug. 
In de derde plaats brengt artikel 8:69, eerste lid Awb (zoals geünterpreteerd door met name de Afdeling Bestuursrechtspraak) met zich dat de rechter zich in beginsel moet beperken tot de door appellant - die regelmatig zélf tegen een besluit opkomt vanwege het ontbreken van verplichte procesvertegenwoordiging - aangevoerde gronden. ${ }^{371} \mathrm{Niet}$ aangevoerde gronden die tot vernietiging van het bestreden besluit zouden kunnen leiden blijven in de regel buiten beschouwing.

Met name in hoger beroep bij de Afdeling Bestuursrechtspraak is het in veel gevallen, vanwege het gehanteerde 'trechtermodel' bovendien niet meer mogelijk (voor een eventueel later ingeschakelde gemachtigde) nieuwe gronden aan te voeren. ${ }^{372}$ Heeft een appellant in een eerdere fase van het geschil niet de juiste gronden aangevoerd dan bestaat de mogelijkheid dat een onrechtmatig boetebesluit formele rechtskracht krijgt vanwege het in het bestuursprocesrecht, op basis van artikel 8:69 Awb, toegepaste 'trechtermodel'. ${ }^{373}$

Mijns inziens is dat bij de oplegging van punitieve sancties bepaald niet wenselijk. Van materiële waarheidsvinding is bij een strikte hantering van het 'trechtermodel' immers géén sprake. ${ }^{374}$ Zie ik het goed dan staat de (in hoger beroep via de rechtbankuitspraak lopende) beperkte wijze van toetsing van het boetebesluit door de bestuursrechter (in het bijzonder de Afdeling Bestuursrechtspraak) op genoemde wijze haaks op de invulling die in het Wetboek van Strafvordering wordt gegeven aan de bevoegdheid van de strafrechter om vast te stellen of de verdachte het ten laste gelegde heeft begaan. Bovendien ontstaat rechtsongelijkheid omdat de Centrale Raad van Beroep (veel) soepeler omgaat met in hoger beroep aangevoerde nieuwe gronden en argumenten. Daarnaast lijkt er tenslotte, met name bij toepassing van het 'trechtermodel', sprake te zijn van een beperking van de verdedigingsrechten, de toegang tot de rechter, en het recht op 'full jurisdiction'.

Wat dit laatste betreft biedt de rechtspraak van het EHRM overigens (nog) weinig duidelijkheid. Gaat het om, geschillen ten aanzien van 'civil rights and obligations' in het kader van de uitoefening van, typische bestuursrechtelijke bevoegdheden met beleidsvrijheid dan is een beperking van de rechterlijke toetsing niet zonder meer uitgesloten. ${ }^{375}$ Of dit anders ligt bij oplegging van punitieve sancties door bestuursorganen kan niet met zekerheid worden gezegd. Aangezien er in een dergelijk geval sprake is van

371 Vermeldenswaardig in dit kader is een artest van de belastingkamer van de Hoge Raad (HR 8 maart 2002, JB 2002/112 m. nt. R.M.P.G. Niessen-Cobben en A.W. Heringa). In genoemd arrest heeft de Hoge Raad bepaald dat, gelet op het uit het EVRM voortvloeiende nemo tenetur-beginsel, de anduiding van gronden van het bezwaar (hetzelfde geldt dan m.i. in het kader van (hoger) beroep) in zaken waar een verhoging (vgl. bestuurlijke boete) aan de orde is, summier mag zijn en onder omstandigheden ook erin kan bestaan dat de belastingplichtige stelt het niet eens te zijn met de voor de verhoging gegeven gronden en daarbij stelt dat standpunt niet nader te kunnen motiveren zonder zichzelf te incrimineren.

372 Zoals gezegd lijkt er in het kader van het bewijs ten aanzien van de feiten bij punitieve sancties géén sprake te zijn van een 'fuik'.

$373 \mathrm{Vgl}$. Widdershoven/Schlossels/Stroink a.w. 2001, p. 223-224. Overigens kan niet zonder meer worden gesteld dat de Afdeling Bestuursrechtspraak ook bij de oplegging van punitieve bestuursrechtelijke sancties onverkort het 'trechtermodel' zal toepassen. Rechtspraak van de Afdeling Bestuursrechtspraak hierover is, voor zover ik dat kon nagaan, (nog) niet voorhanden.

374 Widdershoven/Schlossels/Stroink a.w. 2001, p. 223-224.

375 Vgl. EHRM 22 november 1995, Series A, Vol 335-A (Bryan) en EHRM 7 november 2000, no. 35605/97 (Kingsley). 
een 'criminal charge' is het mijns inziens niet uitgesloten dat het Hof in dat kader hogere eisen stelt. De uitspraak van het EHRM in de zaak 'T. v. Austria' ${ }^{376}$ lijkt in ieder geval duidelijk in die richting te wijzen.

In de zaak 'T. v. Austria' werd aan T. een boete (te vervangen door hechtenis) opgelegd wegens misbruik van procesrecht (abuse of process). De feiten in de zaak 'T. v. Austria' waren kort weergegeven als volgt. $T$. heeft valse en/of incomplete gegevens verstrekt ter verkrijging van (gratis/gesubsidieerde) rechtshulp. Vanwege de verstrekking van onjuiste gegevens, in het bijzonder het verzwijgen van inkomsten, wijst het Bezirksgericht van Hietizing op 5 mei 1994 het rechtshulpverzoek van T., zonder hem gehoord te hebben, af. Daarnaast legt het Bezirksgericht T. een boete van 30.000,- Oostenrijkse Schilling op wegens misbruik van procesrecht. Tegen de uitspraak van het Bezirksgericht gaat $\mathrm{T}$. in beroep bij het Landesgericht in Wenen. Het Weense Landesgericht is, blijkens de uitspraak van 28 februari 1995, van oordeel dat het Bezirksgericht het rechtshulpverzoek terecht heeft afgewezen en dat het ook terecht de boete heeft opgelegd. Nieuwe gegevens die T. bij het Weense Landesgericht voor het eerst aanvoert kunnen niet worden meegenomen in de beroepsprocedure en derhalve ook niet tot een ander oordeel leiden. Op 28 maart 1995 doet het Bezirksgericht $T$. een betalingsbevel toekomen op basis waarvan T. de boete van 30.000 ,- Schilling moet betalen. Op 16 augustus 1995 geeft het Bezirksgericht te kennen dat invordering van de boete tot op dat moment niet mogelijk is gebleken. Derhalve zet het Bezirksgericht de boete om in een gevangenisstraf van 10 dagen. $T$. had de mogelijkheid om tegen dit besluit van het Bezirksgericht in beroep te gaan (hij heeft dit echter achterwege gelaten).

Het Europese Hof voor de Rechten van de Mens dient in de zaak 'T. v. Austria' vervolgens drie vragen te beantwoorden waaronder de vraag of artikel 6 , eerste lid en artikel 6 , derde lid onder a en b, EVRM zijn geschonden. In dat kader overweegt het Hof:

'Like the Commission, the Court notes that the District Court, on 11 April 1994, ordered the applicant to supplement his legal aid request, but did not indicate that it suspected him of having committed the offence punishable under section 69 of the Code of Civil Procedure. Without having held a hearing, it found him guilty of this offence on 5 May 1994 and imposed a fine for abuse of process. Thus, the applicant only leamed about the accusations levelled against him when the District Court's decision was served on him. Contrary to the Government's assertion, the applicant did appeal from this decision (see paragraph 40 above). However, the appeal was not capable of remedying the shortcomings of the first instance proceedings, because the Regional Court confirmed the District Court's decision on 28 February 1995 without a hearing and rejected the submissions made by the applicant in his defence as constituting new facts which were inadmissible on appeal.

The Court concludes, therefore, that there has been a violation of Article $6 \S 1$ taken in conjunction with Article $6 \S 3$ (a) and (b) of the Convention. ${ }^{377}$

Uit de hierboven weergegeven passage uit de uitspraak van het EHRM kan worden afgeleid dat het feit dat de, eerst in beroep aangevoerde feiten, door de beroepsrechter niet meegenomen werden een rol heeft gespeeld in het kader van de constatering dat er sprake was van een schending van artikel 6, eerste lid EVRM in samenhang met artikel 6 , derde lid onder a en b EVRM. Over de vraag of er in casu sprake is van een rechter- 
lijke toetsing die niet voldoet aan het vereiste van 'full jurisdiction' laat het EHRM zich niet expliciet uit.

Desalniettemin kan mijns inziens, mede gelet op de zaak 'T. v. Austria', niet zonder meer ontkend worden dat toepassing van het 'trechtermodel' er (onder omstandigheden) toe leidt dat er sprake is van strijd met artikel $6 \mathrm{EVRM}^{378}$

\section{Slotsom}

Op basis van het voorgaande kom ik tot de volgende slotsom. Bij de oplegging van punitieve bestuursrechtelijke sancties zoals de bestuurlijke boete kan naar mijn mening niet onverkort worden vastgehouden aan de bestuursprocesrechtelijke regels, in het bijzonder artikel 8:69 Awb, vanwege de hiervoor uiteengezette redenen. Met het oog op de rechtszekerheid van de vermoedelijke overtreder is een (bij het wetboek van Strafvordering aansluitende) wettelijke regeling op het punt van het bewijsrecht gewenst. Dit klemt te meer nu de verschillende colleges, die in het bestuursrecht in appèl oordelen, artikel 8:69 Awb niet op gelijke wijze interpreteren.

De taakopvatting van de bestuursrechter zou, in het kader van de oplegging van punitieve bestuursrechtelijke sancties in ieder geval tenminste in essentie moeten aansluiten bij de wijze waarop de strafrechter zijn taak, met name in het kader van de bewijslast, opvat. Met het oog daarop zou de bestuursrechter, onder meer in verband met ongelijkheidscompensatie, zijn bevoegdheid tot ambtshalve aanvulling van rechtsgronden en de algemene (constitutionele) ambtshalve toetsingsbevoegdheid ruim op moeten vatten. Dit klemt temeer als de vermoedelijke overtreder zonder gemachtigde opkomt tegen het boetebesluit.

Daarnaast zou de bestuursrechter afstand moeten nemen van het 'trechtermodel'. Het (hoger) beroep zou in dat kader het karakter van een volledige herkansing moeten krijgen. $^{379}$

\section{Bewijs(lastverdeling) in het Voorontwerp}

De commissie Scheltema heeft in het Voorontwerp géen expliciete regeling getroffen met betrekking tot het bewijs van het onrechtmatige handelen. $\mathrm{Zij}$ gaat er van uit dat toepassing van het algemene bestuurs(proces)recht, en dan in het bijzonder het vereiste van een zorgvuldige voorbereiding (artikel 3:2 Awb), en het vereiste van een deugdelijke motivering (artikel 3:46 Awb), er toe leidt dat géén bestuurlijke boete kan worden opgelegd als de overtreding niet (zo nodig ten genoege van de rechter) is bewezen. ${ }^{380}$

Hierboven is reeds opgemerkt dat er in het bestuursprocesrecht sprake is van een 'vrij' bewijsleer hetgeen, zoals gezegd, inhoudt dat de bestuursrechter in beginsel de bewijslast naar eigen inzicht kan verdelen tussen bestuur en burger. Men kan zich afvragen hoe deze vrij bewijsleer zich verhoudt tot de uit artikel 6, tweede lid EVRM voortvloeiende bewijslastverdeling, nu op basis van laatstgenoemde bepaling het bestursorgaan moet bewijzen dat de burger de overtreding heeft gepleegd.

378 Vgl. Schlossels a.w. 1999, p. 183-185, De Bock a.w. 2000, p. 75-77 en Barkhuysen/Van EmmerikJ Loof a.w. 2000, p. 387.

379 Vgl. uitvoeriger over de ruimere taakopvatting van de bestuursrechter in het kader van de oplegging van bestuurlijke boeten: Albers en Schlossels a.w. 2002, § 5.

380 Voorontwerp p. 102-103. 
Toch lijkt er in de praktijk geen probleem te ontstaan zolang de bestuursrechters strenge eisen stellen met betrekking tot de bewijsvoeringsplicht (die ingelezen dient te worden in het beginsel van zorgvuldige voorbereiding ex artikel 3:2 Awb) en de motiveringplicht (artikel 3:46 Awb) ten aanzien van punitieve sanctiebesluiten. Hiervoor is reeds benadrukt dat de bewijslast naar geldend recht bij het nemen van ambtshalve belastende besluiten, en dan in het bijzonder besluiten tot oplegging van punitieve sancties, (in essentie) rust op het bestuursorgaan. ${ }^{381} \mathrm{Om}$ die reden is de commissie Scheltema dan ook van oordeel dat in de boeteregeling in de vierde tranche van de Awb geen bijzondere bepalingen met betrekking tot bewijs opgenomen hoeven te worden. Hartmann deelt deze mening niet, hij is voorstander van een aparte 'Wet Bestuursstrafrecht' waarin ook regels met betrekking tot het bewijs in het bestuursstrafrecht zouden moeten worden neergelegd. ${ }^{382}$

Mijns inziens wordt in voldoende mate voldaan aan de, uit artikel 6, tweede lid EVRM, voortvloeiende (materiële) eisen als de bestuursrechter inderdaad strenge eisen stelt aan de bewijsvoering van de overtreding en aan de motivering van het sanctiebesluit. Desalniettemin zou de rechtszekerheid ermee gediend zijn als in de Awb enige bepalingen met betrekking tot bewijs zouden worden opgenomen. ${ }^{383}$ In ieder geval dient in de Awb, of in een andere - aparte - wettelijke regeling m.b.t. het bestuursstrafrech ${ }^{384}$, duidelijk aangegeven te worden dat de bewijslast, bij de oplegging van punitieve bestuursrechtelijke sancties, bij het sanctionerende bestuursorgaan moet liggen ${ }^{385}$, of, conform het strafrecht, uiteindelijk bij de (bestuurs)rechter. Voorts zouden, in het kader van het formele bewijsrecht, bepalingen opgenomen kunnen worden met betrekking tot toegestane bewijsmiddelen en de (on)toelaatbaarheid van strafrechtelijk onrechtmatig verkregen bewijs. ${ }^{386}$

Daarnaast zou aandacht uit kunnen gaan naar de werking van artikel 8:69 Awb bij beroep en hoger beroep tegen de opgelegde bestuurlijke boete. Enige kritische reflectie ten aanzien van genoemde bepaling is, in het bijzonder met het oog op het zogenaamde 'trechtermodel', in het kader van het bewijsrecht, mijns inziens noodzakelijk. In de wettelijke regeling moet er zorg voor worden gedragen dat de toegang tot de rechter, de verdedigingsrechten, en het recht op 'full jurisdiction', door de werking van artikel 8:69 Awb niet dusdanig worden beperkt dat er sprake is van schending van artikel 6 EVRM. ${ }^{387}$ Hiervoor is reeds aangegeven dat in dat kader een (bij het wetboek van Strafvordering aansluitende) wettelijke regeling op het punt van het bewijsrecht gewenst is.

Tenslotte dient te worden opgemerkt dat de commissie Scheltema bepalingen in het Voorontwerp heeft opgenomen die relevant zijn in het kader van het bewijs van de overtreding. Dit terwijl genoemde commissie stelt dat er geen bijzondere bepalingen met betrekking tot bewijs in de boeteregeling opgenomen hoeven te worden. Het gaat

381 Vgl. Daalder en Schreuder-Vlasblom a.w. 2000, p. 217.

382 Hartmann a.w. 1998, p. 220-226.

383 Zie hierover ook: Michiels a.w. 1995, p. 89.

384 Ik kom hier later nog op terug.

385 Zie in deze zin ook: Roording a.w. 1994, p. 219.

386 Op beide aspecten wordt hierna nog ingegaan.

387 Vgl. Schlossels a.w. 1999, p. 183-185 en De Bock aw. 2000, p. 75-77. 
dan om het zwijgrecht en de cautieverplichting en om artikel 5.4.2.1 van het Voorontwerp waarin is geregeld dat het bestuursorgaan en de voor de overtreding bevoegde toezichthouder van de overtreding een rapport op kunnen maken. ${ }^{388}$ In de toelichting bij de genoemde bepaling stelt de commissie Scheltema dat het niet altijd noodzakelijk is om een rapport op te maken van een gedraging waarvoor een bestuurlijke boete wordt opgelegd. ${ }^{38}$

'Het verplicht opmaken van een rapport bij overtsedingen van meer administratieve aard (te laat aangifte doen of andere gegevens verstrekken) zou echter tot onnodige lasten leiden. Daamaast lijkt het niet te stroken met artikel 3:2 van de Awb, om het bestuursorgaan bij het nemen van de boetebeschikking te beperken in zijn informatiebronnen. Ook het beginsel van vrije bewijsvoering in het bestuursrecht verzet zich ertegen het rapport teveel status te geven. Fouten in het rapport moeten niet desastreus zijn voor het vervolg van de procedure. Het rapport moet echter wel duidelijk zijn. ${ }^{390}$

Vervolgens wordt in artikel 5.4.2.6 van het Voorontwerp het opmaken van een rapport (of proces-verbaal) verplicht gesteld bij overtredingen waarvoor een boete van meer dan 340 Euro kan worden opgelegd. De commissie stelt vervolgens in de toelichting op laatstgenoemde bepaling, in tegenstelling tot de hierboven weergegeven toelichting bij artikel 5.4.2.1, het volgende:

'Dit (rapport of proces-verbaal [KA]) schept een extra waarborg dat duidelijk is waarvan de overtreder wordt beschuldigd. Het rapport of proces-verbaal speelt in het vervolg van de procedure een belangrijke rol. Het zal veelal één van de belangrijkste bewijsmiddelen zijn. Het verschaft de overtreder voorts belangrijke informatie over hetgeen waartegen hij zich moet verweren. Het rapport of proces-verbaal vormt daarbij de «buitengrens»: de verdere procedure kan uitsluitend betrekking hebben op overtredingen waarvan een rapport of proces-verbaal is opgemaakt, (...). ${ }^{.391}$

Wat de commissie Scheltema nu voor ogen staat met het oog op de bewijstechnische waarde van het rapport is niet geheel duidelijk. De toelichting bij artikel 5.4.2.1 van het Voorontwerp staat in feite haaks op de toelichting bij artikel 5.4.2.6.

In de literatuur wordt in ieder geval, conform het strafprocesrecht ${ }^{392}$, wel uitgegaan van de bewijstechnische waarde van een door een daartoe bevoegde ambtenaar opgemaakt rapport met betrekking tot geconstateerde overtredingen. Michiels en Van Buuren ${ }^{303}$ hebben bijvoorbeeld, evenals de Toetsingscommissie ${ }^{394}$, aangegeven dat het opmaken van een rapport bij bestuurlijke boeten ten zeerste gewenst is, en dat er dienaangaande een wettelijke regeling getroffen zou moeten worden. ${ }^{395}$ De rechter zou dan wel bevoegd moeten zijn tegenbewijs tegen het opgestelde rapport toe te laten. Michiels con-

388 Zie in dit kader ook het rapport van de VAR-werkgroep, a.w. 2000, p. 43.

389 Voorontwerp p. 130.

390 Voorontwerp p. 130-131 en p. 103.

3911 Voorontwerp p. 134.

392 Zie artikel 344, tweede lid Sv. Uit genoemde bepaling kan worden afgeleid dat aan een proces-verbaal als bewijsmiddel veel waarde wordt toegekend.

393 Michiels a.w. 1995, p. 89 en P.J.J. van Buuren, De bestuurlijke boete geregeld? in de bundel: Van boeteatelier tot boetefarbriek, onder redactie van W.G.A. Hazewindus en O.J.D.M.L. Jansen, Deventer 1995 , p. $41-51$, i.h.b. p. $49-50$.

$395 \mathrm{Zie}$ in deze zin voorts het rapport van de VAR-werkgroep a.w. 2000, p. 43. 
cludeert: 'Deze inbreuk op het vrije bewijsstelsel van het bestuursrecht is gezien de aard van de sanctie op zijn plaats. ${ }^{396}$

\section{Strafrechtelijk onrechtmatig verkregen bewijs}

Tenslotte volgt nog een opmerking omtrent het gebruik van strafrechtelijk onrechtmatig verkregen bewijs. Genoemd bewijsmateriaal mag in het strafrecht in de regel niet (ten laste van de verdachte en niet) als bewijs van het ten laste gelegde feit worden gebruikt. ${ }^{397}$ De commissie Scheltema vindt, blijkens de toelichting, dat strafrechtelijk onrechtmatig verkregen bewijs doorgaans wél in een bestuursrechtelijke proceủure tot oplegging van een punitieve sanctie mag worden gebruikt. De commissie verwijst ter onderbouwing van haar stellingname naar een arrest van de Hoge Raad van 1 juli $1992^{398}$ en schrijft, over de in genoemd arrest neergelegde opvatting van de Hoge Raad dat er geen rechtsregel in de weg staat aan het gebruik van strafrechtelijk onrechtmatig verkregen bewijs in een bestuursrechtelijke procedure, het volgende:

'De Hoge Raad tekent daarbij aan dat het enkele feit dat bewijs strafrechtelijk gezien onrechtmatig is verkregen niet zonder meer meebrengt dat dit bewijs ook in een bestuursrechtelijke procedure niet mag worden gebruikt. De eigen aard van het bestuursrecht en strafrecht verzetten zich tegen een dergelijke gelijkstelling. Daarbij is bijvoorbeeld van belang dat in het bestuursrecht relatief veel fouten bij de bewijsgaring - bijvoorbeeld het niet horen van de overtreder - in de bezwaarschriftenprocedure kunnen worden hersteld (...), terwijl vormfouten met toepassing van artikel 6:22 Awb ook door de rechter kunnen worden gepasseerd.

Een en ander neemt vanzelfsprekend niet weg, dat het ook in het bestuursrecht kan voorkomen dat bij de bewijsgaring zodanig fundamentele normen - te denken van aan de essentiële normen van artikel 6 EVRM - zijn geschonden en de overtreder daardoor zozeer in zijn belangen is geschaad, dat het verkregen bewijs niet kan worden gebruikt om een boete op te leggen. ${ }^{399}$

$\mathrm{Bij}$ beantwoording van de vraag of gebruik van strafrechtelijk onrechtmatig verkregen bewijs gebruikt mag worden voor de oplegging van een bestuurlijke boete biedt de rechtspraak van het EHRM geen uitkomst. Het EVRM bevat namelijk, zoals in hoofdstuk drie reeds is aangegeven, geen regels met betrekking tot het bewijs van strafbare feiten. Deze regelgeving laat het EHRM expliciet over aan de partijstaten. ${ }^{400}$ Illustratief in dit kader is de uitspraak van het Hof in de zaak 'Schenk'. ${ }^{401}$ In die zaak bepaalde het EHRM dat het ten aanzien van naar nationale maatstaven onrechtmatig verkregen bewijs geen uitspraken doet omtrent de toelaatbaarheid van die bewijsmiddelen in een

396 Michiels a.w. 1995, p. 89.

397 Zie: Corstens a.w. 1999, p. 654-662 en Ch.J. Enschedé, bewerkt door C.F. Ruter en S.A.M. Stolwijk, Beginselen van strafrecht, Deventer 1995, p. 126 en 132. Zie voorts HR 26 juni 1962, NJ 1962, $470 \mathrm{~m}$. nt. W. Pompe en HR 18 april 1978, NJ 1978, 365, m. nt. Th. W. van Veen. Onder omstandigheden wordt op de regel dat strafrechtelijk onrechtmatig verkregen bewijs niet gebruikt mag worden als bewijs van het ten laste gelegde feit een uitzondering gemaakt (Vgl. Corstens p. 660-662, zie voorts artikel 359a Sv).

398 HR 1 juli 1992, BNB 1992, 306, m. nt. P. den Boer, NJ 1992/621 m. nt. Scheltema.

$399 \mathrm{Vgl}$. Voorontwerp p. 103.

400 Zie EHRM 12 juli 1988, NJ 1988, 85 I m. nt. E.A. Alkema (Schenk tegen Zwitserland), en Van Russen Groen a.w. 1998 , p. 198-213.

401 EHRM 12 juli 1988, NJ 1988, 851 m. nt. E.A. Alkema (Schenk tegen Zwitserland). 
strafrechtelijke procedure. Voor het Hof is immers slechts de vraag relevant of de (strafrechtelijke) procedure in zijn geheel 'fair' was. ${ }^{402}$ Derhalve kan niet worden uitgesloten strafrechtelijk onrechtmatig verkregen bewijs onder omstandigheden toelaatbaar zou kunnen zijn:

'While Art. 6 Convention guarantees the right to a fair trial, it does not lay down any rules on the admissibility of evidence as such, which is therefore primarily a matter for regulation under national law. The Court therefore cannot exclude as a matter of principle and in the abstract that unlawfully obtained evidence of the present kind may be admissible. It has only to ascertain whether Mr. Schenk's trial as a whole was fair. ${ }^{403}$

Hieruit volgt dat niet zonder meer gezegd kan worden dat de hierboven weergegeven opvatting van de commissie Scheltema niet juist is. Ook Feteris lijkt, met het oog op de zaak 'Schenk' en het arrest van de Hoge Raad van 1 juli 1992, uit te gaan van een, met het door de commissie ingenomen, vergelijkbaar standpunt. ${ }^{404}$

Zoals de commissie zelf al aan heeft gegeven, neemt ook de Nederlandse rechter het standpunt in dat gebruik van strafrechtelijk onrechtmatig verkregen bewijs bij de oplegging van een bestuurlijke boete doorgaans niet onrechtmatig is. De Hoge Raad oordeelde immers in het arrest van 1 juli 1992:

'Bij de beoordeling van het middel moet worden vooropgesteld dat - ander dan het middel blijkbaar vooronderstelt - er geen rechtsregel bestaat, die ieder gebruik verbiedt van strafrechtelijk onrechtmatig verkregen bewijsmiddelen voor het vaststellen van de uit de wet voortvloeiende belastingschuld en - zo daartoe gronden aanwezig zijn - voor het opleggen van een verhoging [curs. KA] ${ }^{405}$

Voorts kan gewezen worden op een uitspraak van 4 februari $2000^{406}$ van de Afdeling Bestuursrechtspraak. Op deze plaats moet wel worden opgemerkt dat het in die zaak om sluiting van een horecapand ging. Deze sanctie wordt naar geldend recht aangemerkt als reparatoire sanctie. ${ }^{407}$ In de uitspraak van 4 februari 2000 bepaalde genoemd college dat er geen rechtsregel bestaat die ieder gebruik verbiedt van strafrechtelijk onrechtmatig verkregen bewijs. In een administratiefrechtelijk geding is zodanig bewijs, volgens de Afdeling, slechts dan niet toegestaan indien het bewijs is verkregen op een wijze, die zozeer indruist tegen hetgeen van een behoorlijk handelende overheid mag worden verwacht, dat dit gebruik onder alle omstandigheden ontoelaatbaar moet worden geacht. ${ }^{408}$

De door de Afdeling Bestuursrechtspraak in deze uitspraak weergegeven opvatting vertoont sterke overeenkomsten met de opvatting van de commissie Scheltema inzake

$402 \mathrm{Vgl.} \mathrm{Simmelink} \mathrm{in} \mathrm{Groenhuijsen} \mathrm{en} \mathrm{Knigge} \mathrm{a.w.} \mathrm{1999.} \mathrm{p.} 412$.

403 'Schenk tegen Zwitserland' § 46. Dat het EHRM dit standpunt nog steeds huldigt kan worden afgeleid uit de Ziluk 'Mantovanelli v. France' (EHRM 18 maart 1997, NJ 1998, 278 m. nt. H.J. Snijders (Mantovanclli v. France), i.h.b. \$34).

404 Fiteris a.w. 1493, p. 597.

405 De term 'verhoging' kan in dit kader worden gezien als synoniem voor bestuurlijke boete.

406 ABRS 4 februari 2000, JB 2000/72, Gst. 7120, 3 m.nt. H. Hennekens, AB 2000, 242 m. nt. L. Damen. Vgl. ABRS 21 januari 1988, AB 1989, 36 m. nt. H.J. Simon

407 Zie $\$ 2.2 .3 .3$.b van dit boek.

408 Zie in deze zin ook: Rechthank Amsterdam 31 mei 2000, JB 2000/235 m. nt. C.L.G.F.H. Albers. 
het gebruik van strafrechtelijk onrechtmatig verkregen bewijs in bestuurs(straf)rechtelijke procedures.

De belastingkamer van de Hoge Raad heeft het door de Afdeling gehanteerde criterium, ter beantwoording van de vraag of het gebruik van onrechtmatig verkregen bewijs in een bestuursrechtelijke procedure is toegestaan, in het hogergenoemde arrest van 1 juli 1992, met betrekking tot een belastingaanslag en een fiscale verhoging (boete), reeds aangewend. Zij het dat het hierboven weergegeven criterium in dat arrest slechts eell beperkt onderdeel van éen van de verschillende toetsingscriteria vormt. Er lijkt in de Afdelingsuitspraak sprake te zijn van ongebreideld knip en plakwerk, of om met de woorden van Damen te spreken 'selectief shoppen'. Ter illustratie volgt hier het uitvoerigere, door de Hoge Raad in het arrest van 1 juli 1992 aangedragen, toetsingsschema (de gecursiveerde delen van het arrest heeft de Afdeling bestuursrechtspraak, als toetsingscriterium, ten grondslag gelegd aan de uitspraak van 4 februari 2000):

' 3.2.2. Bij de beoordeling van het middel moet worden vooropgesteld dat - anders dan het middel blijkbaar vooronderstelt - er geen rechtsregel bestaat, die ieder gebruik verbiedt van strafiechtelijk onrechtmatig verkregen bewijsmiddelen voor het vaststellen van de uit de wet voortvloeiende belastingschuld en - zo daartoe gronden aanwezig zijn - voor het opleggen van een verhoging.

3.2.3. In de eerste plaats is het gebruik van zodanige bewijsmiddelen in ieder geval niet ongeoorloofd, indien de bewijsmiddelen niet als jegens de belanghebbende op onrechtmatige wijze verkregen kunnen worden beschouwd. (...).

3.2.4. Overigens heeft te gelden dat, ingeval gesproken kan worden van jegens de belanghebbende op strafrechtelijk onrechtmatige wijze verkregen bewijsmiddelen, dit voor de inspecteur geen beletsel behoeft te zijn om daarvan gebruik te maken. In een dergelijk geval zal met inachtneming van alle ter zake dienende omstandigheden nader moeten worden beoordeeld of de inspecteur handelt in strijd met enig algemeen beginsel van behoorlijk bestuur, en meer in het bijzonder met het zorgvuldigheidsbeginsel, door ter vaststelling of ter ondersteuning van een belastingaanslag van dit strafrechtelijk onrechtmatig verkregen bewijsmiddel gebruik te maken. (...).

3.2.5. Met betrekking tot bewijsmiddelen waarvan de inspecteur, ook indien de onrechtmatige handelingen van de vervolgende instanties niet hadden plaatsgevonden, zonder wettelijke belemmering kennis had kunnen nemen, kan in het algemeen van strijd met algemene beginselen van behoorlijk bestuur niet worden gesproken, zo de inspecteur van deze bewijsmiddelen gebruik maakt.

(...) Gebruik van vorenbedoelde bewijsmiddelen door de inspecteur is slechts dan niet toegestaan, indien zij zijn verkregen op een wijze die zozeer indruist tegen hetgeen van een behoorlijk handelende overheid mag worden verwacht, dat dit gebruik onder alle omstandigheden ontoelaatbaar moet worden geacht.'

Er bestaat, daar zijn de Hoge Raad en de Afdeling Bestuursrechtspraak het over eens, geen rechtsregel die ieder gebruik van strafrechtelijk onrechtmatig verkregen bewijsmiddelen verbiedt. Vervolgens geeft de Hoge Raad aan wanneer gebruik van dergelijk bewijs al dan niet verboden is. Deze nuancering ontbreekt in de Afdelingsuitspraak. Gebruik van strafrechtelijk onrechtmatig verkregen bewijs is ten eerste niet verboden als de bewijsmiddelen niet als jegens de belanghebbende op onrechtmatige wijze ver- 
kregen kunnen worden beschouwd. ${ }^{409}$ Ten tweede zal, zo stelt de Hoge Raad, met inachtneming van de omstandigheden van het geval, nader moeten worden beoordeeld of het sanctionerende bestuursorgaan handelt in strijd met enig algemeen beginsel van behoorlijk bestuur, en meer in het bijzonder met het zorgvuldigheidsbeginsel, door bij het nemen van een besluit, zoals bijvoorbeeld de oplegging van een (punitieve) bestuursrechtelijke sanctie, van een strafrechtelijk onrechtmatig verkregen bewijsmiddel gebruik te maken. Tenslotte bepaalt de Hoge Raad dat niet van strijd met de algemene beginselen van behoorlijk bestuur kan worden gesproken als het gaat om aan een besluit ten grondslag gelegde bewijsmiddelen waarvan het bestuursorgaan, indien de onrechtmatige handelingen van de vervolgende instanties niet hadden plaatsgevonden, zonder wettelijke belemmering kennis had kunnen nemen. Slechts ten aanzien van dit laatste, op onrechtmatige wijze verkregen bewijs, waarvan het bestuursorgaan ook zonder wettelijke belemmering kennis had kunnen nemen, stelt de Hoge Raad dat het alleen dan niet gebruikt mag worden als het is verkregen op een wijze die zozeer indruist tegen hetgeen van een behoorlijk handelende overheid mag worden verwacht, dat dit gebruik onder alle omstandigheden ontoelaatbaar moet worden geacht. ${ }^{410}$

Anders dan de Afdeling Bestuursrechtspraak lijkt de Centrale Raad van Beroep wel volledig aansluiting te zoeken bij de rechtspraak van de Hoge Raad. Dit kan worden afgeleid uit een uitspraak van 28 november 1995 van de Centrale Raad. ${ }^{411}$ In laatstgenoemde uitspraak ging het om, bij een huiszoeking in beslag genomen stukken, die in strafrechtelijke zin als onrechtmatig verkregen bewijs moesten worden aangemerkt. Genoemde stukken werden ten grondslag gelegd aan blokkering en beëindiging van de RWW-uitkering en de afwijzende beslissing op een aanvraag om een ABW-uitkering van appellant. Geen punitieve sancties derhalve. Aangezien het bevoegde bestuursorgaan (volgens de Centrale Raad), ook indien de huiszoeking niet had plaatsgevonden, zonder wettelijke belemmering van deze stukken kennis had kunnen nemen, mochten genoemde stukken ten grondslag worden gelegd aan het bestreden besluit. Dit zou volgens de Centrale Raad, ten aanzien van stukken waarover het bestuursorgaan zonder wettelijke belemmering kan beschikken, slechts anders zijn indien het bewijs verkregen is op een wijze die zozeer indruist tegen hetgeen van een behoorlijk handelende overheid mag worden verwacht, dat dit gebruik onder alle omstandigheden ontoelaatbaar moet worden geacht.

Duidelijk is dat strafrechtelijk onrechtmatig verkregen bewijs, volgens de hierboven genoemde rechters én de commissie Scheltema, onder omstandigheden ten grondslag mag worden gelegd aan besluiten van bestuursorganen in het algemeen én aan punitieve bestuursrechtelijke sanctiebesluiten. De voorwaarden waaronder dit is toegestaan lijken bij de Hoge Raad en de Centrale Raad van Beroep minder ruim gesteld te zijn dan bij de Afdeling Bestuursrechtspraak. Zie ik het goed dan hanteert de commissie

$409 \mathrm{Vgl}$. het Schutznorm-vereiste in het kader van strafrechtelijk onrechtmatig verkregen bewijs (Corstens a.w. 1999, p. 661).

410 Zie voorts: HR 12 maart 1997, BNB 1997/146c, m. nt. P.J. Wattel.

4l I CRvB 28 november 1995, RSV 1996/89. Zie voorts voor een overzicht m.b.t. uitspraken van de CRvB in het kad - van strafrechtelijk onrechtmatig verkregen bewijs het naschrift van De Bruijn onder CRvB 29 januari 2002, Gst. 7164, 2 (uitspraak), en Gst. 7166, 10 (naschrift). 
Scheltema een soortgelijk criterium als door de Afdeling bestuursrechtspraak wordt gebruikt.

Aan de hand van het door de Afdeling en de commissie gehanteerde ruime criterium lijkt het in een bestuursrechtelijke procedure vrijwel altijd mogelijk te zijn om strafrechtelijk onrechtmatig verkregen bewijs ten grondslag te leggen aan een besluit. Dat zal overigens ook in veel gevallen zo zijn als de (iets) strengere criteria van de Hoge Raad-die ook de Centrale Raad toegepast worden - gebruikt worden.

Op deze plaats kan de vraag worden opgeworpen of het, door de Nederlandse rechters en ook door de commissie Scheltema voorgestane, hanteren van (zeer) soepele criteria ten aanzien van de toelaatbaarheid van het gebruik van strafrechtelijk onrechtmatig verkregen bewijs, met name bij de oplegging van punitieve bestuursrechtelijke sancties, wel gewenst is. Toepassing van genoemde criteria leidt er toe dat, ten aanzien van de oplegging van punitieve bestuursrechtelijke sancties minder waarborgen in het kader van de rechtsbescherming van de vermoedelijke overtreder gelden dan in het kader van strafrechtelijke sanctionering. Naar mijn mening is dit niet wenselijk omdat punitieve bestuursrechtelijke sancties naar hun aard vergelijkbaar zijn met strafrechtelijke sancties. ${ }^{412}$ Derhalve dient (zo veel mogelijk) aangesloten te worden bij de waarborgen die ten aanzien van de overtreder gelden in het kader van het strafrecht en het strafprocesrecht. Ook Michiels, De Raat en Widdershoven, Van Russen Groen en Hartmann zijn van mening dat bij de oplegging van punitieve bestuursrechtelijke sancties geen, van het straf(proces)recht afwijkend, (aanzienlijk) ruimer criterium met betrekking tot het gebruik van onrechtmatig verkregen bewijs gehanteerd zou moeten worden. ${ }^{83}$ Hartmann motiveert dit standpunt in zijn dissertatie als volgt:

'Dit (het stellen van minder strenge eisen aan de bewijswaardering in het bestuursrecht dan in het strafrecht [KA]) kan ertoe leiden dat indien strafrechtelijke veroordeling zou zijn uitgesloten als gevolg van onrechtmatig verkregen bewijs, een mogelijke bestraffing door middel van het bestuursstrafrecht zal kunnen worden bewerkstelligd. Het bestuursstrafrecht kan dan als gevolg van minder strenge eisen aan de bewijswaardering gaan fungeren als 'vangnet' voor het strafrecht. Dit dient naar mijn mening gezien het bestraffende karakter van de sanctie in het bestuursstrafrecht te worden afgewezen. ${ }^{414}$

Geconcludeerd kan worden dat, met name bij besluiten met betrekking tot de oplegging van een punitieve bestuursrechtelijke sanctie, zoals de in dit boek centraal staande bestuurlijke boete, de bestuursrechters zich zouden moeten conformeren aan de strafrechtelijke regelgeving en rechtspraak ten aanzien van het gebruik van onrechtmatig verkregen bewijs. Van een 'eigen aard' van het bestuurs(proces)recht, die een onderscheid tussen de waardering van onrechtmatig verkregen bewijs in het strafrecht en het punitieve bestuursrecht rechtvaardigt, kan mijns inziens niet gesproken worden. Ik kan het door de commissie Scheltema ingenomen standpunt, ten aanzien van het gebruik

412 Zie in deze zin ook: Corstens a.w. 2000, p. 1185-1190, i.h.b. p. 1187.

413 Zie: Michiels a.w. 1995, p. 73-74, De Raat en Widdershoven a.w. 2000, p. 783, Van Russen Groen a.w. 1998, p. $208-209$ en Hartmann a.w. 1998 , p. 200 . Roording neemt een meer genuanceerd standpunt in (Roording a.w. 1994, p. 73-74).

Hartmann a.w. 1998, p. 200. 
van strafrechtelijk onrechtmatig verkregen bewijs voor de oplegging van een bestuurlijke boete, dan ook moeilijk onderschrijven.

\section{Resumé}

Hierboven is aandacht besteed aan de vraag of de commissie Scheltema, gelet op artikel 6 lid 2 EVRM, in voldoende mate invulling heeft gegeven aan de onschuldpresumptie. Ik heb daar, tenminste op bepaalde punten, twijfels over. Met name de hoofdregel dat bezwaar en beroep géén schorsende werking hebben, het vereiste van zekerheidsstelling, het ontbreken van bewijsrechtelijke regels in het Voorontwerp en het toestaan van het gebruik van strafrechtelijk onrechtmatig verkregen bewijs ter onderbouwing van het boetebesluit duiden, zoals hiervoor uiteengezet, tenminste tot op zekere hoogte op strijd met voornoemd beginsel. Of het EHRM deze opvatting zal onderschrijven valt echter niet met zekerheid te zeggen.

Wel staat vast dat de door de commissie Scheltema voorgestelde regeling afwijkt van het commune strafrecht. De bestuurlijke boete kan (als hoofdstraf) reeds ingevorderd worden op het moment dat nog niet onherroepelijk op het, door de vermoedelijke overtreder tegen het boetebesluit ingediende, bezwaar, beroep of hoger beroep is beslist. $^{415}$ Een beslissing (ten aanzien van de hoofdzaak) van een strafrechter mag echter eerst ten uitvoer worden gelegd als daartegen géén gewoon rechtsmiddel meer openstaat. Indien een rechtsmiddel is aangewend mag de beslissing van een strafrechter eerst ten uitvoer worden gelegd als dit rechtsmiddel is ingetrokken of als op het rechtsmiddel beslist is. ${ }^{416}$

Voorts is hiervoor reeds ingegaan op het op het bestuursprocesrecht van toepassing zijnde materieel bewijsrecht. In dat kader lijken zich met name problemen te manifesteren bij een onverkorte toepassing van artikel 8:69 Awb zoals dat momenteel in de rechtspraak is uitgekristalliseerd. De taakopvatting van de bestuursrechter zou, in het kader van de oplegging van punitieve bestuursrechtelijke sancties in ieder geval in essentie moeten aansluiten bij de wijze waarop de strafrechter zijn taak, met name in het kader van de bewijslast, opvat. De bestuursrechter zou, zoals gezegd, met name zijn bevoegdheid tot ambtshalve aanvulling van rechtsgronden en de algemene (constitutionele) ambtshalve toetsingsbevoegdheid ruim op moeten vatten. Dit klemt temeer als de vermoedelijke overtreder zonder gemachtigde opkomt tegen het boetebesluit. Ook zou de bestuursrechter afstand moeten nemen van het 'trechtermodel' (en dan in het bijzonder van de argumentatieve fuik ${ }^{417}$ ). Het (hoger) beroep zou in dat kader het karakter van een volledige herkansing moeten krijgen.

Daamaast kan tenslotte, wat betreft de afwijking van het commune strafrecht door de commissie Scheltema, gewezen worden op het (veel ruimer) gebruik van strafrechtelijk onrechtmatig verkregen bewijs ter onderbouwing van het boetebesluit.

415 Zoals gezegd valt in dit kader een paraliel met de voorlopige hechtenis niet te trekken.

416 Art. 557, eerste lid Sv.

417 De bewijsfuik lijkt in het kader van punitieve sancties overigens geen rol te spelen. Het voorgaande kan uit een eerder in dit hoofdstuk aangehaalde uitspraak van de Afdeling Bestuursrechtspraak worden afgeleid. 


\section{Artikel 5.4.1.3 Overlijden van de overtreder}

In artikel 5.4.1.3 van het Voorontwerp is een regeling getroffen met betrekking tot de situatie waarin sprake is van het overlijden van de overtreder aan wie een bestuurlijke boete is, of kan worden, opgelegd. Uit het eerste lid van genoemde bepaling blijkt dat het bestuursorgaan geen boete oplegt indien de overtreder is overleden. Overlijdt de overtreder nadat de boete is opgelegd dan vervalt de opgelegde bestuurlijke boete voorzover de geldsom nog niet is betaald, zo blijkt uit het tweede lid van artikel 5.4.1.3 van het Voorontwerp. ${ }^{418}$ Een soortgelijke regeling is neergelegd in artikel $69 \mathrm{Sr}$. Wanneer de bestuurlijke boete slechts de nalatenschap treft ontbeert zij het punitieve effect volgens de commissie Scheltema. ${ }^{419} \mathrm{Ik}$ kan deze opvatting onderschrijven.

Met de bepaling omtrent het vervallen van de boete bij overlijden van de overtreder komt de commissie tevens tegemoet aan de eisen die uit artikel 6 EVRM voortvloeien. Het EHRM heeft namelijk in de zaak 'E.L., R.L., and J.O.-L. v. Switzerland ${ }^{\text {120 }}$ bepaald dat het opleggen van een bestuurlijke boete aan erfgenamen wegens een overtreding gepleegd door de overleden persoon in strijd is met de onschuldpresumptie en de daaraan ten grondslag liggende essentie.

\section{Artikel 5.4.1.4 Het ne bis in idem-beginsel}

In artikel 5.4.1.4 van het Voorontwerp is een klassiek strafrechtelijk beginsel ${ }^{421}$ neergelegd; het ne bis in idem-beginsel ${ }^{422}$ : 'Het bestuursorgaan legt geen bestuurlijke boete op indien aan de overtreder wegens dezelfde gedraging reeds eerder een bestuurlijke boete is opgelegd, dan wel een kennisgeving als bedoeld in artikel 5.4.2.3, tweede $\mathrm{lid}^{423}$, is bekend gemaakt.' In dit kader is de vraag relevant wanneer er sprake is van één en dezelfde gedraging. ${ }^{424}$ Ter beantwoording van die vraag zoekt de commissie Scheltema aansluiting bij de jurisprudentie van de Hoge Raad met betrekking tot 'hetzelfde feit' (ex. Artikel $68 \mathrm{Sr}$ ). Daaruit leidt de commissie af dat er:

'sprake is van «hetzelfde feib), indien «blijkt van een zodanig verband met betrekking tot de gelijktijdigheid van de gedragingen en de wezenlijke samenhang in het handelen en de schuld van de dader, dat de strekking van het artikel meebrengt dat zij in de zin van deze bepaling als hetzelfde feit zijn aan te merkenn'. ${ }^{425}$

418 Zie in dit kader ook het commentaar op artikel 5.4.1.3 van het Voorontwerp van Feteris (a.w. 2000b, p. 11) en Van der Hulst (a.w. 2000a, p. 70-72).

419 Voorontwerp p. 122.

420 EHRM 29 augustus 1997, no. $20919 / 92$ Reports 1997-V (E.L., R.L., and J.O.-L. v. Switzerland).

421 Zie artikel $68 \mathrm{Sr}$.

422 Zie over het ne bis in idem-beginsel en het una via-beginsel in het bestuursstrafrecht ook: Van Russen Groen a.w. 1998, p. 294-310.

423 In artikel 5.4.2.3, tweede lid is bepaald dat het bestuursorgaan, indien het, na het horen van de 'vermoedelijke' overtreder, besluit geen boete op te leggen of besluit de zaak over te dragen aan het OM, het de 'vermoedelijke' overtreder daarvan in kennis stelt. Oplegging van een bestuurlijke boete is daarna niet meer mogelijk.

$424 \mathrm{Zie}$ voor een helder overzicht van de ontwikkeling in de strafrechtelijke jurisprudentie m.b.t. 'hetzelfde feit': Hazewinkel-Suringa, bewerkt door Remmelink a.w. 1996, p. 596-603.

425 Voorontwerp p. 123 
De commissie Scheltema wijst in dit kader op het 'Emmense bromfietser-arrest'.426 Genoemd arrest spitst zich toe op de volgende casus. Een bromfietser werd veroordeeld wegens openbare dronkenschap. Daarna kon hij volgens het Hof, gelet op artikel $68 \mathrm{Sr}$, niet meer veroordeeld worden voor het rijden onder invloed. De Hoge Raad bevestigt het standpunt van het Hof en overweegt daartoe:

'...dat een en ander evenwel niet wegneemt dat, gelet op de verwantschap in de gedragingen, die in beide bepalingen zijn strafbaar gesteld, beide daarin strafbaar gestelde feiten kunnen worden begaan onder omstandigheden, waaruit blijkt van een zodanig verband met betrekking tot de gelijktijdigheid van de gedragingen en den wezenlijken samenhang in het handelen en in de schuld van den dader, dat de strekking van art. $68 \mathrm{Sr}$. medebrengt, dat degene, te wiens aanzien ter zake van overtreding van een der beide bepalingen onherroepelijk is beslist als in dit artikel bedoeld, niet andermaal kan worden vervolgd ter zake van overtreding van de andere bepaling'.

De commissie Scheltema vervolgt haar uiteenzetting:

'Dit criterium heeft zowel een feitelijke als een juridische dimensie. Overtreding van twee voorschriften levert pas één feit op als de overtredingen niet alleen feitelijk nauw samenhangen, maar ook kan worden gezegd dat de dader van beide overtredingen een verwijt van dezelfde strekking kan worden gemaakt; dat wil zeggen: als de overtreden voorschriften soortgelijke belangen beschermen. ${ }^{427}$

In Hazewinkel-Suringa's 'Inleiding tot de studie van het Nederlandse Strafrecht' wordt genoemde rechtspraak van de Hoge Raad als volgt geanalyseerd:

'In deze formule onderscheiden wij de twee polen: er wordt gekeken naar de wet, de strafbepalingen die er zijn, en die niet te veel uit elkaar mogen lopen; zij moeten 'gelijksoortig' zijn. Anderzijds wordt gelet op het feitelijk gebeuren, de manier waarop de verdachte tezelfder tijd en plaats het criminele gebeuren heeft doen plaatsvinden, en welke juridisch relevante samenhang daarbij is vast te stellen, waartoe de HR aanknoopt bij twee essentiële factoren daarbij: het feitelijk gedrag en de schuld. De HR denkt, blijkens verderop te noemen arresten, hierbij kennelijk aan 'verwijtbaarheidsschuld'. ${ }^{428}$

Gelet op de hierboven opgenomen analyse lijkt het gerechtvaardigd te zeggen dat de commissie Scheltema de 'twee te onderscheiden polen' met elkaar 'vermengd' heeft. Ook al beschermen de overtreden voorschriften soortgelijke belangen, dat wil nog niet zeggen dat dan ook (altijd) ten aanzien van beide overtredingen een verwijt van dezelfde strekking kan worden gemaakt. In Hazewinkel-Suringa's 'Inleiding tot de studie van het Nederlandse Strafrecht' wordt dit aan de hand van een helder voorbeeld duidelijk gemaakt. ${ }^{429}$ Beter zou het zijn als ook de commissie Scheltema uit zou zijn gegaan van het 'twee-stappen-schema'. Daarbij zou eerst gekeken moeten worden naar de gelijksoortigheid van de overtreden wettelijke bepalingen en vervolgens naar het feitelijk gebeuren. Met het oog op het feitelijk gebeuren zou dan vastgesteld moeten worden of

426 HR 21 november 1961, NJ 1962, 89 m. nt. B.V.A. Roling. Meer recent: HR 13 december 1994, NJ $1995,252$.

427 Voorontwerp p. 123. Zie voor een uitvoerigere en meer genuanceerde analyse van deze rechtspraak Hazewinkel-Suringa, bewerkt door Remmelink a.w. 1996, p. 600-601.

428 Hazewinkel-Suringa, bewerkt door Remmelink a.w. 1996, p. 600-601.

429 Hazewinkel-Suringa, bewerkt door Remmelink a.w. 1996, p. 601. 
er sprake is van een verwijt van dezelfde strekking. Ondanks het hierboven weergegeven nuanceverschil in benadering zal de keuze voor de ene, dan wel de andere benadering, niet snel leiden tot uiteenlopende opvattingen over de vraag of er sprake is van hetzelfde feit.

Van gelijksoortigheid van de overtreden bepalingen én een verwijt van dezelfde strekking was volgens de Hoge Raad géén sprake in het geval dat een bestuurder dronken op een autoloze zondag zijn auto bestuurde. ${ }^{430}$ Kernoverweging in het arrest van de Hoge Raad:

'..dat de strekking van art. 26, lid 1, WVW, een geheel andere is dan die van art. 2, lid 1, Beschikking verbniksbeperking motorbrandstoffen tijdens het weekeinde, terwijl ook het verwijt dat de dader kan worden gemaakt wegens overtreding van eerstgemelde bepaling niet van gelijksoortige aard is als wanneer het gaat om overtreding van laatstgemelde bepaling; dat het Hof dan ook terecht heeft geoordeeld, dat art. $68 \mathrm{Sr}$ de onderhavige vervolging niet verbiedt en dat het beroep op niet-ontvankelijkheid van de O.v.J moet worden verworpen:.... ${ }^{431}$

Deze opvatting lijkt mij juist.

De commissie Scheltema merkt op dat overtreden voorschriften doorgaans andere belangen beogen te beschermen als met handhaving van die voorschriften verschillende bestuursorganen zijn belast. 'Eendaadse samenloop zal zich dan niet licht voordoen. Om dezelfde reden zal het niet snel voorkomen dat de oplegging van een sanctie door het ene bestuursorgaan tot gevolg heeft dat sanctie-oplegging door het andere bestuursorgaan in strijd komt met het verbod van dubbele bestraffing. ${ }^{432}$ Ter illustratie wijst de commissie op de hiervoor reeds genoemde uitspraak van de Afdeling Bestuursrechtspraak van 10 februari $1997 .^{433}$

Het verdient opmerking dat de Hoge Raad bij de toepassing van artikel $68 \mathrm{Sr}$ sneller aanneemt dat er sprake is van één feit dan bij de toepassing van de samenloopbepaling

430 HR 25 maart 1975, NJ 1975, 296. Zie voorts; HR 18 januari 1972, NJ 1972, $378 \mathrm{~m}$. nt. C. Bronkhorst, HR 29 april 1980, NJ 1980, 445 m. nt. G.E. Mulder

431 Zie voor een bestuursrechtelijk voorbeeld: ABRS 10 februari 1997, AB 1997, $427 \mathrm{~m}$. nt. N. Verheij, waarin het ging om verzwijging van inkomsten in het kader van de Abw en in het kader van de Wet op de individuele huursubsidie. De ABRS oordeelde in die zaak dat ten aanzien van beide overtredingen een boete mocht worden opgelegd.

432 Voorontwerp 123. Opgemerkt zij overigens dat, zoals direct nog zal blijken, de rechtspraak van de Hoge Raad leert dat eerder sprake is van 'hetzelfde feit' met het oog op het ne bis in idem-beginsel zoals neergelegd in artikel $68 \mathrm{Sr}$ dan in het kader van eendaadse samenloop.

433 Vermeldenswaardig is de meer genuanceerde opvarting van annotator Verheij. Hij stelt in zijn noot onder ABRS 10 februari 1997 (AB 1997, 427): 'De Afdeling overweegt laconiek dat de sancties op grond van de wet IHS geheel los staan van de sancties op grond van de Algemene bijstandswet. Dat is misschien toch iets te kor door de bocht. In het strafrecht weegt bij het beantwoorden van de vraag of sprake is van énn, dan wel meer feiten de feitelijke en maatschappelijke samenhang zwaarder dan de enkele omstandigheid dat meer dan én delictsomschrijving is vervuld. (...) Relevanter is dat appellant de inkomsten van zijn echtgenote heeft verzwegen tegenover twee verschillende bestuursorganen, en vermoedelijk ook op verschillende tijdstippen. Daarom is in dit geval waarschijnlijk ook naar strafrechtelijke maatstaven sprake van twee feiten. Maar als iemand twee uitkeringen heef van hetzelfde bestuursorgaan, en een voor beide uitkeringen relevant gegeven verzwijgt, is dat denk ik éen feit.' 
(eendaadse samenloop). ${ }^{434}$ Dit blijkt uit het 'Joyriding II' arrest. ${ }^{435}$ In die zaak was strafrechtelijke vervolging, voor het rijden zonder in bezit te zijn van een rijbewijs, voorkomen doordat de overtreder ingestemd had met een transactievoorstel. Daarna werd de overtreder echter vervolgd wegens joyriding. Deze tweede vervolging was volgens de overtreder in strijd met artikel $68 \mathrm{Sr}$. In genoemd arrest heeft de HR dienaangaande het volgende overwogen:

'... dat er ook dan sprake kan zijn van hetzelfde feit in evenbedoelde zin, indien de feiten in den zin van de artt. 57 jo. $62 \mathrm{Sr}$. als meerdere feiten zijn op te vatten, omdat dit laatste geval niet uitsluit dat de feiten begaan zijn onder omstandigheden waaruit blijkt van een zodanig verband m.b.t. de gelijktijdigheid van de gedragingen en den wezenlijken samenhang in het handelen en in de schuld van den dader, dat de strekking der artt. 68 en $74 \mathrm{Sr}$. medebrengt, dat zij in den zin van beide laatstgenoemde bepalingen als hetzelfde feit zijn aan te merken;

De achtergrond daarvan is, volgens de commissie Scheltema, dat het voor de burger nog bezwaarlijker is om achtereenvolgens met twee sanctieprocedures te worden lastiggevallen, dan om in één procedure twee sancties opgelegd te krijgen. ${ }^{436}$ Ook volgens de strafrechtelijke literatuur is dit de ratio die ten grondslag ligt aan het verschil in benadering van het feitbegrip in het kader van eendaadse samenloop ten opzichte het ander maal vervolgen voor hetzelfde feit. ${ }^{437}$

De VAR-werkgroep vraagt zich af of artikel 5.4.1.4 van het Voorontwerp, met het oog op artikel 5.0.8, wel toegevoegde waarde heeft. De werkgroep verwijst naar de strafrechtelijke jurisprudentie, waaruit blijkt dat er bij de toepassing van artikel $68 \mathrm{Sr}$ sneller sprake is van één feit dan bij de toepassing van de samenloopbepaling (eendaadse samenloop), en concludeert vervolgens:

'Wanneer deze notie ook voor de onderhavige regeling zou worden gehanteerd, zou dat dienen te betekenen dat bij artikel 5.4.1.4 puur naar de feitelijke gedraging zou moeten worden gekeken. De vraag of sprake is van een of meer gedragingen zou dan niet. zoals naar hierboven bleek wel bij artikel 5.0.8 gebeurt, in het licht van de strekking van de geschonden voorschiften dienen te worden beantwoord. Alsdan beschermt artikel 5.4.1.4 ook tegen het dubbel beboeten van een gedraging die in de termen van meerdere wettelijke bepalingen met verschillende strekking is te vatten. Het zal duidelijk zijn dat hetzelfde dient te worden aangenomen voor artikel 5.4.1.5.438

Zie ik het goed, dan vat de VAR-werkgroep de jurisprudentie van de Hoge Raad toch te ruim op. In het 'Joyriding II-arrest' gaat de Hoge Raad immers niet uit van een materieel feitbegrip. De Hoge Raad bekijkt of een feitelijke handeling (het materieel feit) uiteengerafeld kan worden in meerdere juridische strafbare feiten (formele feiten) neer-

434 Zie in dit kader ook: Hazewinkel-Suringa, bewerkt door Remmelink a.w. 1996, p. 602.

435 HR 17 december 1963, NJ 1964, $385 \mathrm{~m}$. nt. W. Pompe, 'Joyriding II'.

436 Voorontwerp p. 123. Zie cok: VAR-werkgroep a.w. 2000, p. 40-41. Wellicht ten overvloede wordt op deze plaats nogmaals opgemerkt dat in het kader van meerdaadse samenloop bij de oplegging van de afzonderlijke sancties rekening moet worden gehouden met de andere gepleegde feiten (Vgl. artikel 58 $\mathrm{Sr}$ ). Ook de commissie Scheltema gaat er van uit dat de in het kader van meerdaadse samenloop naast elkaar opgelegde sancties tezamen evenredig moeten zijn (Voorontwerp p. 116).

438 VAR-werkgroep a.w. 2000, p. 41 
gelegd in verschillende wettelijke bepalingen. Is dit het geval dan moet op basis van de hierboven weergegeven criteria, zoals neergelegd in het 'Emmense bromfietser-arrest', de vraag worden beantwoord of er (desalniettemin) sprake is van hetzelfde feit in de context van artikel $68 \mathrm{Sr}$. De VAR-werkgroep lijkt genoemde rechtspraak niet aldus te interpreteren en grijpt terug op een concept dat door de Hoge Raad reeds in 1932 is losgelaten. ${ }^{439}$

\section{Intermezzo: rechtspraak van het EHRM in het kader van het ne bis in idem-beginsel}

In hoofdstuk drie is reeds aangegeven dat het ne bis in idem-beginsel uit artikel 4 van het zevende protocol bij het EVRM door Nederland niet is geratificeerd. Ten aanzien van artikel 14, zevende lid, van het IVBPR is door Nederland een voorbehoud gemaakt inhoudende dat uit genoemde bepaling voor Nederland geen verdergaande verplichtingen voortvloeien dan de verplichtingen die voortvloeien uit artikel $68 \mathrm{Sr}^{440}$ Desalniettemin lijkt het de moeite waard een blik te werpen op de rechtspraak van het EHRM. Drie arresten van het Hof zijn in dit kader relevant. In alle te bespreken zaken staat de vraag centraal die ook in de jurisprudentie van de Hoge Raad met betrekking tot artikel $68 \mathrm{Sr}$. de meeste problemen oplevert. Namelijk of er sprake is van hetzelfde feit (the same offence). Vermeldenswaardig is dat de ontwikkelingen in de rechtspraak van het Hof, met betrekking tot het feitbegrip, opvallende parallellen vertonen met de ontwikkeling van het leerstuk door de Hoge Raad. ${ }^{441}$

Het eerste hier te bespreken arrest stamt uit $1995 .{ }^{442}$ In dit arrest, inzake 'Gradinger v. Austria', lijkt het EHRM uit te gaan van een materieel feitbegrip door dood door schuld (gepleegd onder invloed van alcohol) en (het bestuursrechtelijk te handhaven) rijden onder invloed als één feit aan te merken. ${ }^{443}$ Opmerking verdient dat Gradinger in de strafrechtelijke procedure uiteindelijk werd gestraft voor dood door schuld omdat de zwaardere (primair tenlastegelegde) variant, dood door schuld gepleegd onder invloed van alcohol, niet bewezen verklaard werd. Desalniettemin volgt daama een bestuursrechtelijke procedure met betrekking tot het rijden onder invloed. Het EHRM overweegt in genoemd arrest, met betrekking tot de term 'hetzelfde feit', het volgende:

'In reply to $\mathrm{Mr}$ Gradinger's arguments (...), which the Commission endorsed in substance, the Government affirmed that Article 4 of Protocol No. 7 (P7-4) did not preclude applying the two provisions in issue consecutively. The latter were different in nature and pursued different aims: whereas Article 81 para. 2 of the Criminal Code punished homicide committed while under the influence of drink, section 5 of the Road Traffic Act punished the mere fact of driving a vehicle while intoxicated. The former was designed to penalise acts that cause death and threaten public safety, the latter to ensure a smooth flow of traffic. The Court notes that, according to the St Polten Regional Court, the aggravating circumstance referred to in Article 81 para. 2 of the Criminal Code, namely a blood alcohol level of 0.8 grams per litre or higher, was not made out with regard to the applicant. On the

439 Vgl. Van Bemmelen-Van Veen bewerkt door De Jong en Knigge a.w. 1998, p. 254 en de annotatie van Taveme onder het Oude Kijk in 't Jatstraat-arrest; HR 15 februari 1932, NJ 1932, 289.

440 Zie Van Russen Groen a.w. 1998, p. 294 e.v.

441 Zie in dit kader de beschrijving in: Van Bemmelen-Van Veen bewerkt door De Jong en Knigge a.w. 1998 , p. $254-256$.

442 EHRM 23 oktober 1995, Series A 328-C (Gradinger v. Austria).

443 Zie de zaak 'Gradinger' i.h.b. $§ 55$. 
other hand, the administrative authorities found, in order to bring the applicant's case within the ambit of section 5 of the Road Traffic Act, that that alcohol level had been attained. The Court is fully aware that the provisions in question differ not only as regards the designation of the offences but also, more importantly, as regards their nature and purpose. It further observes that the offence provided for in section 5 of the Road Traffic Act represents only one aspect of the offence punished under Article 81 para. 2 of the Criminal Code. Nevertheless, both impugned decisions were based on the same conduct. Accordingly, there has been a breach of Article 4 of Protocol No. 7 (P7-4). ${ }^{444}$

Volgens het Hof verschillen de twee overtreden bepalingen wat betreft hun aard en doel. Toch komt het Hof tot de conclusie dat het, in artikel 4 van het zevende protocol neergelegde, ne bis in idem-beginsel is geschonden. De reden hiervoor is dat beide sancties op hetzelfde handelen van Gradinger gebaseerd zijn. Het Hof hanteert hier derhalve het materieel feitbegrip. ${ }^{45}$

In de drie jaar later gewezen uitspraak in de zaak 'Oliveira' ${ }^{\text {(466 }}$ lijkt het Hof echter een terughoudender standpunt in te nemen door niet langer uit te gaan van het materieel feitbegrip. ${ }^{477}$ Het EHRM bepaalt in die zaak dat één handelen (het veroorzaken van een verkeersongeval) meerdere overtredingen op kan leveren (in casu het niet onder controle houden van een voertuig en het door onachtzaamheid veroorzaken van lichamelijk letsel). Sanctionering van beide overtredingen levert in dat geval volgens het EHRM géén strijd op met artikel 4 van het zevende protocol. ${ }^{48}$ Spijtig genoeg blijft deze uitspraak van het Hof verstoken van een deugdelijke motivering. Het is dan ook moeilijk de zaak 'Gradinger' (in algemene zin ${ }^{449}$ ) met de zaak 'Oliveira' te rijmen.

Kennelijk heeft het Hof dit onderkend. In de zaak 'Fischer ${ }^{1450}$ komt het EHRM dan ook met een nieuw criterium aan de hand waarvan vastgesteld kan worden of het ne bis in idem-beginsel in een concreet geval geschonden wordt. Dit criterium moet tevens het onderscheid tussen de eerder vermelde zaken 'Gradinger' en 'Oliveira' verklaren. ${ }^{451}$

\section{4 'Gradinger' $\$ 54$ en 55}

445 Zoals gezegd heef de Hoge Raad het materiele feitbegrip reeds in 1932 losgelaten i.v.m. de evidente nadelen die daaraan kleefden (in dat kader kan met name gewezen worden op situaties waarin iemand reeds voor een overtreding bestraft was waardoor een misdrijf ongestraft moest blijven).

446 EHRM 30 juli 1998, Reports 1998 -V (Oliveira v. Switzerland).

447 Zie voor een uitvoerige(re) vergelijking en analyse van beide arresten van het Hof ook de annotatie van B.F. Keulen en E.E.V. Lenos onder de zaak 'Oliveira' in het NJCM-bulletin 1999, no. 2, p. 234-240 en H.G.M. Krabbe en W.F. van Hattum, De ne bis in idem-regel in de rechtspraak van het EHRM, DD 2000 , p. 6-20.

448 'Oliveira v. Switzerland' i.h.b. $\$ 25-27$. Opgemerkt zij dat bij vaststelling van de sanctie wegens letsel door schuld rekening werd gehouden met de reeds opgelegde (lage boete) wegens het niet onder controle houden van het voertuig. Het voorgaande neemt $\mathrm{m}$.l. echter niet weg dat er toch sprake is $/ \mathrm{kan} z \mathrm{jjn}$ van een nieuwe berechting van hetzelfde feit. Het bestaan van een dergelijke 'absorptieregeling' mag, zo meen ik, geen rol spelen bij beantwoording van de vraag of er sprake is van 'hetzelfde feit'.

449 De jurisprudentie van het EHRM lijkt ook in het kader van het ne bis in idem-beginsel (erg) casusgericht. De omstandigheden van het concrete geval lijken van doorslaggevend voor de uitkomst van een zaak. Daardoor wordt het vrijwel onmogelijk een lijn te ontwaren in de rechtspraak van het Hof.

450 EHRM 29 mei 2001, no. $37950 / 97$ EHRC 2001/49 m. nt. J. van der Velde (Franz Fischer v. Austria). Zie voorts: J.A.W. Lensing, Een nieuwe worsteling met het feitbegrip bij ne bis in idem, NJCMBulletin 2002, p. 146-153.

451 Opmerking verdient dat Keulen en Lenos in hun annotatie onder de zaak 'Oliviera' het onderscheid tussen die zaak en de zaak 'Gradinger' reeds probeerden te verklaren op een wijze vergelijkbaar met het door het Hof in de zaak 'Fischer' gehanteerde criterium (Keulen en Lenos a.w. 1999, p. 238-239). 
Kernoverweging van het EHRM in de zaak 'Fischer' (die wat de feiten betreft vrijwel vergelijkbaar is met de zaak 'Gradinger'):

'Thus, while it is true that the mere fact that a single act constitutes more than one offence is not contrary to this Article, the Court must not limit itself to finding that an applicant was, on the basis of one act, tried or punished for nominally different offences. The Court. like the Austrian Constitutional Court, notes that there are cases where one act, at first sight, appears to constitute more than one offence, whereas a closer examination shows that only one offence should be prosecuted because it encompasses all the wrongs contained in the others (...). An obvious example would be an act which constitutes two offences, one of which contains precisely the same elements as the other plus an additional one. There may be other cases where the offences only slightly overlap. Thus, where different offences based on one act are prosecuted consecutively, one after the final decision of the other, the Court has to examine whether or not such offences have the same essential elements. (...) What is decisive in the present case is that, on the basis of one act, the applicant was tried and punished twice, since the administrative offence of drunken driving under sections 5 (1) and 99 (1)(a) of the Road Traffic Act, and the special circumstances under Article $81 \S 2$ of the Criminal Code, as interpreted by the courts, do not differ in their essential elements.'

Doorslaggevend lijkt derhalve te zijn of de afzonderlijke delictsomschrijvingen met betrekking tot de wezenlijke bestanddelen (en elementen) overeenkomen. Is dit het geval dan mag slechts één van beide overtredingen (of misdrijven) gesanctioneerd worden. Het Hof heeft met deze uitspraak in ieder geval duidelijkheid geschapen.

\section{Resumé: criteria ter vaststelling of sprake is van hetzelfde feit}

Aan de hand van de hierboven weergegeven beschrijving kan geconcludeerd worden dat zowel de Hoge Raad, het EHRM, als de commissie Scheltema uitgaan van een vergelijkbaar feitbegrip in de context van het ne bis in idem-beginsel. Geen van drieën hanteert een materieel feitbegrip teneinde te bepalen of er sprake is van bis in idem. Één feitelijke handeling kan volgens de twee genoemde rechterlijke instanties en de commissie toch meerdere formele (strafbare) feiten opleveren. De criteria die zij hanteren ter beantwoording van de vraag of deze verschillende formele feiten toch hetzelfde feit betreffen in de context van het ne bis in idem-beginsel verschillen, doch slechts gradueel. Hantering van de verschillende criteria lijkt daardoor in de regel tot hetzelfde resultaat te leiden.

\section{Commentaar op de voorgestelde ne bis in idem-regeling}

De commissie Scheltema gaat er van uit dat bestuursorganen die bevoegd zijn tot het opleggen van bestuurlijke boeten, bij de toepassing van artikel 5.4.1.4 van het Voorontwerp, aansluiting zoeken bij de strafrechtelijke jurisprudentie in het kader van artikel $68 \mathrm{Sr}$. Uit rechtspraak blijkt echter dat de bestuursrechter niet altijd even eenvoudig uit de voeten kan met rechtstreekse toepassing van de jurisprudentie van de Hoge Raad en de door de commissie voorgestelde regeling. ${ }^{452}$ Hoe zit het bijvoorbeeld als een boetebesluit in bezwaar door het bestuursorgaan, of in (hoger) beroep door de bestuursrechter wordt vernietigd? Mag een bestuursorgaan dan nogmaals een boete opleggen of levert dat strijd op met artikel 5.4.1.4 van het Voorontwerp? Ook in dit kader wreekt de 
eigen aard van het bestuursprocesrecht zich. Mijns inziens heeft de commissie Scheltema in het Voorontwerp ten onrechte geen aandacht geschonken aan dit probleem. ${ }^{453}$ Uit het Voorontwerp, en de toelichting daarbij, valt in onvoldoende mate af te leiden wanneer er in het punitieve bestuursrecht gesproken kan worden van bis in idem. Alvorens op deze lacune nader ingegaan wordt volgt echter nog een opmerking van andere aard.

De commissie Scheltema komt in de toelichting niet tot een consistente interpretatie van het ne bis in idem-beginsel. In de toelichting op artikel 5.4.1.4 Voorontwerp wordt eerst verwezen naar artikel $68 \mathrm{Sr}$ inhoudende dat niemand ten tweede male kan worden vervolgd indien de rechter reeds onherroepelijk uitspraak heeft gedaan over hetzelfde feit. Daama wordt in de toelichting ten aanzien van het ne bis in idem-beginsel het volgende gesteld: 'Niettemin wordt algemeen aangenomen dat ook in het bestuursrecht behoort te gelden dat niemand tweemaal mag worden gestraft voor dezelfde overtreding.' Het strafrechtelijke equivalent (artikel $68 \mathrm{Sr}$ ) van artikel 5.4.1.4 Voorontwerp, waarbij de commissie Scheltema met artikel 5.4.1.4 Voorontwerp aansluiting lijkt te willen zoeken, behelst echter het niet ten tweede male vervolgd kunnen worden ongeacht de inhoud van de onherroepelijk geworden uitspraak. Dat is iets anders dan het niet ten tweede male gestraft kunnen worden voor dezelfde overtreding. Er is derhalve sprake van een discrepantie tussen artikel $68 \mathrm{Sr}$ en de interpretatie van de commissie Scheltema van het ne bis in idem-beginsel. Bovendien wijkt de commissie daarmee ook af van de door het EHRM in de zaak 'Fischer' aan het ne bis in idem-beginsel gegeven uitleg. ${ }^{454}$ Of de commissie Scheltema in de toelichting bewust gekozen heeft voor de fornulering 'niet tweemaal mag worden gestraft' is mij niet duidelijk.

Toepassing van het ne bis in idem-beginsel bij de oplegging van bestuurlijke boeten lijkt, zoals gezegd, niet eenvoudig te zijn. Wanneer is er sprake van bis-in-idem? Gelet op de redactie van artikel $68 \mathrm{Sr}$ lijkt het zo te zijn dat er sprake is van bis in idem als ten tweede male een boeteprocedure wordt gevolgd ten aanzien van dezelfde onrechtmatige handeling. Deze onrechtmatige handeling moet bovendien kunnen worden aangemerkt als 'hetzelfde feit' zoals nader uiteengezet in de jurisprudentie van de Hoge Riad.

Malar hoe zit het dan in een geval waarin het primaire boetebesluit gedurende een beroepsprocedure bij de rechter door het bestuursorgaan wordt ingetrokken en vervangen door een nieuw boetebesluit? Moet de rechter dat nieuwe besluit dan meenemen op grond van artikel 6:18 en 6:19 Awb, of zou dat in strijd zijn met het ne bis in idembeginsel? En wat als de bestuursrechter, in beroep of hoger beroep, het boetebesluit vernietigt en het bestuursorgaan opdraagt een nieuw besluit te nemen? Is dat, met het oog op het ne bis in idem-beginsel toegestaan? Ik bespeur hier toch duidelijk een hiaat in het Voorontwerp. Het lijkt er op dat de commissie Scheltema deze problemen over het hoofd heeft gezien bij de totstandkoming van artikel 5.4.1.4. ${ }^{455}$

453 Later in deze paragraaf zal ik aangeven hoe deze problemen m.i. ondervangen kunnen worden.

454 Zie die hierboven aangchaalde passage uit de zaak 'Fischer'.

455 Hierna zal ik aangeven in hoeverre deze typisch bestuursprocesrechtelijke problemen opgelost zouden kunnen worden. 
Volledigheidshalve schets ik hier kort de consequenties van onverkorte toepassing van het bestuursprocesrechtelijke stelsel van vernietigen en opnieuw voorzien. De vernietiging van het boetebesluit door de bestuursrechter werkt ex tunc. Dit brengt met zich dat het boetebesluit wordt geacht nooit bestaan te hebben. Het ne bis in idem-beginsel zou echter geen enkele functie hebben als de situatie na vernietiging gelijk gesteld zou worden met de situatie waarin daadwerkelijk nog geen bestuurlijke boete is opgelegd. Indien het bestuursorgaan, na vernietiging van het boetebesluit, geacht wordt wederom bevoegd te zijn een bestuurlijke boete op te leggen levert dat mijns inziens strijd op met het ne bis in idem-beginsel. Er kan dan immers gesproken worden van een tweede vervolging ten aanzien van hetzelfde feit. De commissie Scheltema lijkt echter wel uit te gaan van de mogelijkheid voor het bestuursorgaan om in de hierboven weergegeven situatie 'opnieuw te voorzien'. 456

Ook hier manifesteert zich weer het probleem dat met de bestuurlijke boete een van oorsprong strafrechtelijke sanctie is ingevoerd in het bestuursrecht terwijl het bestuurs(proces)recht dermate afwijkt van het straf(proces)recht dat dit onherroepelijk tot complicaties leidt.

Binnen het huidige bestuurs(proces)rechtelijke systeem lijkt effectieve handhaving niet mogelijk te zijn indien strikt de hand wordt gehouden aan het ne bis in idem-beginsel zoals neergelegd in artikel $68 \mathrm{Sr}$. Indien echter de bestuursrechter, met betrekking tot de toetsing van boetebesluiten, wordt geoutilleerd met meer bevoegdheden dan gebruikelijk is in het bestuursprocesrecht zou dit probleem vrij eenvoudig ondervangen kunnen worden. Het gaat er dan met name om dat de bestuursrechter besluiten tot oplegging van een bestuurlijke boete in alle gevallen én op alle punten (dus niet alleen wat de hoogte betreft) vol moet kunnen toetsen. Dit impliceert dat hij tevens in alle gevallen zelf in de zaak moet kunnen voorzien. ${ }^{457}$

Misschien is het dan ook beter als er ten aanzien van boetebesluiten, om bis in idem te voorkomen, een andere lijn wordt gevolgd dan normaal gesproken in het bestuursprocesrecht gebruikelijk is. De volgende procedure lijkt mij ten aanzien van boetebesluiten verdedigbaar. Het bestuursorgaan krijgt eventueel ${ }^{458}$ één keer de kans om het boetebesluit te wijzigen of aan te passen, namelijk door een besluit op bezwaar te nemen. Daarna geeft het bestuursorgaan het besluit uit handen. Blijkt het boetebesluit in beroep of hoger beroep geen stand te kunnen houden dan is het aan de rechter om, zelf in de zaak voorziend, een andere boete (of zelfs geen boete) op te leggen. De bestuursrechter zou, wat betreft de invulling van zijn taak, in ieder geval in essentie aansluiting moeten zoeken bij de regeling uit het wetboek van Strafvordering.

Het verdient opmerking dat met de voorgestelde procedure de rechtszekerheid is gediend terwijl daamaast beter invulling kan worden gegeven aan het redelijke termijn-

$456 \mathrm{Vgl}$. Voorontwerp, p. 125-126.

$457 \mathrm{Vgl}$. Albers en Schlossels a.w. 2002, §9.3.

458 Mijns inziens zou het beter zijn de bezwaarschriftprocedure in het kader van bestuurlijke boeten 'over te slaan'. Wellicht bevordert dit de zorgvuldige voorbereiding van het primaire besluit (géen boetefabriek) terwijl de (vermoedelijke) overtreder bovendien sneller toegang heeft tot een onafhankelijke en onpartijdige rechter. In het slotdeel zal hier nog op teruggekomen worden. Vgl. voorts: Albers en Schiossels a.w. 2002, $\S 4.5$. 
vereiste. Bij voorkeur zou de voorgestelde regeling neer moeten worden gelegd in een wet in formele zin. Doch niet zonder meer in de Awb. ${ }^{459}$

\section{Artikel 5.4.1.5 het una via-beginsel}

In artikel 5.4.1.5 van het Voorontwerp is het una via-beginsel ${ }^{460}$ neergelegd. Het una via-beginsel impliceert dat, wanneer ter zake van een gedraging die zowel strafrechtelijk als bestuursrechtelijk kan worden afgedaan, eenmaal een keuze is gemaakt voor de ene of de andere weg, en de daarbij behorende handelingen zijn verricht, deze weg als definitief moet worden aangemerkt. ${ }^{461}$ Het una via-beginsel is nauw verwant aan het ne bis in idem-beginsel. Men zou kunnen stellen dat het una via-beginsel een specialis is van het ne bis in idem-beginsel. ${ }^{462}$ Ook in het kader van artikel 5.4.1.5 is het, hierboven weergegeven, leerstuk (van de Hoge Raad) met betrekking tot 'hetzelfde feit' derhalve relevant.

Het voorgestelde artikel telt drie leden en luidt als volgt:

'1. Het bestuursorgaan legt geen bestuurlijke boete op indien tegen de overtreder wegens dezelfde gedraging:

a. een strafvervolging is ingesteld en het onderzoek ter terechtzitting is begonnen, of

b. het recht tot strafvordering is vervallen ingevolge artikel 74 of $74 \mathrm{c}$ van het Wetboek van Strafrecht, dan wel ingevolge artikel 37 van de Wet op de economische delicten.

2. Indien de gedraging tevens een strafbaar feit is, wordt zij aan het openbaar ministerie voorgelegd, tenzij bij wettelijk voorschrift is bepaald, dan wel met het openbaar ministerie is overeengekomen, dat daarvan kan worden afgezien.

3. Voor een gedraging die aan het openbaar ministerie moet worden voorgelegd, legt het bestuursorgaan slechts een bestuurlijke boete op indien:

a. het openbaar ministerie heeft medegedeeld van strafvervolging tegen de overtreder af tie zien, of

b. sedert het voorleggen van de gedraging dertien weken zijn verstreken en geen reactie van het openbaar ministerie is ontvangen.'

Dit irtikel ziet, zoveel is duidelijk, op de verhouding tussen bestuurlijke boeten en strafrechtelijke sancties. ${ }^{463}$ Is ten aanzien van een bepaalde gedraging reeds een strafrechtelijke sanctie opgelegd, dan kan ten aanzien van diezelfde gedraging niet ook nog een bestuursrechtelijke punitieve sanctie worden opgelegd, en vice versa. ${ }^{464}$

459 Ik kom hier later nog op terug.

460 Zie in dit kader ook de dissertatie van L.J.J. Rogier: Strafsancties, bestuursrechtelijke sancties en het una via-beginsel, disss. EUR, Arnhem 1992.

461 Zie in deze zin ook: Kamerstukken II, 1994/95, 23 909, nr. 3, p. 20.

462 Zie ook Van Russen Groen a.w. 1998, p. 296. Hij spreekt over 'een ne bis in idem-beginsel tussen verschillende rechisgebieden.'

463 Zie in het kader van deze bepaling uit het Voorontwerp: L.J.J. Rogier, Una via, in de bundel: Commentaren op het Voorontwerp Algemene wet bestuursrecht Vierde tranche, onder redactie van L.J.J. Rogier, Rotterdam 2000, i.h.b. p. 91-109.

464 Gelet op het feit dat het bij het una via-beginsel dus gaat om cumulatie van een punitieve bestuursrechtelijke en een punitieve strafrechtelijke sanctie zal ook in het Wetbock van Strafvordering moeten worden voorzien in een regeling waarmee dubbele vervolging (en/of bestraffing) wordt tegengegaan. In het Voorontwerp is daarom voorzien in een spiegelbeeldbepaling die zal worden neergelegd in artikel $243 \mathrm{~Sv}$ 
Opgemerkt zij dat de Hoge Raad inmiddels, anders dan in de tachtiger en negentiger jaren van de vorige eeuw ${ }^{45}$, ook het una via-beginsel in acht lijkt te nemen. In dit kader kan gewezen worden op een arrest van de Hoge Raad van 12 januari $1999^{466}$ waarin het hoogste rechtscollege, met betrekking tot het una via-beginsel het volgende heeft overwogen:

'...Voorts verzet het wettelijk stelsel zich ertegen enerzijds dat, indien een strafrechtelijke vervolging is ingesteld ter zake van overtreding van art. 5 WVW 1994 nadien een administratieve sanctie wordt opgelegd ter zake van een of meer gedragingen die deel uitmaken van het strafrechtelijk verweten verkeersgedrag en anderzijds dat, indien ter zake van een gedraging een administratieve sanctie is opgelegd, die gedraging in aanmerking wordt genomen bij de beoordeling van de vraag of het verkeersgedrag als een overtreding van art. 5 WVW $1994 \mathrm{zal}$ worden vervolgd.'

Zodra strafvervolging is ingesteld en het onderzoek ter terechtzitting is begonnen is de bestuursrechtelijke weg, volgens het Voorontwerp, afgesloten, ongeacht de uitkomst ${ }^{467}$ van de strafzaak. Hetzelfde geldt als het OM een transactie aanbiedt die door de overtreder wordt aanvaard. ${ }^{468}$ Volgens een aantal juristen ligt in het Voorontwerp het omslagpunt, waama niet meer kan worden gekozen voor bestuursrechtelijke afdoening, in de tijd te ver naar achteren. ${ }^{469}$ De VAR-werkgroep stelt daaromtrent het volgende:

'Opgemerkt zij echter dat:

1. voorafgaand aan het onderzoek ter terechtzitting vele, zo niet alle ingrijpende dwangmiddelen in het kader van strafvordering op de verdachte kunnen worden toegepast. Nadat deze dwangmiddelen zijn toegepast en het Openbaar Ministerie de

465 Zie: HR 28 mei 1985, NJ 1986, 127. Nadat een bestuurlijke boete was opgelegd wegens het reizen met een vervalst plaatsbewijs werd de overtreder ook nog eens strafrechtelijk vervolgd wegens valsheid in geschrifte. Het beroep van de overtreder op artikel $68 \mathrm{Sr}$. werd door de Hoge Raad niet gehonoreerd. De Hoge Raad verwijst daartoe naar de door het hof aangevoerde gronden: 'dat het hof het door de raadsman gevoerde verweer dat de OvJ geen strafvervolging meer kon instellen, omdat verdachte het door de Nederlandse Spoorwegen gevorderde bedrag, inclusief een administratieve boete, reeds heeft betaald en art. 20 Algemeen Reglement Vervoer een lex specialis is ten opzichte van art. $225 \mathrm{Sr}$, verwerpt, aangezien betaling van de in art. 20 Algemeen Reglement Vervoer genoemde administratieve boete niet met zich brengt, dat het OM geen vervolging meer kan instellen, zich hier niet een geval voordoet, bedoeld in de art. 68 e.v. Sr en verdachte niet uit het betalen van de administratieve boete het vertrouwen heeft mogen ontlenen dat de OvJ ter zake van het ten laste gelegde feit niet meer tot vervolging kon overgaan'. Er van uit gaande dat in casu sprake was van hetzelfde feit wordt het ne bis in idem-beginsel, of meer in het bijzonder het una via-beginsel, door de Hoge Raad (vooralsnog) niet erkend. Zie in deze context voorts: HR 5 februari 1991, NJ 1991, 402, en voor wat betreft de bestuursrechtelijke colleges: CRvB 21 december 1993, RSV 1994/132 m. nt. H.A. Demeersseman, AGRvS 24 april 1992, AB 1992, 575 m. nt. Stellinga en AGRvS 15 mei 1992, AB 1993, 386 m. nt. A.F.M. Brenninkmeijer.

466 HR 12 januari 1999, NJ 1999, 289.

467 Dus ook in een geval van vrijspraak, ontslag van rechtsvervolging of niet-ontvankelijkheid van het OM (zie Voorontwerp p. 124).

468 De commissie Scheltema geeft de bijzondere wetgever op deze wijze de mogelijkheid te kiezen voor het zogenaamde B-model uit het CTW-rapport (a.w. 1994, p. 68 e.v.), waarbij strafrechtelijke handhaving van dezelfde overtreding niet reeds in de wet wordt uitgesloten. In genoemde rapport spreekt de Toetsingcommissie overigens expliciet de voorkeur uit voor model A waarin de wetgever in de wet in formele zin op alle punten de norm stelt. Met model A wordt duidelijkheid geschapen, tevens dient dit model volgens de Toetsingscommissie de rechtszekerheid (a.w. 1994, p. 70).

Zie bijvoorbeeld de VAR-werkgroep 2000, p. 41-42 en 68-69. 
conclusie trekt dat geen vervolging zal worden ingesteld, blijft het opleggen van een bestuurlijke boete nog steeds mogelijk;

2. ingeval de verdachte tijdens de strafrechtelijke vervolging besluit om een bezwaarschrift tegen de dagvaarding of de kennisgeving van verdere vervolging in te dienen (art. 250 en $262 \mathrm{~Sv}$ ) en de raadkamer van de rechtbank besluit tot gegrondverklaring en de verdachte buiten vervolging stelt, het op grond van artikel 5.4.1.5 mogelijk blijft dat een bestuursorgaan de overtreder/voorheen verdachte alsnog een boete oplegt. Immers het onderzoek ter terechtzitting is nog niet begonnen. ${ }^{470}$

Gelet op het voorgaande vraagt de VAR-werkgroep zich dan ook af op deze wijze een juiste invulling wordt gegeven aan het una via-beginsel.

Omgekeerd zijn er ook auteurs die menen dat het moment waarop alsnog voor strafrechtelijke handhaving gekozen kan worden in de tijd te ver naar achteren ligt. ${ }^{471}$ Rogier wijst er in dit kader op dat het bestuur, alvorens de zaak te verwijzen naar het OM, gebruik kan maken van ingrijpende toezichtsbevoegdheden. De betrokkene dient op grond van hoofdstuk $5 \mathrm{Awb}$ medewerking te verlenen aan de uitoefening van genoemde toezichtsbevoegdheden. 'Zo wordt de bestuursrechtelijke toezichtsfase een voortraject voor het strafrechtelijk onderzoek.' aldus Rogier. ${ }^{42}$ Als de betrokkene op genoemde wijze achtereenvolgens verzeild raakt in twee verschillende procedures zou er, volgens Rogier, sprake kunnen zijn van strijd met het nemo debet bis vexari-beginsel. Laatstgenoemd beginsel, dat deel uit maakt van het ne bis in idem (en una via)beginsel, brengt met zich 'dat niet alleen dubbele bestraffing dient te worden voorkomen, maar ook een dubbele strafprocedure, waarin de betrokkene andermaal over hetzelfde feit wordt 'lastiggevallen'. ${ }^{473} \mathrm{Ik}$ vraag me af of dit beginsel zo ruim opgevat moet worden. Impliceert het niet met name dat na bijvoorbeeld vrijspraak of ontslag van rechtsvervolging ten aanzien van hetzelfde feit niet nog eens een strafrechtelijke of punitieve bestuursrechtelijke procedure mag worden gevolgd? ${ }^{474}$

Toch meen ook ik dat het 'point of no return', zoals Rogier dat noemt, te ver in de tijd naar achteren ligt. Dit geldt evenzeer voor het moment waarop alsnog voor de bestuursrechtelijke weg gekozen kan worden. In dit kader moet niet uit het oog verloren worden dat de commissie Scheltema én de bestuursrechters momenteel erg ruimhartig zijn wat betreft de toelaatbaarheid van strafrechtelijk onrechtmatig verkregen bewijs in een bestuursrechtelijke procedure. Zijn er fouten gemaakt bij de strafrechtelijke bewijsgaring dan kan, op basis van de voorgestelde regeling, altijd nog 'geswitcht' worden. De bestuursrechter gaat immers vrij soepel om met strafrechtelijk onrechtmatig verkregen bewijs. Bestraffing van de overtreder lijkt op deze wijze doorgaans dan ook gerealiseerd te kunnen worden. Men kan zich bovendien afvragen of de toelaatbaarheid van strafrechtelijk onrechtmatig verkregen bewijs in een procedure tot oplegging van een bestuurlijke boete, in samenhang met artikel 5.4.1.5 van het Voorontwerp, op deze wijze niet het oneigenlijk gebruik of misbruik van opsporingsbevoegheden in de hand

470 VAR-werkgroep 2000, p. 41.

471 Zie: Rogier a.w. 2000, p. 99-102. Hij stelt als 'point of no retum' voor het moment waarop (op grond van artikel 5.0.11 van het Voorontwerp) het zwijgrecht in zou gaan. Alsdan zou ook de keuze voor de bestuursrechtelijke dan wel strafrechtelijke weg definitief gemaakt moeten worden (a.w. p. 108). Rogier a.w. 2000, p. 101.

473 Rogier a.w. 2000, p. 101, zie voorts: Hazewinkel-Suringa, bewerkt door Remmelink a.w. 1996, p. 603.

Vgl. Van Bemmelen-Van Veen bewerkt door De Jong en Knigge a.w. 1998, p. 253. 
werkt. Mijns inziens is dergelijk misbruik of oneigenlijk gebruik bij invoering van de voorgestelde regeling niet uitgesloten. Reden te meer voor de commissie Scheltema derhalve om nogmaals te bezien of het 'point of no retum' in de tijd niet verder naar voren kan worden geschoven.

\section{Artikel 5.4.1.6 Vervaltermijnen}

In artikel 5.4.1.6 van het Voorontwerp is een regeling getroffen omtrent het verval van de bevoegdheid tot het opleggen van een bestuurlijke boete. ${ }^{475}$ De bevoegdheid tot het opleggen van een boete vervalt, bij overtredingen waarvoor een (maximum) boete van minder dan 340 Euro kan worden opgelegd, twee jaar nadat de overtreding heeft plaatsgevonden. Deze termijn van twee jaar komt overeen met de verjaringstermijn van strafrechtelijke overtredingen. ${ }^{476}$ De bevoegdheid tot het opleggen van een boete vervalt, bij overtredingen waarvoor een (maximum) boete van meer dan 340 Euro kan worden opgelegd, vijf jaar nadat de overtreding heeft plaatsgevonden. ${ }^{477}$ Gedurende bezwaar en beroep wordt de vervaltermijn opgeschort totdat onherroepelijk op beroep of bezwaar is beslist. Het bestuursorgaan moet ambtshalve nagaan of de termijn van twee, respectievelijk vijf jaar nog niet is verstreken op het moment dat het over wil gaan tot het opleggen van een boete. ${ }^{478}$

De commissie Scheltema heeft bewust gekozen voor de term 'vervaltermijn' omdat de term 'verjaring' in de context van de Awb tot het misverstand zou kunnen leiden dat overschrijding van de termijn slechts aan het opleggen van een boete in de weg zou staan indien de overtreder zich op de termijnoverschrijding beroept. Het bestuursorgaan moet, gelet op het stelstel van ons algemeen bestuursrecht, volgens de commissie, echter ook ambtshalve nagaan of de termijn van respectievelijk twee of vijf jaar verstreken is. ${ }^{479}$ De commissie Scheltema verwijst in dit kader naar de regeling omtrent verjaring en verval van bestuursrechtelijke geldschulden zoals voorgesteld in artikel 4.4.3.1 en verder van het Voorontwerp.

De regeling omtrent verjaring en verval is echter, anders dan het, aan het strafrecht gelieerde, voorgestelde artikel 5.4.1.6 van het Voorontwerp, gebaseerd op het civiele recht. De commissie lijkt de strafrechtelijke term verjaring en de civielrechtelijke termen verjaring en verval ${ }^{480}$ onder te willen brengen in éen bestuursrechtelijk leerstuk. Dit is mijns inziens vreemd en onzuiver. Voor de beantwoording van de vraag of voor een overtreding nog een boete kan worden opgelegd kan gesproken worden van verjaringstermijnen, analoog aan artikel $70 \mathrm{Sr}$. Voor de vraag of het boetebedrag van de

475 Het gaat derhalve om de termijn waarbinnen de boete opgelegd moet worden. Daarnaast geldt voor betaling en invordering van de boete de, eveneens in het Voorontwerp voorgestelde, regeling met betrekking tot verjaring en verval van bestuursrechtelijke geldschulden.

476 Voorontwerp p. 125, zie voorts artikel 70 onder I Sr.

477 Men kan zich overigens afvragen in hoeverre de commissie Scheltema zich in het kader van de regeling met betrekking tot de vervaltermijnen rekenschap heeft gegeven van situaties waarin sprake is van een voortgezette handeling, een ommissiedelict, of een voortdurend delict (Vgl. Corstens a.w. 1999, p. 200).

478 Voorontwerp p. 125.

479 Voorontwerp p. 125.

480 Vgl. J.M.H.F. Teunissen, Verjaring en verval bij publiekrechtelijke geldvorderingen, Gst. 7085, p. 549 553 i.h.b. 553. 
opgelegde boete na de voorgeschreven betalingstermijn nog in rechte gevorderd kan worden geldt de, op civielrechtelijke leest geschoeide, voorgestelde regeling omtrent verjaring en verval van bestuursrechtelijke geldschulden. ${ }^{481}$

Van der Hulst uit zich kritisch over de 'vervaltermijn' van vijf jaar die geldt bij de hogere boeten. In vergelijking met de verjaringstermijnen in het strafrecht is deze termijn volgens hem vrij lang. Deze termijn ligt dicht aan tegen de verjaringstermijn van zes jaar die in het strafrecht geldt voor misdrijven waarop een gevangenisstraf van niet meer dan drie jaar is gesteld. ${ }^{482}$ Bij deze misdrijven is het verwijt dat aan de dader gemaakt wordt doorgaans ernstiger dan bij (strafrechtelijke) overtredingen die slechts met een boete kunnen worden gehandhaafd. Van der Hulst pleit dan ook voor een korlere vervaltermijn, van maximaal drie jaar, bij boeten van meer dan 340 Euro. ${ }^{483} \mathrm{Ik}$ kan me wel vinden in deze redenering van Van der Hulst. Het zou immers vreemd zijn als in het strafrecht voor alle overtredingen, dus ook die waarop een boete staat van méér dan 340 Euro, een verjaringstermijn geldt van twee jaar terwijl bij de regeling van de bestuurlijke boete voor zwaardere overtredingen een langere vervaltermijn bestaat. Hierbij dient niet uit het oog verloren te worden dat overtredingen die nu gehandhaafd worden met bestuurlijke boeten voorheen veelal als strafrechtelijke overtreding werden afgedaan. Terecht zou kunnen worden opgemerkt dat daar tegenover staat dat in het bestuurs(straf)recht in bepaalde gevallen aanmerkelijk hogere boeten op kunnen worden gelegd dan het reguliere strafrecht. Zo kan een boete die op grond van de Mededingingswet wordt opgelegd in de miljoenen Euro's lopen. Dit lijkt echter geen reden te zijn voor een langere verjaringstermijn te pleiten. De boeten zijn in het kartelrecht immers niet zo hoog vanwege de ernst van de overtreding. De samenleving zal door een schending van de mededingingwetgeving in beginsel niet in grotere mate geschokt zijn dan door schending van de inlichtingenplicht door een bijstandsgerechtigde (waarvoor een aanmerkelijk lagere boete wordt opgelegd). De boete is met name zo hoog omdat het punitieve effect pas kan worden bereikt als eerst het financieel voordeel weg is genomen.

\section{Artikel 5.4.1.7 de hoogte van de boete, legaliteit en evenredigheid}

\section{Maximum boete}

Artikel 5.4.1.7 van het Voorontwerp bestaat uit vier leden waarin onder meer invulling is gegeven aan het legaliteitsvereiste en het evenredigheidsbeginsel. De vier artikelleden zullen achtereenvolgens besproken worden. Uit het eerste lid van artikel 5.4.1.7 van het Voorontwerp volgt dat de wet de bestuurlijke boete, die wegens een bepaalde overtreding ten hoogste kan worden opgelegd, dient te bepalen. Met deze bepaling sluit de commissie Scheltema, naar eigen zeggen, aan bij de gangbare uitleg van artikel $89 \mathrm{Gw}$ op basis waarvan in de wet slechts het maximum van de op te leggen boete

$48 \mathrm{~V} \mathrm{Vgl}$. Voorontwerp p. 126. Mevis wijst er overigens op dat de regeling tot invordering bij bestuurlijke boeten daarmee afwijkt van de regeling tot invordering in het kader van het strafrecht. Vgl. P.A.M. Mevis in de noot onder HR 10 oktober 2000, NJ 2001, 266.

482 Zie artikel 70 onder $2 \mathrm{Sr}$.

483 Van der Hulst a.w. 2000a, p. 73. 
moet zijn aangegeven. ${ }^{484}$ Het is in dat kader volgens genoemde commissie voorts niet uitgesloten in de wet slechts één boetemaximum op te nemen voor meerdere overtredingen (van verschillende aard). ${ }^{485}$

In de nu bestaande boeteregelingen variëren de maximum boeten aanzienlijk. Ter illustratie kan gewezen worden op de maximum boete van 340 Euro in de Wet administratiefrechtelijke handhaving verkeersvoorschriften (WAHV) ${ }^{486}$ in vergelijking met de in de Mededingingswet $(\mathrm{Mw})$ opgenomen maximum boete van 450.000 Euro of, indien dat meer is, $10 \%$ van de omzet van de ondememing. ${ }^{487}$ Op basis van het voorgestelde artikel 5.4.1.7 eerste lid kan deze variatie gehandhaafd blijven. De bijzondere wetgever wordt hiermee in de gelegenheid gesteld maatwerk te leveren.

Men zou kunnen stellen dat er een scheefgroei ontstaat tussen de in het strafrecht voor een overtreding maximaal op te leggen boete van 4.500 Euro $^{488}$ en de in het bestuursstrafrecht op te leggen maximum boeten. Van der Hulst meent dan ook dat de hoogte van de (bestuurlijke) boete voor alle deelterreinen in absolute zin gemaximeerd zou moeten worden. Hij wenst in dat kader aansluiting te zoeken bij het strafrecht:

'Aangezien het verwijt dat de overtreder gemaakt kan worden in het strafrecht en het bestuurlijk sanctierecht vergelijkbaar is, zou het voor de hand liggen om ook de absolute hoogte van de bestuurlijke boete te beperken tot $f$ 10.000,-per overtreding. ${ }^{489}$

Inderdaad gaat het bij de met een bestuurlijke boete te sanctioneren normschendingen (wellicht zonder uitzondering) om handelingen die in het strafrecht als overtreding zouden worden gekwalificeerd. Toch ziet Van der Hulst mijns inziens hierbij een niet onbelangrijk aspect over het hoofd. Een punitieve sanctie, zoals de bestuurlijke boete, moet haar naam eer aan doen. Wil zij het beoogde, bestraffende effect hebben dan zal de boete in ieder geval hoger moeten zijn dan het met de normschending door de overtreder behaalde (financiële) voordeel. Met een maximum boete van 4.500 Euro zou, bijvoorbeeld in het mededingingsrecht en fiscale recht, dit doel in veel gevallen niet bereikt worden. Mijns inziens verdient het dan ook de voorkeur te werken met boetemaxima die per bijzondere wet verschillen en die zijn toegespitst op de karakteristieken van de specifieke, in die wet geregelde, materie.

\section{Evenredigheidsbeginsel}

In het tweede lid van artikel 5.4.1.7 is het evenredigheidsbeginsel neergelegd. De bepaling luidt als volgt:

'Tenzij de hoogte van de bestuurlijke boete bij wettelijk voorschrift is vastgesteld, stemt het bestuursorgaan de hoogte van de bestuurlijke boete af op de emst van de overtreding en de mate waarin deze aan de overtreder kan worden verweten. Het bestuursorgaan houdt daarbij zo nodig rekening met de omstandigheden waaronder de overtreding is gepleegd.' 
Indien de wet slechts boetemaxima bevat moet het bestuursorgaan per overtreding een passend boetebedrag vaststellen. Daarbij moet het rekening houden met de ernst van de overtreding, de mate van verwijtbaarheid en de omstandigheden waaronder de overtreding is gepleegd. In bepaalde gevallen kan voorts de draagkracht van de overtreder een rol spelen. ${ }^{490}$

Volgens de commissie Scheltema vloeit het evenredigheidsbeginsel in de eerste plaats voort uit artikel 6 EVRM. ${ }^{491}$ Op zich is deze opmerking juist. Een kleine kanttekening lijkt in dit kader echter op zijn plaats. Van belang is namelijk dat het evenredigheidsbeginsel in het kader van het EVRM met name een rol lijkt te spelen voor wat betreft de toetsingsbevoegdheid van de rechter. Uit rechtspraak van het ERHM blijkt namelijk dat er op grond van artikel 6 EVRM sprake dient te zijn van een daadwerkelijke toegang tot een rechter die beschikt over een volledige toetsingsbevoegdheid ('full jurisdiction' $^{492}$ terwijl die rechter ook voor het overige dient te voldoen aan alle waarborgen die in artikel 6 EVRM zijn neergelegd.

Ten aanzien van (de beoordeling van) besluiten van bestuursorganen heeft het EHRM met het oog op het vereiste van 'full jurisdiction' volgende bepaald:

'The Court reiterates that decisions taken by administrative authorities which do not themselves satisfy the requirements of Article 6 para. 1 (art. 6-1) of the Convention (...) must be subject to subsequent control by a "judicial body that has full jurisdiction" (..... ${ }^{A 9}$

Het EHRM definieert de term 'full jurisdiction' in de zaak Gradinger als: 'the power to quash in all respects, on questions of fact and law, the decision of the body below..$^{494}$ De nationale rechter zal doorgaans dan ook bevoegd moeten zijn tot het toetsen van de evenredigheid van de opgelegde punitieve sanctie ten opzichte van de ernst van de overtreding teneinde te voldoen aan het vereiste van 'full jurisdiction'. ${ }^{495}$ Indien een rechter niet in de mogelijkheid verkeert om de evenredigheid van een opgelegde sanctie te toetsen levert dit doorgaans ${ }^{496}$ strijd op met artikel 6 EVRM.

Het evenredigheidsbeginsel maakt ook deel uit van ons nationale bestuurs(proces)recht. Genoemd beginsel is neergelegd in artikel 3:4, tweede lid, van de Awb. Met deze Awbbepaling richt de wetgever zich in eerste instantie tot het bestuur. Dit impliceert dat bestuursorganen zich er rekenschap van dienen te geven dat besluiten, die op basis van een beleidsvrije bevoegdheid kunnen worden genomen, in overeenstemming met het evenredigheidsbeginsel tot stand komen. Daarnaast kan de bestuursrechter artikel 3:4,

490 Voorontwerp p. 127. De commissie Scheltema verwijst daarbij naar artikel $24 \mathrm{Sr}$.

491 Voorontwerp p. 126.

492 Zie over 'full jurisdiction': A.J. Kuipers, Het recht op 'full jurisdiction', in: R.L. Vucsán (red.), De Awbmens: boeman of underdog? (Damen-bundel), Ars Aequi Libri, Nijmegen 1996, p. 97 en verder.

493 EHRM 23 oktober 1995, Series A vol. 328-C (Gradinger v. Austria) i.h.b. $\$ 42$.

494 'Gradinger v. Austria' i.h.b. $\$ 44$.

495 Zie hierover: EHRM 23 juni 1981, NJ 1982, 602 (Le Compte, Van Leuven, De Meyere), en EHRM 10 februari 1983, NJ 1987, 315 (Albert en Le Compte). Zie voorts: EHRM 29 april 1988, Series A vol. 132 (Belilos case), i.h.b. $\$ 68$ V/m 72 en EHRM 23 oktober 1995, Series A vol. 328-C (Gradinger v. Austria), i.h.b. $\$ 41 \mathrm{Vm} 45$.

496 Hierna zal nog blijken dat op dit vereiste onder bepaalde omstandigheden door het EHRM een uitzondering wordt gemaakt. 
tweede lid, Awb als toetsingsmaatstaf hanteren. Hoewel de bestuursrechter de uitoefening van bevoegdheden met beleidsvrijheid normaal gesproken marginaal ${ }^{497}$ aan het evenredigheidsbeginsel (zoals dat is neergelegd in artikel 3:4, tweede lid, van de Awb) toetst $^{498}$ dient hij een opgelegde punitieve sanctie volledig aan het evenredigheidsbeginsel te toetsen. ${ }^{499}$ De commissie Scheltema onderschrijft dit standpunt. ${ }^{500}$ Volgens de commissie mag de rechter in het kader van deze volle toetsingsbevoegdheid zijn eigen oordeel in de plaats stellen van het oordeel van het bestuursorgaan. Dit betekent dat de bestuursrechter gebruik mag maken van zijn bevoegdheid om zelf in de zaak te voorzien, zoals neergelegd in artikel 8:72, vierde lid Awb. ${ }^{501}$

In de toelichting geeft de commissie Scheltema aan dat de vrijheid van de bestuursrechter (waarmee de commissie doelt op de volle toetsingsbevoegdheid) wel beperkt is in de zin dat de bestuursrechter, gelet op artikel 8:69 van de Awb, geen hogere boete kan opleggen dan het bestuursorgaan heeft gedaan. ${ }^{502}$ De commissie licht dit standpunt als volgt toe:

'Dit volgt uit het in de Awb, in het bijzonder ook in artikel 8:69, neergelegde stelsel dat de rechtsbescherming van de burger de voornaamste functie van het bestuursprocesrecht is. Daarin past niet, dat de rechter buiten het geschil tussen partijen treedt door een uitspraak te doen die de burger in een nadeliger positie brengt dan wanneer hij geen beroep had ingesteld (het zogenaamde verbod van ureformatio in peius»). ${ }^{503}$

Evenals de VAR-werkgroep ${ }^{504}$ vraag ik me af of het verbod van reformatio in peius wel zou moeten gelden bij de oplegging van een punitieve bestuursrechtelijke sanctie. In het strafrecht heeft de rechter immers ook de bevoegdheid om in (hoger) beroep een

497 Ook bij besluiten betreffende 'civil rights and obligations' geldt het vereiste van 'full jurisdiction' (vgl. Widdershoven/Schlossels/Stroink a.w. 2001, p. 39). De bestuursrechter lijkt in beginsel dan ook niet altijd te kunnen volstaan met een marginale toetsing van bevoegdheden met beleidsvrijheid (vgl. EHRM 28 juni 1990, Series A vol. 179, NJ 1995, 491 m. nt. E.A. Alkema (Obermeier) i.h.b. $\$ 70$ en EHRM 21 september 1993, Series A vol. 268-A, NJ 1994, 544 (Zumtobel)). Volledige duidelijkheid ontbreekt op dit punt in de (weinig consistente) rechtspraak van het EHRM echter (vgl. Kuipers a.w. 1996, p. 103-107). Indien sprake is van beoordelingsvrijheid lijkt het Hof, met het oog op het vereiste van 'full jurisdiction', een integrale toetsing voor te staan (vgl. Kuipers a.w. 1996, p. 107-108).

498 ABRS 9 mei 1996, JB 1996/158 m. nt. F.A.M. Stroink (Maxis-Praxis). De rechter dient slechts de vraag te beantwoorden of het bestuursorgaan in redelijkheid kon komen tot het oordeel dat de gevolgen van het besluit niet onevenredig zijn in verhouding tot de met het besluit te dienen doelen. Zie in dit kader voorts: F.A.M. Stroink, Kwantum Nederland BV, in: Rechtspraak bestuursrecht 1995-1996, De Annotaties, p. 155-168.

499 Zie bijvoorbeeld: ABRS 4 juni 1996, JB 1996/172 m. nt. E. v.d. Linden (Huisman APK). In de praktijk wordt overigens (nog) niet altijd vol aan het evenredigheidsbeginsel getoetst bij de oplegging van bestuurlijke boeten, vgl. ABRS 15 februari 1999, AB 1999, 118 m. nt. M. Schreuder-Vlasblom (NellenRaad van Beroep Ned. Alg. Keuringsdienst voor Groente- en Bloemzaden).

500 Voorontwerp p. 127.

501 Zie in dit kader ook: R.J.N. Schlossels, Zelf in de zaak voorzien: kiezen tussen cliché of dogma? in: Rechtspraak bestuursrecht 1996-1997, De Annotaties, p. 35-65. Normaal gesproken zal de bestuursrechter niet zelf in de zaak voorzien als het bestreden besluit is genomen op basis van een bevoegdheid met beleidsvrijheid. Ten aanzien van boetebesluiten bestaat die mogelijkheid, onder meer blijkens het Voorontwerp, wel. Zie voorts Schreuder-Vlasblom, a.w. 2001a, p. 201-204 en CRvB 11 maart 1992, AB 1992, 462 m. nt. W.A.S. Demeersseman.

502 Voorontwerp p. 127.

503 Voorontwerp p. 127.

504 VAR-werkgroep a.w. 2000 , p. 49-50. 
hogere sanctie op te leggen. Daarnaast is er in feite geén sprake van volle toetsing aan het cvenredigheidsbeginsel door de bestuursrechter als hij de boete alleen naar beneden tue kan bijstellen. Tenslotte dient te worden opgemerkt dat het verbod van reformatio in peius. in het bijzonder vanwege de hierboven weergegeven redenen, niet geldt bij de reeds bestaande bestuurlijke boeteprocedures zoals die worden gevolgd in het kader van het sociale zekerheidsrecht. ${ }^{505}$

De commissie Scheltema gaat er, zo bleek hierboven reeds, vanuit dat de bestuursrechter punitieve sancties 'vol' aan het evenredigheidsbeginsel mag toetsen. Daarmee ziet de commissie zich geplaatst voor een probleem. $\mathrm{Zij}$ zal namelijk moeten proberen de volledige toetsingsbevoegdheid bij punitieve sancties een plaats te geven in het huidige bestuursprocesrecht. Dit leidt tot een merkwaardige redenering. Ik wijs in dat kader op de volgende passage uit de toelichting op het Voorontwerp:

'Het bestuursorgaan heeft bij punitieve sancties geen beleids-, maar slechts beoordelingsvrijheid. Dit betekent ook, dat eventuele beleidsregels over de hoogte van de boete het karakter hebben van wetsinterpreterende beleidsregels, waaraan de rechter niet is gebonden, hetgeen overigens onverlet laat dat het uit een oogpunt van rechtszekerheid en rechtsgelijkheid zeer gewenst kan zijn dat het bestuursorgaan beleidsregels over de hoogte van de op te leggen boeten opstelt en bekendmaakt. ${ }^{506}$

De commissie Scheltema probeert door middel van de hier aangehaalde passage uit het Voorontwerp, zoals gezegd, te onderbouwen dat de bestuursrechter vanuit bestuurs(proces)rechtelijke oogpunt bevoegd is tot het volledig toetsen van de evenredigheid van de hoogte van de opgelegde boete. Daarbij kan de bestuursrechter zijn eigen oordeel in de plaats stellen van het oordeel van het bestuursorgaan. De commissie negeert echter dat er, objectief gezien, in die gevallen waar het de commissie in de toelichting om gaat, in de regel sprake is van beleidsvrijheid bij het vaststellen van de hoogte van de op te leggen bestuurlijke boete. Ook negeert de commissie het feit dat beleidsregels doorgaans door middel van de zogenaamde twee-fasen-toetsing marginaal worden getoetst. ${ }^{507}$ Bovendien noemt zij vervolgens iets beoordelingsvrijheid dat in de literatuur bekend staat als beoordelingsruimte. Namelijk de interpretatie van wettelijke bepalingen. ${ }^{508}$

Mocht er toch sprake zijn van beoordelingvrijheid dan is de redenering van de commissie Scheltema mijns inziens ook niet sluitend. Beoordelingsvrije bevoegdheden mogen door de bestuursrechter namelijk, evenals beleidsvrije bevoegdheden, slechts marginaal worden getoetst. ${ }^{509}$ Het lijkt er op dat de commissie Scheltema, overigens weinig suc-

505 Zie: Kamerstukken II 1994/1995, 23 909, no. 3, p. 62-63. Zie voorts ter illustratie artikel I40a ABW.

506 Zie p. 127 Voorontwerp.

507 Zie met betrekking tot beleidsregels ten aanzien van punitieve bestuursrechtelijke sancties de uitspraak van de ABRS van 6 mei 1999, AB 1999, $282 \mathrm{~m}$. nt. M. Schreuder-Vlasblom (Automobielbedriji Schreur). Schreuder-Vlasblom signaleert in haar noot overigens, onder verwijzing naar niet gepubliceerde Afdelingsuitspraken, dat de Afdeling beleidsregels m.b.t. punitieve sancties indringender toetst dan gebruikelijk is t.a.v. beleidsregels. Vgl. in dit kader: A.P. Klap, Rechterlijke toetsing van en aan beleidsregels, JBplus 2002, p. 17-28, i.h.b. voetnoot 19.

508 Zie Van Wijk/KonijnenbeltVan Male a.w. 1999, p. 177-187.

509 Zie hierover Van Wijk/Konijnenbelt/Van Male aw. 1999, p. 177-187, VzABRS 6 november 1998. AB 1999, 128 en ABRS 5 juni 1998, AB 1998, 286. 
cesvol, heeft gezocht naar een dogmatische rechtvaardiging voor de bevoegdheid van de bestuursrechter om de, op basis van beleidsvrijheid opgelegde, punitieve bestuursrechtelijke sancties ${ }^{510}$ volledig aan het evenredigheidsbeginsel te kunnen toetsen.

Op deze plaats kan de vraag gesteld worden of een bestuursorgaan, bij de oplegging van punitieve bestuursrechtelijke sancties, überhaupt enige beleidsvrijheid toekomt in het kader van het bepalen van de hoogte van de boete. Met het oog op het voorgaande dient wederom gewezen te worden op een verschil tussen het straf(proces)recht en het bestuurs(proces)recht. In het strafrecht is er, wat betreft de vaststelling van de strafmaat, géén sprake van daadwerkelijke beleidsvrijheid aan de zijde van het OM. Het strafrechtelijk beleid van het OM (zoals bijvoorbeeld neergelegd in een requireerrichtlijn) brengt derhalve niet met zich dat de strafrechter terughoudendheid moet betrachten bij de strafmaatbepaling. Het is in het strafrecht de strafrechter die de straf vaststelt en de hoogte van de straf bepaalt. Hij, en derhalve niet het OM, bepaalt (uiteindelijk) op dat punt het beleid. ${ }^{511}$ Met betrekking tot de oplegging van punitieve bestuursrechtelijke sancties zou dat mijns inziens niet anders moeten zijn.

Was het dan, met het oog op het voorgaande, ook niet eenvoudiger geweest als de commissie expliciet had aangegeven dat, gelet op het bijzondere karakter van punitieve bestuursrechtelijke sancties, zoals de bestuurlijke boete, de bestuursrechter deze, op basis van een - vanuit bestuursrechtelijke context gezien - (deels) beleidsvrije bevoegdheid opgelegde, sancties volledig dient te toetsen aan het evenredigheidsbeginsel en dat de bestuursrechter derhalve ook zelf over mag gaan tot het 'opleggen' van een lagere óf, conform de regeling in het sociale zekerheidsrecht, hogere sanctie?

De conclusie lijkt gerechtvaardigd dat ten aanzien van het voorgestelde artikel 5.4.1.7, tweede lid, problemen ontstaan die te maken hebben met het vervlechten van twee uiteenlopende procesrechtelijke systemen. Namelijk het bestuursprocesrecht en het strafprocesrecht. Steeds sterker doet zich dan ook de vraag gevoelen of het wel zo'n gelukkige keuze is geweest de bestuurlijke boeteregeling onder te brengen in de Awb. ${ }^{512}$

Bovendien lijkt de commissie Scheltema een belangrijke Awb-bepaling over het hoofd te hebben gezien. Namelijk artikel 8:77, tweede lid Awb. Uit die bepaling volgt immers dat de bestuursrechter een besluit ook wegens strijd met een algemeen rechtsbeginsel kan vernietigen. Met genoemde bepaling wordt volgens de Memorie van Toelichting tot uitdrukking gebracht dat de rechterlijke taak bestaat uit het toetsen van bestuursbeslissingen aan rechtsnormen. ${ }^{5 / 3}$ In beginsel lijkt toetsing aan algemene rechtsbeginselen met name in een behoefte te voorzien op het grensvlak tussen bestuursrecht en het

510 Dat de bevoegdheid om een boete op te leggen (tenminste in bepaalde gevallen) een discretionaire bevoegdheid is blijkt overigens mijns inziens uit de door de commissie Scheltema gegeven toelichting op artikel 5.4.2.6 van het Voorontwerp (zic: p. 134 van het Voorontwerp).

511 Vgl. Corstens a.w. 1999, p. 215. Het voorgaande brengt met zich dat het OM slechts beleidsvrijheid heeft in het kader van het opportuniteitsbeginsel. Besluit het OM over te gaan tot vervolging dan is het (uiteindelijk) aan de strafrechter vast te stellen welke straf opgelegd zal worden.

512 Zie in dit kader ook de kroniek: Bestuursprocesrecht, van M. Schreuder-Vlasblom, NTB 2001/5, p. 126-136, i.h.b. p. 129-130.

513 Zie PG Awb II, p. 500. 
strafrecht en op het grensvlak tussen het bestuursrecht en het privaatrecht. In de Memorie van Toelichting wordt dit expliciet overwogen:

'In aanmerking is genomen dat de verwevenheid van het bestuursrecht, het strafrecht, en het burgerlijk recht in de bestuurspraktijk is toegenomen. In verband daarmee is het ongewenst het tweede lid van artikel 8.2.6.12 (= het huidige artikel 8:77 Awb [KA]) te beperken tot (algemeen verbindende voorschriften en) algemene beginselen van behoorlijk bestuur. ${ }^{514}$

Vervolgens wordt in de toelichting aangegeven dat tot de algemene rechtsbeginselen die niet direct of uitsluitend voor het bestuur zijn geschreven, maar in het bestuursrecht wel gelding behoren te hebben, onder meer behoren het ne bis in idem-beginsel en het beginsel dat de sanctie evenredig behoort te zijn aan de ernst van het feit. ${ }^{515}$ Mijns inziens impliceert dit dat de vreemde motivering van de commissie Scheltema met betrekking tot de volle toetsing aan het evenredigheidsbeginsel uit artikel 3:4, tweede lid Awb achterwege had kunnen blijven. De commissie had eenvoudigweg kunnen verwijzen naar artikel 8:77, tweede lid Awb. Gelet op het bijzondere karakter van de bestuurlijke boete geldt namelijk niet slechts het evenredigheidsbeginsel zoals dit is neergelegd in artikel 3:4, tweede lid Awb, maar ook het algemeen rechtsbeginsel dat de sanctie evenredig behoort te zijn aan de ernst van het feit. ${ }^{516}$

\section{Wettelijk gefixeerde boeten}

'Indien de hoogte van de bestuurlijke boete bij wettelijk voorschrift is vastgesteld, legt het bestuursorgaan niettemin een lagere bestuurlijke boete op indien de overtreder aannemelijk maakt dat de vastgestelde bestuurlijke boete wegens bijzondere omstandigheden te hoog is.' Zo luidt het derde lid van artikel 5.4.1.7 van het Voorontwerp. Kort gezegd komt het erop neer dat een bestuursorgaan het boetebedrag slechts kan matigen wegens bijzondere omstandigheden als in de wet(telijke regeling) exact is voorgeschreven hoe hoog de bestuurlijke boete moet zijn. 'In dat geval heeft de wetgever zelf de afweging gemaakt, welke boete voor een bepaalde overtreding als evenredig moet worden beschouwd. Bestuur en rechter hebben dan in beginsel geen vrijheid meer om een andere boete op te leggen. ${ }^{517}$ Volgens de commissie Scheltema zijn dergelijke gebonden sanctiebepalingen niet in strijd met artikel 6 van het EVRM. Zij onderbouwt haar standpunt als volgt:

'De jurisprudentie van het EHRM inzake de toetsingsbevoegdheid van de rechter heeft betrekking op de verhouding tussen de rechter enerzijds en het bestuur of de vervolgende instantie anderzijds, niet op de verhouding tussen rechter en wetgever. De rechter moet een punitieve sanctie volledig aan het recht kunnen toetsen, maar is daarbij natuurlijk zelf ook gebonden aan het recht, met inbegrip van de eventuele wettelijke bepalingen over de hoogte van de op te leggen sanctie. ${ }^{318}$

515 PG Awb II, p. 500.

516 Zie in dit kader ook: Rechtbank Groningen 2 september 1999, USZ 1999/292 m. nt. Karianne Albers. In die zaak werd een besluit tot oplegging van een bestuurlijke boete vernietigd wegens strijd met het in het algemeen rechtsbewustzijn levend beginsel dat bij wijziging van het sanctieregime toepassing moet worden gegeven aan de gunstigere (nieuwe) regeling.

517 Voorontwerp p. 128.

518 Voorontwerp p. 128. 
Onder verwijzing naar de zaak 'Malige v. France ${ }^{{ }^{5}}{ }^{519}$ stelt de commissie voorts het volgende:

'In theorie is wel denkbaar, dat de rechter tot het oordeel moet komen dat de door de wetgever voorgeschreven sanctic als regel zo onevenredig is, dat de wet wegens strijd met het EVRM of het communautaire evenredigheidsbeginsel buiten toepassing moet worden gelaten. Dat is echter iets anders dan dat de rechter in het geheel niet aan de keuze van de wetgever zou zijn gebonden. Dat is hij wel, mits kan worden gezegd dat in de wettelijke regeling zelf rekening is gehouden met het evenredigheidsbeginsel (..). ${ }^{, 520}$

De door de wetgever voorgeschreven sanctie kan echter in een concreet geval wegens bijzondere omstandigheden onbillijk uitwerken. Indien een dergelijk geval zich voordoet kan op basis van het, door de commissie Scheltema als "anti-hardheidsclausule» bestempelde, derde lid van artikel 5.4.1.7 van het Voorontwerp door het bestuursorgaan een lagere boete worden opgelegd. Genoemde bepaling is niet van toepassing als de overtreder geen enkel verwijt van zijn gedraging gemaakt kan worden. In dat geval is artikel 5.4.1.2 van het Voorontwerp van toepassing. ${ }^{521}$ De overtreder moet zelf een goed onderbouwd beroep doen op de aanwezigheid van bijzondere omstandigheden.

Het voorgaande impliceert mijns inziens dat de bestuursrechter de evenredigheid van de sanctie bij strikt gebonden sanctiebevoegdheden niet daadwerkelijk kan toetsen. ${ }^{522}$ Dit standpunt wordt overigens ook in de bestuursrechtspraak ingenomen. ${ }^{523}$

Het ontbreken van een daadwerkelijke toetsingsmogelijkheid in het geval van wettelijk gefixeerde boeten vloeit mede voort uit feit dat artikel 3:4 lid 2 Awb slechts ziet op de uitoefening van beleidsvrije bevoegdheden door een bestuursorgaan. ${ }^{524}$ Derhalve blijft, bij gebonden sanctiebepalingen, naar nationaal recht, alleen de mogelijkheid van toetsing van de (formele) wetsbepaling aan het ongeschreven evenredigheidsbeginsel over.

519 EHRM 23 september 1998, nr. 68/1997/852/1059 (Malige v. France) verkort weergegeven in het NJCM-bulletin 1999, p. 278-279. Zie ook NJCM-Bulletin 2000, p. 873-879, m. nt. M. Kuijer en E.E.V. Lenos.

520 Voorontwerp p. 128

521 De Afdeling Bestuursrechtspraak lijkt dit in een uitspraak van 15 april 1999 miskend te hebben. Vgl. ABRS 15 april 1999, JB $1999 / 151$ m. nt. C.L.G.F.H. Albers.

522 Van een 'volle' toetsing aan het evenredigheidsbeginsel is in ieder geval geen sprake.

$\$ 23$ Zie in dit kader: ABRS 4 maart 1999, JB $1999 / 69$ m. nt. C.L.G.F.H. Albers. Daarin overweegt de Afdeling Bestuursrechtspraak: 'In zijn algemeenheid kan niet met vrucht worden staande gehouden dat een overeenkomstig de wet, naar aanleiding van een bepaald verzuim opgelegde sanctie, niet voldoet aan het proportionaliteitsvereiste dan wel het evenredigheidsbeginsel.' Zie ook: ABRS 25 maart 1999 , AB 1999, 229 m. nt. B.P. Vermeulen. Uit de uitspraak van de Afdeling Bestuursrechtspraak van 4 maart 1999 volgt overigens dat zeer disproportionele sancties middels een rechtstreekse toetsing aan artikel 6 EVRM onrechtmatig geoordeeld kunnen worden. Tenslotte kan gewezen worden op ABRS 8 maart 1999, RAwb 1999/116 m. nt. O.J.D.M.L. Jansen. In die uitspraak heeft de afdeling bepaald dat een bestuursorgaan in het kader van de oplegging van een wettelijk gefixeerde boete slechts kan kiezen lussen het opleggen van de in de wet vastgestelde boete of het afzien van sanctionering (aangezien de wetsbepaling in die zin beleidsvrijheid kende). Deze keuze (al dan niet sanctioneren) kan de bestuursrechter vervolgens volledig aan het evenredigheidsbeginsel toetsen. Het voorgaande laat echter onverlet dat de bestuursrechter de evenredigheid van de sanctie bij strikt gebonden sanctiebevoegdheden in de regel niet daadwerkelijk kan toetsen.

527 Zie hierover: PG Awb I, p. 209. 
Uit artikel $120 \mathrm{Gw}$ in samenhang met de Doorbraakarresten ${ }^{525}$ en het Harmonisatiewetarrest $^{526}$ volgt echter dat een bepaling van een wet in formele zin slechts in bijzondere, niet door de wetgever verdisconteerde, omstandigheden buiten toepassing kan worden gelaten wegens strijd met een ongeschreven rechtsbeginsel. ${ }^{527}$

Toetsing van een dwingende sanctiebepaling, die is neergelegd in een lager algemeen verbindend voorschrift, aan het ongeschreven evenredigheidsbeginsel of aan een bepaling van een wet in formele zin waarin het evenredigheidsbeginsel is opgenomen is wel mogelijk. Illustratief in dit kader is een uitspraak van 5 juli 2000. In genoemde uitspraak oordeelde de Centrale Raad dat het als dwingend bedoelde artikel 3 lid 1 onder a ten vierde van het SVr-sanctiebesluit in die zaak buiten toepassing diende te blijven wegens strijd met het ongeschreven evenredigheidsbeginsel. ${ }^{528}$ Daarnaast heeft de Centrale Raad in een uitspraak van 7 september 1999 enkele dwingende bepalingen, uit het Boetebesluit in een concreet geval buiten toepassing gelaten wegens strijd met het in art. 27a, tweede lid van de WW neergelegde evenredigheidsbeginsel. ${ }^{529}$

Voorts kan, zoals de commissie Scheltema aangeeft, een dwingende sanctiebepaling, onder omstandigheden - namelijk indien de sanctie in de regel bijzonder onevenredig is - , op grond van artikel $94 \mathrm{Gw}$ buiten toepassing worden gelaten wegens strijd met uit artikel 6 EVRM voortvloeiende evenredigheidsbeginsel. ${ }^{50}$ De Afdeling Bestuursrechtspraak neemt eenzelfde standpunt in. ${ }^{531}$ Met het, wegens strijd met artikel 6 EVRM, buiten toepassing laten van een als dwingend bedoelde sanctiebepaling indien deze bijzonder onevenredig uitwerkt wordt echter niet het zelfde bereikt als met de volle toetsing aan het evenredigheidsbeginsel die de bestuursrechter toepast ten aanzien van beleidsvrije boetebevoegdheden.

Het bestaan van de hiervoor geschetste toetsingsmogelijkheden neemt derhalve niet weg dat (doorgaans) een daadwerkelijke (d.w.z. volle) toetsingsbevoegdheid ontbreekt bij gebonden sanctiebepalingen. Het ontbreken van deze daadwerkelijke toetsingsbevoegdheid zou naar mijn mening wel eens op gespannen voet kunnen staan met artikel 6 EVRM. Op grond van artikel 6 EVRM dient er in beginsel immers sprake te zijn van toegang tot een rechter die beschikt over een volledige toetsingsbevoegdheid ('full jurisdiction'). De nationale rechter zal doorgaans dan ook bevoegd moeten zijn tot het toetsen van de evenredigheid van de opgelegde sanctie ten opzichte van de ernst van de overtreding. Dit klemt mijns inziens te meer in gevallen waarin een punitieve sanctie opgelegd wordt door een bestuursorgaan terwijl de onafhankelijke rechter zich eerst achteraf een oordeel kan vormen over de opgelegde sanctie.

525 HR 12 april 1978, BNB 1978, 135-137 m. nt. C.P. Tuk, NJ 1979, 533 m.nt. M. Scheltema, AB 1979, $262 \mathrm{~m}$. nt. F.H. van der Brug.

526 HR 14 april 1989, AB 1989, 207, m. nt. F.H. van der Burg.

$527 \mathrm{Zie}$ over toetsing door de rechter aan het evenredigheidsbeginsel voorts: E.E.V. Lenos, Boeten en maatregelen met mate? Toetsing door de rechter aan het evenredigheidsbeginsel, Sociaal Recht 1999$7 / 8$, p. $184-189$.

528 Zie: CRvB 5 juli 2000, JB 2000/256 m. nt. C.L.G.F.H. Albers.

529 Zie: CRvB 7 september 1999, AB 1999, 455 m. nt. Broring, ook gepubliceerd in JB 1999/253 m. nt. C.L.G.F.H. Albers.

530 Vgl. Barkhuysen/Van Emmerik/Loof a.w. 2000, p. 237-408, i.h.b. p. 329-330.

531 Zie ABRS 4 maar 1999, JB 1999/69 m. nt. C.L.G.F.H. Albers en ABRS 15 april 1999, JB 1999/151 m. nt. C.L.G.F.H. Albers. 
In ons huidige bestuursrechtelijk sanctiesysteem heeft de bestuursrechter zoals gezegd niet de mogelijkheid gebonden sanctiebevoegdheden te toetsen aan het evenredigheidsbeginsel uit artikel 3:4 lid 2 Awb. Toetsing van een formeel-wettelijke sanctiebepaling aan het ongeschreven evenredigheidsbeginsel is bovendien slechts in uitzonderlijke gevallen mogelijk. Hetzelfde geldt voor toetsing aan het uit artikel 6 EVRM voortvloeiende evenredigheidsbeginsel. De commissie Scheltema is desalniettemin van mening dat een strikt gebonden wettelijk sanctiesysteem toelaatbaar is. $\mathrm{Zij}$ wijst, zoals hierboven reeds is gebleken, ter onderbouwing van dit standpunt op de uitspraak van het EHRM in de zaak Malige v. France. Uit die uitspraak van het EHRM kan worden afgeleid dat een strikt gebonden wettelijk sanctiesysteem niet in strijd is met artikel 6 EVRM indien de wettelijke regeling blijk geeft van evenredigheid van de in de wet neergelegde sancties terwijl de in concreto opgelegde sanctie ook proportioneel is. De commissie Scheltema heeft in het Voorontwerp bovendien een maatregel getroffen teneinde een beperkte toetsingsmogelijkheid te realiseren door in artikel 5.4.1.7 derde lid te bepalen dat matiging van de boete (door het bestuursorgaan) wegens bijzondere omstandigheden is toegestaan. ${ }^{532}$ Op grond van deze bepaling kan de bestuursrechter uiteraard niet dezelfde evenredigheidstoetsing uitvoeren als bij vrije punitieve sanctiebevoegdheden ${ }^{533}$ Het gaat immers om een 'anti-hardheidsclausule', om met de woorden van de commissie te spreken. Derhalve kan mijns inziens niet worden uitgesloten dat de toetsingsbevoegdheid van de bestuursrechter bij gebonden sanctiebevoegdheden te beperkt blijft met het oog op artikel 6 EVRM ${ }^{534}$ Ook Bröring is van mening dat een hardheidsclausule de mogelijkheid om de evenredigheid van een punitieve bestuursrechtelijke sanctie daadwerkelijk te toetsen te zeer beperkt. ${ }^{535}$ Aangezien de rechtspraak van het Europese Hof op het gebied van dwingend voorgeschreven sanctiebepalingen vooralsnog schaars en (voor zover wel voorhanden) casuïstisch is kan echter niet onverkort worden gesteld dat de toetsingsbevoegdheid van de bestuursrechter bij gebonden sanctiebevoegdheden zich niet verdraagt met artikel 6 EVRM.

De verwachting lijkt gerechtvaardigd dat er in de praktijk, bij gebonden sanctiebevoegdheden in een concreet geval regelmatig sprake zou kunnen van een disproportionele sanctie. ${ }^{536}$ De overtreder zal dan zelf aannemelijk moeten maken dat er sprake is

532 Zie ook de toelichting op het artikel op p. 127 en 128 Voorontwerp. Met de regeling in het Voorontwerp lijkt de commissie Scheltema de theorie uit de Doorbraak-arresten voor wat betreft het evenredigheidsbeginsel gecodificeerd te hebben.

533 Ik vraag me af of deze 'anti-hardheidsclausule' ook toegepast kan worden indien wettelijk gefixeerde boeten zich opstapelen omdat een bepaalde handeling in het kader van de meerdaadse samenloopregeling verschillende (afzonderlijk te beboeten) 'gedragingen' oplevert.

534 Vgl. Van Russen Groen a.w. 1998, p. 143.

535 Zie de noot van Bröring bij CRvB 7 september 1999, gepubliceerd in AB 1999, 455. De Raat en Widdershoven lijken deze mening niet te delen (zie: De Raat en Widdershoven a.w. 2000, p. 786).

536 Zie bijvoorbeeld: CRvB 7 september 1999, JB 1999/253 m. nt. dzz., AB 1999, $455 \mathrm{~m}$. nt. Bröring. Het Lisv leed in die zaak een nadeel van $f 22$ i.v.m. het niet voldoen aan de inlichtingenplicht (eiser had verzuimd werkzaamheden (2 uren) voor een uitzendbureau op te geven). De overtreding moest op grond van het Boetebesluit (géen wet in formele zin) gesanctioneerd worden met een boete van $f 300$. Aangezien een boete van $f 300$ volgens de CRvB onevenredig was dienden de aan de boete ten grondslag liggende bepalingen uit het boetebesluit in casu buiten toepassing te blijven omdat met de bepalingen uit het Boetebesluit geen juiste invulling was gegeven aan artikel $27 \mathrm{a} W \mathrm{~W}$. 
van een bijzondere omstandigheid, zo blijkt uit het Voorontwerp. ${ }^{537}$ Omtrent de vraag wanneer er sprake is van een bijzondere omstandigheid wordt echter in het Voorontwerp geen duidelijkheid geschapen. Hoe disproportioneel een boete in een concreet geval noet zijn voordat een bestuursorgaan over dient te gaan tot het opleggen van een lagere bestuurlijke boete blijkt eveneens niet uit het Voorontwerp.

\section{Toepassen lagere boete}

Het vierde lid van artikel 5.4.1.7 luidt tenslotte: 'Indien de bestuurlijke boete wegens een bepaalde overtreding bij wettelijk voorschrift wordt verlaagd, past het bestuursorgaan de verlaging voortaan ook toe op bestuurlijke boeten wegens overtredingen die voor de verlaging hebben plaatsgevonden.' Met deze bepaling heeft de commissie Scheltema beoogd de regel die is neergelegd in artikel 15, eerste lid, derde volzin, IVBPR, over te nemen. ${ }^{538}$ De lagere boete kan alleen worden opgelegd door het bestuursorgaan. Het voorgaande betekent dat de wettelijke regeling moet zijn gewijzigd gedurende de totstandkoming van het primaire boetebesluit of gedurende de bezwaarschriftprocedure. De bestuursrechter heeft volgens de commissie Scheltema niet de bevoegdheid om een lagere boete op te leggen in verband met een tussentijdse wetswijziging tijdens de beroepsprocedure (tenzij hij in (hoger) beroep zelf in de zaak voorziet).

Het vierde lid van artikel 5.4.1.7 van het Voorontwerp heeft bovendien een beperktere strekking dan artikel 1, tweede lid Sr. De commissie schrijft daaromtrent in de toelichting op het Voorontwerp:

'Laatstgenocmd artikel bepaalt dat bij "verandering van wetgeving" de voor de verdachte meeste gunstige bepaling wordt toegepast. Daarbij gaat het dus niet alleen om wijzigingen in de aard of hoogte van de sanctie, maar ook om wijzigingen in het overtreden voorschrift, zij het dat de rechtspraak heett uitgemaakt dat artikel 1, tweede lid, WvSr in dat geval slechts tocpassing vindt indien de wijziging berust op gewijzigd inzicht van de wetgever over de strutwaardigheid van het feit (zie bijv. HR 11 oktober 1989, NJ 1989, 455 tegenover HR 24 november 1987, NJ 1988, 931). ${ }^{539}$

Gelet op onduidelijke situaties die zich hierdoor voordoen in het strafrecht stelt de commissie Scheltema voor de gevolgen van de wijziging van de te handhaven voorschriften aan de bijzondere wetgever over te laten.

Uit de hierboven weergegeven regeling met betrekking tot het toepassen van 'de meest gunstige bepaling ${ }^{540}$ kan mijns inziens worden afgeleid dat de commissie Scheltema de verdragsrechtelijke waarborgen bij voorkeur beperkt uitlegt. Bij lezing van artikel 5.4.1.7, vierde lid van het Voorontwerp springt meteen in het oog dat slechts het be-

537 Zie de toelichting in het Voorontwerp, p. 128.

538 Anders dan de commissie Scheltema ga ik er overigens van uit dat de term 'criminal offence' ziet op alle punitieve sancties (en dus niet alleen op zwaardere bestuurlijke boeten). Zie Voorontwerp p. 128 en $\$ 3.3$ van dit boek.

539 Voorontwerp p. 129.

540 Met de uitdrukking 'het toepassen van de meest gunstige bepaling' doel ik in deze bijdrage, conform artikel 5.4.1.7 van het Voorontwerp, slechts op bepalingen waarin in de oplegging van een lagere (of lichtere) straf is voorzien 
stuursorgaan bevoegd is over te gaan tot het toepassen van de meest gunstige bepaling. Blijkens de toelichting bij het Voorontwerp is dit inderdaad de bedoeling. ${ }^{31}$ Dit betekent dat de wijziging van de wettelijke regeling moet plaatsvinden tussen constatering van de overtreding en de totstandkoming van het primaire besluit of gedurende de periode dat het bezwaar aanhangig is bij het bestuursorgaan, wil de overtreder in aanmerking kunnen komen voor oplegging van de lagere boete. Wordt de wettelijke regeling ten voordele van de beboete persoon gewijzigd op het moment dat het beroep aanhangig is bij de bestuursrechter, dan kan de bestuursrechter het bestreden besluit niet om die reden vernietigen. ${ }^{52}$

In de toelichting bij het vierde lid van artikel 5.4.1.7 van het Voorontwerp wordt de volgende motivering gegeven:

'artikel 15 IVBPR ziet op het opleggen van de boete en de rechter legt geen bestuurlijke boeten op, maar toetst slechts de beschikking van het bestuursorgaan. Deze toetsing geschiedt, overeenkomstig de hoofdregel van het bestuursrecht, "ex tunc»: bepalend zijn de feiten en het recht op het tijdstip waarop de beschikking werd gegeven. Bij een beslissing op bezwaar en indien de rechter zelf in de zaak voorziet, dient echter wel het nieuwe, lagere maximum te worden toegepast, omdat dan "ex nunc" wordt beslist. ${ }^{543}$

Artikel 15, eerste lid, derde volzin IVBPR ${ }^{544}$, waarop artikel 5.4.1.7, vierde lid van het Voorontwerp blijkens de toelichting is gebaseerd ${ }^{54}$, krijgt op deze manier naar mijn mening een te beperkte invulling. Gelet op het doel en de strekking van artikel 15 IVBPR, zou de bestuursrechter óók bevoegd moeten zijn tot het toepassen van de meest gunstige bepaling. De kern van artikel 15 , eerste lid, derde volzin IVBPR is immers dat de overtreder dient te profiteren van een, na het begaan van het strafbare feit, en vóór de 'berechting', tot stand gekomen strafverlaging. Of het nu een bestuursorgaan is of een bestuursrechter, die de meest gunstige bepaling toepast, is dan niet relevant. Ik vraag me dan ook af of de commissie Scheltema van een dergelijke beperkte uitleg van artikel 15, eerste lid, derde volzin IVBPR uit had moeten gaan. ${ }^{546}$

Dit klemt te meer nu de door de commissie gegeven toelichting bij het evenredigheidsbeginsel (uit artikel 5.4.1.7, tweede lid van het Voorontwerp) de voorgestelde regeling omtrent het toepassen van de meest gunstige bepaling niet lijkt te ondersteunen. Uit de toelichting op artikel 5.4.1.7, tweede lid, waarin het evenredigheidsbeginsel is neergelegd, blijkt namelijk, zo is hierboven reeds aangegeven, dat de commissie Scheltema er van uit gaat dat de bestuursrechter de evenredigheid van de opgelegde sanctie - voor zover er geen sprake is van wettelijk gefixeerde boeten - volledig mag toetsen, en dat hij bij geconstateerde onevenredigheid van de sanctie de mogelijkheid heeft om zelf in de zaak te voorzien. ${ }^{547}$

Zie p. 129 Voorontwerp.

543 Zie p. 129 Voorontwerp.

544 Zie p. 129 Voorontwerp.

544 Artikel 15, eerste lid, derde volzin IVBPR luidt: 'Indien, na het begaan van het strafbare feit de wet mocht voorzien in de oplegging van een lichtere straf, dient de overtreder daarvan te profiteren.'

\$45 Op deze plaats wijs ik er nogmaals op dat de commissie Scheltema uitdrukkelijk afstand heeft gedaan van de verder strekkende inhoud van artikel 1, tweede lid $\mathrm{Sr}$ (zie hierover ook $\$ 3.2$ ).

546 Zie in deze zin ook: Feteris a.w. 2000b, p. 7-9, en De Raat en Widdershoven a.w. 2000, p. 787-788.

547 Zie p. 127 Voorontwerp. 
Dit betekent dat de besturursrechter door zelf in de zaak te wownien in ieder geval een lagere boete op zou kunnen leggen. ${ }^{548}$ Hiermee komt de, hierboven wergegeven, aan artikel 5.4 .1 .7 , vierde lid, van het Voorontwerp ten grondslag: liggende redenering mijns inziens onder druk se staan. De bestururstechter kan immers, anders dan in de toelichting wordt aangegeven, wél een bestuurlikke boete op leggen, namelijk door zelf in de zak te voorzien indien een besturlijke boete naar zijn oordeel niet evenredig is. De bestuursrechter zou de regeling uit artikel 5.4.1.7, vierde lid, van het Voorontwerp dan ook op een cenvoudige wijze kunnen onzeilen. Namelijk door te oordelen dat de oude wettelijke regeling, die van toepassing was toen het bestuursongan het bestreden besluit nam, heeft geleid tot de oplegging van een onevenredig zware sanctie. Vervolgens zou de rechter dan zelf in de zaak kunnen voorzien. Aangezien 'ex aunc' toetsing in dat geval well is toegestaan, kan de bestuursrechter toch de lagere boete opleggen. ${ }^{5 / 4}$ 低 zie dan ook niet in waarom in de regeling omtrent het toepassen van de meest gunstige bepaling het uitgangspunt van 'ex tunc' toetsing niet is losgelaten.

De Centrale Raad van Beroep lijkt ook niet in te kumen stemmen met de uitleg die de commissie Scheltema aan de uit artikel 15 , eerste lid, derde volzin IVBPR voortvloeiende eis tot het toepassen van de meest gunstige bepaling, geeft. In een uitspraak van I maart $2000^{550}$ heeft de Centrale Raad, onder verwijzing naar artikel 15 eerste lid, derde volzin IVBPR, bepaald dat wit moet worden gegaan van de meest gunstige bepaling oble indien de strafverlichting tot stand is gekomen tijdens de beroepsprocedure bij de rechter ${ }^{551}$ De Centrale Raad heeft dit standpunt herhaald in een uitspraak van 20 april $2000 .{ }^{552}$ Een afwijkend standpunt werd ingenomen door de rechtbank Amsterdam in een uitspraak van 28 januari $2000 .^{553}$ De Amsterdamse rechtbank gaat in die uitspraak uit van de regeling zoals die is neergelegd in het Voorontwerp. Volgens de Amsterdamse rechtbank moet er sprake zijn van een wijziging van de wettelijke regeling ten voordele van de overtreder, na het begaan van de overtreding maar vóórdat de bestuurlijke besluitvorming is afgerond. Dit wil zeggen dat alleen het bestuursorgaan de bevoegdheid heeft een lichtere sanctie toe te passen bij een tussentijdse wetswijziging.

548 Zie p. 127 Voorontwerp: '... (volledige toetsing aan het evenredigheidsbeginsel [KA]) wil zeggen dat de rechter zijn eigen oordeel over de hoogte van de boete in de plaats mag stellen van het oordeel van het bestuursorgaan. ... Op én punt is de vrijheid van de bestuursrechter echter wel beperkt: hij kan geen hogere boete opleggen dan het bestuursorgaan heeft gedaan.'

549 Ik wijs er op dat deze constructie (op basis van het huidige bestuursprocesrecht) alleen mogelijk is als het bestuursorgaan op grond van de wettelijke regeling de ruimte (beleidsvrijheid) heeft om zelf de hoogte van de op te leggen boete vast te stellen.

550 JB 2000/107, m. nt. C.L.G.F.H. Albers.

551 In de uitspraak van de Centrale Raad van 1 maart 2000 ging het om de oplegging van een bestuurlijke boete op grond van artikel 38 van de Ziektewet. De bestuurlijke boete werd door het Lisv opgelegd wegens een te late herstelmelding. Ten tijde van het begaan van de overtreding en ten tijde van de totstandkoming van het bestreden besluit was het oude artikel 38 van de ZW nog van toepassing op de te late herstelmelding. Op grond van artikel 38 lid $4 \mathrm{ZW}$ (oud) moest wegens niet behoorlijke nakoming van de verplichting tot herstelmelding een boete worden opgelegd van $f 1000$. Vanwege een wijziging van artikel $38 \mathrm{ZW}$ dient dezelfde overtreding per 1 januari 1998 gesanctioneerd te worden met een boete van ten hoogste $f 1000$. Door de wijziging van artikel $38 \mathrm{ZW}$ werd het derhalve mogelijk om een lichtere sanctie op te leggen.

552 JB 2000/146, m. nt. C.L.G.F.H. Albers.

553 JB 2000/81, m. nt. C.L.G.F.H. Albers. 
Het standpunt van de Centrale Raad acht ik zeer wel verdedigbaar met het oog op het doel en de strekking van artikel 15 IVBPR. Mijns inziens zou de wetgever bij de definitieve regeling van de bestuurlijke boete in de vierde tranche ook moeten uitgaan van de ruimere opvatting, ten aanzien van toepassing van de meest gunstige bepaling, zoals die door de Centrale Raad wordt voorgestaan.

Naast de hierboven weergegeven 'onvolkomenheid' in het voorgestelde vierde lid van artikel 5.4.1.7 wijst Feteris nog op een andere tekortkoming. ${ }^{554}$ Volgens hem heeft de commissie Scheltema zich namelijk ten onrechte beperkt tot verlagingen van de bestuurlijke boete bij wettelijk voorschrift. Met een versoepeling van beleidsregels, waarin de hoogte van de boete nader wordt geregeld, kan op grond van de voorgestelde bepaling geen rekening gehouden worden. Feteris acht dit niet terecht omdat ook beleidsregels, waaraan het bestuursorgaan gebonden is, en die voor de rechter kunnen worden ingeroepen, naar zijn oordeel als 'law' in de zin van artikel 15 IVBPR moeten worden aangemerkt. ${ }^{555}$ Voor dit standpunt valt natuurlijk véél te zeggen. Vermoedelijk zullen bij de meeste boeteregelingen in de wet in formele zin immers slechts maximum bedragen ${ }^{556}$ worden vermeld. Onvermijdelijk volgt dan een nadere uitwerking in een $\mathrm{AMvB}$, een andersoortig besluit of in beleidsregels. Wijziging van boetebedragen ten gunste van de overtreder op basis van de laatstgenoemde categorie vallen nu niet onder de werking van artikel 5.4.1.7, vierde lid Voorontwerp. ${ }^{557}$

In dit kader dient overigens nogmaals gewezen te worden op een verschil tussen het straf(proces)recht en het bestuurs(proces)recht. In het strafrecht is, zoals gezegd, géen sprake van beleidsvrijheid aan de zijde van het OM met betrekking tot de vaststelling van de strafmaat. Het strafrechtelijk beleid van het OM (zoals dat bijvoorbeeld is neergelegd in een requireerrichtlijn) brengt derhalve niet met zich dat de strafrechter terughoudendheid moet betrachten bij de strafmaatbepaling. Het is in het strafrecht de strafrechter die de straf vaststelt en de hoogte van de straf bepaalt. Aansluiting bij deze strafrechtelijke praktijk zou met zich brengen dat het probleem van de toepassing van de gunstigere beleidsregel zich niet zou voordoen. De bestuursrechter zou dan immers steeds zijn oordeel over de op te leggen boete in de plaats kunnen stellen van de opvatting van het primair sanctionerende bestuursorgaan.

Tenslotte wijst Feteris er op dat bij de totstandkoming van artikel 5.4.1.7 in samenhang met 5.0.4 geen acht is geslagen op de eis uit 7 EVRM en 15 IVBPR tweede volzin. In genoemde tweede volzin is bepaald dat geen zwaardere straf mag worden opgelegd dan die, die ten tijde van het begaan van het strafbare feit van toepassing was. ${ }^{558}$ Op zich is

554 Zie Feteris a.w. 2000 b, p. 7.

555 Zie Feteris a.w. 2000 b, p. 7.

556 In de wettelijke regeling hoeft slechts eén maximum-bedrag voor alle soorten overtredingen te zijn neergelegd. In een nadere regeling moet dan vervolgens een uitsplitsing plaatsvinden op grond waarvan een maximum-bedrag per afzonderlijke overtreding wordt vastgesteld.

557 Overigens zou ook hier, buiten een regeling in het Voorontwerp om, de lagere sanctie uit de (ver)nieuw(d)e beleidsregel kunnen worden opgelegd door toepassing te geven aan de hiervoor beschreven 'evenredigheidstruc'.

Zie Feteris a.w. 2000b, p. 7. 
dat vereiste mijns inziens zo vanzelfsprekend dat de commissie Scheltema het wellicht wél in acht wilde nemen. Dit blijkt echter niet uit het wetsvoorstel.

\section{Afsluitend - oplegging lagere boete -}

De regeling omtrent het toepassen van de meest gunstige bepaling zoals die is neergelegd in het Voorontwerp illustreert (wederom) duidelijk welke problemen kunnen ontstaan indien de wetgever probeert straf(proces)rechtelijke rechtsnormen te integreren in het bestuurs(proces)recht. Met name uit de hierboven aangehaalde passage uit de toelichting op het Voorontwerp ${ }^{59}$ blijkt dat de commissie Scheltema bij het maken van een algemene regeling omtrent de oplegging van bestuurlijke boeten geconfronteerd wordt met de verschillen tussen het traditionele straf(proces)recht en het bestuurs(proces)recht. Het voorgaande lijkt (mede) te leiden tot een beperkte uitleg van verdragsrechtelijke waarborgen. ${ }^{560}$

\section{Afdeling 5.4.2 De procedure}

Tenslotte wordt in afdeling 5.4.2 van het Voorontwerp de procedure tot het opleggen van bestuurlijke boeten geregeld. Naar deze afdeling gaat in dit boek minder aandacht uit. Volstaan wordt met een beschrijving op hoofdlijnen. Aan de belangrijkste (rechtsbeschermings)aspecten is reeds in het kader van hierboven beschreven bepalingen aandacht besteed. Voor het overige gaat het in genoemde afdeling, dit blijkt ook onmiskenbaar uit de titel, om zuiver procedurele aspecten.

\section{Artikel 5.4.2.1 Opmaken rapport}

In artikel 5.4.2.1 van het Voorontwerp wordt aangegeven welke informatie een eventueel op te maken rapport moet bevatten. Opgemerkt zij dat in ieder geval een rapport moet worden opgemaakt bij boeten die meer bedragen dan 340 Euro. In artikel 5.4.2.1, derde lid, is aangeven op welk moment het rapport uiterlijk aan de vermoedelijke overtreder moet worden toegezonden of uitgereikt. Toezending of uitreiking van het rapport dient uiterlijk plaats te vinden bij de bekendmaking van de beschikking tot oplegging van de bestuurlijke boete aan de vermoedelijke overtreder.

Zoals gezegd bestaat alleen bij de hogere boeten (die meer bedragen dan 340 Euro) de plicht om een rapport op te maken. In de overige gevallen kán een rapport worden opgemaakt. De commissie Scheltema heeft bewust niet gekozen voor een algemene verplichting tot het opmaken van een rapport. Het is namelijk volgens de commissie niet altijd noodzakelijk een rapport op te maken van een gedraging waarvoor een bestuurlijke boete wordt opgelegd. ${ }^{561}$ De commissie wijst uitdrukkelijk op het nut van een rapport met het oog op de bewijsvoering, de toetsing door de rechter en de, uit artikel 6 EVRM voortvloeiende, eis dat de betrokkene zo snel mogelijk wordt geïnformeerd

559 Zie Voorontwerp p. 129.

560 Overigens verdient opmerking dat de Centrale Raad, in het kader van het toepassen van de meest gunstige bepaling. cen ander weg volgt dan de commissie Scheltema. Daarmee geeft de Centrale Raad wèl op een juiste wijze invulling aan deze verdragsrechtelijke waarborg. Wellicht zal in de definitieve bocteregeling rekening gehouden worden met deze rechtspraak. 
over de tegen gerezen verdenking. ${ }^{562}$ Desalniettemin vervolgt de commissie Scheltema haar betoog als volgt:

'Het verplicht opmaken van een rapport bij overtredingen van meer administratieve aard (te laat aangifte doen of andere gegevens verstrekken) zou echter tot onnodige lasten leiden. Daarnaast lijkt het niet te stroken met artikel 3:2 van de Awb, om het bestuursorgaan bij het nemen van een boetebeschikking te beperken in zijn informatiebronnen. Ook het beginsel van vrije bewijsvoering in het bestuursrecht verzet zich ertegen het rapport teveel status te geven. Fouten in het rapport moeten niet desastreus zijn voor het vervolg van de procedure. $^{.563}$

De commissie klampt zich ook hier weer vast aan bestuursrechtelijke dogma's. De commissie lijkt (steeds weer) uit het oog te verliezen dat zij in het kader van bestuurlijke boeten van doen heeft met bestuursrechtelijke beslissingen die van een beduidend andere aard zijn dan de beslissingen waar ons bestuurs(proces)recht op geënt is. Enige kritische kanttekeningen lijken in dit kader niet misplaatst. Reeds eerder in dit hoofdstuk heb ik aangegeven dat de gebruikelijke vrije bewijsvoering in het bestuursstrafrecht niet goed gedijt. ${ }^{564} \mathrm{Ik}$ meen dan ook dat er met betrekking tot het bewijs in het bestuursstrafrecht nadere regels gesteld zouden moeten worden (in afwijking van de nu gehanteerde vrij bewijsleer). In deze regels zou ook kunnen worden aangegeven welke consequentie verbonden wordt aan het maken van fouten in het rapport. Het heeft geen pas alle aan het rapport klevende gebreken te negeren door bijvoorbeeld toepassing te geven aan artikel 6:22 Awb. Er zou in dat kader in ieder geval een regeling moeten worden getroffen met betrekking tot de bevoegdheid tot matiging van de op te leggen boete indien er op enig moment een fout is gemaakt in de voorfase die niet dermate emstig is dat zij aan bestraffing in de weg staat. ${ }^{565}$

Mede met het oog op artikel 6 EVRM vraag ik mij tenslotte af waarom alleen ten aanzien van de hogere boeten verplicht een rapport opgemaakt moet worden. Deze keuze van de commissie Scheltema lijkt grotendeel gebaseerd te zijn op financiële overwegingen en efficiency argumenten. Het EHRM heeft echter de zaak 'Öztürk' aangegeven dat de uit artikel 6 EVRM voortvloeiende waarborgen van toepassing moeten zijn op alle punitieve sancties. Het Hof heeft in dit kader in 1984 het volgende overwogen:

'The fact that it was admittedly a minor offence hardly likely to harm the reputation of the offender does not take it outside the ambit of Article 6 (art. 6). There is in fact nothing to suggest that the criminal offence referred to in the Convention necessarily implies a certain degree of seriousness. In this connection, a number of Contracting States still draw a distinction, as did the Federal Republic at the time when the Convention was opened for the signature of the Governments, between the most serious offences (crimes), lesser offences (delits) and petty offences (contraventions), whilst qualifying them all as criminal offences. Furthermore, it would be contrary to the object and purpose of Article 6 (art. 6), which guarantees to "everyone charged with a criminal offence" the right to a court and to a fair trial, if the State were allowed to remove from the scope of this Article (art. 6) a whole 
category of offences merely on the ground of regarding them as petty. (...) The relative lack of seriousness of the penalty at stake cannot divest an offence of its inherently criminal character. ${ }^{566}$

Gelet op deze overwegingen van het EHRM kan toch niet zonder meer gesteld worden dat het niet nodig is ten aanzien van lagere boeten (beneden de 340 Euro) het opmaken van een rapport verplicht te stellen? Dit lijkt mij in ieder geval niet terecht indien door het ontbreken van een dergelijk rapport de (uit artikel 6 EVRM voortvloeiende) rechten van verdediging van de vermoedelijke overtreder in zeer ernstige mate geschaad worden. Ook voor het ontbreken van een hoorplicht in de primaire fase bij de lagere boeten én het ontbreken het vereiste van functiescheiding kan in de rechtspraak van het EHRM overigens geen rechtvaardiging worden gevonden. ${ }^{567}$ Laatstgenoemde waarborgen spelen met name in het kader van de onschuldpresumptie (uit artikel 6, tweede lid EVRM) een rol. Op grond van de overwegingen van het Hof in de zaak Özturk zouden deze waarborgen, voor zover daarmee invulling wordt gegeven aan uit artikel 6 EVRM voortvloeiende eisen, niet alleen bij de oplegging van de hogere boeten (van meer dan 340 Euro) een rol moeten spelen.

\section{Artikel 5.4.2.2 Inzage dossier}

Op grond van artikel 5.4.2.2 van het Voorontwerp dient het bestuursorgaan de vermoedelijke overtreder, op diens verzoek, inzage te verschaffen in zijn dossier ter voorbereiding van zijn verdediging. Dit dient te geschieden in een voor hem begrijpelijke taal indien de verdediging van de vermoedelijke overtreder dit redelijkerwijs vergt. Het dossier bevat alle stukken die moeten dienen tot onderbouwing van de beslissing tot het opleggen van een bestuurlijke boete. Stukken ten aanzien waarvan het bestuursorgaan meent dat deze geheim moeten blijven kunnen buiten het dossier worden gelaten. In een dergelijk geval kan zo'n stuk echter niet meer ter motivering van de boete worden gebruikt omdat volgens de commissie Scheltema een punitieve sanctie niet kan worden gebaseerd op stukken waartegen de overtreder zich niet kan verweren. ${ }^{568}$ In die zin derogeert het recht op inzage dan ook aan artikel 7:4, zesde lid van de Awb.

Artikel 5.4.2.2 is één van de bepalingen ${ }^{569}$ waarmee de commissie Scheltema invulling heeft willen geven aan het, uit artikel 6, derde lid onder a EVRM, voortvloeiende recht om onverwijld, in een taal die de vermoedelijke overtreder verstaat en in bijzonderheden, op de hoogte te worden gesteld van de aard en de reden van de tegen hem ingebrachte beschuldiging. ${ }^{570}$

Ten aanzien van de overige rechten van verdediging, die uit artikel 6, derde lid EVRM en 14, derde lid IVBPR voortvloeien geeft de commissie aan dat de meeste van deze

Zie: Özt0rk \$53-54 vgl. ook Saunders.

567 Ik ga er van uit dat de commissie Scheltema met genoemde waarborgen invulling wil geven aan de uit het EVRM voortvloeiende eisen.

568 Voorontwerp p. 131.

569 Vgl. bijv. art. 5.4.2.1 en art. 5.4.2.3, eerste lid, onder a en b Voorontwerp.

570 Zie hierover uitvoeriger Van Russen Groen a.w. 1998, p. 215-224. Zie voorts met betrekking tot het 'begrijpelijke taal'-vereiste: EHRM 28 november 1978, Series A, vol. 29 (Leudicke, Belkacem en Koç), EHRM $1^{\circ}$ december 1989, Series A, vol. 168, NJ 1994, 26 m. nt. E.A. Alkema (Kamasinski), en 19 december 1989, Series A, vol. 167, NJ 1994, 25 m. nt. E.A. Alkema (Brozicek). 
rechten reeds in het nationale bestuursprocesrecht zijn gegarandeerd. ${ }^{571}$ Voor zover dit niet het geval is heeft de commissie in het Voorontwerp voorzien in een regeling om die verdedigingsrechten te garanderen, zo stelt de commissie Scheltema. ${ }^{572}$ Ik kan de opvatting van commissie, dat de meeste uit het EVRM en IVBPR voortvloeiende rechten in het nationale bestuursprocesrecht of het Voorontwerp zijn gegarandeerd, niet volledig onderschrijven. Mijns inziens wordt zowel op basis van het nationale bestuursprocesrecht als op basis van het Voorontwerp niet onverkort aan alle toepasselijke verdragsrechtelijke waarborgen voldaan. In dit hoofdstuk is dit bij bepaalde bepalingen uit het Voorontwerp reeds aangegeven. Voorts zal in het slotdeel van dit boek nog aandacht uitgaan naar de vraag in hoeverre op basis van het nationale bestuursprocesrecht, in samenhang met het Voorontwerp, voldoende invulling wordt gegeven aan de verdragsrechtelijke waarborgen die (tenminste) in acht genomen moeten worden bij de oplegging van punitieve bestuursrechtelijke sancties zoals de bestuurlijke boete.

\section{Artikel 5.4.2.3 Zienswijze}

Uit artikel 5.4.2.3 van het Voorontwerp volgt dat de vermoedelijke overtreder in de gelegenheid gesteld kan worden zijn zienswijze naar voren te brengen indien het bestuursorgaan voornemens is een bestuurlijke boete op te leggen. Op grond van artikel 5.4.2.6, derde lid, van het Voorontwerp geldt bij de zware procedure (die toegepast wordt bij boeten van meer dan 340 Euro) een hoorplicht. Ten aanzien van de lichte procedure is afdeling 4.1.2 van de Awb van toepassing. Op grond van artikel 4:12 van de Awb (geen hoorplicht bij financiële beschikkingen) hoeft vervolgens bij een boete, die opgelegd wordt volgens de lichte procedure, niet gehoord te worden. ${ }^{573}$

Men kan zich afvragen of artikel 4:12 Awb wel tot stand is gekomen met het oog op punitieve bestuursrechtelijke sancties zoals de bestuurlijke boete. Bestudering van de Memorie van Toelichting lijkt de conclusie te rechtvaardigen dat artikel 4:12 Awb niet op boetebesluiten ziet. De Awb-wetgever stelt immers voorop dat het ook bij financiële beschikkingen aangewezen kan zijn een belanghebbende te horen voordat ten aanzien van hem een belastend besluit wordt genomen. ${ }^{574}$ Belangrijker nog is de wijze waarop het begrip 'financiële verplichting of aanspraak' in de Toelichting wordt gedefinieerd. Het gaat om alle beschikkingen die primair beogen de financiële betrekkingen tussen burger en bestuur te regelen en derhalve niet om beschikkingen die in eerste instantie wat anders beogen maar tevens financiële consequenties hebben of kunnen hebben. ${ }^{575}$ Dit laatste lijkt voor de bestuurlijke boete te gelden. De boete heeft immers leedtoevoeging ten doel. Met deze leedtoevoeging wordt vervolgens beoogd te voorzien in generale en speciale preventie en in vergelding. In de Memorie van Antwoord wordt echter ontkend dat artikel 4:12, eerste lid Awb niet van toepassing is op de bestuurlijke

571 Voorontwerp p. 132.

572 Voorontwerp p. 132.

573 Zie over het onderscheid tussen de zware en de lichte procedure mijn opmerkingen bij het voorgestelde artikel 5.4.2.1. lk meen dat een dergelijk onderscheid met het oog op de rechtspraak van het EHRM niet te rechtvaardigen is. De extra waarborgen (waaronder een hoorplicht in de primaire fase) dienen te gelden in het gehele bestuursstrafrecht. Dus ook ten aanzien van lage(re) punitieve sancties.

574 PG Awb l, p. 258.

575 PG Awb I, p. 259. Het op grond van de Hinderwet opleggen van een dwangsom valt derhalve niet onder 4:12 Awb (zie: PG Awb l, p. 259). 
boeten die worden opgelegd op grond van de WAHV. Een hoorplicht zou in strijd zijn met de bedoeling van de wet (namelijk efficiënte en effectieve handhaving) ${ }^{576}$ Opmerkelijk is tenslotte dat (onder meer) ten aanzien van de intrekking van een subsidie, op grond van artikel 4:12, tweede lid Awb, wél een hoorplicht bestaat.

Dat het bestuursorgaan niet verplicht is om de vermoedelijke overtreder te horen betekent uiteraard niet tevens dat het bestuursorgaan daartoe niet bevoegd zou zijn. Bovendien is artikel 3:2 van de Awb uiteraard wel van toepassing. Uit laatgenoemde bepaling kan onder omstandigheden ook een hoorplicht voortvloeien. Gelet op de hoge(re) eisen die bij de oplegging van punitieve sancties worden gesteld aan de voorbereiding van het besluit acht ik het niet uitgesloten dat de bestuursrechter bij oplegging van bestuurlijke boeten doorgaans een hoorplicht in de primaire fase eist. ${ }^{377}$ Het verdient dan, onder meer met het oog op de onschuldpresumptie, ook aanbeveling de vermoedelijke overtreder altijd de mogelijkheid te bieden zijn zienswijze naar voren te brengen vóórdat het boetebesluit genomen wordt. Anders zou aan de vermoedelijke overtreder immers reeds een bestuurlijke boete opgelegd kunnen worden voordat hij bijvoorbeeld een beroep heeft kunnen doen op een schulduitsluitingsgrond. Deze, van het van het traditionele strafrecht afwijkende, praktijk is mijns inziens niet gewenst.

Met het oog op de uit artikel 6 EVRM voortvloeiende verdedigingsrechten ${ }^{578}$ zijn er in artikel 5.4.2.3, eerste lid, onder a en b, van het Voorontwerp twee aanvullende bepalingen opgenomen. In artikel 5.4.2.3, eerste lid, onder a, is bepaald dat het rapport of proces-verbaal reeds bij de uitnodiging om zijn zienswijze naar voren te brengen aan de vermoedelijke overtreder wordt toegezonden. Voorts is in artikel 5.4.2.3, eerste lid, onder b, voorzien in taalhulp voor zover blijkt dat de verdediging van de vermoedelijke overtreder dit redelijkerwijs vergt. Taalhulp impliceert niet dat de vermoedelijke overtreder in alle gevallen moet worden bijgestaan door een officiële tolk. Het gaat er volgens de commissie Scheltema om dat het bestuursorgaan en de vermoedelijke overtreder met elkaar kunnen communiceren. ${ }^{579}$

Op grond van het tweede lid van artikel 5.4.2.3 van het Voorontwerp is het bestuursorgaan gehouden de vermoedelijke overtreder na het horen in kennis te stellen van het feit dat geen bestuurlijke boete zal worden opgelegd of dat de overtreding aan het OM zal worden voorgelegd. De schriftelijke kennisgeving van het bestuursorgaan dat geen bestuurlijke boete wordt opgelegd is een besluit in de zin van artikel 1:3 Awb.

Over de vraag of dit ook zo is voor de kennisgeving dat de overtreding aan het OM zal worden voorgelegd laat de commissie Scheltema zich niet uit. Beantwoording van die vraag is volgens de commissie zonder praktisch belang nu een derde daardoor in ieder geval niet rechtstreeks in zijn belang wordt getroffen omdat door genoemde kennisgeving nog niet wordt beslist over het al dan niet opleggen van een sanctie. ${ }^{580}$

576 PG Awb I, p. 260

577 Vgl. ABRS 15 juli 1996, AB 1996, 414 m. nt. F. Michiels (Sluiting café 'De Windmolen') en ABRS 15 februari 2001, JB 2001/88 m. nt. C.L.G.F.H. Albers.

578 In het bijzonder de eisen die voortvloeien uit artikel 6, derde lid, onder a en e EVRM.

579 Voorontwerp p. 133.

580 Voorontwerp p. 133. Zie m.b.t. derden belanghebbenden bij boetebesluiten: Albers en Schlossels a.w. $2002, \$ 3$. 
Dubieus is dat de commissie niet ingaat op de relevantie van de kennisgeving voor de vermoedelijke overtreder. Deze ziet zich immers geconfronteerd met een (eventuele) strafrechtelijke procedure waarin hem in veel gevallen een zwaardere sanctie boven het hoofd hangt. De commissie Scheltema had toch een passage in de toelichting kunnen wijden aan de vraag of de kennisgeving dat de overtreding aan het OM zal worden voorgelegd, aangemerkt moet worden als een publiekrechtelijke rechtshandeling (hetgeen mijns inziens overigens zeer wel verdedigbaar is). ${ }^{581}$ Lang zal het niet duren voordat de bestuursrechter geconfronteerd wordt met deze vraag. Véél (vermoedelijke) overtreders zullen bestuursrechtelijke afdoening prefereren boven het doorlopen van een strafrechtelijke procedure. Zij zullen derhalve bezwaar aan tekenen tegen de kennisgeving dat de overtreding aan het OM zal worden voorgelegd. ${ }^{582}$

\section{Artikel 5.4.2.4 Beslistermijn}

Op grond van artikel 5.4.2.4, eerste lid, van het Voorontwerp moet het bestuursorgaan binnen dertien weken na dagtekening van het rapport (indien dit is opgemaakt) beslissen omtrent het opleggen van een bestuurlijke boete. Uit het tweede lid volgt dat de beslistermijn wordt opgeschort met ingang van de dag waarop de gedraging aan het openbaar ministerie is voorgelegd, tot de dag waarop het bestuursorgaan bevoegd wordt een bestuurlijke boete op te leggen. Is er geen rapport opgemaakt dan geldt geen beslistermijn omdat het niet mogelijk is een eenvoudig vast te stellen beginpunt aan te wijzen. Uit artikel 6, eerste lid, van het EVRM vloeit echter wel de eis van afdoening binnen redelijke termijn voort. ${ }^{583}$

Indien de situatie uit het, hierboven beschreven, tweede lid zich voordoet kan de totale beslistermijn ten hoogste zesentwintig weken bedragen (één half jaar). Het OM heeft namelijk eveneens dertien weken de tijd om te beslissen of strafrechtelijk optreden gewenst is. De commissie Scheltema wijst er nadrukkelijk op dat het gaat om termijnen van orde. Overschrijding van de termijn leidt niet tot het vervallen van de bevoegdheid tot het opleggen van de boete.

\section{Artikel 5.4.2.5 Inhoud boetebeschikking}

In artikel 5.4.2.5 van het Voorontwerp is aangegeven welke gegevens opgenomen moeten zijn in de boetebeschikking. In ieder geval dienen vermeld te worden de naam van de overtreder en het bedrag van de boete. Bovendien moet de boetebeschikking voldoen aan de eisen uit artikel 5.0.9 van het Voorontwerp. ${ }^{584}$ De oplegging van een boete creëert tevens een bestuursrechtelijke geldschuld, derhalve moet de beschikking ook voldoen aan de vereisten die zijn neergelegd in artikel 4.4.1.2, tweede lid, van het Voorontwerp.

581 Daarnaast kan de vraag gesteld worden of een dergelijk publiekrechtelijke rechtshandeling van bezwaar en beroep uitgezonderd zou moeten worden.

582 In dit kader dient niet uit het oog te worden verloren dat het ook mogelijk bezwaar aan te tekenen tcgen de dagvaarding in de strafrechtelijke procedure (zie artikel $262 \mathrm{~Sv}$ ).

583 Voorontwerp p. 133.

584 Voorontwerp p. 134. 


\section{Artikel 5.4.2.6 Zware en lichte procedure}

In artikel 5.4.2.6 van het Voorontwerp wordt voor overtredingen waarvoor een boete van meer dan 340 Euro kan worden opgelegd een zwaardere procedure voorgesteld. De keuze om de grens te leggen op een bedrag van 340 Euro lijkt met name ingegeven te zijn door doelmatigheidsoverwegingen. ${ }^{585}$ De zwaardere procedure houdt in dat er bij de hogere boeten altijd een rapport of proces-verbaal opgemaakt dient te worden, dat de overtreder in alle gevallen gehoord moet worden, en dat de boete niet in mandaat wordt opgelegd door degene die het rapport of proces-verbaal heeft opgemaakt. Tenslotte zij nog opgemerkt dat bij de hogere boeten een verjaringstermijn van vijf jaar geldt. $^{586}$

De verplichting tot het opmaken van een rapport schept een extra waarborg in die zin dat duidelijk is voor de overtreder waarvan hij wordt beschuldigd ${ }^{587}$ Genoemd rapport is in de boeteprocedure een van de belangrijkste bewijsmiddelen en verschaft de overtreder belangrijke informatie over datgene waartegen hij zich moet verdedigen. De zware - boeteprocedure kan dan ook slechts betrekking hebben op overtredingen waarvan een rapport of proces-verbaal is opgemaakt. ${ }^{588}$

Een hoorplicht is volgens de commissie Scheltema bij zwaardere boeten gewenst omdat de overtreder dan 'in alle gevallen' de gelegenheid krijgt om zich tegen de tegen hem ingebrachte beschuldigingen te verweren voordat een boete wordt opgelegd. ${ }^{589}$

In het vierde lid van artikel 5.4.2.6 is een bepaling met betrekking tot functiescheiding opgenomen. De commissie Scheltema wijst er op dat bij de oplegging van de bestuurlijke boete, anders dan in het strafrecht, constatering van de overtreding en strafoplegging niet zijn ondergebracht bij verschillende instanties. In het CTW-rapport is destijds dan ook gepleit voor 'een zekere feitelijke distantie' tussen de toezichthoudende ambtenaar en de boete-oplegger. ${ }^{500}$ Deze opvatting werd in het kabinetsstandpunt door de regering onderschreven. Het kabinet plaatste daarbij de kanttekening dat een algemene regeling met betrekking tot functiescheiding niet voor de hand ligt. De regering merkte destijds voorts op dat de beoogde functiescheiding vaak binnen een bestuursorgaan gerealiseerd zal moeten worden. ${ }^{591}$ De commissie Scheltema wijst er op dat van een dergelijke functiescheiding binnen de organisatie aanvankelijk ook sprake was in het wetsvoorstel fiscale boeten. Naast een met heffing en invordering belaste inspecteur zou een speciale boete-inspecteur in het leven geroepen worden. De Tweede en Eerste Kamer wilden hier echter niet aan. De boete-inspecteur is vervolgens weer uit het wetsvoorstel geschrapt. Derhalve kan de aanslagregelende ambtenaar, op basis van de huidige fiscale boeteregeling, tevens een boete opleggen. ${ }^{592} \mathrm{De}$ commissie Scheltema besluit haar toelichting op het vierde lid van artikel 5.4.2.6 als volgt:

586 Zie de hierboven gegeven beschrijving van het voorgestelde artikel 5.4.1.6.

587 Voorontwerp p. 134.

588 Voorontwerp p. 134.

589 Voorontwerp p. 134. Hier proef ik toch duidelijk dat de commissie Scheltema zich zelf ook realiseert dat niet horen in de primaire fase op gespannen voet staat inet de onschuldpresumptie.

590 Zie CTW-rapport a.w. 1994, p. 48-50 en 70.

591 Zie Kabinetsstandpunt: Handhaving door bestuurlijke boeten, a.w. 1994, p. 12-13.

592 Voorontwerp p. 135. 
'Gelet op een en ander is voor de zware procedure volstaan met de bepaling dat degene die de overtreding constateert, niet tevens in mandaat kan worden belast met de boeteoplegging. Dit sluit dus niet uit dat de wetgever zelf beide functies verenigbaar heeft geacht, zoals in het fiscale recht. Oefent dan het bestuursorgaan zelf beide functies uit, dan is dit in overeenstemming met de beslissing van de wetgever. Maar wanneer mandaatverlening aan de orde is, behoort de hier geformuleerde regel in acht genomen te worden.'

De commissie Scheltema is niet eenduidig in haar formulering. Gaat het nu om functiescheiding in de zin dat het ene bestuursorgaan de overtreding constateert en het andere bestuursorgaan de boete oplegt, of gaat het er om dat twee verschillende ambtenaren werkzaam in ondergeschiktheid aan een bestuursorgaan belast zijn met de verschillende taken? Dat kan aan de hand van de hierboven weergegeven passage niet met zekerheid gesteld worden. 593

Ik meen dat er van uitgegaan kan worden dat in de wet in formele zin (al dan niet) gekozen kan worden voor een functiescheiding waarbij de bevoegdheden verdeeld worden over verschillende bestuursorganen. Gebeurt dat niet dan moet in ieder geval in mandaat voorzien worden in een functiescheiding (tussen ambtenaren die in dienst zijn van één bestuursorgaan). Vanuit doelmatigheidsoverwegingen is deze uitwerking van het functiescheidingsvereiste logisch. Van het traditioneel in het strafrecht gehanteerde onderscheid opsporing - vervolging - bestraffing blijft op deze wijze in het bestuursstrafrecht echter weinig over. Bovendien geldt het vereiste van functiescheiding alleen ten aanzien van overtredingen waarvoor een boete van meer dan 340 Euro kan worden opgelegd.

Dat de commissie Scheltema onderscheidt tussen een lichte procedure - die wellicht niet op alle punten voldoet aan de uit het EVRM en IVBPR voortvloeiende eisen ${ }^{594}$ en een zware procedure, is mijns inziens niet in overeenstemming met de opvatting van het EHRM. Het EHRM gaat er van uit dat de waarborgen uit het EVRM, en dan in het bijzonder uit artikel 6 en 7, in acht genomen moeten worden in alle procedures tot oplegging van een punitieve sanctie. Deze eis geldt óok als het gaat om 'minor offences' waarop een relatief lage sanctie is gesteld.

Het grootste gebrek dat aan de lichte procedure kleeft is dat er géén sprake is van een hoorplicht in de primaire fase. Indien er geen sprake is van een schorsende werking van bezwaar en/of beroep, of een verbod tot invordering van de boete gedurende die fasen, én er is geen sprake van een hooplicht in de primaire fase - hetgeen bij de lagere boeten zeer wel het geval kan zijn - kan oplegging van de bestuurlijke boete door het EHRM wel eens in strijd met de onschuldpresumptie (uit artikel 6, tweede lid EVRM) worden verklaard. ${ }^{595}$ Bovendien zou de nationale bestuursrechter, zoals ik reeds heb aangegeven, wel eens uit kunnen gaan van een hoorplicht op grond van artikel 3:2 Awb bij de oplegging van punitieve bestuursrechtelijke sancties.

593 Hetzelfde euvel kleeft overigens in dit kader aan het CTW-rapport (zic a.w. 1994, i.h.b. p. 49).
594 De commissie Scheltema zal overigens, anders dan ik, - tegen beter weten in (vgl. bijv. de onderbouwing van de hoorplicht bij hogere boeten) - van mening zijn dat de waarborgen uit het EVRM ook in het kader van de lichte procedure voldoende in acht genomen worden.

595 Zie de in dit kader door mij bij artikel 5.4.1.2 geplaatste kritische kanttekeningen in dit hoofdstuk. 
Artikel 5.4.2.7 Overeenkomstige toepassing op andere bestuursrechtelijke sancties

Op basis van artikel 5.4.2.7 van het Voorontwerp is het tenslotte mogelijk titel 5.4. bij wettelijk voorschrift van overeenkomstige toepassing te verklaren op andere bestuursrechtelijke sancties. Daarbij denkt de commissie Scheltema blijkbaar met name aan andere (financiële) punitieve sancties. ${ }^{596}$ Los van de bestuurlijke boete bestaan er momenteel reeds andere punitieve bestuursrechtelijke sancties. Ik wijs bijvoorbeeld op de intrekking bij wijze van sanctie van een begunstigende beschikking. Daarvan staat immers vast dat deze onder bepaalde omstandigheden punitief is. ${ }^{597}$ Waarom zouden ten aanzien van die sancties niet nu reeds de bepalingen uit titel 5.4 van (overeenkomstige) toepassing kunnen zijn? Aangezien een punitieve sanctie meestal ook een 'criminal charge' in de zin van artikel 6 EVRM is moeten de meeste waarborgen uit genoemde titel van het Voorontwerp bij de oplegging van een dergelijke sanctie toch al in acht genomen worden.

\subsection{Resumé}

In deze laatste paragraaf van hoofdstuk vier zal ik mijn oordeel over de voorgestelde boeteregeling weergeven. Een nadere uitwerking van de bevindingen uit dit hoofdstuk, in een ruimere context, zal plaats vinden in deel drie van dit boek.

Uit de bespreking van het Voorontwerp is gebleken dat volgens de commissie Scheltema ten aanzien van de bestuurlijke boete, vanwege haar bijzondere (punitieve) aard, andere regels en waarborgen moeten gelden dan ten aanzien van de, als herstelsancties gekwalificeerde, andere in de Awb opgenomen bestuursrechtelijke sancties. Het vereiste van extra waarborgen vloeit volgens de commissie met name voort uit de intemationale verdragen zoals het EVRM en IVBPR ${ }^{598}$ Het voorgaande brengt naar het oordeel van de commissie met zich dat de regeling van de bestuurlijke boete op enkele wezenliike punten overeen moet komen met het strafrecht. ${ }^{599}$

Om die reden heeft zij op een fragmentarische en eigen wijze bepaalde straf(proces)rechtelijke bepalingen in het Voorontwerp overgenomen. Ik wijs ter illustratie op de termen overtreder, functioneel daderschap, eendaadse samenloop, meerdaadse samenloop, en hetzelfde feit. De uitleg die de commissie Scheltema aan deze termen in het Voorontwerp heeft gegeven wijkt soms af van de uitleg die daaraan, onder meer door de Hoge Raad, in het strafrecht gegeven wordt. Het gevolg daarvan is dat de bestuursrechter bepaalde strafrechtelijke begrippen en leerstukken anders zal gaan uitleggen dan de strafrechter. Dit geldt bijvoorbeeld ook voor het hanteren van een zogenaamd 'open stelsel' van rechtvaardigings- en schulduitsluitingsgronden. Daarnaast kan gewezen worden op een van artikel $29 \mathrm{~Sv}$ afwijkende regeling van het zwijgrecht in het Voorontwerp.

597 De intrekking van de erkenning voor een APK-keuringsplants wordt bijvoorbeeld gekwalificeerd als punitieve sanctie (ABRS 15 februari 2001, JB 2001/88 m. nt. C.L.G.F.H. Albers). Zie in dit kader voorts $\$ 2.2 .3 .2$ van dit boek en Albers a.w. 2001, p. 1157-1162.

599 Voorontwerp p. 100. 
Corstens en Knigge achten de hierboven beschreven ontwikkeling onwenselijk. Ik deel die mening. Knigge vraagt zich in dat kader overigens af of het strafrecht niet zonder meer (dus onverkort) van toepassing zou moeten zijn bij de oplegging van bestuurlijke boeten. Dat laatste is wellicht wat 'overdone'. De commissie Scheltema heeft mijns inziens gelijk als zij stelt dat aan bepaalde strafrechtelijke leerstukken in het punitieve bestuursrecht geen behoefte bestaat omdat bestuurlijke boeten in de regel alleen voor relatief eenvoudige delicten mogen worden opgelegd. ${ }^{600}$ Dit laat echter onverlet dat de bestuurlijke boete, evenals andere punitieve bestuursrechtelijke sancties, tot het strafrecht in ruime zin moet worden gerekend. Dit brengt mijns inziens met zich dat, àls strafrechtelijke leerstukken worden overgenomen, zij conform het geldend (straf)(proces)recht moeten worden overgenomen. Daarnaast moeten de Awb-wetgever en de bestuursrechter waar mogelijk ${ }^{601}$ dezelfde uitleg aan strafrechtelijke bepalingen en leerstukken geven als de strafrechter. Dit is in het Voorontwerp niet op alle punten gebeurd.

Een groot probleem lijkt voorts te schuilen in het feit dat het Nederlandse bestuursprocesrecht niet in voldoende mate toegespitst is op procedures tot het opleggen van punitieve sancties. In het Voorontwerp blijkt dit reeds duidelijk. ${ }^{602}$ Ik wijs op het feit dat de bestuursrechter slechts 'ex tunc' zou mogen toetsen waardoor hij niet bevoegd is een lagere boete op te leggen als er sprake is van een strafverlaging in de wettelijke regeling die tot stand is gekomen tijdens de beroepsprocedure. ${ }^{603}$ Voorts geldt in het bestuurs(proces)recht het verbod van reformatio in peius. Op grond van genoemd verbod mag de bestuursrechter, anders dan de strafrechter, géén hogere boete opleggen dan de door het bestuursorgaan in eerste instantie opgelegde boete. ${ }^{604}$ Verder kan gewezen worden op het feit dat de bestuursrechter de evenredigheid van de boete bij strikt gebonden sanctiebevoegdheden niet daadwerkelijk kan toetsen. Daarnaast ontbreekt schorsende werking bij bezwaar en beroep ${ }^{605}$ waardoor de boete reeds kan worden ingevorderd op het moment dat nog niet onherroepelijk op het tegen het boetebesluit ingediende bezwaar, beroep of hoger beroep is beslist. Dit terwijl er voorts in de lichte procedure géén hoorplicht in de primaire fase bestaat gelet op de naar geldend recht gegeven uitleg aan artikel 4:12 Awb.

Men kan zich voorts afvragen in hoeverre het standpunt, dat er bij meerdaadse samenloop in beginsel sprake zal zijn van een cumulatie van sancties die in overeenstemming is met het evenredigheidsbeginsel, reëel is. In het bestuursprocesrecht zijn in het kader van meerdaadse samenloop, anders dan in het strafrecht, gelet op het specialiteitsbeginsel, immers niet zelden verschillende bestuursorganen bevoegd tot sanctionering. Ook

600 Voorontwerp p. 100.

601 Namelijk voor zover afwijking van het strafrecht niet noodzakelijk is vanwege specifiekt karakteristieken van de te handhaven bestuursrechtelijke regelgeving.

602 In het slothoofdstuk zal ik hier nader op in gaan.

603 Zie de beschrijving van artikel 5.4.1.7, vierde lid van het Voorontwerp eerder in dit hoofdstuk. De Centrale Raad van Beroep onderschrijft dit standpunt overigens niet. Bovendien lijkt het mij waarschijnlijk dat de Awb-wetgever in het definitieve wetsvoorstel dit uitgangspunt zal verlaten.

604 In reeds bestaande boeterelingen wordt overigens niet altijd onverkort vastgehouden aan het verbod van reformatio in peius.

605 Zie artikel 6:16 Awb. 
is onduidelijk op welke wijze in de praktijk, met het oog op het bestuursprocesrecht, invulling moet worden gegeven aan de ne bis in idem-regeling.

Toepassing van (deze) bestuursprocesrechtelijke regels in het bestuursstrafrecht leidt er doorgaans toe dat de rechtsbescherming voor de vermoedelijke overtreder geringer is in het bestuursstrafrecht dan bij sanctionering middels de reguliere strafrechtelijke procedure.

In een enkel geval heeft de commissie Scheltema overigens wél voor afwijking van de, in het algemeen geldende, bestuursrechtelijke regeling gekozen. In dit kader kan gewezen worden op de toetsing aan het evenredigheidsbeginsel bij de oplegging van bestuurlijke boeten. Interessant is echter de verklaring van genoemde commissie waarom bij punitieve sancties door de bestuursrechter niet marginaal maar vol mag worden getoetst aan het evenredigheidsbeginsel. ${ }^{606}$ Mijns inziens moet de commissie Scheltema niet proberen afwijkende regels dogmatisch te rechtvaardigen maar gewoon duidelijk aangeven dat het, gelet op het bijzondere karakter van de op te leggen punitieve sancties, nodig is af te wijken van het 'gewone' bestuursprocesrecht. Bovendien had de commissie Scheltema, zoals uit bovenstaand overzicht blijkt, teneinde de (vermoedelijke) overtreder voldoende rechtsbescherming te bieden, ook nog op andere punten dan de toetsingsbevoegdheid expliciet af moeten wijken van het bestuursprocesrecht.

Toepassing van het bestaande bestuursprocesrecht leidt er in bepaalde gevallen voorts toe dat de verdragsrechtelijke waarborgen door de commissie Scheltema schraal worden uitgelegd. Ik heb reeds de aandacht gevestigd op de problemen die ontstaan ${ }^{607}$ in het kader van artikel 5.4.1.7, vierde lid Voorontwerp met betrekking tot het toepassen van de meest gunstige bepaling. Daarnaast kan worden gewezen op het feit dat de commissie Scheltema blijft vasthouden aan de vrij bewijsleer in het bestuursprocesrecht. Daarmee hangt mijns inziens samen dat in het bestuursrecht nogal soepel wordt omgesprongen met strafrechtelijk onrechtmatig verkregen bewijs. Dit is met het oog op de onschuldpresumptie uiteraard niet wenselijk. Daar komt nog bij dat volgens de commissie uitgegaan mag worden van (soms onweerlegbare) vermoedens van schuld terwijl schorsende werking van bezwaar en beroep en een hoorplicht in de primaire fase vaak (zullen) ontbreken. Ook acht de commissie het niet onmogelijk vormverzuimen te passeren op grond van artikel 6:22 Awb. Dit laatste lijkt ook mogelijk te zijn indien daardoor verdedigingsrechten of andere verdragsrechtelijke waarborgen worden geschonden.

Ten slotte kan gewezen worden op het, op grond van artikel 8:69 Awb, ontstane 'trechtermodel'. Hantering van dit model zou naar mijn mening in ieder geval in het kader van de oplegging van punitieve sancties kunnen leiden tot een rechtsbeschermingsprocedure die wellicht niet voldoet aan de eisen van artikel 6 EVRM. $^{608}$ Ten

606 Zie de beschrijving van artikel 5.4.1.7, tweede lid van het Voorontwerp eerder in dit hoofdstuk.

607 Indien de Awb-wetgever deze bepaling onverkort overneemt in de Vierde tranche.

608 Met name de 'argumentatieve fuik' zou in dat kader problemen op kunnen leveren. Gronden die eerst in beroep of hoger beroep worden aangevoerd kunnen immers, indien toepassing wordt gegeven aan de 'argumentatieve fuik', buiten beschouwing worden gelaten door de bestuursrechter. De 'bewijsfuik' lijkt bij de oplegging van punitieve sanctics door de Afdeling Bestuursrechtspraak overigens niet gehanteerd te worden. 
eerste wordt de toegang tot de rechter door toepassing van het 'trechtermodel' (tenminste ten dele) beperkt en voorts kan naar mijn mening niet meer gesproken worden van een rechter die onverkort voldoet aan het vereiste van 'full jurisdiction' ${ }^{609}$ Wat dit laatste betreft biedt de rechtspraak van het EHRM overigens (nog) weinig duidelijkheid. Gaat het om, geschillen ten aanzien van 'civil rights and obligations' in het kader van de uitoefening van, typische bestuursrechtelijke bevoegdheden met beleidsvrijheid dan is een beperking van de rechterlijke toetsing niet zonder meer uitgesloten. ${ }^{610}$ Of dit anders ligt bij oplegging van punitieve sancties door bestuursorganen kan niet met zekerheid worden gezegd. Aangezien er in een dergelijk geval sprake is van een 'criminal charge' is het mijns inziens niet uitgesloten dat het Hof in dat kader hogere eisen stelt. Het voorgaande lijkt ook uit de zaak 'T. v. Austria' afgeleid te kunnen worden.

De schrale uitleg van verdragsrechtelijke waarborgen vloeit niet alleen voort uit het feit dat het bestuursprocesrecht niet in voldoende mate is toegespitst op de oplegging van punitieve sancties. Doelmatigheidsoverwegingen lijken ook ten grondslag te liggen aan de beperkte uitleg van genoemde waarborgen. In dat kader kan (onder meer) gewezen worden op het door de commissie gemaakte onderscheid tussen de zware en de lichte procedure, de (té) beperkte uitleg van het zwijgrecht en het gebruik van strafrechtelijk onrechtmatig verkregen bewijs. Anderzijds lijkt de commissie Scheltema graag aansluiting te zoeken bij de verdragsrechtelijke waarborgen en de in dat kader bestaande rechtspraak, indien deze waarborgen minder ver rijken dan de in het nationale recht bestaande equivalenten. Ik wijs in dat kader op het zwijgrecht dat volgens de commissie Scheltema, conform de rechtspraak van het EHRM, geldt vanaf het moment dat er sprake is van een 'charge'. Een moment dat later in de tijd gelegen is dan het moment waarop aan een verdachte op grond van artikel $29 \mathrm{~Sv}$ het zwijgrecht wordt toegekend.

Een en ander leidt tot de volgende slotsom. De voorgestelde boeteregeling geeft aanleiding tot veel commentaar. Veelal liggen aan de keuze van afdoening van overtredingen middels bestuurlijke boeten doelmatigheidsoverwegingen ten grondslag. Oplossing of vermindering van het handhavingstekort staat in dat kader centraal. Ook in de voorgestelde regeling lijkt met name prioriteit te zijn gegeven aan het vereiste van efficiënte en effectieve handhaving. Het bestuursprocesrecht lijkt bovendien niet in voldoende mate toegespitst te zijn op de oplegging van punitieve bestuursrechtelijke sancties. De rechtsbescherming van de overtreder laat in het bestuursstrafrecht duidelijk te wensen over en men kan zich dan ook af vragen of de Awb zich wel leent voor een regeling met betrekking tot de oplegging van bestuurlijke boeten.

Met Hartmann en Van Russen Groen deel ik de mening dat de regering een aparte wet bestuursstraf(proces)recht serieus in overweging dient te nemen. ${ }^{611}$ Voorts is het mijns

609 Vgl. Schlossels a.w. 1999, p. 183-185 en De Bock a.w. 2000, p. 75-77. Een genuanceerder standpunt wordt ingenomen in Widdershoven/Schlðssels/Stroink a.w. 2001, p. 35-37. Zie overigens ook de reeds eerder in dit kader aangehaalde zaak 'T. v. Austria'.

$610 \mathrm{Vgl}$. de zaken 'Bryan' en 'Kingsley'.

611 Zie Hartmann en Van Russen Groen a.w. 1998, p. 127 e.v. Het standpunt van Jansen, dat regeling in de Awb de voorkeur verdient kan ik, mede gelet op het voorgaande, niet (onverkort) delen. Jansen lijkt zijn standpunt overigens met name te baseren op pragmatische, positivistische en formalistische argumenten. Voor de typisch bestuursprocesrechtelijke problemen (zoals in dit hoofdstuk geschetst) heeft hij weinig oog (Vgl. Jansen a.w. 2002, p. 188-189). 
inziens de moeite waard naar (in bestaande regelgeving in te passen) alternatieven te kijken. Misschien zou de bestuur(srechte)lijke transactie in dat kader een rol kunnen spelen. Daarnaast lijkt de in de rapporten 'Strafvordering 2001' voorgestelde OMboete ${ }^{612}$ eventueel een alternatief te kunnen vormen ${ }^{613}$ In deel drie van dit boek zal ik op deze suggesties terugkomen.

612 De OM-boete is een bestuurlijke boete die wordt opgelegd door het OM. Rechtsbescherming tegen de opgelegde boete staat open bij de strafrechter die in dat kader het Wetboek van Strafrecht en het Wetboek van Strafvordering toepast.

613 Vgl. Groenhuijsen en Knigge a.w. 1999, p. 27-28 en 41-42, A.R. Hartmann, Buitengerechtelijke afdoening, in: Groenhuijsen en Knigge a.w. 1999, p. 59-90, Groenhuijsen en Knigge a.w. 2001, G. Knigge, De verhouding tot het strafrecht, p. 93-124, i.h.b. p. 119-124. 


\section{Deel II}

De Verenigde Staten 



\title{
Inleiding
}

\begin{abstract}
Algemeen
Nadat in deel éen van dit boek aandacht uit is gegaan naar de Nederlandse bestuurlijke boete(regeling) zal in deel twee aandacht worden besteed aan handhaving door middel van bestuurlijke boeten in de Verenigde Staten. Deel twee bestaat uit een viertal hoofdstukken.

In hoofdstuk vijf zal aandacht uitgaan naar het Amerikaanse administratief recht in het algemeen. De procedure tot oplegging van de bestuurlijke boete, zoals die wordt toegepast in Amerika, en de waarborgen die in dat kader op grond van de boeteregeling in acht genomen moeten worden zullen in hoofdstuk 6 aan de orde komen. Daama komt de rechtsbescherming, die ten aanzien van de vermoedelijke overtreder geboden wordt, bij de oplegging van bestuurlijke boeten aan de orde. In dat kader staan de constitutionele waarborgen centraal (hoofdstuk 7). In hoofdstuk acht volgt dan de conclusie. Daarbij zal vooral ingegaan worden op de vraag in hoeverre oplegging van de bestuurlijke boete in de Verenigde Staten met essentiële straf(proces)rechtelijke waarborgen is omkleed. Aan de hand van het antwoord op die vraag kan tevens worden aangegeven in welke mate in de Verenigde Staten rechtsbescherming geboden wordt bij de oplegging van punitieve bestuursrechtelijke sancties, en dan in het bijzonder ten aanzien van de bestuurlijke boete.

Op basis van het onderzoek in deel twee van dit boek naar de wijze waarop, bij de oplegging van bestuurlijke boeten, in het Amerikaanse systeem invulling wordt gegeven aan de rechtsbescherming van de vermoedelijke overtreder zal in het slotdeel (deel III) van dit boek worden aangegeven in hoeverre de Nederlandse wetgever daar lering uit kan trekken.
\end{abstract}

\section{Essentie deel II}

In de Verenigde Staten bestaat, zoveel is duidelijk, een met de bestuurlijke boete vergelijkbare sanctie. De bevoegdheid tot oplegging van bestuurlijke boeten is bij lange na niet eenduidig neergelegd in wettelijke regelingen. Diverse modaliteiten zijn mogelijk. Zo kan ten aanzien van bepaalde (bijvoorbeeld milieurechtelijke) overtredingen beboet worden per tijdseenheid dat een overtreding voortduurt. Een dergelijke vorm van beboeting ligt dicht aan tegen een last onder dwangsom zoals wij die in Nederland kennen hoewel op grond van de Amerikaanse regeling veelal sprake is van beboeting achteraf (en derhalve niet van het opleggen van een last vóbrdat de (volgende) overtreding plaats gevonden heeft).

Ook de naam van de sanctie is niet eenduidig. Zo wordt onder meer gesproken van '(the administrative assessment of civil penalties'. Daarnaast worden ook, doch in mindere mate, termen gebruikt als; 'administrative civil penalty' en 'administrative penalty'. Bij bestudering van de boeteregelingen blijkt dat het ook in de Verenigde Staten gaat om oplegging van een onvoorwaardelijke verplichting tot betaling van een geldsom aan een overtreder door een bestuursorgaan (zonder voorafgaande tussenkomst van een rechter). Aangezien de boeten doorgaans hoger zijn dan voor herstel van de onrecht- 
matige toestand noodzakelijk is, zien zij mijns inziens (mede) op bestraffing van de overtreder. Daarmee kunnen deze Amerikaanse sancties ondergebracht worden in de categorie 'bestuurlijke boeten' zoals gedefinieerd in hoofdstuk twee van deel I.

Ten slotte verdient nog opmerking dat bestuursorganen in de Verenigde Staten, op basis van bepaalde bijzondere bestuursrechtelijke wetten, de rechter kunnen verzoeken via een civiele procedure (civil action) een boete op te leggen wegens overtreding van een bestuursrechtelijke regeling of een bestuursrechtelijk voorschrift. ${ }^{1}$ Dergelijke boeten vallen niet onder de in dit boek te bespreken bestuurlijke boeten. Zij worden immers niet zonder tussenkomst van een rechter door het bestuursorgaan opgelegd.

In dit deel van het boek zal, zoals hierboven reeds is opgemerkt, in het bijzonder aandacht uitgaan naar de vraag in hoeverre de Amerikaanse bestuurlijke boeteregeling ${ }^{2}$ voldoet aan de essentiële straf(proces)rechtelijke waarborgen die, met het oog op de rechtsbescherming van de vermoedelijke overtreders, op grond van deel I van dit werk van toepassing moeten worden geacht bij de oplegging van een bestuurlijke boete.

Voordat ingegaan wordt op de bovenstaande vraag zal, zoals gezegd, eerst enige aandacht worden besteed aan het Amerikaanse administratief recht. Met name zal ingegaan worden op de bevoegdheid van bestuursorganen om bestuurlijke boeten op te leggen en op de rechterlijke controle ten aanzien van het uitoefenen van die bestuursbevoegdheid.

Vervolgens zal, aun de hand van ean tweetal boteregelingen onderzocht worden in hoeverre in deze boeteregelingen voldaan wordt aan de in deel I weergegeven essentiele straf(proces)rechtelijke waarborgen. Daarbij is gekozen voor twee boeteregelingen die door het Environmental Protection Agency (EPA) worden uitgevoerd. Bij die keuze heeft met name de toegankelijkheid van de regelgeving een rol gespeeld.

Fen en ander betekent overigens niet dat hierdoor een onzuiver beeld van bestuurlijke boeteregelingen, zoals die in de Verenigde Staten bestaan, zal ontstaan. De procedures zoals die door het EPA worden toegepast in verband met de oplegging van bestuurlijke boeten blijken (althans in essentie) ook door andere bestuursorganen te worden gevolgd bij het opleggen van bepaalde bestuurlijke boeten. Ter onderbouwing van dit standpunt kan verwezen worden naar een publicatie van de Amerikaanse jurist Colin Diver. ${ }^{3}$ Diver beschrijft in deze publicatie de diverse bestuurlijke boeteprocedures die op federaal niveau bestaan. Uit het werk van Diver kan worden afgeleid dat de procedures zoals die door het EPA worden toegepast ook door andere bestuursorganen worden gevolgd bij het opleggen van bestuurlijke boeten. Hoewel er derhalve een héél scala aan wettelijke bevoegdheden tot oplegging van bestuurlijke boeten bestaat vertonen de

I Vgl. A.B. Blomberg, Integrale handhaving van milieurecht (diss. VU), Boom juridische uitgevers, Den Haag 2000, p. 241.

2 Voor de duidelijkheid dient op deze plaats opgemerkt te worden dat er in de Verenigde Staten evenals in Nederland - uiteraard tal van bestuurlijke boeten kunnen worden opgelegd. De wijze van oplegging van de bestuurlijke boeten kan dan ook per regeling verschillen. Bij dit onderzoek is met name gebruik gemaakt van een aantal federale bestuurlijke boeteregelingen. In feite kan dan ook niet gesproken worden van 'de Amerikaanse bestuurlijke boete'. Een ander zal later in dit hoofdstuk nog nader aan de orde komen.

3 Colin S. Diver, The Assessment and Mitigation of Civil Money Penalties by Federal Administrative Agencies, Columbia Law Review, december 1979, p. 1435 - p. 1502. 
meeste boeteregelingen in essentie dezelfde kenmerken ten aanzien van de procedure tot oplegging van de boete.

Zoals gezegd zullen twee wettelijke regelingen, waarin aan het EPA de bevoegdheid is toegekend tot het opleggen van een bestuurlijke boeten, getoetst worden aan de uit deel I voortvloeiende essentiële straf(proces)rechtelijke waarborgen die in het kader van de oplegging van punitieve bestuursrechtelijke sancties zouden moeten gelden. Daarna zal nog ingegaan worden op de rechtspraak van het Supreme Court met betrekking tot de toepasselijkheid van de in het vijfde, zesde en achtste amendement opgenomen (strafrechtelijke) waarborgen bij de oplegging van de bestuurlijke boete. 



\section{Korte introductie in het administratief recht van de Verenigde Staten}

\section{$5.1 \quad$ Inleiding}

In dit hoofdstuk gaat aandacht uit naar het Amerikaanse administratief recht. De nadruk zal daarbij liggen op die aspecten van het Amerikaanse administratief recht die van belang zijn voor een beter begrip van dit onderzoek. Bijgevolg zal in dit hoofdstuk geen volledige beschrijving van het Amerikaanse bestuursrechtelijke systeem plaats vinden. Ook op de meer staatsrechtelijk getinte aspecten van de oplegging van bestuurlijke boeten, zoals bijvoorbeeld de (toezichts)relatie tussen ministers en agencies, zal in dit boek niet uitvoerig in worden gegaan. Het recht van de staten zal in dit werk geheel buiten beschouwing blijven.

Twee aspecten van het Amerikaanse administratief recht zijn bijzonder relevant in het kader van dit onderzoek. Het gaat ten eerste om de wijze waarop, door welke bestuursorganen, bestuurlijke boeten opgelegd kunnen worden. Ten tweede is in het kader van dit onderzoek de vraag relevant welke rechterlijke instantie zich kan uitspreken over de door een bestuursorgaan opgelegde bestuurlijke boeten. ${ }^{1}$ Hierna zal dan ook slechts op deze twee onderwerpen worden ingegaan.

\section{$5.2 \quad$ Bevoegde bestuursorgaan}

\subsubsection{Agency}

De bevoegdheid tot het opleggen van een bestuurlijke boete ${ }^{2}$ komt in beginsel toe an een bestuursorgaan. Derhalve zal op deze plaats aandacht uitgaan naar de bevoegdheden van Amerikaanse bestuursorganen. Op de structuur van bestuursorganen zal hier niet ingegaan worden aangezien de structuur van elk afzonderlijk bestuursorgaan verschillend, en in de regel zeer gedetailleerd, is.

De Amerikaanse bestuursorganen worden doorgaans 'agency' genoemd. ${ }^{3}$ Agencies worden veelal onderverdeeld in 'executive agencies' en 'independent agencies' ofwel 'independent regulatory commissions'. In Gellhorn and Byse's 'Administrative Law' de volgende beschrijving van genoemde agencies opgenomen:

l In dit kader zal ook aandacht uitgaan naar de bevoegdheden waarover de rechter bij de toetsing van bestuursbes/uiten beschikt. Met name de toetsingsintensiteit speelt daarbij een rol.

2 In de Amerikaanse literatuur wordt niet eenduidig over 'de bestuurlijke boete' gesproken. Met name de term '(the administrative assessment of) civil penalties' komt veelvuldig voor. Daamaast worden ook, doch in mindere mate, termen gebruikt als; 'administrative civil penalty' en 'administrative penalty'. Ik $z$ al in dit hoofdstuk in de regel gebruik maken van de term 'bestuurlijke boete'. Later in deel II zal nog uitvoeriger ingegaan worden de bevoegdheid tot het opleggen van bestuurlijke boeten.

3 Gelet op het feit dat de Amerikaanse bestuursorganen niet volledig vergelijkbaar zijn met Nederlandse bestuursorganen zal in dit stuk de Amerikaanse term 'agency' worden gebruikt.

4 Peter L. Strauss, Todd Rakoff, Roy A. Schotland, Cynthia R. Farina, Gelhom and Byse's Administrative Law, cases and comments, ninth edition, The Foundation Press, Westbury, New York, 1995 (hiema: 
'By an administrative agency we mean only a unit of government created by statute and made responsible for administering one or a series of related programs. At the federal level, administrative agencies typically but not invariably take one of two forms: An executive agency is headed by a single administrator who serves at the President's pleasure; it may be part of a cabinet department, like the Occupational Health and Safety Administration in the Department of Labor, or stand alone like the Environmental Protection Agency. An independent regulatory commission is headed by a multi-member body whose members serve fixed, staggered terms from which they may be removed only for "cause" - a constraint whose precise dimensions are, as we shall see, strikingly undefined. Usually the number of commissioners and the length of their terms are matched - five-year terms for a five-member commission - so that one vacancy falls open each year. While the President will ordinarily appoint members of his own political party to head executive agencies, statutes usually require bipartisan membership in independent commissions; he is, however, generally free to designate an independent commission's chair from among its members, and the chair usually holds that office at the President's pleasure. As their name suggests, independent commissions are stand-alone agencies although some (...) have complex, specified relations with cabinet departments or other agencies. (...) For our purposes the important thing to note is that details of their relation to the President are virtually all that separate the executive agencies from the independent regulatory commissions. Their internal organization, the procedures they follow, the kind of responsibilities they may be given are essentially the same..$^{5}$

Uit het voorgaande blijkt dat de 'executive agencies' en 'independent agencies' zich met name van elkaar onderscheiden vanwege de invloed die de President uit kan oefenen op de (benoeming van de leiding van de) agencies. In de praktijk blijkt echter dat de verschillen tussen executive en independent agencies ook op dit punt nog nauwelijks tot onderscheid leiden. In Gelhom and Byse's 'Administrative Law' wordt daarover het volgende geschreven:

'The independent agencies are often free, at least in a formal sense, of other relationships with the White House that characterize the executive branch agencies. The President's influence reaches somewhat more deeply into the top layers of bureaucracy at an executive agency than at an independent commission. (...) Yet these differences are at best matters of degree. (...) Even in executive agencies, the layer over which the President enjoys direct control of personnel is very thin and political factors may make it difficult for him to exercise even those controls to the fullest. ${ }^{6}$

Dit lijkt met zich te brengen dat het (formele) onderscheid tussen genoemde agencies in wezen niet bijzonder relevant is. Los van het formeel bestaande onderscheid wat betreft de invloed van de President zijn er nauwelijks verschillen. Dit laatste geldt ook voor wat betreft de bevoegdheid tot het opleggen van bestuurlijke boeten.

Gelet op het voorgaande, en mede met het oog op het feit dat de staatsrechtelijke relatie van het agency tot de President in het kader van de procedure tot oplegging van bestuurlijke boeten met het oog op dit (bestuursrechtelijk) onderzoek niet of nauwelijks van belang is, zal hierna gesproken worden van agencies zonder te onderscheiden tussen 'executive agencies' en 'independent agencies'. 
In dit kader zij overigens nog opgemerkt dat ook in de, tot op zekere hoogte met de Awb vergelijkbare, Administrative Procedure Act (APA) ${ }^{7}$ een definitie wordt gegeven van de term 'agency'. Deze (ruime) definitie luidt als volgt:

'For the purpose of this subchapter-

(1) 'agency' means each authority of the Government of the United States, whether or not it is within or subject to review by another agency, but does not include-

(A) the Congress;

(B) the courts of the United States;

(C) the government of the territories or possessions of the United States;

(D) the government of the District of Columbia; or except as to the requirements of section 552 of this title-

(E) agencies composed of representatives of the parties or of representatives of organisations of the parties to the dispute determined by them;

(F) courts martial and military commissions;

(G) military authority exercised in the field in time of war or in occupied territory; or

(H) functions conferred by sections $1738,1739,1743$, and 1744 of title 12; chapter 2 of title 41 ; subchapter II of chapter 471 of title 49 ; or sections 1884, 1891-1902, and former section 1641 (b)(2), of title 50, appendix; $;^{8}$

\subsubsection{Quasi bevoegdheden en de 'separation of powers' doctrine}

Zoals hier voor reeds bleek worden de, tot op zekere hoogte met de in Nederland bestaande zelfstandige bestuursorganen (ZBO's) vergelijkbare ${ }^{9}$, agencies bij wet in het leven geroepen. De aldus bij formele wet ${ }^{10}$ gecreëerde agencies hebben de opdracht de, in diezelfde formele wet aangegeven, (specifieke) doelstellingen te realiseren. " De formele wet kan worden gezien als een kaderwet waarin, teneinde de in de wet opgenomen doelstellingen te realiseren, diverse bevoegdheden aan het agency ${ }^{12}$ worden toegekend. In de regel gaat het om toebedeling van drie bevoegdheden. Namelijk de 'quasi wetgevende', de 'uitvoerende' en de 'quasi rechtsprekende' bevoegdheid. ${ }^{13}$ Met het $00 \mathrm{~g}$ op de 'separation of powers doctrine ${ }^{14}$ spreekt men uitdrukkelijk van 'quasi'

75 U.S.C. section 551 e.v.

8 In andere Amerikaanse wettelijke regelingen kunnen overigens ander definities aangetroffen worden van de term 'agency'. Zo geldt bijvoorbeeld in regelingen met betrekking tot overheidspersoneel een ruimer 'agency'-begrip waardoor bijvoorbeeld ook mederwerkers van de gerechten onder de regeling vallen (vgl. artikel 1:1, derde lid $A w b$ ).

9 Vgl. m.b.t. zelfstandige bestuursorganen in Nederland: S.E. Zijlstra, Zelfstandige bestuursorganen in een democratische rechtsstaat, 's-Gravenhage 1997.

10 Onder formele wet dient in het kader van deel II van dit boek verstaan te worden wetgeving afkomstig van het Congres. Alle (federale) wetten in formele zin van de Verenigde Staten zijn opgenomen in de 'United States Code (U.S.C.)'. De U.S.C. is volledig te raaplegen op de volgende internet-site: http://liiwarwick.warwick.ac.uk/uscode

I1 Een voorbeeld hiervan is de implementatie van de 'Occupational Safety and Health Act' uit 1970, 29 U.S.C. section 651 e.v. Het doel van deze wet is realisering van veilige en gezonde werkomstandigheden voor werknemers.

12 Fomneel gezien is het agency een orgaan dat behoor tot de uitvoerende macht. In de praktijk worden aan het agency bij wet echter meer bevoegdheden toegekend dan louter uitvoering van de wet. In dit hoofdstuk zal daar nog nader op in worden gegaan.

13 Zie hierover ook Strauss, e.a. a.w. 1995 , p. 40 e.v.

14 In de Amerikaanse Grondwet wordt de scheiding der machten immers uitdrukkelijk aangegeven; 
bevoegdheden. Met name ten aanzien van de 'quasi wetgevende' en de 'quasi rechtsprekende' bevoegdheid kunnen, gelet op de 'separation of powers doctrine' problemen ontstaan. Laatstgenoemde bevoegdheden zijn in de Constitution immers uitdrukkelijk aan respectievelijk het Congres en de rechterlijke macht (in het bijzonder het Supreme Court) toebedeeld.

\subsubsection{Quasi wetgevende bevoegdheid}

Wat de wetgevende bevoegdheid betreft wordt er in de Verenigde Staten uitgegaan van de, op de 'separation of powers doctrine' gebaseerde, 'nondelegation doctrine'. In feite komt het er, blijkens een uitspraak van het Supreme Court uit 1892, op neer dat het Congres in het algemeen zijn wetgevende macht niet kan delegeren aan een van de twee andere machten. ${ }^{15}$ Naderhand is dit standpunt in de uitspraken van het Supreme Court overigens vergaand genuanceerd. ${ }^{16}$ Op basis van genoemd genuanceerd standpunt is delegatie van regelgevende bevoegdheid door het Congres aan (bijvoorbeeld) een agency, ongeacht de 'separation of powers doctrine', toegestaan wanneer deze delegatie voldoende specifiek en gedetailleerd is. ${ }^{17}$ Het Supreme Court neemt het standpunt in dat het bij een dergelijke specifieke, gedetailleerde delegatie nog slechts gaat om het uitoefenen van 'a power to fill up the details ${ }^{18}$, en de 'power to fill up the details', door middel van regelgeving, is geen delegatie van de wetgevende bevoegdheid maar slechts de uitoefening van een administratieve taak welke door het Congres is opgelegd. ${ }^{19}$

Tot op heden heeft het Supreme Court slechts in een enkel geval geconstateerd dat delegatie van regelgevende bevoegdheid in strijd was met de 'nondelegation doctrine'. Bovendien hing de, in die uitzonderlijke gevallen, onderkende strijd, naar men veronderstelt, niet zo zeer samen met de opvatting van het Supreme Court dat de constitutionele waarborgen geschonden werden maar veeleer met (partij)politieke onenigheid tussen het Supreme Court en de President. ${ }^{20}$

The Constitution of the United States:

Article 1, Section 1: All legislative Powers herein granted shall be vested in a Congress of the United States, which shall consist of a Senate and House of Representatives...

Article 1, Section 8: The Congress shall have Power...To make all Laws which shall be necessary and proper for carrying into Execution the foregoing Powers, and all other Powers vested by this Constitution in the Government of the United States, or in any Department or Officer thereof.

Article 2, Section 1: The executive Power shall be vested in a President of the United States of America...

Article 3, Section 1: The judicial Power of the United States, shall be vested in one Supreme Court, and in such inferior Courts as the Congress may from time to time ordain and establish...

15 Field v. Clark, 143 U.S. 649, 692 (1892).

16 Zie voor een uitgebreid overzicht van jurisprudentie aangaande de nondelegation doctrine, Strauss e.a. a.w. 1995 , p. $51 \mathrm{t} / \mathrm{m} 67$.

17 Zie ondermeer de volgende uitspraken; Mistretta v. U.S., 488 U.S. 361 (1989), J.W. Hampton, Jr. \& Co. v. U.S., 276 U.S. 394 (1928), en de concurring opinion van Justice Rehnquist in Industrial Union Department AFL-CIO v. American Petroleum Institute (the 'Benzene Case'), 488 U.S. 607 (1980).

18 U.S. v. Grimaud, 220 U.S. 506 (1911).

19 U.S. v. Grimaud zie ook J.W. Hampton, Jr. \& Co. v. U.S., 276 U.S. 394 (1928)

20 Panama Refining Co. v. Ryan, 293 U.S. 388 (1935), en A.L.A. Schecter Poultry Corp. v. United States, 295 U.S. 495 (1935). Het oordeel van het Supreme Court dat delegatie van regelgevende bevoegdheid in deze zaken in strijd was met de 'nondelegation doctrine' hing volgens de auteurs van Gellhom and Byse's 'Aministrative Law' (a.w. 1995 p. 84), nauw samen met het judiciele verzet tegen de New Deal politiek van Franklin Roosevelt. Er zijn dan ook geen recente voorbeelden van uitspraken waarin het 
Het toekennen van quasi wetgevende bevoegdheden door het Congres aan agencies lijkt in de regel derhalve niet tot problemen te leiden. Het Supreme Court lijkt het Congres in dat kader doorgaans niet veel in de weg te leggen. Justice Rehnquist geeft dit helder weer in zijn concurring opinion in 'Industrial Union Department AFL-CIO v. American Petroleum Institute' ${ }^{21}$ (the 'Benzene Case'):

'This Court also has recognized that a hermetic sealing-off of the three branches of government from one another could easily frustrate the establishment of a National Government capable of effectively exercising the substantive powers granted to the various branches by the Constitution... Later decisions that have upheld congressional delegations of authority to the Executive Branch have done so largely on the theory that Congress may wish to exercise its authority in a particular field, but because the field is sufficiently technical, the ground to be covered sufficiently large, and the Members of Congress themselves not necessarily expert in the area in which they choose to legislate, the most that may be asked under the separation-of-powers doctrine is that Congress lay down the general policy and standards that animate the law, leaving the agency to refine those standards, 'fill in the blanks', or apply the standards to particular cases.'

Uit het voorgaande volgt dat de quasi wetgevende bevoegdheid van het agency doorgaans geen problemen oplevert, aangezien de door het Congres aan een agency toebedeelde regelgevende bevoegdheid zonder al te veel problemen de toets aan de, door het Supreme Court gestelde, ruime vereisten kan doorstaan. Van de zuivere 'nondelegation doctrine' is dan ook niet veel meer over. 'The power to fill up the details ${ }^{22}$ van de agencies blijkt in de praktijk immers niet beperkt te zijn tot de werkelijke details. De regeling afkomstig van het Congres behelst doorgaans niet meer dan een kaderwet van een tiental bladzijden. De daarop gebaseerde agency regelgeving betreft veelal (veel) méer dan duizend bladzijden. ${ }^{23}$

\subsubsection{Quasi rechtsprekende bevoegdheid}

Evenals ten aanzien van de 'quasi wetgevende' bevoegdheid kunnen ten aanzien van de 'quasi rechtsprekende' bevoegdheid van een agency, met het oog op de 'separation of powers doctrine', problemen ontstaan. Zoals reeds eerder is aangegeven impliceert de 'separation of powers doctrine' onder meer een onafhankelijke rechterlijke macht:

'The judicial Power of the United States, shall be vested in one Supreme Court, and in such inferior Courts as the Congress may from time to time establish. The Judges, both of the supreme and inferior Courts, shall hold their Offices during good Behavior, and shall, at

Supreme Court constateert dat delegatie van regelgevende bevoegdheid in strijd is met de 'nondelegation doctrine'.

21 Industrial Union Department AFL-CIO v. American Petroleum Institute (the 'Benzene Case'), 488 U.S. 607, S. Ct. 1980.

$22 \mathrm{Vgl}$. in dit kader aanwijzing 20, tweede lid, Aanwijzingen voor de regelgeving (Den Haag 1996): 'Algemeen verbindende voorschriften kunnen echter ook door een zelfstandig bestuursorgaan worden vastgesteld, voor zover daarin details van andere vanwege het Rijk vastgestelde voorschriften nader worden uitgewerkt.'

23 Vgl. Steven J. Cann, Administrative Law, second edition, Sage Publications, Thousand Oaks, California, 1998, p. 223. 
stated Times, receive for their Services, a Compensation, which shall not be diminished during their Continuance in Office. ${ }^{24}$

Het Congres kan echter de wetgevende bevoegdheid - voortvloeiend uit artikel I van de Grondwet - aanwenden teneinde (bijvoorbeeld) een 'executive' agency in het leven te roepen dat onder meer een 'quasi rechtsprekende' bevoegdheid heeft. ${ }^{25}$ Regelmatig is de constitutionaliteit van de op grond van artikel I van de Grondwet in het leven geroepen 'quasi rechtsprekende' instanties betwist. Doorgaans echter met weinig succes. ${ }^{26}$

In 'Crowell v. Benson' ${ }^{27}$ heeft het Supreme Court een basisregel geformuleerd teneinde te bepalen of toekenning - dan wel delegatie - van rechtsprekende bevoegdheid aan een niet op grond van artikel III van de Grondwet rechtsprekende instantie ${ }^{28}$ de constitutionele toets kan doorstaan. Het Supreme Court maakt in 'Crowell v. Benson' in dat kader een onderscheid tussen 'private rights' en 'public rights':

'As to determinations of fact, the distinction is at once apparent between cases of private rights and those which arise between the government and persons subject to its authority in connection with the performance of the constitutional functions of the executive or legislative departments. The Court referred to this distinction in Murray's Lessee v. Hoboken Land \& Improvement Company, supra, pointing out that 'there are matters, involving public rights, which may be presented in such form that the judicial power is capable of acting on them, and which are susceptible of judicial determination, but which Congress may or may not bring within the cognizance of the courts of the United States, as it may deem proper.' Thus Congress, in exercising the powers confided to it, may establish 'Iegislative' courts (as distinguished from 'constitutional courts in which the power conferred by the Constitution can be deposited') which are to form part of the government of territories or of the District of Columbia, or to serve as special tribunals 'to examine and determine various matters, arising between the governments and others, which from their nature do not require judicial determination and yet are susceptible of it.' But 'the mode of determining matters of this class is completely within congressional control. Congress may reserve to itself the power to decide, may delegate that power to executive officers, or may commit it to judicial tribunals.' (...).'

Wanneer er sprake is van een 'public right' heeft het Congres derhalve de vrijheid te bepalen of er een rechtsgang gecreëerd moet worden ten aanzien van geschillen met betrekking tot dat 'public right'. Vervolgens kan het Congres, bij het creëren van een rechtsgang, bepalen of deze onder dient te worden gebracht bij een 'constitutional court $^{29}$ of bij een 'legislative court'. Indien een agency belast is met rechtspraak ten aanzien van 'public rights' zal dit derhalve geen problemen opleveren met het oog op de 'separation of powers doctrine'.

Artikel III, sectie 1 van de Amerikaanse Constitution.

25 Vaak zijn de ambtenaren van het agency die een 'quasi rechtsprekende' bevoegdheid uitoefenen niet voor het leven benoemd. Derhalve kan op deze functionarissen druk worden uitgeoefend met het oog op herbenoeming. De vrees bestaat dat de 'quasi rechtsprekende' ambtenaren daardoor minder onafhankelijk en minder onpartijdig zijn.

Crowell v. Benson, 285 U.S. 22 (1932).

Een zogenaamd 'constitutional court'.

29 Een 'constitutional court' staat ook bekend als een 'Article III court' in de Verenigde Staten. 
Gaat het om 'private rights', 'that is, of the liability of one individual to another under the law as defined..$^{30}$, dan is het niet vereist dat 'in order to maintain the essential attributes of the judicial power, all determinations of fact in constitutional courts shall be made by judges. ${ }^{.31}$ Hoewel er in laatste instantie nog altijd een 'Article III court' moet kunnen oordelen over een geschil aangaande 'private rights' kan een agency ook een 'rechtsprekende' bevoegdheid hebben ten aanzien van deze 'private rights'. Het agency wordt dan in feite beschouwd als een soort assistent van het 'Article III court'. Derhalve is het agency ook bevoegd te oordelen over 'private rights' zolang er daarna nog een mogelijkheid bestaat voor een 'Article III court' om te oordelen over het geschil, aangezien bepaalde taken - zoals bijvoorbeeld 'the full authority... to deal with matters of ${ }$ aw $^{132}$ - zijn voorbehouden aan de artikel III rechter.

In 'Commodity futures trading commission v. Schor ${ }^{33}$ somt het Supreme Court een vijftal criteria op aan de hand waarvan in die zaak vastgesteld wordt dat de bevoegdheid van een 'legislative court' om te oordelen over 'private rights' niet in strijd is met de Grondwet. Ten eerste is het 'legislative court' slechts bevoegd ten aanzien van een specifiek rechtsgebied. Daarnaast zijn de besluiten van het 'legislative court' alleen afdwingbaar op grond van een 'District Court order'. Vervolgens heeft de artikel III rechter, ten aanzien van de door het agency in 'Commodity futures trading commission v. Schor' genomen 'besluiten', een ruime toetsingsmogelijkheid. ${ }^{34}$ Ten vierde zijn de 'rechterlijke' uitspraken van het agency onderworpen aan een volledige heroverweging van een artikel III rechter en tenslotte oefent het agency niet alle gebruikelijke bevoegdheden van de District Courts uit.

Naast het feit dat nog (hoger) beroep openstaat tegen de uitspraak van het 'legislative court' bij een artikel III rechter, die (in casu) beschikt over een volledige toetsingsbevoegdheid, lijken derhalve nog twee aspecten relevant te zijn. Ten eerste lijkt van belang dat het 'legislative court' slechts bevoegd is te oordelen over 'private rights' binnen een specifiek rechtsgebied. Ten tweede is de uitspraak slechts afdwingbaar via een 'District Court order', waardoor een extra mogelijkheid is ingebouwd om een artikel III rechter bij het geschil te betrekken.

Dit leidt tot de volgende conclusie ten aanzien van de 'quasi rechtsprekende' bevoegdheid van agencies in relatie tot de 'separation of powers doctrine'. Ook bij de 'quasi rechtsprekende' bevoegdheid van het agency zullen in de regel geen problemen ontstaan met het oog op de 'separation of powers doctrine'. Een blik op de rechtspraak over de constitutionaliteit van de niet als 'constitutional court' aan te merken (quasi) rechtsprekende instanties leidt tot de conclusie dat de wetgever in feite vrijwel nooit problemen heeft ondervonden bij het in het leven roepen van een niet op artikel III van de Grondwet terug te voeren 'quasi rechtsprekende' instantie. Indien het gaat om 'public

Crowell v. Benson, 285 U.S. 22 (1932).

Strauss e.a. a.w. 1995, p. 120.

Commodity futures trading commission v. Schor ,478 U.S. 833 (1986).

34 In het kader van de uitoefening van 'public rights' toetst de artikel III rechter (veel) terughoudender. Bovendien toets genoemde rechter ook veelal terughoudender in situaties waarin rechtstreeks of indirect 'private rights' in het geding zijn (vgl, de hiema weergegeven passage uit Wong Yang Sung v. Mc Garth [339 U.S. 33 (1950)]). Ik kom daar later op terug. 
rights' neemt het Supreme Court een erg ruimhartig standpunt in. Geschilbeslechting door een 'quasi rechtsprekende' instantie lijkt ten aanzien van genoemde 'publieke rechten' zonder meer toegestaan te zijn. Maar ook met het in het leven roepen van 'quasi rechtsprekende' instanties, die bevoegd zijn te oordelen ten aanzien van 'private rights', lijkt het Supreme Court niet snel problemen te hebben. In dit kader kan gewezen worden op de zaak 'Thomas v. Union Carbide Agricultural Products Co. ${ }^{35}$, waarin het Supreme Court lijkt uit te gaan van een zeer ruime opvatting:

'Congress, acting for a valid legislative purpose pursuant to its constitutional powers under Article I, may create a seemingly 'private' right that is so closely integrated into a public regulatory scheme as to be a matter appropriate for agency resolution with limited involvement by the Article III judiciary.'

Daarnaast is de zaak Commodity futures trading commission v. Schor ${ }^{36}$ vermeldenswaardig. Uit die zaak blijkt eveneens dat de bevoegdheid van het Congres om een 'quasi rechtsprekende instantie' in het leven te roepen vrij ver gaat. Het Supreme Court geeft aan dat het bewust niet gekozen heeft voor een formele houding in dit kader:

'In determining the extent to which a given congressional decision to authorize the adjudication of Article III business in a non-Article III tribunal impermissibly threatens the institutional integrity of the Judicial Branch, the Court has declined to adopt formalistic and unbending rules [Thomas, 473 U.S., at 587]. Although such rules might lend a greater degree of coherence to this area of the law, they might also unduly constrict Congress' ability to take needed and innovative action pursuant to its Article I powers.'

In deze uitspraak geeft het Supreme Court echter ook aan wanneer het Congres te ver gaat bij creëren van een 'legislative court':

'This is not to say, of course, that if Congress created a phalanx of non-Article III tribunals equipped to handle the entire business of the Article III courts without any Article III supervision or control and without evidence of valid and specific legislative necessities, the fact that the parties had the election to proceed in their form of choice would necessarily save the scheme from constitutional attack. ${ }^{37}$

\subsubsection{Ein algemeen wittelijk kader voor de quasi bevoegdheden}

Hoewel het Supreme Court, blijkens het voorgaande, de opkomst van de agencies, die zowel regelgevende als uitvoerende en rechtsprekende bevoegdheden uitoefenden, niet in strijd met de Amerikaanse Grondwet achtte, hebben het Congres en de President zich terdege gerealiseerd dat deze machtsconcentratie binnen een agency aanleiding zou kunnen geven tot bevooroordeelde en partijdige besluitvorming en rechtspraak. In 'Wong Yang Sung v. Mc Garth ${ }^{138}$ wordt deze bewustwording (achteraf, in 1950,) door het Supreme Court omschreven:

37 Zie hierover ook: Walter Gellhorn, Administrative Prescription and Imposition of Penalties, Washington University Law Quarteriy, 1970, p. 265-287, i.h.b. p. 265.

38 Wong Yang Sung v. Mc Garth, 339 U.S. 33 (1950). 
'Multiplication of federal administrative agencies and expansion of their functions to include adjudications which have serious impact on private rights has been one of the dramatic legal developments of the past half-century. Partly from restriction by statute, partly from judicial self-restraint, and partly by necessity - from the nature of their multitudinous and semilegislative or executive tasks - the decisions of administrative tribunals were accorded considerable finality, and especially with respect to fact finding. The conviction developed, particularly within the legal profession, that this power was not sufficiently safeguarded and sometimes was put to arbitrary and biased use.'

Men was derhalve bevreesd voor bevooroordeelde en partijdige uitoefening van agency bevoegdheden (onder meer in het kader van de 'quasi rechtsprekende bevoegdheid') vanwege het ontbreken van voldoende waarborgen in het kader van de rechtsbescherming tegen de (onder meer) 'quasi rechtsprekende' agencies. Niet geheel onverwachts gaf president Roosevelt, in 1939, dan ook de opdracht aan de Attorney General 'to name a committee of eminent lawyers, jurists, scholars, and administrators to review the entire administrative process in the various departments of the executive Government and to recommend improvements, including the suggestion of any needed legislation. ${ }^{39}$

Deze opdracht resulteerde in de Administrative Procedure Act van 1946 (APA) ${ }^{40}$ waarin werd voorzien in een uniforme bestuursrechtelijke procedure voor de agencies. Deze uniforme bestuursrechtelijke procedure beoogde de hierboven weergegeven nadelige effecten van de vereenzelviging van de drie machten in één bestuursorgaan te reduceren. ${ }^{4}$

Uit het voorgaande kan worden afgeleid dat het in de Verenigde Staten onmogelijk is gebleken vast te houden aan de constitutioneel voorgeschreven zeer strikte 'separation of powers doctrine'. Naarmate de federale overheid op steeds meer gebieden ging ingrijpen is voor het Congres de noodzaak ontstaan om bepaalde delen van de, haar toekomende, regelgevende bevoegdheid te delegeren, aan de, als paddenstoelen uit de grond schietende, aanvankelijk slechts met uitvoering belastte, agencies. Voorts heeft het Congres het noodzakelijk geacht een deel van de rechtspraak (in eerste aanleg) onder te brengen bij een andere instantie dan het 'article III court'. Veelal blijkt die andere instantie (onderdeel van) een agency te zijn.

Op deze wijze heeft de 'fourth branch', bestaande uit 'multifunctionele' bestuursorganen, gestalte gekregen. In de zaak 'Federal Trade Commission v. Ruberoid Co. ${ }^{42}$ uit 1952 stelt Justice Jackson, in zijn dissenting opinion, het volgende over de opkomst van de 'Fourth branch':

'The rise of administrative bodies probably has been the most significant legal trend of the last century and perhaps more values today are affected by their decisions than by those of all the courts, review of administrative decisions apart. They also have begun to have

39 Wong Yang Sung v. Mc Garth, 339 U.S. 33 (1950). Zie verder voor de totstandkoming van de A.PA Strauss e.a. a.w. 1995 , p. 238 e.v.

405 U.S.C. section 551 en verder. De APA is deels vergelijkbaar met de Algemene wet bestuursrecht (Awb).

41 Zie hierover ook: Cass Sunstein, Constitutionalism After the New Deal, Harvard Law Review, 1987, 101 H.L. Rev. 421, p. 446-448.

42 Federal Trade Commission v. Ruberoid Co, 343 U.S. 470 (1952). 
important consequences on personal rights. Cf. United States v. Spector, 343 U.S. 169. They have become a veritable fourth branch of the Government, which has deranged our threebranch legal theories much as the concept of a fourth dimension unsettles our threedimensional thinking. Courts have differed in assigning a place to these seemingly necessary bodies in our constitutional system. Administrative agencies have been called quasilegislative, quasi-executive or quasi-judicial, as the occasion required, in order to validate their functions within the separation-of-powers scheme of the Constitution. The mere retreat to the qualifying 'quasi' is implicit with confession that all recognized classifications have broken [343 U.S. 470, 488] down, and 'quasi' is a smooth cover which we draw over our confusion as we might use a counterpane to conceal a disordered bed.'

Het Supreme Court heeft de opkomst van een 'fourth branch', bestaande uit agencies die naast uitvoerende taken belast zijn met (quasi) wetgeving en (quasi) rechtspraak, niet belemmerd hoewel er toch duidelijk gerede twijfels kunnen bestaan over de constitutionaliteit van de delegatie van regelgevende bevoegdheid en het in het leven roepen van 'legislative' courts. ${ }^{43}$ Teneinde te voorkomen dat een concentratie van de wetgevende, uitvoerende en rechtsprekende macht leidt tot onredelijk en partijdig gebruik, ofwel tot misbruik, van de bevoegdheden van het agency is de Administrative Procedure Act (APA) gecreëerd. De APA voorziet in één uniforme, met waarborgen omklede, bestuursrechtelijke procedure, (onder meer) met betrekking tot 'berechting', en het maken van regelgeving, door agencies. ${ }^{44}$

\subsubsection{Wijze van boete oplegging}

\section{Enkele algemene opmerkingen}

Alvorens in te gaan op de wijze van boete oplegging in een concreet geval komen eerst nog enkele algemene aspecten van de boete oplegging aan de orde. ${ }^{45}$ Zoals reeds aan. gegeven in $\$ 2.1$ worden bij wet in formele zin aan het agency diverse bevoegdheden toebedeeld teneinde de doelstellingen uit de formele wet te realiseren. ${ }^{46}$

De wijze waarop het agency deze bevoegdheden - waaronder met name de regelgevende bevoegdheid - uitoefent wordt feitelijk gecontroleerd door het Congres, de President en, in een later stadium door de rechterlijke macht. ${ }^{47}$ Met name de President en het onder hem ressorterende Office of Information and Regulatory Affairs (OIRA) - dat deel uit maakt van het Office of Management and Budget (OMB) - hebben invloed op

43 De houding van het Supreme Court past echter in de common law traditie waarin de rechter eerst vaststelt welke uikomst van het geschil in zijn ogen het meest wenselijk is en daarop vervolgens zijn argumentatie afstemt. Zie Antonin Scalia, A Matter of Interpretation, federal courts and the law, Princeton University Press, Princeton, New Jersey, 1997, pagina 13: 'But though I have no quarrel with the common law and its process, I do question whether the attitude of the common-law judge - the mindset that asks, 'What is the most desirable resolution of this case, and how can any impediments to the achievement of that result be evaded?' - is appropriate for most of the work that 1 do, and much of the work that state judges do.'

44 Op de inhoud van de APA zal later in dit hoofdstuk nog nader worden ingegaan.

45 In het volgende hoofdstuk zal overingens uitvoerig stil gestaan worden bij het Amerikaanse boetebeleid.

46 Daarbij dient opgemerkt te worden dat het afhangt van de gedetailleerdheid van de wetgeving van het Congres of , en in welke mate, er nog poltieke invloed kan worden uitgeoefend op het agency bij de uitvoering van de wetgeving. Zie hierover: Strauss e.a. a.w. 1995, p. 194. Zie hierover Strauss e.a. a.w. 1995, p. 193 en verder. 
het regelgevende proces van het agency. De wijze waarop het OMB en het OIRA het regelgevende proces van het agency kunnen controleren en beïnvloeden is uitvoerig weergegeven in Executive Order 12866 (van 30 september 1993). ${ }^{48}$

Volgens Steven J. Cann hebben zowel de President (ondanks executive order 12866) als het Congres een vrij beperkte invloed op de agencies en komt de controlerende taak - noodgedwongen - met name toe aan de rechterlijke macht. Dit terwijl het Congres volgens Cann de aangewezen instantie is om de agencies te controleren. Het Congres beschikt daartoe over vier middelen namelijk: '(a) the power to create and organize agencies, (b) the power to control agency budgets, (c) the power to investigate agency activity and (d) guidance legislation. ${ }^{49}$

Na deze korte uiteenzetting van de wijze waarop controle uitgeoefend kan worden op, met name, de uitoefening van de regelgevende bevoegdheid van de agencies, volgt nu een nadere uiteenzetting met betrekking tot de wijze van boete-oplegging door agencies.

Zoals gezegd worden bij wet in formele zin door het Congres aan het agency diverse bevoegdheden toebedeeld teneinde de doelstellingen uit de wet te realiseren. Om naleving van de doelstellingen uit een wet te kunnen bewerkstellingen kan aan het agency door het Congres bijvoorbeeld de bevoegdheid worden verleend om een bestuurlijke boete op te leggen.

In dit kader verdient opmerking dat het Supreme Court geen problemen lijkt te hebben met het feit dat de wetgever bestuursorganen uitrust met (discretionaire) sanctiebevoegdheden. In een uitspraak in de zaak 'Oceanic Steam Navigation Company versus Stranahan ${ }^{50}$ uit 1909 heeft het Supreme Court met betrekking tot de bevoegdheid van het Congres om in wetten bestuursorganen, of ambtenaren van bestuursorganen, uit te rusten met sanctiebevoegdheden het volgende overwogen:

In accord with this settled judicial construction the legislation of Congress from the beginning, not only as to tariff, but as to internal revenue, taxation, and other subjects, has proceeded on the conception that it was within the competency of Congress, when legislating as to matters exclusively within its control, to impose appropriate obligations, and sanction their enforcement by reasonable money penalties, giving to executive officers the power to enforce such penalties without the necessity of invoking the judicial power. ${ }^{\text {s1 }}$

In de formele wet behelst de toebedeling van de bevoegdheid tot het opleggen van een bestuurlijke boete in de regel niet meer dan eén artikel. ${ }^{52}$ In een dergelijk wetsartikel worden doorgaans alleen de maximum bedragen vermeld die per overtreding - van de

48 Een beknopte weergave van de inhoud van deze executive order volgt later in dit hoofdstuk.

49 Zie Steven J. Cann, Administrative Law, second edition, Sage Publications, Thousand Oaks, California, 1998, hoofdstuk 2 en 3, en in het bijzonder p. 62.

50 'Oceanic Steam Navigation Company versus Stranahan', 214 U.S. 320 (1909).

51 Zie hierover nok: Gellhom a.w. 1970, p. 272.

52 Zie bijvoorbeeld 29 U.S.C. section 666 van de Occupational Safety and Ilealth Act: 'Civil and criminal penalties'. Cann geett aan hoe omvangrijk het aandeel van de agencies is in de regelgeving, a.w. 1998, p. 16: The enabling legislation creating OSHA is about 17 pages long. The agency has produced 1,658 pages of rules, regulations, and safety standards.' De rules van het agency hebben dezelfde kracht en verbindendheid als wetgeving in formele zin. De rules zijn echter van lagere orde dan de wetgeving in formele zin. Zie hierover: Steven J. Cann a.w. 1998, p. 223. 
uit de wet voortvloeiende regelgeving ${ }^{53}$ - kunnen worden opgelegd. Het agency, dat in de wet bevoegd wordt verklaard tot het opleggen van een bestuurlijke boete, krijgt vervolgens slechts een paar vingerwijzingen wat betreft de vaststelling van de hoogte van de boete, zo blijkt bijvoorbeeld uit 29 U.S.C. section 666, Occupational Safety and Health Act (OSHA):

'(j) Authority of Commission to assess civil penalties

The Commission shall have the authority to assess all civil penalties provided in this section, giving due consideration to the appropriateness of the penalty with respect to the size of the business of the employer being charged, the gravity of the violation, the good faith of the employer, and the history of previous violations.'

'(k) Determination of serious violation

For purposes of this section, a serious violation shall be deemed to exist in a place of employment if there is a substantial probability that death or serious physical harm could result from a condition which exists, or from one or more practices, means, methods, operations, or processes which have been adopted or are in use, in such place of employment unless the employer did not, and could not with the exercise of reasonable diligence, know of the presence of the violation.'

Het is vervolgens aan het agency om te bepalen op welke wijze het deze ruime bevoegdheid nader invult. Doorgaans zal het agency overgaan tot het formuleren van een bepaald beleid. Talloze variaties zijn daarbij echter nog denkbaar. Het beleid met betrekking tot de vaststelling van de hoogte van de bestuurlijke boete kan bijvoorbeeld zeer algemeen of zeer gedetailleerd geformuleerd zijn, of, intern dan wel algemeen bekend gemaakt worden.

Nog meer discretionaire bevoegdheid wordt geschapen doordat de regels, waarvan de overtreding gesanctioneerd worden met een bestuurlijke boete, geformuleerd zijn door het agency. ${ }^{53}$ Het Congres delegeert in dit kader immers regelmatig zijn wetgevende bevoegdheid aan het agency. ${ }^{56}$ Het agency bepaalt derhalve vaak zelf welke gedragingen beboet moeten worden en welke niet. Bij gebruikmaking van de aan het agency toegekende regelgevende bevoegdheid dient het agency echter wél de bepalingen omtrent totstandkoming van regelgeving uit de Administrative Procedure Act van 1946 (APA) in acht te nemen. ${ }^{57}$

53 Alle agency regelgeving wordt gepubliceerd in het wekelijks verschijnende 'Federal Register'. Deze wekelijks gepubliceerde regelgeving wordt vervolgens op onderwerp gerangschikt weergegeven in de 'Code of Federal Regulations'. Het 'Federal Register' en de 'Code of Federal Regulations' zijn te raaplegen op de volgende internet sites: http://fr.cos.com en http://www.access.gpo.gov/nara/cfr/index.html

54 In hoofdstuk zes zal in worden gegaan op het boetebeleid van het Environmental Protection Agency (EPA).

55 In hoofidstuk zes zal hicrop nog uitvoerig worden teruggekomen.

56 Hoewel het Congres, in tegenstelling tot de uitvoerende macht, doorgaans wel de mogelijkheid heeft om nog enige controle uit te oefenen over het agency (en het agency beleid) maakt het, om diverse redenen, weinig gebruik van die bevoegdheid. Zie met betrekking tot de wijze waarop het Congres invloed kan uitoefenen op het agency(-beleid) en de redenen waarom het Congres zich doorgaans onthoudt van bemoeinissen met het agency(-beleid) Cann a.w. 1998, hoofdstuk 3.

In het kader van de regelgevende bevoegheid van het agency is met name section 553 'Rule making' van belang.

$\S 553$ Rule making:

(a) This section applies, according to the provisions thereof, except to the extent that there is involved-

(1) a military or foreign affairs function of the United States; or 
Daarnaast heeft het onder de President ressorterende Office of Information and Regulatory Affairs (OIRA) - dat deel uit maakt van het Office of Management and Budget (OMB) - enige invloed op het regelgevende proces van het agency op grond van Executive Order 12866 van 30 september 1993. Op grond van deze executive order dient, onder andere belangrijke regelgeving ('major regulations') door het agency te worden voorgelegd aan het OIRA in verband met algemene controle ('general review') en toezicht. Ook moet het agency jaarlijks een plan met betrekking tot voorgenomen regelgeving samenstellen in samenwerking met het OIRA. Daarnaast zijn er in de executive order nog andere maatregelen opgenomen waardoor het OIRA de mogelijkheid heeft invloed op de regelgevende bevoegdheid van de agencies uit te oefenen.

Constitutioneel gezien levert deze controlerende en sturende bevoegdheid van het OIRA ten aanzien van de agencies geen problemen op nu zij beiden deel uitmaken van de uitvoerende macht.

Concluderend kan ten aanzien van de algemene aspecten van boeteoplegging gesteld worden dat er sprake is van een ruime discretionaire bevoegdheid van het agency. Aan het agency wordt veel ruimte gelaten om door middel van regelgeving bepalen welk gedrag beboet dient te worden. Daarnaast is het aan het agency om de hoogte van de boete per specifieke overtreding vast te stellen. ${ }^{58}$ Ten aanzien van de regelgevende

(2) a matter relating to agency management or personnel or to public property, loans, grants, benefits, or contracts.

(b) General notice of proposed rule making shall be published in the Federal Register, unless persons subject thereto are named and either personally served or otherwise have actual notice thereof in accordance with law.

The notice shall include-

(1) a statement of the time, place, and nature of public rule making proceedings;

(2) reference to the legal authority under which the rule is proposed; and

(3) either the terms or substance of the proposed rule or a description of the subjects and issues involved.

Except when notice or hearing is required by statute, this subsection does not apply-

(A) to interpretative rules, general statements of policy, or rules of agency organization,

procedure, or practice; or

(B) when the agency for good cause finds (and incorporates the finding and a brief statement of reasons therefor in the rules issued) that notice and public procedure thereon are impracticable, unnecessary, or contrary to the public interest.

(c) After notice required by this section, the agency shall give interested persons an opportunity to participate in the rulemaking through submission of written data, views, or arguments with or without opportunity for oral presentation. After consideration of the relevant matter presented, the agency shall incorporate in the rules adopted a concise general statement of their basis and purpose. When rules are required by statute to be made on the record after opportunity for an agency hearing, sections 556 and 557 of this title apply instead of this subsection.

(d) The required publication or service of a substantive rule shall be made not less than 30 days before its effective date, except-

(1) a substantive rule which grants or recognizes an exemption or relieves a restriction;

(2) interpretative rules and statements of policy; or

(3) as otherwise provided by the agency for good cause found and published with the rule.

(e) Each agency shall give an interested person the right to petition for the issuance, amendment or repeal of a rule.

58 Hier kan de vraag worden opgeworpen of het wel wenselijk is dat een gebrekkig democratisch gelegtimeerd bestuurorgaan dergelijke ruime bevoegheden bezit met betrekking tot het creèren van punitieve bestuursrechtelijke sanctiebevoegdheden. Op deze vraag zal later, in deel III, in algemen zin, worden 
bevoegdheid is er echter nog enige controle van de zijde van de uitvoerende macht aanwezig in de vorm van het OIRA. Ook het Congres beschikt over een aantal, overigens niet in voldoende mate benutte, controlemiddelen. ${ }^{59}$ Volgens Cann komt het er in de praktijk dan ook op neer dat de controlerende taak met name rust op de rechterlijke macht.

\section{Boete oplegging in een concreet geval}

$\mathrm{Na}$ deze algemene opmerkingen ten aanzien van het opleggen van de bestuurlijke boete zal nu worden ingegaan op de wijze van oplegging van de bestuurlijke boete in een concreet geval. In dat kader zal op deze plaats met name ingegaan worden op de 'formal adjudication procedure' uit de APA. ${ }^{60}$

Voordat hier op de 'formal adjudication procedure' wordt ingegaan volgt nog een korte uiteenzetting met betrekking tot het in de APA gemaakte onderscheid tussen 'formal' en 'informal adjudication'.61 Het belangrijkste onderscheid is dat op basis van de 'informal adjudication procedure' de waarborgen, zoals neergelegd in de APA niet in acht (hoeven te) worden genomen.

Bij bestudering van de procedure tot het opleggen van een bestuurlijke boete (in relatie tot de (strafrechtelijke) rechtsbescherming) dient, in dat kader, niet uit het oog te worden verloren dat er ook boeteregelingen bestaan waarbij het agency de mogelijkheid heeft om op grond van de zogenaamde 'informele procedure' een bestuurlijke boete op te leggen. ${ }^{62}$ Funk signaleert ten aanzien van sanctionering door het EPA op grond van de 'informal adjudication procedure' het volgende:

'In 1986, for apparently the first time, Congress expressly provided for the last of these situations, authorizing the Administrator of the Environmental Protection Agency (EPA) to impose administrative penalties using procedures not subject to Section 554 or 556 of Title 5 but which shall provide a reasonable opportunity to be heard and to present evidence. A person assessed a penalty under these procedures could seek review before a district court, which could set aside the penalty assessment only if there was not substantial evidence on the record, taken as a whole, to support the finding of violation, or if the amount of the penalty assessed constituted an abuse of discretion..$^{63}$

Het voorgaande brengt met zich dat oplegging van punitieve bestuursrechtelijke sancties in de Verenigde Staten ook mogelijk is op basis van een zogenaamde 'informele procedure' die afwijkt van de, hierna te bespreken, in de APA neergelegde procedure. Weliswaar zal het Congres in de wettelijke regeling, op basis waarvan de sanctie opgelegd kan worden, doorgaans de belangrijkste procedurele waarborgen neerleggen. Desalniettemin lijkt de in de APA neergelegde procedure te voorzien in meer waarborgen.

teruggekomen.

59 Zie met betrekking tot de wijze waarop het Congres invloed kan uitoefenen op het agency(-beleid) en de redenen waarom het Congres zich doorgaans onthoudt van bemoeienissen met het agency(-beleid) Cann a.w. 1998, hoofdstuk 3.

60 Zie appendix I.

61 Zie hierover Strauss c.a. a.w. 1995, p. 242 en verder.

62 Zie hierover: William Funk, Close enough for government work?? - Using informal procedures for imposing administrative penalties, Seton Hall Law Review, 1993, 24 Seton Hall L.Rev. p. I e.v.

Funk a.w. 1993, p. 3. 
Formal adjudication op grond van de APA

De procedure tot oplegging van een bestuurlijke boete neemt een aanvang op het moment dat een functionaris van een agency de indruk heeft dat een (rechts)persoon een door het agency geformuleerde regel ('-substantive- rule') heeft overtreden. De bestuurlijke boete wordt in de regel opgelegd door middel van een (administrative) penalty 'order'. ${ }^{(4)}$ De 'order' is blijkens de definitie in de APA vergelijkbaar met een besluit in de zin van de Awb. De definitieve vaststelling van een dergelijke 'order' vindt plaats door middel van 'adjudication'. ${ }^{65}$ De 'adjudication procedure' is volgens de auteurs van Gelhom and Byse's 'Administrative Law' vergelijkbaar met een Amerikaanse civiele procedure. ${ }^{66}$ Hierna volgt een schematische weergave van de 'formal adjudication procedure'.

64 In de APA wordt de term 'order' als volgt omschreven:

\$51 Defenitions

For the purpose of this subchapter-

(6) 'order' means the whole or a part of a final disposition, whether affirmative, negative, injunctive, or declaratory in form, of an agency in a matter other than rule making but including licensing;

65 In de APA wordt de term 'adjudication' als volgt omschreven: $\$ 551$ Defenitions

For the purpose of this subchapter-

(7) 'adjudication' means agency process for the formulation of an order;

In de in appendix I opgenomen $\$ 554$ tot en met 558 van de APA is vervolgens de wijze waarop deze adjudication plaats dient te vinden nader uitgewerkt.

66 Strauss e.a. a.w. 1995 , p. 256. 
Schematische weergave van de 'formal adjudication procedure' ${ }^{67}$

\begin{tabular}{|c|c|c|}
\hline ACTOREN & FASE & $\begin{array}{l}\text { RELEVANTE BEPALIN- } \\
\text { GEN UIT DE APA }\end{array}$ \\
\hline $\begin{array}{l}\text { Afdeling 'Handhaving' van het } \\
\text { agency }\end{array}$ & $\begin{array}{l}\text { Voorval dat aanleiding geeft } \\
\text { tot de aanvang van de proce- } \\
\text { dure }\end{array}$ & geen \\
\hline $\begin{array}{l}\text { - medewerkers van het agency } \\
\text { - overtreder }\end{array}$ & $\begin{array}{l}\text { II } \\
\text { ONDERZOEK }\end{array}$ & 5 U.S.C. 555 (c, en d) \\
\hline $\begin{array}{l}\text { - medewerker van het agency } \\
\text { - (de leider van) een der par- } \\
\text { tijen }\end{array}$ & \begin{tabular}{|l|} 
III \\
Besluit om door te gaan met \\
de procedure/kennisgeving
\end{tabular} & 5 U.S.C. 554,558 \\
\hline $\begin{array}{l}\text { - procespartijen } \\
\text { - medewerkers van het agency } \\
\text { - Administrative Law Judge } \\
\text { (ALJ) }\end{array}$ & $\begin{array}{l}\text { IV } \\
\text { PRE-HOOR-FASE } \\
\text { (pre-hearing) }\end{array}$ & 5 U.S.C. 554,555 , en 557 (d) \\
\hline -idem & $\begin{array}{l}\mathbf{V} \\
\text { HOORPROCEDURE }\end{array}$ & $\begin{array}{l}5 \text { U.S.C. } 554 \text { (c en d), 556, } \\
557 \text { (d) }\end{array}$ \\
\hline $\begin{array}{l}\text { - ALJ of verantwoordelijke } \\
\text { ambtenaar }\end{array}$ & $\begin{array}{l}\text { VI } \\
\text { BESLUUIT }\end{array}$ & 5 U.S.C. 554 (d), 557,558 \\
\hline $\begin{array}{l}\text { - procespartijen } \\
\text { - medewerkers van het agency } \\
\text { - het hoofd of de raad van } \\
\text { bestuur van het agency }\end{array}$ & \begin{tabular}{|l|} 
VII \\
(VERZOEK TOT) HERZIE- \\
NING
\end{tabular} & 5 U.S.C. 557 \\
\hline $\begin{array}{l}\text { - het hoofd of de raad van } \\
\text { bestuur van het agency }\end{array}$ & \begin{tabular}{|l|} 
VIII \\
BESLUIT NA HERZIENING
\end{tabular} & 5 U.S.C. 557 \\
\hline
\end{tabular}

Zoals blijkt uit het voorgaande schema wordt de (rechts)persoon ten aanzien waarvan het agency het voomemen heeft een boete op te leggen voorafgaand aan het nemen van

67 Dit schema is, in het Nederlands vertaald, (deels) overgenomen uit Strauss e.a. a.w. 1995, p. 256. 
het boetebesluit in de gelegenheid gesteld zijn of haar zienswijze kenbaar te maken tijdens een hoorprocedure. Deze hoorprocedure is vrij uitgebreid geregeld in de artikelen 554 (c,en d), 556 en 557 (d) van de APA. Veel waarde wordt, blijkens artikel 554 (d) en 556 (b), gehecht aan de onpartijdigheid van de ambtenaar - doorgaans een Administrative Law Judge (ALJ) - die de hoorzitting voorzit. ${ }^{68}$

Nadat de te beboeten (rechts)persoon is gehoord en het besluit tot oplegging van de boete is genomen bestaat in veel gevallen nog de mogelijkheid om bij het agency in 'bezwaar' te gaan tegen het besluit ('review by agency'- in het schema 'herziening' genaamd). Daarna is - ten aanzien van het definitieve agency-besluit - doorgaans (namelijk voorzover in een bijzondere wet geen andere regeling is getroffen) nog beroep mogelijk bij een 'constitutional court' (ofwel een 'artikel III rechter').

Over de procedure zoals deze hierboven is weergeven dient nog te worden opgemerkt dat het gaat om de algemeen voorgeschreven procedure krachtens de APA. In bijzondere wetgeving kunnen echter (procedure)bepalingen zijn opgenomen die afwijken van regels die in de APA zijn neergelegd. In die zin is de Amerikaanse situatie vergelijkbaar met de Nederlandse. Ten aanzien van de Awb geldt immers ook dat in de bijzondere wetgeving afwijkende bepalingen kunnen zijn opgenomen met betrekking tot het bestuursprocesrecht.

\subsection{Bevoegde (administratief)rechte(r)lijke instanties}

Zoals hierboven reeds zeer summier is aangegeven bestaat, nadat het definitieve agency-besluit tot stand is gekomen de mogelijkheid voor de beboete (rechts)persoon zich te wenden tot de 'artikel III rechter', om het definitieve agency-besluit aan deze rechter voor de te leggen. De 'constitutionele rechter' die bevoegd is kennis te nemen van het beroep tegen het agency-besluit is echter géén speciale bestuursrechter.

Teneinde een (beter) beeld te krijgen van de bevoegde federale 'artikel III rechter(s)' zal hieronder, ten eerste, kort worden ingegaan op de algemene indeling van de (federale) rechterlijke macht in de Verenigde Staten. Vervolgens zal worden aangegeven bij welke rechter in beroep kan worden gegaan tegen een agency-besluit, zoals bijvoorbeeld het besluit tot oplegging van een bestuurlijke boete. Tenslotte zal nog worden ingegaan op de wijze van toetsing van een agency-besluit door de 'artikel III rechter'.

\subsubsection{Indeling federale rechterlijke macht}

Hieronder volgt eerst een globaal overzicht van de indeling van de federale rechterlijk macht in de Verenigde Staten. ${ }^{69}$ Dit globale, schematische overzicht, wordt naderhand toegelicht. Schematisch ziet de indeling van de federale rechterlijke macht er als volgt uit:

68 De Administrative Law Judge is zoals gezegd een ambtenaar van het agency en géén rechter in de zin van artikel III van de Amerikaanse Gondwet.

69 Daarbij is gebruik gemaakt van: William Bumham, Introduction to the law and legal system of the United States, West Publishing Co. St. Paul, Minnesota 1995. 
District Courts:

Dit zijn de rechtbanken die in eerste instantie kennis nemen van 'Federal Law Claims' of van 'State Law Claims' tussen partijen afkomstig uit verschillende staten. Daarnaast vormen de District Courts (in bepaalde gevallen) de beroepsinstantie ten aanzien van besluiten van agencies.

Er zijn 91 District Courts.

II Circuit Courts of Appeals:

Tegen alle definitieve uitspraken van het District Court kan in beroep gegaan worden bij deze rechterlijke instantie. Daarnaast vormen de Circuit Courts of Appeals (in bepaalde gevallen) de beroepsinstantie ten aanzien van besluiten van agencies.

Er zijn 13 Circuit Courts of Appeals.

The United States Supreme Court:

Het Supreme Court is de (hoger) beroepsinstantie ten aanzien van uitspraken van de Circuit Courts of Appeals. Voorts is het beroepsinstantie met betrekking tot de uitspraken van de State Appellate Courts ${ }^{70}$ voor zover het gaat om federale kwesties. Het Supreme Court kan, nadat een verzoek is ingediend om een zaak in behandeling te nemen (petition for certiorari) zelf bepalen of het een bepaalde zaak wenst te behandelen (granting certiorari).

Het Supreme Court bestaat uit negen rechters. ${ }^{71}$

\section{Federal Courts with Specialized Jurisdiction}

Deze aparte categorie bestaat uit rechtbanken die bevoegd zijn ten aanzien van bepaalde geschillen. ${ }^{72}$ Met uitzondering van het Court of International Trade en het Foreign Intelligence Surveillance Court gaat het om zogenaamde 'legislative courts'. ${ }^{73}$ Slechts een onbeduidend aantal zaken wordt afgedaan door deze Specialized Courts in verhouding tot het aantal zaken dat wordt afgedaan door het District Court.

70 De State Appelate Courts zullen hier overigens verder buiten beschouwing worden gelaten.

71 Zie voor een overzicht van de Amerikaanse federale rechterlijke macht ook: A.W. Heringa, Het Amerikaanse Hooggerechtshof, Kluwer, Deventer 1996, hoofdstuk I.

72 Burnham a.w. 1995, p. 183: There are several federal courts with specialized jurisdiction. They are the United States Claims Court, which handles exclusively claims against the federal govemment; the Tax Court, which handles suits involving federal taxes; the court of international Trade, which handles civil matters related to tariff and trade agreements; and the system of Bankruptcy Courts housed with the federal district courts. In addition, there are the District of Columbia Superior Court and the District of Columbia Court of Appeals, which act like 'state' courts for Washington, D.C. where local law is federal law. There is also a Foreign Intelligence Surveillance Court, which determines application by the Attomey General for permission to implement domestic wiretaps in the interest of national security and which uses judges from the regular federal courts. Two specialized courts deal with military and veteran matters: the Court of Military Appeals review court-material convictions for military offences and the Court of Veterans Appeals reviews decisions of the Veterans Administration on claims for veterans benefits.'

Zie $\$ 2.1$ van dit hoofdstuk. 
Voor de District Courts geldt dat zij in de regel rechtspreken in enkelvoudige samenstelling (unus rechter). Indien de District Court rechter bevoegd is van het geschil kennis te nemen is hij tevens bevoegd te oordelen over alle feiten die van belang zijn voor het geding. Gaat het om strafrechtelijke vervolging of een civiel geschil ${ }^{74}$ waarin de vordering een bepaald bedrag te boven gaat dan dient er bij het District Court juryrechtspraak plaats te vinden. ${ }^{75}$

Toetsing van de uitspraak van de District Courts vindt plaats bij het Circuit Court of Appeals. Doorgaans nemen er drie rechters deel aan de zitting van het Circuit Court of appeals. Het Appellate Court mag de door het Trial Court (= District Court) of de jury vastgestelde feiten slechts marginaal toetsen. $\mathrm{Er}$ is derhalve met name sprake van een rechtmatigheidstoetsing door de Courts of Appeal.

Het Supreme Court kan tenslotte, zoals reeds uit bovenstaand overzicht bleek, nadat een verzoek is ingediend om een zaak (afkomstig van een Circuit Court of Appeals of van een State Appellate Court) in behandeling te nemen (petition for certiorari), zelf bepalen of het de zaak wenst te behandelen (granting certiorari). Burnham geeft aan welke criteria het Supreme Court hanteert teneinde te bepalen of een zaak in behandeling zal worden genomen:

'... certiorari will be granted only when there is a conflict on an issue(s) of federal law (which) exists among the federal courts of appeal or between one of them and a state supreme court, or when a state supreme court or the federal court of appeals has decided an important federal question in a manner contrary to decisions of the Supreme Court. ${ }^{.76}$

Naast beroepsinstantie vormt het 'Supreme Court' ten aanzien van een beperkt aantal zaken ook het gerecht in eerste aanleg. Het 'Supreme Court' behandelt in deze hoedanigheid met name zaken aangaande territoriale geschillen tussen staten.

74 Het Amerikaanse recht bestaat voor een groot deel uit common law. De rechtsgebieden die niet worden gevormd door wetgeving dienen in de common law traditie door middel van rechtersrecht te worden geconcretiseerd. Van eerdere uitspraken van de common law rechter gaat een precedentwerking tuit. Dit brengt met zich dat deze uitspraken in acht moeten worden genomen door rechters die vervolgens in een soortgelijke zaak uitspraak moeten doen (stare decisis). In de Verenigde Staten maken onder andere de onrechtmatige daad en het contractenrecht deel uit van de common law. Zie hierover ook: William L. Reynolds, Judicial Process in a Nutshell, West Publishing Co., St. Paul, Minnesota 1980, hoofdstuk 4 'Common Law Adjudication'.

75 Dit blijkt uit het zesde en zevende amendement van de Amerikaanse Grondwet.

Amendment VI

In all criminal prosecutions, the accused shall enjoy the right to a speedy and public trial, by an impartial jury of the State and District wherein the crime shall have been committed, which district shall have been previously ascertained by law, and to be informed of the nature and cause of the accusation; to be confronted with the witnesses against him; to have compulsory process for obtaining witnesses in his favor, and to have the Assistance of Counsel for his defence.

Amendment VII

In Suits at common law, where the value in controversy shall exceed twenty dollars, the right of trial by jury shall be preserved, and no fact tried by jury, shall be otherwise re-examined in any Court of the United States, than according to the rules of the common law. 


\subsubsection{Bevoegde artikel III rechter ten aanzien van agency-besluiten}

Na bovenstaand algemeen overzicht op hoofdlijnen van de rechtsgang in de Verenigde Staten zal op deze plaats ingegaan worden op de rechtsgang die openstaat voor een (rechts)persoon die in beroep wenst te gaan tegen een definitief agency-besluit.

Zoals reeds bij aanvang van deze paragraaf is aangegeven is er in de Verenigde Staten geen speciale bestuursrechter. Wel blijkt het Circuit Court of Appeals in veel gevallen bevoegd te zijn te oordelen over een definitief agency-besluit. ${ }^{77}$ Later in dit hoofdstuk zal nog blijken dat het Circuit Court of Appeals deze bevoegdheid in de regel niet rechtstreeks ontleent aan de bepalingen uit $\$ 702$ tot en met $\$ 706$ van de $\mathrm{APA}^{78}$, nu in deze bepalingen slechts gesproken wordt over 'a court of the United States' ${ }^{79}$ Dit brengt met zich dat de bevoegde rechter doorgaans wordt aangewezen in de diverse wetten in formele zin. ${ }^{80}$ Voor elk afzonderlijk agency-besluit geldt immers als hoofdregel, blijkens $\$ 703$ van de APA, dat in de bijzondere wet vermeld moet worden welke artikel III rechter bevoegd is kennis te nemen van een beroep tegen het definitieve agency-besluit. ${ }^{81}$

In veel formele wetten worden het Circuit Court of Appeals en/of het Court of Appeals for the District of Columbia Circuit bevoegd verklaard kennis te nemen van een beroep tegen een agency-besluit. Het kan echter ook voorkomen dat een Disctrict Court (ofwel Trial Court) bevoegd wordt verklaard te oordelen over een agency-action. Dit is echter minder gebruikelijk. ${ }^{82}$ Een aantal redenen ligt ten grondslag aan de keuze van het Congres om de rechterlijke toetsing van agency-besluiten bij voorkeur toe te bedelen aan het Circuit Court of Appeals.

Ten eerste kan gewezen worden op de overweging van het Congres dat de Appellate Courts meer geschikt zijn om agency-besluiten te beoordelen dan de Trial Courts. Dossiers onderzoeken op fouten en de vaststelling dat adequaat bewijs is geleverd in een zaak zijn immers typisch taken van een Appellate Court. Het zijn deze taken die centraal staan bij de beoordeling van een agency-besluit. Bovendien bestaan de Appellate Courts uit meervoudige kamers die ervaring hebben met het bevorderen van de rechtseenheid in een groter geografisch gebied. Daardoor zijn de Appellate Courts beter in staat de brede en diverse leerstukken zoals neergelegd in de federale (agency)regelgeving te doorgronden en problemen op basis van genoemde regelgeving op te lossen. ${ }^{83}$ Daarnaast is het efficienter en goedkoper om de Appellate Courts in eerste

77 Vgl. Strauss e.a., a.w. 1995. p. 1108.

78 De relevante bepalingen uit de APA zijn opgenomen in Appendix II van dit boek.

79 De bepalingen uit de APA handelen over het recht op herziening van het agency-besluit door een rechter. In dit hoofdstuk zal op bovengenoemde bepalingen nog uitgebreid worden terugekomen, vooralsnog kan met vermelding van de relevante bepalingen worden volstaan.

80 Vgl. Strauss e.a., a.w. 1995. p. 1108-1109.

81 Zie bijvoorbeeld $\$ 660$ van de Occupational Safety and Health Act: Any person adversely affected or aggrieved by an order of the Commission issued under subsection (c)of section 659 of this title may obtain a review of such order in any United States court of appeals for the circuit in which the violation is alleged to have occurred or where the employer has its principal office, or in the Court of Appeals for the District of Columbia Circuit, by filing such court within sixty days following the issuance of such order a written petition praying that the order be modified or set aside. (...)

82 Vgl. Strauss e.a., a.w. 1995. p. 1108-1109.

83 Vgl. Strauss e.a., a.w. 1995, p. $1108-1109$. 
instantie te laten oordelen over agency-besluiten. Op die wijze wordt immers een stap in het rechtbeschermingssysteem overgeslagen (namelijk de Trial Courts) ${ }^{84}$

De beboete (rechts)persoon kan derhalve in de regel op grond van de wettelijke regeling tegen het agency-besluit in beroep gaan bij een Circuit Court of Appeals, tenzij uiteraard in de bijzondere wet een andere rechter bevoegd wordt verklaard kennis te nemen van het beroep. ${ }^{85}$

Tenslotte dient nog kort stil te worden gestaan bij de situatie waarin, in afwijking van de hoofdregel uit $\$ 703$ van de APA, in de wet in formele zin niet is aangegeven welke rechter bevoegd is te oordelen over geschillen met betrekking tot agency-besiuiten. Ontbreekt in de wettelijke regeling een bepaling met betrekking tot rechterlijke toetsing van agency-besluiten dan kan er gebruikt gemaakt worden van 'any applicable form of legal action, including actions for declaratory judgements or writs of prohibitory or mandatory injunction or habeas corpus, in a court of competent jurisdiction' om een agency-besluit aan te vechten. ${ }^{86} \mathrm{De}$ in die gevallen meest gebruikte 'form of legal action' is het recht op herziening zoals neergelegd in $\S 702$ van de APA. ${ }^{87}$ Dat er op grond van $\S 702$ van de APA een recht bestaat op herziening van de agency-action zegt nog niets over de rechter die bevoegd is kennis te nemen van het geschil. In dat kader zijn de bepalingen met betrekking tot het civiel procesrecht relevant. Uit 28 U.S.C. 1331 blijkt dat de district courts in eerste instantie bevoegd zijn te oordelen over 'all civil actions arising under the Constitution, laws, or treaties of the United States.' Het voorgaande brengt met zich dat de district courts (in beginsel ${ }^{88}$ ) bevoegd zijn te oordelen over een op grond van $\S 702$ van de APA aangevochten agency-besluit. ${ }^{89}$

In (zeer) uitzonderlijke situaties ${ }^{90}$ kan de omstandigheid zich voordoen dat ook de vangnetbepaling uit de APA geen soelaas biedt. In die gevallen kan worden teruggegrepen op de zogenaamde 'nonstatutory review'. Het gaat dan om een rechterlijke bevoegdheid tot toetsing van agency-actions die niet is gebaseerd op een bijzondere of algemene wet maar om 'judicial remedies' die buiten de wet om bestaan en kunnen worden gebruikt om een agency-action door de rechter te laten beoordelen. In dit kader moet met name gedacht worden aan uit de common-law traditie stammende remedies (zoals bijvoorbeeld injunctive relief, habeas corpus, en mandamus). ${ }^{91}$ Deze bevoegd-

Vgl. Strauss e.a., a.w. 1995. p. 1109.

85 Op deze plaats dient overigens nog opgemerkt te worden dat het niet veelvuldig voorkomt dat tegen een definitief boetebesluit beroep wordt ingesteld bij een federale rechter. Zie hierover: Administrative Hearings and Trials, National Enforcement Training Institute van het Office of Enforcement and Compliance Assurance van het EPA, pagina 4: '...very few cases are ever appealed to federal courts. (approximately 6-10 per year). En: Michael J. Walker, High Stakes on a Fast Track: Administrative Enforcement at EPA, Federal Bar News \& Journal, Federal Bar Association, Volume 35, No. 10, december 1988, pagina 453-457, pagina 453: 'a very low appeal rate (less than one percent of all filed administrative cases are appealed to federal courts),..' Dit lijkt overigens met name te maken te hebben met het feit dat veel overtreders bereid zijn reeds in een eerder stadium van de procedure tot oplegging van de bestuurlijke boete tot een schikking te komen. Later in deel twee kom ik daar nog op terug.

86 Vgl. $\$ 703$ APA.

87 Zie m.b.t. $\$ 702$ APA: Strauss e.a., a.w. 1995, p. 1111-1113.

88 Vgl. Strauss e.a., a.w. 1995, p. $1110-1111$.

89 Zie m.b.t.: de relatieve competentie 33 U.S.C. 1391.

$90 \mathrm{Vgl}$. de in Strauss e.a (a.w. 1995) aangehaalde voorbeelden (p. 1113).

91 Vgl. de in Strauss e.a., a.w. 1995, p. 1113-1114. 
heid tot 'nonstatutory review' lijkt in de APA overigens expliciet weergegeven te worden in $\S 703 .^{92}$

\subsubsection{Wijze van toetsing door de artikel III rechter}

Tenslotte zal in deze paragraaf beknopt worden ingegaan op de wijze waarop de bevoegde artikel III rechter het agency-besluit toetst. Met name de toetsingsintensiteit speelt in dat kader een rol. Omtrent de wijze waarop de artikel III rechter agencybesluiten moet, dan wel mag, toetsen is een en ander geregeld in $\$ 701$ tot en met $\$ 706$ van de APA. ${ }^{93}$ Deze bepalingen zullen in deze paragraaf besproken worden.

\subsubsection{Toetsing uitgesloten}

Ten eerste wordt in $\$ 701$ van de APA de mogelijkheid tot rechterlijke heroverweging uitgesloten voor zover dat in een wettelijke regeling is bepaald ${ }^{94}$ en voor zover er spra$k e$ is van een handelen van een agency op basis van een - volledige - discretionaire bevoegdheid. ${ }^{95}$ Als eén van de twee hiervoor genoemde gevallen zich voordoet is beroep tegen een agency-besluit bij een 'constitutional court' niet mogelijk.

Ten aanzien van het uitsluiten van een beroep op de rechter in de wet bestaan (in beginsel $^{96}$ ) weinig onduidelijkheden. Lastiger is het echter om vast te stellen wanneer er sprake is van een 'volledige discretionaire bevoegdheid' (een 'mistig' begrip) ${ }^{97}$ Het Supreme Court heeft in de rechtspraak gepoogd aan te geven wanneer er sprake is van een dergelijke volledige discretionaire bevoegdheid ${ }^{98}$ van het agency. Het lijkt echter niet altijd eenvoudig te zijn om vast te stellen of er sprake is van 'volledige discretionaire bevoegdheid' zoals omschreven in \$701(a)(2) APA. In 'Lincoln v. Vigil ${ }^{99}$ heeft het Supreme Court het volgende bepaald omtrent de volledige discretionaire bevoegdheid:

'...under $\$ 701(a)(2)$ agency action is not subject to judicial review 'to the extent that' such action 'is committed to agency discretion by law.' As we explained in Heckler v. Chaney, 470 U.S. 821 (1985), $\$ 701$ (a)(2) makes it clear that 'review is not to be had' in those rare circumstances where the relevant statute 'is drawn so that a court would have no meaningful standard against which to judge the agency's exercise of discretion.' 'In such a case, the statute ('law') can be taken to have 'committed' the decision making to the agency's judgement absolutely.' Heckler, supra, at 830. Over the years, we have read $\$ 701(a)(2)$ to preclude judicial review of certain categories of administrative decisions that courts traditionally have regarded as 'committed to agency discretion.'

Zie de hierboven aangehaalde passage uit $\S 703$ APA.

93 De relevante bepalingen uit de APA zijn opgenomen in Appendix II van dit boek.

94 Zie hierover onder meer: Traynor v. Tumage, 485 U.S. 535 (1988).

95 Blijkens de uitspraak van het Supreme Court in National Labor Relations Board v. Curtin Matheson Scientific, Inc.', 494 U.S. 775 (1990) vindt er ten aanzien van de beleidsvrijheid (policy making) zoals wij die in Nederland kennen echter een marginale toetsing plaats.

96 In dit kader verdient opmerking dat het Supreme Court soms een 'implied preclusion' aanneemt. Dat wil zeggen dat het verbod van rechterlijke toetsing in de wettelijke regeling wordt ingelezen hoewel de wet rechterlijke toetsing niet expliciet verbiedt. Vgl. Strauss e.a., a.w. 1995, p. 1192 e.v.

98 Op grond waarvan rechterlijke toetsing is uitgesloten.

99 Lincoln v. Vigil, 113 S. C. 2024 (1993). 
Het gaat dus om een zeldzame, moeilijk te benoemen, discretionaire bevoegdheid die, als ik het goed zie, verder strekt dan de beleidsvrijheid en de beoordelingsvrijheid die wij in het Nederlandse bestuursrecht kennen. De toegekende vrijheid moet, zo valt uit de rechtspraak van het Supreme Court af te leiden, zo ruim geformuleerd zijn in de wettelijke bepaling dat toetsing niet mogelijk is, omdat aan de wettelijke regeling geen (enkele) toetsingsmaatstaf kan worden ontleend.

Blijkens de uitspraken van het Supreme Court is er slechts in uitzonderlijke situaties sprake van een dergelijke volledige discretionaire bevoegdheid die zich niet leent voor rechterlijke toetsing. Gedacht kan worden aan de bevoegdheid van een bestuursorgaan om te besluiten niet over te gaan tot een onderzoek naar een vermeende overtreding van regelgeving ten aanzien waarvan het agency bevoegd is, of tot bestraffing (in 'civiele' dan wel strafrechtelijke zin) van een overtreder. Dit laatste speelde in 'Heckler v. Chaney'. ${ }^{100}$

In die zaak namen een aantal gedetineerden, aan wie de doodstraf was opgelegd, het standpunt in dat het gebruik van een dodelijke injectie ter voltrekking van de doodstraf een, met de Federal Food, Drug en Cosmetica Act (FDCA), strijdig gebruik van medicijnen opleverde. Zij verzochten de Food and Drug Adminstration (FDA) dan ook handhavend op te treden. De FDA weigerde over te gaan tot handhaving. De gedetineerden gingen tegen dit besluit in beroep bij het District Court.

Het Supreme Court dient vervolgens de vraag te beantwoorden of het District Court, gelet op $\$ 701(a)(2)$ APA bevoegd was de zaak in behandeling te nemen. Ten eerste herinnert het Supreme Court aan de standaardoverweging, zoals hierboven weergegeven, met betrekking tot de 'volledige discretionaire bevoegdheid'. Op basis van die overweging is er sprake van een dergelijke discretionaire bevoegdheid in het geval dat er een zeer ruime wettelijke grondslag is gecreëerd op basis waarvan het niet mogelijk is enige toetsingsmaatstaf te formuleren. Vervolgens stelt het Supreme Court: 'This Court has recognized on several occasions over many years that an agency's decision not to prosecute or enforce, whether through civil or criminal process, is a decision generally committed to an agency's absolute discretion.' Dit zou slechts anders zijn als in de wettelijke regeling richtlijnen zijn opgenomen die het agency in acht moet nemen bij het opsporings- en vervolgingsbeleid. Dergelijke richtlijnen kunnen immers als toetsingsmaatstaf voor de rechter dienen. In de FDCA zijn dergelijke richtlijnen echter naar het oordeel van het Supreme Court niet terug te vinden. Derhalve voorzien de in de FDCA neergelegde handhavingsbepalingen in 'complete discretion to the Secretary to decide how and when they should be exercised.' De conclusie van het Supreme Court is dan ook voor de hand liggend:

'We therefore conclude that the presumption that agency decisions not to institute proceedings are unreviewable under 5 U.S.C. 701(a)(2) is not overcome by the enforcement provisions of the FDCA. The FDA's decision not to take the enforcement actions requested by respondents is therefore not subject to judicial review under the APA. The general exception to reviewability provided by 701 (a)(2) for action 'committed to agency discretion' remains a narrow one, see Citizens to Preserve Overton Park v. Volpe, 401 U.S. 402 (1971), but within that exception are included agency refusals to institute investigative or enforcement proceedings, unless Congress has indicated otherwise. In so holding, we essentially leave to

100 Heckler v. Chaney, 470 U.S. 821 (1985). 
Congress, and not to the courts, the decision as to whether an agency's refusal to institute proceedings should be judicially reviewable.'

Uit deze rechtspraak van het Supreme Court kan worden afgeleid dat er slechts in uitzonderlijke gevallen sprake is van 'absolute agency discretion'. Vast staat dat het initièren van een onderzoeks- of handhavingsprocedure (in beginsel) wél deel uit maakt van deze ruime discretionaire bevoegdheid. ${ }^{101}$ Dat is slechts anders als het Congres dit op enigerlei wijze, bijvoorbeeld middels handhavingsrichtlijnen in de wettelijke regeling, aangeeft. Of er sprake is van volledige discretionaire bevoegdheid is derhalve met name sterk afhankelijk van de wijze waarop het Congres de bevoegdheid heeft geformuleerd. ${ }^{102}$

\subsubsection{Toetsingsbevoegdheid}

Indien de toegang tot de rechter niet op grond van $§ 701(\mathrm{a})(2)$ van de APA is uitgesloten en de (rechts)persoon op grond van $\$ 702$ recht heeft op een rechterlijke heroverweging dan geldt, zo is hiervoor reeds aangegeven, op grond van $\$ 703$ van de APA als hoofdregel dat in de bijzondere bestuursrechtelijke wet de bevoegde artikel III rechter wordt aangewezen, en dat daar tevens de te volgen procedure wordt weergegeven. Mocht in de bijzondere bestuursrechtelijke wet niets geregeld zijn dan fungeert $\$ 703$ als vangnetbepaling. Vooralsnog kan met deze informatie worden volstaan aangezien de specifieke beroepsregelingen met betrekking tot de door het Environmental Protection Agency (EPA) op te leggen bestuurlijke boeten later in dit boek aan de orde zullen komen.

Daarbij dient nog te worden opgemerkt dat de (rechts)persoon zich, op grond van $\$ 704$ van de APA, eerst tot de artikel III rechter kan wenden als alle bestuursrechtelijke procedures, die in het kader van een specifieke agency-action kunnen worden gevolgd, door hem zijn gevolgd. ${ }^{104}$ Er moet derhalve sprake zijn van een 'final agency action'.

Evenals de Nederlandse bestuursrechter dient de Amerikaanse artikel III rechter vast te stellen hoe diepgaand zijn toetsing ten aanzien van een concreet bestuurshandelen mag

101 In dit kader verdient opmerking dat in Nederland (in ieder geval in het ruimtelijk bestuursrecht en in het milieurceht) met betrekking tot de, als reparatoire bestuursrechtelijke sancties bekend staande. (aanschrijving tot) toepassing van bestuursdwang en het opleggen van een last onder dwangsom uit wordt gegaan van een beginselplicht tot handhaving. Zie hierover hoofdstuk twee van dit boek.

102 Zie ook: Citizens to preserve Overton Park v. Volpe, 401 U.S. 402 (1971). In die zaak bepaalde het Supreme Court dat de (wettelijke) bevoegdheid van de minister van transport om vast te stellen dat een snelweg aangelegd moet worden door een nationaal park (omdat er geen altematieve route is voor de snelweg buiten het nationaal park) geen volledige discretionaire bevoegdheid is.

103 Het verdient opmerking dat de bevoegdheid tot rechterlijke toetsing op grond van $\$ 702$ van de APA veel verder strekt dan in het Nederlandse bestuursrecht: 'A person suffering legal wrong because of agency action, or adversely affected or aggrieved by agency action (zie defenitie in $\$ 551(13)$ van de APA) within the meaning of a relevant statute, is entitled to judicial review thereof.' Terwijl in het Nederlandse bestuursrecht, op grond van arlikel 8:1 en 8:2 van de Awb, slechts beroep bij de bestuursrechter mogelijk is door een belanghebbende tegen bepaalde soorten besluiten van bestuursorganen.

104 De bestuursrechtelijke procedures zijn doorgaans per 'agency-action' neergelegd in regelgeving. Zo is de procedure voor het opleggen van een bestuurlijke boete door het EPA geregeld in titel 40 deel 22 van de Code of Federal Regulations (40CFR22); 'Consolidated Rules of Practice Goveming the Administrative Assessment of Civil Penalties and the Revocation/Termination or Suspension of Permits.' 
zijn. Een belangrijk onderscheid wordt gemaakt tussen de vaststelling van feiten en vragen met betrekking tot het recht.

Een probleem met betrekking tot de interpretatie of toepasselijkheid van een wetsbepaling of een bepaling uit de Grondwet mag de rechter volledig toetsen. Worden er echter door het agency vastgestelde feiten betwist dan dient de rechter aanmerkelijk terughoudender te toetsen. ${ }^{105}$ In $\S 706$ van de APA worden de rechter enkele maatstaven aangereikt $^{106}$ aangaande de omvang van zijn toetsingsbevoegdheid. In het bijzonder kan worden gewezen op de 'arbitrary and capricious standard' ${ }^{107}$ (uit $\$ 706,2$ sub A) en de 'substantial-evidence test' (uit $\$ 706,2$ sub E).

Substantial evidence wordt in 'Universal Camera Corp. v. National Labor Relations Board' ${ }^{108}$ gedefinieerd als: '...more than a mere scintilla. It means such relevant evidence as a reasonable mind might accept as adequate to support a conclusion.' ... It 'must do more than create a suspicion of the existence of the fact to be established.' Het Court of Appeals dient derhalve (slechts) vast te stellen dat een definitief agencybesluit kan worden onderbouwd met 'substantial evidence' (wezenlijk bewijsmateriaal). De toetsing aan de bewijsmiddelen door de Amerikaanse rechter op basis van de bepalingen uit de APA is daarmee duidelijk minder diepgaand als de toetsing door de Amerikaanse rechter in een strafrechtelijke procedure. In het strafprocesrecht moet door de aanklager immers aangetoond worden dat de beschuldigde persoon schuldig is 'beyond reasonable doubt. ${ }^{109}$

De 'substantial-evidence' test kan door de rechter overigens alleen worden toegepast ten aanzien van agency-actions warbij tijdens de bestuurlijke fase de hoorprocedure uit $\$ 556$ en $\$ 557$ van de APA is toegepasi terwijl er bij iedere agency-action ${ }^{110}$ getoetst mag worden aan de "arbitrary and capricious standard"."

De Amerikaanse rechter dient bepaalde delen van een bestuursbesluit marginaal te toetsen. ${ }^{112}$ Blijkens de uitspraak van het Supreme Court in de zaak 'National Mufller

105 Zis hierwer odk Strauss ea. a.w. 1995, p. 520 ew. Soms is het moellijk vast te stellen of er sprake is vala een betwisting van een door het agency vastgesteld feit of van interpretatie van een wettelijke bepaling. Een dergelijk probleem doet zich voos in National Labor Relations Board v. Hearst Publications, Incorporated', 322. U.S. 111 (1944) waar het gaat om de vaag of 'newsboys' werknemers zijn. Volgens het Supreme. Cout is dit cen feitelijke vrasg terwijl 'Hearst Publications' dit beschouwd als een rechtsvraag.

106 Zie hierover Strauss e.a. a.w. 1995, p. 5lo e.y.

107 Met name het willekeur-criterium ait de bepaling is daatbij van belang.

108 Universal Camera Corp. v. National Labor Relations Board, 340 U.S. 474 (1951)

109 Zie ook 'State Employees' Retirement System $\psi$. Industrial Accideal Commission', 217 P. 20992 (1950), met betrekking tot de toenassing van de substantial-evidence test.

I10 Ook agency regelgeving the bijvoorbeeld op grond van s553 van de APA tot stand is gekomen is onderworpen aan de 'arbitrary and capricious standard.

II In de Amerikanse literatur bestaat discussie ower de vraag in hoevere de 'arbitrary and capricious. standard" verschilt van de 'substantial evidence test'. Zie hierwer onder meer 'Association of Data Processing Service Organizations, Inc. ₹. Board of Govemors of the Federal Reserve System', U.S. Court of Appeals for the District of Columbia Circuit, 745 F.2d 677 (1984) en Strauss e.a. a.w. 1995, p. 542 e.

112 Zit met betrekking tot marghnale rechterlijke toetsing in het Nedellandse bestuursrecht onder meer; Van Wijk/KonijnerbelvVan Male a.w. 1999, $\$ 6.8,6.9,6.10,6.51,7.51,7.56,14.13$ en 14.14. Daar waar aan het hestuursorgaan enige beleidswrijheid of heoordelingsvrijheid is toebedeeld dient de bestursrechter zich, op grond van antikel 3:4, tweede lid van de Awb, te beperken tot een marginale toet- 
Dealers Association, Inc., v. United States' ${ }^{113}$ behoort de Amerikaanse rechter tot op zekere hoogte terughoudend te toetsen of een bestuursorgaan, in de door het orgaan geformuleerde regelgeving, een wettelijke term (in casu de term 'business league') juist heeft geïnterpreteerd. Cann geeft in dat kader aan dat rechterlijke toetsing ten aanzien van regelgeving van een bestuursorgaan die de interpretatie van een wettelijke term behelst (interpretive rules) ruimer is dan de toetsing van agency-regelgeving waarmee de door het Congres gedelegeerde bevoegdheid wordt uitgewerkt (substantive rules). ${ }^{114}$ 'That is the case because although courts should show some deference toward agency expertise in interpreting congressional intent, courts are just as capable of determining congressional intent as agencies are. ${ }^{115}$ Een dergelijk onderscheid wordt in Nederland gemaakt tussen beoordelingsruimte (ofwel interpretatievrijheid) enerzijds en beoordelingsvrijheid en beleidsvrijheid anderzijds. Opmerking verdient echter dat de Nederlandse bestuursrechter de door een bestuursorgaan aan een wettelijke term gegeven interpretatie volledig terzijde mag schuiven en daar zijn eigen interpretatie voor in de plaats mag stellen. De Amerikaanse rechter lijkt, in ieder geval formeel gezien, een beperktere toetsingsmogelijkheid te hebben.

Illustratief in het kader van het onderscheid (wat betreft de toetsingsintensiteit) tussen 'interpretive rules' en 'substantial rules' is de zaak 'Chevron U.S.A., Incorporated v. Natural Recources Defense Council'. ${ }^{116}$ In die zaak stond de vraag centraal of het EPA de bevoegdheid had de term 'stationary source' op een bepaalde manier te interpreteren en op welke wijze (althans hoe intensief) de Amerikaanse rechter de door het EPA voorgestane wijze van interpretatie zou mogen toetsen.

Het Supreme Court heeft in de zaak 'Chevron' aangegeven dat de rechter zich voor twee vragen gesteld ziet als hij moet beoordelen of de uitleg, die door een agency is gegeven aan (een term uit) een wet die door het agency moet worden uitgevoerd, juist is. Ten eerste moet de rechter beoordelen of het Congres zich in de wettelijke regeling (of de wetsgeschiedenis) expliciet heeft uitgelaten over een bepaalde uitleg van de wet (en dan in het bijzonder ten aanzien van de ter discussie staande term). Is dit het geval dan moeten zowel de rechter als het agency handelen conform deze (ondubbelzinnige) bedoeling van de wetgever. Heeft het Congres, in de wettelijke regeling, echter verzuimd expliciet aandacht te besteden aan een bepaalde kwestie dan kan de rechter niet zomaar zijn eigen interpretatie geven aan de wettelijke bepaling.

sing met betrekking tot het beleid of het oordeel van het bestuursorgaan. Hij dient zich in dat kader slechts af te vragen of het bestuursorgaan in redelijkheid tot het bestreden besluit heeft kunnen komen. Fen uitzondering wordt echter gemaakt voor de als punitieve sanctie te kwalificeren bestuurlijke boete welke de rechter niet marginaal maar diepgaander aan de evenredigheidsmaatstaf van artikel 3:4, tweede lid van de Awb moeten toetsen. De rechter dient zich ten aanzien van punitieve bestuursrechtelijke sancties, waaronder de bestuurlijke boete. namelijk de vraag te stellen of er evenredigheid bestaat tussen de emst van de verweten overtreding en de zwaarte van de opgelegde sanctie zo blijkt uit de uitspraak van de Afdeling bestuursrechtspraak van de Raad van State van 4 juni 1996 (JB 1996/172. m. nt. E. v.d. Linden) Het voorgaande geldt overigens niet voor bestuurlijke boeten die opgelegd moeten worden op hasis van strikt gebonden bestuursbevoegdheden. Zie over toetsing van punitieve bestuursrechtelijke sancties aan artikel 3:4 lid 2 van de Awb ook hoofdstuk twee en vier van dit boek.

113 National Muffler Dealers Association. Inc., v. United States, 440 U.S. 472 (1979).

114 Zie m.b.t. het onderscheid tussen 'interpretive rules' en 'substantive rules': Cann a.w. 1998, p. 223 e.v.

115 Cann a.w. 1998, p. 227.

116 Chevron U.S.A., Incorporated v. Natural Recources Defense Council, 467 U.S. 837 (1984). 
In een dergelijk geval, waarin de wettelijke regeling zwijgt over de wijze waarop (een bepaalde term uit) een regeling moet worden uitgelegd en er geen sprake is van expliciete delegatie van regelgevende bevoegdheid aan het agency in dat kader, mag de rechter de interpretatie van het agency slechts terzijde schuiven als deze uitleg niet kan worden gezien als een redelijke uitleg. De interpretatie van een term door een agency is immers niet zelden het uitvloeisel van bepaalde beleidskeuzes (op basis van de specifieke expertise van een agency) waaraan een belangenafweging ten grondslag ligt, zo stelt het Supreme Court. Juist dit aspect lijkt met zich te brengen dat de rechter (enige) terughoudendheid moet betrachten bij de beoordeling van de uitleg van een bepaalde term door een agency.

Is er, in de wettelijke regeling, echter sprake van een expliciete delegatie van regelgevende bevoegdheid om een bepaald onderdeel nader uit te werken of uit te leggen in agency-regelgeving (middels 'substantive rules') dan wordt aan dergelijke agencyregelgeving in beginsel doorslaggevend gewicht toegekend... 'unless they are arbitrary (willekeurig [KA]), capricious, or manifestly contrary to the statute. ${ }^{117}$ Deze wijze van toetsing is derhalve terughoudender dan de manier waarop mag worden getoetst in geval de wettelijke regeling zwijgt over de wijze waarop een bepaalde regeling moet worden uitgelegd en er geen sprake is van expliciete delegatie van regelgevende bevoegdheid aan het agency in dat kader.

Interessant met het oog op de toetsingsbevoegdheid van de Amerikaanse rechter is voorts een uitspraak in de zaak 'National Labor Relations Board v. Curtin Matheson Scientific Inc. ${ }^{18}$ In genoemde zaak ging het om de toetsing van een zogenaamde 'substantive rule'. Het Supreme Court heeft in die zaak het volgende overwogen:

'This court has emphasized often that the NLRB has the primary responsibility for developing and applying national labor policy. See e.g., Beth Israel Hospital v. NLRB, 437 U.S. 483, 500-501 (1978). 'Because it is to the Board that Congress entrusted the task of 'applying the Act's general prohibitory language in the light of the infinite combinations of events which might be charged as violative of its terms,' that body, if it is to accomplish the task which Congress set for it, necessarily must have authority to formulate rules to fill the interstices of the broad statutory provisions.' Beth Israel Hospital, supra, at 500-50l (quoting Republic Aviation Corp. v. NLRB, 324 U.S. 793, 798 (1945)). This Court therefore has accorded Board rules considerable deference. (...) We will uphold a Board rule as long as it is rational and consistent with the Act, ... even if we would have formulated a different rule had we sat on the Board, ... Furthermore, a Board rule is entitled to deference even if it represents a departure from the Board's prior policy. ${ }^{119}$

117 Vgl. Chevron U.S.A., Incorporated v. Natural Recources Defense Council, 467 U.S. 837 (1984).

118 National Labor Relations Board v. Curtin Matheson Scientific, Inc., 494 U.S. 775 (1990). Zic ook Wisconsin v. City of New York, $116 \mathrm{~S}$. Ct. 109 (1996) waarin een besluit van de minister van handel 'entirely reasonable' wordt geacht.

119 Zie, ter vergelijking, HR 25 februari 1949, NJ 558 m.nt. Veegens, ARB pagina 778, 'Doetinchemse woonruimtevordering', en meer recent ABRS 9 mei 1996, JB 1996/158 m.n. Stroink, 'Maxis \& Praxis'. Daarnaast wordt hier nogmaals gewezen op het feit dat de Nederlandse bestuursrechter ten aanzien van punitieve bestuursrechtelijke sancties zoals de bestuurlijke boete in bepaalde gevallen een diepgaandere toetsing toe moet passen. 
Uit het voorgaande kan afgeleid worden dat er sprake is van een gedifferentieerde toetsingsintensiteit die afhankelijk is van de mate van discretie die aan het agency toekomt in het kader van een bepaalde bevoegdheid. Het verdient opmerking dat het 'palet' van soorten discretionaire bevoegdheden in de Verenigde Staten bepaalde overeenkomsten vertoont met de Nederlandse situatie getuige de hierboven weergegeven rechtspraak van het Supreme Court.

In dat kader moet echter opgemerkt worden dat de beleidsvrijheid zich bij de Amerikaanse bestuursrechtelijke regelingen met name lijkt te manifesteren in de bevoegdheid van agencies om 'substantive rules' te maken. Op basis van deze omvangrijke regelgeving werkt het agency een bepaalde wet in formele zin veelal verder uit. Middels 'substantive rules' regelt het agency bijvoorbeeld op welke wijze of in welke gevallen een bepaalde sanctie opgelegd moet worden. In die zin wijkt het Amerikaanse systeem af van het Nederlandse systeem. In Nederland zijn de bestuur(srechte)lijke bevoegdheden, met het oog op het beginsel van wetmatigheid van bestuur, immers in de regel neergelegd in de bijzondere bestuursrechtelijke wetten. De bevoegdheden worden in genoemde wetten redelijk nauwkeurig omschreven gelet op het legaliteits- en specialiteitsbeginsel. Van beleidsvrijheid is voor het bestuursorgaan derhalve in beginsel slechts sprake ter zake van de concrete toepassing van een in de wet toegekende bestuursbevoegdheid in een specifiek geval. Het bestuursorgaan kan, voorzover het op grond van de wettelijk toegekende bevoegdheid beschikt over beleidsvrijheid, in een concreet geval, na afweging van alle (rechtens relevante) belangen, beslissen of het een bepaald besluit al dan niet neemt. ${ }^{120}$

De intensiteit van de rechterlijke toetsing van bestuursbesluiten en andere bestuurshandelingen ${ }^{121}$, op grond van de bepalingen uit $\$ 701$ tot en met $§ 706 \mathrm{APA}$, is, wat beleidsvrije bevoegdheden betreft, op bepaalde punten vergelijkbaar met de wijze waarop de Nederlandse bestuursrechter dergelijke bestuursbesluiten toetst. Ook de Amerikaanse rechter lijkt een met het 'willekeur-criterium' vergelijkbare toets toe te passen. Indien op basis van een beleidsvrije bevoegdheid door het agency geformuleerde regels (substantive rules) niet willekeurig (ofwel niet onredelijk) zijn terwijl zij voorts in overeenstemming zijn met de wet, dienen zij in stand te blijven. Dit geldt zelfs als de rechter een andere regel geformuleerd zou hebben als hij daartoe bevoegd was. ${ }^{122}$ Op deze plaats dient nog wel opgemerkt te worden dat de Nederlandse bestuursrechter juist ten aanzien van, op basis van een bevoegdheid met beleidsvrijheid opgelegde, punitieve bestuursrechtelijke sancties in bepaalde gevallen niet marginaal maar diepgaander mag toetsen. ${ }^{123}$ Een dergelijke uitzondering lijkt voor de Amerikaanse bestuurlijke boete niet te gelden.

120 Het bestuursorgaan kan ten aanzien van dergelijke beleidsvrije bevoegdheden overigens beleidsregels formuleren. Het formuleren van dergelijke beleidsregels kan worden beschouwd als een vorm van zellbinding.

121 Zic hieruver ondermeer; Universal Camera Corp. v. National Labor Relations Board, 340 U.S. 474 (1951), en National Labor Relations Board v. Curtin Matheson Scientific, Inc., 494 U.S. 775 (1990).

$122 \mathrm{Vgl.} \mathrm{ABRS} 9$ mei 1996. JB 1996/158 m. nt. F.A.M. Stroink (Maxis \& Praxis).

123 Zie hoofdstuk twee en vier van dit boek. 


\subsection{Afsluitend}

Zoals reeds bij aanvang van dit hoofdstuk is opgemerkt is hier slechts op een beknopte wijze ingegaan op het Amerikaanse administratief recht. In het bijzonder is aandacht besteed aan die aspecten van het Amerikaanse bestuursrecht die relevant zijn in het kader van de oplegging van bestuurlijke boeten. Uit de bovenstaande beschrijving van het Amerikaanse bestuursrecht kan worden afgeleid dat de Amerikaanse agencies beschikken over ruime discretionaire bevoegdheden. Op basis van de formele wetgeving van het Congres kan een agency doorgaans zelf een boetebeleid vaststellen terwijl vervolgens ook de sanctionering en 'rechtspraak' (in de vorm van 'beroep') aan het agency zijn toebedeeld. Dat het agency op deze wijze beschikt over een wetgevende, een uitvoerende en een rechtsprekende bevoegdheid heeft het Supreme Court niet in strijd met de Grondwet geacht. De APA, die onbevooroordeelde en onpartijdige agency besluitvorming dient te garanderen, wordt gezien als een waarborg tegen de voomoemde machtsconcentratie.

Ook de oplegging van een bestuurlijke boete dient in de regel plaats te vinden volgens de in de APA neergelegde procedure, met dien verstande, dat het agency in bijzondere regelgeving daarvan kan afwijken. ${ }^{124}$ Tenslotte kan het definitieve boetebesluit nog aangevochten worden bij de artikel III rechter. Doorgaans geschiedt dit bij een District Court of een Circuit Court of Appeals. De artikel III rechter heeft een toetsingsbevoegdheid die, wat de toetsing van beleidsvrije bevoegdheden betreft, op punten vergelijkbaar is met de toetsingsbevoegdheid van de Nederlandse bestuursrechter. Daarbij dient echter wel opgemerkt te worden dat de Amerikaanse rechter, de overigens uiterst spaarzaam voorkomende, 'volledige' beleidsvrije bevoegdheden niet kan toetsen. Belangrijk is, in het kader van dit boek, dat het (al dan niet) initiëren van een onderzoeksof handhavingsprocedure in beginsel valt onder deze ruime discertionaire bevoegdheid. Daarmee wordt de weigering van een agency om (op verzoek van een derde) over te gaan tot handhaving, in beginsel, aan een rechterlijke toetsing onttrokken.

Veelal mag de rechter zich bovendien geen eigen oordeel vormen omtrent de feiten en hoeft het bestuursorgaan in de 'civiele' procedure niet 'beyond reasonable doubt' te bewijzen dat de (vermoedelijke) overtreder de overtreding ook daadwerkelijk gepleegd heeft.

Voorts lijkt de Amerikaanse rechter, anders dan de Nederlandse bestuursrechter, niet te beschikken over een diepgaandere toetsingsmogelijkheid met betrekking tot toetsing van de evenredigheid, van door een bestuursorgaan, op basis van een bevoegdheid met beleidsvrijheid, opgelegde bestuurlijke boeten (en andere punitieve bestuursrechtelijke sancties).

124 Voor de bestuurlijke boete die in dit onderzoek centraal staat is in dat kader titel 40, deel 22, van de Code of Federal Regulations van belang. In die titel is regelgeving opgenomen met betrekking tot de procedure die dient te worden gevolgd bij het opleggen van een bestuurlijke boete door het EPA. 



\section{Hoofdstuk 6}

\section{De Amerikaanse bestuurlijke boete}

Nadat in het voorgaande hoofdstuk aandacht is besteed aan het Amerikaanse bestuursrecht in het algemeen zal in dit hoofdstuk van deel twee aandacht uitgaan naar de wijze waarop de bestuurlijke boete in de Verenigde Staten wordt opgelegd. In dat kader zal eerst kort worden ingegaan op de opkomst van de bestuurlijke boete in de Verenigde Staten. Vervolgens wordt, ter illustratie, de bestuurlijke boete, zoals die wordt opgelegd door het Environmental Protection Agency (EPA) beschreven. In het bijzonder zal daarbij worden ingegaan op de bestuurlijke boeteregelingen die worden toegepast bij overtreding van de (uit de) Clean Air Act en de Marine Protection, Research, and Sanctuaries Act (voortvloeiende regelgeving).

Voor de volledigheid wordt er op deze plaats nogmaals op gewezen dat in de Verenigde Staten géén sprake is van één uniforme bestuurlijke boeteprocedure. Elke bijzondere wet kent een eigen regeling. Doordat nadere uitwerking van de boeteregeling in beginsel plaatsvindt op agency-niveau middels substantive agency-rules vindt echter toch een zekere stroomlijning plaats. Uit efficiëntieoogpunt is het immers voor een agency zinvol één uniforme procedure te creëren die kan worden toegepast in het kader van de aan het agency, op basis van verschillende bijzondere wetten, toekomende bevoegdheden tot het opleggen van een bestuurlijke boete. Het voorgaande brengt met zich dat de (meeste) Amerikaanse boeteregelingen in essentie met elkaar in overeenstemming zijn. Bij de beschrijving van de door het EPA toegepaste boeteregeling(en) zal voorts aandacht uitgaan naar de vraag in hoeverre deze regelingen voldoen aan de essentiële straf(proces)rechtelijke waarborgen die, mijns inziens, in het kader van de oplegging van punitieve sancties in acht moeten worden genomen. Deze benadering is gekozen teneinde de wijze van oplegging van bestuurlijke boeten in Amerika, in het bijzonder met het oog op de in dat kader toepasselijke waarborgen ten aanzien van de rechtsbescherming, te vergelijken met de wijze van oplegging van de bestuurlijke boeten in Nederland.

\subsection{Opkomst van de bestuurlijke boete in de Verenigde Staten}

Reeds in de negentiende eeuw bestond in de Verenigde Staten - weliswaar op zeer kleine schaal - de mogelijkheid tot het opleggen van een bestuurlijke boete. Een van de eerste wetten waarin het opleggen van een bestuurlijke boete mogelijk werd gemaakt was de Tariff Act uit 1842. ${ }^{1}$ Ook in de immigratie wetgeving uit 1903 was de mogelijkheid opgenomen om een bestuurlijke boete op te leggen.

1 Vgl. Lewis Mayers, The American Legal System, revised edition, Harper \& Row Publishers, New York, 1981, pagina 424. '...the custom authorities were autorized, if they concluded that an importer had intentionally under-valued his merchandise, to impose a penalty amounting to 20 per cent of the duty payable...'. Zie verder: William Funk, Close enough for govermment work?? -- Using informal procedures for imposing administrative penalties, Seton Hall Law Review, 1993, 24 Seton Hall L.Rev. 1,5 . 
Aanvankelijk heeft het Congres de mogelijkheid tot bestuursrechtelijke sanctionering beperkt tot gebieden die van oudsher door de overheid gereguleerd werden waaronder scheepvaart, douane, posterijen, en de spoorwegen. ${ }^{2}$ Met het ontstaan van de 'fourth branch' (zoals omschreven in $\S 2.1 .2$ van hoofdstuk vijf) is er echter op steeds meer terreinen overheidsinvloed ontstaan. De groei van de overheidsinvloed betekende tevens een groei van het aantal agencies. Doorgaans heeft het Congres de in het leven geroepen agencies bestuursrechtelijke sanctiebevoegdheden toebedeeld zodat naleving van regelgeving door het agency kon worden afgedwongen.

Aanvankelijk werd door het Congres nog niet veelvuldig gebruik gemaakt van de mogelijkheid om aan agencies de bevoegdheid te verlenen zélf via een bestuursrechtelijke procedure een bestuurlijke boete op te leggen. Hoewel, zoals reeds is aangeven, een aantal agencies al vanaf het begin of midden van de vorige eeuw de bevoegdheid hadden om bestuurlijke boeten op te leggen is die bevoegdheid voor agencies vanaf het midden van de jaren tachtig pas echt explosief gegroeid. ${ }^{3}$

De keuze van het Congres om de sanctionering van de overtreding van bepaalde (bestuursrechtelijke) regelgeving over te laten aan een bestuursorgaan in plaats van aan de strafrechter is gebaseerd op een aantal redenen. In feite zijn de argumenten, die het Congres aan de keuze om over te gaan tot sanctionering door middel van bestuurlijke boeten ten grondslag legt, vrijwel identiek aan de redenen die de Nederlandse Toestingscommissie en de commissie Scheltema daartoe aanvoerden. Kenneth Mann geeft de door het Congres aangedragen redenen als volgt weer:

'Congress acted in the belief that a large portion of the fraud detected escaped sanction because existing institutional structures were inadequate to respond to them. The federal criminal system was already overloaded with complex and serious cases, and expanding its capacity would have entailed heavy costs. The hybrid administrative penalty opened the way for more cost-efficient and streamlined methods for punishing criminals. It expanded the availability of sanctions for false claims and several other regulatory offences, thereby increasing the deterrent powers of government agencies without enlarging the field of criminal law. This change reflected a growing belief that administrative agencies need direct enforcement powers that are similar but not identical to criminal prosecution. Congress gave "prosecutorial" powers to administrative agencies without making these agencies part of the criminal process. Equally important, lawmakers seem to have thought of the criminal process as somehow inappropriate for "less serious" cases. ${ }^{4}$

Op basis van deze heldere uiteenzetting van Mann kan geconcludeerd worden dat ook in de Verenigde Staten het (strafrechtelijk) handhavingstekort ten grondslag heeft gele-

2 Vgl. Mayers a.w. 1981, p. 425 en Gellhom, a.w. 1970, p. 272.

3 Vgl. Kenneth Mann, Punitive Civil Sanctions: The Middleground Between Criminal and Civil Law, Yale Law Journal, juni 1992, 101 Yale L.J. 1795, 1850 en verder. Mann stelt: 'In recent years, Congress has steadily increased both the number of departments and agencies vested with regulatory authority and their powers to seek penalties.' (Mann a.w. 1992, p. 1850). Zie voorts: Strauss e.a. a.w. 1995, p. 687: The impetus has come both from within the agencies themselves and from Congress, which, in the late 1980s and early 1990s, laid down statutory groundwork for a more agressive enforcement approach in many programs. EPA is a leading, but not atypical, example: in 1991-1993 alone, the agency assessed over $60 \%$ of the total environmental penalties assessed since 1974; en Diver a.w. 1979, p. 1436.

Mann a.w. 1992, p. 1851-1852. Vgl. Diver a.w. 1979, p. 1436. 
gen aan de opkomst van de bestuurlijke boete. Door middel van de bestuurlijke boete zouden op een efficiënte (doelmatige en relatief goedkope) wijze ook de minder emstige overtredingen van (bestuursrechtelijke) regelgeving gesanctioneerd kunnen worden.

Kennelijk werd het vanzelfsprekend geacht dat op bepaalde terreinen agencies in het leven werden geroepen die tevens de bevoegdheid hadden om naast reparatoire sancties ook punitieve sancties op te leggen. Het Supreme Court accepteerde een dergelijke keuze van het Congres ook zonder tegenstand. Dit blijkt bijvoorbeeld uit de zaak 'Atlas Roofing Co. versus OSHC. ${ }^{3}$ In de zaak 'Atlas Roofing' uit 1977 wordt, (onder meer) onder verwijzing naar de zaak 'Crowell v. Benson", door het Supreme Court vastgesteld dat het gebruik van een bestuursrechtelijke procedure voor het opleggen van een bestuurlijke boete door een agency rechtmatig is. Het Supreme Court heeft in de zaak Atlas Roofing in dat kader het volgende overwogen:

'At least in cases in which "public rights" are being litigated - e.g., cases in which the Government sues in its sovereign capacity to enforce public rights created by statutes within the power of Congress to enact - the Seventh Amendment does not prohibit Congress from assigning the factfinding function and initial adjudication to an administrative forum with which the jury would be incompatible. ... when Congress creates new statutory "public rights," it may assign their adjudication to an administrative agency with which a jury trial would be incompatible, without violating the Seventh Amendment's injunction that jury trial is to be "preserved" in "suits at common law." Congress is not required by the Seventh Amendment to choke the already crowded federal courts with new types of litigation or prevented from committing some new types of litigation to administrative agencies with special competence in the relevant field. ... We cannot conclude that the Amendment rendered Congress powerless - when it concluded that remedies available in courts of law were inadequate to cope with a problem within Congress' power to regulate - to create new public rights and remedies by statute and commit their enforcement, if it chose, to a tribunal other than a court of law - such as an administrative agency - in which facts are not found by juries. Indeed, as the Oceanic opinion said, the "settled judicial construction" was to the contrary "from the beginning"."?

Op de punitieve aard van de sanctie wordt in de uitspraak in de zaak 'Atlas Roofing Co. v. OSHC' overigens niet ingegaan. In genoemde uitspraak overweegt het Supreme Court dat het - uit het zevende amendement voortvloeiende - recht op juryrechtspraak niet in de weg staat aan de 'definitieve' vaststelling van de feiten in een bestuursrechtelijke procedure. Het zevende amendement ziet - in tegenstelling tot het zesde amendement waar het recht op juryrechtspraak bij 'criminal prosecutions' wordt gegarandeerd - op 'suits at common low'. Het lijkt er dan ook op dat het Supreme Court de 'bestuurlijke boete' uit de zaak 'Atlas-Roofing' niet heeft beschouwd als een punitieve sanctie.

5 Atlas Roofing Co. v. Occupational Safety and Health Review Commission, 430 U.S. 422 (1977). Vgl: Diver a.w. 1979, p. 1437.

6 Crowell v. Benson, 285 U.S. 22 (1932). Zie ook de in hoofdstuk vijf aangehaalde passage uit deze uitspraak.

7 Zie overigens ook de in hoofdstuk vijf aangehaalde passage uit Oceanic Steam Navigation Company v. Stranahan, 24I U.S. 320 (1909). 
Het voorgaande leidt tot de volgende slotsom. In het geval dat het Congres de wetgevende bevoegdheid aanwendt voor het creëren van 'public rights' staat het het Congres tevens vrij in dat kader sanctiebevoegdheden toe te bedelen aan een agency. Het Supreme Court beschouwd de bevoegheid tot het tot stand brengen van 'public rights' derhalve als voldoende basis voor het creëren van punitieve sanctiebevoegdheden voor agencies.

Het voorgaande brengt met zich dat het Supreme Court de keuze van het Congres, om aan een agency, ter uitvoering van de door het Congres tot stand gebrachte regelgeving, sanctiebevoegdheden toe te bedelen, niet snel in strijd acht met de Amerikaanse Grondwet. Het gaat immers om 'public rights' en op het gebied van 'public rights', zo bleek ook reeds in het vorige hoofdstuk, heeft het Congres een zeer nume discretionaire bevoegdheid.

Het Congres kan, als het regelgeving tot stand brengt met betrekking tot 'public rights', zelf bepalen op welke wijze het bepaalde zaken wenst te regelen. Agencies kunnen in dit kader derhalve rechtmatig beschikken over een '(quasi) rechtsprekende functie' bij de oplegging van de bestuurlijke boete. Daarnaast is het toegestaan dat een besturrsorgaan als enige instantie kan oordelen over de feiten.

De Amerikaanse hoogleraar Funk plaats enkele kritische kanttekeningen bij deze ontwikkeling in het Amerikaanse administratieve sanctierecht. ${ }^{8}$ Uit zijn artikel 'Close enough for government work? - Using informal procedures for imposing administrative penalties' blijkt dat het Congres voor agencies steeds meer bestuursrechtelijke sanctiemogelijkheden creeert die door de agencies op basis van informele - niet op de APA gebaseerde - procedures kunnen worden opgelegd. Agencies kunnen mitsdien in veel gevallen op basis van een informele procedure een sanctie opleggen terwijl de rechter in beroep vervolgens het sanctiebesluit slechts op een (zeer) terughoudende wijze kan toetsen. Op deze plaats kan de vraag gesteld worden hoe deze rechtspraak van het Supreme Court zich verhoudt tot de rechtspraak van het EHRM met betrekking tot de in artikel 6 lid 1 van het EVRM opgenomen eis van 'full jurisdiction'.'

\subsection{De bestuurlijke boete zoals die wordt opgelegd door het Environmental Protection Agency (EPA)}

In de inleiding van deel II is reeds aangegeven dat het in feite niet mogelijk is om een beschrijving te geven van dé bestuurlijke boete zoals die door het EPA wordt opgelegd. In de Verenigde Staten bestaat namelijk geen consistente lijn in de wetgeving met betrekking tot bestuurlijke boeten. Dit brengt met zich dat de boeteprocedures slechts op hoofdlijnen overeenstemmen. Door het EPA worden op grond van negen wetten in formele $\operatorname{zin}^{10}$ al meer dan tien verschillende soorten bestuurlijke boeten opgelegd.

8 Vgl. William Funk, Close enough for government work? -- Using informal procedures for imposing administrative penalties, Seton Hall Law Review 1993, 24 Seton Hall L. Rev. 1.

9

10 Het gat dan om de volgende wetten:

- the Federal Insecticide, Fungicide, and Rodendicide Act, as amended, 7 U.S.C. 1361.

- the Clean Air Act, as amended, 42 U.S.C. 7413, 7524, 7545, 7547.

- the Marine Protection, Research, and Sanctuaries Ach, as amended. 33 U.S.C. 1415. 
Sommige boeten worden opgelegd op basis van de 'formal adjudication procedure' uit de APA, zoals die is weergegeven in hoofdstuk vijf van dit boek. Andere boeten worden opgelegd op basis van de, reeds eerder in dit boek genoemde, 'informal adjudication procedure'."

Ten aanzien van een deel van de procedure bestaan weliswaar, sinds 1980, uniforme regels die door het EPA zijn neergelegd in titel 40 deel 22 van de Code of Federal Regulations (CFR). Deze uniforme regels worden de 'Consolidated Rules of Practice Governing the Administrative Assessment of Civil Penalties and the Revocation/Termination or Suspension of Permits' genoemd (hierna: Rules of Practice). De in titel 40 deel 22 van de CFR neergelegde 'Rules of Practice' hebben, zoals reeds is aangegeven in hoofdstuk vijf, dezelfde kracht en verbindendheid als wetgeving in formele zin, met dien verstande dat zij van lagere orde zijn dan de van het Congres afkomstige wetgeving in formele zin. De 'Rules of Practice' zijn derhalve vergelijkbaar met wetten in materiële zin ofwel algemeen verbindende voorschriften. Overigens moet nog worden opgemerkt dat deze regels niet op alle door het EPA op te leggen bestuurlijke boeten van toepassing zijn. ${ }^{12}$ Bovendien verdient opmerking dat het EPA, naast de 'Rules of Practice', per afzonderlijke boeteregeling een beleid heeft ontwikkeld om de hoogte van de bestuurlijke boete vast te stellen.

Hiema zullen twee verschillende boeteregelingen worden weergeven, namelijk de regeling uit sectie 113(d)(1) van de Clean Air Act (42 U.S.C. 7413 (d)(1)) en de regeling uit sectie 105(a) van de Marine Protection, Research, and Sanctuaries Act (33 U.S.C. 1415(a)). Deze twee boeteregelingen verschillen behoorlijk van elkaar. Ter illustratie van het scala aan boeteregelingen is bewust voor twee zeer uiteenlopende regelingen gekozen. Daarbij moet niet uit het oog verloren worden dat het Congres éen bestuursorgaan doorgaans opzadelt met een scala aan, sterk van elkaar verschillende, boeteregelingen. Dit maakt de uitvoering en nadere invulling van die wettelijke regelingen door het agency er niet makkelijker op.

- the Solid Waste Disposal Act, as amended, 42 U.S.C. 6928, 6991, 6992.

- the Toxic Substances Control Act, 15 U.S.C. 2615

- the Clean Water Act, 33 U.S.C. 1319.

- the Comprehensive Environmental Response, Compensation, and Liability Act of 1980, as amended, 42 U.S.C. 9609.

- the Emergency Planning and Community Right-To-Know act of 1986, 42 U.S.C. 11045.

- the Safe Drinking Water Act, as amended, 42 U.S.C. $300 \mathrm{~g}-3$.

11 Zie in het kader van handhaving van het milieurecht door het EPA voorts: Blomberg a.w. 2000, i.h.b. hoofdstuk 8.

12 Zie: G. Harwoord, Hearings Before an EPA Administrative Law Judge, Environmental Law Reporter 17 ELR, 10441-10444, p. 10443, november 1987, waarin aangegeven wordt dat er in ieder geval naast de Rules of Practice nog zeven regelingen zijn op grond waarvan een van de Rules of Practice afwijkende hoorprocedure moet worden toegepast. Zie voorts: Michael J. Walker, High Stakes on a Fast Track: Administrative Enforcement at EPA, Federal Bar News \& Journal, Federal Bar Association, Volume 35, No. 10, december 1988, pagina 453-457, pagina 454: 'ALJ Palmer of the U.S. Department of Agriculture has noted that there are at least 280 different sets of evidentiary rules that apply to adjudicatory proceedings conducted in federal agencies alone.' Tenslotte geeft Funk in zijn artikel: Close enough for govemment work?? - Using informal procedures for imposing administrative penalties, (Seton Hall Law Review, 1993, 24 Seton Hall L.Rev. 1, p. 3 en verder), aan dat agencies op basis van bepaalde wetten bestuurlijke boeten op kunnen leggen zonder het houden van een formele - met waarborgen omkleede - (hoor)procedure. 
Nadat de twee bovenstaande boeteregelingen zijn weergegeven zullen zij worden geanalyseerd. Bij die analyse wordt gekeken in hoeverre in de twee Amerikaanse boeteregelingen invulling is gegeven aan de essentiële straf(proces)rechtelijke waarborgen die, met het oog op de rechtsbescherming van de (vermoedelijke) overtreder, mijns inziens van toepassing zouden moeten zijn bij de oplegging van een bestuurlijke boete. Daarna zal nog worden ingegaan op titel 40 deel 22 van de CFR en op het beleid van het EPA wat betreft de vaststelling van de hoogte van de op te leggen boete in relatie tot de genoemde processuele waarborgen.

\subsubsection{De boeteregeling uit de Clean Air Act en de Marine Protection, Research, and Sanctuaries Act}

Hieronder worden, zoals gezegd, eerst de twee boeteregelingen weergegeven, te beginnen met de regeling uit sectie 113(d)(1) van de Clean Air Act (42 U.S.C. 7413 (d)(1)). $\mathrm{Er}$ is voor gekozen de relevante wetsbepalingen op deze plaats integraal op te nemen in verband met de (on)toegankelijkheid van deze regelingen in Nederland. Bij bestudering van de hieronder weergegeven boeteregelingen zal overigens blijken dat de in de Amerikaanse sanctieregelingen neergelegde bestuurlijke boete soms tot op zekere hoogte een gelijkenis vertoont met de Nederlandse last onder dwangsom. De Amerikaanse regeling verschilt echter in die zin van de Nederlandse last onder dwangsom dat er op grond van de Amerikaanse regeling veelal sprake is van beboeting achteraf (en derhalve niet van het opleggen van een last vóórdat de (volgende) overtreding plaats gevonden heeft). Desalniettemin lijkt de sanctionering per tijdseenheid zich ook soms uit te strekken over in de toekomst liggende dagen dat de overtreding voortduurt. ${ }^{13} \mathrm{Nu}$ volgt, zoals hiervoor reeds was aangekondigd, de boeteregeling uit de Clean Air Act. ${ }^{14}$

Clean Air Act (42 U.S.C. 7413)

- (d) Administrative assessment of civil penalties

- (1) The Administrator may issue an administrative order against any person assessing a civil administrative penalty of up to $\$ 25,000$, per day of violation, whenever, on the basis of any available information, the Administrator finds that such person-

- (A) has violated or is violating any requirement or prohibition of an applicable implementation plan (such order shall be issued

- (i) during any period of federally assumed enforcement, or (ii) more than thirty days following the date of the Administrator's notification under subsection (a)(1) of this section of a finding that such person has violated or is violating such requirement or prohibition); or

- (B) has violated or is violating any other requirement or prohibition of this subchapter or subchapter III, IV-A, V, or VI of this chapter, including, but not limited to, a requirement or prohibition of any rule, order, waiver, permit or plan promulgated, issued, or approved under this chapter, or for the payment of any fee owed the United States under this chapter (other than subchapter II of this chapter);

or

13 Vgl. die hierna opgenomen boeteregeling uit de Clean Air Act.

14 Zie voor een beknopt overzicht van deze boeteprocedure Blomberg a.w. 2000, p. 239. 
- (C) attempts to construct or modify a major stationary source in any area with respect to which a finding under subsection $(a)(5)$ of this section has been made. The Administrator's authority under this paragraph shall be limited to matters where the total penalty sought does not exceed $\$ 200,000$ and the first alleged date of violation occurred no more than 12 months prior to the initiation of the administrative action, except where the Administrator and the Attomey General jointly determine that a matter involving a larger penalty amount or longer period of violation is appropriate for administrative penalty action. Any such determination by the Administrator and the Attomey General shall not be subject to judicial review.

$\cdot(2)$

- (A) An administrative penalty assessed under paragraph (1) shall be assessed by the Administrator by an order made after opportunity for a hearing on the record in accordance with section 554 and 556 of title 5 . The Administrator shall issue reasonable rules for discovery and other procedures for hearings under this paragraph. Before issuing such an order, the Administrator shall give written notice to the person to be assessed an administrative penalty of the Administrator's proposal to issue such an order and provide such person an opportunity to request such a hearing on the order, within 30 days of the date the notice is received by such person.

- (B) The Administrator may compromise, modify, or remit, with or without conditions, any administrative penalty which may be imposed under this subsection.

${ }^{\circ}(3)$ The Administrator may implement, after consultation with the Attomey General and the States, a field citation program through regulations establishing appropriate minor violations for which field citations assessing civil penalties not to exceed $\$ 5,000$ per day of violation may be issued by officers or employees designated by the Administrator. Any person to whom a field citation is assessed may, within a reasonable time as prescribed by the Administrator through regulation, elect to pay the penalty assessment or to request a hearing on the field citation. If a request for a hearing is not made within the time specified in the regulation, the penalty assessment in the field citation shall be final. Such hearing shall not be subject to section 554 or 556 of title 5 , but shall provide a reasonable opportunity to be heard and to present evidence. Payment of a civil penalty required by a field citation shall not be a defence to further enforcement by the United States or a State to correct a violation, or to assess the statutory maximum penalty pursuant to other authorities in the chapter, if the violation continues.

${ }^{\circ}$ (4) Any person against whom a civil penalty is assessed under paragraph (3) of this subsection or to whom an administrative penalty order is issued under paragraph (1) of this subsection may seek review of such assessment in the United States District Court for the District of Columbia or for the district in which the violation is alleged to have occurred, in which such person resides, or where such person's principal place of business is located, by filing in such court within 30 days following the date the administrative penalty order becomes final under paragraph (2), the assessment becomes final under paragraph (3), or a final decision following a hearing under paragraph (3) is rendered, and by simultaneously sending a copy of the filing by certified mail to the Administrator and the Attorney General. Within 30 days thereafter, the Administrator shall file in such court a certified copy, or certified index, as appropriate, of the record on which the administrative penalty order or assessment as issued. Such court shall not set aside or remand such order or 
assessment unless there is not substantial evidence in the record, taken as a whole, to support the finding of a violation or unless the order or penalty assessment constitutes an abuse of discretion. Such order or penalty assessment shall not be subject to review by any court except as provided in this paragraph. In any such proceedings, the United States may seek to recover civil penalties ordered or assessed under this section.

- (5) If any person fails to pay an assessment of a civil penalty or fails to comply with an administrative penalty order-

- (A) after the order or assessment has become final, or

- (B) after a court in an action brought under paragraph (4) has entered a finaljudgement in favour of the Administrator, the Administrator shall request the Attorney General to bring a civil action in an appropriate district court to enforce the order or to recover the amount ordered or assessed (plus interest at rates established pursuant to section 6621(a)(2) of title 26 from the date of the final order or decision or the date of the final judgement, as the case may be). In such an action, the validity, amount, and appropriateness of such order or assessment shall not be subject to review. Any person who fails to pay on a timely basis a civil penalty ordered or assessed under this section shall be required to pay, in addition to such penalty and interest, the United States enforcement expenses, including but not limited to attorneys fees and costs incurred by the United States for collection proceedings and a quarterly non-payment penalty for each quarter during which such failure to pay persists. Such non-payment penalty shall be 10 percent of the aggregate amount of such person's outstanding penalties and non-payment penalties accrued as of the beginning of such quarter.

- (c) Penalty assessment criteria

${ }^{\circ}$ (1) In determining the amount of any penalty to be assessed under this section or section 7604(a) of this title, the Administrator or the court, as appropriate, shall take into consideration (in addition to such other factors as justice may require) the size of the business, the economic impact of the penalty on the business, the violator's full compliance history and good faith efforts to comply, the duration of the violation as established by any credible evidence (including evidence other than the applicable test method), payment by the violator of penalties previously assessed for the same violation, the economic benefit of non-compliance, and the seriousness of the violation. The court shall not assess penalties for non-compliance with administrative subpoenas under section 7607(a) of this title, or actions under section 7414 of this title, where the violator had sufficient cause to violate or fail or refuse to comply with such subpoena or action.

- (2) A penalty may be assessed for each day of violation. For purposes of determining the number of days of violation for which a penalty may be assessed under subsection (b) or (d)(1) of this section, or section 7604(a) of this title, or an assessment may be made under section 7420 of this title, where the Administrator or an air pollution control agency has notified the source of violation, and the plaintiff makes a prima facie showing that the conduct or events giving rise to the violation are likely to have continued or recurred past the date of notice, the days of violation shall be presumed to include the date of such notice and each and every day thereafter until the violator establishes that continuous compliance has been achieved, except to the extent that the violator can prove by a preponderance of the 
evidence that there were intervening days during which no violation occurred or that the violation was not continuing in nature.

Vervolgens volgt hier de boeteregeling uit sectie 105(a) van de Marine Protection, Research, and Sanctuaries Act (33 U.S.C. 1415(a)).

Sec. 1415. Penalties

- (a) Assessment of civil penalty by Administrator; remission or mitigation; court action for appropriate relief

Any person who violates any provision of this subchapter, or of regulations promulgated under this subchapter, or a permit issued under this subchapter shall be liable to a civil penalty of not more than $\$ 50,000$ for each violation to be assessed by the Administrator. In addition, any person who violates this subchapter or any regulation issued under this subchapter by engaging in activity involving the dumping of medical waste shall be liable for a civil penalty of not more than $\$ 125,000$ for each violation, to be assessed by the Administrator after written notice and an opportunity for a hearing. No penalty shall be assessed until the person charged shall have been given notice and an opportunity for a hearing of such violation. In determining the amount of the penalty, the gravity of the violation, prior violations, and the demonstrated good faith of the person charged in attempting to achieve rapid compliance after notification of a violation shall be considered by said Administrator. For good cause shown, the administrator may remit or mitigate such penalty. Upon failure of the offending party to pay the penalty, the Administrator may request the Attomey General to commence an action in the appropriate district court of the United States for such relief as may be appropriate.

In een oogopslag is reeds duidelijk hoe groot de verschillen tussen deze twee boeteregelingen zijn. De boeteregeling uit de Clean Air Act is veel uitvoeriger en er zijn twee verschillende procedures tot oplegging van bestuurlijke boeten opgenomen in de regeling. ${ }^{15}$ De Clean Air Act voorziet namelijk ten aanzien van de in (d)(1) genoemde zwaardere overtredingen in een 'formal adjudication procedure' (zo volgt uit (d)(2)). Ten aanzien van 'minor violations', die gesanctioneerd worden middels lagere boeten, mag op grond van sectie (d)(3) van de boeteregeling uit de Clean Air Act een boete worden opgelegd op basis van de 'informal adjudication procedure'. In de Marine Protection, Research, and Sanctuaries Act wordt niet duidelijk aangegeven of het EPA de 'formal adjudication procedure' of de 'informal adjudication procedure' toe moet passen bij oplegging van de boete. Voorts springt meteen in het oog dat de boeteregeling uit de Clean Air Act meer procedurele waarborgen bevat.

In een nadere analyse zal aan worden gegeven in hoeverre in de beide hierboven weergegeven regelingen aan een aantal (straf(proces)rechtelijke) waarborgen invulling is gegeven. ${ }^{16} \mathrm{Bij}$ deze analyse zal gebruik worden gemaakt van de in deel I verworven

15 Blomberg geeft in haar dissertatie overigens aan dat de lagere boeten die middels een 'field citation' worden opgelegd veel lijken op de bij ons in Nederland bekende (bestuurlijke) transactie (Blomberg a.w. 2000 , p. $240-241$ ).

16 In hoofdstuk $7 \mathrm{zal}$ worden ingegaan op de vraag in hoeverre de Amerikaanse bestuurlijke boete is omkleed met constitutionele waarborgen. In dit hoofdstuk wordt alleen bekeken in hoeverre in de Amerikaanse bestuurlijke boeteregelingen is voldaan aan de eisen die in het kader van de rechtsbescherming van de (vermoedelijke) overtreder aan de oplegging van een bestuurlijke boete moeten worden gesteld. Daarbij dient echter wel rekening te worden gehouden met het feit dat de bestuurlijke boete op grond van hoofdstuk twee aanmerkt moet worden als 'criminal charge' in de zin van artikel 6 van het EVRM. Of de bestuurlijke boete in het Amerikaanse recht (door het Supreme Court) ook 
informatie over de vraag welke straf(proces)rechtelijke waarborgen in het kader van de oplegging van een bestuurlijke boete zouden moeten gelden. In het bijzonder is aansluiting gezocht bij de criteria die voortvloeien uit artikel 6 en 7 EVRM, 14 en 15 IVBPR, het CTW-rapport en het Voorontwerp van de vierde tranche Awb. ${ }^{17}$ Er zal vooralsnog alleen gekeken worden naar de boeteregelingen zoals hierboven weergegeven. Naderhand zal in dit hoofdstuk bekeken worden in hoeverre de 'Consolidated Rules of Practice Governing the Administrative Assessment of Civil Penalties and the Revocation/Termination or Suspension of Permits' eventueel gelezen in samenhang met de APA de boeteregelingen nog aanvullen. Daarbij zal dan tevens worden aangegeven in hoeverre daardoor alsnog invulling wordt gegeven aan bepaalde straf(proces)rechtelijke waarborgen die in de boeteregeling als zodanig buiten beschouwing zijn gebleven. Het vijfde, zesde en achtste amendement van de Amerikaanse Grondwet (evenals de vraag naar de toepasselijkheid van deze amendementen bij de oplegging van een bestuurlijke boete) komen, zoals reeds is opgemerkt, in dit hoofdstuk niet aan de orde. ${ }^{18}$

Overigens dient op deze plaats nog opgemerkt te worden dat, mede gelet op de beperkte ruimte in dit boek, de Amerikaanse boeteregeling minder uitvoerig getoetst zal worden aan de essentiële straf(proces)rechtelijke waarborgen dan de Nederlandse bestuurlijke boeteregeling. De nadruk ligt in dit boek immers op het nationale bestuurs(straf)recht. Bij deze beslissing heeft voorts een rol gespeeld dat in de Verenigde Staten, zoals later in deel II van dit boek nog zal blijken, de bestuurlijke boete in beginsel niet wordt gezien als een sanctie die gerekend moet worden tot het strafrecht in ruime zin. Daardoor zijn in de boeteregelingen in de regel géén uitvoerige procedurebepalingen neergelegd waarmee de wetgever (in formele dan wel materiële zin) invulling heeft willen geven aan bepaalde straf(proces)rechtelijke waarborgen. Dit brengt met zich dat de toetsing aan de, in Nederland in beginsel wél van toepassing geachte, waarborgen veelal vrij beperkt blijft en soms zelfs niet mogelijk is gebleken.

Hiema volgt de toetsing van de Amerikaanse boeteregelingen aan de essentiële straf(proces)-rechtelijke waarborgen.

\subsection{1.a De boeteregeling uit de Clean Air Act en de Marine Protection, Research, and Sanctuaries Act in het kader van de straf(proces)rechtelijke waarborgen}

\section{Uitsluiting strafrecht, una via-beginsel, ne bis in idem-beginsel}

Teneinde de rechtszekerheid te dienen en dubbele bestraffing te voorkomen gaat de Toetsingscommissie bij voorkeur uit van een boeteregeling waarin strafrechtelijke sanctionering van dezelfde overtreding in beginsel is uitgesloten. ${ }^{19}$ Mocht uitsluiting van het strafrecht niet mogelijk zijn dan dient er in ieder geval invulling gegeven te zijn aan het, uit het ne bis in idem-beginsel voortvloeiende, una via-beginsel in de boeteregeling. ${ }^{20}$

wordt aangemerkt als "punishment" (waardoor de straf(proces)rechtelijke waarborgen bij de oplegging van de bestuurlijke boete van toepassing zijn) is nog maar de vraag.

17 Voor een uitgebreide weergave van die criteria wordt op deze plaats verwezen naar hoofdstuk 2 tot en met 4 van dit boek.

18 Zie in dat kader hoofdstuk 7.

19 Vgl. CTW-rapport, a.w. 1994, p. 68-69.

20 Zie $m$. b.t. een nadere uitwerking van genoemde beginselen mat name hoofdstuk vier van dit boek. 
Beide hiervoor weergegeven Amerikaanse boeteregelingen lijken niet aan bovenstaand vereiste te voldoen. In de Clean Air Act (42 U.S.C. 7413) worden in paragraaf (c) de 'Criminal penalties' weergegeven. Op grond van die paragraaf zijn overtredingen die door middel van een bestuurlijke boete te sanctioneren zijn strafbaar als deze overtredingen bewust (knowingly) plaatsvinden. Lezing van paragraaf (c) 'Criminal penalties' in combinatie met (d) 'Administrative assessment of civil penalties' leidt niet tot de conclusie dat het ne bis in idem-beginsel en het una via-beginsel in acht zijn genomen. Het voorgaande geldt in nog sterkere mate voor de Marine Protection, Research, and Sanctuaries Act (33 U.S.C. 1415). Het eerste deel van section 1415(b) 'Criminal penalties' luidt namelijk als volgt:

'In addition to any action that may be brought under subsection (a) of this section-

- (1) any person who knowingly violates any provision of this subchapter, any regulation promulgated under this subchapter, or a permit issued under this subchapter, shall be fined under title 18 or imprisoned for not more than 5 years, or both;'.

Voorgaande bepaling biedt derhalve een expliciete wettelijke grondslag voor dubbele bestraffing van dezelfde overtreding.

Het voorgaande leidt tot slotsom dat in beide hierboven weergegeven boeteregelingen geen invulling is gegeven aan het vereiste dat strafrechtelijke sanctionering van dezelfde overtreding (in beginsel) uit moet zijn gesloten indien sanctionering middels een bestuurlijke boete mogelijk is. Het voorgaande hoeft niet problematisch te zijn zolang een voorziening is getroffen die dubbele bestraffing uit sluit. In dat kader dient er in ieder geval invulling gegeven te worden aan het una via-beginsel in de boeteregeling. Dit laatste is echter in geen van beide boeteregelingen het geval.

Uit de boeteregelingen kan niet worden afgeleid of het ne bis in idem-beginsel als zodanig wel geldt. Aan de vraag of een bestuursorgaan ten aanzien van dezelfde overtreding ten tweede male een procedure tot bestraffing mag starten wordt in de boeteregelingen immers geen aandacht besteed.

\section{Maximum boete in de wet}

Ten tweede is op grond van het legaliteitsbeginsel vereist dat in ieder geval de maximum op te leggen boete in de wet is weergegeven. Beide Amerikaanse boeteregelingen voldoen in beginsel aan deze eis. De Administrator van het EPA moet bij het vaststellen van de hoogte van de boete rekening houden met een aantal factoren die in de boeteregeling genoemd worden. ${ }^{21}$ Daarnaast is er in beide wetsartikelen een clausule opgenomen die het de Administrator mogelijk maakt om ten aanzien van de door hem op te leggen bestuurlijke boete een schikking te treffen, de boete aan te passen, of kwijt te schelden al dan niet onder bepaalde voorwaarden.

In beide boeteregelingen wordt derhalve de maximumboete neergelegd in de wet. Daarmee wordt in belangrijke mate invulling gegeven aan het legaliteitsbeginsel. Met het oog op het, uit het legaliteitsbeginsel voortvloeiende, lex certa-beginsel wekt het in

21 Die factoren kunnen overigens per boeteregeling verschillen. Dit blijkt reeds bij vergelijking van sectie 7413(e) van de Clean Air Act met sectie 1415 van de Marine Protection, Research and Sanctuaries Act. 
sectie 113(d)(1)(c) van de Clean Air Act bepaalde echter enige verbazing. Uit genoemde bepaling volgt dat een hogere boete, dan de maximum boete van $\$ 200.000$, kan worden opgelegd als de Administrator en de Attorney General (minister van justitie) tezamen beslissen dat een dergelijke (hogere) bestuurlijke boete in de concrete zaak de meest geschikte sanctie is. Op dezelfde wijze kan overigens de verjaringstermijn worden opgerekt, hetgeen impliceert dat nog beboet kan worden terwijl het feit 'verjaard' is. Nog meer in het oog springt dat deze beide beslissingen van de Administrator en de Attorney General niet door de rechter getoetst kunnen worden.

\section{Functiescheiding}

Vervolgens is het van belang dat er een functiescheiding is in die zin dat de ambtenaar die de te beboeten overtreding heeft geconstateerd niet zelf de boete oplegt. Dit ter compensatie van het ontbreken van een onafhankelijke rechter die (in eerste instantie) de sanctie oplegt. ${ }^{22}$ Uit de twee hiervoor weergegeven boeteregelingen blijkt niet dat er sprake is van een dergelijke functiescheiding.

\section{Zwijgrecht en cautie}

Ten vierde dient de handhavingsambtenaar van het bestuursorgaan de vermoedelijke overtreder, ten aanzien waarvan het voomemen bestaat een bestuurlijke boete op te leggen, in verband met de cautieplicht, te wijzen op zijn zwijgrecht. In de twee Amerikaanse boeteregelingen is geen bepaling opgenomen waaruit blijkt dat het zwijgrecht en de cautieplicht in acht dienen te worden genomen. ${ }^{23}$ Ook aan deze essentiële straf(proces)rechtelijke waarborg is derhalve niet voldaan in de twee hierboven weergegeven boeteregelingen.

\section{Huorplicht in de primaire fase}

Voorts lijkt het, met het oog op de onschuldpresumptie, gerechtvaardigd de eis te stellen dat de overtreder door het bestuursorgaan wordt gehoord voordat de boete wordi opgelegd. Indien de overtreder de ter plaatse gesproken taal onvoldoende beheerst zou er bovendien een tolk aangewezen moeten worden.

Zoals bekend ziet de commissie Scheltema, in het kader van de Nederlandse boeteregeling, in ieder geval voor wat de lagere boeten betreft, bij voorkeur af van een hoorplicht in de primaire fase. In de Verenigde Staten lijkt dat anders te zijn. Zowel in de Clean Air Act (42 U.S.C. 7413) als in de Marine Protection, Research, and Sanctuaries Act (33 U.S.C. 1415) is er immers sprake van een hoorplicht in de primaire fase. Zoals reeds is aangegeven wordt in de Clean Air Act onderscheid gemaakt tussen 'minor violations' (te sanctioneren middels een 'field citation') en zwaardere overtredingen. De zwaardere overtredingen worden gesanctioneerd met een veel hogere boete. Dit ver-

22. Vil. CTW-rapport a.w. 1994, p. 49.

23 In hoofdstuk $7 \mathrm{zal} \mathrm{nog} \mathrm{worden} \mathrm{ingegaan} \mathrm{op} \mathrm{de} \mathrm{vraag} \mathrm{of} \mathrm{de} \mathrm{vermoedelijke} \mathrm{overtreder,} \mathrm{ten} \mathrm{aanzien}$ waarvan een ambtenaar van een agency voomemens is een bestuurlijke boete op te leggen, zich kan beroepen op het zwijgrecht zoals dat is weergegeven in het vijfde amendement van de Amerikianse Grondwet. Of de waarborgen uit het vijfde en zesde amendement bij de oplegging van bestuurlijke boeten van toepassing zijn hangt af van de vraag of een bestuurlijke boete door het Supreme Court aangemerkt wordt als 'punishment'. Zoals reeds aangegeven komt deze materie in hoofdstuk 7 nog uitvoerig aaun de orde. 
klaart waarom voor de laatstgenoemde overtredingen de hoorprocedure moet voldoen aan de eisen die voortvloeien uit sectie 554 en sectie 556 van de APA (de 'formal adjudication procedure') terwijl deze bepalingen ten aanzien van de 'minor violations' niet gelden. ${ }^{24}$

In de Marine Protection, Research, and Sanctuaries Act wordt slechts aangegeven dat de overtreder gehoord moet worden voordat de boete wordt opgelegd. Welke procedure daarbij door het EPA moet worden gevolgd blijkt niet uit de redactie van de boeteregeling. Op basis van het voorgaande kan geconcludeerd worden dat aan de eis, dat de overtreder door het bestuursorgaan moet worden gehoord voordat de boete wordt opgelegd, is voldaan in beide Amerikaanse boeteregelingen. Bijstand van een tolk is niet aan de orde in de Amerikaanse regelingen.

\section{Inkennisstelling van de gronden waarop de beschuldiging berust in een begrijpelijke taal}

De zesde eis die kan worden gesteld aan de oplegging van een bestuurlijke boete betreft de onverwijlde inkennisstelling van de aard en de reden van een tegen een persoon ingebrachte beschuldiging in een voor de overtreder begrijpelijke taal.

In de twee Amerikaanse boeteregelingen wordt enkel gesproken van een kennisgeving waarin wordt aangegeven dat de Administrator voomemens is een bestuurlijke boete op te leggen. Dat deze kennisgeving ook een motivering voor het opleggen van de boete moet bevatten blijkt niet uit de redactie van de twee boeteregelingen. Een 'begrijpelijke taal-clausule' ontbreekt eveneens in de Amerikaanse regelingen. Aan de zesde eis uit hoofdstuk twee wordt derhalve zeer marginaal voldaan in de Clean Air Act en de Marine Protection, Research, and Sanctuaries Act.

\section{Schorsende werking van bezwaar en beroep}

In het kader van de onschuldpresumptie verdient het voorts de voorkeur als in de boeteregeling voorzien is in de schorsende werking van bezwaar en beroep. In de Clean Air Act wordt voldaan aan deze eis. Het voorgaande blijkt uit sectie 113(d)(5) CAA. In de Marine Protection, Research, and Sanctuaries Act wordt niet aangegeven of er sprake is van schorsende werking tijdens bezwaar en beroep. Er wordt overigens in de regeling in het geheel niet aangegeven of er nog een bezwaar of beroepsmogelijkheid is. Dit zal dus moeten worden afgeleid uit de 'Consolidated Rules of Practice Governing the Administrative Assessment of Civil Penalties and the Revocation Termination or Suspension of Permits' eventueel gelezen in samenhang met de bepalingen uit de APA (indien die van toepassing zijn). ${ }^{25}$ Derhalve kan gesteld worden dat vooralsnog alleen de boeteregeling uit de Clean Air Act voldoet aan het vereiste van schorsende werking van bezwaar en beroep.

24 In sectie 113(d)(3) van de CAA is ten aanzien van de 'minor violations' immers het volgende is bepaald; '... Such hearing shall not be subject to section 554 or 556 of title 5 , but shall provide a reasonable opportunity to be heard and to present evidence.'

25 Later in dit hoofdstuk zal hierop overigens nog uitvoeriger worden teruggekomen. 


\section{Recht op rechtspraak in twee instanties}

Met het oog op de rechtsbescherming van de vermoedelijke overtreder is vervolgens vereist dat er een recht bestaat op rechtspraak in twee (feitelijke) instanties voor degene aan wie de bestuurlijke boete door het bestuursorgaan wordt opgelegd.

Uit sectie 113(d)(4) van de Clean Air Act (42 U.S.C. 7413(d)) blijkt dat oplegging van de bestuurlijke boete door het EPA getoetst kan worden door het District Court. De uitspraak van het District Court kan vervolgens worden aangevochten bij een Court of Appeals. Er is in het kader van de CAA derhalve sprake van recht op rechtspraak in twee instanties. Opmerking verdient wel dat het District Court zich in veel (zo niet alle) gevallen geen eigen oordeel vormt omtrent de feiten. ${ }^{26}$ Ditzelfde geldt voor het Court of Appeals.

In de Marine Protection, Research, and Sanctuaries Act wordt helemaal niets gezegd over rechterlijke herziening van het boetebesluit van de EPA. Dit zal derhalve wederom moeten worden afgeleid uit de 'Consolidated Rules of Practice Governing the Administrative Assessment of Civil Penalties and the Revocation/Termination or Suspension of Permits'. Mocht in de Rules of Practice niets geregeld zijn dan is wellicht de vangnetbepaling uit sectie 703 van de APA van toepassing. Toepasselijkheid van genoemde bepaling op de boetebesluiten in het kader van de Marine Protection, Research, and Sanctuaries Act brengt met zich dat oplegging van de bestuurlijke boete getoetst kan worden door het District Court. De uitspraak van het District Court kan vervolgens worden aangevocitten bij een Court of Appeals.

Beide boeteregelingen lijken (vooralsnog) dan ook niet te voldoen aan het vereiste van rechtspraak in twee feitelijke instanties.

\section{Onschuldpresumptie}

Zeer wezenlijk in het kader van het straf(proces)recht is de onschuldpresumptie. ${ }^{27}$ Hieruit vloeit onder andere voort dat de bewijslast, in een procedure tot oplegging van een bestuurlijke boete, in beginsel op het bestuur rust. In beide Amerikaanse boeteregelingen is niet met zoveel woorden aangegeven dat de bewijslast op het bestuursorgaan rust of dat anderszins sprake is van het in acht nemen van de onschuldpresumptie. Hier zal derhalve vooralsnog verondersteld worden dat in beide Amerikaanse regelingen niet aan de onschuldpresumptie is voldaan.

\section{Opbrengst boete:}

De tiende eis houdt in dat uitdrukkelijk in de wet moet worden geregeld aan wie de opbrengst van de opgelegde bestuurlijke boete toekomt. In de beide hierboven weergegeven Amerikaanse boeteregelingen is niet weergegeven aan wie de opbrengst van de opgelegde boeten toekomt. In beide regelingen wordt echter de minister van justitie (Attomey General) bevoegd verklaard een civiele procedure te starten indien opgelegde bestuurlijke boeten niet voldaan worden. Of normaal gesproken echter de opbrengst toekomt aan het EPA of aan een andere instantie die deel uit maakt van de federale overheid is niet duidelijk.

27 Zie m.b.t. de onschuldpresumptie voorts hoofdstuk 3 en 4 van dit boek. 
Zowel de Clean Air Act als de Marine Protection, Research, and Sanctuaries Act voldoen in dit opzicht dan ook niet aan het tiende vereiste uit hoofdstuk twee.

\section{Verjaringstermijn in de wettelijke regeling}

Tenslotte volgt de laatste eis. Deze houdt in dat er een verjaringstermijn dient te zijn opgenomen in de boeteregeling. Aan deze eis is alleen, en dan ook nog slechts tot op zekere hoogte, voldaan in de Clean Air Act. ${ }^{28}$ Slechts indien de beweerdelijke ingangsdatum van de overtreding niet meer dan twaalf maanden terug ligt mag de Administrator een bestuurlijke boete opleggen. De Administrator kan, zoals hiervoor reeds is aangegeven, echter samen met de minister van justitie besluiten dat ten aanzien van een overtreding die langer dan een jaar geleden voor het eerst heeft pluars gevonden een bestuurlijke boete moet worden opgelegd. Zoals gezegd kan in dat kader de vraag gesteld worden in hoeverre een dergelijke gang van zaken in overeenstemming is met het lex certa-beginsel.

Le voorgaande analyse leidt tot het volgende schematische overzicht: 


\begin{tabular}{|c|c|c|c|}
\hline & WAARBORG & $\begin{array}{l}\text { Clean Air Act } \\
\text { (42 U.S.C. 7413) }\end{array}$ & $\begin{array}{c}\text { Marine Protection, } \\
\text { Research, and Sanctu- } \\
\text { aries Act } \\
\text { (33 U.S.C. 1415) }\end{array}$ \\
\hline 1 & $\begin{array}{l}\text { Uitsluiten van het straf- } \\
\text { recht of inachtnemen } \\
\text { una via-beginsel en } \\
\text { toepasselijkheid ne bis } \\
\text { in idem-beginsel }\end{array}$ & NIET VOLDAAN & NIET VOLDAAN \\
\hline 2 & $\begin{array}{l}\text { De maximum boete is } \\
\text { vastgelegd in de wet } \\
\text { (legaliteitsbeginsel) }\end{array}$ & (DEELS) VOLDAAN & VOLDAAN \\
\hline 3 & $\begin{array}{l}\text { Functiescheiding tussen } \\
\text { constateerder van de } \\
\text { overtreding en boeteop- } \\
\text { legger }\end{array}$ & NIET VOLDAAN & NIET VOLDAAN \\
\hline 4 & $\begin{array}{l}\text { Zwijgrecht en cautie- } \\
\text { plicht }\end{array}$ & NIET VOLDAAN & NIET VOLDAAN \\
\hline 5 & $\begin{array}{l}\text { Hoorplicht in de primai- } \\
\text { re fase + assistentie tolk }\end{array}$ & $\begin{array}{l}\text { VOLDAAN (wat betreft } \\
\text { de hoorplicht) }\end{array}$ & $\begin{array}{l}\text { VOLDAAN (wat betreft } \\
\text { de hoorplicht) }\end{array}$ \\
\hline 6 & $\begin{array}{l}\text { Inkennisstelling van de } \\
\text { gronden waarop de } \\
\text { beschuldiging berust in } \\
\text { begrijpelijke taal }\end{array}$ & $\begin{array}{l}\text { MARGINAAL VOL- } \\
\text { DAAN }\end{array}$ & $\begin{array}{l}\text { MARGINAAL VOL- } \\
\text { DAAN }\end{array}$ \\
\hline 7 & $\begin{array}{l}\text { Schorsende werking van } \\
\text { "bezwaar" en beroep }\end{array}$ & VOLDAAN & NIET VOLDAAN \\
\hline 8 & $\begin{array}{l}\text { Recht op rechtspraak in } \\
\text { twee (feitelijke) instan- } \\
\text { ties }\end{array}$ & $\begin{array}{l}\text { NIET VOLDAAN (w.b. } \\
\text { feitelijke instantie) }\end{array}$ & NIET VOLDAAN \\
\hline 9 & De onschuldpresumptie & NIET VOLDAAN & NIET VOLDAAN \\
\hline 10 & $\begin{array}{l}\text { Vastleggen in de wet } \\
\text { aan wie de opbrengst } \\
\text { van de boete toekomt }\end{array}$ & NIET VOLDAAN & NIET VOLDAAN \\
\hline 11 & $\begin{array}{l}\text { Opname van een verja- } \\
\text { ringstermijn in de wet- } \\
\text { telijke regeling }\end{array}$ & DEELS VOLDAAN & NIET VOLDAAN \\
\hline
\end{tabular}

$\mathrm{Na}$ bestudering van het hierboven weergegeven schema blijkt dat de boeteregeling uit de Clean Air Act slechts volledig aan twee van de elf genoemde waarborgen voldoet. 
Aan drie andere waarborgen wordt in zekere mate voldaan en aan zes waarborgen wordt in de boeteregeling van de Clean Air Act in het geheel niet voldaan. Ten aanzien van de Marine Protection, Research and Sanctuaries Act is het resultaat zelfs nog minder positief. Slechts aan één van de elf waarborgen is volledig voldaan. Aan twee andere waarborgen is tot op zekere hoogte voldaan en aan acht van de elf hierboven weergegeven waarborgen is in het geheel niet voldaan.

Zoals hiervoor echter al is opgemerkt dient na de bespreking van de 'Consolidated Rules of Practice Governing the Administrative Assessment of Civil Penalties and the Revocation/Termination or Suspension of Permits' (gelezen in samenhang met de APA) nogmaals beoordeeld worden of de oplegging van bestuurlijke boeten door het EPA voldoet aan de essentiële (straf(proces)rechtelijke) waarborgen.

\subsubsection{De 'Consolidated Rules of Practice Governing the Administrative Assessment of Civil Penalties and the Revocation/Termination or Suspension of Permits'}

$\mathrm{Na}$ de weergave van twee specifieke boeteregelingen volgt nu een globaal overzicht van procedurele regels die zijn neergelegd in de, door het EPA opgestelde, 'Consolidated Rules of Practice Governing the Administrative Assessment of Civil Penalties and the Revocation/Termination or Suspension of Permits' - de 'Rules of Practice' - (40 CFR 22) ${ }^{29}$ Het doel van de regeling - zo blijkt ook uit de titel van de regeling - bestaat uit het creëren van één uniforme procedure op grond waarvan de verschillende bestuurlijke boeten, uit de verschillende milieurechtelijke wetten, kunnen worden opgelegd.

De in de Rules of Practice neergelegde procedure voldoet aan de eisen uit sectie 554 en verder van de APA. Vreemd is dit niet nu in de wet in formele zin, die oplegging van een bestuurlijke boete mogelijk maakt, doorgaans wordt verlangd dat de 'formal adjudication procedure' uit de APA wordt gevolgd voordat het definitieve boetebesluit wordt genomen.

Het voorgaande geldt ook voor de Clean Air Act (42 U.S.C. 7413). In sectie 113(d)(2) CAA wordt immers aangegeven dat gehoord moet worden overeenkomstig de eisen die neergelegd zijn in sectie 554 en sectie 556 van de APA, voordat de definitieve boete opgelegd wordt. Met het oog op het voorgaande lijkt het derhalve noodzakelijk in de Rules of Practice aansluiting te zoeken bij de procedurele eisen uit sectie 554 en verder van de APA (de zogenaamde 'formal adjudication procedure'). Gezegd kan worden dat het EPA aan de, uit verschillende wetten voortvloeiende, bevoegdheid om, op basis van de 'formal adjudication procedure', bestuurlijke boeten op te leggen (een nadere) invulling heeft gegeven middels de Rules of Practice.

In dit hoofdstuk zullen slechts de meest relevante aspecten van de Rules of Practice aan de orde komen. Om een uitvoeriger en gedetailleerd beeld van de procedure tot opleg-

29 De volledige text van de 'Rules of Practice' is te raadplegen in appendix III en op de volgende intemet site: http:/www.access.gpo.gov/nara/cfr/index.html. Zoals reeds eerder is aangegeven is de regelgeving die een agency maakt evenzeer verbindend als de wetten die door het Congres worden uitgevaardigd. De rules van een agency zijn daarbij uiteraard wel ondergeschikt aan de 'formele' wetgeving van het Congres. Het voorgaande geldt ook voor de Rules of Practice. 
ging van de bestuurlijke boete te krijgen is het noodzakelijk de volledige regeling uit appendix III te bestuderen. ${ }^{30}$

\section{ROP algemeen}

Voordat in de Rules of Practice de boeteprocedure nader uitgewerkt wordt volgen er nog enkele algemene bepalingen. Daarmee wordt het toepassingsbereik van de regeling nader afgebakend. Voorts is er een nadere regeling getroffen in het kader van de uitoefening van de bevoegdheid tot het opleggen van bestuurlijke boeten.

De Rules of Practice worden, in sectie 22.01 van de Rules of Practice, onder andere van toepassing verklaard op de boeteregeling uit de Clean Air Act zoals weergegeven in 42 U.S.C. 7413(d)(1) en op de boeteregeling uit de Marine Protection, Research and Sanctuaries Act (33 U.S.C. 1415(a)). Hieruit kan worden afgeleid dat ten aanzien van de oplegging van de boete uit de Marine Protection, Research and Sanctuaries Act (in ieder geval indirect) de formal adjudication procedure uit de APA van toepassing is (dit volgde immers niet rechtstreeks uit de wet in zelf ${ }^{31}$ ).

$\mathrm{Na}$ de algemene bepalingen, zoals neergelegd in sectie 22.1 tot en met 22.9 van de Rules of Practice, volgt de procedure die op grond van de Rules of Practice gevolgd moet worden bij oplegging van de bestuurlijke boete. De eerste fase die in de Rules of Practice wordt beschreven bestaat uit de zogenaamde 'Prehearing Procedure'.

\section{Prehearing procedure}

Subonderdeel C betreft de 'Prehearing Procedure'. De procedure vangt aan met het uitvaardigen van een aanklacht ('complaint'). Uitvaardiging van een dergelijke complaint vindt plaats, op grond van sectie 22.13 van de Rules of Practice, als de aanklager ('complainant') ${ }^{32}$, die namens het EPA handelt, het vermoeden heeft dat een (rechts)persoon een wetsbepaling of een op de wet gebaseerde regel heeft overtreden. ${ }^{33}$ Een aanklacht die ten doel heeft een bestuurlijke boete op te leggen dient aan de in sectie 22.14 van de Rules of Practice vermelde eisen te voldoen. Er worden in die bepaling acht eisen gesteld aangaande de inhoud van een aanklacht. Op de belangrijkste eisen zal hierna - beknopt - ingegaan worden.

Ten eerste dient in de aanklacht de wettelijke basis voor het opleggen van de bestuurlijke boete te worden opgenomen. Vervolgens dienen de wetsbepalingen en daarop gebaseerde regels, ten aanzien waarvan verondersteld wordt dat die door de (rechts)persoon zijn overtreden, te worden vermeld. Ten derde dient in de complaint een weergave te zijn opgenomen van de feiten die tot de conclusie leiden dat er een overtreding heeft plaatsgevonden. Ook moet de hoogte van de op te leggen bestuurlijke boete zijn vermeld. Voorts dient te worden gemotiveerd waarom het wenselijk is een dergelijke boete, ter hoogte van een bepaald bedrag, op te leggen. Als nog geen specifiek boete-

30 In dit hoofdstuk wordt de oplegging van de bestuurlijke boete beschreven zoals deze plaatsvindt ten aanzien van éen (rechts)persoon zonder dat er derdenbelanghebbenden bij betrokken zijn. Ook zal niet. worden ingegaan op de mogelijkheid om allerlei moties in te dienen en om tussenvonnissen uit te lok. ken.

$31 \mathrm{Vgl} \$ 6.2 .1$ van dit hoofdstuk.

32 Zie voor omschrijving van de term complainant sectie 22.03 'Defenitions' van de Rules of Practice.

33 Vermelde 2 swaardig is overigens dat in de voomoemde bepaling de mogelijkheid wordt geschapen om naast het (tijdelijk) intrekken van een vergunning een bestuurlijke boete op te leggen. 
bedrag wordt genoemd in de aanklacht moet het aantal overtredingen waarvoor een boete zal worden opgelegd worden vermeld. In dit laatste geval moet daarnaast nog ten aanzien van iedere afzonderlijke overtreding iets gezegd worden over de ernst van de overtreding. Bovendien dient per overtreding de wettelijke grondslag tot het opleggen van de boete te worden vermeld. Tenslotte moet in de aanklacht vermeld worden dat de (rechts)persoon tot wie de aanklacht is gericht het recht heeft een verzoek in te dienen om gehoord te worden ten aanzien van het voornemen een bestuurlijke boete op te leggen. ${ }^{34}$

Opmerking verdient nog dat de aanklager, blijkens sectie 22.03 van de Rules of Practice, geen lid mag zijn van de Environmental Appeals Board. Hij mag ook geen Regional Judicial Officer zijn of op een andere wijze invloed hebben op het definitieve boetebesluit (hiermee lijkt in de Rules of Practice invulling te worden gegeven aan een functiescheiding tussen de 'ambtenaar' die de overtreding constateert en 'vervolgt' en de ambtelijke instantie die belast is met het opleggen van de (definitieve) bestuurlijke boete ${ }^{35}$ ).

De (rechts)persoon tot wie de aanklacht is gericht dient, op grond van sectie 22.15 van de Rules of Practice, binnen dertig (30) dagen na betekening van de aanklacht gemotiveerd te reageren als hij het voomemen om een boete op te leggen wil aanvechten. ${ }^{36}$ Deze reactie op de aanklacht moet ingediend worden bij de Regional Hearing Clerk. Tevens moet de respondent aangeven of hij gebruik wenst te maken van zijn recht om gehoord te worden. ${ }^{37}$

Voordat de daadwerkelijke boeteprocedure een aanvang neemt wordt er tijdens de zogenaamde 'prehearing'-fase (sectie 22.19) informatie en bewijs verzameld door de Presiding Officer. Alle voor de zaak relevante documenten en bewijsmiddelen moeten reeds in deze fase overlegd worden. Gebeurt dit niet, of pas in een later stadium, dan kunnen de documenten en bewijsmiddelen (in beginsel ${ }^{38}$ ) niet meer meegenomen worden in het kader van de boeteprocedure. Daarnaast moeten de getuigen reeds genoemd worden. Getuigen die tijdens de prehearing-fase niet zijn aangemeld mogen niet getuigen tijdens de boeteprocedure. Tegelijkertijd, of nadat alle stukken binnen zijn, maar in ieder geval vóórdat de daadwerkelijke boeteprocedure een aanvang neemt, kan de Pre-

34 Een dergelijke uitvaardiging van een complaint wordt tevens gezien als een kennisgeving (notice) welke op basis van de Clean Air Act (42 U.S.C. 7413(d)(1)) nodig is. Dit blijkt uit sectie 22.34 van de Rules of Practice.

35 Vgl. G. Harwood, Hearings Before an EPA Administrative Law Judge, Environmental Law Reporter, 17 ELR 10441, 1987, p. 10441-10444, p. 10441 (i.h.b. voetnoot 2).

36 Uit sectie 22.15(d) blijkt overigens dat, ten aanzien van die feiten uit de complaint, waar de respondent niet op ingaat, wordt veronderstelt dat hij deze erkent.

37 Als er niet binnen dertig dagen is geantwoord op de aanklacht kan de aanklager een verzoek indienen tot het nemen van een besluit tot ingebrekestelling vanwege de niet tijdige reactie op de klacht (a motion for a default order upon faillure to file a timely answer). Dit blijkt uit sectie 22.17 van de Rules of Practice. Ingebrekestelling heeft voor de respondent tot gevolg dat hij daarmee alle feiten uit de complaint erkend en afstand doet van zijn recht om gehoord te worden over die (aldus vastgestelde) feiten. De in de aanklacht voorgestelde boete is dan verschuldigd en moet worden betaald, zonder verdere procedure, dertig (30) dagen na het definitieve besluit tot ingebrekestelling.

Op grond van sectie 22.16(b) heeft de respondent overigens wél de mogelijkheid zijn zienswijze kenbaar te maken ten aanzien van de 'motion for a default order upon faillure to file a timely answer'. Vgl. sectie 22.19(e)(1) waaruit volgt dat dergelijk bewijs in uitzonderlijke gevallen alsnog kan worden meegenomen in de boeteprocedure. 
siding Officer besluiten een 'prehearing conference' plaats te laten vinden. Deze (facultatieve) prehearing conference wordt gehouden onder leiding van de Presiding Officer, op grond van sectie 22.19 van de Rules of Practice. De prehearing conference heeff onder andere ten doel de officiële hoorzitting spoedig te laten verlopen. Daamaast kan de prehearing conference gebruikt worden om tot een schikking te komen. De prehearing conference vormt het sluitstuk van de prehearing procedure. ${ }^{39}$

\section{Hearing Procedure}

In subpart $\mathrm{D}$ van de Rules of Practice zijn de regels met betrekking tot de hoorzitting neergelegd. Vooraf dient nog te worden opgemerkt dat een hoorzitting wordt voorgezeten door een 'Presiding Officer'. Doorgaans wordt de functie van Presiding Officer vervult door een Administrative Law Judge. ${ }^{40}$ De Administrative Law Judge is, anders dan zijn naam misschien doet vermoeden, géén rechter in de zin van artikel III van de Amerikaanse Grondwet maar een ambtenaar van het EPA.

In sectie 22.04(c) van de Rules of Practice wordt de wijze waarop de Presiding Officer de procedure dient te leiden weergegeven. Tevens zijn in die bepaling de bevoegdheden die hem in dat kader toekomen opgenomen. Belangrijk is bijvoorbeeld de bevoegdheid om te oordelen over feitelijke kwesties, rechtsvragen en bevoegdheidskwesties (sectie 22.04(c)(7)). ${ }^{41}$

Uit voomoemde sectie 22.04(c) blijkt dat de Presiding Officer het proces op een eerlijke en onpartijdige manier moet leiden. ${ }^{42} \mathrm{Hij}$ moet zich er van vergewissen dat alle feiten volledig aan het licht komen, hij moet ten aanzien van alle geschilpunten een besluit nemen, en vertragingen in de procedure vermijden.

Na deze korte weergave van de wijze waarop van de Presiding Officer het proces (in essentie) moet leiden, en de bevoegdheden waarover hij in dat kader beschikt, zal nu worden ingegaan op de hoorprocedure zoals deze is geregeld in Subpart D van de Rules of Practice.

De 'Regional Hearing Clerk' dient de, bij hem binnengekomen reactie op de aanklacht, eventueel aangevuld met nadere stukken waaronder de aanklacht, door te zenden naar de 'Chief Administrative Law Judge'. Vervolgens wijst laatstgenoemde zichzelf, of een andere Administrative Law Judge, aan om in de aangebrachte zaak als Presiding Offcer op te treden. De Administrative Law Judge die de zaak toegewezen krijgt moet de partijen daarvan in kennis stellen (sectie 22.21(a) van de Rules of Practice). Tevens dient de Presiding Officer, op grond van sectie 22.21(b), aan te geven wanneer en waar de hoorzitting plaats zal vinden.

In sectie 22.22 is vervolgens een uitvoerige regeling omtrent de bewijsvoering tijdens de hoorzitting opgenomen. Voor de volledige inhoud daarvan verwijs ik naar appendix III.

In feite vindt deze prehearing procedure plaats nadas toepassing is gegeven aan sectie 22.21 uit subpart $D$ van de Rules of Practice.

40 Zie sectie 3105 van de APA (5 U.S.C. 3105) 'Appointment of administrative law judges'.

41 Voor de overige bevoegheden verwijs ik naar sectie 22.04(c) uit appendix 1II.

42 Zie m.b.t. de onpartijdigheid en onafhankelijkheid van de Administrative Law Judge: Harwood aw 1987 , p. 10441 (i.h.b. voutnoot 2). 
In de context van dit onderzoek is met name van belang dat partijen het recht hebben de door de wederpartij meegebrachte getuigen te (ver)horen. Voorts is sectie 22.24 van belang waarin wordt aangegeven dat als hoofdregel geldt dat de aanklager - in de regel een ambtenaar van het EPA - dient te bewijzen dat de overtreding heeft plaats gevonden en dat de op te leggen bestuurlijke boete als sanctie geëigend is.

Van de hoorzitting dient een proces-verbaal te worden opgemaakt, zo blijkt uit sectie 22.25. Op het moment dat het proces-verbaal gereed is dienen de partijen in kennis gesteld te worden van het feit dat het proces-verbaal beschikbaar is. Partijen kunnen binnen dertig (30) dagen na ontvangst van het proces-verbaal, of binnen vijfenveertig (45) dagen na kennisgeving van het feit dat het proces-verbaal beschikbaar is middels een 'motion' correcties aanbrengen in de tekst van het proces-verbaal zodat in het proces-verbaal de daadwerkelijke verklaringen, zoals afgelegd ter zitting, zijn opgenomen. Partijen kunnen daarnaast, op grond van sectie 22.26, bij de Presiding Officer, met het oog op het proces-verbaal, voorstellen doen ten aanzien van de inhoud primaire besluit. Genoemde voorstellen kunnen in het bijzonder betrekking hebben op vast te stellen feiten, de beantwoording van rechtsvragen en de inhoud van het primaire besluit. De Presiding Officer betrekt deze voorstellen in zijn overwegingen. Feitelijk wordt in de Rules of Practice hiermee de hoorprocedure afgesloten. Vervolgens komt in Subpart E van de Rules of Practice het primaire besluit en het verzoek tot heropening van de hoorzitting aan de orde.

Primaire besluit - verzoek tot heropening van de hoorzitting -

Het primaire besluit wordt door de Presiding Officer genomen. Dit blijkt uit sectie 22.27(a) van de Rules of Practice. De Presiding Officer moet in het primaire besluit alle vastgestelde feiten weergeven, daarnaast moet hij in het besluit gemotiveerde conclusies opnemen aangaande alle wezenlijke rechtsvragen en bevoegdheidskwesties. Ook moet de Presiding Officer in het primaire besluit een voorstel doen over de op te leggen bestuurlijke boete, en tenslotte moet hij een definitief besluit presenteren.

Bij het bepalen van de hoogte van de voorgestelde bestuurlijke boete moet de Presiding Officer rekening houden met de criteria die daarvoor in de wet, en daanit voortvloeiende regelgeving, zijn opgenomen. Als de Presiding Officer besluit een bestuurlijke boete op te leggen die van een andere hoogte is dan de door de aanklager voorgestelde bestuurlijke boete moet hij in het primaire besluit motiveren waarom hij de boete heeft verhoogd of verlaagd. Het voorgaande is geregeld in sectie 22.27(b) van de Rules of Practice.

Daarbij moet wel worden opgemerkt dat de Presiding Officer de boete slechts mag verhogen voor zover het niet gaat om een boete die is opgelegd na een ingebrekestelling van de gedaagde partij (omdat deze bijvoorbeeld te laat was met het indienen van stukken). Een boete die na ingebrekestelling wordt opgelegd mag niet hoger zijn dan de door de aanklager voorgestelde boete.

De Regional Hearing Clerk moet een afschrift van het primaire besluit doen toekomen aan de Environmental Appeals Board en de Assistant Administrator for the Office of Enforcement and Compliance Assurance (sectie 22.27(a) van de Rules of Practice). 
Het primaire besluit van de Presiding Officer krijgt, vijfenveertig (45) dagen nadat het besluit is betekend aan de partijen, op grond van sectie 22.27(c) van de Rules of Practice, zonder verdere procedurele handelingen, formele rechtskracht en wordt daarmee het definitieve besluit van de Environmental Appeals Board. Als de 'initial decision' na vijfenveertig dagen formele rechtskracht krijgt wordt genoemd besluit daarmee de 'final order' (het definitieve angency-besluit) op grond van sectie 22.31(a) van de Rules of Practice.

Er is echter een aantal gevallen waarin de initial decision vijfenveertig dagen na de bekendmaking géén formele rechtskracht krijgt. Dit is ten eerste het geval als een van de partijen binnen vijfenveertig dagen een verzoek indient tot heropening van de zaak of (ten tweede) als een van de partijen tegen het primaire besluit in beroep is gegaan bij de Environmental Appeals Board. Daamaast kan het zo zijn dat een partij stappen heeft ondernomen om een default order (ingebrekestelling) ongedaan te maken terwijl de initial decision gebaseerd is op die default order. Tenslotte kan de Environmental Appeals Board zelf de wens te kennen geven om het primaire besluit het herzien. In deze vier situaties krijgt de initial decision géén formele rechtskracht na vijfenveertig dagen. Vermeldenswaardig is tenslotte dat uit sectie 22.27 (d) volgt dat een partij die niet bij de Environmental Appeals Board in 'beroep' gaat tegen de initial decision daarmee ook zijn recht op 'judicial review' verspeelt. Met het oog op de Nederlandse situatie is het bovendien nuttig te signaleren dat uit sectie 22.27 (d) volgt dat de initial decision niet definitief is en nog niet in werking treedt (schorsende werking) gedurende de 'beroepsprocedure' bij de Environmental Appeals Board.

In sectie 22.28 van de Rules of Practice is de mogelijkheid opgenomen om een verzoek in te dienen teneinde de hoorprocedure te heropenen na betekening van het primaire besluit. Een dergelijk verzoek wordt uiteraard slechts gehonoreerd in bepaalde uitzonderlijke gevallen. Voor de exacte regeling in dit kader wordt op deze plaats verwezen naar appendix III.

\section{Bestuurlijke heroverweging van het primaire besluit}

Zoals uit sectie 22.27(c) van de Rules of Practice reeds naar voren kwam bestaat voor de partijen de mogelijkheid om tegen het primaire besluit van de Presiding Officer 'in beroep' te gaan bij de Environmental Appeals Board. De 'beroepsprocedure' is geregeld in Subpart F ('Appeals and Administrative Review') van de Rules of Practice. In genoemd Subpart is ook een regeling getroffen met betrekking tot het instellen van 'beroep' tegen een tussenvonnis (sectie 22.29 van de Rules of Practice). Deze laatste regeling komt hier verder niet aan de orde. De tekst van die regeling is uiteraard te raadplegen in appendix III.

Wel van belang is de regeling uit sectie 22.30 van de Rules of Practice. Op grond van genoemde bepaling bestaat voor de partijen mogelijkheid om het primaire besluit aan te vechten (sectie 22.30(a) van de Rules of Practice). Indien een van de partijen het primaire besluit aan wil vechten moet deze partij binnen dertig (30) dagen na betekening van het primaire besluit een 'beroepschrift' indienen bij de Environmental Appeals Board. Voorts moet de appellant kopieën van het 'beroepschrift' en bepaalde andere stukken doen toekomen aan de griffier (clerk) van de Environmental Appeals Board, de 
Regional Hearing Clerk en de Presideng Officer. Tevens moet de partij de wederpartij en overige bij het geding betrokkenen een 'beroepschrift' doen toekomen. Binnen twintig (20) dagen na indiening van het beroepschrift mogen de wederpartij en de overige bij het geding betrokkenen eveneens een 'beroepschrift' en/óf een verweerschrift (response brief) indienen.

De beoordeling van de zaak vindt in beginsel plaats op basis van de ingediende schriftelijke stukken. Daarnaast kan de Environmental Appeals Board echter een mondelinge discussie met betrekking tot het beroep plannen (sectie 22.30(d) van de Rules of Practice). $\mathrm{Na}$ het beoordelen van het beroepschrift en het verweerschrift, en een eventuele mondelinge discussie, dient de Environmental Appeals Board vervolgens een definitief besluit ten aanzien van het beroep te nemen. De Environmental Appeals Board kan in het definitief 'besluit op beroep' gemotiveerd bevindingen en conclusies, uit het aangevochten primaire besluit, overnemen, wijzigen, of verwerpen..$^{43}$ De Environmental Appeals Board heeft voorts de bevoegdheid om de, op grond van het primaire besluit op te leggen, boete te verhogen of verlagen (voor zover het niet gaat om een boete die is opgelegd na een ingebrekestelling want deze mag - zoals hiervoor al is aangegeven niet verhoogd worden).

Naast de mogelijkheid voor de partijen om in 'beroep' te komen is in sectie 22.30(b), de mogelijkheid opgenomen voor de Environmental Appeals Board om op eigen initiatief over te gaan tot herziening van het primaire besluit. De Environmental Appeals Board moet de griffier van de Environmental Appeals Board, de Regional Hearing Clerk de Presiding Officer en de partijen van een dergelijk besluit in kennis stellen binnen vijfenveertig dagen na betekening van het primaire besluit. In de kennisgeving moet worden aangegeven ten aanzien van welke punten van partijen een schriftelijke zienswijze wordt verwacht. Voorts moet worden aangegeven binnen welke termijn de stukken ingediend moeten worden.

\section{Definitief besluit}

Het definitieve agency-besluit treedt in werking bij bekendmaking (sectie 22.31(b)). De final order vormt het sluitstuk van de (bestuursrechtelijke) procedure bij het agency. De final order staat echter, zo volgt uit sectie 22.31(a), niet in de weg aan de mogelijkheid van het agency om in rechte - civielrechtelijke dan wel strafrechtelijk - op te treden met betrekking tot overtredingen van een wettelijke regeling. Daarnaast ontheft de final order de overtreder niet van zijn verplichting zich conform de wettelijke regeling te gedragen.

In sectie 22.31(c) van de Rules of Practice is de betaling van de bestuurlijke boete geregeld. Het volledige bedrag van de opgelegde bestuurlijke boete moet door de (rechts)persoon betaald worden binnen dertig dagen na inwerkingtreding van het definitieve besluit tenzij omtrent de betaling iets anders is bepaald. Voorts is in genoemde sectie aangegeven dat betaling dient te geschieden door het sturen van een cheque (cashier's check or certified check) naar de persoon of instantie (payee) die is vermeld in de klacht (complaint). De beboete persoon moet tenslotte een kopie van de cheque doen toekomen aan de Regional Hearing Clerk. 
Uit sectie 22.32 van de Rules of Practice blijkt dat het vervolgens nog mogelijk is om binnen tien dagen na betekening van het definitieve besluit een verzoek in te dienen bij de Environmental Appeals Board om het definitieve besluit te heroverwegen. De verzoeker moet dan aantonen dat er fouten zijn gemaakt bij het nemen van het definitieve besluit. Het verzoek tot heroverweging schorst niet de werking van het definitieve agency-besluit (tenzij de Environmental Appeals Board anders bepaalt).

Tenslotte volgt op deze plaats nog een korte opmerking over de 'invordering' van de bestuurlijke boete. Nadat er een definitief besluit ligt van het agency waarbij aan een overtreder een bestuurlijke boete is opgelegd, is de overtreder verplicht de opgelegde boete te betalen. Laat de overtreder dit na dan kan de Administrator de Attorney General verzoeken om namens het agency, middels een 'civil action', in rechte betaling van het bedrag vorderen. ${ }^{44}$

Tot zover de weergave van de formele procedure die door het EPA gevolgd wordt bij de oplegging van een bestuurlijke boete. Naast deze 'formele procedure' is in sectie 22.18 een regeling getroffen met betrekking tot snelle afhandeling (quick resolution) van de procedure tot oplegging van een bestuurlijke boete, schikking van de zaak (settlement) en alternatieve wijzen van geschilbeslechting (alternative dispute resolution).

Snelle afhandeling van de zaak lijkt met name geschikt in het kader van de oplegging van bestuurlijke boeten. In feite komt het er, zo volgt uit sectie 22.18(a) van de Rules of Practice, op neer dat de aangeklaagde gewoon de in de klacht vastgestelde boete betaalt.

Een andere belangrijke 'informele wijze' waarop de boeteprocedure afgedaan kan worden is neergelegd in sectie 22.18(b) van de Rules of Practice. Op basis van die regeling kunnen de aangeklaagde en de aanklager tot een schikking komen wat betreft de op te leggen boete.

\section{Schikking}

Uit sectie 22.18(b) van de Rules of Practice blijkt dat partijen op ieder gewenst moment een poging mogen ondermemen om tot een schikking te komen. ${ }^{45}$ Het agency dient het treffen van een schikking zelfs te bevorderen.

In het kader van de schikking staat de instemmingsovereenkomst (consent agreement) centraal. Als partijen tot een instemmingsovereenkomst komen moeten zij deze overeenkomst in geschreven vorm, vergezeld van een voorstel voor een definitief agencybesluit (proposed final order), doen toekomen aan de Regional Judicial Officer, de Regional Administrator of de Environmental Appeals Board. ${ }^{46}$

In de instemmingsovereenkomst moet worden aangegeven dat de aangeklaagde de juridische bevoegdheid van de aanklager erkent. Daarnaast moet de aangeklaagde aangeven dat hij de feiten in de instemmingsovereenkomst erkent of dat hij de feiten die

44

45
Vgl. 113(d)(5) CAA. Zie voorts: Blomberg a.w. 2000, p. 241-242.

In het volgende deel van deze paragraaf, waarin het boetebeleid van het EPA wordt behandeld, zal nog uitvoeriger worden ingegaan op de schikkingsonderhandelingen en het rendement hiervan met het 008 op een filterende werking (d.w.z. voorkomen dat iedere (rechts)persoon die een bestuurlijke boete opgelegd krijgt gaat procederen).

Afhankelijk van de vraag wie ten aanzien van het concrete boetebesluit de bevoegde instantie is. 
zijn weergegeven in de aanklacht niet toegeeft maar ook niet ontkent. Bovendien moet uit de instemmingsovereenkomst blijken dat de aangeklaagde instemt met de vastgestelde bestuurlijke boete. In de instemmingsovereenkomst moeten ook alle, aan de schikking verbonden, voorwaarden zijn opgenomen. Ook met deze voorwaarden moet de aangeklaagde instemmen. Voorts moet de aangeklaagde afstand doen van zijn recht om in beroep te gaan tegen de voorgestelde final order die de instemmingsovereenkomst vergezelt. Tenslotte moet de overeenkomst getekend worden door de (gemachtigden van) partijen. Deze eisen zijn neergelegd in sectie 22.18(b)(2) van de Rules of Practice.

De Regional Judicial Officer, de Regional Administrator of de Environmental Appeals Board moet vervolgens, op grond van sectie 22.18(c) van de Rules of Practice, de instemmingsovereenkomst bekrachtigen middels een final order.

Het feit dat er onderhandeld wordt in het kader van de schikkingsregeling neemt overigens niet weg dat de aangeklaagde, op grond van sectie 22.15 van de Rules of Practice, tijdig een reactie ten aanzien van de complaint moet indienen, zo blijkt uit sectie 22.18(b)(1) van de Rules of Practice.

De betaling van de boete of een tot stand gekomen schikking staat echter, zo volgt uit sectie 22.18(c) van de Rules of Practice, niet in de weg aan de mogelijkheid van het agency om in rechte - civielrechtelijke dan wel strafrechtelijk - op te treden met betrekking tot overtredingen van een wettelijke regeling. De overtreder kan echter, vanwege de betaling van de boete of een tot stand gekomen schikking, niet meer middels federale 'civil penalties' gesanctioneerd worden voor de overtredingen en feiten die ten grondslag zijn gelegd aan de klacht.

Om een beter beeld te krijgen van de procedure tot oplegging van een bestuurlijke boete zoals die is neergelegd in de Rules of Practice volgt hierna een schematisch overzicht waarin per Subpart van de Rules of Practice aangegeven wordt welke handelingen door welke actor worden verricht en op basis van welke bepaling uit de Rules of Practice dit geschiedt. 
Subpart C: 'Prehearing procedure'

Actor

Aanklager
(complaint)

Aangeklaagde

(respondent)

Aanklager

Aangeklaagde

Presiding officer
Handeling

Bepaling RoP

22.13

(rechts)persoon bepaalde regelgeving heeft overtreden

- Aan de inhoud van de klacht worden een aantal eisen gesteld. Deze eisen houden verband met de motivering van het voomemen om een boete op te leggen en met

22.14 de motivering van de hoogte van de voorgestelde boete.

22.15

- De respondent moet aangeven of hij gebruik wil maken van zijn recht om gehoord te worden.

Reactie/Verweer

(Answer to the complaint)

- Binnen dertig dagen na betekening van de aanklacht dient de reactie te worden gezonden aan de Regional Hearing Clerk. 
Subpart D: 'Hearing procedure'

Actor

Regional Hearing

Clerk

Chief Administrative Law Judge

Administrative

Law Judge

Partijen

Presiding Officer

Reporter

Regional Hearing Clerk

Partijen
Handeling

Bepaling RoP

$22.21(\mathrm{a})$

Administrative Law Judge

22.21 (a)

tive Law Judge die zal optreden als Presiding Officer

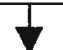

- Partijen in kennis stellen van de toewijzing van de zaak

- Aangeven waar en wanneer de hoorzitting zal plaatsvinden

$22.2 \mathrm{I}(\mathrm{b})$

$22.22 \mathrm{t} / \mathrm{m} 22.24$

22.25

- De reporter maakt het procesverbaal

- De Regional Hearing Clerk stelt de partijen in kennis van de beschikbaarheid van het procesverbaal

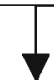

- Binnen dertig (30) dagen na ontvangst van het proces-verbaal, of vijfenveertig (45) dagen na kennisgeving van het geit dat het $\mathrm{p}-\mathrm{v}$ beschikbaar is middels een 'motion'correcties aanbrengen in de tekst van het $\mathrm{p}-\mathrm{v}$

- Partijen kunnen voorstellen doen aan de Presiding Officer m.b.t. feiten, rechtsvragen en de inhoud van het door de Presiding Officer te nemen primaire besluit 
Subpart E: 'Initial Decision (and Motion to Reopen a Hearing)'

Actor

Presiding Officer

Regional Hearing Clerk

Regional Hearing Clerk
Handeling

Bepaling RoP

\section{Primaire Besluit}

- Het besluit dient gemotiveerd te worden door de Presiding Officer - Het besluit moet ook een voorstel bevatten voor de op te leggen boete. De door de Presiding Officer voorgestelde bestuurlijke boete mag afwijken van de door de aanklager voorgestelde boete.

$22.27(\mathrm{a})$

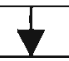

Toezenden aan partijen van het primaire besluit

- Vijfenveertig dagen na betekening van het primaire besluit aan partijen krijgt het besluit formele rechtskracht, tenzij een van de partijen:

(a) een verzoek indient tot heropening van de zaak

(b) tegen het besluit 'beroep' aan tekent, of

(c) stappen heeft ondernomen om een default order ongedaan te maken. Het primaire besluit krijgt eveneens geen formele rechtskracht als het Environmental Appeals Board zelf het besluit wil herzien.

22.27 (c)

22.27 (a) 
Subpart F: 'Appeals and Administrative Review'

Actor

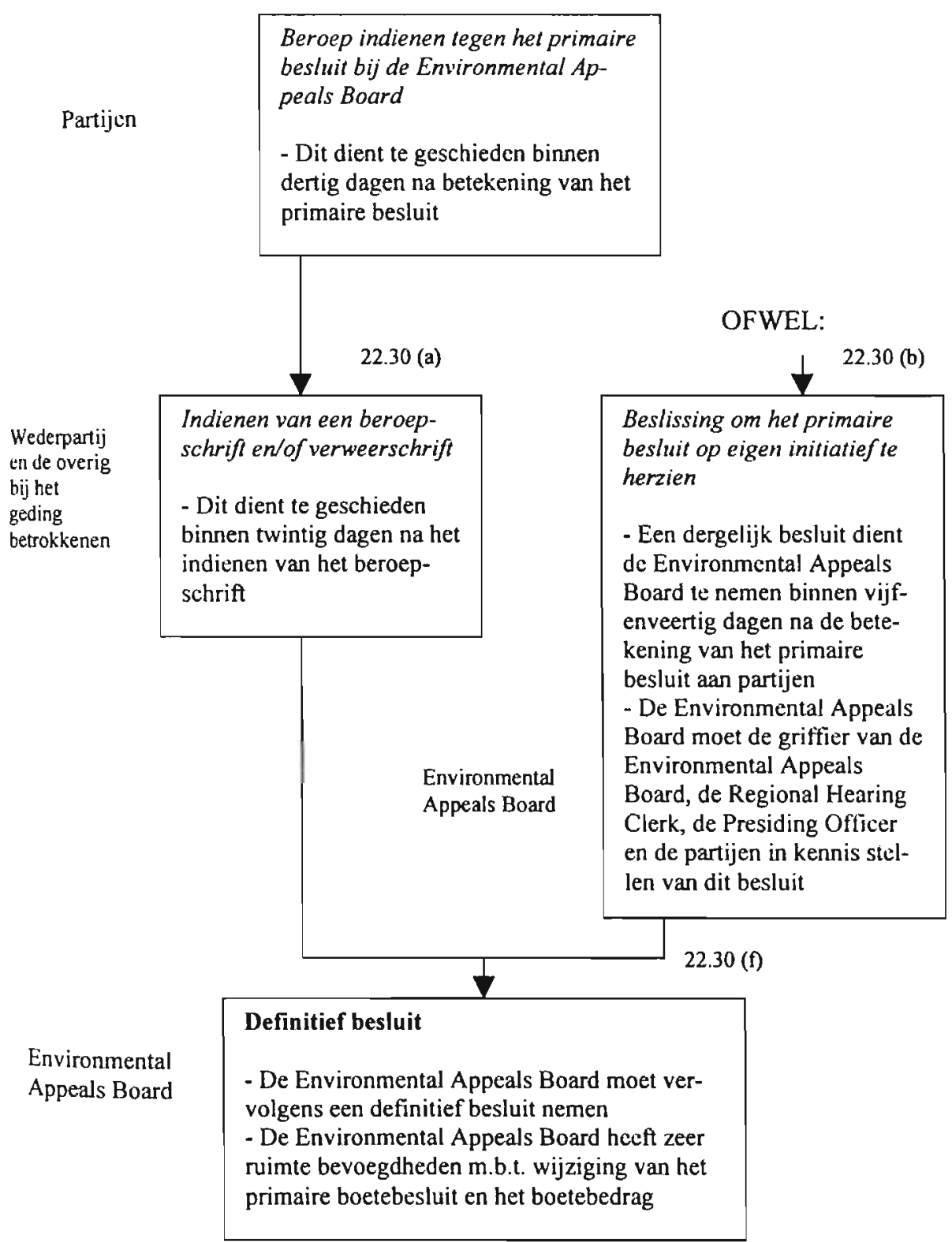




$$
\begin{aligned}
& \text { Betalen van de definitieve boete } \\
& \text { - Dit moet gebeuren binnen dertig } \\
& \text { dagen na inwerkingtreding van het } \\
& \text { definitieve besluit (het definitieve } \\
& \text { agency-besluit treedt in werking bij } \\
& \text { bekendmaking [sectie } 22.31 \text { (b)]) }
\end{aligned}
$$

\subsection{2.a De boeteregeling uit Rules of Practice in het kader van de straf(proces)- rechtelijke waarborgen}

\section{Algemeen}

$\mathrm{Na}$ dit schematische overzicht van de procedure zoals die is neergelegd in de Rules of Practice zal nu nog gekeken worden in hoeverre in de Rules of Practice bepalingen zijn opgenomen die, met het oog op de rechtsbescherming van de (vermoedelijke) overtreder, tegemoet komen aan de hiervoor weergegeven straf(proces)rechtelijke waarborgen. Bij toetsing van de boeteregelingen uit respectievelijk de Clean Air Act en de Marine Protection, Research and Sanctuaries Act is gebleken dat bij de boeteregeling uit de Clean Air Act slechts volledig invulling is gegeven aan twee van de elf, hiervoor weergegeven, waarborgen. Voorts is gebleken dat aan drie andere waarborgen in bepaalde mate invulling is gegeven en dat aan zes waarborgen in de boeteregeling van de Clean Air Act in het geheel geen aandacht is besteed.

Ten aanzien van de Marine Protection, Research and Sanctuaries Act is het resultaat zelfs nog minder positief is gebleken. Slechts aan én van de elf genoemde straf(proces)rechtelijke waarborgen is volledig invulling gegeven in genoemde regeling. Aan twee andere waarborgen is tot op zekere hoogte invulling gegeven en acht van de elf genoemde blijven geheel buiten beschouwing in de Marine Protection, Research and Sanctuaries Act. ${ }^{47}$

In deze subparagraaf gaat aandacht uit naar de vraag in hoeverre er door middel van de Rules of Practice alsnog invulling wordt gegeven aan bepaalde essentielle straf(proces)rechtelijke waarborgen. Ook ten aanzien van de Rules of Practice zullen hiervoor weer de in $\S 6.2 .1$.a aangehaalde (essentiële) straf(proces)rechtelijke waarborgen worden bekeken. Daarbij zal worden aangegeven in hoeverre bij de oplegging van 
bestuurlijke boeten door het EPA, gelet op de Rules of Practice, alsnog de straf(proces)rechtelijke waarborgen in acht moeten worden genomen.

\section{Uitsluiting strafrecht, una via-beginsel, ne bis in idem-beginsel}

Aan vereiste dat het strafrecht in de boeteregeling wordt uitgesloten is in de Rules of Practice geen invulling gegeven. Het is zelfs zo dat op grond van sectie 22.18(c) en sectie 22.31 (a) van de Rules of Practice een definitief boetebesluit, het betalen van de boete en een totstandgekomen schikking niet in de weg staan aan strafrechtelijke handhaving van overtredingen van de wet waarop ook het boetebesluit is gebaseerd. Hoewel de regeling in dat kader niet uitblinkt in helderheid ga ik er van uit dat men daarmee in de Rules of Practice (ook de) strafrechtelijke handhaving ten aanzien van dezelfde overtreding veilig heeft willen stellen.

Eerder in dit hoofdstuk is reeds geconcludeerd dat in de twee wetten in formele zin waarin de boeteregelingen zijn opgenomen het strafrecht niet wordt uitgesloten. Het voorgaande leidt tot de slotsom dat in de Verenigde Staten, in het kader van de oplegging van bestuurlijke boeten, geen regeling is getroffen waarbij strafrechtelijke sanctionering van dezelfde overtreding wordt uitgesloten. Zoals gezegd hoeft dit niet problematisch te zijn zolang er een voorziening is getroffen die dubbele bestraffing uitsluit. In dat kader dient er in ieder geval invulling gegeven te worden aan het una viabeginsel. Dat is in de Rules of Practice uitdrukkelijk niet gebeurd.

Ten aanzien van de eis dat het strafrecht in de boeteregeling moet zijn uitgesloten kan dus gezegd worden dat daaraan (ook) in de Rules of Practice niet is voldaan. Aan het una via-beginsel wordt voorts geen invulling gegeven. Een regeling met betrekking tot het ne bis in idem-beginsel is in de Rules of Practice bovendien ook niet opgenomen. Derhalve kan niet worden uitgesloten dat er door het EPA bestuurlijke boeten worden opgelegd in strijd met het una via-beginsel dan wel in strijd met het ne bis in idembeginsel.

\section{Maximum boete in de wet}

Ten tweede vloeit uit het legaliteitsbeginsel de eis voort dat in ieder geval de maximum boete moet zijn vastgelegd in de wet. Aan dit vereiste was reeds (in essentie ${ }^{48}$ ) voldaan in beide specifieke boeteregelingen. Dat de hoogte van de maximum boete is opgenomen in de bijzondere wet is uiteraard niet vreemd. De Rules of Practice zijn immers van toepassing op negen wetten in formele zin waarin uiteenlopende boeteregelingen zijn opgenomen ten aanzien van verschillende soorten overtredingen. Er kan meer maatwerk en rechtszekerheid worden geboden als per afzonderlijke regeling een maximum boetebedrag is opgenomen. Aan het vereiste dat de maximumboete is neergelegd in de wet was derhalve reeds (in essentie) voldaan in de beide afzonderlijke boeteregelingen. Daarbij dienen overigens niet de kritische kanttekeningen met betrekking tot de regeling uit de Clean Air Act uit het oog verloren te worden.

\section{Functiescheiding}

Vervolgens is in beginsel vereist dat er sprake is van een functiescheiding in die zin dat de ambtenaar die de te beboeten overtreding heeft geconstateerd niet zelf de boete

Vgl. de kritische kanttekeningen met betrekking tot de regeling uit de Clean Air Act. 
oplegt. Dit ter compensatie van het ontbreken van een onafhankelijke rechter die (in eerste instantie) de sanctie oplegt.

In tegenstelling tot de twee hiervoor onderzochte boeteregelingen, waarin niet werd voldaan aan dit vereiste, wordt in de Rules of Practice onmiskenbaar invulling gegeven aan dit derde vereiste. Op meerdere plaatsen in de Rules of Practice zijn bepalingen opgenomen die de functiescheiding beogen te garanderen. De eerste sectie uit de Rules of Practice waarin een bepaling omtrent functiescheiding is opgenomen is sectie 22.03 onder a. Ten aanzien van de aanklager (complainant) - doorgaans een ambtenaar in dienst van het EPA - wordt daar aangegeven dat deze niet lid mag zijn van de Environmental Appeals Board (die uiteindelijk de boete oplegt), dat hij voorts geen deel uit mag maken van de (organisatie van de) Regional Judicial Officer, en dat hij ook niet op enige andere wijze betrokken mag zijn bij de totstandkoming van het boetebesluit of advisering ten aanzien van het boetebesluit. Vervolgens is ook in sectie 22.04(b) nog een bepaling opgenomen die ten doel heeft de functiescheiding te garanderen. Voornoemde bepaling luidt:

'A Regional Judicial Officer shall not have performed prosecutorial or investigative functions in connection with any case in which he serves as a Regional Judicial Officer. A Regional Judicial Officer shall not knowingly preside over a case involving any party concerning whom the Regional Judicial Officer performed any functions of prosecution or investigation within the 2 years preceding the commencement of the case. A Regional Judicial Officer shall not prosecute enforcement cases and shall not be supervised by any person who supervises the prosecution of enforcement cases, but may be supervised by the Regional Counsel.'

Gelet op het voorgaande kan ten aanzien van het vereiste van functiescheiding gesteld worden dat daaraan is voldaan in de Rules of Practice.

\section{Zwijgrecht en cautie}

Ten vierde dient de handhavingsambtenaar van het bestuursorgaan de vermoedelijke overtreder, ten aanzien waarvan het voornemen bestaat een bestuurlijke boete op te leggen, te wijzen op zijn zwijgrecht. In de Rules of Practice komen het zwijgrecht en de cautieplicht niet aan de orde. Derhalve kan gesteld worden dat in de Rules of Practice, evenals in de twee hiervoor weergegeven boeteregelingen, aan deze straf(proces). rechtelijke waarborgen geen invulling is gegeven.

\section{Hoorplicht in de primaire fase}

Voorts lijkt het, zoals gezegd, met het oog op de onschuldpresumptie, gerechtvaardigd de eis te stellen dat de overtreder door het bestuursorgaan wordt gehoord voordat di boete wordt opgelegd. Indien de overtreder de ter plaatse gesproken taal onvoldoendi beheerst zou er bovendien een tolk aangewezen moeten worden.

In de hiervoor weergegeven boeteregelingen werd reeds aangegeven dat er een rech bestaat om gehoord te worden in de primaire fase. Middels de Rules of Practice is di hoorprocedure nader uitgewerkt. Op grond van sectie 22.14(a)(5) van de Rules 0 Practice moet de aanklager in zijn aanklacht aangeven dat de aangeklaagde het rech heeft om gehoord te worden in de primaire fase. De aangeklaagde moet, blijkens secti 22.15(b) van de Rules of Practice, in zijn reactie op de aanklacht, wel zelf aangeven 0 
hij gebruik wenst te maken van zijn recht om gehoord te worden. Omtrent bijstand door een tolk is in de Rules of Practice niets geregeld. Ten aanzien van de vijfde eis blijft de situatie dus hetzelfde als na de bestudering van de twee Amerikaanse boeteregelingen. De aangeklaagde heeft een recht om gehoord te worden in de primaire fase van de procedure tot oplegging van een bestuurlijke boete. Omtrent bijstand door een tolk is echter niets geregeld.

\section{Inkennisstelling van de gronden waarop de beschuldiging berust in een begrijpelijke taal}

De zesde eis die kan worden gesteld aan de procedure tot oplegging van een bestuurlijke boete betreft de onverwijlde inkennisstelling van de aard en de redenen van een tegen een persoon ingebrachte beschuldiging in een voor de overtreder begrijpelijke taal.

In de beide Amerikaanse boeteregelingen werd reeds aangegeven dat de Administrator in een kennisgeving aan moet geven dat hij voornemens is een bestuurlijke boete op te (laten) leggen. Omtrent een motivering van het voornemen om een bestuurlijke boete op te leggen werd in de boeteregelingen niets vermeld. Dit laatste wordt opgevangen in de Rules of Practice. Daar wordt, in sectie 22.14, immers aangegeven op welke wijze een aanklacht inhoudelijk moet worden vormgegeven. ${ }^{49}$

Voor de exacte inhoud van de aanklacht verwijs ik naar het deel van dit hoofdstuk waarin de Rules of Practice uitvoerig zijn beschreven. Hier kan worden volstaan met de conclusie dat aan de zesde eis, die gesteld kan worden in het kader van de straf(proces)rechtelijke waarborgen, is voldaan voor zover het gaat om het toezenden van een gemotiveerde kennisgeving van het voornemen om een bestuurlijke boete op te leggen aan de aangeklaagde. Een begrijpelijke taal-clausule ontbreekt echter. ${ }^{50}$

\section{Schorsende werking bezwaar en beroep}

Met het oog op de onschuldpresumptie verdient het voorts de voorkeur dat in de boeteregeling voorzien wordt in schorsende werking van bezwaar en beroep. Hiervoor is reeds aangegeven dat in de boeteregeling zoals die is opgenomen in de Clean Air Act voldaan is aan deze eis. Daamaast blijkt uit sectie 22.31(c) (gelezen in samenhang met sectie 22.27(d)) van de Rules of Practice dat de boete betaald moet worden binnen dertig dagen na ontvangst van het definitieve besluit. Het gaat dan om het besluit dat genomen wordt nadat (eventueel) 'beroep' is ingesteld bij het Environmental Appeals

49 Terzijde dient het volgende opgemerkt te worden. Op grond van de Clean Air Act wordt een kennisgeving verplicht gesteld. In sectie 22.34 van de Rules of Practice wordt aangegeven dat in een dergelijke kennisgeving wordt voorzien door het uit doen gaan van een aanklacht, als bedoeld in sectie 22.13 van de Rules of Practice.

50 Hierbij dient echter wel te worden opgemerkt dat de begrijpelijke taal-clausule in de Nederlandse regelingen ook niet altijd even strikt in acht genomen wordt. Met name als het gaat om een aan een rechtspersoon op te leggen bestuurlijke boete is een begrijpelijke taal-clausule niet nodig omdat er van uitgegaan kan worden dat er binnen de organisatie van de rechtspersoon altijd wel iemand is die de Nederlandse taal machtig is. Desondanks zijn destijds in het wetsvoorstel bestuurlijke boeten visserij, het wetsvoorstel voor de Mededingingswet en het wetsvoorstel voor de Warenwet wel bepalingen omtrent taalhulp opgenomen. Doorgaans moet de aangeschrevene overigens wel zelf om een vertaling vragen. 
Board. Bij vergelijking met de Nederlandse situatie komt dit neer op een schorsende werking tijdens de bezwaarprocedure (óf gedurende administratief beroep).

Of er gedurende de beroepsprocedure bij een 'constitutional' court ook sprake is van schorsende werking dient te worden afgeleid uit de APA. Uit sectie 705 van de APA blijkt dat zowel de rechtbank als het agency kan beslissen dat de werking van het boetebesluit tijdens het beroep op de rechter geschorst wordt. De rechtbank kan de werking van het besluit alleen schorsen teneinde onherstelbare schade (irreparable injury) te voorkomen. $^{\text {sI }}$

Ten aanzien van het vereiste van schorsende werking tijdens bezwaar en beroep dient dan ook geconcludeerd te worden dat in de Rules of Practice in ieder geval de schorsende werking van het 'bezwaar' (in de vorm van 'beroep' op de Environmental Appeals Board) gegarandeerd is. ${ }^{52}$ Of er sprake is van schorsende werking tijdens het beroep op de rechter hangt af van de vraag of er iets over geregeld is in de bijzondere wet. Is in de bijzondere wet niet voorzien in schorsernde werking dan kan de rechtbank de werking van het besluit alleen schorsen als de opeisbaarheid van het boetebedrag voor de (rechts)persoon aan wie de boete is opgelegd tot onherstelbare schade lijdt. ${ }^{53}$

\section{Recht op rechtspraak in twee instanties}

Met het oog op de rechtsbescherming van de vermoedelijke overtreder is het vervolgens vereist dat er een recht bestaat op rechtspraak in twee (feitelijke) instanties. Nu in de Rules of Practice slechts een soort bezwaarschrift- cq. administratief beroepsprocedure is opgenomen kan in die regeling niet het antwoord worden gevonden op de vraag of invulling is gegeven aan deze straf(proces)rechtelijke waarborg.

Zoals uit het vorige hoofdstuk is gebleken hangt een en ander in eerste instantie af van de wettelijke regeling waarin de bevoegdheid tot oplegging van de boete is geregeld. Wordt immers in die regeling het Court of Appeals bevoegd verklaard dan is hoger beroep (certiorari uitgezonderd ${ }^{54}$ ) niet mogelijk. Wordt in de wettelijke regeling het District Court bevoegd verklaard, of moet de vangnetbepaling uit sectie 703 van de APA worden toegepast waardoor in beginsel ook het District Court bevoegd is, dan kan de uitspraak van het District Court worden aangevochten bij het Court of Appeals.

Zoals hiervoor reeds is uiteengezet is er het kader van de CAA sprake van recht op rechtspraak in twee instanties. In de Marine Protection, Research, and Sanctuaries Act wordt niets gezegd over rechterlijke herziening van het boetebesluit van de EPA. In de Rules of Practice is voorts geen algemene regeling getroffen. Dit is overigens niet vreemd omdat het uitgangspunt op grond van de APA is dat het Congres in de wet in formele zin aan moet geven bij welke instantie verzocht kan worden om rechterlijke herziening. Het voorgaande brengt met zich dat de vangnetbepaling uit de APA van toepassing zal zijn op de definitieve boetebesluiten die zijn genomen op grond van de

51 Vgl. Strauss e.a., a.w. 1995, p. $1119-1120$.

52 De boeteregeling uit de Clean Air Act voldoet, los van de Rules of Practice, reeds volledig aan deze eis.

53 Vgl. in dit kader de Nederlandse voorlopige voorzieningsprocedure en het commentaar op genoemde regeling in hoofdstuk vier.

54 Het indienen van een verzoek bij het Supreme Court om een zaak te beoordelen kan immers niet worden gezien als 'hoger beroep' in de zin dat (her)beoordeling van de zaak altijd plaats vindt. Het Supreme Court bepaalt immers zelf of het een aangebrachte zaak in behandeling wenst te nemen. 
Marine Protection, Research, and Sanctuaries Act. Daarmee is ook in het kader van latstgenoemde regeling invulling gegeven aan het vereiste van rechtspraak in twee instanties.

Derhalve zal er op deze plaats vanuit worden gegaan dat de Amerikaanse regeling tot oplegging van een bestuurlijke boete, voor wat betreft de in dit werk bekeken wetgeving, wel een recht bestaat op rechtspraak in twee instanties. Opmerking verdient wel dat het District Court zich in veel (zo niet alle) gevallen geen eigen oordeel kan vormen omtrent de feiten. ${ }^{55}$ Ditzelfde geldt voor het Court of Appeals. Dit brengt met zich dat er géén sprake is van rechtspraak in twee feitelijke instanties.

\title{
Onschuldpresumptie
}

Zeer wezenlijk in het kader van het straf(proces)recht is de onschuldpresumptie. Op basis van de onschuldpresumptie rust de bewijslast in beginsel op het bestuur in een procedure tot oplegging van een bestuurlijke boete. Uit de beide specifieke boeteregeling bleek niet dat de onschuldpresumptie in acht is genomen door de Amerikaanse wetgever. In de Rules of Practice is echter wel een bepaling opgenomen waarmee invulling lijkt te worden gegeven aan de onschuldpresumptie. Het gaat om sectie 22.24 waarin, als hoofdregel, het volgende is bepaald:

\begin{abstract}
'The complainant has the burdens of presentation and persuasion that the violation occurred as set forth in the complaint and that the relief sought is appropriate. Following complainant's establishment of a prima facie case, respondent shall have the burden of presenting any defence to the allegations set forth in the complaint and any response or evidence with respect to the appropriate relief. The respondent has the burdens of presentation and persuasion for any affirmative defences.'
\end{abstract}

Daarmee lijkt derhalve in de Rules of Practice, weliswaar in wat ondoorzichtige termen, te worden voldaan het vereiste dat de onschuldpresumptie in acht moet worden genomen bij de oplegging van punitieve sancties zoals de bestuurlijke boete.

In de tot juli 2000 geldende Rules of Practice was een en ander in sectie 22.24 wat scherper gesteld:

'The complainant has the burden of going forward with and of proving that the violation occurred as set forth in the complaint and that the proposed civil penalty, revocation, or suspension, as the case may be, is appropriate.'

Met deze inmiddels vervallen bepaling werd mijns inziens onverkort bepaald dat de bewijslast rustte op de aanklager. Op basis van de nieuwe regeling lijkt dit uitgangspunt, tenminste tot op zekere hoogte, afgezwakt te zijn.

\section{Opbrengst boete}

De tiende eis houdt in dat uitdrukkelijk in de wet moet worden geregeld aan wie de opbrengst van de opgelegde bestuurlijke boeten toekomt. In de twee onderzochte boeteregelingen is, zoals reeds eerder in deze paragraaf is weergegeven, hieromtrent niets geregeld. In de Rules of Practice is in sectie 22.31(c) wel bepaald binnen welke termijn en op welke wijze de boete betaald moet worden. Omtrent de vraag aan wie de boete 
toekomt is in die bepaling echter niets geregeld. Aan de tiende eis is derhalve niet voldaan op grond van sectie 22.31(c) van de Rules of Practice.

Verjaringstermijn in de wettelijke regeling

Tenslotte volgt de laatste eis. Deze houdt in dat er een verjaringstermijn moet zijn opgenomen in de boeteregeling. In de Rules of Practice is in dit kader geen regeling getroffen. Zij vormen derhalve geen aanvulling op de twee eerder weergegeven boeteregelingen. De conclusie ten aanzien van deze eis blijft dan ook dat daaraan slechts tot op zekere hoogte is voldaan in de Clean Air Act.

$\mathrm{Na}$ toetsing van de Rules of Practice aan de meest essentiële (straf(proces)rechtelijke) waarborgen, die met het oog op de rechtsbescherming van de vermoedelijke overtreder in acht genomen moeten worden, dient het schematisch overzicht dat opgenomen is na de analyse van de twee Amerikaanse boeteregelingen als volgt gewijzigd te worden: 


\begin{tabular}{|c|c|c|c|c|}
\hline & WAARBORG & Rules of Practice & $\begin{array}{l}\text { Clean Air Act } \\
\text { (42 L.S.C. 7413) }\end{array}$ & $\begin{array}{l}\text { Marine Protec- } \\
\text { tion, Research, } \\
\text { and Senctuaries } \\
\text { Act } \\
\text { (33 U.S.C. 1415) }\end{array}$ \\
\hline$T$ & $\begin{array}{l}\text { Uitsluiten van het } \\
\text { strafrecht of inacht- } \\
\text { nemen una via- begin- } \\
\text { sel en toepasselijkheid } \\
\text { ne bis in idem- begin- } \\
\text { sel }\end{array}$ & NIET VOLDAAN & NIET VOLDAAN & NIET VOLDAAN \\
\hline 2 & $\begin{array}{l}\text { De maximum boete is } \\
\text { vastgelegd in de wet }\end{array}$ & NIET VOLDAAN & $\begin{array}{l}\text { (DEELS) VOL- } \\
\text { DAAN }\end{array}$ & VOLDAAN \\
\hline 3 & $\begin{array}{l}\text { Functiescheiding } \\
\text { tussen constateerder } \\
\text { van de overtreding en } \\
\text { boeteoplegger }\end{array}$ & VOLDAAN & NIET VOLDAAN & NIET VOLDAAN \\
\hline 4 & $\begin{array}{l}\text { Zwijgrecht en cautie- } \\
\text { plicht }\end{array}$ & NIET VOLDAAN & NIET VOLDAAN & NIET VOLDAAN \\
\hline 5 & $\begin{array}{l}\text { Hoorplicht in de pri- } \\
\text { maire fase + assistentie } \\
\text { tolk }\end{array}$ & $\begin{array}{l}\text { VOLDAAN (wat } \\
\text { betreft de hoor- } \\
\text { plicht) }\end{array}$ & $\begin{array}{l}\text { VOLDAAN (wat } \\
\text { betreft de hoor- } \\
\text { plicht) }\end{array}$ & $\begin{array}{l}\text { VOLDAAN (wat } \\
\text { betrefl de hoor- } \\
\text { plicht) }\end{array}$ \\
\hline 6 & $\begin{array}{l}\text { Inkennisstelling van de } \\
\text { gronden waarop de } \\
\text { beschuldiging berust in } \\
\text { begrijpelijke taal }\end{array}$ & $\begin{array}{l}\text { VOLDAAN (m.u.v. } \\
\text { Begrijpelijke taal- } \\
\text { clausule) }\end{array}$ & $\begin{array}{l}\text { MARGINAAL } \\
\text { VOLDAAN }\end{array}$ & $\begin{array}{l}\text { MARGINAAL } \\
\text { VOLDAAN }\end{array}$ \\
\hline 7 & $\begin{array}{l}\text { Schorsende werking } \\
\text { van "bezwaar" en } \\
\text { beroep }\end{array}$ & $\begin{array}{l}\text { VOLDAAN (ta.v. } \\
\text { bezwaar). } \\
\text { DEELS VOL- } \\
\text { DAAN } \\
\text { (t.a.v. beroep) }\end{array}$ & VOLDAAN & NIET VOLDAAN \\
\hline 8 & $\begin{array}{l}\text { Recht op rechtspraak in } \\
\text { twee feitelijke instan- } \\
\text { ties }\end{array}$ & $\begin{array}{l}\text { NIET VOLDAAN } \\
\text { (w.b. feitelijke } \\
\text { instanties) }\end{array}$ & $\begin{array}{l}\text { NIET VOLDAAN } \\
\text { (w.b. feitelijke } \\
\text { instanties) }\end{array}$ & $\begin{array}{l}\text { NIET VOLDAAN } \\
\text { (w.b. feitelijke } \\
\text { instanties) }\end{array}$ \\
\hline 9 & $\begin{array}{l}\text { De onschuld- } \\
\text { presumptie }\end{array}$ & $\begin{array}{l}\text { ZEER MARGI- } \\
\text { NAAL VOLDAAN }\end{array}$ & NIET VOLDAAN & NIET VOLDAAN \\
\hline 10 & $\begin{array}{l}\text { Vastleggen in de wet } \\
\text { aan wie de opbrengst } \\
\text { van de boete toekomt }\end{array}$ & NIET VOLDAAN & NIET VOLDAAN & NIET VOLDAAN \\
\hline$\pi$ & $\begin{array}{l}\text { Opname van een } \\
\text { verjaringstermijn in de } \\
\text { wettelijke regeling }\end{array}$ & NIET VOLDAAN & $\begin{array}{l}\text { DEELS VOL- } \\
\text { DAAN }\end{array}$ & NIET VOLDAAN \\
\hline
\end{tabular}


Indien de afzonderlijke boeteregelingen in samenhang met de Rules of Practice worden beschouwd leidt dit tot de volgende conclusie. De Clean Air Act, gelezen in samenhang met de Rules of Practice voldoet volledig aan drie van de elf eisen die in het kader van de rechtsbescherming gesteld moeten worden bij de oplegging van een bestuurlijke boete. Aan vier eisen wordt vervolgens deels voldaan in de Clean Air Act (gelezen in samenhang met de Rules of Practice), en aan vier eisen wordt in het geheel niet voldaan.

Ten aanzien van de Marine Protection Research, and Sanctuaries Act geldt dat aan vijf straf(proces)rechtelijke waarborgen volledig invulling is gegeven bij lezing in samenhang met de Rules of Practice. Aan twee waarborgen wordt vervolgens deels invulling gegeven en aan vier andere waarborgen wordt in het geheel geen aandacht geschonken.

Nu volgt nog een overzicht waaruit kan worden afgeleid in hoeverre lezing van de Clean Air Act (CAA) en de -Marine Protection Research, and Sanctuaries Act (MPRSA), in samenhang met de Rules of Practice (RoP) een wijziging heeft aangebracht in de mate waarin is voldaan aan de eisen uit hoofdstuk twee.

\begin{tabular}{l|c|c|c|c}
$\begin{array}{l}\text { Voldaan aan } \\
\text { (straf(proces)- } \\
\text { rechtelijke) } \\
\text { waarborg }\end{array}$ & CAA & CAA + RoP & MPRSA & $\begin{array}{c}\text { MPRSA + } \\
\text { RoP }\end{array}$ \\
\hline $\begin{array}{l}\text { GEHEEL } \\
\text { VOLDAAN }\end{array}$ & 2 EISEN & 3 EISEN & 1 EIS & 5 EISEN \\
AAN: & & & & \\
\hline $\begin{array}{l}\text { GEDEELTE- } \\
\text { LIJK VOL- } \\
\text { DAAN AAN: }\end{array}$ & 3 EISEN & 4 EISEN & 2 EISEN & 2 EISEN \\
\hline $\begin{array}{l}\text { NIET VOL- } \\
\text { DAAN AAN: }\end{array}$ & 6 EISEN & 4 EISEN & 8 EISEN & 4 EISEN \\
& & & &
\end{tabular}

Er is derhalve duidelijk invulling gegeven aan een groter aantal straf(proces)rechtelijke waarborgen bij lezing van de afzonderlijke boeteregelingen in samenhang met de Rules of Practice.

Dit neemt niet weg dat het eindresultaat niet bijzonder positief te noemen is. Een aantal essentiële straf(proces)rechtelijke waarborgen blijft immers geheel buiten beschouwing in de bestudeerde regelingen. In dit kader kan onder andere gewezen worden op het feit dat dubbele bestraffing ten aanzien van dezelfde overtreding niet is uitgesloten in de onderzochte regelingen. Zowel aan het una via-beginsel als aan het ne bis in idembeginsel is immers geen invulling gegeven in de Clean Air Act, de Marine Research and Sanctuaries Act en de Rules of Practice. Hetzelfde geldt voor het zwijgrecht en de cautieplicht en het recht op rechtspraak in twee feitelijke instanties (de rechter toetst agency-besluiten in de regel immers zeer terughoudend terwijl hij (in beginsel) uit moet gaan van de feiten zoals ze door het agency zijn vastgesteld). 
Het voorgaande zou verklaard kunnen worden uit het feit dat in de Verenigde Staten de oplegging van bestuurlijke boeten niet wordt gerekend tot het strafrecht in ruime zin. De aard van de sanctie lijkt minder relevant te zijn dan het etiket dat door de wetgever op de sanctie wordt geplakt (in het geval van de bestuurlijke boete 'civil' - the administrative assessment of a civil penalty -). Later in deel twee zal op deze formele en legistische benadering nog uitvoerig worden teruggekomen.

\subsubsection{Het boetebeleid van het EPA}

$\mathrm{Na}$ een uitvoerige weergave van de Rules of Practice en de toetsing van deze regelgeving aan de meest essentiële straf(proces)rechtelijke waarborgen - die in het kader van de oplegging van bestuurlijke boeten in acht genomen zouden moeten worden - zal tenslotte ingegaan worden op het boetebeleid van het EPA. Het beleid van het EPA ziet met name op de wijze waarop de hoogte van de boete wordt vastgesteld.

Zoals kan worden afgeleid uit de twee voorgaande paragrafen worden er per boeteregeling in de wet in formele zin verschillende factoren weergegeven die meegenomen moeten worden bij de vaststelling van de hoogte van de op te leggen boete. ${ }^{56}$ Het EPA zou derhalve op basis van de bijzondere wetten per specifieke boeteregeling een boetebeleid kunnen voeren. Aangezien dit bepaald niet efficiënt zou zijn en bovendien een grote diversiteit aan boetebeleidsregelingen in de hand zou kunnen werken heeft het EPA een algemene beleidslijn ('de Policy on Civil Penalties') in samenhang met een soort basis-(boete)berekenings-model, ontwikkeld. Per bijzondere wettelijke boeteregeling moet het boetebeleid in beginsel worden afgestemd op deze algemene beleidslijn en het boeteberekenings-model. Een dergelijk algemeen boetebeleid bevordert de (rechts)gelijkheid in die zin dat overal in de Verenigde Staten dezelfde boete wordt opgelegd voor vergelijkbare overtredingen ${ }^{57}$ In dit basis-model voor het boetebeleid zijn de, in de wet in formele zin, meest voorkomende factoren die een rol spelen bij de vaststelling van de hoogte van de boete opgenomen.

Hiema zal eerst kort worden ingegaan op de Policy on Civil Penalties. Vervolgens zal het boetebeleid van het EPA worden beschreven zoals dat is neergelegd in de 'Clean Air Act Stationary Source Civil Penalty Policy'. ${ }^{58}$ Het beleid uit de Clean Air Act Stationary Source Civil Penalty Policy wordt toegepast bij bestuurlijke boeten die op grond van de Clean Air Act (42 U.S.C. 7413) worden opgelegd. Dit specifieke beleid ten aanzien van boeten die op grond van de Clean Air Act worden opgelegd is gebaseerd op voornoemde Policy on Civil Penalties van het EPA. ${ }^{59}$

56 Zie de boeteregeling uit de Clean Air Act, 42 U.S.C. 7413(e), en de boeteregeling uit de Marine Protection, Research, an Sanctuaries Act, 33 U.S.C. 1415(a), welke zijn opgenomen eerder in deze paragraaf.

57 Deze beleidslijn en het basis-berekenings-model zijn neergelegd in de Policy on Civil Penalties van 16 februari 1984 (GM-21) en het Framenwork for Statute-specific Approaches to Penalty Assessment eveneens van 16 februari 1984 (GM-22). De Policies van het EPA zijn vergelijkbaar met beleidsregels (ex. artikel 1:3 lid 4 Awb).

58 De Clean Air Act Stationary Source Civil Penalty Policy is voliedig te raadplegen op de volgende intemet-site: http://es.epa.gov/oeca/ore/aed/docs/sectionb/b19.html

59 Dit blijkt uit de inleiding van de Clean Air Act Stationary Source Civil Penalty Policy: 'On february 16, 1984, EPA issued the Policy on Civil Penalties (GM-2I) and a Framework for Statute-Specific 
Zoals reeds bleek bij de weergave van de inhoud van de Rules of Practice wordt er op grond van sectie 22.18(b) de voorkeur aan gegeven te komen tot een schikking met betrekking tot de oplegging van de bestuurlijke boete. ${ }^{60}$ In het begin van de negentiger jaren werd in ruim $97 \%$ van de gevallen, waarin het voornemen bestond een bestuurlijke boete op te leggen, de boeteprocedure vroegtijdig afgedaan door middel van een schikking. ${ }^{6}$

Het EPA bevordert deze wijze van afdoening met name vanwege de aanmerkelijk lagere kosten die verbonden zijn aan informal settlement. Daarnaast is de schikkingsprocedure effectiever gelet op de korte termijn waarbinnen een zaak tot oplegging van een bestuurlijke boete kan worden afgerond. Ook bij het door het EPA vastgestelde boetebeleid is aan de mogelijkheid om tot een schikking te komen veel gewicht toegekend. Een en ander zal blijken uit de hiemavolgende weergave van het boetebeleid.

Hierna zal eerst de schematische weergave van het boetebeleid volgen. Daarna zal aan de hand van het schema een uitvoerige beschrijving volgen. Schematisch overzicht boetebeleid:

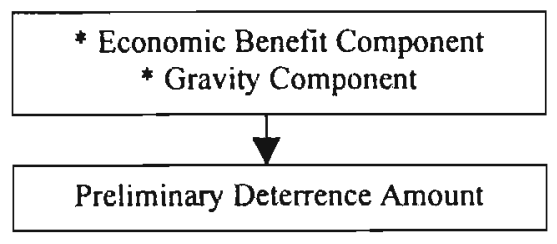

Adjustment Factors

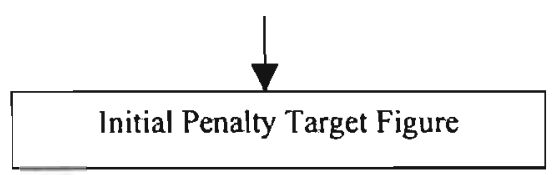

Adjustment after negotiations have begun

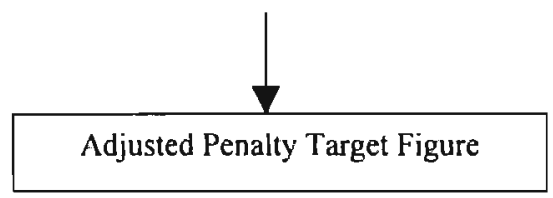

Approaches to Penalty Assessments (GM-22). The Policy focuses on the general philosophy behind the penalty program. The Framework provides guidance to each programm on how to develop nisdium-specific penalty policies. The Air Enforcement programm followed the Policy and the Framework in drafting the Clean Air Act Stationary Source Civil Penalty Policy,...'.

60 Zie m.b.t. de schikkingsbevoegdheid voorts: Blomberg a.w. 2000, p. 242-243 en 252.

61 Zie hierover: Administrative Hearings And Trials, National Enforcement Training Instinte van het Office of Enforcement and Compliance Assurance van het EPA, p. 4, en Diver a.w. 1979, p. 1437. Zie ook: Michael J. Walker, Attitude Can Make A Difference: Dealing with the EPA's Enforcement Office: Some Practical Considerations, The Environmental Corporate Counsel Report, Augustus 1994, p. 6-9, i.h.b. p. 6: '...the vast majority of cases - well over 97 percent - will settle through the negotiation of a judicial consent decree or administrative consent order.' 


\section{Policy on Civil Penalties}

Voordat hier ingegaan wordt op de 'Clean Air Act Stationary Source Civil Penalty Policy' volgen eerst enkele opmerkingen aangaande de Policy on Civil Penalties. Uit de in de Policy on Civil Penalties weergeven beleidslijn blijkt dat het EPA drie doelen nastreeft met het opleggen van bestuurlijke boeten.

\section{Afschrikkende werking}

Ten eerste dient van de op te leggen bestuurlijke boete een afschrikkende werking uit te gaan. ${ }^{62}$ De insteek is dat er, vanwege de afschrikkende werking, minder overtredingen plaats zullen vinden waardoor van genoemde afschrikkende werking een kostenbesparend effect uit zal gaan op het handhavingsbeleid van het EPA. ${ }^{63}$

De afschrikkende werking is tweeledig. Ten eerste is er sprake van afschrikkende werking ten aanzien van de overtreder die geconfronteerd wordt met een bestuurlijke boete (speciale preventie). Met de boete beoogt men hem er van te weerhouden wederom een bepaald (wettelijk) voorschrift te overtreden. Daarnaast gaat er ook een generaal preventieve werking uit van de dreiging met een bestuurlijke boete ten aanzien van andere potentiële overtreders. In dit kader zou gesproken kunnen worden van generale en speciale preventie die wordt nagestreefd door (dreiging met) de oplegging van bestuurlijke boeten. De boete moet dan wel dermate hoog zijn dat er in de samenleving de uvertuiging ontstaat: 'that the penalty places the violator in a worse position than those who have complied in a timely fashion. ${ }^{64}$

Om te bereiken dat de overtreder in een nadeligere positie komt te verkeren dan de (rechts)persoon die zich aan de regelgeving heeft gehouden moet de overtreder ten eerste het economisch voordeel van de overtreding worden ontnomen. Maar blijkens de Policy on Cilvil Penalties is dit nog niet voldoende:

'The removal of economic benefit of noncompliance only places the violator in the same position as he would have been if compliance had been achieved on time. Both deterrence and fundamental faimess require that the penalty include(s) an additional amount to ensure that the violator is economically worse off than if it had obeyed the law. This additional amount should reflect the seriousness of the violation. In doing so, the penalty will be perceived as fair. In addition the penalty's size will tend to deter other potential violators. ${ }^{6566}$

$\mathrm{Na}$ vaststelling van het met de normschending behaalde economisch voordeel wordt de bestuurlijke boete derhalve nog verhoogd met een bepaald bedrag dat in verband staat

62 Op deze plaats wil ik nogmaals wijzen op de rechtspraak van het Europese Hof van de Rechten van de Mens, en wel in het bijzonder naar de zaak Oztürk (Series A vol. 73, 21 februari 1984), waarin de afschrikkende werking van de sanctie genoemd wordt als een van de aspecten die van belang zijn voor de vaststelling dat er sprake is van een 'criminal charge'.

63 Zie in dit kader voorts: J.D. Silberman, Does Environmental Deterrence Work? Evidence and Experience Say Yes, But We Need to Understand How and Why, The Environmental Law Reporter 2000, 30 ELR 10523.

64 Policy on Civil Penalties, 16 februari 1984, (GM-21), 'Deterrence'.

65 Policy on Civil Penalties, 16 februari 1984, (GM-21), 'Deterrence'.

66 Naar mijn mening gaat het derhalve bij 'the administrative assessment of civil penalties' duidelijk om boeten die vergelijkbaar zijn met onze nationale bestuurlijke boete. Er gaat van de Amerikaanse boeten immers een punitieve (en daarmee afschrikkende) werking uit. Een dergelijke sanctie zou door het Europese Hof van de Rechten van de Mens wellicht worden gekwalificeerd als een 'criminal charge'. Voorts dient een dergelijke sanctie tot het strafrecht in ruime zin gerekend te worden. 
met de ernst van de overtreding zodat er ook daadwerkelijk nadeel ontstaat door de milieuregelgeving te overtreden. ${ }^{67}$ Dit leedtoevoegende deel van de, onmiskenbaar als punitieve sanctie aan te merken, boete wordt de 'gravity component' genoemd. Het bedrag dat wordt vastgesteld door de 'economic benefit component' en de 'gravity component' bij elkaar op te tellen vormt het 'preliminary deterrence amount'. Op het voorgaande zal nog worden teruggekomen in verband met toelichting van het bovenstaande schema aan de hand van de Clean Air Act Stationary Source Civil Penalty Policy.

\section{Eerlijke en onpartijdige behandeling van de, aan de regelgeving onderhevige, samenleving}

Ten tweede moet het opleggen van een bestuurlijke boete een eerlijke en onpartijdige behandeling van de, aan de regelgeving onderhevige samenleving, ten doel hebben. Dit houdt in dat het boetebeleid van het EPA consistent moet zijn hoewel er daamaast ruimte moet zijn voor flexibiliteit. ${ }^{68}$ Een consistent boetebeleid voorkomt dat bij de burgers de idee gaat leven dat oplegging van bestuurlijke boeten op basis van willekeur geschiedt. $^{69}$

Doordat echter in de Policy on Civil Penalties ook de mogelijkheid geboden wordt om de 'preliminary deterrence amount' aan te passen aan de hand van bepaalde - voor iedere overtreder, afhankelijk van de omstandigheden van het geval, geldende - 'adjustment factors' kan voor elke overtreder de meest toepasselijke boete worden opgelegd. Dit garandeert 'that a fair and equitable penalty ${ }^{70}$ zal worden opgelegd.

\section{Snelle oplossing van milieurechtelijke overtredingen}

Het derde doel dat het EPA nastreeft met de oplegging van een bestuurlijke boete is een snelle oplossing van milieurechtelijke overtredingen. Door de dreiging met nieuwe, hogere boeten, zal de overtreder snel overgaan tot herstel van de onrechtmatige situatie. Hierdoor zal het milieu minder lang en minder ernstig worden belast. Daarnaast, en dat

Ten aanzien van de bestuurlijke boeten die in Nederland worden opgelegd (bij misbruik van subsidiercgelingen) wordt er - wat het leedtoevoegend aspect van de boete betreft - een vrijwel gelijkluidende redentering gevolgd als in het hierboven weergegeven deel uit de Policy on Civil Penalties. Dit blijkt uit de uitspratak van de Afdeling Bestuursrechtspraak van de Raad van State van 10 februari 1997. AB 1997/427. Daarin wordt namelijk het volgende aangegeven: 'Voorts is de combinatie van terugvordering en het opleggen van een boete uitdrukkelijk door de wetgever gewild, gezien het feit dat bij de totstandkoming van art. 29a (van de Wet individuele huursubsidie [KA]) is vermeld dat dit artikel in de wet is opgenomen als uitwerking van het regeringsstandpunt dat bij misbruik van subsidieregelingen niet alleen tot terugvordering moet worden overgegaan, maar dat de misbruiker ten opzichte van de bonafide burger tevens in een achterstandspositie moet worden gebracht door middel van ten punitieve sanctie.'

68 Policy on Civil Penalties, 16 februari 1984, (GM-21), 'Fair and Equitable Treatment of the Regulated Community'.

69 Als het boetebeleid niet consistent is leidt dit tot nadelige resultaten voor het agency: '...penalties might be seen as abitrarily assessed. Thus violators would be more inclined to litigate over those penalties. This would consume Agency resources and make swift resolutions of environmental problems less likely.' Policy on Civil Penalties, 16 februari 1984, (GM-21), 'Fair and Equitable Treatment of the Regulated Community'. Evenals zojuist bleek ten aanzien van de preventieve afschrikkende werking van de oplegging van een bestuurlijke boete blijkt ook hier weer dat kostenbesparing een belangrijke rol speelt bij het boetebeleid. Zie: de Clean Air Act Stationary Source Civil Penalty Policy, 'I. Introduction.' 
lijkt voor het EPA minstens zo belangrijk te zijn, bespaart het EPA aanzienlijke sommen geld als een handhavingsactie snel kan worden afgerond. ${ }^{71}$

Uit de Policy on Civil Penalties blijkt voorts dat een schikking met betrekking tot de op te leggen bestuurlijke boete de voorkeur verdient boven het (volledig) volgen van de boeteprocedure. Het voorgaande hangt samen met het feit dat een snel herstel van de onrechtmatige situatie, vanwege die hierboven weergegeven uiteenlopende redenen, de absolute voorkeur verdient.

Omdat het EPA er, blijkens de Policy, alles aan wil doen om te voorkomen dat herstel van de (on)rechtmatige toestand wordt vertraagd wordt reeds van tevoren aangegeven dat het EPA bij een langdurigere overtreding de boete zal verhogen. ${ }^{72} \mathrm{Om}$ een schikking, en een snel herstel van de onrechtmatige toestand, te stimuleren kan het EPA bovendien, onder andere, de gravity component van de boete verlagen als de overtreder al voor aanvang van de onderhandelingen de (on)rechtmatige toestand heeft hersteld. ${ }^{73}$

\subsection{3.a Het boetebeleid van het EPA nader belicht}

$\mathrm{Nu}$ volgt een toelichting op het hierboven weergegeven schematische overzicht van het boetebeleid aan de hand van de Clean Air Act Stationary Source Civil Penalty Policy. ${ }^{74}$ Zoals hiervoor reeds is aangegeven moet er eerst een preliminary deterrence amount worden vastgesteld.

Om een preliminary deterrence amount vast te kunnen stellen moeten de economic henifit component en de gravity component bepaald worden. Deze twee bedragen tezamen vormen namelijk het preliminary deterrence amount. Op deze plaats zal dan ook eerst ingegaan worden op de wijze waarop, op basis van de Clean Air Act Stationary Source Civil Penalty Policy, de economic benefit component en de gravity component moet worden berekend.

\section{Econumic benefit component}

Op grond van de Clean Air Act Stationary Source Civil Penalty Policy zijn drie factoren relevant bij het bepalen van de economic benefit component. Ten eerste wordt in dat kader rekening gehouden met het voordeel dat voor de overtreder ontstaat doordat hepaalde uitgaven uitgesteld kunnen worden door het onrechtmatige handelen. Daarnaast is het voordeel dat voor de overtreder voorvloeit uit zijn onrechtmatige handelen, in die zin dat daardoor kosten definitief vermeden zijn, relevant voor de vaststelling van de economic benefit component. Tenslotte is van belang of de overtreder winst

71 Vgl. Policy on Civil Penalties, 16 februari 1984, (GM-21), 'Swift Resolutions of Environmental Problems': 'In addition, swift compliance conserves Agency personnel and resources.'

72 Policy on Civil Penalties, 16 februari 1984, (GM-21), 'Provide discentives to delaying compliance.'

73 Policy on Civil Penalties, 16 februari 1984, (GM-21), 'Provide incentives to settle and institute prompt remedial action.'

74 Daarbij wordt uitgegaan van vaststelling van de 'economic benefit component' en de 'gravity component' aan de hand van de Clean Air Act Stationary Source Civil Penalty Policy in het algemeen. De Clean Air Act Stationary Source Civil Penalty Policy is echter aangevuld met acht appendices waarin ten aanzien van een aantal specifieke overtredingen aangegeven is dat de 'economic benefit component' en/of de 'gravity component' anders moeten worden berekend dan is weergegeven in de Clean Air Act Stationary Source Civil Penalty Policy. 
heeft gemaakt door illegaal te handelen. De bedragen die aan de hand van deze drie factoren vastgesteld worden ${ }^{75}$ vormen tezamen de economic benefit component.

\section{Grovity component}

$\mathrm{Na}$ vaststelling van de economic benefit component dient de gravity component te worden vastgesteld. De gravity component bestaat uit een aantal factoren die zijn afgeleid van de, in de Clean Air Act (42 U.S.C. 7413(e)) opgenomen, "Penalty assessment criteria". ${ }^{76}$ Het gaat, blijkens de Clean Air Act Stationary Source Civil Penalty Policy, om objectieve factoren die gebruikt kunnen worden om de ernst van de overtreding vast te stellen. Aan de hand van de objectieve factoren is het eenvoudiger om het bedrag van de grovity component vast te stellen. ${ }^{77}$ Bovendien biedt vaststelling van de gravity component aan de hand van die objectieve factoren het EPA de mogelijkheid overtredingen van vergelijkbare ernst met een vergelijkbare boete af te doen zodat de rechtsgelijkheid gewaarborgd wordt. ${ }^{78}$

In de Clean Air Act Stationary Source Civil Penalty Policy worden drie objectieve factoren genoemd. In bepaalde gevallen zijn ten aanzien van een factor nog subfactoren opgenomen om de emst van de overtreding gedetailleerder vast te kunnen stellen. Hieronder komen de afzonderlijke objectieve factoren en de daarbij behorende subfactoren aan de orde.

\section{Grovity component - werkelijke of mogelijke schade aan het milieu-}

Als eerste objectieve factor, die een rol speelt bij vaststelling van de gravity component, wordt in de Clean Air Act Stationary Source Civil Penalty Policy de werkelijke of mogelijke schade aan het milieu genoemd. Bij het vaststellen van de 'actual or possible harm' wordt gekeken naar de emissies door de vervuiler die boven het toegestane emissieniveau uitgaan. Om de werkelijke of mogelijke schade aan het milieu vast te stellen kan het EPA op grond van de Clean Air Act Stationary Source Civil Penalty Policy gebruik maken van vier subfactoren.

De eerste subfactor heeft betrekking op de mate van vervuiling. Daarbij wordt nagegaan met hoeveel procent de emissienorm wordt overschreden. Per percentage waarmee de emissienorm wordt overschreden is in de Clean Air Act Stationary Source Civil Penalty Policy aangegeven welk bedrag op grond daarvan aan de boete moet worden toegevoegd. ${ }^{79}$ Als tweede subfactor wordt in de Clean Air Act Stationary Source Civil

75 Voor de exacte berekening van de economic benefit component maakt het EPA onder andere gebruik van de 'Methodology for Computing the Economic Benefit of Noncompliance', doorgaans 'BEN' genaamd. Met dit berekeningsprogramma kan het economisch voordeel van overtreding van milieuregelgeving berekend worden aan de hand van een gedetailleerde economische analyse. Dit blijkt uit de Clean Air Act Stationary Source Civil Penalty Policy onderdeel II.A.1. 'Benefit from delayed costs'. Zie voor een volledige weergave van de tekst van sectie 7413(e) van de Clean Air Act paragraaf 6.2.1 van dit werk.

77 In de Clean Air Act Stationary Source Civil Penalty Policy wordt vrij uitvoerig per (sub)factor van de gravitycomponent aangegeven welke boetbedragen in welke gevallen verbonden zijn aan een bepaalde factor.

Dit blijkt uit de Clean Air Act Stationary Source Civil Penalty Policy onderdeel II.B. 'THE GRAVITY COMPONENT.

79 Dit blijkt uit de Clean Air Act Stationary Source Civil Penalty Policy onderdeel II.B.1.a. Level of Violation'. 
Penalty Policy de kwetsbaarheid van het milieu genoemd. Vervuiling in een kwetsbaarder gebied leidt tot een hoger boetebedrag dan vervuiling in een minder kwetsbaar gebied.

De derde subfactor die van belang is voor het vaststellen van de werkelijke of mogelijke schade voor het milieu is de giftigheid van de door de emissie vrijgekomen stoffen. Vanzelfsprekend geldt daarbij; hoe giftiger de vrijgekomen stoffen hoe hoger de boete. Tenslotte wordt in de Clean Air Act Stationary Source Civil Penalty Policy als laatste subfactor genoemd de (lengte van de) periode gedurende welke de overtreding van de milieurechtelijke regelgeving heeft geduurd. Hoe langer de overtreding duurt hoe groter de kans is op werkelijke of mogelijke schade aan het milieu en hoe hoger dus ook de boete is. ${ }^{80}$

\section{Gravity component - belang van de overtreden regel --}

De tweede objectieve factor die een rol speelt bij vaststelling van de grovity component is het belang van de regel die is overtreden binnen de volledige regeling. Het gaat er dan om hoe belangrijk bepaalde vereisten uit de Clean Air Act, en de daarop gebaseerde regelingen, zijn met het oog op de met de voomoemde regelgeving te bereiken doelen. Hoe ernstiger door overtreding van bepaalde regelgeving het bereiken van de in de Clean Air Act (en de daaruit voortvloeiende regelgeving) neergelegde doelstelling(en) wordt belemmerd hoe hoger de boete. ${ }^{81}$

Gravity component - omvang van de rechtspersoon die de overtreding heeft begaan Tenslotte wordt in de Clean Air Act Stationary Source Civil Penalty Policy als derde objectieve factor genoemd de omvang van de rechtspersoon die de overtreding heeft begaan. Hoe groter het bedrijf hoe meer de gravity component verhoogd moet wor$\operatorname{den}^{82}$

Alle verhogingen van het boetebedrag die voortvloeien uit de drie hiervoor weergegeven objectieve factoren vormen tezamen de gravity component.

\section{Preliminary deterrence amount}

Zoals reeds is aangegeven worden de boetebedragen met betrekking tot de economic benefit component en de gravity component vervolgens bij elkaar opgeteld. Dit resulteert dan in een preliminary deterrence amount.

$\mathrm{Na}$ vaststelling van het preliminary deterrence amount wordt aan de hand van aanpassingsfactoren ("adjustment factors") bekeken of het preliminary deterrence amount nog

80 De boetebedragen zijn opgenomen in de Clean Air Act Stationary Source Civil Penalty Policy onderdeel II.B.I.d. 'Length of time of violation' en varièren van een boete van $\$ 5,000$ bij een overtreding van de regelgeving gedurende een periode van 0 tot 1 maand tot $\$ 55,000$ voor een overtreding van de regelgeving gedurende een periode van 55 tot 60 maanden.

81 Dit blijkt uit de Clean Air Act Stationary Source Civil Penalty Policy onderdeel II.B.2 Importance to the regulatory scheme' waar per overtreding wordt aangegeven met welk bedrag de gravity component verhoogd moet worden.

82 Dit blijkt uit de Clean Air Act Stationary Source Civil Penalty Policy onderdeel II.B.3 'Size of the violator'. 
enige aanpassing behoeft. Het kan daarbij zowel om een verlaging als om een verhoging van het preliminary deterrence amount gaan.

Hierna zal worden ingegaan op de aanpassingsfactoren die relevant zijn voor de vaststelling van de bestuurlijke boete. Eerst zal worden gekeken naar de aanpassingfactoren ten aanzien van de economic benefit component, vervolgens komen de aanpassingsfactoren ten aanzien van de grovity component aan de orde en tenslotte zal worden ingegaan op de aanpassingsfactoren die gelden ten aanzien van het volledige preliminary deterrence amount.

\section{Aanpassing van de economic benefit component}

Aanpassing van de economic benefit component vindt in beginsel niet plaats. ${ }^{83}$ Slechts in drie uitzonderlijke situaties is aanpassing van de economic benefit component aan de orde. Het gaat dan in de eerste plaats om de situatie waarin het economisch voordeel te verwaarlozen is. ${ }^{84}$

Ten tweede kan in verband met zwaarwegende maatschappelijke omstandigheden afgezien worden van het (deels) verrekenen van het economisch voordeel. Vermindering van de economic benefit component is echter alleen aan de orde als dit absoluut noodzakelijk is in verband met de zwaarwegende maatschappelijke omstandigheden. Het gaat bijvoorbeeld om situaties waarin een bedrijf failliet zal gaan als het het boetebedrag van de economic benefit component moet betalen terwijl er zwaarwegende maatschappelijke redenen ${ }^{85}$ zijn die het noodzakelijk maken dat het bedrijf behouden blijt. De tweede aanpassingfactor wordt echter niet toegepast in gevallen dat een bedrijf (ongeacht de bestuurlijke boete) toch gesloten zou moeten worden en in gevallen waarin naar alle waarschijnlijkheid overtreding van de regelgeving op een voor het milieu schadelijke wijze zal worden voortgezet. ${ }^{86}$

Tenslotte kan de economic benefit component worden aangepast als samenloop dreigt plaats te vinden van bestuurlijke sanctionering. Het kan namelijk voorkomen dat ten aanzien van dezelfde gedraging, op grond verschillende wetten een bestuurlijke boete kan worden opgelegd. Ter illustratie kan in dit kader gewezen worden op de oplegging van een bestuurlijke boete op grond van 42 U.S.C. 7420 (luchtvervuiling) én de oplegging van een bestuurlijke boete op grond van de Clean Air Act (42 U.S.C. 7413) ten aanzien van dezelfde gedraging. Het voorgaande brengt echter niet met zich dat aanpassing van de economic benefit component in dat kader noodzakelijk geacht wordt

83 Dit blijkt uit de Clean Air Act Stationary Source Civil Penalty Policy onderdeel II.A.3 'Adjusting the Economic Benefit Component'.

84 Ook bij het besluit om, bij een zeer gering economisch voordeel, de economic benefit component niet mee te wegen spelen, blijkens de Clean Air Act Stationary Source Civil Penalty Policy onderdeel II.A.3.a ('Economic benefit component involves insignificant amount'), de procesecnomische aspecten voor het EPA een doorslaggevende rol. Als de overtreder het economische voordeel amper in zijn portemonnee voelt maar wel bereid is ten aanzien van dat deel van de boete een dure en tijdrovende procedure bij het EPA te beginnen blijft de economic benefit component buiten beschouwing.

85 Zoals bijvoorbeeld het in stand houden van werkgelegenheid in een economisch zwak deel van het land.

86 Zie: de Clean Air Act Stationary Source Civil Penalty Policy onderdeel II.A.3.b 'Compelling public concerns' 
want: 'The Clean Air Act allows dual recovery of the economic benefit.... ${ }^{87}$ Van belang is dat de afschrikkende werking van de boete gegarandeerd is. ${ }^{88}$

De drie hiervoor weergegeven aanpassingsfactoren ten aanzien van de economic benefit component kunnen tot gevolg hebben dat het boetebedrag wordt verminderd met het geheel of een deel van de economic benefit component. Zoals reeds is aangegeven vindt aanpassing slechts plaats in zeer uitzonderlijke omstandigheden.

\section{Aanpassing van de gravity component}

De aanpassingfactoren die toegepast kunnen worden om het deel van het boetebedrag dat de grovity component vormt aan te passen zijn niet beperkt tot uitzonderlijke gevallen. De reden daarvoor is, blijkens de Clean Air Act Stationary Source Civil Penalty Policy, dat de aanpassingsfactoren bij de gravity component noodzakelijk worden geacht om de flexibiliteit én rechtsgelijkheid bij het opleggen van de boete te kunnen garanderen. ${ }^{89}$

Ten aanzien van de gravity component zijn er vier aanpassingsfactoren. Drie aanpassingsfactoren zien op een verhoging van het boetebedrag, één aanpassingfactor heeft tevens ten doel het bedrag van de gravity component te verlagen.

\section{Aanpassing gravity component - mate van opzet of schuld -}

De eerste van de vier aanpassingsfactoren die relevant met het oog op de gravity component heeft betrekking op de mate van opzet of onachtzaamheid die aan de overtreding ten grondslag heeft gelegen. Deze aanpassingsfactor kan alleen worden gebruikt om de boete te verhogen. Hoewel het al dan niet met opzet overtreden van de regelgeving niet relevant is voor wat betreft de aansprakelijkheid van de overtreder speelt de aanwezigheid van opzet of onachtzaamheid dus wel een rol wat betreft de vaststelling van de hoogte van de boete. Vier subfactoren zijn van belang voor het vaststellen van de mate van opzet of onachtzaamheid. Ten eerste is relevant in hoeverre de overtreder invloed had op de omstandigheden die de overtreding van de regelgeving hebben veroorzaakt. De tweede subfactor voor het vaststellen van de mate van opzet of onachtzaamheid betreft de mate van voorzienbaarheid van omstandigheden die de overtreding veroorzaken. Ten derde moet bij de vaststelling van de mate van opzet of onachtzaamheid gekeken worden naar de geavanceerdheid in de bedrijfstak in relatie tot het handelen conform de regelgeving en de toegankelijkheid van geschikte controle technologieën. Tenslotte is van belang in hoeverre de overtreder zich bewust was van het wettelijke voorschrift dat hij heeft overtreden. ${ }^{90}$

87 Zie: de Clean Air Act Stationary Source Civil Penalty Policy onderdeel II.A.3.c 'Concurrent section 120 administrative action'.

88 Op. cit. 144

89 Zie: de Clean Air Act Stationary Source Civil Penalty Policy onderdeel II.A.4 'Adjusting the Gravity Component': '..., in order to promote equity, the system for penalty assessment must have enough flexibility to account for the unique facts of each case. Yet it still must produce consistent enough results to ensure similarly-situated violators are treated similarly. This is accomplished by identifying many of the legitimate differences between cases and providing guidelines for how to adjust the gravity component amount when those facts occur.'

90 Zie: de Clean Air Act Stationary Source Civil Penalty Policy onderdeel II.A.4.a 'Degree of willfulness or negligence'. 
Aanpassing gravity component - medewerking aan opheffing overtreding -

De tweede aanpassingsfactor die ziet op de grovity component betreft de mate waarin de overtreder meewerkt aan het opheffen van de overtreding. Vaststelling van de mate waarin de overtreder al dan niet meewerkt aan het opheffen van de overtreding kan leiden tot een verhoging of een verlaging van de gravity component. ${ }^{91}$

Verlaging van het boetebedrag vindt slecht plaats in drie gevallen. Ten eerst is verlaging van de boete mogelijk bij onmiddellijke melding van de overtreding door de overtreder die een bepaling uit, of gebaseerd op, de Clean Air Act heeft overtreden. Ten tweede kan een verlaging van het boetebedrag plaatsvinden als de overtreder de onrechtmatige situatie onmiddellijk herstelt. Tenslotte is een vermindering van het deel van de boete dat de gravity component vormt mogelijk als de overtreder zich reeds welwillend en coöperatief opstelt ten aanzien van het EPA tijdens het onderzoek met betrekking tot de mate waarin het bedrijf conform de regelgeving handelt of tijdens een onderzoek dat plaats vindt ten aanzien van een specifieke (luchtverontreinigende) gebeurtenis.

Aanpassing gravity component - recidive -

Als derde aanpassingsfactor ten aanzien van de gravity component wordt in de Clean Air Act Stationary Source Civil Penalty Policy genoemd de voorgeschiedenis van de overtreder ('history of noncompliance'). Het gaat dan om de voorgeschiedenis van de overtreder in die zin dat van belang is of de overtreder al vaker bepalingen uit, of op gebaseerd op, door het EPA te handhaven wetgeving, heeft overtreden. Deze factor mag alleen worden gebruikt om het boetebedrag te verhogen. Reden om over te gaan tot een verhoging bij een herhaalde overtreding van milieuregelgeving is, blijkens de Clean Air Act Stationary Source Civil Penalty Policy, gelegen in het feit dat de overtreder kennelijk door eerder opgelegde boeten niet in voldoende mate is afgeschrikt. Ook hier worden weer vijf subfactoren genoemd die relevant zijn voor het bepalen van de exacte verhoging van het boetebedrag.

De eerste subfactor die bepalend is voor de omvang van de verhoging van de boete is de vergelijkbaarheid van de overtreding met eerdere overtredingen. Ten tweede is relevant hoeveel tijd verstreken is tussen de te beboeten overtreding en de eerdere overtreding(en). De derde subfactor betreft het aantal eerdere overtredingen. Vervolgens is van belang hoe de overtreder bij eerdere overtredingen heeft gereageerd wat betreft het herstellen van de (on)rechtmatige toestand en welke pogingen hij heeft ondernomen om toekomstige overtredingen te voorkomen. Tenslotte moet gekeken worden in hoeverre de grovity component al is verhoogd in verband met herhaalde overtreding van milieuregelgeving - bijvoorbeeld op basis van een van de regelingen uit de appendix van de Clean Air Act Stationary Source Civil Penalty Policy -.

Verhoging van de gravity component bij recidive vindt niet plaats als één van de overtredingen heeft plaatsgevonden zonder dat de overtreder enige invloed had op de omstandigheden die de overtreding hebben veroorzaakt (overmacht).

Zie: de Clean Air Aut Stationary Source Civil Penalty Policy onderdeel II.A.4.b 'Degree of Cooperation'.

92 Zie: de Clean Air Act Stationary Source Civil Penalty Policy onderdeel Il.A.4.c 'History of Noncompliance'. 
Aanpassing gravity component - schade aan het milieu -

Tenslotte wordt als vierde aanpassingsfactor voor de gravity component genoemd de schade die ten aanzien van het milieu is aangericht door de overtreding. Hoewel bij de aanvankelijke berekening van de grovity component al wordt gekeken naar de schade die door de overtreding aan het milieu is aangericht kan de gravity component onder omstandigheden in verband met de milieuschade nog verder verhoogd worden. Dit is met name het geval als de schade aan het milieu dermate ernstig is dat de 'blote' grovity component op zich niet afschrikkend genoeg werkt. ${ }^{93}$

\section{Aanpassing van het totale preliminary deterrence amount}

Tenslotte zijn er nog drie factoren die van invloed kunnen zijn op de hoogte van het volledige boetebedrag zoals weergegeven in het preliminary deterrence amount.

Ten eerste zal het EPA de boete verlagen als er sprake is van proces-risico (litigation risk). Er is sprake van 'litigation risk' als de kans groot is dat een Administrative Law Judge of een (constitutional) court de boete zal verlagen, maar ook als de berekende boete hoger is dan de wettelijk toegestane maximum boete. ${ }^{94}$ In dergelijke gevallen kan (en zal) het EPA derhalve de boete zoals vastgesteld in het preliminary deterrence amount verlagen.

Een tweede reden om het preliminary deterrence amount aan te passen is gelegen in de (on)mogelijkheid van de overtreder om de boete te betalen. Het moet echter niet zo zijn de bedrijven die moeite hebben om het hoofd boven water te houden overtreding van milieuregelgeving zien als een manier om hun bedrijf te redden. Het EPA heeft derhalve de bevoegdheid om, onder omstandigheden, een boete op te leggen die kan (of zal) leiden tot het faillissement van de overtreder. ${ }^{95}$

Ten slotte kan het preliminary deterrence amount worden aangepast als er ten aanzien van dezelfde overtreding door de overtreder al een boete is betaald aan een bestuursorgaan van een van de staten, aan een plaatselijk bestuursorgaan of aan (een groep) belanghebbende burgers. Het boetebedrag hoeft echter niet zonder meer verminderd te worden. De resterende boete moet daarnaast altijd voldoende afschrikkend blijven. ${ }^{96}$

Nadat het EPA de economic benefit component, de gravity component, en het preliminary deterrence amount heeft aangepast komt het initial penalty target figure tot stand. Met dit initial penalty target figure gaat het EPA de onderhandelingen in. Dit bedrag is tevens het boetebedrag dat wordt opgelegd in de complaint. ${ }^{97}$

Indien de aangeklaagde tot een schikking wil komen kan deze zelf tijdens de onderhandelingen nogmaals ingaan op de hierboven weergegeven aanpassingsfactoren. De bewijslast rust in dat geval op de overtreder. Hij moet aantonen dat er redenen zijn om het boetebedrag aan de hand van een (of enkele) specifieke aanpassingsfactoren te verla-

93 Zie: de Clean Air Act Stationary Source Civil Penalty Policy onderdeel II.A.4.d 'Environmental Damage'.

94 Zie: de Clean Air Act Stationary Source Civil Penalty Policy onderdeel III. 'LITIGATION RISK'.

95 Zie: de Clean Air Act Stationary Source Civil Penalty Policy onderdeel IV. 'ABILITY TO PAY'.

96 Zie: de Clean Air Act Stationary Source Civil Penalty Policy onderdeel V. 'OFFSETTING PENALTIES PAID TO STATE AND LOCAL GOVERNMENTS OR CITIZEN GROUPS FOR THE SAME VIOLATIONS'.

97 Zie hierover $\$ 6.3 .2 .2$ van dit hoofdstuk. 
gen. ${ }^{98}$ Indien vervolgens het initial penalty target figure, aan de hand van door de overtreder naar voren gebrachte feiten en omstandigheden, is aangepast, levert dit het adjusted penalty target figure op. Met dit boetebedrag worden de onderhandelingen afgesloten. Het is van belang dat door het EPA, bij de vaststelling van het definitieve boetebedrag, uitvoerig wordt gemotiveerd hoe het tot het adjusted penalty target figure is gekomen. ${ }^{99}$

Indien de overtreder instemt met het adjusted penalty target figure is hiermee de zaak afgedaan (op grond van sectie 22.18(b)(3) van de Rules of Practice moet de schikking dan overigens nog geformaliseerd worden door middel van een final order). Kan de overtreder echter niet instemmen met het definitieve boetebedrag, dan zal de procedure tot oplegging van een bestuurlijke boete uit de Rules of Practice verder moeten worden gevolgd.

Het moge duidelijk zijn dat het beleid, met betrekking tot het vaststellen van de hoogte van een bestuurlijke boete door het EPA, behoorlijk uitvoerig en gedetailleerd is. Evenals in Nederland lijkt men in de Verenigde Staten de bestuurlijke boete te beschouwen als een efficiënte en effectieve vorm van (punitieve) bestuursrechtelijke handhaving. Bestudering van het Amerikaanse boetebeleid leidt tot de conclusie dat met name (bestuursrechtelijke) sanctionering tegen zo laag mogelijke kosten wordt bevorderd.

Opvallend, in het kader van dit rechtsvergelijkend onderzoek, is het eerste doel dat ten grondslag ligt aan het boetebeleid. Er wordt namelijk veel waarde gehecht aan de afschrikkende werking van de op te leggen bestuurlijke boete. Het leedtoevoegende aspect lijkt bij het realiseren van afschrikkende werking - voor het boetebeleid van het EPA - onmisbaar te zijn. ${ }^{100}$ Er wordt immers (vrijwel) altijd een boete opgelegd die (vele malen) hoger is dan voor herstel van de onrechtmatige toestand nodig is. Het komt zelfs regelmatig voor dat het met de overtreding behaalde economisch voordeel nihil wordt geacht terwijl er wel een fikse boete (van bijvoorbeeld $\$ 47.000,-{ }^{101}$ ) wordt opgelegd. Aan genoemde boete ligt dan slechts de idee van afschrikkende werking (door middel van leedtoevoeging) ten grondslag. Dit duidt op een punitieve bestuursrechtelijke sanctie. ${ }^{102}$ Het opleggen van een dergelijke punitieve bestuursrechtelijke

Zie: de Clean Air Act Stationary Source Civil Penalty Policy onderdeel IV. 'ABILITY TO PAY: The burden to demonstrate inability to pay, as with the burden of demonstrating the presence of any other mitigating circumstances, rests on the defendant.'

99 Zie: de Clean Air Act Stationary Source Civil Penalty Policy onderdeel X. 'CONCLUSION'.

$100 \mathrm{Vgl}$. in dit kader hoofdstuk 2, i.h.b. \$2.2.3.2.b.

$101 \mathrm{Vgl}$. United States Environmental Protection Agency (Region 5), complaint, and notice of opportunity for hearing on proposed administrative order assessing penalties, against 'Ashbach Construction Company', 31 januari 1997, docket no. 5-CAA-97-003. In genoemde klacht werd de hierboven weergegeven boete voorgesteld. Ter illustratie wordt op deze plaats voorts verwezen naar de homepage van het EPA (http://www.epa.gov). Via genoemde homepage zijn vele boetebesluiten en rechterlijke uilspraken met betrekking tot boetebesluiten te raadplegen.

102 Vgl. Blomberg a.w. 2000, p. 251 en Mann a.w. 1992. Zie voorts een uitspraak van het Supreme Court inzake Tull v. United States, 481 U.S. 412 (1987). Het Supreme Court bestempelt een 'civil penalty' in die zaak (mede met het oog op de wetgeschiedenis) als punitief (en als 'the imposition of punishment') vanwege 'the need for retribution and deterrence, in addition to restitution'. Zie voorts: United States versus Ha'per, 490 U.S. 435 (1989), waarin het Supreme Court het volgende overweegt: 'From these premises, it follows that a civil sanction that cannot fairly be said solely to serve a remedial purpose, 
sanctie wordt door het Europees Hof voor de Rechten van de Mens in de regel aangemerkt als een 'criminal charge'. De vraag of de aan Amerikaanse bestuurlijke boete door het Supreme Court ook de kwalificatie 'criminal' wordt toebedeeld komt in het volgende hoofdstuk aan de orde.

\subsection{Afsluitend}

Zoals aan het begin van dit hoofdstuk werd aangegeven bestond in Amerika de mogelijkheid tot het opleggen van een bestuurlijke boete al in de negentiende eeuw. Als vanaf het begin van de twintigste eeuw de overheidsinvloed zich vervolgens tot steeds meer terreinen uit gaat breiden leidt dit tot de opkomst van vele agencies die al snel worden ondergebracht onder de noemer 'fourth branch'. Ieder agency houdt zich bezig met een specifiek (deel)gebied van het bestuursrecht. In het kader van het milieurecht is bijvoorbeeld het Environmental Protection Agency (EPA) in het leven geroepen.

Zoals uit hoofdstuk vijf reeds is gebleken maken agencies, ter uitvoering van de wet in formele zin, nadere regelgeving, zijn zij bezig met de uitvoering en handhaving van regelgeving en doen zij aan (een bepaalde vorm van) eerstelijnsrechtspraak (te vergelijken met een vorm van bezwaar c.q. administratief beroep). De onder de fourth branch vallende agencies hebben van de wetgever doorgaans ook bestuursrechtelijke sanctiebevoegdheden gekregen ${ }^{103}$, waaronder de mogelijkheid tot het opleggen van een bestuurlijke boete.

De opkomst van de bestuurlijke boete vertoont duidelijke parallellen met de opkomst van de fourth branch. In de loop van de twintigste eeuw is de bestuurlijke boete in de Verenigde Staten derhalve meer en meer in zwang gekomen. De laatste twee decennia van de twintigste eeuw is de administratiefrechtelijke sanctionering, waaronder oplegging van bestuurlijke boeten, in de Verenigde Staten echter nog aanzienlijk omvangrijker geworden. ${ }^{104}$ Men zou zelfs kunnen spreken van een explosieve groei van de mogelijkheid voor bestuursorganen om bestuurlijke boeten op te leggen.

In de Verenigde Staten bestaat geen uniforme bestuurlijke boeteregeling die van toepassing is bij de oplegging van (alle uit de bijzondere wetten voortvloeiende) bestuurlijke boeten. In iedere wet in formele zin is oplegging van de bestuurlijke boete weer op een enigszins andere wijze geregeld. Toch is het mogelijk om op basis van een specifieke regeling, in combinatie met meer algemene (agency-)regelgeving zoals de Rules of Practice en de Policy on Civil Penalties, een beeld te krijgen van de bestuurlijke boete zoals die in de Verenigde Staten wordt opgelegd.

Gebleken is dat bij oplegging van een bestuurlijke boete - op grond van de Clean Air Act of de Marine Protection Research, and Sanctuaries Act - conform de Rules of Practice slechts invulling wordt gegeven aan een beperkt aantal (essentiële) straf(proces)rechtelijke waarborgen die in acht genomen zouden moeten worden bij de oplegging van een bestuurlijke boete. Aan enkele fundamentele eisen wordt in de Ame-

but rather can only be explained as also serving either retributive or deterrent purposes, is punishment,

Zie hoofdstuk vijf van dit boek.

l04 Vgl. Mann a.w. 1992. 
rikaanse boeteregelingen niet voldaan. Zo kan gewezen worden op het feit dat zowel aan het una via-beginsel als aan het ne bis in idem-beginsel geen invulling is gegeven in de bestudeerde boeteregelingen. Hetzelfde geldt voor het zwijgrecht en de cautieplicht en het recht op rechtspraak in twee feitelijke instanties. Dat genoemde waarborgen in de Amerikaanse boeteregeling ontbreken leidt tot de conclusie dat er ernstige tekortkomingen - met betrekking tot de rechtsbescherming van de vermoedelijke overtreder - kleven aan de boeteregeling.

Tenslotte volgt nog een opmerking over het beleid met betrekking tot het vaststellen van de hoogte van de op te leggen bestuurlijke boete. Het beleid dat door het EPA wordt gevoerd met betrekking tot het vaststellen van de hoogte van de op te leggen bestuurlijke boete is vrij uitvoerig en gedetailleerd. Blijkens de toelichting op de Policy on Civil Penalties en de Clean Air Act Stationary Source Civil Penalty Policy heeft de gedetailleerde beleidslijn (onder meer) ten doel de rechtsgelijkheid in de Verenigde Staten te bevorderen in die zin dat ten aanzien van vergelijkbare overtredingen vergelijkbare boeten worden opgelegd. Door een dergelijk consistent beleid wordt tevens voorkomen dat bij de burgers de indruk ontstaat dat oplegging van de boeten willekeurig geschied. Dit neemt niet weg dat er ruimte is om, met betrekking tot specifieke (de overtreder betreffende) feiten rekening te houden.

Belangrijker dan de rechtsgelijkheid is wellicht nog de afschrikkende werking die van de op te leggen boete uit moet gaan. Op grond van het gedetailleerde boetebeleid wordt er voor gezorgd dat er naast herstel van de onrechtmatige toestand (onder meer door het wegnemen van het economisch voordeel van de overtreding) ook leedtoevoeging wordt gerealiseerd. Genoemde leedtoevoeging bestaat uit een verhoging van het boetebedrag in verband met bepaalde, in beleidsregel weergegeven, (de overtreder betreffende) (aanpassing)factoren. Deze verhogingen van het boetebedrag, die met name een afschrikkende werking beogen, kunnen er niet meer toe leiden dat de onrechtmatige situatie hersteld wordt in een rechtmatige. Voorts zien genoemde verhogingen niet slechts op compensatie van de geleden schade. Zij hebben derhalve (mede) bestraffing (achteraf) ten doel. De Amerikaanse bestuurlijke boete is daarmee, evenals de Nederlandse bestuurlijke boete, te kwalificeren als een punitieve sanctie. 


\section{Constitutionele waarborgen bij de oplegging van de bestuurlijke boete}

\subsection{Inleiding}

In hoofdstuk zeven staat de vraag centraal of er in Amerika bepaalde constitutionele waarborgen zijn die in acht moeten worden genomen bij oplegging van de bestuurlijke boete. Nadat deze vraag beantwoord is kan beoordeeld worden in hoeverre oplegging van de bestuurlijke boete in de Verenigde Staten met essentiële straf(proces)rechtelijke waarborgen is omkleed. Daarmee kan tevens worden aangegeven in welke mate in de Verenigde Staten rechtsbescherming geboden wordt bij de oplegging van punitieve bestuursrechtelijke sancties, en dan in het bijzonder ten aanzien van de bestuurlijke boete. $^{1}$

In dat kader zal in het bijzonder ingegaan worden op die waarborgen die normaal gesproken een rol spelen in de strafrechtelijke context. ${ }^{2}$ Het gaat derhalve om waarborgen die vergelijkbaar zijn met de waarborgen die met betrekking tot de Nederlandse bestuurlijke boete onder meer voortvloeien uit artikel 6 van het EVRM. Met name speelt in dit hoofdstuk de vraag of het ne bis in idem-beginsel, het una via-beginsel en het zwijgrecht ${ }^{3}$ van toepassing zijn bij oplegging van de Amerikaanse bestuurlijke boete, een belangrijke rol. ${ }^{4}$ De toepasselijkheid van de genoemde waarborgen, zo zal hiema nog blijken, zal in het bijzonder afhangen van de vraag of het Supreme Court de bestuurlijke boete kwalificeert als een straf (punishment).

In dit hoofdstuk zal ten eerste (beknopt) beschreven worden welke straf(proces)rechtelijke constitutionele waarborgen van toepassing zouden kunnen zijn. Vervolgens wordt aan de hand van een analyse van de rechtspraak van het Supreme Court aangegeven of deze waarborgen ook daadwerkelijk gelden bij de oplegging van de bestuurlijke boete in de Verenigde Staten. Naar aanleiding van genoemde jurisprudentie-studie kan dan worden aangegeven in hoeverre de procedure tot oplegging van de bestuurlijke boete in de Verenigde Staten met essentiele straf(proces)rechtelijke waarborgen is omkleed.

Tenslotte dient nog te worden opgemerkt dat er voor is gekozen in dit hoofdstuk de relevante (soms vrij omvangrijke) passages uit de uitspraken van het Supreme Court integraal op te nemen. De reden die aan deze keuze ten grondslag ligt is dat de Ameri-

1 Deze laatste vraag zal overigens in hoofdstuk acht beantwoord worden.

2 Met name het vijfde, zesde en achtste amendement van de Amerikaanse Grondwet zijn daarbij relevant nu daarin een aantal waarborgen zijn opgenomen die op grond van het karakter van de bestuurlijke boete dienen te gelden bij oplegging van een bestururlijke boete. Daamaast zal naar het achtste amendement gekeken worden omdat daarin een proportionaliteitseis besloten ligt voor wat betreft de hoogte van de boete in verhouding tot de begane overtreding.

3 Of het verder strekkende nemo tenetur-beginsel in ruimere zin. Vgl. m.b.t. het onderscheid tussen het nemo tenetur-beginsel in ruimere en engere zin: Quaedvlieg a.w. 2001, p. 354 e.v.

$4 \quad \mathrm{Zie} \$ 6.2 .2$. Deze twee waarborgen (nr. I en 4 uit het schema in $\$ 6.2 .2$ ) hoeven, in het Amerikaanse recht, niet in acht genomen te worden op basis van de Rules of Practice en ook niet op basis van de bijzondere wet waarin de specifieke boeteregeling is opgenomen. 
kaanse jurisprudentie vanuit Nederland niet voor eenieder op een eenvoudige wijze toegankelijk is.

\subsection{Constitutionele waarborgen}

In deze paragraaf zal - beknopt - worden ingegaan op de constitutionele waarborgen die (met name) voortvloeien uit het vijfde, zesde en achtste amendement van de Amerikaanse Grondwet. Zoals reeds is aangegeven zijn in genoemde amendementen een aantal strafrechtelijke waarborgen terug te vinden die vergelijkbaar zijn met de waarborgen die zijn opgenomen in artikel 6 van het EVRM.

\section{$\checkmark$ ijfde amendement}

Het vijfde amendement bevat onder andere een bepaling omtrent het 'privilege against self-incrimination' en de 'double jeopardy clause' en is daarmee het meest relevant voor dit onderzoek gelet op de vraag die centraal staat in dit hoofdstuk. Hier zal eerst de (Engelstalige) tekst van het vijfde amendement worden weergegeven:

\section{AMENDMENT V \\ No person shall be held to answer for a capital, or otherwise infamous crime, unless on a presentment or indictment of a Grand Jury, except in cases arising in the land of naval forces, or in the Militia, when in actual service in time of War or public danger; nor shall any person be subject for the same offence to be twice put in jeopardy of life or limb; nor shall be compelled in any criminal case to be a witness against himself, nor be deprived of life, liberty, or property, without due process of law; nor shall private property be taken for public use, without just compensation.}

In het vijfde amendement zijn vijf straf(proces)rechtelijke waarborgen neergelegd. Ten eerste is de 'double jeopardy clause' - inhoudende dat: 'no person shall be subject for the same offence to be twice put in jeopardy of life or limb' - opgenomen in het vijfde amendement. De 'double jeopardy clause' brengt volgens het Supreme Court bescherming met zich tegen drie verschillende inbreuken op de fundamentele rechten van de burger. De drie inbreuken met betrekking tot de 'double jeopardy clause' bestaan uit: 'a second prosecution for the same offence after acquittal; a second prosecution for the same offence after conviction; and multiple punishment for the same offence. ${ }^{5}$

De 'double jeopardy clause' lijkt derhalve vergelijkbaar te zijn met het ne bis in idembeginsel dat van toepassing is bij de oplegging van een bestuurlijke boete in Nederland. ${ }^{6}$ Daarnaast lijkt ook dubbele bestraffing bij eendaadse samenloop uitgesloten te worden op grond van de 'double jeopardy clause' zoals neergelegd in het vijfde amendement.

Naast de reeds genoemde 'double jeopardy clause' zijn er nog drie 'clauses' opgenomen in het vijfde amendement. Het gaat om de 'grand jury clause', de 'due process clause', en de 'takings clause'.' In de - voor dit onderzoek relevante - rechtspraak van het Su-

6 Het una via-beginsel maakt zo bezien geen deel uit van de in het vijfde amendement opgenomen 'double jeopardy clause'.

7 Zie: Carol S. Steiker, Twenty-sixth anual review of criminal procedure: foreword: Punishment and Procedure: Punishment Theory and the Criminal-Civil Procedural Devide, Georgetown Law Joumal, 
preme Court gaat het echter doorgaans om de 'double jeopardy clause'. Voor dit onderzoek is uiteraard ook het in het vijfde amendement neergelegde - met het nemo tenetur-beginsel vergelijkbare - 'privilege against self-incrimination' van belang. Omtrent de toepasselijkheid van het nemo tenetur-beginsel bij het opleggen van een (Amerikaanse) bestuurlijke boete zullen hierna enkele uitspraken van het Supreme Court aan de orde komen. Overigens lijkt men in de Verenigde Staten uit te gaan van een enge interpretatie van het nemo tenetur-beginsel. Cann schrijft over de reikwijdte van het nemo tenetur-beginsel het volgende:

'The court has restricted the concept of "self-incrimination" so that it applies only to individuals and not to businesses. It applies only in cases in which criminal charges could result and hence does not apply in civil actions such as administrative law. Finally, selfincrimination applies only to oral testimony. It does not apply to physical evidence, such as records or test results. ${ }^{8}$

Daarmee lijkt het Supreme Court het nemo tenetur-beginsel te beperken tot bewijs van 'testimonial or communicative nature'. In de regel gaat het dan om mondelinge verklaringen. Er is in beginsel, op grond van het vijfde amendement, dan ook slechts sprake van een zwijgrecht (ofwel van het nemo tenetur-beginsel in enge zin). ${ }^{9}$

\section{Zesde amendement}

Het zesde amendement luidt als volgt:

\section{AMENDMENT VI}

In all criminal prosecutions, the accused shall enjoy the right to a speedy and public trial, by an impartial jury of the State and district wherein the crime shall have been committed, which district shall have been previously ascertained by law, and to be informed of the nature and cause of the accusation; to be confronted with the witnesses against him; to have compulsory process for obtaining witnesses in his favour, and to have the Assistance of Counsel for his defence.

Bestudering van het zesde amendement leidt tot de conclusie dat in genoemd amendement een aantal waarborgen is opgenomen die ook deel uit maken van artikel 6 van het EVRM. Zo is in het zesde amendement (onder meer) invulling gegeven aan het redelijke termijnvereiste, het vereiste van openbaarheid van de zitting, het onpartijdigheidsvereiste (onpartijdigheid van de jury), het vereiste van inkennisstelling van de gronden waarop de beschuldiging berust, het beginsel van hoor en wederhoor en het recht op rechtsbijstand. In de volgende subparagraaf zal echter blijken dat bij oplegging van een bestuurlijke boete in de Verenigde Staten vrijwel nooit een beroep wordt gedaan op dit amendement.

9 Vgl. P. Bal, Murphy's law? Over de uitholling van het nemo tenetur beginsel in Amerika, in de bundel: Nemo tenetur, onder redactie van J.M. Reijntjes, Gouda Quint bv, Amhem 1996, p. 23-40, en E.E.V. Lenos, De sociale en fiscale inlichtingenplicht en het zwijgrecht sinds Saunders, NJB 1997, p. $795-$ 800 , i.h.b. p. 796 . Zie in deze zin ook Reijntjes a.w. 1996, p. 17-18. Zie voorts $\$ 3.4 .3$ van dit boek. 


\section{Achtste amendement}

Het achtste amendement, dat vaker een rol speelt in de hierna te behandelen jurisprudentie van het Amerikaanse Supreme Court, luidt als volgt:

\section{AMENDMENT VIII}

Fixcessive bail shall not be required, nor excessive fines imposed, nor cruel and unusual punishment inflicted.

Voor dit onderzoek is in het bijzonder de 'excessive fines clause' relevant. Deze 'excessive fines clause' heeft met name ten doel rechtstreeks door de overheid, als straf (punishment) voor een bepaalde overtreding, opgelegde boeten wat betreft de hoogte te beperken. ${ }^{10}$ In de volgende paragraaf zal in worden gegaan op de vraag of de Amerikaanse bestuurlijke boete ook valt onder de 'fines' waarop het achtste amendement ziet.

\subsection{Opvattingen in de rechtspraak}

In de Amerikaanse literatuur en rechtspraak is geen eenduidig antwoord te vinden op de vraag of bij oplegging van een bestuurlijke boete de waarborgen uit het vijfde, zesde en achtste amendement van toepassing zijn. " Doorslaggevend voor een positieve beantwoording van genoemde vraag is of oplegging van de bestuurlijke boete aangemerkt kan worden als de oplegging van een sanctie met een 'criminal' karakter en of er sprake is van 'punishment'.

De rechtspraak van het Supreme Court is in dat kader zeer wisselend. Gedurende bepaalde momenten in de vorige eeuw vertoont de rechtspraak van het Supreme Court (sterke) overeenkomsten met de rechtspraak van het Europees Hof voor de Rechten van de Mens (in het kader van het 'criminal charge-begrip'). Ook niet 'typisch strafrechtelijke sancties' worden dan (onder meer vanwege hun punitieve aard) aangemerkt als 'punishment'. Dit zou met zich kunnen brengen dat in de Verenigde Staten de waarborgen uit het vijfde, zesde en achtste amendement in acht moeten worden genomen bij de oplegging van bestuurlijke boeten.

Uit het hierna volgende jurisprudentie-overzicht zal echter blijken dat de kans van slagen van een beroep op het vijfde, zesde of achtste amendement bij de oplegging van een bestuurlijke boete in de Verenigde Staten niet erg groot is. Dit heeft met name te

10 Zie Browning-Ferris Industries v. Kelco Disposals, 492 U.S. 257, S. Ct. 1989: '..., the history of the Eight Amendment convinces us that the Excessive Fines Clause was intended to limit only those fines directly imposed by, and payable to, the government.'

11 De rechtspraak van het Supreme Court is zo onduidelijk dat er zelfs ten aanzien van cén overheidsmaatregel verschillende uitspraken bestaan. Zo oordeelt het Supreme Court ten aanzien van dezelfde maatregel bijvoorbeeld in een zaak dat de maatregel 'punishment' betreft terwijl op dit oordeel in een andere zaak vervolgens weer wordt teruggekomen. Zie in dit kader Austin v. U.S., 509 U.S. 602, S. Ct. 1993, en U.S. v. Ursery, 518 U.S. 267, S. Ct. 1996. In beide zaken paste de overheid dezelfde maatregel toe (in rem civil forfeiture). In de zaak Austin merkte het Supreme Court deze maatregel aan als 'criminal' en als 'punishment'. Derhalve was in de zaak Austin het achtste amendement van toepassing. In de zaak Ursery, waar het om dezelfde 'sanctie' ging, was er volgens het Supreme Court geen sprake van 'punishment'. Het Supreme Court was dan ook van mening dat in de zaak Ursery het vijfde amendement niet van toepassing was. Zie over de inconsistente benadering van het Supreme Court ook: Carol S. Steiker, Twenty-sixth anual review of criminal procedure: foreword: Punishment and Procedure: Punishment Theory and the Criminal-Civil Procedural Devide, Georgetown Law Journal, april 1997. 85 Geo. L.J. 775 , p. 797 en verder. 
maken met het feit dat het Supreme Court zich de laatste jaren terughoudend opstelt wat betreft de kwalificatie van 'niet typisch strafrechtelijke sancties' als 'punishment'.

In deze paragraaf zal, zoals gezegd, de rechtspraak van het Supreme Court besproken worden. In de diverse te bespreken uitspraken gaat het om de toepasselijkheid van verschillende amendementen. De rechtspraak ziet niet alleen op de oplegging van bestuurlijke boeten. Daamaast spelen ook diverse 'civil remedies' ${ }^{12}$ een rol in de te bespreken uitspraken. De eisende partij stelt zich, in de uitspraken die hiema volgen, steeds op het standpunt dat de toegepaste 'civil remedy', of de opgelegde bestuurlijke boete, aangemerkt moet worden als een sanctie die 'criminal' van aard is, of dat er sprake is van 'punishment'. ${ }^{13}$ Dit brengt met zich dat bepaalde straf(proces)rechtelijke waarborgen (uit de hiervoor genoemde amendementen) bij oplegging van de bestuurlijke boete of bij de toepassing van een 'civil remedy' in acht genomen zouden moeten worden.

In de uitspraken die aan de orde komen staat doorgaans de vraag centraal of er sprake is van 'punishment'. ${ }^{14} \mathrm{Op}$ basis van de constatering dat een sanctie 'punishment' behelst wordt vervolgens meestal bekeken of er in strijd met het vijfde, zesde of achtste amendement gehandeld is. ${ }^{15}$

12 Naast de bevoegdheid tot oplegging van bestuurlijke boeten beschikken bestuursorganen vaak over de mogelijkheid om middels 'civil remedies' handhaving van gestelde normen te bewerkstelligen. Zie Mary $M$. Cheh, Constitutional Limits on Using Civil Remedies To Achieve Criminal Law Objectives: Understanding and Transcending the Criminal-Civil Law Distinciton, Hastings Law Joumal, july 1991, 42 Hastings L.J. 1325, 1334. Cheh beschrijft onder andere de volgende Civil Remedies: (1) Restitution en Recompense, (2) Statutory Fines and Penalties, (3) Loss of Govemment Benefits and Privileges, (4) Forfeitures, (5) Injunctions and Civil Protection Orders, (6) Detention and Civil Commitment. Met het oog op het voorgaande dient opgemerkt te worden dat er een onderscheid gemaakt moet worden tussen de oplegging van een bestuurlijke boete door een angency (middels een administrative penalty order) en de oplegging van een 'civil fine' door de rechter op grond van een namens het bestuursorgaan geěntameerde rechterlijke procedure (civil remedy) (vgl. Blomberg a.w. 2000, p. 239-242). Zie ter illustratie 33 U.S.C. 1319 (d) en 33 U.S.C. 1319(g). Uit genoemde bepalingen blijkt dat er op grond van de Clean Water Act bestuurlijke boeten kunnen worden opgelegd door het EPA terwijl daamaast voor bepaalde overtredingen hogere boeten middels een 'civil fine' door de rechter kunnen worden opgelegd. Tenslotte zij nog opgemerkt dat er in de Verenigde Staten géén principieel onderscheid tussen publiekrecht en privaatrecht wordt gemaakt. Dit brengt met zich dat alle zaken waarvoor een rechterlijke procedure moet worden gevoerd (met uitzondering van strafzaken) worden gekwalificeerd als 'civil'. Of het gaat om een geschil tussen overheid en burgers of tussen burgers onderling is in dat kader niet relevant (vgl. Blomberg a.w. 2000, p. 237).

13 In dit kader dient niet uit het oog verloren te worden dat in de Verenigde Staten (op basis van 'civil remedies') zelfs voor burgers mogelijkheden zijn gecrečerd om (bestuurlijke) boeten op te (laten) leggen ten aanzien van (rechts)personen die bepaalde bestuursrechtelijke regelgeving hebben overtreden. De burger fungeert in dat kader als een soort 'openbare aanklager'. In bepaalde gevallen wordt bovendien, indien de overtreding gesanctioneerd wordt, een deel van het boetebedrag uitgekeerd aan de 'aanklagende' burger. Zie in dit kader: Peter M. Shane, Returning Separation-of-Powers Analysis to Its Normative Roots: The Constitutionality of Qui Tam Actions and Other Private Suits to Enforce Civil Fines, Environmental Law Reporter, december 2000, 30 ELR 11081.

14 De rechtspraak van het Supreme Court is (op zijn zachtst gezegd) behoorlijk casuirstisch. Er bestaat geen consistente lijn in rechtspraak van het Supreme Cour waanuit kan worden afgeleid wanneer er sprake is van 'punishment'. Het is derhalve vaak moeilijk vast te stellen waneer een bepaalde 'civil remedy' resulteert in een vorm 'punishment' die dusdanig is dat de waarborgen uit de hiervoor genoemde amendementen dienen te gelden, Zie hierover ook: Steiker a.w. 1997, p. 780-781.

15 Zie Matthew C. Solomon, The Perils of Minimalism: United States v. Bajakajian in the Wake of the 
Aan de hand van de hierna volgende analyse van de rechtspraak van het Supreme Court zal worden aangegeven of de, uit de hierboven genoemde amendementen voortvloeiende, waarborgen ook daadwerkelijk gelden bij de oplegging van de bestuurlijke boete in de Verenigde Staten. Naar aanleiding van genoemde jurisprudentie-studie kan dan worden aangegeven in hoeverre oplegging van de bestuurlijke boete in de Verenigde Staten met essentiële straf(proces)rechtelijke waarborgen is omkleed.

\subsubsection{De rechtspraak van het Supreme Court}

Nu volgt een weergave van de rechtspraak van het Supreme Court met betrekking tot de vraag of de oplegging van een bestuurlijke boete, of de toepassing van een bepaalde 'civil remedy', aangemerkt moet worden als 'punishment' en derhalve als 'criminal sanction' ofwel als 'criminal prosecution'. Op basis van het hierna volgende jurisprudentie-onderzoek wordt met name getracht vast te stellen of er bepaalde (algemene) criteria door het Supreme Court zijn geformuleerd die kunnen worden gehanteerd bij het beantwoorden van de vraag of er sprake is van 'punishment'. De rechtspraak van het Supreme Court zal hieronder in chronologische volgorde worden besproken.

\subsection{I.a Boyd versus United States (1886)}

De eerste uitspraak die hier aan de orde komt is 'Boyd versus United States' ${ }^{16}$ uit 1886. In deze uitspraak stond de wijze waarop ontduiking van invoerrechten werd gesanctioneerd centraal. Naast het opleggen van een strafrechtelijke boete en/of gevangenisstraf kon de handelswaar die op een frauduleuze wijze was ingevoerd (in een civiele procedure) verbeurdverklaard worden (in rem civil forfeiture ${ }^{17}$ ). In deze 'civiele' procedure tot verbeurdverklaring werd de gedaagde - op grond van de wet waarin de procedure tot verbeurdverklaring geregeld was - gedwongen om tegen zichzelf te getuigen. Het Supreme Court merkt de 'civiele procedure' tot verbeurdverklaring aan als een procedure van strafrechtelijke aard. Derhalve was het in het vijfde amendement opgenomen 'privilege against self-incrimination' volgens het Supreme Court van toepassing op de 'civiele procedure' tot verbeurdverklaring. Aangezien de gedaagde in de procedure tot verbeurdverklaring gedwongen werd om tegen zichzelf te getuigen werd genoemde procedure door het Supreme Court in strijd met het vijfde amendement verklaard. ${ }^{18}$ Het voorgaande blijkt uit de nu volgende overwegingen van het Supreme Court in de zaak Boyd versus the United States:

'We are also clearly of opinion that [116 U.S. 616,634$]$ proceedings instituted for the purpose of declaring the forfeiture of a man's property by reason of offenses committed by

Supreme Court's Civil Double Jeopardy Excursion, Georgetown Law Joumal, February 1999, 87 Geo. L.J. 849, 88I: 'Recall that in order to invoke the protection of either the Excessive Fines Clause or the Double Jeopardy Clause, a court must determine that the sanction at issue constitutes punishment.'

16 Boyd v. U.S., 116 U.S. 616 (1886).

17 Zie: Cheh a.w. 1991, p. 1340. In haar artikel geeft zij aan wat het verschil is tussen 'criminal forfeitures' en 'civil forfeitures': 'Criminal forfeitures are in personam proceedings instituted as part of the criminal case against a defendant. ... A civil forfeiture is an in rem procceding. It is an action brought against the property, not against any particular person having an interest in the property. Historically, the proceeding was justified by the legal fiction that the property itself was guilty of wrongdoing.'

18 Zie met betrekking tot het in het vijfde amendement neergelegde 'privilege aganist self-incrimination' ook: Cheh a.w. 1991, p. 1384 en verder. 
him, though they may be civil in form, are in their nature criminal [curs. KA]. In this very case the ground of forfeiture, as declared in the twelfth section of the act of 1874, on which the information is based, consists of certain acts of fraud committed aguinst the public revenue in relation to imported merchandise, which are mude criminal by the statute; and it is declared, that the offender shall be fined not exceeding \$5,000, nor less than \$ 50, or be imprisoned not exceeding two years, or both; and in addition to such fine such merchandise shall be forfeited. These are the penalties affixed to the criminal acts, the forfeiture sought by this suit being one of them [curs. KA]. If an indictment had been presented against the claimants, upon conviction the forfeiture of the goods could have been included in the judgment. If the government prosecutor elects to waive an indictment, and to file a civil information against the claimants, - that is, civil in form, - can he by this device take from the proceeding its criminal aspect [curs. KA] and deprive the claimants of their immunities as citizens, and extort from them a production of their private papers, or, as an alternative, a confession of guilt? This cannot be. The information, though technically a civil proceeding. is in substance and effect a criminal one [curs. $\mathrm{KA}$ ]. As showing the close relation between the civil and criminal proceedings on the same statute in such cases we may refer to the recent case of Coffey v. U.S., 116 U.S., S.C. ante, 432 , in which we decided that an acquittal on a criminal information was a good plea in bar to a civil information for the forfeiture of goods, arising upon the same acts. As, therefore, suits for penalties and forfeitures, incurred by the commission of offenses against the law, are of this quasi criminal nature, we think that they are within the reason of criminal proceedings for all the purposes of the fourth amendment of the constitution, and of that portion of the fifth amendment which declares that no person shall be compelled in any criminal case to be a witness against himself: [curs. KA]'

De (civiele) verbeurdverklaringsprocedure is volgens het Supreme Court van quasi strafrechtelijke aard. De verbeurdverklaringsprocedure moet dan ook worden aangemerkt als een strafrechtelijke procedure voor wat betreft de toepasselijkheid van het vierde amendement en het nemo tenetur-beginsel uit het vijfde amendement. Waarom het Supreme Court de (civiele) verbeurdverklaringsprocedure aanmerkt als een strafrechtelijke procedure wordt niet volledig duidelijk uit de uitspraak. Twee aspecten lijken van belang te zijn. Namelijk ten eerste het feit dat de 'bijkomende' sanctie van (civiele) verbeurdverklaring deel uit maakt van de strafbepaling. ${ }^{19}$ Daarnaast verwijst het Supreme Court naar de zaak Coffey versus de United States. ${ }^{20}$ In genoemde zaak

19 De bepaling luidde als volgt: 'Any, owner, importer, consignee, etc, who shall, with the intent to defraud the reveneu, make, or attempt to make, any entry of imported merchandise, by means of any fraudulent or false invoice or affidavit, letter, or paper, or by means of any false statement, written or verbal, or who shall be guilty of any willful act or omission, by means whereof the United States shall be deprived of the lawfull duties, or any protion thereof, accruing upon the merchandise, or any portion thereof, embraced or referred to in such invoice, affidavit, letter, papaer, or statement, or affected by such act or omission, shall for each offense be fined in any sum not exceeding $\$ 5,000$ nor less than $\$ 50$, or be imprisoned for any time not exceeding two years, or both; and, in addition to such fine, such merchandise shall be forfeited.' (twelfth section of the 'Act to amend the customs revenue laws' passed 22 june 1874, (18 St. 186.)).

20 Coffey v. United States, 116 U.S. 436 (1886). Het Supreme Court heeft in deze zaak onder meer het volgende overwogen: '[W]here an issue raised as to the existence of the act or fact denounced has been tried in a criminal proceeding, instituted by the United States, and a judgment of acquittal has been rendered in favor of a particular person, that judgment is conclusive in favor of such person, on the subsequent trial of a suit in rem by the United States, where, as against him, the existence of the same act or fact is the matter in issue, as a cause for the forfeiture of the property prosecuted in such suit in rem. It is urged as a reason for not allowing such effect to the judgment, that the acquittal in the crimi- 
werd Coffey verdacht van belastingfraude gepleegd ten aanzien van de overheid met betrekking tot gedistilleerde (sterke) dranken. Coffey werd in het kader van de strafrechtelijke procedure met betrekking tot de belastingfraude vrijgesproken. Het Supreme Court oordeelt vervolgens dat vrijspraak in een strafrechtelijke procedure een daarop volgende procedure tot civiele verbeurdverklaring, gelet op de double jeopardyclause, uitsluit omdat de (civiele) verbeurdverklaring moet worden aangemerkt als 'punishment'. 21

Waarom de procedure tot civiele verbeurdverklaring gekwalificeerd moet worden als 'punishment' wordt echter niet duidelijk uit de zaken 'Boyd versus United States' en 'Coffey versus United States'. Enige onderbouwing door het Supreme Court op dat punt ontbreekt helaas.

\subsection{1.b Helvering versus Mitchell (1938)}

De tweede zaak die in het kader van deze jurisprudentie-analyse aan de orde komt is 'Helvering versus Mitchell'. ${ }^{22}$ Mitchell werd er van verdacht de inkomstenbelasting te hebben ontdoken. Het zou gaan om een bedrag van $\$ 728,709.84$. In de strafrechtelijke procedure die plaats vond wegens de vermeende belastingontduiking werd Mitchell vrijgesproken. Vervolgens werd hem een administratieve sanctie opgelegd. De sanctie bestond uit een verhoging van de te betalen belasting met $50 \%{ }^{23}$

Bij het Supreme Court stond vervolgens de vraag centraal of de administratieve sanctie aangemerkt moest worden als 'punishment' (bestraffing). Indien de sanctie inderdaad een bestraffing zou behelzen zou de 'double jeopardy'-clausule uit het vijfde amendement van toepassing zijn op de belastingverhoging van $50 \%$. Het voorgaande zou met zich brengen dat deze belastingverhoging niet opgelegd zou mogen worden vanwege de eerdere vrijspraak ten aanzien van hetzelfde vergrijp.

Met betrekking tot de vraag of de administratieve sanctie (die zeer grote gelijkenissen vertoont met de bestuurlijke boete) gekwalificeerd moest worden als punishment heeft het Supreme Court het volgende overwogen:

'The question for decision is thus whether section 293(b) imposes a criminal sanction. That question is one of statutory construction. (...) The remedial character of sanctions imposing ildditions to a tax has been made clear by this Court in passing upon similar legislation. They are provided primarily as a safeguard for the protection of the revenue and to

nal case may have taken place because of the rule requiring guilt to be proved beyond a reasonable doubt, and that, on the same evidence, on the question of preponderance of proof, there might be a verdict for the United States, in the suit in rem. Nevertheless, the fact or act has been put in issue and determined against the United States; and all that is imposed by the statute, as a consequence of guilt, is a punishment therefor. There could be no new trial of the criminal prosecution after the acquittal in it: and a subsequent trial of the civil suit amounts to substantially the same thing, with a difference only in the consequences following a judgment adverse to the claimant.'

21 Zic hierover ook: Stone v. United States, 167 U.S. 178 (1897) waarin het Supreme Court zowel op Coffey v. United States als op Boyd v. United States ingaat.

22 Helvering v. Mitchell, 303 U.S. 391 (1938).

23 De relevante bepaling uit de Amerikaanse belastingwet van 1928 (26 U.S.C.A. 293) luidde als volgt: '(b) Fraud. If any part of any deficiency is due to fraud with intent to evade tax, then 50 per centum of the total amount of the deficiency (in addition to such deficiency) shall be so assessed, collected, and paid.' 
reimburse the Government for the heavy expense of investigation and the loss resulting from the taxpayer's fraud. 4 In Stockwell v. United States, 13 Wall. 531, 547, 551, the Court said of a provision which added double the value of the goods:

"It must therefore be considered as remedial, as providing indemnity for loss. And it is not the less so because the liability of the wrongdoer is measured by double the value of the goods received, concealed, or purchased, instead of their single value. The act of abstracting goods illegally imported, receiving, concealing, or buying them, interposes difficulties in the way of a government seizure, and impairs, therefore, the value of the government right. It is, then, hardly accurate to say that the only loss the government can sustain from concealing the goods liable to seizure is their single value, or to assert that the liability imposed by the statute of double the value is arbitrary and without reference to indemnification. Double the value may not be more than complete indemnity. (...) The act of 1823 was, as we have seen, remedial in its nature. Its purpose was to secure full compensation for interference with the rights of the United States."

That Congress provided a distinctly civil procedure for the collection of the additional 50 per centum indicates clearly that it intended a civil, not a criminal, sanction. Civil procedure is incompatible with the accepted rules and constitutional guarantees governing the trial of criminal prosecutions, and where civil procedure is prescribed for the enforcement of remedial sanctions, those rules and guarantees do not apply. Thus the determination of the facts upon which liability is based may be by an administrative agency instead of a jury, or if the prescribed proceeding is in the form of a civil suit, [303 U.S. 391, 403] a verdict may be directed against the defendant; there is no burden upon the Government to prove its case beyond a reasonable doubt, and it may appeal from an adverse decision; furthermore, the defendant has no constitutional right to be confronted with the witnesses [303 U.S. 391, 404] against him, or to refuse to testify; and finally, in the civil enforcement of a remedial sanction there can be no double jeopardy. (...)

The fact that the Revenue Act of 1928 contains two separate and distinct provisions imposing sanctions, and that these appear in different parts of the statute, helps to make clear the character of that here invoked. (...) The sanction of 50 per centum addition "if any part of any deficiency is due to fraud with intent to evade tax," prescribed by section 293(b), introduced into the act under the heading "Additions to the tax," was clearly intended as a civil one. (...) Obviously all of these "additions to the Tax" were intended by Congress as civil incidents of the assessment and collection of the income tax.'

Het Supreme Court kwalificeert, in de zaak 'Helvering versus Mitchell', de administratieve sanctie, inhoudende een verhoging van de inkomstenbelasting met $50 \%$, niet als 'punishment' of als een 'criminal sanction'. Deze conclusie lijkt gebaseerd te zijn op twee argumenten.

Het eerste argument dat het Supreme Court aanvoert is dat de opgelegde belastingverhoging aangemerkt moet worden als reparatoire sanctie. De belastingverhoging voorziet, in de ogen van het Supreme Court, immers slechts in compensatie van de door de overheid gemaakte (handhavings)kosten. Dat er geen reëel verband is tussen de door de overheid gemaakte kosten en de opgelegde 'boete' lijkt in dat kader niet relevant te zijin. ${ }^{24}$

24 Zie hierover: Mann a.w. 1992, p. 1822: '...the compensatory approach, views money sanctions as "rough compenstation" rather than punishment. The money sanction is understood as a means to repay the government for the cost of enforcing the law. The idea that the sanction is more than compensatory does not prevent the courts from finding an essentially compensatory arrangement.' 
Ten tweede beoordeelt het Supreme Court de sanctie vanuit een puur legistische visie. Volgens het Supreme Court blijkt duidelijk uit de regelgeving dat het Congres een civiele procedure op het oog had zodat derhalve niet gezegd kan worden dat de administratieve sanctie een 'criminal sanction' is. Op basis van het voorgaande komt het Supreme Court tot de conclusie dat de waarborgen uit het vijfde amendement niet van toepassing zijn op de sanctie inhoudende een verhoging van de inkomstenbelasting.

Dit is wel een zeer enge en formele benadering van de termen 'punishment' en 'criminal sanction', of beter gezegd, een ruime interpretatie van de term reparatoire sancties. ${ }^{25} \mathrm{De}$ redenering van het Supreme Court doet nogal pragmatisch aan. Het lijkt er op dat het Supreme Court probeert vast te houden aan de civiele procedure om te voorkomen dat bij sanctionering de strafrechtelijke procedure, die met meer waarborgen is omkleed, moet worden gevolgd. Efficiënte en effectieve handhaving lijken dan ook voorop te staan.

Kenneth Mann heeft kritiek op de 'compensatory approach' van het Supreme Court. Hij stelt het volgende:

Mitchell and Marcus became part of a broader dynamic that transformed the term "remedial" into a catchall label for sanctions that courts did not want to define as punitive in the criminal sense, but that were clearly not simply compensatory damages. By referring to money sanctions as remedial, the Court could approve the use of civil procedures to impose sanctions designed to punish wrongdoers and could send a deterrent message to the community. By finding civil implications in a statute that certainly had punitive meaning for legislators, administrators, and the public, the Court made deft use of a legal fiction to facilitate and legitimate the increased use of punitive sanctions. ${ }^{26}$

Ik deel de kritiek van Mann. Men kan immers niet eenvoudigweg het etiket 'reparatoir' op een sanctie plakken en daarmee de ware aard van de sanctie 'verloochenen' met als enige doel efficiënte en effectieve handhaving. Het zou beter zijn als het Supreme Court de belastingverhoging aan de hand van materiële criteria had beoordeeld.

Het Supreme Court heeft in de zaak 'Helvering v. Mitchell' echter voor een andere weg gekozen en op grond van een nogal gekunstelde motivering de sanctie van belastingverhoging aangemerkt als een reparatoire sanctie. De 'double jeopardy-clause' uit het vijfde amendement werd derhalve niet van toepassing geacht in die zaak. In het kader van de rechtsbescherming van de (vermoedelijke) overtreder kan een dergelijke uitspraak uiteraard niet toegejuicht worden.

\subsection{I.c Kennedy versus Mendoza-Martinez (1963)}

De volgende uitspraak van het Supreme Court die aan de orde komt is 'Kennedy versus Mendoza-Martinez ${ }^{\prime 27}$ uit 1963. Deze uitspraak vertoont overeenkomsten met de zaak Öztürk van het Europees Hof voor de Rechten van de Mens (EHRM) ${ }^{28}$ wat betreft de criteria die volgens het Supreme Court relevant zijn voor beantwoording van de vraag of er sprake is van 'punishment'.

28 De ziak Oztïrk, Furopees Hof voor de Rechten van de Mens, 21 februari 1984, Series A vol. 73. 
Mendoza-Martinez werd het land uitgezet omdat hij (bij wijze van sanctie) zijn Amerikaans burgerschap had verloren. Mendoza-Martinez had het Amerikaanse burgerschap verloren omdat hij tijdens de Tweede Wereldoorlog de Verenigde Staten was ontvlucht om te voorkomen dat hij in militaire dienst zou moeten. Het ontnemen van het Amerikaans burgerschap vond destijds automatisch - zonder voorafgaande juridische of bestuurlijke procedure - plaats indien een persoon in tijd van oorlog het land verliet om de militaire dienstplicht te ontduiken.

De vraag die in de zaak 'Kennedy v. Mendoza-Martinez' centraal stond was of de sanctie (verlies van het Amerikaans burgerschap) strafrechtelijk van aard was. Indien deze vraag bevestigend beantwoord zou worden dan zou de wettelijke regeling op basis waarvan de sanctie werd opgelegd in strijd met (het vijfde en zesde amendement van) de Grondwet zijn.

\section{Het Supreme Court overweegt als volgt:}

'We hold 401 (j) and 349 (a) (10) invalid because in them Congress has plainly employed the sanction of deprivation of nationality as a punishment - for the offense of leaving or remaining outside the country to evade military [372 U.S. 144, 166] service - without affording the procedural safeguards guaranteed by the Fifth and Sixth Amendments. (...)

The punitive nature of the sanction here is evident under the tests traditionally applied to determine whether an Act of Congress is penal or regulatory in character, even though in other cases this problem has been extremely difficult and elusive of solution. Whether the sanction involves an affirmative disability or restraint, whether it has historically been regarded as a punishment, whether it comes into play only on a finding of scienter ${ }^{29}$, whether its operation will promote the traditional aims of punishment - retribution and deterrence, whether the behavior to which it applies is already a crime, whether an alternative purpose to which it may rationally be connected is assignable for it, and whether it appears excessive in relation to the alternative purpose assigned are all relevant to the inquiry, and may often point in differing directions. Absent conclusive evidence of congressional intent as to the penal nature of a statute, these factors must be considered in relation to the statute on its face [curs. KA]. Here, although we are convinced that application of these criteria to the face of the statutes supports the conclusion that they are punitive, a detailed examination along such lines is unnecessary, because the objective manifestations of congressional purpose indicate conclusively that the provisions in question can only be interpreted as punitive. A study of the history of the predecessor of 401 (j), which "is worth a volume of logic," New York Trust Co. v. Eisner, 256 U.S. 345, 349, coupled with a reading of Congress' reasons for enacting 401 (j), compels a conclusion that the statute's primary function is to serve as an additional penalty for [372 U.S. 144, 170] a special category of draft evader. (...)

The immediate legislative history of 401 (j) confirms the conclusion, based upon study of the earlier legislative and judicial history, that it is punitive in nature. (...)

Indeed, as indicated, the Attomey General's letter specificalty relied on the predecessor statute as precedent for this enactment, and both the letter and the debates, consistent with the character of the predecessor statute, referred to reasons for the enactment of the bill which were fundamentally retributive in nature. When all of these considerations are weighed. as they must be, in the context of the incontestably punitive nature of the predecessor statute, the conclusion that 401 (j) was itself dominantly punitive becomes

Scienter: knowingly, willens en wetens, opzettelijk. 
inescapable. The legislative history of 349 (a) (10) of the Immigration and Nationality Act of 1952, which re-enacted 401 (j), adds [372 U.S. 144, 184] nothing to disturb that result. Our conclusion from the legislative and judicial history is, therefore, that Congress in these sections decreed an additional punishment for the crime of draft avoidance in the special category of cases wherein the evader leaves the country. It cannot do this without providing the safeguards which must attend a criminal prosecution.'

Zoals hierboven reeds is aangegeven doet het Supreme Court in de zaak 'Kennedy v. Mendoza-Martinez' een uitspraak die enigszins vergelijkbaar is met de uitspraak van het EHRM in de zaak 'Öztürk'. Evenals het EHRM - in de zaak 'Öztürk' - lijkt het Supreme Court in 'Kennedy v. Mendoza-Martinez' de kwalificatie van het vergrijp door de wetgever (slechts) doorslaggevend te achten als de wetgever de sanctie de kwalificatie 'criminal' heeft gegeven. ${ }^{30}$ Volgt uit de wet of uit de wetsgeschiedenis dat het gaat om 'punishment' dan hoeven de (materiële) criteria niet meer bekeken te worden. Het strafrechtelijke karakter van de sanctie staat daarmee vast. Dit blijkt uit de volgende overweging van het Supreme Court: 'Absent conclusive evidence of congressional intent as to the penal nature of a statute, these factors must be considered in relation to the statute on its face. ${ }^{31}$

Spijtig genoeg gaat het Supreme Court in de zaak 'Kennedy v. Mendoza-Martinez' niet in op alle zeven genoemde factoren omdat volgens het Supreme Court uit oude regelgeving en uit de wetsgeschiedenis van de toegepaste bepalingen voldoende blijkt dat het gaat om een sanctie van punitieve aard. Bijzonder is wel dat het Supreme Court het vijfde en het zesde amendement in zijn geheel van toepassing verklaard op de, in de zaak 'Kennedy v. Mendoza-Martinez', opgelegde punitieve sanctie. ${ }^{32}$ Het Supreme Court geeft daarmee in feite te kennen dat alle daar genoemde strafprocessuele waarborgen moeten gelden in het kader van de oplegging van punitieve sancties. Helaas heeft het Supreme Court zich na 'Kennedy v. Mendoza-Martinez' niet meer zo ruimhartig over de toepasselijkheid van de constitutionele waarborgen bij de oplegging van punitieve (bestuursrechtelijke) sancties uitgelaten. ${ }^{33}$

\subsection{J.d United States versus Ward (1980)}

In de zaak 'United States v. Ward ${ }^{34}$ ging het om milieuvervuiling - veroorzaakt door het bedrijf dat door Ward werd geëxploiteerd - in de vorm van het lekken van olie in

30 Vgl. \$3.2. L.a van dit boek. Het EHRM lijkt in beginsel ook van de standpunt uit te gaan.

31 Zie ook Mary M. Cheh a.w. 1991, p. 1358: '...the Court in Mendoza made clear that it would shift to the multi-factor or comparative approach only if there was a real doubt about whether the legislature intended a proceeding to be civil or criminal. ... Only if there is marked uncertainty over what the legislature intended, or if the defendant provides 'clear proof' that 'the statutory scheme [was] so punitive either in purpose or in effect as to negate [the State's] intention', will the court engage in the factor analysis.'

32 Bij bestudering van de rechtspraak die in dit hoofdstuk is opgenomen zal nog blijken dat het Supreme Court doorgaans een bepaalde sanctie slechts als punitieve sanctie aanmerkt met het oog op de toepasselijkheid van een bepaalde 'clause' uit een amendement. Derhalve kan dan ook gezegd worden dat het Supreme Court in 'Kennedy v. Mendoza-Martinez' een ruime opvatting had wat betreft de toepasselijkheid van constitutionele waarborgen bij de daar aan de orde zijnde punitieve sanctie.

33 Zie ook Carol S. Steiker (aw. 1997, p. 798) die hierover het volgende opmerkt: 'Mendoza-Martinez is the only case in which the Supreme Court has held a statute denominated civil by a legislature to be 'really' criminal for all [curs. KA] procedureal purposes.' United States versus Ward, 448 U.S. 242 (1980). 
de Arkansas River. De wettelijke regeling (de Federal Water Pullution Control Act) voorziet in een meldingsplicht (op straffe van een geldboete of gevangenisstraf) bij dergelijke 'ongelukken' terwijl de watervervuiling (vervolgens) gesanctioneerd wordt door middel van een bestuurlijke boete. ${ }^{35}$ Door de meldingsplicht wordt Ward derhalve gedwongen om aan zijn eigen 'bestuursrechtelijke' bestraffing mee te werken.

De vraag, die voor het Supreme Court centraal staat in de zaak 'Ward', is of de hierboven weergeven wijze van bestuurs(straf)rechtelijke sanctionering in strijd is met het in het vijfde amendement neergelegde nemo tenetur-beginsel. Om die vraag te kunnen beantwoorden moet het Supreme Court eerst vast stellen of de procedure op grond waarvan de bestuurlijke boete door het EPA wordt opgelegd een 'criminal case' betreft. In dat kader dient het Supreme Court de vraag te beantwoorden of er sprake is van een 'criminal penalty'. Dienaangaande heeft het Supreme Court het volgende overwogen:

'This Court has often stated that the question whether a particular statutorily defined penalty is civil or criminal is a matter of statutory construction. See, e. g., One Lot Emerald Cut Stones v. United States, 409 U.S. 232, 237 (1972); Helvering v. Mitchell, supra, at 399. Our inquiry in this regard has traditionally proceeded on two levels. First, we have set out to determine whether Congress, in establishing the penalizing mechanism, indicated either expressly or impliedly a preference for one label or the other. See One Lot Emerald Cut Stones v. United States, supra, at 236-237. Second, where Congress has indicated an intention to establish a civil penalty, we have inquired further whether the statutory scheme was so punitive either in purpose or effect as to negate that intention. See Flemming v. Nestor, 363 U.S. 603, 617-621 (1960). In regard to this latter inquiry, we have noted that "only the clearest proof could suffice to establish the unconstitutionality of a statute on such a ground." Id., at 617. See also One Lot Emerald Cut Stones v. United Statcs, supra, at 237; Rex Trailer Co. v. United States, 350 U.S. 148, 154 (1956).[curs. KA] (...)

As for our first inquiry in the present case, we believe it quite clear that Congress intended to impose a civil penalty upon persons in Ward's position. Initially, and importantly, Congress labeled the sanction authorized in 311 (b) (6) a "civil penalty," a label that takes on added significance given its juxtaposition with the criminal penalties set forth in the immediately preceding subparagraph, 311 (b) (5). Thus, we have no doubt that Congress intended to allow imposition of penalties under 31 I (b) (6) without regard to the procedural protections and restrictions available in criminal prosecutions.

Het Supreme Court geeft de relevante bepalingen in de zaak 'Ward' weer: 'Section 311 (b) (5) of the Act imposed a duty upon "any person in charge of a vessel or of an onshore facility or an offshore facility" to report any discharge of oil or a hazardous substance into navigable waters to the "appropriate agency" of the United States Govemment. Should that person fail to supply such notification, he or she was liable to a fine of not more than $\$ 10,000$ or imprisonment of not more than one year.

Section 31 I (b) (5) also provided for a form of "use immunity", specifying that "[n]otification received pursuant to this paragraph or information obtained by the exploitation of such notification shall not be used against any such person in any criminal case, except a prosecution for perjury or for giving a false statement." 33 U.S.C. 1321 (b) (5).3

Section 311 (b) (6) provided for the imposition of a "civil penalty" against "[a]ny owner or operator of any vessel, onshore facility, or offshore facility from which oil or a hazardous substance is discharged in violation" of the Act. In 1975, that subsection called for a penalty of up to $\$ 5,000$ for each violation of the Act. In assessing penalties, the Secretary of the appropriate agency was to take into account "the appropriateness of such penalty to the size of the business or of the owner or operator charged, the effect on the owner or operator's ability to continue in business, and the gravity of the violation. . . " 33 U.S.C. 1321 (b) (6).' 
We turn then to consider whether Congress, despite its manifest intention to establish a civil, remedial mechanism, nevertheless provided for sanctions so punitive as to "transfor[m] what was clearly intended as a civil remedy into a criminal penalty." Rex Trailer Co. v. United States, supra, at 154 . In making this determination, both the District Court and the Court of Appeals found it useful to refer to the seven considerations listed in Kennedy v. MendozaMartinez, supra, at 168-169. This list of considerations, while certainly neither exhaustive nor dispositive, has proved helpful in our own consideration of similar questions, see, e. g., Bell v. Wolfish, 441 U.S. 520, 537-538 (1979), and provides some guidance in the present case. (...)

Without setting forth here our assessment of each of the seven Mendoza-Martinez factors, we think only one, the fifth, aids respondent. That is a consideration of whether "the behavior to which [the penalty] applies is already a crime." 372 U.S., at 168-169. (..)

While we agree that this consideration seems to point toward a finding that 311 (b) (6) is criminal in nature, that indication is not as strong as it seems at first blush. We have noted on a number of occasions that "Congress may impose both a criminal and a civil sanction in respect to the same act or omission." Helvering v. Mitchell, supra, at 399; One Lot Emerald Cut Stones v. United States, supra, at 235. Moreover, in Helvering, where we held a $50 \%$ penalty for tax fraud to be civil, we found it quite significant that "the Revenue Act of 1928 contains two separate and distinct provisions imposing sanctions," and that "these appear in different parts of the statute..." 303 U.S., at 404. See also One Lot Emerald Cut Stones v. United States, supra, at 236-237. To the extent that we found significant the separation of civil and criminal penalties within the same statute, we believe that the placement of criminal penalties in one statute and the placement of civil penalties in another statute enacted 70 years later tends to dilute the force of the fifth Mendoza-Martinez criterion in this case.'

De toetsing van de opgelegde bestuurlijke boete in de zaak 'Ward' vindt, zoals uit het hierboven weergegeven deel van de uitspraak blijkt, plaats in twee stappen. Ten eerste kijkt het Supreme Court naar de intenties die het Congres had bij het in het leven roepen van een sanctiemechanisme. Op basis daarvan moet worden vastgesteld of het Congres impliciet dan wel expliciet de voorkeur heeft gegeven aan de kwalificatie van een sanctie(mechanisme) als 'civil' of 'criminal'.

Uit de wijze waarop het Supreme Court de boeteregeling uit de Federal Water Pollution Control Act aan dit eerste criterium toetst blijkt dat het Supreme Court weer - dezelfde - legistische (formele) benadering voorstaat als in de zaak 'Helvering versus Mitchell' uit $1938 .^{36}$ Eigenlijk komt het erop neer dat het Congres, als het een sanctieregeling in het leven roept, door het etiket dat het op de regeling plakt, kan bepalen of belangrijke strafrechtelijke waarborgen van toepassing zijn bij oplegging van de sanctie. ${ }^{37}$ Het tweede toetsingscriterium, dat door het Supreme Court wordt gehanteerd in de zaak 'Ward', lijkt vervolgens niet meer veel heil te kunnen bieden. Het tweede toetsingscriterium hoeft alleen toegepast te worden als de sanctieregeling na toetsing aan het eerste criterium aangemerkt wordt als een 'civiele' regeling. ${ }^{38}$ Als de rechter op basis van het eerste criterium tot de conclusie is gekomen dat het Congres een 'civiele procedure' voorstond moet hij vervolgens bepalen of de wettelijke regeling, wat betreft het doel of gevolg van de sanctie, dermate punitief is dat daardoor de intentie van het Congres om

$38 \mathrm{Vgl}$. in dit kader $\S 3.2 .1$ van dit boek. 
een 'civiele' regeling te treffen teniet gedaan wordt. Met andere woorden; gelet op het onmiskenbaar punitieve karakter van de sanctie kan deze slechts aangemerkt worden als een strafsanctie (criminal penalty), ongeacht de intentie van het Congres om een civieje sanctie te creëren. Het Supreme Court stelt in dat kader echter resoluut: 'only the clearest proof could suffice to establish the unconstitutionality of a statute on such a ground. ${ }^{39}$

Of het doel en het gevolg van de sanctie dermate punitief zijn dat er sprake is van een 'criminal penalty' kan (onder andere) bepaald worden aan de hand van de zeven factoren die het Supreme Court heeft opgesomd in de zaak 'Kennedy versus MendozaMartinez: ${ }^{40}$ Op basis van één van de factoren uit de zaak 'Kennedy versus MendozaMartinez' lijkt er in de zaak Ward sprake te zijn van een 'criminal penalty'. Het gaat dan om de vijfde factor uit de zaak 'Kennedy versus Mendoza-Martinez' inhoudende dat het gedrag waarop de sanctie van toepassing is al een (mis)daad is die gesanctioneerd wordt door middel van een strafrechtelijke sanctie.

Hoewel het voorgaande in casu het geval was - het lozen van olie in de Arkansas River leverde tevens een strafbaar feit op - ontwijkt het Supreme Court de conclusie dat oplegging van de bestuurlijke boete een 'criminal penalty' behelst. De wijze waarop het Supreme Court dit doet is wekt op zijn minst enige verbazing. Onder verwijzing naar (onder andere) 'Helvering versus Mitchell' bepaalt het Supreme Court dat het is toegestaan om ten aanzien van een zelfde gedraging zowel een 'civiele' als een strafrechtelijke sanctie op te leggen. Het feit dat een dergelijke samenloop van sancties mogelijk is 'verflauwt' het effect van de van toepassing zijnde factor uit de zaak 'Kennedy versus Mendoza-Martinez'. Dit laatste is te meer het geval als de boeteregeling zeventig jaar later tot stand is gekomen dan de (strafrechtelijke) strafbepaling en als genoemde bepalingen zijn neergelegd in verschillende wetten. In de zaak 'Ward' was dat volgens het Supreme Court het geval.

Zie ik het goed dan 'verflauwt' de toegestane samenloop van sancties niet alleen de waarde van de toepasselijke factor maar wordt hiermee de waarde van die factor volledig teniet gedaan. Iets anders valt niet op te maken uit de conclusie van het Supreme Court dat er geen sprake is van een 'criminal penalty' en dat de Water Pollution Control Act dan ook niet in strijd is met het nemo tenetur-beginsel uit het vijfde amendement.

De wijze waarop het Supreme Court de factoren uit de zaak 'Kennedy versus MendozaMartinez' in zijn overwegingen betrekt in de zaak 'Ward' getuigt wederom van een zeer legistische en formele benadering. Op de punitieve aard van de bestuurlijke boete wordt niet ingegaan. Uit de overweging met betrekking tot de samenloop van 'civiele' en strafrechtelijke sancties kan bovendien worden afgeleid dat het Supreme Court in beginsel het standpunt inneemt dat de 'civiele' sancties (doorgaans) onbetwist civiel zijn en ieder punitief element ontberen.

Het lijkt er dan ook op dat het Supreme Court, na de verfrissende uitspraak in de zaak 'Kennedy versus Mendoza-Martinez', in de zaak 'Ward' weer terugvalt op de formele en

39 United States versus Ward, 448 U.S. 242 (1980).

40 Kennedy v. Mendoza-Martinez, 372 U.S. 144 (1963). Zie ook de eerder in deze paragraaf weergegeven delen uit de uitspraak van het Supreme Court in de zaak 'Kennedy versus Mendoza-Martinez'. 
pragmatische benadering van de termen 'punishment' en 'criminal penalty' uit de zaak 'Helvering versus Mitchell.' ${ }^{41}$

\subsection{1.e United States versus One Assortment of 89 Firearms (1984)}

In de zaak 'United States versus One Assortment of 89 Firearms $^{42}$ werd Mulcahey strafrechtelijk vrijgesproken van het willens en weten verhandelen van vuurwapens zonder in het bezit te zijn van de daartoe benodigde vergunning. Nadat Mulcahey strafrechtelijk was vrijgesproken werden de - voor de strafzaak in beslag genomen vuurwapens - verbeurd verklaard in een 'civiele' verbeurdverklaringsprocedure (in rem civil forfeiture). Mulcahey stelde zich (onder andere) op het standpunt dat de 'civiele' verbeurdverklaring in strijd zou zijn met de in het vijfde amendement opgenomen 'double jeopardy-clause'. Het Supreme Court overweegt ten aanzien van die stelling van Mulcahey het volgende:

'Mulcahey next contends that a forfeiture proceeding under 924(d) is barred by the Double Jeopardy Clause of the Fifth Amendment. Unless the forfeiture sanction was intended as punishment, so that the proceeding is essentially criminal in character, the Double Jeopardy Clause is not applicable [curs. KA]. Helvering v. Mitchell, 303 U.S., at 398-399. The question, then, is whether a 924(d) forfeiture proceeding is intended to be, or by its nature necessarily is, criminal and punitive, or civil and remedial [curs. KA]. Resolution of this question begins as a matter of statutory interpretation. Id., at 399. As the Court noted in United States v. Ward, 448 U.S. 242, 248 (1980): (Vervolgens volgt een weergave van de overweging in de zaak 'Ward' met betrekking tot de 'twee-staps' toetsing [KA]. $)^{4.3}$

Applying the first prong of the Ward test to the facts of the instant case, we conclude that Congress designed forfeiture under 924(d) as a remedial civil sanction. Congress' intent in this regard is most clearly demonstrated by the procedural mechanisms it established for enforcing forleitures under the statute. Section 924(d) does not prescribe the steps to be followed in effectuating a forfeiture, but rather incorporates by reference the procedures of the Intemal Revenue Code of 1954 (Code), 26 U.S.C. 7321-7328. The Code in tum provides that an action to enforce a forfeiture "shall be in the nature of a proceeding in rem in the United States District Court for the district where such seizure is made." 26 U.S.C. 7323. In contrast to the in personam nature of criminal actions, actions in rem have traditionally been viewed as civil proceedings, with jurisdiction dependent upon seizure of a physical object. See Calero-Toledo v. Pearson Yacht Leasing Co., 416 U.S. 663, 684 (1974). In addition to establishing the in rem nature of the action, the Code authorizes a summary administrative proceeding for forfeiture of items valued at $\$ 2,500$ or less, for which notice of a seizure may be by publication. See 26 U.S.C. 7325 . By creating such distinctly civil procedures for forfeitures under 924(d), Congress has "indicate[d] clearly that it intended a civil, not a criminal, sanction." Helvering v. Mitchell, supra, at 402. (...) Moreover, 924(d) is somewhat broader in scope than the criminal provisions of 18 U.S.C. 922 . (...) Finally, the forfeiture provision of 924(d) furthers broad remedial aims. (...) Keeping potentially dangerous weapons out of the hands of unlicensed dealers is a goal plainly more remedial than punitive. (...) Accordingly, we hold that Congress viewed 924(d) forfeiture as a remedial civil sanction rather than a criminal punishment.

41 Zie de eerder in deze paragraaf opgenomen uitspraak van het Supreme Court in de zaak 'Helvering versus Mitchell' en het conmentaar dezerzijds op die uitspraak.

42 United States versus One Assortment of 89 Firearms, 465 U.S. 354 (1984).

43 Zie de eerder in deze paragraaf opgenomen passages uit de zaak 'Ward'. 
We now tum to the second aspect of our inquiry: "whether the statutory scheme [is] so punitive either in purpose or effect as to negate" Congress' intention to establish a civil remedial mechanism. United States v. Ward, 448 U.S., at 248-249. "'Only the clearest proof" that the purpose and effect of the forfeiture are punitive will suffice to override Congress' manifest preference for a civil sanction. Id., at 249 (quoting Flemming v. Nestor, 363 U.S. 603, 617 (1960)). In Kennedy v. Mendoza-Martinez, 372 U.S. 144, 168-169 (1963), we set forth a list of considerations that has proved helpful in the past in making such determinations. See, e. g., United States v. Ward, supra, at 249-251; Bell v. Wolfish, 441 U.S. 520, 537-538 (1979). Only one of the Mendoza-Martinez factors - whether or not the proscribed behavior is already a crime - lends any support to Mulcahey's position that 924(d) imposes a criminal penalty. The fact that actions giving rise to forfeiture proceedings under 924(d) may also entail the criminal penalties of 922(a)(1) admittedly suggests that 924(d) is criminal in nature. But that indication is not as strong as it might seem at first blush. United States v. Ward, supra, at 250 . Clearly "Congress may impose both a criminal and a civil sanction in respect to the same act or omission," Helvering v. Mitchell, 303 U.S., at 399; indeed, it has done so on other occasions. Moreover, Congress in fact drafted 924(d) to cover a broader range of conduct than is proscribed by the criminal provisions of 922(a)(1). See supra, at 363-364. Because the sanction embodied in 924(d) is not limited to criminal misconduct, the forfeiture remedy cannot be said to be coextensive with the criminal penalty. What overlap there is between the two sanctions is not sufficient to persuade us that the forfeiture proceeding may not legitimately be viewed as civil in nature. In short, an analysis of the Mendoza-Martinez factors in no way undermines Congress' classification of the 924(d) forfeiture action as a civil sanction. Mulcahey has failed to establish by the "clearest proof" that Congress has provided a sanction so punitive as to "transfor[m] what was clearly intended as a civil remedy into a criminal penalty." Rex Trailer Co. v. United States, 350 U.S. 148, 154 (1956). We accordingly conclude that the forfeiture mechanism set forth in 924 (d) is not an additional penalty for the commission of a criminal act, but rather is a separate civil sanction, remedial in nature. Because the 924(d) forfeiture proceeding brought against Mulcahey's firearms is not a criminal proceeding, it is not barred by the Double Jeopardy Clause.'

Het Supreme Court gebruikt in de zaak 'United States versus One Assortment of 89 Firearms' het toetsingsschema uit de zaak 'Ward'. Evenals in de zaak 'Ward' komt het Supreme Court op basis van een legistische (en formele) redenering tot de conclusie dat de 'civiele' verbeurdverklaring geen strafsanctie is en dat derhalve de 'double jeopardy clause' uit het vijfde amendement niet van toepassing is op de verbeurdverklaringsprocedure.

Opvallend is, dat ten aanzien van de tweede test ('whether the statutory scheme is so punitive either in purpose or in effect as to negate Congress' intention to establish a civil remedial mechanism') volgens het Supreme Court maar één van de zeven factoren uit de zaak 'Kennedy versus Mendoza-Martinez' relevant is. Het gaat dan om dezelfde factor als in de zaak 'Ward'. In beide zaken wordt vervolgens op dezelfde - enigszins gekunstelde - manier naar het gewenste resultaat (namelijk dat er geen sprake is van een 'criminal penalty') toegeredeneerd. ${ }^{44}$

Op de zes andere factoren wordt in beide zaken niet ingegaan door het Supreme Court. Enige (steekhoudende) motivering waarom dat niet gebeurt ontbreekt in de hiervoor

Zie daaromtrent de opmerkingen die geplaatst zijn bij de uitspraak van het Supreme Court in de zaak 'Ward'. 
genoemde uitspraken. In dat kader is op het zijn minst vreemd te noemen dat het Supreme Court in beide zaken geen enkele aandacht schenkt aan de (ham)vraag of met oplegging van de sanctie de traditionele doelen van bestraffing worden nagestreefd. Die traditionele doelen zijn vergelding en afschrikkende werking (middels leedtoevoeging).

Het lijkt er op dat het Supreme Court op deze wijze probeert zijn vingers niet te branden aan deze hachelijke materie. Een en ander heeft wellicht te maken met de rechtsstatelijke verhouding tussen het Supreme Court als rechter en het Congres als (democratisch gelegitimeerde) wetgevende macht. Het Supreme Court lijkt immers niet snel het oordeel van de (democratisch gelegitimeerde) wetgever in twijfel te willen trekken.

\subsection{I.f United States versus Halper (1989)}

Gelet op de hiervoor weergegeven formele houding van het Supreme Court met betrekking tot de kwalificatie van een sanctie als 'punishment' lijkt de nu te bespreken zaak 'United States versus Halper ${ }^{\text {45 }}$ een spreekwoordelijke vreemde eend in de bijt te zijn. Het Supreme Court gaat in deze zaak aan de hand van materiële criteria na of er sprake is van 'punishment'.

In de zaak 'United States versus Halper' staat (wederom) de toepasselijkheid van de 'double jeopardy-clause' uit het vijfde amendement centraal. Halper heeft 65 valse verzoeken tot vergoeding van medische zorg ingediend. Ten aanzien van deze frauduleuze handelingen is Halper strafrechtelijk veroordeeld tot een gevangenisstraf van twee jaar en een geldboete van $\$ 5,000$. Na de strafrechtelijke procedure wordt Halper op basis van de 'civil False Claims Act' in een 'civiele procedure' nogmaals beboet. Het gaat om een boete van $\$ 2,000$ per overtreding (in casu dus 65 maal $\$ 2,000$ ) en een boete ten bedrage van de dubbele hoogte van het bedrag dat ten onrechte van de overheid ontvangen is (in casu 2 maal $\$ 585$ ). In het geval van Halper komt dat neer op een boete van meer dan $\$ 130,000$.

Het moge duidelijk zijn dat in de zaak 'Halper' de vraag centraal staat of de 'civil penalty' die op basis van de 'civil False Claims Act' wordt opgelegd een 'second punishment' vormt in de zin van de 'double jeopardy clause' uit het vijfde amendement. Het Supreme Court heeft ten aanzien van die vraag het volgende overwogen:

'We turn, finally, to the unresolved question implicit in our cases: whether and under what circumstances a civil penalty may constitute punishment for the purpose of the Double Jeopardy Clause. As noted above, the Government takes the position that punishment in the relevant sense is meted out only in criminal proceedings, and that whether proceedings are criminal or civil is a matter of statutory construction. (...)

In making this assessment, the labels "criminal" and "civil" are not of paramount importance. (...)

Simply put, a civil as well as a criminal sanction constitutes punishment when the sanction as applied in the individual case serves the goals of punishment [curs. KA]. (..)

These goals are familiar. We have recognized in other contexts that punishment serves the twin aims of retribution and deterrence [curs. KA]. See, e. g., Kennedy v. MendozaMartinez, 372 U.S. 144, 168 (1963) (these are the "traditional aims of punishment"). Furthermore, "[r]etribution and deterrence are not legitimate nonpunitive governmental 
objectives." Bell v. Wolfish, 441 U.S. 520, 539, n. 20 (1979). From these premises, it follows that a civil sanction that cannot fairly be said solely to serve a remedial purpose, but rather can only be explained as also serving either retributive or deterrent purposes, is punishment, as we have come to understand the term [curs. KA]. Cf. Mendoza-Martinez, 372 U.S., at 169 (whether sanction appears excessive in relation to its non-punitive purpose is relevant to determination whether sanction is civil or criminal). We therefore hold that under the Double Jeopardy Clause a defendant who already has been punished in a criminal prosecution may not be subjected to an additional civil sanction to the extent that the second sanction may not fairly be characterized as remedial, but only as a deterrent or retribution [curs. KA]. (...)

(...) as we have observed above, the process of affixing a sanction that compensates the Government for all its costs inevitably involves an element of rough justice. Our upholding reasonable liquidated damages clauses reflects this unavoidable imprecision. Similarly, we have recognized that in the ordinary case fixed-penalty-plus-double-damages provisions can be said to do no more than make the Government whole. (...)

We cast no shadow on these time-honored judgments. What we announce now is a rule for the rare case, the case such as the one before us, where a fixed-penalty provision subjects a prolific but small-gauge offender to a sanction overwhelmingly disproportionate to the damages he has caused [curs. KA]. The rule is one of reason: Where a defendant previously has sustained a criminal penalty and the civil penalty sought in the subsequent proceeding bears no rational relation to the goal of compensating the Government for its loss, but rather appears to qualify as "punishment" in the plain meaning of the word, then the defendant is entitled to an accounting of the Government's damages and costs to determine if the penalty sought in fact constitutes a second punishment. (...)

We do not consider our ruling far reaching or disruptive of the Govemment's need to combat fraud. Nothing in today's ruling precludes the Government from seeking the full civil penalty against a defendant who previously has not been punished for the same conduct, even if the civil sanction imposed is punitive. In such a case, the Double Jeopardy Clause simply is not implicated. Nor does the decision prevent the Government from seeking and obtaining both the full civil penalty and the full range of statutorily authorized criminal penalties in the same proceeding. In a single proceeding the multiple-punishment issue would be limited to ensuring that the total punishment did not exceed that authorized by the legislature [curs. KA]. (...)

In other words, the only proscription established by our ruling is that the Govemment may not criminally prosecute a defendant, impose a criminal penalty upon him, and then bring a separate civil action based on the same conduct and receive a judgment that is not rationally related to the goal of making the Government whole.'

De uitspraak van het Supreme Court in de zaak 'Halper' lijkt in eerste instantie zeer positief uit te vallen voor wat betreft de rechtsbescherming in bestuursstrafrecht. $\mathrm{Na}$ gedetailleerde lezing blijkt echter dat deze uitspraak een vrij beperkte invloed heeft op voomoemde rechtsbescherming. ${ }^{46}$

Het Supreme Court gaat in deze zaak, zoals gezegd, aan de hand van materiële criteria na of er sprake is van 'punishment'. Tevens benadrukt het Supreme Court echter dat het de uitvoerende macht in het kader van de handhaving niet voor de voeten wil lopen en zwakt op die wijze het effect van de materiële benadering direct weer af door de materiële benadering te formuleren als 'a rule for the rare case'. Deze 'rule' is alleen van toepassing op 'a sanction overwhelmingly disproportionate to the damages caused'. Het

Zie hierover ook: Cheh a.w. 1991, p. 1375 en verder, en Mann a.w. 1992, p. 1840 en verder. 
lijkt er dan ook op dat het Supreme Court niet 'om is gegaan' in de zaak 'Halper' maar in beginsel vast zal blijven houden aan de legistisch aandoende 'twee-stappenbenadering' uit de zaak 'Ward'.

\section{Materiële benadering}

Anders dan in de uitspraak in de zaak 'Ward' en 'One Assortment of 89 Firearms' geeft het Supreme Court, zoals gezegd, in deze zaak aan dat de (wettelijke) kwalificatie van een sanctie als 'criminal' dan wel 'civil' niet het belangrijkste is voor beantwoording van de vraag of een sanctie 'punishment' behelst. Het gaat erom dat toepassing van de sanctie in een individueel geval bestraffing ('punishment') ten doel heeft. Dit kan zowel het geval zijn bij een als 'civiel' gekwalificeerde sanctie als bij een als strafsanctie gekwalificeerde sanctie. Onder andere onder verwijzing naar twee criteria uit de zaak 'Kennedy versus Mendoza-Martinez ${ }^{147}$ komt het Supreme Court in de zaak 'Halper' tot een (materiële) definitie van de term 'punishment':

'From these premises, it follows that a civil sanction that cannot fairly be said solely to serve a remedial purpose, but rather can only be explained as also serving either retributive or deterrent purposes, is punishment, as we have come to understand the term.'

\section{'Punishment' slechts in uitzonderlijke gevallen}

Zoals gezegd lijkt het Supreme Court door middel van deze materiële benadering een nieuwe weg te zijn ingeslagen die meer mogelijkheden biedt om een effectieve rechtsbescherming te garanderen in het bestuursstrafrecht. Het effect van de materiële benaderingen wordt echter weer voor een groot deel de kop ingedrukt door de daaropvolgende overwegingen in de uitspraak van het Supreme Court.

Om vast te stellen of een sanctie vergelding of afschrikking ('retribution' of 'deterrence') ten doel heeft, en derhalve 'punishment' betreft, dient namelijk (ook) de (dis)proportionaliteit van de sanctie in ogenschouw genomen te worden, zo stelt het Supreme Court in de zaak 'United States versus Halper'. Met name met het oog op het proportionaliteitsvereiste komt het Supreme Court vervolgens tot de conclusie dat er slechts in (zeer) zeldzame gevallen sprake is van een sanctie die dermate overweldigend disproportioneel is ('overwhelmingly disproportionate'), ten opzichte van de schade die door de overtreder is veroorzaak ${ }^{48}$, dat er geen sprake meer is van 'rough remedial justice' maar van 'punishment'.

In de zaak 'Halper' wordt de oplegging van de 'civiele' boete als 'overwhelmingly disproportionate' gekwalificeerd. Om die reden is de opgelegde 'civiele' boete volgens het Supreme Court in strijd met de 'double jeopardy clause', uit het vijfde amendement.

47 Het gaat dan om deze twee criteria uit de zaak 'Kennedy versus Mendoza-Martinez': 'whether its operation will promote the traditional aims of punishment - "retribution and deterrence"', en 'whether it appears excessive in relation to the alternative purpose assigned [to it]'.

48 Zie hierover ook de opmerking van Mann: 'This finding raises concern, not because the civil sanction is more than compensatory, but because it may he disproportionate to the seriousness of the wrongtill hehaviour that it punishes, thus violating due process principles. In punitive cases, the correct measure of sanctions is the seriousness of the wrong, not the extent of the damage.' Mann a.w. 1992, p. 1843 (voetnoot 173). 
Het Supreme Court geeft in de zaak 'Halper' echter nadrukkelijk aan dat de materiële benadering moet worden gezien als 'a rule for the rare case'. Deze 'rule' is, zoals gezegd, alleen van toepassing op 'a sanction overwhelmingly disproportionate to the damages caused'. Een civiele of bestuurlijke boete zal derhalve niet snel aangemerkt kunnen worden als 'punishment'. Aan deze overweging lijkt mede ten grondslag te liggen dat het Supreme Court de uitvoerende macht bij de uitoefening van handhavingsbevoegdheden niet voor de voeten wil lopen.

\section{Beperkte strekking 'double jeopardy-clause'}

Voorts lijkt het Supreme Court in de uitspraak de civiele boete alleen aan te merken als 'punishment' in de context van de 'double jeopardy-clause'. Of er ook sprake zou zijn van 'punishment' als Halper zich had beroepen op een andere constitutionele (strafprocesrechtelijke) waarborg blijft derhalve de vraag. Bovendien wordt de civiele boete alleen onconstitutioneel geacht met betrekking tot bepaalde vormen van cumulatie van sancties in het kader van de 'double jeopardy clause'. ${ }^{49}$ Het Supreme Court overweegt in dit kader immers:

'Nothing in today's ruling precludes the Government from seeking the full civil penalty against a defendant who previously has not been punished for the same conduct, even if the civil sanction imposed is punitive. In such a case, the Double Jeopardy Clause simply is not implicated. Nor does the decision prevent the Government from seeking and obtaining both the full civil penalty and the full range of statutorily authorized criminal penalties in the same proceeding. In a single proceeding the multiple-punishment issue would be limited to ensuring that the total punishment did not exceed that authorized by the legislature.'

Opmerking verdient echter dat ook in het kader van de Nederlandse boeteregeling bepaalde vormen van cumulatie van (straf)sancties zijn toegestaan. Dit is met name het geval indien de sancties in dezelfde procedure worden opgelegd en daarbij tevens rekening gehouden kan worden met de proportionaliteit van de op te leggen sancties tezamen. $^{50}$

\section{Slotsom}

Voorgaande analyse van de uitspraak van het Supreme Court in de zaak 'Halper' leidt tot de slotsom dat door het Supreme Court in de zaak 'Halper' een stap is gezet in de richting van een verhoogde rechtsbescherming bij de oplegging van punitieve sancties die op basis van de wetgeving niet worden gekwalificeerd als 'punishment'. Gelet op het uitzonderingskarakter van de toegepaste materiële benadering blijft het echter bij een zeer minimale stap.

49 Zie de laatste - hierboven opgenomen - overweging: 'In other words, the only proscription established by our ruling is that the Government may not criminally prosecute a defendant, impose a criminal penalty upon him, and then bring a separate civil action based on the same conduct and receive a judgment that is not rationally related to the goal of making the Government whole.' Vgl. Mann: Now, a civil penalty so disproportionate to the damage caused that it no longer can carry the label "remedia" is permissible on the condition that the government has not sought criminal penalties first. Without a prior criminal conviction, it appears that the $\$ 130,000$ civil penalty would have been upheld as a constitutionally legitimate exercise of state law enforcement authority.', Mann a.w. 1992, p. 1843.

50 Vgl. in dit kader hoofdstuk vier van dit boek, i.h.b. de toelichting op artikel 5.0.6, 5.0.8, 5.4.1.4 en 5.4.1.5 van het Voorontwerp en HR I2 januari 1999, NJ 1999/289. 


\subsection{I.g Austin versus United States (1993)}

In de zaak 'Austin versus United States ${ }^{151}$ wordt wederom strafrechtelijk en civielrechtelijk gesanctioneerd ten aanzien van één vergrijp. Aan Austin wordt een gevangenisstraf van zeven jaar opgelegd in verband met het bezit van cocaïne met het oogmerk om die te verspreiden. Daarnaast worden Austins camper en auto-werkplaats verbeurd verklaard in een 'civiele' verbeurdverklaringsprocedure. Genoemde camper en autowerkplaats waren namelijk gebruikt bij het plegen van een drugsmisdrijf. ${ }^{52}$ Het Supreme Court ziet zich nu voor de vraag gesteld of de 'civiele' verbeurdverklaring van de camper en de auto-werkplaats in strijd is met de 'excessive fines clause' van het achtste amendement. Het Supreme Court beantwoordt deze vraag als volgt:

'In Browning-Ferris Industries of Vt., Inc., v. Kelco Disposal, Inc., 492 U.S. 257 (1989). (...) The Court concluded that both the Eighth Amendment and 10 of the English Bill of Rights of 1689 , from which it derives, were intended to prevent the government from abusing its power to punish, see id., at 266-267, and therefore that "the Excessive Fines Clause was intended to limit only those fines directly imposed by, and payable to, the government," id., at 268. (...)

Some provisions of the Bill of Rights are expressly limited to criminal cases. (...) The text of the Eighth Amendment includes no similar limitation. (...)

The Excessive Fines Clause limits the government's power to extract payments, whether in cash or in kind, "as punishment for some offense." Id., at 265 (emphasis added). "The notion of punishment, as we commonly understand it, cuts across the division between the civil and the criminal law." United States v. Halper, 490 U.S. 435, $447-448$ (1989). "It is commonly understood that civil proceedings may advance punitive and remedial goals, and, conversely, that both punitive as well as remedial goals may be served by criminal penalties." (...) Thus, the question is not, as the United States would have it, whether forfeiture under 881 (a)(4) and (a)(7) is civil or criminal, but rather whether it is punishment. (..)

We said in Halper that a "civil sanction that cannot fairly be said solely to serve a remedial purpose, but rather can only be explained as also serving either retributive or deterrent purposes, is punishment as we have come to understand the term." 490 U.S., at 448 . We turn, then, to consider whether, at the time the Eighth Amendment was ratified, forfeiture was understood at least in part as punishment, and whether forfeiture under $881(a)(4)$ and (a)(7) should be so understood today. (...)

We find nothing in these provisions or their legislative history to contradict the historical understanding of forfeiture as punishment. Unlike traditional forfeiture statutes, 881(a)(4) and (a)(7) expressly provide an "innocent owner" defense. (...)

The inclusion of innocent-owner defenses in 881 (a)(4) and (a)(7) reveals a similar congressional intent to punish only those involved in drug trafficking. Furthermore, Congress has chosen to tie forfeiture directly to the commission of drug offenses. Thus, under 881(a)(4), a conveyance is forfeitable if it is used or intended for use to facilitate the transportation of controlled substances, their raw materials, or the equipment used to manufacture or distribute them. Under 881(a)(7), real property is forfeitable if it is used or intended for use to facilitate the commission of a drug-related crime punishable by more than one year's imprisonment. See n. I, supra.

The legislative history of 881 confirms the punitive nature of these provisions. When it added subsection (a)(7) to 881 in 1984, Congress recognized "that the traditional criminal sanctions of fine and imprisonment are inadequate to deter or punish the enormously

7.ie artikel 21 U.S.C. 881 (a)(4) en (a)(7). 
profitable trade in dangerous drugs." S.Rep. No. 98-225, p. 191 (1983).13 It characterized the forfeiture of real property as "a powerful deterrent." (...)

Concededly, we have recognized that the forfeiture of contraband itself may be characterized as remedial because it removes dangerous or illegal items from society. See United States v. One Assortment of 89 Firearms, 465 U.S. 354, 364 (1984). The Court, however, previously has rejected government's attempt to extend that reasoning to conveyances used to transport illegal liquor. See One 1958 Plymouth Sedan v. Pennsylvania, 380 U.S. 693, 699 (1965). In that case it noted, "There is nothing even remotely criminal in possessing an automobile." Ibid. The same, without question, is true of the properties involved here, and the Government's attempt to characterize these properties as "instruments" of the drug trade must meet the same fate as Pennsylvania's effort to characterize the 1958 Plymouth sedan as "contraband." (...)

Fundamentally, even assuming that $881(\mathrm{a})(4)$ and $(\mathrm{a})(7)$ serve some remedial purpose, the Government's argument must fail. "[A] civil sanction that cannot fairly be said solely to serve a remedial purpose, but rather can only be explained as also serving either retributive or deterrent purposes, is punishment, as we have come to understand the term." Halper, 490 U.S., at 448 (emphasis added). In light of the historical understanding of forfeiture as punishment, the clear focus of $881(\mathrm{a})(4)$ and $(\mathrm{a})(7)$ on the culpability of the owner, and the evidence that Congress understood those provisions as serving to deter and to punish, we cannot conclude that forfeiture under $881(\mathrm{a})(4)$ and (a)(7) serves solely a remedial purpose. We therefore conclude that forfeiture under these provisions constitutes "payment to a sovereign as punishment for some offence," Browning-Ferris, 492 U.S., at 265, and, as such, is subject to the limitations of the Eighth Amendment's Excessive Fines Clause.'

Deze uitspraak van het Supreme Court sluit aan bij de uitspraak van genoemd rechtscollege in de zaak 'Halper'. Evenals in de zaak 'Halper' geeft het Supreme Court ook in de zaak 'Austin' een materiële invulling aan het begrip 'punishment'. Het Supreme Court stelt immers expliciet dat er zowel in civiele zaken als in strafzaken sprake kan zijn van 'punishment'.

In de zaak 'Austin' lijkt het Supreme Court daarmee een iets ruimer standpunt ten aanzien van de toepassing van het materiële criterium in te nemen dan op basis van de zaak 'Halper' te verwachten was. Onder verwijzing naar de zaak 'Halper' geeft het Supreme Court aan dat niet gezegd kan worden dat de 'civiele' verbeurdverklaring slechts een reparatoir doel heeft ('serves a solely remedial purpose') maar dat met de verbeurdverklaring ook leedtoevoeging en afschrikkende werking is beoogd. Derhalve is er sprake van 'punishment' en is de 'excessive fines clause' van toepassing op de 'civiele' verbeurdverklaring. De frase uit de zaak 'Halper' dat er bij een 'civiele' sanctie slechts sprake kan zijn van 'punishment' als het gaat om een zeldzaam geval waarin een extreem disproportionele sanctie wordt opgelegd blijft in casu achterwege.

Niettemin moet de strekking van de uitspraak in de zaak 'Austin' niet overschat worden. Uit de uitspraak kan afgeleid worden dat het nog maar de vraag is of toetsing aan de materiële criteria in een civiele zaak ook leidt tot toepasselijkheid van (bijvoorbeeld) het vijfde amendement. In de zaak 'Austin' stond immers het achtste amendement ter discussie en dit ziet (volgens het Supreme Court) niet expliciet op 'criminal cases':

'Some provisions of the Bill of Rights are expressly limited to criminal cases. (...) The text of the Eighth Amendment includes no similar limitation. (...) "It is commonly understood that civil proceedings may advance punitive and remedial goals, and, conversely, that both punitive as well as remedial goals may be served by criminal penalties." (...) Thus, the 
question is not, as the United States would have it, whether forfeiture under 881(a)(4) and (a)(7) is civil or criminal, but rather whether it is punishment. (...)'.

Bovendien zou het zo kunnen zijn dat het Supreme Court in casu de 'civiele' verbeurdverklaring op materiële gronden heeft gekwalificeerd als 'punishment' omdat het Congres blijkens de wetsgeschiedenis ook het standpunt in lijkt te nemen dat er sprake is van 'punishment'. In de zaak 'Austin' wordt de 'civiele' verbeurdverklaring, immers mede op basis van een rechtshistorisch onderzoek en de wetsgeschiedenis, aangemerkt als 'punishment' ten opzichte van de eigenaar van de verbeurdverklaarde zaken.

\subsection{1.h Montana Dept. of Revenue versus Kurth Ranch (1994)}

In de zaak 'Montana Dept. of Revenue versus Kurth Ranch ${ }^{53}$ wordt de familie Kurth strafrechtelijk vervolgd en gestraft in verband met het in bezit hebben van drugs met het oogmerk om deze te verhandelen. Ook wordt ten aanzien van de familie Kurth een belasting geheven in verband met het - illegaal - bezit van gevaarlijke drugs. Het gaat om een belastingbedrag van acht maal de marktwaarde van de aangetroffen drugs. Het Supreme Court ziet zich voor de vraag gesteld of de belasting die geheven wordt over de drugs 'punishment' betreft met het oog op de 'double jeopardy clause' uit het vijfde amendement. Ter beantwoording van die vraag overweegt het Supreme Court het volgende:

'In Halper, we considered "whether and under what circumstances a civil penalty may constitute "punishment" for the purpose of double jeopardy analysis." 490 U.S., at 436 . Our answer to that question does not decide the different question whether Montana's tax should be characterized as punishment.(...)

On direct appeal to this Court, we rejected the Government's submission that the Double Jeopardy Clause only applied to punishment imposed in criminal proceedings, reasoning that its violation "can be identified only by assessing the character of the actual sanctions imposed on the individual by the machinery of the state." Id., at 447.14 In making such an assessment, "the labels "criminal" and "civil" are not of paramount importance." Ibid. Accepting the District Court's findings, we held that "a defendant who already has been punished in a criminal prosecution may not be subjected to an additional civil sanction to the extent that the second sanction may not fairly be characterized as remedial, but only as a deterrent or retribution." Id., at 448-449. Halper thus decided that the legislature's description of a statute as civil does not foreclose the possibility that it has a punitive character. (...)

As a general matter, the unlawfulness of an activity does not prevent its taxation. Marchetti, 390 U.S., at 44; United States v. Constantine, 296 U.S. 287, 293 (1935); James v. United States, 366 U.S. 213 (1961). Montana no doubt could collect its tax on the possession of marijuana, for example, if it had not previously punished the taxpayer for the same offense, or, indeed, if it had assessed the tax in the same proceeding that resulted in his conviction. Missouri v. Hunter, 459 U.S. 359, 368-369 (1983); see also Halper, 490 U.S., at 450.

Here, we ask only whether the tax has punitive characteristics that subject it to the constraints of the Double Jeopardy Clause. (...) the Montana legislature intended the tax to deter people from possessing marijuana is beyond question. The DOR reminds us, however, that many taxes that are presumed valid, such as taxes on cigarettes and alcohol, are also both high and motivated to some extent by an interest in deterrence. (...) Thus, while a high 
tax rate and deterrent purpose lend support to the characterization of the drug tax as punishment, these features, in and of themselves, do not necessarily render the tax punitive. Cf. Sonzinsky $v$. United States, 300 U.S. 506, 513-514 (1937). (...)

Other unusual features, however, set the Montana statute apart from most taxes. First, this so-called tax is conditioned on the commission of a crime. That condition is "significant of penal and prohibitory intent, rather than the gathering of revenue." Moreover, the Court has relied on the absence of such a condition to support its conclusion that a particular federal tax was a civil, rather than a criminal, sanction. In this case, the tax assessment not only hinges on the commission of a crime, it also is exacted only after the taxpayer has been arrested for the precise conduct that gives rise to the tax obligation in the first place. Persons who have been arrested for possessing marijuana constitute the entire class of taxpayers subject to the Montana tax. (...)

The Montana tax is exceptional for an additional reason. Although it purports to be a species of property tax - that is, a "tax on the possession and storage of, dangerous drugs," Mont. Code Ann. 15-25-111 (1987) - it is levied on goods that the taxpayer neither owns nor possesses when the tax is imposed. (...)

A tax on "possession" of goods that no longer exist and that the taxpayer never lawfully possessed has an unmistakable punitive character. This tax, imposed on criminals and no others, departs so far from normal revenue laws as to become a form of punishment. (...)

Taken as a whole, this drug tax is a concoction of anomalies, too far removed in crucial respects from a standard tax assessment to escape characterization as punishment for the purpose of Double Jeopardy analysis. (...)

This drug tax is not the kind of remedial sanction that may follow the first punishment of a criminal offense. Instead, it is a second punishment within the contemplation of a constitutional protection that has "deep roots in our history and jurisprudence," Halper, 490 U.S., at 440 , and therefore must be imposed during the first prosecution or not at all. The proceeding Montana initiated to collect a tax on the possession of drugs was the functional equivalent of a successive criminal prosecution that placed the Kurths in jeopardy a second time "for the same offence".'

Evenals in de zaken 'Halper' en 'Austin' wordt ook in de zaak 'Kurth Ranch' weer beoordeeld of er sprake is van 'punishment' aan de hand van de materièle criteria zoals het Supreme Court die voor het eerst naar voren heeft gebracht in de zaak 'Halper'. Wederom geeft het Supreme Court aan dat kwalificatie door de wetgever van een regeling als 'criminal' of 'civil' daarbij niet van doorslaggevende betekenis is. Relevant is slechts of de sanctie vergeldend of afschrikkend beoogt te werken. De sanctie moet derhalve, zo stelt het Supreme Court, punitief van aard zijn.

De afschrikkende werking die (overigens ook volgens de wetgever) uit gaat van de belastingheffing, en de enorme hoogte van de belasting op zich, leiden volgens het Supreme Court niet zonder meer tot de conclusie dat de belastingheffing punitief is. Twee (andere) aspecten, die de belastingheffing in casu onderscheidt van andere vormen van belastingheffing, zijn van (doorslaggevend) belang bij het aanmerken van de belastingheffing op drugsbezit als 'punishment'. Het gaat er dan ten eerste om dat de belasting alleen geheven kan worden op basis van beschuldiging van een strafbaar feit. Ten tweede is van belang dat de belasting wordt geheven ten aanzien van drugs die op dat moment niet (meer) in eigendom of bezit van de persoon zijn ten aanzien waarvan de aanslag opgelegd wordt. 
Overigens leidt de kwalificatie van de belastingheffing als 'punishment' in de zaak 'Kurth Ranch' slechts tot de toepassing van een beperkt deel van het vijfde amendement, namelijk de 'double jeopardy-clause'. In hoeverre de kwalificatie van de belastingheffing als 'punishment' ook consequenties zou kunnen hebben voor de toepasselijkheid van andere constitutionele (strafprocesrechtelijke) waarborgen, zoals bijvoorbeeld het nemo tenetur-beginsel, valt op basis van deze sterk casuïstische rechtspraak van het Supreme Court dan ook moeilijk te zeggen.

\subsection{1.i United States versus Ursery (1996)}

In de zaak 'United States versus Ursery' ${ }^{\text {IS4 }}$ lijkt het Supreme Court weer terug te grijpen op de (formele) legistische benadering. De materiële toetsingscriteria worden op een zijspoor gezet.

In 'United States versus Usery' behandelt het Supreme Court twee zaken die zijn gevoegd. Het gaat om een zaak uit het zesde, en een zaak uit het negende Circuit. In beide zaken gaat het om drugscriminaliteit. De centrale vraag is of een strafrechtelijke veroordeling en een 'civiele' verbeurdverklaring 'multiple punishment' vormen met betrekking tot 'the same offence'. In dat kader dient het Supreme Court in de zaak 'United States versus Ursery' de vraag te beantwoorden of de 'civiele' verbeurdverklaring als 'punishment' gekwalificeerd moet worden. Dit met het oog op de vraag of de 'double jeopardy-clause' uit het vijfde amendement op de 'civiele' verbeurdverklaring van toepassing is. Het Supreme Court overweegt, zich vastklampend aan de (formele) legistische benadering, ten aanzien van die vraag het volgende:

'We think that the Court of Appeals for the Sixth Circuit and the Court of Appeals for the Ninth Circuit misread Halper, Austin, and Kurth Ranch. None of those decisions purported to overrule the well-established teaching of Various Items, Emerald Cut Stones, and 89 Firearms. Halper involved not a civil forfeiture, but a civil penalty. That its rule was limited to the latter context is clear from the decision itself, from the historical distinction that we have drawn between civil forfeiture and civil penalties, and from the practical difficulty of applying Halper to a civil forfeiture.

In Halper, we emphasized that our decision was limited to the context of civil penalties: (...) The narrow focus of Halper followed from the distinction that we have drawn historically between civil forfeiture and civil penalties. Since at least Various Items, we have distinguished civil penalties such as fines from civil forfeiture proceedings that are in rem. While a "civil action to recover (...) penalties, is punitive in character," and much like a criminal prosecution in that "it is the wrongdoer in person who is proceeded against (...) and punished," in an in rem forfeiture proceeding, "it is the property which is proceeded against, and by resort to a legal fiction, held guilty and condemned." Various Items, 282 U. S., at 580-581. Thus, though for Double Jeopardy purposes we have never balanced the value of property forfeited in a particular case against the harm suffered by the Government in that case, we have balanced the size of a particular civil penalty against the Government's harm. (...)

It is difficult to see how the rule of Halper could be applied to a civil forfeiture. (...)

Civil forfeitures, in contrast to civil penalties, are designed to do more than simply compensate the Government. Forfeitures serve a variety of purposes, but are designed primarily to confiscate property used in violation of the law, and to require disgorgement of 
the fruits of illegal conduct. Though it may be possible to quantify the value of the property forfeited, it is virtually impossible to quantify, even approximately, the nonpunitive purposes served by a particular civil forfeiture. Hence, it is practically difficult to determine whether a particular forfeiture bears no rational relationship to the nonpunitive purposes of that forfeiture. Quite simply, the case-by-case balancing, test set forth in Halper, in which a court must compare the harm suffered by the Government against the size of the penalty imposed, is inapplicable to civil forfeiture. (...)

In the cases that we review, the Courts of Appeals did not find Halper difficult to apply to civil forfeiture because they concluded that its case-by-case balancing approach had been supplanted in Austin by a categorical approach that found a civil sanction to be punitive if it could not "fairly be said solely to serve a remedial purpose." See Austin, 509 U.S., at 610; see also Halper, supra, at 448 . But Austin, it must be remembered, did not involve the Double Jeopardy Clause at all. Austin was decided solely under the Excessive Fines Clause of the Eighth Amendment, a constitutional provision which we never have understood as parallel to, or even related to, the Double Jeopardy Clause of the Fifth Amendment. (...)

Forfeitures effected under 21 U. S. C. Section(s) $881(\mathrm{a})(4)$ and (a)(7) are subject to review for excessiveness under the Eighth Amendment after Austin; this does not mean, however, that those forfeitures are so punitive as to constitute punishment for the purposes of double jeopardy. The holding of Austin was limited to the Excessive Fines Clause of the Eighth Amendment, and we decline to import the analysis of Austin into our double jeopardy jurisprudence. (...)

In sum, nothing in Halper, Kurth Ranch, or Austin, purported to replace our traditional understanding that civil forfeiture does not constitute punishment for the purpose of the Double Jeopardy Clause. Congress long has authorized the Government to bring parallel criminal proceedings and civil forfeiture proceedings, and this Court consistently has found civil forfeitures not to constitute punishment under the Double Jeopardy Clause. It would have been quite remarkable for this Court both to have held unconstitutional a wellestablished practice, and to have overruled a long line of precedent, without having even suggested that it was doing so. Halper dealt with in personam civil penalties under the Double Jeopardy Clause; Kurth Ranch with a tax proceeding under the Double Jeopardy Clause; and Austin with civil forfeitures under the Excessive Fines Clause. None of those cases dealt with the subject of this case: in rem civil forfeitures for purposes of the Double Jeopardy Clause. (...)

We turn now to consider the forfeitures in these cases under the teaching of Various Items, Emerald Cut Stones, and 89 Firearms. Because it provides a useful analytical tool, we conduct our inquiry within the framework of the two-part test used in 89 Firearms. (...) First, we ask whether Congress intended proceedings under 21 U. S. C. Section(s) 881, and 18 U. S. C. Section(s) 981 , to be criminal or civil. (...) There is little doubt that Congress intended these forfeitures to be civil proceedings. (...)

Moving to the second stage of our analysis, we find that there is little evidence, much less the "'clearest proof" that we require, see 89 Firearms, supra, at 365 , quoting Ward, 448 U.S., at 249 , suggesting that forfeiture proceedings under 21 U. S. C. Section(s) $881(\mathrm{a})(6)$ and (a)(7), and 19 U. S. C. Section(s) $981(\mathrm{a})(1)(A)$, are so punitive in form and effect as to render them criminal despite Congress' intent to the contrary. The statutes involved in this case are, in most significant respects, indistinguishable from those reviewed, and held not to be punitive, in Various Items, Emerald Cut Stones, and 89 Firearms. (...)

Most significant is that Section(s) $981(a)(1)(A)$, and Section(s) $881(a)(6)$ and (a)(7), while perhaps having certain punitive aspects, serve important nonpunitive goals. (...) 
Requiring the forfeiture of property used to commit federal narcotics violations encourages property owners to take care in managing their property and ensures that they will not permit that property to be used for illegal purposes. (...)

The same remedial purposes served by Section(s) $881(a)(7)$ are served by Section(s) $881(\mathrm{a})(6)$ and Section(s) $981(\mathrm{a})(1)(\mathrm{A})$. Only one point merits separate discussion. To the extent that Section(s) 881 (a)(6) applies to "proceeds" of illegal drug activity, it serves the additional nonpunitive goal of ensuring that persons do not profit from their illegal acts. (...) First, in light of our decisions in Various Items, Emerald Cut Stones, and 89 Firearms, and the long tradition of federal statutes providing for a forfeiture proceeding following a criminal prosecution, it is absolutely clear that in rem civil forfeiture has not historically been regarded as punishment, as we have understood that term under the Double Jeopardy Clause.

Second, there is no requirement in the statutes that we currently review that the Government demonstrate scienter in order to establish that the property is subject to forfeiture; (...)

Third, though both statutes may fairly be said to serve the purpose of deterrence, we long have

held that this purpose may serve civil as well as criminal goals. (...)

Finally, though both statutes are tied to criminal activity, as was the case in 89 Firearms, this fact is insufficient to render the statutes punitive.'

De uitspraak van het Supreme Court in de zaak 'Ursery' is, gelet op de met de zaken 'Halper', 'Austin' en 'Kurth Ranch' door het Supreme Court ingeslagen weg, teleurstellend te noemen. ${ }^{55}$ De (beperkte) extra rechtsbescherming die sinds de zaak 'Halper' buiten het strafrecht lijkt te gelden, in het kader van de oplegging van punitieve sancties, wordt met de uitspraak in de zaak 'Usery' weer grotendeels tenietgedaan doordat het Supreme Court terug lijkt te grijpen op de 'oude' (formele) legistische benadering. Zonder daadwerkelijk aan de materiële criteria te toetsen en onder verwijzing naar de 'twee-staps-toetsing' uit de zaak 'Ward' lijkt het Supreme Court naar het resultaat toe te redeneren. Het voorgaande is - onder andere - af te leiden uit de volgende overweging van het Supreme Court:

'In sum, nothing in Halper, Kurth Ranch, or Austin, purported to replace our traditional understanding that civil forfeiture does not constitute punishment for the purpose of the Double Jeopardy Clause. Congress long has authorized the Government to bring parallel criminal proceedings and civil forfeiture proceedings, and this Court consistently has found civil forfeitures not to constitute punishment under the Double Jeopardy Clause. It would have been quite remarkable for this Court both to have held unconstitutional a wellestablished practice, and to have overruled a long line of precedent, without having even suggested that it was doing so. Halper dealt with in personam civil penalties under the Double Jeopardy Clause; Kurth Ranch with a tax proceeding under the Double Jeopardy Clause; and Austin with civil forfeitures under the Excessive Fines Clause. None of those

55 Getuige ook de deels afwijkende opvatting van Justice Stevens in United States versus Ursery, (No. 95-345 (1996)): 'Remarkably, the Court today stands Austin on its head - a decision rendered only three years ago, with unanimity on the pertinent points - and concludes that Section(s) 881 (a)(7) is remedial rather than punitive in character. Every reason Austin gave for treating Section(s) 881 (a)(7) as punitive-the Court rejects or ignores. Every reason the Court provides for treating Section(s) 881 (a)(7) as remedial-Austin rebuffed. The Court claims that its conclusion is consistent with decisions reviewing statutes "indistinguishable" "in most significant respects" from Section(s) 881(a)(7), ante, at 20, but ignores the fact that Austin reached the opposite conclusion as to the identical statute under review here.' 
cases dealt with the subject of this case: in rem civil forfeitures for purposes of the Double Jeopardy Clause.'

Kennelijk is de doctrine uit 'Halper', 'Austin', en 'Kurth Ranch' niet van toepassing in de zaak 'Ursery' omdat geen van de drie voorgaande zaken betrekking had op dezelfde feiten als de zaak 'Ursery'. Deze redenering doet op zijn minst pragmatisch en te eenvoudig aan. In de drie voorgaande zaken stond telkens de vraag centraal of een nietstrafrechtelijke sanctie aangemerkt moest worden als 'punishment' in verband met de toepasselijkheid van een van de waarborgen uit het vijfde of achtste amendement. Vergelding en de afschrikkende werking van de sanctie (middels leedtoevoeging) speelden, in genoemde zaken, een centrale rol bij de constatering dat er sprake was van 'punishment'. 56

Indien het Supreme Court vast had gehouden aan de doctrine zoals deze is ontwikkeld in de zaken 'Halper', 'Austin', en 'Kurth Ranch' - namelijk de toetsing aan de in de zaak 'Halper' geformuleerde materiële criteria - had het wellicht, gelet op de zaak 'Austin', de 'civiele' verbeurdverklaring ook in de zaak 'Ursery' als 'punishment' aan moeten merken. Het Supreme Court geeft echter aan dat de redenering uit de zaak 'Austin' niet van toepassing is in de zaak 'Ursery'. De 'argumentatie' (voor zover daar sprake van is) van het Supreme Court teneinde tot de conclusie te komen dat de 'civiele' verbeurdverklaring in deze casus, anders dan in de zaak 'Austin', geen 'punishment' behelst is ronduit vreemd:

\begin{abstract}
'Forfeitures effected under 21 U. S. C. Section(s) 881(a)(4) and (a)(7) are subject to review for excessiveness under the Eighth Amendment after Austin; this does not mean, however, that those forfeitures are so punitive as to constitute punishment for the purposes of double jeopardy. The holding of Austin was limited to the Excessive Fines Clause of the Eighth Amendment, and we decline to import the analysis of Austin into our double jeopardy jurisprudence. ${ }^{57}$
\end{abstract}

Het kan toch niet zo zijn dat een bepaalde (formeel) niet-strafrechtelijke sanctie in het ene geval wel 'punishment' vormt en in het andere geval niet. Daarbij dient niet uit het oog verloren te worden dat het nota bene in beide zaken om dezelfde wettelijke regeling ging! ${ }^{58}$ Het Supreme Court geeft in feite geen duidelijke motivering ter onderbouwing van het standpunt dat de 'civiele' verbeurdverklaring uit 21 U.S.C. 881 alleen een punitieve sanctie is in het kader van de 'excessive fines-clause' uit het achtste amendement en niet in het kader van de 'double jeopardy-clause' uit het vijfde amendement. Bovendien heeft het Supreme Court in de zaak 'Ward' nog een ander standpunt ingenomen door het volgende te bepalen:

56 Zie hierover de eerder in dit hoofdstuk opgenomen delen van de drie uitspraken en het commentaar daarop.

57 Zie ook Sarah Jean Watterson, Putting the Halper Genie Back in the Bottle: Examining United States v. Ursery in Light of Halper, Austin, and Kurth Ranch, Brigham Young University Law Review, 1997, 1997 B.Y.U.L. Rev. 235: '...the Court's decision in Ursery is somewhat forced.', 1997 B.Y.U.L. Rev. 252.

58 In beide gevallen is de 'civiele' verbeurdverklaring gebaseerd op 21 U.S.C. 881 (Forfeitures). (Title 21 - Food and Drugs, Chapter 13 - Drug Abuse Prevention and Control, Subchapter 1 - Control and Enforcement, Part E-Administrative and Enforcement Provisions). 
'...it would be quite anomalous to hold that 311 (b)(6) created a criminal penalty for the purposes of the Self-Incrimination Clause but a civil penalty for all other purposes'. ${ }^{59}$

Al met ail kan niet gezegd worden dat de argumentatie van het Supreme Court in het eerste deel van de uitspraak in de zaak 'Ursery' erg sterk is. ${ }^{60}$

Nadat het Supreme Court op basis van deze weinig verhelderende (en pragmatische) redenering heeft aangeven dat de, in de zaken 'Halper', 'Austin', en 'Kurth Ranch' gehanteerde, materiële criteria niet van toepassing zijn op 'civil fofeiture' in het kader van de 'double jeopardy clause' past het de 'twee-staps-toetsing' uit de zaken 'Ward' en '89 Firearms' toe. In feite betekent dit dat het Supreme Court weer teruggrijpt naar de oude legistische benadering. ${ }^{61}$

Na lezing van het eerste deel van de uitspraak zal het niemand meer verbazen dat het Supreme: Court aan de hand van de test uit de zaak 'Ward' tot de conclusie komt dat er in de zaak 'Usery' geen sprake is van 'punishment'. Het oordeel van het Supreme Court ten aanzien van het eerste criterium, inhoudende dat de bedoeling van het Congres gericht was op het in het leven roepen van een civiele procedure, is niet zonder meer onjuist te achten.

De redenering van het Supreme Court ten aanzien van het tweede criterium ('whether the proceedings are so punitive in fact') is echter bepaald niet sterk te noemen. Nadat het Supreme Court heeft aangegeven dat de 'civiele' verbeurdverklaring belangrijke 'nonpunitive goals' dient presenteert het nog vier argumenten die moeten leiden tot de conclusie dat de 'civiele' verbeurdverklaring geen 'punishment' behelst. Deze vier argumenten zullen hierna afgezet worden tegen de eerdere uitspraken van het Supreme Court $^{62}$ - die overigens, gelet op het eerste deel van de uitspraak in de zaak 'Ursery', in casu volgens het Supreme Court niet van toepassing zijn-.

Het eerste argument dat door het Supreme Court wordt aangevoerd is het volgende: 'First, in light of our decisions in Various Items, Emerald Cut Stones, and 89 Firearms, and the long tradition of federal statutes providing for a forfeiture proceeding following a criminal prosecution, it is absolutely clear that in rem civil forfeiture has not historically been regarded as punishment, as we have understood that term under the Double Jeopardy Clause..$^{63}$

In de zaak 'Austin' kwam het Supreme Court echter, op basis van een uitvoerig rechtshistorisch onderzoek naar de aard van 'in rem forfeiture' ('civil' forfeiture), nog tot de volgende conclusie: 'We conclude, therefore, that forfeiture generally and statutory

59 United States versus Ward, 448 U.S. 242 (1980)

60 Zie ook Watterson a.w. 1997, p. 253 en verder: 'It is consequently both surprising and confusing for the court to suggest in Ursery that civil forfeiture should not be influenced by the Court's treatment of other civil sanctions.'

61 Zie: Solomon a.w. 1999, p. 866: 'In reverting to a more restrictive punishment standard, the Ursery Court placed a new emphasis on Congress's semantic denomination of a penalty: only the 'clearest proof suffices to subject a so-called 'civil' penalty to double jeopardy scrutiny. Once again, this retreat to formalism was at odds with the Court's pronouncements in Halper, Austin, and Kurth Ranch that the 'civil' or 'criminal' label affixed to a sanction was essentially unimportant in determining the scope of constitutional protections.'

62 Namelijk 'e zaken Halper, Austin, en Kurth Ranch.

63 United States versus Ursery, No. 95-345 (1996). 
in rem forfeiture in particular historically have been understood, at least in part, as punishment. ${ }^{64}$

Vervolgens overweegt het Supreme Court in de zaak 'Austin' ten aanzien van de 'civiele' verbeurdverklaringsprocedure uit 21 U.S.C. 881: 'We find nothing in these provisions or their legislative history to contradict the historical understanding of forfeiture as punishment. ${ }^{65}$

De argumentatie van het Supreme Court in de zaak 'Ursery' staat haaks op de argumentatie van genoemd rechtscollege in de zaak 'Austin'. Het is onbegrijpelijk dat het Supreme Court drie jaar na 'Austin' met een volledig tegengestelde redenering komt.

Ook het tweede argument: '... there is no requirement in the statutes that we currently review that the Government demonstrate scienter in order to establish that the property is subject to forfeiture; ...' is niet uitermate sterk. Aanwezigheid van opzet is, blijkens de uitspraak in de zaak 'Kennedy versus Mendoza-Martinez', slechts eén van de zeven factoren die relevant zijn bij de vaststelling dat een sanctie 'punishment' behelst.

Daarnaast is nog van belang dat, hoewel opzettelijke betrokkenheid bij drugsmisdrijven dan wel niet vereist is, er toch zeker een bepaalde mate van schuld aanwezig moet zijn bij de eigenaar van de verbeurdverklaarde goederen of zaken. Het voorgaande blijkt ook uit de volgende overwegingen van het Supreme Court in de zaak 'Austin': 'Unlike traditional forfeiture statutes, $881(\mathrm{a})(4)$ and $(\mathrm{a})(7)$ expressly provide an "innocent owner" defense. (...) These exemptions serve to focus the provisions on the culpability [curs. $\mathrm{KA}$ ] of the owner in a way that makes them look more like punishment, not less.' Hoewel dus inderdaad geen opzet vereist is om tot verbeurdverklaring over te gaan is enige mate van schuld kennelijk wel vereist. Bovendien hoeft de constatering dat opzet niet vereist is op zich nog niet zonder meer tot de conclusie te leiden dat er geen sprake is van 'punishment', omdat dit slecht één van de zeven factoren is die op grond van de zaak 'Kennedy versus Mendoza-Martinez' relevant is (of kan zijn) bij de vaststelling dat er sprake is van 'punishment'.

Het derde argument dat door het Supreme Court naar voren wordt gebracht in de zaak 'Ursery' is, met het oog op de zaken 'Halper', 'Austin' en 'Kurth Ranch', ook niet bijzonder sterk te noemen. Het argument luidt als volgt: 'Third, though both statutes may fairly be said to serve the purpose of deterrence, we long have held that this purpose may serve civil as well as criminal goals. ...'. Het Supreme Court verwijst ter onderbouwing naar de zaak 'Calero-Toledo'66 uit 1974 en naar de zaak '89 firearms' uit 1984.

65 Austin versus United States, 509 U.S. 602 (1993). Het Supreme Court onderbouwde deze stelling in de zaak 'Austin' als volgt: 'Unlike traditional forfeiture statutes, $881(\mathrm{a})(4)$ and (a)(7) expressly provide an "innocent owner" defense. ... The inclusion of innocent-owner defenses in 881 (a)(4) and (a)(7) reveals a similar congressional intent to punish only those involved in drug trafficking. Furthermore, Congress has chosen to tie forfeiture directly to the commission of drug offenses. The legislative history of 881 confirms the punitive nature of these provisions. When it added subsection (a)(7) to 881 in 1984 , Congress recognized "that the traditional criminal sanctions of fine and imprisonment are inadequate to deter or punish the enormously profitable trade in dangerous drugs." S.Rep. No. 98-225, p. 191 (1983). 13 It characterized the forfeiture of real property as "a powerful deterrent." ...' 
In beide zaken is geruime tijd voor de uitspraak in de zaken 'Halper', 'Austin' en 'Kurth Ranch' door het Supreme Court uitspraak gedaan. Het Supreme Court verwijst ten slotte, ter onderbouwing van het derde argument, naar de uitspraak in de zaak 'Bennis versus Michigan' uit $1996 .{ }^{67}$ In die uitspraak heeft het Supreme Court overwogen: '... forfeiture also [curs. KA] serves deterrent purpose distinct from any punitive purpose.' Een nadere onderbouwing van deze stelling is niet te vinden in 'Bennis versus Michigan'.

Ook wordt in de zaak 'Bennis versus Michigan' niet ingegaan op de doctrine uit de zaken 'Halper', 'Austin' en 'Kurth Ranch' met betrekking tot de kwalificatie van een sanctie als 'punishment'. Dit was echter wel wenselijk geweest omdat de stelling in de zaak 'Bennis' totaal niet past in de lijn van de drie genoemde zaken getuige de volgende passage uit 'Halper': 'From these premises, it follows that a civil sanction that cannot fairly be said solely to serve a remedial purpose, but rather can only be explained as also serving either retributive or deterrent purposes [curs. $\mathrm{KA}$ ], is punishment, as we have come to understand the term.' Op grond van de zaak 'Halper' is er derhalve sprake van 'punishment' als een sanctie niet slechts reparatoir is maar tevens vergelding of afschrikkende werking ten doel heeft.

Ook ten aanzien van het derde argument, dat door het Supreme Court wordt aangevoerd in de zaak 'Ursery', kan derhalve niet gezegd worden dat het dermate deugdelijk onderbouwd is dat het de lezer overtuigt van het niet-punitieve karakter van de 'civiele' verbeurdverklaring.

Tenslotte gaat hier nog aandacht uit naar het vierde en laatste argument van het Supreme Court: 'Finally, though both statutes are tied to criminal activity, as was the case in 89 Firearms, this fact is insufficient to render the statutes punitive.' Opvallend is dat zowel in de zaak 'Austin' als in de zaak 'Kurth Ranch' het feit dat de nietstrafrechtelijke sanctie opgelegd werd naar aanleiding van het plegen van een strafbaar feit juist éen van de redenen vormde om de niet-strafrechtelijke sanctie aan te merken als 'punishment'. Ook het vierde argument moet kennelijk weer stand kunnen houden onder verwijzing naar rechtspraak van vóór de zaak 'Halper' zonder ook maar enigszins gefundeerd aan te geven waarom van de met de zaak 'Halper' ingezette lijn afgeweken wordt. ${ }^{68}$

Het lijkt erop dat het Supreme Court de zaken 'Halper', 'Austin', en 'Kurth Ranch' volledig probeert te negeren. Het uitstapje (misstapje?) van het Supreme Court naar een omvangrijkere rechtsbescherming bij niet-strafrechtelijke (punitieve) sancties is kennelijk slecht bevallen. Zoals reeds eerder is opgemerkt is dat zeer spijtig.

67 Bennis v. Michigan. No.94-8729 (1996). Deze uit 1996 daterende uitspraak is slechts drie maanden ouder dan de uitspraak van het Supreme Court in de zaak 'Ursery'.

68 Tenzij men het eerste deel van de uitspraak in de zaak 'Ursery' wenst op te vatten als een deugdelijke onderbouwing voor de conclusie dat de in de zaken 'Halper', 'Austin', en 'Kurth Ranch' uitgezette koers in de zaak 'Ursery' niet van toepassing is. 


\subsection{1.j Hudson Et Al versus United States (1997)}

De laatste uitspraak die in het kader van dit jurisprudentieoverzicht aan de orde komt is 'Hudson Et Al versus United States'. ${ }^{69}$ In verband met het overtreden van de federale wetgeving voor het bankwezen wordt (onder andere) Hudson administratiefrechtelijk gesanctioneerd. De sanctie bestaat aanvankelijk uit een bestuurlijke boete van $\$ 100,000$ terwijl het Hudson daamaast verboden wordt zijn beroep nog langer uit te oefenen ('occupational debarment'). Hudson komt tot een schikking ('Stipulation and Consent Order') met het bestuursorgaan dat de sanctie oplegt. Hudson betaalt een boete van \$16,500 en komt daarnaast met het agency overeen dat hij slechts actief zal zijn in het bankwezen nadat hij toestemming daartoe heeft gekregen van alle agencies die een rol spelen in het bankwezen.

Nadat de bestuursrechtelijke sanctionering, op de hierboven beschreven wijze, heeft plaatsgevonden wordt Hudson ook nog strafrechtelijk aangeklaagd voor dezelfde handeling. Centraal staat de vraag of de (latere) strafrechtelijke vervolging is uitgesloten op basis van de 'double jeopardy-clause' uit het vijfde amendement. Het Supreme Court overweegt dienaangaande het volgende:

'Our opinion in United States v. Halper marked the first time we applied the Double Jeopardy Clause to a sanction without first determining that it was criminal in nature. (...)

The analysis applied by the Halper Court deviated from our traditional double jeopardy doctrine in two key respects. First, the Halper Court bypassed the threshold question: whether the successive punishment at issue is a "criminal" punishment. Instead, it focused on whether the sanction, regardless of whether it was civil or criminal, was so grossly disproportionate to the harm caused as to constitute "punishment." In so doing, the Court elevated a single Kennedy factor-whether the sanction appeared excessive in relation to its nonpunitive purposes-to dispositive status. But as we emphasized in Kennedy itself, no one factor should be considered controlling as they "may often point in differing directions." 372 U.S., at 169. The second significant departure in Halper was the Court's decision to "asses[s] the character of the actual sanctions imposed," 490 U.S., at 447 , rather than, as Kennedy demanded, evaluating the "statute on its face" to determine whether it provided for what amounted to a criminal sanction, 372 U.S., at 169.

We believe that Halper's deviation from longstanding double jeopardy principles was ill considered. As subsequent cases have demonstrated, Halper 's test for determining whether a particular sanction is "punitive," and thus subject to the strictures of the Double Jeopardy Clause, has proved unworkable. We have since recognized that all civil penalties have some deterrent effect. See Department of Revenue of Mont. v. Kurth Ranch, 511 U.S. 767, 777, n. 14 (1994); United States v. Ursery , 518 U. S. , n. 2 (1996) (slip op., at 16-17, n. 2). If a sanction must be "solely" remedial (i.e ., entirely nondeterrent) to avoid implicating the Double Jeopardy Clause, then no civil penalties are beyond the scope of the Clause. Under Halper's method of analysis, a court must also look at the "sanction actually imposed" to determine whether the Double Jeopardy Clause is implicated. Thus, it will not be possible to determine whether the Double Jeopardy Clause is violated until a defendant has proceeded through a trial to judgment. But in those cases where the civil proceeding follows the criminal proceeding, this approach flies in the face of the notion that the Double Jeopardy Clause forbids the government from even "attempting a second time to punish criminally." Helvering, 303 U.S., at 399 (emphasis added). 
Finally, it should be noted that some of the ills at which Halper was directed are addressed by other constitutional provisions. The Due Process and Equal Protection Clauses already protect individuals from sanctions which are downright irrational. Williamson v. Lee Optical of Okla., Inc., 348 U.S. 483 (1955). The Eighth Amendment protects against excessive civil fines, including forfeitures. Alexander v. United States, 509 U.S. 544 (1993); Austin v. United States, 509 U.S. 602 (1993). The additional protection afforded by extending double jeopardy protections to proceedings heretofore thought to be civil is more than offset by the confusion created by attempting to distinguish between "punitive" and "nonpunitive" penalties.

Applying traditional double jeopardy principles to the facts of this case, it is clear that the criminal prosecution of these petitioners would not violate the Double Jeopardy Clause. It is evident that Congress intended the OCC money penalties and debarment sanctions imposed for violations of 12 U. S. C. $\$ \$ 84$ and $375 b$ to be civil in nature. (...)

That such authority was conferred upon administrative agencies is prima facie evidence that Congress intended to provide for a civil sanction. (...)

Turning to the second stage of the Ward test, we find that there is little evidence, much less the clearest proof that we require, suggesting that either OCC money penalties or debarment sanctions are "so punitive in form and effect as to render them criminal despite Congress' intent to the contrary." Ursery, supra , at ___ (slip op., at 22). First, neither money penalties nor debarment have historically been viewed as punishment. (...) Second, the sanctions imposed do not involve an "affirmative disability or restraint," as that term is normally understood. (...) Third, neither sanction comes into play "only" on a finding of scienter. (...) Fourth, the conduct for which OCC sanctions are imposed may also be criminal (and in this case formed the basis for petitioners' indictments). This fact is insufficient to render the money penalties and debarment sanctions criminally punitive, (...) Finally, we recognize that the imposition of both money penalties and debarment sanctions will deter others from emulating petitioners' conduct, a traditional goal of criminal punishment. But the mere presence of this purpose is insufficient to render a sanction criminal, as deterrence "may serve civil as well as criminal goals." (...)

In sum, there simply is very little showing, to say nothing of the "clearest proof" required by Ward, that OCC money penalties and debarment sanctions are criminal. The Double Jeopardy Clause is therefore no obstacle to their trial on the pending indictments, and it may proceed.'

Nadat het Supreme Court het in de zaak 'Halper' voor het eerst gehanteerde, en in de zaken 'Austin' en 'Kurth Ranch' nader uitgewerkte, (materiële) toetsingsmodel volledig probeert te bagatelliseren gaat het, in de zaak 'Hudson Et $\mathrm{Al}^{\prime}$, ongemoeid verder met de toepassing van het in de zaak 'Ward' ontwikkelde (semantische) 'twee-stapstoetsingsmodel'. ${ }^{70}$

Het materiële toetsingsmodel uit 'Halper' zou 'ill considered' en 'unworkable' zijn. Het voorgaande leidt volgens het Supreme Court tot de conclusie dat: 'The additional protection afforded by extending double jeopardy protections to proceedings heretofore thought to be civil is more than offset by the confusion created by attempting to distinguish between 'punitive' and 'nonpunitive' penalties.'

Deze conclusie en de daaraan ten grondslag liggende motivering doet toch op zijn minst enigszins pragmatisch en gekunsteld aan. Het lijkt erop dat het Supreme Court koste wat koste terug wil naar het toetsingsmodel uit de zaak 'Ward' maar geen steek- 
houdende argumenten kan vinden om het in de zaak 'Halper' tot stand gekomen (materiële) toetsingsmodel te ontkrachten.

Het voorkomen van 'verwarring' (die volgens het Supreme Court gesticht is door het toetsingsmodel in de zaak 'Halper') weegt toch niet op tegen het beperken van de rechtsbescherming bij punitieve sancties? Men kan zich dan ook op zijn minst afvragen of het niet mogelijk zou zijn gewieest voor het Supreme Court om de verwarring met betrekking tot het onderscheid tussen punitieve en niet-punitieve sancties in de rechtspraak te verhelderen waardoor de 'additional protections' (uit het vijfde en zesde amendement) wel op bepaalde, niet als strafrechtelijk gekwalificeerde, punitieve sancties van toepassing zouden zijn.

Het Supreme Court zou toch ook de (zogenaamde) 'verwarring' tegen kunnen gaan door op een heldere wijze aan te geven wanneer er sprake is van 'punishment'. Een stap in de juiste richting was in dat kader immers als gezet in de zaken 'Halper', 'Austin' en 'Kurth Ranch'. Bij een nadere uitwerking van de term 'punishment' aan de hand van de materiele criteria uit genoemde zaken zouden op sancties met een punitief karakter de waarborgen uit het vijfde en zesde amendement van toepassing verklaard kunnen worden. ${ }^{71}$ In dat geval zou er toch duidelijk sprake zijn geweest van meer rechtsbescherming (ten aanzien van punitieve sancties) dan nu gerealiseerd kan worden op basis van de door het Supreme Court in de zaak 'Hudson Et Al' aangehaalde 'other constitutional provisions'.

Ten aanzien van het, vervolgens door het Supreme Court, toegepaste toetsingsmodel uit de zaak 'Ward' wordt verwezen naar het commentaar daarop in de zaak 'Ursery'. De motivering van het Supreme Court in 'Ursery' en 'Hudson' is namelijk grotendeels het zelfde. Op basis van het reeds ten aanzien van de zaak 'Ursery' naar voren gebrachte commentaar moge duidelijk zijn dat de motivering van het Supreme Court ter onderbouwing van de 'civiele aard' van de opgelegde sanctie niet bijzonder sterk te noemen is.

In het kader van de toetsing op basis van het 'twee-staps-toetsingsmodel' uit de zaak 'Ward' spreekt het Supreme Court in de zaak 'Hudson Et Al' vervolgens niet langer meer over 'punitive' en 'punishment' maar over 'criminal' en 'criminally punitive'. Daarmee lijkt het Supreme Court in deze zaak van een extreem formele en extreem legistische benadering uit te gaan. De conclusie van het Supreme Court doet vervolgens werkelijk de deur dicht. Om die reden zal deze conclusie hier (nogmaals) weergegeven worden:

'Finally, we recognize that the imposition of both money penalties and debarment sanctions will deter others from emulating petitioners' conduct a traditional goal of criminal punishment. But the mere presence of this purpose is insufficient to render a sanction criminal, as deterrence "may serve civil as well as criminal goals." (...)

In sum, there simply is very little showing, to say nothing of the "clearest proof" [curs. KA] required by Ward, that OCC money penalties and debarment sanctions are criminal. The Double Jeopardy Clause is therefore no obstacle to their trial on the pending indictments, and it may proceed.' 
Het Supreme Court geeft aan dat oplegging van een bestuurlijke boete en een verbod tot het uitoefenen van beroep of bedrijf een afschrikkende werking hebben. Afschrikkende werking is een typisch traditioneel strafrechtelijke sanctiedoel, zo vervolgt het Supreme Court het betoog. Het is echter niet zo dat de sancties vanwege genoemd sanctiedoel 'criminal' van aard zijn. Afschrikkende werking kan immers, volgens het Supreme Court, zowel civiele als strafrechtelijke doelen dienen.

Van deze redenering kan moeilijk chocolade gemaakt worden. Het Supreme Court gebruikt mijns inziens bewust de termen 'criminal' en 'criminally punitive' omdat de sancties door de wetgever gekwalificeerd zijn als 'civiele' sancties. Dit neemt echter niet weg dat deze 'civiele' sancties op basis van materiële criteria zeer wel een punitief effect zouden kunnen hebben. Het Supreme Court lijkt bewust de ogen te sluiten voor deze idee.

Door geen aandacht te schenken aan de materiële vraag of de 'civil penalty' punitief van aard is, is de conclusie van het Supreme Court is in feite nietszeggend. De tweede stap uit de zaak 'Ward' zou genoemd rechtscollege dan ook niet hoeven te zetten. Bij een dergelijke formele benadering zal toetsing aan de criteria uit de zaak 'Kennedy versus Mendoza-Martinez' immers niet (snel) tot de conclusie leiden dat de sanctie punitief is.

Al met al moet worden geconstateerd dat het Supreme Court, door in de uitspraken in de zaken 'Ursery' en 'Hudson' terug te komen op de zaken 'Halper', 'Austin' en 'Kurth Ranch', het personen, aan wie een niet-strafrechtelijke punitieve sanctie wordt opgelegd, (vrijwel) onmogelijk maakt een beroep te doen op de procedurele waarborgen uit het vijfde en zesde amendement. De rechtsbescherming in het Amerikaanse bestuursstrafrecht voldoet dan ook niet aan de Europese (EVRM-)maatstaven. ${ }^{72}$ Tot op heden lijkt het Supreme Court niet voornemens te zijn om terug te komen van de met de zaken 'Ursery' en 'Hudson' wederom ingeslagen (formele) legistische weg. ${ }^{73}$ Een verhoogde rechtsbescherming in het kader van de oplegging van punitieve (bestuursrechtelijke) sancties lijkt er in de Verenigde Staten (voorlopig) dan ook niet in te zitten.

\subsubsection{Schematisch overzicht}

Om een beter beeld te krijgen van de rechtspraak van het Supreme Court in het kader van de toepasselijkheid van de essentiële straf(proces)rechtelijke waarborgen bij de oplegging van niet-strafrechtelijk gekwalificeerde (punitieve) sancties volgt op deze plaats een schematisch overzicht van de hierboven opgenomen rechtspraak.

72 In het slotdeel van deel II en in deel III zal hier nader op ingegaan worden.

73 Vgl. 'Seling, superintendent, special commitment center v. Young', No. 99-1185 (2001). 


\begin{tabular}{|c|c|c|c|c|}
\hline & UITSPRAAK & AMENDEMENT & SANCTIE & $\begin{array}{l}\text { PUN- } \\
\text { ISH- } \\
\text { MENT? }\end{array}$ \\
\hline 1 & $\begin{array}{l}\text { Boyd v. U.S. } \\
\text { (1886) } 116 \text { U.S. } 616\end{array}$ & $\begin{array}{l}5^{\text {th }} ; \text { privilege against } \\
\text { self-incrimination } \\
\text { (nemo tenetur-beginsel) }\end{array}$ & $\begin{array}{l}\text { 'civiele verbeurdver- } \\
\text { klaring', ('in rem civil } \\
\text { forfeiture') }\end{array}$ & ja \\
\hline 2 & $\begin{array}{l}\text { Helvering v. Mitchell } \\
\text { (1938) } 303 \text { U.S. } 391\end{array}$ & $\begin{array}{l}5^{\text {th }} ; \text { double jeopardy- } \\
\text { clause }\end{array}$ & $\begin{array}{l}\text { belastingverhoging van } \\
50 \%\end{array}$ & nee \\
\hline 3 & $\begin{array}{l}\text { Kennedy v. Mendoza- } \\
\text { Martinez } \\
\text { (1963) } 372 \text { U.S. } 144\end{array}$ & $\begin{array}{l}5^{\text {th }} \text { en } 6^{\text {th }} \text { (vrijwel alle } \\
\text { strafrechtelijk waarbor- } \\
\text { gen derhalve) }\end{array}$ & $\begin{array}{l}\text { ontnemen van het Ame- } \\
\text { rikaans burgerschap }\end{array}$ & ja \\
\hline 4 & $\begin{array}{l}\text { U.S. v. Ward } \\
\text { (1980) } 448 \text { U.S. } 242\end{array}$ & $\begin{array}{l}5^{\mathrm{th}} \text {; privilege against } \\
\text { self-incrimination } \\
\text { (nemo tenetur-beginsel) }\end{array}$ & 'bestuurlijke' boete & nee \\
\hline 5 & $\begin{array}{l}\text { U.S. v. } 89 \text { firearms } \\
\text { (1984) } 465 \text { U.S. } 354\end{array}$ & $\begin{array}{l}5^{\text {th }} \text {; double jeopardy- } \\
\text { clause }\end{array}$ & $\begin{array}{l}\text { 'civiele verbeurdver- } \\
\text { klaring', ('in rem civil } \\
\text { forfeiture') }\end{array}$ & nee \\
\hline 6 & $\begin{array}{l}\text { U.S. v. Halper } \\
\text { (1989) } 490 \text { U.S. } 435\end{array}$ & $\begin{array}{l}5^{\text {th }} ; \text { double jeopardy- } \\
\text { clause }\end{array}$ & $\begin{array}{l}\text { 'civiele' boete ('in per- } \\
\text { sonam civil penalty') }\end{array}$ & ja \\
\hline 7 & $\begin{array}{l}\text { Austin v. U.S. } \\
\text { (1993) } 509 \text { U.S. } 602\end{array}$ & $8^{\text {th }} ;$ excessive fines-clause & $\begin{array}{l}\text { 'civiele verbeurdver- } \\
\text { klaring', ('in rem civil } \\
\text { forfeiture') }\end{array}$ & ja \\
\hline 8 & $\begin{array}{l}\text { Montana Dept. of Reve- } \\
\text { nue v. Kurth Ranch } \\
\text { (1994) No. 93-114 }\end{array}$ & $\begin{array}{l}5^{\text {th }} ; \text { double jeopardy- } \\
\text { clause }\end{array}$ & belastingheffing & ja \\
\hline 9 & $\begin{array}{l}\text { U.S. v. Ursery } \\
\text { (1996) No. 95-345 }\end{array}$ & $\begin{array}{l}5^{\text {th }} ; \text { double jeopardy } \\
\text { clause }\end{array}$ & $\begin{array}{l}\text { 'civiele verbeurdver- } \\
\text { klaring', ('in rem civil } \\
\text { forfeiture') }\end{array}$ & nee \\
\hline 10 & $\begin{array}{l}\text { Hudson et. al. v. U.S. } \\
\text { (1997) No. 96-976 }\end{array}$ & $\begin{array}{l}5^{\text {th }} \text {; double jeopardy- } \\
\text { clause }\end{array}$ & $\begin{array}{l}\text { 'bestuurlijke' boete (en } \\
\text { cen verbod tot het } \\
\text { uitoefenen van beroep } \\
\text { of bedrijf) }\end{array}$ & nee \\
\hline
\end{tabular}

\subsection{Afsluitend}

Uit de in deze paragraaf weergegeven rechtspraak van het Supreme Court blijkt dat er niet echt een consistente lijn te onderkennen is in de jurisprudentie wat betreft de toe- 
passelijkheid van het vijfde, zesde en achtste amendement bij oplegging van een bestuurlijke boete. ${ }^{74}$

In de zaak 'Kennedy versus Mendoza-Martinez' uit 1963 komt het Supreme Court met een toetsingsmodel dat vergelijkbaar is met het model dat door het EHRM wordt gebruikt ter beantwoording van de vraag of er sprake is van een 'criminal charge'. In die zaak leidt toetsing aan genoemd model tot de conclusie dat er sprake is van 'punishment'. Dit brengt met zich dat op de opgelegde (punitieve) sanctie alle strafrechtelijke waarborgen uit het vijfde en het zesde amendement van toepassing zijn. Een dergelijke vergaande uitspraak zal het Supreme Court naderhand niet meer doen.

Met de zaak 'Ward' uit 1980 valt het Supreme Court weer min of meer terug op de oude, enge en hoofdzakelijk legistische benadering van de term 'punishment' uit de zaak 'Helvering versus Mitchell' uit 1938. Negen jaar later, in 1989, komt daar weer verandering in als het Supreme Court uitspraak doet in de zaak 'Halper'. Het Supreme Court bepaalt niet langer op een legistische wijze of er sprake is van 'punishment' maar hanteert een materieel criterium. Het gaat er om dat de sanctie vergeldend en/of afschrikkend van aard moet zijn wil de sanctie als 'punishment' gekwalificeerd kunnen worden. De sanctie moet volgens het Supreme Court in ieder geval niet slechts reparatoir van aard zijn ('solely remedial'). Het voorgaande brengt mijns inziens met zich dat er (slechts) sprake moet zijn van leedtoevoeging. ${ }^{75}$ Een vrij ruime benadering dus.

Vervolgens gaat het Supreme Court (na de uitspraak in de zaken 'Halper', 'Austin', en 'Kurth Ranch'), in de zaken 'Ursery' en 'Hudson' opnieuw zeer terughoudend oordelen op basis van het 'twee-staps-toetsingsmodel' uit de zaak 'Ward'. Een succesvol beroep op een van de waarborgen uit het vijfde of zesde amendement bij een niet tot het strafrecht behorende punitieve sanctie wordt daardoor vrijwel onmogelijk.

Op zich kan dus gezegd worden dat het Supreme Court de afgelopen eeuw doorgaans terughoudend is geweest met het aanmerken van een niet tot het strafrecht behorende punitieve sanctie als 'punishment'. In die gevallen waarin het Supreme Court een niet tot het strafrecht behorende punitieve sanctie echter wel als 'punishment' heeft aangemerkt was dat, behoudens in de zaak 'Kennedy versus Mendoza-Martinez', slechts ten aanzien van een bepaalde waarborg uit het vijfde (, zesde) of achtste amendement.

Een verklaring, voor de doorgaans terughoudende opstelling van het Supreme Court, zou kunnen zijn dat de - minder democratisch gelegitimeerde - rechters niet al te snel willen concluderen dat de - democratisch gelegitimeerde - wetgever zich 'vergist' heeft door een bepaalde 'sanctie' niet als 'crime' of 'criminal' te kwalificeren. ${ }^{76}$ En als al geconcludeerd wordt door het Supreme Court dat de wetgever zich vergist heeft dan wordt die conclusie in de uitspraak vaak - voorzover mogelijk - beperkt tot de concrete

74 Vgl. Solomon a.w. 1999, p. 850. Blijkens de uistpraak van het Supreme Court in de zaak 'Hudson' geldt de regel uit de zaak 'Austin' nog wel. Forfeiture moet dus, met het oog op toepasselijkeid van het achtste amendement nog steeds als 'punishment' worden aangemerkt.

$75 \mathrm{Vgl}$. in dit kader hoofdstuk twee.

76 Vgl. Solomon a.w. 1999, p. 851. '...that the Court should use the passive virtues - or techniques of "not doing" - to avoid intruding on democratic process. Judicial inaction effected through the passive virtues, Bickel argued, serves to mitigate the "counter-majoritan difficulty" inherent in an unelected Court deciding major constitutional issues.' 
casus. ${ }^{77}$ Daarnaast is er mijns inziens nog een belangrijke reden voor de terughoudendheid van het Supreme Court wanneer het gaat om het aanmerken van een nietstrafrechtelijke punitieve sanctie als punishment.

Ik doel dan op het feit dat de strafrechtelijke waarborgen worden gezien als een obstakel voor effectieve rechtshandhaving. ${ }^{78}$ Uitbreiding van de strafrechtelijke rechtsbescherming heeft tot gevolg dat de overheid minder overtredingen zal kunnen sanctioneren. Dat de overheid dan minder kan sanctioneren heeft onder andere te maken met het feit dat handhaving van regelgeving door middel van strafrechtelijke procedures duurder is voor de overheid. ${ }^{79}$ Ook het feit dat de bewijslast in het strafrecht veel zwaarder is dan in het bestuursrecht ${ }^{80}$, waardoor een persoon minder snel veroordeeld kan worden, heeft tot gevolg dat er minder gesanctioneerd kan worden of dat er vaak afgezien wordt van vervolging. ${ }^{81}$ Zowel het Congres als de rechters lijken zich dan ook alle moeite te getroosten om te voorkomen dat zij een bepaalde sanctie als 'punishment' moeten kwalificeren. Dit om te voorkomen dat de strafrechtelijke waarborgen uit het vijfde en zesde amendement toegepast moeten worden. ${ }^{82}$

Bestudering van de ronduit zwakke motivering van het Supreme Court in de zaken 'Ursery' en 'Hudson' - ter onderbouwing van de stelling dat een bepaalde nietstrafrechtelijk gekwalificeerde (punitieve) sanctie geen 'punishment' betreft - kan bijna niet tot een andere conclusie leiden dan dat ók Supreme Court ${ }^{83}$ in deze zaken absoluut heeft willen voorkomen dat de strafrechtelijke waarborgen in acht genomen zou-

77 Vgl. Solomon a.w. 1999, p. 851. 'Professor Cass Sunstein recently built upon the restrained judicial philisophy underlying Bickel's "passive virtues" in advancing his theory of "decisional minimalism": the phenomenon of courts "saying no more than necessary to justify an outcome, and leaving as much as possible undecided".' Een dergelijke minimalistische benadering van het Supreme Court, - inhoudende dat alleen gekeken wordt naar de voor de casus relevante rechtsvraag, terwijl daamaast de uitspraak zeer nauw aansfuit bij de feiten uit de casus -, is niet verhelderend voor de rechtseenheid en de rechtsvorming met betrekking tot belangrijke rechtsvragen zoals de vraag of een bestuurlijke boete 'punishment' is in die zin dat het vijfde, zesde en achtste amendement van toepassing zijn.

78 Vgl. Mann a.w. 1992, p. 1853. Op deze plaats wil ik ook verwijzen naar de eerder in dit hoofdstuk aangehaalde passage uit het artikel van Mann. Zie voorts Funk, a.w. 1993, die in zijn artikel aangeeft dat het Congres, in overleg met de uitvoerende instanties (agencies), op basis van pragmatische en financiële argumenten, steeds meer boeteregelingen geïntroduceer heeft teneinde de voorheen toegepaste strafrechtelijke procedures te omzeilen. Zie tenslotte Kerrigan a.w. I993, p. 369.

79 Vgl. Mann a.w. 1992, p. 1852 en verder.

80 De toetsing door de Amerikaanse rechter in een bestuursrechtelijke zaak is duidelijk lang niet zo diepgaand als de toetsing door de Amerikaanse rechter in een strafrechtelijke procedure. In het bestuursrecht geldt de 'substantial-evidence test' terwijl in het strafprocesrecht door de aanklager aangetoond moet worden dat de beschuldigde persoon schuldig is 'beyond reasonable doubt'. (zie hierover ook \$ 5.3.3.2 uit dit boek). Vgl. Kerrigan a.w. 1993, p. 374.

81 Het besluit om ten aanzien van bepaalde zaken niet tot vervolging over te gaan heefl uiteraard ook te maken met de financiele aspecten van vervolging. Is de kans van slagen klein dan wegen de kosten van het doorzetten van de procedure niet op tegen de eventuele veroordeling. Zie ook: Mann a.w. 1992, p. 1854.

82 Vgl. Mann a.w. 1992, p. 1801: 'At the same time, Congress has also enlaged existing powers and provided new authority to administrative agencies to punish offenders in civil proceedings. While legislatures and courts have busily created punitive civil sanctions for the state to impose, they have gone to great lenghts to avoid labeling them as "punitive" to circumvent the application of criminal-type procedural rules. In many instances, the very motivation for the creation of civil punitive sanctions was to avoid criminal procedural protection.'

83 En derhatve niet alleen het Congres. 
den moeten worden. Effectieve en efficiënte handhaving hebben dus blijkbaar een hogere prioriteit dan rechtsbescherming in het bestuursstrafrecht in de Verenigde Staten.

Het voorgaande leidt tot de conclusie dat ook op basis van de hierboven weergegeven rechtspraak van het Supreme Court niet gesteld kan worden dat bij de oplegging van een bestuurlijke boete de essentiële straf(proces)rechtelijke waarborgen, die in het kader van de rechtsbescherming van de (vermoedelijke) overtreder zouden moeten gelden, in acht genomen worden. 


\section{Hoofdstuk 8}

\section{Verenigde Staten - conclusie -}

\subsection{Inleiding}

In deel twee van dit boek is aandacht uitgegaan naar handhaving door middel van bestuurlijke boeten in de Verenigde Staten. Achtereenvolgens is ingegaan op het Amerikaanse administratief recht in het algemeen (hoofdstuk 5), de oplegging van de bestuurlijke boete in Amerika en de waarborgen die in dat kader op grond van de boeteregeling in acht genomen moeten worden (hoofdstuk 6) en tenslotte is de rechtsbescherming die ten aanzien van de (vermoedelijke) overtreder geboden wordt bij de oplegging van bestuurlijke boeten, met name met het oog op de constitutionele waarborgen, aan de orde gekomen (hoofdstuk 7).

In het kader van dit onderzoek stond in deel twee van dit boek de vraag centraal in hoeverre oplegging van de bestuurlijke boete in de Verenigde Staten met essentiële straf(proces)rechtelijke waarborgen is omkleed. Na beantwoording van die vraag zou tevens aangegeven moeten kunnen worden in welke mate in de Verenigde Staten rechtsbescherming geboden wordt bij de oplegging van punitieve bestuursrechtelijke sancties, en dan in het bijzonder ten aanzien van de bestuurlijke boete.

\subsection{Het Amerikaanse administratief recht}

In hoofdstuk vijf is het voor dit onderzoek relevante deel van het Amerikaanse administratief recht in een notendop onderzocht. Daaruit blijkt dat het Amerikaanse administratief recht zich met name is gaan ontwikkelen vanaf het einde van de negentiende eeuw en het begin van de twintigste eeuw.

Vanaf het begin van de vorige eeuw is de overheidsinvloed zich in de Verenigde Staten tot steeds meer terreinen uit gaan breiden. Deze uitbreiding van de overheidsinvloed leidt tot de opkomst van vele agencies. Genoemde agencies worden door de wetgever (in formele zin) in het leven geroepen. ${ }^{1}$ De agencies hebben van de wetgever doorgaans (onder andere) bestuursrechtelijke sanctiebevoegdheden toebedeeld gekregen, waaronder de mogelijkheid tot het opleggen van een bestuurlijke boete. Pas de laatste (twee) decennia is de administratiefrechtelijke sanctionering, en dan in het bijzonder de mogelijkheid tot oplegging van bestuurlijke boeten, in de Verenigde Staten zeer fors toegenomen.

De Amerikaanse agencies beschikken in het algemeen, en derhalve ook bij de oplegging van bestuurlijke boeten, over ruime discretionaire bevoegdheden. Op basis van de formele wetgeving van het Congres kan het agency doorgaans zelf een boetebeleid vaststellen (voor een deel in de vorm van wetgeving in materiêle zin) terwijl vervol-

1 Op basis van de wet in formele zin waarbij zij in het leven geroepen zijn beschikken de agencies doorgaans niet alleen over 'uitvoerende' bevoegdheden maar ook over een 'quasi-wetgevende' en een 'quasi-rechtsprekende' bevoegdheid. 
gens ook de sanctionering en 'rechtspraak' (in eerste instantie) aan het agency zijn toebedeeld.

Het feit dat het agency op deze wijze beschikt over een ('quasi'-)wetgevende, een uitvoerende en een ('quasi'-)rechtsprekende bevoegdheid heeft het Supreme Court niet in strijd geacht met de Grondwet. De APA, die onbevooroordeelde en onpartijdige agency besluitvorming dient te garanderen, wordt immers gezien als een waarborg tegen misbruik van voornoemde concentratie van bevoegdheden. Op de oplegging van een bestuurlijke boete door een agency zijn de procedureregels uit de APA in beginsel ook van toepassing.

De toepasselijkheid van de APA laat echter onverlet dat enige kritische kanttekeningen kunnen worden geplaatst ten aanzien van de procedure tot oplegging van bestuurlijke boeten in Amerika. Tijdens de bestuurlijke fase van de boeteoplegging wordt namelijk, zo is gebleken, lang niet altijd de 'formal adjudication procedure' uit de APA gevolgd. Bovendien voldoet de procedure tot oplegging van een bestuurlijke boete, ook als de bepalingen uit sectie 554 en verder van de APA in acht worden genomen, niet aan alle essentiële straf(proces)rechtelijke waarborgen die in het kader van de rechtsbescherming van de (vermoedelijke) overtreder van toepassing zouden moeten zijn bij de oplegging van een bestuurlijke boete. ${ }^{3}$

Het definitieve boetebesluit kan aangevochten worden bij de artikel III rechter. Doorgaans geschiedt dit (in eerste aanleg) bij een 'District Court' of een 'Circuit Court of Appeals'. De artikel III rechter heeft ten aanzien van boetebesluiten slechts een beperkte (marginale) toetsingsbevoegdheid. Veelal mag de rechter zich bovendien geen eigen oordeel vormen omtrent de feiten terwijl het bestuursorgaan in de 'civiele' procedure niet 'beyond reasonable doubt' hoeft te bewijzen dat de (vermoedelijke) overtreder de overtreding ook daadwerkelijk gepleegd heeft.

Ook ten aanzien van de rechtsbescherming bij de rechter wordt dus niet het niveau bereikt dat vereist is bij oplegging van punitieve sancties. De Amerikaanse rechter heeft geen volledige toetsingbevoegdheid ten aanzien van de opgelegde bestuurlijke boete. Bovendien is er soms geen hoger beroep mogelijk tegen een rechterlijke uitspraak aangaande de opgelegde bestuurlijke boete.

\subsection{Verhoogde rechtsbescherming?}

In hoofdstuk zes is een tweetal boeteregelingen, die uitgevoerd worden door het EPA. nader belicht. Daarbij is aandacht uitgegaan naar de boeteregelingen zoals die zijn neergelegd in de wet in formele zin (de Clean Air Act en de Marine Protection, Research and Sanctuaries Act), naar de, de boeteregelingen overkoepelende, Rules of Practice en naar het boetebeleid van het EPA in het kader van de vaststelling van de hoogte van de boete. Vervolgens is beoordeeld in hoeverre in genoemde regelingen invulling wordt gegeven aan essentiële straf(proces)rechtelijke waarborgen die in het

2 In het kader van de Awb zouden wij Nederlanders wellicht eerder spreken van bezwaar en/of administratief beroep.

3 Ik ga er van uit dat de bestuurlijke boete (in iedere zich zelf respecterende rechtsstaat) gerekend moet worden tot het strafrecht in ruime zin. Dit brengt met zich dat in het kader van de oplegging van een bestuurlijke boete tenminste de essentięle straf(proces)rechtelijke waarborgen moeten gelden ( $\delta \delta \hat{k}$ in de Verenigde Staten). 
kader van de rechtsbescherming van de vermoedelijke overtreder van toepassing zouden moeten zijn bij de oplegging van een bestuurlijke boete.

Het eindresultaat van dit onderzoek is niet bijzonder positief te noemen is. Een aantal essentiële straf(proces)rechtelijke waarborgen blijft immers geheel buiten beschouwing in de bestudeerde regelingen. In dit kader kan onder andere gewezen worden op het feit dat dubbele bestraffing ten aanzien van dezelfde overtreding niet is uitgesloten in de onderzochte regelingen. Zowel aan het una via-beginsel als aan het ne bis in idembeginsel is immers geen invulling gegeven. Hetzelfde geldt voor het zwijgrecht en de cautieplicht, en het recht op rechtspraak in twee feitelijke $e^{4}$ instanties.

Het voorgaande zou verklaard kunnen worden uit het feit dat in de Verenigde Staten de oplegging van bestuurlijke boeten niet wordt gerekend tot het strafrecht in ruime zin. De aard van de sanctie lijkt in dat kader minder relevant te zijn dan het etiket dat door de wetgever op de sanctie wordt geplakt (in het geval van de bestuurlijke boete 'civil' - the administrative assessment of a civil penalty -).

In hoofdstuk zeven in onderzocht in hoeverre op basis van de rechtspraak van het Supreme Court alsnog invulling is gegeven aan bepaalde essentiële straf(proces)rechtelijke waarborgen. In dat kader stond de vraag centraal of de oplegging van een bestuurlijke boete (en sanctionering middels bepaalde (andere) 'civil remedies') gekwalificeerd kan worden als 'punishment' in de zin van het vijfde, zesde of achtste amendement van de Amerikaanse constitutie.

Op basis van een jurisprudentie-analyse kan gezegd worden dat het Supreme Court de afgelopen eeuw doorgaans terughoudend is geweest met het aanmerken van een nietstrafrechtelijke gekwalificeerde (punitieve) sanctie als 'punishment'. In die gevallen waarin het Supreme Court een niet-strafrechtelijk gekwalificeerde punitieve sanctie echter wel als 'punishment' heeft aangemerkt was dat, behoudens in de zaak 'Kennedy versus Mendoza-Martinez', slechts ten aanzien van een bepaalde waarborg uit het vijfde (, zesde) of achtste amendement. De laatste jaren oordeelt het Supreme Court zeer terughoudend. Dit brengt met zich dat een succesvol beroep op een van de waarborgen uit genoemde amendementen bij de oplegging van een punitieve sanctie die geen deel uit maakt van het strafrecht in beginsel niet mogelijk is.

In het vorige hoofdstuk is aangegeven dat een verklaring, voor de terughoudende opstelling van het Supreme Court, zou kunnen zijn dat de - minder democratisch gelegitimeerde - rechters niet al te snel willen concluderen dat de - democratisch gelegitimeerde - wetgever zich 'vergist' heeft door een bepaalde 'sanctie' niet als 'crime' of 'criminal' te kwalificeren. Het voorgaande lijkt bovendien met zich te brengen dat, als al geconcludeerd wordt door het Supreme Court dat de wetgever zich vergist heeft, die conclusie in de uitspraak vaak - voor zover mogelijk - beperkt wordt tot de concrete casus.

Daarnaast is nog een belangrijke reden aan te wijzen voor de terughoudendheid van het Supreme Court wanneer het gaat om het aanmerken van een niet-strafrechtelijke (punitieve) sanctie als punishment. Deze tweede - mijns inziens zwaarwegendere - reden, voor het Supreme Court om terughoudendheid te betrachten, is namelijk dat de straf-

De rechter toetst agency-besluiten in de regel immers zeer terughoudend terwijl hij (in beginsel) voorts uit moet gaan van de feiten zoals ze door het agency zijn vastgesteld. 
rechtelijke waarborgen worden gezien als een obstakel voor effectieve rechtshandhaving. Uitbreiding van de strafrechtelijke rechtsbescherming heeft tot gevolg dat de overheid minder overtredingen zal kunnen sanctioneren. Dat de overheid dan minder kan sanctioneren heeft onder andere te maken met het feit dat handhaving van regelgeving door middel van strafrechtelijke procedures duurder is voor de overheid. Ook het feit dat de bewijslast in het strafrecht veel zwaarder is dan in het bestuursrecht, waardoor een persoon minder snel veroordeeld kan worden, heeft tot gevolg dat er minder gesanctioneerd kan worden of dat er vaak afgezien moet worden van vervolging. Zowel het Congres als de rechters lijken zich dan ook veel moeite te getroosten om te voorkomen dat zij een bepaalde sanctie als 'punishment' moeten kwalificeren. Dit om te voorkomen dat de strafrechtelijke waarborgen uit het vijfde en zesde amendement toegepast moeten worden. Effectieve en efficiënte handhaving hebben dus blijkbaar een hogere prioriteit dan rechtsbescherming in (onder andere) het bestuursstrafrecht in de Verenigde Staten.

Het voorgaande brengt met zich dat ook op basis van de hierboven weergegeven rechtspraak van het Supreme Court niet gesteld kan worden dat bij de oplegging van een bestuurlijke boete de essentiële strafprocesrechtelijke waarborgen, die in het kader van de rechtsbescherming van de (vermoedelijke) overtreder zouden moeten gelden in acht genomen worden.

\subsection{Afsluitend}

Bestudering van de voorgaande hoofdstukken leert dat in de Verenigde Staten de essentiële strafprocesrechtelijke waarborgen, die in het kader van de rechtsbescherming van de vermoedelijke overtreder zouden moeten gelden bij de oplegging van een bestuurlijke boete, niet allemaal in acht genomen worden.

Dat bepaalde essentiële strafprocesrechtelijke waarborgen bij de oplegging van bestuurlijke boeten niet in acht worden genomen vloeit met name voort uit het feit dat deze sancties niet worden gerekend tot het strafrecht in ruime zin. De aard van de sanctie lijkt in dat kader minder relevant te zijn dan het etiket dat door de wetgever op de sanctie wordt geplakt (in het geval van de bestuurlijke boete 'civil' - the administrative assessment of a civil penalty -). Dit brengt met zich dat zowel in de wet in formele zin, waarin de boeteregeling is neergelegd, als in de algemene procedureregels géén rekening wordt gehouden met de essentiële strafprocesrechtelijke waarborgen.

Het Supreme Court grijpt de wettelijke regeling, die door het Congres het etiket 'civiel' mee heeft gekregen, aan om de oplegging van (bijvoorbeeld) een bestuurlijke boete niet aan te merken als 'punishment'. Het democratisch gelegitimeerde Congres heeft immers bepaald dat het gaat om een 'civil' penalty. In beginsel zal het Congres, zo stelt het Supreme Court, de sanctie terecht als 'civiele sanctie' hebben gekwalificeerd. Dit is, volgens het Supreme Court slechts anders als de straf zó punitief is dat de duidelijk als civiele sanctie bedoelde straf daarmee verandert in een strafrechtelijke sanctie. Uit bestudering van de in hoofdstuk zeven opgenomen rechtspraak is gebleken dat dit laatste (vrijwel) nooit het geval is volgens het Supreme Court. Dit brengt met zich dat het op de sanctie geplakte etiket in de regel doorslaggevend is. 
Wellicht wordt de bestuurlijke boete niet gerekend tot het strafrecht in ruime zin met het oog op efficiënte en effectieve handhaving. De hoge prioriteit die wordt gegeven aan rechtshandhaving lijkt daarmee ten grondslag te liggen aan het ontbreken van bepaalde fundamentele strafrechtelijke waarborgen bij de oplegging van bestuurlijke boeten. Zowel het Congres als het Supreme Court lijken alles op alles te zetten om de bestuurlijke boete uit de strafrechtelijke sfeer te houden. De strafrechtelijke waarborgen worden blijkbaar gezien als een obstakel voor effectieve rechtshandhaving.

Met name de laatste jaren komt het Supreme Court op basis van verbazingwekkende redeneringen tot de conclusie dat er geen sprake is van 'punishment' in de zin van het vijfde of zesde amendement bij de oplegging van een bestuurlijke boete. De redenen om de bestuurlijke boete niet als 'punishment' te kwalificeren lijken overwegend van pragmatische aard te zijn. Effectieve en efficiënte handhaving wegen dus blijkbaar zwaarder dan de rechtsbescherming in het Amerikaanse bestuursstrafrecht. Een en ander leidt tot de conclusie dat bij de procedure tot oplegging een bestuurlijke boete in de Verenigde Staten geen invulling wordt gegeven aan een aantal fundamentele straf(proces)rechtelijke waarborgen die in acht genomen zouden moeten worden bij de oplegging van een punitieve bestuursrechtelijke sanctie. 



\section{Deel III}

\section{Tot besluit}





\section{Inleiding}

In deel I van dit boek (de hoofdstukken 2 tot en met 4) is ingegaan op de Nederlandse bestuurlijke boete(regeling). In deel II (de hoofdstukken 5 tot en met 8 ) is vervolgens aandacht besteed aan handhaving door middel van bestuurlijke boeten in de Verenigde Staten. Nu wordt het tijd de balans op te maken. Centraal in dit onderzoek staat de vraag of er voldoende rechtsbescherming geboden wordt bij de oplegging van punitieve bestuursrechtelijke sancties en dan in het bijzonder bij de oplegging van bestuurlijke boeten. In dat kader is aandacht uitgegaan naar de vraag in welke mate de vermoedelijke overtreder rechtsbescherming geniet en zou moeten genieten.

Aan de hand van de uit deel I en II naar voren gekomen bevindingen zal hiema worden aangegeven of er, op basis van de momenteel in Nederland bestaande en voorgestelde boeteregelingen, voldoende rechtsbescherming geboden kan worden aan de vermoedelijke overtreder in het kader van de oplegging van bestuurlijke boeten. Voorts zullen, naar aanleiding van genoemde bevindingen enige suggesties worden gedaan ter verbetering van de rechtsbeschermingspositie van de vermoedelijke overtreder bij de oplegging van bestuurlijke boeten. 



\section{Hoofdstuk 9}

\section{Rechtsbescherming bij bestuurlijke boeten. Balanceren op een magische lijn?}

\subsection{Inleiding}

In dit boek is aandacht uitgegaan naar de oplegging van punitieve bestuursrechtelijke sancties. Meer in het bijzonder naar de oplegging van bestuurlijke boeten. Deze relatief jonge bestuursrechtelijke sanctie werd ingevoerd met het doel een einde te maken aan het (overigens niet met empirische bewijzen gestaafde ${ }^{l}$ ) handhavingstekort op het terrein van het bestuursrecht. De boete werd, zo zou men kunnen stellen, als van oorsprong strafrechtelijke sanctie, geïmporteerd in het bestuursrecht. Met invoering van de bestuurlijke boete werd beoogd op een doelmatige wijze, via een relatief eenvoudige procedure, schending van bestuursrechtelijke normen 'met een geringe normatieve lading' te sanctioneren. ${ }^{2}$

Genoemde doelmatige handhaving staat nog steeds voorop bij de handhaving van het bestuursrecht door middel van bestuurlijke boeten. ${ }^{3}$ De vraag is hoe de met de bestuurlijke boete te dienen doelen, waaronder in het bijzonder efficiënte en effectieve handhaving, zich verhouden tot de rechtsbescherming van de vermoedelijke overtreder. Wil men immers genoemde doelstellingen realiseren dan zal dat onmiskenbaar gepaard gaan met een inkrimping van de rechtswaarborgen, ten opzichte van de in het strafrecht toepasselijke waarborgen, van de (vermoedelijke) overtreder. ${ }^{4}$

Centraal in dit onderzoek staat de vraag of voldoende rechtsbescherming geboden wordt in het bestuursstrafrecht, en dan in het bijzonder bij de oplegging van bestuurlijke boeten. In dat kader is aandacht uitgegaan naar de vraag in welke mate rechtsbescherming geboden wordt en geboden zou moeten worden bij de oplegging van bestuurlijke boeten.

Met het oog beantwoording van de vraag of er voldoende rechtsbescherming geboden wordt in het bestuursstrafrecht, en dan in het bijzonder bij de oplegging van bestuurlijke boeten, dient ten eerste vastgesteld te worden tot welk rechtsgebied de oplegging van bestuurlijke boeten, in materieel opzicht, gerekend moet worden. Formeel gezien, zoveel is duidelijk, valt de oplegging van een bestuurlijke boete onder het bestuurs-

1 Vgl. Corstens a.w. 1995, p. 13-14, G.J.M. Corstens, Bestuurlijke boetes, in het bijzonder in hei financiele recht' SEW 2001, p. 242-247, i.h.b. p. 242, Ten Berge en Michicls, a.w. 2001, p. 388 en Quaedvlieg, a.w. 2001, p. 188-189.

2 Zie CTW-rapport a.w. 1994, p. 7 en hoofdstuk twee van dit boek. Onder normschendingen met een geringe normatieve lading lijken alleen de werkelijk moreel verwerpelijke delicten zonder meer niet te vallen. Ten aanzien van die delicten staat vast dat zij strafrechtelijk gehandhaafd moeten worden. Dit hangt samen met het feit dat van sanctionering van die delicten een stigmatiserende werking uit moet gaan. Het voorgaande brengt met zich dat in feite alle normschendingen die niet onmiskenbaar moreel verwerpelijk zijn middels een bestuurlijke boete af zouden kunnen worden gedaan.

3 Zie Voorontwerp p. 95.

$4 \mathrm{Vgl}$. Schaffmeister a.w. 1984 p. 137. Zie in meer algemene zin: Barkhuysen/Van Emmerik/Loof a.w. 2000, p. 383. 
recht. Desalniettemin blijkt al in één oogopslag dat de oplegging van een bestuurlijke boete op wezenlijke punten verschilt van de doorgaans door bestuursorganen te verrichten publiekrechtelijke rechtshandelingen, terwijl de bestuurlijke boete anderzijds opmerkelijke overeenkomsten vertoont met strafrechtelijke sancties. Wezenskenmerk van de bestuurlijke boete is immers dat zij gericht is op bestraffing van de overtreder. Leedtoevoeging is daarmee - anders dan bij de van oudsher in het bestuursrecht voorkomende reparatoire sancties, die zien op herstel van de rechtmatige toestand ${ }^{5}-$ een belangrijk doel van deze punitieve bestuursrechtelijke sanctie. De bestuurlijke boete maakt, vanwege haar leedtoevoegende karakter, deel uit van het bestuursstrafrecht ofivel van het strafrecht in ruime zin. Dit brengt met zich dat bij de oplegging van de bestuurlijke boete, óók los van het verdragsrecht, bepaalde (fundamentele) strafrechtelijke beginselen in acht moeten worden genomen. ${ }^{6}$

De Nederlandse wetgever en rechter ${ }^{7}$ lijken zich echter in het bijzonder verplicht te voelen om deze strafrechtelijke beginselen in acht te nemen vanwege het feit dat de oplegging van een bestuurlijke boete aangemerkt moet worden als 'criminal charge' in de zin van artikel 6 EVRM ${ }^{8}$ Bij de totstandkoming van de regeling omtrent oplegging van bestuurlijke boeten in het Voorontwerp van de vierde tranche van de Awb lijkt dan ook de meeste aandacht uit te zijn gegaan naar het realiseren van de (minimum)waarborgen die voortvloeien uit genoemde verdragsbepaling (en de daarmee nauw verband houdende artikelen 7 EVRM, en 14 en 15 IVBPR). Het nationale straf(proces)recht is in elk geval niet onverkort van toepassing bij de oplegging van punitieve bestuursrechtelijke sancties zoals de bestuurlijke boete.

In het Voorontwerp is een regeling getroffen voor de oplegging van bestuurlijke boeten waarin, ter invulling van de verdragsrechtelijke waarborgen, bepaalde essentiële straf(proces)rechtelijke waarborgen (tot op zekere hoogte) zijn neergelegd, terwijl die regeling tevens ingepast is in het bestaande bestuursprocesrecht. Aangezien veelal onverkort wordt vastgehouden aan het bestuursprocesrecht leidt dit in bepaalde gevallen tot ongewenste situaties met het oog op de rechtsbescherming van de vermoedelijke overtreder. De uitgangspunten die ten grondslag liggen aan het bestuursprocesrecht zijn immers (tenminste deels) van een beduidend andere aard dan de beginselen die aan het strafprocesrecht ten grondslag zijn gelegd. ${ }^{10}$

Uit dit boek kan worden afgeleid dat de rechtsbescherming van de vermoedelijke overtreder op basis van de voorgestelde regeling, in ieder geval op bepaalde (belangrijke)

$5 \quad$ Vgl. CTW-rapport a.w. 1994, p. 9.

6 Vgl. G.J.M. Corstens, Bestuurlijke boeten, in het bijzonder in het financiele recht, SEW 2001, p. 242 247, i.h.b. p. 244. Dat dit standpunt niet nieuw is moge blijken uit; W.P.J. Pompe, Handboek van het Nederlandse strafrecht, vijfde herziene druk, Zwolle 1959, i.h.b. p. 68-69.

7 Zie bijv. HR 7 sepiember 1988, BNB 1988/298 i.h.b. r.o. 4.1, en HR 9 oktober 1996, BNB $1997 / 6 \mathrm{~m}$. nt. M.W.C. Feteris.

8 Vgl. CTW-rapport a.w. 1994, p. 40-42, i.h.b. p. 42: 'De Toetsingcommissie meent dat vooralsnog kan worden volstaan met regeling van de meest essentiele waarborgen, dat wil zeggen de waarborgen die op grond van artikel 6 EVRM en 14 IVBPR noodzakelijk zijn.' Zie voorts: (weliswaar in mindere mate) Voorontwerp p. 95 en 98-100 en Albers a.w. 2000, p. 140-141.

9 Zie artikel 53 EVRM en artikel 5, tweede lid IVBPR. Zie voorts: Van Russen Groen a.w. 1998, p. 6366.

$10 \mathrm{Vgl}$. in dit kader ook: Albers en Schlussels a.w. 2002. 
punten, te wensen over laat. Hierna zal stil gestaan worden bij de eerder geconstateerde lacunes op het gebied van de rechtsbescherming van de vermoedelijke overtreder. Genoemde lacunes lijken samen te hangen met het feit dat de commissie Scheltema in het Voorontwerp de verdragsrechtelijke waarborgen als uitgangspunt neemt, terwijl zij genoemde waarborgen vervolgens in bepaalde gevallen 'schraal' uitlegt. Onverkorte toepassing van het straf(proces)recht en strafprocesrechtelijke beginselen is niet aan de orde. Daarnaast brengt de commissie de boeteregeling onder in het reguliere bestuursprocesrecht. Daarmee miskent zij dat het bestuursprocesrecht niet onverkort toegepast kan worden bij de oplegging van punitieve sancties zoals de bestuurlijke boete. Hierna zal aan de orde komen in hoeverre de rechtsbescherming van de vermoedelijke overtreder beperkt wordt door onverkorte toepassing van het bestuursprocesrecht.

Vervolgens zal aandacht uitgaan naar het, in deel II van dit boek beschreven, Amerikaanse boetesysteem. Op basis van een vergelijking van de wijze waarop, bij oplegging van bestuurlijke boeten, in het Amerikaanse systeem invulling wordt gegeven aan de rechtsbescherming van de vermoedelijke overtreder zal aangegeven worden in hoeverre de Nederlandse wetgever daar lering uit kan trekken. Tenslotte volgen, op basis van de hierboven weergegeven bevindingen, enkele suggesties en aanbevelingen in het kader van de rechtsbescherming van de vermoedelijke overtreder. Genoemde suggesties en aanbevelingen zijn bedoeld als een handreiking voor de wetgever.

\section{$9.2 \quad$ Knelpunten}

Zoals hierboven reeds is aangegeven zal ten eerste aandacht uitgaan naar de regeling van de bestuurlijke boete zoals voorgesteld in het Voorontwerp. In dat kader zal ingegaan worden op de beperkingen ten aanzien van de rechtsbescherming van de vermoedelijke overtreder die ontstaan door de wijze waarop in het Voorontwerp de verdragsrechtelijke waarborgen zijn uitgewerkt. Daarna zal aandacht uitgaan naar de problemen die zich voor doen met betrekking tot de beperking van de (omvang van de) rechtsbescherming doordat het bestuursprocesrecht onverkort van toepassing is op de procedure tot oplegging van bestuurlijke boeten. In dat kader wordt ingegaan op de noncontentieuze en contentieuze fase van het bestuursprocesrecht.

\subsubsection{Verdragsrecht als uitgangspunt}

De commissie Scheltema geeft in de algemene toelichting op het Voorontwerp aan dat zij zich realiseert dat het bestraffende karakter van de boete niet over het hoofd gezien kan worden en dat de boeteregeling derhalve, in het bijzonder vanwege artikel 6 EVRM, op enkele wezenlijke punten overeen moet komen met het strafrecht. ${ }^{11}$ Desalniettemin hoeven volgens de commissie niet alle (nationale) strafrechtelijke leerstukken overgenomen te worden in de bestuurlijke boeteregeling. Het gaat, bij de handhaving middels bestuurlijke boeten, immers om relatief eenvoudige delicten. ${ }^{12}$

Dat bepaalde beginselen van het Nederlandse straf(proces)recht slechts op fragmentarische en eigen wijze door de commissie Scheltema zijn overgenomen blijkt onmisken- 
baar bij bestudering van het Voorontwerp. In hoofdstuk vier is uitvoerig aangegeven in hoeverre straf(proces)rechtelijke regels en beginselen geheel dan wel gedeeltelijk, en eventueel (bewust dan wel onbewust) voorzien van een eigen interpretatie, zijn overgenomen. Volledigheidshalve volgt hier een beknopte weergave van fragmentarisch overgenomen strafrechtelijke leerstukken en begrippen.

Gewezen kan worden op termen als overtreder, functioneel daderschap, eendaadse samenloop, meerdaadse samenloop, hetzelfde feit, en de daarmee samenhangende leerstukken. De uitleg die de commissie Scheltema aan deze termen en leerstukken in het Voorontwerp heeft gegeven wijkt, zoals gezegd, soms af van de uitleg die daaraan (onder meer door de Hoge Raad) in het strafrecht gegeven wordt. Dientengevolge bestaat het gevaar dat de bestuursrechter bepaalde strafrechtelijke begrippen en leerstukken anders zal gaan uitleggen dan de strafrechter. Dit geldt bijvoorbeeld ook voor het hanteren van een zogenaamd 'open stelsel' van rechtvaardigings- en schulduitsluitingsgronden. Daarnaast kan gewezen worden op een van artikel $29 \mathrm{~Sv}$ afwijkende regeling van het zwijgrecht in het Voorontwerp.

Corstens en Knigge achten, zo bleek reeds in hoofdstuk vier, de hierboven beschreven ontwikkeling onwenselijk. Laatstgenoemde strafrechtspecialist lijkt zelfs te pleiten voor onverkorte toepassing van het strafrecht bij de oplegging van bestuurlijke boeten. Dat is wellicht wat 'overdone'. De commissie Scheltema heeft mijns inziens namelijk gelijk als zij stelt dat aan bepaalde strafrechtelijke leerstukken in het (punitieve) bestuursrecht geen behoefte bestaat omdat bestuurlijke boeten in de regel alleen voor relatief eenvoudige delicten mogen worden opgelegd. ${ }^{13}$ Mijns inziens is echter wél van belang dat, als strafrechtelijke leerstukken worden overgenomen, zij, met het oog op rechtseenheid en rechtszekerheid, conform het geldend (straf)(proces)recht worden overgenomen. ${ }^{14}$ Daarnaast moeten de Awb-wetgever en de bestuursrechter waar mogelijk dezelfde uitleg aan strafrechtelijke bepalingen en leerstukken geven als de strafrechter. Dit is in het Voorontwerp niet op alle punten gebeurd.

De conclusie lijkt gerechtvaardigd dat de commissie Scheltema in het Voorontwerp hoofdzakelijk bepaalde straf(proces)rechtelijke beginselen heeft opgenomen omdat dit op grond van de mensenrechtenverdragen (in het bijzonder het EVRM en IVBPR) noodzakelijk werd geacht. Gelet op de voormamelijk pragmatische doelstellingen waaronder in het bijzonder efficiënte en effectieve handhaving - die hoofdzakelijk ten grondslag lagen aan de invoering van de (mogelijkheid tot oplegging van de) bestuurlijke boete (op grote schaal) lijkt de commissie Scheltema hier echter niet in alle gevallen geheel welwillend tegenover te hebben gestaan. Het is dan wellicht ook daardoor

Voorontwerp p. 100.

14 Waarom zou immers in het kader van de oplegging van een bestuurlijke boete een andere uitleg aan (bijv.) de samenloopregeling moeten worden gegeven dan in het kader van de oplegging van een boete door de strafrechter wegens het plegen van een strafbaar feit. Beide sancties maken deel uit van het strafrecht in ruime zin. Ten aanzien van beide sancties dient dan ook (bijv.) dezelfde samenloopregeling te geiden. Er lijkt immers ten aanzien van (de meeste) als strafbaar feit gekwalificeerde overtredingen (afgezien van pragmatische argumenten) geen wezenlijke reden te zijn om ze onder te brengen in het strafrecht in plaats van in het bestuursrecht. Dit blijkt ook uit het gemak waarmee inmiddels een aantal strafrechtelijke overtredingen is overgeheveld van het strafrecht naar het bestuursrecht. 
dat de commissie bepaalde verdragsrechtelijke minimum waarborgen, bij de uitwerking daarvan in de voorgestelde boeteregeling, nogal 'schraal' uitlegt. In dat kader kan onder meer gewezen worden op het door de commissie gemaakte onderscheid tussen de zware en de lichte procedure, de (té) beperkte uitleg van het zwijgrecht in diverse opzichten en het toestaan van gebruik van strafrechtelijk onrechtmatig verkregen bewijs. ${ }^{15}$ Anderzijds lijkt de commissie Scheltema graag aansluiting te zoeken bij de verdragsrechtelijke waarborgen en de in dat kader bestaande rechtspraak indien deze waarborgen minder ver reiken dan de in het nationale recht bestaande equivalenten. Ik wijs in dat kader op het zwijgrecht dat volgens de commissie Scheltema, conform de rechtspraak van het EHRM, geldt vanaf het moment dat er sprake is van een 'charge'. Een moment dat later in de tijd gelegen is als het moment waarop aan een verdachte op grond van artikel 29 Sv het zwijgrecht wordt toegekend.

Schaffmeister heeft in 1984 in zijn preadvies voor de NJV aangegeven dat afsplitsing van bepaalde gedeeltes van het strafrecht, terwijl een sanctionerend optreden middels een vereenvoudigde procedure wordt gehandhaafd, een inkrimping op de rechtswaarborgen van de vermoedelijke overtreder met zich zal brengen. ${ }^{16}$ Bestudering van het Voorontwerp en de reeds bestaande bijzondere bestuursrechtelijke wetten waarin de bevoegdheid is neergelegd tot oplegging van bestuurlijke boeten, leert dat er inderdaad sprake is van een inkrimping van de rechtswaarborgen ten opzichte van de strafrechtelijke procedure.

Men kan zich echter afvragen of ten aanzien van de, middels bestuurlijke boeten te handhaven, bestuursrechtelijke normen 'met een geringe normatieve lading', álle strafrechtelijke waarborgen van toepassing zouden moeten zijn. Schaffmeister meent van niet. Met het oog op het handhavingstekort en het bereiken van een hoger handhavingsniveau moeten volgens hem bepaalde overtredingen middels een vereenvoudigde procedure afgedaan worden. Deze vereenvoudigde procedure hoeft slechts te voldoen aan de minimumnormen die voortvloeien uit het verdragsrecht. ${ }^{17}$ Anderen nemen een verdergaand standpunt in door te stellen dat (onverkorte) toepassing van de verdragsrechtelijke waarborgen bij sanctionering van ordeningswetgeving door middel van punitieve sancties niet plaats zou moeten vinden omdat dit de devaluatie van de mensenrechten in de hand werkt. ${ }^{18}$ Door sommige auteurs worden echter kritische kanttekeningen geplaatst bij een dergelijke minimalistische interpretatie van bepalingen uit het EVRM. ${ }^{19}$ Van Russen Groen meent bijvoorbeeld dat de wetgever niet de grens zou moeten opzoeken van wat op grond van de mensenrechtenverdragen nog net toelaat-

15 Zie voor een uitvoerige beschrijving van de schrale uitleg van verdragsrechtelijke waarborgen hoofdstuk vier van dit boek. De schrale uitleg van de waarborgen vloeit niet alleen voort uit doelmatigheidsoverwegingen. In de volgende paragraaf zal blijken dat de inpassing van de bestuurlijke boeteregeling in het bestaande bestuursprocesrecht ook leidt tot een beperkte uitleg van de verdragsrechtelijke waarborgen op bepaalde punten.

16 Schaffmeister aw. 1984, p. 137. Zie ook: P. Baauw, Strafrecht en de schaduwzijden van 50 jaar EVRM: een impressie, in de bundel: 50 jaar Europees Verdrag voor de Rechten van de Mens, onder redactie van R.A. Lawson en E. Myjer, Leiden 2000, p. 409-420, i.h.b. p. 418.

17 Schaffmeister aw. 1984, p. 152.

18 Zie voor een overzicht van auteurs die genoemd standpunt innemen: Van Russen Groen a.w. 1998, p. 68-69.

19 Zie: Van Russen Groen a.w. 1998, p. 64-65 en Barkhuysen/Van Emmerik/Loof a.w. 2000, p. 407. 
baar is. Veel meer zou de wetgever met het oog op het doel en de strekking van de verdragsrechtelijke waarborgen deze ruimhartig door moeten laten werken in de nationale rechtsorde. ${ }^{20}$

Hoewel overheveling van de sanctionering van bepaalde bestuursrechtelijke normschendingen van het strafrecht naar het bestuursrecht, mede vanuit doelmatigheidsoverwegingen, verdedigbaar is moeten mijns inziens toch ten minste de essentiële strafrechtelijke waarborgen, die veelal tevens zijn neergelegd in de mensenrechtenverdragen $^{21}$, in voldoende mate in acht genomen worden. Dit impliceert dat in ieder geval niet altijd volstaan kan worden met de, door de commissie Scheltema in bepaalde bepalingen uit het Voorontwerp weergegeven, beperkte uitleg van de verdragsrechtelijke bepalingen. De invulling die de nationale wetgever in de regeling tot oplegging van bestuurlijke boeten aan de verdragsrechtelijke waarborgen gaat geven zal, mede met het oog op de incorporatietheorie ${ }^{22}$, tenminste in overeenstemming moeten zijn met de interpretatie die door het EHRM wordt gegeven aan genoemde waarborgen.

In dit kader dient nogmaals benadrukt te worden dat het EHRM reeds in de zaak 'Öztürk' heeft aangegeven dat de uit artikel 6 EVRM voortvloeiende waarborgen van toepassing moeten zijn op alle punitieve sancties. Het Hof heeft immers in 1984 het volgende overwogen:

'The fact that it was admittedly a minor offence hardly likely to harm the reputation of the offender does not take it outside the ambit of Article 6 (art. 6). There is in fact nothing to suggest that the criminal offence referred to in the Convention necessarily implies a certain degree of seriousness. In this connection, a number of Contracting States still draw a distinction, as did the Federal Republic at the time when the Convention was opened for the signature of the Governments, between the most serious offences (crimes), lesser offences (délits) and petty offences (contraventions), whilst qualifying them all as criminal offences. Furthermore, it would be contrary to the object and purpose of Article 6 (art. 6), which guarantees to "everyone charged with a criminal offence" the right to a court and to a fair trial, if the State were allowed to remove from the scope of this Article (art. 6) a whole category of offences merely on the ground of regarding them as petty. (...) The relative lack of seriousness of the penalty at stake cannot divest an offence of its inherently criminal character. ${ }^{23}$

Voor een onderscheid tussen een lichte boeteprocedure - waarin naar mijn mening bepaalde waarborgen tot op zekere hoogte tekort worden gedaan - en een zware procedure die alleen van toepassing is als er boeten van meer dan 340 Euro opgelegd kumnen worden, kan in de rechtspraak van het EHRM dan ook géen steun worden gevonden. ${ }^{24}$ Op basis van het voorgaande moet geconcludeerd worden dat ten aanzien van bestuursrechtelijke punitieve sancties, die tevens als 'criminal charge' gekwalificeerd kunnen

20 Van Russen Groen a.w. 1998, p. 72.

21 Zie in dit kader de opsomming in hoofdstuk 3.

22 Zie: Barkhuysen/Van Emmerik/Loof a.w. 2000, p. 331.

23 Zie: Oztürk \$ 53-54.

24 De keuze van de commissie Scheltema, om te onderscheiden tussen een lichte en een zware boeteprocedure, lijkt grotendeel gebaseerd te zijn op doelmatigheidsargumenten. Zie Voorontwerp p. 97: 'Bij boeten van minder dan $€ 340$ zou de zware procedure in de meeste gevallen tot onevenredige lasten leiden.' 
worden, de straf(proces)rechtelijke minimum waarborgen uit artikel 6 en 7 EVRM en 14 en 15 IVBPR in ieder geval ten volle van toepassing (zouden moeten) zijn.

\subsubsection{Het eigen karakter van de bestuurlijke boete verzet zich tegen onverkorte toepassing van het bestuursprocesrecht}

\subsubsection{Algemeen}

Een groot probleem, wat betreft het realiseren van voldoende rechtsbescherming voor de vermoedelijke overtreder, lijkt voorts te schuilen in het feit dat het Nederlandse bestuursprocesrecht niet in voldoende mate toegespitst is op procedures tot het opleggen van punitieve sancties. In het Voorontwerp blijkt dit, zo volgt uit hoofdstuk vier van dit boek, duidelijk. In genoemd hoofdstuk is een aantal tekortkomingen, die kleven aan het bestuursprocesrecht met het oog op de rechtsbescherming die bij de oplegging van punitieve sancties geboden zou moeten worden, aan de orde gesteld.

Ik wijs bijvoorbeeld op het feit dat de bestuursrechter, op grond van de in het Voorontwerp voorgestelde regeling, slechts 'ex tunc' zou mogen toetsen. Wellicht het grootste nadeel van deze wijze van toetsing is dat de bestuursrechter niet bevoegd is een lagere boete op te leggen als er sprake is van een strafverlaging in de wettelijke regeling die tot stand is gekomen tijdens de beroepsprocedure. ${ }^{25}$ Voorts kan gewezen worden op het feit dat de bestuursrechter de evenredigheid van de boete bij strikt gebonden sanctiebevoegdheden veelal niet daadwerkelijk kan toetsen. Daamaast ontbreekt schorsende werking bij bezwaar en beroep ${ }^{26}$, kan de boete reeds worden ingevorderd op het moment dat nog niet onherroepelijk op het tegen het boetebesluit ingediende bezwaar, beroep of hoger beroep is beslist en bestaat er in de lichte procedure géen hoorplicht in de primaire fase gelet op (de naar geldend recht gegeven uitleg aan) artikel 4:12 Awb. Ook is onduidelijk op welke wijze in de praktijk, met het oog op het bestuursprocesrecht, invulling moet worden gegeven aan de ne bis in idem-regeling. Op basis van het voorgaande kan in ieder geval gesteld worden dat toepassing van de bestuursprocesrechtelijke regels in het bestuursstrafrecht er doorgaans toe leidt dat de rechtsbescherming voor de overtreder geringer is in het bestuursstrafrecht dan bij sanctionering middels de reguliere strafrechtelijke procedure. ${ }^{27}$

In een enkel geval heeft de commissie Scheltema wél voor afwijking van de, in het algemeen geldende, bestuursrechtelijke regeling gekozen. In dit kader kan gewezen worden op de toetsing aan het evenredigheidsbeginsel bij de oplegging van bestuurlijke boeten. Interessant is de verklaring van genoemde commissie waarom bij punitieve

$25 \mathrm{Hij}$ kan in deze situatie op basis van het huidige bestuursprocesrecht (in beginsel) veelal niet zelf in de zaak voorzien. Mocht dit wel het geval zijn dan zou hij wél de lagere boete op kunnen leggen omdat hij, zelf in de zaak voorziend, ex nunc mag toetsen. Zie in dit kader voorts de beschrijving van artikel 5.4.1.7, vierde lid van het Voorontwerp in hoofdstuk vier. Overigens verdient opmerking dat de Centrale Raad wél over gaat tot toepassing van de nieuwe regeling die in strafverlaging voorziet als deze regeling pas tot stand in gekomen gedurende de (hoger) beroepsprocedure. Ik ga er van uit dat ook de regering in de vierde tranche van dit standpunt uit zal gaan.

26 Zie artikel 6:16 Awb.

27 Vgl. Albers en Schlossels a.w. 2002 
sancties door de bestuursrechter niet marginaal maar vol mag worden getoetst aan het evenredigheidsbeginsel. ${ }^{28}$

Opvallend is dat de commissie Scheltema op een geforceerde wijze probeert afwijkende regels dogmatisch te rechtvaardigen. Het zou beter zijn als de commissie gewoon duidelijk aangegeven had dat het gelet op het bijzondere karakter van de op te leggen punitieve sancties nodig is af te wijken van het 'gewone' bestuursprocesrecht. De verhouding tussen rechter en bestuur is immers in het 'traditionele' bestuursrecht van een andere aard dan in het kader van de oplegging van een punitieve sanctie. In het kader van de oplegging van punitieve sancties, waaronder de bestuurlijke boete, moet de bestuursrechter mijns inziens immers óbk aansluiting zoeken bij het strafrecht en de (meest) essentiële regels die zien op een goede strafvordering.

Logischerwijs stelt de bestuursrechter zich doorgaans terughoudend op waar het gaat om de rechtmatigheid van de uitoefening van bevoegdheden (met beleidsvrijheid) door het bestuursorgaan. ${ }^{29} \mathrm{Bij}$ de oplegging van punitieve sancties zou dit, in het bijzonder met het oog op de (ruime) (toetsings)bevoegdheden van de strafrechter in het strafproces, echter anders moeten zijn. ${ }^{30}$ De commissie Scheltema lijkt dit niet in volle omvang onder ogen te willen zien en volstaat met een poging de volle toetsing aan het evenredigheidsbeginsel in een bestuursprocesrechtelijk dogmatisch verantwoord keurslijf te persen.

\subsubsection{Toegang tot een rechter die beschikt over 'full jurisdiction'}

Bij het bestuursorgaan vindt, bij de oplegging van punitieve sancties, een (mijns inziens onwenselijke) concentratie van bevoegdheden plaats. De bevoegdheid tot opsporing, vervolging en bestraffing zijn immers in de regel geconcentreerd binnen één bestuursorgaan. ${ }^{31}$ Dit komt de transparantie van de procedure niet ten goede ${ }^{32}$ Bovendien zal ten aanzien van de vermoedelijke overtreder de indruk worden gewekt dat sanctionering niet op een onpartijdige en onafhankelijke wijze is geschied. ${ }^{33}$ Ten slotte kan de rechter alléén een oordeel vormen over de rechtmatigheid van de opgelegde boete als de vermoedelijke overtreder tijdig bezwaar aantekent tegen het boetebesluit en vervolgens, indien het bezwaar ongegrond wordt verklaard, binnen de beroepstermijn een beroepschrift in dient.

Hoewel het Europese Hof voor de Rechten van de Mens in beginsel niet afwijzend staat tegenover de ontwikkeling die in verschillende partijstaten heeft plaatsgevonden, waarbij de bevoegdheid tot (opsporing, vervolging en) oplegging van punitieve sancties in eerste instantie bij het bestuur is neergelegd, geeft het tegelijkertijd uitdrukkelijk aan dat er daarna wel een rechtsgang voorhanden moet zijn die voldoet aan de in artikel 6 EVRM neergelegde waarborgen. ${ }^{34}$ De vraag is echter of een dergelijke rechtsgang op grond van het huidige bestuursprocesrecht geboden kan worden. Met name ten aanzien

Zie de beschrijving van artikel 5.4.1.7, tweede lid van het Voorontwerp eerder in dit hoofdstuk.

Later in dit hoofdstuk kom ik daar op terug.

Vgl. bijv. Oostenbrink a.w. 1967, p. 134 en (kritisch hierover) Corstens aw. 2000, p. 1188.

Vgl. Corstens a.w. 2000 , p. 1189.

Het zogenaamde 'piepsysteem'. Corstens a.w. 2001, p. 242.

Zie: Ozturk $\$ 56$. 
van de eis van toegang tot de bestuursrechter en het vereiste dat deze rechter beschikt over 'full jurisdiction' lijkt op zijn minst twijfelachtig te zijn of, op basis van het huidige bestuursprocesrecht, daaraan in voldoende mate invulling gegeven te kan worden.

Een aantal uitgangspunten en beginselen zoals die bestaan in het huidige bestuursprocesrecht lijken de toegang tot een rechter, die bovendien vaak niet in alle opzichten lijkt te beschikken over 'full jurisdiction', te beperken. Hierboven is reeds een aantal regels en beginselen genoemd die in dat kader wellicht als beperking van de verdragsrechtelijke waarborgen te beschouwen zijn. Daarnaast kan bijvoorbeeld worden gewezen op artikel 8:41 Awb, op grond waarvan de vermoedelijke overtreder griffierecht dient te betalen teneinde toegang te krijgen tot de bestuursrechter in beroep en hoger beroep. ${ }^{35}$ Heffing van genoemd griffierecht kan onder omstandigheden leiden tot een, met artikel 6 van het EVRM strijdige, beperking van het recht op toegang tot de rechter. ${ }^{36}$ Hetzelfde geldt overigens voor de, in bepaalde gevallen door de commissie Scheltema voorgestane, zekerheidsstelling ten bedrage van de opgelegde boete.

Daarnaast zal de bestuursrechter beleidsvrije aspecten van het boetebesluit - voor zover van dergelijke aspecten sprake kàn zijn bij punitieve sancties - die niet samenhangen met de evenredigheid van de boete marginaal moeten toetsen. Mijns inziens staat dit, zeker nu het gaat om punitieve sancties ${ }^{37}$, op gespannen voet met het vereiste van 'full jurisdiction'. ${ }^{38}$ Met zekerheid kan dit echter niet gesteld worden aangezien (vooralsnog) ten aanzien van, als 'criminal charge' aan te merken, sancties nog geen rechtspraak van het EHRM voorhanden is.

Ten slotte kan gewezen worden op het, op grond van artikel 8:69 Awb, ontstane 'trechtermodel'. ${ }^{39}$ Toepassing van dit, met name door de Afdeling Bestuursrechtspraak gehanteerde, model leidt, in samenhang met het ontbreken van verplichte procesvertegenwoordiging ${ }^{40}$, naar mijn mening in ieder geval in het kader van de oplegging van punitieve sancties tot een rechtsbeschermingsprocedure die vermoedelijk niet voldoet aan de eisen van artikel 6 EVRM. ${ }^{41}$ Ten eerste wordt de toegang tot de rechter door

35 Hetzelfde geldt uiteraard indien de vermoedelijke overtreder de president verzoekt een voorlopige voorziening te treffen hangende bezwaar, beroep of hoger beroep.

36 Vgl. Barkhuysen/Van Emmerik/Loof, a.w. 2000 p. 386-387 en Heringa in zijn noot onder Rechtbank Assen 6 januari 1999, JB 1999/37. Zie in dit kader ook: EHRM 19 juni 2001, no. 28249/95 (Kreuz v. Poland). Zie voorts: CRvB 4 januari 2001, JB 2001/55, Pres. rechtbank Groningen 13 februari 1996, JB 1996/179 m. nt. Annemiek Derks en Malva Driessen, Rechtbank Assen 8 november 1995, JB 1995/321 m. nt. Henk Simon, CRvB 9 mei 1995, JB 1995/163 m. nt. A.B.J. van der Ham en E.L. Benetreu en Rechtbank Assen 21 maart 1994, JB 1994/77.

37 Met marginale toetsing van typisch bestuursrechtelijke besluiten, die de 'determination of civil rights and obligations' behelzen, lijkt het EHRM geen problemen te hebben. Vgl. EHRM 22 november 1993, Series A, Vol 335-A (Bryan) en EHRM 7 november 2000, no. 35605/97 (Kingsley).

38 Vgl. de zaak Belilos $\$ 68$, en $71-72$.

39 Zoals gezegd lijkt er in het kader van het bewijs ten aanzien van de feiten bij punitieve sancties geén sprake te zijn van een 'fuik'. Dit laat echter onverlet dat het 'trechtermodel' in het kader van niet tijdig naar voren gebrachte gronden onverkort toegepast zou kunnen worden in het kader van de oplegging van punitieve sancties.

40 In het strafrecht is (uiteraard) geen sprake van het ontbreken van verplichte procesvertegenwoordiging. Kiest een verdachte niet zelf een door hem betaalde raadsman dan wordt ambtshalve een raadsman toegevoegd. Vgl. Costens a.w. 1999, p. 87-96, en de artikelen 37 tot en met 49 Sv.

4l Vgl. Barkhuysen/Van Emmerik/Loof, a.w. 2000 p. 387 en 389-390. 
toepassing van het 'trechtermodel' (tenminste gedeeltelijk) beperkt. ${ }^{42}$ Op basis van het 'trechtermodel' wordt de omvang van het geding immers reeds definitief vastgesteld (d.w.z. beperkt) in de voorprocedure, namelijk tijdens de bezwaarschriftprocedure of de (uitgebreide) openbare voorbereidingsprocedure. Alleen de reeds gedurende deze voorprocedure naar voren gebrachte bezwaren kunnen immers een rol spelen in de procedure bij de bestuursrechter indien hij het 'trechtermodel' toepast. Niet eerder aangevoerde gronden die zouden kunnen leiden tot vernietiging van het bestreden besluit mag de rechter op basis van het 'trechtermodel' niet meenemen. De materiële waarheidsvinding staat daarmee in het bestuursprocesrecht onder druk. ${ }^{43}$

Hoewel de Afdeling Bestuursrechtspraak erkent dat middels deze praktijk de toegang tot de rechter wordt beperkt acht zij deze beperking niet zodanig dat er sprake is van strijd met artikel 6 EVRM. ${ }^{44}$ Een nadere onderbouwing van deze stelling ontbreekt in de Afdelingsuitspraak van 27 augustus 1998 overigens. Annotator Schlössels geeft aan dat er sprake is van een feitelijke beperking van de toegang tot de rechter indien deze toegang in het nationale procesrecht afhankelijk wordt gesteld van het geschil in de bestuurlijke voorprocedure. De effectiviteit van de toegang tot de rechter wordt daarmee volgens hem immers (mede) afhankelijk van de alertheid van de rechtszoekende burger in de voorprocedure. Schlossels meent dat deze beperking van het beroepsrecht tegen de achtergrond van artikel 6 EVRM in ieder geval kwestieus te noemen is. Ik kan dit standpunt onderschrijven.

Uit het voorgaande volgt dat er mijns inziens - en dit klemt te meer nu het gaat om de oplegging van punitieve sancties - in beginsel niet meer gesproken kan worden van een rechter die voldoet aan het vereiste van 'full jurisdiction' gelet op de, op grond van (de huidige interpretatie van) artikel 8:69 Awb geldende, beperkingen ten aanzien van de toetsingsbevoegdheid van de bestuursrechter. ${ }^{45}$

Wat dit laatste betreft biedt de rechtspraak van het EHRM overigens (nog) weinig duidelijkheid. Gaat het om, geschillen ten aanzien van 'civil rights and obligations' in het kader van de uitoefening van, typische bestuursrechtelijke bevoegdheden met beleidsvrijheid dan is een beperking van de rechterlijke toetsing niet (zonder meer) uitgesloten. ${ }^{46}$ Of dit anders ligt bij oplegging van punitieve sancties door bestuursorganen kan niet met zekerheid worden gezegd. In een dergelijk geval is er sprake van een 'criminal charge'. Bovendien kan er in dat kader naar mijn mening niet over bevoegdheden met beleidsvrijheid (in de zuiver bestuursrechtelijke zin) worden gesproken. Dit brengt met zich dat het mijns inziens niet onwaarschijnlijk is dat het Hof in dat kader hogere eisen stelt aan de rechterlijke toetsingsbevoegdheid. Ik sluit dan ook niet uit dat er, bij de oplegging van bestuurlijke boeten, niet volstaan kan worden met marginale toetsing,

$\mathrm{Vgl}$. Simon in zijn noot onder ABRS 21 september 1998, JB 1998/241 (Sliedrecht).

In dit kader is ook relevant dat in het bestuursprocesrecht uitgegaan wordt van het zogenaamde 'piepsysteem'. Komt de vermoedelijke overtreder niet binnen de gestelde bezwaar- of beroepstermijn op tegen het boetbesluit dat krijgt genoemd besluit formele rechtskracht en wordt het als rechtmatig beschouwd, ongeacht of het besluit daadwerkelijk rechtmatig is. ABRS 27 augustus 1998, JB 1998/273 m. nt. R.J.N. Schløssels.

Vgl. Schlössels a.w. 1999, p. 183-185 en De Bock a.w. 2000, p. 75-77. Een genuanceerder standpunt wordt ingenomen in het Evaluatie-onderzoek 'Hoger beroep in het bestuursrecht' (Vgl. Widdershoven' Schlossels/Stroink a.w. 2001, p. 40-41).

$\mathrm{Vgl}$. de zaken Bryan en Kingsley. 
een grievenstelsel waarbij een 'trechtermodel' gehanteerd wordt of beperkingen anderszins van de rechterlijke bevoegdheid om alle relevante aspecten met betrekking tot de feiten en het recht te toetsen. Er zijn in ieder geval aanwijzingen dat ook het EHRM het aldus geschetste 'trechtemnodel' in het kader van punitieve sancties niet zal accepteren. $^{47}$

\subsubsection{Andere verdragsrechtelijke waarborgen}

Toepassing van het bestaande bestuursprocesrecht leidt er in bepaalde gevallen voorts toe dat andere verdragsrechtelijke waarborgen door de commissie Scheltema schraal worden uitgelegd. Ik heb reeds de aandacht gevestigd op de problemen die ontstaan in het kader van artikel 5.4.1.7, vierde lid Voorontwerp met betrekking tot het toepassen van de meest gunstige bepaling. Daarnaast kan worden gewezen op het feit dat de commissie Scheltema blijft vasthouden aan de vrij bewijsleer in het bestuursprocesrecht. Daarmee hangt mijns inziens samen dat in het bestuursrecht nogal soepel wordt omgesprongen met strafrechtelijk onrechtmatig verkregen bewijs. Dit is met het oog op de onschuldpresumptie uiteraard niet wenselijk. Daar komt nog bij dat volgens de commissie uitgegaan mag worden van (soms onweerlegbare) vermoedens van schuld terwijl schorsende werking van bezwaar en beroep en een hoorplicht in de primaire fase vaak (zullen) ontbreken. Ook acht de commissie het niet onmogelijk vormverzuimen te passeren op grond van artikel 6:22 Awb. Men kan zich afvragen of daardoor niet het risico ontstaat dat verdedigingsrechten of andere verdragsrechtelijke waarborgen worden geschonden. Het is immers niet ondenkbaar dat de bestuursrechter te lichtvaardig gebruik maakt van zijn bevoegdheid ex artikel 6:22 Awb. ${ }^{48}$

\subsubsection{Ten slotte}

De bestuursrechtelijke rechtsbescherming laat zo bezien, in het kader van de oplegging van punitieve bestuursrechtelijke sancties als de bestuurlijke boete, (ten minste op bepaalde punten) te wensen over. De Toetsingscommissie en de commissie Scheltema lijken daar anders over te denken. In het CTW-rapport stelt de Toetsingscommissie ten aanzien van het rechtsbeschermingsgehalte het volgende:

'Belangrijker is, dat de bestuursrechtelijke rechtsbescherming vergeleken met zo'n twintig jaar geleden aanzienlijk is verbeterd, en dat aan de bestuurlijke besluitvorming thans beduidend strengere zorgvuldigheidseisen worden gesteld. De inwerkingtreding van de Algemene wet bestuursrecht per 1 januari 1994 en de definitieve afschaffing van het Kroonberoep accentueren die ontwikkeling. Daarmee is onder meer, in overeenstemming met de eisen van artikel 6 EVRM, over de hele linie van het bestuursrecht een effectieve toegang tot de rechter verzekerd. ${ }^{49}$

De commissie Scheltema gaat nog een stap verder door het volgende te stellen:

47 Vgl. EHRM 14 november 2000, no. 27783/95, EHRC 2000/94 m. nt. C.L.G.F.H. Albers (T. v. Austria).

48 Vgl. ABRS 28 augustus 2002, LJN-nummer AE 6927 (WN-boete Zeist).

49 CTW-rapport a.w. 1994, p. 9. Vgl. de hiervoor gemaakte opmerkingen m.b.t. effectieve toegang tot de rechter en 'full jurisdiction' in relatie tot artikel 8:69 Awb. 
'Heden ten dage biedt het bestuursrecht de burger een aan het strafrecht gelijkwaardige rechtsbescherming. Met name is thans ook in het bestuursrecht gewaarborgd, dat een opgelegde sanctie altijd door de onafhankelijke rechter kan worden getoetst. Daardoor hehoeft het tockennen van punitieve sanctiebevoegdheden aan het bestuur thans niet meer op rechtsstatelijke bezwaren te stuiten. ${ }^{50}$

Ik kan mij, zo volgt reeds uit het voorgaande, niet vinden in de stelling van de Toetsingscommissie en de commissie Scheltema dat op basis van het bestuursprocesrecht zoals neergelegd in de Awb een aan het strafrecht gelijkwaardige rechtsbescherming gerealiseerd kan worden bij de oplegging van punitieve bestuursrechtelijke sancties. Zie ik het goed dan deelt Schreuder-Vlasblom mijn mening. Zij geeft aan dat de idee, dat de in het strafrecht geldende waarborgen in het bestuursprocesrecht, bij de oplegging van punitieve sancties, behouden zouden kunnen blijven wel eens een 'riskante illusie' zou kunnen blijken. ${ }^{51} \mathrm{Zij}$ wijst in dit kader op de specifieke eigenschappen van het huidige nationale bestuursprocesrecht die beperkend werken ten aanzien van de rechtsbescherming bij de oplegging van punitieve bestuursrechtelijke sancties zoals de bestuurlijke boete. ${ }^{52}$ Niet alleen vanuit de bestuursrechtelijke hoek wordt dit gesignaleerd. Ook strafrechtelijke auteurs wijzen er op dat er voor gewaakt moet worden dat er voldoende rechtsbescherming gerealiseerd wordt bij de oplegging van punitieve bestuursrechtelijke sancties. ${ }^{53}$

Mijns inziens zal in de boeteregeling op een aantal punten uitdrukkelijk afgeweken moeten worden van het bestaande bestuursprocesrecht. Alleen op die wijze kan in voldoende mate tegemoet gekomen worden aan de essentiële verdragsrechtelijke én strafrechtelijke waarborgen die ook in het kader van de oplegging van punitieve bestuursrechtelijke sancties in acht moeten worden genomen. Een dergelijke (ver)heldere(nde) regeling is voorts in het kader van de rechtszekerheid van belang. In $\S$ vier van dit hoofdstuk kom ik daar op terug.

\subsubsection{Doelmatigheidsargumenten lijken de overhand te hebben}

Het voorgaande leidt, met betrekking tot het nationale recht, tot de volgende slotsom. Het (volgens sommigen niet empirisch aangetoonde) handhavingstekort vormde een belangrijke (wellicht zelfs dé belangrijkste) drijfveer voor de grootschalige overheveling van afdoening van overtredingen vanuit het strafrecht naar het bestuursrecht. Efficiënte en effectieve handhaving hebben daarmee prioriteit gekregen. De kwaliteit van de rechtsbescherming van de vermoedelijke overtreder lijkt in dat kader van lagere orde te zijn. ${ }^{54}$

Voorontwerp p. 95.

51 Schreuder-Vlasblom a.w. $200 \mathrm{lb}$, p. 129.

52 Schreuder-Vlasblom a.w. 200 lb, p. 129-130. Jansen lijkt dit overigens, in zijn NJV-preadvies, over het hoofd te zien als hij verklaart dat hij niet overtuigd is van de noodzaak om af te wijken van het bestuursrechtelijk model. Vgl. Jansen, a.w. 2002, p. 167-255, i.h.b. p. 187-189, p. 239-240, p. 254-255.

53 Vgl. 't Hart a.w. 2001, p. 195-196 en Knigge in: Groenhuijsen en Knigge a.w. 2001, p. 111 e.v. en i.h.b. 114.

54 Vgl. o.m. Kelk a.w. 1994, p. 25-27. 
Reeds in het CTW-rapport wordt onomwonden aangegeven dat een doelmatige wijze van handhaving voorop zou moeten staan. De Toetsingscommissie kiest bij de afdoening van delicten waardoor de rechtsorde niet in ernstige mate geschokt is dan ook niet voor het strafrecht omdat de strafrechtelijke procedure, door de waarborgen waarmee zij is omkleed, relatief zwaar, tijdrovend en kostbaar is. ${ }^{55}$

Bestuursrechtelijke afdoening zoals (onder meer) voorgesteld in het CTW-rapport en het Voorontwerp van de vierde tranche is op zich reeds minder tijdrovend en kostbaar dan de strafrechtelijke procedure, zélfs als bepaalde verdragsrechtelijke (minimum)waarborgen in acht moeten worden genomen. Toch blijkt in het Voorontwerp dat op bepaalde punten de rechtsbescherming, vanuit doelmatigheidsoverwegingen nóg verder is gereduceerd. Evident komt dit naar voren bij de toelichting op de keuze van de commissie voor het invoeren van een lichte procedure bij boeten lager dan 340 Euro. Bij die boeten zou immers de zware procedure tot 'onevenredige lasten' leiden, aldus de commissie Scheltema. ${ }^{56}$ Daarnaast worden verdragsrechtelijke waarborgen soms nogal beperkt uitgelegd teneinde de mogelijkheid tot doelmatige handhaving niet al te zeer te ondermijnen.

Doelmatige handhaving en voldoende rechtsbescherming lijken dan ook (tenminste tot op zekere hoogte) contradictoir. Reeds in 1995 signaleerde Corstens in zijn afscheidsrede in dat kader het volgende:

'Men mist - geheel in de trant van het huidig debat - de notie dat bij strafrechtelijke rechtshandhaving de burger die voorwerp is van onderzoek, meer bescherming wordt geboden dan in een stelsel van bestuursboeten. Dat meerdere bestaat er onder andere in dat de rechter de sanctie-oplegger is. Bovendien kent de strafrechtspleging een traditie van zorgvuldig afgewogen sanctie-oplegging die voor een deel in geschreven en ongeschreven rechtsnormen is vastgelegd en voor een ander deel een kwestie van wijzen van bejegening en van mores is. In een bestuursrechtelijk sanctiestelsel dat in hoge mate kan convergeren naar het stelsel van strafrechtelijke rechtshandhaving, kan diezelfde traditie nooit in diezelfde mate groeien, omdat daarin het bestuur dat primair uit is op effectieve handhaving, de toon zet. ${ }^{57}$

Op basis van het in $\$ 2.2,2.3$ en 2.4 van dit hoofdstuk gestelde meen ik de opvatting van Corstens (en anderen die hem daarin steunen) te kunnen onderschrijven. Dit brengt echter niet met zich dat ik van mening ben dat handhaving door middel van punitieve bestuursrechtelijke sancties moet voldoen aan alle vereisten en waarborgen die gelden bij strafrechtelijke handhaving. ${ }^{58}$

Zoals gezegd zullen in ieder geval de essentiële strafrechtelijke waarborgen ${ }^{59}$, die voor een deel tevens zijn neergelegd in de mensenrechtenverdragen, bij de oplegging van bestuurlijke boeten in acht moeten worden genomen. Mede met het oog daarop lijkt het uitgesloten het huidige bestuursprocesrecht onverkort, althans zoals voorgesteld in het

55 CTW-rapport a.w. 1994, p. 7.

56 Voorontwerp p. 97.

57 G.J.M. Corstens, Een stille revolutie in het strafrecht (Afscheidsrede Nijmegen 1995), Gouda Quint bv, Amhem 1995, p. 18.

58 Zie in dit kader ook $\$ 2.2$ van dit hoofdstuk.

59 Denk daarbij bijvoorbeeld aan het 'geen straf zonder schuld-beginsel', regels m.b.t. eendaadse en meerdaadse samenloop, de ne bis in idem-regeling, het legaliteitsbeginsel, het lex certa-vereiste, het zwijgrecht, enz. 
Voorontwerp, toe te passen bij de oplegging van bestuurlijke boeten. Voorts moet worden gewaakt voor een té beperkte uitleg van de verdragsrechtelijke waarborgen. In paragraaf vier van dit hoofdstuk wordt op het voorgaande nog nader ingegaan.

\subsection{Externe rechtsvergelijking}

\subsubsection{Boete oplegging en waarborgen in de Verenigde Staten}

\subsubsection{Algemeen}

In het kader van externe rechtsvergelijking is in gegaan op het Amerikaanse recht. Daarbij is in het bijzonder aandacht uit gegaan naar de vraag hoever de rechtsbescherming bij de oplegging van punitieve bestuursrechtelijke sancties in de Verenigde Staten strekt. Op basis van deze externe rechtsvergelijking kan het volgende geconcludeerd worden.

De mogelijkheid tot oplegging van bestuurlijke boeten bestond in de Verenigde Staten al in de negentiende eeuw. Op dat moment was er echter slechts op een beperkt aantal terreinen sprake van overheidsinvloed. Toen vanaf 1900 de overheidsinvloed zich tot steeds meer terreinen uit ging breiden leidde dit tot de opkomst van veel (zelfstandige) bestuursorganen (zogenaamde 'agencies'). De agencies - die ook wel de 'fourth branch' van de Amerikaanse federatie worden genoemd - werden belast met wetgeving, uitvoering, handhaving en 'rechtspraak' (in eerste aanleg) op terreinen van het 'bijzonder bestuursrecht'. Teneinde de regelgeving, waarvoor het agency verantwoordelijk is, te kunnen handhaven zijn door de formele wetgever aan het agency doorgaans sanctiebevoegdheden toegekend. De bestuurlijke boete incluis.

Het voorgaande brengt met zich dat de opmars van de bestuurlijke boete duidelijke parallellen vertoont met de opkomst van de fourth branch. Tenslotte blijkt uit bestudering van het tweede deel van dit boek dat in de Verenigde Staten, evenals in Nederland, met name de laatste twee decennia van de vorige eeuw de mogelijkheid tot administratiefrechtelijke handhaving (onder meer door middel van de bestuurlijke boete) explosief gegroeid is.

\subsubsection{De boeteregeling in de Verenigde Staten}

In de Verenigde Staten bestaat geen uniforme regeling waarin in algemene zin de procedure tot oplegging van bestuurlijke boeten is neergelegd. De wetgever in formele zin heeft in iedere afzonderlijke bestuursrechtelijke regeling, die nader ingevuld en uitgevoerd moet worden door een in de wet aangewezen agency, al dan niet een mogelijkheid gecreëerd tot handhaving middels bestuurlijke boeten. Bijgevolg worden in de Verenigde Staten verschillende boeteregelingen en dito procedures aangetroffen. Een algemeen beeld van de wijze waarop in de Verenigde Staten bestuurlijke boeten worden opgelegd is dan ook niet zonder meer te vormen. Wel is het zo dat de diverse bestaande Amerikaanse boeteregelingen op hoofdlijnen met elkaar in overeenstemming zijn.

In dit onderzoek is een aantal boeteregelingen, die zijn neergelegd in milieurechtelijke wetgeving, bekeken. Deze regelingen worden door het Environmental Protection 
Agency (EPA) uitgevoerd. In nadere regelgeving is op federaal- of agency niveau een uitwerking gegeven aan de, in de milieuwetgeving in essentie neergelegde, boeteprocedures. Op basis van bestudering van de regelingen tezamen is het mogelijk een beeld te krijgen van de Amerikaanse bestuurlijke boeteregeling.

Centraal in dit boek staat de rechtsbescherming van de vermoedelijke overtreder, in het kader van de oplegging van een punitieve sanctie. Vanuit dat oogpunt is dan ook in het bijzonder naar de Amerikaanse regeling gekeken. Daarbij is met name aandacht uitgegaan naar de vraag of de Amerikaanse boeteregeling, zoals beschreven in deel II, voldoet aan bepaalde essentiële strafrechtelijke en verdragsrechtelijke waarborgen die (naar Nederlands recht) van toepassing zouden moeten zijn bij de oplegging van punitieve bestuursrechtelijke sancties. Ten eerste is daarbij aandacht uitgegaan naar de vraag in hoeverre de waarborgen deel uit maken van de boeteregeling zelf (inclusief de daarop gebaseerde lagere regelgeving). Vervolgens is bekeken of waarborgen die niet zijn neergelegd in de boeteregeling over de band van de constitutie van toepassing zijn en derhalve in acht moeten worden genomen bij de oplegging van een bestuurlijke boeten.

Bestudering van de in deel II beschreven Amerikaanse boeteregeling leert dat bepaalde essentiële waarborgen niet hun weerslag vinden in die regeling. Zo is in ieder geval in de boeteregeling zelf niet voorzien in een regeling met betrekking tot rechtspraak in twee feitelijke instanties, het ne bis in idem-beginsel en het nemo tenetur-beginsel. Het zijn derhalve in het bijzonder de strafrechtelijk getinte waarborgen die ontbreken. In het kader van de bestuurlijke fase kan echter niet zonder meer gezegd worden dat het met de rechtsbescherming van de vermoedelijke overtreder enorm slecht gesteld is.

Ten eerste is er een duidelijke functiescheiding tussen de aanklagende ambtenaar van het EPA en de Administrative Law Judge (ALJ) die uiteindelijk de boete oplegt. De ALJ lijkt in te staan voor een onafhankelijk en onpartijdig oordeel met betrekking tot de op te leggen boete.

Voorts is het beleid dat door het EPA met betrekking tot het vaststellen van de hoogte van de op te leggen bestuurlijke boete wordt gevoerd vrij uitvoerig en gedetailleerd. De gedetailleerde beleidsregels hebben onder meer ten doel de rechtsgelijkheid in de Verenigde Staten te bevorderen in die zin dat ten aanzien van vergelijkbare overtredingen vergelijkbare boeten worden opgelegd. Door een dergelijk consistent beleid wurdt tevens voorkomen dat bij burgers de indruk ontstaat dat oplegging van de boeten willekeurig geschiedt. De gedetailleerde regeling van het beleid neemt overigens niet weg dat er ruimte is om, met specifieke - de overtreder betreffende - feiten rekening te houden.

De beleidsregels hebben voorts ten doel te garanderen dat van de opgelegde boete daadwerkelijk een afschrikkende werking uitgaat. Op grond van het gedetailleerde boetebeleid wordt er dan ook voor gezorgd dat de sanctie een, met het oog op (speciale en generale ${ }^{60}$ ) preventie noodzakelijke, punitieve uitwerking heeft. Nadat middels de boete het economisch voordeel dat door overtreding van milieuwetgeving is ontstaan is weggenomen (het reparatoire deel van de sanctie), wordt het boetebedrag verhoogd in 
verband met bepaalde, in de beleidsregels weergegeven, (de overtreder betreffende) (aanpassings)factoren.

Opvallend is dat middels het boetebeleid (en de Rules of Practice) een vroegtijdige oplossing van het geschil wordt bevorderd door bijvoorbeeld schikkingen tussen de overtreder en het EPA te stimuleren. Van genoemde schikkingsmogelijkheid wordt in veel gevallen gebruik gemaakt. In het begin van de jaren negentig van de vorige eeuw werd, zo blijkt uit deel II van dit boek, in ruim $97 \%$ van de gevallen waarin het voornemen bestond een bestuurlijke boete op te leggen, oplegging van de boete afgedaan door middel van een schikking. ${ }^{61}$ Het EPA bevordert deze wijze van afdoening met name vanwege de aanmerkelijk lagere kosten die verbonden zijn aan 'informal settlement'. Daarnaast is de schikkingsprocedure effectiever gelet op de korte termijn waarbinnen de zaak dan kan worden afgerond. Beide genoemde voordelen gelden overigens ook voor de overtreder. Een derde voordeel voor de overtreder hangt samen met het feit dat hij, door akkoord te gaan met een schikking, negatieve publiciteit kan vermijden. ${ }^{62}$

Ten aanzien van de procedure tot oplegging van bestuurlijke boeten in de Verenigde Staten kan het volgende geconcludeerd worden. Hoewel de boete mijns inziens van punitieve aard is - sanctiedoelen als speciale en generale preventie wijzen daar immers op - wordt de boete in de Amerikaanse regelgeving uitdrukkelijk buiten het strafrechtelijke circuit gehouden. De boete wordt immers steevast omschreven als '(administrative assessment of a) civil penalty' of - in meer uitzonderlijke gevallen - als 'administrative penalty'. Op de vraag of deze boete niet tevens wezenlijke kenmerken van een strafrechtelijke sanctie vertoont wordt in de regelgeving niet ingegaan. Een dergelijk strafrechtelijk karakter lijkt dan ook ontkend te worden.

Los van de vraag naar de wijze waarop door de wetgever in formele zin de boete heeft gekwalificeerd staat de vraag hoe het Supreme Court oplegging van bestuurlijke boeten karakteriseert. Gaat het bij de oplegging van bestuurlijke boeten om 'punishment' dan dienen namelijk de, met de uit het EVRM en IVBPR voortvloeiende, vergelijkbare, waarborgen uit het vijfde, zesde en achtste amendement in acht genomen te worden.

\subsubsection{Straf(proces) rechtelijke constitutionele waarborgen?}

Uit de bestudeerde rechtspraak van het Supreme Court is geen consistente lijn te distilleren wat betreft de toepasselijkheid van de waarborgen die voortvloeien uit het vijfde, zesde en achtste amendement van de Amerikaanse constitutie. Na een reeks wisselende uitspraken komt het Supreme Court (reeds) in 1963, in de zaak 'Kennedy versus Mendoza-Martinez', met een toetsingsmodel, dat ten minste tot op zekere hoogte vergelijkbaar is met het model dat door het EHRM in de zaken 'Engel' en 'Öztürk' is geïntroduceerd, ter beantwoording van de vraag of er sprake is van een 'criminal charge'. In de zaak 'Kennedy versus Mendoza-Martinez' oordeelt Supreme Court dat er sprake is van

61 Zie: Michael J. Walker a.w. 1994, p. 6. Vgl. Colin S. Diver a.w. 1979, p. 1437 en p. 1450-1451 m.b.t. hoge schikkingspercentages bij andere boeteregelingen die door andere agencies worden uitgevoerd.

62 Zie: Michael J. Walker a.w. 1988, p. 453: The ability to identify and resolve compliance disputes quickly through informal settlement conferences with agency personnel can avoid the need for substantial counsel fees, drawn-out pleadings practice, negative publicity and delays associated with congested federal district court calendars.' 
'punishment' indien bij wijze van sanctie het Amerikaans burgerschap wordt ontnomen. ${ }^{63}$ Op basis van deze conclusie acht het Supreme Court vervolgens alle strafrechtelijke waarborgen die voortvloeien uit het vijfde en zesde amendement van toepassing in genoemde zaak. Een dergelijke vergaande uitspraak zal het Supreme Court daarna niet meer doen.

In 1980 oordeelt het Supreme Court in de zaak 'Ward', op basis van een enge en (hoofdzakelijk) formele en legistische benadering van de term 'punishment', dat oplegging van een bestuurlijke boete geen 'punishment' vormt. Met de zaak 'Halper' (waarin het ging om een 'civiele' boete - 'in personam civil penalty' -) komt daar, in 1989, weer verandering in. Het Supreme Court bepaalt niet langer op een legistische wijze of er sprake is van 'punishment' maar hanteert een materieel criterium. Is de sanctie afschrikwekkend en leedtoevoegend dan is er volgens het Supreme Court sprake van 'punishment'. Een benadering die overeenkomt met de benadering van het EHRM. Vervolgens gaat het Supreme Court in de zaken 'Ursery' (uit 1996, waarin het ging om een 'civiele' verbeurdverklaring) en 'Hudson' (uit 1997, waarin het - onder meer - ging om een bestuurlijke boete), opnieuw (behoorlijk) terughoudend toetsen op basis van het in de zaak 'Ward' ontwikkelde 'twee-stappen-model'. Aan de hand van dit model dient de rechter eerst te onderzoeken hoe de sanctie door de wetgever is gekwalificeerd. Gaat het om een civiele, bestuursrechtelijke of strafrechtelijke sanctie? Heeft de wetgever de sanctie aangemerkt als 'civil (of administrative) penalty' dan kan er géen sprake zijn van 'punishment' tenzij het de sanctie onmiskenbaar punitief van aard is. De wetgever moet zich pertinent vergist hebben. Of de aard van de sanctie onmiskenbaar punitief is, en de wetgever zich derhalve pertinent heeft vergist, wordt vervolgens zéér terughoudend getoetst aan de hand van de criteria uit de zaak 'Kennedy versus MendozaMartinez'. In alle zaken waar de 'twee-stappen-toets' wordt toegepast komt het Supreme Court tot de conclusie dat er geen sprake is van 'punishment'.

Dit leidt tot de volgende slotsom. Gezegd kan worden dat het Supreme Court de afgelopen eeuw hoofdzakelijk terughoudend is geweest wat betreft het aanmerken van een (in de formele wet) niet-strafrechtelijk gekwalificeerde punitieve sanctie als 'punishment'. Werd een niet-strafrechtelijke sanctie wél aangemerkt als 'punishment' dan was dat, behoudens in de zaak 'Kennedy versus Mendoza-Martinez', slechts ten aanzien van een bepaalde waarborg uit het vijfde, zesde of achtste amendement.

Een verklaring voor de schrale uitleg van de term 'punishment' door het Supreme Court zou kunnen zijn dat de - minder democratisch gelegitimeerde - rechters niet al te snel willen concluderen dat de - democratisch gelegitimeerde - wetgever zich heeft 'vergist' door een bepaalde sanctie niet als 'criminal' te kwalificeren. Een tweede, en wellicht belangrijkere (en meer plausibele), reden voor het Supreme Court om terughoudendheid te betrachten vloeit voort uit het feit dat de strafrechtelijke waarborgen worden gezien als een obstakel voor effectieve rechtshandhaving. Zowel het Congres als de rechters lijken dan ook veel moeite te doen om te voorkomen dat zij een bepaalde sanctie als 'punishment' moeten kwalificeren. 'Punishment' impliceert immers toepasselijkheid van de, als obstakel voor de rechtshandhaving beschouwde, waarborgen uit het vijfde, zesde en achtste amendement.

Zie voor een uitvoerigere beschrijving van de casus deel II van dit boek. 
Uit de meest recente uitspraken van het Supreme Court kan worden afgeleid dat er zich vrijwel nooit een situatie voor zal doen waarin, ten aanzien van punitieve bestuursrechtelijke sancties, de strafrechtelijke waarborgen die uit de amendementen voortvloeien in acht moeten worden genomen. Het lijkt gerechtvaardigd te stellen dat efficiente en effectieve handhaving hogere prioriteit hebben dan de rechtsbescherming in het bestuursstrafrecht in de Verenigde Staten. Dat deze houding kan leiden tot zéér onbillijke situaties voor de vermoedelijke overtreder moge, mede op basis van de in deel II besproken jurisprudentie duidelijk zijn.

\subsubsection{Vergelijking met de Nederlandse procedure - wijze lessen? -}

\subsubsection{Algemeen}

Externe rechtsvergelijking is met name relevant omdat op basis van vergelijking van het eigen stelsel met een afwijkend rechtsstelsel kan worden beoordeeld in hoeverre op basis van het nationale boetestelsel, in vergelijking met de buitenlandse boeteregeling, voldoende rechtsbescherming geboden wordt aan de vermoedelijke overtreder. Bovendien zouden in de buitenlandse regeling oplossingen kunnen worden aangedragen voor problemen die zich in de nationale regeling manifesteren en waarvoor vooralsnog (door de Nederlandse wetgever) geen oplossing is gevonden.

\subsubsection{Hellend vlak?}

Op basis van de vergelijking van de Amerikaanse boeteregeling met de Nederlandse regeling springt één aspect meteen in het oog. Beide landen zijn met het oog op efficiente en effectieve handhaving niet al te royaal wat betreft de inachtneming van de essentiêle straf(proces)rechtelijke waarborgen. In de Verenigde Staten is de rechtsbescherming op dat punt zeer gering. In Nederland lijkt men ook niet welwillend te staan tegenover de inachtneming van straf(proces)rechtelijke waarborgen. Desalniettemin wordt in Nederland toch ten minste op een redelijk niveau voldaan aan essentiële strafprocesrechtelijke waarborgen.

Gelet op de ontwikkelingen in de jurisprudentie met betrekking tot de term 'punishment' in de Verenigde Staten blijft de vermoedelijke overtreder bij de oplegging van punitieve bestuursrechtelijke sancties aldaar verstoken van de (essentiële) straf(proces)rechtelijke waarborgen. Een dergelijke ontwikkeling lijkt zich in Nederland ook voor te doen ten aanzien van bepaalde, als reparatoir gekwalificeerde, bestuursrechtelijke sancties die in wezen, in ieder geval onder bepaalde omstandigheden, punitief zijn. Het is belangrijk dat de Nederlandse wetgever en rechters ervoor waken dat ons nationale bestuurs(straf)rechtelijke systeem niet zover doorslaat dat er Amerikaanse toestanden ontstaan waarbij nog slechts de naam die in de wettelijke regeling aan de sanctie is gegeven doorslaggevend is. Daarmee wordt immers 'Etikettenschwindel' pur sang bevorderd.

Ten aanzien van de bestuurlijke boete doet dit probleem van 'Etikettenschwindel' zich niet voor. Deze sanctie wordt in Nederland zonder meer gezien als punitieve sanctie. Bovendien gaan wetgever en rechter er (in Nederland) vanuit dat op genoemde sanctie vanwege het punitieve karakter de (minimum) verdragsrechtelijke waarborgen van 
toepassing zijn. In hoofdstuk vier en in \$ twee van dit hoofdstuk is reeds naar voren gekomen dat er in Nederland sprake is van een tendens waarbij de verdragsrechtelijke waarborgen ten minste op bepaalde punten schraal worden uitgelegd.

Een blik op het Amerikaanse systeem leert ons dat wetgever en rechter behoedzaam om moeten springen met de verdragsrechtelijke waarborgen. Zij dienen er zorg voor de dragen dat, bij oplegging van punitieve bestuursrechtelijke sancties, ten minste de verdragsrechtelijke minimum waarborgen in acht worden genomen. Voor de Nederlandse wetgever en rechter kan het Europese Hof voor de Rechten van de Mens in dat kader overigens functioneren als stok achter de deur. Is een vermoedelijke overtreder van oordeel dat Nederland in strijd handelt met artikel 6 of 7 EVRM dan kan hij, na uitputting van de nationale rechtsmiddelen, de zaak voorleggen aan het EHRM. Daarbij verdient aantekening dat ook het EHRM er zorg voor zal moeten dragen dat het (in de toekomstige rechtspraak) geen afbreuk gaat doen aan (mede op basis van jurisprudentie) geldende waarborgen.

Bij bestudering van de jurisprudentie van het EHRM lijkt, ten aanzien van bepaalde waarborgen, de vrees gerechtvaardigd dat het Hof niet altijd in lijkt te staan voor handhaving van de waarborgen op het niveau waarop zij zich in de tachtiger jaren van de vorige eeuw bevonden. Ter illustratie kan gewezen worden op het in de zaak 'Funke' erkende nemo tenetur-beginsel dat na 'Saunders' en 'J.B. versus Austria' niet veel meer lijkt te behelzen dan een ruim zwijgrecht. Een vergelijkbare ontwikkeling heeft zich voorgedaan ten aanzien van het ne bis in idem-beginsel. ${ }^{64}$ Niet wenselijk is dat het EHRM even ver 'doorslaat' naar het 'nulpunt', wat betreft de afkalving van de rechtsbescherming bij de oplegging van punitieve (bestuursrechtelijke) sancties, als het Supreme Court in de Verenigde Staten.

Mocht dit al gebeuren dan dient een zichzelf respecterende democratische rechtsstaat deze ontwikkeling mijns inziens niet welwillend te volgen met het oog op efficiënte en effectieve handhaving van overtredingen van bestuursrechtelijke regels. Punitieve sancties blijven immers deel uitmaken van het strafrecht in ruime zin. Extra waarborgen, buiten de traditionele bestuursrechtelijke rechtsbescherming om, dienen dan ook, op zijn minst op een basaal niveau, in acht genomen te worden.

\subsubsection{Pluspunten}

Naast waarschuwingen die uit mogen gaan van de wijze waarop in Amerika de straf(proces)rechtelijke waarborgen bij de oplegging van punitieve sancties worden veronachtzaamd kan ook op positieve wijze lering worden getrokken uit de Amerikaanse boeteregeling.

In ieder geval lijkt in de Verenigde Staten een betere invulling te worden gegeven aan het functiescheidingsvereiste in de bestuursrechtelijke fase. Een aanklager (in dienst) van het EPA moet een aanklacht indienen wegens overtreding van een bepaald milieurechtelijk voorschrift. De vermoedelijke overtreder kan zich daar tegen verweren tijdens een hoorzitting bij de onafhankelijke en onpartijdige Administrative Law Judge,

Ook m.b.t. de onschuldpresumptie is de rechtspraak van het EHRM niet bijzonder positief te noemen.

Zo sluit het EHRM de toelaatbaarheid van strafrechtelijk onrechtmatig verkregen bewijs niet zonder meer uit. Bovendien kan volgens het Hof in bepaalde gevallen reeds overgegaan worden tot invordering van de boete voordat de opgelegde boete formele rechtskracht heeft verkregen. 
die vervolgens het primaire boetebesluit neemt. ${ }^{65}$ Door middel van deze functiescheiding zal in ieder geval bij de vermoedelijke overtreder in grotere mate vertrouwen worden gewekt dat hem op een onpartijdige en onafhankelijke wijze een sanctie wordt opgelegd. Een dergelijke wijze van sanctionering zou een filterende werking kunnen hebben wat betreft het instellen van beroep tegen het definitieve agency-besluit bij een District Court of Appellate Court. ${ }^{66}$

Daarnaast valt bij bestudering van de Amerikaanse boeteregeling op dat een zéér aanzienlijk gedeelte van de boetezaken middels een schikking afgedaan wordt. Positief voor het bestuursorgaan, dat de boeten oplegt, is, dat de (handhavings)kosten door deze schikkingen gereduceerd worden. Bovendien zijn de zaken véél sneller afgedaan dan wanneer het formele (juridische) traject tot aan het Appellate Court moet worden doorlopen. Ook de overtreder doet zijn voordeel met de schikking, getuige het schikkingspercentage van $97 \%$. Voor de overtreder is de schikking immers eveneens kostenbesparend met name voor wat betreft de proceskosten. Daarnaast lijkt voor de overtreder ook van belang te zijn dat hij door te schikken aan de aandacht van de pers weet te ontkomen en daardoor niet op een negatieve wijze in de publiciteit komt.

Met het oog op effectieve en efficiënte handhaving zou ook de Nederlandse boeteregeling kunnen worden voorzien van een dergelijke schikkingsregeling. Gedacht zou kunnen worden aan een, tot op zekere hoogte met de Amerikaanse schikkingsregeling vergelijkbaar, bestuursrechtelijk transactievoorstel. Gaat de vermoedelijke overtreder daarmee akkoord dan is daarmee de procedure afgedaan. Stemt de vermoedelijke overtreder niet in met het transactievoorstel dan kan alsnog de bestuurlijke boeteprocedure in gang worden gezet. De commissie Scheltema heeft echter te kennen gegeven geen aanleiding te zien voor een algemene regeling van de bestuursrechtelijke transactie. ${ }^{67}$ $\mathrm{Zij}$ heeft daartoe het volgende overwogen:

'De bestuursrechtelijke transactie is een andere figuur. Zoals de strafrechtelijke transactie een alternatief is voor strafvervolging, zou de bestuursrechtelijke transactie een altematief moeten zijn voor het opleggen van een bestuurlijke boete. In plaats van een bestuurlijke boete te betalen, zou de overtreder kunnen volstaan met het betalen van een lager bedrag, mits hij in ruil daarvoor afziet van bezwaar en beroep.

Uit een oogpunt van bestuurslasten en «lik-op-stuk»-beleid zou een dergelijke regeling ontegenzeggelijk voordelen kunnen hebben. Zij roept echter ook de nodige vragen op. Mede doordat op vele beleidsterreinen nog maar beperkte ervaring met de bestuurlijke boete is opgedaan, is het niet duidelijk of een bestuursrechtelijke transactie voor de overtreder voldoende aantrekkelijk zou zijn om tot een substantiêle beperking van de bestuurslasten te leiden. De strafrechtelijke transactie is voor burgers en bedrijven mede aantrekkelijk, omdat daardoor een strafvervolging, met alle negatieve publiciteit van dien, wordt vermeden. Omdat een bestuurlijke boete als veel minder stigmatiserend wordt ervaren, is onzeker of dit voor een bestuursrechtelijke transactie wel in dezelfde mate zou gelden.

Voorts zou een regeling van de bestuursrechtelijke transactie waarschijnlijk relatief uitvoerig moeten zijn. De bevoegdheid van het bestuursorgaan om betaling van een lager

Tegen dit besluit kan vervolgens ('administratief) beroep worden ingesteld bij de Environmental Appeals Board.

66 Vgl. Walker a.w. 1988, p. 453. Walker geeft aan dat in minder dan $1 \%$ van de bestuursrechtelijke (handhavings)zaken beroep werd ingesteld bij een federale rechter. 
bedrag te verlangen zou in de wet neergelegd en genormeerd moeten worden. Daarbij zou ook het afstand doen van bezwaar en beroep nader moeten worden ingekaderd. Hoewel afstand van rechtsbescherming onder omstandigheden mogelijk is zouden wel zekere waarborgen nodig zijn om te voorkomen dat burgers zich onder druk gezet voelen om afstand van rechtsbescherming te doen. ${ }^{68}$

De Amerikaanse regeling leert dat de bestuurslasten bij een vroegtijdige schikking in belangrijke mate beperkt worden. Bovendien leert de regeling dat de schikking, die in Amerika overigens niet lager hoeft uit te vallen dan de op te leggen boete, voor de overtreder voldoende voordelen met zich brengt om er mee in te stemmen. Het vermijden van negatieve publiciteit speelt in dat kader, ook bij niet-strafrechtelijke sancties, een rol.

Hoewel de Amerikaanse schikkingsregeling niet volledig vergelijkbaar is met de transactieregeling ${ }^{69}$ blijkt dat volstaan kan worden met één bepaling in Rules of Practice ${ }^{70}$ van drie paragrafen. Wellicht valt het dan ook wel mee wat betreft de mate van uitvoerigheid van de transactieregeling. Bovendien kunnen de commissie Scheltema en de Awb-wetgever gebruik maken van de ervaring die (sinds 1 november 2000) is opgedaan met de experimentele bestuursrechtelijke transactie in het milieurecht. ${ }^{71} \mathrm{De}$ commissie bestuursrechtelijke en privaatrechtelijke handhaving geeft in het rapport 'Handhaven op niveau' ook aan dat bij de transactiebevoegdheid doorgaans volstaan kan worden met een betrekkelijk eenvoudige regeling. ${ }^{72} \mathrm{Zij}$ toont zich dan ook een voorstander van invoering van de bestuursrechtelijke transactie op grotere schaal. ${ }^{73}$

lk deel overigens de opvatting van de commissie Scheltema dat er, in het kader van de invoering van een bestuursrechtelijke transactieregeling, waarborgen nodig zijn om te voorkomen dat burgers zich onder druk gezet voelen om afstand te doen van rechtsbescherming. De vermoedelijke overtreder moet een daadwerkelijke keuzevrijheid hebben. ${ }^{74}$ Dit brengt met zich dat de weg naar een met essentiële straf(proces)rechtelijke

68 Voorontwerp p. 102.

69 Op grond van de schikkingregeling kan immers onderhandeld worden terwijl het bij de transactie gaat om een (eenmalig) voorstel om de overtreding buiten de procedure om af te doen door een, door het bestuursorgaan (of $O M$ ) voorgesteld, (in beginsel niet discutabel) bedrag te betalen.

70 Zie: section 22.18 van de Rules of Practice, opgenomen in appendix III.

71 Zie over de bestuursrechtelijke transactie: A.B. Blomberg en F.C.M.A. Michiels, Handhaven met effect, VUGA Uitgeverij B.V., Den Haag 1997, i.h.b. p. 346-347; Commissie Michiels, Handhaven op niveau, W.E.J. Tjeenk Willink, Deventer 1998, p. 81-82; F.C.M.A. Michiels, De bestuurlijke boete in het milieurecht, Milieu en Recht 1998 no. 3, p. 69-73, i.h.b. p. 71 en 72 . Zie voorts het Transactiebesluit milieudelicten, Stb. 2000, 320, op grond waarvan vanaf 1 november 2000 door een aantal in het besluit aangewezen bestuursorganen op experimentele wijze overgegaan kan worden tot het doen van een strafrechtelijke transactievoorstel.

72 Commissie Michiels a.w. 1998, p. 81.

73 Commissie Michiels a.w. 1998, p. 82. De Commissie Michiels geeft daarbij overigens aan dat twee transactievarianten denkbaar zijn. Bij de eerste variant wordt de zaak overgedragen aan het OM als de (vermoedelijke) overtreder niet instemt met het transactievoorstel. Bij de tweede variant volgt een bestuurlijke boeteprocedure als de door het bestuursorgaan voorgestelde transactie wordt verworpen (zie: Commissie Michiels a.w. 1998, p. 81).

74 Vgl. F.C.M.A. Michiels, Een kans voor open doel, Over handhaving van milieurecht met bestuurlijke transacties, in de bundel: Recht op het doel af, onder redactie van F.C.M.A. Michiels, Deventer 1998, p. 269-286 (hierna: Michiels a.w. 1998b). Op p. 274 e.v. geeft Michiels aan dat naar mening de keuzevrijheid, zeker in het kader van economische delicten (waartoe ook de milieurechtelijke overtredingen behoren), in voldoende mate aanwezig is. 
waarborgen omklede sanctieprocedure altijd open moet staan, zonder dat daaraan nadelige gevolgen zijn verbonden voor de vermoedelijke overtreder. Corstens geeft aan dat de daadwerkelijke keuzevrijheid bevordert kan worden 'door de transactie te reserveren voor eenvoudige zaken waarin een veroordeling gemakkelijk haalbaar is en door het transactiebedrag het plafond te laten vormen voor de eis ter zitting en de rechterlijke straftoemeting.' ${ }^{75}$

Gelet op de positieve ervaringen die in de Verenigde Staten door het EPA zijn opgedaan met de schikkingen lijkt een nader onderzoek naar een vergelijkbare maatregel, eventueel in de vorm van een bestuursrechtelijke transactie, met name met het oog op effectieve en efficiënte handhaving aanbevelenswaardig. Daarbij kan er niet onverkort van uit worden gegaan dat de Nederlandse overtreders even welwillend tegenover een transactievoorstel staan als de Amerikanen tegenover een schikkingvoorstel. Culturele verschillen kunnen immers bijdragen aan een andere proceshouding. Bovendien is een transactie niet volledig vergelijkbaar met een schikking zoals die op basis van de Amerikaanse regeling plaats vindt. Tenslotte zou de bereidheid om in te stemmen met een transactie ook per bestuursrechtelijke deelgebied kunnen verschillen. Op het terrein van het economische ordeningsrecht en het milieurecht (voor zover ook daar de bestuurlijke boete wordt ingevoerd) kunnen argumenten als hoge proceskosten en negatieve publiciteit misschien soms zwaarder wegen dan in het sociale zekerheidsrecht. ${ }^{76}$ Denk daarbij bijvoorbeeld aan bepaalde multinationals die, met betrekking tot een door hen gepleegde overtreding van de Mededingingswet, gevrijwaard willen blijven van (elkaar gedurende lagere tijd opvolgende) negatieve berichten in de pers ${ }^{77}$ en exorbitante proceskosten door aanvechting van het boetebesluit tot aan de hoogste instantie.

Ongeacht de hiervoor geschetste onduidelijkheden moet de bestuurlijke transactievariant mijns inziens serieus in overweging worden genomen. In dat kader moet overigens ook aandacht besteed worden aan de vraag of de bestuursrechtelijke transactie ook met het oog op de rechtsbescherming van de vermoedelijke overtreder voldoende te bieden heeft. Mijns inziens hoeft die vraag niet zonder meer negatief beantwoord te worden. Ik kom hier in de volgende paragraaf op terug.

\subsection{Suggesties aan de hand van de bevindingen}

Uit $\S 9.2$ volgt dat de rechtsbescherming bij de oplegging van bestuurlijke boeten te wensen over laat. Met name typisch straf(proces)rechtelijke regels en beginselen komen niet goed uit de verf in de in het Voorontwerp voorgestelde boeteregeling. In het laatste deel van dit boek worden enkele suggesties gedaan ter verbetering van de rechtsbescherming in het bestuursstrafrecht.

76 Vgl. Michiels a.w. 1998b.

77 Een transactie vormt overigens in de praktijk, zoals de recente bouwfraudezaken illustreren, geen onvoorwaardelijke garantie voor een vrijwaring van negatieve publiciteit. Bovendien zal het transactiebeleid aan banden moeten worden gelegd zodat 'moreel verwerpelijke' normschendingen niet meer middels een transactie afgedaan kunnen worden. 
Ten eerste zal aandacht uitgaan naar een variant waarbij de door de commissie Scheltema gepresenteerde regeling gehandhaafd wordt. Tekortkomingen in de rechtsbescherming zullen dan ondervangen moeten worden door de bestuursrechter(s). Zij zullen in hun rechtspraak invulling moeten geven aan de essentiële strafprocesrechtelijke waarborgen. Het bestuursprocesrecht lijkt in beginsel afdoende open en flexibel voor een zodanige benadering.

In § 9.4.2 wordt vervolgens aandacht besteed aan de invoering van een aparte wettelijke regeling inzake het bestuursstrafrecht. In dat kader worden twee subvarianten gepresenteerd.

In de derde plaats zal bekeken worden of de (in het bijzonder door $\mathrm{Knigge}^{78}$ ontwikkelde) OM-boete met het oog op de rechtsbescherming van de vermoedelijke overtreder een alternatief vormt. De OM-boete wordt opgelegd door het Openbaar Ministerie. Als de vermoedelijke overtreder niet kan instemmen met de opgelegde boete kan hij beroep in stellen bij de strafrechter. In dat kader zal de strafrechter de regels uit het Wetboek van Strafvordering toe moeten passen. De bestuursrechter en het bestuursrecht blijven bij deze variant buiten beeld.

Tenslotte gaat aandacht uit naar de bestuursrechtelijke transactie. De transactie kan niet worden gezien als een aparte variant. De bestuursrechtelijke transactiebevoegdheid kan bijvoorbeeld worden gekoppeld aan de bestuurlijke boetebevoegdheid. Een en ander zal worden uiteengezet in $\S 9.4 .4$.

\subsection{Regeling uit het Voorontwerp van de vierde tranche}

De eerste mogelijkheid is met name vanuit praktisch oogpunt interessant. In het kader van deze eerste variant kan de voorgestelde boeteregeling immers grotendeels gehandhaafd worden. Alleen in die gevallen waarin een voorgestelde bepaling zich duidelijk niet verdraagt met bijvoorbeeld het verdragsrecht zal de wetgever de regeling aan moeten passen. In dit kader kan bijvoorbeeld gewezen worden op de bepaling omtrent het toepassen van de meest gunstige bepaling ex artikel 5.4.1.7 lid 4 Voorontwerp.

Voor het overige zal de bestuursrechter aan de rechtsbescherming van de vermoedelijke overtreder invulling moeten geven. In dit kader kan bijvoorbeeld gewezen worden op regels met betrekking tot de bewijslastverdeling en de toepassing van artikel 8:69 Awb in ruimere zin. Het bestuursprocesrecht biedt de rechter daartoe immers de ruimte. Van deze ruimte heeft de bestuursrechter ook in het verleden al gebruik gemaakt. ${ }^{79}$ Het belangrijkste voordeel van deze variant is de praktische uitvoerbaarheid. De wetgever kan de in het Voorontwerp voorgestelde regeling voor het overgrote deel gewoon overnemen. Er kleven echter ook belangrijke nadelen aan deze 'pragmatische' variant. Ten eerste is de rechtszekerheid van de burger er niet mee gediend als de rechtsbescherming tegen bestuurlijke boeten de komende jaren nog moet uitkristalliseren in de rechtspraak. Ten tweede lijkt de consistentie van de rechtsbescherming ook van uit rechtseenheidsoogpunt niet gewaarborgd. 'Extern' zal de rechtseenheid te wensen over laten omdat in het Voorontwerp bepaalde strafrechtelijke leerstukken op een fragmen-

78 Vgl. bijv. G. Knigge, De strafvordering in het geding. Handelingen NJV 1994-1, Zwolle 1994, p. 37. 116.

79 Vgl. bijv. ABRS 15 april 1999, JB 1999/150 m. nt. C.L.G.F.H. Albers. 
tarische en eigen wijze zijn over genomen terwijl aan deze strafrechtelijke leerstukken vervolgens in de bestuursrechtspraak een andere invulling wordt gegeven dan in de strafrechtspraak. 'Intern' is de rechtseenheid niet gegarandeerd zolang de verschillende bestuursrechtelijke hoger beroepsinstanties ieder hun eigen lijn uitstippelen. ${ }^{80}$

Gelet op de hiervoor geschetste nadelen gaat mijn voorkeur niet uit naar de hierboven geschetste variant waarin vastgehouden wordt aan de in het Voorontwerp voorgestelde regeling.

\subsubsection{Aparte regeling}

\subsubsection{Algemeen}

Gelet op de hierboven geschetste problemen die zich manifesteren bij het 'inweven' van de bestuurlijke boeteregeling in het bestaande, in de Awb neergelegde, bestuursprocesrecht verdient het mijns inziens de voorkeur een aparte regeling te creëren waarin bestuursstraf(proces)rechtelijke regels worden neergelegd. ${ }^{81}$ Middels deze wettelijke regeling dient de rechtsbescherming van de vermoedelijke overtreder ten minste te voldoen aan de (minimum) verdragsrechtelijke eisen. ${ }^{82}$ Los daarvan dient in de regeling invulling te worden gegeven aan bepaalde andere fundamentele straf(proces)rechtelijke leerstukken waaronder bijvoorbeeld het leerstuk van strafrechtelijk onrechtmatig verkregen bewijs.

De vraag is of voor die regeling de, onder meer op de 'wederkerige rechtsbetrekking'idee gebaseerde, Awb als uitgangspunt genomen moet worden. Indien de wetgever daarvoor kiest zal op een aantal punten expliciet afgeweken moeten worden van de Awb. In nauw verband met dit laatste staat de vraag wat de positie van het bestuursorgaan is in het kader van de oplegging van punitieve bestuursrechtelijke sancties. Wellicht valt er wat voor te zeggen het bestuursorgaan bij de oplegging van punitieve bestuursrechtelijke sancties een met het Openbaar Ministerie vergelijkbare functie toe te dichten.

Op basis van het voorgaande zijn twee subvarianten denkbaar. Relevant is daarbij of vastgehouden wordt aan het besluit-begrip als rechtsingang en de hoofdstructuur van het Awb-procesrecht. Wordt niet vastgehouden aan de Awb en het besluit-begrip dan bestaat de mogelijkheid een, volledig van de Awb losstaande, met het strafrecht vergelijkbare procedure te creëren.

\subsubsection{Volledig van de Awb losstaande regeling}

In het kader van een, volledig van de Awb losstaande, met het strafrecht vergelijkbare procedure dient het bestuursorgaan een 'verzoekschrift' in bij de bestuursrechter. Een dergelijk verzoekschrift bevat de mededeling dat de vermoedelijke overtreder een bepaalde bestuursrechtelijke bepaling heeft overtreden die gesanctioneerd kan worden middels een bestuurlijke boete. Het bestuursorgaan onderbouwt deze beschuldiging aan de hand van bewijzen en stelt de rechter voor een boete van een bepaald bedrag op te leggen. Dit verzoekschrift wordt ook aan de vermoedelijke overtreder toegezonden.

80 Vgl. reeds de uiteenlopende interpretatie van artikel 8:69 Awb door de ABRS en de CRvB.

81 Vgl. Hartmann en Van Russen Groen a.w. 1998. p. 127 e.v. en Corstens a.w. 2000, p. 1188.

82 Zie daarover hoofdstuk drie. 
Aan de vermoedelijke overtreder wordt vervolgens de keuze gelaten of hij wil berusten in de in het verzoekschrift neergelegde beschuldiging en de voorgestclde boete of dat hij deze aan wil vechten. Kiest hij voor de laatste mogelijkheid - het aanvechten van het verzoekschrift bij de bestuursrechter - dan moet hij binnen een bepaalde periode (bijvoorbeeld zes weken) aangeven dat hij de zaak wil laten voorkomen bij de bestuursrechter. ${ }^{83}$ Daarmee vangt de procedure bij de bestuursrechter aan.

De bestuursrechter heeft bij het beoordelen van de gegrondheid van het verzoekschrift dezelfde ruimte als de strafrechter (de relevante bepalingen uit het wetboek van Strafvordering zouden in dat kader van overeenkomstige toepassing kunnen worden verklaard). Hij participeert derhalve actief in de bewijsgaring en stelt zélf, aan de hand van wettige bewijsmiddelen, vast of het tenlastegelegde feit bewezen is, of de vermoedelijke overtreder strafbaar is en hoe hoog de boete moet zijn. Hoger beroep tegen de uitspraak van de bestuursrechter is uiteraard mogelijk. Dit hoeft echter niet noodzakelijkerwijs bij de bestaande bestuursrechtelijke appèlcolleges te geschieden. Gedacht zou kunnen worden aan hoger beroep bij een (te creëren) bestuursstrafrechtelijke kamer van de Gerechtshoven met de mogelijkheid tot cassatie bij de Hoge Raad. ${ }^{84}$

Berust de overtreder in de in het verzoekschrift neergelegde beschuldiging en voorgestelde boete, doordat hij niet reageert binnen de gestelde termijn, dan wordt de voorgestelde boete, zonder zitting, invorderbaar na het verstrijken van die termijn. Weliswaar moet in de regeling op enigerlei wijze worden voorzien in de mogelijkheid nog na de gestelde termijn te reageren als de vermoedelijke overtreder onmiskenbaar niet te verwijten is dat hij niet binnen de gestelde termijn heeft gereageerd.

De procedure tot oplegging van een bestuurlijke boete wordt op deze wijze in grote mate vergelijkbaar met de strafrechtelijke procedure bij bestraffing van overtredingen. Zeer belangrijk in dat kader is de rol van de onafhankelijke en onpartijdige rechter. Hij vervult immers zelf een actieve rol bij de bewijsgaring en bewijswaardering. Bovendien bepaalt hij op basis van het voorhanden zijnde (rechtmatig verkregen) bewijs of de vermoedelijke overtreder strafbaar is (middels toetsing aan de rechtvaardigings- en schulduitsluitingsgronden) en of derhalve bestraffing plaats moet vinden. Indien de overtreder gestraft moet worden is het bovendien de rechter die de hoogte van de bocte vaststelt.

Gevreesd zou kunnen worden voor een grotere belasting van de bestuursrechters bij toepassing van dit boetesysteem. Geheel onterecht is die vrees niet maar doordat van de vermoedelijke overtreder wél gevraagd wordt binnen bepaalde termijn een reactie tegen

83 Ik ben me er van bewust dat er dan nog steeds sprake is van een soort 'piepsysteem' (vgl. bijv. Knigge a.w. 2000 , p. 86). Ondanks dat kan op basis van de voorgestelde regeling meer rechtsbescherming worden geboden dan op basis van de in het Voorontwerp voorgestelde boeteregeling. De vermoedelijke overtreder hoeft in het hier voorgestelde systeem immers alleen aan te geven dat hij het verzoekschrift aan wil vechten. Hij hoeft bijvoorbeeld niet meteen (alle relevante) gronden aan te voeren. De rechter heeft bovendien een uitgebreide eigen taak in het kader van de materiêle waarheidsvinding (argumentatieve fuiken bestaan in de voorgestelde regeling bijgevolg niet). Bovendien zal er in de voorgestelde regeling een vangnetbepaling opgenomen moeten worden op grond waarvan onder omstandigheden op basis van een te late reactie desalniettemin de gerechtelijke procedure in gang gezet kan worden.

84 Op genoemde wijze kan immers gebruik gemaakt worden van de bij genoemde colleges aanwezige strafrechtelijke expertise. 
het verzoekschrift in te dienen bij de bestuursrechter kan toch nog een filterende werking uitgaan van de voorgestelde regeling. Bovendien zou de bestuursrechter een hogere boete op kunnen leggen dan de in het verzoekschrift voorgestelde boete. Dit laatste zou de schuldige overtreder moeten weerhouden van een al te lichtvaardig gebruik van de bestuursrechtelijke procedure.

Deze regeling neemt ten principale afstand van het bestaande bestuursprocesrecht en het besluit als rechtsingang. Het zou dan ook niet onbegrijpelijk zijn als de wetgever de voorkeur zou geven aan een regeling die gebaseerd is op het bestaande bestuursprocesrecht. Daarbij zal dan wel op een aantal punten een afwijkende regeling gecreëerd moeten worden voor besluiten tot oplegging van punitieve sancties (zoals de boetebesluiten).

\subsubsection{Awb-conforme regeling}

In het kader van de meer Awb-conforme regeling zou de primaire fase hetzelfde kunnen blijven als nu, mits voldaan is aan de essentiële straf(proces)rechtelijke waarborgen die voortvloeien uit het verdragsrecht en het nationale recht. Aansluiting bij de regeling uit de Awb brengt met zich dat het bestuursorgaan een primair boetebesluit neemt. Voordat het bestuursorgaan daartoe overgaat zal het echter eerst de vermoedelijke overtreder moeten horen. ${ }^{85}$ Bovendien zou uitdrukkelijk moeten worden voorzien in een functiescheiding tussen de ambtenaren die de overtredingen constateren en ambtenaren die de bestuurlijke boeten opleggen. ${ }^{86}$

De bezwaarschriftprocedure zou in het kader van de oplegging van bestuurlijke boeten kunnen worden overgeslagen. ${ }^{87}$ De bezwaarschriftprocedure blokkeert immers langer dan noodzakelijk de toegang tot een onafhankelijke en onpartijdige rechter. Daarnaast lijkt de herkansingsmogelijkheid die het bestuursorgaan middels het besluit op bezwaar geboden wordt bepaald niet de zorgvuldige besluitvorming aan de zijde van het bestuursorgaan in de hand te werken (vgl. de zogenaamde 'boetefabriek'). Uitgangspunt zou derhalve, bij de oplegging van bestuurlijke boeten, moeten zijn 'altijd horen en géén bezwaar'. ${ }^{8}$

Het boetebesluit kan worden aangevochten bij de bestuursrechter. Anders dan in de normale bestuursrechtelijke procedure zou de bestuursrechter het boetebesluit integraal moeten kunnen toetsen. Van beleidsvrije bevoegdheden - in de zin dat de bestuursrechter (delen van) het boetebesluit slecht marginaal zou mogen toetsen - kan men in het punitieve bestuursrecht mijns inziens immers niet spreken. De bestuursrechter dient, naar mijn mening dezelfde ruimte te hebben als de strafrechter ${ }^{89}$ De bestuursrechter zou derhalve na vernietiging ook altijd zelf in de zaak moeten voorzien (zélfs ten nadele van de overtreder) als de in het besluit op bezwaar opgelegde boete naar zijn oordeel niet juist is. Uiteindelijk is het de bestuursrechter die de boete oplegt, indien

Vgl. Albers en Schlossels a.w. 2002, § 4.5. In ieder geval moet dan de vermoedelijke overtre-der de gelegenheid worden geboden zijn zienswijze mondeling dan wel schriftelijk kenbaar te maken.

86 Hoewel deze functiescheiding bij de vermoedelijke overtreder wellicht niet de indruk wekt dat sanctionering op een onpartijdige wijze heeft plaats gevonden. Opsporing, vervolging en bestraffing gaan immers uit van hetzelfde bestuursorgaan.

87 Vgl. Albers en Schlossels a.w. 2002, \$4.5.

88 Vgl. Albers en Schlossels a.w. 2002, \$4.5.

89 Zie in dit kader ook hoofdstuk 4 
naar zijn oordeel in voldoende mate, aan de hand van rechtmatig verkregen bewijs, is komen vast te staan dat het 'tenlastegelegde' feit is bewezen en overtreder strafbaar is (vanwege het ontbreken van een rechtvaardigings- of schulduitsluitingsgrond). Derhalve kan de bestuursrechter zich, bij de toetsing van boetebesluiten, niet zonder meer beperken tot een 'ex tunc' toetsing zoals voorgesteld in het Voorontwerp. ${ }^{90}$ Bovendien zal hij afstand moeten nemen van het, met name door de Afdeling Bestuursrechtspraak veelvuldig toegepaste, 'trechtermodel'. Materiële waarheidsvinding en ongelijkheidscompensatie zullen immers in het kader van het punitieve sanctierecht voorop moeten staan.

Na een vernietiging van het primaire boetebesluit door de bestuursrechter is terugverwijzing van de zaak naar het bestuursorgaan, zoals gezegd, niet op zijn plaats. Dit klemt te meer nu die praktijk bovendien met het oog op het ne bis in idem-beginsel tot kwestieuze situaties zal leiden. De artikelen 6:18 en 6:19 Awb zouden eveneens, in elk stadium van het geding, buiten toepassing moeten worden verklaard met het oog op het ne bis in idem-beginsel."

De boete zou bovendien pas invorderbaar mogen worden op het moment dat de opgelegde boete definitief is. Het boetebesluit of de uitspraak van de rechtbank moet derhalve formele rechtskracht hebben verkregen. Is hoger beroep ingesteld, dan moet de appèlrechter uitspraak hebben gedaan voordat tot invordering van de boete kan worden overgegaan.

Procedurele gebreken en vormverzuimen zouden niet zonder meer op grond van artikel 6:22 Awb gepasseerd moeten worden. Afhankelijk van de inbreuk die daardoor is gemaakt op de rechtsbescherming van de burger zou verlaging van de boete plaats mocten vinden. Bij ernstige inbreuken op de rechtsbescherming van de vermoedelijke overtreder, bijvoorbeeld door het op onrechtmatige wijze vergaren van belastend bewijsmateriaal, zou beboeting zelfs in het geheel achterwege moeten blijven. ${ }^{92}$

Hiervoor is reeds aangegeven op welke andere punten het huidige bestuursprocesrecht niet in voldoende mate rechtsbescherming kan bieden bij de oplegging van punitieve sancties. Teneinde niet in herhaling te vallen wordt daar op deze plaats naar verwezen. ${ }^{93}$ Ook op die punten moet in de wettelijke regeling een uitzondering gemaakt worden op de, op basis van de Awb geldende, regels.

Het lijkt, met het oog op het voorgaande, zinvol enderzijds bepaalde bepalingen uit het wetboek van Strafrecht en Strafvordering van overeenkomstige toepassing te verklaren op de procedure tot oplegging van bestuurlijke boeten door de bestuursrechter, terwijl anderzijds in de regeling op punten expliciet zal moeten worden afgeweken van bepaalde Awb-bepalingen.

\subsubsection{Ten slotte}

Of de wetgever nu kiest voor een boeteregeling gebaseerd op de eerste, los van de Awb staande, variant, of voor de tweede, meer Awb-conforme variant, hij zal tenminste de essentiële straf(proces)rechtelijke waarborgen moeten garanderen. Tot die waarborgen

$90 \mathrm{Vgl}$. hoofdstuk 4.

$91 \quad$ Zie in dit kader ook hoofdstuk 4.

92 Vgl. artikel 359a Sv.

93 Zie voorts Albers en Schlossels a.w. 2002. 
behoren in ieder geval de uit artikel 6 en 7 EVRM en de uit artikel 14 en 15 IVBPR voortvloeiende minimum garanties. Spijtig genoeg kan op basis van de bestaande rechtspraak van het EHRM ten aanzien van een aantal waarborgen niet eenvoudig de reikwijdte worden aangegeven. Derhalve zal, bij een beperkte uitleg van de waarborgen door de wetgever, onzekerheid blijven bestaan of wel in voldoende mate invulling is gegeven aan de uit het verdragsrecht voortvloeiende waarborgen.

Voor zover deze verdragsrechtelijke waarborgen ook terug te vinden zijn in het Nederlandse straf(proces)recht dient mijns inziens aan die waarborgen in het bestuursstrafrecht dezelfde nationale invulling te worden gegeven. Dit klemt te meer nu de bestuurlijke boete gezien kan worden als een sanctie die deel uitmaakt van het strafrecht in ruime zin.

Door aansluiting te zoeken bij de waarborgen uit het wetboek van Strafrecht en het wetboek van Strafvordering wordt voorkomen dat ten aanzien van strafrechtelijke overtredingen meer en/of betere waarborgen in het kader van de rechtsbescherming van de overtreder gelden dan ten aanzien van bestuursrechtelijke overtredingen die door middel van een bestuurlijke boete worden gesanctioneerd. Bovendien is de kans dat de verdragsrechtelijke waarborgen dan té beperkt worden uitgelegd aanzienlijk kleiner. Voor een gedetailleerd overzicht van die waarborgen verwijs ik naar hoofdstuk drie en vier van dit boek.

\subsection{3 'Derde spoor'}

Binnen het strafrechtelijk kader bestaat (mede met het oog op het handhavingstekort) reeds jarenlang belangstelling voor het creëren van een zelfstandige sanctiebevoegdheid van het $\mathrm{OM}^{94}$ Met het oog hierop zijn in de loop der jaren diverse sanctiebevoegdheden gepresenteerd. ${ }^{95}$ De voorgestelde sanctiebevoegdheden hebben met elkaar gemeen dat het $\mathrm{OM}$, evenals (andere) bestuursorganen in het kader van de oplegging van bestuurlijke boeten, zonder voorafgaande tussenkomst van (de verdachte of) een onafhankelijke en onpartijdige strafrechter bevoegd is tot oplegging van financiële sancties.

In het kader van de te creëren zelfstandige sanctiebevoegdheid voor het $O M$ heeft aanvankelijk met name Knigge zich beziggehouden met de ontwikkeling van een regeling tot oplegging van de zogenaamde OM-boete. ${ }^{96}$ Van meet af aan heeft Knigge in dat kader het 'strafrechtelijke spoor' afgezet tegen de bestuurlijke boete. Knigge stelt dat in het kader van de oplegging van vermogenssancties de procesverplichting, ook binnen het strafrecht, niet langer als een onmisbare en wezenlijke waarborg wordt beschouwd. ${ }^{97}$ De reden om de bestuurlijke boete buiten het strafrecht te situeren komt daarmee te vervallen. Derhalve meent Knigge dat de meest aangewezen plaats, om de procedure tot oplegging van geldboeten te regelen, het Wetboek van Strafvordering is. Knigge wil aan deze regeling vorm geven middels het creëren van een zogenaamd

94 Vgl. A.R. Hartmann, Buitengerechtelijke afdoening, in: Groenhuijsen en Knigge a.w. 1999, p. 59-90, i.h.b. p. 69.

95 Vgl. voor een overzicht van genoemde sanctiebevoegdheden: A.R. Hartmann, Buitengerechtelijke afdoening, in: Groenhuijsen en Knigge a.w. 1999, p. 59-90, i.h.b. p. 62-69.

96 Vgl. Knigge a.w. 1994.

97 Vgl. Knigge in: Groenhuijsen en Knigge a.w. 2001 , p. 119. 
'derde spoor' op grond waarvan (onder meer) de OM-boete kan worden opgelegd door het OM.

Op deze plaats lijkt het zinvol een blik te werpen op de door Knigge voorgestelde, en in het kader van het onderzoeksproject 'Strafvordering 2001' nader uitgewerkte, regeling tot oplegging van (bestuurlijke) boeten door het $\mathrm{OM} .{ }^{98}$ Hierna zal de aanvankelijk door Knigge voorgestelde regeling op hoofdlijnen beschreven worden. De voordelen die deze, binnen het straf(proces)recht vallende, regeling met zich brengt zullen daarbij aan de orde komen. Daama zal aandacht uitgaan naar de vraag in hoeverre de door Knigge voorgestelde, en in het kader van het onderzoeksproject 'Strafvordering 2001' nader uitgewerkte, regeling zou kunnen dienen als alternatief voor de door de commissie Scheltema voorgestelde bestuurlijke boeteregeling.

\subsubsection{Voorgestelde regeling}

Knigge toont zich geen voorstander van buitengerechtelijke afdoening, middels transacties (binnen het strafrechtelijk kader), of de oplegging van bestuurlijke boeten, van 'minder ernstige' strafbare feiten. ${ }^{99}$ Volgens hem moet op een andere manier voorzien worden in een gedifferentieerde strafvorderlijke regeling. De differentiatie van de regeling moet zijn toegesneden op hetgeen voor de verdachte op het spel staat. ${ }^{100}$ Knigge stelt in dat kader dan ook voor aan de hand van de emst van het ten laste gelegde feit (in concreto) en de zwaarte van de mogelijk op te leggen sancties te onderscheiden tussen drie strafvorderlijke procedures (het zogenaamde 'drie sporenmodel'). ${ }^{101} \mathrm{Hij}$ staat daarmee een materieel criterium voor wat betreft de differentiatie binnen het strafvorderlijke kader. ${ }^{102}$

Het 'eerste spoor' ziet op situaties waarin sprake is van een tenlastegelegd strafbaar feit dat gesanctioneerd kan worden met een vrijheidsstraf van meer dan zes maanden. Dergelijke zaken moeten door een meervoudige kamer worden behandeld. Bovendien dienen in het kader van de berechting van de verdachte 'toegespitste' procedurele waarborgen in acht te worden genomen. Het 'tweede spoor' ziet op tenlastegelegde strafbare feiten die gesanctioneerd kunnen worden met een vrijheidsstraf van kortere duur. Behandeling van zaken in het kader van het tweede spoor vindt plaats door een enkelvoudige strafkamer. Tenslotte volgt het, in het kader van dit onderzoek meest relevante, 'derde spoor'. Het 'derde spoor' bestaat uit een buitengerechtelijke procedure waarbij aan het OM onder meer de bevoegdheid toekomt 'OM-boeten' op te leggen. Deze procedure is geschikt voor veel voorkomende strafbare feiten van geringe ernst die kunnen worden afgedaan met een betrekkelijk lichte sanctie. ${ }^{103}$

98 Spijtig genoeg was het derde interimrapport van het onderzoeksproject 'Strafvordering 2001', waarin het derde spoor nader is uitgewerkt, bij het afsluiten van dit onderzoek nog niet verschenen. Een gedetailleerde weergave van de procedure tot oplegging van de OM-boete is in dit boek dan ook niet opgenomen.

99 Vgl. Ḱnigge a.w. 1994, p. 50 en p. 57-60.

$100 \mathrm{Vgl.} \mathrm{Knigge} \mathrm{a.w.} \mathrm{1994,} \mathrm{p.} 75$.

101 Vgl. Knigge a.w. 1994, p. 49-50, p. 71, p. 75-78, en A.R. Hartmann, Buitengerechtelijke afdoening, in: Groenhuijsen en Knigge a.w. 1999, p. 59-90, i.h.b. p. 70.

102 Vgl. H.J. Scholten, Kemvragen rond de gewone rechtsmiddelen in het kader van strafvordering 2001, DD 2002, p. 261-282, i.h.b. p. 274.

103 Vgl. Groenhuijsen en Krigge a.w. 1999, p. 41-42. Gedacht kan worden aan overtredingen en een- 
In het eerste interimrapport van het onderzoeksproject 'Strafvordering 2001 ' worden de 'basiskenmerken' van het derde spoor opgesomd:
'Het meest essentiele kenmerk van dit spoor is gelegen in het wegvallen van de procesverplichting. Waar het gaat om grote aantallen feiten, terwijl in het gros van die gevallen er bij de naast betrokkenen materieel geen behoefte bestaat aan inschakeling van de rechter, kan het opleggen van een betrekkelijk lichte sanctie in de eerste fase van dit spoor worden overgelaten aan de officier van justitie. Uitgangspunt is dat de opportuniteit van deze vorm van afdoening wordt bepaald - en dus beperkt - door de zogenaamde 'ernst in concreto' van het feit. Het OM is vooralsnog in beginsel alleen bevoegd om vermogens- sancties op te leggen. De maximale hoogte daarvan moet nog worden vastgesteld bij het uitwerken van deze procedure in het tweede projectjaar. Het opleggen van de boete is steeds vatbaar voor beroep op de onafhankelijke rechter. De aanduiding van het derde spoor als 'afdoening buiten geding' heeft dus alleen betrekking op de eerste fase daarvan. Daarna is ook in dit spoor de rol van de rechter essentieel. De in beroep oordelende rechter kijkt niet alleen naar de hoogte van de opgelegde boete, maar beoordeelt ook de schuldvraag in volle omvang en heeft daarbij oog voor alle andere omstandigheden van het geval (volgens het vragenschema van het huidige art. 348 en $350 \mathrm{~Sv}$ ). De beslissing van de rechter kan evenwel alleen ten gunste van de verdachte zijn: de zogeheten reformatio in peius is uitgesloten. ${ }^{104}$

Op basis de gegevens uit het onderzoeksproject 'Strafvordering 2001' en de publicaties van Knigge kan ten aanzien van de procedure tot oplegging van de OM-boete in het kader van het zogenaamde 'derde spoor' het volgende worden gezegd. De (aan een maximum gebonden) boete wordt, in de vorm van een beschikking, opgelegd door de Officier van Justitie. ${ }^{105}$ Evenals in het bestuursrecht zal de verdachte zelf het initiatief moeten nemen om de boete aan te vechten. Aan een bezwaarschriftprocedure bestaat in dat kader geen behoefte. ${ }^{106}$ De OM-boete wordt aangevochten ten overstaan van de strafrechter die in dat kader gebruik zou kunnen maken van de ruime bevoegdheden die hem met het oog op zijn rechtsprekende functie ten dienste staan en die kenmerkend zijn voor zijn niet-lijdelijke rol en de waarde die in het strafproces wordt gehecht aan materiële waarheidsvinding. In die zin lijkt de procedure tot oplegging van een OMboete in ieder geval in potentie met meer waarborgen, in het kader van de rechtsbescherming van de verdachte, te zijn omkleed dan de procedure tot oplegging van de bestuurlijke boete zoals hiervoor (onder meer in hoofdstuk vier) geschetst.

In dit kader dient echter niet uit het oog te worden verloren dat Knigge bepaalde strafvorderlijke aspecten enigszins marginaliseert in zijn voorstel. Zo acht hij reformatio in peius uitgesloten. ${ }^{107}$ Daarnaast wil hij de Officier van Justitie vóór aanvang van de zitting nog de gelegenheid bieden de boetebeschikking (vanwege in het beroepschrift naar voren gebrachte punten) te herzien. ${ }^{108}$ Voorts lijkt Knigge zich, in het kader van de

voudige misdrijven die momenteel veelal middels een transactie worden afgedaan (Vgl. Knigge a.w. 1994, p. 71). Op deze plaats dient overigens opgemerkt te worden dat er van uit gegaan wordt dat artikel $113 \mathrm{Gr}$.W. zich niet verzet tegen oplegging van een OM-boete ( $\mathrm{Vgl}$. Hartmann in: Groenhuijsen en Knigge a.w. 1999, i.h.b. p. 80-82 en p. 90).

104 Vgl. Groenhuijsen en Knigge a.w. 1999, p. 41-42.

105 Vgl. Knigge a.w. 1994, p. 76.

106 Vgl. Jansen a.w. 2002, p. 189.

107 Vgl. Knigge a.w. 1994, p. 76. In het derde interimrapport lijkt overigens het standpunt ingenomen te worden dat reformatio in peius wel mogelijk is (Vgl. Jansen a.w. 2002, p. 189).

108 Vgl. Knigge a.w. 1994, p. 77. 
OM-boete, voorstander te tonen van een soort 'grievenstelsel'. De ruime toetsingsbevoegdheid van de strafrechter lijkt daarmee niet ten volle benut te hoeven worden. ${ }^{109}$ óf en in hoeverre hierdoor tekort zal worden gedaan aan de idee van materiële waarheidsvinding is moeilijk te zeggen. Tenslotte is hoger beroep uitgesloten. Volgens Knigge kan worden volstaan met cassatie. ${ }^{110}$

Zoals gezegd was het derde interimrapport van het onderzoeksproject 'Strafvordering 2001 ', waarin het 'derde spoor' nader is uitgewerkt, bij het afsluiten van dit onderzoek nog niet verschenen. Derhalve zal moeten worden volstaan met deze enigszins beknopte beschrijving van het 'derde spoor'. Overigens is het wel mogelijk, aan de hand van het NJV-preadvies van Jansen, op bepaalde punten inzicht te verwerven in de wijze waarop in het derde interimrapport (nader) invulling zal worden gegeven aan de OMboete.

Het lijkt er op dat in het kader van het 'derde spoor' de strafvorderlijke uitgangspunten, onder meer met het oog op artikel 6 EVRM, in grotere mate worden onderschreven dan Knigge aanvankelijk (in 1994) voor ogen had. ${ }^{111}$ In die zin wordt in het derde interimrapport duidelijk afstand genomen van de in het Voorontwerp van de vierde tranche Awb voorgestelde regeling.

Uitgangspunten zijn, volgens Jansen, dat de rechter de zaak in volle omvang moet beoordelen en dat hij een eigen antwoord moet geven op de vragen van artikel 348 en $350 \mathrm{~Sv}$. De feitsomschrijving van de (boete)beschikking dient in dat kader als tenlastelegging te fungeren. ${ }^{112}$ Deze feitsomschrijving mag de Officier van Justitie binnen de grenzen van artikel $68 \mathrm{Sr}$ aanvullen. ${ }^{113}$ De volgende overwegingen worden in het derde interimrapport aan deze keuze ten grondslag gelegd (zo volgt uit het NJV-preadvies van Jansen):

'Het bestuursrechtelijke model is niet geschreven voor de oplegging van punitieve sancties en kan daarom alleen met enig kunst en vliegwerk in overeenstemming worden gebracht met de eisen die art. 6 EVRM stelt. Op grond van dat artikel kan de rechter niet volstaan met een toetsing van de beslissing van het $\mathrm{OM}$, maar dient hij zich een eigen oordeel ten gronde te vormen over de schuld van de verdachte. Daar komt bij dat het bestuursrechtelijke model niet is afgestemd op de processuele waarborgen waarom art. 6 EVRM vraagt (zoals het horen van de getuigen à charge ter terechtzitting). Dat gaat zwaarder wegen naarmate de sancties die in het derde spoor worden opgelegd, ingrijpender zijn. Tenslotte kan worden opgemerkt dat de keuze voor een strafvorderlijke invulling bewerkstelligt dat zaken uit het derde spoor door de rechter steeds volgens hetzelfde grondmodel worden afgehandeld. ${ }^{114}$

109 Vgl. Knigge a.w. 1994, p. $77-78$

110 Vgl. Knigge a.w. 1994, p. 78. De vraag is hoe dit zich verhoudt tot het recht op rechtspraak in twee feitelijke instanties.

111 Vgl. Jansen a.w. 2002 , p. 189 en p. 238-240.

112 Onder bepaalde omstandigheden wordt in het kader van het onderzoeksproject Strafvordering 2001 echter vitgegaan van een meer contradictoire gedingstructuur. Vgl. G. Knigge, De krenten in de pap; het onderzoeksproject Strafvordering 2001 en de actuele ontwikkelingen op het terrein van de wetgeving, DD 2002, p. 221-236, i.h.b. p. 234-235.

113 Vgl. Jansen a.w. 2002 , p. $238-240$.

114 M.S. Groenhuijsen en G. Knigge, Algemeen deel (concept), in: M.S. Groenhuijsen en G. Knigge (red. Dwangmiddelen en Rechtsmiddelen. Derde interimrapport onderzoeksproject Strafvordering 2001 , blz. 27 (Bron: Jansen a.w. 2002, p. 239). 
Uit hoofdstuk vier en dit slotdeel moge duidelijk zijn dat ik deze standpunten van de onderzoeksgroep 'Strafvordering 2001', anders dan Jansen ${ }^{115}$, kan onderschrijven.

Tenslotte verdient opmerking dat het 'derde spoor', zo volgt uit het derde interimrapport, niet beperkt blijft tot buitengerechtelijke afdoening (in eerste instantie) middels boeten. Ook sancties als een straatverbod en ontzegging van de rijbevoegdheid kunnen op basis van het, in het derde interimrapport voorgestelde, 'derde spoor' worden opge. legd. ${ }^{116}$

\subsubsection{Voordelen OM-boete}

Knigge heeft, onder meer in zijn NJV-preadvies uit 1994, aangegeven welke voordelen het opleggen van een OM-boete ten opzichte van een bestuurlijke boete met zich brengt. Genoemde voordelen zullen hierna in essentie worden weergegeven. Ten eerste gaat volgens Knigge de eenheid en overzichtelijkheid bij het straffen van personen niet verloren. ${ }^{117}$ Mijns inziens is dit een steekhoudend argument. De mogelijkheid tot punitieve sanctionering van normschendingen blijft immers voorbehouden aan het strafrechtelijk apparaat. Dit bevordert niet alleen de eenheid en overzichtelijkheid in feitelijke zin. Daarnaast wordt de rechtszekerheid er mee gediend. Een situatie waarbij door verschillende bestuursorganen ten aanzien van een zelfde handeling, zonder enige afstemming met betrekking tot de hoogte van de totale boete, bestuurlijke boeten op kunnen worden gelegd omdat er sprake is van meerdaadse samenloop zal zich in het kader van het door Knigge en de onderzoeksgroep 'Strafvordering 2001' voorgestelde 'derde spoor' niet snel voordoen.

Een tweede, door Knigge genoemd, voordeel is dat de band met het materiële strafrecht en met het Wetboek van Strafvordering niet wordt verbroken. ${ }^{118}$ Als de band met het materiële strafrecht en het Wetboek van Strafvordering niet wordt doorbroken hoeft in het kader van strafrechtelijke vraagstukken niet steeds opnieuw het wiel te worden uitgevonden. ${ }^{119}$ De strafrechtelijke en strafvorderlijke leerstukken zijn immers gewoon van toepassing. ${ }^{120}$ De op dit punt in het Voorontwerp naar voren komende problemen, zoals hiervoor gesignaleerd, zullen zich dan ook niet voordoen. In dat kader gaat het dan niet alleen om de afwijkende uitleg van begrippen uit het materiële strafrecht maar ook om de problemen die zich voordoen als het bestuursprocesrecht onverkort wordt toegepast bij de oplegging van bestuurlijke boeten.

Het voorgaande leidt als vanzelf tot een derde voordeel. De wettelijke regeling kan zich, indien de band met het materiële strafrecht en het Wetboek van Strafvordering niet wordt verbroken, immers beperken tot punten waarop het 'derde spoor' afwijkt van het naar geldend recht normale strafvorderlijk patroon. ${ }^{121}$

115 Vgl. Jansen a.w. 2002, p. 239-240

116 Vgl Jansen a.w. 2002, p. 239.

117 Knigge a.w. 1994, p. 50. Vgl. Albers en Schlossels §9.1.

118 knigge aw. 1994, p. 50.

119 Knigge a.w. 1994, p. 50.

$120 \mathrm{Vgl}$. Hartmann in: Groenhuijsen en Krigge a.w. 1999, i.h.b. p. 78-79.

$121 \mathrm{Vgl}$. G. Knigge, De verhouding tot het strafrecht in: Groenhuijsen en Knigge a.w. 2001, p. 93-124, i.h.b. p. 120. De daar door Knigge geopperde idee om, wat het beroep op de rechter betreft, eventueel aansluiting te zoeken bij de regeling in de Awb is mijns inziens niet bijzonder toe te juichen. Gelet op de in het derde interimrapport voorgestelde regeling lijkt de onderzoeksgroep 'Strafvordering 2001', 
Belangrijk is voorts dat de opportuniteit van deze vorm van afdoening, zoals hierboven reeds is aangegeven, wordt bepaald - en dus beperkt - door de zogenaamde 'ernst in concreto' van het feit. Dit brengt met zich dat ook commune delicten via het 'derde spoor' afgedaan zouden kunnen worden (voor zover zij 'in concreto' niet zo ernstig zijn dat de zwaardere, stigmatiserend werkende, procedure uit het 'tweede (of eerste?) spoor' moet worden toegepast). ${ }^{122}$ Deze mogelijkheid zou niet onverkort bestaan indien bepaalde strafbare feiten uit het strafrecht worden gehaald door ze middels de bestuurlijke boete zoals voorgesteld in het Voorontwerp te bestraffen. Om een soortgelijk resultaat via de bestuurlijke boeteregeling te bereiken zou in ieder geval afstemming op grond van de una via-regeling plaats moeten vinden. De te bestraffen handeling zou dan zowel strafrechtelijk als bestuursrechtelijk strafbaar moeten worden gesteld.

\subsubsection{Vormgeving regeling}

Wil de door Knigge en door de Onderzoeksgroep 'Strafvordering 2001' voorgestelde regeling van het 'derde spoor' worden toegepast als alternatief voor de door de commissie Scheltema voorgestelde bestuurlijke boete dan zal aan een aantal randvoorwaarden moeten worden voldaan.

Ten eerste lijkt het, met het oog op doelmatigheidsoverwegingen noodzakelijk dat niet alleen de Officier van Justitie maar ook bestuursorganen de bevoegdheid krijgen ten aanzien van bepaalde normschendingen boeten op te leggen. ${ }^{123}$ Het gaat het bestek van dit boek te buiten om in dat kader te schetsen hoe een en ander precies geregeld zou moeten worden. Zinvol lijkt het wel om het in het CTW-rapport voorgestelde 'model A' toe te passen. Dit brengt met zich dat ten aanzien van een bepaalde normschending in de wettelijke regeling bepaald moet worden wie bevoegd is tot oplegging van de boete. Dit is dus ofwel de Officier van Justitie ofwel een bepaald bestuursorgaan.

Daarnaast zal in het kader van de boeteregeling in ieder geval acht moeten worden geslagen op de hiervoor in het Voorontwerp gesignaleerde tekortkomingen. Mijns inziens dient er voor gewaakt te worden dat aspecten uit het Voorontwerp, die zich niet goed verdragen met de oplegging van punitieve sancties terugkeren in de, op de door de Onderzoeksgroep 'Strafvordering 2001 ' voorgestelde regeling gebaseerde, boeteregeling. Dit brengt met zich dan in ieder geval de fundamentele strafvorderlijke principes in het kader van het 'derde spoor' onverkort van toepassing zullen moeten zijn (bijvoorbeeld het vooropstellen van de materiële waarheidsvinding). Daamaast moeten ook de (relevante) materieel strafrechtelijke bepalingen onverkort worden toegepast (bijvoorbeeld de regels over cumulatie van sancties, ne bis in idem, deelnemings- en daderschapsfiguren). Dit laatste lijkt echter, gelet op de standpunten van Knigge en de onderzoeksgroep 'Strafvordering 2001', geen problemen op te gaan leveren. Anderzijds lijkt echter vooralsnog het recht op rechtspraak in twee feitelijke instanties te ontbreken

waar ook Knigge deel van uit maakt, inmiddels ook tot die conclusie te zijn gekomen (Vgl. de hiervoor aangehaalde passage uit het derde interimrapport).

122 Vgl. Knigge in: Groenhuijsen en Knigge a.w. 2001, p. 120.

$123 \mathrm{Ik}$ ben me er van bewust dat, door het $\mathrm{OM}$ en andere bestuursorganen boetebevoegdheden toe te kennen, (ongewenste) cumulatie van boeten niet is uitgesloten. Uit praktische overwegingen lijkt het echter niet zinvol alle boetebevoegdheden toe te kennen aan het OM. Dit zou slechts leiden tot een handhavingstekort. Uitbreiding van het $\mathrm{OM}$ met gespecialiseerde sub-onderdelen lijkt ook weinig effect te sorteren. Ook dan wordt onderlinge afstemming immers steeds lastiger. 
in het kader van het 'derde spoor' - de oplegging van de boete zelf door de Officier van Justitie kan mijns inziens immers niet als rechtspraak gekwalificeerd worden. ${ }^{124}$ Wellicht staat dit op gespannen voet met artikel 14, vijfde lid IVBPR gelet op hetgeen daaromtrent in hoofdstuk drie van dit boek is weergegeven.

Er dienen wel enkele kanttekeningen te worden geplaatst bij de uitvoerbaarheid van de door de Onderzoeksgroep 'Strafvordering 2001' voorgestelde boeteregeling als deze tevens door bestuursorganen wordt toegepast als alternatief voor de bestuurlijke boete. De capaciteit van het strafrechtelijk apparaat zou namelijk een belemmering kunnen vormen voor toepassing van de boeteregeling uit het 'derde spoor' in het strafrecht én in het bestuursrecht. Althans voor zover de beroepsprocedure in alle gevallen bij de strafrechter zou moeten worden gevoerd. Gelet op bevordering van de rechtseenheid en het feit dat in het bijzonder regels van materieel strafrecht en van strafvorderlijke aard zullen worden toegepast in het kader van de oplegging van de boete uit het 'derde spoor' lijkt het bovendien gewenst dat de strafrechter bij uitsluiting bevoegd is te oordelen over het beroep. Daarmee lijkt de vrees voor een capaciteitsprobleem aan de zijde van de strafrechter gerechtvaardigd.

Een ander nadeel dat kleeft aan invoering van de 'derde spoor-boete', in de plaats van de bestuurlijke boete, is dat een aantal door Knigge gesignaleerde voordelen wegvalt als een dergelijke boete niet langer binnen de strafrechtelijke kolom wordt opgelegd. Gewezen kan worden op de opportuniteitsidee. Deze zal weg vallen als een bestuursorgaan de boeteregeling uit het 'derde spoor' toepast. Bestuursorganen kunnen immers in beginsel alleen de boetebevoegdheid uitoefenen ten aanzien van normschendingen waarvan niet alleen 'in concreto' maar ook 'in abstracto' vaststaat dat zij niet dermate emstig zijn dat onder omstandigheden het commune strafrecht toegepast moet worden. Dit zou slechts anders zijn indien een vrij ingewikkelde afstemmingsregeling zou worden gecreêerd op grond waarvan de officier van justitie en het bestuursorgaan overleg moeten plegen indien onduidelijk is hoe 'ernstig' de normschending is.

Omgekeerd bestaan in het bestuursrecht sancties die 'in concreto' soms punitief van aard zijn en soms reparatoir. In hoeverre zouden deze sancties ondergebracht kunnen worden bij het 'derde spoor'? Hier lijkt zich, weliswaar gespiegeld, een vergelijkbaar probleem voor te doen.

Het voorgaande brengt met zich dat het strafrechtelijke 'derde spoor' in eerste opzicht een aardig alternatief lijkt te kunnen vormen voor de bestuurlijke boete zoals die is voorgesteld in het Voorontwerp. Bij nadere bestudering blijkt echter dat dit alternatief niet vrij is van haken en ogen. Wil het 'derde spoor' (en dan in het bijzonder de 'OMboete') in het kader van het punitieve bestuursrecht zijn diensten bewijzen dan zal dit gepaard gaan met een behoorlijke inspanning van de wetgever. Terwijl het voorts nog maar de vraag is of de inspanningen van de wetgever uiteindelijk tot een bevredigend resultaat leiden. Een volledig binnen het strafrechtelijk kader vallende regeling, op grond waarvan zowel effectief bestuursrechtelijke punitieve sancties als strafrechtelijke sancties kunnen worden opgelegd, lijkt in derhalve moeilijk realiseerbaar. 


\subsubsection{Bestuursrechtelijke transactie}

\subsubsection{Algemeen}

Hierboven is reeds aangegeven dat het met het oog op effectieve en efficiënte handhaving aanbevelenswaardig is de idee in overweging te nemen om over te gaan tot de invoering van de bestuursrechtelijke transactie op ruimere schaal. Het lijkt immers niet onwaarschijnlijk dat de efficiënte en effectieve handhaving, in ieder geval op bepaalde bijzondere bestuursrechtelijke gebieden ${ }^{125}$, daarmee gediend is. In dat kader is niet alleen relevant dat door het EPA in de Verenigde Staten positieve ervaringen zijn opgedaan met de (weliswaar niet volledig vergelijkbare) schikkingsvariant. Ook de ervaringen die in het nationale strafrecht zijn opgedaan met de transactie ${ }^{126}$ lijken te wijzen op een welwillende houding van de vermoedelijke overtreder ten opzicht van transactievoorstellen. 't Hart geeft bijvoorbeeld aan dat verreweg de meeste strafbare feiten met een transactie worden afgedaan. ${ }^{127}$

Voor het OM vormt de strafrechtelijke transactie een snelle en goedkope wijze van sanctionering in strafzaken. Voornamelijk daardoor is de transactie in het strafrecht een belangrijke wijze van afdoening geworden. ${ }^{128}$ Ook de verdachte heeft belang bij het accepteren van een transactievoorstel. ${ }^{129}$ Het belangrijkste voordeel van de transactie is voor de verdachte wellicht dat hij niet in het openbaar terecht hoeft te staan. ${ }^{130}$

De strafrechtelijke transactie kan worden aangemerkt als een publiekrechtelijke overeenkomst. Deze overeenkomst houdt een toezegging van het $\mathrm{OM}$ of de politie in dat van strafvervolging wordt afgezien indien de verdachte de, in het transactievoorstel, gestelde voorwaarde $(n)^{131}$ heeft vervuld. ${ }^{132}$ Veelal bestaat de in het transactievoorstel neergelegde voorwaarde uit betaling van een geldsom.

Het EHRM is van mening dat dergelijke transactievoorstellen niet in strijd zijn met artikel 6 EVRM. De vermoedelijke overtreder moet dan wél op basis van vrijwilligheid instemmen met het transactievoorstel; anders kan het recht op toegang tot de rechter, zoals gewaarborgd in artikel 6 EVRM, in het geding komen. ${ }^{13 .}$

\subsubsection{Bestuursrechtelijke en gemengde variant}

Ten aanzien van de bestuursrechtelijke transactie zijn twee varianten denkbaar. Er kan worden uitgegaan van een volledig binnen de bestuursrechtelijke kolom gesitueerd bestuursrechtelijk transactiemodel en van een gemengd transactiemodel waarbij het initiatief bij het bestuursorgaan ligt terwijl de rechtsbescherming strafrechtelijk van aard is.

125 Zoals bijvoorbeeld het milieurecht en de economische ordeningsrecht.

126 Zie artikel 74 Sr. Zie m.b.t. de strafrechtelijke transactie voorts: Corstens a.w. 1999, p. 775-778.

127 't Hart a.w. 2001, p. 30. Zie ook Michiels a.w. 1998b, p. 273-274.

128 Corstens a.w. 1999 , p. 776 .

129 Corstens a.w. 1999 , p. 776.

I30 Knigge toont zich echter geen voorstander van de transactie. Instemming van de verdachte levert volgens hem geen voldoende waarborg op tegen willekeurige en onterechte bestraffing (van de onschuldige verdachte) (Vgl. Knigge a.w. 1994, p. 57).

131 In artikel 74, tweede lid, $\mathrm{Sr}$ is aangegeven welke voorwaarden gesteld kunnen worden.

132 Corstens a.w. 1999, p. 776.

133 Vgl. EHRM 27 februari 1980, Series A vol. 35, NJ 1980, 561 (Deweer). 


\section{Bestuursrechtelijk transactiemodel}

Ten eerste zou, voorafgaand aan de procedure tot oplegging van de bestuurlijke boete, een transactievoorstel gedaan kunnen worden. Stemt de vermoedelijke overtreder in met de voorgestelde transactie dan is daarmee de zaak afgedaan. Gaat de vermoedelijke overtreder niet akkoord met het transactievoorstel dan kan alsnog een bestuurlijke boete worden opgelegd. Oplegging van de bestuurlijke boete zou dan plaats moeten vinden op basis van de nog te creëren (bestuurs)straf(proces)rechtelijke wettelijke regeling. ${ }^{134}$ Die nieuwe regeling zal weliswaar iets omslachtiger - want met meer waarborgen omkleed - zijn dan de in het Voorontwerp neergelegde regeling maar zij zal minder frequent moeten worden toegepast indien de transactiebevoegdheid in voldoende mate wordt benut en effect blijkt te sorteren.

\section{Gemengd transactiemodel}

Bij de tweede variant is het bestuursorgaan bevoegd een transactie aan te bieden in geval van overtredingen van bestuursrechtelijke regels ten aanzien waarvan het wenselijk is dat zij middels punitieve sancties worden bestraft. Stemt de vermoedelijke overtreder niet in met het transactievoorstel dan wordt vervolgens de strafrechtelijke procedure ingezet. Het bestuursorgaan draagt het dossier over aan het OM. Het OM draagt zorg voor de vervolging van de vermoedelijke overtreder.

Voordeel van deze tweede variant is dat er geen aparte bestuursstrafrechtelijke regeling ontworpen hoeft te worden. Opmerking verdient echter dat dit argument alléén geldt als oplegging van punitieve sancties bij overtreding van bestuursrechtelijke regelgeving dan ook volledig wordt overgeheveld naar het strafrecht. Wellicht is dat een sisyfusarbeid. Reeds om die reden lijkt deze variant dan ook niet aanbevelenswaardig.

De vraag is bovendien of het handhavingstekort op deze wijze niet vergroot wordt indien tenminste het strafrechtelijke apparaat niet uitgebreid wordt. Niet uitgesloten kan immers worden dat vanwege ontbrekende handhavingscapaciteit bij de strafrechtelijke instanties de bestuursrechtelijke overtredingen, ten aanzien waarvan de vermoedelijke overtreder niet wilde transigeren, niet (met voortvarendheid) worden vervolgd en bestraft. Indien dit het geval is vormt de bestuursrechtelijke transactiebevoegdheid naar alle waarschijnlijkheid slechts een 'papieren tijger'. Hoe kleiner de kans is dat strafrechtelijk gehandhaafd wordt hoe geringer wellicht de bereidwilligheid zal zijn om te transigeren. Derhalve gaat mijn voorkeur uit naar de eerste variant waarbij de eigen (handhavings)verantwoordelijkheid van het bestuursorgaan voorop staat.

\subsubsection{Bezwaren}

De commissie Scheltema meent, zoals gezegd, dat er een redelijk omslachtige regeling gecreëerd zal moeten worden teneinde de bestuursrechtelijke transactiebevoegdheid op een juiste wijze (juridisch) in te kaderen. Dit zou mijns inziens echter wel eens mee kunnen vallen. De wetgever kan immers - indien ervoor gekozen wordt een wettelijke regeling te treffen voor de bestuursrechtelijke transactie - gebruik maken van de ervaring die (sinds 1 november 2000) is opgedaan met de experimentele bestuursrechtelijke

134 In dat kader zou gekozen kunnen worden voor één van de in \$4.1 aangegeven varianten. 
transactie in het milieurecht. ${ }^{135}$ De daartoe getroffen regeling zou als uitgangspunt kunnen dienen. Bovendien zou teruggegrepen kunnen op de ervaring die in het strafrecht is opgedaan met de transactie.

Indien blijkt dat de bestuursrechtelijke transactie effect sorteert zullen de bestuurslasten in het kader van punitieve handhaving in de toekomst aanzienlijk beperkt worden. Daarnaast zal de bestuursrechter voor een deel ontlast worden. Er zullen hem immers minder geschillen met betrekking tot de oplegging van bestuurlijke boeten (en eventuele andere punitieve sancties) bereiken. Deze voordelen - kort gezegd; snelle en goedkope bestuursrechtelijke handhaving - wegen mijns inziens op tegen het creëren van een nieuwe wettelijke regeling.

Aan de bestuursrechtelijke transactie kleeft voorts een aantal nadelen waaraan meer gewicht moet worden toegekend. Ten eerste wordt wel beweerd dat door de beperkte openbaarheid ernstige normschendingen verdwijnen in de doofpot. ${ }^{136}$ Voorts zou aan deze 'binnenskamerse' leedtoevoeging geen betekenis toekomen omdat er geen generale preventie van uit gaat. ${ }^{137}$ Daarnaast ontbreekt uiteraard het stigmatiserende effect. Tenslotte wordt wel gesteld dat een vermoedelijke overtreder veelal instemt met een transactievoorstel op basis van 'schijnvrijwilligheid' - bijvoorbeeld uit angst om gedurende de strafrechtelijke procedure geconfronteerd te worden met een nog hogere boete. ${ }^{138}$ Instemming van de verdachte levert volgens Knigge vanwege genoemde 'schijnvrijwilligheid' geen voldoende waarborg op tegen willekeurige en onterechte bestraffing. ${ }^{139}$ Met name dit laatste geeft aanleiding de bestuursrechtelijke transactie enigszins terughoudend te benaderen. Indien vermoedelijke overtreders inderdaad niet daadwerkelijk vrijwillig instemmen met een (bestuursrechtelijk) transactievoorstel komt dit de rechtsbescherming niet ten goede. Aangezien niet duidelijk is in hoeverre in de praktijk gesproken moet worden van 'schijnvrijwilligheid' bij het aangaan van een transactie $e^{140}$ $\mathrm{zal}$ in ieder geval onderzocht moeten worden of, en zo ja, in hoeverre, daarvan sprake is. Hiervoor heb ik al aangegeven dat het volgens Michiels, in ieder geval in het kader van economische delicten, wel mee valt met genoemde 'schijnvrijwilligheid'. ${ }^{141}$ Boven-

135 Zie het Transactiebesluit milieudelicten, Stb. 2000, 320, op grond waarvan vanaf I november 2000 door een aantal in het besluit aangewezen bestuursorganen op experimentele wijze overgegaan kan worden tot het doen van een (strafrechtelijk) transactievoorstel. In dit kader dient te worden opgemerkt dat het bij dit experiment gaat om het verlenen van een bevoegdheid aan bestuursorganen tot het aanbieden van een strafrechtelijke transactie. Hierboven heb ik reeds aangegeven dat mijn voorkeur niet uitgaat naar deze variant.

$136 \mathrm{Vgl}$. de commotie die hierover omstreeks november 2001 ontstond vanwege het feit dat het OM te Haarlem ten aanzien van een drietal bouwbedrijven een transactievoorstel had gedaan met betrekking tot valsheid in geschrifte in het kader van de bouw van de Schipholtunnel. Zie in dit kader o.m. Kamerstukken II, 2001/2002, 28 093, nrs. 1, 5, 14, 15, 16, 17, 20, en 21 alle getiteld 'bouwfraude en comuptie bij ambtenaren'.

137 Vgl. Knigge a.w. 1994, p. 57-58.

138 Vgl. Jansen a.w. 2002 , p. 237.

139 Vgl. Knigge a.w. 1994, p. 57.

140 Vgl. De opmerking van Doorenbos tijdens de NJV-jaarvergadering 2002: P.C. Vegter, Herziening van het sanctiestelsel. Verslag van de jaarvergadering van de Nederlandse Juristen-Vereniging, NJB 2002, p. 1288-1293, i.h.b. p. 1293.

141 Vgl. Michiels a.w. 1998 b, p. 274 e.v. 
dien kan gewezen worden op de suggesties van Corstens teneinde de keuzevrijheid te bevorderen. Namelijk het reserveren van de transactie voor eenvoudige zaken waarin een veroordeling gemakkelijk haalbaar is en het hanteren van het transactiebedrag als plafond voor de eis ter zitting en de rechterlijke straftoemeting. ${ }^{142}$

De andere hierboven aangevoerde bezwaren lijken in het kader van de bestuursrechtelijke transactie een kleinere rol te spelen. De bestuursrechtelijke transactie is, als (eventueel) voorportaal voor de bestuurlijke boete, met name relevant voor normschendingen met een geringe normatieve lading. Dit brengt met zich dat 'ernstige' normschendingen - ik denk daarbij met name aan onder de strafrechtelijk noemer 'misdrijven' te plaatsen overtredingen - zich niet (snel) voor zullen doen. Bovendien kan het 'doofpot'-effect verminderd worden door duidelijke transactierichtlijnen op te stellen. Voorts wordt gewezen op het feit dat middels een transactie geen generale preventie kan worden bewerkstelligd. Dit laat echter onverlet dat de andere doelstellingen van leedtoevoeging; namelijk speciale preventie en vergelding, wél gerealiseerd kunnen worden door middel van een bestuursrechtelijke transactie. Ten aanzien van de stigmatiserende werking kan volstaan worden met een verwijzing naar de bestuurlijke boete. Ook daar gaat immers geen stigmatiserende werking van uit.

\subsubsection{Slotsom}

Dit leidt tot de volgende slotsom. Invoering van de bestuursrechtelijke transactie lijkt, met name op bepaalde terreinen van het bijzonder bestuursrecht, nuttig. Er dient dan wel voor gewaakt te worden dat de vermoedelijke overtreder niet op basis van 'schijnvrijwilligheid' instemt met een transactievoorstel. In dat kader kunnen in ieder geval de suggesties van Corstens wellicht een dienst bewijzen.

Invoering van de bestuursrechtelijke transactie ten aanzien van normschendingen die door middel van een bestuurlijke boete kunnen worden afgedaan brengt een belangrijk voordeel met zich. Indien namelijk de overtredingen, die eenvoudig zijn vast te stellen en ten aanzien waarvan het bewijs geen problemen oplevert, afgedaan worden middels een transactie blijft er meer ruimte over om de lastigere zaken af te doen op basis van een van de hierboven voorgestelde - op strafrechtelijke leest geschoeide - wettelijke boeteregelingen.

\subsubsection{Variatie}

In de voorgaande paragrafen zijn enkele procedurele suggesties gedaan ter verbetering van de rechtsbescherming in het bestuursstrafrecht. Daaruit volgt dat op diverse wijze invulling kan worden gegeven aan verbetering van de rechtsbescherming. Tal van variaties zijn in dat kader denkbaar. Het initiatief tot het opleggen van een bestuurlijke boete kan bijvoorbeeld liggen bij het $\mathrm{OM}$ of bij een (ander) bestuursorgaan. In het kader van de boeteoplegging of veroordeling kan de bestuursrechter of de strafrechter een rol spelen. Het toepasselijk recht kan het straf(proces)recht, het bestuurs(proces)recht of het, in een nieuwe regeling neer te leggen, bestuursstraf(proces)recht (gemengd procesrecht) zijn. De boete kan worden opgelegd door een bestuursorgaan bij besluit of door een rechter naar aanleiding van een verzoekschrift of een dagvaarding. Aan het 
boetebesluit, het verzoekschrift of de dagvaarding kan een transactievoorstel vooraf gaan.

In het onderstaande schema is een overzicht opgenomen van de diverse combinaties die mogelijk zijn op basis van de hierboven weergegeven varianten:

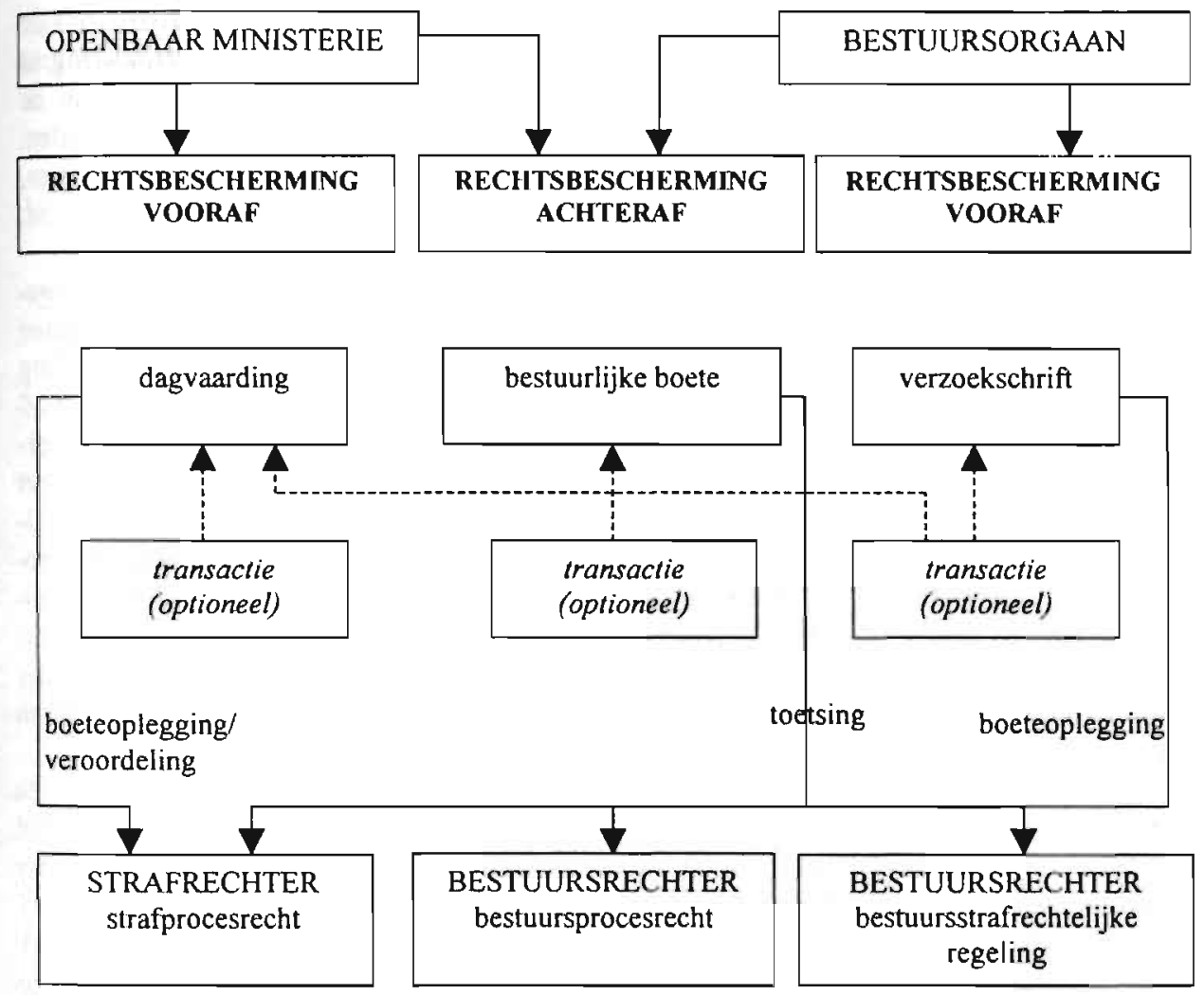

\subsection{Slot}

De vraag naar de mate van rechtsbescherming bij de oplegging van bestuurlijke boeten staat in dit boek centraal. Deze vraag is met name relevant vanwege het bijzondere, van de traditionele bestuursrechtelijke sancties (zoals bijvoorbeeld bestuursdwang) afwijkende, karakter van de bestuurlijke boete. Het punitieve - bestraffende - karakter van de boete is in dat kader van wezenlijk belang. Vanwege dit essentiële kenmerk kan de bestuurlijke boeteregeling niet eenvoudigweg geruisloos in de Awb geschoven worden zoals dat in de derde tranche het geval was met de zo genaamde herstelsancties.

Het bestraffende karakter maakt dat de bestuurlijke boete gerekend kan worden tot het bestuursstrafrecht of tot het strafrecht in ruime zin. Dit brengt met zich dat de essentiële 
straf(proces)rechtelijke waarborgen bij de oplegging van bestuurlijke boeten in acht moeten worden genomen.

In dit boek wordt betoogd dat de rechtsbescherming van de vermoedelijke overtreder op dit punt (in ieder geval deels) te wensen over laat. Verdragsrechtelijke waarborgen, zoals die zijn neergelegd in artikel 6 en 7 EVRM en 14 en 15 IVBPR worden in bepaalde gevallen schraal uitgelegd. Enerzijds lijkt dit te komen doordat de commissie Scheltema er van uitgaat dat de Awb onverkort van toepassing is in het kader van de voorgestelde boeteregeling. Anderzijds doordat effectieve en efficiënte handhaving in het gedrang zouden kunnen komen als er te veel waarborgen in het kader van de rechtsbescherming van de vermoedelijke overtreder in acht genomen moeten worden. Voor zover in het Voorontwerp, ter invulling van verdragsrechtelijke waarborgen, aansluiting is gezocht bij het nationale strafrecht is dit veelal niet onverkort gebeurd. Ook dit komt de rechtsbescherming van de vermoedelijke overtreder niet ten goede.

Daar waar de straf(proces)rechtelijke waarborgen niet in voldoende mate in de voorgestelde regeling uit de verf komen zal de regeling tot oplegging van bestuurlijke boeten aangepast moeten worden. Mijns inziens zou in dat kader een aparte wettelijke regeling voor de oplegging van punitieve bestuursrechtelijke sancties moeten worden getroffen ${ }^{143}$ In die regeling moeten bestuursstraf(proces)rechtelijke regels neergelegd worden op grond waarvan bij de oplegging van bijvoorbeeld een bestuurlijke boete het rechtsbeschermingniveau tenminste gelijk is aan de uit het EVRM voortvloeiende (minimum) waarborgen. Gelet op het feit dat punitieve (bestuursrechtelijke) sancties gerekend kunnen worden tot het strafrecht in ruime zin lijkt het zinvol in dat kader aansluiting te zoeken bij de relevante bepalingen uit het Wetboek van Strafrecht en het Wetboek van Strafvordering. ${ }^{144}$ In de bestuursstraf(proces)rechtelijke regeling zal in ieder geval op punten (bijvoorbeeld ten aanzien van artikel 8:69 Awb) expliciet afgeweken moeten worden van de Awb.

Wellicht is de, op grond van de nieuwe bestuursstraf(proces)rechtelijke regeling, te volgen procedure wat omslachtiger omdat zij met meer waarborgen omkleed is. Dit hoeft echter geen probleem te zijn als aan de oplegging van de bestuurlijke boete onder hepaalde omstandigheden een transactievoorstel vooraf kan gaan. Deze (extra) bestuurs(strat)rechtelijke sanctiemogelijkheid kan effectieve en efficiënte rechtshandhaving bevorderen. ${ }^{145} \mathrm{Bij}$ invoering van de bestuursrechtelijke transactie moet echter de

143 Een dergelijke bestuursstraf(proces)rechtelijke regeling verdient mijns inziens de voorkeur boven het onder brengen van de bestuurlijke boete in het 'derde spoor', dit mede vanwege de in $\$ 4.3 .3$ van dit hoofdstuk geschetste problemen die zich zullen voordoen in dat kader.

144 De sectoren bestuursrecht en het gerechtshof (zoals gezegd gaat mijn voorkeur uit naar een (aan te wijzen) gerechtshof als hoger beroepsinstantie), zouden in het kader van de (overeenkomstige) toepassing van bepalingen uit het Wetboek van Strafrecht en het Wetboek van Strafvordering gebruik kunnen maken van de bij de sectoren strafrecht aanwezige expertise. Gelet op het feit dat van rechters verwacht wordt dat zij 'circuleren' binnen de sectoren van de rechtbank of het hof lijkt ook de mogelijkheid te bestaan een van de strafsector afkomstige rechter in te zetten bij bestuursstrafrechtelijke zaken.

145 Het verdient de voorkeur de (nieuwe) bestuursrechtelijke handhavingmogelijkheden, indien mogelijk, gelijktijdig te regelen in de nieuw wettelijke regeling tot oplegging van punitieve bestuursrechtelijke sancties. De regeling zou niet alleen betrekking moeten hebben op de bestuurlijke boete en (eventueel) de bestuursrechtelijke transactie. Ook de intrekking van een begunstigende beschikking bij wijze van punitieve sanctie zou daarin geregeld kunnen worden. Voorts zou de wettelijke regeling ook kunnen zien op andere sancties die in wezen punitief van aard (kunnen) zijn. Zie in dit kader ook hoofdstuk 2 
nodige behoedzaamheid worden betracht. Er dient voor gewaakt te worden dat er geen 'doofpotten-cultuur' ontstaat. Daarnaast, en dit weegt mijns inziens zwaarder, moet voorkomen worden dat een vermoedelijk overtreder op basis van 'schijnvrijwilligheid' instemt met een transactievoorstel. ${ }^{146}$ Voor de (vermoedelijke) overtreder moet immers de reële mogelijkheid bestaan te kiezen voor bestraffing door een onafhankelijke en onpartijdige rechter op basis van een (in een nieuwe bestuursstraf(proces)rechtelijke regeling neer te leggen) procedure waarin tenminste rechtsbescherming geboden wordt conform de essentiële nationale strafrechtelijke én verdragsrechtelijke eisen. 



\section{Summary}

The principal theme of this dissertation is administrative fines. They entail an unconditional obligation to pay a sum of money, intended to punish the offender. Administrative fines are imposed by an administrative organ without prior court intervention. They are governed by the General Administrative Law Act (Algemene wet bestuursrecht $[$ Awb]).

This dissertation deals in particular with the question as to whether administrative law offers sufficient legal protection to (alleged) violators of administrative rules. With the introduction of the administrative fine, a traditionally criminal sanction has entered into administrative law. The author therefore also examines the question as to whether rules and principles of criminal law (ought to) apply with regard to legal protection in the case of imposition of administrative fines by administrative organs and judicial review of administrative fines. In view of the above, attention is paid to national criminal (procedural) law and conventional guarantees in the area of criminal (procedural) law. A comparison with the United States is also made.

The book comprises three parts. Part One, which consists of three chapters, deals with the imposition of administrative fines as has developed in the Netherlands. The rules governing fines proposed in the Fourth Phase Awb Draft Bill play a central role in th is Part. Part Two, which is subdivided into four chapters, discusses the US rules governing administrative 'penalties'. This external comparison is followed by Part Three, which examines the question as to whether the rules proposed in the Fourth-Phase Awb Draft Bill (potentially) offer, sufficient legal protection where punitive sanctions are imposed. Where such legal protection is defective, the author offers suggestions to the (Awb) legislator for improving the alleged offender's legal protection status.

\section{Part I}

In Chapter 2 of Part One, a general theoretical and legal-historical framework is outlined, the core of which is formed by the nature and emergence of administrative fines. In addition to this, imposition of administrative fines is compared with both criminal sanctioning and imposition of other administrative sanctions. Attention is also paid to the type of norm violation that lends itself particularly to sanctioning by way of administrative fine.

The case law of the European Court of Human Rights (ECHR) (Chapter 3), in particular case law on the concept of 'criminal charge', is relevant in examining the question as to the substantive legal area under which imposition of administrative fines can be classified. In the Netherlands, much weight is attached to ECHR case law on legal protection in the area of administrative "fining". Since, on the basis of relevant ECHR case law, it may be assumed that the imposition of administrative fines must be seen as a 'criminal charge' within the meaning of Article 6 European Convention for the Protection of Human Rights and Fundamental Freedoms (ECHR), the procedural guarantees ensuing from the article must be duly observed. Article 7 ECHR must be taken into account as well and national fining practice must also meet the requirements en- 
suing from Articles 14 and 15 of the International Covenant on Civil and Political kights (ICCPR). The author examines the way in which the ECHR gives meaning to the term 'criminal charge'. The Court's construction of a number of specific guarantees of criminal procedure is also discussed in this Chapter. The presumption of innocence, the nemo-tenetur principle (together with the right to remain silent), the nullum crimen sine lege principle, the mulla poena sine lege principle, the lex certa requirement and the principle that the offender must be given the benefit of a change in the law after the fact, if it involves the imposition of a lesser punishment, are discussed individually.

Chapter 4, the final chapter of Part One, deals with past and future development of Dutch procedure relating to the imposition of administrative fines. Legal normalisation of procedures for the imposition of administrative fines and the legal protection of the (alleged) offender are the central themes here. The fine regulation as proposed by the Scheltema Commission in the Fourth-Phase Awb Draft Bill has been taken as a point of reference, because it may be seen as a general regulation in which most, if not all, aspects of existing Dutch regulations governing administrative fines have been laid down. Upon the coming into force of the Fourth Phase, the general provisions on the imposition of administrative fines laid down in the special statutes will disappear as a rule. In the same chapter, the proposed fine regulation is discussed and examined in the light of such fundamental procedural guarantees of (criminal) procedure as ensue from, for instance, Articles 6 and 7 ECHR and Articles 14 and 15 ICCPR. First, the author discusses whether the Scheltema Commission has given sufficient consideration to conventional guarantees, in particular those analysed in Chapter 3. Special attention is paid to those conventional guarantees that seem to have been insufficiently developed by the Commission. In addition to this, the author examines the question of whether, in view of the alleged offender's legal protection, administrative law offers a good basis for the imposition of punitive administrative sanctions, in particular administrative fines.

\section{Part II}

The theme of Part II is enforcement of administrative fines in the United States. It consists of four chapters. In Chapter 5, general federal administrative law is discussed. The way in which these administrative fines are imposed is the subject of Chapter 6 , whereby the safeguards to be observed under the fine regulation are also discussed. The question as to the degree to which constitutional (criminal [procedural]) guarantees must be respected is dealt with in Chapter 7 . Chapter 8 , finally, serves to take stock. Put briefly, in the United States administrative fines are not seen as a punitive sanction. This entails that (most of) the fundamental guarantees under US criminal law do not apply to the imposition of administrative fines. The conclusion that may be drawn from this is that the procedure for imposing administrative fines fails to provide for a number of fundamental guarantees existing in criminal law, which should be taken into account when imposing punitive administrative sanctions.

\section{Part III}

In this Part, the author indicates whether, in her opinion, the legal protection provided under the regulation proposed in the Fourth-Phase Draft Bill is sufficient with regard to 
imposing administrative fines (and other punitive administrative sanctions) in the Netherlands. Where the legal protection offered shows deficiencies, the author makes suggestions to the (Awb) legislator for improving the alleged offender's legal protection in relation to imposing administrative fines and other punitive administrative sanctions.

\section{Conclusion}

The following may be inferred from Parts One, Two and Three: the enforcement deficit under the criminal law is an important motive, perhaps the most important, for lifting disposition of lesser breaches of the law out of the criminal law and placing it under the regime of the administrative law. Administrative fines were created as a result of the envisaged increase in administrative disposition of lesser breaches of the law. Administrative organs have the authority to impose punitive sanctions under special administrative statutes. In large part, this authority has been stripped of the impractical and time-consuming snags that plague criminal procedure. Efficiency and effectiveness of enforcement have been given priority, since administrative procedure does not include the (time-consuming) guarantees provided under the law of criminal procedure. There is no actual barrier in the Draft Bill against transferring the disposition of norm violations from criminal to administrative law. A criterion with sufficient distinguishing potential, making it possible to determine whether the sanctioning of norm violations can be taken out of the criminal law, is missing and therefore 'the violation's minor normative charge' criterion has been preserved. Only offences that are morally reprehensible cannot be taken out of the criminal law domain, since punishment for these offences must have a stigmatising effect. This effect will only ensue from (public) criminal proceedings.

According to the European Court of Humans Rights (ECHR), administrative fines must be considered a 'criminal charge' within the meaning of Article 6 ECHR. This entails that the minimum guarantees ensuing from the Article, and the closely related Articles 7 ECHR and 14 and 15 ICCPR, must be taken into account when imposing administrative sanctions. This is acknowledged in the Draft Bill. In this dissertation, however, the question is posed whether the essential procedural guarantees provided under the criminal law apply regardless of conventional law. In this context, the author deals with the question of characterisation of administrative sanctions on the basis of substantive criteria.

From a procedural perspective, administrative fining is govemed by administrative law. Nevertheless, it becomes immediately clear that imposing administrative fines differs fundamentally from administrative juridical acts usually performed by administrative organs; administrative fines show remarkable similarity to criminal sanctions. Essential feature of administrative sanctions is that they are aimed at punishing the lawbreaker. Other than reparatory sanctions traditionally featuring in administrative law, which are intended to restore lawfulness, inflicting suffering is a major objective of administrative sanctions of a punitive nature. The author contends that, because of its injurious nature, the administrative fine is part of administrative criminal law or of criminal law per se. This entails that, also divorced from conventional law, certain (fundamental) 
principles $^{1}$ of criminal (procedural) law must be observed in imposing administrative fines.

Departing from this premise, the author examines the fine regulation as proposed in the Draft Bill. She concludes that in the proposed fine regulation the alleged offender's legal protection leaves to be desired in a number of (important) areas. This seems to relate to the fact that in the Draft Bill the Scheltema Commission takes the conventional minimum guarantees as its point of departure, whereas, in part for reasons of efficiency and effectiveness of enforcement, it defines these guarantees too restrictively in certain circumstances. The Draft Bill does not provide for unlimited application of criminal (procedural) law and its principles as laid down in Dutch national rules and regulations and in case law. Additionally, the Scheltema Commission places the fine regulation within general administrative law. In so doing, it fails to appreciate that the law of administrative procedure, the essence of which is lawfulness of administrative action rather than the criminal liability of the offender, cannot be applied without restriction in imposing such, originally criminal, punitive sanctions as the administrative fine. If the current rules of administrative procedure were applied, insufficient attention would be paid to important principles of criminal (procedural) law. For instance, the presumption of innocence, the prohibition against double jeopardy and evidentiary doctrines would have little impact. Furthermore, the administrative judge's conception of his current role is too restricted: as a result of his passivity, his too narrow view of how to compensate for the parties' inequality of arms, and his less intensive search for the concrete truth, the administrative judge cannot serve as a punishing judge under current administrative procedure.

It is to be preferred, therefore, that the possibility of imposing administrative fines be regulated in a separate statute. Such a statute must contain those rules of administrative (procedural) law on the basis of which the degree of legal protection relating to the imposition of administrative fines is at least equal to the (minimum) guarantees ensuing from the ECHR. In such a statute, both provisions of administrative (procedural) law and of criminal (procedural) law can be made applicable. In addition to this, certain aspects need to be expressly regulated. Attention should be paid, in any case, to aspects that under the current regulation have resulted in insufficient legal protection. On the basis of this new statute, administrative judges are to be afforded the same powers as criminal judges.

If newly regulated, fining procedure will be more complex. In order not to hamper efficient and effective enforcement, it is suggested that a possibility be created to offer administrative transactions to alleged offenders, so that readily establishable violations can be thus disposed of. If the alleged offender does not accept the offer, fine proceedings provided under for the proposed statute will be instituted. With the introduction of the transaction arrangement governed by administrative law, care must be taken, however, that the alleged offender's legal protection is sufficiently guaranteed. In particular, acceptance of such a transaction offer must not be based on apparent consent. The regulation proposed by the author is to be preferred over large-scale introduction of fines imposed by the Department of Public Prosecution. jeopardy, the principle of legality. the lex certa requirement and the right to remain silent. 


\section{Appendix I}

\section{APA "formal adjudication"}

De meest relevante bepalingen ten aanzien van "adjudication" in de APA worden hieronder weergegeven:

\section{$\S 554$ Adjudication}

(a) This section applies, according to the provisions thereof in every case of adjudication required by statute to be determined on the record after opportunity for an agency hearing, except to the extent that there is involved-

(1) a matter subject to a subsequent trial of the law and facts de novo in a court;

(2) the selection or tenure of an employee, except an administrative law judge appointed under section 3105 of this title;

(3) proceedings in which decisions rest solely on inspections, tests, or elections;

(4) the conduct of military or foreign affairs functions;

(5) cases in which an agency is acting as an agent for the court; or

(6) the certification of worker representatives.

(b) Persons entitled to notice of an agency hearing shall be timely informed of-

(1) the time, place, and nature of the hearing;

(2) the legal authority and jurisdiction under which the hearing is to be held; and

(3) the matters of fact and law asserted.

When private persons are the moving parties, other parties to the proceeding shall give prompt notice of issues controverted in fact or law; and in other instances agencies may by rule require responsive pleading. In fixing the time and place for hearings, due regard shall be had for the convenience and necessity of the parties or their representatives.

(c) The agency shall give all interested parties opportunity for-

(1) the submission and consideration of facts, arguments, offers of settlement, or proposals of adjustment when time, the nature of the proceedings, and the public interest permit; and

(2) to the extent that the parties are unable so to determine a controversy by consent, hearing and decision on notice and in accordance with section 556 and 557 of this title.

(d) The employee who presides at the reception of evidence pusuant to section 556 of this title shall make the recommended decision or initial decision required by section 557 of this title, unless he becomes unavailable to the agency. Except to the extent required for the disposition of ex parte matters as authorized by law, such an employee may not-

(1) consult a person or party on a fact in issue, unless on the notice and opportunity for all parties to participate; or

(2) be responsible to or subject to the supervision or direction of an employee or agent engaged in the performance of investigative or prosecuting functions for an agency.

An employee or agent engaged in the performance of investigative or prosecuting functions for an agency in a case may not, in that or a factually related case, participate or advise in the decision, recommended decision or agency review pusuant to section 557 of this title, exept as wittness or counsel in public proceedings. This subsection does not apply-

(A) in determining applications for initial licenses;

(B) to proceedings involving the validity or application of rates, facilities, or practices of public utilities or carriers; or

(C) to the agency or a member or members of the body comprising the agency. 
(e) The agency, with like effect as in the case of other orders, as in its sound discretion, may issue a declaratory order to terminate a controversy or remove uncertainty.

\section{$\oint 555$ Ancilliary matters}

(a) This section applies, according to the provisions thereof, except as otherwise provided by this subchapter.

(b) A person compelled to appear in person before an agency or representative thereof is entitled to be accompanied, represented, and advised by counsel or, if permitted by the agency, by other qualified representative. A party is entitled to appear in person or by or with counsel or other duly qualified representative in an agency proceeding. So far as the orderly conduct of public business permits, an interested person may appear before an agency or its responsible employees for the presentation, adjustment, or determination of an issue, request, or controversy in a proceeding, whether interlocutory. summary, or otherwise, or in connection with an agency function. With due regard for the convenience and necessity of the parties or their representatives and within a reasonable time, each agency shall proceed to conclude a matter presented to it. This subsection does not grant or deny a person who is not a lawyer the right to appear for or represent others before an agency or in an agency proceeding.

(c) Process, requirement of a report, inspection or other investigative act or demand may not be issued, made, or enforced except as authorized by law. A person compelled to submit data or evidence is entitled to retain or, on payment of lawfully prescribed costs, procure a copy or transcript thereof, except that in a nonpublic investigatory proceeding the witness may for good cause be limited to inspection of the official transcript of his testimony.

(d) Agency subpenas authorized by law shall be issued to a party on request and, when required by rules of procedure, on a statement or showing of general relevance and reasonable scope of the evidence sought. On contest, the court shall sustain the subpena or similar process or demand to the extent that it is found to be in accordance with law. In a proceeding for enforcement, the court shall issue an order requiring the appearance of the witness or the production of the evidence or data within a reasonable time under penalty of punishment for contempt in case of contumacious failure to comply.

(e) Prompt notice shall be given of the denial in whole or in part of a written application, petition, or other request of an interested person made in connection with any agency proceeding. Except in affirming a prior denial or when the denial is self-explanatory, the notice shall be accompanied by a brief statement of the grounds for denial.

$\S 556$ Hearings; presiding employees; powers and duties; burden of proof; evidence; record as basis of decision.

(a) This section applies, according to the provisions thereof, to hearings required by section 553 or 554 of this title to be conducted in accordance with this section.

(b) There shall preside at the taking of evidence-

(1) the agency;

(2) one or more members of the body which comprises the agency; or

(3) one or more administrative law judges appointed under section 3105 of this title.

This subchapter does not supersede the conduct of specified classes of proceedings, in whole or in part, by or before boards or other employees specially provided for by or desingnated under statute. The functions of presiding employees and of employees participating in decisions in accordance with section 557 of this title shall be conducted in an impartial manner. A presiding or participating employee may at any time disqualify himself. On the filing in good faith of a timely and sufficient affidative of personal bias or other disqualification of a presiding or partici- 
pating employee, the agency shall determine the matter as a part of the record and decision in the case.

(c) Subject to published rules of the agency and within its powers, employees presiding at hearing may-

(1) administer oaths and affirmations;

(2) issue subpenas authorized by law;

(3) rule on offers of proof and receive relevant evidence;

(4) take depositions or have depositions taken when the ends of justice would be served;

(5) regulate the course of the hearing;

(6) hold conferences for the settlement or simplification of the issues by consent of the parties or by the use of alternative means of dispute resolution as provided in subchapter IV of this chapter [5 U.S.C. $\$ \$ 581$ et seq.];

(7) inform the parties as to the availability of one or more alternative means of dispute resolution, and encourage use of such methods;

(8) require the attendance at any conference held pursuant to paragraph (6) of at least one representative of each party who has the authority to negotiate conceming resolution of issues in controversy;

(9) dispose of procedural requests or similar matters;

(10) make or recommend decisions in accordance with section 557 of this title; and

(11) take other action authorized by agency rule consistent with this subchapter.

(d) Except as otherwise provided by statute, the proponent of a rule or order has the burden of proof. Any oral or documentary evidence may be received, but the agency as a matter of policy shall provide for the exclusion of irrelevant, immaterial, or unduly repetitious evidence. A sanction may not be imposed or rule or order issued except on consideration of the whole record or those parts thereof cited by a party and supported by and in accordance with the reliable, probative, and substantial evidence. The agency may, to the extent consistent with the interests of justice and the policy of the underlying statutes administered by the agency, consider a violation of section 557(d) of this title sufficient grounds for a decision adverse to a party who has knowingly commited such violation or knowingly caused such violation to occur. A documentary evidence, to submit rebuttal evidence, and to conduct such cross-examination as may be required for a full and treu disclosure of the facts. In rule making or determining claims for money or benefits or applications for initial licenses an agency may, when a party will not be prejudiced thereby, adopt procedures for the submission of all or part of the evidence in written form.

(e) The transcript of testimony and exhibits, together with all papers and requests filed in the proceeding, constitutes the exclusive record for decision in accordance with section 557 of this title and, on payment of lawfully prescribed costs, shall be made available to the parties. When an agency decision rests on official notice of a material fact not appearing in the evidence in the record, a party is entitled, on timely request, to an opportunity to show the contrary.

\section{$\S 577$ Initial decisions; conclusiveness; review by agency; submission by parties; contents of decisions; record}

(a) This section applies, according to the provisions thereof, when a hearing is required to be conducted in accordance with section 556 of this title.

(b) When the agency did not preside at the reception of the evidence, the presiding employee or, in cases not subject to section 554(d) of this title, an employee qualified to preside at hearings pursuant to section 556 of this title, shall initially decide the case unless the agency requires, either in specific cases or by general rule, the entire record to be certified to it for de- 
cision. When the presiding employee makes an initial decision, that decision, that decision then becomes the decision of the agency without further proceedings unless there is an appeal to, or review on motion of, the agency within time provided by rule. On appeal from or review of the initial decision, the agency has all the powers which it would have in making the initial decision except as it may limit the issues on notice or by rule. When the agency makes the decision without having presided at the reception of the evidence, the presiding employee or an employee qualified to preside at haering pursuant to section 556 of this title shall first recommend a decision, except that in rule making or determining application for initial licenses-

(1) instead thereof the agency may issue a tentative decision or one of its responsible employees may recommend a decision; or

(2) this procedure may be ommited in a case in which the agency finds on the record that due and timely execution of its functions imperatively and unavoidable so requires.

(c) Before a recommended, initial, or tentative decision, or a decision on agency review of the decision, or a decision on agency review of the decision of subordinate employees, the parties are entitled to a reasonable opportunity to submit for the consideration of the employees participating in the decisions-

(I) proposed findings and conclusions; or

(2) exceptions to the decisions or recommended decisions of subordinate employes or to tentative agency decisions; and

(3) supporting reasons for the exeptions or propsed findings or conclusions.

The record shall show the ruling on each finding, conclusion, or exception presented. All decisions, including initial, recommended, and tentative decisions, are a part of the record and sha: include a statement of-

(A) findings and conclusions, and the reasons or basis therefor, on all the material issues of fact, law, or discretion presented on the record; and

(B) the appropriate rule, order, sanction, relief, or denial thereof.

(d) (1) In any agency proceeding which is subject to subsection (a) of this section, except to the extent required for the disposition of ex parte matters as autorized by law-

(A) no interested person outside the agency shall make or knowingly cause to be made to any member of the body comprising the agency, administrative law judge, or other employee who is or may reasonble be expected to be involved in the decisional process of the proceeding, and ex parte communication relevant to the merits of the proceeding;

(B) no member of the body comprising the agency, administrative law judge, or other employee who is or may reasonably be expected to be involved in the decisional process of the proceeding, shall make or knowingly cause to be made to any interested person outside the agency an ex parte communication relevant to the merits of the proceeding;

(C) a member of the body comprising the agency, administrative law judge, or other employee who is or may reasonably be expected to be involved in the decisional process of such proceedings who receives, or who makes or knowingly causes to be made, a communication prohibited by this subsection shall place on the public record of the proceeding:

(i) all such written communications:

(ii) memoranda stating the substance of all such oral communications; and

(iii) all written responses, and memoranda stating the substance of all oral responses, to the materials described in clauses (i) and (ii) of this subparagraph;

(D) upon receipt of a communication knowingly made or knowingly caused to be made by a party in violation of this subsection, the agency, administrative law judge, or 
other employee presiding at the hearing may, to the extent consistent with the interests of justice and the policy of the underlying statutes, require the party to show cause why his claim or interest in the proceeding should not be dismissed, denied, disregarded, or otherwise adversely affected on account of such violation; and

(E) the prohibitions of this subsection shall apply beginning at such time as the agency as the agency may designate, but in no case shall they begin to apply later than the time at which a proceeding is noticed for hearing unless the person responsible for the communication has knowledge that it will be noticed, in which case the prohibitions shall apply beginning at the time of his acquisition of such knowledge.

(2) This subsection does not constitute authority to withhold infromation from Congress.

\section{$\$ 558$ Imposition of sanctions; determination of applications for licenses; suspen-} sion, revocation, and expiration of licences

(a) This section applies, according to the provisions thereof, to the exercise of a power or authority.

(b) A sanction may not be imposed or a substantive rule or order issued except within jurisdiction delegated to the agency and as authorized by law.

(c) When application is made for a license required by law, the agency, with due regard for the rights and privileges off all the interested parties or adversely affected persons and within a reasonable time, shall set and complete proceedings required to be conducted in accordance with sections 556 and 557 of this title or other proceedings required by law and shall make its decision. Except in cases of willfulness or those in which public health, interest, or safety requires otherwise, the withdrawal, suspension, revocation, or annulment, of a license is lawful only if, before the institution of agency proceedings therefor, the license has been given-

(1) notice by the agency in writing of the facts or conduct which may warrant the action; and

(2) opportunity to demonstrate or achieve compliance with all lawfull requirements.

When the licensee has made timely and sufficient application for a renewal or a new license in accordance with continuing nature does not expire until the application has been finally determined by the agency. 



\section{Appendix II}

\section{APA "judicial review"}

\section{$\$ 701$ Application; Definitions}

(a) This chapter applies, according to the provisions thereof, except to the extent that-

(1) statutes preclude judicial review; or

(2) agency action is committed to agency discretion by law.

(b) For the purpose of this chapter-

(1) "agency" means each authority of the Government of the United States, whether or not it is within or subject to review by another agency, but does not include-

(A) the Congress;

(B) the courts of the United States;

(C) the government of the territories or possessions of the United States;

(D) the gevernment of the District of Columbia;

(E) agencies composed of representatives of the parties or of representatives of organizations of the parties to the disputes determined by them;

(F) court martial and military commissions;

(G) military authority exercised in the field in time of war or in occupied territory, or;

(H) functions conferred by sections 1738, 1739, 1743, and 1744 of title 12; chapter 2 of title 41 ; or sections $1622,1884,1891-1902$, and former section 1641 (b)(2), of title 50 , appendix; and

(2) "person", "rule", "order", "license", "sanction", "relief", and "agency action" have the meanings given them by section 551 of this title.

\section{$\$ 702$ Right of review}

A person suffering legal wrong because of agency action, or adversely affected or aggrieved by agency action within the meaning of a relevant statute, is entitled to judicial review thereof. An action in a court of the United States seeking relief other than money damages and stating a claim that an agency or an officer or employee thereof acted or failed to act in an official capacity or under color of legal authority shall not be dismissed nor relief therein be denied on the ground that it is against the United States or that the United States is an indispensable party. The United States may be named as a defendant in such an action, and a judgement or decree may be entered against the United States: Provided, That any mandatory or injuncitve decree shall specify the federal officers or officers (by name or by title), and their succersors in office, personally responsible for compliance. Nothing herein (1) affects other limitations on judicial review or the power or duty of the court to dismiss any action or deny relief on any other appropriate legal or equitable ground; or (2) confers authority to grant relief if any other statute that grants consent to suit expressly or impliedly forbids the relief which is sought.

\section{$\$ 703$ Form and venue of proceeding}

The form of proceeding for judicial review is the special statutory review proceeding relevant to the subject matter in a court specified by the starute or, in the absence or inadequacy thereof, any applicable form of legal action, including actions for declaratory judgements or writs of court of competent jurisdiction. If no special statutory review proceedings is applicable, the action for judicial review may be brought against the United States, the agency by its official 
title, or the appropriate officer. Except to the extent that prior, adequate, and exclusive opportunity for judicial review is provided by law, agency action is subject to judicial review in civil or criminal proceedings for judicial enforcement.

\section{$\$ 704$ Actions reviewable}

Agency action made reviewable by statute and final agency action for which there is no other adequate remedy in a court are subject to judicial review. A preliminary, procedural, or intermediate agency action or ruling not directly reviewable is subject to review on the review of the final agency action. Except as otherwise expressly required by statute, agency action otherwise final is final for the purposes of this section whether or not there has been presented or determined an application for a declaratory order, for any form of reconsideration, or, unless the agency otherwise requires by rule and provides that the action meanwhile is inoperative, for an appeal to superior agency authority.

\section{$\$ 705$ Relief pending review}

When an agency finds that justice so requires, it may postpone the effective date of action taken by it, pending judicial review. On such conditions as may be required and to the extend necessary to prevent irreparable injury, the reviewing court, including the court to which a case may be taken on appeal from or on application for certiorary or other writ to a reviewing court, may isseu all necessary and appropriate process to postpone the effective date of an agency action or to preserve status or rights pending conclusion of the review proceedings.

\section{$\$ 706$ Scope of review}

To the extent necessary to decision and when presented, the reviewing court shall decide all relevant questions of law, interpret constitutional and statutory provisions, and determine the meaning or applicability of the terms of an agency action. The reviewing court shall-

(1) compel agency action unlawfully witheld or unreasonably delayed; and

(2) hold unlawful and set aside action, findings, and conclusions found to be-

(A) arbitrary, capricious, an abuse of discretion, or otherwise not in accordance with law;

(B) contrary to constitutional right, power, privilege, or immunity;

(C) in excess of statutory jurisdiction, authority, or limitations, or short of statutory right;

(D) without observance of procedure required by law;

(E) unsupported by substantial evidence in a case subject to sections 556 and 557 of this title or otherwise reviewed on the record of an agency hearing provided by statute; or

(F) unwarranted by the facts to the extent that the facts are subject to trial de novo by the reviewing court.

In making the foregoing determinations, the court shall review the whole record or those parts of it cited by a party, and due account shall be taken of the rule of prejudicial error. 


\section{Appendix III}

\section{CFR 22 - Consolidated Rules of Practice -}

\section{Title 40 protection of environment}

\section{Chapter I Environmental Protection Agency}

Part 22 Consolidated Rules of Practice Governing the Administrative Assessment of Civil Penalties and the Revocation/Termination or Suspension of Permits -- table of contents --

\section{Subpart A -- General}

Sec. 22.1 Scope of this part.

(a) These Consolidated Rules of Practice govern all administrative adjudicatory proceedings for:

(1) The assessment of any administrative civil penalty under section 14(a) of the federal Insecticide, Fungicide, and Rodenticide Act as amended (7 U.S.C. 1361(a));

(2) The assessment of any administrative civil penalty under sections 113(d), 205(c), 211(d) and 213(d) of the Clean Air Act, as amended (42 U.S.C. 7413(d), 7524(c), 7545(d) and 7547(d));

(3) The assessment of any administrative civil penalty or for the revocation or suspension of any permit under section 105(a) and (f) of the Marine Protection, Research, and Sanctuaries Act as amended (33 U.S.C. 1415(a) and (f));

(4) The issuance of a compliance order or the issuance of a corrective action order, the termination of a permit pursuant to section 3008(a)(3), the suspension or revocation of authority to operate pursuant to section 3005(e), or the assessment of any civil penalty under sections 3008, 9006, and 11005 of the Solid Waste Disposal Act, as amended (42 U.S.C. 6925(d), 6925(e), 6928, 6991e, and 6992d)), except as provided in part 24 of this chapter;

(5) The assessment of any administrative civil penalty under sections 16(a) and 207 of the Toxic Substances Control Act (15 U.S.C. 2615(a) and 2647);

(6) The assessment of any Class II penalty under sections $309(\mathrm{~g})$ and $311(\mathrm{~b})(6)$, or termination of any permit issued pursuant to section 402(a) of the Clean Water Act, as amended (33 U.S.C. 1319(g), 1321(b)(6), and 1342(a));

(7) The assessment of any administrative civil penalty under section 109 of the Comprehensive Environmental Response, Compensation, and Liability Act of 1980, as amended (42 U.S.C. 9609);

(8) The assessment of any administrative civil penalty under section 325 of the Emergency Planning and Community Right-To-Know Act of 1986 ("EPCRA") (42 U.S.C. 11045);

(9) The assessment of any administrative civil penalty under sections $1414(\mathrm{~g})(3)(B)$, 1423(c), and 1447(b) of the Safe Drinking Water Act as amended (42 U.S.C. $300 \mathrm{~g}$ $3(\mathrm{~g})(3)(B), 300 \mathrm{~h}-2(\mathrm{c})$, and $300 \mathrm{j}-6(\mathrm{~b}))$, or the issuance of any order requiring both compliance and the assessment of an administrative civil penalty under section 1423(c);

(10) The assessment of any administrative civil penalty or the issuance of any order requiring compliance under Section 5 of the Mercury-Containing and Rechargeable Battery Management Act (42 U.S.C. 14304). 
(b) The supplemental rules set forth in subparts $\mathrm{H}$ and $\mathrm{I}$ of this part establish special procedures for proceedings identified in paragraph (a) of this section where the Act allows or requires procedures different from the procedures in subparts $A$ through $G$ of this part. Where inconsistencies exist between subparts A through $G$ of this part and subpart $H$ or I of this part, subparts $\mathrm{H}$ or I of this part shall apply.

(c) Questions arising at any stage of the proceeding which are not addressed in these Consolidated Rules of Practice shall be resolved at the discretion of the Administrator, Environmental Appeals Board, Regional Administrator, or Presiding Officer, as provided for in these Consolidated Rules of Practice.

Sec. 22.2 Use of number and gender.

As used in these Consolidated Rules of Practice, words in the singular also include the plural and words in the masculine gender also include the feminine, and vice versa, as the case may require.

Sec. 22.3 Definitions.

(a) The following definitions apply to these Consolidated Rules of Practice: Act means the particular statute authorizing the proceeding at issue.

Administrative Law Judge means an Administrative Law Judge appointed under 5 U.S.C. 3105.

Administrator means the Administrator of the U.S. Environmental Protection Agency or his delegate.

Agency means the United States Environmental Protection Agency.

Business confidentiality claim means a confidentiality claim as detined in 40 CFR $2.201(\mathrm{~h})$.

Clerk of the Board means the Clerk of the Environmental Appeals Board, Mail Code 1103B, U.S. Environmental Protection Agency, 1200 Pennsylvania Ave., NW., Washington, DC 20460.

Commenter means any person (other than a party) or representative of such person who timely:

(1) Submits in writing to the Regional Hearing Clerk that he is providing or intends to provide comments on the proposed assessment of a penalty pursuant to sections $309(\mathrm{~g})(4)$ and $311(\mathrm{~b})(6)(\mathrm{C})$ of the Clean Water Act or section 1423(c) of the Safe Drinking Water Act, whichever applies, and intends to participate in the proceeding; and

(2) Provides the Regional Hearing Clerk with a return address.

Complainant means any person authorized to issue a complaint in accordance with Secs. 22.13 and 22.14 on behalf of the Agency to persons alleged to be in violation of the Act. The complainant shall not be a member of the Environmental Appeals Board, the Regional Judicial Officer or any other person who will participate or advise in the adjudication.

Consolidated Rules of Practice means the regulations in this part.

Environmental Appeals Board means the Board within the Agency described in $40 \mathrm{CFR}$ 1.25 .

Final order means:

(1) An order issued by the Environmental Appeals Board or the Administrator after an appeal of an initial decision, accelerated decision, decision to dismiss, or default order, disposing of the matter in controversy between the parties;

(2) An initial decision which becomes a final order under Sec. 22.27(c); or

(3) A final order issued in accordance with Sec. 22.18. 
Hearing means an evidentiary hearing on the record, open to the public (to the extent consistent with Sec. $22.22(\mathrm{a})(2)$ ), conducted as part of a proceeding under these Consolidated Rules of Practice.

Hearing Clerk means the Hearing Clerk, Mail Code 1900, U.S.

Environmental Protection Agency, 1200 Pennsylvania Ave., NW., Washington, DC 20460. Initial decision means the decision issued by the Presiding Officer pursuant to Secs. 22.17(c), $22.20(\mathrm{~b})$ or 22.27 resolving all outstanding issues in the proceeding.

Party means any person that participates in a proceeding as complainant, respondent, or intervenor.

Permit action means the revocation, suspension or termination of all or part of a permit issued under section 102 of the Marine Protection, Research, and Sanctuaries Act (33 U.S.C. 1412) or termination under section 402(a) of the Clean Water Act (33 U.S.C. 1342(a)) or section 3005 (d) of the Solid Waste Disposal Act (42 U.S.C. $6925($ d)).

Person includes any individual, partnership, association, corporation, and any trustee, assignee, receiver or legal successor thereof; any organized group of persons whether incorporated or not; and any officer, employee, agent, department, agency or instrumentality of the Federal Government, of any State or local unit of government, or of any foreign government. Presiding Officer means an individual who presides in an administrative adjudication until an initial decision becomes final or is appealed. The Presiding Officer shall be an Administrative Law Judge, except where Secs. $22.4(\mathrm{~b}), 22.16$ (c) or 22.51 allow a Regional Judicial Officer to serve as Presiding Officer.

Proceeding means the entirety of a single administrative adjudication, from the fiting of the complaint through the issuance of a final order, including any action on a motion to reconsider under Sec. 22.32.

Regional Administrator means, for a case initiated in an EPA Regional Office, the Regional Administrator for that Region or any officer or employee thereof to whom his authority is duly delegated.

Regional Hearing Clerk means an individual duly authorized to serve as hearing clerk for a given region, who shall be neutral in every proceeding. Correspondence with the Regional Hearing Clerk shall be addressed to the Regional Hearing Clerk at the address specified in the complaint. For a case initiated at EPA Headquarters, the term Regional

Hearing Clerk means the Hearing Clerk.

Regional Judicial Officer means a person designated by the Regional Administrator under Sec. 22.4(b).

Respondent means any person against whom the complaint states a claim for relief.

(b) Terms defined in the Act and not defined in these Consolidated Rules of Practice are used consistent with the meanings given in the Act.

Sec. 22.4
Powers and duties of the Environmental Appeals Board, Regional Judicial Officer and Presiding Officer; disqualification, withdrawal, and reassignment.

(a) Environmental Appeals Board.

(1) The Environmental Appeals Board rules on appeals from the initial decisions, rulings: and orders of a Presiding Officer in proceedings under these Consolidated Rules of Practice; acts as Presiding Officer until the respondent files an answer in proceedings under these Consolidated Rules of Practice commenced at EPA Headquarters; and approves settlement of proceedings under these Consolidated Rules of Practice commenced at EPA Headquarters. The Environmental Appeals Board may refer any case or motion to the Administrator when the Environmental Appeals Board, in its discretion, 
deems it appropriate to do so. When an appeal or motion is referred to the Administrator by the Environmental Appeals Board, all parties shall be so notified and references to the Environmental Appeals Board in these Consolidated Rules of Practice shall be interpreted as referring to the Administrator. If a case or motion is referred to the Administrator by the Environmental Appeals Board, the Administrator may consult with any EPA employee concerning the matter, provided such consultation does not violate Sec. 22.8. Motions directed to the Administrator shall not be considered except for motions for disqualification pursuant to paragraph (d) of this section, or motions filed in matters that the Environmental Appeals Board has referred to the Administrator.

(2) In exercising its duties and responsibilities under these Consolidated Rules of Practice. the Environmental Appeals Board may do all acts and take all measures as are necessary for the efficient, fair and impartial adjudication of issues arising in a proceeding, including imposing procedural sanctions against a party who without adequate justification fails or refuses to comply with these Consolidated Rules of Practice or with an order of the Environmental Appeals Board. Such sanctions may include drawing adverse inferences against a party, striking a party's pleadings or other submissions from the record, and denying any or all relief sought by the party in the proceeding.

(b) Regional Judicial Officer. Each Regional Administrator shall delegate to one or more Regional Judicial Officers authority to act as Presiding Officer in proceedings under subpart I of this part, and to act as Presiding Officer until the respondent files an answer in proceedings under these Consolidated Rules of Practice to which subpart I of this part does not apply. The Regional Administrator may also delegate to one or more Regional Judicial Officers the authority to approve settlement of proceedings pursuant to Sec. 22.18(b)(3). These delegations will not prevent a Regional Judicial Officer from referring any motion or case to the Regional Administrator. A Regional Judicial Officer shall be an attomey who is a permanent or temporary employee of the Agency or another Federal agency and who may perform other duties within the Agency. A Regional Judicial Officer shall not have performed prosecutorial or investigative functions in connection with any case in which he serves as a Regional Judicial Officer. A Regional Judicial Officer shall not knowingly preside over a case involving any party concerning whom the Regional Judicial Officer performed any functions of prosecution or investigation within the 2 years preceding the commencement of the case. A Regional Judicial Officer shall not prosecute enforcement cases and shall not be supervised by any person who supervises the prosecution of enforcement cases, but may be supervised by the Regional Counsel.

(c) Presiding Officer. The Presiding Officer shall conduct a fair and impartial proceeding, assure that the facts are fully elicited, adjudicate all issues, and avoid delay. The Presiding Officer may:

(1) Conduct administrative hearings under these Consolidated Rules of Practice;

(2) Rule upon motions, requests, and offers of proof, and issue all necessary orders;

(3) Administer oaths and aftirmations and take affidavits;

(4) Examine witnesses and receive documentary or other evidence;

(5) Order a party, or an officer or agent thereof, to produce testimony, documents, or other non-privileged evidence, and failing the production thereof without good cause being shown, draw adverse inferences against that party;

(6) Admit or exclude evidence;

(7) Hear and decide questions of facts, law, or discretion;

(8) Require parties to attend conferences for the settlement or simplification of the issues, or the expedition of the proceedings;

(9) Issue subpoenas authorized by the Act; and 
(10) Do all other acts and take all measures necessary for the maintenance of order and for the efficient, fair and impartial adjudication of issues arising in proceedings govemed by these Consolidated Rules of Practice.

(d) Disqualification, withdrawal and reassignment.

(1) The Administrator, the Regional Administrator, the members of the Environmental Appeals Board, the Regional Judicial Officer, or the Administrative Law Judge may not perform functions provided for in these Consolidated Rules of Practice regarding any matter in which they have a financial interest or have any relationship with a party or with the subject matter which would make it inappropriate for them to act. Any party may at any time by motion to the Administrator, Regional Administrator, a member of the Environmental Appeals Board, the Regional Judicial Officer or the Administrative Law Judge request that he or she disqualify himself or herself from the proceeding. If such a motion to disqualify the Regional Administrator, Regional Judicial Officer or Administrative Law Judge is denied, a party may appeal that ruling to the Environmental Appeals Board. If a motion to disqualify a member of the Environmental Appeals Board is denied, a party may appeal that ruling to the Administrator. There shall be no interlocutory appeal of the ruling on a motion for disqualification. The Administrator, the Regional Administrator, a member of the Environmental Appeals Board, the Regional Judicial Officer, or the Administrative Law Judge may at any time withdraw from any proceeding in which he deems himself disqualified or unable to act for any reason.

(2) If the Administrator, the Regional Administrator, the Regional Judicial Officer, or the Administrative Law Judge is disqualified or withdraws from the proceeding, a qualified individual who has none of the infirmities listed in paragraph (d)(1) of this section shall be assigned as a replacement. The Administrator shall assign a replacement for a Regional Administrator who withdraws or is disqualified. Should the Administrator withdraw or be disqualified, the Regional Administrator from the Region where the case originated shall replace the Administrator. If that Regional Administrator would be disqualified, the Administrator shall assign a Regional Administrator from another Region to replace the Administrator. The Regional Administrator shall assign a new Regional Judicial Officer if the original Regional Judicial Officer withdraws or is disqualified. The Chief Administrative Law Judge shall assign a new Administrative Law Judge if the original Administrative Law Judge withdraws or is disqualified.

(3) The Chief Administrative Law Judge, at any stage in the proceeding, may reassign the case to an Administrative Law Judge other than the one originally assigned in the event of the unavailability of the Administrative Law Judge or where reassignment will result in efficiency in the scheduling of hearings and would not prejudice the parties.

Sec. 22.5

Filing, service, and form of all filed documents; business confidentiality claims.

(a) Filing of documents.

(1) The original and one copy of each document intended to be part of the record shall be filed with the Regional Hearing Clerk when the proceeding is before the Presiding Officer, or filed with the Clerk of the Board when the proceeding is before the Environmental Appeals Board. A document is filed when it is received by the appropriate Clerk. The Presiding Officer or the Environmental Appeals Board may by order authorize facsimile or electronic filing, subject to any appropriate conditions and limitations. 
(2) When the Presiding Officer corresponds directly with the parties, the original of the correspondence shall be filed with the Regional Hearing Clerk. Parties who correspond directly with the Presiding Officer shall file a copy of the correspondence with the Regional Hearing Clerk.

(3) A certificate of service shall accompany each document filed or served in the proceeding.

(b) Service of documents. A copy of each document filed in the proceeding shall be served on the Presiding Officer or the Environmental Appeals Board, and on each party.

(1) Service of complaint.

(i) Complainant shall serve on respondent, or a representative authorized to receive service on respondent's behalf, a copy of the signed original of the complaint, together with a copy of these Consolidated Rules of Practice. Service shall be made personally, by certified mail with return receipt requested, or by any reliable commercial delivery service that provides written verification of delivery.

(ii) (A) Where respondent is a domestic or foreign corporation, a partnership, or an unincorporated association which is subject to suit under a common name, complainant shall serve an officer, partner, a managing or general agent, or any other person authorized by appointment or by Federal or State law to receive service of process.

(B) Where respondent is an agency of the United States complainant shall serve that agency as provided by that agency's regulations, or in the absence of controlling regulation, as otherwise permitted by law. Complainant should also provide a copy of the complaint to the senior executive official having responsibility for the overall operations of the geographical unit where the alleged violations arose. If the agency is a corporation, the complaint shall be served as prescribed in paragraph (b)(I)(ii)(A) of this section.

(C) Where respondent is a State or local unit of govemment, agency, department, corporation or other instrumentality, complainant shall serve the chief executive officer thereof, or as otherwise permitted by law. Where respondent is a State or local officer, complainant shall serve such officer.

(iii) Proof of service of the complaint shall be made by affidavit of the person making personal service, or by properly executed receipt. Such proof of service shall be filed with the Regional Hearing Clerk immediately upon completion of service.

(2) Service of filed documents other than the complaint, rulings, orders, and decisions. All filed documents other than the complaint, rulings, orders, and decisions shall be served personally, by first class mail (including certified mail, return receipt requested, Overnight Express and Priority Mail), or by any reliable commercial delivery service. The Presiding Officer or the Environmental Appeals Board may by order authorize facsimile or electronic service, subject to any appropriate conditions and limitations.

(c) Form of documents.

(1) Except as provided in this section, or by order of the Presiding Officer or of the Environmental Appeals Board there are no specific requirements as to the form of documents.

(2) The first page of every filed document shall contain a caption identifying the respondent and the docket number. All legal briefs and legal memoranda greater than 20 pages in length (excluding attachments) shall contain a table of contents and a table of authorities with page references.

(3) The original of any filed document (other than exhibits) shall be signed by the party filing or by its attorney or other representative. The signature constitutes a representation by the signer that he has read the document, that to the best of his knowledge, in- 
formation and belief, the statements made therein are true, and that it is not interposed for delay.

(4) The first document filed by any person shall contain the name, address, and telephone number of an individual authorized to receive service relating to the proceeding. Parties shall promptly file any changes in this information with the Regional Hearing Clerk, and serve copies on the Presiding Officer and all parties to the proceeding. If a party fails to fumish such information and any changes thereto, service to the party's last known address shall satisfy the requirements of paragraph (b)(2) of this section and Sec. 22.6.

(5) The Environmental Appeals Board or the Presiding Officer may exclude from the record any document which does not comply with this section. Written notice of such exclusion, stating the reasons therefor, shall be promptly given to the person submitting the document. Such person may amend and resubmit any excluded document upon motion granted by the Environmental Appeals Board or the Presiding Officer, as appropriate.

(d) Confidentiality of business information.

(1) A person who wishes to assert a business confidentiality claim with regard to any information contained in any document to be filed in a proceeding under these Consolidated Rules of Practice shall assert such a claim in accordance with 40 CFR part 2 at the time that the document is filed. A document filed without a claim of business confidentiality shall be available to the public for inspection and copying.

(2) Two versions of any document which contains information claimed confidential shall be filed with the Regional Hearing Clerk:

(i) One version of the document shall contain the information claimed confidential. The cover page shall include the information required under paragraph (c)(2) of this section and the words "Business Confidentiality Asserted". The specific portion(s) alleged to be confidential shall be clearly identified within the document.

(ii) A second version of the document shall contain all information except the specific information claimed confidential, which shall be redacted and replaced with notes indicating the nature of the information redacted. The cover page shall state that information claimed confidential has been deleted and that a complete copy of the document containing the information claimed confidential has been filed with the Regional Hearing Clerk.

(3) Both versions of the document shall be served on the Presiding Officer and the complainant. Both versions of the document shall be served on any party, non-party participant, or representative thereof, authorized to receive the information claimed confidential by the person making the claim of confidentiality. Only the redacted version shall be served on persons not authorized to receive the confidential information.

(4) Only the second, redacted version shall be treated as public information. An EPA officer or employee may disclose information claimed confidential in accordance with paragraph (d)(1) of this section only as authorized under 40 CFR part 2.

Sec. 22.6 Filing and service of rulings, orders and decisions.

All rulings, orders, decisions, and other documents issued by the Regional Administrator or Presiding Officer shall be filed with the Regional Hearing Clerk. All such documents issued by the Environmental Appeals Board shall be filed with the Clerk of the Board. Copies of such rulings, orders, decisions or other documents shall be served personally, by first class mail (including by certified mail or retum receipt requested, Overnight Express and Priority Mail), by EPA's internal mail, or any reliable commercial delivery service, upon all parties by the Clerk of 
the Environmental Appeals Board, the Office of Administrative Law Judges or the Regional Hearing Clerk, as appropriate.

\section{Sec. $22.7 \quad$ Computation and extension of time.}

(a) Computation. In computing any period of time prescribed or allowed in these Consolidated Rules of Practice, except as otherwise provided, the day of the event from which the designated period begins to run shall not be included. Saturdays, Sundays, and Federal holidays shall be included. When a stated time expires on a Saturday, Sunday or Federal holiday, the stated time period shall be extended to include the next business day.

(b) Extensions of time. The Environmental Appeals Board or the Presiding Officer may grant an extension of time for filing any document: upon timely motion of a party to the proceeding, for good cause shown, and after consideration of prejudice to other parties; or upon its own initiative. Any motion for an extension of time shall be filed sufficiently in advance of the due date so as to allow other parties reasonable opportunity to respond and to allow the Presiding Officer or Environmental Appeals Board reasonable opportunity to issue an order.

(c) Service by mail or commercial delivery service. Service of the complaint is complete when the retum receipt is signed. Service of all other documents is complete upon mailing or when placed in the custody of a reliable commercial delivery service. Where a document is served by first class mail or commercial delivery service, but not by overnight or same-day delivery, 5 days shall be added to the time allowed by these Consolidated Rules of Practice for the filing of a responsive document.

\section{Sec. $22.8 \quad$ Ex parte discussion of proceeding.}

At no time after the issuance of the complaint shall the Administrator, the members of the Environmental Appeals Board, the Regional Administrator, the Presiding Officer or any other person who is likely to advise these officials on any decision in the proceeding, discuss ex parte the merits of the proceeding with any interested person outside the Agency, with any Agency staff member who performs a prosecutorial or investigative function in such proceeding or a factually related proceeding, or with any representative of such person. Any ex parte memorandum or other communication addressed to the Administrator, the Regional Administrator, the Environmental Appeals Board, or the Presiding Officer during the pendency of the proceeding and relating to the merits thereof, by or on behalf of any party shall be regarded as argument made in the proceeding and shall be served upon all other parties. The other parties shall be given an opportunity to reply to such memorandum or communication. The requirements of this section shall not apply to any person who has formally recused himself from all adjudicatory functions in a proceeding, or who issues final orders only pursuant to Sec. $22.18(b)(3)$.

Sec. 22.9

Examination of documents filed.

(a) Subject to the provisions of law restricting the public disclosure of confidential information, any person may, during Agency business hours inspect and copy any document filed in any proceeding. Such documents shall be made available by the Regional Hearing Clerk, the Hearing Clerk, or the Clerk of the Board, as appropriate.

(b) The cost of duplicating documents shall be borne by the person seeking copies of such documents. The Agency may waive this cost in its discretion. 


\title{
Subpart B -- Parties and Appearances
}

\author{
Sec. 22.10 Appearances.
}

Any party may appear in person or by counsel or other representative. A partner may appear on behalf of a partnership and an officer may appear on behalf of a corporation. Persons who appear as counsel or other representative must conform to the standards of conduct and ethics required of practitioners before the courts of the United States.

\section{Sec. 22.11 Intervention and non-party briefs.}

(a) Intervention. Any person desiring to become a party to a proceeding may move for leave to intervene. A motion for leave to intervene that is filed after the exchange of information pursuant to Sec. 22.19(a) shall not be granted unless the movant shows good cause for its failure to file before such exchange of information. All requirements of these Consolidated Rules of Practice shall apply to a motion for leave to intervene as if the movant were a party. The Presiding Officer shall grant leave to intervene in all or part of the proceeding if: the movant claims an interest relating to the cause of action; a final order may as a practical matter impair the movant's ability to protect that interest; and the movant's interest is not adequately represented by existing parties. The intervenor shall be bound by any agreements, arrangements and other matters previously made in the proceeding unless otherwise ordered by the Presiding Officer or the Environmental Appeals Board for good cause.

(b) Non-party briefs. Any person who is not a party to a proceeding may move for leave to file a non-party brief. The motion shall identify the interest of the applicant and shall explain the relevance of the brief to the proceeding. All requirements of these Consolidated Rules of Practice shall apply to the motion as if the movant were a party. If the motion is granted, the Presiding Officer or Environmental Appeals Board shall issue an order setting the time for filing such brief. Any party to the proceeding may file a response to a non-party brief within 15 days after service of the non-party brief.

Sec. 22.12

\section{Consolidation and severance.}

(a) Consolidation. The Presiding Officer or the Environmental Appeals Board may consolidate any or all matters at issue in two or more proceedings subject to these Consolidated Rules of Practice where: there exist common parties or common questions of fact or law; consolidation would expedite and simplify consideration of the issues; and consolidation would not adversely affect the rights of parties engaged in otherwise separate proceedings. Proceedings subject to subpart 1 of this part may be consolidated only upon the approval of all parties. Where a proceeding subject to the provisions of subpart I of this part is consolidated with a proceeding to which subpart I of this part does not apply, the procedures of subpart I of this part shall not apply to the consolidated proceeding.

(b) Severance. The Presiding Officer or the Environmental Appeals Board may, for good cause, order any proceedings severed with respect to any or all parties or issues.

\section{Subpart C -- Prehearing Procedures}

Sec. 22.13

Commencement of a proceeding.

(a) Any proceeding subject to these Consolidated Rules of Practice is commenced by filing with the Regional Hearing Clerk a complaint conforming to Sec. 22.14. 
(b) Notwithstanding paragraph (a) of this section, where the parties agree to settlement of one or more causes of action before the filing of a complaint, a proceeding may be simultaneously commenced and concluded by the issuance of a consent agreement and final order pursuant to Sec. $22.18(b)(2)$ and (3).

\section{Sec. 22.14 Complaint.}

(a) Content of complaint. Each complaint shall include:

(1) A statement reciting the section(s) of the Act authorizing the issuance of the complaint;

(2) Specific reference to each provision of the Act, implementing regulations, permit or order which respondent is alleged to have violated;

(3) A concise statement of the factual basis for each violation alleged;

(4) A description of all relief sought, including one or more of the following:

(i) The amount of the civil penalty which is proposed to be assessed, and a brief explanation of the proposed penalty;

(ii) Where a specific penalty demand is not made, the number of violations (where applicable, days of violation) for which a penalty is sought, a brief explanation of the severity of each violation alleged and a recitation of the statutory penalty authority applicable for each violation alleged in the complaint;

(iii) A request for a Permit Action and a statement of its proposed terms and conditions; or

(iv) A request for a compliance or corrective action order and a statement of the terms and conditions thereof;

(5) Notice of respondent's right to request a hearing on any material fact alleged in the complaint, or on the appropriateness of any proposed penalty, compliance or corrective action order, or Permit Action;

(6) Notice if subpart I of this part applies to the proceeding;

(7) The address of the Regional Hearing Clerk; and

(8) Instructions for paying penalties, if applicable.

(b) Rules of practice. A copy of these Consolidated Rules of Practice shall accompany each complaint served.

(c) Amendment of the complaint. The complainant may amend the complaint once as a matter of right at any time before the answer is filed. Otherwise the complainant may amend the complaint only upon motion granted by the Presiding Officer. Respondent shall have 20 additional days from the date of service of the amended complaint to file its answer.

(d) Withdrawal of the complaint. The complainant may withdraw the complaint, or any part thereof, without prejudice one time before the answer has been filed. After one withdrawal before the filing of an answer, or after the filing of an answer, the complainant may withdraw the complaint, or any part thereof, without prejudice only upon motion granted by the Presiding Officer.

Sec. 22.15

Answer to the complaint.

(a) General. Where respondent: Contests any material fact upon which the complaint is based; contends that the proposed penalty, compliance or corrective action order, or Permit Action, as the case may be, is inappropriate; or contends that it is entitled to judgment as a matter of law, it shall file an original and one copy of a written answer to the complaint with the Regional Hearing Clerk and shall serve copies of the answer on all other parties. Any such answer to the complaint must be filed with the Regional Hearing Clerk within 30 days after service of the complaint.

(b) Contents of the answer. The answer shall clearly and directly admit, deny or explain each of the factual allegations contained in the complaint with regard to which respondent has any 
knowledge. Where respondent has no knowledge of a particular factual allegation and so states, the allegation is deemed denied. The answer shall also state: The circumstances or arguments which are alleged to constitute the grounds of any defense; the facts which respondent disputes; the basis for opposing any proposed relief; and whether a hearing is requested.

(c) Request for a hearing. A hearing upon the issues raised by the complaint and answer may be held if requested by respondent in its answer. If the respondent does not request a hearing. the Presiding Officer may hold a hearing if issues appropriate for adjudication are raised in the answer.

(d) Failure to admit, deny, or explain. Failure of respondent to admit, deny, or explain any material factual allegation contained in the complaint constitutes an admission of the allegation.

(e) Amendment of the answer. The respondent may amend the answer to the complaint upon motion granted by the Presiding Officer.

Sec. 22.16

Motions.

(a) General. Motions shall be served as provided by Sec. $22.5(\mathrm{~b})(2)$. Upon the filing of a motion, other parties may file responses to the motion and the movant may file a reply to the response. Any additional responsive documents shall be permitted only by order of the Presiding Officer or Environmental Appeals Board, as appropriate. All motions, except those made orally on the record during a hearing, shall:

(1) Be in writing;

(2) State the grounds therefor, with particularity;

(3) Set forth the relief sought; and

(4) Be accompanied by any affidavit, certificate, other evidence or legal memorandum relied upon.

(b) Response to motions. A party's response to any written motion must be filed within 15 days after service of such motion. The movant's reply to any written response must be filed within 10 days after service of such response and shall be limited to issues raised in the response. The Presiding Officer or the Environmental Appeals Board may set a shorter or longer time for response or reply, or make other orders concerning the disposition of motions. The response or reply shall be accompanied by any affidavit, certificate, other evidence, or legal memorandum relied upon. Any party who fails to respond within the designated period waives any objection to the granting of the motion.

(c) Decision. The Regional Judicial Officer (or in a proceeding commenced at EPA Headquarters, the Environmental Appeals Board) shall rule on all motions filed or made before an answer to the complaint is filed. Except as provided in Secs. 22.29(c) and 22.51, an Administrative Law Judge shall rule on all motions filed or made after an answer is filed and before an initial decision has become final or has been appealed. The Environmental Appeals Board shall rule as provided in Sec. 22.29(c) and on all motions filed or made after an appeal of the initial decision is filed, except as provided pursuant to Sec. 22.28.

(d) Oral argument. The Presiding Officer or the Environmental Appeals Board may permit oral argument on motions in its discretion.

\section{Sec. 22.17 Default.}

(a) Default. A party may be found to be in default: after motion, upon failure to file a timely answer to the complaint; upon failure to comply with the information exchange requirements of Sec. 22.19(a) or an order of the Presiding Officer; or upon failure to appear at a conference or hearing. Default by respondent constitutes, for purposes of the pending proceeding only, an admission of all facts alleged in the complaint and a waiver of respondent's right to contest such factual allegations. Default by complainant constitutes a waiver of complainant's 
right to proceed on the merits of the action, and shall result in the dismissal of the complaint with prejudice.

(b) Motion for default. A motion for default may seek resolution of all or part of the proceeding. Where the motion requests the assessment of a penalty or the imposition of other relief against a defaulting party, the movant must specify the penalty or other relief sought and state the legal and factual grounds for the relief requested.

(c) Default order. When the Presiding Officer finds that default has occurred, he shall issue a default order against the defaulting party as to any or all parts of the proceeding unless the record shows good cause why a default order should not be issued. If the order resolves all outstanding issues and claims in the proceeding, it shall constitute the initial decision under these Consolidated Rules of Practice. The relief proposed in the complaint or the motion for default shall be ordered unless the requested relief is clearly inconsistent with the record of the proceeding or the Act. For good cause shown, the Presiding Officer may set aside a default order.

(d) Payment of penalty; effective date of compliance or corrective action orders, and Permit Actions. Any penalty assessed in the default order shall become due and payable by respondent without further proceedings 30 days after the default order becomes final under Sec. 22.27(c). Any default order requiring compliance or corrective action shall be effective and enforceable without further proceedings on the date the default order becomes final under Sec. 22.27(c). Any Permit Action ordered in the default order shall become effective without further proceedings on the date that the default order becomes final under $\operatorname{Sec} .22 .27$ (c).

\section{Sec. 22.18 Quick resolution; settlement; alternative dispute resolution.}

(a) Quick resolution.

(1) A respondent may resolve the proceeding at any time by paying the specific penalty proposed in the complaint or in complainant's prehearing exchange in full as specified by complainant and by filing with the Regional Hearing Clerk a copy of the check or other instrument of payment. If the complaint contains a specific proposed penalty and respondent pays that proposed penalty in full within 30 days after receiving the complaint, then no answer need be filed. This paragraph (a) shall not apply to any complaint which seeks a compliance or corrective action order or Permit Action. In a proceeding subject to the public comment provisions of Sec. 22.45 , this quick resolution is not available until 10 days after the close of the comment period.

(2) Any respondent who wishes to resolve a proceeding by paying the proposed penalty instead of filing an answer, but who needs additional time to pay the penalty, may file a written statement with the Regional Hearing Clerk within 30 days after receiving the complaint stating that the respondent agrees to pay the proposed penalty in accordance with paragraph $(a)(1)$ of this section. The written statement need not contain any response to, or admission of, the allegations in the complaint. Within 60 days after receiving the complaint, the respondent shall pay the full amount of the proposed penalty. Failure to make such payment within 60 days of receipt of the complaint may subject the respondent to default pursuant to Sec. 22.17.

(3) Upon receipt of payment in full, the Regional Judicial Officer or Regional Administrator, or, in a proceeding commenced at EPA Headquarters, the Environmental Appeals Board, shall issue a final order. Payment by respondent shall constitute a waiver of respondent's rights to contest the allegations and to appeal the final order.

(b) Settlement.

(1) The Agency encourages settlement of a proceeding at any time if the settlement is consistent with the provisions and objectives of the Act and applicable regulations. The 
parties may engage in settlement discussions whether or not the respondent requests a hearing. Settlement discussions shall not affect the respondent's obligation to file a timely answer under Sec. 22.15.

(2) Consent agreement. Any and all terms and conditions of a settlement shall be recorded in a written consent agreement signed by all parties or their representatives. The consent agreement shall state that, for the purpose of the proceeding, respondent: Admits the jurisdictional allegations of the complaint; admits the facts stipulated in the consent agreement or neither admits nor denies specific factual allegations contained in the complaint; consents to the assessment of any stated civil penalty, to the issuance of any specified compliance or corrective action order, to any conditions specified in the consent agreement, and to any stated Permit Action; and waives any right to contest the allegations and its right to appeal the proposed final order accompanying the consent agreement. Where complainant elects to commence a proceeding pursuant to Sec. 22.13(b), the consent agreement shall also contain the elements ocscribed at Sec. 22.14(a)(1)-(3) and (8). The parties shall forward the executed consent agreement and a proposed final order to the Regional Judicial Officer or Regional Administrator, or, in a proceeding commenced at EPA Headquarters, the Environmental Appeals Board.

(3) Conclusion of proceeding. No settlement or consent agreement shall dispose of any proceeding under these Consolidated Rules of Practice without a final order from the Regional Judicial Officer or Regional Administrator, or, in a proceeding commenced at EPA Headquarters, the Environmental Appeals Board, ratifying the parties' consent agreement.

(c) Scope of resolution or settlement. Full payment of the penalty proposed in a complaint pursuant to paragraph (a) of this section or settlement pursuant to paragraph (b) of this section shall not in any case affect the right of the Agency or the United States to pursue appropriate injunctive or other equitable relief or criminal sanctions for any violations of law. Full payment of the penalty proposed in a complaint pursuant to paragraph (a) of this section or settlement pursuant to paragraph (b) of this section shall only resolve respondent's liability for Federal civil penalties for the violations and facts alleged in the complaint.

(d) Alternative means of dispute resolution.

(1) The parties may engage in any process within the scope of the Alternative Dispute Resolution Act ("ADRA"), 5 U.S.C. 581 et seq., which may facilitate voluntary settlement efforts. Such process shall be subject to the confidentiality provisions of the ADRA.

(2) Dispute resolution under this paragraph (d) does not divest the Presiding Officer of jurisdiction and does not automatically stay the proceeding. All provisions of these Consolidated Rules of Practice remain in effect notwithstanding any dispute resolution proceeding.

(3) The parties may choose any person to act as a neutral, or may move for the appointment of a neutral. If the Presiding Officer grants a motion for the appointment of a neutral, the Presiding Officer shall forward the motion to the Chief Administrative Law Judge, except in proceedings under subpart I of this part, in which the Presiding Officer shall forward the motion to the Regional Administrator. The Chief Administrative Law Judge or Regional Administrator, as appropriate, shall designate a qualified neutral. 

discovery.

(a) Prehearing information exchange.

(1) In accordance with an order issued by the Presiding Officer, each party shall file a prehearing information exchange. Except as provided in Sec. 22.22(a), a document or exhibit that has not been included in prehearing information exchange shall not be admitted into evidence, and any witness whose name and testimony summary has not been included in prehearing information exchange shall not be allowed to testify. Parties are not required to exchange information relating to settlernent which would be excluded in the federal courts under Rule 408 of the Federal Rules of Evidence. Documents and exhibits shall be marked for identification as ordered by the Presiding Officer.

(2) Each party's prehearing information exchange shall contain:

(i) The names of any expert or other witnesses it intends to call at the hearing, together with a brief narrative summary of their expected testimony, or a statement that no witnesses will be called; and

(ii) Copies of all documents and exhibits which it intends to introduce into evidence at the hearing.

(3) If the proceeding is for the assessment of a penalty and complainant has already specified a proposed penalty, complainant shall explain in its prehearing information exchange how the proposed penalty was calculated in accordance with any criteria set forth in the Act, and the respondent shall explain in its prehearing information exchange why the proposed penalty should be reduced or eliminated.

(4) If the proceeding is for the assessment of a penalty and complainant has not specified a proposed penalty, each party shall include in its prehearing information exchange all factual information it considers relevant to the assessment of a penalty. Within 15 days after respondent files its prehearing information exchange, complainant shall file a document specifying a proposed penalty and explaining how the proposed penalty was calculated in accordance with any criteria set forth in the Act.

(b) Prehearing conference. The Presiding Officer, at any time before the hearing begins, may direct the parties and their counsel or other representatives to participate in a conference to consider:

(1) Settlement of the case;

(2) Simplification of issues and stipulation of facts not in dispute;

(3) The necessity or desirability of amendments to pleadings;

(4) The exchange of exhibits, documents, prepared testimony, and admissions or stipulations of fact which will avoid unnecessary proof;

(5) The limitation of the number of expert or other witnesses;

(6) The time and place for the hearing; and

(7) Any other matters which may expedite the disposition of the proceeding.

(c) Record of the prehearing conference. No transcript of a prehearing conference relating to settlement shall be made. With respect to other prehearing conferences, no transcript of any prehearing conferences shall be made unless ordered by the Presiding Officer. The Presiding Officer shall ensure that the record of the proceeding includes any stipulations, agreements, rulings or orders made during the conference.

(d) Location of prehearing conference. The prehearing conference shall be held in the county where the respondent resides or conducts the business which the hearing concerns, in the city in which the relevant Environmental Protection Agency Regional Office is located, or in 
Washington, DC, unless the Presiding Officer determines that there is good cause to hold it at another location or by telephone.

(e) Other discovery.

(1) After the information exchange provided for in paragraph (a) of this section, a party may move for additional discovery. The motion shall specify the method of discovery sought, provide the proposed discovery instruments, and describe in detail the nature of the information and/or documents sought (and, where relevant, the proposed time and place where discovery would be conducted). The Presiding Officer may order such other discovery only if it:

(i) Will neither unreasonably delay the proceeding nor unreasonably burden the nonmoving party;

(ii) Seeks information that is most reasonably obtained from the non-moving party, and which the non-moving party has refused to provide voluntarily; and

(iii) Seeks information that has significant probative value on a disputed issue of material fact relevant to liability or the relief sought.

(2) Settlement positions and information regarding their development (such as penalty calculations for purposes of settlement based upon Agency settlement policies) shall not be discoverable.

(3) The Presiding Officer may order depositions upon oral questions only in accordance with paragraph (e)(1) of this section and upon an additional finding that:

(i) The information sought cannot reasonably be obtained by alternative methods of discovery; or

(ii) There is a substantial reason to believe that relevant and probative evidence may otherwise not be preserved for presentation by a witness at the hearing.

(4) The Presiding Officer may require the attendance of witnesses or the production of documentary evidence by subpoena, if authorized under the Act. The Presiding Officer may issue a subpoena for discovery purposes only in accordance with paragraph (e)(1) of this section and upon an additional showing of the grounds and necessity therefor. Subpoenas shall be served in accordance with Sec. 22.5(b)(1). Witnesses summoned before the Presiding Officer shall be paid the same fees and mileage that are paid witnesses in the courts of the United States. Any fees shall be paid by the party at whose request the witness appears. Where a witness appears pursuant to a request initiated by the Presiding Officer, fees shall be paid by the Agency.

(5) Nothing in this paragraph (e) shall limit a party's right to request admissions or stipulations, a respondent's right to request Agency records under the Federal Freedom of Information Act, 5 U.S.C. 552, or EPA's authority under any applicable law to conduct inspections, issue information request letters or administrative subpoenas, or otherwise. obtain information.

(f) Supplementing prior exchanges. A party who has made an information exchange under paragraph (a) of this section, or who has exchanged information in response to a request for information or a discovery order pursuant to paragraph (e) of this section, shall promptly supplement or correct the exchange when the party learns that the information exchanged or response provided is incomplete, inaccurate or outdated, and the additional or corrective information has not otherwise been disclosed to the other party pursuant to this section.

(g) Failure to exchange information. Where a party fails to provide information within its control as required pursuant to this section, the Presiding Officer may, in his discretion:

(1) Infer that the information would be adverse to the party failing to provide it;

(2) Exclude the information from evidence; or

(3) Issue a default order under Sec. 22.17(c). 
(a) General. The Presiding Officer may at any time render an accelerated decision in favor of a party as to any or all parts of the proceeding, without further hearing or upon such limited additional evidence, such as affidavits, as he may require, if no genuine issue of material fact exists and a party is entitled to judgment as a matter of law. The Presiding Officer, upon motion of the respondent, may at any time dismiss a proceeding without further hearing or upon such limited additional evidence as he requires, on the basis of failure to establish a prima facie case or other grounds which show no right to relief on the part of the complainant.

(b) Effect.

(1) If an accelerated decision or a decision to dismiss is issued as to all issues and claims in the proceeding, the decision constitutes an initial decision of the Presiding Officer, and shall be filed with the Regional Hearing Clerk.

(2) If an accelerated decision or a decision to dismiss is rendered on less than all issues or claims in the proceeding, the Presiding Officer shall determine what material facts exist without substantial controversy and what material facts remain controverted. The partial accelerated decision or the order dismissing certain counts shall specify the facts which appear substantially uncontroverted, and the issues and claims upon which the hearing will proceed.

\section{Subpart D - Hearing Procedures}

Sec. 22.21

Assignment of Presiding Officer; scheduling the hearing.

(a) Assignment of Presiding Officer. When an answer is filed, the Regional Hearing Clerk shall forward a copy of the complaint, the answer, and any other documents filed in the proceeding to the Chief Administrative Law Judge who shall serve as Presiding Officer or assign another Administrative Law Judge as Presiding Officer. The Presiding Officer shall then obtain the case file from the Chief Administrative Law Judge and notify the parties of his assignment.

(b) Notice of hearing. The Presiding Officer shall hold a hearing if the proceeding presents genuine issues of material fact. The Presiding Officer shall serve upon the parties a notice of hearing setting forth a time and place for the hearing not later than 30 days prior to the date set for the hearing. The Presiding Officer may require the attendance of witnesses or the production of documentary evidence by subpoena, if authorized under the Act. upon a showing of the grounds and necessity therefor, and the materiality and relevancy of the evidence to be adduced.

(c) Pustponement of hearing. No request for postponement of a hearing shall be granted except upon motion and for good cause shown.

(d) I. ocation of the hearing. The location of the hearing shall be determined in accordance with the method for determining the location of a prehcaring conference under Sec. 22.19(d).

\section{Sec. $22.22 \quad$ Evidence.}

(a) General.

(1) The Presiding Officer shall admit all evidence which is not irrelevant, immaterial, unduly repetitious, unreliable, or of little probative value, except that evidence relating to settlement which would be excluded in the federal courts under Rule 408 of the Federal Rules of Evidence (28 U.S.C.) is not admissible. If, however, a party fails to provide any document, exhibit, witness name or summary of expected testimony required to be exchanged under Sec. 22.19 (a), (e) or (f) to all parties at least 15 days before the hearing date, the Presiding Officer shall not admit the document, exhibit or testimony 
into evidence, unless the non-exchanging party had good cause for failing to exchange the required information and provided the required information to all other parties as soon as it had control of the information, or had good cause for not doing so.

(2) In the presentation, admission, disposition, and use of oral and written evidence, EPA officers, employees and authorized representatives shall preserve the confidentiality of information claimed confidential, whether or not the claim is made by a party to the proceeding, unless disclosure is authorized pursuant to 40 CFR part 2. A business confidentiality claim shall not prevent information from being introduced into evidence, but shall instead require that the information be treated in accordance with 40 CFR part 2, subpart B. The Presiding Officer or the Environmental Appeals Board may consider such evidence in a proceeding closed to the public, and which may be before some, but not all, parties, as necessary. Such proceeding shall be closed only to the extent necessary to comply with 40 CFR part 2 , subpart B, for information claimed confidential. Any affected person may move for an order protecting the information claimed confidential.

(b) Examination of witnesses. Witnesses shall be examined orally, under oath or affirmation, except as otherwise provided in paragraphs (c) and (d) of this section or by the Presiding Officer. Parties shall have the right to cross-examine a witness who appears at the hearing provided that such cross-examination is not unduly repetitious.

(c) Written testimony. The Presiding Officer may admit and insert into the record as evidence, in lieu of oral testimony, written testimony prepared by a witness. The admissibility of any part of the testimony shall be subject to the same rules as if the testimony were produced under oral examination. Before any such testimony is read or admitted into evidence, the party who has called the witness shall deliver a copy of the testimony to the Presiding Officer, the reporter, and opposing counsel. The witness presenting the testimony shall swear to or affirm the testimony and shall be subject to appropriate oral cross-examination.

(d) Admission of affidavits where the witness is unavailable. The Presiding Officer may admit into evidence affidavits of witnesses who are unavailable. The term "unavailable" shall have the meaning accorded to it by Rule 804(a) of the Federal Rules of Evidence.

(e) Exhibits. Where practicable, an original and one copy of each exhibit shall be filed with the Presiding Officer for the record and a copy shall be furnished to each party. A true copy of any exhibit may be substituted for the original.

(f) Official notice. Official notice may be taken of any matter which can be judicially noticed in the Federal courts and of other facts within the specialized knowledge and experience of the Agency. Opposing parties shall be given adequate opportunity to show that such facts are crroneously noticed.

Sec. 22.23

Objections and offers of proof.

(a) Objection. Any objection concerning the conduct of the hearing may be stated orally or in writing during the hearing. The party raising the objection must supply a short statement of its grounds. The ruling by the Presiding Officer on any objection and the reasons given for it shall be part of the record. An exception to each objection overruled shall be automatic and is not waived by further participation in the hearing.

(b) Offers of proof. Whenever the Presiding Officer denies a motion for admission into evidence, the party offering the information may make an offer of proof, which shall be included in the record. The offer of proof for excluded oral testimony shall consist of a brief statement describing the nature of the information excluded. The offer of proof for excluded documents or exhibits shall consist of the documents or exhibits excluded. Where the Environmental Appeals Board decides that the ruling of the Presiding Officer in excluding the information 
from evidence was both erroneous and prejudicial, the hearing may be reopened to permit the taking of such evidence.

Sec. 22.24

Burden of presentation; burden of persuasion; preponderance of the evidence standard.

(a) The complainant has the burdens of presentation and persuasion that the violation occured as set forth in the complaint and that the relief sought is appropriate. Following complainant's establishment of a prima facie case, respondent shall have the burden of presenting any defense to the allegations set forth in the complaint and any response or evidence with respect to the appropriate relief. The respondent has the burdens of presentation and persuasion for any affirmative defenses.

(b) Each matter of controversy shall be decided by the Presiding Officer upon a preponderance of the evidence.

\section{Sec. $22.25 \quad$ Filing the transcript.}

The hearing shall be transcribed verbatim. Promptly following the taking of the last evidence, the reporter shall transmit to the Regional Hearing Clerk the original and as many copies of the transcript of testimony as are called for in the reporter's contract with the Agency, and also shall transmit to the Presiding Officer a copy of the transcript. A certificate of service shall accompany each copy of the transcript. The Regional Hearing Clerk shall notify all parties of the availability of the transcript and shall fumish the parties with a copy of the transcript upon payment of the cost of reproduction, unless a party can show that the cost is unduly burdensome. Any person not a party to the proceeding may receive a copy of the transcript upon payment of the reproduction fee, except for those parts of the transcript ordered to be kept confidential by the Presiding Officer. Any party may file a motion to conform the transcript to the actual testimony within 30 days after receipt of the transcript, or 45 days after the parties are notified of the availability of the transcript, whichever is sooner.

Sec. 22.26

Proposed findings, conclusions, and order.

After the hearing, any party may file proposed findings of fact, conclusions of law, and a proposed order, together with briefs in support thereof. The Presiding Officer shall set a schedule for filing these documents and any reply briefs, but shall not require them before the last date for filing motions under Sec. 22.25 to conform the transcript to the actual testimony. All submissions shall be in writing, shall be served upon all parties, and shall contain adequate references to the record and authorities relied on.

\section{Subpart E -- Initial Decision and Motion To Reopen a Hearing}

\section{Sec. $22.27 \quad$ Initial Decision.}

(a) Filing and contents. After the period for filing briefs under Sec. 22.26 has expired, the Presiding Officer shall issue an initial decision. The initial decision shall contain findings of fact, conclusions regarding all material issues of law or discretion, as well as reasons therefor, and, if appropriate, a recommended civil penalty assessment, compliance order, corrective action order, or Permit Action. Upon receipt of an initial decision, the Regional Hearing Clerk shall forward copies of the initial decision to the Environmental Appeals Board and the Assistant Administrator for the Office of Enforcement and Compliance Assurance. 
(b) Amount of civil penalty. If the Presiding Officer determines that a violation has occurred and the complaint seeks a civil penalty, the Presiding Officer shall determine the amount of the recommended civil penalty based on the evidence in the record and in accordance with any penalty criteria set forth in the Act. The Presiding Officer shall consider any civil penalty guidelines issued under the Act. The Presiding Officer shall explain in detail in the initial decision how the penalty to be assessed corresponds to any penalty criteria set forth in the Act. If the Presiding Officer decides to assess a penalty different in amount from the penalty proposed by complainant, the Presiding Officer shall set forth in the initial decision the specific reasons for the increase or decrease. If the respondent has defaulted, the Presiding Officer shall not assess a penalty greater than that proposed by complainant in the complaint, the prehearing information exchange or the motion for default, whichever is less.

(c) Effect of initial decision. The initial decision of the Presiding Officer shall become a final order 45 days after its service upon the parties and without further proceedings unless:

(1) A party moves to reopen the hearing;

(2) A party appeals the initial decision to the Environmental Appeals Board;

(3) A party moves to set aside a default order that constitutes an initial decision; or

(4) The Environmental Appeals Board elects to review the initial decision on its own initiative.

(d) Exhaustion of administrative remedies. Where a respondent fails to appeal an initial decision to the Environmental Appeals Board pursuant to Sec. 22.30 and that initial decision becomes a final order pursuant to paragraph (c) of this section, respondent waives its rights to judicial review. An initial decision that is appealed to the Environmental Appeals Board shall not be final or operative pending the Environmental Appeals Board's issuance of a final order.

$\operatorname{Sec} .22 .28$

Motion to reopen a hearing.

(a) Filing and content. A motion to reopen a hearing to take further evidence must be filed no later than 20 days after service of the initial decision and shall state the specific grounds upon which relief is sought. Where the movant seeks to introduce new evidence, the motion shall: state briefly the nature and purpose of the evidence to be adduced; show that such evidence is not cumulative; and show good cause why such evidence was not adduced at the hearing. The motion shall be made to the Presiding Officer and filed with the Regional Hearing Clerk.

(b) Disposition of motion to reopen a hearing. Within 15 days following the service of a motion to reopen a hearing, any other party to the proceeding may file with the Regional Hearing Clerk and serve on all other parties a response. A reopened hearing shall be governed by the applicable sections of these Consolidated Rules of Practice. The filing of a motion to reopen a hearing shall automatically stay the running of the time periods for an initial decision becoming final under Sec. 22.27(c) and for appeal under Sec. 22.30. These time periods shall begin again in full when the motion is denied or an amended initial decision is served.

\section{Subpart F -- Appeals and Administrative Review}

\section{Sec. 22.29 Appeal from or review of interlocutory orders or rulings.}

(a) Request for interlocutory appeal. Appeals from orders or rulings other than an initial decision shall be allowed only at the discretion of the Environmental Appeals Board. A party seeking interlocutory appeal of such orders or rulings to the Environmental Appeals Board shall file a motion within 10 days of service of the order or ruling, requesting that the Presiding Officer forward the order or ruling to the Environmental Appeals Board for review, and stating briefly the grounds for the appeal. 
(b) Availability of interlocutory appeal. The Presiding Officer may recommend any order or ruling for review by the Environmental Appeals Board when:

(1) The order or ruling involves an important question of law or policy concerning which there is substantial grounds for difference of opinion; and

(2) Either an immediate appeal from the order or ruling will materially advance the ultimate termination of the proceeding, or review after the final order is issued will be inadequate or ineffective.

(c) Interlocutory review. If the Presiding Officer has recommended review and the Environmental Appeals Board determines that interlocutory review is inappropriate, or takes no action within 30 days of the Presiding Officer's recommendation, the appeal is dismissed. When the Presiding Officer declines to recommend review of an order or ruling, it may be reviewed by the Environmental Appeals Board only upon appeal from the initial decision, except when the Environmental Appeals Board determines, upon motion of a party and in exceptional circumstances, that to delay review would be contrary to the public interest. Such motion shall be filed within 10 days of service of an order of the Presiding Officer refusing to recommend such order or ruling for interlocutory review.

Sec. 22.30

\section{Appeal from or review of initial decision.}

(a) Notice of appeal.

(1) Within 30 days after the initial decision is served, any party may appeal any adverse order or ruling of the Presiding Officer by filing an original and one copy of a notice of appeal and an accompanying appellate brief with the Environmental Appeals Board (Clerk of the Board (Mail Code 1103B), United States Environmental Protection Agency, 1200 Pennsylvania Ave., NW., Washington, DC 20460. Hand deliveries may be made at Suite 500,607 14th Street, NW.). One copy of any document filed with the Clerk of the Board shall also be served on the Regional Hearing Clerk. Appellant also shall serve a copy of the notice of appeal upon the Presiding Officer. Appellant shall simultaneously serve one copy of the notice and brief upon all other parties and nonparty participants. The notice of appeal shall summarize the order or ruling, or part thereof, appealed from. The appellant's brief shall contain tables of contents and authorities (with page references), a statement of the issues presented for review, a statement of the nature of the case and the facts relevant to the issues presented for review (with appropriate references to the record), argument on the issues presented, a short conclusion stating the precise relief sought, alternative findings of fact, and alternative conclusions regarding issues of law or discretion. If a timely notice of appeal is filed by a party, any other party may file a notice of appeal on any issue within 20 days after the date on which the first notice of appeal was served.

(2) Within 20 days of service of notices of appeal and briefs under paragraph (a)(1) of this section, any other party or non-party participant may file with the Environmental Appeals Board an original and one copy of a response brief responding to argument raised by the appellant, together with reference to the relevant portions of the record, initial decision, or opposing brief. Appellee shall simultaneously serve one copy of the response bricf upon each party, non-party participant, and the Regional Hearing Clerk. Response briefs shall be limited to the scope of the appeal brief. Further briefs may be filed only with the permission of the Environmental Appeals Board.

(b) Review initiated by the Environmental Appeals Board. Whenever the Environmental Appeals Board determines to review an initial decision on its own initiative, it shall file notice of its intent to review that decision with the Clerk of the Board, and serve it upon the Regional Hearing Clerk, the Presiding Officer and the parties within 45 days after the initial de- 
cision was served upon the parties. The notice shall include a statement of issues to be briefed by the parties and a time schedule for the filing and service of briefs.

(c) Scope of appeal or review. The parties' rights of appeal shall be limited to those issues raised during the course of the proceeding and by the initial decision, and to issues concerning subject matter jurisdiction. If the Environmental Appeals Board determines that issues raised, but not appealed by the parties, should be argued, it shall give the parties reasonable written notice of such determination to permit preparation of adequate argument. The Environmental Appeals Board may remand the case to the Presiding Officer for further proceedings.

(d) Argument before the Environmental Appeals Board. The Environmental Appeals Board may, at its discretion, order oral argument on any or all issues in a proceeding.

(e) Motions on appeal. All motions made during the course of an appeal shall conform to Sec. 22. 16 unless otherwise provided.

(f) Decision. The Environmental Appeals Board shall adopt modify, or set aside the findings of fact and conclusions of law or discretion contained in the decision or order being reviewed, and shall set forth in the final order the reasons for its actions. The Environmental Appeals Board may assess a penalty that is higher or lower than the amount recommended to be assessed in the decision or order being reviewed or from the amount sought in the complaint, except that if the order being reviewed is a default order, the Environmental Appeals Board may not increase the amount of the penalty above that proposed in the complaint or in the motion for default, whichever is less. The Environmental Appeals Board may adopt, modify or set aside any recommended compliance or corrective action order or Permit Action. The Environmental Appeals Board may remand the case to the Presiding Officer for further action.

\section{Subpart G - Final Order}

\section{Sec. 22.31}

\section{Final order.}

(a) Effect of final order. A final order constitutes the final Agency action in a proceeding. The final order shall not in any case affect the right of the Agency or the United States to pursue appropriate injunctive or other equitable relief or criminal sanctions for any violations of law. The final order shall resolve only those causes of action alleged in the complaint, or for procecdings commenced pursuant to Sec. 22.13(b), alleged in the consent agreement. The final order does not waive, extinguish or otherwise affect respondent's obligation to comply with all applicable provisions of the Act and regulations promulgated thereunder.

(b) Effective date. A final order is effective upon filing. Where an initial decision becomes a final order pursuant to Sec. 22.27 (c), the final order is effective 45 days after the initial decision is served on the parties.

(c) Payment of a civil penalty. The respondent shall pay the full amount of any civil penalty assessed in the final order within 30 days after the effective date of the final order unless otherwise ordered. Payment shall be made by sending a cashier's check or certified check to the payee specified in the complaint, unless otherwise instructed by the complainant. The check shall note the case title and docket number. Respondent shall serve copies of the check or other instrument of payment on the Regional Hearing Clerk and on complainant. Collection of interest on overdue payments shall be in accordance with the Debt Collection Act, 31 U.S.C. 3717.

(d) Other relief. Any final order requiring compliance or corrective action, or a Permit Action, shall become effective and enforceable without further proceedings on the effective date of the final order unless otherwise ordered.

(e) Final orders to Federal agencies on appeal. 
(1) A final order of the Environmental Appeals Board issued pursuant to Sec. 22.30 to a department, agency, or instrumentality of the United States shall become effective 30 days after its service upon the parties unless the head of the affected department, agency, or instrumentality requests a conference with the Administrator in writing and serves a copy of the request on the parties of record within 30 days of service of the final order. If a timely request is made, a decision by the Administrator shall become the final order.

(2) A motion for reconsideration pursuant to Sec. 22.32 shall not toll the 30 -day period described in paragraph (e)(1) of this section unless specifically so ordered by the Environmental Appeals Board.

\section{Sec. 22.32 Motion to reconsider a final order.}

Motions to reconsider a final order issued pursuant to Sec. 22.30 shall be filed within 10 days after service of the final order. Motions must set forth the matters claimed to have been erroneously decided and the nature of the alleged errors. Motions for reconsideration under this provision shall be directed to, and decided by, the Environmental Appeals Board. Motions for reconsideration directed to the Administrator, rather than to the Environmental Appeals Board, will not be considered, except in cases that the Environmental Appeals Board has referred to the Administrator pursuant to Sec. 22.4(a) and in which the Administrator has issued the final order. A motion for reconsideration shall not stay the effective date of the final order unless so ordered by the Environmental Appeals Board.

\section{Subpart H -- Supplemental Rules}

Sec. 22.34

Supplemental rules governing the administrative assessment of civil penalties under the Clean Air Act.

(a) Scope. This section shall apply, in conjunction with Secs. 22.1 through 22.32 , in administrative proceedings to assess a civil penalty conducted under sections 113(d), 205(c), 211(d), and 213(d) of the Clean Air Act, as amended (42 U.S.C. 7413(d), 7524(c), 7545(d), and 7547(d)). Where inconsistencies exist between this section and Secs. 22.1 through 22.32, this section shall apply.

(b) Issuance of notice. Prior to the issuance of a final order assessing a civil penalty, the person to whom the order is to be issued shall be given written notice of the proposed issuance of the order. Service of a complaint or a consent agreement and final order pursuant to Sec. 22.13 satisfies this notice requirement.

Stc. 22.35

Supplemental rules governing the administrative assessment of civil penalties under the Federal Insecticide, Fungicide, and Rodenticide Act.

(a) Scope. This section shall apply, in conjunction with Secs. 22.1 through 22.32 , in administrative proceedings to assess a civil penalty conducted under section 14(a) of the Federal Insecticide, Fungicide, and Rodenticide Act as amended (7 U.S.C. 1361(a)). Where inconsistencies exist between this section and Secs. 22.1 through 22.32 , this section shall apply.

(b) Venue. The prehearing conference and the hearing shall be held in the county, parish, or incorporated city of the residence of the person charged, unless otherwise agreed in writing by all parties. For a person whose residence is outside the United States and outside any territory or possession of the United States, the prehearing conference and the hearing shall be held at the EPA office listed at 40 CFR 1.7 that is closest to either the person's primary place 
of business within the United States, or the primary place of business of the person's U.S. agent, unless otherwise agreed by all parties.

Sec. 22.37

Supplemental rules governing administrative proceedings under the Solid Waste Disposal Act.

(a) Scope. This section shall apply, in conjunction with Secs. 22.1 through 22.32 , in administrative proceedings under sections 3005(d) and (e), 3008, 9003 and 9006 of the Solid Waste Disposal Act (42 U.S.C. 6925(d) and (e), 6928, 6991b and 699le) ("SWDA"). Where inconsistencies exist between this section and Secs. 22.1 through 22.32, this section shall apply.

(b) Corrective action and compliance orders. A complaint may contain a compliance order issued under section 3008(a) or section 9006(a), or a corrective action order issued under section 3008(h) or section $9003(\mathrm{~h})(4)$ of the SWDA. Any such order shall automatically become a final order unless, no later than 30 days after the order is served, the respondent requests a hearing pursuant to Sec. 22.15 .

Sec. 22.38

Supplemental rules of practice governing the administrative assessment of civil penalties under the Clean Water Act.

(a) Scope. This section shall apply, in conjunction with Secs. 22.1 through 22.32 and Sec. 22.45, in administrative proceedings for the assessment of any civil penalty under section $309(\mathrm{~g})$ or section 311(b)(6) of the Clean Water Act ("CWA") (33 U.S.C. 1319(g) and 1321(b)(6)). Where inconsistencies exist between this section and Secs. 22.1 through 22.32, this section shall apply.

(b) Consultation with States. For proceedings pursuant to section $309(\mathrm{~g})$, the complainant shall provide the State agency with the most direct authority over the matters at issue in the case. an opportunity to consult with the complainant. Complainant shall notify the State agency within 30 days following proof of service of the complaint on the respondent or, in the case of a proceeding proposed to be commenced pursuant to Sec. 22.13(b), no less than 40 days before the issuance of an order assessing a civil penalty.

(c) Administrative procedure and judicial review. Action of the Administrator for which review could have been obtained under section 509(b)(1) of the CWA, 33 U.S.C. 1369(b)(1), shall not be subject to review in an administrative proceeding for the assessment of a civil penalty under section 309(g) or section $311(\mathrm{~b})(6)$.

Sec. 22.39

Supplemental rules governing the administrative assessment of civil penalties under section 109 of the Comprehensive Environmental Response, Compensation, and Liability Act of 1980, as amended.

(a) Scope. This section shall apply, in conjunction with Secs. 22.10 through 22.32. in administrative proceedings for the assessment of any civil penalty under section 109 of the Comprehensive Environmental Response, Compensation, and Liability Act of 1980, as amended (42 U.S.C. 9609). Where inconsistencies exist between this section and Secs. 22.1 through 22.32, this section shall apply.

(b) Judicial review. Any person who requested a hearing with respect to a Class II civil penalty under section 109(b) of CERCLA, 42 U.S.C. 9609(b), and who is the recipient of a final order assessing a civil penalty may file a petition for judicial review of such order with the United States Court of Appeals for the District of Columbia or for any other circuit in which such person resides or transacts business. Any person who requested a hearing with respect to a Class I civil penaity under section 109(a)(4) of CERCLA, 42 U.S.C. 9609(a)(4), and who is the recipient of a final order assessing the civil penalty may file a petition for judicial 
review of such order with the appropriate district court of the United States. All petitions must be filed within 30 days of the date the order making the assessment was served on the parties.

(c) Payment of civil penalty assessed. Payment of civil penalties assessed in the final order shall be made by forwarding a cashier's check, payable to the "EPA, Hazardous Substances Superfund," in the amount assessed, and noting the case title and docket number, to the appropriate regional Superfund Lockbox Depository.

Sec. 22.41

Supplemental rules governing the administrative assessment of civil penalties under Title II of the Toxic Substance Control Act, enacted as section 2 of the Asbestos Hazard Emergency Response Act (AHERA).

(a) Scope. This section shall apply, in conjunction with Secs. 22.1 through 22.32 , in administrative proceedings to assess a civil penalty conducted under section 207 of the Toxic Substances Control Act ("TSCA") (15 U.S.C. 2647). Where inconsistencies exist between this section and Secs. 22.1 through 22.32 , this section shall apply.

(b) Collection of civil penalty. Any civil penalty collected under TSCA section 207 shall be used by the local educational agency for purposes of complying with Title II of TSCA. Any portion of a civil penalty remaining unspent after a local educational agency achieves compliance shall be deposited into the Asbestos Trust Fund established under section 5 of AHERA.

Sec. 22.42

Supplemental rules governing the administrative assessment of civil penalties for violations of compliance orders issued to owners or operators of public water systems under part B of the Safe Drinking Water Act.

(a) Scope. This section shall apply, in conjunction with Secs. 22.1 through 22.32, in administrative proceedings to assess a civil penalty under section $1414(\mathrm{~g})(3)(\mathrm{B})$ of the Safe Drinking Water Act, 42 U.S.C. $300 \mathrm{~g}-3(\mathrm{~g})(3)(B)$. Where inconsistencies exist between this section and Secs. 22.1 through 22.32 , this section shall apply.

(b) Choice of forum. A complaint which specifies that subpart I of this part applies shall also state that respondent has a right to elect a hearing on the record in accordance with 5 U.S.C. 554 , and that respondent waives this right unless it requests in its answer a hearing on the record in accordance with 5 U.S.C. 554. Upon such request, the Regional Hearing Clerk shall recaption the documents in the record as necessary, and notify the parties of the changes.

Sec. $22.43 \quad$ Supplemental rules governing the administrative assessment of civil penalties against a federal agency under the Safe Drinking Water Act.

(a) Scope. This section shall apply, in conjunction with Secs. 22.1 through 22.32, in administrative proceedings to assess a civil penaity against a federal agency under section 1447(b) of the Safe Drinking Water Act, 42 U.S.C. 300j-6(b). Where inconsistencies exist between this section and Secs. 22.1 through 22.32 , this section shall apply.

(b) Effective date of final penalty order. Any penalty order issued pursuant to this section and section 1447(b) of the Safe Drinking Water Act shall become effective 30 days after it has been served on the parties. 
(c) Public notice of final penalty order. Upon the issuance of a final penalty order under this section, the Administrator shall provide public notice of the order by publication, and by providing notice to any person who requests such notice. The notice shall include:

(1) The docket number of the order;

(2) The address and phone number of the Regional Hearing Clerk from whom a copy of the order may be obtained;

(3) The location of the facility where violations were found;

(4) A description of the violations;

(5) The penaity that was assessed; and

(6) A notice that any interested person may, within 30 days of the date the order becomes final, obtain judicial review of the penalty order pursuant to section 1447(b) of the Safe Drinking Water Act, and instruction that persons seeking judicial review shall provide copies of any appeal to the persons described in 40 CFR 135.11(a).

Sec. 22.44

\section{Supplemental rules of practice governing the termination of permits under section 402(a) of the Clean Water Act or under section 3008(a) (3) of the Resource Conservation and Recovery Act.}

(a) Scope of this subpart. The supplemental rules of practice in this subpart shall also apply in conjunction with the Consolidated Rules of Practice in this part and with the administrative proceedings for the termination of permits under section 402(a) of the Clean Water Act or under section 3008(a)(3) of the Resource Conservation and Recovery Act. Notwithstanding the Consolidated Rules of Practice, these supplemental rules shall govern with respect to the termination of such permits.

(b) In any proceeding to terminate a permit for cause under Sec. 122.64 or Sec. 270.43 of this chapter during the term of the permit:

(1) The complaint shall, in addition to the requirements of Sec. 22.14(b), contain any additional information specified in Sec. 124.8 of this chapter;

(2) The Director (as defined in Sec. 124.2 of this chapter) shall provide public notice of the complaint in accordance with Sec. 124.10 of this chapter, and allow for public comment in accordance with Sec. 124.11 of this chapter; and

(3) The Presiding Officer shall admit into evidence the contents of the Administrative Record described in Sec. 124.9 of this chapter, and any public comments received.

Secs. 22.46-22.49 [Reserved]

\section{Subpart I - Administrative Proceedings Not Governed by Section 554 of the Ad-} ministrative Procedure Act

Sec. 22.50

Scope of this subpart.

(a) Scope. This subpart applies to all adjudicatory proceedings for:

(1) The assessment of a penalty under sections $309(\mathrm{~g})(2)(\mathrm{A})$ and $311(\mathrm{~b})(6)(\mathrm{B})(\mathrm{i})$ of the Clean Water Act (33 U.S.C. $1319(\mathrm{~g})(2)(\mathrm{A})$ and $1321(\mathrm{~b})(6)(\mathrm{B})(\mathrm{i})$ ).

(2) The assessment of a penalty under sections $1414(\mathrm{~g})(3)(\mathrm{B})$ and $1423(\mathrm{c})$ of the Safe Drinking Water Act (42 U.S.C. $300 \mathrm{~g}-3(\mathrm{~g})(3)(\mathrm{B})$ and $300 \mathrm{~h}-2(\mathrm{c})$ ), except where a respondent in a proceeding under section $1414(\mathrm{~g})(3)(B)$ requests in its answer a hearing on the record in accordance with section 554 of the Administrative Procedure Act, 5 U.S.C. 554. 
(b) Relationship to other provisions. Sections 22.1 through 22.45 apply to proceedings under this subpart, except for the following provisions which do not apply: Secs. 22.11, 22.16(c), 22.21(a), and 22.29. Where inconsistencies exist between this subpart and subparts A through $G$ of this part, this subpart shall apply. Where inconsistencies exist between this subpart and subpart $\mathrm{H}$ of this part, subpart $\mathrm{H}$ shall apply.

Sec. 22.51

Presiding Officer.

The Presiding Officer shall be a Regional Judicial Officer. The Presiding Officer shall conduct the hearing, and rule on all motions until an initial decision has become final or has been appealed.

Sec. 22.52

Information exchange and discovery.

Respondent's information exchange pursuant to $\mathrm{Sec}$. 22.19(a) shall include information on any economic benefit resulting from any activity or failure to act which is alleged in the administra. tive complaint to be a violation of applicable law, including its gross revenues, delayed or avoided costs. Discovery under Sec. 22.19(e) shall not be authorized, except for discovery of information concerning respondent's economic benefit from alleged violations and information concerning respondent's ability to pay a penalty. 


\section{Overzicht van geraadpleegde literatuur}

Addink, G.H. en Sluijs, M.J.

De Algemene wet bestuursrecht op scherp, NTB 1992, p. 33-45

Addink, G.H. en Duijkersloot, A.P.W.

Kanttekingen bij 'Bestuurlijke handhaving' in voorontwerp 4e tranche Awb, NTB 1999, p.

255-266

Albers, C.L.G.F.H.

De bestuurlijke boete. Magische lijn of hellend vlak?, in JBplus 2000, p. 138-152

Albers, C.L.G.F.H.

'Etikettenschwindel' in het administratieve sanctierecht?, NJB 2001, p. 1157-1162

Albers, C.L.G.F.H. en Schlössels, R.J.N.

De bestuurlijke boete: een koekoeksei in het bestuursprocesrecht, NTB 2002, p. 187-198

Alkema, E.A.

Regels voor bestuurlijke sancties in Awb, bijzondere wet of verdrag?, in de bundel: De grootste gemene deler (Drupsteen bundel), onder redactie van M. Lurks, W. den Ouden, J.E.M. Polak en A.E. Schilder, Leiden 2002, p. 111-124

Akehurst, $M$.

A Modern Introduction to International Law, sixth edition, London 1987

\section{Baauw, P.}

Strafrecht en de schaduwzijden van 50 jaar EVRM: een impressie, in de bundel: 50 jaar Europees Verdrag voor de Rechten van de Mens, onder redactie van R.A. Lawson en E. Myjer, Leiden 2000, p. 409-420

Bal, P.

Murphy's law? Over de uitholling van het nemo tenetur beginsel in Amerika, in de bundel: Nemo tenetur, onder redactie van J.M. Reijntjes, Gouda Quint bv, Amhem 1996, p. 23-40

Barkhuysen, T., Emmerik, van, M.L. en Loof, J.P.

50 jaar EVRM en het Nederlandse staats- en bestuursrecht - ontwikkelingen en vooruitzichten in de bundel: 50 jaar Europees Verdrag voor de Rechten van de Mens, onder redactie van R.A. Lawson en E. Myjer, Leiden 2000, p. 237-408

Belinfante, A.D.

Strafrechtelijke en administratiefrechtelijk sancties, in: De verhouding van administratieve sancties en straffen, Geschriften van de vereniging voor administratiefrecht no. XXXVI, H.D. Tjeenk Willink \& Zoon N.V., Haarlem 1957

Bellekom, Th.L., Heringa, A.W., Velde, van der, J. en Verhey, L.F.M.

Koopmans' Compendium van het Staatsrecht, Kluwer, Deventer 2002

Berge, ten J.B.J.M. en Tak, A.Q.C.

Hoofdlijnen van het Nederlands administratief procesrecht, tweede herziene druk, Zwolle 1990

Berge, ten J.B.J.M. en Michiels, F.C.M.A.

Besturen door de overheid, vierde druk, Deventer 2001

Berge, ten J.B.J.M. en Widdershoven, R.J.G.M.

Bescherming tegen de overheid, zesde druk, Deventer 2001 
Blomberg, A.B. en Michiels, F.C.M.A.

Handhaven met effect, VUGA Uitgeverij B.V., Den Haag 1997

Blomberg, A.B.

Integrale handhaving van milieurecht (diss. VU), Boom juridische uitgevers, Den Haag 2000

Bock, de, R.H.

Hoger beroep in het bestuursrecht: herkansing, afvalrace, of roulette?, NJB 1999, p. 1148 -

1156 (met reacties van Schreuder-Vlasblom en Blommestein en een nawoord van De Bock in NJB 1999, p. 1651-1655)

Bock, de, R.H.

De toetsing van feiten door de bestuursrechter en het vriespunt van de afdeling bestuursrechtspraak, JBplus 2000, p. 66-77

Boos, S.T.M.

Kentekenaansprakelijkheid in vergelijkend perspectief, VR 2000/4 p. 109-1 18

Bos, J.T.K.

De bestuurlijke boete, raakvlakken van bestuurs- en strafrecht, in Handhaving van het bestuursrecht, VAR-Reeks no. 114, Samsom H.D. Tjeenk Willink, Alphen aan den Rijn, 1995, p. $119-167$

Burg, van der F.H., Cartingy, G.J.M. en Overkleeft-Verburg, G.

Rechtsbescherming tegen de overheid, vijfde herziene druk, Nijmegen 1985

Burnham, W.

Introduction to the law and legal system of the United States, West Publishing Co. St. Paul, Minnesota 1995

Buruma, Y.

De strafrechtelijke handhaving van bestuurswetten (diss. RUL), Gouda Quint, Arnhem 1993

Buuren, van, P.J.J.

De bestuurlijke boete geregeld? in de bundel: Van boeteatelier tot boetefabriek, onder redactie van W.G.A. Hazewindus en O.J.D.M.L. Jansen, Deventer 1995, p. $41-51$

Buuren, van, P.P.J., Jurgens, G.T.J.M. en Michiels, F.C.M.A.

Bestuursdwang en dwangsom, tweede druk, W.E.J. Tjeenk Willink, Deventer 1999

Cann, S.J.

Administrative Law, second edition, Sage Publications, Thousand Oaks, California, 1998 Cheh, M.M.

Constitutional Limits on Using Civil Remedies To Achieve Criminal Law Objectives: Understanding and Transcending the Criminal-Civil Law Distinction, Hastings Law Journal, 42 Hastings L.J. 1325-1413, july 1991

Corstens, G.J.M.

Interne en externe convergentie van strafprocesrecht, in: D.R. Doorenbos en R.J. Verweij (red.), Hercodificatie Wetboek van Strafvordering, Nijmegen 1991, i.h.b. p. 9-13

Corstens, G.J.M.

Een stille revolutie in het strafrecht (Afscheidsrede Nijmegen 1995), Gouda Quint bv, Arnhem 1995

Corstens, G.J.M.

Het Nederlands strafprocesrecht, derde druk, Gouda Quint, Deventer 1999 
Corstens, G.J.M.

Bestuurlijke boeten in de vierde tranche Awb, NJB aflevering 24, 16 juni 2000, p. 1185 1190

Corstens, G.J.M.

Bestuurlijke boetes, in het bijzonder in het financiële recht, SEW 2001, p. 242-247

Daalder, E.J. en Groot, de, G.R.J.

De parlementaire geschiedenis van de Algemene wet bestuursrecht Eerste Tranche, Alphen aan den Rijn 1993

Daalder, E.J., Groot, de, G.R.J. en Breugel, van, J.M.E.

De parlementaire geschiedenis van de Algemene wet bestuursrecht Tweede Tranche, Alphen aan den Rijn 1994

Daalder, E.J., Groot, de, G.R.J. en Breugel, van, J.M.E.

De parlementaire geschiedenis van de Algemene wet bestuursrecht Derde Tranche, Alphen aan den Rijn 1998

Daalder, E.J. en Schreuder-Vlasblom, M.

Balanceren boven nul. De vaststelling van feiten in het bestuursprocesrecht, NTB 2000, p. 214-221

Damen, L.J.A.

Bestaat de Awbmens? In: Aantrekkelijke gedachten, beschouwingen over de Algemene wet bestuursrecht, Deventer 1993, p. 109 e.v.

Damen. L.J.A. (voorzitter VAR-werkgroep vierde tranche)

De vierde tranche Awb. Commentaar en vraagpunten, Den Haag, Boom Juridische uitgevers, 2000

Damen, L.J.A.

De bewijsfuik: hoe en wanneer moet een oud-mijnwerker zijn silicose bewijzen?, Ars Aequi 2000, p. 61-69

Damen, L.J.A.

Van algemene rechtsbeginselen en gemene rechtsleren, in de bundel: De autonomie van het bestuursrecht, onder redactie van H. Koning en E.J.M. Crombag, Boom juridische uitgevers 2001, p. 57-71

Demeersseman, H.A.

De autonomie van het materiële strafrecht (diss. VU), Amhem 1985

Diver, C.S.

The Assessment and Mitigation of Civil Money Penalties by Federal Administrative Agencies, Columbia Law Review, december 1979, p. 1435-p. 1502

Doelder, de, H., Rogier, L.J.J., en Russen Groen, van, P.M. (red.)

De wet Mulder in perspectief, Amhem 1990

Doelder, de, H. en Rogier, L.J.J. (red.)

Opstellen over bestuursstrafrecht, SI-EUR-reeks, deel 3, Gouda Quint, Amhem 1994

Doelder, de, H., Meijer M.E. en Otto, D. (red.)

De bestuurlijke boete in perspectief, Gouda Quint 1999

Doorenbos D.R. en Verweij R.J. (red.)

Hercodificatie Wetboek van Strafvordering, Nijmegen 1991

Drumpt, van, M.V. en Addink, G.H.

De bestuurlijke waarborgsom in het bestuursrecht: begrip, plaats, inhoud en karakter, NTB 1999, p. 118-126 
Duk, W.

Tanden van het recht -oriënterende beschouwingen over sancties-, Tjeenk Willink, Zwolle 1973

Duk, W.

Handhaving van bestuursrecht, NTB 1988, p. 105-110

Dijk, van, $P$.

Bendenoun binnen proporties, NJB 1994, p. 1526- 1527

Dijk, van, P. en Hoof, van, G.J.H. in samenwerking met Heringa, A.W., Schokkenbroek, J.G.C. , Vermeulen, B.P., Viering, M.L.W.M. en Zwaak, L.F.

Theory and Practice of the European Convention on Human Rights, third edition, Kluwer Law intemational, The Hague/London/Boston 1998

Enschedé, Ch.J., bewerkt door Rüter, C.F. en Stolwijk, S.A.M. Beginselen van strafrecht, Deventer 1995

Feteris, M.W.C.

Fiscale administratieve sancties en het recht op een behoorlijk proces (diss. UvA), Kluwer, Deventer 1993

Feteris, M.W.C.

De bestuurlijke boete in het Voorontwerp vierde tranche Awb, Weekblad voor Fiscaal Recht 2000/6380, p. 465- 478

Feteris, M.W.C.

De fiscale bestuurlijke boete en de Vierde tranche van de Awb in de bundel: Commentaren op het Voorontwerp Algemene wet bestuursrecht Vierde tranche, onder redactie van L.J.J. Rogier, Rotterdam 2000, p. 1-35

Feteris, M.W.C.

Belastingen en mensenrechten, NJCM-bulletin 2002, p. 43-60

Foqué, R. en Hart, 't, A.C.

Instrumentaliteit en rechtsbescherming, Amhem/Antwerpen 1990

Funk, W.

Close enough for government work?? -- Using informal procedures for imposing administrative penalties, Seton Hall Law Review, 1993, 24 Seton Hall L.Rev. p. l e.v.

Gellhom, W.

Administrative Prescription and Imposition of Penalties, Washington University Law Quarterly, 1970, p. 265-287

Goldschmidt, J.

Das Verwaltungsstrafrecht. Eine Untersuchung der Grenzgebiete zwischen Strafrecht und Verwaltungsrecht auf rechtsgeschichtlicher und rechtsvergleichender Grundlage, Berlin 1902

Göhler, E.

Ordnungswidrigkeitengesetz, 12. neubearbeitete Auflage, Verlag C.H. Beck, München 1998

Groenhuijsen, M.S. en Knigge, G.(red.)

Het onderzoek ter zitting. Eerste interimrapport Onderzoeksproject Strafvordering 2001, Groningen 1999 
Groenhujisen, M.S. en Knigge, G.(red.)

Het vooronderzoek in strafzaken. Tweede intermapport Onderzoeksproject Strafvordering 2001. Deventer 2001

Groenhuijzen, M.S. en Knigge, G.(red.)

Dwangmiddelen en Rechtsmiddelen. Derde interimrapport onderzoeksproject Strafvordering 2001 (concept)

Haan, de, P., Drupsteen, Th. G. en Fernhout, $P$.

Bestuurstecht in de sociale rechtsstaat, Deel II, Bestuurshandelingen en waarborgen, vierde, geheel herziene druk, Kluwer, Deventer 1998

Haan, de, P., Drupsteen, Th. G. en Fernhout, R.

Bestuursrecht in de sociale rechtsstaat, Deel I, organisatie, ontwikkeling, instrumentarium, vijfe, geheel herziene druk, Kluwer, Deventer 2001

Hart, $1, A, C$.

Openbaar Ministerie en rechtshandhaving, Gouda Quint, Amhem 1994

Hart, "t, A.C.

Straf, recht en waarden, in de bundel: Hoe punitief is Nederland?, onder redactie van $M$. Moerings, Amhem 1994, p. $31-44$

$\operatorname{Hath}_{3}{ }^{*} t, A, C$.

Her gelden wetten! Over strafrecht, Openbaar Ministerie en multiculturalisme, Leiden 2001

Hartmann, A.R. en Van Russen Groen, P.M.

Bestuursstrafrecht, in: Opstellen over bestuursstrafrecht, onder redactie van $\mathrm{H}$. de Doelder en L.J.J. Rogier, SI-EUR-reeks, deel 3, Gouda Quint, Amhem 1994, p. 21-59

Hartmann, A.R. en Van Russen Groen, P.M.

'Criminal charge' uitgekleed? Bendenoun gerelativeerd, NJB 1994, p. 1520-1526

Hartmann, A.R.

Bewijs in het bestuursstrafrecht (diss. EUR), Deventer 1998

Hartmann, A.R. en Van Russen Groen, P.M.

Van strafrecht naar bestuursstrafrecht: de derde decriminaliseringsgolf?, in: Opstellen over bestuursstrafrecht onder redactie van H. de Doelder en L.J.J. Rogier, SI-EUR-reeks, deel 3, Gouda Quint, Amhem 1994, p. 61-78

Hartmann, A.R. en Van Russen Groen, P.M.

Contouren van het bestuursstrafrecht (diss. EUR), Deventer 1998

Hartmann, A.R.

Buitengerechtelijke afdoening, in: Het onderzoek ter zitting. Eerste interimrapport Onderzoeksproject Strafvordering 2001, Groningen 1999, onder redactie van M.S. Groenhuijsen en G. Knigge a.w. 1999, p. 59-90

Hartmann, A.R.

Het zwijgrecht en de cautieverplichting, in de bundel: Commentaren op het Voorontwerp Algemene wet bestuursrecht Vierde tranche, onder redactie van L.J.J. Rogier, Rotterdam 2000 , p. 37-63

Hartog, den, A.

Artikel 6 EVRM: grenzen aan het streven de straf eerder op de daad te doen volgen (diss. RUG), MAKLU uitgevers, Antwerpen - Apeldoorn 1992

Harwoord, G.

Hearings Before an EPA Administrative Law Judge, Environmental Law Reporter, november 1987, 17 ELR, 10441-10444 
Hazewindus, W.G.A.

De administratieve dwangsom: een situatieve èn punitieve sanctie, NJB 1992, p. 1068 1072

Hazewindus, W.G.A.

Administratieve sancties en vreemdelingenrecht (diss. UvA), Gouda Quint bv, Amhem 1994

Hazewindus, W.G.A. en Jansen, O.J.D.M.L. (red.)

Van boeteatelier tot boetefabriek, Deventer 1995

Heldeweg, M.A., Linden, van der, E.C.H.J. en Schlössels, R.J.N. (red.)

Uit de school geklapt, Den Haag 1999

Heringa, A.W.

Van Europese Conventie tot Nederlandse Constitutie voor de rechten van de mens, in de bundel: 40 jaar Europees verdrag voor de Rechten van de Mens: opstellen over de ontwikkeling van het EVRM in Straatsburg en in Nederland, onder redactie van A.W. Heringa en J.G.C. Schokkenbroek, Leiden 1990, p. 317-335

Heringa, A.W. en Schokkenbroek, J.G.C. (red.)

40 jaar Europees verdrag voor de Rechten van de Mens: opstellen over de ontwikkeling van het EVRM in Straatsburg en in Nederland, Leiden 1990

Heringa, A.W. en Zwart, T.

De Nederlandse Grondwet, derde druk, W.E.J. Tjeenk Willink, Zwolle 1991

Heringa, A.W.

Het Amerikaanse Hooggerechtshof, Kluwer, Deventer 1996

Hirsch Ballin, E.M.H.

Wederkerig bestuursrecht, RM Themis $1989 / 1$, p. 1 e.v.

Hoogenboom, T. en Damen, L.J.A. (red)

In de sfeer van administratief recht (Konijnenbeltbundel), Utrecht 1994

Hoogenboom, $T$.

De Afdeling bestuursrechtspraak van de Raad van State als appèlrechter, NTB 1998, p. 126-135

Hulst, van der, J.W. (red.)

De wet Mulder in bedrijf, Arnhem 1994

Hulst, van der, J.W.

Artikel 6 EVRM en de WAHV, VR 1999/6 p. 164-167

Hulst, van der, J.W.

Tien jaar administratiefrechtelijke handhaving verkeersvoorschriften, NTB 2000, p. 271 276

Hulst, van der, J.W.

Enige bepalingen over de bestuurlijke boete belicht vanuit strafrechtelijk perspectief, in de bundel: Commentaren op het Voorontwerp Algemene wet bestuursrecht Vierde tranche, onder redactie van L.J.J. Rogier, Rotterdam 2000, p. 65-76

Jacobs, F.G. en White, R.C.A.

The European Convention on Human Rights, second edition, Oxford 1995

Jansen, A.M.L.

De redelijke termijn met name in het bestuursrecht, Den Haag, Boom Juridische Uitgevers 2000 
Jansen, O.J.D.M.L.

Bestuursrecht en strafprocesrecht: doorwerken of afgrenzen? in: T. Hoogenboom en L.J.A. Damen (redactie), In de sfeer van administratief recht (Konijnenbeltbundel), Utrecht 1994, p. 257-283

Jansen, O.J.D.M.L.

De eindige toekomst van artikel 1:6 Awb, NTB 1999, p. 150-156 Jansen, O.J.D.M.L.

Het Handhavingsonderzoek (diss. UvA 1999), Nijmegen 1999 Jansen, O.J.D.M.L.

Punitief en evenredig? Jurisprudentiële ontwikkelingen bij punitieve sancties en het evenredigheidsbeginsel, in JBplus 2000 , p. 38-49 Jansen, O.J.D.M.L.

De dynamiek van het publiekrechtelijke sanctierecht, Handelingen NJV 2002-I, p. 167255

Jong, de, D.H. en Knigge, G.

Van Bemmelen - Van Veen: Het materiële strafrecht, Algemeen deel, dertiende druk, Gouda Quint, Deventer 1998

Kastner, B.

Verdachtsunabhängige Personenkontrollen im Lichte des Verfassungsrechts, Verwaltungsarchiv 922001 , p. 216-260

Kelk, C.

Verbreding van het punitieve spectrum, in de bundel: Hoe punitief is Nederland?, onder redactie van M. Moerings, Arnhem 1994, p. 13-29

Keulen, B.F. en Lenos, E.E.V.

Naschrift bij de zaak "Oliveira", NJCM-bulletin 1999, no. 2, p. 234-240

Klap, A.P.

Rechterlijke toetsing van en aan beleidsregels, JBplus 2002, p. 17-28 Klerk, Y.

De ontstaansgeschiedenis van de Europese Conventie, in de bundel: 40 jaar Europees verdrag voor de Rechten van de Mens: opstellen over de ontwikkeling van het EVRM in Straatsburg en in Nederland, onder redactie van A.W. Heringa en J.G.C. Schokkenbroek, Leiden 1990, p. 3-15

Koning-de Jong, de, E.M.

Het rapport: 'Handhaving door Bestuurlijke Boeten' op de keper beschouwd, in de bundel: Opstellen over bestuursstrafrecht, onder redactie van H. de Doelder en L.J.J. Rogier, Gouda Quint, Amhem 1994, p. 173-189

Koning, H. en Crombag, E.J.M. (red.)

De autonomie van het bestuursrecht, Boom juridische uitgevers 2001

Kooper, R.

Wie is er bang voor de aanvulling van rechtsgronden? Over de terminologie van 8:69 Awb, NTB 2000, p. 167-177 Kors, A.

Administratiefrechtelijke handhaving: toekomstperspectief, in de bundel: De wet Mulder in perspectief onder redactie van H. de Doelder, L.J.J. Rogier en P.M. van Russen Groen, Amhem 1990, p. 77-84

Kortmann, C.A.J.M.

Constitutioneel recht, Kluwer Deventer 2001 
Knigge, $\mathbf{G}$.

De strafvordering in het geding, Handelingen NJV 1994-I, Zwolle 1994, p. 37-116

Knigge, G.

De bestuurlijke boete als teken aan de wand, Milieu en Recht 1998, no 3, p. 63-68

Knigge, G.

De verhouding tot het strafrecht in: M.S. Groenhuijsen en G. Knigge (red.), Het vooronderzoek in strafzaken. Tweede interimrapport Onderzoeksproject Strafvordering 2001, Deventer 2001 p. 93-124

Knigge, G.

De verkalking voorbij... over de verhouding van het strafrecht tot het bestuursrecht, RM Themis 2000 , p. $83-96$

Knigge, G.

De krenten in de pap; het onderzoeksproject Strafvordering 2001 en de actuele ontwikkelingen op het terrein van de wetgeving, DD 2002, p. 221-236

Kooijmans, P.H.

Intemationaal publiekrecht in vogelvlucht, Wolters-Noordhoff, Groningen 1997

Krabbe, H.G.M. en Hattum, van, W.F.

De ne bis in idem-regel in de rechtspraak van het EHRM, DD 2000, p. 6-20

Kuipers, A.J.

Het recht op 'full jurisdiction', in: R.L. Vucsán (red.), De Awb-mens: boeman of underdog? (Damen-bundel), Ars Aequi Libri, Nijmegen 1996, p. 97 e.v.

Lawson, R.A. en Myjer, E. (red.)

50 jaar Europees Verdrag voor de Rechten van de Mens, Leiden 2000

Lenos, E.E.V.

De sociale en fiscale inlichtingenplicht en het zwijgrecht sinds Saunders, NJB 1997, p. 795-800

Lenos, E.E.V.

Bestuurlijke sanctietoepassing en strafrechtelijke waarborgen in de sociale zekerheid, Koninklijke Vermande 1998

Lenos, E.E.V.

Boeten en maatregelen met mate? Toetsing door de rechter aan het evenredigheidsbeginsel, Sociaal Recht 1999-7/8, p. 184-189

Lensing, J.A.W. en Mertens, Th.

Het Europees Hof voor de rechten van de mens en de 'muurschutters'. De 'formulering van Radbruch' of innerlijke tegenstrijdigheid, NJB 2001, p. 1699-1706

Lensing, J.A.W.

Een nieuwe worsteling met het feitbegrip bij ne bis in idem, NJCM-Bulletin 2002, p. 146153

Linden, van der, E.C.H.J. en Tak, A.Q.C. (red.)

Eenzijdig en wederkering?, Kluwer Deventer 1995

Linden, van der, E.C.H.J.

Formele en materiële rechtskracht. De kleren van de keizer (diss. UM), Den Haag 1998

Lurks, M., Den Ouden, W, Polak, J.E.M., Schilder, A.E. (red.)

De grootste gemene deler (Drupsteen bundel), Leiden 2002 
Mann, $\mathrm{K}$.

Punitive Civil Sanctions: The Middleground Between Criminal and Civil Law, Yale Law Joumal, juni 1992, 101 Yale L.J. 1795

Mayer, M.E.

Rechtsnormen und Kulturnormen, Strafrechtliche Abhandlungen, heft 50, Breslau 1903 Mayers, L.

The American Legal System, revised edition, Harper \& Row Publishers, New York, 1981 Meulen, van der, B.J.M.

Handhaving, in de bundel: Eenzijdig en wederkerig?, onder redactie van E.C.H.J. van der Linden en A.Q.C. Tak, Deventer 1995, i.h.b. p. 223-247

Michels, H.G.

Strafbare Handlung und Zuwiderhandlung. Versuch einer materiellen Unterscheidung zwischen Kriminal- und Verwaltungsstrafrecht, Neue Kölner Rechtswissenschaftliche Abhandlungen, herausgegeben von der Rechtswissenschaftlichen Fakultät der Universität zu Köln, Heft 24, Walter de Gruyter \& Co., Berlin 1963

Michiels, F.C.M.A.

De boete in opmars?, W.E.J. Tjeenk Willink, Zwolle 1994

Michiels, F.C.M.A.

Bestuurlijke handhaving in ontwikkeling, in: Handhaving van het bestuursrecht, VAR preadvies no. 114, Alphen aan den Rijn; Samsom H.D. Tjeenk Willink 1995, p. 7-119

Michiels, F.C.M.A.

De bestuurlijke boete in het milieurecht, Milieu en Recht 1998 no. 3, p. 69-73

Michiels, F.C.M.A.

Een kans voor open doel, Over handhaving van milieurecht met bestuurlijke transacties, in: Recht op het doel af, onder redactie van F.C.M.A. Michiels, Deventer 1998, p. 269286

Michiels, F.C.M.A. (red.)

Recht op het doel af, Deventer 1998

Michiels, F.C.M.A.

Het handhavingstekort en de bestuurlijke boete, in: De bestuurlijke boete in perspectief, onder redactie van H. de Doelder, M.E. Meijer en D. Otto, Gouda Quint 1999, p. 63-77

Michiels, F.C.M.A.

Belangenafweging bij sanctiebesluiten, Ars Aequi 2000, nr. 2, p. 111-117

Moerings, M. (red.)

Hoe punitief is Nederland?, Arnhem 1994

Mols, G.P.M.F.

Het rapport van de commissie-werkbelasting strafkamer hoge raad, DD 1997, p. 651-659 Mols, G.P.M.F. (red.)

Hoofdstukken strafprocesrecht, Gouda Quint, Deventer 1999

Moor-van Vugt, de, A.

Maten en gewichten, Het evenredigheidsbeginsel in Europees perspectief (diss. KUB), Zwolle 1995

Moor-van Vugt, de A.J.C.

Toezicht achter matglas (oratie KUB), Den Haag 2001 Mulder, A.

De verhouding van administratieve sancties en straffen, Geschriften van de vereniging voor administratiefrecht no. XXXVI, H.D. Tjeenk Willink \& Zoon N.V., Haarlem 1957 
Neerhof, A.R. en Schlössels, R.J.N.

De vierde tranche van de Algemene wet bestuursrecht en het ruimtelijk bestuursrecht, Bouwrecht 2000 p. 1020-1038

Nicolaï, $P$.

Het tandvlees van het recht, in de bundel: Recht op scherp ("Duk-bundel"), W.E.J. Tjeenk Willink, Zwolle 1984

Nowak, $M$.

U.N. Convenant on Civil and Political Rights, CCPR commentary, N.P. Engel Publisher, Kehl, Strasbourg, Arlington 1993

Nijboer, J.F.

Ongelijkheidscompensatie en ongelijkheidsarticulatie in het strafrecht, in: Ongelijkheidscompensatie als roode draad in het recht, Liber Amicorum voor Prof.mr. M.G. Rood (red.

Betten, Boelhouwer e.a.), Deventer 1997, p. 218-220

Nijboer, J.F.

Strafrechtelijk bewijsrecht, vierde herziene druk, Nijmegen 2000

Ommeren, van, F.J.

De verplichting verankerd (diss. UU), Utrecht 1996

Oostenbrink, J.J.

Administratieve sancties, Serie Bestuursrechtelijke Verkenningen, Uitgeverij VUGA nv, 's-Gravenhage, 1967

Poel, van der, J.

Rondom compositie en compromis (fiscale studie in bestuurs- en strafrecht) (diss. RUU), Uitg. -Mij. NV Kemink en Zn., Utrecht 1942

Pompe, W.P.J.

Handboek van het Nederlandse strafrecht, vijfde herziene druk, Zwolle 1959

Quaedvlieg, H.M.J.

Ondernemende autoriteiten (diss. UM), Maastricht 2001

Raat, de, I.Y.

De bestuurlijke boete in het milieurecht, Ars Aequi no. 6, 1993, p. 445-450

Raat, de, Y. en Widdershoven, R.J.G.M.

De bestuurlijke boete in de algemene wet bestuursrecht, NJCM-bulletin 2000, p. 771-788

Remmelink, J.

Mr. D. Hazewinkel-Suringa's 'Inleiding tot de studie van het Nederlandse Strafrecht', vijftiende druk, Gouda Quint bv, Deventer 1996

Reijntjes, J.M. (red.)

Nemo tenetur, Gouda Quint bv, Amhem 1996

Reijntjes, J.M.

Nemo tenetur: een holle leus?, in de bundel: Nemo tenetur, onder redactie van J.M. Reijntjes, Gouda Quint bv, Amhem 1996, p. 9-21

Reynolds, W.L.

Judicial Process in a Nutshell, West Publishing Co., St. Paul, Minnesota 1980

Rikmenspoel, M.J.H.T.

De bestuurlijke boete: traditie, trend en toekomst, Gemeentestem No. 6990, 15 juli 1995, p. $321-324$ 
Rikmenspoel, M.J.H.T.

De bestuurlijke boete en artikel 113 Grondwet: een spanningsveld, de Gemeentestem No. 7023, p. $7-11$

Roef, D.

De ommekeer in Pikmeer. Over de vervolgbaarheid van overheden na Pikmeer II, JB $1998 / 47$, p. $215-226$

Roef, D.

Strafbare overheden (diss. UM), Antwerpen-Groningen 2001

Rogier, L. en Hartmann, A.

Verschillen en overeenkomsten tussen strafrecht en bestuursrecht, DD 1993, p. 10421058

Rogier, L.J.J.

Strafsancties, administratieve sancties en het una-via beginsel (diss. EUR), Gouda Quint, Arnhem 1992

Rogier, L.J.J.

De bestuurlijke boete in de Algemene wet bestuursrecht?, in de bundel: Opstellen over bestuursstrafrecht, onder redactie van H. de Doelder en L.J.J. Rogier, SI-EUR-reeks, deel 3, Gouda Quint, Amhem 1994, p. 157-172

Rogier, L.J.J. (red.)

Commentaren op het Voorontwerp Algemene wet besturursrecht Vierde tranche, Rotter$\operatorname{dam} 2000$

Rogier, L.J.J.

Una via, in de bundel: Commentaren op het Voorontwerp Algemene wet bestuursrecht Vierde tranche, onder redactie van L.J.J. Rogier, Rotterdam 2000, i.h.b. p. 91-109

Rogier, L.J.J.

Straffend bestuur, Gouda Quint, Rotterdam 2001

Rogier, L.J.J.

Kroniek handhaving van het bestuursrecht, NTB 2001, p. 77-84

Rogier, L.J.J.

Kroniek handhaving van het bestuursrecht, NTB 2002, p. 68-75

Roording, J.F.L.

Sanctierecht in de belastingen en de sociale zekerheid (diss. KUN), Ars Aequi Libri, Nijmegen 1994

Roos, de, Th. A.

Beheerste reactie of overkill? Hedendaagse punitiviteit in de strafrechtspolitiek, in de bundel: Hoe punitief is Nederland?, onder redactie van M. Moerings, Amhem 1994, p. 45-58

Roos, de, Th. A.

Groepsgeweld en strafrecht, AA 1998, p. 148-155

Roos, de, Th. A.

De Mensenrechtenverdragen en het strafproces, in: Hoofdstukken strafprocesrecht, onder redactie van G.P.M.F. Mols, Gouda Quint, Deventer 1999, p. 65-80

Rosenkötter, G.

Das Recht der Ordnungswidrigkeiten, Richard Boorberg Verlag, Stutgart/München/Hannover/Berlin/Weimar/Dresden 1995

Russen Groen, van, P.M.

Een juridische evaluatie van de Wet Mulder, in de bundel: De wet Mulder in bedrijf, onder redactie van J.W. van der Hulst, Amhem 1994, p. 71-88 
Russen Groen, van, P.M.

Rechtsbescherming in het bestuursstrafrecht (diss. EUR), Deventer 1998

Scalia, A.

A Matter of Interpretation, federal courts and the law, Princeton University Press, Princeton, New Jersey, 1997

Schaffmeister, D.

Politiële en justitiële delikten, in "Handelingen 1984 der Nederlandse Juristen-Vereniging deel I, eerste stuk", W.E.J. Tjeenk Willink, Zwolle 1984, p. 127-291

Schaffmeister, D.

Handhaving van het bestuursrecht door boete of straf?, in de bundel: Van boeteatelier tot boetefabriek, onder redactie van W.G.A. Hazewindus en O.J.D.M.L. Jansen, Deventer 1995, p. $58-80$

Schalken, T. en Rozemond, $K$.

Straatburgse duidelijkheid over nemo tenetur, NJB 1997, p. 808-809

Schlössels, R.J.N.

Wederkerigheid en specialiteit in het bestuursrecht, in de bundel: Eenzijdig en wederkerig?, onder redactie van E.C.H.J. van der Linden en A.Q.C. Tak, Deventer 1995, p. 153190

Schlössels, R.J.N.

Zelf in de zaak voorzien: kiezen tussen cliché of dogma? in: Rechtspraak bestuursrecht 1996-1997, De Annotaties, p. 35 -65

Schlössels, R.J.N.

Het specialiteitsbeginsel. Over de structuur van bestuursbevoegdheden, wetmatigheid van bestuur en beleidsvrijheid (diss. UM), Den Haag 1998

Schlössels, R.J.N.

Tussen finaliteit en fuik? Over de omvang van het bestuursrechtelijk geding in eerste aanleg en appèl, in de bundel: Uit de school geklapt?, onder redactie van M.A. Heldeweg, E.C.H.J. van der Linden en R.J.N. Schlössels, Den Haag 1999, p. 177-203

Schlössels, R.J.N.

Het besluitbegrip: doos van Pandora of hoofd van Medusa?, NTB 2000, p. 1-13

Schlossels, R.J.N.

Het specialiteitsbeginsel. Een verkenning van recente rechtspraak, JBplus 2001, p. 33-47

Scholten, H.J.

Kernvragen rond de gewone rechtsmiddelen in het kader van strafvordering 2001, DD 2002, p. 261-282

Schreuder-Vlasblom, $\mathrm{M}$.

De afbakening van het geding in hoger beroep door de Centrale Raad van Beroep, NTB 1998, p. 117-125

Schreuder-Vlasblom, M. en Hoogenboom, T.

Nawoord, NTB 1998, p. 136

Schreuder-Vlasblom, $M$.

Reactie op A.Q.C. Tak, NTB 1998, p. 212-213

Schreuder-Vlasblom, $M$.

Kroniek bestuursprocesrecht, NTB 2001, p. 126-136

Schreuder-Vlasblom, $M$.

De Awb; het bestuursprocesrecht, Deventer 2001 
Shane, P.M.

Returning Separation-of-Powers Analysis to Its Normative Roots: The Constitutionality of Qui Tam Actions and Other Private Suits to Enforce Civil Fines, Environmental Law Reporter, december 2000, 30 ELR 11081

Silberman, J.D.

Does Envirnomental Deterrence Work? Evidence and Experience Say Yes, But We Need to Understand How and Why, The Environmental Law Reporter 2000, 30 ELR 10523

Simmelink, J.B.H.M.

Bewijsrecht en bewijsmotivering, in: Het onderzoek ter zitting. Eerste interimrapport Onderzoeksproject Strafvordering 2001, onder redactie van M.S. Groenhuijsen en G. Knigge, Groningen 1999, p. 397 e.v.

Simon, H.J.

Publiekrecht of privaatrecht? (diss. VU), Zwolle 1993

Simon, H.J.

Handboek bestuurs(proces)recht volgens de Awb, Den Haag 1997

Simon, H.J.

Bewijzen in het bestuursrecht, JBplus 1999, p. 25-39

Solomon, M.C.

The Perils of Minimalism: United States v. Bajakajian in the Wake of the Supreme Court's Civil Double Jeopardy Excursion, Georgetown Law Joumal, February 1999, 87 Geo. L.J. 849

Steenbrink, J.H.A. en Westerbeke, F.K.G.

De risico-aansprakelijkheid van de kentekenhouder, in de bundel: De wet Mulder in perspectief onder redactie van H. de Doelder, L.J.J. Rogier en P.M. van Russen Groen, Arnhem 1990 , p. $51-65$

Steiker, C.S.

Twenty-sixth anual review of criminal procedure: foreword: Punishment and Procedure: Punishment Theory and the Criminal-Civil Procedural Devide, Georgetown Law Journal, april 1997, 85 Geo. L.J. 775

Stolwijk, S.A.M.

Schuld, DD 1998, p. 983-987

Strauss, P.L., Rakoff, T., Schotland, R.A. en Farina, C.R.

Gelhorn and Byse's Administrative Law, cases and comments, ninth edition, The Foundation Press, Westbury, New York, 1995

Stroink, F.A.M.

De algemene wet bestuursrecht en het sociale zekerheidsrecht, Tijdschrift voor Sociaal Recht, $1989 / 10$, p. 256 en 257

Stroink, F.A.M.

Boekbeschouwing C.P.J. Goorden, 'Rechtsbevoegdheid in het bestuursrecht', NTB 1990, $295-297$

Stroink, F.A.M.

Kwantum Nederland BV, in: Rechtspraak bestuursrecht 1995-1996, De Annotaties, p. 155-168

Stroink, F.A.M.

Kem van de bestuursrechtspraak, Elesevier bedrijfsinformatie bv, 's-Gravenhage 2000 Sunstein, C.

Constitutionalism After the New Deal, Harvard Law Review, 1987, 101 H.L. Rev. 421, p. 446-448 
Tak, A.Q.C.

Het moment X, TvO 1990/6, p. 134 ev.

Tak, A.Q.C.

De Algemene wet bestuursrecht, Zwolle 1992

Tak, A.Q.C. en Teunissen, J.M.H.F.

Wie zorgt er voor de rechtsstaat? Een voortgezet debat, Recht en Kritiek, 1994, p. 340354

Tak, A.Q.C.

De overheid in het burgerlijk recht, 's-Gravenhage 1997

Tak, A.Q.C.

Devolutieve werking van het appèl, NTB 1998, p. 210-211

Tak, A.Q.C.

Het Nederlandse bestuursprocesrecht in theorie en praktijk, deel I, 's-Gravenhage 2002

Tak, A.Q.C.

Het Nederlandse bestuursprocesrecht in theorie en praktijk, deel II, 's-Gravenhage 2002

Teunissen, J.M.H.F. en Tak, A.Q.C.

Recht ist was der Umwelt nützt?, NJB 1994, p. 605-616

Teunissen, J.M.H.F.

Het burgerlijk kleed van de staat (diss. RL), W.E.J. Tjeenk Willink, Zwolle 1996

Teunissen, J.M.H.F.

De emancipatie van het bestuursrecht. Een beschouwing over de opkomst van een publiekrechtelijk vermogensrecht en over de betekenis van het legalteitsbeginsel, in de bundel: Uit de school geklapt, onder redactie van M.A. Heldeweg, E.C.H.J. van der Linden en R.J.N. Schlössels, Den Haag 1999, p. 245-274

Teunissen, J.M.H.F.

Verjaring en verval bij publiekrechtelijke geldvorderingen, Gst. 7085, p. 549-553

Vegter, P.C.

Herziening van het sanctiestelsel. Verslag van de jaarvergadering van de Nederlandse Juristen-Vereniging, NJB 2002, p. 1288-1293

Vegting, W.G.

Het algemeen Nederlands administratiefrecht, eerste deel, N. Samsom N.V., Alphen aan den Rijn, 1954

Verheij, $N$.

Onder dexel van politie, het Nederlands bestuursrecht onder het EVRM, in de bundel: 40 jaar Europees verdrag voor de Rechten van de Mens: opstellen over de ontwikkeling van het EVRM in Straatsburg en in Nederland, onder redactie van A.W. Heringa en J.G.C. Schokkenbroek, Leiden 1990, p. 225-248

Vermeer, F.R.

De beginselplicht tot handhaving en de ruimte om te gedogen, JBplus 2001, p. 76-85

Verweij, J.H.

De bestuurlijke dwangsom (diss. UU), Utrecht 1997

Viering, M.L.W.M.

Het arrest Bendenoun: een stap terug?, NJB 1994, p. 1061-1063

Viering, M.L.W.M.

Het toepassingsbereik van artikel 6 EVRM (diss. KUN), W.E.J. Tjeenk Willink, Zwolle 1994 
Viering, M.L.W.M. en Fleuren, J.W.A.

Bendenoun revisited, NJB 1997, p. 1932-1943

Visser, M.J.C.

Zorgplichtbepalingen in het strafrecht (diss. UM), Gouda Quint, 2001

Vucsán, R.L. (red.)

De Awb-mens: boeman of underdog? (Damen-bundel), Ars Aequi Libri, Nijmegen 1996

Walker, M.J.

High Stakes on a Fast Track: Administrative Enforcement at EPA, Federal Bar News \& Joumal, Federal Bar Association, Volume 35, No. 10, december 1988, pagina 453-457

Walker, M.J.

Attitude Can Make A Difference: Dealing with the EPA's Enforcement Office: Some Practical Considerations, The Environmental Corporate Counsel Report, Augustus 1994, p. 6-9

Wattel, P.J.

Bendenoun, boeten en belastingen, NJB 1994, p. 1527-1529

Wattel, P.J.

Enkele mensenrechtelijke problemen in belastingszaken, in de bundel: 45 jaar Europees verdrag voor de rechten van de mens, onder redactie van A.W. Heringa en E. Myjer, Leiden 1996, p. $187-202$

Watterson, S.J.

Putting the Halper Genie Back in the Bottle: Examining United States v. Ursery in Light of Halper, Austin, and Kurth Ranch, Brigham Young University Law Review, 1997, 1997

B.Y.U.L. Rev. 235

Werd, de, M.F.J.M.

Ius curia novit. Ambtshalve aanvulling van rechtsgronden door de bestuursrechter, NJB 1998 , p. $687-694$

Widdershoven, R.J.G.M.

NTB-kroniek Bestuursprocesrecht, NTB 1997, p. 351-364

Widdershoven, R.J.G.M., Schlössels, R.J.N., en Stroink, F.A.M.

Hoger beroep, Boom juridische uitgevers 2001

Wiewel, P.G.

Rechtsbescherming tegen bestraffing (diss. UvA 2001), Nijmegen 2001

Wijk, van, H.D., Konijnenbelt, W., en Male, van, R.M.

Hoofdstukken van bestuursrecht, elfde druk, Elsevier Bedrijfsinformatie B.V., Den Haag 1999

Zijlstra, S.E.

Zelfstandige bestuursorganen in een democratische rechtsstaat, 's-Gravenhage 1997 



\title{
Kamerstukken, beleidsnota's en overige overheidspublicaties
}

\author{
Nationaal \\ Verslag van de Commissie tot herziening van het fiscaal strafrecht en strafprocesrecht, \\ (commissie Van den Dries), Alg. Landsdrukkerij 1936 \\ Kamerstukken II, 1987/1988, 20 329, nr. 3 \\ Kamerstukken II, 1987/1988, 20329 , nr. 6 \\ Kamerstukken II, 1990/1991, 21829 , nr. 1-2, Recht in beweging \\ Kamerstukken II, 1990/1991, 22 045, nr. 1-2, Met vaste hand \\ Sancties in de sociale zekerheid: bestuursstrafrecht of strafrechtelijk bestuursrecht?, rapport \\ opgesteld door de werkgroep "Sancties in de sociale zekerheid" onder voorzitterschap van J. \\ Riphagen, Kluwer, Deventer 1994
}

Handhaving door bestuurlijke boeten, Commissie voor de toetsing van wetgevingsprojecten, (CTW 94/1 - 12 januari 1994)

Kamerstukken II, 1993/1994, nr. 23400 VI, nr. 48, Kabinetsstandpunt bestuurlijke boeten 1994

Kamerstukken II, 1994/95, nr. 23 909, nr. 3

Commissie Michiels, Handhaven op niveau, W.E.J. Tjeenk Willink, Deventer 1998

Kamerstukken II, 1999/2000, 26800 VI, nr. 67, Kabinetsstandpunt Handhaven op Niveau,

Voorontwerp Algemene wet bestuursrecht vierde tranche, Commissie wetgeving algemene regels van bestuursrecht, Den Haag 7 september 1999

Transactiebesluit milieudelicten, Stb. 2000, 320

Kamerstukken II, 2001/2002, 26604 en 26 345, nr. 14, Kabinetsstandpunt inzake het toezicht en het publiek domein

Commissie Roelvink, Strafrechtelijke aansprakelijkheid van de staat, Den Haag 2002

Kamerstukken II, 2001/2002, 25 294, nr. 15, Strafrechtelijke aansprakelijkheid van overheidsorganen, brief van de minister van justitie 
Kamerstukken II, 2001/2002, 28 093, nr. 1, Interpellatie inzake bouwfraude en corruptie bij ambtenaren, motie van de leden Van Gijzel en Leers

Kamerstukken 1I, 2001/2002, 28 093, nr. 5, Interpellatie inzake bouwfraude en corruptie bij ambtenaren, motie van het lid Van den Berg

Kamerstukken II, 2001/2002, 28 093, nr. 14, Bouwfraude en corruptie bij ambtenaren, motie van het lid De Graaf c.s.

Kamerstukken II, 2001/2002, 28 093, nr. 15, Bouwfraude en corruptie bij ambtenaren, motie van het lid Van Oven c.s.

Kamerstukken II, 2001/2002, 28 093, nr. 16, Bouwfraude en corruptie bij ambtenaren, gewijzigde motie van de leden Rosenmöller en Poppe, ter vervanging van die gedrukt onder nrs. 12 en 13

Kamerstukken II, 2001/2002, 28 093, nr. 17, Bouwfraude en corruptie bij ambtenaren, brief van de minister van justitie

Kamerstukken II, 2001/2002, 28 093, nr. 20 (herdruk), Bouwfraude en corruptie bij ambtenaren, brief van de minister van justitie

Kamerstukken II, 2001/2002, 28 093, nr. 21, Bouwfraude en corruptie bij ambtenaren, verslag van een algemeen overleg

\section{Raad van Europa}

Council of Europe, collected edition of the "Traveaux Préparatoires" of the European Convention on Human Rights, Volume I-VIII, Martinus Nijhoff Publishers, Dordrecht' Boston/Lancaster, 1985

\section{Environmental Protection Agency}

Administrative Hearings and Trials, National Enforcement Training Institute van het Office of Enforcement and Compliance Assurance van het EPA

Policy on Civil Penalties, 16 februari 1984 (GM-21)

Framenwork for Statute-specific Approaches to Penalty Assessment, 16 februari 1984 (GM22)

Clean Air Act Stationary Source Civil Penalty Policy

United States Environmental Protection Agency (Region 5), complaint, and notice of opportunity for hearing on proposed administrative order assessing penalties, against "Ashbach Construction Company", 31 januari 1997, docket no. 5-CAA-97-003 


\section{Rechtspraak}

\section{Human Rights Committee}

Human Rights Committee 20 juli 2000, nr. 701/1996, FED 2000/683 (C. Gómez Vázquez. v. Spain)

\section{Europees Hof voor de Rechten van de Mens}

\section{EHRM 27 juni 1968, Series A vol. 8, (Neumeister)}

EHRM 17 januari 1970, Series A vol. 11, (Delcourt)

EHRM 8 juni 1976, Series A vol. 22, NJ 1978, 223 (Engel and Others v. the Netherlands) EHRM 28 november 1978, Series A, vol. 29 (Leudicke, Belkacern en Koç)

EHRM 26 april 1979, Series A vol. 30, NJ 1980, 146 m. nt. Alkema (Sunday Times) EHRM 27 februari 1980, Series A vol. 35, NJ 1980, 561 (essentie), (Deweer v. Belgium) EHRM 23 juni 1981, NJ 1982, 602 (Le Compte, Van Leuven, en De Meyere) EHRM 26 maart 1982, Series A vol. 49, (Adolf)

EHRM 10 december 1982, Series A vol. 56, NJ 1987, 828, m. nt. P. van Dijk (Foti and Others)

EHRM 10 februari 1983, NJ 1987, 315 (Albert en Le Compte)

EHRM 25 maart 1983, Series A vol. 62, NJ 1986, 698 m. nt. E.A. Alkema (Minelli) EHRM 21 juni 1983, Series A vol. 65, (Eckle v. Germany)

EHRM 21 februari 1984, Series A, Vol. 73, NJ 1988, 937 m. nt. E.A. Alkema (Öztürk) EHRM 28 juni 1984, Series A vol. 80, (Campbell and Fell)

EHRM 25 augustus 1987, Series A vol. 123, NJ 1988, 938 m. nt. E.A. Alkema (Lutz) EHRM 29 april 1988, Series A vol. 132, (Belilos case)

EHRM 24 mei 1988, Series A vol. 133, (Müller and others)

EHRM 12 juli 1988, Series A vol. 140, NJ 1988, 851 m. nt. E.A. Alkema (Schenk tegen Zwitserland)

EHRM 7 oktober 1988, Series A vol. 14 I-A, NJ 1991, 351, m. nt. E.A. Alkema (Salabiaku) EHRM 6 december 1988, Series A no. 146, (Barberà, Messegué and Jabardo) EHRM 7 juli 1989, Series A vol. 159, (Tre Traktörer Aktiebolag v. Sweden)

EHRM 19 december 1989, Series A, vol. 168, NJ 1994, 26 m. nt. E.A. Alkema (Kamasinski)

EHRM 19 december 1989, Series A, vol. 167, NJ 1994, 25 m. nt. E.A. Alkema (Brozicek) EHRM 28 juni 1990, Series A vol. 179, NJ 1995, 491 m. nt. E.A. Alkema (Obermeier) EHRM 22 mei 1990, Series A vol. 177, (Weber)

EHRM 27 augustus 1991, Series A vol. 210, (Demicoli v. Malta)

EHRM 25 februari 1992, Series A vol. 226-A, (Margareta and Roger Andersson v. Sweden) 25 september 1992, Series A vol. 243, NJ 1995, 593 m. nt. E.A. Alkema (Pham Hoang v. France)

EHRM 25 februari 1993, NJ 1993, 485 m. nt. Knigge (Funke) EHRM 25 mei 1993, Series A vol. 260 - A, (Kokkinakis v. Greece) EHRM 25 augustus 1993, Series A vol. 266-A, NJ 1994, 1, m. nt. Knigge (Sekanina) EHRM 21 september 1993, Series A vol. 268-A, NJ 1994, 544 (Zumtobel) 
EHRM 24 november 1993, Series A vol. 275, (Imbrioscia v Switzerland)

EHRM 24 februari 1994, Series A vol. 284, NJ 94, 496, m. nt. E.A. Alkema (Bendenoun)

EHRM 23 maart 1994, Series A vol. 283-B, (Ravnsborg v. Sweden)

EHRM 21 september 1994, Series A vol. 294-B, NJ 1995, 463, (Fayed tegen GrootBrittannië)

EHRM 9 februari 1995, Series A vol. 307-A, NJ 1995, 606, m. nt. Knigge (Welch v. UK)

EHRM 10 februari 1995, Series A vol. 308, NJ 1997, 523, m. nt. E.J. Daalder (Allenet de Ribemont v. France)

EHRM 8 juni 1995, NJ 1996, 1, m. nt. Knigge (Jamil v. France)

EHRM 13 juli 1995, Series A vol. 316-B, (Tolstoy Miloslavsky v. UK)

EHRM 26 september 1995, Series A vol. 323, (Vogt)

EHRM 27 september 1995, Series A vol. 325-B, NJ 1996, 49 m. nt. Knigge (G. v. France)

EHRM 23 oktober 1995, Series A vol. 328-C, (Gradinger v. Austria)

EHRM 23 oktober 1995, Series A vol. 328-B, (Umlauft v. Austria)

EHRM 23 oktober 1995, Series A vol. 328-A, (Schmautzer v. Austria)

EHRM 22 november 1995, Series A vol. 335-B, (S.W. v. the United Kingdom)

EHRM 22 november 1995, Series A vol. 335-A, NJ 1997, 1, m. nt. Knigge (C.R. v. the United Kingdom)

EHRM 22 november 1995, Series A, Vol 335-A (Bryan)

EHRM 8 februari 1996, ECHR-Reports 1996-1, NJ 1996, 725, m. nt. Knigge (Murray v. the United Kingdom)

EHRM 22 februari 1996, no. 18892/91, (Putz v. Austria)

EHRM 15 november 1996, no. 17862/91, (Cantoni v. France)

EHRM 17 december 1996, EHRC Reports 1996-VI, p. 2044, NJ 1997, 699, m. nt. Knigge, (Saunders v. the United Kingdom)

EHRM 18 maart 1997, ECHR Reports 1997-II, NJ 1998, 278 m. nt. H.J. Snijders, (Mantovanelli v. France)

EHRM 29 augustus 1997, no. 19958/92 ECHR Reports 1997-V (A.P., M.P. and T.P. v. Switzerland)

EHRM 29 augustus 1997, no. 20919/92 ECHR Reports 1997-V (E.L., R.L., and J.O.-L. v. Switzerland)

EHRM 24 september 1997, no. 93/1996/712/909, JB 1997/281, m. nt. A.W. Heringa (Garryfallou AEBE)

EHRM van 25 november 1997, no. 24348/94, (Grigoriades v. Greece)

EHRM 30 juli 1998, Reports 1998-V, (Oliveira v. Switzerland)

EHRM 2 september 1998, no. 26138/95, (Lauko v. Slovakia)

EHRM 2 september 1998, no. 27061/95, (Kadubec v. Slovakia)

EHRM 23 september 1998, no. 68/1997/852/1059 (Malige v. France)

EHRM 15 juni 1999, no. 37607/97, (W.S. v. Poland)

EHRM 8 juli 1999, no. 23536/94 en 24408/94, (Başkaya and okçuoğlu judgement)

EHRM, 29 september 1999, no. 00037475/97 en 00039036/97, (Smith and Ford v. the United Kingdom)

EHRM 28 oktober 1999, no. 26780/95, EHRC 1999/6 m. nt. Karianne Albers (Escoubet tegen België)

EHRM 21 maart 2000, no. 28389/95, (Asan Rushiti v. Austria)

EHRM 2 mei 2000, no. 35718/97, (Condron v. the UK)

EHRM 6 juni 2000, no. 36408/97, (Averill v. UK) 
EHRM 19 september 2000, no.'s: 29522/95, 30056/96 en 30574/96, (I.J.L., G.M.R. and A.K.P. V. the UK)

EHRM 7 november 2000, no. 35605/97 (Kingsley)

EHRM 14 november 2000, no. 27783/95, EHRC 2000/94 m. nt. C.L.G.F.H. Albers, (T. v. Austria)

EHRM 21 december 2000, no. 34720/97, (Heaney and Mc Guinness v. Ireland)

EHRM 21 december 2000, no. 36887/97, (Quinn v. Ireland)

EHRM 27 februari 2001, no. 29295/95 en 29363/95, (Ecer and Zeyrek v. Turkey)

EHRM 20 maart 2001, no. 33501/96 (Telfner v. Austria)

EHRM 22 maart 2001, no. 37201/97, (K.-H. W. v. Germany)

EHRM 22 maart 2001, no.'s 43044/96, 35532/97, en 44801/98 (Streletz, Kessler and Krenz v. Germany)

EHRM 3 mei 2001, no. 31827/96, EHRC 2001/45, m. nt. K. Albers (J.B. tegen Zwitserland) EHRM 29 mei 2001, no. 37950/97 EHRC 2001/49 m. nt. J. van der Velde, (Franz Fischer v. Austria)

EHRM 19 juni 2001, no. 28249/95 (Kreuz v. Poland)

EHRM 26 februari 2002, no. 38784/97, (Morris v. the United Kingdom)

EHRM 23 juli 2002, no. 36985/97, (Västberga Taxi Aktiebolag an Vulic v. Sweden)

EHRM 23 juli 2002, no. 34619/97, (Janosevic v. Sweden)

\section{Europese Commissie voor de Rechten van de Mens}

ECRM 6 maart 1989, BNB 1997/5 m. nt. M.W.C. Feteris onder BNB 1997/6 (Källander)

\section{Hoge Raad}

HR 14 februari 1916, NJ 1916,681

HR 7 mei 1923, NJ 1923, 932, W 11082

HR 15 februari 1932, NJ 1932, 289 m. nt. Taverne (Oude Kijk in 't Jatstraat-arrest)

HR 3 april 1947, NJ 1947, 381 m. nt. E.M. Meijers (Loosdrechts Bootenhuis)

HR 23 februari 1954, NJ 1954, 378 (IJzerdraadarrest)

HR 21 november 1961, NJ 1962, 89 m. nt. B.V.A. Röling

HR 26 juni 1962, NJ 1962, 470 m. nt. W. Pompe

HR 17 december 1963, NJ 1964, 385 m. nt. W. Pompe (Joyriding II)

HR 18 januari 1972, NJ 1972, 378 m. nt. C. Bronkhorst

HR 25 maart 1975, NJ 1975, 296

HR 1 december 1975, NJ 1976, 254

HR 12 april 1978, BNB 1978, 135-137 m. nt. C.P. Tuk, NJ 1979, 533 m.nt. M. Scheltema, AB 1979, 262 m. nt. F.H. van der Brug

HR 18 april 1978, NJ 1978, 365, m. nt. Th. W. van Veen

HR 19 februari 1980 , NJ 1980, 384

HR 29 april 1980, NJ 1980, 445 m. nt. G.E. Mulder

HR 1 juli 1981, NJ 1982, 80 m. nt. Th. W. van Veen (Kabeljauwvangst)

HR 1 juli 1981, NJ 1981, 616 m. nt. Th.W. van Veen

HR 22 september 1981, NJ 1981, 644 m. nt. Th.W. van Veen

HR 19 januari 1982, NJ 1982, 354

HR 11 mei 1982, NJ 1982, 592 
HR 3 januari 1984, NJ 1984, 420 m. nt. 't Hart

HR 24 april 1984, NJ 1984, 639

HR 28 mei 1985, NJ 1986, 127

HR 24 november 1987, NJ 1988, 665

HR 7 september 1988, BNB 1988/298

HR 14 april 1989, AB 1989, 207, m. nt. F.H. van der Burg

HR 5 februari 1991, NJ 1991, 402

HR 14 januari 1992, NJ 1992, 413 m. nt. 't Hart (Firma Café Nol)

HR 1 juli 1992, BNB 1992, 306, m. nt. P. den Boer, NJ 1992/621 m. nt. Scheltema

HR 9 november 1993, NJ 1994, 198

HR 15 juli 1993, NJ 1994, 177, m. nt. Corstens

HR 25 januari 1994, NJ 1994, 598, m. nt. Corstens (Vliegbasis Volkel)

HR 28 juni 1994, NJ 1994, 657

HR 13 december 1994, NJ 1995, 252

HR 31 januari 1995, NJ 1995, 598, m. nt. Corstens

HR 12 maart 1996, NJ 1996, 539

HR 19 maart 1996, NJ 1996, 540 m. nt. Schalken

HR 9 oktober 1996, BNB 1997/6 m. nt. M.W.C. Feteris

HR 12 maart 1997, BNB 1997/146c, m. nt. P.J. Wattel

HR 3 juni 1997, NJ 1997, 584

HR 21 oktober 1997, NJ 1998, 173

HR 14 april 1998, NJ 1998, 609

HR 10 november 1998, NJ 1999, 139

HR 12 januari 1999, NJ 1999, 289

HR 20 april 1999, VR 2000, 52

HR 22 juni 1999, NJ 1999, 648

HR 26 oktober 1999, NJ 2000, 240 m. nt. Knigge (Police Dog)

HR 10 oktober 2000, NJ 2001, 266 m. nt. P.A.M. Mevis

HR 30 maart 2001, JB 2001/107, m. nt. R.J.N. Schlössels, Gst. 2001, 7143 no. 3, m. nt. H.

Hennekens, en AA 2001, p. 657 - 663, m. nt. L.J.A. Damen (Staat/Lavrijsen)

HR 8 maart 2002, JB 2002/112 m. nt. R.M.P.G. Niessen-Cobben en A.W. Heringa

\section{Afdeling Geschillen van Bestuur voor de Raad van State}

AGRvS 24 april 1992, AB 1992, $575 \mathrm{~m}$. nt. Stellinga

AGRvS 15 mei 1992, AB 1993, 386 m. nt. A.F.M. Brenninkmeijer

\section{Afdeling Rechtspraak van de Raad van State}

ARRS 17 november 1977, AB 1987, 97 m. nt. B. de Goede (Mw. Cupido)

ARRS 9 december 1977, AB 1978, 76 m. nt. F.H. van den Burg (Faraomieren)

\section{Voorzitter Afdeling Bestuursrechtspraak van de Raad van State}

Vz. ABRS 6 november 1998, AB 1999, 128

Vz. ABRS 1 februari 1999, AB 1999, 302 m. nt. G. Jurgens

$V z$. ABRS 21 november 2000, AB 2000, $318 \mathrm{~m}$. nt. G. Jurgens 
Vz. ABRS 7 december 2000, AB 2001, 317 m. nt. G.Jurgens

\section{Afdeling Bestuursrechtspraak van de Raad van State}

ABRS 21 januari 1988, AB 1989, 36 m. nt. H.J. Simon

ABRS 4 november 1993, AB 1994, $182 \mathrm{~m}$. nt. N. Verheij

ABRS 5 juli 1994, AB 1994, 636 m. nt. F. Michiels (Nuisker Car Coating)

ABRS 24 februari 1995, AB 1995, $527 \mathrm{~m}$. nt. F. Michiels

ABRS 16 januari 1996, AB 1996, $409 \mathrm{~m}$. nt. G. Jurgens (Ahold)

ABRS 9 mei 1996, JB 1996/158 m. nt. F.A.M. Stroink (Maxis \& Praxis)

ABRS 4 juni 1996, JB 1996/172, m. nt. E. v.d. Linden (Huisman APK)

ABRS 15 juli 1996, AB 1996, 414 m. nt. F. Michiels (Sluiting café "De Windmolen")

ABRS 19 september 1996, JB 1996/215 m. nt. R.J.N. Schlössels, AB 1997, 91 m. nt. P. van Buuren

ABRS 10 februari 1997, AB 1997, 427 m. nt. N. Verheij

ABRS 28 april 1997, AB 1999/43, m. nt. C.L. Knijff onder AB 1999/45

ABRS 4 september 1997, AB 1997, 396 m. nt. F. Michiels

ABRS 2 februari 1998, AB 1998, $181 \mathrm{~m}$. nt. F. Michiels (Lisse)

ABRS 5 juni 1998, AB 1998, 286

ABRS 11 juni 1998, AB 1998, 297 m. nt. F. Michiels (Sluiting café "Lindsay's Place")

ABRS 27 augustus 1998, JB 1998/273 m. nt. R.J.N. Schlössels (melkrundveehouderij Hoogwoud)

ABRS 21 september 1998, JB 1998/241 m. nt. H.J. Simon (woonruimtevordering Sliedrecht)

ABRS 15 oktober 1998, JB 1998/278 m. nt. R.J.N. Schlössels (Verkeersbesluit Weert)

ABRS 15 februari 1999, AB 1999, 118 m. nt. M. Schreuder-Vlasblom (Nellen - Raad van

Beroep Ned. Alg. Keuringsdienst voor Groente- en Bloemzaden)

ABRS 4 maart 1999, JB 1999/69 m. nt. C.L.G.F.H. Albers

ABRS 8 maart 1999, RAwb 1999/116 m. nt. O.J.D.M.L. Jansen

ABRS 25 maart 1999, AB 1999, 229 m. nt. B.P. Vermeulen

ABRS 15 april 1999, JB 1999/150 m. nt. Karianne Albers

ABRS van 6 mei 1999, AB 1999, 282 m. nt. M. Schreuder-Vlasblom (Automobielbedrijf Schreur)

ABRS 1 juni 1999, AB 1999, 326 m. nt. M. Schreuder-Vlasblom (Rechtsbijstand Kombé)

ABRS 28 juni 1999, JB 1999/197 m. nt. R.J.N. Schlössels, AB 1999, 360 m. nt. M. Schreuder-Vlasblom (HRCT-scan)

ABRS 13 juli 1999, AB 2000, 140 (Crematorium Bilthoven-Noord)

ABRS 15 juli 1999, AB 2000, 141 ("Bourgondische Hoeve" Elsloo) m. nt. Jurgens

ABRS 19 augustus 1999, AB 1999, 403 m. nt. M. Schreuder-Vlasblom

ABRS 1 november 1999, JB 1999/301 m. nt. C.L.G.F.H. Albers en R.J.G.H. Seerden

ABRS 28 december 1999, AB 2000/107

ABRS 30 december 1999, AB 2000, 47 m. nt. M. Schreuder-Vlasblom (intrekking wapenverlof)

ABRS 4 februari 2000, JB 2000/72, Gst. 7120, 3 m.nt. H. Hennekens, AB 2000, 242 m. nt. L. Damen

ABRS 8 februari 2000, JB 2000/91 m. nt. C.L.G.F.H. Albers, AB 2001, 118 m. nt. L. Damen (Haagse woningverbeteringssubsidies) 


\section{RECHTSPRAAK}

ABRS 11 februari 2000, JB 2000/75 m. nt. C.L.G.F.H. Albers

ABRS 3 april 2000, AB 2000, $222 \mathrm{~m}$. nt. M. Schreuder-Vlasblom (nadeelcompensatie reconstructie Venloseweg)

ABRS 3 april 2000, AB 2000, 406 m. nt. Struiksma (Kampwinkel Garderen)

ABRS 11 september 2000, JB 2000/299 m. nt. C.L.G.F.H. Albers (Tuincentrum Milder)

ABRS 29 september 2000, JB 2000/304 m. nt. C.L.G.F.H. Albers (Brandende oplegger)

ABRS 12 oktober 2000, JB 2000/328 (Coffeeshop Amsterdam)

ABRS 15 februari 2001, JB 2001/88 m. nt. C.L.G.F.H. Albers

ABRS 13 maart 2001, JB 2001/95 m. nt. C.L.G.F.H. Albers

ABRS 30 maart 2001, JB 2001/129 m. nt. C.L.G.F.H. Albers, AB 2001, 189 m. nt. L. Damen (Standplaatsvergunning Amsterdam)

ABRS 10 juli 2001, AB 2001, $411 \mathrm{~m}$. nt. De Gier

ABRS 26 september 2001, AB 2002, $67 \mathrm{~m}$. nt. F.R. Vermeer

ABRS 10 oktober 2001, JB 2001/315 m. nt. C.L.G.F.H. Albers (Sanders Beneden Leeuwen $\mathrm{BV}$ )

ABRS 14 november 2001, JB 2002/3 m. nt. C.L.G.F.H. Albers (Stillegging bouwwerkzaamheden Steenbergen)

ABRS 21 november 2001, JB 2002/7 m. nt. A.W. Heringa

ABRS 27 februari 2002, AB 2002, 224 m. nt. F. Michiels (Tuinbouwbedrijf Van den Wijngaart)

ABRS 28 augustus 2002, LJN-nummer AE 6927 (WIN-boete Zeist)

\section{President Centrale Raad van Beroep}

Pres. CRvB 22 juni 1994, RSV 1995/16

Pres. CRvB 14 april 1999, JABW 1999/90

\section{Centrale Raad van Beroep}

CRvB 11 maart 1992, AB 1992, 462 m. nt. Demeersseman

CRvB 21 december 1993, RSV 1994/132 m. nt. H.A. Demeersseman

CRvB 9 mei 1995, JB 1995/163 m. nt. A.B.J. van der Ham en E.L. Benetreu

CRvB 28 november 1995, RSV 1996/89

CRvB 23 juli 1996, RSV 1997, 17

CRvB 24 april 1997, AB 1997, 319 m. nt. H. Hennekens

CRvB 28 oktober 1997, AB 1998, 14 m. nt. FP

CRvB 6 oktober 1998, JB 1998/264 m. nt. R.J.N. Schlössels

CRvB 18 december 1998, JB 1999/18 m. nt. R.J.N. Schlössels

CRvB 26 januari 1999, JB 1999/54 m. nt. R.J.N. Schlössels

CRvB 29 juni 1999, JB 1999/206

CRvB 7 september 1999, AB 1999, 455 m. nt. Bröring, ook gepubliceerd in JB 1999/253

m. nt. C.L.G.F.H. Albers

CRvB 14 oktober 1999, JB 1999/303 m. nt. H.L. Janssen

CRvB 1 maart 2000, JB 2000/107 m. nt. C.L.G.F.H. Albers

C.RvB 5 april 2000, JB 2000/144 m. nt. C.L.G.F.H. Albers

CRvB 29 juni $2000 \mathrm{JB} 2000 / 254 \mathrm{~m}$. nt. C.L.G.F.H. Albers

CRvB 5 juli 2000, JB 2000/256 m. nt. C.L.G.F.H. Albers 
CRvB 4 januari 2001, JB 2001/55

CRvB 29 januari 2002, Gst. 7164, 2 (uitspraak), en Gst. 7166, 10 (naschrif), met naschrift W.P.F. de Bruijn

CRvB 29 januari 2002, JB 2002/100 m. nt. C.L.G.F.H. Albers

\section{President College van Beroep voor het bedrijfsleven}

Pres. CBB 10 november 1994, KG 1994/447

Pres. CBB 28 januari 1998, AB 1998, $228 \mathrm{~m}$. nt. J.H. van der Veen

\section{College van Beroep voor het bedrijfsleven}

CBB 29 februari $2000, A B 2000,206$ m. nt. J.H. v.d. Veen

CBB 8 februari 2001, ELRO-nummer, AB0037

CBB 17 juli 2001, ELRO-nummer, AB3002

CBB 17 juli 2001, ELRO-nummer, AB2999

CBB 17 juli 2001, ELRO-nummer, AB3000

CBB 17 juli 2001, ELRO-nummer, AB2997

\section{Voorzitter College van Beroep Studiefinanciering}

Vz. College van Beroep Studiefinanciering, 25 oktober 1999, JB 2000/15 m. nt. C.L.G.F.H. Albers, AB 2000, 278 m. nt. G.A.C.M. van Ballegooij

\section{Overig}

Gerechtshof Leeuwarden, 27 februari 2002, JB 2002/136 m. nt. C.L.G.F.H. Albers (Ooststellingerwerf - Stichting Woningbeheer Noord-Nederland)

Rb. Assen 21 maart 1994, JB 1994/77

Rb. Assen 8 november 1995, JB 1995/321 m. nt. Henk Simon

Pres. Rb. Groningen 13 februari 1996, JB 1996/179 m. nt. Annemiek Derks en Malva Driessen

Rb. Den Haag, 23 december 1998, JB 1999/57 m. nt. Karianne Albers

Rb. Assen 6 januari 1999, JB 1999/37 m. nt. A.W. Heringa

Rb. Groningen 2 september 1999, USZ 1999/292 m. nt. Karianne Albers

Rb. Amsterdam 31 mei 2000, JB 2000/235 m. nt. C.L.G.F.H. Albers

$\mathrm{Rb}$. Amsterdam 4 september 2000, JABW 2001/12, ELRO-nummer AA8926

Rb. Groningen van 11 oktober 2000, USZ 2001/21 m. nt. Karianne Albers

Pres. Rb. Den Bosch, 20 oktober 2000, TAR 2001/10

Rb. Maastricht 5 februari 2001, JB 2001/84 m. nt. C.L.G.F.H. Albers (In den Ouden Vogelstruys)

Rb. Dordrecht, 14 december 2001, JB 2002/57 m. nt. C.L.G.F.H. Albers (Woningstichting Progrez) 


\section{US Supreme Court}

116 U.S. 436, 1886 (Coffey v. United States)

116 U.S. 616, 1886 (Boyd v. U.S.)

143 U.S. 649, 1892 (Field v. Clark)

167 U.S. 178, 1897 (Stone v. United States)

214 U.S. 320, 1909 (Oceanic Steam Navigation Company versus Stranahan)

220 U.S. 506, 1911 (U.S. v. Grimaud)

276 U.S. 394, 1928 (J.W. Hampton, Jr. \& Co. v. U.S.)

285 U.S. 22, 1932 (Crowell v. Benson)

293 U.S. 388, 1935 (Panama Refining Co. v. Ryan)

295 U.S. 495, 1935 (A.L.A. Schecter Poultry Corp. v. United States)

303 U.S. 391, 1938 (Helvering v. Mitchell)

322 U.S. 11 1, 1944 (National Labor Relations Board v. Hearst Publications, Incorporated)

339 U.S. 33, 1950 (Wong Yang Sung v. Mc Garth)

340 U.S. 474, 1951 (Universal Camera Corp. v. National Labor Relations Board)

343 U.S. 470, 1952 (Federal Trade Commission v. Ruberoid Co.)

372 U.S. 144, 1963 (Kennedy v. Mendoza-Martinez)

401 U.S. 402, 1971 (Citizens to preserve Overton Park v. Volpe)

416 U.S. 633, 1974 (Calero-toledo v. Pearson Yacht Leasing Co.)

430 U.S. 422, 1977 (Atlas Roofing Co. v. Occupational Safety and Health Review Commission)

440 U.S. 472, 1979 (National Muffler Dealers Association, Inc., v. United States)

448 U.S. 242, 1980 (United States v. Ward)

488 U.S. 607, 1980 (Industrial Union Department AFL-CIO v. American Petroleum Insti-

tute (the "Benzene Case"))

465 U.S. 354, 1984 (United States versus One Assortment of 89 Firearms)

467 U.S. 837, 1984 (Chevron U.S.A., Incorporated v. Natural Recources Defense Council)

470 U.S. 821,1985 (Heckler v. Chaney)

473 U.S. 568, 1985 (Thomas v. Union Carbide Agricultural Products Co.)

478 U.S. 833, 1986 (Commodity futures trading commission v. Schor)

481 U.S. 412,1987 (Tull v. United States)

485 U.S. 535, 1988 (Traynor v. Turnage)

488 U.S. 361,1989 (Mistretta v. U.S.)

490 U.S. 435, 1989 (United States versus Halper)

492 U.S. 257, 1989 (Browning-Ferris Industries v. Kelco Disposals)

494 U.S. 775, 1990 (National Labor Relations Board v. Curtin Matheson Scientific, Inc.)

509 U.S. 602,1993 (Austin v. U.S.)

113 S. Ct. 2024, 1993 (Lincoln v. Vigil)

No. 93-114, 1994 (Montana Dept. of Revenue versus Kurth Ranch)

116 S. Ct. 109, 1996 (Wisconsin v. City of New York)

No.94-8729, 1996 (Bennis v. Michigan)

518 U.S. 267, 1996 (U.S. v. Ursery)

No. 96-976, 1997 (Hudson Et Al versus United States)

No. 99-1185, 2001 (Seling, superintendent, special commitment center v. Young) 
RECHTSPRAAK

\section{Overige rechtspraak Verenigde Staten}

217 P. 2D 992, 1950 (State Employees' Retirement System v. Industrial Accident Commission)

745 F.2d 677, 1984 (Association of Data Processing Service Organizations, lnc. v. Board of Governors of the Federal Reserve System) 



\section{Trefwoordenregister}

aard van de overtreding

89-95

aard en zwaarte van de sanctie

$95-110$

aard van de sanctie

96-100

accessibility

accusatoir proces

206-207

afschrikkend

96-100

afschrikkende werking

$51,96-100,345-346$

agency

275-284

autonome zienswijze

19-21

autonoom

$82,84-88$

beginselplicht tot handhaving

40,165

beleidsvrijheid

$25,52,53,215,218,245-247,255,267$

beoordelingsruimte

beoordelingsvrijheid

beslistermijn

261

bestraffend

$1,25-37,212,243$

bestraffing

bestuurlijke boete

bestuurlijke sanctie

bestuurlijke waarborgsom

bestuursdwang

bestuursrechtelijke transactie

bestuursstrafrecht

bewijs

bewijs; strafrechtelijk onrechtmatig verkregen

bewijsfuik

bewijslast

bewijslast; omkering van de

bewijslast; verschuiving van de

bewijslastverdeling

bewijsmiddelen

$157,169,184,297$

$2-4,17-19,48-52,184$

164

24

$40-43,154,165$

$24,69,71,79,441-444$

1,30

$125,181-184,204-228,294,299$

$125,223-228$

210

$131,204-228$

130

128-129

204-228

206

bewijsvermoedens

192

boeteprocedure; lichte

158-159

boeteprocedure; zware

158-159

boetestelsel; wettelijk gefixeerd

$174,248-252,253$

buitengerechtelijke afdoening

cautieplicht

177-184

charge

$115-118,178,180$

civiele rechter 
classificatie van de normschending naar nationaal recht contradictoir procesrecht

criminal charge

criminal offence

84-120, 120-121, 155-156, 178-181

$89-95,120-121,121-124$

cumulatie (van sancties)

$170-171$

dader

$160-164$

daderschap

$160-164$

decriminalisering

$55,71,72$

deelneming

161-162

deelnemingsvormen

$161-162$

discretionaire bevoegdheid

285-287, 296-298, 302-303

doelmatige

152,407

doelmatigheidsargumenten

418-420

doelmatigheidsoverwegingen

doen plegen

$61,68,153,262,263,267,412,439$

161-162

dossier; inzage in het

258-259

dwangbevel

dwangsom

43-46

effectieve handhaving

efficiènte handhaving

evenredig

evenredigheid

evenredigheidsbeginsel

executiegeschil

$53,73,194,200,203,237,260,267$,

$407,410,418,423-428,441,446$

$53,73,194,200,203,260,267,407$,

$410,418,424-428,441,446$

$174-175$

174-175

$25,40,42,171-174,242,243-252$

fair trial

$124-131,131-138,178,224,257$

foreseeability

formal adjudication procedure

228-291

formele rechtskracht

$193-199,218$

frequentiecriterium

63-65

full jurisdiction

functiescheiding

$122,218-221,244,250,267$

$258,262-263$

functioneel daderschap

$160-164,264$

geen straf zonder schuld

gedraging

gedraging; één

172-174, 229-235

generale preventie

geringe normatieve lading

$56-63,153$

griffierecht 
handhaving; partiële

handhaving; preventieve

42,171

handhavingstekort

$3,54,152,267$

hardheidsclausule

$154,249,251$

$25-37,162$

herstel

herstelsanctie

heteronome zienswijze

$25-37,155,164$

19-21

hetzelfde feit

229-235

hoorplicht

$155,192,193,199-200$

inlichtingenplicht

181-183

inquisitoir proces

206, 208

interpretive rules

300

$37-40$

intrekking van een begunstigende beschikking

$192-200$

invorderbaar

$43-46,177,192-200$

invordering; verbod tot

$195,198,200,263$

kennisgeving

$180,229,240,260-261$

kostenverhaal

$42,44,162$

lagere boete

leedtoevoeging

$147-149,166,199,252-256,258,265$

$25-37,97-100,131,189,259$

$166-167$

legaliteitsbeginsel

139-143, 167-169

lex certa-beginsel

$206,207,208$

lijdelijk

46-48

maatregel

$26,245,246,266$
207,218

marginale toetsing

materiële waarheidsvinding

161

medeplegen

161

medeplichtigheid

$133,181,183,211$

medewerkingsplicht

meest gunstige bepaling

$147-149,252-256$

model A

153-154

model B

153-154

motivering; deugdelijke

$214-216,220,221,234$

ne bis in idem-beginsel

$170,229-235$

nemo tenetur-beginsel

$131-138,177-184$

278-279

nondelegation doctrine

89-95

normadressaat-criterium

$143-147,166$

nulla poena sine lege-beginsel

139-143

nullem crimen sine lege-beginsel 
OM-boete

$268,434-441$

ongelijkheidscompensatie

$207,208,217,220$

onrechtmatig verkregen bewijs

$125,223-228$

onschuldpresumptie

$124-131,189-228$

opsporing

originaire rechtsbetrekking

$180,203,240,263$

overtreder

overtreding

160-164

160

overtreding; door een rechtspersoon

$162-164$

overtredingen van disciplinaire aard

$89-95$

partijautonomie

208,217

penalty

144-146

preventieve werking

$96-98,131$

proces-verbaal

$216,222,260,262$

punishment

$216,222,260,262$

punitief

$25-37,97-100,131$

punitieve bestuursrechtelijke sanctie

punitieve sanctie

quasi rechtsprekende bevoegdheid

279-282

quasi wetgevende bevoegdheid

278-279

rapport; opmaken van een

$222,256-258,262$

rechtsbescherming

4-11

56-63

rechtsdelicten

$156,157,214$

rechtseenheid

218

rechtsgelijkheid

157

rechtsonzekerheid

$121-124$

rechtspraak in twee feitelijke instanties

$154,170,175,220,221,237,246$

rechtszekerheid

rechtvaardigingsgrond

25-37

reparatoir

$25-37$

reparatoire sanctie

203-204

risico-aansprakelijkheid

samenloop

172-175

samenloop; eendaadse

$172-175,231,232,264$

samenloop; meerdaadse

$172-175,265$

sanctiedoel

96-100

sanctiedoel-criterium

96-100

sanctiezwaarte-criterium

100-110

schorsende werking

schorsende werking; ontbreken van

201,263

schuld

$191,193-199,228,265,266$

$124-131,189-229$ 
schulduitsluitingsgrond

$169,260,264$

schikking

secundaire rechtsbetrekking

$315,328-329,344,347$

separation of powers doctrine

277-284

speciale preventie

specialiteitsbeginse]

$27,97,111,259$

173,265

stigmatiserend effect

$58-59,72$

strafrecht in ruime(re) zin

25-37

19-23

strafrechtelijke boete

$170,190,191$

strafuitsluitingsgrond

300

toegang tot de rechter; recht op

122,192

147-149

toepassen lagere boete

$209,220,228$

toetsing; ambtshalve

toetsing; ex tunc

toetsing; marginale

toetsingsbevoegdheid

toetsingsintensiteit

transactie

trechtermodel

tuchtrechtelijke overtredingen

uitlokken

$161-162$

una via-beginsel

238-241

verdachte

180-184

verdedigingsrechten

vergelding

verjaringstermijn

vermoeden van schuld; weerlegbaar

vermoeden van schuld; wettelijk of feitelijk

$208,209,211,217,253,254,265$

$26,245,246,266$

$156,174,244-251,266$

$296,300,302$

$268,441-444$

$213,218,220,221,228,266,267$

89-95

vervaltermijn

verwijtbaarheid

voorlopige voorziening

voorlopige voorzieningsprocedure

$127,131,218,221,259,260,266$

$241,242,262$

124-131, 191, 192, 201-204

$124-131,191,192$

241-242

$124-131,190,244$

195-198

195-198

voorzienbaarheidsvereiste

140,167

vormverzuim

176,266

vormverzuim; passeren van

176,266

vrij bewijsleer

vrijheidsberovende maatregel

214 e.v., 417

vrijheidsberovende straf

$100-110$

$100-110$

vrijheidsberoving

$100-110$ 
wederkerig

wederkerige rechtsbetrekking

wederkerigheid

wetsdelicten

wettelijk gefixeerde boeten

willekeur

zekerheidsstelling

zelf in de zaak voorzien

zienswijze

zorgplichtbepalingen

zorgvuldige voorbereiding

zorgvuldigheidsbeginsel

zwaarte van de sanctie

zwijgrecht

zwijgrecht in strikte zin
$185-188,189$ 208

189

56-63

174, 248-252, 253

142,346

$192,199,200-201,228$

$237,245,253,254$

$155,192,193,199-200$

$167,168,169$

214-216, 220, 221

226

$100-110$

$131-138,177-184,222,264,267$

$178-180,183$ 


\section{Curriculum Vitae}

Karianne Albers werd op 4 juli 1972 geboren te Venray. In 1991 behaalde zij het diploma atheneum-alfa aan de Katholieke Scholengemeenschap Jerusalem te Venray. Vervolgens studeerde zij Nederlands recht aan de Rijksuniversiteit Limburg (de huidige Universiteit Maastricht). Hier studeerde zij in 1996 af. Van november 1996 tot juni 1997 was zij werkzaam bij de afdeling Materie, Instructie en Opleiding van de Stichting Uitvoeringsinstelling Sociale Zekerheid voor Overheid en Onderwijs (USZO) te Heerlen. Aansluitend was zij werkzaam als gerechtssecretaris bij de sector bestuursrecht van de rechtbank Maastricht. Met ingang van januari 1998 trad zij in dienst van de Universiteit Maastricht als docent vergelijkend publiekrecht bij de capaciteitsgroep publiekrecht. Bij diezelfde capaciteitsgroep is zij sinds september 1999 universitair docent staats- en bestuursrecht. 
De bestuurlijke boete vormt het centrale onderwerp van dit boek. Een bestuurlijke boete betreft een onvoorwaardelijke verplichting tot betaling van een geldsom die gericht is op bestraffing van de overtreder. De bestuurlijke boete wordt opgelegd door een bestuursorgaan zonder voorafgaande tussenkomst van een rechter. In het kader van de rechtsbescherming bij de oplegging van de bestuurlijke boete is de Algemene wet bestuursrecht (Awb) van toepassing.

In dit boek staat de vraag naar de mate waarin rechtsbescherming zou moeten worden geboden bij een procedure tot oplegging van bestuurlijke boetes centraal. Aangezien met de invoering van de bestuurlijke boete een bestraffende sanctie haar intrede heeft gedaan in het bestuursrecht wordt in dit proefschrift ingegaan op de vraag of in het kader van de rechtsbescherming bij de oplegging van de bestuurlijke boete strafrechtelijke regels en beginselen (zouden moeten) gelden. Met het oog op het voorgaande gaat aandacht uit naar het nationale straf(proces)recht en de verdragsrechtelijke (straf(proces)rechtelijke) waarborgen. Voorts vindt rechtsvergelijking plaats met de Verenigde Staten.

De belangrijkste conclusie in dit boek is dat onverkorte toepassing van het huidige bestuursprocesrecht (inclusief de boeteregeling uit het voorontwerp van de vierde tranche van de Awb) niet leidt tot een sanctieprocedure waarin aan de vermoedelijke overtreder voldoende rechtsbescherming wordt geboden.

Karianne Albers (1972) is als universitair docent bestuursrecht verbonden aan de capaciteitsgroep Publiekrecht van de Universiteit Maastricht. 